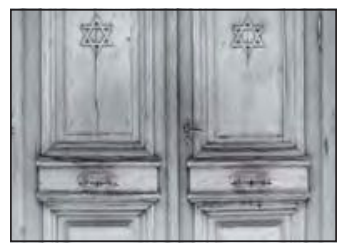

\title{
Historia y memoria de la colonización judía agraria en Entre Ríos
}

La experiencia de Colonia Clara, 1890-1950

\section{Patricia Graciela Flier}

Director: Dr. Waldo Ansaldi. Universidad de Buenos Aires

Co-Director: Dr. Fernando Barba. Universidad Nacional de La Plata

Universidad Nacional de la Plata

Marzo de 2011 

A mi padre, quien me enseñó a confiar en la vida y por su optimismo inconmensurable.

A Salvador 



\section{Agradecimientos}

Señalan que una investigación de tesis es un trabajo de una gran soledad, que sumerge al investigador en un micromundo que no siempre es fácil de compartir. Sin embargo, mi tarea contó con la ayuda, el acompañamiento y el interés de una gran cantidad de personas a las que estoy profundamente agradecida.

Realizar esta tarea fue infinitamente movilizador, pues me acerqué a transitar los complejos caminos constitutivos de nuestra identidad, y en este enriquecedor recorrido encontré los anclajes académicos y personales para los cuales sólo tengo gratitud y reconocimiento. A mi Director, el Dr. Waldo Ansaldi, interlocutor imprescindible, maestro y amigo, a mi Co-Director, Fernando Barba, que hizo todo lo posible para que llegara al fin de esta etapa.

A mis interlocutores, que me brindaron su tiempo y la lectura atenta con aportes y reflexiones: Sandra McGhee Deutsch, Patricia Funes, Pablo Ghigliani, Bruno Groppo, María Eugenia Horvitz, Talia Meschiany, Emmanuel Kahan, Soledad Lastra y María Teresita Minellono.

A mis amigas, que se comprometieron y me ayudaron de infinitas formas: Mirta Cabanes, Diana Sansano, María Eugenia López y, de manera particular, mi reconocimiento a Andrea López Osornio, quien no sólo me dio su tiempo y su arte sino que hizo que el texto adquiriera belleza.

A Osvaldo Quiroga, cuyo trabajo en el Museo y Archivo de las colonias judías de Villa Domínguez hace posible el resguardo de este pedazo de historia. A mi hermana Liliana Flier, a Norberto Fortunato y a Ethel López, con quienes empezamos a descubrir los legados de la colonización agraria judía en Entre Ríos, mi reconocimiento.

A Carolina Scalcini, quien me ayudó con las fuentes, y a mis entrevistados, por su entrega y por la confianza que depositaron en mí.

Finalmente, a mi familia, a mis hijos Nicolás y Guillermina y a mis amores, a quienes les quité tiempo y presencia. Confío en que este texto compense la ausencia. 

$\begin{array}{ll}\text { Introducción } & 13\end{array}$

$\begin{array}{ll}\text { Breve panorama del objeto dentro de los estudios migratorios } & 15\end{array}$

$\begin{array}{ll}\text { Memoria y representación del pasado } & 22\end{array}$

Los trabajos de las memorias: la vuelta a "el fuera-de-lugar” $\quad 26$

$\begin{array}{ll}\text { Recorridos de la investigación } & 30\end{array}$

Capítulo 1

Los imaginarios. Del miedo a la esperanza... $\quad 45$

Poblar la nación $\quad 45$

$\begin{array}{ll}\text { La imagen del país } & 49\end{array}$

Las puertas de salida $\quad 53$

La travesía $\quad 54$

El Hotel de Inmigrantes

La pampa santafesina $\quad 58$

Nace Moisés Ville $\quad 64$

$\begin{array}{ll}\text { La imagen del paisaje local } & 68\end{array}$

$\begin{array}{ll}\text { Capítulo } 2 & 71\end{array}$

$\begin{array}{ll}\text { Exilio y enraizamiento en Argentina } & 73\end{array}$

$\begin{array}{ll}\text { Las causas de las migraciones } & 73\end{array}$

$\begin{array}{lr}\text { Argentina: el lugar elegido } & 81\end{array}$

¿A dónde emigrar? Entre Palestina y América del Sur $\quad 85$

Mauricio de Hirsch $\quad 86$

La creación de la Jewish Colonization Association $\quad 90$

Las condiciones de la colonización $\quad 96$

Extensión de las tierras $\quad 99$

El Barón de Hirsch y los administradores de la JCA en Argentina 105

$\begin{array}{ll}\text { Distribución de las tierras adquiridas por la JCA } & 108\end{array}$

¿Cuántos fueron los colonos judíos? 109

Capítulo $3 \quad 113$

$\begin{array}{ll}\text { Nace Colonia Clara } & 115\end{array}$

$\begin{array}{ll}\text { Colonia Clara tuvo a sus "pampistas" } & 116\end{array}$

$\begin{array}{ll}\text { En Mar del Sur } & 120\end{array}$

$\begin{array}{ll}\text { Colonia Clara } & 121\end{array}$

Los administradores de la JCA 130

$\begin{array}{ll}\text { Anexo } & 147\end{array}$ 
Capítulo $4 \quad 155$

La vida religiosa en Colonia Clara $\quad 157$

Las festividades $\quad 159$

$\begin{array}{ll}\text { En Colonia Clara } & 163\end{array}$

$\begin{array}{ll}\text { Las sinagogas y cementerios } & 168\end{array}$

Sinagoga de Colonia Clara $\quad 170$

En los pueblos $\quad 172$

Sinagoga de La Capilla $\quad 172$

Pueblo Dominguez $\quad 173$

Villa Clara $\quad 174$

Cementerio Israelita Clara-Bélez $\quad 175$

La mikve, el baño ritual $\quad 176$

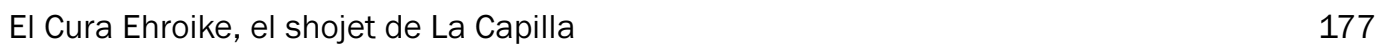

$\begin{array}{ll}\text { La Capilla } & 179\end{array}$

$\begin{array}{ll}\text { El matrimonio } & 181\end{array}$

$\begin{array}{ll}\text { Capítulo } 5 & 187\end{array}$

$\begin{array}{lr}\text { Educación en Colonia Clara } & 189\end{array}$

$\begin{array}{lr}\text { Cuestiones iniciales } & 189\end{array}$

Argentinizar al judío inmigrante 193

El sistema educativo y el currículum escolar $\quad 202$

Los recursos humanos: los maestros marroquíes $\quad 202$

Las escuelas en Colonia Clara $\quad 205$

Establecimientos educativos y nuevos maestros $\quad 208$

$\begin{array}{ll}\text { Ausentismo } & 210\end{array}$

La relación de los maestros con los colonos $\quad 215$

Desnudando las tensiones: el Informe Bavio de $1908 \quad 220$

Los recursos humanos para la docencia: los maestros alberdinos y los cursos de verano 224

Los nuevos desafíos $\quad 227$

Las bibliotecas y los clubes $\quad 231$

La educación hebrea y los cursos religiosos israelitas $\quad 235$

Un nuevo escenario: el abandono de las colonias $\quad 241$

Capítulo 6

El cooperativismo en Colonia Clara: el Fondo Comunal 247

Las cooperativas en las Colonias de la JCA en Entre Ríos y sus redes de acción 251

Sociedad Cooperativa Agrícola Fondo Comunal de Colonia Clara 255

Primera etapa: Nacimiento del Fondo Comunal. 1904-1908 260

Segunda etapa: Miguel Sajaroff presidente del Fondo Comunal. 1908-1917 275

La invasión de langosta $\quad 283$

Contactos políticos $\quad 287$

Tercera etapa: Afianzamiento del Fondo Comunal. 1917-1930 288

Las corrientes internas $\quad 288$

La agenda: cómo enfrentar los desalojos y los alcances de las transferencias de tierras 291 "Invocando" una vez más al barón de Hirsch para hacer frente a una agenda compleja: la colonización de los hijos, los impuestos a la tierra y los desalojos 
Tramitar en la justicia $\quad 305$

Colonización y tierra para los hijos $\quad 313$

Las reformas estatuarias $\quad 316$

El impacto de la crisis de 1930

Cuarta Etapa: resurgimiento, consolidación y crecimiento 1938-1954 323

La actividad económica $\quad 323$

Los colonos: la propiedad de la tierra, las transferencias

y la recuperación de tierra para los judíos

La reunión en Londres: final de época $\quad 339$

Recapitulando $\quad 342$

$\begin{array}{ll}\text { Consideraciones finales } & 345\end{array}$

$\begin{array}{ll}\text { Bibliografía } & 363\end{array}$

Bibliografía citada $\quad 363$

Memorias e Informes citados $\quad 368$

Bibliografía General Consultada $\quad 370$

$\begin{array}{ll}\text { Archivos consultados } & 375\end{array}$

Entrevistas realizadas por la autora 376

Cuestionarios semi estructurados respondidos por... 376

$\begin{array}{ll}\text { Anexos } & 377\end{array}$

Listado de pasajeros en el barco "Orione», 22 de junio de 1894379

Listado de pasajeros en el barco "Sirio», 20 de septiembre de 1894391

Colonos en Colonia Clara por grupo o aldea (1941) 397

Colonos en Colonia Clara por orden alfabético y grupo 409

Colonos asentados en colonias de la JCA en Argentina 419

Actividades culturales realizadas en Colonia Clara entre 1924 y 1943 -selección- 527 



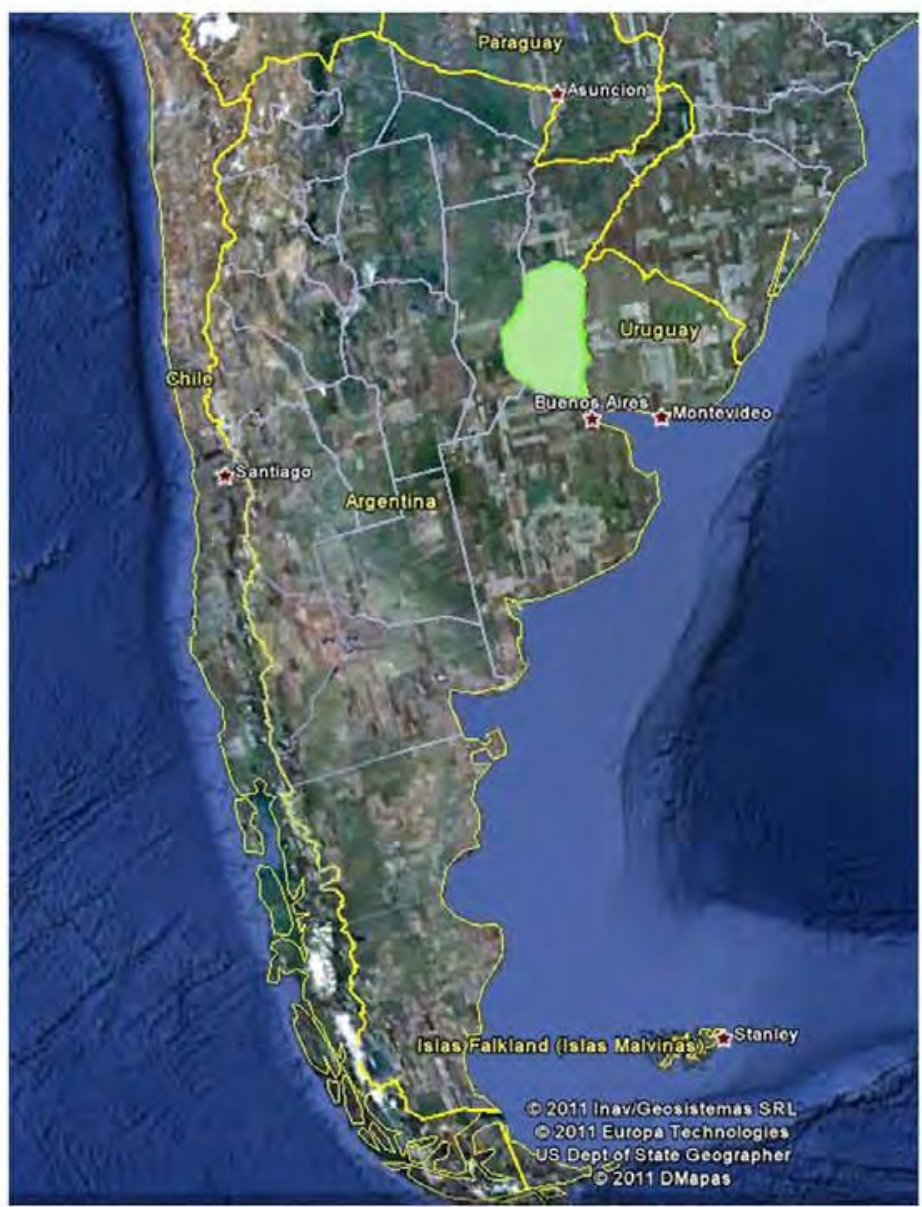

REPÚBLICA ARGENTINA
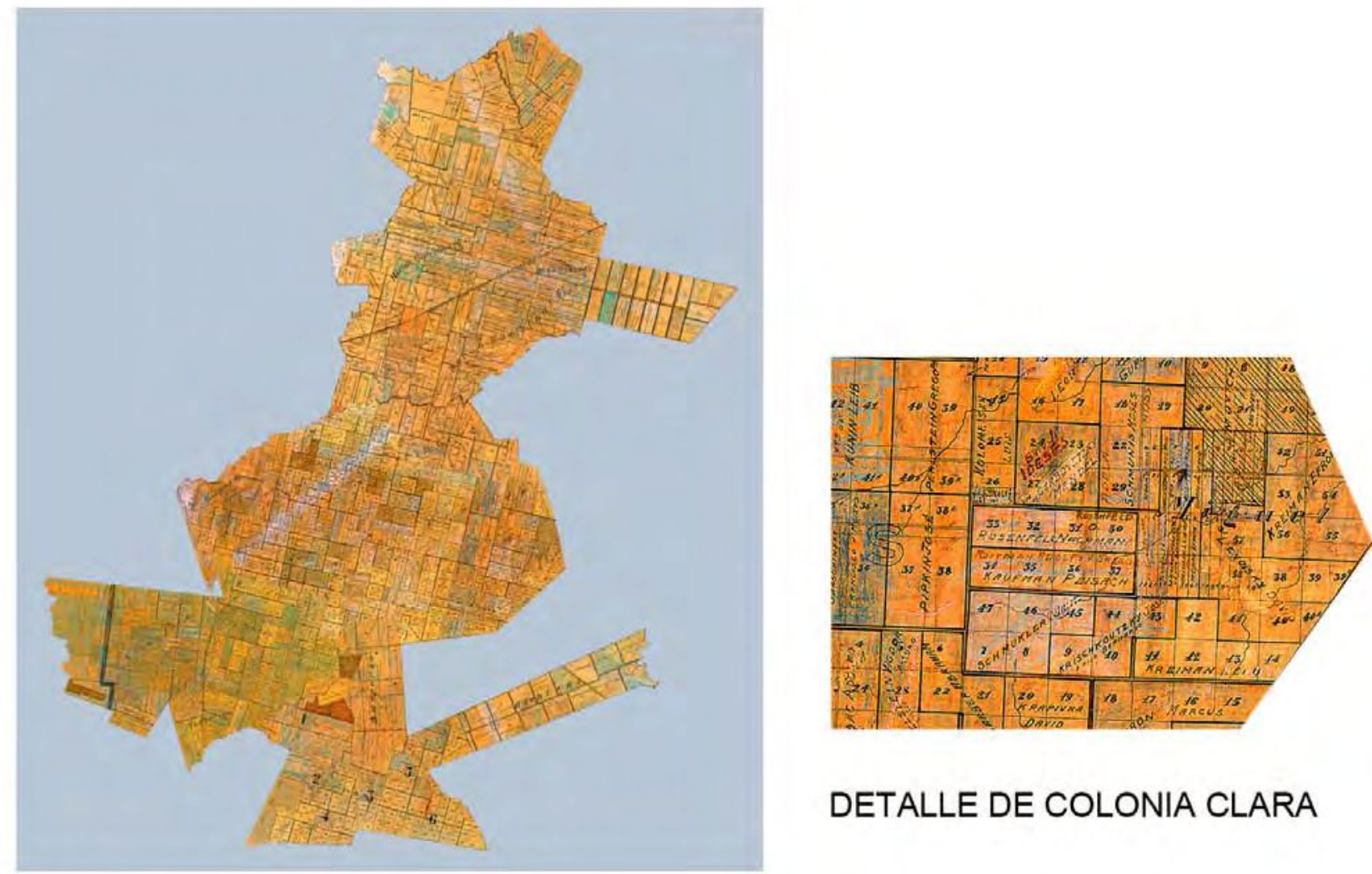

DETALLE DE COLONIA CLARA

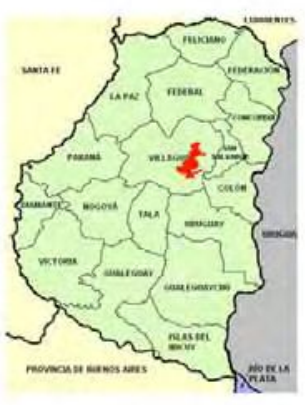

ENTRE RÍOS / COLONIA CLARA 



\section{Historia y memoria de la colonización judía agraria en Entre Ríos. La experiencia de Colonia Clara, 1890-1950}

La historia de una partícula social ilustra

la historia de toda una Nación

Luis González y González, Pueblo en Vilo

\section{Introducción}

En estos últimos años, en los que se observa un "giro hacia el pasado" ${ }^{1}$, estamos asistiendo a procesos de activación de la memoria que han movilizado importantes sectores de la sociedad a preguntarse por sus identidades o sus genealogías, así como para buscar nuevos anclajes que les devuelvan mayores certezas para enfrentar el futuro que se presenta tan incierto. Acordando con las palabras de Huyssen, este giro hacia la memoria recibe el impulso subliminal del deseo de arraigarnos en un mundo caracterizado por una creciente inestabilidad del tiempo y por la fractura del espacio en el que vivimos.

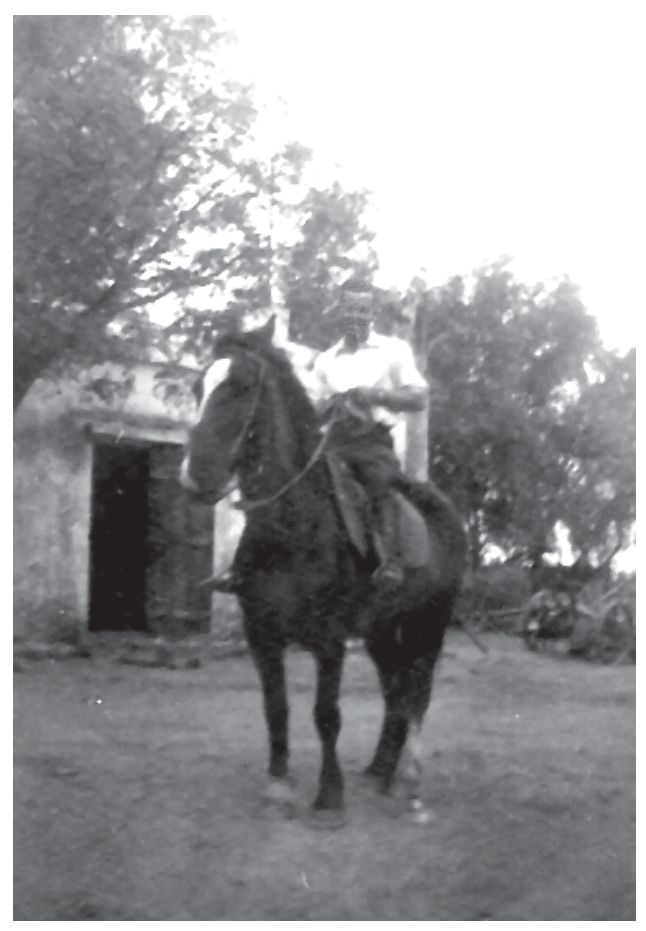

Mauricio Flier, Grupo Desparramados, Colonia Clara.

${ }^{1}$ Huyssen, Andrea, "Medios, política y memoria”, en Revista Puentes, Año 1, N² 2, diciembre de 2000; Huyssen, A., En busca del futuro perdido. Cultura y memoria en tiempos de globalización, México, FCE, 2002. 
Distinguidos autores advierten la emergencia de una "obsesión memorialista" como producto del declive de la experiencia trasmitida, en un mundo que ha perdido sus referencias, ha sido desfigurado por la violencia y atomizado por un sistema social que borra las tradiciones y fragmenta las existencias ${ }^{2}$.

En particular, sectores importantes de la colectividad judía han iniciado una búsqueda de sus raíces identitarias en las colonias agrarias que se establecieron en nuestro país a fines del siglo xIx. En ellas se asentaron los judíos asquenazíes, víctimas de las intolerancias raciales y religiosas, perseguidos y expulsados de la Rusia zarista, quienes recibieron con beneplácito el proyecto del barón Mauricio de Hirsch para convertirlos en colonos agricultores en las pampas argentinas. Estas activaciones de la memoria, motorizadas en acciones orientadas a dar sentido al pasado, interpretándolo y trayéndolo al escenario del drama presente, cobran centralidad en el proceso de interacción social y de afirmación en la identidad. ${ }^{3}$ Estas búsquedas actualizan viejas preguntas y ponen de manifiesto el peso de la memoria colectiva. ¿Quiénes eran estos judíos y en qué consistía el proyecto colonizador? ¿Cómo fue la experiencia de vida en las colonias? ¿Cuánto peso tuvo en la construcción de la identidad judía y de la identidad nacional? ¿Qué se recuerda y cómo se recuerda esta experiencia que ha sido narrada por la literatura y sentida como una epopeya llevada a cabo por pioneros que encontraron en Argentina la "tierra prometida" y que en este espacio de libertad se comprometieron como "gauchos judíos" en la construcción de la nación, con intercambios fecundos con la sociedad receptora? Una sociedad, y una nación, que también estaba en proceso de construcción. Curiosamente, estos trabajos de la memoria han dejado también al descubierto significativos olvidos y silencios, así como la detección de enormes vacíos historiográficos que expliquen la experiencia de la colonización agraria en nuestro país.

En este escenario se erige nuestro objeto de estudio. Nuestra investigación se propone contribuir a la reconstrucción de la historia de la inmigración judía en Argentina, centrada en la experiencia de la colonización judía agraria en Colonia

\footnotetext{
2 Traverso, Enzo, El pasado, instrucciones de uso. Historia, memoria, política. Madrid, Marcial Pons, 2007.

3 Jelin, Elizabeth, Los trabajos de la memoria, Madrid-Buenos Aires, Siglo XXI, 2002.
} 
Clara, la más importante de las colonias de Entre Ríos, no sólo por la extensión geográfica, sino por el establecimiento de diversas instituciones económicas, sociales y culturales que imprimieron las notas características del modo y ritmo del proceso de integración al país receptor.

\section{Breve panorama del objeto dentro de los estudios migratorios}

Para comprender y poder explicar la historia argentina contemporánea, es necesario analizar la dimensión del fenómeno inmigratorio. Así, podremos observar que la "Argentina aluvional", con un enorme territorio para poblar, fue -en tiempos ya lejanos- una política de Estado. El torrente inmigratorio conformó una sociedad abigarrada y polifónica que ha sido abordada por innumerables estudios. Sin embargo, se observan aún muchas insuficiencias en el conocimiento del tema: hay mayor información sobre ciertos períodos, sobre algunos grupos étnicos más que otros, todo ello con bibliografía dispersa y despareja.

Si bien los estudios sobre la inmigración siguen concitando la atención, porque, como dice Fernando Devoto en su Historia de la inmigración en la Argentina ${ }^{4}$ (uno de los últimos libros sobre la temática editado en nuestro país $)^{5}$, se trata de un "tema demasiado atractivo y demasiado vasto", llama poderosamente la atención la escasez de estudios provenientes del mundo académico sobre la inmigración

\footnotetext{
${ }^{4}$ Devoto, Fernando, Historia de la inmigración en la Argentina, Buenos Aires, Sudamericana, 2003.

${ }^{5}$ Una renovación de los estudios sobre inmigración se produjo en nuestro país en los años ochenta, conformando una nutrida historiografía de las migraciones. Entre las aportaciones recientes, ver: Bjerg, María, Historia de la inmigración en la Argentina, Buenos Aires, Edhasa, 2009; Armus, Diego, "Diez años de historiografía sobre la inmigración masiva a la Argentina", en Estudios Migratorios Latinoamericanos, 1986, № 4; Fernández, Alejandro E. (ed.), La inmigración española en la Argentina, Buenos Aires, Biblos, 1999; Reguera, Andrea, "La individualización de la inmigración. Inserción e identidad en tierras nuevas. Argentina (1840-1904)", en Boletín Americanista, 2003, № 53; Moya, José C., "Notas sobre las fuentes para el estudio de la inmigración española en Buenos Aires", en Estudios Migratorios Latinoamericanos, N 4, 1986; Míguez, Eduardo José, "Acerca de la Inmigración Italiana en una compilación reciente (L'Italia nella società argentina, F. Devoto, G. Rosoli, 1988)", en Estudios Migratorios Latinoamericanos, 1988, № 10; Korol, Juan Carlos y Sábato, Hilda, Cómo fue la inmigración irlandesa en Argentina, Buenos Aires, Plus Ultra, 1981; López, Susana Mabel, Representaciones de la Patagonia. Colonos, científicos y políticos (1870-1914), La Plata, Ediciones Al Margen, 2002; Otero, Hernán (dir.), El mosaico argentino. Modelos y representaciones del espacio y de la población, siglos XIX-XX, Buenos Aires, Siglo XXI, 2004.
} 
judía en Argentina. El trabajo pionero de Boleslao Lewin, ¿Cómo fue la inmigración judía a la Argentina?, publicado en 1971, inaugura la breve lista de textos académicos sobre la temática. La valiosa obra de Haim Avni, Argentina y la historia de la inmigración judía. 1810-1950, publicada en 1983, se convirtió en un texto de consulta ineludible por la magnitud y seriedad del trabajo de investigación, la amplitud temporal y las problemáticas abordadas, tanto como por la original rigurosidad interpretativa. Este voluminoso texto (593 páginas) reúnen los aportes de dos publicaciones previas, productos de una larga estadía de investigación del autor en Argentina, donde redactó su tesis doctoral. El estudio fue publicado en hebreo e inglés: Argentine Jewry, Its Socio-Politicak Status and Organizational Patterns (1971) y "La tierra prometida". La obra de colonización del Barón de Hirsch a la República Argentina, publicado en hebreo en 1973. Avni, profesor de Historia Judía Moderna y Contemporánea de la Universidad Hebrea de Jerusalén, delimita cronológicamente su historia de la inmigración judía en Argentina entre los tiempos de la Revolución de Mayo y la independencia "del yugo español", cuando se cierra una época en la cual estaba prohibida toda forma de existencia judía dentro de las fronteras del imperio español, y la concluye con el establecimiento del Estado de Israel y la instalación de relaciones diplomáticas entre el Estado judío y la República Argentina. El autor señala que entre esas dos guerras de liberación se inscribe su estudio sobre la inmigración judía, "y que resume asimismo, en forma fehaciente, las relaciones existentes entre el pueblo judío y la Argentina".

A estos aportes se suman los textos de Leonardo Senkman, La colonización judía. Gente y Sociedad (1984), así como la breve pero precisa presentación que realiza en Tierra de promesas. 100 años de colonización judía en Entre Ríos, publicada en 1995, libro que recoge variados y emotivos testimonios de colonos y sus descendientes radicados en las colonias Clara, San Antonio y Lucienville.

El primero de los títulos citados pertenece a la colección de Historia Testimonial Argentina del Centro Editor de America Latina. El objeto mismo de esta colección da cuenta de los alcances del estudio: una breve introducción y planteamiento del problema en diez páginas y un corpus de fuentes muy significativas.

En un tono más cercano a los trabajos de divulgación se destacan los textos de Ricardo Feierstein, Historia de los judíos argentinos (2003), y Vida cotidiana de los 
judíos argentinos. Del gueto al country (2007). Existen también pequeños estudios monográficos sobre colonias, muchos de ellos impulsados por la celebración de aniversarios o fechas activadoras que sirvieron para la narración sintética de los logros en el país, así como otros trabajos descriptivos, como los de Celia López de Borche, que se dedica a presentar Villa Domínguez en Colonia Clara, los de Nora Fistein sobre Basabilbaso en Colonia Lucienville, y el de Susana S. Carioli sobre Colonia Mauricio, en la provincia de Buenos Aires.

Listado breve pero suficientemente efectivo o incitador para realizar nuestra propuesta. Nuestra labor intenta dar respuesta a un desafío que Senkman ${ }^{6}$ dejó planteado en los inicios de los años ochenta. Este autor nos señalaba que los mejores trabajos publicados se hicieron sobre la base de los archivos e informes de la Jewish Colonization Association (JCA) (Avni, 1973, 1983) y que, por fuera de algunas memorias y libros generales (Alpershon, 1930; Verbisky, 1955; Marchevsky, 1964; Katzovich, 1947), la perspectiva del colono no fue tomada como punto de partida de la reconstrucción histórica, social, cultural e ideológica de la inmigración en las colonias de la JCA.

Desde el campo de la historia social, ${ }^{7}$ nuestro interés está justamente en analizar la experiencia y estudiar las condiciones materiales de vida de los colonos asentados en Colonia Clara.

Una historia social interpretativa y crítica que se preocupa por los grupos sociales, que coloca el objeto de la historia en coordenadas sociales y económicas, reemplazando el relato fáctico positivista, y que se propone superar la ilusión de objetividad del historiador y la supuesta neutralidad axiológica, reemplazándola por un involucramiento ético y político que lo obliga a reflexionar sobre sus prácticas y métodos, construye nuestra perspectiva de abordaje.

Una historia que replantea la relación del historiador y su objeto en varios sentidos. En primera instancia, una relación nueva entre el pasado y el presente. La

\footnotetext{
${ }^{6}$ Senkman, Leonardo, La colonización judía. Gente y Sociedad, Buenos Aires, Centro Editor de América Latina, 1984, p. 9.

${ }^{7}$ Cfr. Casanova, Julián, La historia social y los historiadores, Barcelona, Crítica, 1997; Fontana, Josep, Historia: análisis del pasado y proyecto social, Barcelona, Crítica, 1999; Haupt, Georges, El historiadory el movimiento obrero, Madrid, Siglo XXI, 1986; Hobsbawm, Eric, Sobre la historia, Barcelona, Crítica, 1998; Moradiellos, Enrique, El oficio del historiador, Madrid, Siglo XXI, 1994; Samuel, Raphael, "Historia popular. Historia del pueblo", en Historia popular y teoría socialista, Madrid, Crítica, 1984.
} 
historia es concebida no como resultado de unos datos exteriores al historiador, sino que desde los datos, es construida por este. En el ordenamiento, en la selección, incluso en las formas de narración de esos hechos, está tramada la interpretación del historiador, sus preguntas, las formas de interpelar esos datos. Así, la interpretación del pasado depende en gran medida de los desafíos, los interrogantes, incluso las angustias del presente, más que de la "materia prima" del pasado.

Esa actitud también lleva a ponderar más las preguntas que las respuestas. Por eso se requieren marcos teóricos, caminos metodológicos, preguntas más complejas que la mera causalidad lineal, y por ello se apela a otras disciplinas. La historia social dialoga con la geografía, la sociología, la economía, la literatura, la política, el psicoanálisis. Esto guarda relación con otra manera de pensar los sujetos y predicados de la historia: ya no los "grandes hombres", sino los colectivos y las estructuras en el tiempo.

Nuevos campos temáticos se abrieron, como la historia de la vida y la muerte, de la infancia, de la vida cotidiana, de la sociabilidad. Incluso un retorno a la historia política o, mejor, del poder, el género biográfico, las memorias colectivas y los lugares de memoria.

Se retorna al sujeto y a los análisis microhistóricos, tanto temporales como espaciales, y se enriquece con los aportes del marxismo inglés a partir de las contribuciones de las obras de Eric Hobsbawm y Edward P. Thompson. La "historia desde abajo", la historia de la "gente sin historia", se impuso para estos historiadores como un proyecto intelectual y político que, más que una atención sectorial, implicó una gran democratización de los sujetos de la historia. Una obra fundamental que se convirtió casi en un paradigma de la historia social fue La formación de la clase obrera en Inglaterra (1963) de Thompson. Uno de los aportes más importantes fue la noción de "experiencia" para definir las clases sociales, sobre todo la clase obrera. Sin abandonar la perspectiva marxista y materialista, para Thompson las clases sociales no surgían mecánicamente de su posición "material", sino que eran un fenómeno histórico en el que la experiencia y la conciencia gravitaban tanto o más que las "condiciones objetivas" 8 .

${ }^{8}$ Cfr. Funes, Patricia y López, María Pía, Historia social argentina y latinoamericana, Buenos Aires, Ministerio de Educación de la Nación, 2010. 
Distintas corrientes teóricas y una polifonía temática caracterizan el actual campo de la historia: el regreso del sujeto y el giro lingüístico, las microfísicas del poder, la deconstrucción de los relatos nacionales. Lo biográfico y subjetivo hoy forma una parte importante de los relatos del pasado. La sexualidad, las mujeres, la vida privada, la enfermedad, las relaciones entre mito e historia. El campo de estudios de historia reciente ha obligado a replantear la relación entre historia y memoria, también las fuentes para su reconstrucción (el relato oral, el testimonio), ${ }^{9}$ y a revisar "nuestra caja de herramientas" para abordar un tema que interpela por igual al historiador, al ciudadano y al ser humano. Al primero le impone la necesidad de aceptar el reto de repensar sus categorías y métodos, desbordados cognitivamente por las experiencias del terror; le exige reordenar la tensión entre sus registros de las historias personales y colectivas, entre lo particular y lo general, entre lo privado y lo público; le plantea una vez más la necesidad de historiar con rigor el pasado reciente; le demanda una mayor conciencia respecto a lo vano de pretender monopolizar "el relato de la tribu" o la reconstrucción de la memoria colectiva; lo estimula a converger -desde las reglas intransferibles de su disciplina- en una faena que es más plural y que requiere de otros saberes; entre otras exigencias. ${ }^{10}$

Las reflexiones teóricas y metodológicas de la microhistoria ${ }^{11}$ nos brindaron las claves para la elección del caso en estudio, focalizado en Colonia Clara.

En este sentido, el libro de Carlo Ginzburg, El queso y los gusanos (1976), nos habla de muchas más cosas que del proceso judicial por herejía de la Inquisición

\footnotetext{
${ }^{9}$ Una aproximación a los desafíos del campo puede verse en Franco, M. y Levín, F. (comp.), Historia reciente. Perspectivas y desafíos para un campo en construcción, Buenos Aires, Paidós, 2007.

${ }^{10}$ Flier, Patricia, Los desvelos de los historiadores ante el pasado reciente: los desafíos metodológicos al incorporar los estudios de los imaginarios autoritarios. Los archivos del terror, Quito, junio de 2009. Publicado en Actas.

${ }^{11}$ Sus impulsores más destacados son los historiadores próximos a la revista italiana Quaderni Storici: Giovanni Levi (cuya aportación ha sido calificada de microhistoria social), Carlo Ginzburg (que ha aportado la microhistoria cultural), Carlo María Cipolla (con estudios de mayor escala, como Cañones y Velas), entre otros. También pueden encontrarse tratamientos precedentes fuera de Italia, como Clifford Geertz, Georges Duby (EI Domingo de Bouvines), Emmanuel Le Roy Ladurie (Montaillou, aldea occitana de 1294 a 1324), Natalie Zemon Davis (El regreso de Martine Guerre, llevada al cine), Robert Darnton (La gran matanza de gatos y otros episodios en la historia de la cultura francesa), etcétera. La microhistoria se presta muy bien a la reflexión metodológica, como hacen Edoardo Grendi (Microanalisi e storia sociale) y, en España, Justo Serna y Anaclet Pons (Cómo se escribe la microhistoria. Ensayo sobre Carlo Ginzburg).
} 
al campesino Menocchio en el siglo xvı. El trabajo, que dialoga explícitamente con la antropología y es un excepcional ejercicio de interpretación sobre fuentes judiciales, nos acerca a los imaginarios de la cultura popular y sus modos de pensar el orden de las cosas, las subjetividades, las redes de relaciones.

Sin lugar a dudas, las reflexiones de Luis González y González, cuando señala que la microhistoria es también "la historia que nos cuenta el pasado de nuestra propia existencia, nuestra familia, nuestro terruño, de la pequeña comunidad y por lo tanto al historiador lo mueve un amor a las raíces, un amor melancólico, no por eso carece de rigor científico", nos brindan elementos y perspectivas de análisis que nos cobijan en esta tarea. ${ }^{12}$

Todo microhistoriador busca afanosamente los datos reales en archivos tras una paciente investigación, porque lo que pretende es reconstruir lo más exacta posible la verdad. Las fuentes más frecuentadas por el microhistoriador son los archivos parroquiales, los libros de notarios, los vestigios arqueológicos, los cementerios, las crónicas de viaje, los censos, los informes de munícipes y gobernadores, estatutos, reglamentos, leyes, periódicos y tradición oral. ${ }^{13}$

Para historiar la experiencia de la colonización agraria, tomamos como punto de partida las expectativas y demandas de los colonos, sus dolores y pasiones, sus instituciones sociales, culturales y políticas. La voz del colono asentado en las tierras vírgenes entrerrianas, el peso del mandato colonizador y la redención por la agricultura, los enfrentamientos con la empresa colonizadora para convertirse en

\footnotetext{
${ }^{12}$ Cfr. Hacia una teoría de la microhistoria. Discurso de recepción del doctor Luis González y González en la Academia Mexicana de la Historia, leído en la sesión solemne del 27 de marzo de 1973, disponible en http://www.bisabuelos.com/microhistoria.html.

${ }^{13}$ Concluye su discurso en la Academia Mexicana de la Historia con el elocuente párrafo siguiente: "La microhistoria es la especie historia que se ocupa de la añorada matria, la gente de tamaño normal y las acciones típicas y triviales del quehacer cotidiano. Es, desde otro punto de vista, la rama menos científica, menos arrogante y menos emperifollada de la frondosa Clío. Es, por último, la menuda sabiduría que hace libres a las minisociedades y las promueve para el cambio; vacuna a los niños contra el horror a los policías grandotes llamados héroes y caudillos; permite hacer generalizaciones válidas a los científicos de las ciencias humanas sistemáticas; proporciona viejas verdades a esos revendedores que son los moralistas, y procura salud a los prófugos del ajetreo". De sus libros podemos destacar como los más importantes: Pueblo en vilo (1968), Invitación a la microhistoria (1972), Los artífices del cardenismo (1978), Zamora (1979), La querencia (1982), La ronda de las generaciones (1984), El oficio de historiar (1988) y Todo es historia (1989).
} 
chacarero propietario de la tierra, el desasosiego de los que fueron vencidos por la naturaleza o por el régimen económico, la estratificación social en la colonia: los que ganaron y los que perdieron, los alcances de las instituciones de ayuda mutua y de educación, los establecimientos escolares y las entidades religiosas, la integración como ciudadanos y la preservación de su identidad judía, el impacto de su pensamiento y acción en la historia social entrerriana y nacional y la construcción de la memoria colectiva. Todos estos son nuestros puntos de partida y también los de llegada.

Quisimos salir del binomio éxito o fracaso de la colonización agraria judía como categoría explicativa de la experiencia en los estudios, preocupados más por el papel o los logros de la empresa colonizadora, ${ }^{14}$ para volver a reconstruir una historia de este colectivo social que se enraíza, se comprende y se explica desde la historia provincial y nacional. También nos parece pertinente señalar que nuestro enfoque en la reconstrucción histórica intentar soslayar el excesivo protagonismo que ha tenido la mirada "porteñocéntrica" de narrar y pensar la historia judía en Argentina. Mi familiaridad se funde en el interior y desde allí se pone en diálogo con la producción nacional. ${ }^{15}$

Los habitantes de Colonia Clara fueron productos de la intolerancia racial y religiosa que los expulsó de la Rusia zarista. Asentados en una tierra fértil pero virgen, tuvieron que dejar en el olvido o en el silencio las marcas de las pérdidas y del exilio, para abocarse a la construcción de una experiencia colonizadora que es recordada desde la literatura canónica como una gesta heroica y desde la memoria de los colonos como un desafío trascendente, plagado de infortunios, pero también de pequeñas pero maravillosas realizaciones.

\footnotetext{
${ }^{14}$ Cfr. Avni, Haim, "La agricultura judía en Argentina ¿Éxito o fracaso?», en Desarrollo Económico, Vol. 22, № 88, enero-marzo de 1983; Zablotsky, Edgardo, El proyecto del Barón de Hirsch. ¿Éxito o fracaso?, Universidad CEMA, mayo de 2005.

${ }^{15}$ Quien escribe este texto es nieta de David Flier, oriundo de una pequeña aldea en la provincia de Gerson, Ucrania, que al tiempo de su exilio estaba bajo el dominio del imperio ruso zarista. Obtuvo su Contrato de Promesa de Venta de 74 hectáreas en el grupo Desparramados de Colonia Clara en 1923 y logró la propiedad en 1949. Su hijo, es decir, mi padre, y los cuatro hermanos de mi padre nacieron en Villa Domínguez. Si bien mis hermanas y yo no nacimos en Villaguay, ese se ha convertido en nuestro pueblo. Los estudios universitarios me trajeron a la Universidad Nacional de La Plata, donde transité mi vida profesional. Este escrito era una asignatura pendiente: con la historia social de mi provincia y con mi abuelo, a quien, a pesar de los denodados esfuerzos, el correcto castellano siempre le fue esquivo.
} 


\section{Memoria y representación del pasado}

Nos parece muy importante prestar atención a las diferentes representaciones de ese pasado que han llegado hasta nosotros en diferentes soportes: en manuales y libros de textos, en memorias oficiales, en las obras de creación literaria y de escrituras autobiográficas. Lo significativo es que todos ellos producen memoria, ya que la literatura es, antes que nada, la larga memoria de todos nosotros. Por ese motivo, conocer cuáles fueron las representaciones de ese pasado, cómo surgieron, cómo se modificaron y por qué, cuáles son sus huellas y dónde buscarlas, es una tarea que emprendemos en este estudio.

Entre la literatura y la historia, así como entre la literatura y la memoria, existen préstamos ineludibles. El primer binomio comparte ciertas formas y procedimientos propios del acto de escritura, aunque epistemológicamente se orienten tras propósitos diferentes, fundamentalmente, la búsqueda de la verdad, como nos lo advierte Roger Chartier. ${ }^{16}$

Sabemos que la narrativa aporta matices significativos a la conformación de una memoria colectiva y, por supuesto, interesantes polifonías interpretativas para la reconstrucción del pasado. Entonces, ¿es posible considerar la literatura como una fuente para el historiador? ¿Cómo debemos usarla?

Podemos recurrir a Beatriz Sarlo, quien nos advierte:

la literatura no puede ser leída haciendo abstracción de su régimen estético, y esto quiere decir que el historiador no debe leerla sólo como depósito de contenidos e informaciones [...] la literatura dice algo respecto de lo social en dimensiones que no son exclusivamente las explícitas [...] La literatura ofrece mucho más que una representación del mundo social [...] La literatura puede ofrecer modelos según los cuales una sociedad piensa sus conflictos, ocluye o muestra sus problemas, juzga a las diferencias culturales, se coloca frente a su pasado o imagina su futuro. ${ }^{17}$

${ }^{16}$ Chartier, Roger, El mundo como representación, Barcelona, Gedisa, 1999.

${ }^{17}$ Sarlo, Beatriz, "Literatura e Historia", en Boletín de Historia Social Europea, № 3, La Plata, 1991, p. 27. 


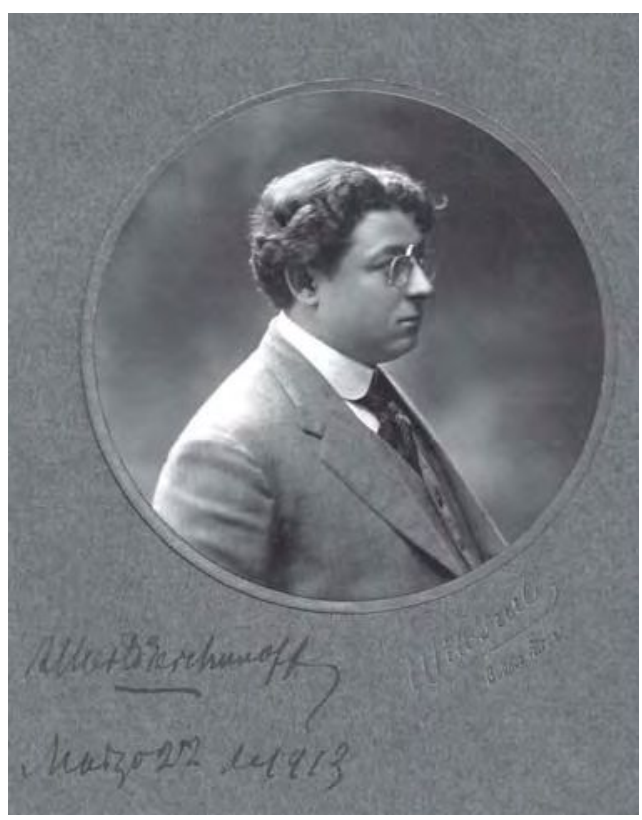

Alberto Gerchunoff
Son estas posibilidades las que abren una nueva entrada a nuestra investigación. ${ }^{18} \mathrm{La}$ experiencia colonizadora ha sido abordaba por la narrativa desde múltiples géneros. Sin lugar a dudas, la obra que ha concitado mayor atención es Los gauchos judíos, de Alberto Gerchunoff (quien vivió en Colonia Clara), publicada en 1910, en el marco de la conmemoración del primer centenario de la República Argentina. Se trata de un escrito con un espíritu lírico, una colección de viñetas que combina cierto sabor bíblico y tono arcaizante con expresiones castizas cervantinas. Las páginas traen a la memoria los libros del Anti-

guo Testamento, se funden las tradiciones hebreas y gauchescas. Existe una hermosa armonía recíproca entre el criollo y el judío. Gerchunoff canta su agradecimiento a la tierra hospitalaria, al nuevo Sión. Todos los matices emotivos de los cuales es capaz el ser humano se encuentran en el libro: el humor, lo patético, lo trágico, la ironía.

Esta obra literaria, recogida más tarde por el cine, ha sido un hito de la literatura judeo latinoamericana. Tuvo tanta gravitación que ocluyó Tierra Soñada. Episodios de la colonización agraria judía en la Argentina. 1889-1959 de José Liebermann, ${ }^{19}$ publi-

18 Onega, Gladys S., La inmigración en la literatura argentina (1880-1910), Buenos Aires, CEAL, 1982; Prieto, Adolfo, La literatura autobiográfica argentina, Buenos Aires, CEAL, 1982; Jitrik, Noé, El ejemplo de la familia. Ensayos y trabajos sobre literatura argentina, Buenos Aires, Eudeba, 1998; Jitrik, Noé, La historia crítica de la literatura argentina, Buenos Aires, Emecé, 2007.

${ }^{19}$ El autor de este libro nació en Colonia Clara el 26 de diciembre de 1897. César Tiempo escribe: "Cuarenta y cuatro días más tarde veía la luz en el mismo lugar Joseph Kessel, que no tardaría en abandonar el terruño para desarrollar en Francia la magnífica carrera literaria que todos conocen. Cuando Kessel se hizo un nombre viajó a la patria ancestral donde el verbo de los antiguos profetas se había hecho carne y escribió Tierra Santa. Por su parte, José Lieberman, luego de no pocas andanzas y después de forjarse una reputación de escritor y de hombre de ciencia, volvió al rincón argentino donde se habían afincado sus padres huyendo del alud sangriento de los pogroms y escribió Tierra Soñada, un libro demetérico que perfecciona y completa la parábola abierta en 1910 por Los Gauchos Judíos de Gerchunoff. José Liebermann pudo ser, de habérselo propuesto, un exquisito narrador de historias telúricas, un exégeta disciplinado en los arduos escolios de la Masora, un talmudista capaz de salir airoso de todas las emboscadas dialécticas, un Talmid Jajam, un filósofo indulgente y perspicuo capaz de empuñar la esteva del arado, atajar a un redomón con una mangana infalible, conducir un tractor y dialogar con las causas. 
cada en 1959, ganadora del concurso y recomendada por el jurado literario integrado por Enrique Banchs, Jorge Luis Borges, Fermín Estrella Gutiérrez, Alberto Guirri y Miguel Alfredo Olivera. Es una obra que tiene el mismo tono de agradecimiento al país, pero va mucho más allá de ello. Es un extenso libro que narra las esperanzas, las alegrías, pero también incorpora los pesares, las angustias y las desazones de los colonos judíos, cuyos detalles, considera el autor, son pertinentes dejar en el olvido.

Pero si de olvidos se trata, un texto menos conocido es el de Natalio Budasoff, Lluvias Salvajes, ${ }^{20}$ libro publicado en 1952 y también ambientado en Colonia Clara. Las siete historias de esta colección son en gran parte autobiográficas, ya que forman parte de recuerdos de sus primeros años de vida en Entre Ríos. Lejos de ser gente perfecta o ideal en un mundo poéticamente pastoril, sus protagonistas son personas reales que luchan con sus semejantes y con una naturaleza dura que las castiga con lluvias, vientos, y las pérdidas de cosechas. El autor describe la tirantez que existe entre el rico y el pobre, la envidia criolla nutrida por un antisemitismo latente, la antipatía del administrador burocrático de la agencia colonizadora, la tozudez, la violencia, la envidia, la mentira que forma parte de la personalidad y de las conductas de algunos de los colono judíos. El rescate de la escritura de Budasoff es importante, principalmente, por la presentación de la otra cara de la moneda que muestra Gerchunoff, su extracción está lejos del aura embellecida de la nostalgia, para mostrar el inevitable lado más oscuro de la experiencia del inmigrante.

Recurrimos además a un importante corpus de literatura testimonial: las biografías, autobiografías y memorias que recogen episodios de la vida en las colo-

\footnotetext{
Pero a un hombre de la irrenunciable vocación pedagógica de Liebermann sólo podía atraerle la posibilidad de volcar en los demás su inagotable caudal de conocimientos, llevando la claridad hasta el esplendor. Es así que entre sus muchos títulos podemos citar los de maestro rural, maestro normal, profesor de enseñanza secundaria, doctor en ciencias naturales, periodista agrario, investigador, acridiólogo, profesor universitario, funcionario de la Dirección de Parques Nacionales, académico, etc. Lleva publicados más de mil doscientos trabajos de divulgación, pronunciadas más de doscientas conferencias y recorrido todo el país, a lo ancho y a lo largo, conduciendo su alma a voluntad, agradecido al pájaro que canta, al árbol que frutece y a la gracia natural de las aguas, principio de las cosas y fuente natural de la vida. Autor y traductor de libros fundamentales, el doctor Liebermann es siempre el maestro fervoroso, el mentor acatado y respetado que guió a tantas generaciones de discípulos. Tierra Soñada es la culminación de su obra. Hay que creer en el destino, esa mano lúcida de la divinidad, que le permitió vivir todo el poema épico de la inmigración, conocer de cerca a los protagonistas, compartir sus angustias y sus esperanzas y dejar fijado en un friso imborrable la trayectoria de un sueño. Moisés no pudo entrar a la tierra prometida. Los héroes de José Liebermann, sín.

${ }^{20}$ Budasoff, Natalio, Lluvias salvajes, Buenos Aires, Ediciones Mosaicos, 1962.
} 
nias que nos acercan fuentes para descubrir la sensibilidad, las costumbres y cubrir los vacíos que ha dejado el relato de la historia reconstruida por los historiadores tradicionales. Realizamos una minuciosa tarea de rescate de fuentes documentales, las que se hallaban dispersas en diversos repositorios tanto oficiales como privados, contribuimos a la recuperación y conservación del patrimonio tangible e intangible, realizando para ello una recuperación integral de los bienes patrimoniales identitarios en base al rescate de fuentes escritas diversas y de las voces de sus protagonistas.

Nos propusimos realizar nuestro trabajo con combinación adecuada entre fuentes documentales - provenientes de archivos institucionales ${ }^{21}$ y personales ${ }^{22}$ - y las voces de los actores. Planteamos un diálogo entre fuentes diversas que combinen las vidas "célebres" (que son por ello emblemáticas y devienen en objeto de identificación) y las "comunes" (que ofrecen la posibilidad del autorreconocimiento). Es decir, relatar la experiencia y contar la vida "a varias voces» o como polifonía. Así, rescatamos las biografías del los líderes ${ }^{23}$ de la primera hora y las voces y trayectorias de los que se quedaron, ${ }^{24}$ los que se fueron y regresaron ${ }^{25}$ y los que abandonaron ${ }^{26}$ las colonias. Proponemos la complementariedad de los relatos. La incorporación de la historia oral nos aporta riqueza: la voz se hace significante para la construcción de un paisaje de época.

\footnotetext{
${ }^{21}$ Los informes elevados a la administración central de la JCA en París, los informes de los directores locales elevados a la administración de la empresa en Buenos Aires, planos, mapas y croquis de las tierras de la JCA en Argentina, catastros locales y provinciales, memorias y balances de los ejercicios anuales de las Cooperativa Fondo Comunal, memorias de las diferentes instituciones culturales y sociales, censos e informes nacionales y provinciales, censos de las colonias, entre otras.

${ }^{22}$ Los archivos personales de Miguel Sajaroff, de Miguel Kipen, de ledidio Efron, compuestos por cartas, informes y escritos de variada procedencia, los que nos permitirán reconstruir la circulación de ideas, los debates intelectuales y políticos y los modos de comprender el mundo, la experiencia colonizadora, la cotidianeidad y la vida privada. En Archivo WIO y Archivo y Museo de Villa Domínguez.

${ }^{23}$ Ing. Miguel Sajaroff, Dr. Noé Yarcho, Alter Braslavky, Miguel Kipen, Déborah Davidovich, David Merenguer, Marcos Wortman, las hermanas Chercoff, ledidio Efron, entre otros.

${ }^{24}$ Entrevistas en profundidad realizadas por la autora a Olga Kipen (maestra, hija de Miguel Kipen y sobrina de Sajaroff) y Juan Flier (maestro).

${ }^{25}$ Valerio Kipen (hijo de Miguel Kipen, dirigente comunista) y Mauricio Flier.

${ }^{26}$ Entrevistas en profundidad realizadas por la autora a Rodolfo Kipen (hijo de Valerio Kipen, sobrino de Olga Hipen) y cuestionarios estructurados aplicados a Daniel Aldo Teveles (Buenos Aires, Argentina), Julio Mazo Efron (Tel Aviv, Israel), Luis Carlos Caplan (Nueva York, Estados Unidos), Yauda Kuzniecky Levit (Panamá), Mauricio Soiget (Buenos Aires, Argentina), Silvio Huberman (Buenos Aires, Argentina), Nina Irene Stein (Buenos Aires, Argentina) y Judith Noemí Freidenberg (Maryland, Estados Unidos).
} 


\section{Los trabajos de las memorias: la vuelta a "el fuera-de-lugar"}

¡Que lindo! Sí, a pesar de la pobreza, a pesar de tantas penurias, ¡qué linda era la vida en nuestras colonias! ¡Qué bien nos llevábamos todos! Testimonio de Celia Nijamkin, Vida en las colonias

Colonia Clara fue un espacio pequeño donde los "paisanos" construyeron su paisaje identitario y la vividura de la experiencia colonizadora les dio los elementos que conformaron su identidad, pues, como lo dice tan bien Héctor Schmuckler al reflexionar sobre la memoria e identidad judía, «las identidades son producto de una experiencia del vivir ${ }^{27}$. Esa experiencia ha sido trasmitida de los abuelos a los padres y estos a los hijos, conformando la memoria colectiva de los judíos argentinos a los que la literatura los nombró como "los gauchos judíos». Los recorridos de esta memoria que ha tenido ciclos de activación y otros de silenciamientos, el abandono voluntario de la colonia, los desplazamientos de los chacareros a los centros urbanos, el enraizamiento en la cultura citadina y en particular con los embrujos de la ciudad de Buenos Aires, todo esto dejó la experiencia colonizadora en el pasado.

En Argentina, a partir de mediados de los años cuarenta se produjo una transformación política y social que brindó amplias posibilidades de ascenso social, y la aplicación de políticas universales permitió la democratización del bienestar -aunque de manera diferenciada en los centros urbanos-, que operó como un imán que atrajo a la población rural. La ciudad no sólo ofrecía mayores oportunidades laborales y mejoras sustantivas en el estándar de vida, sino también las posibilidades del acceso a la educación secundaria y superior. Los jóvenes, hijos de colonos, que no lograron tierras cercanas a las de sus padres ni los recursos económicos para asentarse en las colonias, fueron los primeros que se trasladaron a la ciudad, y desde aquí llamaron a los hermanos, a los progenitores, y así, en un proceso lento pero continuo, se despobló la campiña entrerriana. Proceso migratorio que tuvo un impacto diferenciado en Entre

\footnotetext{
${ }^{27}$ Schmuckler, Héctor, "La memoria en riesgo". Quinta ponencia de "Crecer en el Gueto-Crecer en el Mundo", Tercer Encuentro Internacional de Intelectuales Judíos, Rosario, Argentina. Disponible en: www.jccenters.org.
} 
Ríos, ya que ha sido la provincia que ha perdido mayor población debido a los desplazamientos poblacionales.

Ahora bien, estos traslados también fueron posibles porque la mayoría de los chacareros de Colonia Clara habían accedido a la propiedad de la tierra y libremente pudieron optar por la venta de sus chacras o por seguir trabajándolas con peones mientras se instalaban en las ciudades. Habían transcurrido largamente las veinte anualidades mínimas que los ataban a la vida en la chacra y, por supuesto, estos colonos sobrevivientes habían conseguido los recursos económicos para saldar las deudas con la empresa colonizadora.

No sólo hubo abandono voluntario de los colonos. Cuando indagamos sobre las causas de las deserciones, sobre el abandono de las colonias y en especial el incumplimiento de la misión de hacerse agricultores en la pampa argentina, las respuestas se aglutinan, en primer lugar, en torno a la torpeza e incompetencia de los administradores de la JCA, que, estableciendo condiciones desmedidas, expulsaron a los colonos. En segundo lugar, en la dureza del trabajo agrario y la escasa rentabilidad que la experiencia colonizadora brindaba a estos hombres y mujeres. Finalmente, se abandonaba la colonia buscando "un sitio más poblado y más culto, en el que sus conocimientos lingüísticos llorasen menos" 28 .

Pero menos conocidas son las historias de los colonos que fueron desalojados, los que fueron expulsados de la experiencia colonizadora por no poder cumplir con las anualidades o el pago del canon por el arrendamiento de las chacras. Sus recuerdos son diferentes y sus voces dolientes fueron silenciadas $u$ ocultadas.

Nuestro trabajo recupera las disputas y los enfrentamientos de los que, agremiados en instituciones cooperativas y en federaciones de segundo grado, libraron contra los intereses de los grandes monopolios comercializadores de granos, pero también contra los intereses de la empresa colonizadora representada por diferentes elencos administrativos, los que, aplicando normas rígidas e inflexibles, perseguían el cumplimiento estricto de los contratos y la rentabilidad económica de la empresa, aunque ello condenara a la expulsión a los que no podían cumplir con estas exigencias. Los administradores de la JCA nada respondían a las denuncias que realizaba la

${ }^{28}$ Dujovne Ortiz, Alicia, El Camarada Carlos. Itinerario de un enviado secreto, Buenos Aires, Aguilar, 2007, p. 24. 
Fraternidad Agraria sobre los desalojo, en un promedio de cuarenta por año entre 1921 y 1927.

Nos preocupa dar cuenta de las marcas del exilio en la colectividad judía. Si entendemos que el exilio es una parte fundante de su historia, pues la intolerancia y la persecución en la Rusia zarista provocaron el desplazamiento a la pampa argentina, muchos años después las nuevas generaciones fueron victimas de regímenes autoritarios: las dictaduras del Cono Sur obligaron a hombres y mujeres a abandonar el país.

El obligado desarraigo los envuelve en búsquedas que, de manera casi inmediata, encuentran anclajes en la memoria familiar, donde la experiencia de diásporas anteriores estaba presente. Los años setenta fueron decisivos en sus vidas personales, y cruciales en la dolorosa percepción de vivir una diáspora que hasta entonces sólo era recordada como "el fuera-de-lugar" de sus abuelos inmigrantes. Nunca antes se imaginaron que estarían obligados a desandar, desde el entrañable sur latinoamericano, las rutas de destierro que transitaron padres, abuelos, bisabuelos emigrantes.

En el momento en que la represión les hizo descubrir que los extranjeros ya no eran "otros" sino ellos mismos en tierras de exilio, sintieron la imperiosa necesidad de conocer los antiguos éxodos de sus ancestros mientras desandaban el camino. La literatura, ahora la literatura del exilio, vuelve a brindarnos las pistas necesarias para pensar el peso de la experiencia colonizadora de la JCA. La autora chilena Ana Vásquez Bronfman, exiliada en Francia, escribe Las jaulas invisibles. ${ }^{29}$ Alicia Dujovne Ortiz, escritora argentina también exilada en Francia, escribe El árbol de la gitana ${ }^{30}$ y El Ca-

\footnotetext{
${ }^{29}$ En su novela Las jaulas invisibles, la patria lejana de su familia de principios de siglo en Kishinev se le mezcla con Santiago de Chile, imaginándose la huída de sus padres y abuelos de Rusia como el exilio de los "míos" que había precedido muchas décadas antes su propia fuga del régimen de Pinochet. En el capítulo III narra la más remota imagen de la memoria del padre sobre el pogroms de Kishinev y la huida a Argentina a través de la JCA, antes de pasar a residir en Chile. "Compartimos la tragedia que en esta larga enrancia nos narramos incansablemente, los laberintos de mi pasado han surgido bajo otras luces: si no he vivido la ruptura como un drama, ha sido porque he tomado conciencia de otros exilios que ya estaban en mi, incluso antes que naciera [...] Mi linaje es el de los rechazados, el de los perseguidos, el de los condenados a la huida. En mí se condensan Bobes humildes y los Zheides barbudos de voz ronca, que cruzaron el océano para que por lo menos nosotros viviéramos sin miedo". Vásquez Bronfman, Ana "De rupturas y distancias" En: Revista NOAJ, № 2, 1988, p.61 y Vásquez Bronfman, Ana, Las jaulas Invisibles, LOM Ediciones, 2002, 65.

${ }^{30} \mathrm{~A}$ pesar del aire juguetón y levemente frívolo, El árbol de la gitana es una novela sobre la condición de extranjería más radical que produjo la reciente literatura del exilio argentina. Senkman, L., "La nación imaginaria de los escritores judíos latinoamericanos", en Revista Iberoamericana, Vol. LXVI, № 19, abriljunio de 2000. p. 294.
} 
marada Carlos. ${ }^{31}$ Y Arnoldo Liberman, nacido en el grupo Sonnenfeld de Colonia Clara, desde su exilio en España nos entrega Éxodo y exilio. Saldos y retazos de una identidad. ${ }^{32}$

Compartimos que historia y memoria, como conocimiento y como recuerdo, no son la misma cosa ni crecen con idéntica dirección y con el mismo ritmo. Así, la historia pretende una reconstrucción "sabia y abstracta" del pasado y mantiene su pretensión "crítica y laica" sin aceptar que se le vede ningún terreno. La memoria está sometida a cambios permanentes, inducidos por las exigencias del presente, por la biografía de quien quiere recordar, por lo que se decide olvidar, por las políticas de la historia elaboradas desde los poderes públicos o por meras oportunidades e incitaciones del mercado actual.

Mientras la historia busca conocer, comprender, interpretar o explicar, y actúa bajo la exigencia de totalidad y objetividad, la memoria pretende legitimar, rehabilitar u honrar o condenar, y actúa de manera siempre selectiva y subjetiva.

Conocer el pasado y rememorarlo, con nostalgia, con pesar o con irritación, son operaciones diferentes. Saber es una cuestión de estudio, de documentación, de lectura, y aspira a la universalidad en un doble sentido: no dejar nada fuera de foco y ser compartido por todos. Recordar, sin embargo, es una cuestión de política, de celebración, de voluntad, y tiene que ver con la relación del sujeto con su propio pasado y con lo que, al traerlo al presente, quiere hacer con su futuro. Es obvio que nadie puede recordar aquello que no ha vivido, que no forma parte de su experiencia personal: "recuperar el pasado" en el sentido estricto de asomarse a él para conocerlo no es, ni puede ser, función de la memoria. Es la historia, no la memoria, la que se esfuerza por conocer el pasado y la que requiere, por lo tanto, un ejercicio de aprendizaje: la historia se aprende, no se recuerda. La memoria, por su parte, aspira a

\footnotetext{
${ }^{31}$ Alicia Duvojne Ortiz en muy clara en este sentido: "Ochenta y dos años después, 15 de octubre de 2005, zarpo del aeropuerto de París, donde vivo desde 1978, rumbo a Moldavia o Besarabia. He invertido a mi vez el viaje de mis abuelos y perpetuando la tendencia a cambiar de tierra. Las razones para partir también se reproducen. 1978 no es una fecha casual en Argentina: tiempos de dictadura militar, tiempos de exilio". En Dujovne Ortiz, Alicia, El camarada Carlos. Itinerario de un enviado secreto, Buenos Aires, Aguilar, 2007, p. 33.

${ }^{32}$ Este autor escribe: «Por imperio de la historia el viaje de retorno lo habíamos hecho los nietos y desde allí ser argentino era una especie de ida y vuelta; ellos buscando en Argentina la tierra prometida o huyendo de una maraña europea hostil; nosotros regresando a Europa para poder seguir amando la libertad y la vida". En Liberman, Arnoldo, Éxodo y exilio. Saldos y retazos de una identidad, España, Sefarad Editores, 2006, p. 125.
} 
mantener la relación afectiva con tal o cual acontecimiento que reviste un significado especial para quien recuerda, sea un grupo o una persona, como sustrato de su identidad, como cumplimiento de un deber hacia el grupo o sus ancestros o, en fin, como una exigencia del presente.

Paul Ricoeur ${ }^{33}$ escribió hace unos años que, si el pasado es inmodificable, su sentido no está fijado para siempre: mientras la historia se ocupa de buscar la verdad -toda la verdad, si fuera posible-, la memoria trata de encontrar o construir un sentido para quien recuerda un aspecto, un acontecimiento de ese pasado con el que se siente unido por un vínculo especial.

Como muy bien señala Tzvetan Todorov, ${ }^{34}$ la memoria, como la elección de los hechos pasados que nos acompañan en el presente y nos ayudan a construir el futuro, es forzosamente una selección, la interacción de la supresión y la conservación.

\section{Recorridos de la investigación}

El diseño de la investigación adoptado fue más exploratorio que experimental, ya que intentamos realizar en esta etapa una aproximación a un vasto y complejo tema de estudio que adquirirá riqueza interpretativa cuando se pueda explicar la experiencia colonizadora desde una historia social entrerriana, que no sólo cubra ese enorme vacío historiográfico sino que brinde las claves del funcionamiento económico, de la rentabilidad agraria, de las trasformaciones de la estructura social y el comportamiento y dinámica poblacional entrerriana y que a la vez ponga en diálogo las singularidades regionales con la historia nacional. No obstante en esta investigación se persiguió probar la hipótesis que la empresa colonizadora imprimió un estatus peculiar a los migrantes, que incidió en el acceso a la propiedad de la tierra, a formas productivas y económicas diferenciadas y a tramitar la experiencia de convertirse en chacareros en la llanura entrerriana en una labor no libre de tensiones y de múltiples defecciones.

\footnotetext{
${ }^{33}$ Ricoeur, Paul, La lectura del tiempo pasado: memoria y olvido, Madrid, Universidad Autónoma de Madrid, 1999, p. 49.

34 Todorov, Tzvetan, Los abusos de la memoria, Barcelona, Paidós, 2000.
} 


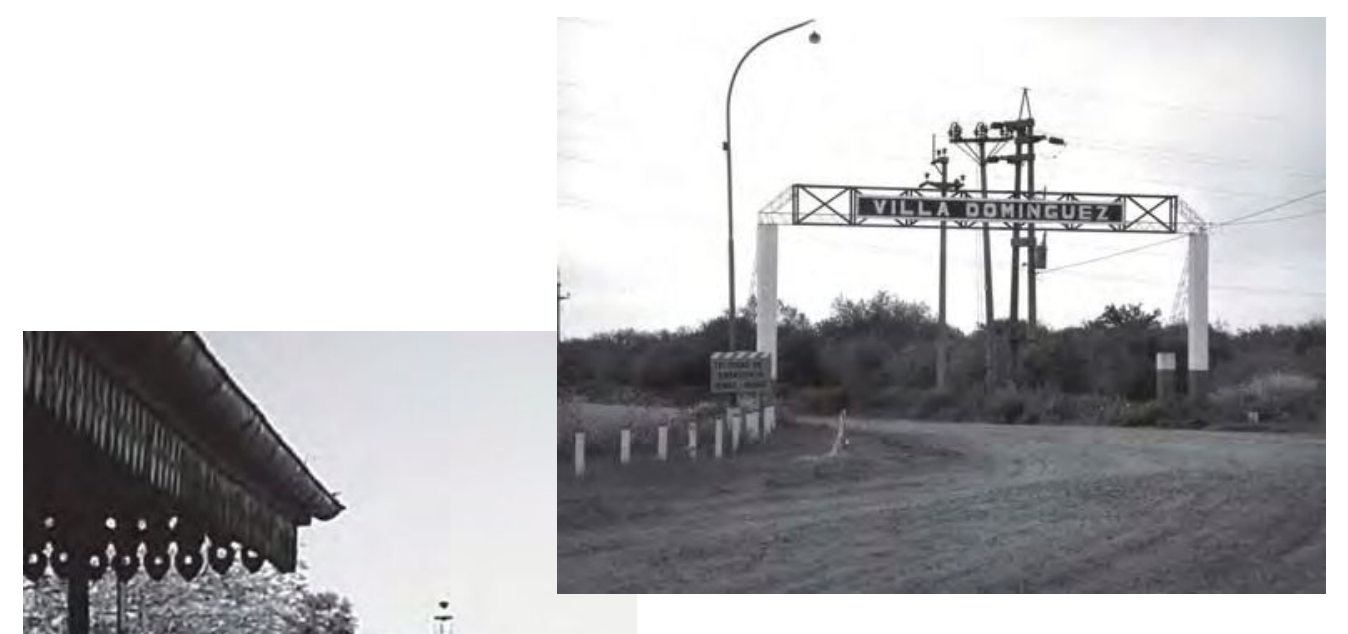

Para comprender y poder explicar la experiencia hicimos nuestra tarea de campo recorriendo largamente el extenso territorio donde se asentó Colonia Clara. Cien años después, con las construcciones del paisaje hechas por el hombre, con los trazados de caminos más estables y alambrados que delinean los senderos, las imágenes del espacio -las distancias y los escollos geográficos naturales- y el recorrido in situ -con ojos de un ciudadano del siglo XXI- provocan un sentimiento de admiración por la tarea realizada por esos hombres y mujeres que sin instrumentos técnicos sofisticados transformaron el territorio en un espacio apto para la vida comunitaria. Cien años después, es nuevamente un espacio despoblado. Sin embargo, se nos presenta con marcas o huellas que activan la memoria. Un conjunto de árboles, solos en medio de la inmensidad del terreno, dando señales de una casa y del colono que ya no está, un suelo verde y ondulado producto de una nueva gramínea que desplazó el enmarañado de los espinillos, son algunos de los testimonios mudos pero significativos de la experiencia colonizadora. Al final del camino que recorremos para volver al lugar de emplazamiento de Colonia Clara aparece un pequeño poblado, con un cartel que advierte la llegada a una silenciosa Villa Domínguez. Ingresamos por un sendero serpentino que atraviesa las vías de un tren que ya no funciona, para arribar a una esquina en las que los carteles anuncian la intersección de las calles que llevan por nombre Barón Hirsch y General San Martín. 


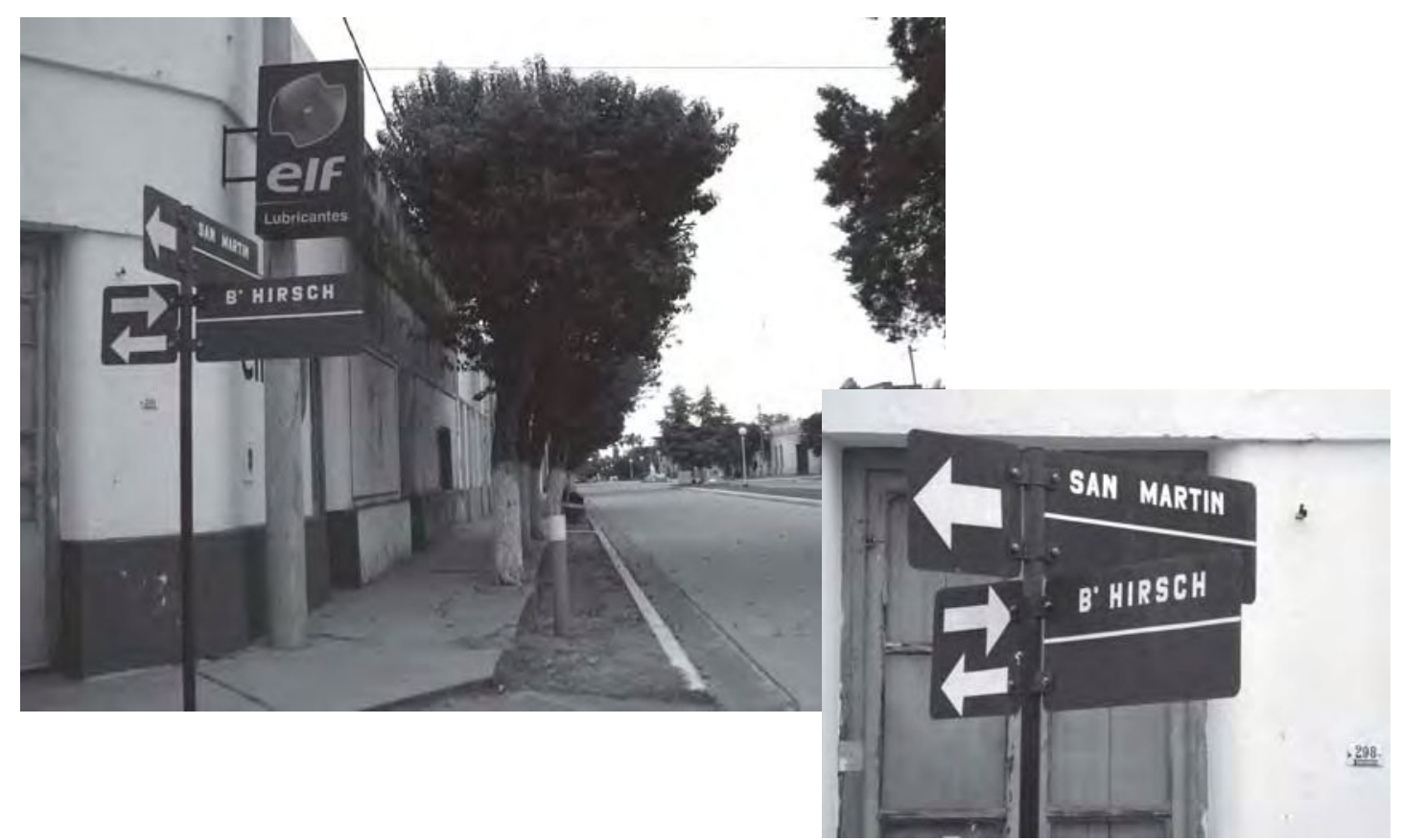

Esta imagen es fundante y condensa múltiples sentidos, y justamente en ese entrecruzamiento físico y simbólico se erige nuestro trabajo.

Los imaginarios convergen dando lugar a la experiencia colonizadora. Por un lado, desde mediados del siglo xIx se empezaba a delinear el proyecto de una nueva Argentina, moderna y civilizada. El imperativo era dejar atrás un pasado de violencias, de guerras civiles, erradicar la «barbarie» e imaginar la nación. Había que dotar la nación de una carta fundacional que explicitara las bases y los puntos de partida para el desarrollo del proyecto modernizador. Así, los hombres de la organización nacional tuvieron en cuenta dos factores determinantes para el progreso del país: fomentar la inmigración e incorporar capitales externos, con carácter de préstamos o de inversiones, con el propósito de aplicarlos a la ganadería, la agricultura y algunas industrias derivadas, condicionándolas a las nuevas perspectivas que se ofrecían al país. Luego, se trabajó en la difusión de esta Argentina, invitando a los hombres del mundo a poblar su inmenso territorio, destacando la imagen de una sociedad que vivía un clima de enérgica confianza en el futuro.

Por otro lado están las condiciones políticas de Europa del Este que obligaban a buscar puertos de salida a los judíos asquenazíes para preservar la vida, que iniciaron la travesía buscando una nueva Sión. En el imaginario de aquellos inmigrantes que cruzaban el océano hacia América del Sur había un país que simbolizaba la tierra 
utópica, y deseaban llegar con el fin de recomenzar sus vidas en un ámbito de libertad y rápido progreso. Para muchos de ellos, las pampas argentinas eran ese otro lugar, la alteridad lejana del Viejo Mundo, pero identificada como la Tierra Prometida.

Nos abocamos a analizar las condiciones de vida de los judíos en la Rusia zarista para comprender lo que representó la propuesta del barón de Hirsch y las condiciones que la empresa (Jewish Colonization Association) impuso a aquellos hombres y mujeres que accedieron a formar parte del contingente inmigratorio que se trasladarían a América. Si la misión de Hirsch fue salvar de los pogroms a los judíos de Rusia, la misión de los migrantes fue convertirse en agricultores, redimidos por el trabajo de la tierra, construyendo un espacio de acogida no sólo para ellos y sus familias, sino para todos los hermanos judíos oprimidos por la Europa xenófoba que deberían partir al exilio. Indagamos en particular sobre el peso de este mandato y las formas que adquirió la administración de la experiencia colonizadora recurriendo a fuentes oficiales de la empresa (Memorias de la Jewish Colonization Association. Su obra en la República Argentina. 1891-1941, y los Informes de los Directores y Administradores en Argentina), así como las memorias de los primeros colonos que narraron la experiencia (Boris Garfunkel, Narro mi vida; S. I. Hurvitz, Colonia Lucienville; Adolfo Leibovich, Apuntes íntimos; Enrique Dickman, Recuerdo de un militante socialista; Mauricio Chajchir, Viaje al país de la esperanza; Israel Fingerman, Inmigración judía).

La vida en Colonia Clara ¿fue una época dorada como la rememoran las memorias? ${ }^{35}$ ¿Cuántos fueron los logros y cuántas las tensiones? La literatura advierte que los primeros inmigrantes se hicieron argentinos en el campo, pero esta experiencia hubo que transitarla con muchos avatares: desarrollar la agricultura en una tierra virgen, adquirir la calificación necesaria para enfrentar la naturaleza y alcanzar la destreza para obtener sus frutos y dar densidad a la utopía de encontrar un mundo nuevo donde vivir en libertad con múltiples oportunidades. Estas prácticas no estuvieron libres de tensiones. Asentados los inmigrantes en Colonia Clara en la primera etapa de acomodamientos, las disputas y deserciones

35 Entre muchas otras fuentes podemos citar: Seidel Zeiner, Carmel. La hija del Coronel. Recuerdos de Infancia, mimeo, 1975; Gukowski, Hélène, Rescate de la herencia cultural. Vida en las colonias, Buenos Aires, Contexto, 1991; Jurkowicz, Marta, Cuando las mujeres hacen Memoria. Testimonios de historia oral de la inmigración judía en la Argentina, Buenos Aires, Grupo Editor Latinoamericano, 1999; Gukowski, Hélène, Vidas. Rescate de la herencia cultural, Sociedad Hebraica Argentina, 1995. 
estuvieron a la orden del día. El contacto con la naturaleza bravía y los intercambios con los criollos, el delineado con el poblamiento en distintos grupos o aldeas, las relaciones con los administradores de la empresa, hasta la creación de una institución de ayuda mutua y de defensa de los colonos que creó una instancia que otorgó posibilidades de cooperación y lazos de solidaridad para favorecer el arraigo a la tierra, fueron los primeros temas reconstruidos con un abanico de documentos escritos puestos en diálogo con las voces de los actores volcadas en las memorias y en entrevistas en profundidad.

¿Cómo fueron los procesos para imaginar y construir la nacionalidad? ${ }^{36}$ ¿Qué formas adquirió la participación democrática y la construcción del sentido de pertenencia y de ciudadanía? ¿Cómo se concreta la idea de integración sin asimilación, de inclusión a un nuevo "nosotros" sin pérdida da la identidad previa o de origen $?^{37}$ El papel de las escuelas israelitas en las colonias, los cursos religiosos, la enseñanza del idish y del hebreo y de la historia judía son objetos clave para este análisis. En particular nos propusimos responder a cómo fue la vida religiosa en Colonia Clara. Los recién Ilegados prontamente construyeron sus sinagogas, sus cementerios, se reunieron a conmemorar sus festividades. Pero estos pobladores no eran un grupo homogéneo y ello no es menor, ya que la vida religiosa judía estará siempre impregnada por las diversas experiencias históricas y sociales de distintos grupos. Una característica preponderante de la comunidad asentada en Colonia Clara fue su sentido libertario, que no sólo estaba incluido en la tradición y las costumbres, sino también en la religión. Las diferentes tendencias, las transiciones y tramitaciones en el campo religioso, dieron una nota peculiar a estos colonos, y hemos podido observarlas en las diversas memorias que dan cuenta de la preservación de prácticas por religiosos judíos de formación sistemática, como ledidio Efron, que fundó la pri-

\footnotetext{
36 "¿Cómo se hace para aprender a hablar, pensar y hasta soñar en un idioma que no es el propio? ¿Cómo se hace para decirle adiós al pasado, para despedirse de aquellos a los que se siente y sabe que no se volverá a ver más? Todos vinieron buscando el amparo del techo, del pan, de la ilusión bajo la solemne protección de la Cruz del Sur". Estas son algunas de las reflexiones que nos traslada Silvia C. Fairman, en su libro Mate y Samovar, Buenos Aires, Lumen, 2000, p. 9.

37 "Como buen judío padezco de una insistente interrogación ontológica sobre mi identidad y, como buen argentino, mi obstinada lealtad a mi país y mi sentimiento de integración nunca desmentido", nos señala Arnoldo Liberman, escritor y ensayista nacido en las colonias.
} 
mera Yeshivá ${ }^{38}$ en Argentina en la aldea Fainberg, la ruptura con la ortodoxia de Enrique Dickmann, o el caso de Don Miguel Sajaroff, quien no era religioso, no practicaba rituales de ninguna especie, pero tampoco era antirreligioso. ${ }^{39}$ Instituciones, prácticas y modos de comprender la judeidad que se tramitan en el ámbito privado - los casamientos entre miembros del mismo grupo étnico, por ejemplo- y los que se instauran en el ámbito público en torno a la educación.

Si los judíos habían sido convocados a vivir en el suelo argentino con el espíritu liberal de la constitución de 1853 -con su libertad de cultos y de enseñar y aprender-, el nuevo proyecto político para pensar la nación y construir la nacionalidad argentina de fines del siglo XIX y principio del xx los ponía en una encrucijada con las exigencias asimilatorias. El debate estaba abierto. La identidad judía no aceptaba esa uniformidad y rechazaba el proyecto que bajo el nombre de la unidad nacional buscaba la supresión de las diversidades.

Nuestro trabajo se propone realizar una aproximación al análisis del papel del Estado como formador de la nacionalidad, observando el debate sobre la educación de los inmigrantes como herramienta y el idioma nacional como medio de expresión de la nacionalidad e instrumento en la absorción en el marco de una argentinidad proyectada. Ante la ausencia del Estado en el ámbito rural, fue la empresa colonizadora quien estableció un sistema educativo integral con enseñanza laica y religiosa que debió dirimir con el estado provincial las incumbencias para pensar la ciudadanía.

La política oficial estableció que la escuela era el lugar donde se construía la identidad denominada "nacional» como una identidad homogénea y monolítica a partir de la trasmisión de las formas simbólicas referentes a la argentinidad, el patriotismo y la

\footnotetext{
38 Una Yeshivá (en hebreo: éúéáä, yeshivot en plural) es un centro de estudios de la Torá y del Talmud, frecuentemente dirigido a varones en el judaísmo ortodoxo. Cada yeshivá está dirigida generalmente por un Rav, llamado "Rosh Yeshivá" (literalmente "cabeza de yeshivá»). En algunas puede haber más de un Rosh Yeshivá. A los instructores se les denomina Rebeim (en yidish) o Ramim (en hebreo). En la facultad de la mayoría de las yeshivot existe un mashguiaj rujaní o consejero espiritual, quien ayuda a los alumnos con problemas personales, y un Meshiv dedicado a responder preguntas académicas.

39 Jamás criticó o menoscabó a los creyentes de buena conducta y solía decir: "Si a mi casa viniera alguien que quisiera comer, pero deseara cumplir antes de la comida con algún precepto religioso, haré lo posible para suministrarle lo necesario, pidiéndolo entre el vecindario, para que pueda cumplir con su conciencia y comer tranquilo". En Kaplan, Isaac, Anécdotas, cartas y discurso de Don Miguel Sajaroff, Buenos Aires, Circulo de Estudios Cooperativistas de Buenos Aires, 1965, p. 10.
} 
nación. Los colonos inmigrantes acordaron dar a sus hijos una educación formal que facilitara su integración al país y, al mismo tiempo, sostener una educación judía que permitiera conservar y reproducir su herencia cultural y religiosa.

La investigación nos permite observar las tensiones, las vivencias de las personas implicadas y el significado de sus acciones, y en tal sentido identificar el tipo de relaciones sociales que se forjan en el interior de las escuelas, pero también pensar otros problemas que van mucho más allá: la integración, la discriminación, la etnicidad; finalmente la identidad y la otredad.

Abordar este capítulo nos hizo recorrer la producción académica abordada desde el campo de la Historia de la Educación, para reconocer las instrumentalidades y tramitaciones que se producen en el sistema educativo, en particular, los alcances del sistema entrerriano que tuvo en la colonización judía un laboratorio donde probar sus misiones y evaluar los resultados. Contamos con la valiosa contribución de estudiosos del tema que con textos ${ }^{40}$ y monografías ${ }^{41}$ nos brindaron aportes conceptuales y la descripción de derroteros políticos sobre la cuestión educativa, los que confrontamos con documentación e informes producidos por y para la JCA, por la Alliance Israélite Universelle -entidad que proporcionó los primeros maestros judíos que podían enseñar castellano-, memorias del Consejo Nacional de Educación, Dirección General de Escuelas, archivos escolares, crónicas, memorias y las voces de los entrevistados.

\footnotetext{
${ }^{40}$ Cfr. Puiggrós, A., Historia de la educación en la Argentina, Tomo IV: "La educación en las Provincias y Territorios Nacionales", Buenos Aires, Galerna, 1993; Ascolani, Adrián (comp.), La educación en Argentina. Estudios de Historia, Rosario, Ediciones del Arca, 1999; Tedesco, Juan Carlos, Educación y Sociedad en la Argentina (1880-1945), Buenos Aires, Siglo XXI, 1986; Bertoni, Lilia Ana, Patriotas, cosmopolitas y nacionalistas. La construcción de la nacionalidad argentina a fines del Siglo XX, Buenos Aires, FCE, 2001; Gutiérrez, Talía Violeta, Políticas educativas agrícolas: una preocupación de los pedagogos normalistas, Entre Ríos (Argentina), 1900-1920, disponible en: www.fee.tche.br/sitefee/download/jornadas/2/h10-03.pdf.

${ }^{41}$ Cfr. Gómez Sollano, Marcela y Corenstein Zaslav, Martha, La educación judía en México y Argentina. tendencias pedagógicas y zonas fronterizas, disponible en: www.comie.org.mx/congreso/memoria/v9/ .../PRE1178898469.pdf; Bargman, Daniel, "Construcción de la Nación entre la asimilación de inmigrantes y el particularismo. Las escuelas de las colonias agrícolas judías", en Maronese, Leticia (comp.), Patrimonio Cultural y Diversidad Creativa en el Sistema Educativo. Buenos Aires, Gobierno de la Ciudad de Buenos Aires, 2006; Epstein, Diana, "Maestros marroquíes. Estrategia educativa e integración. 18921920", en Anuario IEHS, N 12, Facultad de Ciencias Humanas, Universidad Nacional del Centro, Tandil, 1997; Zadoff, Efraim, «La educación judía en Buenos Aires Organización e institucionalización (19351967)", en Mundo Israelita, 28 de agosto de 2007; Rubel, Yaacov, "Creación, apogeo y crisis de los institutos de formación docente dependientes de la AMIA", en Mundo Israelita, 8 y 15 de diciembre de 2000 , entre otros.
} 
Finalmente, nos dedicamos a estudiar la Sociedad Cooperativa Fondo Comunal porque su historia es también la historia de Colonia Clara. Es un ángulo privilegiado para explicar los alcances de una institución creada por los inmigrantes que trajeron consigo el ideario cooperativista y que, al ingresar al modelo de acumulación capitalista agroexportador, signado por la libre empresa y la competencia comercial, buscaron los instrumentos necesarios para cumplir el papel de base empresarial de los productores agropecuarios con un doble objetivo: el primero, de carácter social, estaba destinado a la prestación de un servicio basado en principios de solidaridad, libre asociación y gestión democrática; el segundo, de carácter económico, estaba orientado a la defensa de los intereses y a la mejora de los ingresos y situación económica de sus asociados.

Sin embargo, el Fondo Comunal no sólo cumplió con ellos, sino que fue mucho más allá. La particularidad del cooperativismo en las colonias judías estuvo en que fue, además, un instrumento de educación y generador de formas de convivencia para una vida armoniosa basada en el bien común, así como el espacio político y de defensa de los colonos ante los embates y las exigencias impuestas por la empresa colonizadora.

Las cooperativas agrarias judías, y en particular las federaciones de estas cooperativas, trazaron un proyecto de defensa de los colonos judíos frente a los programas de acción de los distintos elencos administrativos de la JCA, que perseguían el cumplimiento estricto de normas establecidas por la Oficina Central de París, las que se distanciaban y se contraponían -en demasiadas ocasiones- a las necesidades, expectativas y demandas que la experiencia colonizadora en el país imponía a los colonos. Estas tensiones y las formas de resistencia marcaron la acción gremial, que se movía en dos planos: por un lado, la búsqueda de acción cooperativa en la esfera económica, trabajando mancomunadamente con entidades provinciales y nacionales, y, por otro, una acción solidaria con base étnica que, si bien contenía estrategias de acción económica, iba más allá para construir un frente común de resistencia y de sobrevivencia ante la JCA.

Otra singularidad es que esta cooperativa fue creada por la acción directa de la empresa colonizadora, aportando recursos económicos y colaboración franca para el desarrollo de la ayuda mutua y la solidaridad entre los colonos. Sin embargo, a 
medida que la institución cooperativa fue adquiriendo experiencia y solidez en el plano social y algunos avances en el plano económico, comenzó un largo proceso de enfrentamientos signados por una relación asimétrica debida a los niveles de dependencia de los colonos y por las estrictas demostraciones de estas asimetrías ejercidas por los administradores de la JCA.

El Fondo Comunal fue la más importante de las cooperativas agrícolas entrerrianas, por la cantidad de socios - cerca del millar-, por el capital social suscripto y realizado y sus fondos sociales, por la magnitud de las actividades que cubrían (distribución de mercaderías - provisión de implementos agrícolas y artículos de consumo- y comercialización de cereales y productos de granja y ganado que sus socios entregaban), por la capacidad de alentar la incorporación tecnológica y conocimiento estratégico en la producción agropecuaria y sus derivados industriales. Al tiempo de ser un centro para la actividad económica, la cooperativa se convirtió en un punto de reunión, de encuentro, al que se concurría no sólo por necesidades materiales, sino también a conversar, a tomar una copa, a intercambiar opiniones con los conocidos.

El Fondo Comunal fue un ámbito de gestión democrática con activa participación de los socios en las asambleas generales, foro donde el debate, la confrontación y la búsqueda de consenso otorgaron una práctica política para el abordaje de temas que iban más allá de las preocupaciones económicas. En este espacio adquirieron prácticas donde los habitantes se fueron convirtiendo en ciudadanos.

La lectura de las actas de las sesiones quincenales ordinarias del Consejo Directivo y de las asambleas ordinarias y extraordinarias mensuales nos permitió periodizar e historiar

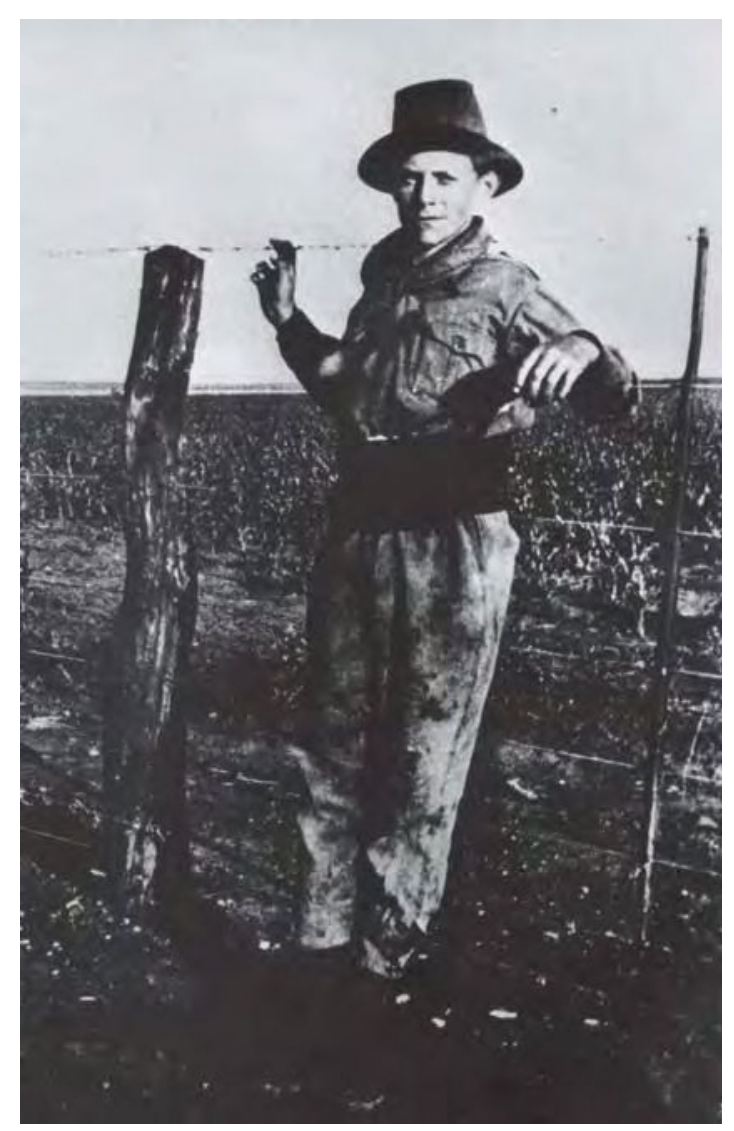


la vida de la institución que fue la caja de resonancia de la experiencia colonizadora. Es justamente este análisis desde los orígenes en 1904 hasta mediados de los años cincuenta el que nos brindó los elementos para determinar los marcos cronológicos para nuestro trabajo de investigación.

Desde su fundación en 1892 y durante los primeros años de Colonia Clara, la experiencia estuvo plagada de conflictos y deserciones de los primeros pobladores, que no encontraban los anclajes para afianzarse como agricultores en la Ilanura entrerriana. El arraigo llegó de la mano de la cooperativa, que brindó la ayuda social, económica y política para fortalecerlos como productores agrarios, y a través de la acción gremial, que defendió sus derechos. Fue la acción combativa de los dirigentes la que intentó poner freno a las arbitrariedades de los elencos administrativos, a los desalojos y expulsiones que la empresa colonizadora imponía a aquellos chacareros que no podían cumplir con las anualidades y otras deudas contraídas con la JCA. Fueron ellos los que reclamaron por la tierra para los hijos de los colonos, que no encontraban forma de insertarse en el campo y se marchaban a las ciudades, dando inicio a un lento pero constante proceso de desplazamiento de la población hacia los centros urbanos y de despoblamiento de la colonia.

La primera etapa, a la que denominaremos génesis del Fondo Comunal, abarcó los años 1904 a 1908. Fue producto de una alianza estratégica entre la empresa colonizadora y los colonos, donde se delinearon los objetivos y se pusieron a prueba los alcances de la solidaridad y la ayuda mutua para lograr el arraigo de los colonos a la tierra. La segunda etapa, que cubrió el período de 1908 a 1916, se inició con la asunción de un colono, Miguel Sajaroff, como presidente del Fondo Comunal. Allí se perfila cierta autonomía de la cooperativa de la JCA, producto de la autoadministración. Una tercera etapa, que denominaremos de afianzamiento y desarrollo del Fondo Comunal, entre 1917 y 1930, está caracterizada por la emergencia de líneas internas y corrientes ideológicas que enfrentan decididamente la política de la empresa colonizadora, con activa participación gremial reivindicativa y de fortalecimiento de los lazos cooperativos que le otorgan proyección nacional. Finalmente, una cuarta etapa se desarrolla a partir de los cambios y reacomodamientos impuestos por la crisis del treinta, a la que denominaremos de resurgimiento, consolidación y creci- 
miento, entre 1938 y 1954, donde las notas características surgen del entrecruzamiento de un sostenido crecimiento económico y diversidad productiva incentivada por la institución -ahora multivalente-, con la introducción de cambios tecnológicos en el ámbito de la producción y el comercio, lo que sin duda favoreció el proceso de desarrollo rural en su sentido más amplio, es decir, desde la perspectiva de la mejora en las condiciones materiales de existencia de la población rural, fenómeno que se traduce en un amplio acceso de los socios a la propiedad de la tierra y, concomitantemente, al despoblamiento rural debido al desplazamiento de los colonos del campo hacia las ciudades. Todas estas transformaciones estratégicas se traducen en un distanciamiento efectivo con la empresa colonizadora.

Reconstruimos la historia de la institución a través de las Actas de Sesiones, importante acervo documental resguardado en el Archivo y Museo de Villa Domínguez, los intercambios epistolares y correspondencia de los principales dirigentes reunidos en los archivos personales, ${ }^{42}$ las memorias institucionales, ${ }^{43}$ los informes de los administradores de la JCA, ${ }^{44}$ las publicaciones periódicas propias -EI Colono Israelita Argentino y El colono cooperador-y las editadas por los actores del cooperativismo -El Campo-, así como artículos publicados en periódicos locales y nacionales. ${ }^{45}$

La reunión en Londres en 1952 marca el fin de una época. Por primera vez, los colonos agremiados en la Fraternidad Agraria fueron invitados a una mesa de diálogo con los administradores de la JCA, en la sede central de Inglaterra, para entablar un nuevo acuerdo, al que los colonos denominaron sugestivamente "Nueva página". Las asimetrías eran ahora inversas, y los chacareros lo expresaron con contundencia a los directores: "sostenemos que los verdaderos ejecutores de la

\footnotetext{
${ }^{42}$ Archivos personales de Miguel Sajaroff, Miguel Kipen, Isaac Kaplan, Fundación IWO, Buenos Aires; Kaplan, Isaac, Recuerdos de un agrario cooperativista, 1895-1925, Buenos Aires, Ciirculo de Estudios Cooperativistas de Buenos Aires, 1962; Leibovich, Adolfo, Apuntes Íntimos. 1870-1946, Buenos Aires, Imprenta López, 1947; Kaplan, Isaac, Anécdotas, cartas y discursos de Don Miguel Sajaroff, Buenos Aires, Círculo de Estudios cooperativistas de Buenos Aires, 1965.

${ }^{43}$ Fondo Comunal, Cincuenta años de su vida (1904-1954), Villa Domínguez, Sociedad Cooperativa Agrícola Limitada, 1957; Fraternidad Agraria, Historia de la Fraternidad Agraria, noviembre de 1948.

${ }^{44}$ Informe Anual 1939 de Colonia Clara, Ingeniero Samuel Kogan, Informe Anual de 1939; Informe sobre Colonia Clara. Estrictamente Confidencial, elevado a Dirección General de la JCA, sobre movimientos de colonos habidos durante los 10 últimos años. 1944-1954.

45 La Vanguardia, Di Prese, Idische Zeitung, Mundo Israelita, El Atlántico.
} 
misión de la JCA son los colonos". Cambio sustantivo que resume las transformaciones operadas en la experiencia colonizadora. Aproximadamente el $80 \%$ de colonos que sobrevivieron y superaron las exigencias impuestas por la JCA se convirtieron en propietarios de las tierras - los que fueron denominados colonos emancipados por la JCA-, y muchos de sus hijos ya se habían marchado a la ciudad.

Esta "nueva página" es simbólica y también fundante de un nuevo ciclo. Los colonos judíos, como tantos otros pobladores del campo entrerriano, migran a las ciudades. En vano se redoblan los esfuerzos para buscar alternativas para afianzar a los jóvenes a la tierra fértil de la provincia. El campo, lenta pero inexorablemente, se deshabita y sólo quedan, firmes, los paraísos.

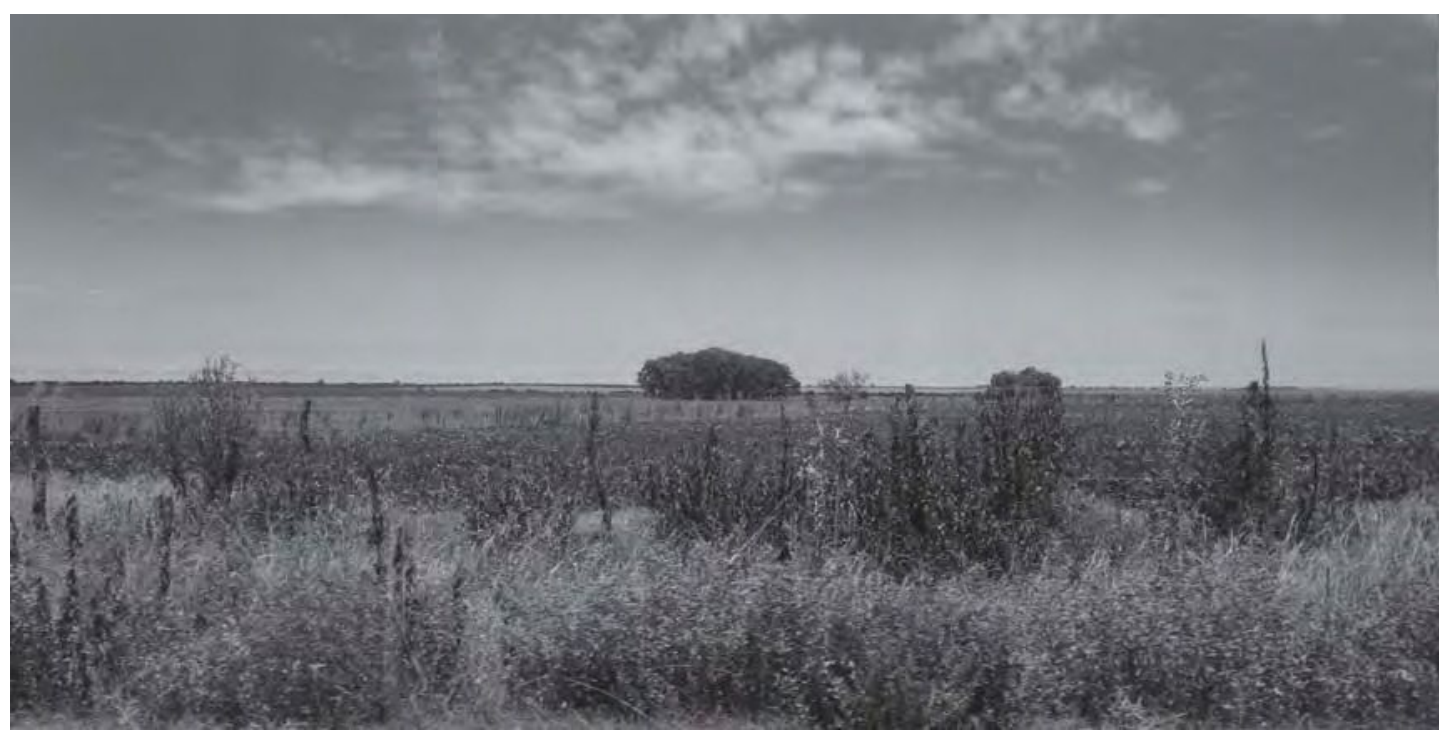





\section{capítulo uno}





\section{Los imaginarios. Del miedo a la esperanza...}

obligados a buscar un refugio lejos de los horrores de su país natal, tuvieron la suerte de encontrar aquí no sólo refugio y paz sino un nuevo hogar por el que suspiraban, la patria nueva a la que habrían de incorporarse en cuerpo y alma.

\section{Poblar la nación}

A mediados del siglo xIX se empieza a delinear el proyecto de una nueva Argentina, moderna y civilizada. El imperativo era dejar atrás un pasado de violencias, de guerras civiles, erradicar la «barbarie» e imaginar la nación. Había que dotarla de una carta fundacional que explicitara las bases y los puntos de partida para el desarrollo del proyecto modernizador. Así, los hombres de la organización nacional tuvieron en cuenta dos factores determinantes para el progreso del país: fomentar la inmigración e incorporar capitales externos, con ca-

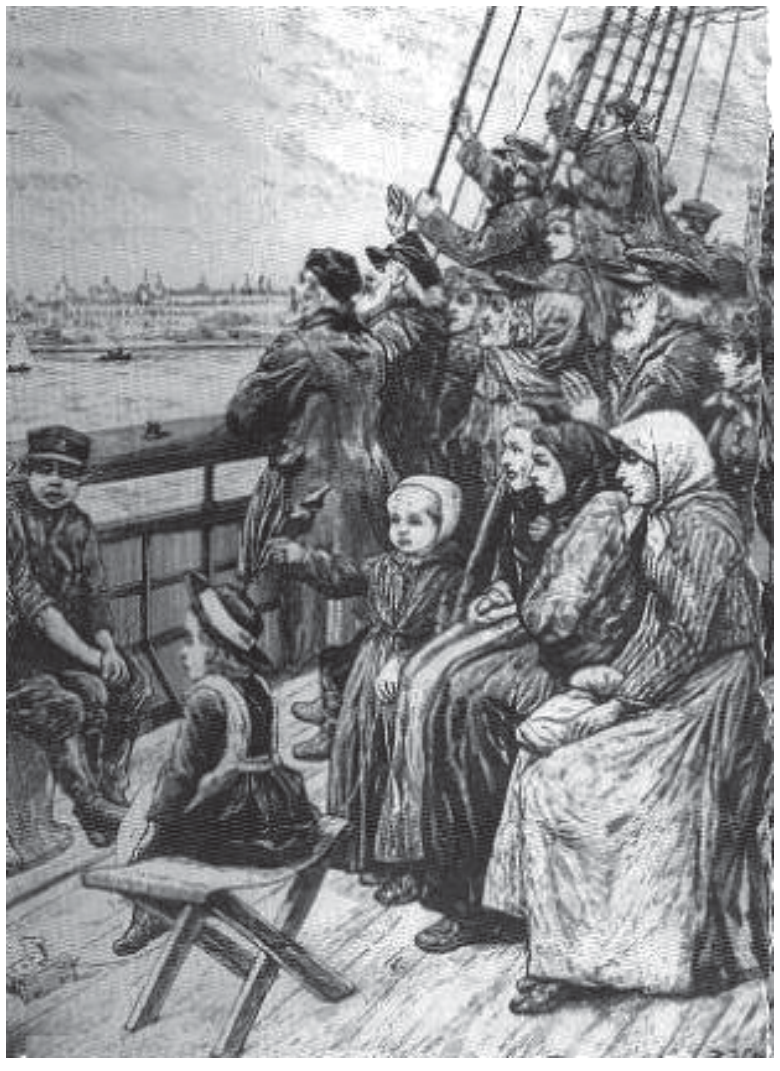

Llegada de inmigrantes israelitas a Buenos Aires, grabado de 1893. 
rácter de préstamos o de inversiones, con el propósito de aplicarlos a la ganadería, la agricultura y algunas industrias de ellas derivadas, condicionándolas a las nuevas perspectivas que se ofrecían al país.

Ahora bien, para lograr que la mano de obra y los capitales arribasen era necesario imponer orden e instaurar la paz. También crear una legislación nacional adecuada.

Esta nueva gobernabilidad estaba relacionada con la necesidad de ampliar el control sobre el territorio, dentro del cual grandes extensiones permanecían aún casi desconocidas. La idea de conquistar el territorio considerado "desierto" e incorporarlo al ámbito nacional implicaba asimismo la sustitución de la población que lo habitaba por otra que pudiera "trabajarlo». La Campaña al Desierto borra al elemento indígena y permite poner en marcha y concretar el proceso de transformación de la realidad a través de la incorporación de trabajadores extranjeros provenientes de Europa.

Para poblar el país "desierto" había que convocar a todos los hombres que quisieran habitar el suelo argentino trayendo consigo su fuerza de trabajo, su ciencia e ilustración para construir la nación en un ámbito de libertad y de respeto a los nuevos derechos conseguidos e instaurados.

Poblar el país se convirtió en una política de Estado, y para ello se trabajó en la instrumentación legal y simbólica necesaria.

La carta constitucional de 1853 era portadora de este proyecto poblacional y muy clara en este sentido. El preámbulo presuponía todo tipo de inmigración posible, ya que otorgaba derechos y garantías de la Constitución a "todos los hombres del mundo de buena voluntad que quieran habitar en suelo argentino". Más preciso en este sentido es el artículo 25, que por una parte promueve la inmigración europea ("el gobierno federal fomentará la inmigración europea") y por otra realiza una definición extensiva en términos ocupacionales, donde señala que propiciará la entrada de "extranjeros que traigan por objeto labrar la tierra, mejorar la industria e introducir y enseñar las ciencias y las artes".

Ahora bien, considerar inmigrantes sólo a los que venían en tercera clase significaba asociarlos estrechamente con la noción de pobreza relativa y la imagen de esas multitudes de campesinos europeos que se desplazaban de Europa hacia América. En Argentina, la inmigración estuvo vinculada con la idea civilizatoria. Los 
inmigrantes eran mucho más que trabajadores manuales calificados o no calificados, ya que se esperaba de ellos la difusión del conocimiento y la cultura europea. ${ }^{1}$

Un nuevo hito en el andamiaje legal fue la Ley de Inmigración y Colonización sancionada en 1876, durante la presidencia de Nicolás Avellaneda, en momentos de una crisis económica con fuerte impacto en la sociedad que detiene también los flujos migratorios. Los objetivos primarios de la ley tendían a organizar el conjunto de iniciativas nacionales, provinciales y privadas sobre la materia, pero también respondían a impulsar un salto cuantitativo del flujo migratorio y un cambio cualitativo a través del fomento de las migraciones desde algunas regiones de Europa en particular: los agricultores del norte de Europa con los cuales ya soñaba Alberdi. Las Bases y Puntos de partida para la organización política de la República Argentina, obra publicada en 1852, propone que "gobernar es poblar", pero no poblar de cualquier manera, sino con educación, propendiendo al progreso, la grandeza y la prosperidad de la patria. Del mismo modo, Domingo F. Sarmiento confiaba que ese inmigrante -anglosajón - sería el poblador del desierto y, como agente civilizador, trasladaría sus hábitos industriosos y metódicos para erradicar la "barbarie», ese mal enquistado en las repúblicas latinoamericanas.

El proyecto era una convocatoria para construir la nación, por lo tanto se pondrán en marcha una serie de dispositivos propagandísticos para alentar la concurrencia. La invitación fue cursada a

todo extranjero jornalero, artesano, industrial, agricultor o profesor, que siendo menor de sesenta años y acreditando su moralidad y sus aptitudes, llegase a la república para establecerse en ella, en buques a vapor o a vela, abonando pasaje de segunda o tercera clase, o teniendo el viaje pagado por cuenta de la Nación, de las provincias o de las empresas particulares, protectoras de la inmigración y la colonización.

Por medio de la ley se crea el Departamento General de Inmigración, dependiente del Ministerio del Interior (art. 1), dándole al Poder Ejecutivo la facultad de nombrar agentes en aquellos puntos de Europa o de América que considere

\footnotetext{
${ }^{1}$ Devoto, Fernando, Historia de la inmigración en la Argentina, Buenos Aires, Sudamericana, 2003, p. 34.
} 
convenientes para fomentar la inmigración hacia la República Argentina, los que tendrán como función

desarrollar una continua propaganda, proporcionar gratuitamente informes a los interesados, certificar sobre la conducta y actitud industrial del inmigrante, intervenir en los contratos de transporte y, en algunos casos, pagar sus pasajes. (art. 4)

El Ejecutivo podrá también nombrar comisiones de inmigración en los puntos del país interesados en el problema, con la función de alojar, colocar y trasladar inmigrantes (art. 8). Las Oficinas de trabajo y de colocación colaborarán con el Departamento de Inmigración de Buenos Aires y con las comisiones locales para atender los pedidos de "profesores, artesanos, jornaleros o labradores que se les hicieses" y "procurar condiciones ventajosas para la colocación de los inmigrantes" (art. 10) "en el arte, oficio o industria a que prefiriesen dedicarse" (art. 48).

El Departamento de Inmigración deberá «propender por todos los medios a su alcance a fomentar y facilitar la internación de inmigrantes en el Interior» (art. 3).

Todo inmigrante, siempre que "acreditase suficientemente su buena conducta y su aptitud para cualquier industria, arte u oficio útil", gozaba del derecho de ser alojado y mantenido a expensas del Estado durante los cinco días siguientes a su desembarco (art. 45). Además, el Poder Público se hacía también cargo de su traslado al lugar del país que eligiese como residencia. Por otra parte, cuando el inmigrante así lo desease, podía obtener ocupación a través de la Oficina del Trabajo. En caso de dirigirse al interior del país, y si en el lugar de destino había Comisión de Inmigración, esta debía otorgarle al inmigrante alojamiento y alimentación por un plazo de hasta diez días.

Los capítulos referidos a la Colonización eran siete. El primero de ellos creaba la Oficina de Tierras y Colonias, organismo encargado de centralizar la acción estatal. La ley preveía diversos sistemas: colonización directa por el Estado en territorios nacionales y en tierras cedidas por los gobiernos de provincia, colonización indirecta a través de empresas particulares en tierras ya mensuradas y divididas o en lugares que no hubieran sido explotados, colonización por iniciati- 
va individual, colonización de los gobiernos provinciales estimulados por el gobierno nacional y colonización por particulares amparados por el gobierno.

\section{La imagen del país}

Una vez sancionada la ley comenzó su difusión en todos los países, fundamentalmente en Europa, y allí, haciendo mayor hincapié en Italia y Austria. En estas dos naciones se nombraron agentes de inmigración que debían organizar las tareas relativas a hacer conocer a fondo las ventajas que ofrecía el gobierno argentino a toda persona que quisiera radicarse en este territorio para colonizarlo. Luego, el gobierno comenzó una agresiva campaña de captación de inmigrantes, reemplazando su tradicional política de fomento de la inmigración "espontánea" por otra de fuerte estímulo a través de medidas "artificiales" como el subsidio estatal de los pasajes. Se organizó un complejo plan de fomento: el Departamento de Inmigración se trasladó al área de Relaciones Exteriores y se creó una red de oficinas de Información y Propaganda en Europa. Esta tenía sede en París y oficinas en Londres, Basilea, Berlín, Bruselas y otras ciudades europeas. ${ }^{2}$ Las mismas actuaron desde el principio como asesoras del gobierno argentino y se encargaron de difundir, en los países donde estaban instaladas, los progresos habidos en Argentina. Con tal fin se distribuyeron folletos, se dictaron conferencias y se insertaron notas de interés en los periódicos.

La propaganda y difusión de conocimientos sobre la realidad productiva nacional formó parte del dispositivo de promoción y consolidación de la inmigración, como la publicación oficial Noticias útiles para inmigrantes, trabajadores y capitalistas.

\footnotetext{
2 En noviembre de 1886, la Comisión General de Inmigración y la Oficina de Tierras y Colonias pasaron al Ministerio de Relaciones Exteriores. El $1^{\circ}$ de enero de 1887 se crearon las Oficinas de Información y Propagandas. El 3 de noviembre de 1887 se establecieron los pasajes subsidiados (Ley 2.201) y se creó la Comisión Central de Inmigración (Ley 2.252). El 19 de septiembre de 1889 se otorgaron por decreto 5.000 pasajes subsidiados a estancieros, industriales y otros empresarios, con el fundamento de la necesidad de mano de obra. Citado por Bertoni, Lilia Ana, Patriotas, cosmopolitas y nacionalistas. La construcción de la nacionalidad argentina a fines del siglo XIX, Buenos Aires, FCE, 2001, p. 20.
} 


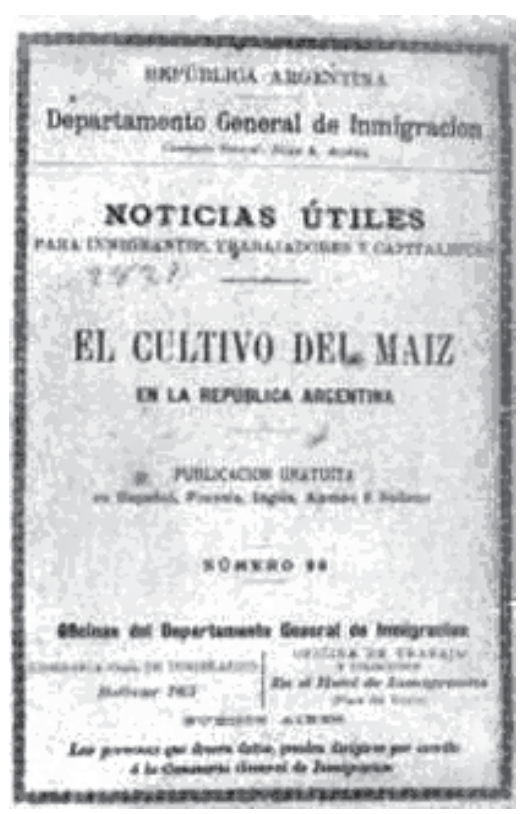

Fuente: Museo Nacional de la Inmigración, Buenos Aires.

La imagen de Argentina en 1880 era la de una sociedad que vivía un clima de enérgica confianza en el futuro.

La convicción de que se había entrado en una edad que rompía con el pasado fue característica del discurso del roquismo como parte de su imagen autolegitimante. Lo expresaba el presidente Julio A. Roca en 1883 cuando formuló votos por que

sea ésta nuestra aspiración pública, la paz y el orden; realicemos este programa, y la luz que empieza a irradiar sobre la República se convertirá en un foco que, cual otra estrella de Oriente anunciará al mundo que existe en este extremo Sur del continente americano, abarcando cuatro veces mayor espacio que la Francia y no menos fértil que ella, una nación abierta a todas las corrientes del espíritu, sin casta, sin preocupaciones religiosas ni sociales, sin tiranías ni comuna; nuevo templo sobre la faz de la tierra donde se consagran todas las libertades y todos los derechos del hombre ${ }^{3}$

\footnotetext{
${ }^{3}$ Botana, Natalio y Gallo, Ezequiel, De la República posible a la República verdadera (1889-1910), Buenos Aires, Ariel, 1997, p. 199.
} 
José Hernández, autor de Martín Fierro y entonces también legislador, afirmaba, con motivo del debate sobre la federalización de Buenos Aires:

He visto en los periódicos la noticia de la llegada de tres o cuatro vapores con un número considerable de inmigrantes. Esta es la única República sudamericana que recibe la inmigración europea en ese alto grado. ¿Por qué? Porque encuentra en nuestro país lo que ninguna República les ofrece. Encuentra un territorio fértil, un clima benigno, una producción valiosa, una legislación liberal, un erario generoso, una índole como es la índole argentina que no tiene grandes preocupaciones, no tiene fanatismos religiosos arraigados, ni esa resistencia nativa contra el extranjero tan común en todas partes. ${ }^{4}$

Los valores de progreso, paz, laicidad, seguridad y prosperidad, en torno a los cuales se había desplegado todo el aparato estratégico y político, debieron conjugarse con elementos que anteriormente habían sido señalados de manera reprobatoria. Como vemos en el discurso de Hernández, en el momento de auge de la inmigración europea se exaltan positivamente aquellos rasgos culturales que antes habían sido denostados, como la "índole argentina sin preocupaciones", antes llamada "holgazanería" y encarnada, sobre todo, por la figura del gaucho o criollo pobre. Asimismo, el territorio que había sido señalado como un desierto causante de la barbarie fue transmutado discursivamente en "fértil" y de "clima benigno", atrayente para los colonos europeos portadores de la fuerza de trabajo de la que, se había dicho, carecía la población autóctona.

La fuerza de estas imágenes hegemónicas no ocluía otras preocupaciones provenientes de los sectores subalternos de la sociedad porteña.

Juan Patroni, un obrero gráfico argentino, se interesó especialmente por la propaganda que se hacía en el exterior sobre las bondades y potencialidades de la República Argentina. Con un tono de reclamo por la utilización de fondos públicos para contar con mano de obra que era demandada por el sector privado, ofrece un catálogo de los folletos impresos para ser distribuidos en las comarcas europeas

4 Ídem, p. 137. 
conteniendo las Noticias útiles para inmigrantes, publicado por el Departamento General de Inmigración y repartido por millones en el viejo continente. Este obrero pudo reunir 120 folletos publicados en varios idiomas -español, francés, inglés, alemán, italiano, dinamarqués- que explicaban los adelantos de las industrias y comercios en las provincias argentinas, de la cría del ganado, de la minería, de la vitivinicultura, del algodón, del cultivo de cereales y su aprovechamiento industrial, del desarrollo de la instrucción primaria y la educación en general en todo el país. Con estos materiales a la vista, reflexiona:

hemos tenido la oportunidad de leer algunos de estos folletos, que tan profusamente han circulado por el viejo mundo, y que confesamos que si en vez de ser americanos, nos hubiéramos hallado en alguna de aquellas aldeas, llegando a nuestras manos programas tan halagadores hubiéramos hecho cualquier sacrificio, a fin de venir a esta nueva tierra de promisión.

Continúa Patroni su descripción descarnada, que dará origen a su texto "Los trabajadores en la Argentina", con la clara intención de ilustrar las duras condiciones de vida y el malestar de los obreros en el país.

Después de leer esas clásicas descripciones, uno se apercibe como es que han venido, y aún siguen viniendo a millares, los campesinos europeos; tampoco debe extrañarnos que los que vienen estibados en grandes trasatlánticos, al divisar la Iontananza de la costa Argentina, crean sinceramente hallarse a pasos de la tierra de promisión solada y hábilmente descripta en los libritos leídos allá, en el fondo de la cabaña.

Concluye su presentación denunciando a la clase capitalista que "con el dinero del pueblo engañan a nuestros hermanos los trabajadores del viejo mundo", ya que en Europa circulan "esas leyendas y la asquerosa propaganda que también realizan los agentes de las compañías de navegación" mintiendo e ilusionando con datos falsos que seducen a los trabajadores, para finalmente explicar: 
nosotros deseamos que vengan millones de inmigrantes, puesto que el país los necesita; pero queremos que esa pobre gente, antes de abandonar el terruño, sepa en qué condiciones nos hallamos los trabajadores en la Argentina. ${ }^{5}$

\section{Las puertas de salida}

La presencia y las gestiones realizadas por las oficinas de información en Francia serán un artífice vital en los traslados de los primeros contingentes judíos de Rusia a nuestro país. La memoria judía argentina reconoce como el hito fundante del proceso migratorio la llegada de los pasajeros del Weser que partió de Bremen, Alemania, en 1889, a partir de los contactos e intermediación de la Agencia de Emigración y Colonización en París. La delegación de Kámenetz-Podolia encabezada por Lázaro Kaufman había tomado contacto con la Oficina oficial de informaciones de la República Argentina (Bureau officiel d'informations de la République Argentine) que hacía intensa propaganda a favor de la emigración. Allí se iniciaron los contactos de esa primera expedición que estaría signada por fuertes desengaños.

Esta oficina estaba a cargo de Pedro S. Lamas, redactor en jefe de la Revue SudAmericaine y que justamente ese año había publicado un folleto titulado "Notice sus les conditions et formalités de l'emigration pour la République Argentine", donde informaba sobre la posibilidad de compra de tierras y la hospitalidad propugnada por el gobierno nacional. Kaufman se dirigió a la Agencia de Emigración y Colonización para la República Argentina y tomó contacto con el agente del gobierno argentino, J. B. Frank, quien ofreció en venta las tierras de propiedad de Rafael Hernández. Luego se iniciaron los trámites para que las 120 familias de judíos rusos que él representaba pudieran trasladarse a Argentina. Convinieron que cada uno de los colonos abonaría cuatrocientos francos "a deducir de la suma principal de 3.000 francos, importe de la concesión de un lote de terreno de 25 hectáreas" ${ }^{6}$. El propietario se compro-

\footnotetext{
${ }^{5}$ Patroni, Adrián, Los trabajadores en la Argentina, Buenos Aires, Imprenta, Litografía y Encuadernación Chacabuco 664 y 67, 1897.

${ }^{6}$ Se estableció asimismo que la mitad de ese total debería ser amortizado en 22 anualidades por intermedio del Banco Hipotecario, con un interés del 2\% anual, y el resto en cuotas anuales, con el interés corriente en la vida comercial de Buenos Aires. En Schallman, Lázaro, Orígenes de la colonización agrícola judía en la Argentina, Buenos Aires, Instituto Judío Argentino de cultura e información, 1964.
} 
metía a facilitar al colono una vivienda temporaria, los elementos necesarios para su manutención en los primeros tiempos y todos los útiles e implementos de labranzas indispensables. El futuro colono se comprometía a reembolsar el importe de estos en cuotas a largo plazo, si bien se reservaba expresamente el derecho a saldar la totalidad de la deuda con toda la anticipación que deseara.

A los preparativos para el viaje no les faltaron inconvenientes ni peripecias de todo tipo. Los emigrantes provenían de las aldeas y pueblitos de Podolia y Besarabia. Cruzaron las fronteras de Rusia en pequeños grupos y se concentraron en Berlín. De allí se trasladaron a Hamburgo, donde aguardaron las instrucciones que el Consulado Argentino de París establecería para el traslado.

Las noticias sobre Argentina no eran nada halagüeñas. El gran Rabino de Berlín, Azriel Hildesheimer, les advertía sobre los peligros del viaje y la radicación en un país tan alejado y desconocido. Un colaborador del Gran Rabino, Sigmund Simmel, intercedió en este escenario trasladándose a París para cerciorarse sobre las condiciones para la emigración, y a su regreso comunicó a los "Podolier» que, a juzgar por informaciones fehacientes, "la Argentina era un país ejemplarmente libre, en el que podrían seguir profesando sin entorpecimiento alguno la fe judaica y labrarse un futuro próspero" ${ }^{7}$.

\section{La travesía}

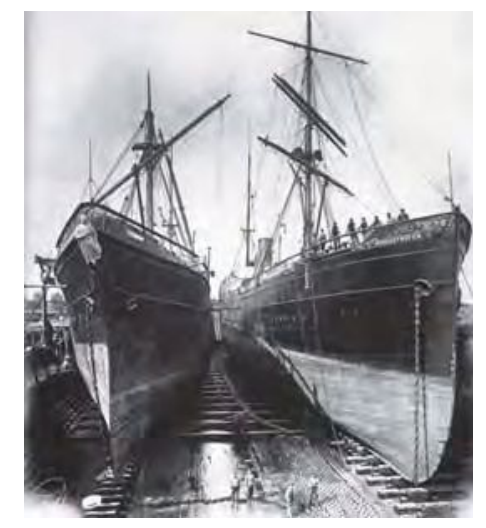

El Wesser

Una larga travesía pondría a distancia la tierra de origen. El idish, la lengua de los inmigrantes, recoge la palabra Argentina, en idish cantan y lloran la partida. El poeta judío Moishe Dovid Guiser capta el sentimiento de congoja por el desarraigo:

\footnotetext{
${ }^{7}$ Schallman, Lázaro, op. cit., p. 4.
} 


\begin{abstract}
¡Capitán, capitán! Ven a nuestro camarote
cuando duermen los ánimos cansados, cuando el aliento de pueblos se une y mezcla

y el aire se hace una encendida llamarada y comienzan a sollozar hasta los muros de acero

y las cuchetas chorrean lágrimas ardientes, y doloridos se quejan y rechinan los lechos de paja deseosos de que los escuche alguno al menos.
\end{abstract}

¡Capitán, capitán! Cómo puedes dormir ahora sin ser torturado por las oscuras imágenes que aparecen en sueños y que exigen airadas por aquellos que en sus propios lechos desnudos, sarnosos, no encuentran consuelo, ¡Capitán...! ¡Capitán.... ${ }^{8}$

Congoja e incertidumbres. ¿Cómo será la vida en esta nueva y lejana tierra? ¿Cómo se hace para aprender a hablar, pensar y hasta soñar en un idioma que no es el propio? ¿Cómo se hace para decirle adiós al pasado, para despedirse de aquellos a los que se siente y sabe que no se volverá a ver más? Todos vinieron buscando el amparo del techo, del pan, de la ilusión bajo la solemne protección de la Cruz del Sur. ${ }^{9}$

\title{
El Hotel de Inmigrantes
}

El 14 de agosto de 1889, embarcados en el Weser, arribaron a Buenos Aires y comenzaron los nuevos inconvenientes. Las tierras prometidas en la Colonia «Nueva Plata" ya no están disponibles. Nunca se pudo determinar si por responsabili-

\footnotetext{
${ }^{8}$ En Toker, Eliahu (selección y traducción), El resplandor de la palabra judía. Antología de la poesía ídish del siglo XX, Buenos Aires, Pardés, 1981. Original en ídish: Dos gezang fun a lebn (Canto de una vida), Buenos Aires, Tzentral Farband fun polishe idn in Arguentine, 1953.

${ }^{9}$ Estas son algunas de las reflexiones que nos traslada Silvia C. Fairman, en su libro Mate y Samovar, Buenos Aires, Lumen, 2000, p. 9.
} 
dad de Frank o de Hernández, que a los efectos ya no era importante, pues los únicos perjudicados eran los inmigrantes judíos. La Dirección de Inmigración toma cartas en el asunto en la búsqueda de nuevas tierras, el gobierno nacional devuelve a los recién llegados la suma que habían abonado y estos se quedan en "la Casa de Inmigrantes, solitarios, aislados, sin perspectivas..."10.

La desesperación de los recién llegados era indecible. Carecían de recursos y se encontraban en un país que les era totalmente extraño. Ignoraban el idioma y no sabían a quién dirigirse en busca de ayuda. Se explica que anduvieran abatidos por las calles de la ciudad como perdidos en un desierto. Para colmo de las desgracias, el 23 de agosto se produjo una fuerte marejada del río y cayeron aguaceros fuertes y seguidos que anegaron parte de la ciudad, obligando a los "podolier" a recluirse en la barraca de madera que hacía las veces del Hotel de Inmigrantes. ${ }^{11}$

El creciente flujo inmigratorio exigía en forma permanente la apertura de nuevos alojamientos en Buenos Aires, por lo cual se decidió acondicionar las instalaciones de lo que había sido el Panorama del Retiro -conocido como "La Rotonda"-, edificio de madera y forma octogonal. Hacia allí eran trasladados los recién llegados desde el desembarcadero, edificio que era también insuficiente para hacer frente a las nuevas necesidades. Fue planeado para albergar a unas ochocientas personas y su función era proteger al «recién venido desde su llegada hasta que sea colocado a su gusto, desembarcándolo con su bagaje gratis, dándole casa y comida y libre pasaje por ferrocarril y vapor ${ }^{12}$.

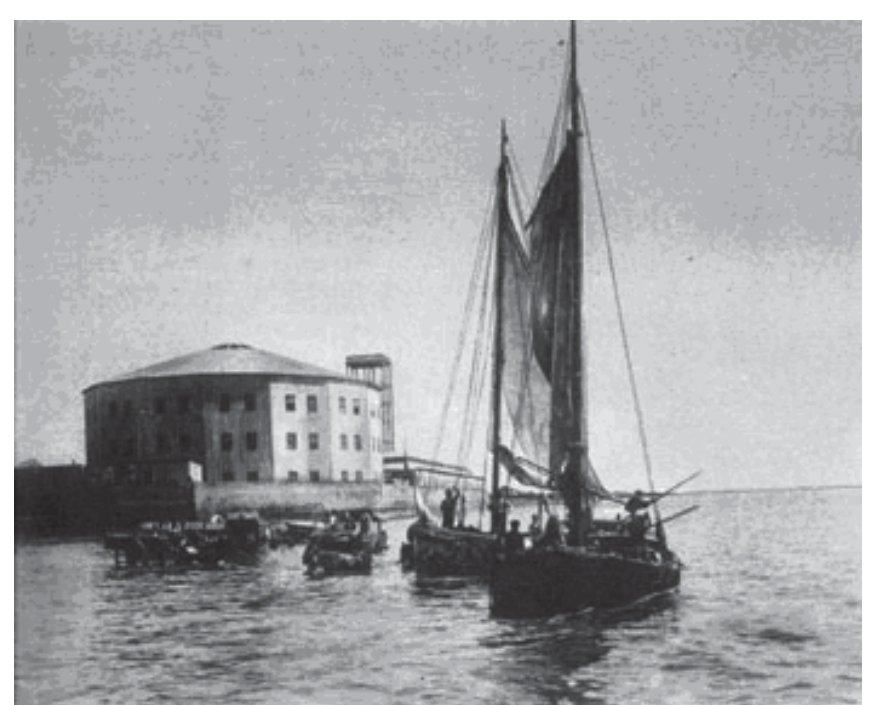

Primer hotel de inmigrantes

\footnotetext{
${ }^{10}$ Mendelson, José, "Génesis de la colonia judía en la Argentina", en 50 años de colonización judía en la Argentina, Buenos Aires, DAIA, 1939, p. 113.

${ }^{11}$ Schallman, Lázaro, op. cit., p. 5.

12 Mulhall, M. G., Manual de las Repúblicas del Plata, Buenos Aires, Imprenta del Standard, Londres, Edward Stanford, 1876, p. 24.
} 


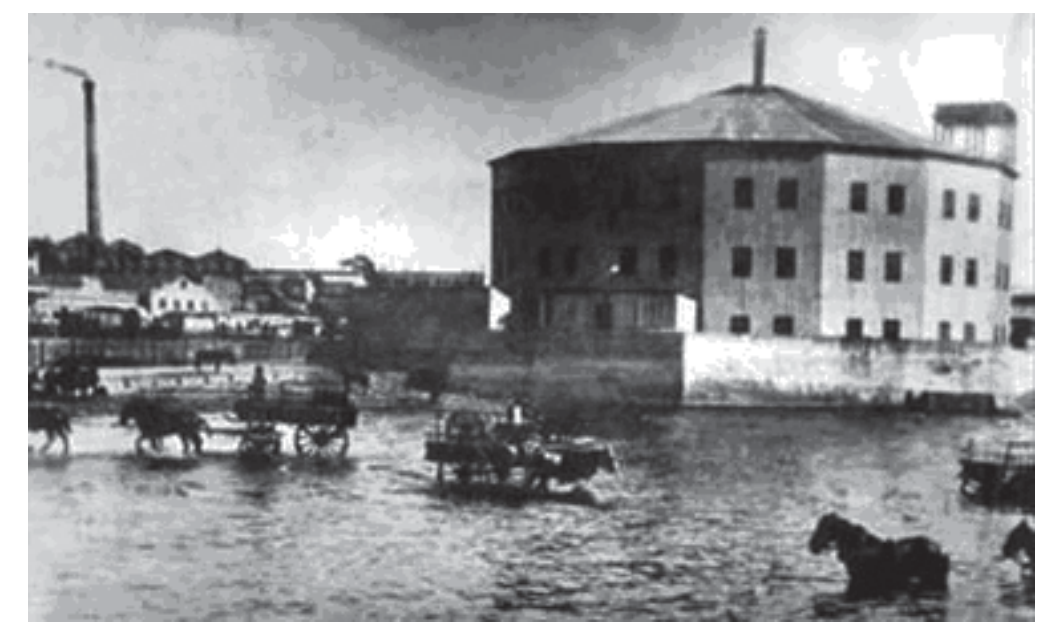

El edificio, preparado por el ingeniero Stavelius - miembro del Departamento de Ingenieros-, construido en tres pisos, en madera y hierro, empleó para su base la estructura de una rotonda de hierro que había servido para el antiguo Panorama emplazado en el Retiro. La forma resultante fue un polígono de dieciséis lados. El conjunto se integró con otro edificio alargado, orientado de Norte a Sur sobre la ribera, donde se hallaban las cocinas, comedores y oficinas de administración, patio y gran tanque de agua.

Este Hotel de Inmigrantes estaba en pésimas condiciones, situación que contrastaba fuertemente con las promesas de la Ley de Inmigración y Colonización. Con fecha 22 de octubre de 1889, el Poder Ejecutivo informó al Congreso de la Nación que

la barraca de madera que presta provisionalmente el servicio de hospedaje, tiene capacidad escasa para 2.500 personas y el número de inmigrantes que llega, obliga a hospedar a 6 a 8 mil, con todas las dificultades, gastos excesivos y privaciones que el más estricto servicio no puede evitar y con graves peligros para la higiene de la casa y de la ciudad.

La memoria de la Dirección de Inmigración explica:

En el año que transcurre [1889], se ha producido el caso de ocuparlo cinco mil inmigrantes en un día y eso que, el Hotel; tiene todos los inconvenientes y ofrece todos los peligros que V. E. puede imaginar... ${ }^{13}$

13 "Memoria de la Dirección de Inmigración 1889", en Ochoa de Eguileor, Jorge, ¿Dónde durmieron nuestros abuelos. Los hoteles de inmigrantes de la ciudad de Buenos Aires, Buenos Aires, ICOMOS, 2000. 
En 1889 se aprobó finalmente la construcción del edificio que debía ser la imagen tangible de una "patria de prosperidad" prometida al inmigrante. Sin embargo, las obras no comenzaron hasta 1906 y se prolongaron durante cinco años. Durante ese período, la opinión pública, a través de la prensa y la literatura, había criticado sistemáticamente el "asilo" de La Rotonda, caracterizado de "vergüenza pública" o "pajarera feroz". ${ }^{14}$

\section{La pampa santafesina}

Los pasajeros del Weser, estando alojados en el "Hotel" de Inmigrantes, recibieron el socorro del rabino de la incipiente colectividad judía radicada en Buenos Aires, Henry Joseph, que estaba vinculado a un rico terrateniente de la provincia de Santa Fe, el Dr. Pedro Palacios, quien ofrecía colonizarlos en los campos de su propiedad. A once días del desembarco en Buenos Aires, casi la totalidad de esos inmigrantes firmaron con José G. Palacios, apoderado general del dueño de las tierras, los respectivos boletos de compra-venta. Estos contratos fueron leoninos: fijaban el precio de 1.000 pesos para cada concesión de 25 hectáreas, lo que representaba un promedio de 40 pesos por hectárea, una enormidad, pues en aquella zona se vendía entonces la tierra a razón de 5 a 10 pesos la hectárea. Los contratos fijaban un plazo de seis años para el pago de esa suma y un interés anual del 8\%.

La arbitrariedad de este compromiso se extendía hasta límites increíbles, sobre los cuales los inmigrantes no tomaron cuenta en el momento de firmar, confiados en la buena fe y moral del colonizador y más aun en el aval del rabino Joseph como testigo del acto. Los colonos debieron suscribir pagarés por el capital más los intereses. En caso de no pagar los documentos en sus respectivos vencimientos, abonarían el $12 \%$ por interés penal, capitalizable cada año por las cantidades que hubiesen vencido. Como si esto fuera poco, se establecía que

\footnotetext{
${ }^{14}$ Gerstner, Laura Oliva, Biblio 3W. Revista Bibliográfica de Geografía y Ciencias Sociales, Universidad de Barcelona, Vol. XIII, № 779, 25 de marzo de 2008.
} 
si vencido el primer año el comprador no hubiese arado la tierra, no hubiese llenado la condición relativa a la plantación de árboles y no hubiese pagado la multa estipulada para ese caso, ni abonado la cuota correspondiente a la primera anualidad, el propietario tendrá derecho a rescindir el contrato, quedando a su favor la cuota que se hubiera entregado al firmar el boleto y lo que hubiera hecho o construido en el terreno, como indemnización de daños y perjuicios. ${ }^{15}$

En los primeros días de septiembre partieron sin titubeo, en vapor, para Rosario, y desde allí en tren hasta las proximidades de la Estación Palacios.

La primera impresión que recogieron al descender del tren fue desoladora: no había allí casa alguna, ni siquiera una carpa. Por indicación del mayordomo de Palacios, algunas familias fueron alojadas en destartalados vagones de carga que estaban estacionados al lado de las vías férreas en construcción y otras, en un galpón viejo y maloliente. Nada de lo pactado se cumplió. No fueron trasladados a las tierras adquiridas ni se les brindaron las viviendas y útiles de labranzas prometidos. El hambre y la miseria fueron la nota cotidiana. Se propagaron enfermedades, lo que condujo a la muerte a cincuenta niños.

La desolación llevó a que algunos de los colonos se dirigieran a Monigotes. Otros, que contaban con recursos, se establecieron en Sunchales, donde instalaron pequeños comercios. Otros optaron por volver a Buenos Aires o marcharon a Rosario y a Santa Fe. Un pequeño núcleo de los inmigrantes se quedó firme en las tierras de Palacios, por fortaleza o intransigencia, o quizás por que no podían separarse de los restos de sus hijos muertos, enterrados en el cementerio inaugurado con ellos. ${ }^{16}$

La situación de desamparo y miseria de este contingente fue advertida por Wilhelm Loewenthal, de paso en el país cumpliendo con una misión de estudio

${ }^{15}$ En hoja aparte el colonizador se comprometía a suministrar animales y herramientas a los futuros colonos y los medios de subsistencia hasta la primera cosecha. Parece que la no inclusión de estas obligaciones en el boleto de compra-venta propiamente dicho hubiera respondido a un propósito sutil de escamoteo que se cumplió en perjuicio de los colonos. En Schallman, Lázaro, Orígenes de la colonización agrícola, op. cit, p. 6.

${ }^{16}$ David Goldman, en su Historia de los judíos, relata este hecho trágico que ha sido repetido y trasmitido de generación en generación. Era tanta la pobreza y precariedad de la vida que, "aunque parezca increí- 


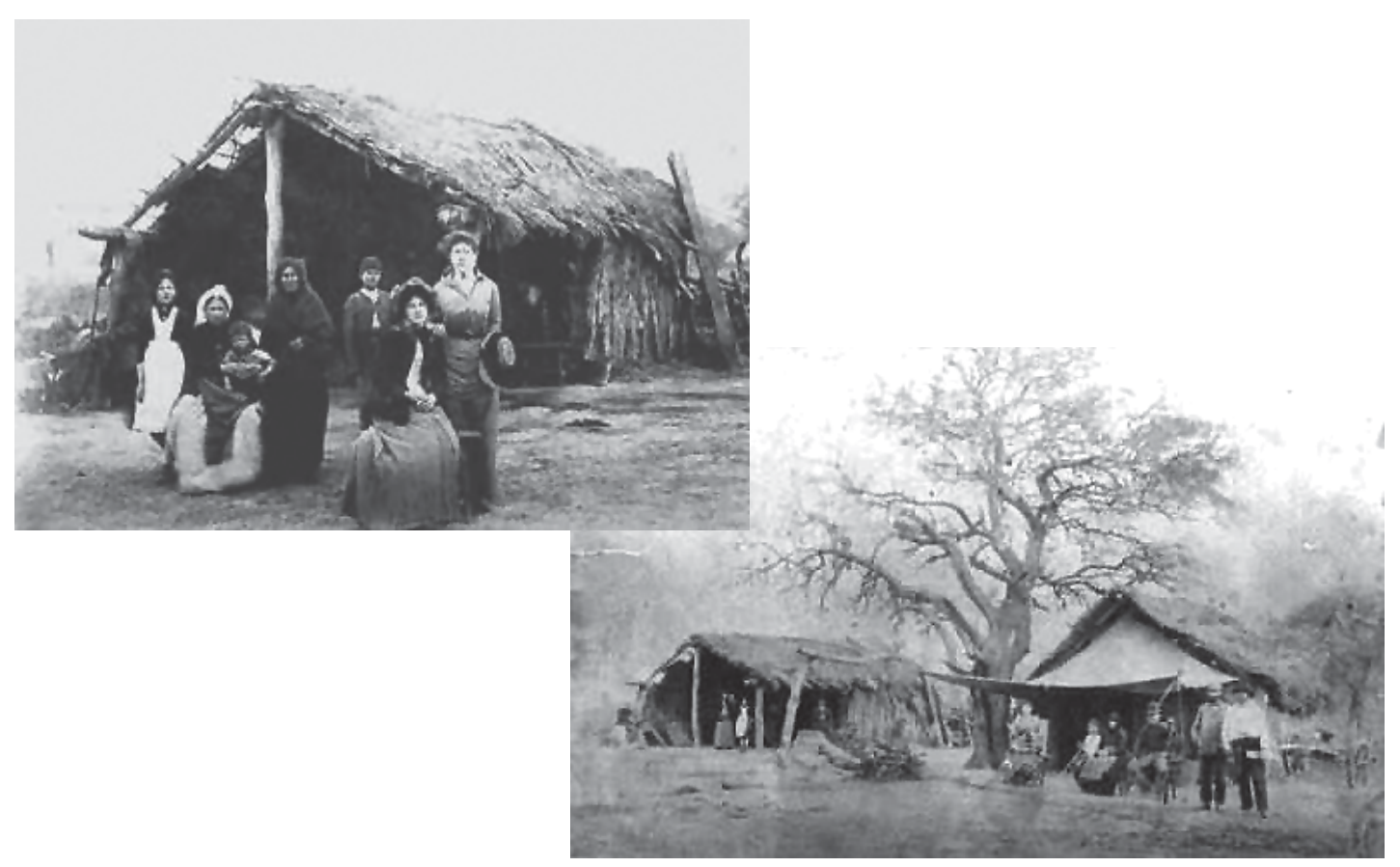

Familias Leibovich y Guibert, fotografía de Ernesto Schlie, 1890.

encomendada por el gobierno argentino, quien solicita la intervención del Ministerio de Relaciones Exteriores de la Nación. El ministro Dr. Estanislao Zeballos dio orden inmediata al Comisario General de Inmigración de que averiguara sin demoras "las causas que habían producido la difícil situación de estos inmigrantes que estaban sufriendo muchas necesidades ${ }^{17}$.

La imagen desoladora acompañó a Loewenthal, quien tomó el destino de estas personas en sus manos hasta conseguir, un tiempo después, el apoyo del barón de Hirsch.

Esta experiencia penosa nutrió la memoria que recuerda los inicios de la colonización judía en Argentina. El hambre, la miseria, el abandono, la soledad en el "desierto" de Palacios, como un tributo de dolor a la tierra con la vida de los pequeños, tuvieron un eco permanente en el relato de la génesis de una gesta heroica de los pioneros.

Los dos cementerios, el de Palacios y el Monigotes, luego un tercero en el villorio de Moisés Ville, fueron las anclas a la tierra santafesina. En este último estaba enterrada una nueva víctima, Gerson Gerchunoff, apuñalado por un matrero gaucho.

\footnotetext{
${ }^{17}$ La Nación, 29 de octubre de 1889.
} 
Ya antes habíanse reunido los judíos en la sinagoga y juraron no irse de allí y transportar al campo santo de Moisesville los restos mortales de los niños sepultados en cementerios Palacios y Monigotes. ${ }^{18}$

El juramento fue cumplido gracias a la tenacidad de Loewenthal y del barón de Hirsch, que hizo comprar los campos de Palacios en 1891. Recuerda Mendelson:

Todo eso fue lo que salvó a Moisesville, lo que lo convirtió en un centro judío. Esos difuntos y el trabajo judío, el sudor, el esfuerzo, las alegrías y los dolores, así como la sangre de sus víctimas caídas, fueron los que fecundaron las hasta entonces desoladas pampas de la provincia de Santa Fe y lo que permitió que en el curso de los años surgiere una hermosa población agrícola judía y que naciese Moisesville, el pueblo más judío de las colonias israelitas de la Argentina; el más judío, decimos sin que esto aminore ni disminuya en nada su carácter netamente argentino.

¡Cuán bello y exacto ha resultado -lo vemos ahora, a cincuenta años- el aforismo talmúdico que señala: Si encuentras un camposanto en un lugar yermo, sabe que cerca de allí llegarás a un poblado! ${ }^{19}$

Dolor fundante y experiencia dramática que se entrecruzan con elementos de la cultura judía dan forma al mito originario portador de la fortaleza que fue necesaria para la integración al suelo argentino.

El tiempo era frío y los niños comenzaron a enfermarse; no contaban con atención médica y no es de extrañarse que a las pocas semanas los inmigrantes tuvieran la tremenda desgracia de llorar a 64 niños fallecidos. De esa manera se colocó el fundamento de una comunidad judía: con un cementerio. ${ }^{20}$

La mirada atenta de Wilhelm Loewenthal por la suerte de los pasajeros del Weser no fue casual. Isidore Loeb, en nombre de la "Alliance», le había trasladado la inquietud sobre la suerte de estos inmigrantes en París, al tomar conocimiento de su

\footnotetext{
${ }^{18}$ Mendelson, José, Génesis de la colonia judía en la Argentina, op. cit., p. 117.

19 Ibídem, p. 118.

${ }^{20}$ Cociovich, Noé, Génesis de Moises Ville, Buenos Aires, Milá, 1987.
} 
próximo viaje a Argentina. Lo mismo le había solicitado su amigo Sigmund Simmel de Berlín. Fue así que, al conocer la situación de abandono, solicita la intervención del Ministerio de Relaciones Exteriores y se entrevista con Palacios, encareciéndole el cumplimiento de sus obligaciones contractuales. Días después se embarca rumbo a Europa y al llegar a París solicita la intervención del Gran Rabino ZadocKahn, y por su intermedio de la Alliance Israélite Universelle, a favor de los inmigrantes que sufrían hambre en Palacios.

En su memorándum del 12 de diciembre de 1889, presenta a la República Argentina como un país singularmente propicio para su iniciativa, haciendo mérito de la inmensa extensión que ofrecía todas las posibilidades imaginables a una población que no pasaba de tres millones de almas, señalando asimismo la salubridad del clima, la fertilidad de la tierra, la facilidad del cultivo hasta para los colonos más inexpertos, el liberalismo del régimen político, las ventajas que ofrecían las leyes del país a los inmigrantes interesados en el trabajo del campo, el éxito de las colonias bien administradas.

Concluye su presentación descontando el éxito de la colonización de principalmente judíos rusos:

a quienes la ley, en sus países respectivos, prohibía el trabajo y los oficios rurales; ellos hallarían en la República Argentina un trabajo libre, fácil, honesto y remunerador; auguraba a esas colonias un porvenir tal que vendría a ser un refugio sólido y perdurable para todos los oprimidos, y afirmaba que la prosperidad de las mismas sería el comienzo de una nueva era destinada a hacer época, algún día, en los anales de la civilización, no judía , sino humana. ${ }^{21}$

El proyecto colonizador ideado por Loewenthal se asentaba en la posibilidad de una inmigración anual de cinco mil personas al principio y diez mil después, a las que se les daría una chacra de cincuenta a cien hectáreas con los implementos necesarios para su instalación. Haciendo números llega a la conclusión de que

\footnotetext{
${ }^{21}$ Shallman, Lázaro, "Evocación de una figura olvidada de la colonización judía”, en Mundo israelita, 27 de agosto de 1960.
} 
con un millón de francos era factible colonizar anualmente a no menos de cien familias, un total de mil personas. Yendo más lejos, deja reseñado que si se disponía de un capital inicial de cincuenta millones de francos se podía colonizar en breve plazo a cinco mil familias. Era la misma cifra que había ofrecido el barón de Hirsch para la creación de escuelas especiales para los judíos en el imperio zarista.

Por lo tanto, no era descabellada la idea, ni la presunción de que se podría contar con el apoyo generoso del barón para llevar a cabo el proyecto colonizador en la República Argentina. En Gran Rabino recibió con simpatía la propuesta, sin embargo la Alliance la rechazó de plano. Esta institución no era proclive a la emigración de grandes masas de judíos de Rusia ni de ningún país de Europa oriental, pues insistía que era preferible ayudarlos a mejorar sus condiciones de vida en los países de origen con los medios necesarios para su educación espiritual y profesional. Sin embargo, y considerando que era "difícilmente realizable», ${ }^{22}$ eleva la propuesta de Loewenthal al barón de Hirsch.

Mauricio de Hirsch recibió con beneplácito el proyecto, coincidente con su propósito de encarar la ayuda por fuera del sistema de la caridad, con el ideal de la filantropía, ya que "sólo así puede aliviarse el sufrimiento de los seres humanos a quienes el destino ha tratado con dureza, y transformarlos en seres útiles a la sociedad" ${ }^{23}$.

La muerte de su hijo Lucien, en 1887, ya lo había decidido a "hacer del pueblo judío el principal heredero de su fortuna». En este contexto llega el proyecto de Loewenthal, pronunciando la expresión que signa la experiencia colonizadora argentina y que es repetida como un rezo en cualquier acto importante de memoria: "He perdido a mi hijo, pero no a mi heredero. La humanidad recibirá mi herencia».

Comunica su aprobación del proyecto por carta a la Alliance, fechada en Londres el 20 de enero de 1890, donde manifiesta su disposición para fundar grandes colonias en la Argentina que convertirán a este país «en el hogar de aquellos de nuestros correligionarios que se viesen obligados a buscar refugio en países lejanos, con el fin de forjarse una vida nueva, lejos de los horrores de su país natal». ${ }^{24}$

\footnotetext{
22 Acta de la sesión del 23 de enero de 1890 celebrada en París.

${ }^{23}$ North American Review, № 416, julio de 1891.

${ }^{24}$ Leven, Narcisse, Cinquante ans d'historie, Tomo II, París, París, 1920, p. 475.
} 
Decide enviar una misión a la Argentina constituida por hombres expertos, encargados de estudiar en el terrero la mejor forma que debería adoptar el sistema de colonización y los requerimientos prácticos para poner en marcha cuanto antes el traslado de la población.

La misión -integrada por Loewenthal, Cullen, Vanvinkeroy- recibe precisas instrucciones en cuanto a la decisión de Hirsch de ayudar a los israelitas de Rusia a partir de generar las condiciones para la emigración de la opresión zarista, adquirir tierras para instalarlos en América del Sur y en particular en la Argentina, ya que ofrecían las condiciones necesarias para el desarrollo y éxito de la experiencia colonizadora, y esta empresa, puramente filantrópica en sus comienzos, tendría que organizarse y conducirse como un negocio en que los capitales invertidos obtuvieran la acostumbrada remuneración y que los beneficios logrados sirvieran para desarroIlar la obra y ampliarla en beneficio del mayor número de emigrantes. ${ }^{25}$

La misión parte el 14 de octubre de 1890 con las «Instrucciones para la misión argentina". El octavo punto se refería concretamente a los "polonier»:

Ruego investigar la situación de los judíos rusos que emigraron últimamente a la Argentina y la mayor parte de los cuales están establecidos sobre los campos del Dr. Palacios, y que se nos informe, si hay lugar, acerca de los medios para ayudarles, si es que es necesario ayudarles. ${ }^{26}$

\section{Nace Moisés Ville}

Entre tanto, el Dr. Palacios comienza a realizar algunas gestiones para la instalación de los colonos. Un dato importante fue el nombramiento de D. Hurwitz como mayordomo, quien sirvió de puen-

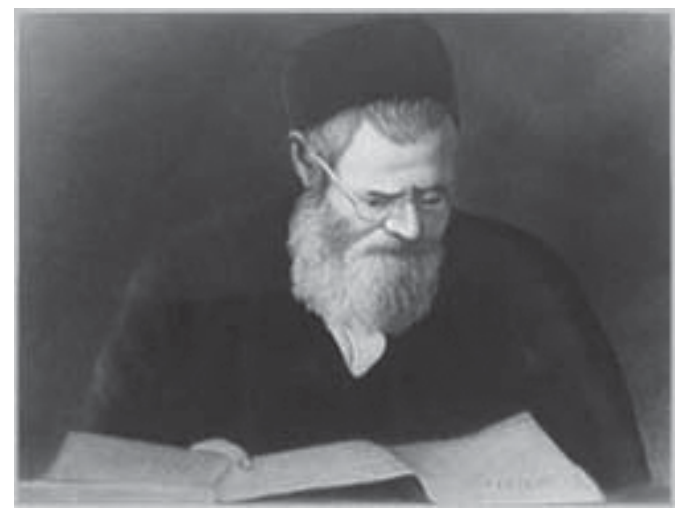

\footnotetext{
25 Ibídem.

${ }^{26}$ Archivo JCA, citado también por Mendelson. José, Génesis de la colonia judía en la Argentina.
} 
te lingüístico. Los colonos podían entenderse con él en idish y por su intermedio con Palacios.

David Goldman relata en su Historia de los Judíos que "a cada familia se le dio una carpa de lona gruesa y resistente y postes de hierro hundidos bien adentro en el suelo" como vivienda. Una colonización sin casas. Tan sólo se construye una de lampacho y se entrega al Rabí Goldman, rabino integrante del grupo. Más tarde los colonos construyen sus casas de barro y paja, cuando les entregan sus lotes sin alambrados.

Cuando el propietario empezó a instalarnos, entregó a uno un par de bueyes, a otros el yugo y a un tercero las lonjas. No había nada que hacer. Los campos no estaban alambrados todavía y los bueyes chúcaros se escapaban. ${ }^{27}$

El primer año de instalación concentra todas las penurias posibles. Los "colonos de Palacios" fueron un emblema de la sobrevivencia. Algunos consiguieron trabajar como medieros en las estancias de Ortiz o Rodríguez (tierras luego adquiridas por la JCA), otros como jornales en la recolección de cosechas. Los de familias numerosas se desmembraron hacia las ciudades y pudieron enviar remesas de dinero a los que quedaron en la chacra.

Mas el nombre de la localización era una promesa. Moisés Ville fue el nombre elegido para dar un anclaje en la tradición judía y para renovar los votos a una nueva epopeya fundante.

A fines de noviembre, ante la visita del Dr. Palacios y su familia, todas las familias encabezadas por el rabino Goldman salieron a su encuentro y lo recibieron con pan y sal. Con la traducción de Hurwitz se establece un diálogo:

- ¿Cómo quisieran ustedes que se llamara la colonia? - preguntó, dirigiéndose al rabino Goldman.

-Kiriath Moische (Villa Moisés). Moisés sacó a los judíos de las penurias del Egipto y los condujo hacia un país propio. Nosotros, después de haber salido de la Rusia

\footnotetext{
${ }^{27}$ Mendelson. José, Génesis de la colonia judía en la Argentina, op. cit., pp. 66-67.
} 
Zarista y después de haber llegado a la libre Argentina nos sentimos, a semejanza de nuestros lejanos antepasados, en un lugar que será nuestra patria. -Que la colonia lleve, pues, el nombre de "Villa Moisés" -respondió Goldman en idish. A partir de la traducción de Hurwitz, que gustó a Palacios, se funda "Moisesville».

En Europa se seguía con vivo interés el destino de estos colonos, reforzando y apurando el establecimiento de un sistema de colonización, ahora organizado, bajo la dirección del barón de Hirsch. La memoria judía fija esta experiencia como el hito fundacional de la colonización judía en Argentina, con todo el dramatismo que tuvo.

La misión de Loewenthal en Argentina cumple con los objetivos trazados. Visita a los colonos de Palacios con el doble propósito de conocer sus condiciones de vida e informarles de la puesta en marcha del proyecto colonizador. Se dedica de lleno a las tratativas con el gobierno para la adquisición de tierras fiscales en las distintas provincias del país. En marzo de 1891 adquiere las tierras en las inmediaciones de la estación Carlos Casares, en la provincia de Buenos Aires -futura Colonia Mauricio-, momento clave en que se acentuó la emigración caótica de los judíos rusos que empezaban a concentrarse en las ciudades limítrofes de Galitzia, en los puestos de Alemania y en Constantinopla, hacia donde las masas afluían desde la Rusia meridional, a través de Odesa, con la esperanza de poder llegar a Palestina.

Regresa Loewenthal a Moisesville con las noticias de la adquisición de las primeras tierras en Argentina, acontecimiento festejado con verdadera alegría. Los pioneros de Palacios se reúnen en la sinagoga para hacer la bendición del comienzo y recitan el "halel». Era el mes de Adar, que, según la tradición, está destinado a la alegría. Reinó, pues, un verdadero júbilo entre las decenas de familias de los sufridos "pioneers", empeñados en erigir una población civilizada en medio de la desolada pampa santafecina. ${ }^{28}$

Se reúnen luego en asambleas y deciden fundar una asociación de carácter cooperativo para administrar el primer préstamo de dinero -quince mil francosotorgado por el barón de Hirsch para el desarrollo del plan colonizador. Nace de este modo la "Sociedad cooperativa de agricultores de Moisesville", precursora de

\footnotetext{
${ }^{28}$ Mendelson, J., Génesis de la colonia judía en la Argentina, op. cit., p. 141.
} 
"La Mutua Agrícola". Luego de arduas tratativas con Palacios, queda concertada la adquisición de Moisesville el 19 de noviembre de 1891. Es la segunda propiedad adquirida por la JCA, que en primera instancia obtiene diez mil hectáreas, para completar luego las 118.262.

A fines de 1891 se adquieren tierras en Entre Ríos, donde algunos meses después se fundarán Colonia Clara y San Antonio.

La situación europea era cada vez más difícil y los clamores se difundían en los diversos comités de socorro de París, Berlín, Hamburgo y Constantinopla y en las oficinas del barón Hirsch en París. Se acelera entonces la emigración y se la encausa hacia Argentina. El 18 de agosto de 1891 Ilega el Lisboa, trayendo 323 inmigrantes. El 25 de agosto el Tiyuca, con 338 pasajeros que serán localizados en Colonia Mauricio, San Antonio y Moisés Ville.

Dos núcleos de inmigrantes judíos, cuyo número no excedía los 150, habían arribado el 6 de agosto de 1891 en los vapores Río Negro y Rosario, del Lloyd Alemán. A juzgar por la prensa periódica, no se trataban de judíos rusos ni fueron reclutados por las JCA. La prensa porteña describe así la llegada de estos pasajeros:

El grupo es de lo más pintoresco y abigarrado, así por la razón de la edad como por la variedad de los tipos de los trajes y de los idiomas que hablan. Difícilmente podría descubrirse, al través de tanto elemento heterogéneo, los rasgos característicos de la raza semítica [...] El mayor número de los hombres son de constitución fuerte, usan larga barba y visten trajes de color oscuro y sobretodos que les llegan por debajo de las rodillas. También vienen bastantes jóvenes y párvulos de ambos sexos. Las mujeres son esbeltas, más bien delgadas, llamando especialmente la atención el color negro de los ojos, brillantes y animados. En general se nota bastante descuido en el vestir; pero vimos alguna con traje muy elegante y sombrero de buen gusto, que tenía todo el aire de una distinguida señorita. ${ }^{29}$

El 22 de diciembre arribó el Pampa con ochocientas personas. Los "pampistas" hicieron un recorrido particular: de Constantinopla viajaron en el vapor Fresina

${ }^{29}$ La Prensa, 6 agosto de 1891, citado por Boleslao Lewin, "Los judíos en el agro argentino", en Mundo Israelita , 5 de junio de 2008. 
hacia Marsella, en tren a Burdeos y en el Pampa hacia Buenos Aires. Desde allí serían enviados a Entre Ríos, a Colonia Clara: "obligados a buscar un refugio lejos de los horrores de su país natal, tuvieron la suerte de encontrar aquí no sólo refugio y paz sino un nuevo hogar por el que suspiraban, la patria nueva a la que habrían de incorporarse en cuerpo y alma" concluye Lázaro Shallman.

\section{La imagen del paisaje local}

Una carta escrita por uno de los integrantes del grupo Leizer Kaufman a su rabí, que había quedado en Rusia, nos permite entender el asombro de los recién llegados frente a una naturaleza totalmente distinta de la que habían abandonado semanas atrás. Ese "jasid» del Grupo de Palacios caracterizó así a la Argentina:

Todo aquí es al revés de lo acostumbrado. El calor viene del Norte y el frío del Sur. La Oración del Rocío y de la Lluvia la pronuncian en invierno. El 17 del mes de Tamuz resulta se un corto día de invierno, si a eso se lo puede llamar así pues no hay nieve ni para remedio ni se encienden los hogares. ${ }^{30}$

El primer decenio de vida en la colonia (1889-1899), dice Noé Cociovitch, transcurrió

entre búsquedas y experimentos en campos incultos, y en zonas desoladas y desconocidas. Año tras año debía esperarse a que la suerte nos fuese favorable y que la cosecha del cereal fuera abundante [...] Durante muchos años nuestras colonias permanecieron incomunicadas debido a las grandes distancias que las separaban; y tampoco existían diarios.

De ahí se desprende que, además de las dificultades de adaptación a un país nuevo, a un clima distinto, a un idioma desconocido, además de las múltiples frus-

30 Goldman, Nora, "Arón Goldman, primer rabí de Moisés Ville", en Gukowski, Hélène, Rescate de la herencia cultural. Vida... en las colonias, Buenos Aires, Contexto, 1991, p. 53. 
traciones debidas a los desastres ecológicos, los núcleos judíos de asentamiento agrario fueran como islotes en la inmensidad argentina, con la carga de soledad y de angustias que esto suponía.

Sus conocidas estrellas ya no estaban. Este era otro cielo, estrelladísimo, puro y diferente. Con el tiempo supieron ubicar las constelaciones: la Cruz del Sur, las Tres Marías, el lucero del alba. ${ }^{31}$

El rabí Abraham, en visita en la casa del criollo Estanislao, comentaba:

En toda la tierra no se ve cielo como aquí [...] El cielo entrerriano es protector y suave. Hallándose solo, por ejemplo, en medio del campo, el espíritu no sufre sugestiones de miedo, su luz es benigna.

El comentario del judío caló hondo en el alma del paisano, quien levantó su brazo para tomar la guitarra y de sus labios nació una vieja copla del pago:

\section{Entre Ríos, tierra mía}

¿dónde hay cielo como el tuyo?

Tus lomadas y tus ríos. ${ }^{32}$

El paraíso ${ }^{33}$ y los inmigrantes judíos fueron elementos exóticos para la Argentina. Sin embargo, se entrelazaron en una nueva simbología. El paraíso se convirtió en un símbolo de la vivienda rural. Las casas de los colonos se vieron siempre rodeadas por una isleta de este árbol que les daba no sólo sombra en verano, sino perfumes agradables que ponían una nota de alegría al ambiente. En invierno, si bien las hojas se caían, los paraísos se revestían del amarillo oro de sus frutos y el suelo quedaba alfombrado con ellos. El imaginario de la cultura agropecuaria tendrá como símbolo este árbol de inflorescencia violeta, frutos de oro y tronco verdo-

\footnotetext{
${ }^{31}$ Fairman, Silvia, Mate y samovar, op. cit., p. 14.

32 Gerchunoff, Alberto, Los gauchos judíos, Buenos Aires, CEAL, 1968, p. 59.

${ }^{33}$ Eleagnus angustifolia. Es originario de Asia occidental y central, desde el sur de Rusia y Kazajistán hasta Turquía. "La J.C.A. ha hecho plantar muchos árboles; además había distribuido entre sus colonos más de cien mil plantas de árboles, particularmente álamos de Italia y paraísos", explica Eugenio Sheppens en "Resumen del Informe de la JCA en Entre Ríos», 25 de junio de 1904, p. 10, Archivo JCA.
} 
so y grisáceo. Trayectorias de extrañezas que se unen en un proyecto de colonización y arraigo. Ícono también para aquel colono que no pudo sostener en el tiempo su instalación en el campo, que se trasladó a otro lugar levantando la casa construida con tanto empeño, son los paraísos verdinegros, cada vez más lozanos, que, muchos años después, evocan una experiencia frustrada. ${ }^{34}$

Cuando llegaron a Entre Ríos los esperaba un cielo increíblemente azul, el rumor de los arroyos escondidos, los espinillos, el ñadubay y una fauna extraña que capturó su atención y los llevó a emocionarse hasta las lágrimas o tiritar de miedo. La flora y la fauna produjeron una prolífica y fecunda literatura de paisaje. Benito Bendersky ${ }^{35}$, Alberto Gerchunoff ${ }^{36}$, Samuel Eichenbaum ${ }^{37}$, entre otros hombres amantes de las letras oriundos de Colonia Clara, nos pintan la escena con una pluma brillante, haciendo que, mágicamente, el paisaje se transforme en una imagen en movimiento.

\footnotetext{
${ }^{34}$ Lieberman, José, Tierra Soñada. Episodios de la colonización agraria judía en la Argentina. 18891959, Buenos Aires, L y L ediciones, 1959.

${ }^{35}$ Bendersky, Benito, Oif ídishe felder (En campos judíos), en ídish, traducción de Rafael Bekenstein, Buenos Aires, 1931. Nació en 1880 en Demankevich. Sus padres llegaron como colonos a Entre Ríos y se asentaron en el Grupo Sonenfeld (San Gregorio). Comenzó a publicar sus trabajos en la revista De Idische Hofenung (La Esperanza Judía) en 1908. Posteriormente publicó varios cuentos en Di Idische Zaitung, Di Presse, Di Naie Zait. Falleció en Villa Domínguez en 1953. En AA.VV., Crónicas Judeoargentinas/ 1. Los pioneros en idish 1890/1944, Buenos Aires, Milá, 1987.

${ }^{36}$ Nació en Proskuroff, Rusia en 1884. Llegó a Argentina en 1889. Vivió en Colonia Moisés Ville y en el grupo Rajil, de Colonia Clara, hasta establecerse definitivamente en Buenos Aires, en 1895. Fue Director de El Censor (Rosario), redactor de La Nación y director de El Mundo. se desempeñó a su vez como docente, conferencista y traductor. Algunos de sus títulos de su vasta obra son Los gauchos judíos, Cuentos de Ayer, La jofiana maravillosa, Los amores de Baruj Spinoza, El problema Judío, Entre Ríos, mi país. Muere en 1950.

${ }^{37}$ Nació en Villa Domínguez en 1894. Periodista, director escénico, critico teatral y dramaturgo, escribió más de veinte obras de teatro, entre las que sobresalen Un guapo del 900, La mala sed, Soledad es tu nombre, Un tal Servando Gómez, Vergüenza del querer y El Judío Aron. En narrativa, es autor de Un monstruo en libertad, Tormenta de Dios y El viajero inmóvil. En Heffes, Gisela (comp.), Judíos/Argentinos/Escritores, Buenos Aires, Atril, 1999.
} 

capítulo dos 



\section{Exilio y enraizamiento en Argentina}

\section{Las causas de las migraciones}

Las causas que determinan la emigración de los judíos son diferentes de las de otros grupos migrantes en la Argentina.

En los últimos ciento cincuenta años, la migración se constituyó en uno de los factores decisivos de su existencia. El proceso de desarraigo de los países anteriores de residencia y el de enraizamiento en los nuevos sitios se convirtió en el transcurso de ese siglo y medio en una vivencia familiar y personal de la mayor parte de los judíos. ${ }^{1}$

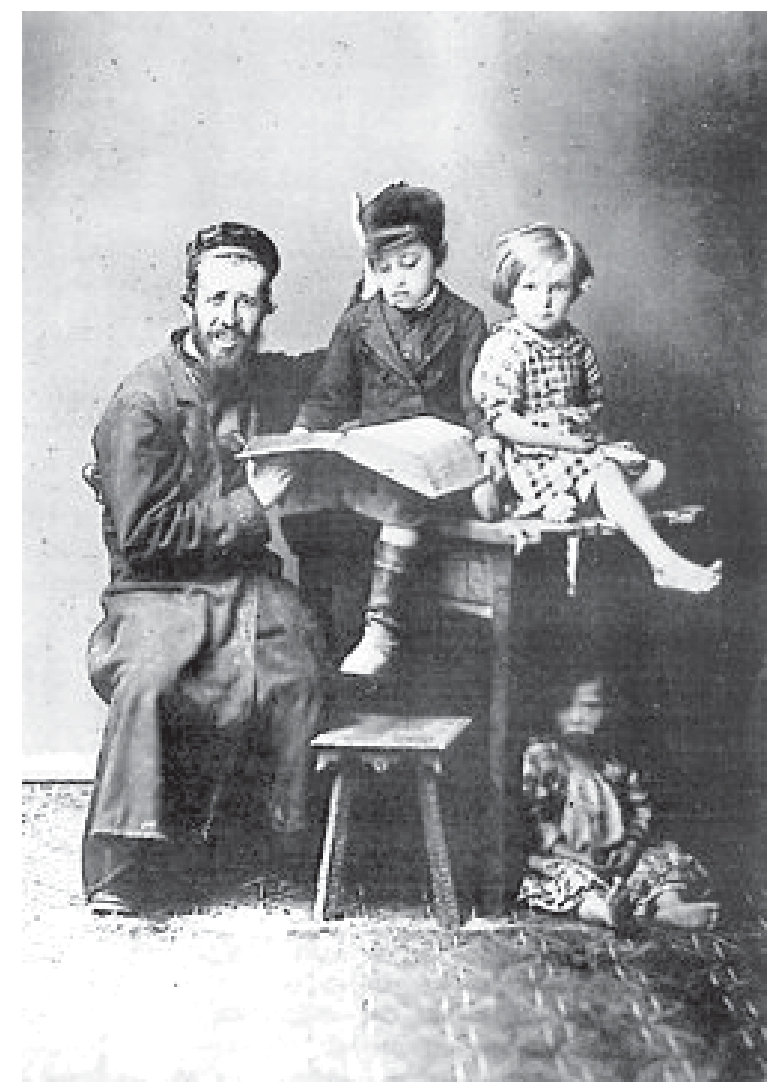

${ }^{1}$ Avni, Haim, Argentina y la historia de la inmigración judía. 1810-1950, Jerusalén, Editorial Universitaria Magnes, 1983, p. 11. 
La violencia y persecución a las que fueron sometidos hizo que la decisión de emigrar, en la mayoría de los casos, fuera distinta a la de los grupos no judíos. Para ellos, el dilema a afrontar no era la emigración para "hacer la América" y regresar luego al terruño, sino que significaba el destierro definitivo.

Pero este grupo no sólo se diferencia por las causas de sus migraciones. Las modalidades en la admisión insertas en las políticas del país receptor, el estatus de inmigrante judío y la medida en que fue aceptado por la sociedad a la que se incorporaba son también notas distintivas.

Los judíos se convirtieron en migrantes cuando comenzaron a huir de los pogroms ${ }^{2}$ y las discriminaciones violentas y legales que se distribuyeron sistemáticamente por todo el territorio del Imperio Ruso. La discriminación y la xenofobia se refuerzan en una espiral interminable. El gobierno de Alejandro III, que se inicia en 1881, es uno de tantos indicios de este camino. Buscó orientar hacia los judíos la ira del populacho por la muerte del zar Alejandro II, incentivando, o por lo menos tolerando, la serie de pogroms que sacudieron el sur del imperio entre 1881 y 1882 (alrededor de doscientos en un período de un año), los cuales no fueron sino los primeros de una serie de ataques físicos a ellos y a sus bienes. Las Ilamadas Leyes de Mayo o Edictos Temporarios, promulgadas en mayo de 1882, restablecieron la Zona de Residencia. Aun dentro de la misma, se les prohibió asentarse en las afueras de ciudades y pueblos, adquirir tierras en zonas rurales y realizar negocios en domingos y días feriados para el cristianismo. Aquellos que residían en zonas urbanas no tuvieron otra alternativa que permanecer en las mismas, y quienes residían en zonas rurales fueron forzados a trasladarse a las primeras. El territorio en el cual podían legalmente residir se redujo en un $90 \%$.

De esta manera, quedaron encerrados en una gigantesca prisión, en ese extraño y vasto gueto llamado Zona de Residencia que se componía de ciudades y villorrios de una serie de gobernaciones y provincias de Ucrania, Lituania, Wohlinia, Polonia y Rusia Blanca. El resto del gigantesco imperio quedó vedado para ellos. ${ }^{3}$

\footnotetext{
2 De acuerdo con la definición brindada por la Enciclopedia Judaica Castellana, «la palabra rusa pogrom significa alboroto, tumulto, disturbio, se emplea en otros idiomas para designar los violentos ataques a Ios judíos". Enciclopedia Judaica Castellana, México, 1950, p. 475. Otros autores prefieren resaltar su significado en ruso: "como un rayo".

${ }^{3}$ Mendelson, José, "Génesis de la colonia Judía en la Argentina", op. cit., p. 99.
} 


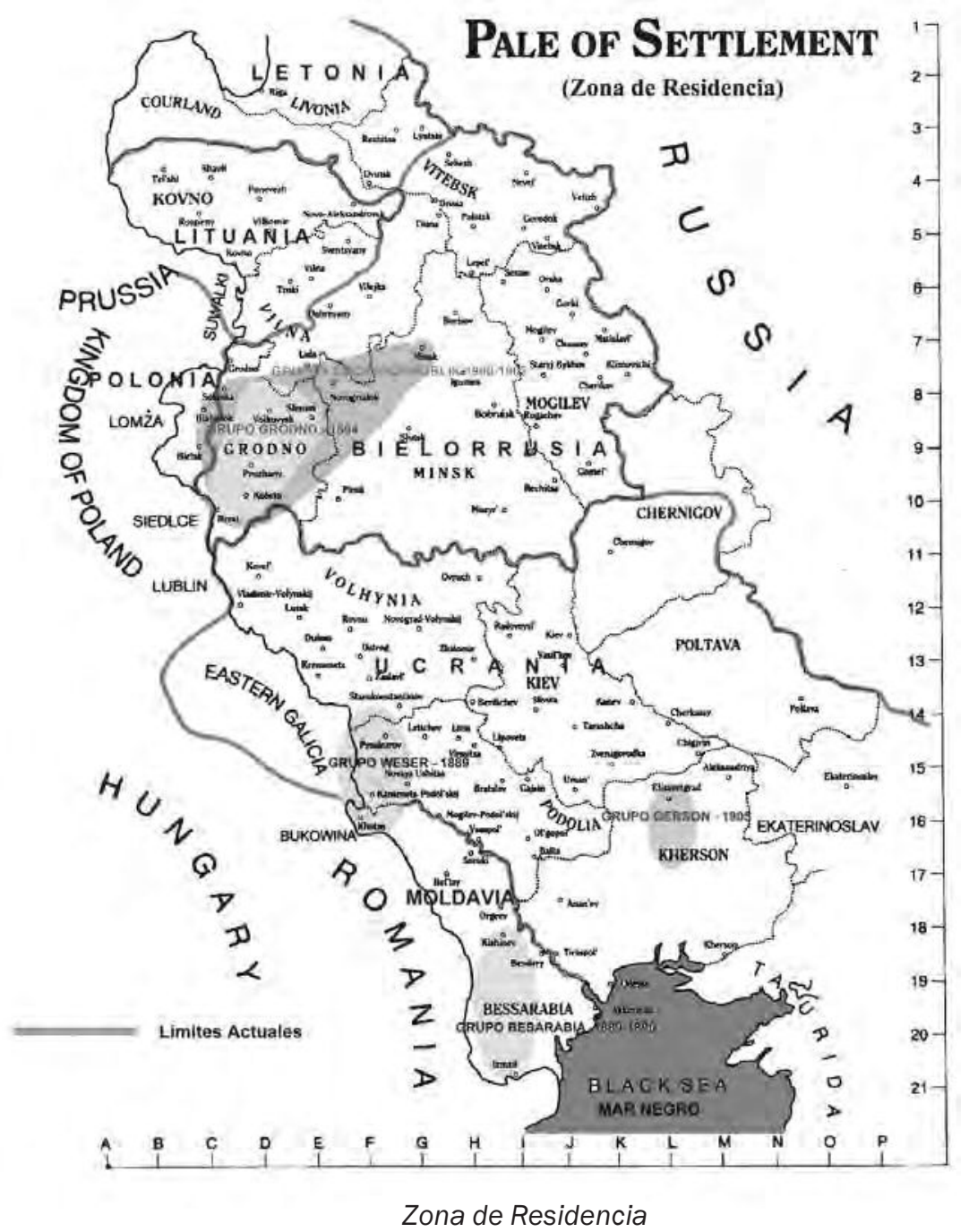

La población judía, atemorizada por la violencia y las nuevas restricciones, comenzó a buscar la manera de salir del Imperio Ruso. Miles de personas se pusieron en camino hacia las fronteras. La inmigración, que había comenzado en pequeña escala en la segunda mitad de la década del setenta, cobró nuevo aliento. Al trasponer la frontera occidental se encontraban en Brody, en el Imperio AustroHúngaro, donde sus condiciones de vida no eran mucho mejores, lo que provocaba una fuerte inmigración espontánea hacia Estados Unidos. Allí se habría de duplicar la población judía en el término de diez años. ${ }^{4}$

\footnotetext{
${ }^{4}$ Ver con mayor detalle Edgardo Zablotsky, "El proyecto del Barón de Hirsch. ¿Éxito o fracaso?", Universidad CEMA, mayo, 2005. En www.ucema.edu.ar/ eez/Publicaciones/...UCEMA/Revista_Analisis-9-06.pdf.
} 
En 1888, el zar intensificó las restricciones, lo que condujo a las autoridades provinciales a reducir aún más el territorio abierto a los asentamientos. Al redefinir pequeñas villas y poblados como zonas rurales - por ende, prohibidas para los judíos-, aquellos que se habían trasladado a dichas áreas luego de los decretos de 1882 fueron nuevamente obligados a emigrar.

El servicio militar obligatorio era el terror de la juventud. ${ }^{5}$ Hasta los dos primeros años del reinado del zar Alejandro II (1855-1881), la permanencia en los cuarteles dependía de la voluntad caprichosa del gobierno. Con Alejandro II se estableció que la duración del servicio se extendiera a tres años y ocho meses, como asimismo la finalización del sistema "cartonista" -aplicado en 1805 y 1857 -, que consistía en el reclutamiento de niños judíos, muchas de las veces verdaderas cacerías, arrancados de sus hogares y obligados a prestar servicio militar durante veinte o más años, en cuyo transcurso eran compelidos a convertirse al cristianismo.

Por otra parte, existían otras fuertes restricciones, tales como el número clausus, establecido en 1887, que imponía cupos para las escuelas secundarias y superiores (por ejemplo, en la Zona de Residencia, las escuelas aceptaban un 10\% de judíos, mientras que fuera de la Zona dicha relación disminuía al 5\%, y en las áreas de Moscú y San Petersburgo, al 3\%), y limitaciones especiales impuestas en 1889 para la admisión de abogados judíos al foro.

En 1891, aquellos judíos que aún habitaban en Moscú y San Petersburgo fueron súbitamente forzados a vender las propiedades en las cuales habían residido por generaciones y dejar las ciudades. Quienes no podían venderlas rá-

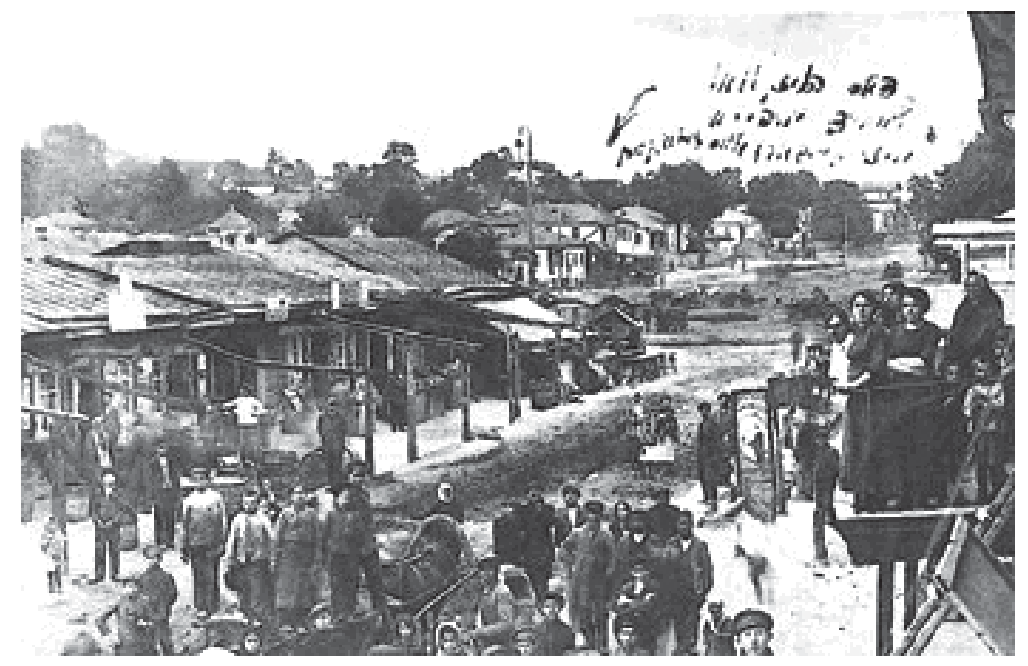

Rzhishchev, Ucrania.

\footnotetext{
${ }^{5}$ Garfunkel, Boris, Narro mi vida, Buenos Aires, Optimus, 1960, p. 104.
} 
pidamente (en la mayoría de los casos a precios viles) eran encarcelados. De esta forma 20.000 judíos que residían en Moscú fueron obligados a trasladarse a la Zona de Residencia.

La suma de estas restricciones condujo a que el censo de 1897 reportara que, de 5.215.805 judíos, el 94\% radicaba en la Zona de Residencia, el 80\% de ellos en zonas urbanas, representando el 38\% de la población urbana de dicha región.

El confinamiento en la sobrepoblada Zona de Residencia, la imposibilidad de adquirir tierras y realizar tareas agropecuarias, así como de acceder a la educación y de entrar en ciertas profesiones, sumado al fuerte crecimiento demográfico, deterioró considerablemente el nivel de vida, al incrementar la competencia entre los pequeños comerciantes y reducir sus ya minúsculos ingresos en virtud de la urbanización del Imperio Ruso durante la segunda mitad del siglo xIx. Dicha urbanización había creado una enorme demanda de bienes de consumo, desplazando el trabajo individual de los artesanos por la producción industrial, desarrollando redes ferroviarias que afectaron a muchos negociantes pueblerinos y prácticamente eliminando la función, típicamente judía, del carretero. El comercio en gran escala, alentado por la industrialización, pasó de largo al pequeño comerciante local, judío por lo general, en virtud de las restricciones impuestas al ejercicio de cualquier otra actividad. Hacia fines de la década del ochenta, el extremo deterioro de las condiciones de vida otorgó un nuevo impulso a la emigración espontánea.

Miles de familias quedaron sin medios de vida, perdieron sus fortunas y se vieron expuestas a tomar el camino de errantes, a emigrar y buscar una nueva vida laboral, ya sea trabajos manuales, ya en la agricultura. Los pogroms por un lado y las restricciones y persecuciones por otro provocaron una fuerte crisis espiritual en el pueblo judío. Comenzó una revolución de las verdades y valores que hasta entonces eran consideradas inobjetables.

Nació allí el movimiento sionista "Bilu», que tuvo su expresión en la tendencia de emigración de la juventud hacia Palestina con el fin de consagrarse al cultivo de la tierra. Por otro lado, comenzó una corriente migratoria hacia los Estados Unidos, animada del propósito de reformar allá la vida propia, sobre la base del trabajo.

Entre la bandera del retorno a Sión y la emigración a Norteamérica, adquirió nueva actualidad entre los judíos el viejo anhelo del movimiento iluminista, que 


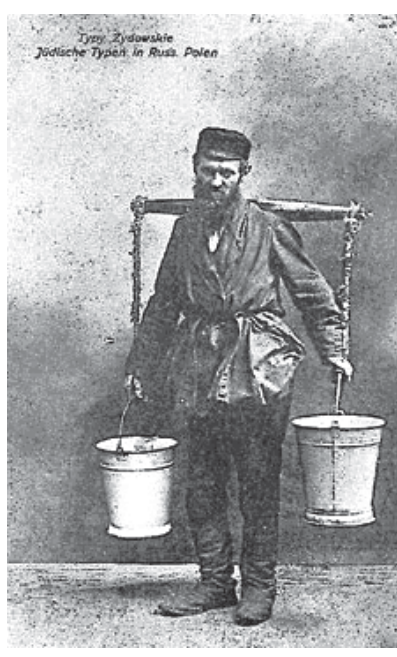

Un portador de agua. La mayoría de las ciudades de la Zona no tenían otra forma de distribución de agua.

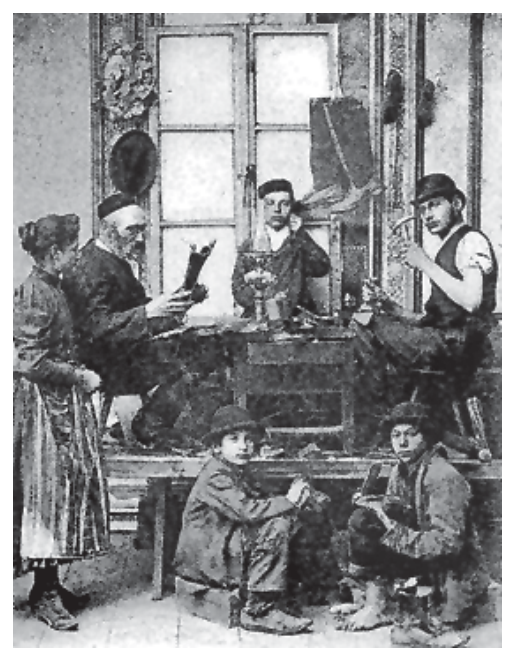

Zapateros y aprendices en su taller, 1900.

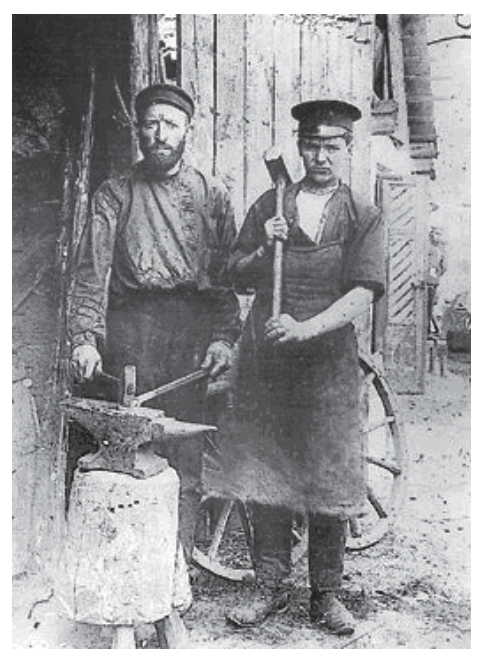

Dos herreros en Plonnoye, Ucrania.

década antes había resonado a través de las aldeas rusas de densa población israelita. "iRetornemos a las agricultura!", deseo lanzado por Isaac Ber Lebensohn y cantado por el trovador Zunzer en su poema "La azada" que se convirtió en una canción popular. ${ }^{6}$

En 1887 entró en vigor una nueva disposición que establecía que los judíos no podían residir en las aldeas a cincuenta kilómetros de la frontera. Las perspectivas de una expulsión amenazaban a millares de judíos, sobre todo en los límites de Polonia, en las gobernaciones de Podolia, en las fronteras con la antigua Austria. Vivían allí numerosos arrendatarios israelitas, que actuaban en parte como agricultores y en parte como artesanos y comerciantes. Todo eso debía ser liquidado, había que tomar el cayado del errante y buscar un nuevo hogar.

Esta disposición perjudicó de manera más pronunciada y violenta a los judíos que residían en Besarabia y Kamemetz-Podolsk, a lo largo de la frontera. Empezaron a realizar reuniones, a buscar consejos y soluciones, y resolvieron realizar una asamblea en Catovitz (Katowice, hoy Polonia) en 1887, donde el tema principal no era el de emigrar, sino hacia dónde. Se hizo notar la existencia de la Alliance Israélite Universelle, única entidad que había incluido en su programa de ayuda a los perse-

${ }^{6}$ Mendelson, José, op cit., p. 100. 
guidos judíos de la Europa oriental, resolviendo enviar una delegación de cinco personas para averiguar allí acerca de algún país donde existiesen condiciones adecuadas para radicarse (posibilidades de cultivar la tierra) y la probabilidad de obtener apoyo. Se propuso además reunir los recursos económicos para cubrir los gastos de la misión, estableciéndose que cada familia representada por los delegados debía contribuir con veinticinco rublos. Tardaron meses para reunir los fondos, período en el que renunciaron los dos miembros que debían representar a los judíos de Besarabia, lejiel Bergrois y José Rapaport, quienes decidieron separarse de los de Kamenetz y organizar un grupo separado. La delegación quedó constituida por Lázaro Kaufman, arrendatario rural de la aldea de Krentchow, Pinjas Glasberg y José Ludmer ${ }^{7}$, ambos de la aldea Starautha en la región de Kamenetz. Estos últimos serán luego integrantes del contingente Weser que fundará Moisésville en Argentina.

La delegación llegó a París en 1888 y, luego de dos largos meses de gestiones sin avistar posibilidades concretas, sólo quedó Kaufman, empecinado en conseguir sus propósitos. En esos días se encontró casualmente con otro judío oriundo de Rusia, Ilamado Gersón Baratz, quien le informó que el cónsul argentino invitaba a los agricultores a ir a establecerse en su país, ofreciendo tierra y los implementos necesarios para la instalación Luego del contacto con el cónsul, quien le detalló las condiciones para la emigración -cada familia debía abonar antes de partir cuatrocientos marcos para gastos de traslado-, regresó a Rusia para motivar y reunir a las 136 familias, entre ellos un rabino y matarife ritual, Rabí Aarón Goldman, quienes embarcaron hacia nuestro país el 15 de junio de 1889. El grupo de Kamenetz marchó con un propósito bien definido: hacerse agricultores, lograr una chacra en un país lejano. El imaginario estaba atravesado por el lema «Retornemos a la tierra" con los acordes del himno "La azada", que se cantaba en idish y en hebreo, más la poesía en ruso que el poeta judío Simón Frug ${ }^{8}$ había compuesto

\footnotetext{
7 José Ludmer fue quien recibió la noticia, a través de su cuñado residente en los Estados Unidos, que para colonizarse era más conveniente dirigirse a la Argentina, donde el suelo era mejor y más barato. ${ }^{8}$ Variantes de nombres: Samuel Frug Simeón, Semen Grigorievich Frug, Shmuel Shimon Frug. Nace el 15 de noviembre 1859 en Kut Bobrowy y muere el 22 de septiembre 1916 sin que se pueda precisar si fue en San Petersburgo u Odessa. Fue el poeta judío más popular en su tiempo. Simón Dubnov, "Los recuerdos de Frug", en Jewrejskaja Starina IV de 1916 e Historia contemporánea del pueblo judío, Buenos Aires, Asociación Hebraica, 1925. Versión castellana de Salomón Resnick y León Dujovne.
} 


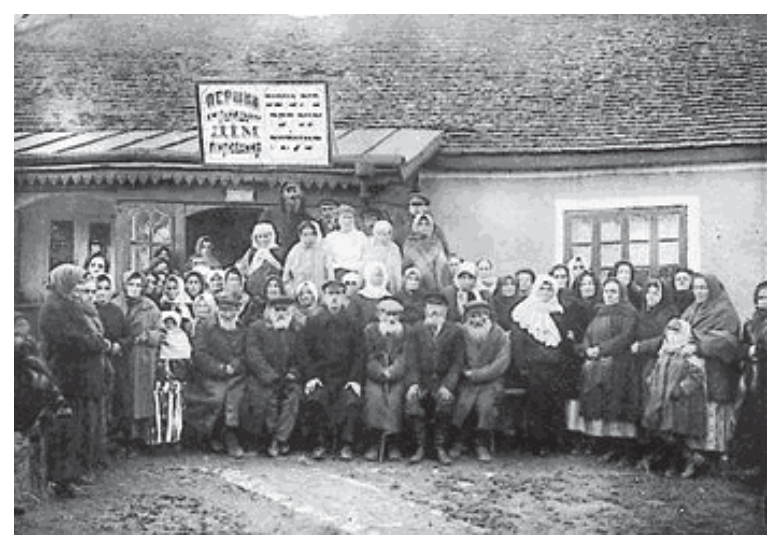

Hogar de ancianos, Kiev.

para los que se fueron a Palestina con el fin de restaurar la patria histórica por medio de la nueva agricultura judía. Las peripecias del viaje fueron múltiples estafas, cárcel, pérdidas de equipaje-, desde las tensiones iniciales en la conformación de los grupos en veinte familias en el territorio ruso, su partida hacia Cracovia, luego a Berlín, de allí a Hamburgo, luego el desvío a Bremen para embarcar en el Weser y arribar a Buenos Aires el 14 de agosto de 1889, donde comenzaría un nuevo terrible derrotero.

En este contexto de exclusión y privaciones, el barón de Hirsch intentó primero mejorar las condiciones de vida en la Zona de Residencia, como ya lo había hecho en el Cercano Este y en el Imperio Austro-Húngaro. ${ }^{9}$ Con dicho fin propuso al gobierno del zar crear un fondo dotado de U\$S 10.000.000 -cincuenta millones de rublos- con el objeto de fundar y operar escuelas técnicas y agrícolas en la Zona de Residencia. La negociación con el gobierno duró un año, pero su iniciativa sería rechazada a menos que el fondo fuese administrado por el mismo gobierno, condición por completo inaceptable para Hirsch, quien a partir de ese momento consideró que la única alternativa viable consistía en la emigración organizada y el reasentamiento en otros países.

Si bien Estados Unidos era el destino preferido de la emigración espontánea, no era el adecuado para un proyecto de inmigración organizada de la magnitud imaginada por Hirsch. El American Relief Committee ya se había opuesto a facilitar la

\footnotetext{
${ }^{9}$ En sus viajes por Rumania, Austria y Turquía como empresario de construcciones ferroviarias, observó la pobreza y el estado de abandono de los judíos y decidió fundar escuelas de artesanos para ellos.
} 
inmigración masiva al tiempo de establecer el Fondo Barón de Hirsch, y él mismo pensaba que no era conveniente incrementar la concentración ni para el país en sí ni para los judíos exilados. Por esto, consideró que este nuevo asentamiento debería distribuirse en otras tierras y dispersarse sobre una amplia superficie, de tal forma que no existiese la oportunidad de que se produjera una fractura religiosa o social. Enfrentado a la búsqueda de otros destinos, el barón de Hirsch se habría de inclinar por la Argentina.

\section{Argentina: el lugar elegido}

Pero ¿por qué en la Argentina? Para encontrar una respuesta a este interrogante es necesario remontarnos al 19 de octubre de 1876, cuando Nicolás Avellaneda promulgó la Ley de Inmigración y Colonización ${ }^{10}$ que habría de configurar la imagen de la Argentina como país. Si bien la misma no limitaba la inmigración espontánea, daba un fuerte estímulo a la artificial, es decir, aquella incentivada por el gobierno Argentino. A los efectos de instrumentar la ley se crearía el Departamento de Inmigración, el cual, entre otras funciones, debería abrir una red de agencias en los países de Europa que se ocuparían de la publicidad y de la organización de los pasajeros, y al mismo tiempo constituir comisiones locales que se encargarían de encauzar a los recién llegados a lo largo de la república. El Departamento debía supervisar los barcos que los transportaban, intervenir en su desembarco, ayudarlos a encontrar trabajo, especialmente en localidades del interior, representarlos ante las autoridades en todo problema legal relacionado con su viaje y llevar un detallado registro.

\footnotetext{
${ }^{10}$ La Ley 817 de Inmigración, de 1876, dio cuenta a las claras de las intenciones del Estado argentino, como lo hemos visto en el capítulo anterior. También establecía el derecho de los inmigrantes a ser alojados y mantenidos convenientemente a expensas de la nación durante los cinco días siguientes a su desembarco (art. 45); el propósito de las autoridades de propender por todos los medios a su alcance a la colocación de los inmigrantes en el arte, oficio o industria a que prefiriesen dedicarse (art. 48), lo mismo que, para aquel que prefiera fijar su residencia en cualquiera de las provincias interiores de la república o en alguna de sus colonias, la obligación del Estado de transportarlo inmediatamente con su familia y equipajes hasta el punto de su elección, sin pagar remuneración alguna (art. 51).
} 
A partir de 1880 comenzó la inmigración europea masiva. El período transcurrido entre 1881 y 1889 fue, salvo una pequeña disminución en 1886, de incesante aumento. El fomento de la inmigración judía a nuestro país se evidencia con el decreto que el presidente Julio A. Roca firma el 6 de agosto de 1881, disponiendo que un agente especial argentino en Europa fuera el encargado de dirigir hacia el país la emigración israelita iniciada en el Imperio Ruso. Sin embargo, parece que esta invitación nunca llegó de manera efectiva hasta la población judía europea, ya que, según los datos del Departamento, entre 1881 y 1885 los inmigrantes judíos que ingresaron no pasaron de unos pocos casos individuales.

No debe extrañar pensar cuánto peso tuvo la Exposición de París en 1889 para poner de manifiesto la grandeza de Argentina, pero también la crisis de 1890 tiñe y enmarca fuertemente el escenario.

Como bien explica Panettieri, ${ }^{11}$ las inversiones del Imperio Británico en empresas por acciones de la Argentina, que antes de la presidencia de Julio A. Roca llegaban a una suma de alrededor de 25 millones de libras, habían aumentado, en 1885, a 45 millones, y en 1890 sumaban 150 millones. Cabe destacar que en 1889 Argentina absorbió entre el 40 y el 50\% de todas las inversiones británicas hechas fuera del Reino Unido.

Las perspectivas de los inversores no eran en otras partes del mundo tan halagüeñas como en el hemisferio sur. Aquí, las inversiones determinaban un aumento de la producción y esta un incremento de las ventas, que entre 1886 y 1889 alcanzaban holgadamente para cubrir los desembolsos de capital y los salarios, dejando además un saldo atrayente para los inversores y especuladores.

Alrededor de un 65 y 70 \% de todo el capital británico invertido en la Argentina durante los años prósperos de 1886 a 1889 se empleó para financiar ferrocarriles, en forma directa por compañías o de modo indirecto a través de los empréstitos al gobierno. Las inversiones mismas y los intereses del capital invertido (por ejemplo, intereses sobre títulos del gobierno o debentures ferroviarios y acciones garantidas) fueron anteriores en varios años al crecimiento físico de los ferrocarriles, y en unos cuatro años al funcionamiento efectivo de los mismos.

\footnotetext{
${ }^{11}$ Panettieri, José, La crisis de 1890, Buenos Aires, CEAL, 1984, p. 8.
} 
Este flujo de capitales, destinados en gran parte a inversiones en el capital social básico, impulsó la actividad económica en la Argentina y estimuló vigorosamente el desarrollo agrícola del país.

La formidable expansión iniciada a partir de los años ochenta no hubiera sido posible sin una coyuntura mundial favorable: la economía argentina también se benefició por la caída de los precios del transporte por mar debido a las mejoras técnicas introducidas en la construcción y el funcionamiento de barcos oceánicos, en especial a vapor y construidos con acero. Dadas estas condiciones, los precios de los productos de exportación argentinos aumentaron. Esta momentánea prosperidad, que alentó la ilusión de su mantenimiento por tiempo indefinido, fue acompañada por un progresivo endeudamiento como consecuencia del abuso del crédito externo.

La confianza del inversor extranjero se acrecentó debido a la apertura de las tierras del Sur como consecuencia de la Conquista del Desierto. A esto debe agregarse el dictado de la ley de unidad monetaria de 1881, que, al crear una moneda nacional, terminó con el caos monetario existente.

La afluencia de capitales extranjeros se intensificó a partir de 1885 . Tanto es así que en el quinquenio comprendido entre dicho año y 1890 rondaron alrededor de los 710 millones de pesos oro (140 millones de libras). Aproximadamente la mitad de dicha suma había sido obtenida por medio de nuevas emisiones en la Bolsa de Londres, mientras los inversores británicos suscribieron una considerable proporción de las cédulas hipotecarias, además de las inversiones privadas que se habían hecho en empresas y bienes raíces argentinos.

Una gran parte de ese dinero circulante, producto del auge comercial y de los empréstitos contratados, fue canalizada hacia una especulación desmedida. El gasto interno recibió mayor impulso por el aumento de la inmigración y por la continua emisión de papel moneda, en la medida que entraban en actividad los nuevos bancos autorizados por la Ley de Bancos Nacionales Garantidos. El gobierno, al propiciar su fundación, tuvo en vista proveer al país de más papel moneda, es decir, de mayor circulante, para acrecentar la actividad económica y, fundamentalmente, procurar atraer al país mayores cantidades de oro.

Ahora bien, mientras los préstamos del exterior fueron aumentando la oferta de moneda extranjera -entre 1885-1889-, la economía argentina no tuvo problema 
alguno en pagar los servicios de la deuda y mantener o aumentar, al mismo tiempo, las importaciones. Pero cuando esos empréstitos disminuyeron, y luego se interrumpieron, las obligaciones en moneda extranjera recayeron exclusivamente en el producto de las exportaciones. Como el valor de estos productos agropecuarios no experimentó, por muchos años, ningún aumento respecto de las cifras de 1889 - debido a la lenta concreción de los planes de inversión, a las condiciones climáticas y sobre todo a la repentina caída de los precios mundiales de las exportaciones agropecuarias-, no hubo solución al problema y se precipitó la crisis. Al paralizarse algunas de las grandes obras públicas por causa del quiebre financiero, se afectó el proceso de desarrollo general del país, reduciéndose entonces el ritmo de crecimiento y la capacidad de consumo. La moneda comenzó a desvalorizarse. El peso papel, que en 1883 equivalía a cien centavos oro, llegó a cotizarse en 1891 a solamente 0,44 de dicho metal. A esta baja del papel moneda se fue agregando la de otros valores. El de la tierra, por ejemplo, se redujo a la mitad.

La crisis de 1890-1891 no interrumpió el movimiento de colonización ni el desarrollo agropecuario sino que, por el contrario, ayudó en cierta medida, puesto que detuvo brevemente el ascenso del precio de la tierra. Así también continuó beneficiándolo la desvalorización del papel moneda. Durante la década del ochenta y principios de la del noventa, la inflación resultó conveniente para el agricultor, como lo fue asimismo para quienes entonces constituían los más importantes intereses económicos del país: los ganaderos y los exportadores.

Intentando responder la pregunta sobre el porqué de la elección de la Argentina, desde la perspectiva de Maurice de Hirsch, sus entrevistas con periodistas ingleses y norteamericanos dan pistas en este sentido. ¿Por qué eligió usted a la Argentina?, interrogaban los periodistas

porque cuentan con un clima templado y vastas extensiones de tierra para la agricultura y la ganadería. Al comienzo se pueden construir viviendas de cualquier tipo que aseguren suficiente protección provisoria a los colonos. El problema es que los terrenos están dispersos entre distintos propietarios con los cuales es difícil negociar, ya que sus títulos de propiedad no siempre están claros. Lo que complica más las cosas es que la mayor parte de esas propiedades tienen centenares de hectá- 
reas. Mi idea es crear una sociedad que les dé a los inmigrantes el dinero necesario para que adquieran su tierra y les provea las herramientas y semillas para cultivar legumbres y cereales... Con una buena cosecha, al cabo de un año estarán en condiciones de devolver el dinero que se les haya prestado. Eso los independizará y evitará que se conviertan en menesterosos... Una vez que estén bien adaptados y cómodamente instalados, escribirán a sus familias y a sus amigos, quienes sentirán deseos de seguir su ejemplo y ser pioneros ellos también. Ejercerán una fuerza magnética que atraerá hacia ellos una parte de su pueblo. Claro que es imposible trasladar a cuatro millones de personas, pero sin dudas se logrará hacerlos con cientos de miles. ${ }^{12}$

\section{¿A dónde emigrar? Entre Palestina y América del Sur}

Las informaciones del pogroms de Moscú en 1890 preanunciaban noticias nada halagüeñas.

Sentía que en el ambiente donde había nacido y arraigado comenzaban a crecer malas hierbas que tarde o temprano me ahogarían. Vislumbraba como única solución el trasplante a nuevas tierras, aun con todos los riesgos que la aventura implicaba. Pero ¿dónde ir? Cada vez que me planteaba ese interrogante surgía automáticamente en mi pensamiento la sagrada Eretz Israel. Es que hasta la diaria liturgia impulsa al judío a buscar con su corazón la Tierra Santa. A fuerza de tanto repetir oraciones que expresan la esperanza del Retorno, en cada judío devoto se hace carne la añoranza que como una antorcha ha permanecido encendida de generación en generación. ${ }^{13}$

El movimiento sionista romántico de los "Jovevé Sion" difundía con fuerza su ideario a través de conferencias realizadas en locales semiocultos. Algunos perió-

12 Herald Tribunem, edición del 27 de julio de 1891. Citado en Frischer, Dominique, El Moisés de las Américas. Vida y obra del barón de Hirsch, Buenos Aires, El Ateneo, 2004. p. 449.

${ }^{13}$ Garfunkel, Boris, Narro mi vida, op. cit., p. 150. 
dicos $^{14}$ daban noticias sobre la posibilidad de adquirir tierras en las proximidades de las colonias agrícolas del barón de Rothschild en Israel y establecerse en ellas. También la posibilidad que brindaba el barón de Hirsch, potentado judío de Austria, a través de la JCA, cuya misión consistía en trasladar gratuitamente a los judíos que deseaban emigrar de sus países por razones de discriminación racial y religiosa que hacían imposible su subsistencia económica y hasta su seguridad personal.

La travesía para llegar al nuevo mundo podía adquirir diferentes ribetes. Desde recurrir a la Agencia pro Emigración de judíos de Europa Oriental, atravesar la frontera ruso-austríaca para ir a la búsqueda de un tren internacional que los condujera al puerto de Hamburgo, localizar allí la Agencia de emigración judía para adquirir los pasajes a precio de costo (si contaban con el dinero necesario) o solicitar los pasajes gratuitos que proveía la empresa colonizadora. Boris Garfunkel relata que compró sus pasajes en el barco Petrópolis y luego de una travesía de dos meses arribó a Buenos Aires (4/09/91).

\section{Mauricio de Hirsch}

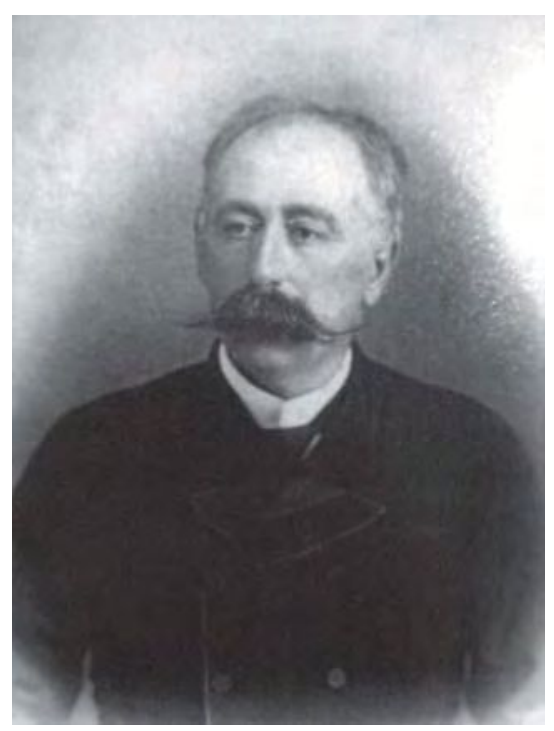

Mauricio de Hirsch

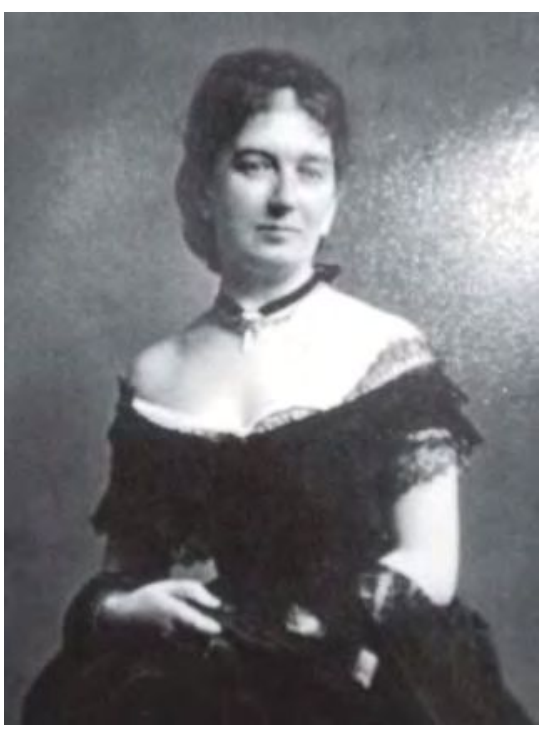

Clara Bischoffsheim

${ }^{14}$ Hatzefirá (La Aurora), semanario hebreo editado en Varsovia. 
El nombre de Mauricio de Hirsch comenzó a circular en el ámbito judío, convirtiéndose inicialmente en una convocante posibilidad para encontrar una vida mejor en un lugar fuera de Europa, hasta llegar a ser considerado el más grande benefactor de la humanidad.

Jaim Weizman, primer presidente del Estado de Israel, al evocar su infancia en Motal, pueblo de una lejana provincia rusa, recuerda que en las paredes de su casa familiar su padre había colgado cuatro imágenes frente a las cuales solía orar: la de Maimónides, la del Muro de los Lamentos, la de Anton Chéjov y la del barón de Hirsch. ${ }^{15}$

Nahum Sokolov, otro ruso líder del sionismo, señalaba que las promesas de Hirsch habían permitido a los judíos olvidar el horror y creer en un futuro mejor, y que

En Rusia, no existía un solo hogar judío pobre en el cual el nombre de Hirsch no fuese bendecido todos los días, no por lo que él haya dado, tampoco por lo que se proponía dar, sino porque en el fondo de su miseria habían percibido su mano tendida y, de pronto gracias a él, habían dejado de sentirse abandonados. Ese gesto de bondad que emanaba de una mano invisible les había devuelto el coraje, la voluntad, la esperanza. ${ }^{16}$

Mauricio de Hirsch encarnó una imagen fundante del judaísmo, representando al nuevo Moisés tan esperado que los liberaría de la barbarie zarista y los guiaría hasta la Tierra Prometida, que no era la Palestina con la que judíos religiosos y otros seculares comenzaban a soñar en la Europa central.

Este hombre descendía de una familia judía-bábara que prestó servicios al Estado. Tuvo un itinerario similar al de los Rothschild, que lo elevó a la consideración pública, sin que la religión o el orgullo de la aristocracia del reino alemán cohibieran su ascenso social. En esos tiempos, como luego de la unificación del imperio bajo los Hohenzollern, existía el antisemitismo, activo en la política y difuso en las capas directivas, pero que no recurría a las medidas brutales y coercitivas de Rusia, lo que permitió a la familia desenvolverse. Jacobo de Hirsch, el abuelo, fue un banquero de talento, con mentalidad moderna y empuje mercantil. Le unía una amistad con el rey

\footnotetext{
${ }^{15}$ Weizman, Jaim, Naissance d'Israel, París, Gallimard, 1955. Citado por Frischer, D., op. cit., p. 25.

${ }^{16}$ Sokolov, Nahum, Histoire du sionisme, Londres, 1910.
} 
de Baviera y con el Gran Duque de Toscana, con los que mantuvo fecundos intercambios, no sólo lazos de negocios. El rey de Baviera le otorgó en 1818 el título de barón de Gereuth. Así, este judío ennoblecido se dedicó a la agricultura y sacó provecho de los cambios tecnológicos y la apertura de nuevos productos del comercio internacional. Poseía una particularidad que lo diferenciaba del resto de los de su comunidad: un amor inquebrantable por la tierra y por la agricultura que trasmitió a sus descendientes. Su hijo José, padre de Mauricio, se encargó de la dirección de la casa bancaria de Munich, y Joel, el tío, de la de Wurzburg, conformando una estirpe de prestamistas de países y de banqueros de las dinastías filtrados por el romanticismo de la nueva Europa y de la nueva Alemania. Mauricio nació en 1831, en un hogar de fuerte tradición judía y practicantes religiosos. En el banco de Munich se inició en el álgebra del comercio del oro, en el misterioso manipuleo de los empréstitos y de los papeles de renta. Cuando se independizó de la tutela paterna, su fortuna no pasaba de unos cuantos millones de francos, importante pero no suficiente para un hombre con marcada intención de progreso personal y material. Los ferrocarriles fueron un incentivo para este hombre de acción. Sedujo a gobiernos, a consorcios y construyó ferrocarriles en las naciones balcánicas y asiáticas, conectando los «interlands" con los puertos en zonas separadas de las arterias continentales del tráfico. Esa carrera de organizador de comunicaciones le trajo la fama -construyó las líneas del Orient Express-, lo recompensó con ganancias que parecieron inverosímiles y lo transformó en poseedor de una de las fortunas más considerables de Europa. Se codeaba con la alta aristocracia. Hábil diplomático, utopista pragmático que creía que la redención de su pueblo pasaba obligatoriamente por el regreso a la tierra. Viajaba sin pompa, con la simplicidad de comerciante reposado, continuamente de una capital a otra, se detenía en los centros estratégicos en que tendían rieles o se instalaban estaciones. En esos viajes se adentraba en la vida de las juderías, y con esos contactos comenzó a desarrollar obras de filantropía reemplazando la limosna por organización. Fundó en Austria una corporación que dirigía y costeaba -la Barón Hirsch Stiftung-, encargada de impartir educación a los judíos, y tomó a su cargo la faraónica misión de promover la emigración de millares de judíos rusos y rumanos para quienes creó colonias agrícolas en América del Sur y del Norte. En esta última establece dos primeras instituciones, en Canadá a través de comités encargados de recibir y colocar a los 
judíos que desembarcan y aclimatarlos en el trabajo industrial y en los Estados Unidos la Barón Hirsch Fund, que tenía como misión acoger y distribuir a los judíos, buscarles ocupación, proporcionarles tierras y habilitarlos para las tareas urbanas a partir de la educación e instrucción profesional. ${ }^{17}$

Su proyecto de colonización agraria estaba bastante avanzado cuando Theodor Hertz, intelectual judío considerado como el principal promotor político del movimiento sionista y de la emigración a Palestina, tomó contacto con él. Los detalles de estos intercambios están volcados en el diario privado de Hertz. ${ }^{18}$ Tuvieron un solo encuentro personal en París. Hertz no ahorró críticas contra Hirsch, ${ }^{19}$ por su no adhesión al sionismo y por considerar que el proyecto de colonización en América del Sur no era una solución para el problema judío. El pragmatismo de Hirsch le indicaba que las posibilidades de la emigración a Palestina y la instalación de los judíos requerirían de un tiempo que la situación en Rusia no podía esperar.

El caso Dreyfus conmovió profundamente a Hertz, transformando radicalmente su mirada sobre el problema judío, lo que llevó a terminar con sus contactos antisemitas, como León Daudet y Édouard Drumont, y con su pertenencia a una corriente asimilacionista con el anhelo de conversión masiva para los judíos. Retoma la idea de regresar a la Tierra Prometida que ya había florecido en Rusia y Polonia a mediados del siglo xVIII, pero despojado de la connotación religiosa. El sionismo de Hertz era una teoría política laica y nació debido a la aparición de movimientos nacionalistas y antisemitas de fines del siglo xIX.

Hertz solicitó una entrevista en mayo de 1895 para explicar su proyecto y contar con la colaboración económica de su propuesta, la que se produjo el 10 de junio. Su obra El Estado Judío, manifiesto fundacional de sionismo, nació de los borradores que preparó para la reunión con Hirsch y fueron perfeccionados para presentar como Discurso a los Rothschild, ${ }^{20}$ texto que no llegó a manos de Hirsch por su orgullo desmedido y por la muerte prematura del barón.

${ }^{17}$ Gerchunoff, Alberto, «Noticias sobre la inmigración judía”, en 50 años de colonización judía en la Argentina, Buenos Aires, DAIA, 1939, p. 57.

18 Hertz, Theodor, The complete Diary, 1895.

19 "Este hombre de negocios no es más que un frívolo que dilapida ostentosamente su fortuna en limosnas, es decir, que se ocupaba de los judíos de una forma visionaria y millonaria". En Herzl, T., Extrait du Journal, París, Stock, 1981, p. 144

${ }^{20}$ Hertz escribe en su diario que, tal como lo advirtiera Hirsch, no contaría tampoco con el apoyo de los judíos multimillonarios. 
Años después, Hertz reconoció que aquel crucial momento para aunar esfuerzos fue malogrado debido a su propia precipitación.

\section{La creación de la Jewish Colonization Association}

El 24 de agosto de 1891 se formalizó en Londres la creación de la Jewish Colonization Association (JCA $)^{21}$, empresa filantrópica ${ }^{22}$ fundada por el barón Mauricio de Hirsch a la cual se le concedió personería jurídica en la República Argentina el 17 de febrero de 1892. Si bien el primer contingente de judíos ya había arribado en el Weser en 1889, el proceso histórico de la inmigración judía a la Argentina se inició a partir de la fundación de la JCA y se desenvolverá durante cincuenta años en el marco de esta institución. La JCA contaba con la infraestructura agrícola, la capacidad económica para las inversiones y una política eficaz para el reclutamiento de colonos judíos residentes en Europa, sobre todo en Europa Oriental.

Para comprender algunos de los mecanismos que compusieron el engranaje de la colonización, es importante conocer acerca de la historia de la Jewish Colonization Asocciation. Era una asociación filantrópica de asistencia a los judíos que atravesaban circunstancias muy difíciles, tanto económica como existencialmente por las persecuciones de las que eran objeto en Europa Oriental. Su objetivo era colaborar con la emigración y el asentamiento en donde la vida fuera apacible y digna para los emigrantes.

Los otros accionistas que integraban la dirección de la Asociación eran el barón de Rothschild, J. Goldsmid, Sir Ernest Cassel, F. D. Mocatta, Benjamín Cohen, S. Goldschmidt y Salomón Reinach. En 1893, las acciones de Hirsch fueron distribui-

\footnotetext{
${ }^{21}$ La magnitud de esta empresa habría de convertir a la JCA, según la Enciclopedia Británica de 1929, en el mayor trust filantrópico de su tiempo.

${ }^{22}$ Es un ejemplo de filantropía no asistencialista, al tener los inmigrantes el derecho de acceder a la propiedad de la tierra, pero no en forma gratuita, sino luego de haberla abonado, al igual que la totalidad de los préstamos en especie recibidos durante el traslado y hasta las primeras cosechas, y aun el respectivo interés sobre los mismos. En Edgardo Zablotsky, "Colonia Mauricio. Reinterpretación de su aparente fracaso", Doc. de Trabajo 264, UCEMA, mayo, 2004.
} 
das entre la Asociación Anglojudía y las comunidades judías de Bruselas, Berlín y Frankfurt. La donación básica fue aumentada más tarde a 8 millones de libras.

Las oficinas estaban instaladas en París, hasta que fueron transferidas en primer lugar a Lisboa - por los efectos del desastre que afectó a los judíos en 1940y luego a Londres. El barón Mauricio de Hirsch fue presidente hasta su muerte en 1896. Fue sucedido por Salomon Goldsmid (1896), Narcisse Leven (1896-1919), Franz Philippson (1919-1929), Lionel Leonard Cohen (1929-1934), Sir Osmond d'Avigdor Goldsmid (1934-1940), Leonard Montefiore (1940-1947), Sir Henry Joseph d'Avigdor Goldsmid (1947). ${ }^{23}$

La primera asamblea general de la JCA tuvo lugar el 14 de octubre de 1891, con la presidencia del barón de Hirsch. Todos los integrantes del primer directorio eran de nacionalidad británica: algunos pertenecían a la alta banca, otros tenían importantes funciones en instituciones laicas y religiosas israelitas o eran renombrados intelectuales judíos.

La JCA era una sociedad por acciones, conforme a la legislación inglesa, ${ }^{24}$ que dispuso de un capital inicial de 50 millones de francos ${ }^{25}$ donados por su creador, cifra que superaba en monto a todos los fondos públicos judíos de Europa y América sumados. Más tarde, el barón se las ingenió para inyectar nuevas donaciones de increíble envergadura (180 millones de francos oro más). Las biografías escritas sobre el fundador dan cuenta de la versatilidad de sus acciones y su magnífica habilidad para manejar fondos, en particular su predilección por buscar formas ingeniosas para eludir pago de impuestos a los distintos estados.

Fue Maurice de Hirsch, con la ayuda de abogados ingleses y franceses, quien definió los marcos jurídicos, la forma, los objetivos y el funcionamiento de la JCA. Se ocupó también de colocar el capital en el banco de Rothschild de Londres, que le garantizaba un interés del 3\% anual, lo cual le aseguraba en cierto modo la

\footnotetext{
${ }^{23}$ Benmergui, Alicia, "Historia de Rivera», en www.milimcultural.com.ar/historia/index.htm.

${ }^{24}$ Se trata de una sociedad que recibe la donación en vida de casi la totalidad de la fortuna del barón, conservando tan sólo una renta para él y su esposa. La legislación francesa no permitía este tipo de sociedad. Por esta razón se establece en Londres.

${ }^{25}$ Equivalentes en esa época a unos 2 millones de libras esterlinas o casi 10 millones de dólares. Un año más tarde, legó el barón de Hirch el grueso de su patrimonio, que constituía la enorme suma de 7.337.857 libras esterlinas y que la JCA recibiría luego de su muerte. Avni, Haim, "La agricultura judía en Argentina ¿Éxito o fracaso?», en Desarrollo Económico, Vol. 22, № 88, enero-marzo de 1983, p. 535.
} 
realización del plan de colonización y la permanencia de una obra concebida para sobrevivir durante mucho tiempo a su fundador. ${ }^{26}$

El objeto de la entidad estaba fijado en el artículo $3^{\circ}$ :

Facilitar la emigración de israelitas de los países de Europa y Asia donde ellos son deprimidos por leyes restrictivas especiales y donde están privados de los derechos políticos, hacia otras regiones del mundo donde puedan gozar de éstos y demás derechos inherentes al hombre. Al efecto la Asociación se propone establecer colonias agrícolas en diversas regiones de América del Norte y del Sud ${ }^{27}$, como también en otras comarcas. ${ }^{28}$

\section{En extenso se describe:}

Para asistir y promover la emigración de los judíos de todas partes de Europa y Asia y en particular de aquellos países donde sean sometidos, en este preciso momento, a impuestos especiales, restricciones de los derechos de ciudadanía u otros abusos, y crear y establecer colonias para ellos en distintas partes del mundo, en particular en Sudamérica, para que se dediquen a la agricultura, al comercio y a cualquier otro proyecto a instalar, poner en funcionamiento y ayudar, en cualquier lugar del mundo, a instituciones para la educación y el aprendizaje de oficios, granjas modelo, cajas de

\footnotetext{
${ }^{26}$ Frischer, D., op. cit., p. 443.

${ }^{27}$ El año 1894 marcó la llegada de los inmigrantes judíos a Brasil, destinados a la Colonia Phillipson, cercana a Santa Marta, en Río Grande do Sul, que fue la primera colonia judía que se instaló organizadamente en el país. Esos primeros inmigrantes, de origen ashkenazí -cerca de 37 familias-, procedían principalmente de Besarabia. La mayoría de ellos estaba formada por artesanos que debieron reciclarse en agricultores, de acuerdo con el proyecto de colonización agraria de la JCA. Recibieron lotes de veinticinco a treinta hectáreas, pequeñas casas de madera, animales, instrumentos agrícolas y semiIlas, con financiamiento a largo plazo. Pero el desconocimiento del idioma portugués, la falta de familiaridad con el cultivo de la tierra y el hecho de ser gente esencialmente urbana, fueron factores que dificultaron su asentamiento en el agro. Posteriormente, la JCA adquirió la hacienda Quatro Irmãos, en la zona de Passo Fundo y Erechim, adonde originariamente fueron tres decenas de familias, sumando luego más de mil personas. Muchas de ellas continuaron en la región y algunos de sus descendientes son hacendados en los lugares en los que sus padres y abuelos se instalaron inicialmente. Otras colonias judías surgieron en la región norteña del estado. Corrente WIZO, publicación oficial de la WIZO do Brasil, traducido del portugués al español por el director de comunicación del Congreso Judío Latinoamericano, Pedro Olschansky, mayo de 2005.

${ }^{28}$ Memorias de la Jewish Colonization Association. Su obra en la República Argentina. 1891-1941, Buenos Aires, p. 6.
} 
préstamos, industrias, fábricas y cualquier otra institución o asociación que, a juicio del comité, convenga a los judíos y favorezca su emigración y su instalación en cualquier parte del mundo, menos en Europa (artículo 3 del Acta).

Un punto central era dejar fijado el carácter filantrópico de la Asociación. Así, el artículo 6 rezaba lo siguiente:

"Las entradas y los bienes de la Sociedad serán empleados exclusivamente para la realización del objeto establecido en sus estatutos. De ninguna manera y en ninguna forma, directa o indirectamente, será destinada una parte cualquiera de sus entradas o bienes en calidad de dividendos o primas de beneficios a favor de los miembros de la Asociación». ${ }^{29}$

Desde su fundación, la JCA se caracterizó por su independencia financiera. No necesitó de otras donaciones o aportes públicos como aconteció con otras instituciones que aparecieron posteriormente. Tenía el control sobre el capital del barón de Hirsch y sus intereses permitían a los fideicomisarios de la asociación financiera las operaciones de un año al otro. Otro rasgo distintivo de la empresa fue su organización jerárquica e inflexible. Desde la oficina central de París, la administración central ejercía un control autoritario sobre todo lo que hacían sus funcionarios en Argentina o en otros países. La administración local en Buenos Aires tenía a su frente, en general, a dos directores. Se pretendía que la oficina regional elevara informes semanales muy precisos sobre todo lo que estaba pasando en las colonias y obtuviera la aprobación de las oficinas centrales en lo que se refería a sus actividades principales. Avni ${ }^{30}$ señala que había, por lo tanto, una abundante correspondencia entre París y Buenos Aires. Los dos administradores de Buenos Aires controlaban las actividades de las colonias a través de directores regionales que recibían la ayuda de numerosos funcionarios menores, inspectores y agentes que debían realizar informes regulares y precisos sobre todo lo que pasaba en torno al proyecto.

\footnotetext{
${ }^{29}$ Ibídem.

${ }^{30}$ Avni, Haim, «La agricultura judía en Argentina ¿Éxito o fracaso?», op. cit., p. 536.
} 
Los primeros beneficiarios de la empresa colonizadora JCA fueron los inmigrantes judíos arribados en el barco Wesser, como explicamos en el capítulo anterior estos habían llegado al puerto de Buenos Aires en 1889 con la promesa del cónsul argentino en París de que en Argentina los esperaban tierras y trabajo. Sin embargo, estas tierras ya estaban ocupadas y los colonos fueron trasladados a la provincia de Santa Fe debido a los negocios que se pudieron establecer con el terrateniente de Buenos Aires, Pedro Palacios. Llegados a la estación ferroviaria de Palacios, los inmigrantes no contaban con viviendas ni construcciones adecuadas y subsistían con limosnas. Varias familias de esta primera colonia se trasladaron a Buenos Aires, y muchas otras se opusieron ante la propuesta de reinstalarse en la primera colonia de la JCA en Entre Ríos. Esta fuerte negativa convenció a los funcionarios de la JCA de que adquirieran las tierras de Pedro Palacios y pusieran en funcionamiento un plan de emergencia, que se llevó adelante en 1891.

Entre 1892 y 1914 confluyen en nuestro país el proyecto agroexportador y el plan colonizador que apuntaba a insertar a los inmigrantes judíos en el nuevo modelo, convirtiéndolos en productores del campo argentino. Las tierras con las que contaba la JCA aumentaron considerablemente, llegando a abarcar zonas de las provincias de Entre Ríos, Santa Fe, Buenos Aires, Santiago del Estero y La Pampa. Este aumento se debió a las continuas inversiones en el asentamiento de inmigrantes judíos.

La independencia económica de la JCA le facilitó a la empresa el obrar conforme a su propia política de inversiones y de programación sin verse afectada por las críticas que recibía de la opinión pública europea o americana.

Prontamente, el 20 de octubre de 1891, la JCA celebraría un contrato con el gobierno argentino, firmado por el Dr. Wilhelm Lowenthal en representación del barón de Hirsch, que establecía los criterios de la empresa donde el Estado vendía a la JCA 1.300 leguas kilométricas cuadradas de tierras nacionales (en territorios de Misiones o en el Chaco) aptas para la colonización por el precio de 200 libras esterlinas por legua, debiendo abonar 260.000 en letras sobre Londres al momento de la firma del contrato. ${ }^{31}$

\footnotetext{
${ }^{31}$ ¡3.250.000 hectáreas! Sin embargo, estos planes grandiosos de colonización no pudieron realizarse en los territorios nacionales del Norte del país. A pesar de no haberse cumplido las previsiones del barón de asentar a centenares de miles de colonos judíos, durante los primeros cinco años de existencia de la JCA el sueño utópico tomó cuerpo en proporciones más humildes: se levantaron cinco grandes colonias en las provincias de Buenos Aires, Entre Ríos y Santa Fe, con una superficie total de 200.619 hectáreas,
} 
Los compradores tenían cuatro años para determinar la ubicación de las tierras vendidas y durante ese plazo el gobierno nacional abonaría un interés del 5\% anual, pagado en Buenos Aires por semestres vencidos. ${ }^{32}$

La JCA disponía de un estricto plan para seleccionar a los futuros inmigrantes, reclutando mano de obra campesina de países como Rusia y Rumania, donde los judíos estaban siendo expulsados y perseguidos.

Los viajes y el asentamiento completo de los inmigrantes eran costeados por la misma JCA. Sin embargo, se les exigía que parte de los gastos también los solventaran ellos. Los colonos que llegaban al país por su cuenta, de forma espontánea, eran aceptados por la empresa con la condición de que trabajasen durante un prolongado período de prueba como peones de los chacareros veteranos. El administrador de la empresa era quien tenía la decisión de incorporar a este tipo de colonos, aunque para ello también debían demostrar aptitud y adaptación a las tareas rurales, además de ahorrar parte de sus salarios para sufragar el costo de la colonización. Los agricultores independientes podían convertirse en colonos de la JCA si disponían de un monto mínimo de 2.000 rublos. A cambio, la empresa pondría a su disposición tierras y un pequeño préstamo para la construcción de sus viviendas.

La burocracia jerárquica de la JCA a través de la Administración general de París, los dos administradores generales de Buenos Aires, los administradores regionales y sus funcionarios diseminados por todo el país, aseguraron una inflexible ejecución y control de la política de reclutamiento, adiestramiento laboral y ejecución de las obligaciones contractuales contraídas por los colonos, quienes no tenían participación directa en los órganos consultivos y en la toma de decisiones de la JCA.

La colonización agrícola en Argentina constituyó el pivote fundamental del proceso inmigratorio y del asentamiento de la comunidad judía en el país. La característica distintiva de este proceso reside en que, en la plenitud de la inmigración espontánea, el gobierno nacional había concertado un convenio especial con una empresa colonizadora internacional para estimular la inmigración dirigida de agricultores judíos.

donde se asentaron 6.757 colonos con sus familias en 910 chacras. Leonardo Senkman, "Los gauchos judíos - una lectura desde Israel”, en Estudios Interdisciplinarios de América Latina y el Caribe, Vol. 10, Nº 1, enero-junio, 1999.

32 Citado por Leonardo Senkman, La colonización Judía, Buenos Aires, CEAL, 1984, pp. 22-24. 


\title{
Las condiciones de la colonización
}

El proceso comenzaba en Rusia y reconocía diferentes derroteros en los criterios que se adoptarían para la selección de inmigrantes. El barón de Hirsch estaba convencido de que el éxito del proyecto dependía ante todo de la acertada elección de los futuros inmigrantes:

\begin{abstract}
Si esta primera selección de pioneros y delegados está bien hecha, si todos comprenden bien cuáles son las instrucciones y si las llevan a cabo con habilidad y economía, habremos dados un inmenso paso hacia el futuro. De modo que debo recomendarles la mayor prudencia en esta selección, de modo de dejar la menor cantidad posible de elementos librados al azar. La fecha de partida de esta vanguardia puede ser la que se elija, puesto que las tierras ya están adquiridas. ${ }^{33}$
\end{abstract}

Pero varios acontecimientos internacionales fijaban alteraciones al proyecto. Por un lado, el cierre de la frontera norteamericana al flujo migratorio de judíos al país. El presidente Harrison llamó la atención en 1891 al Congreso sobre el inquietante aumento de la inmigración, que en los dos últimos años sobrepasaba las 50.000 personas por año y que amenazaba, según la previsión de los expertos, con aumentar considerablemente, con el riesgo de aumentar la recesión que reinaba en el país y, por lo tanto, la necesidad de controlar los ingresos a través de la reducción de cupos. Por otro lado, la virulenta represión del gobierno ruso a los judíos que exponía a condiciones de vida inhumanas a los pobladores, alentaban y urgía el proceso migratorio. ${ }^{34}$

En este contexto, el barón tuvo que dar instrucciones para frenar la inmigración, ya que temía que los candidatos que habían proyectado emigrar a los Estados Unidos se dirigieran súbitamente a Argentina. También pesaban en esta decisión los primeros informes de los administradores que llegaban de Buenos Aires dando cuenta de las dificultades de adaptación de algunos colonos, que imponía tener precaución en las cantidades de emigrantes.

\footnotetext{
${ }^{33}$ Circular redactada por Hirsch el 9 de marzo de 1892, Kohler's Papers, AJHS, Nueva York. En Frischer, D., op. cit., p. 455.

${ }^{34}$ Frischer, D., ibídem.
} 
El barón comunicaba entonces que:

es evidente que al comienzo la cantidad de emigrantes no será muy importante, ya que se trata de no sólo encontrar lugares que acojan a los primeros que partan, sino de tomar las disposiciones necesarias para poder establecer a quienes lleguen después de estos. Más adelante la emigración podrá constar de contingentes más importantes... Para concluir, les digo: son ustedes los herederos de sus padres, quienes han soportado tanto sufrimiento a lo largo de los siglos. Soporten ese legado durante un tiempo más con la misma resignación que ellos tuvieron. Tengan paciencia y dejen a quienes puedan auxiliarlos que así lo hagan. Que Dios los ayude y nos dé, a mí y a los muchos que me secundan con tanta lealtad, su protección para que podamos ayudarlos. ${ }^{35}$

Mauricio de Hirsch formaba parte de la corriente filosófica del lluminismo judío, sostenedora de que el estatus político y social de los judíos que vivían en las zonas de residencia rusa podía mejorar mediante su transformación en agricultores modernos. Se trataba de una empresa de regeneración humana y moral más que de una cuestión de progreso económico. Más allá de la filantropía, el propósito cardinal de la empresa era asentar a los inmigrantes en el campo para crear una clase campesina y de chacareros judíos en Argentina. La mayoría de estos inmigrantes no eran trabajadores agrícolas, a pesar de que muchos venían de zonas rurales atrasadas.

Si bien se procedía a realizar una cuidadosa y muchas veces excesivamente meticulosa ${ }^{36}$ selección de inmigrantes en Rusia, muchos de los que arribaban poseían una escasa preparación para trabajar en la tierra. ${ }^{37}$

En 1894, David Feinberg, como representante del Comité Central de la Jewish, realizó una segunda visita a las colonias rusas con el fin de preparar los grupos dispuestos a emigrar a Argentina. Nombró como agentes colaboradores a Zalmer

${ }^{35}$ Circular redactada por Hirsch, 9 de marzo de 1892, Kohler'sPpaper, ALHS, Nueva York. Citado por Frischer, D., op. cit., p. 456.

${ }^{36}$ Ver Avni, Haim, op. cit., p. 137.

${ }^{37}$ En junio de 1892 fue seleccionado el primer contingente de cincuenta familias enviado a la Argentina, elegidos sobre un total de doscientas familias de Besarabia. 
Lewenstein y a Akerman, quienes serian los responsables de indicar las personas, residentes en la provincias de Gersaner y en Besarabia, ${ }^{38}$ a las que consideraban apropiadas y capaces de inscribirse como candidatos. Entre los requisitos se destacaban que fueran agricultores, que tuvieran hijos adolescentes y que dispusieran de un pequeño capital. ${ }^{39}$

La condición de agricultor era una exigencia relevante. ${ }^{40} \mathrm{Si}$ no poseían esta capacidad debían realizar su aprendizaje en las colonias con técnicos aportados por la Compañía y luego de ello estaban en condiciones de realizar en forma independiente la explotación de un lote de terreno. Los principios generales que regulaban este proceso eran los siguientes: La tierra era vendida al colono al precio de compra, aumentando con los gastos de mensura, escrituración, establecimiento de caminos, canales de riego, etcétera. El colono recibía un anticipo de dinero por gastos de viaje, para la construcción y arreglo de la casa para el establecimiento de su familia y la adquisición de material de trabajo. ${ }^{41}$ Se firmaba un contrato de promesa de venta, por el cual se obligaba a reembolsar a la empresa el precio de la tierra y el total del anticipo en cierto número de anualidades, que no podía ser superior a veinte, con un interés de $5 \%$ anual, y después de satisfechos esos requisitos recibía sus títulos de propiedad definitivos. Para evitar que el colono, seducido por el valor que hubiera adquirido su tierra, vendiera el lote y abandonara la explotación, el contrato contenía cláusulas que hacía muy difícil ese desprendimiento. También se fijaba que el lote debía ser trabajado por el colono con los miembros de su familia y que quedaba prohibida la sublocación. ${ }^{42}$

\footnotetext{
${ }^{38}$ Estos dos grupos, uno en las colonias judías de Gersaner (Ilamado Grupo Noverburguer) y el segundo de Besaravia (Ilamado Grupo Akerman) fueron los que fundaron las primeras cuatro colonias cerca de la estación Basavilbaso, en Entre Ríos.

39 Hurvitz, S. I., Colonia Lucienville. $37^{\circ}$ aniversario de la colonización. Homenaje a Mauricio de Hirsch, Buenos Aires, 1932 (en idish, traducido por Jorge Zentner).

${ }^{40}$ Este criterio unidireccional llevó -en el momento de seleccionar e integrar los grupos- a que David Fainberg preguntara a Noaj Katzovich, un intelectual que quiso incorporarse a los emigrados, "¿No cree Usted que los elementos progresistas causarán daños a las colonias?». Citado por Avni, op. cit., p. 141. ${ }^{41}$ Véase, por ejemplo, el Contrato de Promesa de Venta № 836 realizado entre la JCA y José Chiger, firmado el 30 de noviembre de 1900. La Asociación promete vender al citado colono en la colonia Sonenfeld dos lotes de 83 hectáreas al precio de $\$ 50$ por hectárea y una quinta de una superficie de 3 hectáreas, lo que asciende a la suma de $\$ 4.394,03 \mathrm{~m} / \mathrm{n}$, más el adelanto citado por una importe de $\$ 7.707$, por lo que el colono asume el compromiso de pagar \$11.470 más los intereses de esta suma a 5\% al año, mediante veinte anualidades de $\$ 920 \mathrm{~m} / \mathrm{n}$ cada una, de las cuales la primera será pagada el 1 de abril de 1901 y la última el 1 de abril de 1920. En Caja A, JCA, Archivo IWO, Buenos Aires.

42 Revista de Tierras y Colonización, marzo de 1921, pp. 16/24. Citado por Leonardo Senkman, op. cit., p. 52.
} 


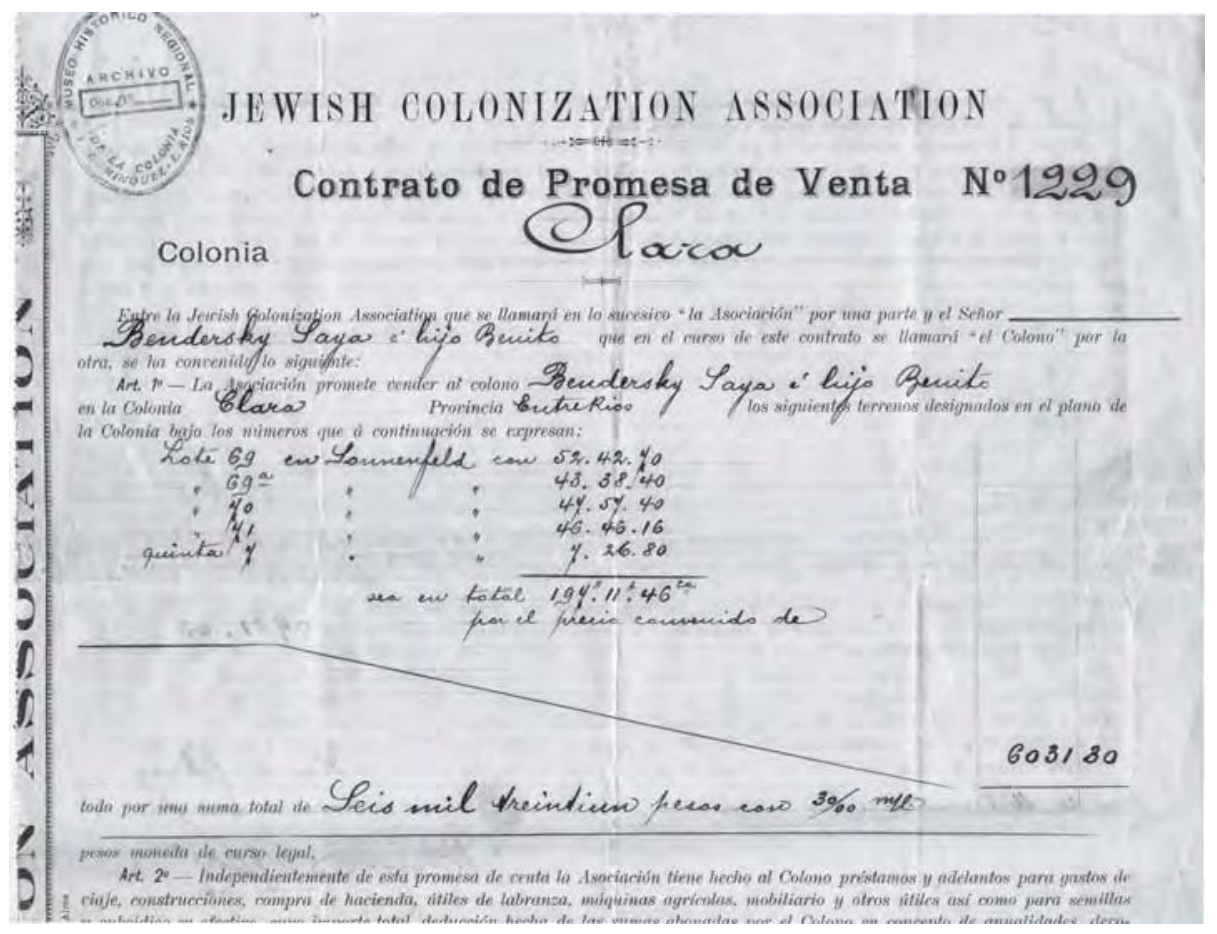

Contrato de promesa de venta

\section{Extensión de las tierras}

La JCA, además de una parcela de tierra, en este caso con casa, les entregaban subsidios, eran 74 has. dado en propiedad en plan de pago. Le costó muchísimos pagarlo, recién pudo cancelar la deuda después de 20 años, durante el gobierno peronista. Cuando volvía de Domínguez de entregar la cuota le comentaba a mamá de las discusiones acaloradas con el administrador, que siempre los amenazaba con desalojarlos si no cumplían con el pago; además estaba la langosta que cubría arboledas, frutales, maizales, devoraba todo. ${ }^{43}$

El modo en que la JCA subdividía las colonias eran tres: aldeas con chacras y potreros dependientes de aquellas; en grupos, es decir que cuatro colonos se establecían muy vecinos unos de otros; y en desparramados, en que cada colono se instalaba en su chacra.

${ }^{43}$ Entrevista a Mauricio Flier, octubre de 2008. 
Las extensiones de tierra otorgadas fueron modificándose con el transcurso del tiempo. Al principio -señala la empresa en sus eufóricos informes oficiales- se entregaron a los colonos superficies entre 150 y 400 hectáreas, pero al introducir procedimientos de cultivos intensivos las extensiones se fueron reduciendo de 75 hectáreas el lote a 25, por ejemplo en la colonia Dorá a orillas de Salado.

A principio de los años 1920, la superficie media de la concesión se establecía en 140 hectáreas, de las cuales 85 o 90 se cultivaban y el resto se utilizaba con fines de pastoreo. El mismo informe de la JCA señalaba que la situación del colono era, en general, satisfactoria y le permitía amortizar sin dificultades la deuda en anualidades medias de $\$ 625$ por lote. ${ }^{44}$

Sin embargo, las Memorias de los primeros colonos señalaban que las extensiones de tierras obtenidas fueron menores. Por ejemplo, el grupo Novibuko y el grupo Akerman, al arribar en 1894 a las tierras cercanas a la estación ferroviaria de Basavilbaso, las cuatro colonias ocuparon 7.000 hectáreas y a cada colono se le adjudicaron 50 hectáreas para arar y sembrar y 25 para pastoreo. ${ }^{45}$

Algunos informes dan cuenta de que la obra de colonización tuvo dificultades y se debieron bajar las exigencias para aceptar a nuevos colonos, sin poder analizar en cada caso sus "condiciones de laboriosidad y honradez". Para salvar de un posible fracaso esta colonización no seleccionada, empleaban el procedimiento de arrendar el campo "a prueba" durante un período de tres años. ${ }^{46} \mathrm{Al}$ cabo de este tiempo, los administradores podían tener una idea del "valor" de cada colono y proceder a conceder un Contrato de Promesa de Venta de los terrenos arrendados, entendiéndose que las sumas abonadas por el arrendatario les serían tomadas a cuenta como pagos efectuados de las anualidades.

\footnotetext{
${ }^{44}$ Revista de Tierras y Colonización, marzo, 1921, p. 47.

${ }^{45}$ Hurvitz, S.I., op. cit., p. 3.

${ }^{46}$ Véase, por ejemplo, el contrato de arrendamiento celebrado entre la JCA y Fridel Rabinovich el $1^{\circ}$ de abril de 1906, renovado en 1907 por un año más. Se arrienda una fracción de campo de 137 hectáreas y una quinta en el Grupo Barón Hirsch de la Colonia Clara. El valor del arrendamiento fue fijado en \$515 $\mathrm{m} / \mathrm{n}$ por año, pagaderos en efectivo o en grano al pie de la trilladora o de otros productos de los terrenos alquilados, debiendo ser efectivizado antes del 31 de marzo de 1907 (Art. 3). Se establece que para facilitar su trabajo, la JCA presta al arrendatario los animales y útiles de labranza cuyo detalle figura con los precios correspondientes en el inventario adjunto al contrato (Art. 9), los que deberán ser devueltos en buen estado de conservación y uso y puestos en el galpón y corral indicado por la Administración, finalizado el contrato (Art. 12). Archivo IWO, Caja JCA, b.
} 
David no era campesino, no conocía el oficio, en Rusia no tenían tierras, los nativos (peones) colaboraban con las tareas de campo, eran una amalgama entre nativos y colonos. Éramos 5 hermanos y todos colaborábamos en las tareas, arrimábamos a las lecheras, teníamos huertas y frutales, recuerdo los durazneros florecidos. ${ }^{47}$

Para la instalación de los colonos, la compañía entregaba a cada uno el lote totalmente alambrado y con una división interior que formaba un potrero. En el interior se hallaba construida una casa de material cocido compuesta por dos piezas de 4 × 4 metros, la entrega de un horno situado junto a la pared de la casa, un techo de 4 × 6 para galpón, un arado de asiento, una rastra de dientes, un carro de cuatro ruedas y otros elementos que a veces eran compartidos con el colono vecino. Se les entregaban diez lecheras, diez a doce caballos y un toro cada dos concesiones que eran compradas por la Compañía. Con el transcurso del tiempo, estas adquisiciones las hacían los colonos, con dinero y marca de la empresa.

La casa era revocada exteriormente por la Compañía, siendo obligación de los colonos el revoque interior. ${ }^{48}$

Ya en los años veinte, todos los nuevos colonos debían ser previamente arrendatarios durante tres años. Después, si su conducta era satisfactoria, se les permitía firmar el contrato, promesa de venta, pagar sus anualidades y obtener la escrituración transcurridos cinco o más años, pagando previamente el total de precio y anticipos recibidos. De este modo, se les exigía un tiempo mínimo de residencia y explotación personal igual a ocho años, incluidos los tres de arrendamiento a prueba.

La Memorias de la JCA ${ }^{49}$ explican recurrentemente que han tratado de favorecer la formación de cooperativas y mutuales en sus colonias. También sociedades sanitarias con el propósito de facilitar la asistencia médica a sus asociados y mantener el hospital Clara existente en Villa Domínguez (Entre Ríos). El apoyo a estas iniciativas se concretó en adelantos de dinero a un interés que oscilaba entre el 4 y el $6 \%$ anual, que las cooperativas reembolsaban en varias anualidades.

\footnotetext{
${ }^{47}$ Entrevista a MF.

${ }^{48}$ Un dato que aparentemente parece anecdótico es la referencia a que, si se revocaba el interior, los colonos no se preocuparían por el aspecto exterior de sus viviendas.

${ }^{49}$ Memoria de la Jewish Colonization Association, op. cit., p. 50.
} 
Paralelamente, la acción cultural era un objetivo central, por lo que se crearon establecimientos de enseñanza primaria, profesional y de perfeccionamiento. La escuela primaria en las colonias era una prioridad para intentar que los colonos que arribaban al país pudieran vencer las dificultades que se les presentaban por la diferencia de lenguaje y de costumbres. Como señala Boris Garfunkel en sus memorias:

A la administración de la J.C.A. se le pueden censurar no pocas cosas, pero al mismo tiempo no faltan por cierto algunos motivos de alabanza. Entre estos últimos está sin duda el modo en que se encaró la educación de los hijos de los colonos... Desde el principio la J.C.A. se empeñó en proporcionarnos buenos maestros, tanto en lo concerniente a la educación judaica como en lo relativo a las materias de los grados de la instrucción primaria ${ }^{50}$

Las condiciones económicas estructurales del país acotaron la actividad de los colonos judíos e incidieron en la configuración de los asentamientos, disgregación y producción de las colonias. En Argentina, los colonos fueron afectados por las oscilaciones de los precios del grano en el mercado de exportación y el sistema de tenencia latifundista, el monocultivo, el sistema de comercialización monopólica en el mercado de cereales y carnes, las dificultades para acceder al crédito y la ausencia de silos y forma de almacenamiento de los granos. Además, debieron enfrentar problemas de índole ecológica (sequía, langostas, heladas, inundaciones) y topográfica (las distancias enormes de los centros poblados, el aislamiento).

La política de asentamiento de la JCA para crear una clase de campesinos colonos buscaba áreas distantes de los centros urbanos. Sin embargo, el proceso de éxodo de las colonias no tardó en aparecer, coincidiendo con la corriente nacional del éxodo rural-urbano de los años treinta y con el intenso proceso de urbanización del país, el aumento del sector de servicios y la industrialización sustitutiva de las grandes ciudades del litoral.

\footnotetext{
${ }^{50}$ Boris Garfunkel, junto con su familia, decide incorporarse a uno de los contingentes emigratorios de la JCA. Un 4 de septiembre del año 1891 pisa tierra argentina y se establece en el paraje denominado Algarrobos, ubicado en la zona norte del actual partido de Carlos Casares, donde trabaja la tierra que la JCA le ha facilitado. Sus hijos publican sus memorias, Narro mi Vida, en 1960.
} 
Los colonos comenzaron a tener conflictos con la JCA cuando observaron que las directivas -con las que la empresa funcionaba diariamente- no respondían al paternalismo filantrópico en base al cual había sido fundada. El barón de Hirsch había fundado la JCA con el objeto de convertir al pueblo judío en el único depositario de su fortuna, sobre todo a partir de la muerte de su único hijo y heredero en 1887.

La voluntad expresa de la JCA era convertirlos en productores agrícolas, mediante una disciplina laboral sistemática. Esto se observa claramente en los alcances del contrato que el colono firmaba cuando recibía su parcela. La tierra no le era vendida directamente, sino que, como señalamos anteriormente, recibía una promesa de venta. Cuando transcurrieran los veinte años podría obtener la titularidad. De esta manera, las autoridades de la empresa colonizadora trataron de fijar o asentar a los colonos de la primera generación. Existieron casos concretos de solicitud de acortamiento de los contratos (colonia Mauricio) en los años previos a la Primera Guerra Mundial. En esa ocasión, la solicitud fue denegada. Sin embargo, con el transcurso de los años la empresa tuvo que flexibilizar este intento de fijación.

Los conflictos se debieron a las contradicciones básicas de los intereses personales de los colonos que querían extraer ventaja de las oportunidades no agrarias que les ofrecía el desarrollo argentino y los principios de productividad que los directores del proyecto trataban de imponerles. ${ }^{51}$ Otro capítulo de enfrentamientos

\footnotetext{
${ }^{51}$ El dirigente León Chasanowich, luego de su visita a Argentina en 1910, denuncia las relaciones tirantes entre los colonos y la JCA, ya que las describe como de un "feudalismo filantrópico" que genera importantes tensiones más allá de las buenas intenciones de la empresa. Citado en Avni, H., op. cit., p. 545.

La presencia de Jazanovich fue el resultado de los esfuerzos por traer un "agitador talentoso" que señaló Sorkin en su carta, y del deseo del candidato de visitar las colonias (Meiern). Así llegó Jazanovich (Katriel Shuv) - periodista, orador, conocido activista y dirigente del partido en el Imperio Ruso y en Austria- en 1909 a la Argentina a cumplir una misión en el Poalei Sion. Es interesante destacar, como ejemplo de las influencias locales sobre el estilo de cada partido, que Katriel Shuv cambió (por influencia del Partido Poalei Sion de EE.UU.) su nombre hebreo por un nombre con una «imagen" más "atractiva" (mezcla del nombre latino europeo usado en Alemania -León-, del hebreo Jazan y del ruso la terminación -ich). Su llegada a la Argentina despertó muchas esperanzas entre los miembros del Poalei Sion, quienes esperaban poder superar las debilidades y reforzar las cualidades del Partido: (a) el reducido número de miembros del partido cobraría fuerzas con la llegada de nuevos adherentes atraídos por la influencia personal del visitante como dirigente, como periodista y como orador; (b) el sentido de misión y la sensación de pertenecer a un movimiento se verían fortalecidos por los conocimientos y la capacidad ideológica del recién llegado; (c) la pobreza organizacional y económica podría aliviarse con la contribución de la actividad de Jazanovich y de los medios que este lograra movilizar. Sobre este último punto conviene mencionar
} 
vendrá posteriormente, a partir de la solicitud de asignación de lotes a los hijos de los colonos.

La experiencia colonizadora fue un éxito a pesar de algunas opiniones al respecto.

Primero porque "salvó las vidas" de los judíos que residían en gran parte de Europa

Oriental, y luego por el nazismo. A su vez, según los estudios de economistas que

analizaron la experiencia colonizadora, explicaron que se le dio al colono la posibili-

dad de trabajar sin "DADIVAS" y esto favoreció la formación de una mentalidad muy

particular, creativa y productiva. Y por otro lado, ayudó a que otros inmigrantes lle-

garan en forma independiente a estas tierras. Además al inmigrante, a pesar de los

problemas de adaptación, subsistió y creció. ${ }^{52}$

Siguiendo esta línea directriz, más allá de las medidas legales y administrativas, la JCA trató de promover la productividad a través de la adaptación y la educación. Las escuelas establecidas en las colonias tenían la intención explícita de imbuir a la juventud del amor al campo. Con este objetivo, se agregaron a los planes de estudio

que Jazanovich daba conferencias públicas por las que se cobraba la entrada, y fue un factor decisivo en la venta de acciones que debían financiar la aparición del periódico que planeaba publicar y que apareció luego bajo el nombre de Broit un Ehere (Pan y Honor). A modo de ilustración, señalaremos que la entrada que se cobraba era de 30 cts., en tanto el peluquero judío que rasuraba en el patio del conventillo cobraba sólo 10 cts. "por cabeza". Los miembros del Poalei Sion de Argentina veían en la venida de Jazanovich la oportunidad de crear un partido fuerte, parecido a los de Europa. Pero Jazanovich tenía sus propias ideas y planes. Ante todo, quería luchar contra la Jewish Colonization Association. Esta lucha estaba destinada a crear una organización de los propios agricultores de las colonias avasallados por la burocracia de la Jewish. La nueva organización que Jazanovich se proponía crear iba a defender los intereses de dichos agricultores y "desburocratizar" la colonización judía. En su opinión, la JCA practicaba no sólo la burocracia, sino que era un fenómeno de "feudalismo filantrópico" (Jazanovich, 1910). Él esperaba poder influir sobre el manejo de los fondos que la JCA poseía en Londres. Su plan era ambicioso, su estrategia compleja. Su relevancia a la realidad del momento judeoargentina, en cambio, no tan manifiesta. Jazanovich quiso crear una organización "techo" que abarcara a todos los obreros judíos, como el Farband de los EE.UU., pero tampoco esta tuvo continuidad significativa, ya que el Farband quedó en una organización débil de ayuda mutua, que después de algunos años desapareció. Jazanovich fue denunciado -él sospechaba que por la Jewish- por anarquista. Fue detenido y traído a Buenos Aires de su gira por las colonias y deportado. Se le aplicó la Ley de Residencia. Ver Jazanovich, L., Der Crizis fun der idisher colonizatzie in Argentine un der moralisher bankrot fun der JCA-Administratzie (La crisis de la colonización judía en Argentina y la bancarrota moral de la Administración de la J.C.A.). Citado por David Schers, Inmigrantes y política: Ios primeros pasos del Partido Sionista Socialista Poalei Sion en la Argentina, 1910-1916, EIAL, Universidad de Tel Aviv, Vol. 3, № 2, julio-diciembre, 1992.

52 Téveles es nieto de colonos y fue otro informante clave en este estudio. "Mis abuelos vendieron el campo y prefirieron la vida citadina, pero mi padre volvió a comprar otro campo en las colonias, cerca de Villa Clara y en realidad NUNCA se fue." 
lecciones de agricultura. La elección de campesinos y los "período de pruebas" a los que eran sometidos los candidatos a ser colonizados dan cuenta de la obsesión de la compañía por respaldar la agricultura judía e impedir la desintegración.

\section{El barón de Hirsch y los administradores de la JCA en Argentina}

los administradores obraron como enviados de "una empresa económica" que perdió el espíritu que el Barón de Hirsch le quiso dar. Por eso muchos colonos se sublevaron y algunos se fueron a La Pampa, otros al Chaco y muchos abandonaron los campos y se fueron a las ciudades. Además si había colonos que protestaban contra arbitrariedades de los administradores, éstos los "marcaban" y tarde o temprano les hacían abandonar sus chacras. En términos generales el modelo administrativo no fue el que quiso implantar el Barón de Hirsch, pero no se adecuó a las necesidades de los colonos. Muchos tuvieron suerte, o falta de oportunidades y continuaron en las chacras y al final progresaron. ${ }^{53}$

Un capítulo especial requiere dar cuenta sobre las formas de administración que instauró el barón de Hirsch a su empresa colonizadora. Más allá de lo poco conocido que fue su mal carácter, su inestabilidad emocional, su obsesión por controlar todo y su necesidad de protagonismo excesivo, como lo demuestra in extenso Dominique Frischer ${ }^{54}$ en la reciente biografía publicada sobre el fundador de la JCA, nos parece más que pertinente dar cuenta del papel que ejercieron los administradores elegidos para desempeñarse en Argentina. Desde su fundación hasta la muerte del barón, en un lapso de cinco años se sucedieron seis administradores a la cabeza de la JCA. Son muchos los testimonios que señalan que estos adolecían de tres grandes cualidades imprescindibles: conocer a los migrantes provenientes de Rusia, tener conocimiento sobre los procesos y la experiencia de la colonización y, por supuesto, conocer las características tan peculiares del país receptor. Veamos.

\footnotetext{
53 Julio Mazo Efron, nieto y sobrino de colonos que vivieron en la Colonia Barón Hirsch, es el autor de este párrafo en respuestas a nuestras preguntas.

${ }^{54}$ Frischer, D., op, cit.
} 
Al comienzo, el barón depositó su confianza en el Dr. Wilhelm Loewenthal, a quien le había encomendado la compra de las primeras tierras y organizar las primeras colonias. Sin embargo, las adquisiciones de tierras negociadas prontamente fueron anuladas por el barón al momento de concretarse la operación. Los motivos estaban en los criterios diferenciados. El barón, sin detenerse a considerar los motivos de Loewenthal para su elección, por lo general juzgaba que el precio de la hectárea era demasiado elevado. El administrador seleccionaba terrenos fáciles de cultivar y mejor ubicados desde el punto de vista climático. Se lo acusó de proteger excesivamente a los colonos y, aprovechando los sucesos de la colonia Mauricio, ${ }^{55}$ fue despedido en 1891. Desmoralizado, murió dos años después, dejando a su familia en la mayor miseria y sin el apoyo del barón, que se negó sistemáticamente a ayudarlos por considerar que el médico había traicionado su confianza al empañar para siempre la imagen de la JCA. Claro es que el fundador pasaba todo el tiempo quejándose de la incompetencia de los administradores y buscando nuevos, a los cuales sometía a todo tipo de presiones autoritarias y limitaban su autonomía.

Fue sustituido por un judío argentino, Adolfo Roth (quien compró las tierras de Colonia Clara), que hizo maravillas en materia de adquisición de tierras, secundado por el ingeniero inglés Cullen. Prontamente cayeron en desgracia, el primero por ser acusado (parece que injustamente) de haber embolsado importantes comisiones en perjuicio de la JCA y el segundo por el desatino de proponer comprar tierras en el Chaco.

Fue reemplazado por un coronel del ejército británico, A. E. Goldsmid (1892), confiando en su capacidad de mando para (re)establecer prontamente el orden en las colonias. Recibió instrucciones directas del barón de "mandar de vuelta a los colonos que considerase poco aptos para el trabajo o demasiados ambiciosos" y, en caso de desórdenes prolongados o insubordinaciones manifiestas, a no dudar en expulsar a los agitadores. A su llegada a Argentina realizó una gira por las colonias con el objetivo de conocer los problemas específicos de cada una de ellas. Por supuesto que no conocía el ruso, ni el alemán, ni el idish, lo que generaba enormes

\footnotetext{
${ }^{55}$ Colonia Mauricio, cercana a Carlos Casares, provincia de Buenos Aires, se estableció en 1891 sobre las primeras tierras adquiridas por la JCA en nuestro país y, por lejos, las más fértiles.
} 
dificultades de comunicación. Sin embargo, pudo poner cierto orden en las colonias a partir de introducir algunas reformas que fueron apreciadas por los colonos. En su visita a Colonia Clara, el coronel se vio obligado a expulsar a muchas familias "que habían dado pruebas de incompetencia manifiesta o pereza notoria, sobre todo cuando se los comparaba con vecinos más prósperos». ${ }^{56}$

En Moisés Ville efectúo la repartición definitiva de tierras y distribuyó las herramientas que faltaban, y reemplazó los animales otorgados que no fueran aptos para el uso doméstico. Si bien intentó poner orden, desgastado por los conflictos y desautorizado por Hirsch, presentó su renuncia a los quince meses de comenzar su tarea.

Fue sucedido por el agrónomo ruso Maxime Kogan (1893), el primer directivo que hablaba ruso e idish, que, si bien estaba familiarizado con la mentalidad de los rusos judíos, no logró establecer relaciones armoniosas con los colonos y tampoco el favor sostenido del fundador de la JCA. Kogan tuvo un enfrentamiento con una delegación de Odessa que tuvo como misión evaluar la experiencia y que produjo un informe que sirvió como base para plantear nuevas colonias, y sustancialmente demostró que la cantidad de hectáreas y capital entregados a los colonos eran insuficientes y que era indispensable duplicar las tierras y triplicar el dinero para mitigar las penurias de los años con cosechas malas.

Otra de las propuestas de estos delegados consistía en que las colonias se inspirasen en el modelo ruso de casas agrupadas en torno a una construcción central, para evitar que los colonos se sintieran muy lejos de sus hogares natales. Señalaban que su intención era ponerlas formando esquina en los extremos de cada terreno, de modo que no estuvieran muy lejos unas de otras. Esta propuesta no tuvo la aceptación de Kogan, lo cual se tradujo en un enfrentamiento que trató de superar rápidamente el barón enviando a dos nuevos directores administrativos: David Cazès y Samuel Hirsch, quienes habían tenido una destacada actuación en la Alliance Israélite Universelle. El primero, judío francés, se había desempeñado como director de una escuela agrícola en Palestina. El segundo, judío marroquí (sefardí), ex director de la misma Alliance en Túnez. ${ }^{57}$ Ambos trabajaron,

\footnotetext{
${ }^{56}$ Frischer, D., op. cit., p. 469.

57 Leibovich, Adolfo, Apuntes íntimos. 1870-1946, Buenos Aires, Imprenta López, 1947, p. 64.
} 
no sin problemas, por quince años desde su nombramiento en 1893 , aunque con grado mayor de autonomía y con una posición más conciliadora que sus predecesores. Los inicios de esta administración estuvieron plagados de serios enfrentamientos y revueltas con los colonos de Clara y Mauricio.

Fue designado como contador general Alejandro Charlamb, encargado de reorganizar el área financiera y administrativa. Fue su secretario Adolfo Liebovich, quien explicó que al tiempo de su designación la empresa había invertido alrededor de 50 millones de pesos que, por los resultados alcanzados, resultaban muy difíciles de justificar. ${ }^{58}$

Con este contexto, el barón de Hirsch envió a dos representantes, David Feinberg y Sigmund Sonnenfeld (directores de sus oficinas en París), a analizar la colonización en Argentina, con la intención explícita de que sus informes fueran gravitantes para decidir si continuar o dar por finalizada la experiencia. Arribaron a Buenos Aires el 19 de enero de 1896. Antes de recibir los informes ya el barón había reducido sus aspiraciones en cuanto a trasladar sólo a 200.000 o 300.000 inmigrantes de los 3 millones previstos inicialmente.

En 1902 ocupó el lugar de director general en Buenos Aires David Veneziani en dupla con Walter Moss. Veneziani ostentaba ser el hijo de uno de los asesores de la obra de beneficencia del barón de Hirsch, judío francés, ingeniero de ferrocarriles, con gran formación y preocupación por el desarrollo de la experiencia colonizadora.

\section{Distribución de las tierras adquiridas por la JCA}

El total de los terrenos adquiridos hasta 1941 por la JCA fue de 617.468 hectáreas, distribuidas de la siguiente manera:

Colonia Mauricio (Buenos Aires)

43.485 has

Colonia Barón Hirsch (Buenos Aires y La Pampa). 110.866 has.

\footnotetext{
58 «hubo que visitar colono por colono para establecer las cuentas de lo invertido. La tarea duró un año y medio. Para ello fue necesario, naturalmente, recorrer detenidamente todas las colonias, lo que me dio la oportunidad de conocerlas a fondo desde todos los aspectos, así como también las provincias donde estaban radicadas y me permitió asimismo conocer individualmente a cada colono", ibídem, p. 65 .
} 
Colonia Moisés Ville (Santa Fe).

118.266 has.

Colonia Clara (Entre Ríos) 80.625 has.

Colonia Narcisse Leven (La Pampa) 46.466 has.

Colonia Lucienville (Entre Ríos). 40.630 has.

Propiedad no colonizada "El Cascabel» (La Pampa) 35.000 has.

Colonia Montefiore (Santa Fe) 29.075 has.

Colonia San Antonio (Entre Ríos).... 22.386 has.

Colonia Avigdor (Entre Ríos) 17.175 has.

Colonia Leonardo Cohen (Entre Ríos) 13.835 has.

Colonias Walter Moss y Curbelo (Entre Ríos). 12.826 has.

Colonia Santa Isabel (Entre Ríos). 12.970 has.

Colonia Palmar Yatay (Entre Ríos) 11.368 has.

Colonias López y Berro (Entre Ríos). 10.640 has.

Colonia Louis Oungre (Entre Ríos). 9.239 has.

Colonia Dora (Santiago del Estero). 2.980 has. Total. 617.468 has.

\section{¿Cuántos fueron los colonos judíos?}

Se trata de una pregunta muy importante, pero las debilidades de los datos estadísticos impiden brindar respuestas certeras. El texto de mayor envergadura sobre la Historia de la Inmigración Judía, escrito por Haim Avni, que utilizamos como consulta ineludible, da cuenta de las dificultades que mencionamos. En particular, nuestra atención está en detectar su volumen a través de la información cuantitativa otorgada por la JCA, que recoge de distintos informes. Para el año 1914 se señala la radicación de 19.133 granjeros en las colonias, más un número aproximado de 1.024 "colonos" que abandonaron el campo hasta 1910. Cifra esta que podría haber llegado a 1.264 hacia 1914. A manera de hipótesis se sostiene que, de haber permanecido en el campo la población total de chacareros, se hubiera visto aumentada por lo menos en 8.000 almas, llegando a más de 27.000. A este guarismo hay que agregarle el número de inmigrantes 


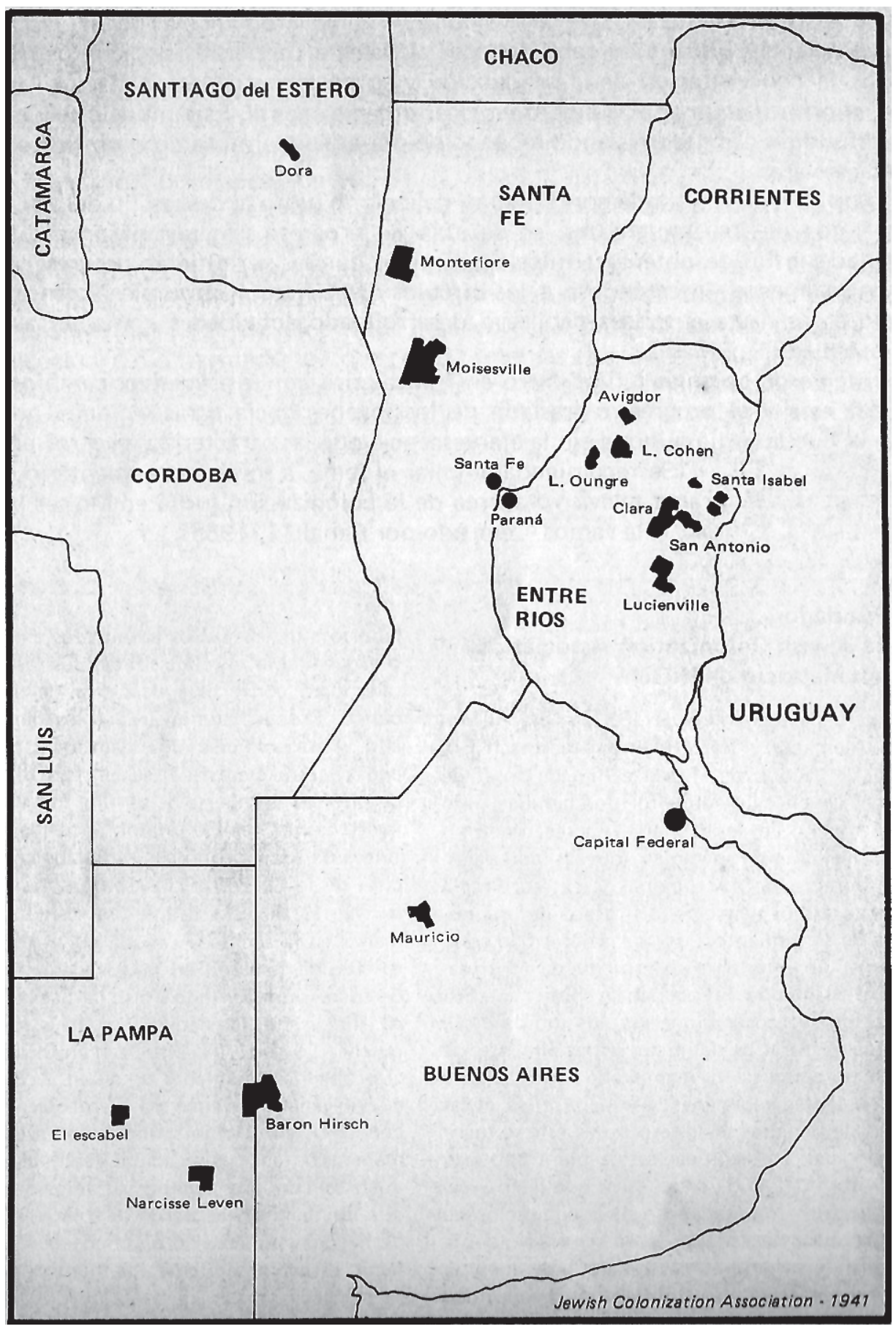

Las colonias de la JCA en Argentina.

Extraído del: Jewish Colonization Association. Su obra en la Rep. Arg. 1891-1941. 
que fueron orientados a las colonias para trabajar como asalariados. Se informa que este contingente era de 2.700 hombres en 1906 y que ascendía a 7.700 en 1913, advirtiendo que, por la modalidad productiva, muchos de ellos no permanecían en un solo lugar, por lo que esas cifras podrían representar una población mucho mayor. Junto con los colonos, se debía sumar el número de judíos ocupados en tareas agrícolas, fuera en forma temporal o permanente, ascendiendo a los 35.000 habitantes, por lo menos.

Todo el período está atravesado por una importante preocupación: el abandono de las colonias por los granjeros. Muchos textos intentan dar cuenta de este fenómeno ligado al éxito o fracaso de la colonización. Tema al que regresaremos más adelante. $^{59}$

La Memoria de la $\mathrm{JCA}^{60}$ señala que hasta el $1^{\circ}$ de enero de 1941 , cuando se cumplieron cincuenta años de la experiencia se colonizaron, 413.058 hectáreas en el país estaban ocupadas por 1.717 colonos propietarios y 1.737 colonos con contratos. Es decir, 3.454 colonos que agrupaban a 3.946 familias con un total de población de 27.448 personas.

A esta extensión se deben agregar otras 11.032 hectáreas, compuestas por terrenos no aptos para la colonización y por fracciones de tierra destinadas a la creación de pueblos ubicados en los centros de las colonias, que fueron vendidos con grandes facilidades de pagos a "elementos" elegidos, pero sin distinción de nacionalidad o de religión.

Poseían todavía 193.377 hectáreas como reservas, cuya mejor parte estaría destinada ulteriormente a la colonización.

\footnotetext{
${ }^{59}$ La etapa de declinación coincide con el éxodo a las ciudades, la concentración urbana, los obstáculos para acceder a la tierra, la falta de apoyo gubernamental y las dificultades propias de las tareas rurales. La crisis de la colonización agraria judía está inserta en la crisis global del campo argentino y en la invasión de las grandes ciudades por los "provincianos".

60 Op. cit., p. 16.
} 



\section{capítulo tres}





\title{
Nace Colonia Clara
}

Sed felices en vuestra nueva patria y en la noble profesión de agricultores que tendréis en adelante.

\begin{abstract}
Nuestra investigación se propone contribuir a la reconstrucción de la historia de la inmigración judía en la Argentina, centrada en la experiencia de la colonización agraria en Colonia Clara, la más importante de las colonias de Entre Ríos, no sólo por la extensión geográfica,
\end{abstract}

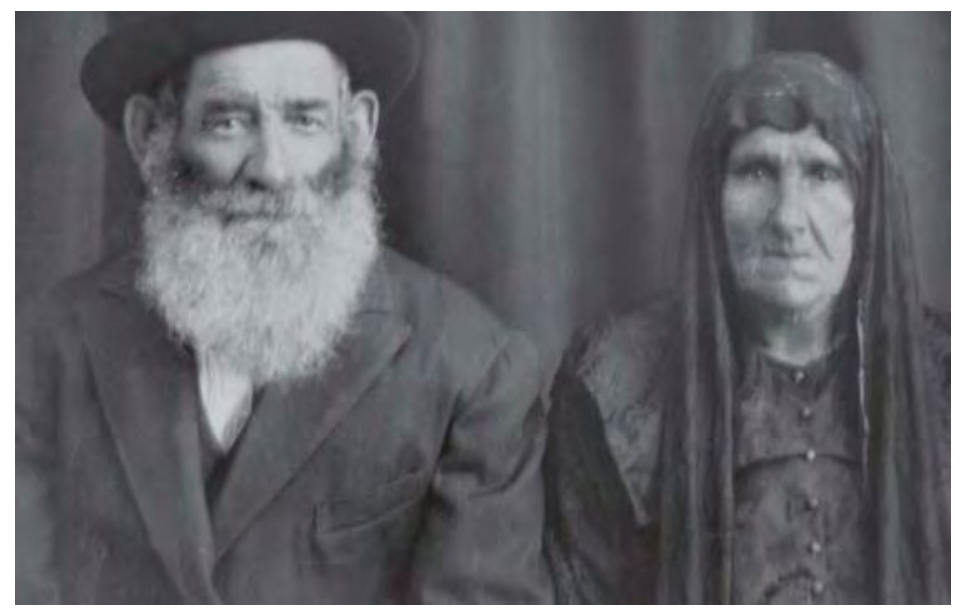

El matrimonio Kosoy, Grupo Achiras, Colonia Clara. sino por el establecimiento de diversas instituciones económicas, sociales y culturales que imprimieron las notas características del modo y el ritmo del proceso de integración al país receptor.

Colonia Clara, fundada en 1892, recibió el nombre en homenaje a la esposa del barón de Hirsch, Clara Bischoffsheim, ${ }^{1}$ y es representativa del conjunto de colo-

\footnotetext{
${ }^{1}$ Asentada en una extensión de 80.625 hectáreas, en el actual departamento de Villaguay, estuvo dividida en las aldeas Sonenfeld o San Gregorio, Miguel, Ida, Barreros, Jurado, Rosh Pina, Rajil, Barón Hirsch, Guinzburg, Desparramados, y sus pueblos más emblemáticos fueron Villa Domínguez, Villa Clara y La Capilla.
} 
nias que cobijaron a inmigrantes provenientes de la Europa Oriental, quienes, huyendo de la discriminación y la persecución política de la Rusia zarista, se asentaron en la pampa argentina para poner en marcha una experiencia productiva y social condensadora de múltiples sentidos. Luego de los acomodamientos iniciales que se extendieron hasta la primera década del siglo xx y de una prolongada etapa de consolidación, comenzó a partir de mediados de los años cuarenta un lento pero permanente proceso de despoblamiento de las colonias por el traslado de sus habitantes a los centros urbanos.

Como podemos observar, los objetivos de este estudio son múltiples y se abren como un amplio abanico de cuestiones que demandan nuestra atención. En este capítulo haremos un recorte y centraremos la descripción sobre algunos tópicos iniciales que relatan la instalación en Colonia Clara. En particular, trataremos de demostrar el peso del mandato que estos migrantes traían consigo y lo difícil de sostener el compromiso frente a los variados escollos que imponía la experiencia colonizadora. La literatura nos advierte que los primeros inmigrantes se hicieron argentinos en el campo, ${ }^{2}$ pero esta experiencia hubo que transitarla con muchos avatares: «inventar" la agricultura en una tierra virgen, adquirir la calificación necesaria para enfrentar la naturaleza, alcanzar la destreza para obtener sus frutos y dar densidad a la utopía de encontrar un mundo nuevo, donde vivir en libertad con múltiples oportunidades. Estas prácticas no estuvieron libres de tensiones. En esta primera etapa de acomodamientos, las disputas y deserciones estuvieron a la orden del día. La creación de una institución de ayuda mutua y de defensa de los colonos fue una instancia que otorgó posibilidades de cooperación y lazos de solidaridad para favorecer el arraigo.

\section{Colonia Clara tuvo a sus "pampistas"}

Escriben los testigos presenciales que el 4 de julio de 1891 en el puerto de Estambul se aglutinó un público inmenso, pues toda la colectividad judía se dio cita

\footnotetext{
2 Sin lugar a dudas, la obra que ha concitado mayor atención ha sido Los gauchos judíos, de Alberto Gerchunoff (quien vivió en el grupo Rachel en Colonia Clara), publicada en 1910; Tierra Soñada. Episodios de la colonización agraria judía en la Argentina. 1889-1959, de José Liebermann, nacido en Colonia Clara el 26 de diciembre de 1897; Lluvias salvajes, de Natalio Budasoff (1962) entre otros tanto textos.
} 
para la despedida a ciento cuarenta familias y sesenta personas solas que fueron embarcadas en el buque Galatz rumbo a Marsella, quienes luego de una travesía en tren que los llevó a Burdeos subieron a bordo del vapor Pampa que los conduciría a la Argentina, para arribar a Buenos Aires el 16 de diciembre del mismo año.

En esa despedida, el director de la Escuela de la Alliance Israélite Universelle, el Sr. M. Dallen, pronunció un elocuente discurso donde fijó fuertemente la "santa misión que les había confiado el destino". La elocuencia del mandato fue muy clara y trascendental: se debía asumir un deber personal, pero también un deber con los demás judíos, para demostrar al mundo que podían ser agricultores. Por otro lado, debían ser los responsables de crear las condiciones para consolidar la oportunidad de vivir en libertad, y de ese modo poder sacar de la esclavitud a sus hermanos oprimidos. Fueron los portadores de una promesa inicial que perduró fuertemente en la conciencia y en la memoria de los colonos. La alocución fue la siguiente:

Vais para abrir un camino para todos vuestros hermanos de cautiverio, a quienes acusan de despreciar el trabajo honesto de la agricultura les dijo conmovidamente y agregó: El Barón de Hirsch quiere demostrar al mundo por vuestro intermedio que la acusación es falsa y que también los hebreos pueden ser buenos labradores cuando tienen los medios para ello. Vais, hermanos, hacia un país hermoso, libre, rico y fértil. Allí formaréis vuestro hogar. Se os dará tierra, casa y todos los elementos de trabajo. Es posible que a vuestra llegada no halléis todo listo. No desalentéis por eso. Como la mayoría de vosotros no fuisteis agricultores, deberéis aprender a serlo. Alli encontraréis personas que tiene el encargo de enseñaros el manejo de las herramientas y el trabajo de la tierra. Tratad de trabajar con amor porque así labraréis vuestro propio progreso y el de vuestros hermanos. Llegaréis primero a Buenos Aires, la capital de la República Argentina, donde deberéis permanecer algunos días, acaso unas semanas, hasta que os lleven a vuestro destino, donde entraréis en posesión de la tierra, de las casas y del ganado. Tened en cuenta que vais a la vanguardia, como pioneros de todos vuestros hermanos oprimidos en pueblos extraños y que os han de seguir a la tierra de libertad. No olvidéis pues vuestro deber de prepararles un sitio para cuando lleguen. 
Ellos lo prepararán a su vez para los otros, y así continuamente. En esta forma llegaréis a un hogar propio. Vuestra misión es grande y santa: velar por vuestro propio porvenir y el de vuestros hermanos. Lo que exigimos ahora de vosotros es vuestra formal promesa de cumplir con vuestro deber hacia vosotros mismos y hacia vuestros hermanos. Sed felices en vuestra nueva patria y en la noble profesión de agricultores que tendréis en adelante ${ }^{3}$.

El Pampa fue el barco mítico para los descendientes de los colonos de Colonia Clara. Sus pasajeros constituyeron el primer contingente organizado por la ya creada JCA que llegó a las colonias de la provincia de Entre Ríos, conformado por emigrantes que habían salido de Rusia rumbo a Palestina pero que quedaron varados en Estambul. El gobierno otomano no les permitía continuar al destino fijado y tampoco podían regresar a sus aldeas. ${ }^{4}$

Anclados en Estambul, algunos vagaban por sus calles buscando información y cobijo, otros estaban encarcelados, cuando llegó la ayuda del barón de Hirsch que mantenía contactos con el gobierno local por ser el contratista encargado de la construcción del Ferrocarril El Expreso de Oriente (Viena-Estambul). Tras rápidas gestiones logró la liberación de los migrantes y los embarcó en la travesía que los conduciría finalmente a tierras argentinas.

La urgencia del caso hizo que las condiciones requeridas para la selección de los candidatos fueran alteradas. Según Enrique Dickman, ${ }^{5}$ se abrió un registro

\footnotetext{
${ }^{3}$ Schallman, Lázaro, Historia de los "pampistas", Buenos Aires, Congreso Judío Latinoamericano, 1971, p. 7.

${ }^{4}$ Las razones fueron múltiples, pero prevalecía entre ellas que un grupo importante había desertado del servicio militar obligatorio, la carencia de recursos económicos y fundamentalmente la ola de violencia desatada por el gobierno zarista.

${ }^{5}$ Dickman, Enrique, Recuerdo de un militante socialista, Buenos Aires, La Vanguardia, 1949. En la lista de pasajeros del Pampa figura un Haim Dickman, 18 años, soltero, que es el mismo de este relato. En 1895 se naturalizó argentino y comenzó su militancia en el socialismo. Dos años después asumió por primera vez la dirección de La Vanguardia. Médico egresado de la Universidad de Buenos Aires, fue diputado nacional por Capital Federal en seis oportunidades, entre 1914 y 1943. En 1952, luego de su expulsión del Partido Socialista, fundó junto con su hijo Emilio y otros socialistas disidentes el Partido Socialista de la Revolución Nacional. Escribió un gran número de libros y folletos, entre ellos Inmigración y latifundio, Buenos Aires, Imprenta French, 1915; Democracia y Socialismo, Buenos Aires, Ponzinibbio, 1917; "Marx y Bakunin" (1923); "Pensamiento y Acción” (1937); La infiltración nazifascista en la Argentina, Buenos Aires, Ediciones Sociales Argentinas, 1939; y Recuerdos de un militante socialista, Buenos Aires, La Vanguardia, 1949.
} 
con más de 5.000 candidatos a colonos, entre los cuales se eligió el primer contingente, descripción que fue coloreada por Mauricio Chajchir en sus Memorias:

se abrió el comité del Barón de Hirsch. Fue una salvación para los judíos y empezó el registro de las familias. Aceptaban solamente familias con hijos varones. Los que no los tenían, se daban maña. Hacían inscribir a un soltero como hijo y la cosa marchaba. ${ }^{6}$

Sin embargo, como queda claro, no todos fueron aceptados. La consigna brindada al Comité era admitir solamente a hombres fuertes y sanos, aptos para las rudas labores de la tierra y que tuviesen hijos en condiciones de ayudarles en las tareas agrícolas. La cultura espiritual de los candidatos era asunto secundario, se requería fuerza y coraje. Sin embargo, llegó un nuevo requisito para los que ya estaban seleccionados. Los representantes del barón dieron la noticia. Los que querían ir a la Argentina debían someterse a dos condiciones irrevocables: raparse la barba y acortar sus largos gabanes para transformarlos en sacos de corte común. También debían eliminar las típicas patillas judías, emblemas de la grey estudiosa. Para aquellos hombres sinceros en sus emociones, las barbas eran parte de su personalidad, para otros su significado era religioso, en algunos contenía un valor estético o tradicional. ${ }^{7}$ Esta anécdota que se siguió contando por mucho tiempo en las colonias fue un hecho que mezclaba comicidad con dramatismo, pero tenía una profunda significación simbólica. Aquellos restos de barbas y gabanes esparcidos por el suelo señalaban el rompimiento definitivo con un mundo y el paso a otro. ${ }^{8}$

Al llegar a Buenos Aires, los "pampistas" fueron alojados en el Hotel de los Inmigrantes. ${ }^{9}$ Los funcionarios de la empresa del barón de Hirsch en esta ciudad

\footnotetext{
${ }^{6}$ Mauricio Chajchir integraba el contingente de las familias que sumaban un total de 818 pasajeros.

${ }^{7}$ Pocos días antes de la partida hubo que descartar también a algunos religiosos que se negaban terminantemente a dejarse recortar el cabello y la barba. Eran judíos ortodoxos que no aceptaban por nada del mundo que se les cortaran las peiot (aladares). Informe fechado en Constantinopla el 6 de noviembre de 1891, en Schallman, Lázaro, Historia de los "pampistas", op. cit., p. 6.

${ }^{8}$ Lieberman, José, Tierra soñada, op. cit., p. 87.

9 "No sé de dónde surgió la versión que los cocineros y el personal eran judíos españoles y por consiguiente todo era kosher. Y jah! Por primera vez durante todo el viaje, todo el pasaje disfrutó de una buena cena. Al día siguiente una comisión de mujeres fue a investigar a la cocina para ver si salaban la carne y se encontraron con una cabeza de cerdo sobre la mesa. Volvieron amargadas y tratando de vomitar lo que habían comido la noche anterior». Ibídem.
} 
Ios recibieron en el puerto. La JCA no había adquirido hasta entonces las tierras en Entre Ríos, resultando incierto el futuro de todas las familias. Un rumor, echado a correr por tratantes de blancas de la época, causó el pánico y la agitación de los inmigrantes que reclamaban ante las autoridades de la Congregación Israelita de Buenos Aires. Ellos creían que iban a ser vendidos como esclavos a unos terratenientes de la provincia del Chaco. ${ }^{10}$ Ardua fue la tarea de la Congregación para dar por tierra con estas historias y lograr la aceptación de la propuesta de un viaje transitorio a Mar del Plata, hasta que se hiciera efectiva la compra de tierras en Entre Ríos.

\section{En Mar del Sur}

Luego de innumerables discusiones, en los primeros días de enero de 1892, los "pampistas" se establecieron en el hotel Boulevard Atlantique, ${ }^{11}$ ubicado en Mar del Sur, en las afueras de Mar del Plata. El 12 de enero, Mar del Sur se vio envuelta en una fuerte tormenta seguida de inundaciones. El hotel sufrió serios daños, entre los que se contaron el derrumbe de una pared, resultando heridos varios inmigrantes que fueron trasladados rápidamente al hospital de Mar del Plata. Sin embargo, las angustias no terminarían allí. A los quince días de haberse originado el temporal, se produjo en la zona una fuerte epidemia de tifus, causando la muerte de algunos de los inmigrantes más pequeños. A causa de esto, el traslado a Entre Ríos se postergó para marzo de ese año.

\footnotetext{
${ }^{10}$ Loewenthal iniciaba gestiones ante la Administración de las colonias Florencia y Brasil, asentadas en la provincia de Chaco, pero ante las condiciones leoninas que pretendía imponerle la empresa fueron desechadas. En Shallman, L., op. cit., p. 13.

${ }^{11}$ ¿Cómo fueron a parar al Boulevard Atlántico, un lujoso hotel de estilo francés en Mar del Sur, un aislado lugar de la costa? No deben haber sido ajenas a este milagro las múltiples relaciones del barón Hirsch como empresario ferroviario, ya que ese hotel era utilizado y posiblemente propiedad de los funcionarios ingleses de ferrocarriles en Argentina. En Fondo Comunal, 50 años de vida. (19041954), Villa Domínguez, 1957.
} 


\section{Colonia Clara}

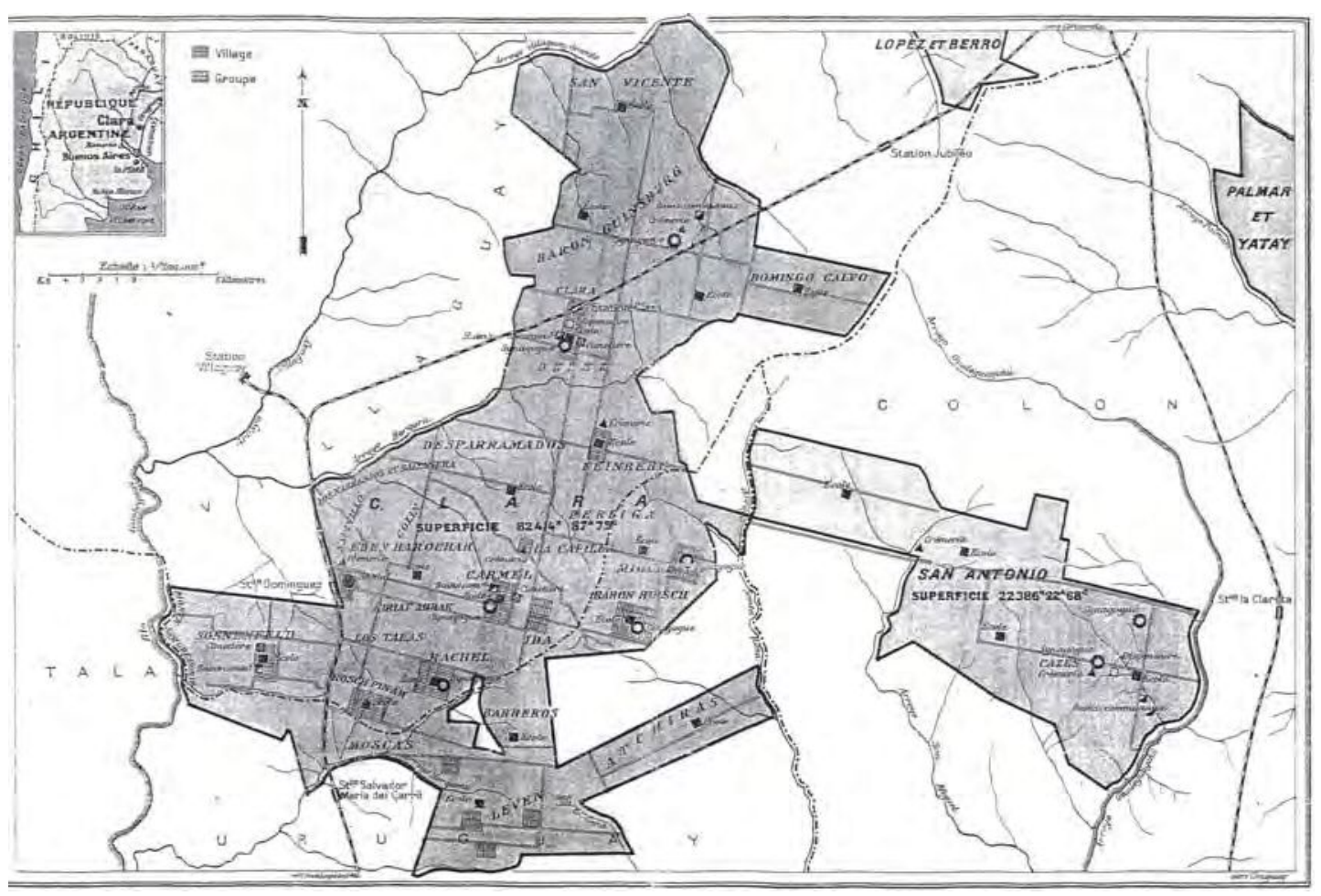

Los pasajeros del Pampa estaban en Mar del Sur cuando comenzaron las gestiones para la adquisición de tierras en la provincia de Entre Ríos. En febrero de 1892, Adolfo Roth, como representante de la JCA, compró 1.459 hectáreas al Dr. Honorio Quiroga y González. El 9 de marzo adquirió las tierras a la Sociedad Anónima "La Agricultora", en dos compras sucesivas de 6.631 y 2.024 hectáreas. El 24 de marzo compró a Pedro Espíndola 1.316 hectáreas. El 9 de diciembre, Alberto Eduardo Goldsmitd, en representación de la JCA, adquirió 3.640 hectáreas a Doña Elena Dirkson de Elía. ${ }^{12}$ Estas fueron las primeras adquisiciones ubicadas en el departamento de Villaguay, distrito Bergara, en las inmediaciones de la Estación Domínguez. La compra de tierra siguió evolucionando hasta 1904, cuando se completaron las 80.226 hectáreas de Colonia Clara. ${ }^{13}$

\footnotetext{
12 En marzo de 1892 la JCA se presenta al Juez en $1^{\circ}$ Instancia de Concepción del Uruguay, Dr. Amado Tahier, solicitando la mensura de estos campos, para cuyos efectos se nombró al agrimensor Arístides Sol. Documento en el Museo de la Colonias, Villa Domínguez. Ver Osvaldo Quiroga, Villa Domínguez... 100 años de Historia. 1890-1990, Comisión Pro festejo del Centenario, p. 11.

${ }^{13}$ Chiaramonte, S., Finvarb, E. y otros, Tierra de promesas. 100 años de colonización judía en Entre Ríos. Colonia Clara, San Antonio y Lucienville, Buenos Aires, Ediciones Nuestra Memoria, 1995, p. 87.
} 
Colonia Clara estaba ubicada en el departamento Villaguay, ${ }^{14}$ localizado en el centro de la provincia de Entre Ríos. El río Gualeguay que corre de Norte a Sur lo divide en dos secciones: la del Oeste, del Montiel enmarañado, y la del Este, del monte más limpio y alto. Los arroyos Sauce Luna, Mojones, Tigre, Raíces, Bergara, Villaguay, Lucas desaguan en él. El monte (tierra sin cultivar, cubierta de árboles, arbustos o matas) otorga el tono al paraje. La llamada selva de Montiel ${ }^{15}$ es su paisaje natural. No está de más decir que el panorama se completa con un denso sotobosque de gramíneas y pajonales inundables, además de selvas en galería a orillas de los ríos y arroyos que lo surcan. La formación de Montiel corresponde a la provincia fitogeográfica del Espinal, más precisamente al distrito del Ñandubay, nombre que recibió debido a lo abundante que era esta especie. Entretejen su espesura algarrobos, talas, coronillos, chañares, pencas, tunas. Poblada por yararaes, zorros, gatos monteses, perros cimarrones, chanchos salvajes, yeguada matrera, vacunos alzados y el canto de los pájaros, calandrias, zorzales, cardenales, jilgueros, darán la bienvenida a los hombres que transformarán lentamente el paisaje natural. ${ }^{16}$

Dos estaciones ferroviarias, la estación Domínguez ${ }^{17}$ y Villa Clara, fueron las anclas del ferrocarril que surcaba el territorio de la colonia. Entre una y otra estación se halla la ciudad de Villaguay, cabeza departamental del mismo nombre, y en medio de la colonia existe un pequeño centro urbano, La Capilla. El Ferrocarril Central Entrerriano fue el canal de vida para la región.

La trama de la colonia se irá delineando con el poblamiento en distintos grupos o aldeas: Even Horoischo (en hebreo, "primera piedra" o "piedra fundamental»); Kiriat Arbá (nombre que ostentaba en los tiempos bíblicos la ciudad de Jevrón y

\footnotetext{
${ }^{14}$ Este departamento linda al Norte con Concordia y Federal, al Sur, con Tala y Nogoyá, al Este, con Colón y Uruguay y al ${ }^{15}$ La llamada Selva de Montiel es una formación vegetal incluida en la unidad biogeográfica conocida como sabana mesopotámica, que se caracteriza por una elevación de las ondulaciones de las planicies del litoral que forman lomadas o cuchillas por donde discurren numerosos cursos de agua que desaguan en los ríos Uruguay y Paraná. El clima es subtropical, húmedo y cálido, con precipitaciones medias anuales que varían entre los $1.000 \mathrm{~mm}$ en el Suroeste y los $1.200 \mathrm{~mm}$ en el Noreste. Se extiende principalmente en el Centro-Norte de Entre Ríos y se presenta como un bosque semixerófilo bajo que alterna con praderas y palmares. En http://www.fundacionazara.org.ar/Investigacion/Proyectos/ Selva_montiel.htm.

${ }^{16}$ Miranda, Justo José, Villaguay, mi pueblo, Entre Ríos, Ediciones Comarca, 1977.

${ }^{17}$ Fondo Comunal, Cincuenta años de su vida (1904-1954), Villa Domínguez, 1957.Oeste, con Paraná y La Paz. Tiene $6.654 \mathrm{~km}^{2}$ de superficie.
} 
que resultaba adecuado para significar en dos palabras el agrupamiento de cuatro casas en línea); Barón Hirsch (nombre solicitado por los colonos); Mijael o Miguel (en honor al director de la JCA en Argentina, coronel Goldsmid); Idah (nombre de la esposa); Rajel y Carmel (en homenaje a las hijas del coronel); Sonnensfeld o San Gregorio, Barreros, Jurado, Rosh Pina, Barón Guinzburg, Desparramados, Bélez, entre otros; todos ellos rodeando los pueblos que se creaban alrededor de las estaciones Villa Domínguez y Villa Clara y la emblemática La Capilla, que quedó fuera del trazado del ferrocarril.

El suelo de esta región se caracterizaba por ser un terreno quebrado, con numerosas corrientes de aguas y algunos restos de vegetación arbórea, muy arcilloso, favorable para la vegetación herbácea natural, un desafío que esperaba paciente e indolente que los colonos lo transformaran con su trabajo en tierra productiva. Propuesta muy interesante pero que requirió de enormes esfuerzos.

El mapa adquirió nuevas formas con la adquisición de tierra. Faltaban ahora los pobladores. Se decidió entonces el traslado de los "pampista" desde Mar del Sur a Entre Ríos. Nuevamente la travesía: Ios viajeros fueron transportados en grupos, los dos primeros en carro hasta Mar del Plata, tren a Buenos Aires y desde Dársena Sur en barco a Concepción del Uruguay, en cuyos alrededores permanecieron algunos meses, mientras se ultimaban los preparativos para la marcha hacia el interior de la provincia. ${ }^{18}$ Un tercer grupo fue trasladado a Moisés Ville, donde fueron alojados en carpas, y posteriormente trasladados a Entre Ríos acompañados por Adolfo Leibovich, que ya era por ese entonces empleado de la JCA y futuro administrador de Colonia Clara.

Se estaban colocando los rieles del tramo Uruguay-Basabilbaso, y de esta localidad la línea que seguiría hasta Villaguay, pasando por la Estación Domínguez, donde deberían establecerse muchos de estos colonos. Mientras se realizaban estas tareas, fueron "instalados" en una larga fila de vagones de carga detenidos sobre un ramal muerto, y en aquella "habitaciones" permanecieron hasta muy entrado el invierno. Estos tres meses de alojamiento forzado fueron consolidando las amistades que se prolongarían después en la colonia. Las "memorias" señalan

18 Lieberman, José, Tierra soñada, op. cit., p. 45. 
que aquello fue una hermosa prueba de solidaridad humana, expresión real del idealismo que guió al grupo pionero en busca de un hogar. ${ }^{19}$

Hacinamiento y carencia de comodidades mínimas se conjugaban con las lecturas de la Biblia y el descubrimiento del nuevo ambiente. Fue a las orillas del Uruguay donde los "rusos" aprendieron a tomar mate, a chapalear en el barro que las Iluvias del otoño trajeron, a encender fuego con leña mojada, a encontrarse con un nuevo espacio.

Lo que recuerdo de allí y lo conservo aún hoy día, es el gusto del té recocido y endulzado con azúcar negra, la que no era refinada y que hoy la llaman azúcar rubia. Ah! Hasta me parece que siento el gusto y el olor del té recocido con azúcar negra. $^{20}$

Por las vías férreas recién terminadas marcharon hacia Basabilbaso y luego a la estación Domínguez, donde debieron acomodarse en dos galpones grandes hasta la asignación de las parcelas respectivas. Allí no había más que la estación del ferrocarril y una casa de ladrillos rojos perdida entre los pastos. A cierta distancia de la estación ferroviaria se veía, en medio de la tupida vegetación, el único edificio de cinc, enorme, donde los estancieros de la zona depositaban sus productos del año. Ese sería el nuevo «hotel» que los alojaría, galpón que carecía de todo lo necesario para las mínimas comodidades: no había camas, ni sillas, ni nada. Mas había abundante comida provista por la Administración de la JCA: bolsa de galletas, azúcar, té, arroz, pimienta, jabón, carne, etcétera, que se distribuían a cada familia en cantidad adecuada según el número de componentes. Escaseaba la sal y ello contrariaba fuertemente a las mujeres, que no podían disponer de la cantidad necesaria para salar la carne a la usanza tradicional judía, pero, trasladada la inquietud al administrador, aumentó la provisión de sal y se zanjaron las diferencias. ${ }^{21}$

\footnotetext{
19 Ibídem, p. 48.

${ }^{20}$ Mauricio Chajchir, en sus memorias de 1891. "Viaje al país de la esperanza. Relato de un viajero del Pampa", en La Opinión, Buenos Aires, 8 de agosto de 1976, reproducido en Asociación de Genealogía Judía de Argentina, Toldot N 8, noviembre de 1998.

${ }^{21}$ Lieberman, José, op. cit., p. 62.
} 


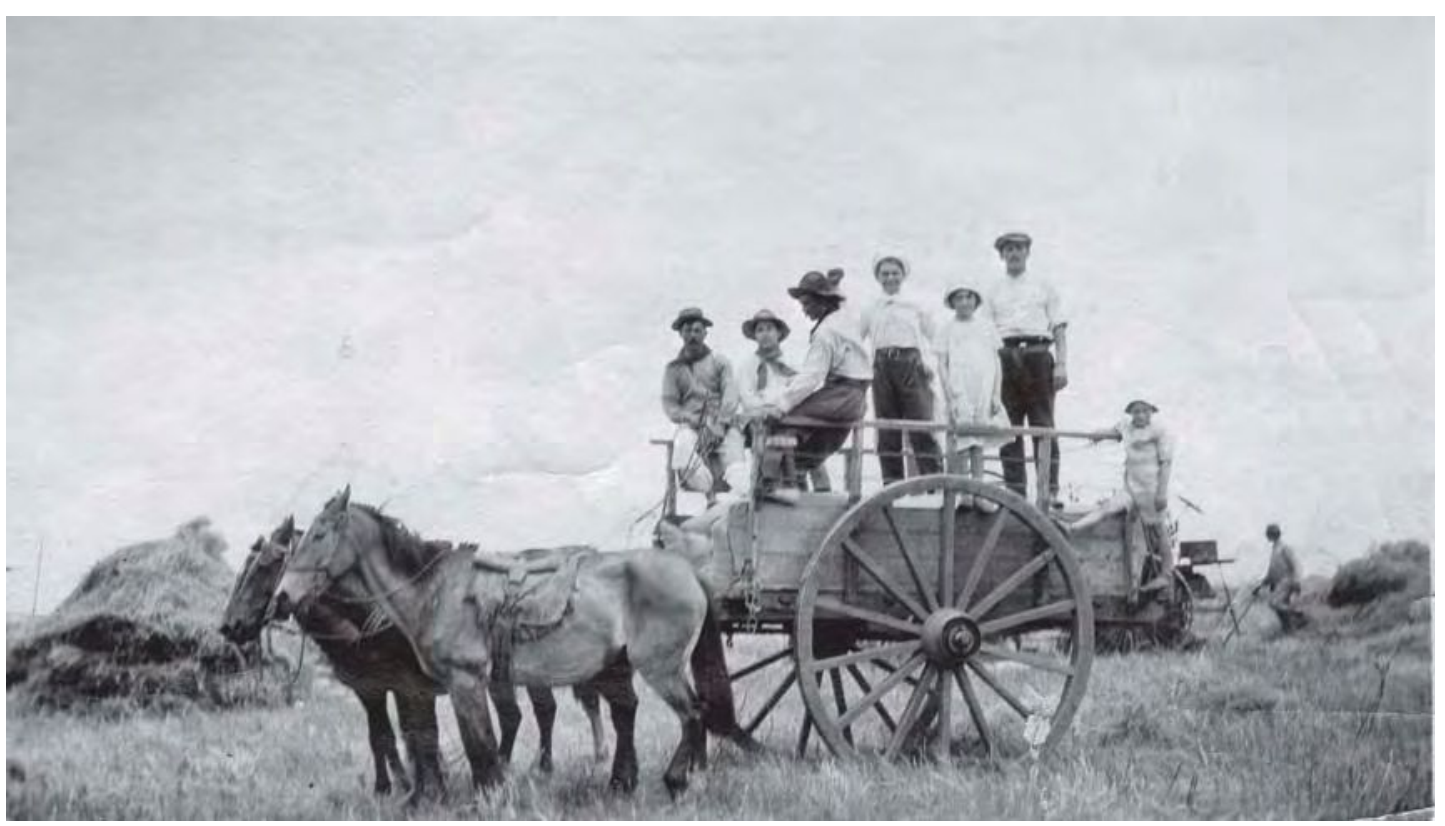

Vera Sajaroff, Grupo Leven, Colonia Clara.

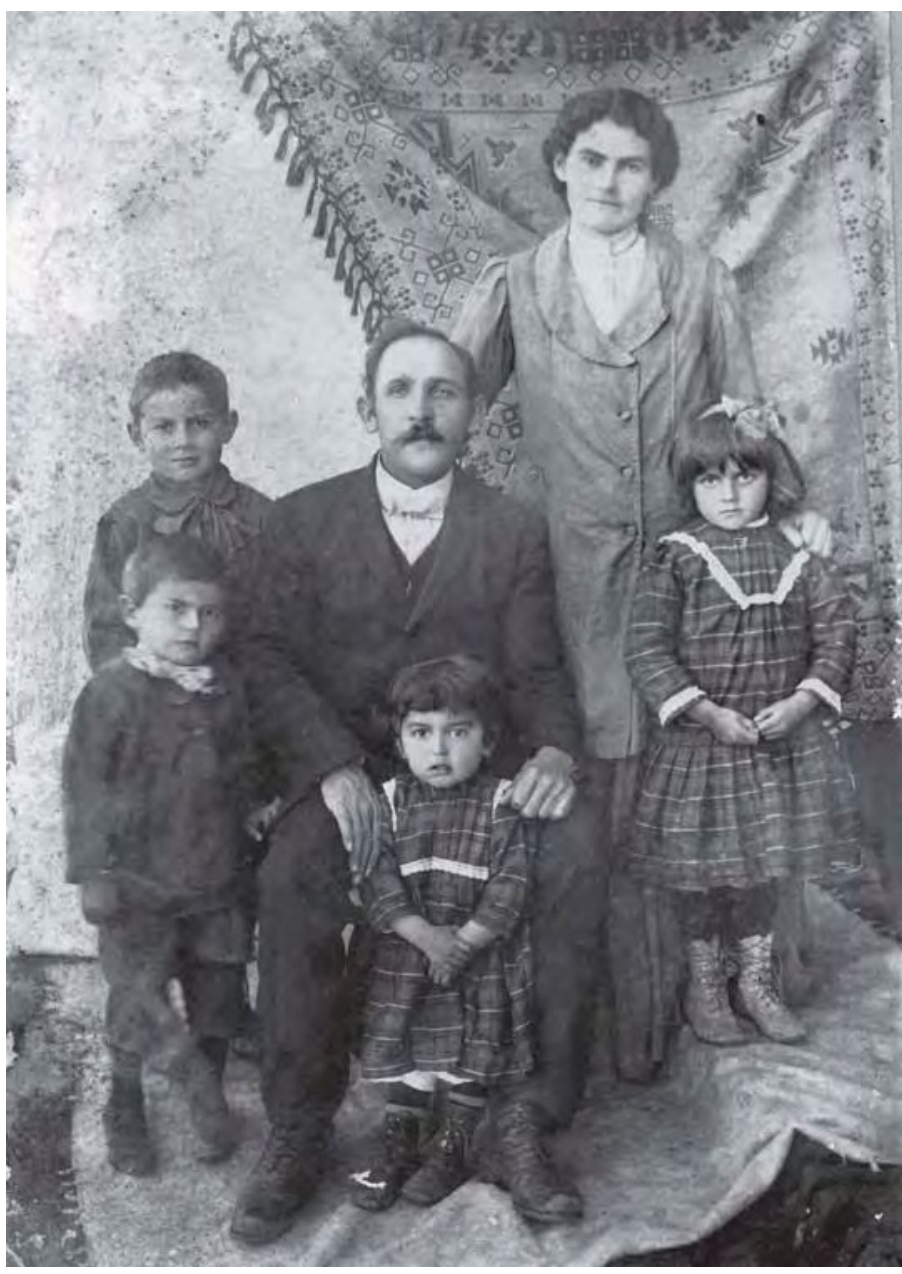

Jedidio Efron y flia., Grupo Rosh Pina, Colonia Clara. La niña pequeña es $\mathrm{Pa}$ loma Efron (Blackie). 
A los pocos días del arribo comenzaron los enfrentamientos entre los colonos y el administrador, con el cual no se entendían no sólo porque este hablaba en inglés, sino porque tenía muy poca experiencia en el manejo de grupos. Surgieron prontamente otros motivos de agitación y de disconformidad frente a la disposición de que cada uno de los futuros colonos tenía la obligación de construir sus propias viviendas en los terrenos que se les asignaban. También originó acaloradas protestas la prerrogativa acordada a los mismos para que se pusieran de acuerdo entre sí no sólo para la distribución de chacras, sino también para la elección de sus vecinos.

Se había dispuesto que las viviendas se construyeran en grupos de a cuatro, una cerca de la otra dejando entre ellas un espacio de treinta metros para el trazado de caminos. Se resolvió proceder al sorteo de las chacras para evitar favoritismo, con un incentivo adicional: los predios más cercanos a la estación se otorgarían a aquellos que primero se decidieran a instalarse. Las rencillas estaban a la orden del día. Algunos insistían en que era obligación de la empresa la construcción de las viviendas, y que no se trasladarían hasta que se cumpliera con esta obligación. Ahogados por este clima de discordia, cuatro jefes de familia decidieron comenzar con la obra, construyendo las cuatro primeras viviendas muy cercanas a la estación, que fueron sorteadas entre ellos con el beneplácito del administrador. Más allá del empeño, la falta de capacitación como albañiles hacía que la construcción fuera mucho más lenta de lo esperado. El administrador decidió entonces solicitar la colaboración de los jolostoies (solteros) para ayudar en la construcción de las casas, ofreciéndoles un salario digno por el trabajo, pero se negaron rotundamente a ello, alegando que en todo caso construirían sus propios ranchos. La indignación del administrador frente a la falta de solidaridad llegó a tal grado que decidió darles un escarmiento, ordenando al mayordomo que les suspendiese la provisión de alimentos y el retiro de las frazadas y ropas que les había facilitado la Administración. ${ }^{22}$ En vista de que los jolostíes se negaban a devolver nada, el administrador solicitó apoyo a algunos agentes de policía de Villaguay. Lejos de amedrentarse con la presencia policial, los hombres les hicieron frente

\footnotetext{
22 Fingerman, Israel, Di Idische Záitung, edición del 8 de julio de 1927.
} 
con piedras y ladrillos. Pero, como bien señala el narrador, la sangre no llegó al río porque el propio administrador se esforzó, con lágrimas en los ojos, por aquietar los ánimos, y esta primera insubordinación no pasó a mayores. ${ }^{23}$

Poco a poco, y sorteando muchos obstáculos, se fue extendiendo el poblamiento de la Colonia:

En 8 carretas tiradas por tres yuntas de bueyes nos trasladaron a los lotes que después se llamaron Rosh-Pina. Era un día de mayo, de mucho calor y sofocante. Se acomodaron a los gringos en las carretas, mujeres, hombres, niños, cachivaches, leña y además 8 chapas de zinc para cada familia, para hacer las viviendas, porque en el lugar no había absolutamente nada. Todos iban arriba en las carretas [...] No había alambrado alguno.

La primera carreta volteaba los cardos altos que crecen en tierra virgen. La última ya marchaba por una huella [...] Se armaron las carpas, una para cada familia. A eso de la medianoche se largó a llover. Por suerte no era fría. El temporal siguió como unos ocho días. Cuando paró el temporal, la JCA mandó maderas de sauce y blanquillo, también paja. Un capataz con varios peones empezaron a hacer los ranchos.

Las paredes tenían que hacerlas los mismos colonos con adobes o de chorizos según el gusto. Algunos se ingeniaron para hacer las paredes cortando directamente de la tierra húmeda y colocándolos con las raíces y pastos que aún tenían. Y estos transformados en paredes seguían creciendo. ${ }^{24}$

Indicaron y marcaron los lotes, clavaron los mojones. A una distancia de mil metros trazaron dos líneas paralelas, de Norte a Sur, ubicadas sobre las altas cuchillas que dejaban en el centro el valle con sus cañadones. Sobre cada una de estas líneas, separadas por cien o doscientos metros, hincaron los mojones indicadores, cada uno con su número, donde el colono debía empezar a construir su casa. Entre las dos filas de casas se extendía el campo colectivo, en cuya parte media estaba el cañadón y corría el arroyuelo. El predio colectivo o de "quintas"

\footnotetext{
23 Ídem.

${ }^{24}$ Chajchir, op. cit.
} 
estaba destinado al ganado lechero y los bueyes de labranza, porque los campos de cultivo estaban alejados de la colonia. Diez casa de un lado y diez del otro, que miraban de frente, pero a excesiva distancia, con las tierras dispuestas en los alrededores, en lotes de cien hectáreas.

En la fila oriental estaban los Lefcovich; hábiles colonos que en Rusia ya trabajaban la tierra; los Efron, gente de cultura hebraica; Ios Anijovich; los Salkind, los Bekenstein. En la fila occidental se establecieron los Steimberg, los Lierbermann, los Yankelevich, Ios Roisman, los otros Efron, los Rabinovich, arribados en el barco Pampa. ${ }^{25}$

Cada familia recibió algunas chapas de cinc, tirantes de madera, clavos, tablones, una pala, algunos bueyes, un arado Paraná, de mancera, dos yugos y algunos elementos indispensables para iniciar el trabajo de campo y al mismo tiempo la orden de construir las viviendas, el pozo del agua, el galpón, los corrales.

Algunos meses después de aquel día inicial aparecieron las primeras casas, modestas, pero cómodas. Nunca los colonos judíos vivieron en los ranchos criollos, tan comunes en la campiña de las provincias, sino que prefirieron siempre las casas, aunque pequeñas, de material, asevera Lieberman.

Las paredes se levantaron con adobes, unidos con barro amasado, y fueron revocadas por dentro y por fuera, lo mismo que el suelo, con barro mezclado con estiércol y pajas secas. El piso se renovaba cada semana y daba la sensación de limpieza.

Comenzaron las relaciones con los colonos suizos asentados en Villaguay, que fueron los que hicieron las excavaciones para los pozos de agua y los que les vendieron los primeros árboles frutales. Más tarde trajeron las bolsas de cal de Domínguez y blanquearon las casas por dentro primero, por fuera después. Construyeron hornos de ladrillos en los patios, donde pudieron cocer sus comidas. La harina era distribuida por la JCA, que mensualmente daba una bolsa a cada familia, que por supuesto se cobraba.

\footnotetext{
${ }^{25}$ Lieberman, José, op. cit, p. 70.
} 
En junio de 1894 llegó otro grupo de inmigrantes a la estación de Domínguez: esta vez, 150 familias con un total de 620 personas. Habían llegado a la Argentina en el vapor Orione. Traían consigo algunos casos de fiebre tifoidea, por lo que el Dr. Noé Yarcho ${ }^{26}$ tuvo que atenderlos en los galpones, donde provisoriamente fueron alojados hasta su instalación definitiva. Los recién llegados no tardaron en ponerse en contacto con los "pampistas" ya instalados, pero todavía en forma provisoria.

En el mismo año arribaron otros tres núcleos de inmigrantes que fueron ubicados en tres grupos de 50 casas en Belez, Fienberg y Sonnenfeld. Otras 150 familias en Perlisa y Desparramados y unas 40 más en el grupo de Barón Guinzburg. ${ }^{27}$

Fue muy dura la adaptación al campo y sus tareas. No es sencillo abrir surcos en la tierra virgen, amansar novillos chúcaros, limpiar los campos y arrancar los raigones de la tierra, sembrar sin maquinarias adecuadas, ordeñar las vacas cimarronas, aprender el manejo de la segadora, acarrear las bolsas llenas del grano, luchar contra la invasión de orugas, ni soportar el desastre de una manga de langosta. $^{28}$

Lentamente fueron aprendiendo las destrezas en el oficio de trabajar la tierra, copiando y asimilando poco a poco el saber de los criollos, a costa de pagar un enorme precio en accidentes, enfermedades y hasta algunas muertes. Acostumbrándose a todo, como nos relata con conmovedora sorpresa Enrique Dickmann:

poner el yugo en la cerviz de un buey o la montura en el lomo de un potro, y luego atar la yunta de bueyes al arado o montar un potro es tarea para hombres vigorosos, decididos y diestros. Pero tienen sus atractivos y encantos. ¡Es el triunfo de la inteligencia, es el dominio del hombre sobre la bestia! ${ }^{29}$

\footnotetext{
${ }^{26}$ Noé Yarcho se recibió de médico en Rusia, luego realizó estudios de posgrado en Alemania y en Londres. En 1891 se ofreció al barón de Hirsch y como médico viajó con los contingentes que llegaron a Colonia Clara. Asentado en el grupo Sonnenfeld, será un artífice señero en la vida de la Colonia. En 1895 presenta al Comisario General del Departamento General de Inmigración, Juan Alsina, el informe sobre la epidemia de tifus, en el cual explica que la epidemia no fue importada del exterior, que su propagación fue muy rápida y que afectó a 230 personas. La epidemia duró cinco meses y la mortalidad fue del $10 \%$. En Tierra de Promesas, op. cit., p. 159.

${ }^{27}$ Ídem, p. 87. Ver listados de pasajeros en el Anexo.

${ }^{28}$ Lieberman, José, op. cit., p. 54.

${ }^{29}$ Dickmann, Enrique, op. cit., p. 42.
} 


\section{Los administradores de la JCA}

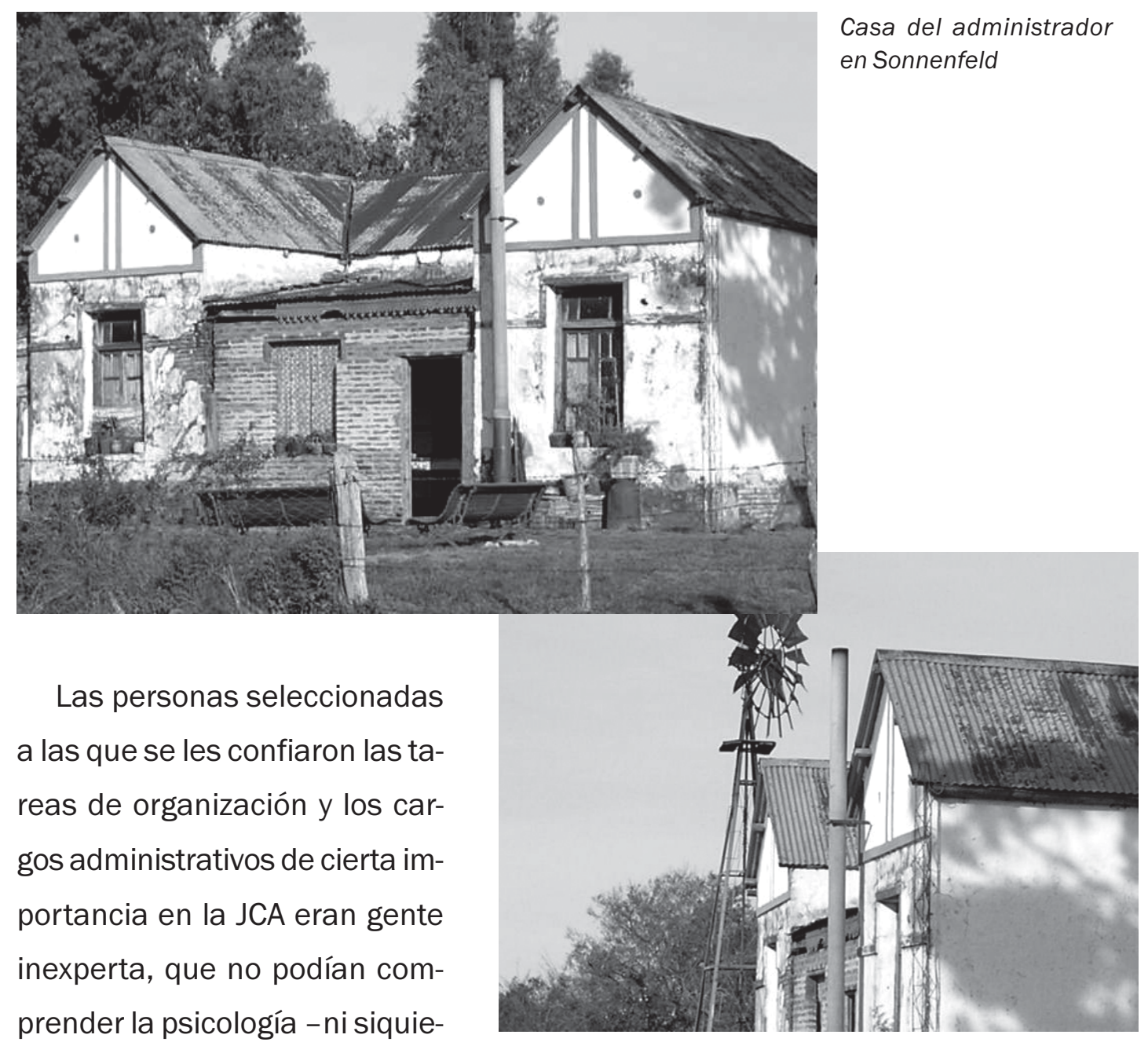

ra la lengua- de los colonos, y

menos aun tomar conciencia de la magnitud de la empresa. Los colonos tuvieron que sufrir la ineptitud y la negligencia de ese personal improvisado, que ni siquiera les había preparado las herramientas necesarias ni provisto de animales adecuados de trabajo.

Los caballos que nos dieron eran redomones, y nosotros éramos malos jinetes: los bueyes para el arado eran medio chúcaros y mañeros. La tierra virgen, excesivamente dura, necesitaba no dos yuntas, sino cuatro y hasta seis para ser roturada. ${ }^{30}$

30 Ídem, p. 41. 
Los administradores de la JCA fueron un núcleo conflictivo en la experiencia coIonizadora. ${ }^{31} \mathrm{El}$ inspirador y primer representante, el Dr. Loewenthal, fue apartado arbitrariamente de las funciones encomendadas y abandonó el país el 28 de enero de 1892. Fue sustituido por Adolfo Roth y Carlos Eduardo Cullen, quienes estuvieron en el cargo tan sólo dos meses. Debido a su ineptitud manifiesta y los conflictos suscitados, el barón de Hirsch los reemplazó por el coronel Albert Goldsmid, quien asumió como Director General de las Colonias

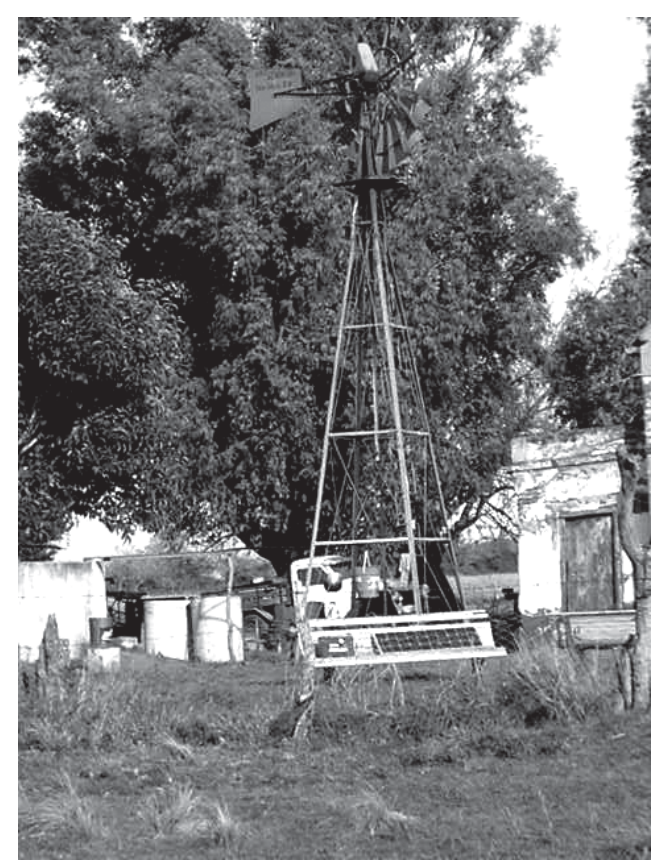
el 13 de abril de 1892, con la recomendación expresa de implantar en ellas una disciplina severísima. Llegó al país en compañía de un ingeniero danés, Mr. Borgen, quien habría de acompañarlo en su gestión como colaborador técnico. ${ }^{32}$

Goldsmid inició su gestión con firmeza, aplicando la rígida disciplina militar que lo investía: revocó al personal administrativo en casi todas las colonias y nombró algunos inspectores de distrito, que no titubeaban en atenerse estrictamente a sus instrucciones, con puntualidad y disciplina casi militar. Resolvió poner término a la distribución de productos alimenticios y de ropas a los colonos, instituyendo el subsidio en efectivo o schtitze (en idish, "Sostén", "respaldo"), y visitó personalmente las colonias. Viajó a Colonia Mauricio, luego a Colonia Clara y terminó su gira en Moisés Ville.

A Colonia Clara llegó con su esposa e hijas y recorrió a caballo las aldeas tomando contacto con los colonos y poniendo los nombres a los diversos grupos. Desde Balvanera tomó una serie de decisiones con la intención de fijar ejemplaridad: por

\footnotetext{
${ }^{31}$ La burocracia jerárquica de la JCA, a través de la Administración General de París, los dos administradores generales de Buenos Aires, los administradores regionales y sus funcionarios diseminados por todo el país, aseguraron una inflexible ejecución y control de la política de reclutamiento, adiestramiento laboral y de las obligaciones contractuales contraídas por los colonos. No había participación directa de estos en los órganos consultivos y en la toma de decisiones de la JCA.

32 Schallman, Lázaro, Historia de los pampistas, op. cit., p. 29.
} 
ejemplo, expulsó a cuatro familias que se habían negado hasta entonces a trabajar en el campo. De nada sirvió el clamor y el compromiso de enmendarse en lo inmediato, tampoco ningún peso tuvo el pedido que formularon a su favor los demás colonos, congregados frente a las Administración. El coronel mantuvo firmemente su resolución y esas cuatro familias abandonaron la colonia pocos días después, sirviendo de escarmiento a todos.

Se preocupó por la demanda de los jolosties que clamaban que se hiciera venir de Rusia a sus familias y se los instalara de una vez como a los demás colonos. A su regreso a Buenos Aires, Goldsmid se ocupó personalmente de este asunto.

Sin embargo, la medida más acertada, ya que intentaba poner límites a las artimañas y arbitrariedades de los delegados de la JCA, fue la asignación de subsidios monetarios para la adquisición de todo aquello que necesitaran los colonos para su instalación. De este modo, se perseguía que:

ni alimentos ni implementos agrícolas, ni ganado, ni herramientas, nada en absoluto fuese adquirido en lo futuro para los colonos, por empleados de la JCA, sino que fuesen los mismo pobladores o colonos los que se ocuparan de sus compras, bajo su propia responsabilidad. ${ }^{33}$

El monto previsto fue de $\$ 12$ mensuales por adulto y $\$ 6$ a cada hijo menor de 12 años. Las Memorias dan cuenta de que este sistema no resultó mucho mejor que el anterior, ni siquiera sirvió para prevenir desinteligencias entre los colonos y algunos administradores o personal subalterno. No falto quien, aduciendo descortesía o insolencia, aplicaba una multa a los colonos, que era descontada del subsidio. Fingermann señala que:

Era habitual que los agentes e inspectores se valieron de dicha arman para perjudicar a los colonos que les eran antipáticos; en la lista de los subsidios solían tildarlos con una marca azul y les aplicaban multas de diez o veinte pesos. ${ }^{34}$

\footnotetext{
${ }^{33}$ Carta del coronel Goldsmid fechada el 11 de mayo de 1892.

${ }^{34}$ Fingermann, Israel D., Di Idische Záitung, edición del 20 de junio de 1928.
} 
Las acciones de resistencia estuvieron también presentes. Fue Colonia Clara el ámbito donde se generaron los primeros movimientos de unidad para la defensa contra la explotación de la empresa colonizadora. Señala Hurvitz que los habitantes del grupo Carmel fueron pioneros en advertir y difundir los peligros que se avecinaban para los colonos. En una visita que realizaron los colonos de Lucienville tratando de reconocer el terreno y ponerse en contacto con los vecinos, emprendieron una travesía en carro por la región llegando a Carmel. Allí observaron que los de allí provenían de diferentes lugares de la Europa Oriental, que no tenían ninguna noción del trabajo de la tierra, que las viviendas, todas de adobe, eran precarias y extendidas a lo largo de un kilómetro, lo que les otorgaba características "anormales" y contribuyó a que se forjaran una impresión negativa de sus vecinos. Pero si de asombro se trataba, ayudó a profundizarlo mucho más lo que por estos colonos escucharon, de lo cual nada sabían:

Allí se comentaba que el barón de Hirsch había "conducido" a la gente a las regiones salvajes, para convertirlos en esclavos. Incluso se afirmaba que oportunamente se procedería a "marcarlos», se los obligaría a firmar contratos en los que se diría: "quedan por vida esclavos del barón y así"... ${ }^{35}$

A partir de ese momento tuvo lugar el germen de un movimiento que se opuso a la firma de los contratos con la JCA y de todo documento que los administradores locales exigieran a los colonos. En 1896, la prédica de este grupo se extendió por las colonias, teniendo pocos adeptos en Lucienville, quienes no entendían por qué no debían firmar los contratos sobre la tierra y la documentación relativa a la recepción de bueyes, implementos y otros elementos entregados por los administradores. El movimiento de resistencia los llamó «infieles" y se los dejó de lado, pues se sabía que no se contaba con ellos. Las estrategias de acción fueron generando enconos y desconfianzas, formándose dos grupos antagónicos. Los «infieles" contaban con el apoyo y con los beneficios que los administradores podían brindarles, en particular, con la entrega de máquinas segadoras para la recolección de la

${ }^{35}$ Hurvitz, S. I., Colonia Lucienville. 37 años de colonización israelita, Buenos Aires, 1932, p. 6. 


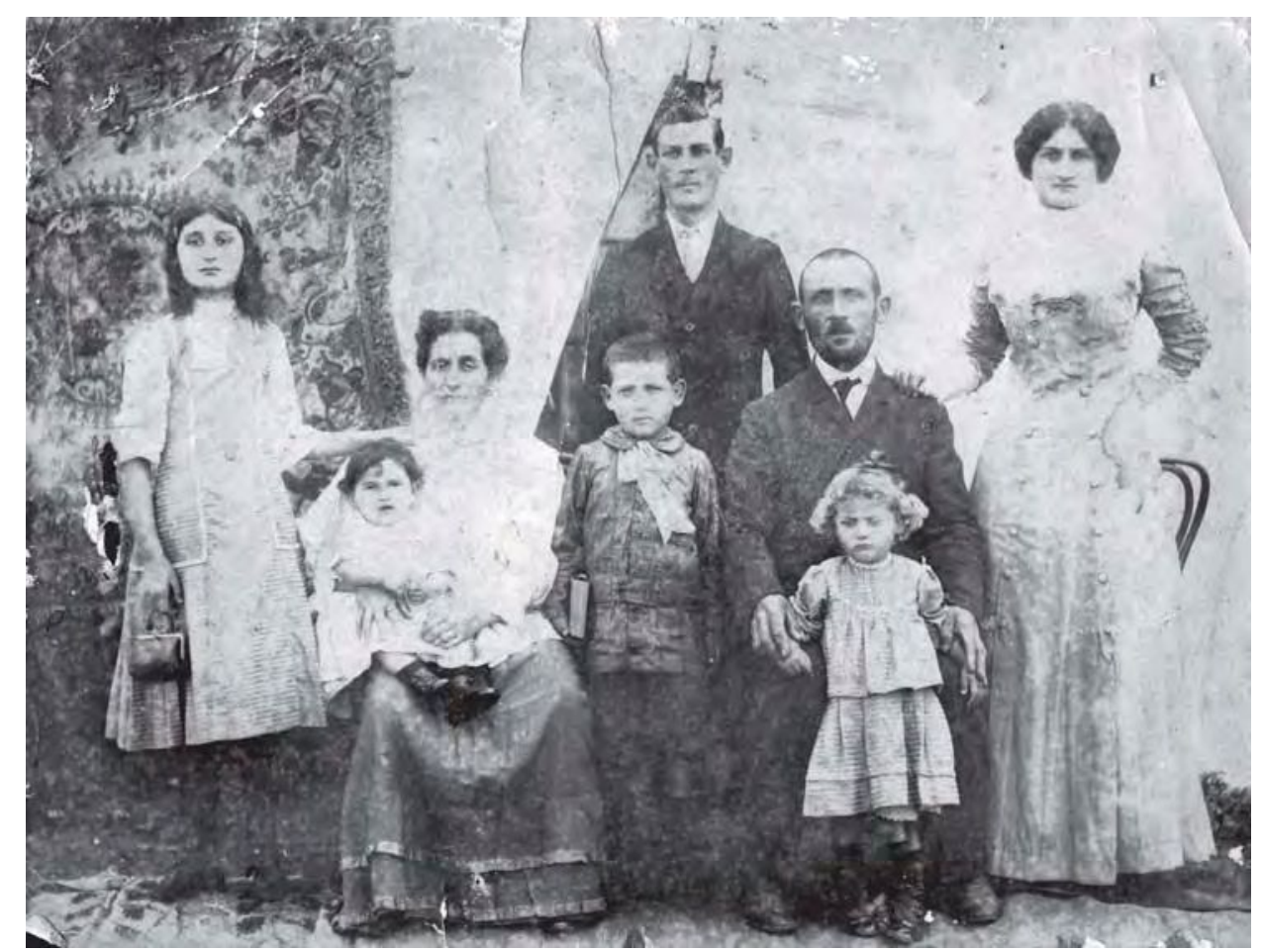

Schaye Bindirsky y flia., Grupo San Gregorio o Sonnenfeld.

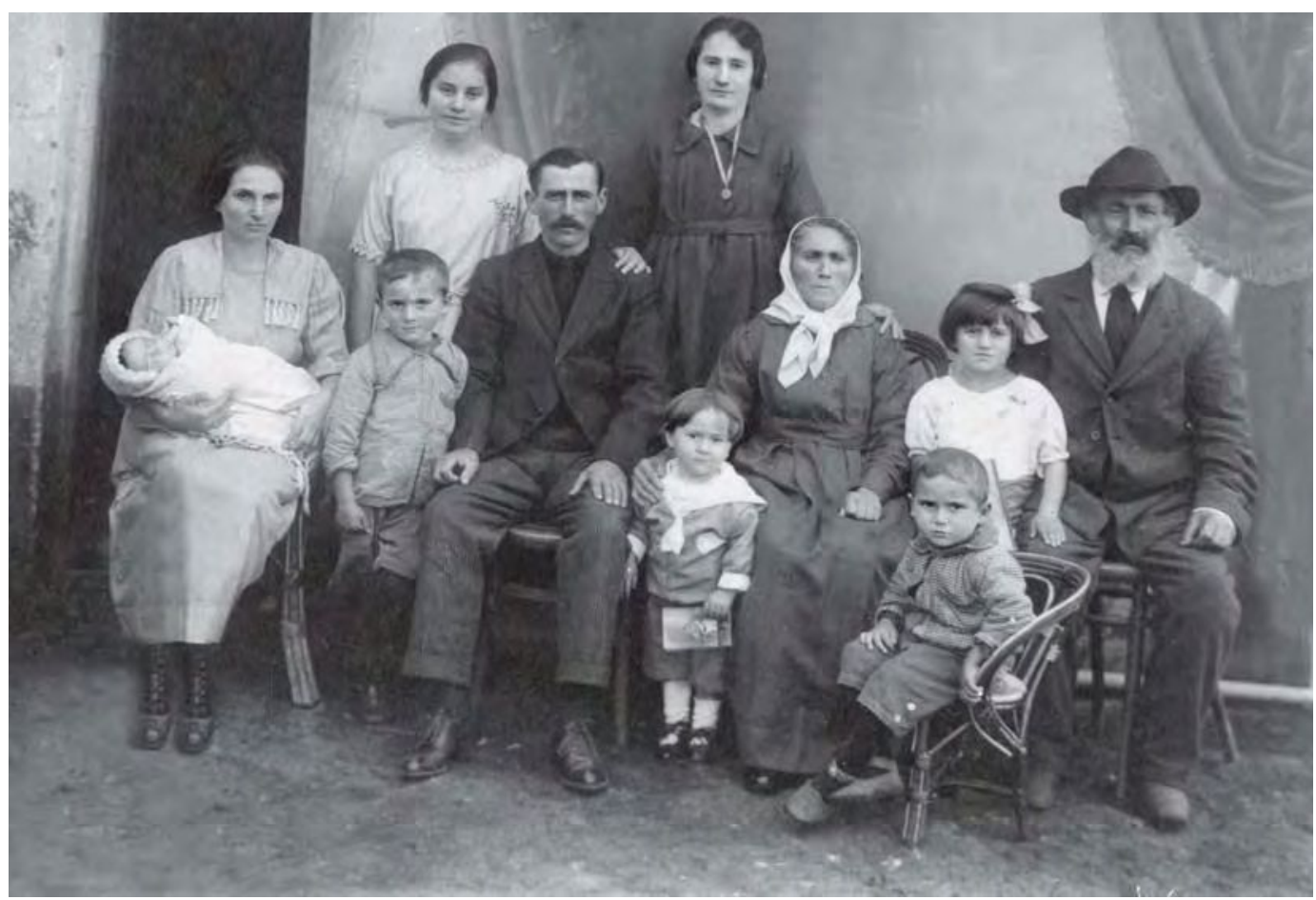

Flia. Yusim-Korsunsky, Grupo Barón Hirsch. 
cosecha. Estos firmaron los documentos de entrega de las máquinas y los "revolucionarios" se quedaron sin ellas. Entonces, los "revoltosos" se dirigieron a la estación donde se hallaban las máquinas depositadas y, sin que mediaran palabras, las cargaron en sus carros y regresaron a sus campos. El jefe de la estación solicitaba a los gritos la firma de la documentación necesaria, lo que fue, por supuesto, desoído. Entonces envió un telegrama a Buenos Aires solicitando ayuda a la Administración. Llegó el administrador Hirsch para reunirse con los colonos. Uno de los asambleistas llamó a otro a un rincón y le dijo en "secreto", pero de forma que todos lo escucharan, "Hay que dar fuego". Al escuchar la frase, Hirsch descontó que se prendería fuego el edificio donde estaban con el objeto de quemarlo a él, saltó por la ventana para marcharse con premura, impotente frente a la acción colectiva y de resistencia de los colonos frente a las arbitrariedades cotidianas basadas en dirigir la experiencia con mano dura. ${ }^{36}$

El afianzamiento de las familias en las colonias fue un tema trascendental. Una vez superadas las instancias y dificultades de los traslados hasta la asignación de las parcelas, había que comenzar a "construir la epopeya" para emprender una vida como colonos agricultores. Como casi todos los inmigrantes que llegaron al país, fueron una "generación de sacrificio". Con los instrumentos de labranza rudimentarios otorgados y los escasos conocimientos, había que "inventar" la agricultura en un suelo fértil pero virgen. Dos dificultades iniciales se conjugaban entrelazadas. Por un lado, la naturaleza con todos sus elementos agresivos: años de interminables sequías, lluvias pertinaces del otoño entrerriano, tremendas tormentas de verano. Por otro, la orfandad de criterios técnicos para el uso del suelo y de los cultivos idóneos que dieran los rindes necesarios para cubrir los gastos que demandaba la cuota anual del Contrato de Promesa de Venta firmado con la JCA, ${ }^{37}$ a

\footnotetext{
${ }^{36}$ Ibídem, p. 10.

${ }^{37}$ Como explicábamos en el capitulo anterior se firmaba un contrato de promesa de venta, por la cual se obligaba a reembolsar a la empresa el precio de la tierra y el total del anticipo en cierto número de anualidades, que no podía ser superior a 20 , con un interés de $4 \%$ anual, luego de lo cual se recibía el título de propiedad definitivo. La tierra era vendida al colono al precio de compra, aumentado con los gastos de mensura, escrituración, establecimiento de caminos, canales de riego, etcétera. El colono recibía un anticipo en pesos para la construcción de la casa, el establecimiento de su familia y la adquisición de material de trabajo. Para evitar que, seducido por el valor que pudiera haber adquirido su tierra, vendiera el lote y abandonase la explotación, el contrato contenía cláusulas que hacían muy difícil ese desprendimiento. También se fijaba que el lote debía ser trabajado por el colono con los miembros de su familia y que quedaba prohibida la sublocación.
} 
los que se debía sumar los adelantos otorgados por los instrumentos de labranza y otros gastos de instalación. Si bien en los primeros años recibieron subsidios monetarios para cubrir las necesidades primarias, todo ello pasó a engrosar la deuda con la empresa colonizadora.

La inexperiencia fue cubierta con el apoyo de los peones locales, que les enseñaron el manejo de los animales y las formas necesarias para la roturación y siembra de la tierra. Tareas estas que fueron emprendidas en cada grupo y relatadas de múltiples maneras por los pioneros de la experiencia.

Nosotros, paulatinamente, fuimos convirtiéndonos en verdaderos agricultores y aprendimos a mirar con los ojos bien abiertos la naturaleza y a interpretar sus panoramas. El vuelo de los pájaros nos anunciaba el cambio del tiempo; las golondrinas con sus veloces revoleos y sus acrobacias, nos revelaban la proximidad de las lluvias; las vacas aspirando intensamente en aire nos inquietaban y las hormigas, al llevar apresuradamente sus huevos y larvas de un lado a otro, nos traían el infalible presagio de tormenta, así como la alegría de los potros señalaba buen tiempo. Nunca nos fallaron los indicios del sol y de la luna... y hoy pienso que fue el "picazo" aquel buey providencial, el que nos vinculó con la naturaleza y que gracias a su influencia nos hicimos observadores y aprendimos a leer en las páginas misteriosas de la vida. ${ }^{38}$

El arraigo a la tierra requería de esfuerzos, coraje y valentía, ya que estaban comprometidos a demostrar que esta experiencia les permitiría dejar atrás los vejámenes y penurias. Tenían libertad y la posibilidad de conseguir con su trabajo, el pan para sus familias.

Pero es necesario confesar que, a pesar de todo, si bien sufríamos lo indecible (y muchos no resistieron aquella vida y desertaron) también experimentamos goces que nos hicieron felices en medio de la rudeza de aquel desierto. Sabíamos que era una experiencia de vastos alcances en la que estábamos actuando y que trasfor-

\footnotetext{
${ }^{38}$ Lieberman, José, op. cit., p. 144.
} 
maría de raíces nuestra historia si triunfábamos... y fue la conciencia de aquella misión histórica y de la propia redención las que nos alentaban en las horas más desoladas, cuando los chicos andaban descalzos y no había con qué comprar una bolsa de harina. ${ }^{39}$

Luego de las cosechas, en 1896 llegó a las colonias la visita del director del la JCA en París, Dr. Sonnelfeld. Eran los tiempos en que los colonos organizaban los movimientos contra la firma de los contratos, las cosechas no daban rindes ni siquiera mínimos y las necesidades aumentaban, las ayudas no alcanzaban y crecía la tensión entre la administración y los colonos. Todos esperaban que la visita de los representantes del barón de Hirsch trajera las soluciones necesarias. Un tiempo después llegó la noticia de que las deudas de los campos se reducirían en un 25\%.

pero eso no trajo la mejoría esperada, además, la verdad es que los colonos no tenían pensado pagar la deuda. La langosta arruinó la cosecha. Se presentaba un problema concreto: ¿cómo sobrevivir y poder dar pan a los hijos? ${ }^{40}$

La Administración ajustaba los mecanismos para regularizar las cobranzas en la misma medida que la inquietud aumentaba entre los colonos. El sistema implementado establecía que para depositar la cuota del grano correspondiente se construyeran galpones en las colonias más alejadas. Allí, los colonos estaban obligados a depositar la cuota del $20 \%$ de la producción anual establecida por la Administración. Un sector de los colonos no creyó que fuera posible llegar a pagar lo adeudado por el campo y de este modo convertirse, con el paso de los años, en propietarios. La administración de Eugenio Lapine insistía en mantener las extensiones de los lotes en cincuenta hectáreas, cuyos rindes no alcanzaban para nada. Entonces apareció un movimiento de gente dispuesta a emigrar, a irse de las colonias. En la provincia de Buenos Aires se creó un movimiento de colonización llamado "Stroider", que contó con la concurrencia de jóvenes colonos que se traslada-

\footnotetext{
39 Ibídem, p. 140.

${ }^{40}$ Hurvitz, S. I., op, cit., p. 11.
} 
ron a dicha provincia, abandonando sus campos. Algunos cerraron convenio con aquella organización, otros giraron por la zona durante semanas, para finalmente regresar a su colonia solicitando a la JCA que les permitieran ubicarse nuevamente con sus implementos en los campos que habían abandonado. ${ }^{41}$

En aquellos primeros años del siglo xx, el movimiento de emigración retornó con fuerza, inquietud que motivó que, por segunda vez, los administradores de París, los doctores Sonnenfeld y Averbuj, viajaran a la Argentina.

El año 1904 fue una bisagra en la vida en Colonia Clara. Las razones fueron diversas, pero un agente fundamental para la transformación fue Adolfo Leibovich, quien asumió la Administración de la colonia y creó ese año la Cooperativa Fondo Comunal, que constituyó no solamente un fuerte elemento de contención y de ayuda - por las acciones desplegadas desde sus orígenes como una herramienta de organización defensiva-, sino que representó también un instrumento de trasformación de la vida de los inmigrantes, dado que se ocupó de la enseñanza, de la asistencia sanitaria, hasta de las múltiples relaciones entabladas con otras instituciones y con el Estado.

Leibovich fue un administrador singular. Había emigrado de Rusia junto con sus padres, arribando a la Argentina en 1889. La suya fue una las primeras familias que fundaron la colonia Monigotes, en la provincia de Santa Fe, ${ }^{42}$ por lo tanto fue un conocedor en profundidad de los avatares de la experiencia de convertirse en colono

\footnotetext{
${ }^{41}$ Hurvitz, S. I., op. cit., p. 15.

42 Monigotes la Vieja fue fundada por dos inmigrantes del grupo de Besarabia que llegó a la Argentina a bordo del barco Karlsruhe el 12 de diciembre de 1889, proveniente de Bremen. Se trata de Jacobo Leibovich e Hirsch Guibert. Con esta fecha cierta de llegada puede concluirse que la colonia fue fundada, como muy pronto, en los primeros meses de 1890. Según el relato de Adolfo Leibovich, hijo de uno de los fundadores, su padre agotó las posibilidades de apoyo en Buenos Aires para colonizarse y viajó en busca de alguna perspectiva a Esperanza, Santa Fe, que ya era una colonia establecida y pujante. Allí conoció a Alberto Gaffner, suizo y propietario de un almacén en las inmediaciones de un aserradero ubicado entre San Cristóbal y Moisés Ville, que proveía durmientes para el ferrocarril San CristóbalTucumán (FC Belgrano). Ambos gestionaron ante el Banco Colonizador la posibilidad de colonizar en ese lugar las familias mencionadas, y fue así como después de un largo viaje Buenos Aires-Sunchales, y dos jornadas de viaje en carro, llegaron al lugar asignado, un claro en medio del monte donde también estaban ubicados el aserradero y el almacén. Durante el año siguiente, el señor Jacobo Leibovich logró incorporar a la colonia a varios integrantes del grupo de la Alliance que se habían establecido en la ciudad de Santa Fe y en Esperanza. También se incorporaron varios colonos pertenecientes al grupo del Weser. La colonia se desgranó rápidamente al cabo de dos años (1891). Sólo quedó durante varios años más el señor Samuel Rotman con un pequeño almacén, que su esposa cuidaba revólver en mano cuando él se ausentaba. En http://www.generacionesmv.com/Generaciones/Monigotes.htm.
} 
agrario en Argentina. Trabajó junto a Loewenthal cuando pusieron en marcha los primeros pasos en la adquisición de tierras, se vinculó luego a la Administración de la JCA en Argentina, donde se desempeñó como uno de sus primeros empleados. Su conexión con Colonia Clara data desde los orígenes de su instalación, pues fue el encargado de trasladar las primeras cien familias que provenían del "campamento" de Palacios, Santa Fe, y las que fueron ubicadas en los grupos Barón de Hirsch, Miguel, Carmel, Ida y Rachel. ${ }^{43}$ Al poco tiempo fue designado en la Administración de la Colonia: primero como subadministrador y contador, bajo la Administración de Eugenio Lapine, quien al retirarse dejó en su puesto a Leibovich, que fue designado como administrador en $1904 .{ }^{44}$

Su tarea se concentró en reorganizar la colonia, intentando poner fin a las múltiples dificultades que atravesaban sus habitantes. En primer lugar, se propuso terminar con la determinación obstinada del anterior administrador Lapine, quien se había empeñado en organizar las primeras colonias con la asignación de lotes con una extensión de 25 a 50 hectáreas, según el modelo y estilo que había conocido en Rusia, sin tener en cuenta las necesidades y requerimientos para una explotación rural que brindase posibilidades de subsistencia. Así, debió reagrupar y reasignar los lotes, ahora de 150 hectáreas aproximadamente, "lo que se considera hasta hoy día como 'tipo de chacra' suficiente para que un colono, mediante su trabajo, pueda prosperar en ella». ${ }^{45}$

Las tareas del administrador fueron mucho más allá de la reorganización de la colonia: a partir de sus propuestas se formó la primera cooperativa agrícola denominada Fondo Comunal de Colonia Clara; por otro lado, fue el responsable de la renegociación de las deudas que los colonos habían adquirido con la empresa ante la Administración Central de la JCA en París. Las deudas acumuladas por los colonos eran imposibles de saldar con el trabajo en la chacra, por lo que se imponía la necesidad de una reducción sustancial. Había que convencer a la JCA de rebajar lo adeudado y aceptar que, si bien representaba una disminución

\footnotetext{
${ }^{43}$ Leibovich, Adolfo, Apuntes Íntimos. 1870-1946, Buenos Aires, Imprenta López, 1947, p. 56.

${ }^{44}$ Leibovich narra que tuvo que dejar su casa de Collin para instalarse en la suntuosa "Balvanera", residencia señorial, que por sus comodidades, sus parques y jardines, era entonces considerada como la más hermosa de la región (p. 71).

${ }^{45}$ Leibovich, Adolfo, op. cit., p. 72.
} 
de sus ingresos, era el único camino. Esta misión fue encarada personalmente por Leibovich, quien viajó a París para negociar con el presidente de la JCA, Narcisse Leven, y con los señores Sonnenfeld y Meyerson, representantes de la Administración Central, a los que debía demostrarles con argumentos convincentes que los colonos no podrían firmar un contrato aceptando pagar una deuda que acumularon a su pesar y que les sería imposible pagar. Contó con la ayuda del ex director de Buenos Aires, David Cazés, que se encontraba allí en calidad de asesor en los asuntos de Argentina, para coronar con éxito su misión. La JCA aceptó que se rebajara la deuda de los colonos "haciéndoles una quita a todo aquello en lo que en ella había habido de superfluo e improductivo y colocando al colono en una situación financiera saneada y normal». ${ }^{46}$

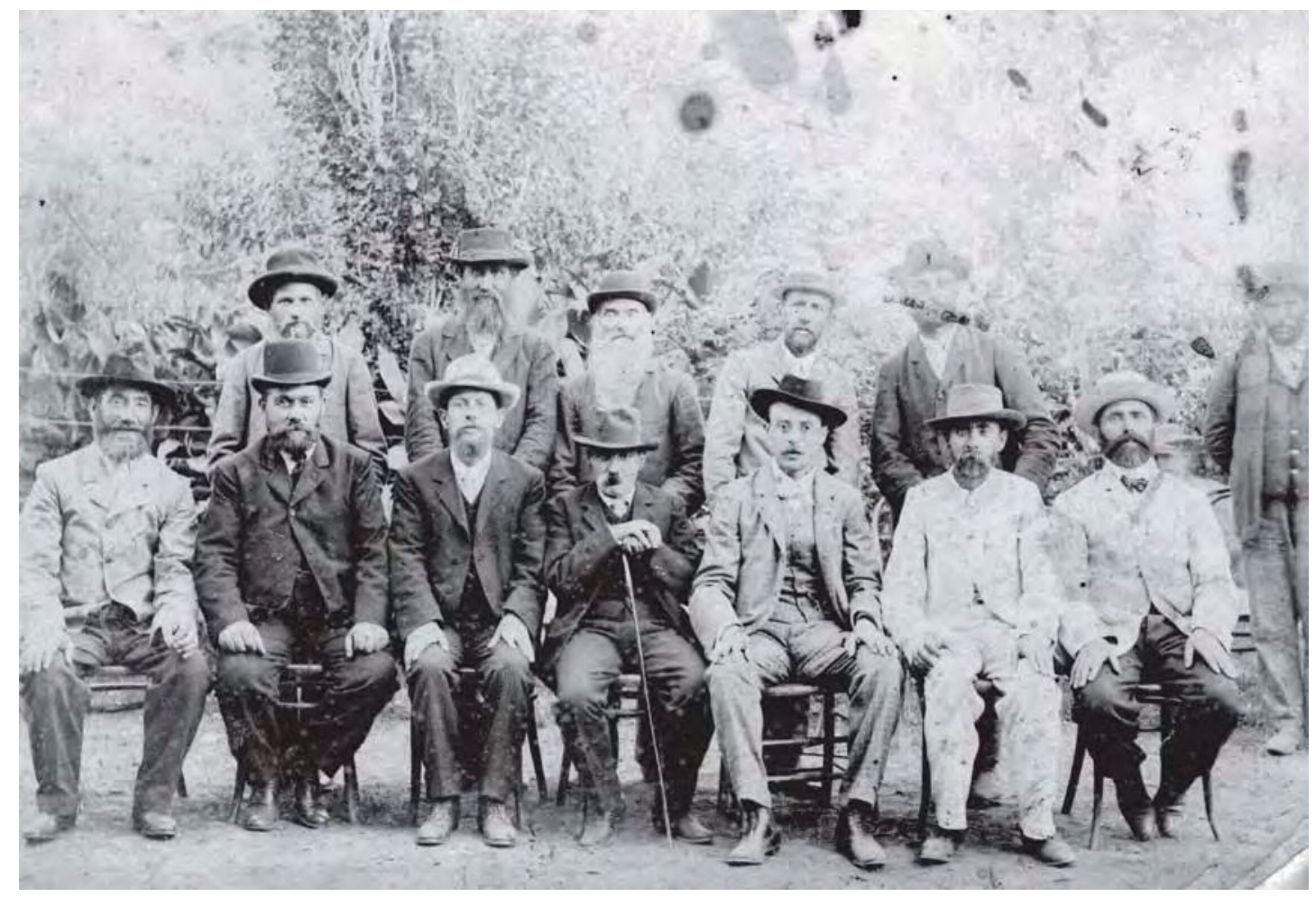

El primer Consejo Directivo del Fondo Comunal (foto de 1907).

\footnotetext{
${ }^{46}$ Leibovich, Adolfo, op. cit., p. 75. En octubre de 1907, Leibovich tuvo que dejar la administración de Colonia Clara pues recibió la orden de hacerse cargo de las colonias de la JCA en Brasil.
} 
El siguiente cuadro muestra lo dicho anteriormente. Luego de 1904, el movimiento emigratorio se detiene.

Evolución de instalación de colonos en Colonias Clara

\begin{tabular}{|c|c|c|}
\hline Años & Clara & Salieron \\
\hline 1895 & 569 & 20 \\
\hline 1896 & 545 & 63 \\
\hline 1897 & 494 & 100 \\
\hline 1898 & 475 & 32 \\
\hline 1899 & 459 & 17 \\
\hline 1900 & 527 & - \\
\hline 1901 & 557 & - \\
\hline 1902 & 523 & 24 \\
\hline 1903 & 515 & 8 \\
\hline 1904 & 475 & 40 \\
\hline 1905 & 516 & - \\
\hline 1906 & 493 & \\
\hline 1907 & 565 & 23 \\
\hline 1908 & 650 & - \\
\hline 1909 & 687 & - \\
\hline 1910 & 696 & - \\
\hline 1911 & 699 & - \\
\hline 1912 & 743 & - \\
\hline
\end{tabular}

Fuente: Fraternidad Agraria, La historia de la Fraternidad Agraria, nov. 1948.

La deserción se detuvo y no fue por arte de magia. El 21 de noviembre de 1904 se fundó el Fondo Comunal como institución de ayuda y luego como cooperativa. La reunión se llevó a cabo en La Capilla, en el salón "Zijron Moische», y se nombró a los señores Adolfo Leibovich como presidente y a Benjamin Mellibovsky como secretario (ambos pertenecientes a la Administración de la JCA). El Consejo Direc- 
tivo estuvo compuesto por Noe Yarcho, Moisés Abramovich, M. Kostianovsky, Isaac M. Sas, Schaye Toff, Ch. Bakman, Pinjos Saltzman, I. Idelshon, León Garbovetzky, Gregorio Glass, D. Venziani y W. Moss, estos últimos directores de la JCA.

Isaac Fridland fue el responsable de la redacción del «Reglamento de la Sociedad Protectora y de Socorros Mutuos de la Colonia Clara de la JCA». El artículo segundo fijaba claramente los objetivos a cumplir:

Su finalidad es aconsejar, apoyar y defender los intereses de los socios, ser mediadores en las relaciones entre la Dirección General de la JCA o su representante en la colonia y los colonos que pertenecen a esta sociedad, y velar porque siempre haya entendimiento entre ellos.

a) ser mediadora en las relaciones de los asociados entre sí.

b) Crear los fondos necesarios, que destinará para ayudar a los socios en caso de fracasos de cosechas o desgracias imprevistas, crear instituciones de interés general, administrándolas, y regular todo asunto que pertenezca a los asociados en general.

c) Estar siempre inclinada hacia toda buena acción que no se aparte de la base fundamental de protección y ayuda mutua. ${ }^{47}$

Debemos destacar que ya están en ese reglamento las reglas de convivencia que marcan fuertemente la experiencia colonizadora judía en Entre Ríos. La Comisión Directiva fue la encargada de establecer los modos de protección y en particular las mediaciones en las diferentes divergencias que pudieran devenir entre los colonos y la JCA, así como las controversias entre los socios de la institución, cuyo veredicto sería terminante.

Ahora bien, la iniciativa de crear una entidad representativa de los colonos fue de la Administración de la JCA, pero el sostenimiento en el tiempo y el arduo proceso para concitar la adhesión obedeció al esfuerzo de los pioneros que se trazaron un ideal cooperativo y solidario, como señala Isaac Kaplan, que fue la brújula que pudo guiar la empresa que estuvo plagado de inconvenientes y de oposiciones

\footnotetext{
${ }^{47}$ Archivo Miguel Sajaroff, Fundación IWO, Buenos Aires. Texto en idish y la traducción al español.
} 
férreas, que se denominaban en la época discrepancias "por elementales razones prácticas". ${ }^{48}$

Los objetivos iniciales se fueron transformando lentamente para tornar al Fondo Comunal en una institución organizadora de la vida de la colonia. En las primeras sesiones se trataron los nuevos alcances: la asignación de subvenciones provisorias de ayuda a viudas y ancianos, la necesidad de contar con formas de capacitación de los productores en consumidores para el manejo de la economía, a partir de conferencias a cargo de especialistas, así como una circulación de información concientizadora de los alcances del cooperativismo, para lograr la adhesión y el compromiso de los socios y la obligación de intervenir en la prestación de servicios sanitarios a la comunidad, a partir de la asignación de fondos al Hospital Clara, para cubrir sus déficit permanentes.

El Fondo Comunal fue una institución que convirtió a los colonos en activos actores del desenvolvimiento social y económico de la región. El conocimiento integral del movimiento les dio a los socios la posibilidad de ejercer, desde fuera o desde dentro, un estricto contralor de las acciones emprendidas. Ser socio del FC era la oportunidad para acceder a importantes beneficios económicos, pero también era la tabla de salvación en los momentos de penurias. La pertenencia se constituía en un compromiso moral, donde deberes y obligaciones se conjugaban con derechos. El contralor de los socios sobre la actuación de sus dirigentes fue siempre muy severo: "en el Fondo Comunal no se concibe que un miembro del Directorio pueda pecar en lo más mínimo en su condición de socio". ${ }^{49}$

Las asambleas fueron siempre numerosas y las críticas a la labor de los Consejos son cosas normales; se las considera muy saludables, pero no se escucha al socio que haya faltado a sus deberes para con la cooperativa; en las asambleas predomina el concepto de que no critica el que sabe, sino el que puede, es decir, el que tiene

\footnotetext{
${ }^{48}$ Kaplan, Isaac, Recuerdos de un agrario cooperativista, 1895-1925, Buenos Aires, Ciirculo de Estudios Cooperativistas de Buenos Aires, 1962.

${ }^{49}$ Fondo Comunal, Cincuenta años de su vida. (1904-1954), Villa Domínguez, Sociedad Cooperativa Agrícola Limitada, 1957, p. 70.
} 
autoridad moral para ello y está acreditado como tal en su ficha de operaciones con

la cooperativa..$^{50}$

Esta institución fue un espacio donde el colono aprendió a defender sus intereses y también a escuchar e intercambiar opiniones. Un espacio de socialización, de contención y de ayuda para vivir la experiencia de colono agrícola en suelo argentino a la que los judíos «vinieron buscando el amparo del techo, del pan, de la ilusión bajo la solemne protección de la Cruz del Sur». ${ }^{51}$

Mauricio de Hirsch, poseedor de una de las fortunas más considerables de Europa a fines del siglo xIX, decidió crear la JCA, empresa filantrópica que dispuso de un capital inicial de 50 millones de francos ${ }^{52}$ donados por su creador, cifra que superaba en monto a todos los fondos públicos judíos de Europa y América sumados. ${ }^{53}$

Los objetivos de la empresa estaban establecidos en el artículo $3^{\circ}$ del Reglamento:

Facilitar la emigración de israelitas de los países de Europa y Asia donde ellos son deprimidos por leyes restrictivas especiales y donde están privados de los derechos políticos, hacia otras regiones del mundo donde puedan gozar de éstos y demás derechos inherentes al hombre. Al efecto la Asociación se propone establecer colonias agrícolas en diversas regiones de América del Norte y del Sud como también en otras comarcas. ${ }^{54}$

\footnotetext{
50 Ibídem.

${ }^{51}$ Fairman, Silvia C., Mate y Samovar, Buenos Aires, Lumen, 2000, p. 9.

52 Equivalentes en esa época a unos 2 millones de libras esterlinas o casi 10 millones de dólares. Un año más tarde, el barón de Hirsch legó el grueso de su patrimonio, que constituía la enorme suma de 7.337.857 libras esterlinas y que la JCA recibiría luego de su muerte. En Avni, Haim, "La agricultura judía en Argentina ¿Éxito o fracaso?", op. cit., p. 535.

53 Más tarde, el barón se las ingenió para inyectar nuevas donaciones de increíble envergadura (aproximadamente 180 millones de francos oro más).

${ }^{54}$ Memoria de la Jewish Colonization Association. Su obra en la República Argentina. 1891-1941, Buenos Aires, p. 6.
} 
Mauricio de Hirsch formaba parte de la corriente filosófica del lluminismo judío, sostenedora de que el estatus político y social de los judíos que vivían en las zonas de residencia rusa podía mejorar mediante su transformación en agricultores modernos. Se trataba de una empresa de regeneración humana y moral más que de una cuestión de progreso económico. Más allá de la filantropía, el propósito cardinal de la empresa era asentar a los inmigrantes en el campo para crear una clase campesina y de chacareros judíos en Argentina. Y sus palabras fueron un mandato que los colonos recibieron al partir de Europa y se convirtió en una promesa a cumplir para los primeros colonos. Para millones de judíos perseguidos, Mauricio de Hirsch encarnó una imagen fundante del judaísmo, representando al nuevo Moisés tan esperado que los liberaría de la barbarie zarista y los guiaría hasta la Tierra Prometida. Tierra que no era la Palestina con la que judíos religiosos y otros seculares comenzaban a soñar en la Europa central, sino América, y en este caso la República Argentina. El barón de Hirsch murió en 1896 y la dirección de la empresa quedó en manos de hombres que lo secundaban, quienes asumieron una administración férrea para el logro de los objetivos trazados.

Desde las perspectivas de los colonos, estos administradores traicionaron el legado filantrópico y de salvación que imprimió Mauricio de Hirsch a la JCA, imponiéndoles condiciones leoninas que hacían imposible su permanencia en la colonia:

los administradores obraron como enviados de "una empresa económica" que perdió el espíritu que el Barón de Hirsch le quiso dar. Por eso muchos colonos se sublevaron y algunos se fueron a La Pampa, otros al Chaco y muchos abandonaron los campos y se fueron a las ciudades. Además si había colonos que protestaban contra arbitrariedades de los administradores, éstos los "marcaban" y tarde o temprano les hacían abandonar sus chacras. En términos generales el modelo administrativo no fue el que quiso implantar el Barón de Hirsch, porque no se adecuó a las necesidades de los colonos. Muchos tuvieron suerte, o falta de oportunidades y continuaron en las chacras y al final progresaron. ${ }^{55}$

\footnotetext{
55 Julio Mazo Efron, nieto y sobrino de colonos que vivieron en la colonia Barón Hirsch, es el autor de este párrafo en respuestas a nuestras preguntas.
} 
En la memoria colectiva de la comunidad judía, la figura del barón de Hirsch representa una mano tendida. Un hombre excepcional que con un gesto de bondad sacó a millares de hogares sumidos en la pobreza, en el abandono y a merced de los pogroms, para devolverles el coraje, la voluntad y la esperanza. Ahora bien, cuando intentamos indagar sobre las causales de las deserciones, el abandono de las colonias y en especial el incumplimiento de la misión de hacerse agricultores en la pampa argentina, las respuestas se aglutinan, en primer lugar, en torno a la torpeza e incompetencia de los administradores de la JCA, que, estableciendo condiciones desmedidas, expulsaron a los colonos. En segundo lugar, en la dureza del trabajo agrario y en la escasa rentabilidad que la experiencia colonizadora brindaba a estos hombres y mujeres. Finalmente, otras más silenciadas en que se abandona la colonia buscando "un sitio más poblado y más culto, en el que sus conocimientos lingüísticos llorasen menos». ${ }^{56}$

\footnotetext{
56 "Mis abuelos Samuel Dujovne y Sara Brun venían de Moguilev-Podolski, hoy Ucrania. Corría el año 1900. Viajaron junto con Isaac, hermano de Samuel, y con su esposa. Pero no bien posados sus baúles en el Hotel de Inmigrantes, los administradores de la Jewish les anunciaron que habían sido destinados a colonias distantes entre sí. El hermano de Samuel era un hombre religioso. El respetó el contrato firmado con la Jewish, se estableció, se hizo "gaucho judío" y sus hijos y nietos fueron en sulky a la escuela. En cambio, mi abuelo no era religioso, sino socialista, luego desobediente. Y quiso el destino que le tocara en suerte una colonia próxima a la de Villa Domínguez, cuyos habitantes de ideas avanzadas tampoco solían aceptarlo todo como palabra santa. Samuel no aprendió a andar a caballo ni a sembrar nada, salvo un canterito con flores. Era maestro. En Colonia Carmel lo esperaban con su escuelita lista y hasta con dos perros con nombre: Pleve y Stolipin, los dos ministros antisemitas del zar. Fiel a sus convicciones, Samuel enseñó a sus alumnos la historia bíblica buscando la explicación racional (...) Allí, en 1903 y en esa escuela de campo nació mi padre. Pocos años después, mis abuelos abandonaron el campo. En 1905, Samuel se fue de Colonia Carmel. Buscaba un sitio más poblado y más culto. Se fue a Moisés Ville. Dudo de que en esa colonia el sánscrito tampoco le haya servido de mucho. En: Dujovne Ortíz. Alicia. El Camarada Carlos. Itinerario de un enviado secreto. Buenos Aires, Aguilar, 2007, p.24.
} 
ANEXO

Lista de los viajeros del Pampa

\begin{tabular}{|c|c|c|c|c|c|c|c|}
\hline APELLIDO & CANT. & APELLIDO & CANT. & APELLIDO & CANT. & APELLIDO & CANT. \\
\hline$?$ & 6 & FRIEDMANN & 1 & KUJUCHNER & 1 & RUDAIEFF & 1 \\
\hline ABDECHMAN & 1 & FROMOWITZ & 1 & KUKUGEW & 1 & SACHALINSKY & 2 \\
\hline ABRAHAM & 1 & GALKIN & 3 & LABSOFSKY & 1 & SACHOWITZ & 6 \\
\hline ABRAHAMSON & 1 & GEBURKMAN & 1 & LAHRMAN & 5 & SAKOL & 3 \\
\hline ABRAMOW & 5 & GELBGIS & 6 & LAUFER & 1 & SALOMON & 6 \\
\hline ABRAMOWITZ & 8 & GERSCHIN & 4 & LAVERNE & 2 & SCHABOLSKY & 8 \\
\hline ABRANOFF & 3 & GERSON & 8 & LEHRMAN & 4 & SCHAFKLIN & 5 \\
\hline AGINOSKY & 3 & GEWNIN & 1 & LEIDERER & 1 & SCHAMSCHON & 3 \\
\hline AISENBERG & 2 & GLANZ & 4 & LERPER & 1 & SCHAPIRO & 6 \\
\hline ARON & 2 & GLUCKMAN & 3 & LEWIT & 1 & SCHAPLIGIN & 5 \\
\hline BACKERMAN & 1 & GOLDENBERG & 12 & LIEBERMAN & 1 & SCHEININ & 5 \\
\hline BADCHEN & 5 & GOLDENFLEITER & 1 & LIPKOWITZ & 2 & SCHIMAKOFSKY & 2 \\
\hline BARST & 6 & GOLDENVEISER & 7 & LOEW & 4 & SCHLOIMOWITZ & 5 \\
\hline BASS & 3 & GOLDIN & 5 & MAISEL & 2 & SCHOCKLANDER & 1 \\
\hline BEHRMAN & 2 & GOLDSTEIN & 23 & MALNIVIG & 1 & SCHUEHMACHER & 9 \\
\hline BELINKY & 8 & GREITER & 7 & MARKO & 9 & SCHUKIN & 5 \\
\hline BELSOHN & 6 & GRITCHINER & 1 & MEERBAUM & 2 & SCHUSTER & 8 \\
\hline BENGMAN & 3 & GRODNISTANSKY & 2 & MELAMEDOFF & 3 & SCHWARZ & 5 \\
\hline BENZMANN & 1 & GRUMSTEIN & 4 & MENACHELN & 6 & SCHWARZMAN & 6 \\
\hline BERCOWITZ & 2 & GRUNBERG & 7 & MENTZNISKOW & 4 & SCHWEIZER & 1 \\
\hline BERFELD & 5 & GRUNFELD & 15 & MEUROW & 7 & SILBERMAN & 11 \\
\hline BERKOWITZ & 8 & GUITELMAN & 4 & MICHAILOWITZ & 1 & SKOPF & 5 \\
\hline BERSCHANITZ & 1 & GULLIN & 11 & MITZKOWITZ & 2 & SMIRIN & 7 \\
\hline BESNOSSOF & 1 & GURSCHKOWITZ & 2 & MOISEI & 7 & SOBILIENSKY & 1 \\
\hline BLANK & 4 & HALPERN & 5 & MOLDAWSKY & 2 & SPAISKY & 3 \\
\hline BLAUSEIN & 1 & HANZESKY & 1 & NASKOFF & 1 & SPARKEL & 1 \\
\hline BOCKSTEIN & 1 & HEBERNITZ & 6 & NISSEN & 7 & STAATMAN & 4 \\
\hline BRAUN & 5 & HELMAN & 1 & OFFENGERDER & 6 & STCSKLOMITZ & 3 \\
\hline BRAUNSTEIN & 14 & HERSCHKOWITZ & 1 & OSWILOFF & 1 & STEINBERG & 9 \\
\hline BRISLER & 7 & $\mathrm{HIRSCH}$ & 1 & PAGREBINSKY & 3 & STEINGARD & 7 \\
\hline BRONSTEIN & 12 & HUN & 9 & PALKINHOFF & 2 & STEMBERG & 1 \\
\hline BRUCK & 1 & IAKELENWITZ & 7 & PIMSTEIN & 1 & TIRANOFSKY & 7 \\
\hline BRUDER & 1 & IAKOLEWITZ & 2 & PINSKRER & 1 & TISCHASCHIR & 5 \\
\hline BUCHALEZ & 3 & ITCHILOFF & 10 & PRAGERMAN & 2 & TOPPELBERG & 7 \\
\hline COHAN & 3 & ITZKOWITZ & 1 & RABINOWITZ & 4 & TRAB & 7 \\
\hline
\end{tabular}




\begin{tabular}{llllllll} 
COHEN & 3 & JUSIK & 1 & RACHLIN & 6 & TRAIRN & 4 \\
\hline DANSTOFF & 4 & KALISCH & 3 & RANSOVER & 6 & VENGEROFF & 3 \\
\hline DAVIDOWITZ & 1 & KAPLAN & 25 & REMEROFF & 5 & WAPNIASKY & 1 \\
\hline DICKMAN & 1 & KATZ & 3 & RICHLIN & 3 & WEINBERG & 1 \\
\hline EDELMAN & 1 & KERMACH & 2 & RIELES & 6 & WEINSTEIN & 5 \\
\hline EPSTEIN & 3 & KLEIZKIN & 1 & ROBERT & 1 & WEINTRAUB & 1 \\
\hline ETKIN & 1 & KLIMAN & 7 & ROISMAN & 3 & WEINZWEIG & 1 \\
\hline FEIERSTEIN & 2 & KLIMANS & 5 & ROMER & 6 & WEISS & 9 \\
\hline FEIGEN & 9 & KOHN & 1 & ROSENBLUM & 7 & WEXLER & 7 \\
\hline FINGERMANN & 7 & KONIG & 5 & ROSENTHAL & 3 & WIGLER & 1 \\
\hline FINKELSTEIN & 10 & KOPLOW & 2 & ROSSEN & 1 & WILFOWITZ & 1 \\
\hline FRACHTMAN & 4 & KORMAN & 1 & ROTLESTEIN & 2 & WOLF & 7 \\
\hline FRANKEL & 1 & KORNBLUT & 8 & ROUVINSKY & 4 & WOLFSOHN & 1 \\
\hline FRIEDBERG & 3 & KORTRAWSKY & 4 & RUBIN & 2 & YAKOB & 1 \\
\hline & & KRINOWITZ & 7 & RUBINSTEIN & 12 & YENKOLEWITZ & 2 \\
\hline
\end{tabular}

Fuente: http://www.generacionesmv.com/Generaciones/Grupos.htm.

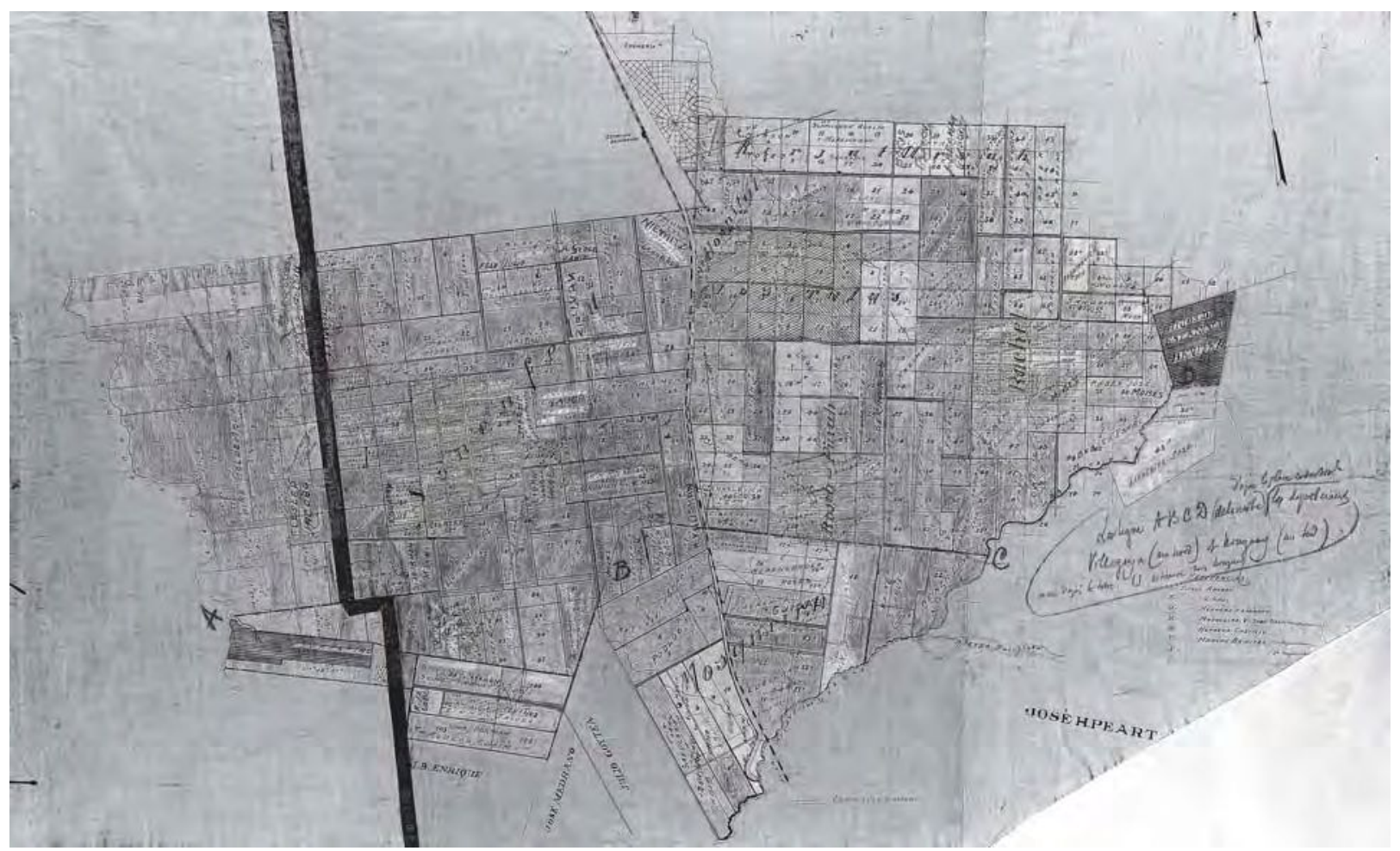




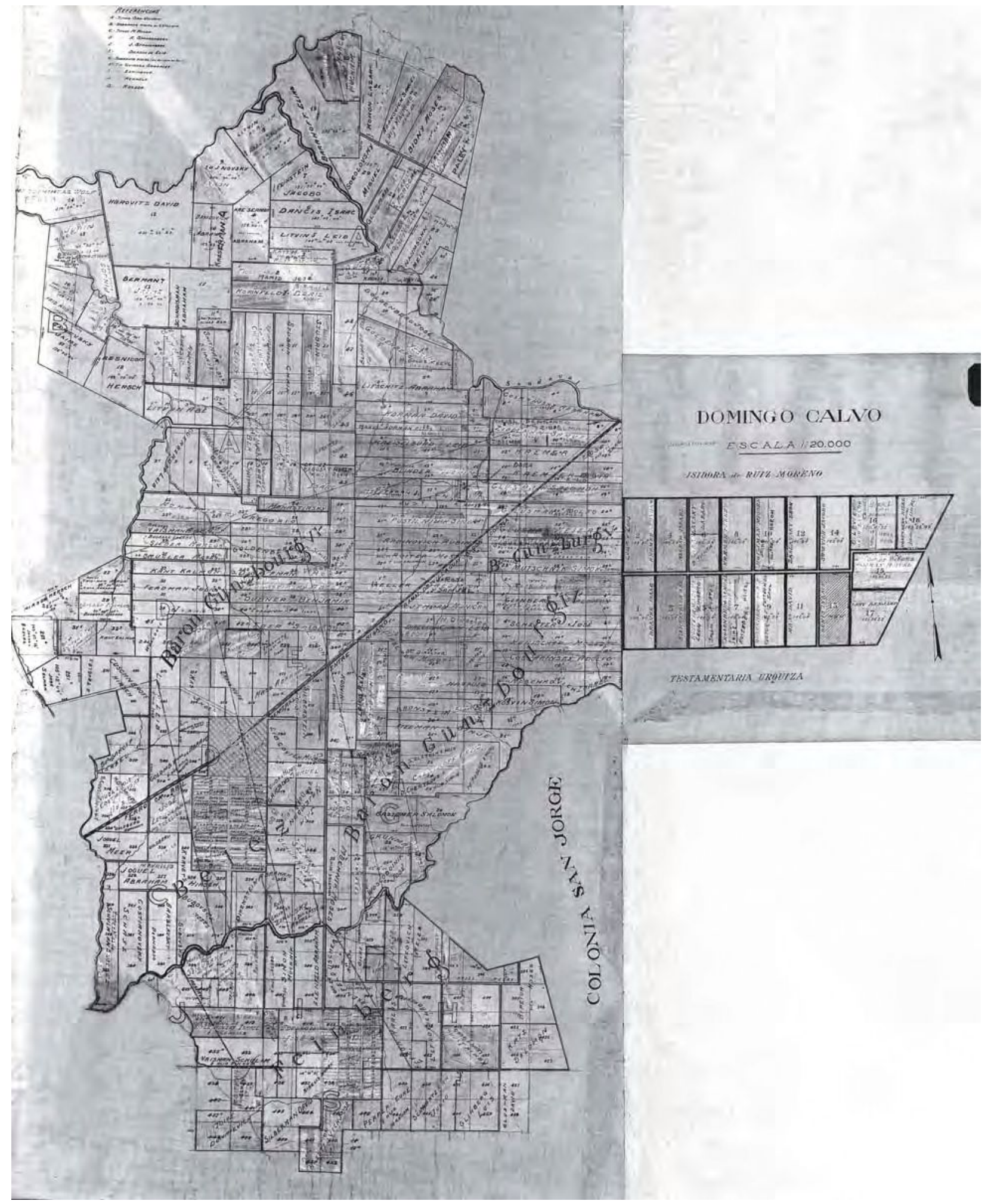

Historia y memoria de la colonización Judía agraria en Entre Ríos. La experiencia de Colonia Clara, 1890-1950 | 149 


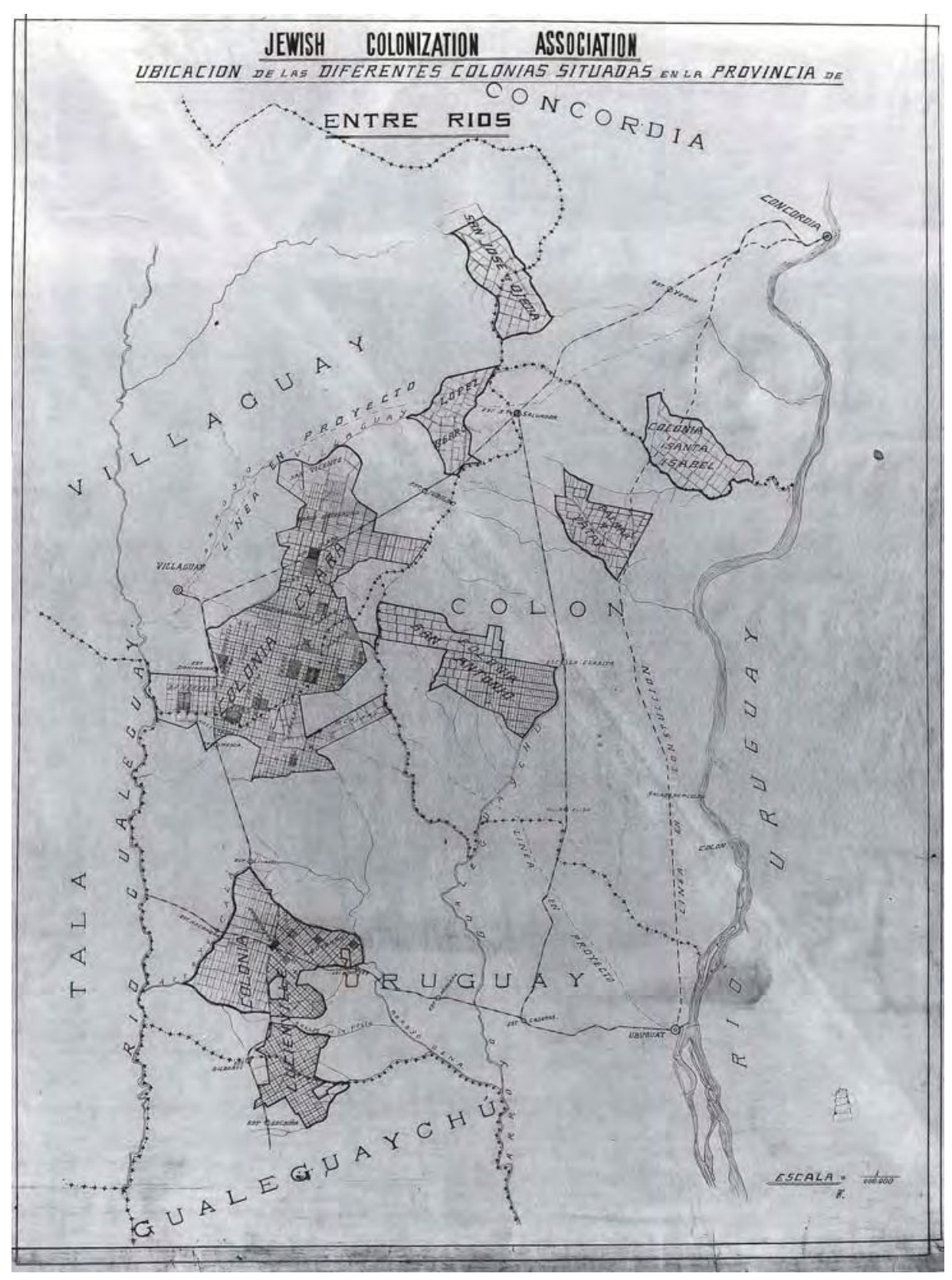




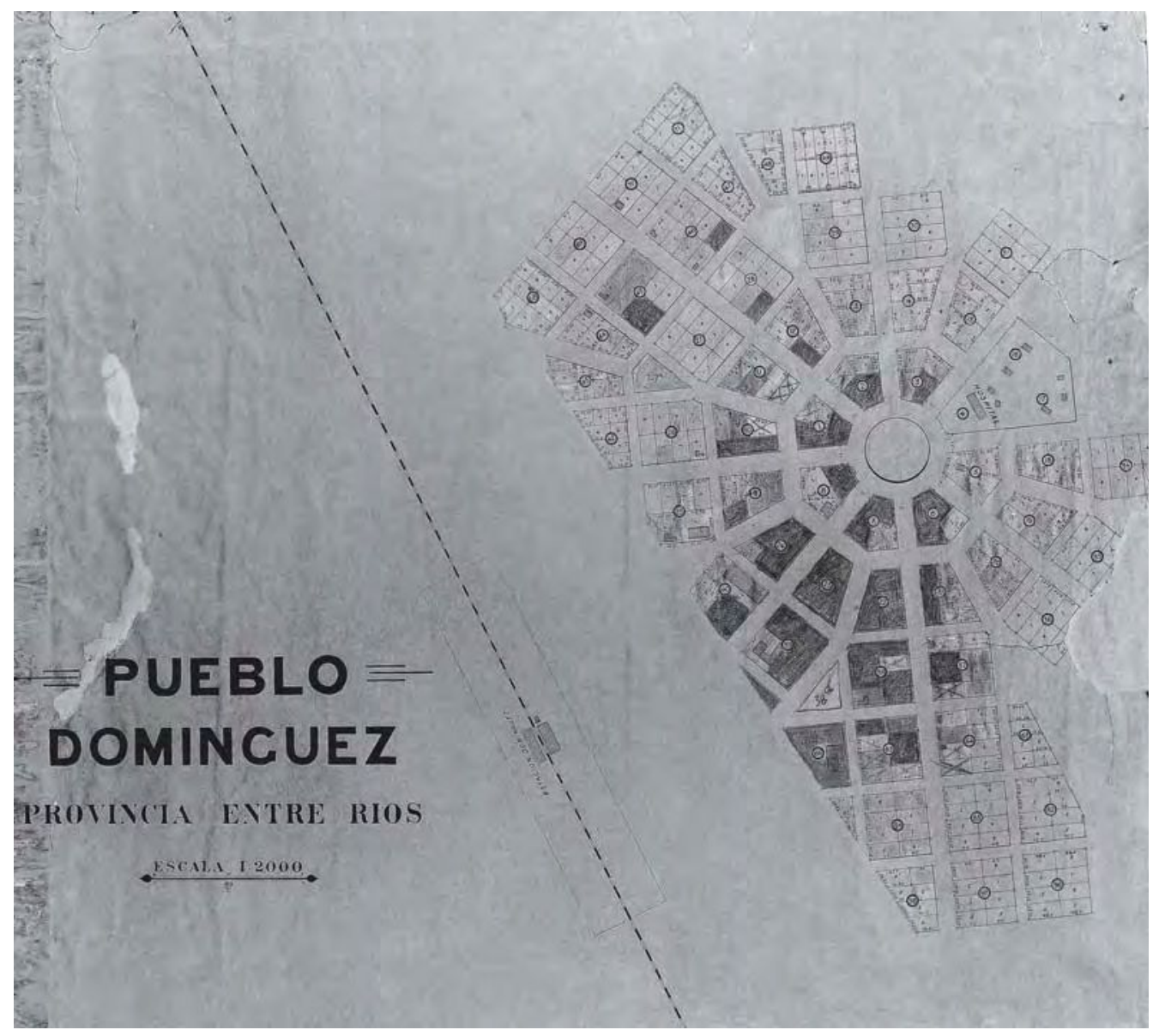

Historia y memoria de la colonización Judía agraria en Entre Ríos. La experiencia de Colonia Clara, 1890-1950 | 151 


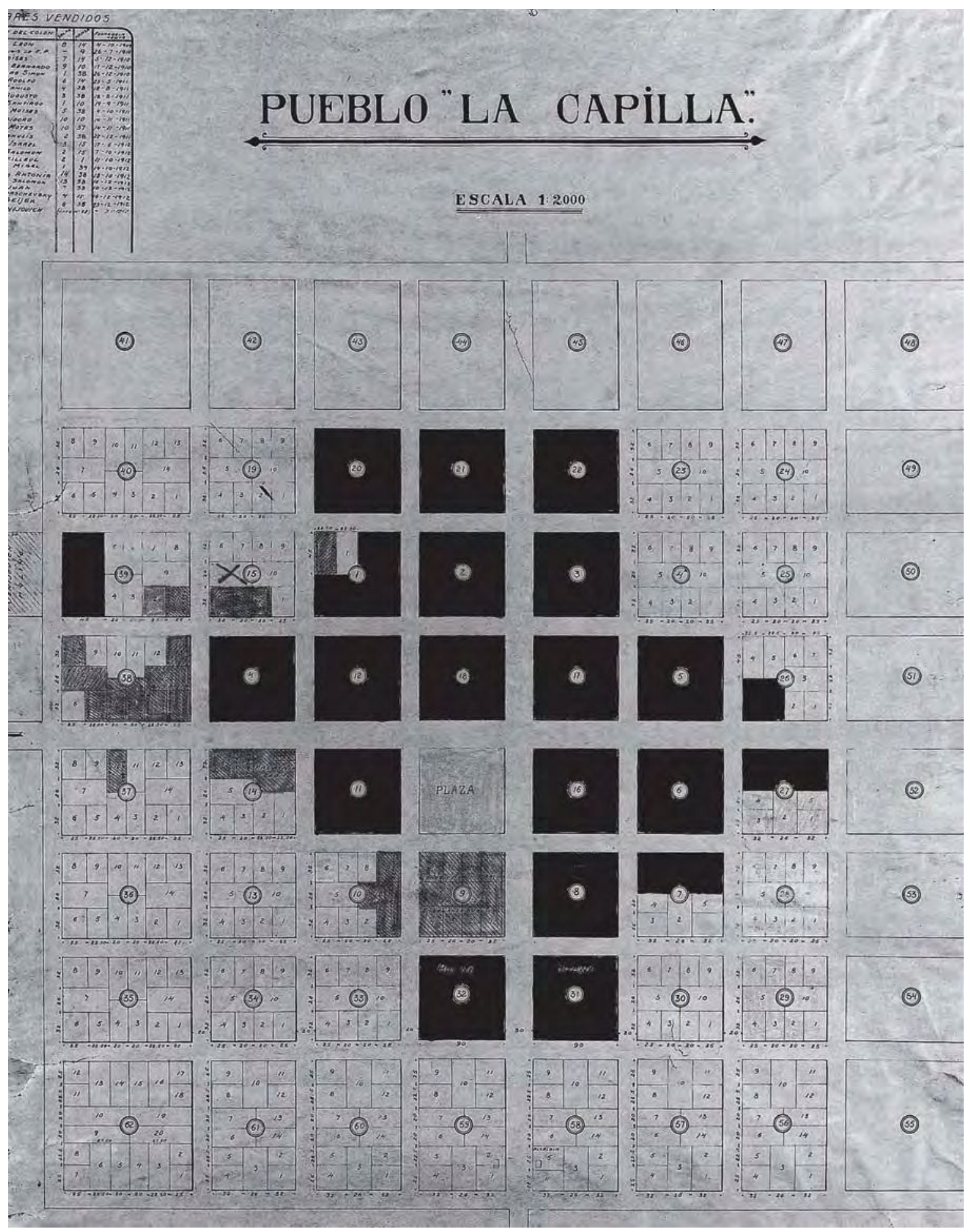




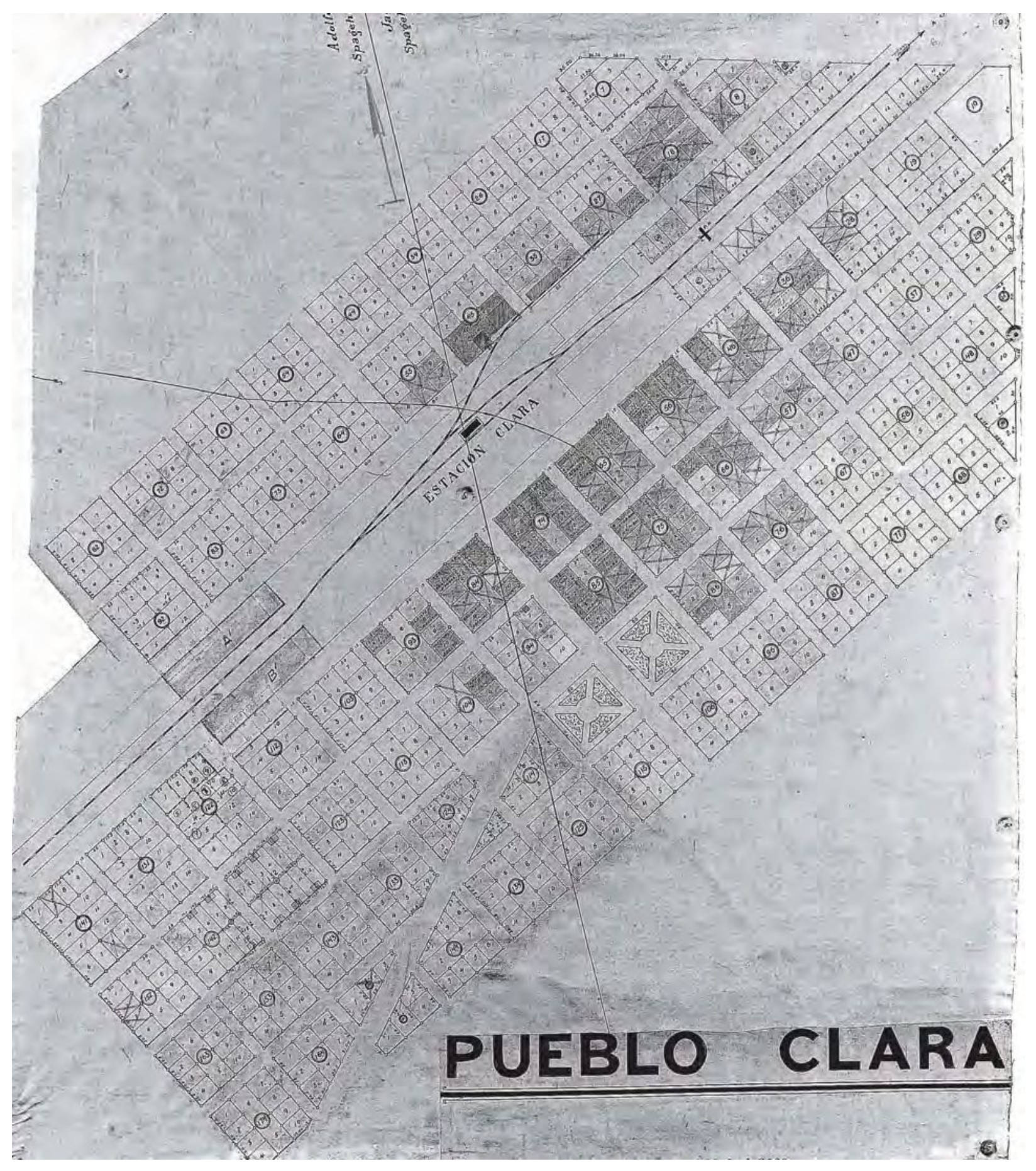

Historia y memoria de la colonización Judía Agraria en Entre Ríos. La experiencia de Colonia Clara, 1890-1950 | 153 



\section{capítulo cuatro}





\section{La vida religiosa en Colonia Clara}

Los pobladores de Colonia Clara no fueron un grupo homogéneo. Provenían de distintos lugares o aldeas de la Europa Oriental. La mayoría eran rusos de Besarabia, Podolia, Wolhyna, GrodnoMinsk, Kiev; otros eran

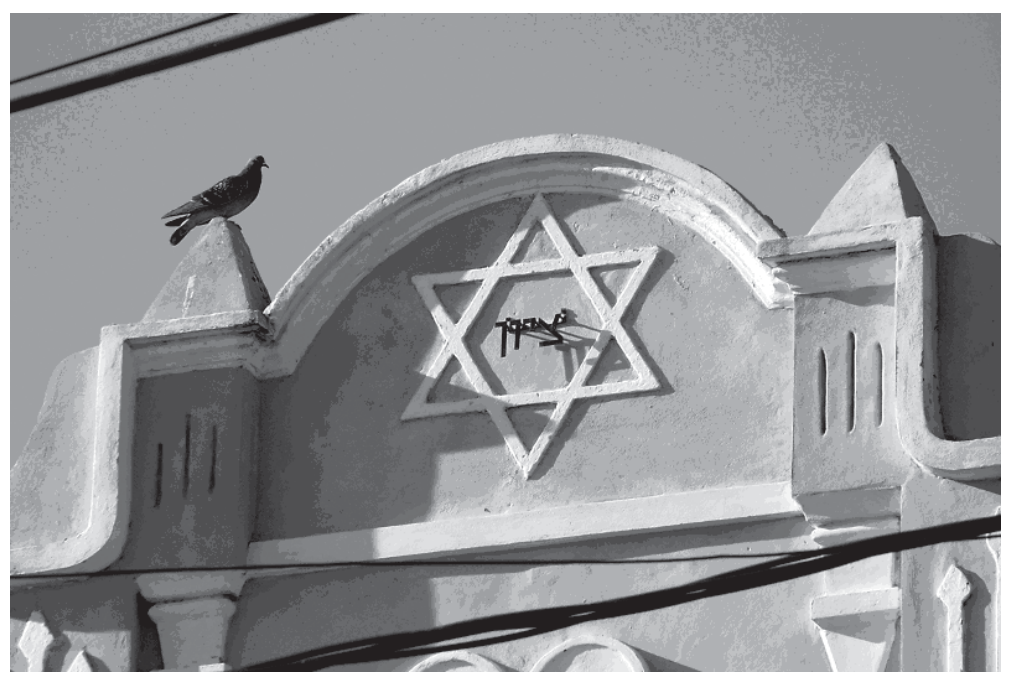
nativos de Rumania, Austria Hungría, Turquía, Ucrania, Lituania, Polonia.

«Il faut remarquer aussi que la population des colons dans l'Entre-Ríos n'est pas homogène comme dans les autres colonies. Une partie d'entre eux a éte envoyée en Argentine lors du deuxième exodo des juifs de Russie; ils on été choisis dans l'agglomération d'émigrés qui s'était formée à Constantinople», señalaba el informe elaborado en 1898 por la Administración de la JCA. ${ }^{1}$ Esta descripción no es

\footnotetext{
${ }^{1}$ Rapport de L’Administration Centrale pour 1898, Archivo JCA, Fundación IWO.
} 
menor ni ociosa, ya que la vida religiosa judía estará siempre impregnada por las diversas experiencias históricas y sociales de distintos grupos judíos.

El judaísmo es la más antigua de las religiones monoteístas de difusión universal, pero entenderlo como fenómeno estrictamente religioso es insuficiente, pues, además de lo teológico y de lo ritual, se manifiesta en determinados comportamientos tanto individuales como sociales y culturales.

Es esencial en la fe judía la creencia en un solo Dios creador, cuya unidad es indivisible; inmaterial, y por ello irrepresentable; eterno, y por ello inmortal; infinito, y por ello inabarcable por la mente humana. Los hombres están dotados de libertad para elegir entre el bien y el mal y reciben el premio o castigo que merecen por su elección. El Dios del judaísmo se manifiesta en el mundo y en la historia: en el mundo, al regirlo con su providencia mediante la renovación continua de su obra de creación; y en la historia, al haber elegido a Israel como su pueblo para servirle y dar testimonio de él en la Tierra, elección que se sella con un pacto (berit) por el cual Israel recibe la Torá y acepta la responsabilidad de cumplirla.

La fuente de la doctrina judía es la revelación divina contenida en la Torá (ley, enseñanza), nombre hebreo del Pentateuco, que por extensión se refiere a todo el contenido del judaísmo: las Escrituras, su tradición oral y la interpretación inspirada de las mismas (Misná, Talmud, Midrás, comentarios bíblicos, etcétera). La Torá es también guía y norma de vida. El estudio y la erudición en la ley no alcanzan su objetivo si no van acompañados por la práctica, que, lejos de limitarse a lo litúrgico o cultural, halla su expresión en la totalidad de la vida de un judío. Los 613 preceptos (misvot) del judaísmo, tanto los positivos o mandatos como los negativos o prohibiciones, se refieren a los deberes del hombre para con Dios, para con el prójimo y para consigo mismo, y rigen la totalidad de la vida de un judío. El judaísmo tiene, además, unas muy complejas leyes de pureza alimentaria (kaserut). El rabino ( $r a b, r a b i ̂)$ es el experto conocedor de la Torá, que además ha obtenido la titulación para ejercer como tal. Su función consiste en ordenar el culto, velar por el cumplimiento de los preceptos y enseñar, interpretar, aplicar y siempre estudiar la Torá. Puede ocupar el cargo de dirigente espiritual de una sinagoga, de una comunidad o de un conjunto de ellas; pero con independencia del cargo que ejerza, su autoridad vendrá determinada no por razones de jerarquía centralizada, 
sino por el prestigio que le dé su saber y el reconocimiento de este en el seno de la sociedad judía.

El cumplimiento de los preceptos no está limitado a un lugar específico. Los rabinos subrayaron la santidad de la casa: la mesa se convirtió en el altar y el padre en el sacerdote que daba gracias a Dios en las celebraciones.

El nivel de cumplimiento de los preceptos, variable en las diversas corrientes del judaísmo tradicional, es máximo entre los judíos ortodoxos, quienes rigen toda su vida conforme a la Halajá. ${ }^{2}$ Por su parte, las diversas corrientes del judaísmo reformado prestan a otros valores religiosos una atención mayor que al puntual cumplimiento de los preceptos. ${ }^{3}$

El lugar habitual de culto es la sinagoga, palabra de origen griego que significa "reunión" o "lugar de reunión", y traduce exactamente el término hebreo bethakenéset. El servicio religioso, fijado en el Talmud, se ha mantenido sin cambios básicos a lo largo de sus 2.500 años de historia, y sólo con el paso del tiempo ha sufrido algunas ampliaciones que varían de unas comunidades a otras. Las oraciones, de alabanza y súplica a Dios, son todas en hebreo con algunos fragmentos en arameo.

Durante el rezo, los varones se cubren la cabeza con cualquier sombrero o cubrecabezas, o específicamente con un solideo (quipá), y se recubren con el taled (talit) o manto de oración de forma rectangular, hecho habitualmente de lana, blanco y con franjas azules o negras, que se pone encima de la ropa; de sus cuatro ángulos penden unos flecos blancos o sisit (plural: sisiyot).

\section{Las festividades}

Las festividades del judaísmo tienen una doble significación religiosa e histórica. Algunas conservan, además, la memoria de la primitiva organización agrícola

\footnotetext{
2 El nombre Halajá deriva de la palabra hebrea halaj (äîê), que quiere decir "ir en la vía correcta”. Es la recopilación de las principales leyes judías, que incluyen los 613 mitzvot, y posteriormente las leyes talmúdicas y rabínicas, así como sus tradiciones y costumbres.

${ }^{3}$ Romero, Elena, "La Religión Judía", en La espiral, Espacio para el Pensamiento y las Culturas del Valle del Ebro. Disponible en http://www.laespiral.es/.
} 
propia de la sociedad en que nacieron. Entre ellas se destacan: el shabat («sábado"), que recuerda cada semana el reposo divino en el séptimo día, es dentro del calendario festivo la más importante institución del judaísmo; el año litúrgico se abre con los llamados Días solemnes, dedicados al arrepentimiento y a la penitencia (tesubá), que se inician con Ros hasaná ("Año nuevo", en septiembre-octubre), cuya celebración dura dos días; el Yom kipur ("Día del perdón o de la expiación") es el más solemne del calendario judío y con él culminan los diez días de penitencia iniciados con el Año nuevo. Otras fiestas religiosas son la fiesta de Pésah ("Pascua", en marzo-abril), que dura siete días (ocho en la diáspora); siete semanas después del inicio de la Pascua se celebra la fiesta de Sabuot ("Pentecostés", en mayo-junio), que dura dos días; la fiesta Sukot o de las Cabañuelas (octubre), en el tiempo de la cosecha, dura siete días; a continuación se celebra el día de Simhat Torá ("Alegría de la ley"), en el que concluye el ciclo anual de la lectura pública del Pentateuco y se inicia el nuevo. Son fiestas menores: la de Hanuká ("Luminarias o Consagración", en diciembre); la de Tu-bisbat ("15 del mes de sebat", en febrero); la fiesta de Ester o de Purim ("Suertes", en febrero-marzo).

Sus ritos de tránsito o ceremonias preceptivas del ciclo vital se inician con la circuncisión (berit milá) del varón judío al octavo día de su nacimiento. A los trece años este llega a su mayoría de edad religiosa, es decir, se convierte en Bar Mitzvah

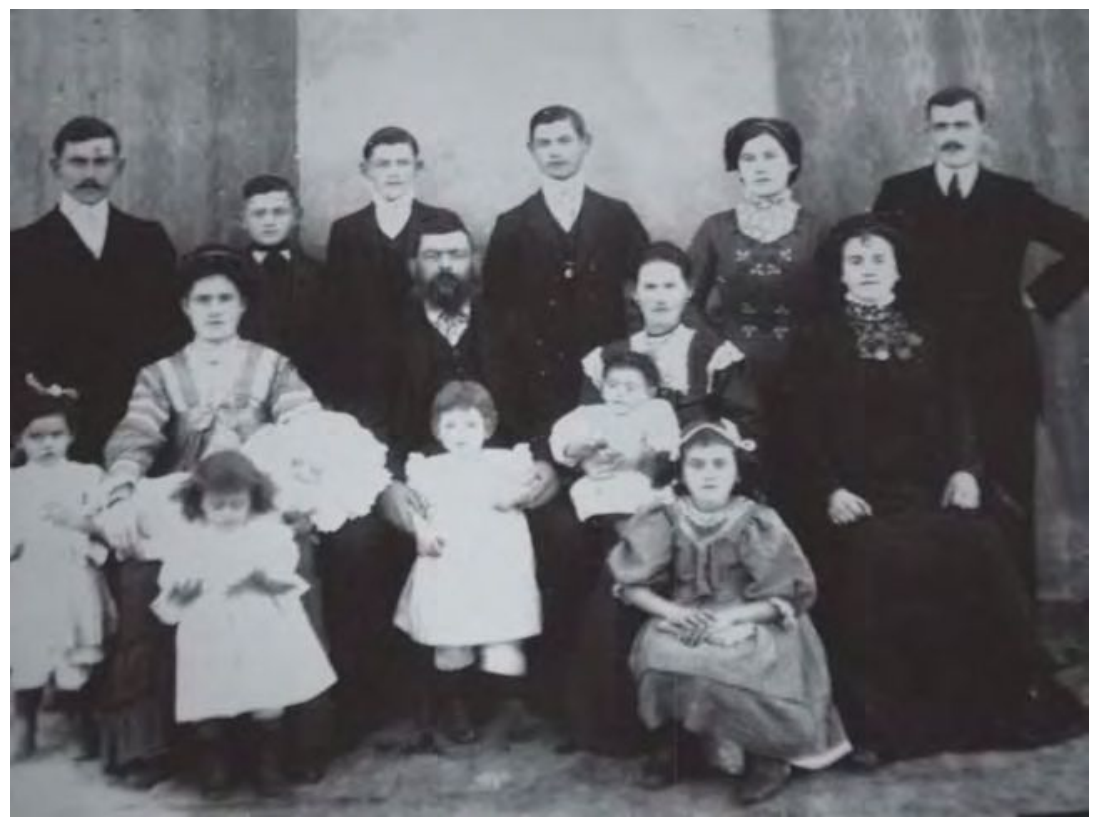

Berit milá de David Kosoy 
("sujeto a los preceptos"), siendo a partir de entonces responsable de sus acciones. La ceremonia del matrimonio ${ }^{4}$ consta de dos etapas consecutivas, la consagración (quidusín) y las nupcias (nisuín). Y culmina con los ritos fúnebres (velorio, entierro, inauguración de la lápida, conmemoraciones anuales) y en particular con el kadish de duelo, que es la oración pronunciada por los hijos. ${ }^{5}$

Las entradas para llegar a conocer algunas características más destacadas del pueblo judío son múltiples, pero una altamente significativa es la de asomarse a sus tradiciones, expresadas de un modo unívoco en sus ceremonias, en sus ritos, en sus días festivos y luctuosos. Veamos.

Una característica preponderante de la comunidad judía asentada en Colonia Clara fue su sentido libertario, que no sólo estaba incluido en la tradición y en las costumbres, sino también en la religión.

Como sabemos, cuando un grupo de creyentes que se reúnen a orar -lo que constituye un minián, ${ }^{6}$ el mínimo quórum de diez personas necesario para hacerlo en conjunto-, no implica que el ritual se siga de la misma manera ni a coro: cada uno habla con Dios a su manera y a su velocidad, de modo que es común que unos terminen antes que otros en el recitado de los textos sagrados en cada ocasión. ${ }^{7}$

Un dato significativo en la construcción de la identidad comunitaria en la Colonia Clara fue que un porcentaje muy alto de los colonos fueron de base laica o, por

\footnotetext{
${ }^{4}$ Ricardo Feiertein narra detalladamente los ritos en torno al matrimonio. El compromiso matrimonial se llama erusin y se realiza suscribiendo un documento denominado tenaim ("condiciones"). La ceremonia se realiza bajo la jupá (palio nupcial). En la jupá se rompe una copa (por lo común, envuelta en una servilleta y colocada bajo el pie del novio, que la destroza de un golpe) para recordar la destrucción de Jerusalén y el hecho que aun en los momento de mayor felicidad no hay que olvidar el destino del pueblo y su historia. Firman los contrayentes la ketubá (contrato matrimonial), que es el comprobante del matrimonio de acuerdo con la tradición judía. Desde muchos siglos atrás está contemplado el divorcio (que en hebreo se denomina gerushin), y es el varón el que otorga el divorcio y no a la inversa. En Feiertein, Ricardo, Vida cotidiana de los judíos argentinos. Del gueto al country, Buenos Aires, Sudamericana, 2007, p. 121.

${ }^{5}$ Durante el entierro se produce la keirá (desgarro de la prenda o vestido superior de los deudos), costumbre antigua que simboliza el desagarro del alma por el que se va, y, luego del servicio religioso de despedida, el cuerpo es trasladado a su fosa y descendido tras un breve responso, donde el oficiante se disculpa por participar del rito sin ser conocido del difunto, exhorta a los presentes a hacer las paces, explica brevemente el sentido de la muerte en el judaísmo, reza por el eterno descanso y se despide con el kadish. Ibídem, p. 125.

${ }^{6}$ Esa necesidad de reunir un mínimo de personas para conformar un quórum que puede rezar tiene raíces históricas: desalienta la dispersión individua y reestablece una suerte de solidaridad implícita en las tradiciones sociales judías, ya que la congregación representa a la casa de Israel.

${ }^{7}$ Feierstein, Ricardo, Vida cotidiana de los judíos argentinos, op. cit., p. 92.
} 
lo menos, no observantes religiosos ortodoxos. Ello respondía a razones políticas, de las que estuvieron imbuidos desde su emergencia en la Europa de fines del siglo xIx y en los primeros años del siglo xx -clima en el que participaban activamente, como lo demuestra la correspondencia e intercambios epistolares que consultamos para este estudio-, ya que muchos de ellos tenían ideas anarquistas o socialistas, o una tendencia bien marcada hacia los partidos que propugnaban un cambio social y una mejor distribución de la riqueza entre las clases sociales. Los efectos de las propuestas filosóficas del lluminismo judío (Haskalá) llevaron a grandes transformaciones en sus modos de vida religiosa, adoptando una actitud liberal en la educación, la cultura, la filosofía y la teología que caló hondo en el pueblo. La haskalá también dio lugar a un renacimiento de la identidad secular judía, con un énfasis en la historia y la tradición judía. El resultado fue el surgimiento del compromiso con la vida política de los países en los cuales residían. Esto se expresó de múltiples maneras, incluyendo la lucha por la emancipación y el nacimiento de nuevos movimientos políticos judíos, y, en última instancia, el desarrollo del sionismo frente a las persecuciones a fines del siglo xIx. En gran medida, pavimentó el camino hacia la modernización, aunque indudablemente sirvió como estímulo para la aculturización y asimilación, en particular para los de Europa Central. A la vez, abrió canales para dar pie a corrientes renovadoras dentro del judaísmo y de manera singular en la Europa del Este. Los pogroms contribuían a reforzar el aislamiento de los judíos de Rusia y levantaban la barrera contra la asimilación en el medio circundante. El desarrollo capitalista y la apertura a Occidente del imperio zarista habían derribado los muros del gueto, pero, al mismo tiempo, el ascenso del antisemitismo perpetuaba la separación entre judíos, rusos y polacos. El estallido del mundo hebreo tradicional no desembocó en asimilación, sino, más bien, en el nacimiento de una nación judía de tipo moderno. Muy bien explica Traverso que la yiddishkeit era el marco natural en el que la comunidad judía podía apropiarse de ideas nuevas: la democracia, el socialismo, el nacionalismo, etcétera. Este autor sintetiza la situación de los israelitas del Este europeo en los siguientes términos: una estructura social formada esencialmente por un proletariado de origen artesanal y una pequeña burguesía empobrecida, un proceso de asimilación muy débil o inexistente, la conservación del idish en tanto lengua nacional, un 
apego importante a la tradición religiosa y una identidad étnica influida por un contexto ampliamente impregnado de antisemitismo. ${ }^{8}$

\section{En Colonia Clara}

Un inspector enviado por el gobierno de la provincia de Entre Ríos en 1904 vuelca del siguiente modo sus impresiones de su visita a Colonia Clara:

El Israelita descansa el día Sábado (se pretende que muchos descansan casi todos los días del año). El sábado, las mujeres rezan en sus casas, los varones van a las sinagogas. Adonde no hay propiamente una sinagoga, se juntan en la Escuela de las localidades o en su defecto en una salita de una casa particular. El Sábado no se hace ningún trabajo: ni ordeñar, ni traer agua, ni cocinar, ni cuidar las haciendas dañinas, a menos que haya cristianos para ejecutar tales tareas. Observadores atentos opinan que "hay mucho fanatismo y poca religión. ${ }^{9}$

Si bien arribaron a la llanura entrerriana hombres pertenecientes a una línea fanática y ortodoxa, al mismo tiempo, muchos otros, aunque provenían de hogares muy ligados a la tradición y costumbres de fines del siglo xIx en los pueblos y aldeas de la Europa Oriental, profesaban una mayor liberalidad religiosa. Con mayor o menor profundidad habían recibido enseñanza religiosa en el jeder ${ }^{10}$ (escuela de hebreo), por lo que, más allá de sus ideas de avanzada, tenían una adecuada noción de aquello en lo que no creían.

\footnotetext{
${ }^{8}$ Traverso, Enzo, Los marxistas y la cuestión judía, La Plata, Ediciones Al Margen, 2003, p. 39.

${ }^{9}$ Ministerio de Gobierno de Entre Ríos, Resumen del Informe sobre las Colonias de la J.C.A. en Entre Ríos, Confeccionado por Eugenio Scheppens, 25 de junio de 1904. p. 5. Archivo WIO, Carpeta JCA.

${ }_{10}$ Adolfo Leibovich en sus memorias recuerda: "Chicanas burocráticas de todo orden me impidieron ingresar en alguna escuela primaria común rusa, así que mis primeras letras las aprendí en 'idisch', en un jeder (traducción literal del hebreo pieza o ambiente) ya era entonces una institución arcaica, semireligiosa, en la cual, desde la edad de cuatro años se enseñaba a rezar en hebrei ('Loschen Kodesch') a la vez que todos los ritos religiosos: la oración que se dice para honrar a los padres, para bendecir el vino o el pan en las horas de las comidas, cuando uno se levanta o se acuesta, cuando truena o aparece el arco iris después de la lluvia y otras menudencias por el estilo. Todo eso matizado con algunas nociones de escritura y lectura en idish, así como las primeras nociones de aritmética". Leibovich, Adolfo, Apuntes Íntimos. 1870-1946, Buenos Aires, imprenta López, 1947, p. 15.
} 


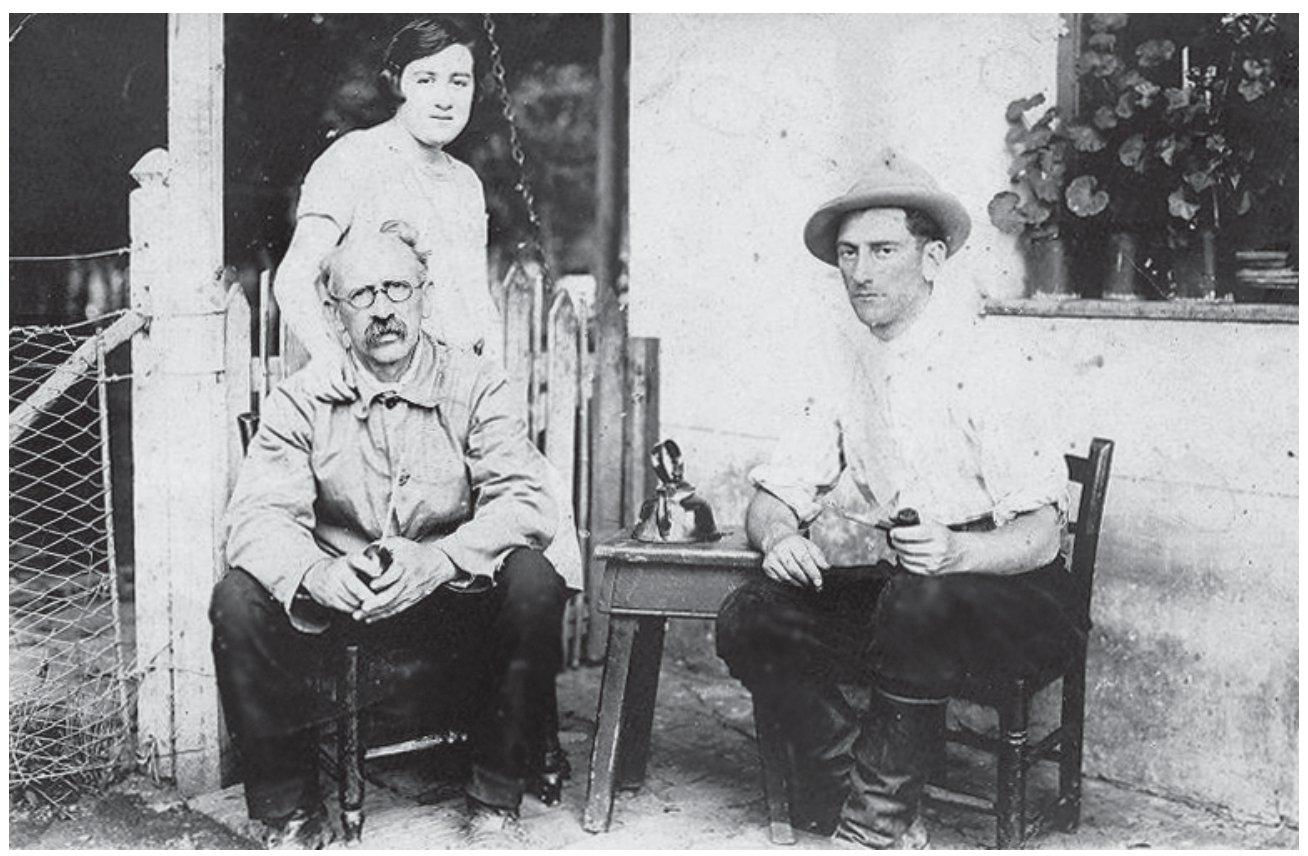

Vera, Miguel Sajaroff y visitante, Colonia Leven.

Un caso paradigmático fue don Miguel Sajaroff, quien no era religioso, no practicaba rituales de ninguna especie, pero no era antirreligioso. Jamás criticó o menoscabó a los creyentes de buena conducta y solía decir:

Si a mi casa viniera alguien que quisiera comer, pero deseara cumplir antes de la comida con algún precepto religioso, haré lo posible para suministrarle lo necesario, pidiéndolo entre el vecindario, para que pueda cumplir con su conciencia y comer tranquilo. ${ }^{11}$

Ahora bien, en una carta enviada a su amigo y colaborador entrañable en la construcción de las bases del cooperativismo en las colonias y que por esta misma razón se encontraba viviendo en Buenos Aires para afianzar la estrategia federativa de las mismas, le contaba "algo sobre la actualidad espiritual de Villa Domínguez" que es muy significativo sobre su concepción religiosa:

\footnotetext{
${ }^{11}$ Kaplan, Isaac, Anécdotas, cartas y discurso de Don Miguel Sajaroff, Buenos Aires, Circulo de Estudios Cooperativistas de Buenos Aires, 1965, p. 10.
} 
Hoy es pesaj. Excluyendo el Fondo Comunal, todos los comercios mercados, panaderías, billares, etc. judíos están abiertos, en plena función. Un cuadro que me insinúa a mí, tan lego en la materia, no tan sólo un crimen de lesa religiosidad, sino también de lesa espiritualidad, al despreciarse deliberadamente la sublime oportunidad de conmemorar la liberación del pueblo a que se pertenece. ${ }^{12}$

Estudios comparados sobre religión y tradición entre las colonias establecidas en la provincia de Entre Ríos describen las modalidades y las especificidades que adquiere Colonia Clara.

Celia López explica que en el tema religioso, casi naturalmente y de acuerdo con el orden de llegada, los judíos ortodoxos se nuclearon en colonia San Antonio y Lucienville, mientras que los librepensadores, mucho más numerosos, lo hicieron en Clara, reconocida en todos los estamentos comunitarios como el foco cultural del judaísmo argentino.

Desde un primer momento se estableció una marcada diferencia entre jóvenes y adultos [...] Los primeros se mostraron deseosos de integrarse y fueron dejando de lado, insensiblemente, las viejas tradiciones: concurrencia a la sinagoga - no encender el fuego los sábados - consumir alimentos tradicionales - casarse únicamente con miembros de su raza [...] Los segundos, si bien no se mostraron en general reacios ni adustos, conservaron durante mayor tiempo todo lo que significaba honrar el alma y el sentir judíos... ${ }^{13}$

Un ejemplo de estas transiciones y tramitaciones en el campo religioso lo narra Enrique Dickmann, al relatar el arribo de sus padres a la Colonia. Él había venido sólo con 14 años de edad en el trasatlántico Pampa. Trabajó arduamente en el lote asignado por la JCA e hizo todo lo necesario para traer a su familia completa que había quedado en Rusia. Les envió los pasajes y agrandó el rancho, transformándolo en una casa de tres habitaciones y una cocina. En abril de 1894 arribaron sus

\footnotetext{
${ }^{12}$ Kaplan, Isaac, op. cit., p. 46.

13 López, Celia G., "De la Rusia de los zares a la Mesopotamia Argentina", en http:// www.ariadnatucma.com.ar/view.php?id=12\&type=article.
} 
padres, Moisés y Josefa, y sus hermanos menores, Máximo, Alejandro y Adolfo, quienes se instalaron en la chacra en las cercanías de la estación de trenes Gobernador Domínguez. Debido a la ampliación familiar, la JCA le otorgó otras 25 hectáreas. Señala Dickmann que la adaptación de la familia a la nueva vida rural fue un tanto difícil y laboriosa. Si bien los hermanos se adaptaron rápidamente, a sus padres -cuyas costumbres y hábitos eran difíciles de cambiar, en especial por "su modo de ser religioso y fanático" - les demandó mayores esfuerzos.

Para cambiar radicalmente este aspecto de la vida familiar, procedió de manera enérgica y contundente. Sabía el significado profundo del culto de los días sábados - día que comienza el viernes con la puesta del sol y que termina el sábado al anochecer-, en el que no se puede realizar ningún trabajo, ni siquiera de orden doméstico. No se puede prender fuego, no se pueden cocinar los alimentos, no se puede andar a caballo ni en coche, no se puede caminar más de un kilómetro, no se puede llevar encima ningún objeto extraño a la ropa de uno. Entendía que el reposo bíblico se había convertido en un absurdo día de fanatismo antisocial, que su padre era un intransigente y que él estaba dispuesto a acabar con ello con toda la firmeza necesaria, y para ello obró de la siguiente manera:

El primer sábado de la llegada de mis padres a las colonias, me levanté muy temprano. Hice fuego en la cocina. Puse a hervir agua para el mate. Ensillé mi caballo. Ordené los trabajos del día en la chacra, etc. Papá se puso a rezar. Mamá a llorar. Pero mis hermanos obedecieron mis órdenes porque estaban de acuerdo conmigo. Mi proceder fue violento pero eficaz y produjo el resultado que yo buscaba: acabar con el fanatismo ancestral, producto de persecuciones religiosas y servidumbres raciales de los viejos países del Viejo Mundo y empezar una vida nueva y libre en el Nuevo Mundo, en la libre Argentina.

Pronto mi padre comprendió que la lucha era inútil e inconducente. El no abandonó sus prácticas religiosas, pero no trató de imponerlas a sus hijos, se resignó a todo lo que ellos hicieran y la convivencia familiar se restableció sobre nuevas bases éticas. ${ }^{14}$

\footnotetext{
${ }^{14}$ Dickmann, Enrique, op. cit., p. 43.
} 
Otras familias persistieron en su religiosidad ortodoxa. Entre muchos testimonios, podemos rescatar el que nos brinda Isaac Muchinik: ${ }^{15}$

Mi abuelo materno era muy religiosos y mi abuela ni qué decirlo. Ella no daba la mano a un desconocido ni a nadie, únicamente a un pariente porque la religión no le permite tener contacto. Cuando yo iba a pasar unos días a la casa de ellos, tenía que respetar todo: hacer la bendición antes de comer, bendecir el pan. Mis abuelos me daban un libro para rezar, yo lo hojeaba, por ahí lo dejaba, pero aprendí a rezar correctamente.

Los estudiosos de los textos tradicionales -religiosos judíos de formación sistemática-, sector fiel a la venerable tradición del amor a los libros, también llegaron a la Colonia. Muchos más son estos casos, sin embargo tan sólo elegiremos algunos de ellos.

ledidio Efron, más conocido como liedidie, nació en Amdur, provincia de Grodno, el 11 junio de 1878. A los 5 años comenzó sus estudios en el jeder y estudió Tanaj, Talmud, Rashi y otros comentarios e interpretaciones que a través de los años realizaron las grandes personalidades del judaísmo. En 1895 arribó a los campos entrerrianos con sus padres y hermanos, para asentarse como hijo de un agricultor en la aldea de Barón Hirsch. Aprendió rápidamente el idioma castellano y pronto adoptó muchas de las costumbres y tradiciones del gaucho argentino. En 1903 comenzó su carrera docente en las escuelas de la JCA en Entre Ríos, y en 1911 fundó la primera Yeshivá ${ }^{16}$ en Argentina, en la aldea Fainberg de Colonia Clara. Por su solvencia intelectual judaica y su dominio del idioma castellano fue designado director de una escuela de enseñanza castellano-hebreo. Luego se graduó como maestro nacional en la Escuela Alberdi de Paraná, y en 1914 fue designado inspector de los Cursos Religiosos Israelitas de la JCA para las zonas de Basavilbaso y

\footnotetext{
${ }^{15}$ Chiaramonte, S., Finvarb, E. y otros, Tierra de Promesas, 100 años de colonización judía en Entre Ríos, Buenos Aires, Nuestra Memoria, 1995, p. 97.

${ }^{16}$ Recordemos que una Yeshivá (en hebreo: éùéää, yeshivot en plural) es un centro de estudios de la Torá y del Talmud, generalmente dirigida a varones en el judaísmo ortodoxo. Cada yeshivá está dirigida generalmente por un Rav, Ilamado Rosh Yeshivá (literalmente, "cabeza de yeshivá"). En algunas puede haber más de un Rosh Yeshivá. A los instructores se les denomina Rebeim (en yidish) o bien Ramim (en hebreo). En la facultad de la mayoría de las yeshivot existe un mashguiaj rujaní o consejero espiritual que ayuda a los alumnos con problemas personales y un Meshiv dedicado a responder preguntas académicas.
} 
Moisés Ville, pasando luego a Buenos Aires para hacerse cargo de la Dirección de los mencionados Cursos.

Su prestigiosa fama de gran docente, no sólo por sus conocimientos y vasta cultura, sino además por su sabiduría y calidad humana, hizo que su nombre trascendiera en su época dentro del mundo judaico argentino. ${ }^{17}$

\section{Las sinagogas y cementerios}

Al poco tiempo del asentamiento de los primeros colonos y sorteadas las dificultades iniciales vinculadas al acceso a los lotes asignados y la construcción de sus viviendas, surgió la iniciativa de construir la sinagoga. Se resolvió ubicar el edificio en la parte central de la colonia, en medio de aquel campo antes colectivo, a fin de facilitar el acceso para todos.

La primera sinagoga fue levantada en 1893 en Sonnenfeld, siendo, junto con la casa

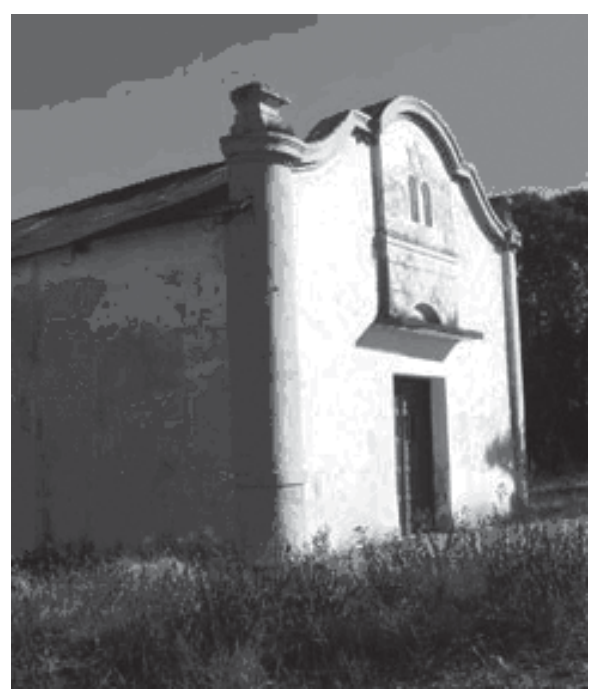

Sinagoga en Sonnenfeld del administrador de la colonia, una de las primeras construcciones firmes, de ladrillos, barro y techo a dos aguas. El templo era un gran salón con una pared divisoria que separaba el sector de los hombres

\footnotetext{
${ }^{17}$ Creador de la "Liga de Maestros de la J.C.A", fue nombrado inspector de los Cursos Religiosos de la JCA y hasta llegó a ser su director general en Buenos Aires, donde se radicó después la familia Efron. Se dedicó a la educación judía en la Argentina, Chile, Uruguay y Paraguay. La red escolar judía que organizó, orientó e inspeccionó fue única en la diáspora, valiéndole el nombre de "el Sarmiento de la cultura judía». Durante la Segunda Guerra Mundial, en 1943, fundó el Majón Lelimudei Haiahadut -Instituto Superior de Estudios Judaicos- para la formación de jóvenes maestros argentinos, que sería posteriormente el basamento de la Escuela Normal para Maestras de Religión y Hebreo («Mejona»). Su personalidad y el respeto que la colectividad argentina le profesaba dejarían una imborrable herencia en Taibele (como la nombraba su madre) o Paloma (como la llamaba su padre), luego conocida por el público argentino como Blackie, la brillante periodista tanto radial como televisiva que cantaba jazz maravillosamente, con una voz personal, distinta. En Horvath, Ricardo, Memoria y recuerdos de Blackie, Buenos Aires, Colección Todo es Historia, 1979.
} 

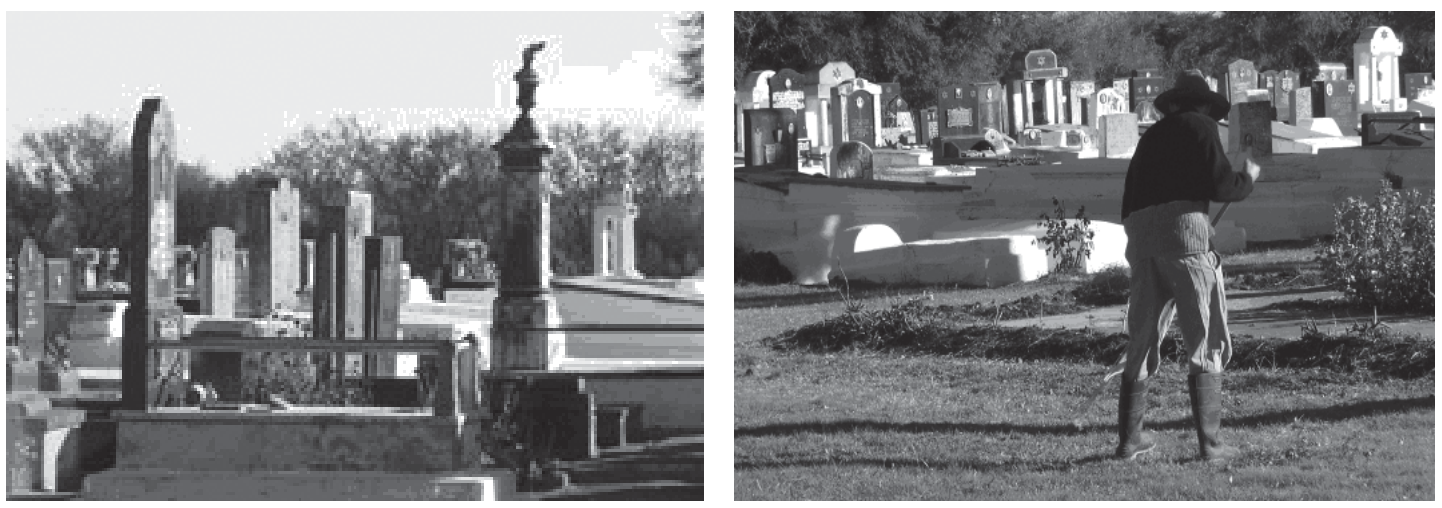

Cementerio San Gregorio, Sonnenfeld.

del de las mujeres. ${ }^{18}$ Fue la oportunidad de ubicar el Erón Hakodes y dos candelabros que fueron traídos de Rusia. En la entrada estaba el lavamanos y la fachada blanca con dos columnas a los costados que permitían que resaltara la Estrella de David centrada en la parte superior.

La edificación era de ladrillo y no de adobes, material entonces común en las construcciones. Fue un trabajo colectivo. Algunos trajeron ladrillos, cal y arena de Villaguay, otros hicieron las mezclas de tierra y arcilla y levantaron los muros en poco tiempo. Los colonos carpinteros construyeron los bancos, largos y con espaldera, y las mesas. El tabernáculo para guardar el Libro Sagrado, construido de madera fina, fue ubicado frente a la entrada principal, protegido por una hermosa cortina de terciopelo rojo que alguien encontró en sus baúles. Antes de llegar las fiestas de Fin de Año, la sinagoga quedó terminada y los colonos estallaron de alegría. La inauguración fue una fiesta que duró varios días y los cantos litúrgicos resonaron extraños y profundos en las cuchillas entrerrianas. Después vino el Día del Perdón y el templo ya estaba para celebrarlo como establecen las tradiciones. ${ }^{19}$

El cementerio de Sonnenfeld fue dolorosamente inaugurado con una tumba colectiva. El 1894 fue un trágico año en el que se desató una epidemia de tifus arrastrada por los inmigrantes del vapor Orione. Entre la cincuentena de víctimas

\footnotetext{
18 Esta división estuvo hasta que, hacia 1960, en razón de ser muy pocos los concurrentes, se decidió compartir el espacio. Poco tiempo después, las puertas del shil (templo) se cerraron y los objetos de valor se trasladaron al museo de Villa Domínguez (el Arón Hakodesh de 1902, los dos candelabros traídos de Rusia y el lavamanos que se hallaba en la entrada), quedando el interior sin objetos. En diciembre de 2000 se reciclaron la fachada y la estructura, volviendo a lucir blanqueada, con columnas renovadas y la estrella de David al frente.

19 Liebermann, José, op. cit., p. 176.
} 
allí enterradas estaba Isabel, la hija recién nacida del doctor Yarcho, que había convertido en sala de hospital su propia casa. Un extenso texto en hebreo, impreso sobre esta tumba comunitaria, deja constancia de la desgracia. En este cementerio están enterrados los hombres que forjaron colonia Clara: el Dr. Noé Yarcho, el médico milagroso; Miguel Sajaroff y Miguel Kipen, líderes del cooperativismo; León Sidi, destacado funcionario administrativo de la JCA; Benito Bendersky, el literato de las colonias judías, son algunos de ellos.

Para la instalación del cementerio alguien debía ceder el terreno, y en esta ocasión recayó en Aarón Yankilevich, que tenía uno de los terrenos más altos. La primera tumba individual fue la de un primo de Yugospky padre, que llegó enfermo de Rusia con bronconeumonía y que, a pesar de los esfuerzos del Dr. Yarcho, muere. Como estaba solo, los mozos del lugar se turnaron para hacerle compañía

porque eran medio cabalistas. Esto es extraordinario [...] Eran muchachos jóvenes y tenían miedo de dormir con un muerto, por eso se turnaban de a dos por noche. Dormían en la piecita en la que se hace el baño al muerto. ${ }^{20}$

\section{Sinagoga de Colonia Carmel}

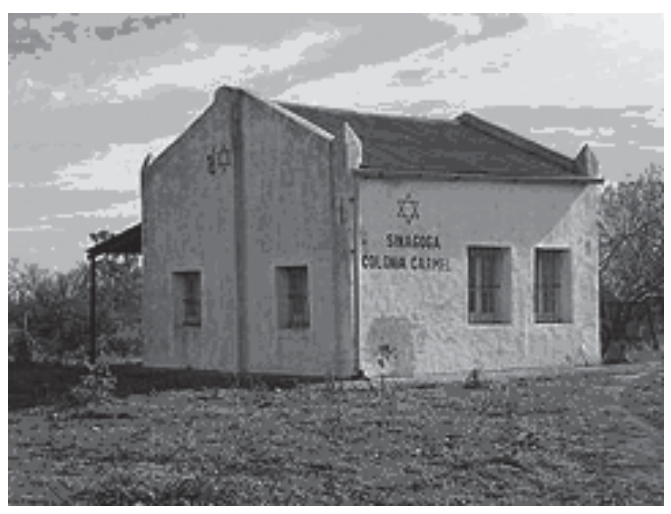

Sinagoga de Carmel.

Carmel era una calle llana de 2 kilómetros de longitud trazada de dirección Norte-Sur, polvorienta en verano y frecuentemente convertida en un largo lodazal

\footnotetext{
${ }^{20}$ Yaguspky, en entrevista realizada por Daniel Bargman el $1^{\circ}$ de diciembre de 1988. En Archivo Oral de
} AMIA, carpeta 68, p. 7. 

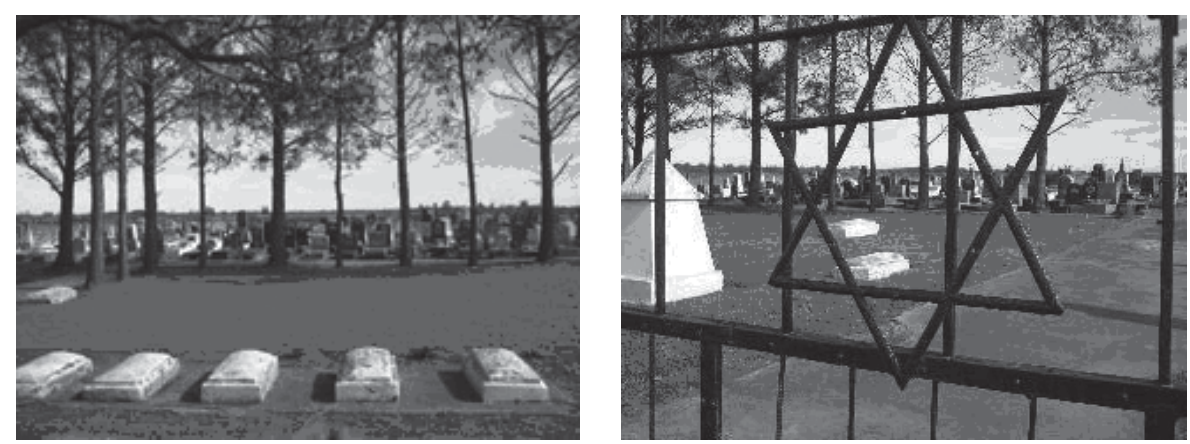

Cementerio de Carmel

en el transcurso del invierno. A ambos lados, regularmente distribuidas, una treintena de modestas viviendas, de ladrillos sin revocar unas y de adobes otras, habitadas por familias de agricultores que hablaban un idioma extraño y tenían hábitos y creencias desconocidas para los hijos del país, que en escaso número vivían en la zona. Así describe Seidel Zeigner ${ }^{21}$ su aldea.

En el punto medio se levantaba la sinagoga. Hasta el año 1900, cuando se construyó el templo, los encuentros religiosos de los colonos de Carmel se realizaban en casas particulares. Pero años después, en los mejores tiempos de la colonia, más de cien familias llegaban a juntarse en esta sinagoga, a la que también se acercaban habitantes de Jurado y de Rajil. Solían venir a pie, porque para el shabat no podían andar a caballo. La construcción contaba con dos ambientes, un cuarto grande para los hombres y otro chico para las mujeres.

Estoy orgullosa... porque yo ayudé a acarrear los ladrillos para la sinagoga y trabajé para construirla, recé las oraciones del sábado y acompañé las procesiones religiosas en los largos caminos de la colonia, cuando los abuelos marchaban adelante, bailando con el Libro Sagrado en sus brazos. ${ }^{22}$

En Carmel también había un enorme galpón de chapa de hierro galvanizado destinado al almacenamiento de los productos de la cosecha y el edificio escolar. Un bosque de espinillo y atrás el cementerio.

\footnotetext{
${ }^{21}$ Zeigner, Seidel, Carmel. La Hija del Coronel. Recuerdos de Infancia, mimeo, 1975, p. 4.

22 Cuenta una mujer que vino en el vapor Pampa, que fue colonizada en Colonia Carmel, alojada en el Asilo de Ancianos de Burzaco. Citado por Liebermann, José, op. cit.
} 
En el terreno donado por Moisés Jaimovich se ubicó el cementerio, fundado en 1898. Todas sus tumbas están orientadas hacia el Este, en dirección a Jerusalén. En el sector derecho están las de los varones y en la parte izquierda las de las mujeres. Muy cerca de la puerta de ingreso está la tumba de un bebé, uno de los primeros inhumados: Mauricio Mizrahi, nacido en 1899 y fallecido en 1900. La lápida es una especie de obelisco pequeño de color blanco.

En el sector derecho del actual cementerio se encuentran las tumbas de los primeros pobladores de las colonias, lápidas sencillas, despojadas. Lugar de memoria y de conmemoración.

No pasa desapercibido entre los monumentos un pequeño banco de piedra frente a la tumba de Julio Schatzky que nadie nunca se atrevió a sacar. Un tiro volvió imposible un amor verdadero: fue asesinado en 1940, a los 25 años, por el prometido de una maestra de la que se enamoró. Los vecinos recuerdan a la joven maestra sentada durante largas horas en ese banco, mirando como si entablara un diálogo eterno con el joven que le devolvía la mirada con una sonrisa en color sepia. ${ }^{23}$

\section{En los pueblos}

\section{Sinagoga de La Capilla}

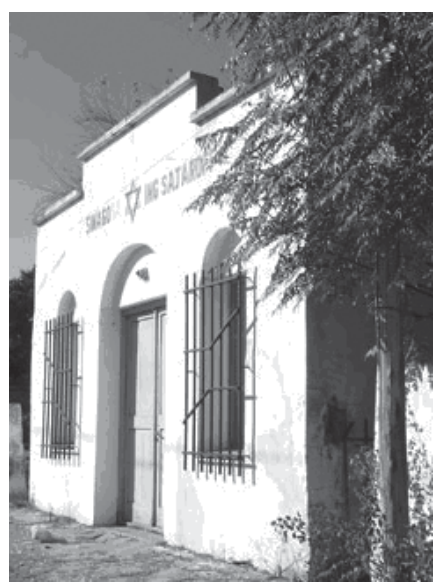

La primera sinagoga fue construida en los albores del siglo pasado. Constaba de una sola habitación dividida por una cortina para separar hombres de mujeres. Una vez por semana funcionaba una escuela hebrea a la que concurrían los niños del lugar. En la década del cincuenta fue demolida debido al estado de precariedad de su construcción, conservándose en la actualidad el Arón Hakodesh y la Bimá ("púlpito») originales.

Sinagoga de La Capilla

\footnotetext{
${ }^{23}$ Shalom Argentina: huellas de la colonización judía, Buenos Aires, Ministerio de Turismo, Cultura y Deporte,
} 2001, p. 276. 


\section{Pueblo Domínguez}

Esta localidad fue fundada en 1890, cuando se habilitó la estación del ferrocarril que llevaba el nombre de «Gobernador Domínguez". A partir de 1908, numerosas familias se instalaron en el pueblo Domínguez, en su gran mayoría ex colonos. La necesidad religiosa fue cubierta con la construcción de la sinagoga sostenida por la Asociación "Kneset Israel», que funcionaba también como escuela hebrea. El templo original se levantó en 1923 y, en sus tiempos de esplendor, cada viernes a la noche recibía a

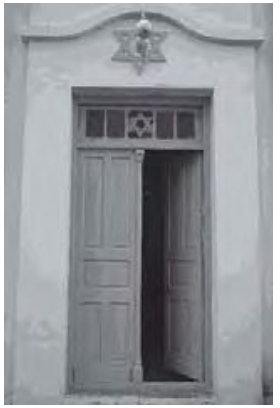

Sinagoga en Villa Domínguez más de 120 personas para celebrar el Kabalat Shabat (Bienvenida del Sábado).

La puerta de acceso al templo es de madera pintada en colores claros, conservando en la parte superior una Estrella de David y parte de un viejo vitreaux de colores violeta, turquesa y blanco. Cuenta con ocho amplias ventanas que permiten la iluminación natural. En su interior se conserva el techo original de madera de pinotea, pintado de un suave color lila. Los bancos de madera fueron hechos en la carpintería de la Cooperativa Agrícola de Villa Domínguez. La Bimá original conserva dos escalones de mármol y un pequeño balcón de hierro dorado. ${ }^{24}$

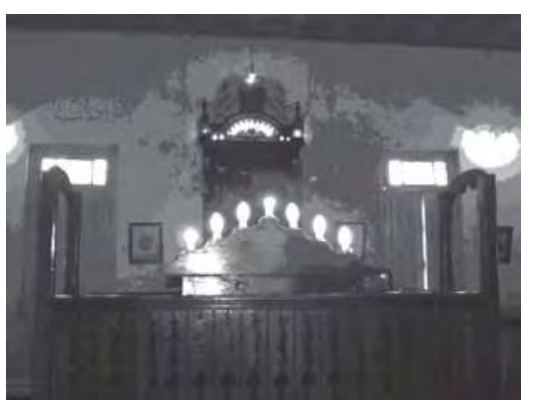

Sinagoga en Villa Domínguez, interior. una de esas historias que recordamos con precisión se refería a la construcción de la sinagoga, que siempre ha ocupado un lugar privilegiado en la vida de la colonia. Para su construcción se levantaron los hornos de ladrillos junto al arroyo; el lugar elegido fue la unión de la mitad de los patios de dos vecinos, la de mis padres y la del vecino cercano, señor Jacobo Lebenson. Ambos fueron los albañiles que seguramente contaban con la asesoría de algún criollo servicial. El templo tenía dos ambientes: uno destinado al sector masculino y el otro para las mujeres. La pared medianera tenía pequeños ventanucos para facilitar la llegada

\footnotetext{
${ }^{24}$ La Sinagoga, reciclada en 1999, posee paredes de ladrillo asentadas sobre barro. Están pintadas de color crema y el techo, a dos aguas, sorprende con un rojo brillante.
} 
de la voz del jazán (cantor sinagogal) hacia todos los concurrentes. El jazán procedía de los habitantes de la colonia que poseían buenos conocimientos y una discreta voz...25

\section{Villa Clara}

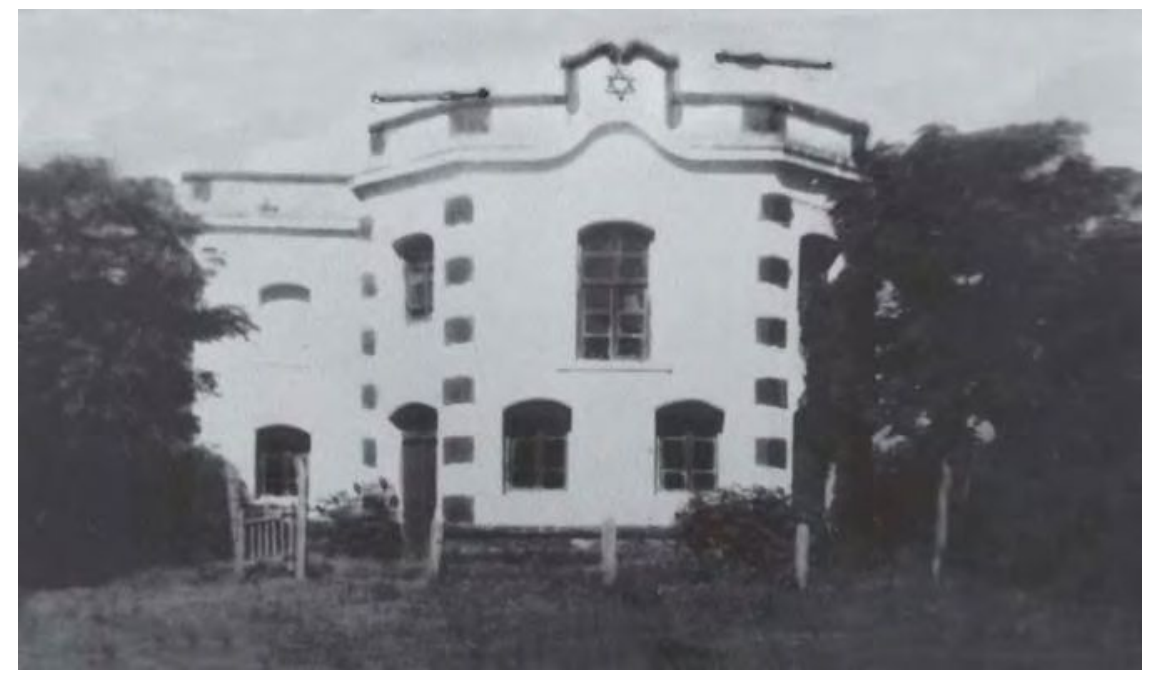

La estación de trenes de Villa Clara se inauguró en 1902 y en sus alrededores ya se había instalado un numero no preciso de colonos: algunos señalan cincuenta, otros que eran setenta las familias pioneras.

En los primeros años de vida del poblado, en la aldea Belez los artesanos y pequeños comerciantes construyeron una pequeña sinagoga (denominada "de los Artesanos") que también fue Casa de Estudios Talmúdicos y posteriormente se destinó exclusivamente para el funcionamiento de la escuela hebrea.

Luego se construyó la segunda sinagoga, entre los años 1911 y 1917, la Sinagoga Beith lacob. La fachada sorprende por sus ladrillos a la vista, combinados con una entrada de colores claros y un interior con colores brillantes. Luces tenues y claras alumbran el Arón Hakodesh ubicado sobre una pequeña tarima. En su interior hay tres Torot (plural de Torá) traídas por los primeros inmigrantes de Rusia y Polonia.

\footnotetext{
${ }^{25}$ Naúm Erijimovich, "Algunas Experiencias de Pioneros. Colonización Judía", en MEKOROT, Periódico de la Asociación Israelita de Paraná, (AIP), Año III, Nº 36, Paraná, noviembre 1994, p. 18.
} 
El templo se distribuye en dos plantas. En la parte superior se ubicaban las mujeres, que permanecían separadas de los hombres durante los oficios religiosos. ${ }^{26}$

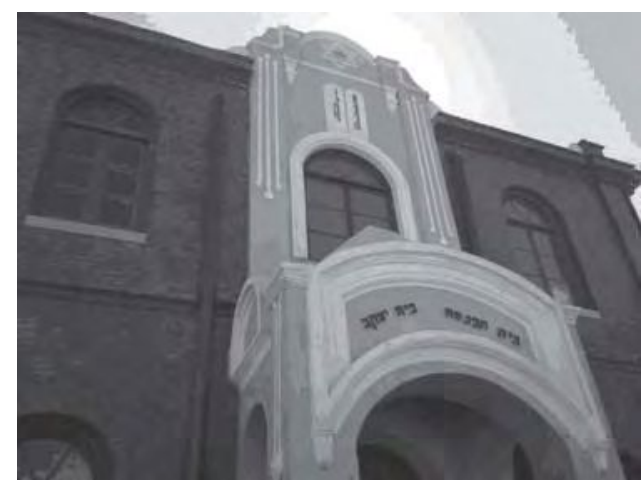

\section{Cementerio Israelita Clara-Bélez}

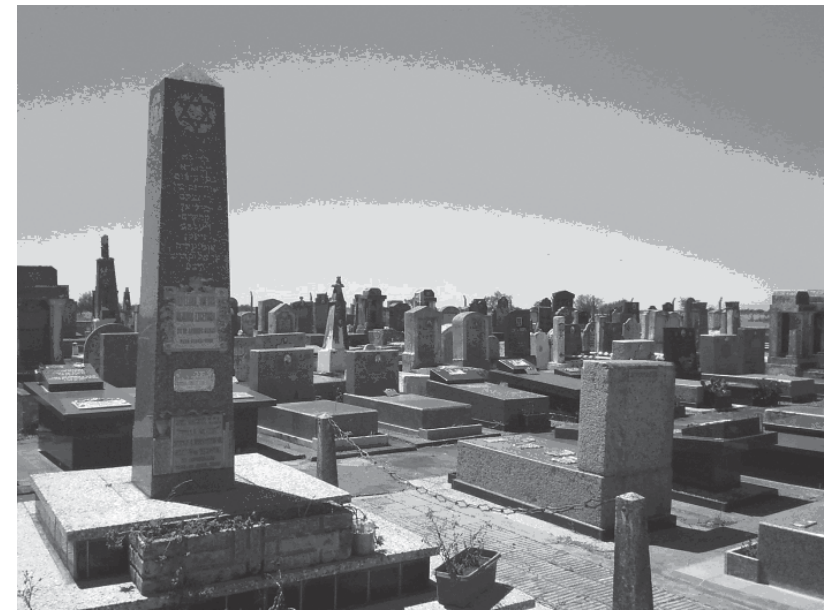

Como la JCA no había previsto un lugar para los entierros, el cementerio se ubicó en uno de los terrenos más bajos de la colonia, cedido por la familia Najenson. En el centro del cementerio hay un monumento de color blanco erigido al cumplirse veinte años del Levantamiento del Gueto de Varsovia (1943-1963) y una placa "a los seis millones de hermanos cuyas vidas fueron inmoladas en aras del pueblo judío y de la tierra de Israel. 1938-1948".

\footnotetext{
${ }^{26}$ A mediados de la década de 1960 se abandonó esa vieja costumbre, y desde entonces ambos sexos presencian juntos las ceremonias. La sinagoga se encuentra restaurada y en perfecto estado de conservación.
} 


\section{La mikve, el baño ritual}

La observación del plano de CoIonia Clara realizado por la JCA demuestra la existencia de cuatro baños rituales. ${ }^{27}$ Sin embargo, el relevamiento de información nos dio señales de que se trataba de un tema cubierto de secretos y de discreción.

Fue utilizado por hombres y mujeres observantes religiosos orto-

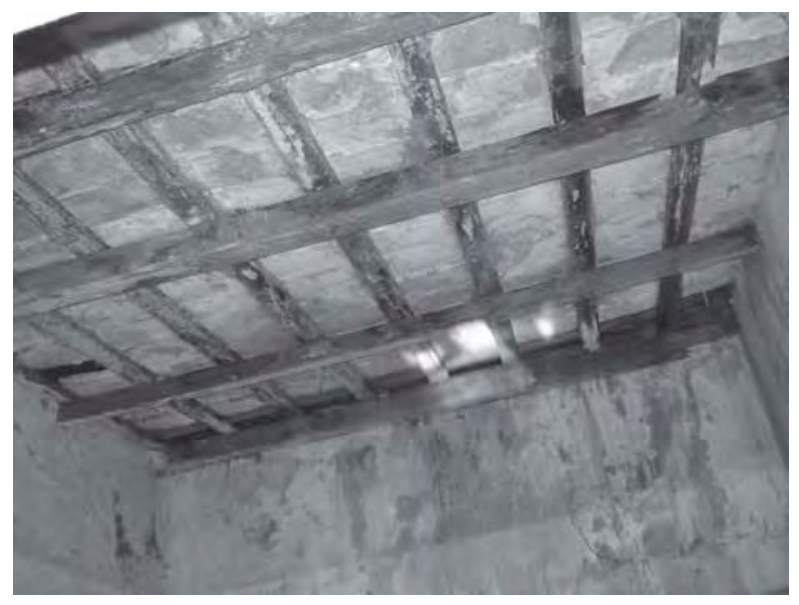

Mikve en Villa Clara doxos que, a través del cumplimiento de los preceptos, realizaban una invitación a Dios para que ingrese al hogar y al matrimonio. Si bien la preparación y la mikve en sí mismas son actos físicos, la razón detrás de ellas es espiritual. Cada mes, cuan-
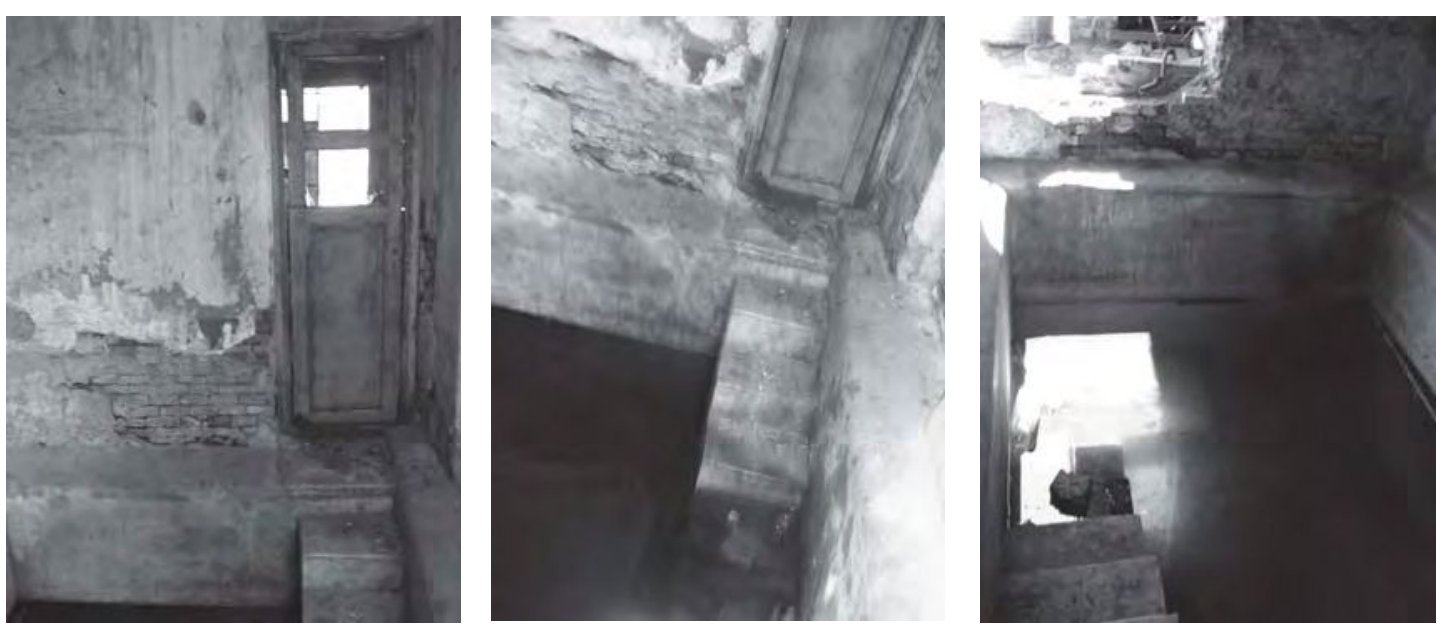

\footnotetext{
${ }^{27}$ Los mismos estaban emplazados en Sonnenfeld, Carmel, Clara y Barón Guinzburg. En Atlas des Colonies et Domaines de la JCA, 1914. La construcción del baño ritual se basa en reglas antiguas y complejas. La capa inferior es de agua pura, natural de lluvia. Se llama "agua viva" y es un símbolo del renacimiento y del flujo Divino de la creación. Encima del agua de lluvia fría hay otra piscina de agua caliente, donde ocurre el baño real. Las dos aguas no deben mezclarse, para que el agua de lluvia pueda mantener su calidad prístina. Solo se "tocan" en una abertura entre ambas, pero no se mezclan. El agua en la cual una se baña se cambia con frecuencia, así es higiénica. El agua de lluvia, que nunca se ha contaminado, sigue de este modo inalterada e intacta. En Chabad. Org. Disponible en http://www.es.chabad.org/library/ article_cdo/aid/496576/jewish/.
} 
do la mujer menstrúa - un óvulo que no fue fertilizado- hay un potencial de vida que no se llegó a concretar. La mujer se sumerge en el agua, que es la fuente de la vida. Cuando emerge, es como si renaciera, y la energía Divina de la creación puede fluir otra vez. Es una renovación, una limpieza espiritual. Se entiende que la relación matrimonial se renueva cada mes gracias a la mikve. El marido y la esposa se separan y este alejamiento puede ser muy duro. Pero también mantiene vivo el deseo. Cuando la pareja se reúne otra vez, se aprecian mucho más. Y el sacrificio para la ejecución de la mitzvá lleva la relación física a un nivel espiritual.

\section{El cura Ehroike, el shojet de La Capilla}

Máximo G. Yagupsky cuenta que su abuelo Jaim llegó en compañía de su padre y de una hermana más pequeña, en el segundo vapor que condujo a los pobladores de Colonia Clara. Este abuelo se desempeñaba como Shojet (Shoijet) y complementariamente como Mohel en Chernovicz, pueblecillo de Rumania situado en las cercanías del río Dniester. Una espada de Damocles pesaba sobre este hombre. Su hijo, Afroike, ya venía cumpliendo su Bar Mitzvá o ceremonia de confirmación religiosa, lo que daba el anuncio que ya pesaba sobre él de la obligación del servicio militar. Abrumadora carga para un niño que por nueve años lo mantendría lejos del hogar, de la vida espiritual judía, sin ritos, privado de estudio, condenado a la ignorancia. El padre hizo sus cálculos y se inscribió para la obra del barón de Hirsch, no como aspirante a agricultor en tierras argentinas, sino como Shojet para servicio ritual de la colonia cuando esta se fundara.

Ser Shojet es una profesión ritual, religiosa, semejante a la del veterinario de los tiempos modernos, al cual la religión judía le encomienda, entre otras cosas, la matanza de las reses destinadas a la alimentación humana. Los estudios que debe cursar el aspirante a esa profesión son de alto rigor académico, según lo testifican los tratados que forman parte del acervo halájico y que hasta el presente son aceptados por las escuelas modernas como válidas por su contenido. Además del peritaje profesional, el Shojet debe cumplir, paralelamente, estudios judaicos, al término de los cuales debe ser sometido a rigurosos exámenes por parte de especializa- 
das escuelas superiores rabínicas. De ahí que la jerarquía del Shojet es de nivel rabínico. A esta profesión se agrega, por lo común, la de Mohel o retajador o perito en circuncisión. Estas dos funciones cuasi doctorales asignan autoridad intelectual, religiosa y social, sucedánea a la del rabí.

Jaim cuidó a su hijo Afroike ${ }^{28}$ con las pocas armas con que contaba. Para huir de la opresión zarista, y para despistar mejor la fuga, cambió el apellido a su hijo, estrategia compartida por muchos de los emigrantes.

Los trece años de edad y la inscripción en la llamada bajo bandera aceleraban la salida. Para cambiar el apellido, el padre pensó un largo rato y se le ocurrió un nombre que representaba todo un simbolismo exegético. Recordó las tribulaciones del patriarca Jacob cuando hubo de salvarse de la vengativa mano de su hermano Esaú y huyó refugiándose en la casa del tío Laban. Así, eligió para su hijo el nombre de Efraim Yagupsky, que significa que es un vástago del patriarca Yacob.

Afroike ya había comenzado su preparación para continuar la profesión de su padre concurriendo en su pueblo natal al Beth-Hamidrash, la academia donde se cursaban dichos estudios. Allí estudiaba bajo la tutela de su tío, el profesor Rabí Meyer. Los estudios que realizó no sólo tenían conexión directa con las materias pertinentes a la profesión, sino con "algo superior", con lo que se llama en términos superiores "Torá y Jojmá", que involucra Biblia, Exégesis y Talmud. El tío Meyer fue un maestro relativamente liberal que lo incitó también a leer libros "profanos" de los pensadores hebreos que consagraban su pluma a temas universales: Luzzato, Zederbaum, Faierberg, Peretz, Smolenskin, figuraban entre los autores de su humilde pero contundente bagaje de libros.

Su padre se preocupó por el fortalecimiento de la formación de Efraim. Enseñó la circuncisión y los rudimentos que sobre la materia indicaban los trabajos escritos en lengua sagrada, pero ello no era suficiente. En Entre Ríos fueron sus profesores el rabino Israel Halperín, Yacob Winocur -luego sería su suegro-, Yacob Gueventer y el reputado talmudista Rabí Mazovetsky, quienes debieron suplir la autoridad de una Yeshiva, que no había en estas tierras. Los objetivos de esta formación eran algo más que la enseñanza de la profesión: que el dominio de la

\footnotetext{
${ }^{28}$ En verdad, el nombre genuino era Efraim, cuya pronunciación en idish es Efroim y en diminutivo decíase Froike o Afroike, que en ambos casos es la forma cariñosa.
} 
técnica no se convirtiese en "el destral que hace un buen corte" -según la expresión de la Mishná-, sino que la alta escuela de sabiduría reinara soberana en el alma y en la mente del titular. De otra manera, peligraba la autoridad moral que el Shojet habría de ejercer, necesariamente.

La obtención del diploma de Efraim no fue nada fácil. Se lo entregó un tribunal examinador, sumamente severo, integrado por el Rabí y Shojet Josef Mazavesky, por el Reb Moshe Efron, ${ }^{29}$ por Jacob Gueventer y por el Rabí Israel Halperín. Además de ellos participaban otros dos miembros, uno en función de fiscal detractor y uno de defensor. El primero fue su padre Yacob y el otro, el Shojet Mendel Serebrinsky, con jurisdicción en Carlos Casares, provincia de Buenos Aires, llamado especialmente al efecto.

La práctica primicial de Efraim tuvo lugar en Colonia Mauricio, aledaña de CarIos Casares, bajo la supervisión del Rabi Mendel Serebrinsky. Como era de práctica, para ejercer tal profesión era más decoroso ser casado, y es lo que hizo el joven Shojet con una bella señorita de 17 años hija de Yacob Winocur, el Shojet de la colonia Barón Hirsch. Su estadía en Colonia Mauricio fue breve, ya que fue trasladado para ejercer su profesión en La Capilla.

\section{La Capilla}

Este pueblo se llamaba así porque originariamente constaba de un solo edificio rodeado de chozas. Era la pequeña iglesia católica de la zona, lugar donde concurrían los estancieros y gauchos para el cumplimiento de los deberes de culto. En el lugar se alojaban el sacerdote y el alcalde, y además se aglutinaban los registros de las haciendas, así como también los nacimientos, casamientos y defunciones. Con el asentamiento de las colonias con gente del culto judío, el sacerdote migró a otra zona y puso en venta la casa.

La familia de los judíos Roisman compró el edificio de la iglesia de La Capilla, donde habitaron durante cierto tiempo, y luego se lo vendieron a Efraim Yagupsky. ${ }^{29}$ "Padre de ledidia Efron, el gran maestro que tuvimos aquí, explica Yaguspky en entrevista realizada
por Daniel Bargman, el $1^{\circ}$ de diciembre de 1988. En archivo Oral de AMIA, carpeta 68. 
Mis padres lo refaccionaron y lo embellecieron: le añadieron una cocina de amplias dimensiones, plantaron numerosos árboles de paraíso los que en el estío exhalan un perfume paradisíaco; mi madre plantó unos rosales y jazmines. Un cerco de alambre tejido circundaba el vasto patio, de modo que ni las aves de corral ni los caballos o vacas que pululaban por el pueblecillo lo penetrasen a estropear plantas ni flores. ${ }^{30}$

Sus vecinos, los gauchos entrerrianos con los que entabló una cordial relación, tenían dificultades para pronunciar su nombre y profesión, razón por la cual fue nuevamente bautizado: se lo llamó cura Ehroike o simplemente curita. El humor judío tan presente en la vida cotidiana recupera esta trasposición.

Como señalábamos, Yaguspky compró el edificio donde funcionaba la única capilla católica del pueblo, transformándose en un centro de estudios talmúdicos. Entonces, en lugar de llamarse La Capilla, se la llamó "Capiye».

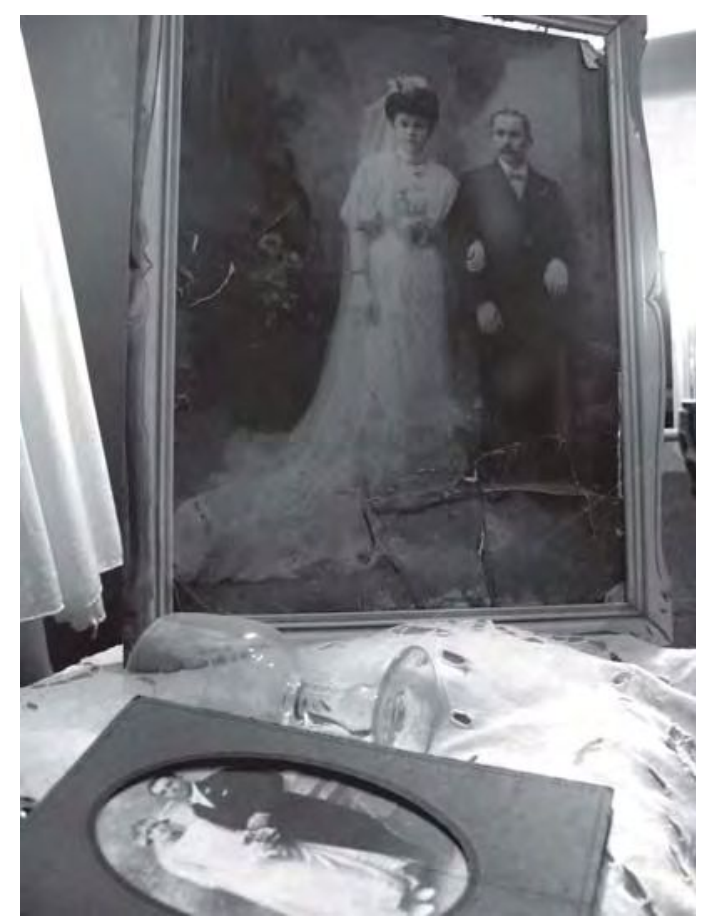

La Capilla estaba rodeado de las aldeas o grupos ubicados en forma de panóptico. Colonia Barón Hirsch estaba a 6 kilómetros, Carmel a 3 Km, al Este estaba Desparramados, al Sudeste la colonia Ilamada "La Calbola" y al Sur la colonia Barón Eche, en realidad Barón Guinsburg; a 20 kilómetros estaba Villa Domínguez, pueblo con el que estaba muy ligado. Con el transcurso del tiempo se irá poblando -la mayoría de sus habitantes eran judíos- y, si bien quedó fuera de la línea del ferrocarril, esta carencia fue suplida por un vida social intensa y por la porfiada persistencia en la demanda de instalaciones que dieran densidad económica y social al

\footnotetext{
30 Máximo G. Yagupsky, "Daguerrotipo de un judío de las colonias", en Mundo israelita, edición del 5 de septiembre de 2007.
} 
pueblo. Entre las autoridades del pueblo se encontraban el director de la escuela, el jefe de correo, ${ }^{31}$ el jefe del Registro Civil y el shoijet.

El "Curita” era un hombre inteligente y agudo "y era maskil porque leía literatura hebrea moderna; incluso estaba suscripto a Sfirá ("Hatzefirá»), el periódico de la ilustración sionista de aquel entonces. Además era un verdadero idealista como hombre, como judío". ${ }^{32}$

Fue en La Capilla un actor social muy importante. Además de ser el primer shoijet independiente no sostenido por la Kahal, estimuló la creación de la escuela Talmud Torá moderno en la que se estudiaba hebreo y dikduk (gramática), y se interesó por la enseñanza pública, en la que se desempeñó como presidente de la comisión escolar. Participaba en los actos por las efemérides patrias llevando la bandera argentina, y propiciaba importantes intercambios culturales entre los lugareños.

Estos intercambios encontraban a judíos y no judíos cantando "Sabeinu mitubeja vesamaj nafsheinu bishnateja", y los ojos y oídos abiertos de los gauchitos que se acercaban a la sinagoga a espiar y escuchar y terminaban cantando melodías litúrgicas judías. ${ }^{33}$

Son múltiples los testimonios que señalan que las mujeres que trabajaban en el servicio doméstico hablaban idish y que aprendieron a preparar y cocinar las comidas típicas con tanta destreza o mayor que las judías amas de casa

\section{El matrimonio}

Ningún hombre sin esposa, ni tampoco ninguna mujer sin esposo, ni ninguno de los dos sin Dios.

Bereshit Raba 8:9, Talmud

\footnotetext{
${ }^{31}$ El jefe del correo Reb MendI Sachtein viajaba todos los días a Domínguez a buscar la correspondencia que llegaba. Los judíos hacían cola porque estaban ansiosos por leer Di Idishe Tzaitung de Buenos Aires y Di Gazete, que llegaba de Estados Unidos, para tener noticias de lo que pasaba en el mundo, narra Yaguspky en la entrevista citada.

32 Relata Yaguspky en entrevista realizada por Daniel Bargman el $1^{\circ}$ de diciembre de 1988. En archivo Oral de AMIA, carpeta 68.

33 Ibídem, p. 4.
} 
El matrimonio es una de las instituciones consideradas sagradas en la vida judía. El concepto de casarse tiene su origen en la Torá, es decir, se entiende a la institución del matrimonio como una idea Divina. Las fuentes talmúdicas y cabalísticas enseñan que el matrimonio no es meramente la unión entre dos individuos totalmente independientes entre sí, sino una reunión entre dos mitades de una y la misma unidad. La pareja comparte la misma alma que, al nacer, se dividió en dos. Al casarse, vuelven a reunirse y completarse. Se trata de una unión no sólo a nivel físico, emocional y/o intelectual, sino a nivel esencial.

Para el que cree en la Torá, el concepto de matrimonio asume una importancia y significado mucho más profundos y sustanciales. El matrimonio cumple una función esencial por constituir la base de la familia, el núcleo de la sociedad y el centro de la vida espiritual. Si un hogar es sólido en valores, la totalidad de la vida judía en todas sus vertientes, incluyendo la institucional, se verá enriquecida. Si bien el matrimonio es considerado como una institución permanente dentro del judaísmo, se acepta la separación luego de realizados todos los esfuerzos necesarios para lograr la paz y la armonía. La Torá o Antiguo Testamento permite que los lazos matrimoniales se disuelvan por medio del divorcio religioso, que debe estar avalado por el "Bet Din» o tribunal rabínico, integrado por tres rabinos competentes en las leyes de matrimonio y divorcio.

A pesar de que la Torá permite el divorcio y estipula que puede realizarse cuando la causa es la incompatibilidad entre los cónyuges, se establece que nunca debe ser llevado a cabo en forma arbitraria o apresurada. Se debe luchar por mantener un hogar sano, en el que se facilite la transmisión de los valores inherentes al judaísmo.

Como el matrimonio es la institución que transmite la perpetuación de la cadena judía milenaria, se opone al casamiento con personas no judías o al casamiento mixto. La fuente primaria en la cual se basa la prohibición para el judío de casarse con alguien que no lo es está en la Torá (Deut. 7 Corazón: «No te cases con ellos [los gentiles, de los cuales hace mención en los versículos anteriores], no des a tu hija al hijo de él, y no tomes la hija de él para tu hijo"). El motivo de dicha prohibición sigue en el siguiente versículo: "Porque él va a desviar a tu hijo de Mí y servirán a dioses ajenos..." (se puede entender el término "dioses ajenos" también como ideales que no concuerdan con los de la Torá, por los cuales uno inclina la cabeza y les rinde culto). 
Los sabios señalan el Talmud (levamot 23a), y el comentarista Rashi lo trae en su comentario sobre el versículo citado, que de la expresión precisa de dicho versículo ("él [y no ella] va a desviar a tu hijo") se desprenden dos cosas. En el caso de que tu hija se case con el hijo de ellos, el "hijo de ellos" (esposo de tu hija) va a terminar alejando a tus hijos (o sea, nietos) del camino de la Torá. En el caso de que tu hijo se case con la "hija de ellos", ya los nietos que nazcan no están considerados como tus hijos, sino hijos de ella, o sea ya no son judíos. ${ }^{34}$

Shemtov explica los alcances:

Teniendo en cuenta que el deber principal del judío es cumplir con sus obligaciones como tal, respetando los preceptos de la Torá, es evidente que deviene indispensable casarse entre judíos, porque, de lo contrario no podrán cumplir debidamente con sus responsabilidades fundamentales de manifestar la dimensión Divina en el mundo, que es posible solamente por medio del cumplimiento de Su voluntad.

Para cumplir con este mandato existió y existe una defensa encendida de la endogamia, así como la preocupación por los entrecruzamientos o matrimonios mixtos, que recogemos en los testimonios y en la literatura sobre la vida en Colonia Clara. En la emblemática obra Los Gauchos judíos, Gerchunoff con su pluma brillante describe en "El episodio de Myriam»" el amor nacido entre la hija hebrea y el bravío criollo Rogelio Míguez, los que se entendían con la mirada y se amaban por medio del canto, que sólo pudieron consumar este lazo huyendo de la colonia.

Si bien el transcurso del tiempo fue aliviando la preocupación y la rigurosidad con que se vivían los casamientos mixtos - debido a un aumento sostenido de los mismos-, no siempre se pudo lograr que las rupturas familiares iniciales y las hondas heridas cicatrizasen a tiempo. Disputas que se mantenían en el seno familiar provocando discriminaciones o distanciamientos que señalaban la presencia de "otros" dentro de un nosotros judío.

El encuentro de los jóvenes dispersos en las distintas colonias era posible por las mediaciones de la shándjente (casamentera), quien recorría largas distancias

${ }^{34}$ Rabino Eliezer Shemtov, "El matrimonio mixto en la religión hebrea", en Hebreos.net, martes 16 de mayo de 2006.

${ }^{35}$ Gerchunoff, Alberto, Los gauchos judíos, Buenos Aires, Biblioteca Nacional y Ediciones Colihue, 2007, p. 75. 
para poner en contacto a los pretendientes con las jóvenes casaderas. Hermosa ocupación de estas celestinas que cuidaban con celo sus libretas, en las que asentaban los listados de los mozos y mozas de las colonias.

Logrados los encuentros y las aprobaciones, se producían las bodas, motivo para una gran fiesta. Una enorme carpa levantada en el patio de la casa, manjares y músicos. Si el padre poseía dinero, lo gastaba con gusto en esta ocasión. Si no lo tenía, todos acompañaban el festejo con lo que traían.

Eso sí, se invitaba a toda la gente de la colonia y de algunas colonias vecinas. Eran casamientos grandes, 200, 250 personas, ique algarabía, que revolución en la coIonia, cómo nos divertíamos! ${ }^{36}$

Las lonas se pedían prestadas a los ferrocarriles, al zarandero o al dueño de la trilladora, quienes las facilitaban gustosos para armar la carpa que resistiera el viento, la lluvia o el frío. "¡Y era fundamental que todo el suelo estuviese bien apisonado para que se pudiese bailar, y mucho!» ${ }^{37}$

No era una fiesta de la familia solamente, era la fiesta de toda la colonia. Si se podía, se contrataba a una saverte. ${ }^{38}$ Si la situación económica no lo permitía, eran las vecinas las que ayudaban a la majeteineste (suegra o consuegra) a cocinar. Desde unos cuantos días antes de la boda había que preparar pollos y los knisbes, el lekaj y el struld. Se bebía vishnik, grapa y cerveza y se bailaba con la maravillosa música klezmer ${ }^{39}$ que entregaban estos músicos que posaron para nosotros en la foto siguiente:

\footnotetext{
${ }^{36}$ Nijamkin, Celia, Rescate de la Herencia Cultural. Vidas en las Colonias, op, cit., p. 209.

${ }^{37}$ Gershanik, Bernardo, ibídem, p. 209.

38 Persona que se ocupa de cocinar para ocasiones especiales.

${ }^{39} \mathrm{~A}$ lo largo de la historia judía la música siempre tuvo un papel predominante. El klezmer es la música de la cultura del idish. Es fácilmente reconocible por sus características melodías expresivas, con reminiscencias de la voz humana, con la incorporación de risas, llantos y aullidos. Al principio, los músicos recorrían grandes extensiones como artistas ambulantes, desplazándose de aldea en aldea y realizando actuaciones en tabernas, en la calle, en teatros, en casamientos tanto judíos como cristianos y en fiestas familiares. De estas circunstancias surge el músico ambulante y ocasional, que anima la fiesta del pueblo arrancando unas notas que a algunos pueden parecer nostálgicas pero que, por el contrario, son la máxima expresión de la alegría por la vida, como lo atestiguan los nombres de algunos estilos, por ejemplo, el freilaj (alegre). El canto folclórico pronto comenzó a empaparse también de melodías para el baile. De esa manera, la música se acercó al alma del pueblo. Como dice Joachim Stutschewsky en su libro Klezmorim (Jewish Folk Musicians) (Tel Aviv, 1977), "la cuna de la música klezmer no está en las cortes de los nobles, ni en los salones de los aristócratas y ricos, ni en las aulas junto al piano y, por supuesto, que tampoco lo está en las partituras".
} 


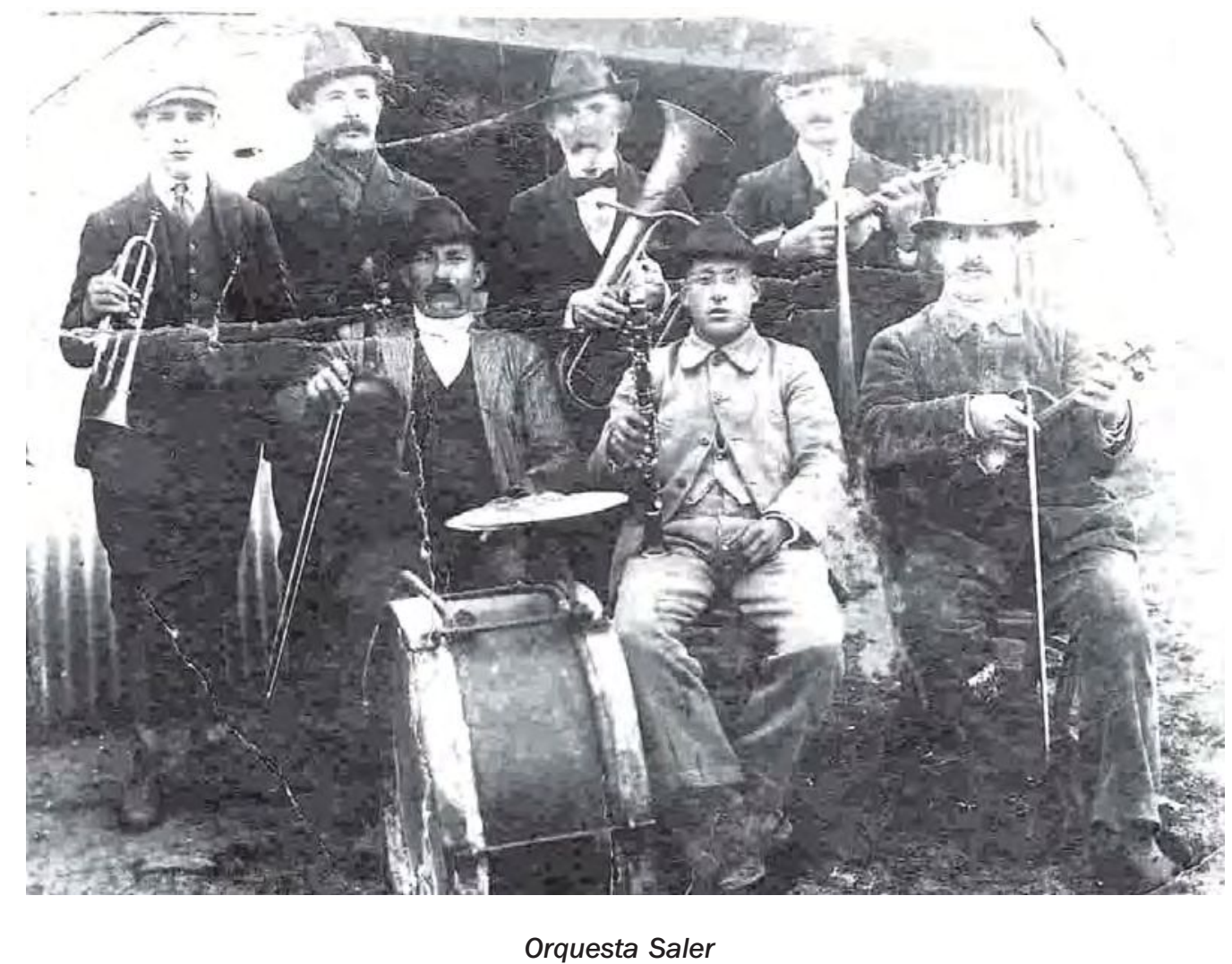

Posan en la foto: Rejtman, Tevie, Kolodetzky, Saler, Jacobo Kohan. 



\section{capítulo cinco}





\section{Educación en Colonia Clara}

A la administración de la J.C.A. se le puede censurar no pocas cosas, pero al mismo tiempo no faltan por cierto algunos motivos de alabanza.

Entre estos últimos está sin duda el modo en que se encaró la educación de los hijos de los colonos... Desde el principio la J.C.A. se empeñó en proporcionarnos buenos maestros, tanto en lo concerniente a la educación judaica como en lo relativo a las materias de los grados de la instrucción primaria. ${ }^{1}$
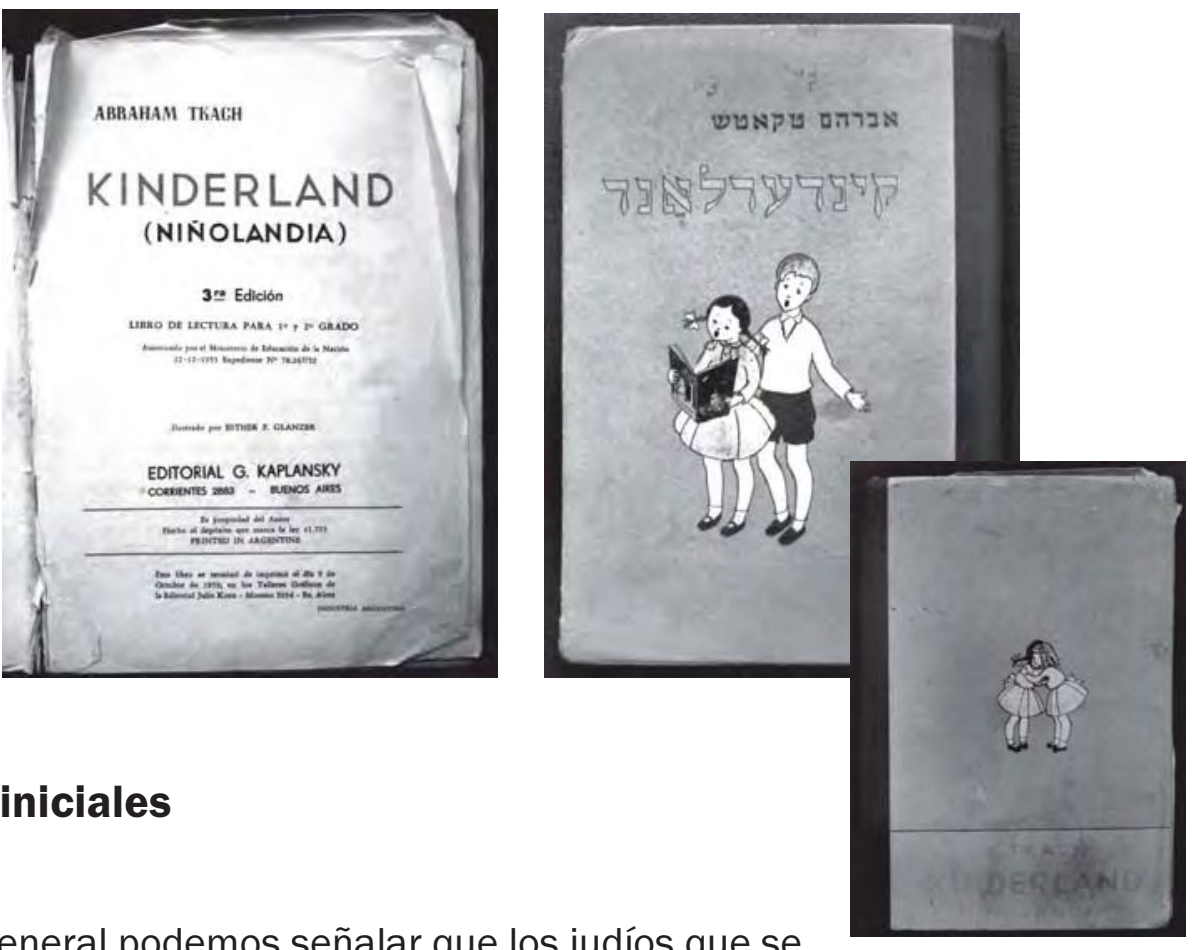

De modo general podemos señalar que los judíos que se asentaron en las colonias agrarias de Entre Ríos intentaron dejar atrás los padecimientos debidos a la exclusión, a la discriminación y las persecuciones, así como el entorno de guerras constantes y de crisis económicas, para poder integrarse al

\footnotetext{
${ }^{1}$ Boris Garfunkel junto con su familia decide incorporarse a uno de los contingentes emigratorios de la JCA. Un 4 de septiembre del año 1891 pisa tierra argentina y se establece en el paraje denominado Algarrobos, ubicado en la zona norte del actual partido de Carlos Casares, donde trabaja la tierra que la JCA le ha facilitado. Sus hijos publican sus memorias: Narro mi Vida, en 1960.
} 
país receptor. Expulsados de la Rusia zarista, eran los portadores del legado tradicional de pertenecer al pueblo del libro, traían la riqueza de la cultura y el pensamiento judío y entendían que el saber, el conocimiento y la lectura son una herramienta transformadora para la condición humana.

Estos inmigrantes comprendieron que la educación formal de sus hijos era el camino para la integración. No sólo se trataba de aprender el idioma, sino también de acceder a los conocimientos que les estuvieron vedados por una serie de disposiciones del régimen ruso -cuyo detalles describimos en capítulos precedentes-, para integrarse como ciudadanos plenos al país que los albergaba, sin dejar a un lado la educación judía que les permitiera conservar y reproducir su herencia cultural y religiosa.

Si los judíos habían sido convocados a vivir en el suelo argentino con el espíritu liberal de la constitución de 1853 -con su libertad de cultos y de enseñar y aprender-, el nuevo proyecto político para pensar la nación y construir la nacionalidad argentina de fines del siglo xıx y principio del xx los ponía en una encrucijada con las exigencias asimilatorias. El debate estaba abierto. La identidad judía no aceptaba esa uniformidad y rechazaba el proyecto que bajo el nombre de unidad nacional buscaba la supresión de las diversidades.

Nuestro trabajo se propone realizar una aproximación al análisis del papel del Estado como formador de la nacionalidad, observando el debate sobre la educación de los inmigrantes como herramienta y el idioma nacional como medio de expresión de la nacionalidad y como instrumento en la absorción de inmigrantes en el marco de una argentinidad proyectada. Ante la ausencia del Estado en el ámbito rural, fue la empresa colonizadora (Jewish Colonization Association) quien estableció un sistema educativo integral con enseñanza laica y religiosa que debió dirimir con el Estado provincial las incumbencias para pensar la ciudadanía.

La política oficial estableció que la escuela era el lugar donde se construía la identidad denominada "nacional" como una identidad homogénea y monolítica a partir de la trasmisión de las formas simbólicas referentes a la argentinidad, al patriotismo y la nación.

La investigación nos permite observar las tensiones, las vivencias de las personas implicadas y el significado de sus acciones, y en tal sentido identificar el tipo 
de relaciones sociales que se forjan en el interior de las escuelas, pero también pensar otros problemas que va mucho más allá: la integración, la discriminación, la etnicidad, finalmente la identidad y la otredad.

Abordar este capítulo nos hizo recorrer la producción académica abordada desde campo de la historia de la educación, para reconocer las instrumentalidades y tramitaciones que se producen en el sistema educativo, en particular los alcances del sistema entrerriano, que tuvo en la colonización judía un laboratorio donde probar sus misiones y evaluar los resultados. Contamos con el valioso aporte de estudiosos del tema que con textos ${ }^{2}$ y monografías ${ }^{3}$ nos brindaron aportes conceptuales y la descripción de derroteros políticos sobre la cuestión educativa, a los que confrontamos con la documentación y los informes inéditos producidos por y para la JCA, por la Alliance Israélita Universelle -entidad que proporcionó los primeros maestros judíos que podían enseñar castellano-, Memorias del Consejo Nacional de Educación, Dirección General de Escuelas, Archivos Escolares, las crónicas, las memorias y las voces de los entrevistados.

Nos proponemos entonces realizar, en este capítulo, un acercamiento al complejo proceso educativo, lo que nos permite destacar que, desde la llegada de los primeros inmigrantes judíos a fines del siglo xIx, se puso especial énfasis en la formación

\footnotetext{
${ }^{2}$ Cfr. Puiggrós, A., Historia de la educación en la Argentina, Tomo IV: La educación en las Provincias y Territorios Nacionales, Buenos Aires, Galerna, 1993; Ascolani, Adrián (comp.), La educación en Argentina. Estudios de Historia, Rosario, Ediciones del Arca, 1999; Tedesco, Juan Carlos, Educación y Sociedad en la Argentina. (1880-1945), Buenos Aires, Siglo XXI, 1986; Bertoni, Lilia Ana, Patriotas, cosmopolitas y nacionalistas. La construcción de la nacionalidad argentina a fines del Siglo XX, Buenos Aires, FCE, 2001; Gutiérrez, Talía Violeta, Educación, agro y sociedad. Políticas educativas en la región pampeana. 1897-1955, Buenos Aires, Universidad Nacional de Quilmes, 2007; Carli, Sandra, Entre Ríos. Escenario Educativo, 1883-1930, Paraná, Facultad de Ciencias de la Educación de la UNER, 1995.

${ }^{3}$ Cfr. Gómez Sollano, Marcela y Corenstein Zaslav, Martha, La educación judía en México y Argentina. Tendencias pedagógicas y zonas fronterizas. Disponible en: www.comie.org.mx/congreso/memoria/v9/ .../PRE1178898469.pdf; Bargman, Daniel, "Construcción de la Nación entre la asimilación de inmigrantes y el particularismo. Las escuelas de las colonias agrícolas judías", en Maronese, Leticia (comp.), Patrimonio Cultural y Diversidad Creativa en el Sistema Educativo, Buenos Aires, Gobierno de la Ciudad de Buenos Aires, 2006; Epstein, Diana, "Maestros marroquíes. Estrategia educativa e integración. 18921920", en Anuario IEHS, N 12, Facultad de Ciencias Humanas, Universidad Nacional del Centro, Tandil, 1997.; Zadoff, Efraim, "La educación judía en Buenos Aires Organización e institucionalización (19351967)", en Mundo Israelita, 28 de agosto de 2007; Rubel, Yaacov, "Creación, apogeo y crisis de los institutos de formación docente dependientes de la AMIA", en Mundo Israelita, 8 y 15 de diciembre de 2000; Gutiérrez, Talía Violeta, "Políticas educativas agrícolas: una preocupación de los pedagogos normalistas, Entre Ríos (Argentina), 1900-1920", disponible en www.fee.tche.br/sitefee/download/jornadas/2/h10-03.pdf; entre otros.
} 
de las nuevas generaciones, lo que llevó a que la gran mayoría de estas comunidades dedicaran un espacio significativo a la actividad educativa formal y/o no formal. Instrucción que no estuvo libre de tensiones, debido a un complicado proceso que intentaba, por un lado, fortalecer la identidad judía y, por otro, generar los modos para la producción de mecanismos para la integración al país que los cobijaba, en tanto se constituían, a la vez, en agricultores en la provincia de Entre Ríos.

Esa educación estuvo lejos de ser homogénea ya que en ella se condensaban las significativas diferencias que giran en torno al "ser judío" en una sociedad particular. Son el resultado de cientos de años de historia, pero el siglo xx particularmente aceleró el desarrollo de un sujeto que cuestionó la creencia religiosa y la autoridad suprema de los rabinos, para dar paso a otras formas de judaísmo. La literatura especializada ${ }^{4}$ reconoce, a grandes rasgos, tres propuestas pedagógicas judías: el sionismo, la ortodoxia y el progresismo. Todas ellas son necesarias para entender cada una en particular, porque su presencia explica la existencia de las demás. Esas tendencias se han construido como producto de posiciones disidentes cuya diversidad se materializa también, y principalmente, en prácticas educativas concretas. Si bien los habitantes de Colonia Clara eran de origen asquenazí, ello no obtura la diversidad de sentidos y multiplicidad de significados que las distintas vertientes dieron al sentido de la educación judía, lo que complejiza su análisis.

Así, podemos observar la coexistencia de escuelas religiosas ortodoxas conservadoras o reformistas; orientarse a una educación laica o sionista; propiciar la enseñanza del idish o el hebreo, contar con una modalidad formal, no formal o integral, y podríamos seguir enumerando variables. Si a ello añadimos el factor histórico-temporal, las posibilidades aumentan. Podríamos, por ejemplo, concentrar la atención en las escuelas idishistas o las talmudistas a principios de siglo, en las redes que comenzaban a formarse en tiempos de la segunda guerra mundial, en las de antes o después de la creación del Estado de Israel y en las actuales, entre otras expresiones posibles.

\footnotetext{
${ }^{4}$ Gómez Sollano, Marcela y Corenstein Zaslav, Martha, «La educación judía en México y Argentina. tendencias pedagógicas y zonas fronterizas", en: http://www.comie.org.mx/congreso/memoria/v9/ponencias/at12/PRE1178898469.pdf.
} 
Cuando arribaron estos inmigrantes al país, se estaba también construyendo una nueva idea e imagen de nación, sustentada en el delineado de un proyecto de conformación de la identidad nacional dirigido desde el Estado, que se proponía borrar las diferencias étnicas y culturales en un modelo homogéneo y homogeneizador del ser nacional. Este proyecto se planteaba la asimilación de los inmigrantes a la nación para generar una nueva Argentina, moderna, que debía dejar en el olvido las pautas culturales propias de los diferentes grupos migrantes que arribaban en forma masiva al país. Desprenderse de todo su acervo cultural para integrarse y asimilarse a una "comunidad imaginada" 5 en la que la escuela debía alfabetizar y homogeneizar las diferencias culturales a fin de construir, a través de sus rituales y la enseñanza de la historia, de la geografía y de la lengua, una nación y una identidad nacional común.

De modo que la fundación del sistema educativo moderno en Argentina a partir de las últimas décadas del siglo xıx se construyó como parte de una estrategia global de normalización social, de integración de las capas inmigrantes y de una profunda hibridación entre modernidad pedagógica y reproducción de lazos de autoridad tradicionales, como nos señala una especialista en el tema. ${ }^{6}$

\section{Argentinizar al judío inmigrante}

Con el propósito de contextualizar los alcances de la educación en Colonia Clara, debemos tener en cuenta varios elementos que servirán de antecedentes para comprender cómo fue el proceso de integración y definición de la identidad del sujeto judío inmigrante agrario de fines del siglo xIx y principios del xx.

Esta Argentina, denominada como la Argentina aluvional o de la inmigración masiva, estuvo fuertemente influenciada por la política educativa de Domingo Faustino Sarmiento, que propuso también el fomento y secularización de la educación pública.

\footnotetext{
${ }^{5}$ Cfr. Anderson, Benedict, Reflexiones sobre el origen y la difusión del nacionalismo, México, FCE, 1993; Rojas Mix, Miguel, El Imaginario. Civilización y cultura del siglo XXI, Buenos Aires, Prometeo Libros, 2006. ${ }^{6}$ Puiggros, Adriana, "Historia de la Educación judía en la Argentina”, en Índice. Revista de Ciencias Sociales, Año 35, № 22, Buenos Aires, DAIA, 2004.
} 


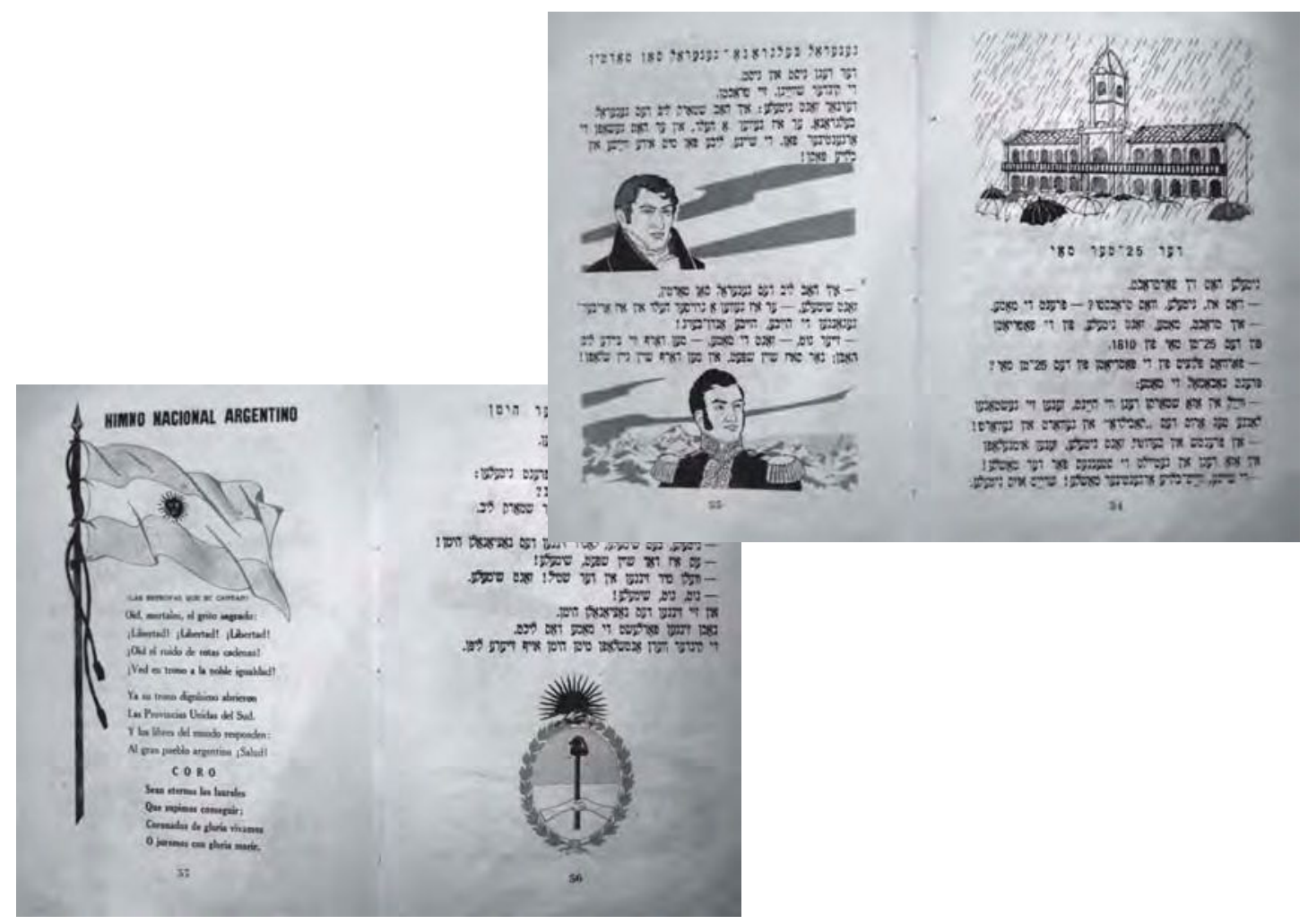

Como señalamos en capítulos anteriores, fueron Sarmiento y Alberdi quienes imaginaron una nación poblada por europeos cultos y trabajadores. Pregonando, además, por un sistema educativo masivo, igualitario y homogéneo que focalizara en una educación basada en los valores del «ser nacional». Este cúmulo de deseos logró su primer marco legislativo en la Constitución Nacional de 1853, que expresa en su artículo 5 que "cada provincia dictará para sí una constitución [...] que asegure su educación primaria". ${ }^{7}$

Este es un buen punto de inicio para focalizar nuestro estudio, ya que es imprescindible prestar especial atención al desempeño y el papel que la provincia de Entre Ríos dio al sistema educativo.

La Constitución de la provincia de Entre Ríos de 1883, sancionada durante el gobierno de Eduardo Racedo (1883-1887), establecía que la educación debía ser gratuita, obligatoria y laica antes aun de la sanción de la Ley 1.420, aprobada un

\footnotetext{
${ }^{7}$ Art. 5.Cada provincia dictará para sí una Constitución bajo el sistema representativo republicano, de acuerdo con los principios, declaraciones y garantías de la Constitución Nacional; y que asegure su administración de justicia, su régimen municipal, y la educación primaria. Bajo estas condiciones el Gobierno federal garantiza a cada provincia el goce y ejercicio de sus instituciones.
} 
año después a nivel nacional. Esta misma normativa disponía la función y el deber de las municipalidades en el fomento de la educación común, creando dentro del municipio las escuelas que sus recursos permitieran. Los dos organismos designados para la administración y la dirección de la educación fueron el Consejo General de Educación ${ }^{8}$ (CGE) y los Consejos Escolares Departamentales (CED), dependientes estos últimos de aquel.

Una reconocida investigadora del tema, Sandra Carli, explica que la organización de este sistema educativo provincial fue "un dispositivo estratégico de poder", y que la política educativa que los gobiernos de la década de 1880 implementaron comprendía «la instalación de un sistema educativo provincial integral, que por un lado proponía la formación de maestros e inspectores para cubrir las necesidades que el sistema requería y que por otro, realizaba una convocatoria a la participación de la sociedad civil como corresponsable de las tareas educativas»`.

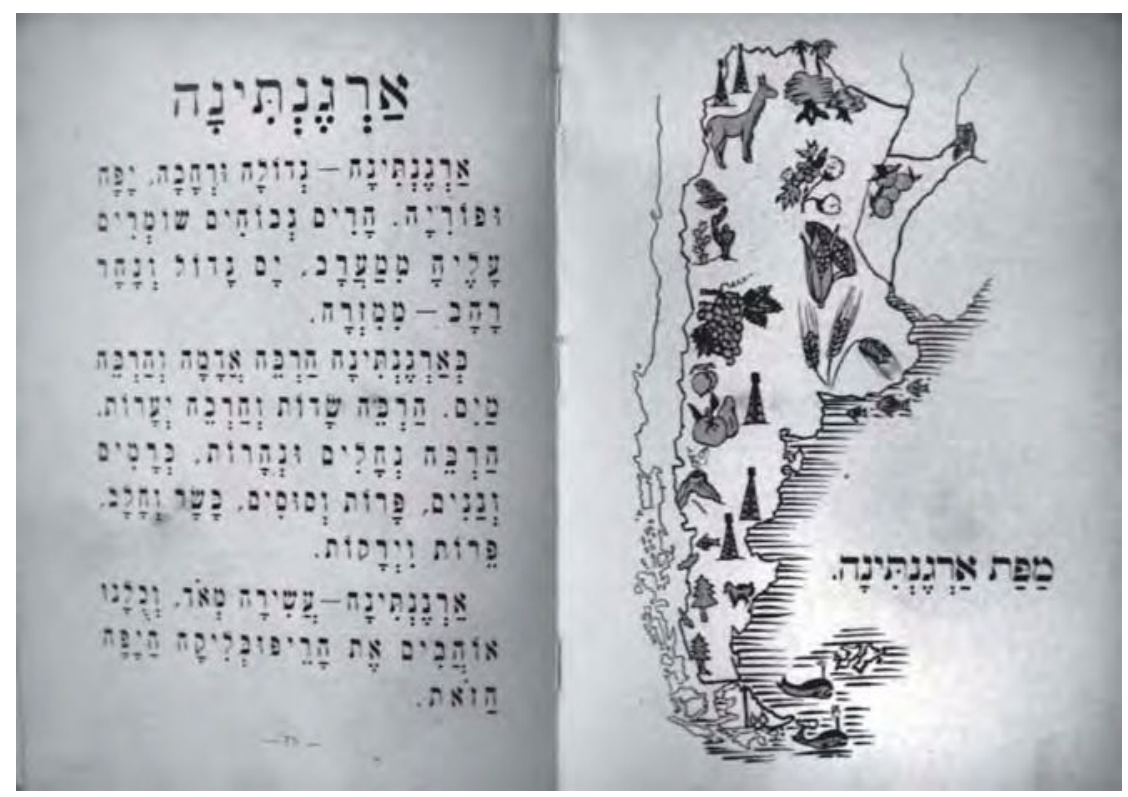

\footnotetext{
${ }^{8}$ El CGE adquirió un rol protagónico disponiendo y reglamentando las conferencias pedagógicas de maestros, promoviendo la constitución de asociaciones con fines útiles a la enseñanza, fomentando la formación de bibliotecas populares y editando, a partir de 1887, el primer Boletín de Educación. Esta publicación se convertiría en una herramienta de información y de formación para los maestros. Se distribuía gratuitamente en las escuelas y difundía, entre sus principales temas, fragmentos de obras de pedagogos y entendidos en educación, legislación escolar, estadística educativa, informes de inspectores, síntesis de las conferencias pedagógicas, metodología de la enseñanza, fragmentos literarios, movimiento de compra de útiles, textos y material escolar, y síntesis de las memorias anuales del CGE.

${ }^{9}$ Carli, Sandra, "Modernidad, diversidad cultural y democracia en la historia educativa entrerriana. (18831930), en Puiggrós, A., Historia de la educación en la Argentina, Tomo IV, op. cit., Buenos Aires, Galerna, 1993.
} 
Si consideramos como válido hablar en términos de un "dispositivo de control", al constatar la presencia que tuvo el "cuerpo de inspección" creado en ese mismo período, conformado por un inspector general e inspectores seccionales que tenían como responsabilidad visitar las escuelas y vigilar el cumplimiento de las disposiciones vigentes, ${ }^{10}$ podemos aseverar que estos tuvieron en las escuelas y en la enseñanza brindada en las colonias judías su ámbito de acción por excelencia.

Tempranamente, la presencia y permanencia de la educación judía en la provincia fue objeto de debates. En 1892, el Boletín de Educación reproducía un artículo del diario Actualidad que recriminaba al gobierno su falta de autoridad al permitir que los colonos judíos educasen a sus hijos en hebreo como si estuvieran en su propia patria, proponiendo recurrir a la severidad de la propuesta "normalizadora", que no dudaba en aplicar la clausura de escuelas como correctivos a quienes no cumplían con establecido por el Estado. No obstante, dentro del dispositivo escolar entrerriano también circulaban discursos que apelaban a una mirada diferente sobre la situación de la educación en las colonias judías. ${ }^{11}$ Estos debates y enfrentamientos recorren todo el período de nuestro estudio, como demostraremos en las páginas siguientes.

\footnotetext{
${ }^{10}$ A nivel nacional, señala Teobaldo que: "La figura del Inspector fue tomando cuerpo en el diseño de las políticas educativas del Consejo Nacional de Educación como la herramienta que garantizaba la aplicación y difusión de los principios de la Ley 1420. Respecto de este tema ya Sarmiento había dicho, en 1849, en su obra Educación Popular, que la Inspección debía ser ejercida por autoridades especiales, profesionales, que tuvieran aptitudes en el ejercicio la enseñanza y en la administración de 'ese ramo de los intereses públicos'. Con estos conceptos forjados al calor de las experiencias europeas y americanas introdujo, en el debate de la época, la problemática de la Inspección, proponiendo no sólo la obligación del Estado de inspeccionar a fin de que '...todos sus miembros reciban en la infancia aquella parte de educación que es indispensable... para que el hombre salga de su estado de naturaleza...', sino también, la necesidad de participación de las autoridades municipales y civiles en la administración a los efectos de garantizar "por la doble acción de los inspectores y de la administración pública, los fines de la institución'. En la misma línea argumentativa, en 1885, el presidente del Consejo Nacional de Educación (C.N.E), Benjamín Zorrilla, en su Memoria Anual, sostenía respecto de los Inspectores: 'No se concibe la existencia de un sistema regular de educación común, sin el personal técnico que visita los establecimientos de Educación, dándole vida por la vijilancia (sic), el estímulo, la indicación útil y todo tipo de conocimientos y reglas que una inspección preparada e ilustrada lleva a las escuelas públicas y privadas [...] Esos empleados, en una palabra, son el vínculo ilustrado que une y encarna los esfuerzos combinados de la Nación y las provincias para facilitar el progreso y el adelanto de la educación". En Teobaldo, María Elena, "Los inspectores escolares en los orígenes del sistema educativo en la Patagonia Norte. Argentina: 1884-1957", en Educere et educare. Revista de Educacao, Vol. 1, № 2, jul./dic., 2006, p. 14. ${ }^{11}$ Es el caso del inspector Maldonado, que en su informe de 1897 intentaba alivianar el hecho de que diariamente se enseñaban cinco horas de hebreo dentro de curriculum escolar, en tanto se destinaba una hora para la enseñanza del castellano, historia y geografía nacional y demás ramos del programa oficial. Citado por López, María del Pilar, "La educación de rusos judíos y alemanes del Volga en Entre Ríos. Conflictos políticos-pedagógicos (1880-1910)", en Ascolani, Adrián (comp.), op. cit., p. 73.
} 
Las escuelas particulares, de importante proporción en la provincia, fueron especial objeto de control y vigilancia por parte de los inspectores. En 1890 se promueve especialmente la acción particular, aumentándose el número de subvenciones. Así, se eleva de 65 a 122 el número de escuelas particulares en 1891. En 1892 se dispone que, para acceder a las subvenciones, las escuelas deben seguir el plan de estudios de escuelas elementales. ${ }^{12}$

Dentro del mismo cuerpo de inspectores había opiniones dispares sobre la importancia de la educación particular: unos la rechazaban y querían clausurar las escuelas (les criticaban la deficiencia de los locales, el no cobro de matrícula dispuesto por la ley de educación, el no cumplimiento con el mínimo de enseñanza obligatoria y la falta de idoneidad docente) y otros creían que eran un gran aporte al objetivo estatal de extender el servicio educativo, por lo tanto había que tolerarlas hasta tanto el Estado pudiera sostener los reclamos en su totalidad.

Estas polémicas cobraban especial sentido, ya que, como hemos señalado, justamente es la provincia de Entre Ríos, cuna de la colonización, la que recibe enormes contingentes inmigratorios ${ }^{13}$ a los que hay que integrar al proyecto de nación, para lo cual el dispositivo educacional es el instrumento idóneo por excelencia.

Como señala Ernest Gellner, ${ }^{14}$ el Estado es la única agencia capaz de proveer a las sociedades modernas la homogeneidad cultural que requieren para funcionar, a través de su apoyo a un sistema educativo masivo, público, obligatorio y estandarizado.

De modo que en Argentina, a la vuelta del siglo

se reveló con claridad a los grupos dirigentes que el proceso social y cultural no podía abandonarse a su movimiento espontáneo, y que aquellos aspectos cultura-

\footnotetext{
12 Ibídem, p. 207.

${ }^{13}$ Entre Ríos había recibido un importante contingente inmigratorio conformado en una primera etapa por suizos, italianos y franceses favorecidos por la Ley de Inmigración y Colonización de 1876. Un segundo oleaje inmigratorio se produjo por la ley de 1888 que permitió el asentamiento de los alemanes del Volga, los belgas, catalanes y valencianos. A partir de 1892, el asentamiento de rusos y judíos. En 1895, según el segundo censo nacional, la provincia contaba con 291.324 habitantes, de los cuales 20.564 eran italianos y 10.445 rusos. En Bosh, Beatriz, Historia de Entre Ríos, Buenos Aires, Plus Ultra, 1978. 14 Gellner, Ernest, Naciones y nacionalismo, Madrid/Buenos Aires, Alianza, 1991.
} 
les que tenían que ver con la formación de una identidad nacional requerían de una decidida, intensa y constante acción del Estado nacional. ${ }^{15}$

La solución que encontraron fue lanzar un fuerte emprendimiento de construcción de la nacionalidad, logrando, entre otras cosas, que los hijos de extranjeros nacidos aquí se hicieran argentinos plenos también por la lengua, las costumbres, la manifiesta adhesión a la patria. A la vez, cercenaron el crecimiento y desarrollo de enclaves de nacionalidades extranjeras, como extensamente lo explica Lilia Bertoni. ${ }^{16}$

De esa manera se procuró integrar a los inmigrantes a una nacionalidad argentina que incluía a todos sus habitantes.

Para lograr argentinizar al inmigrante, que abrazara la idea e imagen de nación y que se convirtiera en ciudadano argentino, se requería la implementación de estrategias y de tácticas que desbordaban el ámbito pedagógico y que remiten a dimensiones culturales, psicológicas, lingüísticas, entre otras, así como a la observación atenta de la organización social propia de las comunidades inmigrantes. La llegada de los inmigrantes estimuló también a un grupo de médicos positivistas argentinos, preocupados por la higiene social y muy vinculados a la oligarquía, para ocupar un espacio de poder dentro del Estado conservador, y desde allí impusieron su mirada, lo que les permitió moldear al sistema educativo.

Sostenemos también que la marca del fenómeno inmigratorio en general está reflejada en los esfuerzos de las comunidades extranjeras por conservar su cultura. Uno de estos fue la intención de estructurar sus propias escuelas, donde se pretendía enseñar en el idioma de origen. Como nos advierte Tedesco: «Hay una correspondencia muy significativa entre altos porcentajes de extranjeros y de enseñanza privada. Los mayores porcentajes se registran en Buenos Aires y el Litoral». ${ }^{17}$

\footnotetext{
15 Bargman, Daniel, "Construcción de la Nación entre la asimilación de inmigrantes y el particularismo. Las escuelas de las colonias agrícolas judías", en Maronese, Leticia (comp.), Patrimonio Cultural y Diversidad Creativa en el Sistema Educativo, Buenos Aires, Gobierno de la Ciudad de Buenos Aires, 2006. ${ }^{16}$ Bertoni, Lilia Ana, Patriotas, cosmopolitas y nacionalistas. La construcción de la nacionalidad argentina a fines del Siglo XX, Buenos Aires, FCE, 2001, p. 38.

${ }_{17}$ Tedesco, Juan Carlos, Educación y Sociedad en la Argentina. (1880-1945), Buenos Aires, Siglo XXI, 1986, p. 157.
} 
Nuestro trabajo nos permite aseverar que la colectividad judía de Argentina no estaba dispuesta a una fusión total y pasiva en el crisol de razas. Al igual que en las otras colectividades de inmigrantes, también entre los judíos se desa-

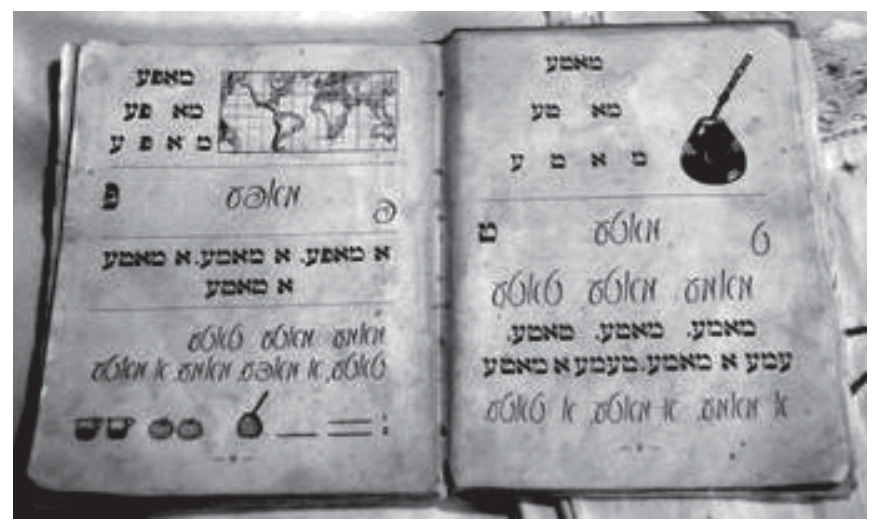
rrollaron sentimientos particularistas específicos. Su intento de legar su identidad a sus hijos y perseverar en su cultura podía aparecer como un desafío contra la hegemonía espiritual de la élite argentina.

Ahora bien, de modo general podemos señalar que los judíos de la colonización agrícola educaban a sus hijos en la fe mosaica y en la tradición judía, y que la instrucción y el conocimiento ocupaban un espacio relevante entre sus preocupaciones.

Este desvelo fue compartido por la Jewish Colonization Association, que instaló en las colonias una amplia red de instituciones educativas fundadas y dirigidas por ella, destinando los recursos para su financiamiento. En el año 1910, esa red abarcaba 50 instituciones con 155 maestros y 3.538 alumnos.

Jedidio Efron, ${ }^{18}$ uno de los inspectores y luego director del Consejo Central de Educación Israelita en Argentina, explicaba que la implantación de escuelas para

${ }^{18}$ En 1895 arribó a los campos entrerrianos con sus padres y hermanos, para asentarse como agricultor en las colonias de la JCA.En 1903 comenzó su carrera docente en las escuelas de la JCA, en Entre Ríos. Debido a su solvencia intelectual judaica y a su dominio del idioma castellano, fue designado director de una escuela de enseñanza castellano-hebreo. Luego se graduó como maestro nacional en la Escuela Alberdi de Paraná. En 1914 fue designado Inspector de los Cursos Religiosos Israelitas de la JCA para las zonas de Basavilbaso y Moisés Ville, pasando luego a Buenos Aires para hacerse cargo de la Dirección de los mencionados cursos religiosos En 1943, junto con el Rabino Schlesinguer, fundaron el Majón Lelimudei Haiahaduth (Instituto Superior de Estudios Judaicos), que abasteció durante décadas de maestros judíos a Argentina y a toda América Latina. En 1950 fundó la Escuela Normal para Maestras de Religión y Hebreo (Majoná). Su actuación como docente y creador de escuelas no se circunscribió a Argentina, sino que hizo lo propio en países vecinos como Chile, Uruguay y Paraguay. En 1941, la JCA le encomendó la realización de un censo económico-social del judaísmo argentino. Sentía devoción por Rashi y publicó diversos estudios sobre temas de cultura, tradición y religión judías. Era religioso, pero lejos del fanatismo, porque era comprensivo y tolerante, aunque nunca vaciló en jugarse por la verdad y la justicia, con amor a la tradición judía y a la libertad. Fue dirigente y guía espiritual en la Congregación Israelita de la República Argentina y uno de los líderes muy calificados de la Federación Sionista. Además, colaboró con numerosas instituciones como SOPROTIMIS, Ezrath Nashim, HICEM, KKL y Keren Hayesod. Falleció en Buenos Aires el 18 de febrero de 1951. En Prólogo del Prof. Lázaro Schallman al libro escrito por J. Efron, Amdur, mi pueblo natal (en idisch), Edic. "Comité de Homenaje a la Memoria de ledidio Efron», Buenos Aires, 1973, pp. 5-33. 
la educación primaria laica, religiosa o hebrea fue realizada con el objetivo de dotar a la nueva generación de las herramientas culturales que la mantuvieran integradas en suelo argentino. Como la enseñanza rural estaba muy poco diseminada, sobre todo en las provincias de Santa Fe y Entre Ríos, ya que existía una sola escuela en cada radio de 30 o 40 kilómetros debido a la escasa población escolar de esas regiones casi deshabitadas, obligó a la empresa a ocuparse de la problemática educativa.

La educación hebrea fue exigida por los padres de los educandos que se oponían a que quedase a cargo de la iniciativa privada. Así, la JCA tomó el compromiso de instalar escuelas comunes, edificó locales -construyó 78 escuelas en todas la colonias de Argentina - y convocó a los docentes para impartir la enseñanza judía junto al programa educativo que ya estaba estipulado en la Ley de Enseñanza Común Obligatoria de nuestro país.

Los docentes convocados eran de origen judío, formados por las escuelas de la Alianza Israelita Universal, conocedores del español para que fueran los responsables de la enseñanza de la lengua, ya que en las colonias los judíos no lo hablaban ni lo entendían. Los maestros extranjeros debían no sólo conocer la dicción eslava, idish o hebrea, sino estar en condiciones de comprender la mentalidad de los padres de los alumnos. Tan pronto como las escuelas judías crecieron en las colonias de la JCA, la empresa comenzó a seleccionar como maestros a los hijos de la colonia, ya sea entre los alumnos egresados o entre los jóvenes que llegaban a nuestro país con conocimientos suficientes para transmitir enseñanzas laicas.

Posteriormente, casi todos los maestros de Entre Ríos se graduaron en una escuela de maestros rurales que tenía por objetivo perfeccionarlos en el arte de enseñar de acuerdo con el programa de la escuela superior. Propuesto por el representante de la Educación Común de Entre Ríos, el Consejo General de Educación concedió diez becas anuales a los mejores alumnos de las escuelas israelitas de las colonias que deseaban ingresar a la Escuela Alberdi. ${ }^{19}$ Con la incorporación de

\footnotetext{
${ }^{19}$ Las propuestas de los inspectores hacían hincapié en que el gobierno provincial ofreciera becas en la Escuela Normal Rural Provincial Alberdi. Por una parte, porque al brindar una formación más extensa -3 años de duración- era más factible el aprendizaje del idioma, y por otra, porque ofrecía una preparación en tareas agrícolas y ganaderas que permitiría efectos multiplicadores en las colonias (específicamente en el caso de los judíos) y, por ende, en el desarrollo económico provincial. En síntesis, saldar los problemas del manejo del idioma y de la formación pedagógica de los maestros (los buenos métodos) era
} 
Ios maestros normales y los recibidos en los Cursos Temporarios, se obtuvo el personal diplomado para la enseñanza en las colonias judías de Entre Ríos.

De esta forma, fueron construidas en todas ellas 78 escuelas de enseñanza mixta, que se sostuvieron gracias a la inversión de la JCA (con excepción de unos cuantos años antes de su concesión al gobierno nacional, durante los cuales los colonos debieron contribuir con treinta pesos por año para el mantenimiento de la enseñanza común).

En el año 1916, las escuelas de la JCA, los edificios y todas las dependencias de las colonias Moisés Ville, Montefiore, Dora, Barón Hirsch y Narcisse Leven fueron entregados al Consejo Nacional de Educación. En el año 1919 fueron traspasadas las que restaban: las escuelas de las colonias Clara y Lucienville.

En el proceso de traspaso al gobierno nacional, los colonos entrerrianos se vieron afectados por una cláusula dispuesta por el entonces gobernador de la provincia, Celestino Marcó, al reglamento educativo de su región, determinando que dentro del territorio de la provincia no podría dictarse la enseñanza religiosa en el mismo local donde se suministrara la enseñanza laica. Es decir que los maestros de hebreo no podrían dar las clases religiosas dentro de los locales cedidos al Consejo Nacional de Educación. A pesar de ser de dependencia nacional, los maestros debían someterse a las leyes imperantes en el territorio de la provincia. Ante este problema, el Director General de la JCA en París, Luis Oungre, dispuso la construcción de nuevos edificios, independientes y separados por completo de las escuelas laicas, quedando sólo a disposición de la enseñanza religiosa en Entre Ríos.

Como bien señala Avni, ${ }^{20}$ el móvil de la JCA al fundar esa red educativa era formar una generación joven de "argentinos de fe mosaica" que fuera también una generación continuadora de campesinos afincados en la nueva tierra. De hecho, las escuelas oficiales en general, y las judías en particular, desarrollaron un papel socializador central que fue el cimiento del proceso de integración de los colonos al país.

condición necesaria para obtener resultados positivos en otros rubros de la educación nacionalizante: Historia, Geografía y Moral Cívica. A los contenidos curriculares pertinentes a la educación nacional, los inspectores sumaban la relevancia del culto a los símbolos y la práctica de los rituales cívicos patrióticos escolares con la participación activa de la sociedad civil. Citado por María del Pilar López, op. cit.

${ }^{20}$ Avni, Haim, Argentina y la Historia de la inmigración judía. 1810-1950, Buenos Aires, Editorial Universitaria Magnes, 1983. 
De modo que podemos sostener que la llegada al país y su posterior asentamiento en las colonias del interior fue la consecuencia de una rígida decisión de preservación, no sólo de la vida, sino también de ideales y costumbres, y la defensa de sus creencias más arraigadas como la religión y los saberes que fueron adquiriendo a lo largo de las generaciones.

El pueblo judío tiene una tradición educativa que forma parte sustancial de su historia. Desde el momento en que se identificaron como una entidad distintiva, los judíos han desarrollado sistemas para preservar su legado cultural, que de hecho ha contribuido al avance de la educación, tanto a nivel nacional como a nivel mundial. El sistema pedagógico judío de la antigüedad no sólo anticipó sino que tuvo un impacto decisivo en la educación moderna. Las escuelas judías en Argentina pasaron por tres etapas fuertemente diferenciadas. La primera consta de las escuelas que empezaron con la JCA, la segunda con el Vaad Hajinuj Arashi (Comité Principal de Educación o Consejo Central de Educación Judía) y la tercera en 1958 con el Vaad Hajinuj Hamerkazi (Consejo Central de Educación Judía de la República Argentina). Tiempo más tarde, el templo Lelimudei tomó a su cargo todas las escuelas del JCA. ${ }^{21}$ Tema sobre el que volveremos en páginas posteriores.

\section{El sistema educativo y el currículum escolar}

\section{Los recursos humanos: los maestros marroquíes}

Una vez establecida la necesidad de la creación de las escuelas donde se impartiría la educación laica elemental y la religiosa, quedaban muchas cuestiones por resolver. Una de las dificultades a las que tuvieron que atender fue la búsqueda de docentes. Era indispensable que estos agentes estuvieran altamente capacitados en relación con la enseñanza elemental, ser capaces de enseñar el idioma

\footnotetext{
${ }^{21}$ Avellaneda, María Elena y Cassanello, Carina Alejandra, Las escuelas judías en las colonias agrícolas:

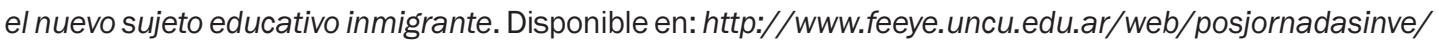
area2/Identidad\%20-\%20sujetos/162\%20-\%20Avellaneda\%20y\%20Cassanello\%20-\%20UBA.pdf p.10.
} 


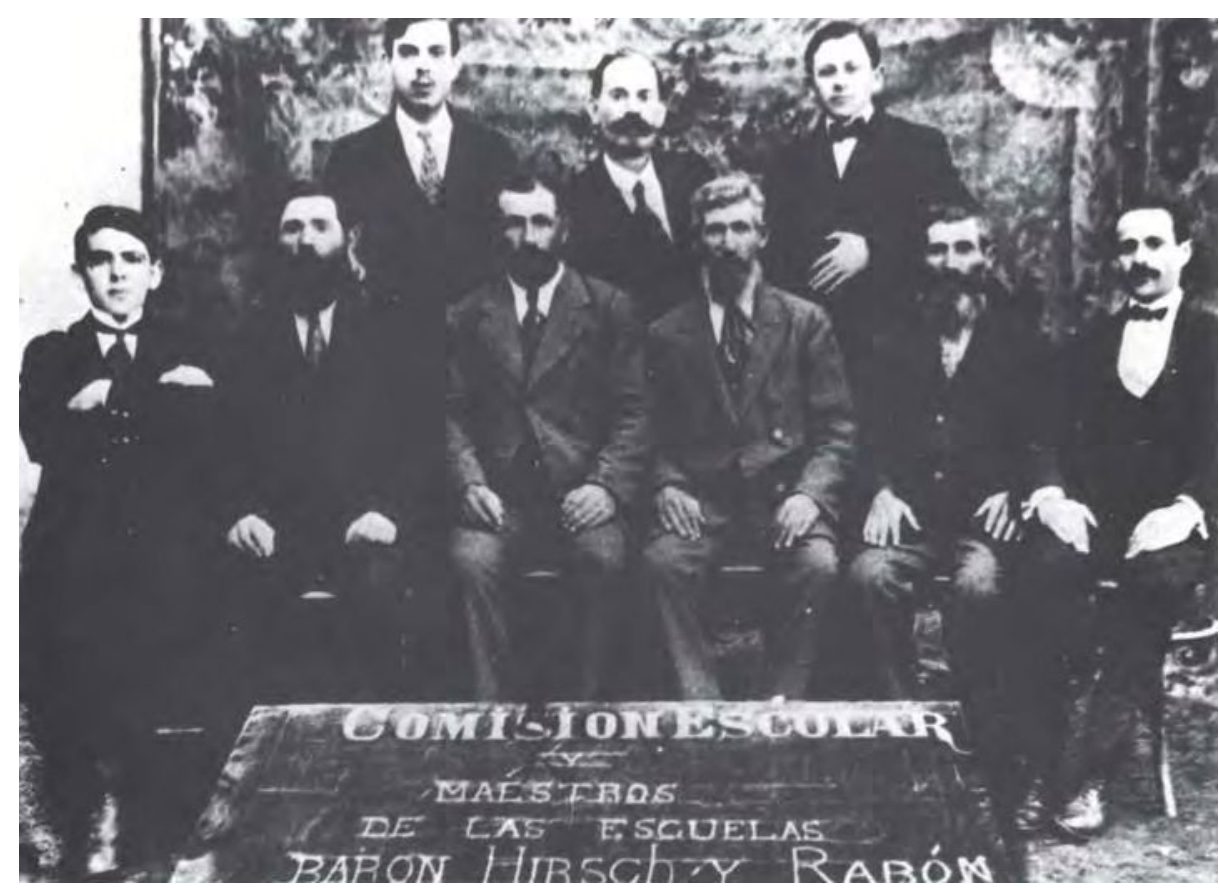

(ya que debían atender a una población que desconocía el castellano) y, necesariamente, ser judíos para entender la idiosincrasia de los colonos.

La JCA recurrió a la experiencia de la Alliance Israélite Universelle (AIU), institución creada en 1860 por Benjamín Crémieux, quien contó para su desarrollo con el apoyo de la alta burguesía judeo-francesa y de financistas de otras procedencias que vivían en París, donde se localizaba la sede. La Alliance tenía como objetivo lograr el progreso de la población judía en sus propios países de origen por medio de la instrucción, desechando la idea de la emigración propuesta por la JCA. Efectivamente, la educación era considerada un instrumento eficaz de promoción social y económica, que además tenía el beneficio adicional que se irradiaba también a las familias de quienes estudiaban. Por ello, la AIU impulsó la creación de una red de escuelas que divulgaran la instrucción europea entre la población judía instalada en las regiones que consideraban atrasadas del Mediterráneo.22

22 Epstein, Diana, "Maestros marroquíes. Estrategia educativa e integración. 1892-1920", en Anuario IEHS, N¹2, Facultad de Ciencias Humanas, Universidad Nacional del Centro, Tandil, 1997. 
La primera escuela que la Alianza creó para su ensayo político fue en Tetuán, Marruecos. ${ }^{23}$ Este proyecto pronto se universalizaría, traspasando las fronteras marroquíes para instalar nuevos colegios en otros países y continentes. Tetuán se convirtió así en matriz de profesores para las escuelas que la Alianza estableció en el resto del norte de África, los Balcanes y el Imperio Turco.

El castellano era la lengua materna de los judíos de Tetuán (hablaban un dialecto castellano, la jaketía). La AIU estableció que la enseñanza que recibirían estos alumnos sería en francés, aunque también instrucción en castellano, mantenido como segunda lengua. Fue justamente el conocimiento de español que recibieron quienes egresaban de las escuelas de la Alianza en Marruecos lo que determinó que la JCA los eligiera para que fueran sus primeros maestros en las colonias judías de la Argentina, ya que se podían comunicar desde un primer momento con sus alumnos y conocían y compartían la mentalidad y la religión de sus padres.

A comienzos de la década de 1890, gradualmente comenzaron a llegar al país los primeros maestros enviados por la Alianza, quienes mantuvieron una fluida correspondencia con su central en París y con la dirección de la JCA.

Recurrimos a estas cartas y a extensos informes que realizaron para poder reconstruir las actividades que llevaron a cabo. La lectura detenida de estos documentos -en francés y español- nos brindó información estratégica para describir los primeros pasos del sistema educativo en las colonias, pero también nos permitió descubrir las sensibilidades y modos de percepción de los mismos agentes sobre la experiencia colonizadora y las tensiones del dispositivo escolar en ciernes.

Constituyen estas cartas - cuyas copias están en el Archivo y Museo de Villa Domínguez-, así como las memorias institucionales y personales, nuestro acervo documental, cuya consulta nos permite la redacción de este apartado.

\footnotetext{
${ }^{23}$ Los mejores estudiantes fueron enviados a París para ampliar sus estudios. Allí, todos sus gastos eran costeados por la Alianza, con el compromiso de parte de los alumnos de quedar adscriptos a la institución y marchar como profesores o directores hacia los lugares donde fueran destinados. En el supuesto caso de que alguno de estos profesores quisiera romper con el compromiso contraído con la AIU, excepto por razones de salud, estaba obligado a indemnizarla con una suma previamente fijada por el Consejo Superior.
} 


\section{Las escuelas en Colonia Clara}

La construcción de las escuelas en las colonias fue un proceso largo y complejo. Si bien es cierto que las primeras escuelas fueron muy precarias, no podemos dejar de reconocer que, a medida que el proceso de colonización avanzaba, se fueron dando los pasos necesarios para la inclusión de los niños al sistema educativo elemental y sin dejar de lado la enseñanza de la religión y la tradición judía. El idioma es un elemento esencial en la conformación de la identidad de un sujeto o grupo social, ${ }^{24}$ ámbito donde se ponen en tensión la conservación de la tradición y la resignificación de saberes. Esto era resuelto en la colonia por la coexistencia de las dos enseñanzas en el mismo establecimiento con doble escolaridad: la instrucción primaria de acuerdo con las normas de la educación provincial y la enseñanza en los cursos religiosos, en idish y hebreo. La enseñanza formal se completaba con cursos especiales para los adultos.

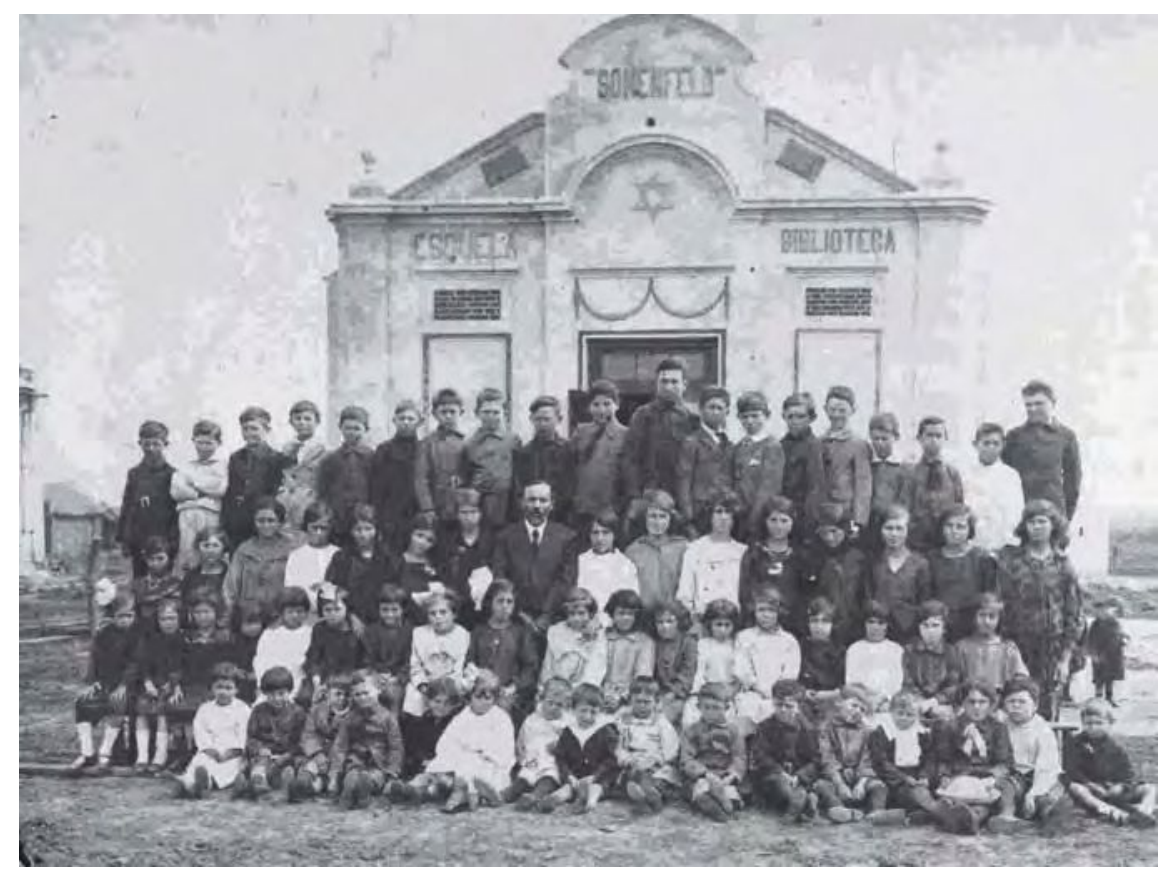

Salón, biblioteca y escuela hebrea, Sonnenfeld (1923)

\footnotetext{
${ }^{24}$ Por lo que muchos de los colonos buscaban que sus hijos hablaran en la escuela el mismo idioma con el que se comunicaban en sus casas, intentando de esta manera no perder las tradiciones y los saberes que los habían caracterizado e identificado dentro de la comunidad. Por esta razón, el tema idiomático fue tan crucial en la educación de las generaciones escolarizadas que llegaron y se instalaron en el país. En María Elena Avellaneda y Carina Alejandra Cassanello, Las escuelas judías en las colonias agrícolas: el nuevo sujeto educativo inmigrante, op. cit.
} 
Marcos Levy, maestro en el Grupo Sonnenfeld, informaba a la Administración de la JCA en Buenos Aires sobre los cursos nocturnos destinados a la población adulta. Relataba que la primera noche eran sólo veinte los alumnos, pero a medida que el trabajo en el campo disminuía, la audiencia en clases aumentaba progresivamente:

Actualmente asisten más de 25 alumnos regularmente. Casi todos los adultos, que tienen entre 15 y 24 años, están comenzando. Se dictan cinco clases por semana, de una hora y media de duración. Son clases puramente prácticas y se dan los materiales que los jóvenes necesitan. Se utilizan dos clases por semana para el estudio de cálculo, otras dos para la lectura y escritura y la otra restante al estudio de la historia y geografía argentina. ${ }^{25}$

El señor José Sabah fue uno de los primeros maestros marroquíes que llegó a Colonia Clara, quien inauguró la primera escuela denominada la Central. ${ }^{26}$ Los avatares para su instalación fueron reseñados en cartas que el maestro envió a la Administración Central de la JCA en París, que nos permiten reconstruir su historia. Por un lado, la descripción de las aulas en donde los bancos fueron alineados en dos filas, por otro, las cartas de zoología, los mapas y las pizarras colgadas en las paredes. Aclara que tuvo el cuidado de añadir un cuadro representando al barón de Hirsch para que "los hijos de los primeros pobladores aprendan a conocer el nombre de su benefactor». ${ }^{27}$

Una tarea no menor fue la de entusiasmar a los padres para el envío de los niños a la escuela. Con este objetivo se esforzó en conversar y discutir con los vecinos de los grupos Rachel, Carmel, Eben Aroscha y Kyriat Arbah, a los que propuso establecer un servicio de traslado en diligencia para los hijos de colonos que

\footnotetext{
${ }^{25}$ Carta enviada por M. Lévy a la Dirección General de la JCA, Buenos Aires, 22 de junio de 1899. Sonnenfeld, Archivo y Museo de Villa Domínguez, p. 6.

${ }^{26}$ Se desempeñó luego como director de la escuela de Carmel, luego inspector regional de Colonia Clara y después ocupó el mismo cargo en Colonia Moisés Ville. Por este traslado ocupó las funciones de inspector en la colonia Clara Moisés Cohen, reemplazado posteriormente por los Jerusalmy y Levy. En Jedidio Efron, La Obra escolar en las colonias Judías, op. cit, p. 244.

${ }^{27} 27$ de mayo de 1895. Carta escrita por el profesor de castellano de la primera escuela de Colonia Clara, Estación Domínguez, dirigida al presidente del Comité Central de París de la JCA. En Archivo y Museo de Villa Domínguez, p. 6.
} 
fueran a la escuela. Todos estaban de acuerdo, aunque el problema que se presentaba era el costo de $\$ 100$ por dicho traslado. Entonces, propusieron que la Administración se hiciera cargo de esos honorarios, por adelantado, hasta la nueva cosecha, salida transitoria y que significaba una nueva forma de endeudamiento con la JCA. Los habitantes de Rachel estuvieron de acuerdo en enviar a sus hijos, en tanto los de Carmel rechazaron la propuesta por la distancia que los niños debían recorrer y reclamaron la construcción de una escuela más cerca de su pueblo y de Ida. El profesor les solicitó paciencia, insistiendo en que debían aprovechar la única escuela existente sin hacerles perder tiempo a sus hijos, a lo que lo padres contestaron, intransigentes, que sus hijos podían seguir esperando, incluso después de estar tanto tiempo "sin cultura intelectual".

El maestro Sabah buscaba todo tipo de incentivos para atraer a los niños, como donar su propio caballo para que fuera la guía o "monitor» de los demás niños en el camino a la escuela. Tarea nada fácil: el trayecto a recorrer era de cuatro a seis kilómetros para luego tener seis horas de clase. Se entiende que es un camino respetable para los niños pequeños, pero la estancia en la escuela les permitiría reponerse suficientemente como para emprender el camino de regreso a casa sin fatiga excesiva, explicaba el docente.

En 1895, el profesor Sabah destacó los inconvenientes que debió superar para atraer a los niños en su primer día de clase:

muy temprano fui... de casa en casa reclamando a los niños para llevarlos a la escuela... Llegué a Raquel hacia las 7 y media de la mañana. A las 9,45 dejé la aldea con mi pequeño regimiento... los esencial era salir a pie para la escuela... Un niño venía a caballo; yo había dado el mío al mayor, que hablaba un poco de español y a quien designé como lugarteniente del batallón escolar para los días siguientes. Así había dos caballeros. Nosotros, los peatones, los seguimos alegremente a pié. Desgraciadamente hacia calor... A pesar de ello el trayecto no pareció muy largo. Alentaba a los niños para que charlen, para que rían, para que me pregunten; les llamaba la atención sobre los campos cubiertos de pasto que se extendían a nuestro alrededor... y ellos no tardaron en expresar su admiración por medio de exclamaciones simples e infantiles. Parecían estar encantados del paseo matinal... 
A mitad del camino nos extendimos sobre la hierba para reponer el aliento. Era necesario, desde los primeros días, interesar y ganar a los niños haciéndolos apreciar la escuela... distribuí caramelos, regalo de su maestro... A la mañana siguiente envié al profesor de hebreo a Raquel para que acompañase a los alumnos a la escuela y le recomendé especialmente que él viniese a pié, como lo había hecho yo en la víspera. Yo retomaría mi turno el $3^{\circ}$ día, hasta crear en los niños el hábito de venir a la escuela... ${ }^{28}$

\section{Establecimientos educativos y nuevos maestros}

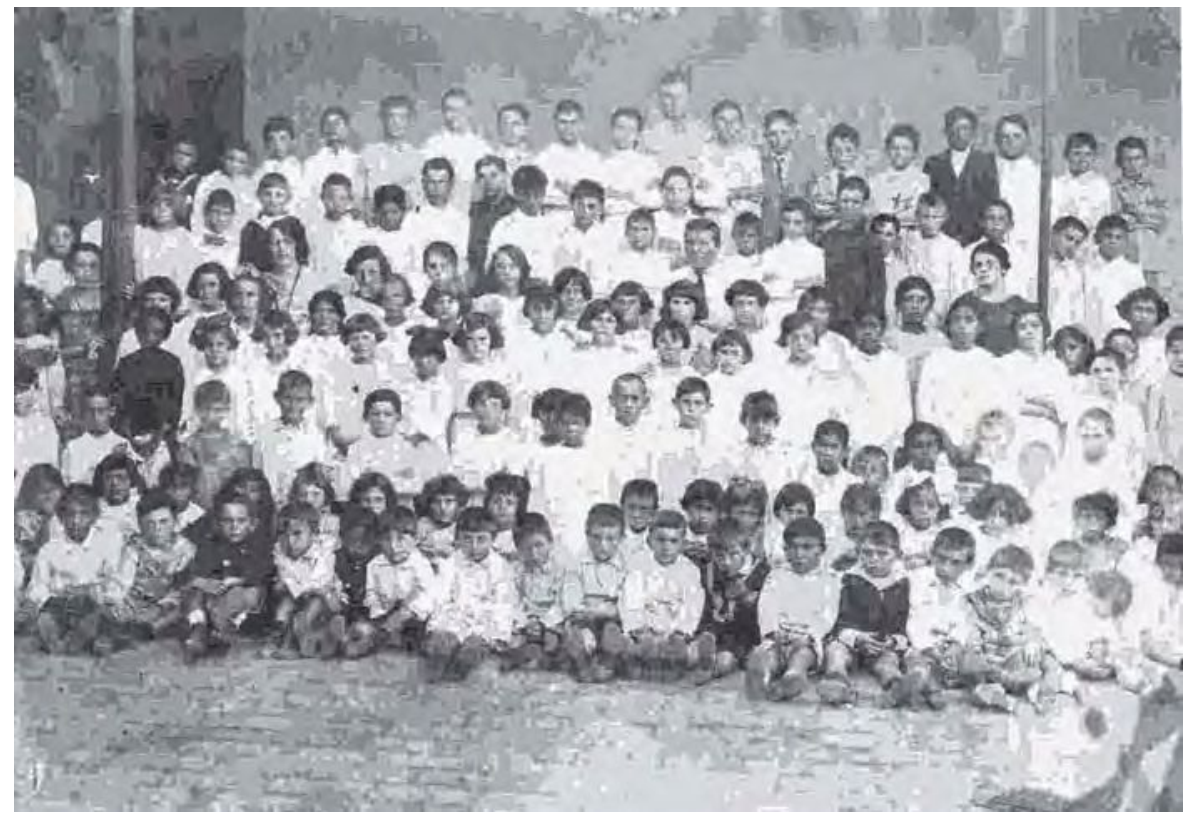

Isidoro Suárez, Villa Domínguez

La empresa educativa requería de más establecimientos y nuevos maestros. Para lograr el éxito de la "obra", era necesario encontrar personal consciente, difícil - pensaban- de reclutar en el país. Sin duda, esta fue la causa por la cual en 1895 recurrieron nuevamente a la Alianza para obtener la contratación de otros quince profesores, reconociendo, definitivamente, que esta institución era la más

\footnotetext{
${ }^{28}$ Alianza, Correspondencia, profesor Sabah, 1895, Colonia Clara, Argentina I 0 2, Archivo AlU, París, Citado por Diana Epstein, Maestros Marroquíes Estrategia Educativa e Integración, op. cit.
} 
indicada para proporcionarlos. Por eso, enviaron una carta solicitándoles urgentemente el envío de nuevos profesores o adjuntos capacitados para organizar los establecimientos. Estos docentes deberían cubrir las necesidades que implicaba la apertura de al menos quince centros escolares, que se crearían con el objetivo de evitar las largas distancias que debían recorrer los alumnos para concurrir a las escuelas. ${ }^{29}$

Además, la escasez de recursos materiales era indudable. La precariedad de los edificios y la ausencia de elementos didácticos se deducen por el énfasis con que los reclamaban a los directores de la JCA en Buenos Aires.

No tengo bancos ni lugar suficiente para una $3^{\circ}$ clase ¿qué hago? Les pido pues, señores directores, dar las instrucciones necesarias para la buena organización de la escuela que Uds. me han confiado. ${ }^{30}$

Se solicitaba también con frecuencia el envío de libros escolares (Historia Sagrada de V. Duruy, traducción de Mariano Urrebida, Historia Argentina de Benigno T. Martínez, Ciencias Naturales de E. Taboada, Curso de Geografía de E. Bavio, Idioma Nacional de Isaac Larrain, la Santa Biblia versión castellana) y mapas (hemisferios, de la República Argentina, de la provincia de Entre Ríos) para facilitar sus clases. Por otro lado, les preocupaba mejorar las condiciones por el "estado silvestre de la quinta" propia de la escuela. Deseaba enseñar a los alumnos agricultura y horticultura y así poder plantar árboles y flores en ese sector. Pide que le envíen palas, rastrillos, semillas y árboles. ${ }^{31}$

Otra inquietud manifestaban los maestros: la competencia que «maestros improvisados" les hacían al establecer aulas en domicilios particulares, quienes, cobrando \$1 por persona, raleaban las filas de los alumnos matriculados. Confiaban en que el Consejo Escolar de Villaguay obligara a cerrar las puertas de estos locales. Uno de ellos se instaló en Villa Domínguez - dirigido por una maestra argentina- al que concurrían niños católicos y judíos. Esta situación estaba en franca

\footnotetext{
${ }^{29}$ Alianza, Correspondencia, 11 de enero de 1895, Archivo AIU, París. Carta enviada por los directores de la JCA en Buenos Aires, Hirsch y Cazés, a la Alianza en París.

${ }^{30}$ Alianza, Correspondencia, 1897, profesor Sabah, Colonia Clara, Argentina I 0-2, Archivo AlU, París

${ }^{31}$ Hermann Ascher, maestro de la escuela Belez de Colonia Clara, carta a la Dirección de la JCA solicitando material bibliográfico, septiembre de 1898.
} 
oposición con las demandas que habían cursado los colonos, que requerían más horas de enseñanza del hebreo, ya que "los alumnos israelitas de la pequeña escuela de Domínguez pierden de vista la enseñanza religiosa». ${ }^{32}$

Las instrucciones recibidas desde la Administración de Buenos Aires eran seguir mejorando la calidad de la educación en las escuelas, los buenos resultados traccionaría la voluntad de los padres de sacar a sus hijos de los Jeder (escuela religiosa donde los niños reciben formación judía) particulares para reinsertarlos en las escuelas de la colonia. ${ }^{33}$

\section{Ausentismo}

Más allá de las dificultades vinculadas a los escasos edificios escolares y de recursos didácticos para la enseñanza, preocupaba a los docentes las reiteradas inasistencias de los alumnos, que se explicaban por variadas causas. El ausentismo se debía a las largas distancias que debían recorrer los niños, a la falta de un sistema de transporte ${ }^{34}$ - que nadie tomaba las medidas para su instalación-, también a los problemas climáticos que incidían en la azarosa asistencia a las clases.

hace 10 días hay lluvias torrenciales que volvieron imposible las comunicaciones [...] Los alumnos no vienen [...] Hay numerosas ausencias [...] Lo peor es que esas ausencias pueden durar todo el año escolar. En efecto, en el invierno son las Iluvias, en el verano la cosecha, en el otoño el laboreo y el sembrado: no hay estación que me permita tener todos los alumnos un poco cerca [...] Se podría remediar levantando escuelas cerca de los grupos habitados. ${ }^{35}$

\footnotetext{
${ }^{32}$ Carta enviada por J. Sabah desde Colonia Clara al señor director de la JCA, 5 de junio de 1899.

336 de junio 1899. Carta enviada por la JCA, firmada por Hirsch desde Buenos Aires, al señor M. Levy de la Colonia Clara.

${ }^{34}$ Colonos del grupo Novobug N², pertenecientes a la Colonia Lucienville, se dirigieron en 1901 a la Dirección General de la JCA en París, señalando en su precario castellano «la falta de caballos (pues), necesitando el colono los caballos para su trabajo agrícola, no puede servirse de ellos para llevar los niños a la escuela". Agregaban que "Hemos hecho ya una prueba para llevarlos en carros, pero es también inejecutable, generalmente en la época de trabajo [...] Todo esto causa una ausencia de días y aun semanas. Y nosotros los padres observamos con mucho dolor la mala educación de nuestros desgraciados niños los cuales quedan idiotas sin tener instrucción mas elemental necesitada para un campesino simple».

35 Ibídem.
} 
En abril de 1899 se inauguró la escuela en Barón Guinzburg N. Se terminó la construcción de la escuela y las casas para los maestros de castellano y de hebreo. ${ }^{36}$ La escuela abría sus puertas para dar cabida a 65 alumnos, 34 varones y 31 mujeres, a los que se sumaron otros 20 luego de finalizada la siembra. En el conjunto de alumnos inscriptos figuraban 8 argentinos, 5 niñas y 3 niños. El maestro Habib comunicaba:

Me pone feliz que se presenten para ser admitidos. No es necesario extenderse sobre todos los beneficios que pueden tener nuestros hijos al estar en contacto con ellos que hablan constantemente en español. ${ }^{37}$

En un extenso informe, el maestro describe las modalidades y las expectativas para analizar los progresos del proceso educativo, donde se combinaba la enseñanza de la lengua española, la hebrea y la agricultura. La riqueza de la narración nos invita a reproducirlo en toda su extensión:

Así se organizan las cosas en la escuela de la colonia: «el maestro forma 4, 5, 6 o más divisiones. A veces se ocupa de uno, a veces de otro. Así que si usted entra en un salón de clase verá un pequeño grupo en lectura, otro en escritura y otro grupo más allá charlando sin hacer nada». No son clases homogéneas sino que hay 4 o 5 alumnos de la división que van más adelantados, una mayoría que avanza a ritmo parejo y una proporción de éstos abandona antes de fin de año, pero saben leer, escribir y contar bastante bien. La división superior cuenta con 39 alumnos: 24 varones y 15 mujeres. En la división inferior son 26 en total: 10 varones y 16 mujeres. De manera rotativa entramos en estas dos clases el maestro de hebreo y yo, de manera que los alumnos tengan alternativamente una hora en español y una hora en hebreo. Estoy muy contento con mis alumnos: son inteligentes, aplicados y res-

\footnotetext{
${ }^{36}$ La casa que me han construido es bien cómoda, pero tiene un gran defecto: es húmeda y eso hace que yo sufra de vez en cuando de reumatismo. La casa del maestro de hebreo es más húmeda que la mía y eso la convierte en inhabitable. Esto se debe a que han construido la casa bajo la lluvia total y de manera precipitada. 27 de junio 1899. Carta dirigida a los directores, firmada por M. Habib desde Colonia Clara, Barón Guinzburg N.

3727 de junio 1899. Carta dirigida a los directores, firmada por M. Habib desde Colonia Clara, Barón Guinzburg N.
} 
petuosos. Algo a tener en cuenta es que en general son más estudiosas las mujeres que los varones, ellas asisten regularmente y van más avanzadas. Esto se relaciona con que los varones son reclamados para trabajos en el campo y por esta razón se ausentan durante algunos días o meses. Con respecto al programa adoptado para las dos clases, se restringe a la enseñanza de la lectura, escritura, cálculo y especialmente el idioma. "Hasta que los niños no sean capaces de entender lo que digo en español, no pasaré a otro tema. Que sepan hablar, leer y escribir después de dejar la escuela ya será un buen resultado". Respecto de la enseñanza de historia y la geografía en este momento sólo se les dará algunas ideas generales al respecto. No acepto que pasemos, como se hace en algunas escuelas de la colonia, una o dos horas por semana enseñando estas materias, cuando los niños aun no saben ni los nombres más usuales de la lengua española. Debemos entender que el tiempo es corto y que los padres envían con lamento/tristeza a sus hijos a la escuela. "No nos preocupamos por hacer de nuestros hijos pequeños científicos, sino de enseñarles español, un idioma europeo y americano a la vez". Ponemos en sus manos un instrumento de educación, que si más tarde con buena voluntad, pueden mejorar (la lectura, la agricultura, etc.). Además, aprender el idioma les posibilitará leer obras de todo tipo. Uno de los problemas de los alumnos es la mala pronunciación que tienen al leer, pero van mejorando a lo largo del trimestre. Con respecto a los demás niños utiliza el método del sistema argentino que consiste en una primera lectura por sílabas, recurriendo a una pizarra. Es el método más eficiente para enseñar el abecedario.

Los libros que existen son buenos para las escuelas a las que van los pequeños argentinos, pero no para las nuestras. Por eso, he desarrollado algunos ejercicios que contienen sólo palabras comunes del lenguaje. De esta manera los niños ya saben un montón de nombres, adjetivos y verbos que utilizan con relativa facilidad y con los que hacen bien las oraciones. También uso de vez en cuando una hora para charlar con los niños y hacerlos hablar entre ellos en español.

El maestro de hebreo se llama M. Schapira y sabe mucho sobre el arte de enseñar. M. Sidi es el encargado de enseñar agricultura en la escuela, durante cuatro horas semanales. Hemos donado a cada alumno de la división superior una porción de tierra que cada uno cultiva y cuida. Ya han realizado un buen trabajo en el patio de 
la escuela, cada uno en su parcela de tierra, cosechando sus frutos. Se trabaja principalmente sobre las plantaciones cultivadas en la región: maíz, alfalfa y cebada. Como las tareas de agricultura sólo son para varones, esta pensando abrir un curso de corte y confección para las mujeres. El curso lo puede dar la hija de la maestra de hebreo, pero deberíamos pagarle entre 15 y 20 pesos al mes. Si se pudiera hacer ese sacrificio, nuestras alumnas tendrían el curso este mismo mes. ${ }^{38}$

El inspector José Millán elogiaba los esfuerzos que realizaban los maestros en colonia Clara. Refiriéndose a José Sabah, decía:

desde el primer día ha impartido la enseñanza en la lengua española [...] Explica Historia Nacional [...] Nuestras fiestas cívicas han sido conmemoradas y nuestro bello Himno Nacional se recita y es cantado por los ciento veinte alumnos de la escuela [...] Mi propósito ha sido dar a conocer que en esta escuela, destinada a la población escolar extranjera, costeada por la Empresa Colonizadora Judía [...] se nacionaliza la enseñanza y se instruye a los niños para incorporarse a la obra del progreso argentino. ${ }^{39}$

A la normativa educativa provincial que prescribía cuáles eran los contenidos mínimos a impartir -enseñanza del idioma, historia, geografía nacional, derechos y obligaciones de los ciudadanos, nociones de urbanidad, etcétera- se agregaron otras acciones que remitían al plano simbólico, como la instalación de los rituales cívicos patrióticos escolares. El dispositivo cívico patriótico se consolidó en mayo de 1899, cuando la CGE estableció que los inspectores debían hacer efectiva la conmemoración de los aniversarios patrios en las escuelas -especialmente las rurales- trabajando con los directores, quienes debían reunir a los alumnos y explicarles el himno nacional. Los inspectores debían realizar una crónica de las actitudes de las escuelas de la provincia frente a la conmemoración de las fechas patrias y remitirlas a la Inspección General.

\footnotetext{
38 Ídem.

39 "Interesantes datos sobre una escuela rural israelita en Villaguay", en La Educación, 15 de noviembre de 1895, pp. 270-271. Citado por Bertoni, op. cit., 2001, p. 202.
} 
Desde el poder central se concebían estos rituales como el vehículo eminente de moralización cívica. Además, se proponía atraer a los vecinos a estos actos esperando que dicha enseñanza operara como multiplicador del sentimiento ciudadano. Como bien señala Carli, futuro ciudadano era el niño pero también el colono adulto. ${ }^{40}$

De modo que los rituales cívicos patrióticos eran concebidos como un espacio público común donde escolares, maestros, padres y vecinos se reunían para rendir culto a esa entidad superior construida por la patria. Como describe López, el desarrollo ritual se enmarcaba en la delimitación de momentos claves: concentración alrededor del monumento donde se entonaba el himno nacional, el ágape en la escuela y la concurrencia de los padres para conocer el trabajo de sus hijos, el Te Deum, la procesión cívica, una nueva entonación del himno nacional para cerrar el programa diurno y por último la velada nocturna. La jornada se constituía en un verdadero espacio público común que reunía escuela, Iglesia, sociedad y fuerzas policiales y/ militares. ${ }^{41}$

Recuerda Yauda Kuzniecky Levit, colono que cursó su enseñanza primaria en la Escuela Nº 11, Isidoro Suárez, en Villa Domínguez:

Las fiestas patrias, 25 de Mayo, 9 de Julio, 20 de Junio, día de la Bandera, se celebraban con desfiles escolares desde la escuela hasta la plaza y en algunas ocasiones tuvimos la participación de la Banda del Regimiento de Villaguay, de muy reciente creación. ${ }^{42}$

En ocasión de la fiesta nacional del 9 de julio de 1906, el director Jerusalmy informaba a la Administración Central que en el ámbito de la escuela se reunieron seiscientas personas.

\footnotetext{
${ }^{40}$ Carli, S., op. cit., p. 86.

${ }^{41}$ Crónica general del las fiestas del 25 de mayo de 1899. Boletín de Educación, p. 1601. Citado por López, M. P., op. cit., p. 75.

42 Entrevista a Yauda Kuzniecky Levit. "Nací el 19 de Enero de 1934 en La Capilla, hoy Ingeniero Sajaroff. Cuando tenía tres años y medios mis padres se trasladaron a Villa Domínguez, lugar donde curse mi escuela Primaria en la escuela Numero 11, Isidoro Suárez. En Villa Domínguez pasé mi infancia, celebré mi Bar Mitzva, mayoría de edad religiosa en la religión judía y a esa misma edad me trasladé a Buenos Aires donde permanecí en un internado cursando mis estudios secundarios, pues en Villa. Domínguez no había escuela secundaria."
} 
en vísperas de despertar un poco de movimiento y alegría en la colonia y con el fin de despertar una sensación de patriotismo entre nuestros colonos e inspirar el amor por este país en el que viven libres y felices, organizamos una representación teatral y una rifa. ${ }^{43}$

\section{La relación de los maestros con los colonos}

El establecimiento de la red educativa tuvo sus matices conflictivos, como toda la experiencia colonizadora. El desencanto, los enfrentamientos y las disputas estuvieron a la orden del día. Jedidio Efron, el destacado maestro e inspector de la enseñanza en las colonias, con tono mesurado las manifestó:

la selección de dicho personal no dio siempre resultado positivo, por cuanto muchos de estos maestros, no obstante ser judíos, no pudieron comprender la mentalidad de sus hermanos de raza y congeniar con ellos. ${ }^{44}$

Los maestros marroquíes demostraban su descontento y decepción por las características que había adoptado la misión que les habían encomendado en estas tierras: algunos se mostraban sorprendidos y contrariados por las tareas que les había asignado la empresa colonizadora en la administración de la colonia, cuando su formación era exclusivamente docente y el contrato se había realizado por esta alta calificación; ${ }^{45}$ las condiciones de vida no eran las esperadas ni a las que estaban acostumbrados, los salarios eran bajos y el costo de vida alto; ${ }^{46}$ el clima

\footnotetext{
${ }^{43}$ Carta enviada por H. Jerusalmy desde Basavilbaso, el 14 de julio de 1906, a los directores de la JCA en Buenos Aires.

${ }^{44}$ Efron, Jedidia, "La Obra escolar en las colonias Judías", en 50 años de colonización judía en la Argentina, Buenos Aires, DAIA, 1939.

${ }^{45}$ El maestro Sabah no disimuló su asombro y malestar cuando los directores de la JCA en Buenos Aires "le hablaron de administración [...] todo esto es nuevo par mí (señalaba) que no sabía que debía salir de la pedagogía al venir a la Argentina”. Esta situación ambivalente generó las primeras tensiones en estos docentes, que no se sintieron capacitados para cumplir con esa doble tarea, "ya que su rama (era) la educación".

46 "Si no les damos a los maestros los medios para tener un interior confortable, de procurarles algún bienestar, no se quedarán en las colonias, donde su existencia, es necesario convenir, será penosa desde ciertos puntos de vista y donde el género de vida difiere completamente de aquél al que están acostumbrados. O volverán a su país o encontrarán una mejor situación en Argentina», explicaba el administrador en Buenos Aires a la Oficina Central de París.
} 
horrible les provocaba la pérdida de la salud (no está de más recordar que sólo problemas de salud podían poner fin al contrato de adscripción con la AIU que los ligaba a la misión en Argentina); el exceso de trabajo, la soledad, la distancia con la familia, la falta de contacto con el mundo civilizado (solicitaban encarecidamente el envío de material de lectura: "Anales políticos y literarios", el "Univers" y los boletines mensuales de la AIU, como mínimo).

Sin embargo, otro problema no menor flotaba en el aire debido a la desconfianza mutua entre los colonos asquenazíes y los maestros sefarditas. Los colonos llamaban a los maestros marroquíes occidentalizados "judíos españoles", lo cual era una forma de decir que eran «judíos, pero que parecen no judíos». También los llamaban "turcos", e incluso surgieron dudas sobre su judaicidad. Por otro lado, las tareas administrativas que muchos de estos maestros desempeñaban los ponían muy cerca de la empresa colonizadora, por lo que adquirían posturas intransigentes frente a las demandas y reclamos de los colonos. Muchos testimonios dan cuenta de la imagen y concepto que tenían de estos. Sobre todo durante los primeros años, realizaron referencias relacionadas con su comportamiento, tildándolos en general de impacientes e indisciplinados y en determinados casos de "malos elementos". El maestro Sabah los definía como impacientes y obstinados, señalando que "el desaliento se apodera de ellos y se propaga". Tal vez, esta es la razón que los lleva -según su opinión- a tomar decisiones apresuradas, entre otras la de dejar las colonias e irse a Buenos Aires o a las pequeñas ciudades de Entre Ríos, «a trabajar en oficios fáciles y poco lucrativos". Esta disconformidad y el posterior abandono de las colonias fueron considerados por Sabah como un acto irreflexivo.

\begin{abstract}
Estos imprudentes -señalaba- no conocen el valor de la perseverancia y que, tarde o temprano, obtendrían su recompensa del trabajo laborioso [...] la generación actual de colonos no parece ser digna de todo el interés que le manifestamos. La mayoría desea explotar la situación. Acá, como en otras colonias, falta disciplina [...] puede(n) dirigirse así, hacia la anarquía. ${ }^{47}$
\end{abstract}

\footnotetext{
47 Alianza, Correspondencia, profesor Sabah, 12 de agosto de 1895, Colonia Clara, Argentina I 0 2, Archivo AIU, París. Citado por Diana Epstein, Maestros marroquies, op. cit.
} 


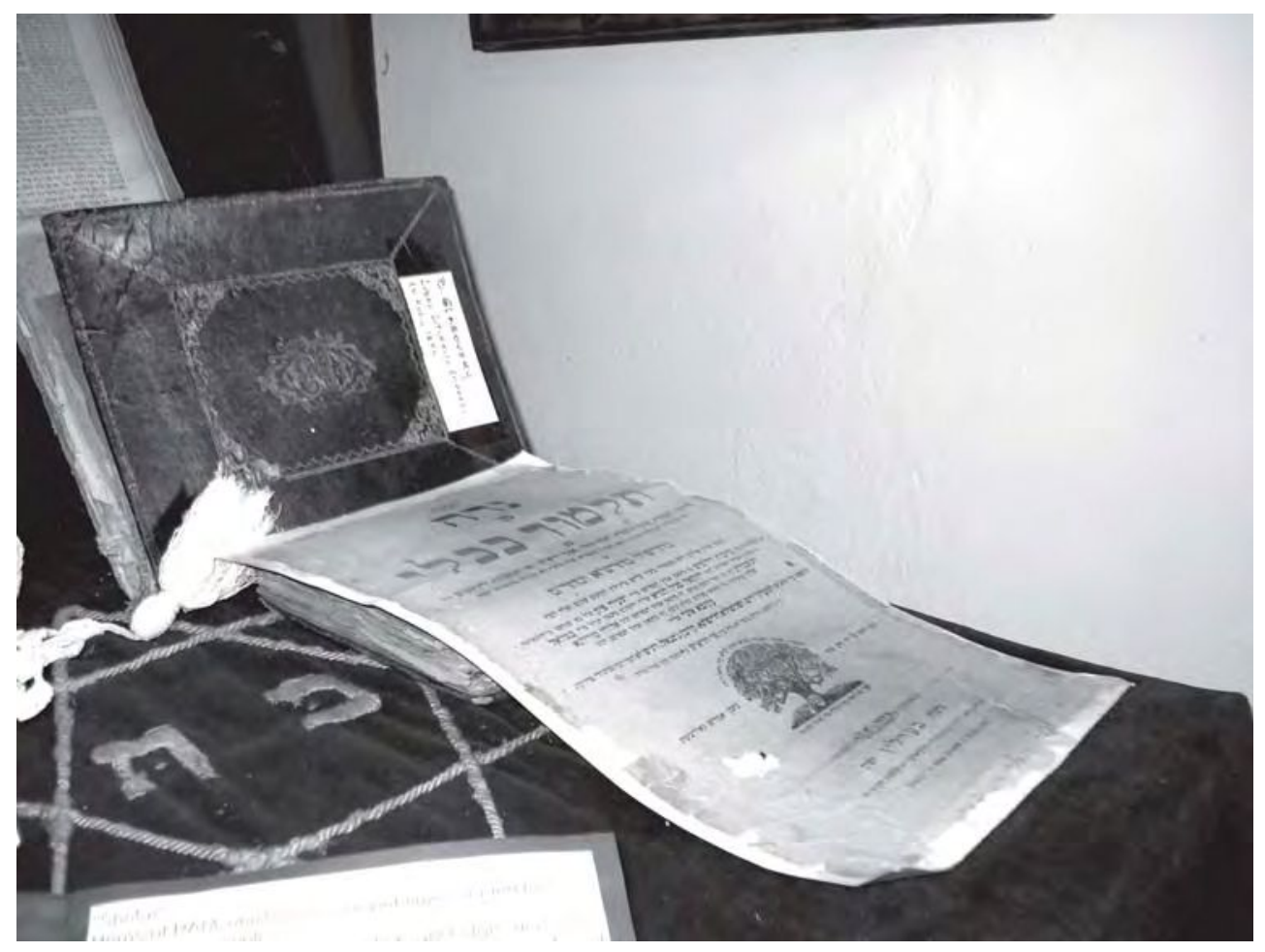

Sidur de la familia Glagovsky traido de Rusia (1898).

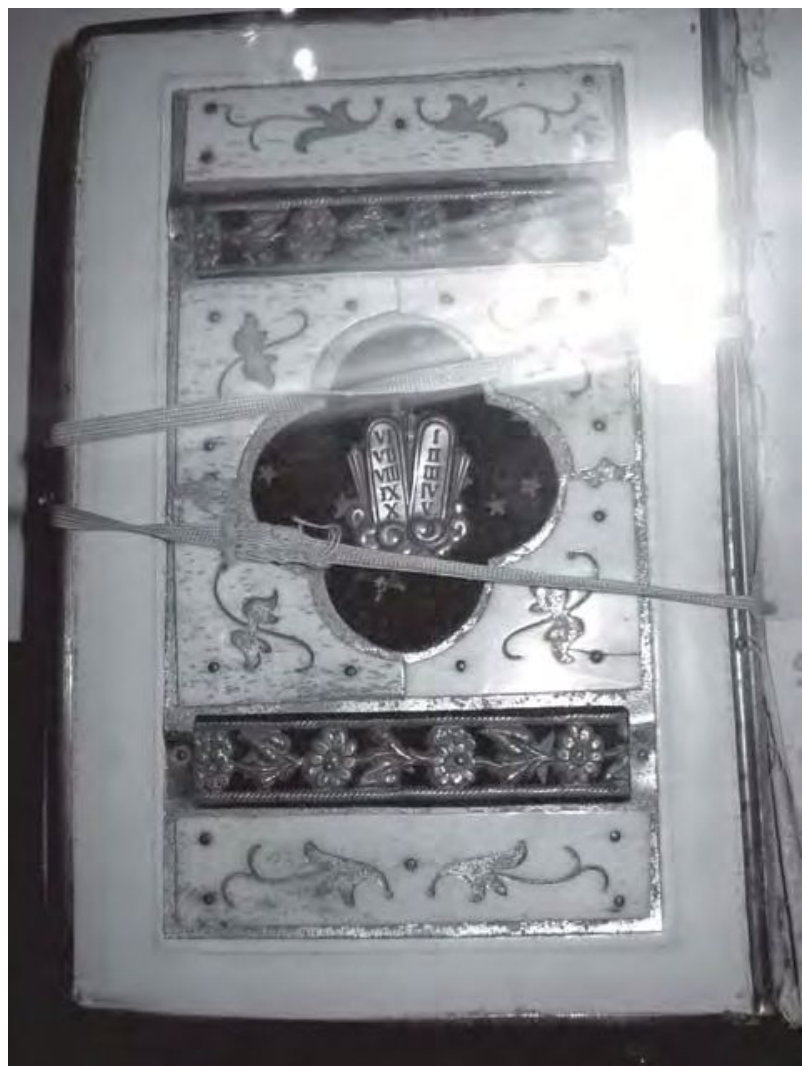

Sidur de Fabián Efron 
La literatura abunda y pinta con todo realismo estos enfrentamientos. La mirada que nos dejó Marcos Alpersohn ${ }^{48}$ del profesor Haym es reveladora de la suspicacia con que los colonos veían a estos maestros:

arribó a la colonia un nuevo personaje, un hombre bajo y grueso, de rostro blanco y pequeñas manitas [...] Su nombre era profesor Haim y los colonos lo bendijeron con un sobrenombre: "el jesuita blanco" o «el espía francés». El era, me parece un francés-hispano-marroquí, un producto de la Alliance Israélite Universelle, la ultraasimilada asociación judeo-francesa. Formalmente había sido enviado para ocuparse sólo de las escuelas, pero a los problemas de la educación no se dedicó en absoluto. Solamente espiaba a los colonos, los mortificaba y los mordía, como una víbora por la espalda.

En relación con la llegada de estos docentes, Alpersohn opinaba con ironía que para la enseñanza del español, la JCA había conseguido de su amiga, la Alliance Israélite Universelle, un manojo de jóvenes maestros marroquíes salidos de sus fábricas de educadores. Esos maestros enseñaban a los chicos castellano gangueándolo con el acento francés. ${ }^{49}$

La literatura y otra serie de testimonios dan cuenta de los excesos y de la crudeza en la aplicación de normas disciplinarias que imponían los maestros marroquíes, así como las deficiencias en la formación pedagógica y en la didáctica utilizada.

\footnotetext{
${ }^{48}$ Arribado a Buenos Aires el 23 de agosto de 1891 a bordo del vapor Tioko junto con otros trescientos inmigrantes judíos, Marcos Alpersohn es trasladado a Carlos Casares y de allí a la Colonia Mauricio, de la cual fuera uno de los primeros integrantes. Durante muchos años, desde los días de su llegada al país, fue recopilando pacientemente, con visión de cronista, datos, impresiones, recuerdos, que le sirvieron luego como base para la redacción de su obra. Este trabajo aparece publicado en Buenos Aires en tres volúmenes que llevan el título de Colonia Mauricio y fueron escritos en idish. Algunos de los capítulos de esta obra, traducidos al castellano, integran varios ejemplares de la revista Judaica, dirigida por Salomón Resnick.

${ }^{49}$ Alpherson, Marcos, Colonia Mauricio: memorias de un colono judío, Comisión Centenario de la colonización judía Informe del administrador de Colonia Clara, 1944-1954. Algunas Impresiones sobre Colonia Clara sobre movimientos de colonos habidos durante los 10 últimos años. 1944-1954. Estrictamente Confidencial en colonia Mauricio, Carlos Casares.
} 
Tomemos un solo caso, el de Seidel Zeigner, ${ }^{50}$ egresado de la Escuela Normal Rural Alberdi, quien se desempeñó por largos años como maestro en las escuelas de la colonia. En sus recuerdos de infancia nos relata cómo fue su experiencia con los maestros marroquíes: ${ }^{51}$

Mi iniciación escolar coincidió con la inauguración del edificio escolar de Carmel, el único edificio de la colonia revocado por fuera y pintado de blanco y que al compararlo con las modestas y rústica viviendas de los colonos nos parecía una lujosa mansión. Allí conocí al que fue mi primer maestro, don J.S., hombre severo en extremo, sumamente autoritario e irascible, cuyo rígido sistema disciplinario hacía digno "pendant» con el desastroso método pedagógico que regía la enseñanza. No se toleraban las faltas más insignificantes ni se perdonaban las menores transgresiones a las disposiciones reglamentarias instituidas por el maestro según su voluntad y entendimiento. ${ }^{52}$

Los castigos consistían en poner de rodillas a los niños sobre el piso de ladrillos, en el que se esparcían granos de maíz para hacer más duro el escarmiento, golpes con la regla tanto de plano como de canto para rectificar conductas, repetición hasta el agotamiento de las treinta letras del abecedario, entre otros. Un caso extremo fue el aplicado al niño que tomó una tiza:

Descubierto el hurto, su autor fue condenado a recorrer la calle de la colonia de extremo a extremo y llevando en la frente una cartulina con una inscripción hecha en grandes caracteres: LADRON.

\footnotetext{
${ }^{50}$ Seidel Zeigner (Carmel, 1898-La Calera, 1974). Fue un querido maestro rural, y como homenaje a su pueblo natal escribió un libro de recuerdos Ilamado "Carmel. La hija del Coronel". Su iniciación escolar fue en Carmel y sus primeros maestros fueron los israelitas sefaradíes. Cursó en la escuela agropecuaria Justo J. de Urquiza, de Villaguay, donde, al finalizar sus estudios, fue becado para seguir la carrera de Magisterio en la Escuela Normal Rural Juan Bautista Alberdi. Se graduó de maestro en 1912. La primera escuela que le toco dirigir estaba en Nogoyá, luego la escuela № 10 de Colón y posteriormente la escuela № 104, en el Grupo Eben Haroscha, a 6 kilómetros de Villa Domínguez. Fue, además, un gran cooperativista y consagrado periodista. En Chiaramonte, S., Finvarb, E. y otros, Tierra de promesas. 100 años de colonización judía en Entre Ríos. Colonia Clara, San Antonio y Lucienville, Buenos Aires, Ediciones Nuestra Memoria, 1995, p. 131.

${ }^{51}$ La descripción del maestro en la "clase mayor": "tuve como maestro a un señor de alta estatura, cara chata adornada con una hermosa barba, de habla gangosa y nariz tan pequeña y aplastada que se perdía entre su pómulos salientes. Mejor jinete que pedagogo, no tenía noción alguna de la ciencia y el arte de enseñar; pero eso sí; manejaba a la perfección la regla y el puntero", p. 32.

52 Zeigner, Seidel, Carmel, La Hija del Coronel. Recuerdos de Infancia, 1975, p. 10.
} 
Concluye Zeiner comentando:

han transcurrido muchas décadas y este recuerdo perdura en mi memoria, fuertemente impresionada por la brutalidad del castigo y el gesto de dolor y de vergüenza reflejado en el rostro de mi compañero de banco. ${ }^{53}$

Las arbitrariedades y mal trato de estos maestros no fueron casos excepcionales. En 1912 la Dirección General de JCA envió una circular a los directores de las Escuelas en la que señalaba que:

es terminantemente prohibido pegar a los alumnos y que no permitimos, bajo ningún concepto, que se empleen en caso de necesidad, otros castigos para con los alumnos que los que pueden afectar el amor propio de los alumnos y que son mucho más eficaces que los medios brutales que abogan muy poco a favor de la enseñanza. Recomendamos además a los Sres. Directores de escuela hacer extensiva dicha prohibición a los profesores que estén bajo sus órdenes y así mismo velar para que estas instrucciones sean observadas muy rigurosamente. ${ }^{54}$

\section{Desnudando las tensiones: el Informe Bavio de 1908}

A partir de la sanción de la Ley Láinez de 1905, que establecía la ayuda del Estado nacional para la creación de escuelas elementales en las provincias que lo necesitaran, se encomendó al Inspector General de Escuelas de la provincia de Entre Ríos, Ernesto Bavio, que realizara una gira de inspección para determinar en qué puntos de la provincia era indispensable su instalación. El resultado de su misión fue dado a conocer en 1908, mediante un informe en el que Bavio denuncia que:

\footnotetext{
53 Idem, p. 20.

${ }^{54}$ Dirección General Jewish Colonization Association, Circular N 154 del 9 de abril de 1912. Caja JCA, Archivo IWO, 1005/831. Concluye la circular previniendo a los docentes que en el caso de infracción a esta disposición y si resultaran ciertos los cargos de esa índole contra un profesor, la empresa se vería obligada a "despedirlo de nuestro servicio sin consideración de ninguna clase».
} 
En las escuelas de las aldeas ruso-alemanas la enseñanza que se trasmite es en su letra y en su espíritu exclusivamente extranjera [...] Si el lenguaje, si la lectura y la escritura es dada en idioma extranjero es claro que lo propio sucede con la geografía, aritmética y demás ramos [...]

En una palabra nada nos recordaba allí que estuviéramos en escuelas argentinas parecía aquél un pedazo de territorio conquistado.

Lo que ocurre en las "aldeas judías" es todavía peor, pues son los colonos más cerrados y excluyentes: allí toda la enseñanza transmitida en las escuelas, absolutamente toda, es en hebreo y no hay más libro de lectura que la Biblia.

Las colonias judías pertenecen a una gran compañía con asiento en el extranjero, propietaria de la tierra y de sus judíos. Representada por una administración local que monopoliza todos los servicios, hasta el de la educación, pues ella es la que organiza las escuelas, que designa el personal y lo que es increíble, las hace subvencionar por el gobierno de la Provincia. ${ }^{55}$

La gravedad de las acusaciones y la repercusión de las mismas -fueron publicadas en los diarios capitalinos- generaron un campo de disputas complejo que puso de un lado a los representantes del Consejo Nacional de Educación y una serie de actores del campo pedagógico -el subinspector Juan José Nissen, Fermín Uzín, el profesor Benancio López (regente de la Escuela Normal de Paraná), el señor Federik (profesor de la Escuela Primaria Nacional)- y del otro, al Director General del CGE, Manuel Antequeda, respaldado por el gobierno provincial y por el periódico provincial oficialista El Tribuno.

Este informe sirvió como el disparador de una serie de conflictos que daban cuenta de diferentes criterios sobre la concepción educativa, pero que iban más allá, pues estos actores también disputaban por proyectos políticos antagónicos que se encarnaban en las luchas políticas partidarias. Una visión integradora, gradualista y respetuosa de las diversidades sostenida por Antequeda se oponía a la propuesta homogeneizadora y coercitiva de Bavio. Este último evaluaba como un peligro nacional la enseñanza impartida en las escuelas ruso-alemanas y en las

${ }^{55}$ El Monitor, Tomo XXVII, Buenos Aires, noviembre de 1908, № 428 al 432, Serie 2, № 48 al 52, agosto 31 diciembre de 1908, pp. 601-602. También Citado por López, M. P., op. cit. p. 76. 
judías entrerrianas, y bregaba por una escuela «normalizadora», por lo que las escuelas extranjeras "se deben mandar a clausurar, por estar fuera de la ley y en pugna con los más sagrados intereses nacionales». ${ }^{56}$

Para contar con mejores elementos, Antequeda solicitó al inspector general Olegario Maldonado y a los inspectores seccionales la realización de un informe sobre las escuelas de dichas colectividades. El informe presentado por Maldonado sobre su observación de las escuelas israelitas de los Departamentos de Villaguay y Uruguay explicita que "algunas" se encuentran en muy buen estado, están dirigidas por maestros preparados, enseñan un mínimum de instrucción primaria estipulado por ley, usan iguales textos que las oficiales y adornan sus aulas con retratos de prohombres argentinos; sus alumnos más adelantados hablan castellano, prestan alguna atención a la instrucción cívica, geografía e historia nacional y cantan el himno nacional.

Sin embargo, otras tienen deficiencias provenientes de la falta de preparación de algunos de los maestros especiales encargados de la enseñanza religiosa, "la que invariablemente se da en todas las escuelas y principalmente de la población judía misma, inasimilable y refractaria a nuestro modo de ser y costumbres". ${ }^{57}$

Los informes de los inspectores regionales señalaban la existencia de escuelas con funcionamiento y situación heterogénea. Con algunos matices, los problemas detectados como más importantes obedecían al endeble manejo del idioma, ya que muchos de los maestros no hablaban correctamente el castellano, lo que impedía su correcta enseñanza. Por otro lado, la debilidad de la formación pedagógica de los mismos, que, si bien concurrían a los cursos temporarios, no era suficiente para alcanzar un cabal aprendizaje del idioma nacional. Por lo que las recomendaciones que realizaban los inspectores estaban vinculadas a brindar una formación más extensa a los maestros en la Escuela Alberdi que les permitiría el aprendizaje del idioma, además de brindarles una preparación agrícola y ganadera que redundaría efectivamente en la economía de las colonias y, por ende, en el desarrollo económico provincial.

\footnotetext{
${ }^{56}$ La Prensa, 12 de diciembre de 1908, p. 9.

${ }^{57}$ Antequeda, Manuel, Breve exposición sobre las escuelas ruso-alemanas e israelitas. Escuelas nacionales. Ley Láinez de la provincia de Entre Ríos, Buenos Aires, Imprenta Mentruyt, 1909, p. 48.
} 
La polémica se saldó con un nuevo reglamento de Escuelas Comunes de la provincia, que empezaba a regir a partir del $1^{\circ}$ de enero de 1909 y establecía: la obligatoriedad de la entonación del himno nacional, de cantos morales y patrióticos en todas las escuelas; la responsabilidad de los directores de escuelas en la organización de los actos de las fechas patrias, convocando a las familias y sociedad civil a los rituales patrióticos; la obligación de destinar una hora de clase diaria para realizar lecturas, recitaciones, cantos o lecciones relacionados con las fechas patrias nacionales y los hombre memorables de la Revolución de Mayo y de la Independencia. ${ }^{58}$

En particular para las colonias judías, se establecía:

a) Acordar diez de las becas que el presupuesto creaba para la Escuela Alberdi a jóvenes israelitas argentinos, quienes, a su vez, debían asumir el compromiso de servir por lo menos tres años en las escuelas judías una vez diplomados como Maestros Normales Rurales.

b) Requerir al Directorio de la Jewish Colonization Association que en toda escuela de su dependencia que tuviera dos o más maestros, hubiese al menos un maestro argentino que se encargara de la enseñanza del idioma nacional, historia y geografía argentina, instrucción moral y agricultura.

c) Las escuelas debían adoptar el programa de las escuelas fiscales, por lo menos en la parte que comprende el mínimum de la instrucción obligatoria, y debían observar el horario de clases que regía para las mismas.

d) Toda escuela israelita o rusa debían tener anexa una biblioteca infantil, formada principalmente de obras de autores argentinos y de carácter circulante.

e) La bandera nacional debía ser izada todos los domingos y días de fiesta.

f) Un inspector de la Dirección General visitaría las escuelas judías y rusas al menos seis veces al año.

g) Las salas de clase de todas las escuelas debían ostentar retratos de nuestros héroes y cuadros que representasen episodios nacionales.

h) Los maestros que carecían de títulos debían someterse a un examen de la Escuela Alberdi, en el tiempo y forma que determinaba el Reglamento General.

58 Boletín de Educación de la provincia de Entre Ríos, diciembre de 1908. 


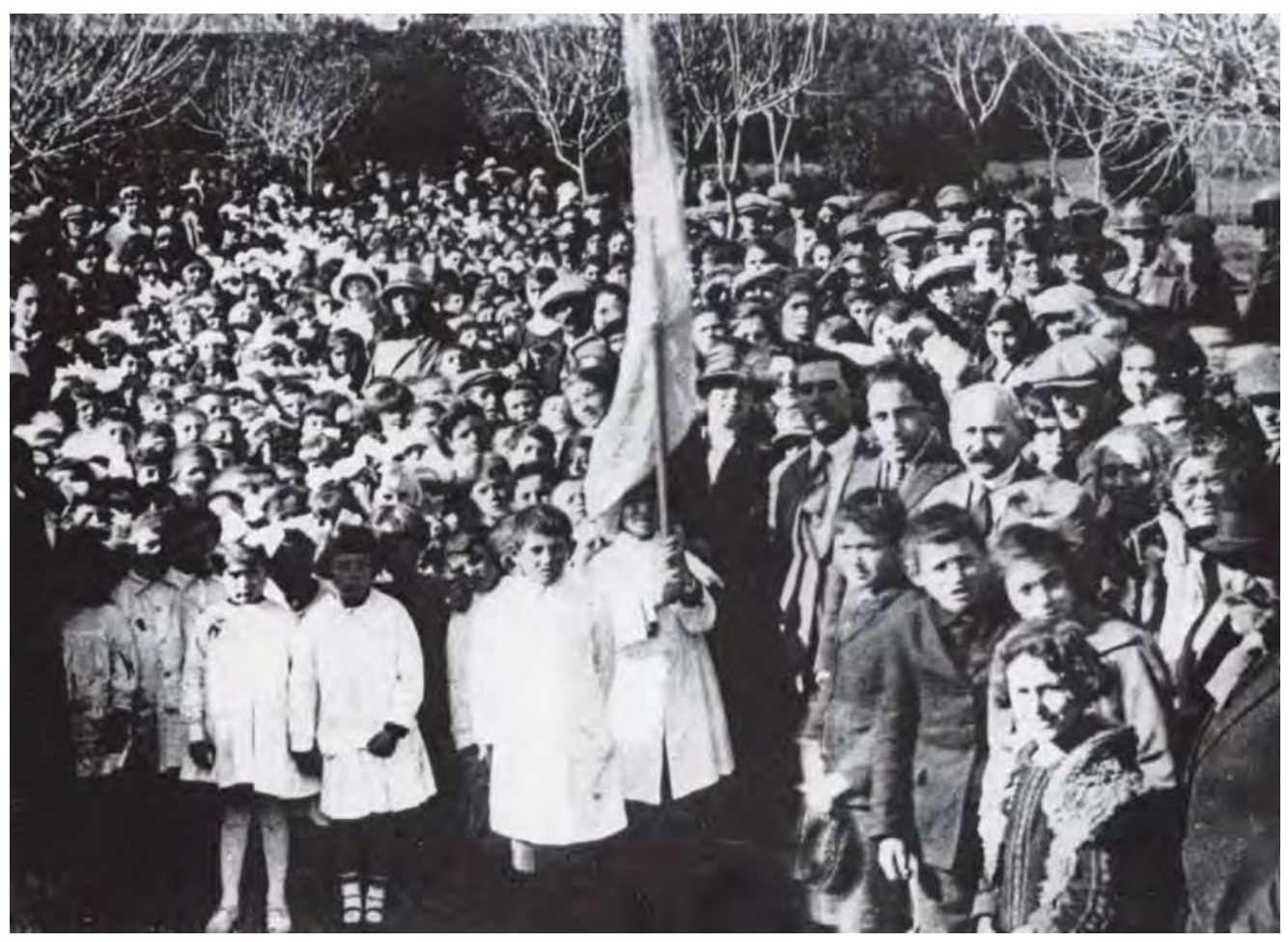

i) Las composiciones que hicieran los alumnos en los diversos grados debían ser copiadas en cuadernos especiales y conservadas durante el año escolar, a fin de exhibirlas en cualquier momento a los inspectores.

j) Las escuelas rusas y judías debían celebrar las fiestas patrias y del árbol. ${ }^{59}$

Exigencias y condiciones que fueron cumplidas según pudimos constatar en libros de actas de las escuelas e informes oficiales. ${ }^{60}$

\section{Los recursos humanos para la docencia: los maestros alberdinos y los cursos de verano}

Con el transcurso de los años, la matrícula escolar se ampliaba y se recurría a aumentar el número de maestros con los hijos de la colonia, ya sea entre los alumnos egresados o entre los jóvenes que llegaban a nuestro país con conocimientos

\footnotetext{
${ }^{59}$ El Monito, Año XXVII, N 433, Tomo XXVIII, Serie 2, № 53, Buenos Aires, 31 de enero de 1909, pp. $42-44$. ${ }^{60}$ Actas de la Escuela Elemental No 11, 1910-1954. En Museo y Archivo de Villa Domínguez, Sección Escuelas.
} 
suficientes para transmitir enseñanzas laicas. Para ello se pudo aprovechar muy bien el sistema educacional implantado en la provincia. Los alcances del normalismo entrerriano, en particular la cultura pedagógica normalista, sumado a la orientación ruralista y agraria propuesta en el ámbito provincial -que incluían el propósito de lograr el arraigo de la familia en el campo y la asimilación del inmigrante, en el marco del control social vigente-, permitirán la formación de los maestros rurales que luego se desempeñarán en la colonia. ${ }^{61}$

Eran en este caso los pedagogos egresados de la Escuela Normal ${ }^{62}$ de Paraná quienes encabezaban los proyectos para la capacitación especial de los maestros rurales, con una orientación agraria que permitiera apoyar la introducción de los trabajos agrícolas en la escuela primaria. El impulso fue del profesor normal Manuel Antequeda (1860-1920), egresado de la escuela de Paraná en 1879, y apoyado por el gobernador Enrique Carbó, quien inauguró en 1904 la escuela Alberdi con el carácter de "normal de maestros rurales, agropecuaria e industrial», para varones.

Antequeda, ${ }^{63}$ como Director General de Escuelas, promocionó la escuela Alberdi, situada en la localidad de Oro Verde, a muy pocos kilómetros de la ciudad de Paraná. El objetivo de esta innovadora escuela entrerriana estaba centrado en formar maestros "capaces de difundir después los procedimientos, métodos y sistemas mejores y más ventajosos en las fuentes de donde nace la prosperidad pública y privada de nuestro país". ${ }^{64}$

El programa, de tres años de duración, incluía las materias respectivas de una escuela normal de maestros, a las que se agregaban las de especialización

\footnotetext{
${ }^{61}$ Ver en detalle este tema en Gutiérrez, Talía Violeta. Políticas educativas agrícolas: una preocupación de los pedagogos normalistas, Entre Ríos (Argentina), 1900-1920. Disponible en: http://www.fee.tche.br/ sitefee/download/jornadas/2/h10-03.pdf.

62 Fue centro de irradiación de las ideas normalistas y "normalizadoras" (en el sentido de adaptación a determinadas normas) hacia todo el país a través de la actuación de sus egresados en el sistema de formación docente que se fue estableciendo en la república. Basado en las ideas positivistas, el krausismo y otras influencias europeas, el normalismo defendía la posibilidad de educar efectivamente al sujeto, la primacía de la ciencia, el progreso y la necesidad de una pedagogía científica que estableciera los métodos más adecuados para la enseñanza, en base a una minuciosa reglamentación que contemplara hasta los más mínimos detalles de comportamiento, ejercitación motriz y mobiliario adecuado (Tedesco, 1986; Puiggrós, 1993; Dussel, 1993). Citado por Talía Gutierrez, op. cit., p. 4.

${ }^{63}$ Como dato relevante de su acción en la Dirección, se destacó la construcción de edificios escolares tanto en ciudades como en la campaña y el gran incremento de la matrícula escolar, en los diez años que permaneció en su cargo, de 17.000 en 1903 a 55.000 en 1913.

${ }^{64}$ Provincia de Entre Ríos, Dirección General de Enseñanza Pública, Memorias, 1906, p. 109.
} 
agropecuaria, en las que tenían gran importancia los trabajos prácticos sobre el terreno. También se enfatizaba en su formación -según se afirmaba desde la Dirección de Escuelas- la historia, geografía, instrucción moral y cívica, completada con cantos patrióticos, "para imprimir en la escuela el sello característico de la nacionalidad"65. Al término del período se obtenía el título de maestro normal rural, que habilitaba sólo para ejercer en ese medio, aunque como contrapartida se establecían ciertas preferencias para los egresados en el momento de cubrir los cargos directivos en las escuelas rurales.

La escuela Alberdi, de jurisdicción provincial, entendía que el maestro debía ser un guía no sólo en el aspecto pedagógico, sino también ser el difusor de sistemas de explotación más racionales. Como el resto de las escuelas normales, contaba con un departamento de aplicación anexo, considerado una escuela rural modelo, donde los "alumnos-maestros" realizaban sus prácticas docentes. Existían en la escuela Alberdi las categorías de alumnos pensionistas y becados. ${ }^{66}$ La provincia intentaba así asegurarse un plantel de docentes convenientemente preparados en la campaña, que a su vez sirvieran de difusores de las mejores técnicas agrícolas. En particular, Colonia Clara contó con estos maestros, hijos de colonos que se transformaron ellos mismos en difusores del trabajo rural. Entre los egresados de la Escuela Alberdi podemos señalar a Simón Steinberg, Salomón Pavé, Jacobo Liebermann, Samuel Dorfman, Bernardo Vladimirsky, Benjamín Millicovsky, Gregorio Braslavsky, David Zentner, Jedidio Efron, Seidel Ziegner, con activa participación en la vida social y comunitaria de la colonia. ${ }^{67}$

Sin embargo, uno de los problemas más urgentes a resolver en los inicios del siglo xx fue el de la preparación de los maestros en ejercicio, que provenían de diferentes trayectorias y por lo general no poseían títulos habilitantes para la docencia. Desde la fundación de la escuela Alberdi se habían propuesto los cursos temporarios para maestros rurales para revertir esa situación, brindándoles capacitación no sólo en la especialidad agrícola, sino también completando la calificación con contenidos de historia, cívica, instrucción moral y cantos patrióticos.

\footnotetext{
65 Provincia de Entre Ríos, Dirección General de Escuelas, Memorias, 1911, p. 37.

${ }^{66}$ Provincia de Entre Ríos, Dirección General de Escuelas, Memorias, 1912.

67 Tierra de Promesas. 100 años de colonización judía en Entre Ríos. Colonia Clara, San Antonio y Lucienville, Buenos Aires, Ediciones Nuestra memoria, 1995, p. 130.
} 
En 1909, Manuel Antequeda, ante la solicitud de un grupo de maestros que deseaban completar su formación para ejercer la docencia, impuso los cursos de verano a realizar en la sede de la escuela. Esta iniciativa tuvo un efecto directo sobre las colonias judías, ya que se fijaron cupos específicos para el personal propuesto desde ellas. El 4 de enero de 1910, la Dirección General de la Enseñanza aprobó el ingreso de los siguientes maestros al curso temporario: Jacobo Steinberg, S. Pertzovsky, Jorge Deiloff, Claudio Formosa, Adan Regner, Luis Risetto, Enrique Rascoff, Antonio Berim y Gregorio Braslavsky. ${ }^{68}$

Las estadísticas escolares señalan que en el año 1913 Colonia Clara contaba con 21 escuelas en las que se desempeñaban 45 docentes, como directores y maestros, para atender a 1.255 niños. ${ }^{69}$ La currícula que se impartía estaba compuesta "por los contenidos en Idioma Hebraica y los en Idioma Laica (sic) establecidos los contenidos según correspondieran a Primera, Segunda, Tercera y Cuarta Clase o grados (siempre y cuando este último curso estuviera abierto)", señalaban los informes de la AlU. ${ }^{70}$

\section{Los nuevos desafíos}

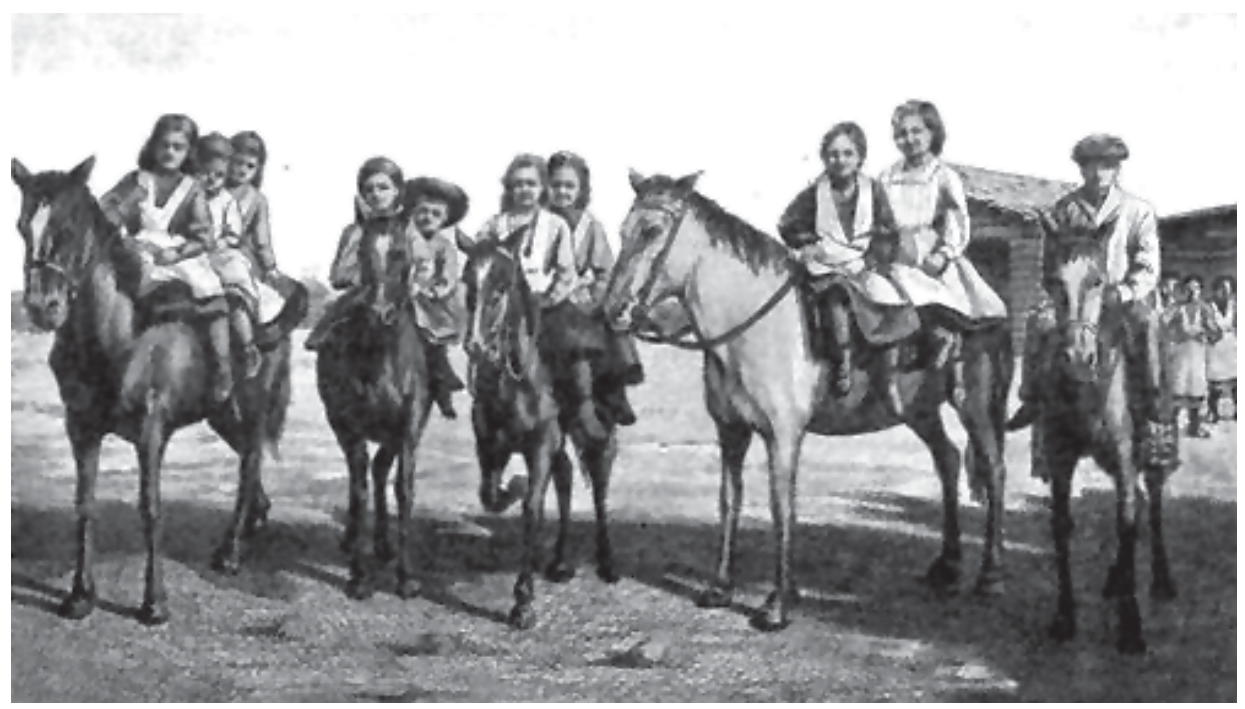

68 Solicitudes de ingreso al curso temporario (Hojas 38-56), Museo y Archivo de Villa Domínguez, p. 57. Citado también por Talia Violeta Gutiérrez, op. cit., p. 9.

69 Tabla Statistiques des Ecoles, IV Trimestre, 1913, AlU, Argentina V-0, Archivo y Museo Villa Domínguez. 70 AlU, Argentina I-0, Archivo y Museo Villa Domínguez. 
Con el transcurso de los años, los establecimientos educativos se multiplicaron y la denuncia del problema de las distancias fue desapareciendo, por lo menos si tomamos en cuenta las demandas que realizaban los maestros a la Administración de la JCA.

Cuando recurrimos al testimonio de los hijos de los primeros colonos, nos señalan que los seis o siete kilómetros que debían recorrer hasta llegar hasta las escuelas no eran un impedimento para la no concurrencia:

La escuela estaba a 7 km de distancia, recuerdo mi primer día, papá nos buscó el caballo, yo iba con Juan, mi hermano mayor, el caballo era brioso, yo tenía mucho temor, me apreté enancado con Juan y marché. Había 2 escuelas, 1 hebrea y una castellana, estábamos 2 horas en cada una. Recuerdo a mi maestro de hebreo, porque nos hablaba mucho de la Biblia, de Adán, de Eva, tema que a mi me interesaba, con relatos interesante, amenos. Nos daban la merienda en una bolsita, generalmente una fruta (naranja). ${ }^{71}$

La enseñanza recibida marcó profundamente a los niños de entonces.

La experiencia de ir a la escuela era todo novedad, quedaba distante, era modesta, pegado al aula una galería de ladrillo y un patio de tierra. El maestro nos enseñaba cómo se conformaba un cuadro de fútbol y luego salíamos a jugar olvidándonos de los lugares y roles de cada puesto. Nos enseñaban historia, lo que más me interesaba. Siempre respondía a mis curiosidades. Había una biblioteca, podíamos retirar

\footnotetext{
${ }^{71}$ Elegimos recobrar historias de vida de actores sociales que nacieron en las colonias y que en la actualidad viven en la región. Así, entrevistamos a Olga Kipen y a Mauricio Flier, informantes que nos brindaron su testimonio en largas conversaciones de naturaleza profesional, las cuales fueron también filmadas. Los dos entrevistados fueron hijos de colonos y nacieron en Villa Domínguez. Nos brindaron información sobre los avatares de la experiencia colonizadora: el trabajo duro y constante del campo, las inclemencias del clima y las sequías, las pestes y la langosta; las restricciones económicas y las dificultares en cubrir las mensualidades a devolver a la JCA; las limitaciones para que todos los hijos pudieran estudiar y particularmente para forjarse un futuro independiente en las colonias; la imposibilidad de acceder a la propiedad de nuevas tierras, lo que llevaba al desplazamiento de los hijos a los centros urbanos. Describieron el traslado a ciudades, las posibilidades de inserción laboral y de ascenso social que el país en tiempos de la "democratización del bienestar" brindaba a los distintos actores sociales. La vida en las colonias es recordada como una experiencia sin dudas durísima y de mucho esfuerzo, pero vivida o rememorada como un tiempo de felicidad y libertad.
} 
un libro por semana. También me gustaba la poesía. Cuando fui a Domínguez en $4^{\circ}$

grado, recitaba. A mi me tocó debutar con una del negro Falucho por primera vez.

Estrofas que nuestro entrevistado recita perfectamente como si las hubiera repasado un momento antes de nuestro encuentro, y ante nuestro asombro, con tono complacido, nos dice que "lo aprendido en la niñez queda grabado a fuego".

Sin embargo, otros inconvenientes emergían y tenían que ver con las posibilidades de continuar los estudios en la colonia. Finalizar el cuarto grado equivalía a completar la escuela obligatoria, pero para ello había que trasladarse al pueblo o la ciudad para acabar los estudios tanto oficiales como judaicos. Para cumplimentar los estudios secundarios y para acceder a los estudios universitarios, debían necesariamente trasladarse a las grandes ciudades, ya que sólo allí se impartía este tipo de educación. ${ }^{72}$

Empecé la escuela a los 8 años. Tío me regaló el primer caballo, (Miguel Sajaroff). Había 7 km de distancia. Entré a $1^{\circ}$ superior a mitad de año. Mamá me metió en la cartera un libro que creo que era de $4^{\circ}$ grado. La maestra me hizo leer y yo leía mejor que todos los chicos. Yo sabía leer y escribir. Sabía aritmética, sumas, restas, multiplicación. Nos enseñaban en casa. Terminé $4^{\circ}$ grado y en Domínguez más no había, entonces era un problema. ${ }^{73}$

\footnotetext{
${ }^{72}$ En los pueblos - La Capilla, Domínguez y Villa Clara- las escuelas elementales brindaban el ciclo completo del servicio educativo: $1^{\circ}$ grado inferior, $1^{\circ}$ grado superior, $2^{\circ}$ grado, $3^{\circ}$ grado y $4^{\circ}$ grado. En las aldeas o grupos, sólo hasta el tercer curso. Por lo tanto, para completar el ciclo de enseñanza primaria había que trasladarse a otro lugar.

${ }^{73}$ Olga Kipen, hija de Miguel Kipen, un destacado actor social de las colonias judías de Entre Ríos. Estudiante de ingeniería que, luego de ser deportado a la Siberia zarista, de donde logra escapar, vive en Suiza, donde se recibe de abogado y se casa con Débora Davinovich. Su hermana se había casado con el Ingeniero Sajaroff. Llega a las colonias imbuido del ideario socialista a partir del llamado de sus familiares ya radicados. Olga nace en las colonias. Si bien su vida es presentada, por la humildad de la entrevistada, como común, distaba mucho de la vida de las mujeres "normales" de la Argentina de la época. Al pertenecer a un hogar donde sus integrantes poseían una alta calificación profesional y militancia política, pudo desarrollar una trayectoria profesional como maestra, profesora de matemática y directora de escuela. Su relato pormenorizado nos permitió recorrer los caminos de la experiencia de la colonización. Así pudimos compartir el enorme afecto al tío Sajaroff, la simpatía que le profesara al «loco" Wortman, la descripción profunda sobre los aportes del cooperativismo, ámbito donde se destacaban por sus trabajos sus familiares directos; los debates ideológicos y el compromiso político; su amor a la lectura, al aprendizaje y la enseñanza; la vida cotidiana y los sabores; el arte, la música y su clara visión sobre el compromiso en llevar una vida llena de valores de solidaridad y responsabilidad social.
} 
Sin embargo, esta no era la única limitación para completar los estudios: la escasez de recursos económicos era también determinante. El traslado requería contar con las posibilidades pecuniarias para el pago de los estudios y la vida lejos de la colonia, en tanto que se perdía la mano de obra para seguir trabajando la chacra.

En invierno era terrible por el frío, llegábamos con las manos duras. Todos íbamos a la escuela, era sagrado. Donde se terminaba la enseñanza gratuita, se abortaba la posibilidad de seguir estudiando. Yo no pude conseguir una beca y se interrumpieron mis estudios. Los hijos se tenían que ir de la Colonia para seguir estudiando, a grandes distancias. La suerte hizo que mi hermano mayor consiguiera una beca en la escuela Alberdi. Yo me quedé ayudando a mis padres. ${ }^{74}$

Celia Nijamkin, quien vivía en Barón Guinzburg solamente con su madre y hermanos, pues su padre había muerto, concurrió a la escuela desde los cinco hasta los doce años, y como se desesperaba por aprender más su madre decidió enviarla a la escuela de Villa Clara.

Era una escuela muy buena, nos parecía que estábamos en las nubes pues tenían buenas maestras, una para cada grado, además estudiábamos canto y declamación. Lamentablemente ni mis hermanos ni yo pudimos continuar nuestros estudios, pues nuestra situación económica en aquella época era de extrema pobreza. Con terrible pesar dejé de estudiar a los 12 años, al terminar el $4^{\circ}$ grado. ${ }^{75}$

Salvo algunos jóvenes que lograron trasladarse a las ciudades y con mucho esfuerzo continuaron una carrera, la mayoría de los chicos de la colonia no pudieron continuar sus estudios. Muchos hacían cursos de distintas materias por correspondencia y enriquecían sus conocimientos con la lectura de buenos libros, señala Bernardo. ${ }^{76}$

\footnotetext{
${ }^{74}$ Entrevista a Mauricio Flier.

${ }^{75}$ Testimonios de Celia Nijamkin, integrante del grupo de adultos mayores. En Gutkoweky, Helene (coord.), Rescate de la Herencia Cultural. Vidas en las Colonias, Buenos Aires, Contexto, 1991, p. 200.

76 Ibídem.
} 
Cuando terminé la primaria, me interesó una propaganda de la National School de Los Ángeles. Me interesaba la radiotelefonía, lo que tuviera que ver con imanes. Me inscribí a un curso que se dictaba por correo desde Estados Unidos, pagaba 3 dólares (12 pesos) y armé un radioreceptor. Sentí que tocaba el cielo con las manos. Con ese curso, me presenté en Buenos Aires al representante de la National School, él me recomendó y conseguí mi primer trabajo. Al poco tiempo me tocó el servicio militar. Cuando me consultaron sobre el oficio, contesté radiotécnico. Bienvenido, señor!!! Fue la respuesta. ${ }^{77}$

\section{Las bibliotecas y los clubes}

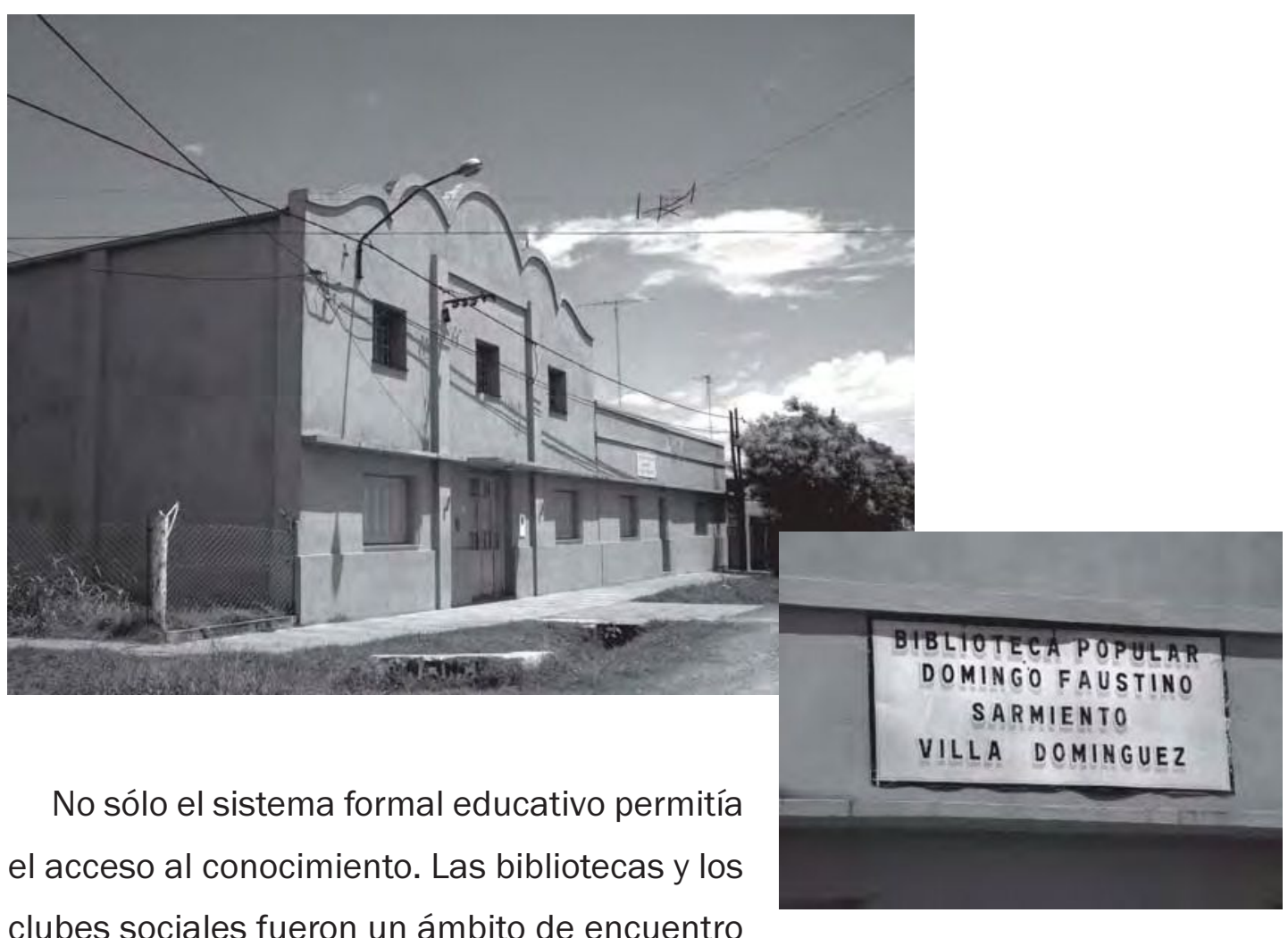
con la cultura letrada y la artística en general. Las primeras bibliotecas fueron las que se dispusieron en los hogares de los pioneros de la colonización. Muchos testimonios rescatan, entre muchas otras, la perteneciente a la familia Chertkoff, aquel

\footnotetext{
77 Entrevista a Mauricio Flier.
} 
anciano estudioso que junto a sus hijas incentivaban la lectura y la difusión de conocimientos en la colonia.

Wortman era un hombre culto porque vivía cerca de la familia Chertkoff. Le pasaban libros. El viejo Wortman se enojaba porque en lugar de trabajar, su hijo leía. Los Chertkoff hicieron mucho por la cultura. En general el pueblo judío siempre gustó de la cultura. ${ }^{78}$

Cuando asumió la dirección de la Cooperativa Fondo Comunal en 1908, su presidente, Miguel Sajaroff, propuso la creación de una pequeña biblioteca: "no concibo una cooperativa sin un lugar donde los socios puedan leer".

Un grupo de vecinos de Villa Domínguez se abocó a fundar un club, como ámbito de encuentro, esparcimiento y para desarrollar actividades culturales, que fuera bautizado como Club Barón de Hirsch. Como uno de los objetivos trazados era conformar una biblioteca en idish, fue nombrada una bibliotecaria en la primera sesión constitutiva del club, y rápidamente fue donado el material bibliográfico de la cooperativa. En 1913 se transformó en la Biblioteca Popular Domingo Faustino Sarmiento, recibiendo subsidios del gobierno de la provincia y de la JCA para nutrir sus vitrinas de libros, que eran prestados a los alumnos y vecinos. ${ }^{79}$

La actividad de la biblioteca fue intensa, como lo demuestran las memorias de las asambleas generales celebradas anualmente. Estos encuentros eran nuevos espacios de socialización donde se observaban las demandas culturales, las preferencias intelectuales y los intercambios sociales, así como algunas de las preocupaciones de los socios. En la sesión del $1^{\circ}$ de noviembre de 1931, uno de ellos, Bernardo Hugovitzky, pidió la palabra para llamar la atención sobre la disminución de las lecturas en idish y para solicitar una mayor promoción y difusión de esta literatura. Las estadísticas minuciosas daban cuenta de la preferencia por la literatura francesa y en español. El doctor Filer, al replicar, sostuvo que la disminución

\footnotetext{
78 Entrevista a Olga Kipen.

${ }^{79}$ Compraba los libros de textos que eran solicitados por la escuela para el préstamo a los alumnos: primero inferior, Paso a Paso; primero superior, Progresa; segundo grado, Batir las Alas; tercer grado, Adelante y cuarto grado, El niño argentino.
} 
residía en que cada vez eran menos los lectores del idish, ya que los hijos de los colonos reclamaban literatura en castellano. ${ }^{80}$

Los 82 socios activos y 23 socios lectores de la biblioteca en 1932, que poseían un manejo adecuado del idioma nacional, iban lentamente relegando el idish para la comunicación en el ámbito familiar.

En el Salón Casa del Pueblo se realizaban conciertos, conferencias, obras de teatro, bailes, exposiciones de pintura, proyecciones de cine, entre tantas otras actividades culturales. ${ }^{81}$

En 1936, los socios que concurrían asiduamente a la biblioteca eran 117 y 4.395 las personas que visitaron la sala de lectura. Lentamente se irán produciendo transformaciones e intercambios con los nuevos vecinos de Villa Domínguez, ya no sólo eran socios los judíos. En 1954 sobre el total de 220 asociados 35 eran no judíos. El acervo bibliográfico ascendía a 6.307 volúmenes, "de los cuales la mayor parte son en idioma castellano" explicaba el informe del Administrador ${ }^{82}$

En 1938 se creó la cooperativa escolar, integrando al ámbito educativo el espíritu cooperativo. ${ }^{83}$ Para concitar el apoyo de los pobladores se mandó a imprimir un folleto que llevaba como título "Cooperación que se impone al vecino progresista", que, repartido en cada uno de los hogares, invitaba a sumarse al proyecto.

\footnotetext{
${ }^{80}$ Archivo Biblioteca Popular Domingo Faustino Sarmiento, Acta No 101, p. 199.

${ }^{81}$ El listado de actividades es inmenso. Los folletos de propaganda se encuentran en el Museo y Archivo de Villa Domínguez. De un listado de aproximadamente trescientas, y tan sólo a modo de ejemplos, citamos algunas actividades: el profesor José M. Lunazzi (docente de la Facultad de Humanidades de la UNLP) ofrece una serie de conferencias sobre "Las nuevas corrientes educacionales", domingo 3 de julio de 1938; Salomón Resnik brinda cinco conferencias sobre "La evolución de la Literatura judía”, "Novelistas Judíos contemporáneos" y "El sentido de la Historia judía” (en Idish); Concierto Vocal- Musical a cargo de Pedro Borenstein, 14 de abril de 1938); el doctor Julio Filer "La lepra. Problema médico social", ilustrado con proyecciones luminosas; El cuadro Filodramático de la Biblioteca pone en escena la obra de José Berruti, "El señor maestro", y a continuación baile familiar con excelente buffet y mejor orquesta. En Archivo Biblioteca Popular Domingo Faustino Sarmiento, Villa Domínguez, Entre Ríos. Ver en Anexo, selección de carteles con anuncios de actividades culturales.

82 Informe del administrador de Colonia Clara, 1944-1954. Algunas Impresiones sobre Colonia Clara sobre movimientos de colonos habidos durante los 10 últimos años. 1944-1954. Estrictamente Confidencial, p.9. ${ }^{83}$ Miguel Sajaroff fue designado como presidente honorario, el director de la escuela, Isauro Coria, como síndico, y una comisión integrada por Olga Raifaisen (presidente), Salvador Gleser (vice), Nelly Sajaroff (secretaria), Luis Schapira (prosecretario) y vocales. En Archivo Cooperativa Escolar la Colmena, Acta $N^{\circ}$ 1, f. 1. Eran socios alumnos, padres y maestros, con una cuota mínima de $\$ 0,05$ cts. o acciones de $\$ 1$. En López, Celia, Cooperativismo y Cultura. Historia de Villa Domínguez, 1890-1940, Editorial de Entre Ríos, 1987, p. 118.
} 
Hay razones de patriotismo y de interés colectivo que nos imponen solicitar su cooperación en pro de una obra que cimienta la instrucción de la niñez presente y futura de Villa Domínguez y colonias adyacentes. ${ }^{84}$

La cooperadora La Colmena tenía como objetivos: 1) practicar la cooperación entre los alumnos proveyendo a sus asociados material escolar; 2) destinar parte de las utilidades para la adquisición de material didáctico para las escuelas de la localidad; 3) proveer de material para los trabajos manuales de los socios que lo desearen; 4) adquirir útiles e implementos para los trabajos mensuales de los socios.

Los fondos recaudados, más las donaciones recibidas, le permitieron ayudar a niños con necesidades económicas para que no abandonaran sus estudios, comprar un mástil para el patio escolar y un mimeógrafo para que tuvieran la posibilidad de editar un boletín informativo, ágil y entretenido, que les brindara a la vez la posibilidad de capacitarse en el arte de la comunicación social. Esta cooperativa escolar nacía desde la escuela Isidoro Suárez de Villa Domínguez, creada en tiempos del primer centenario, a cuyas aulas iban mancomunados niños judíos y no judíos, que sigue funcionando hasta la actualidad. Es la única escuela primaria de Villa Domínguez, a la que concurren más de trescientos alumnos de la localidad y de zonas rurales aledañas, niños argentinos, en su inmensa mayoría no judíos. Quizás sea más grafico señalar que en los tiempos del festejo del centenario de la escuela, sólo un niño judío concurre a la Isidoro Suárez.

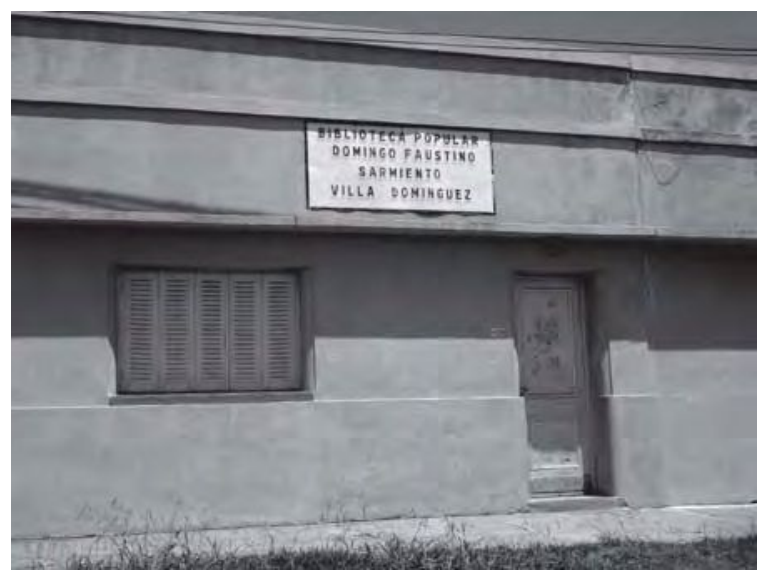

${ }^{84}$ Cooperación que se impone al vecino progresista, folleto de junio de 1937, Caja Sajaroff, 1005/975, Archivo IWO. 


\section{La educación hebrea y los cursos religiosos israelitas}

La educación oficial no alcanzaba para perpetuar la cultura judía. Por esta razón, los colonos judíos abogaron por conseguir una educación tanto oficial como aquella que incorporara los preceptos del judaísmo. Las comunidades judías de la diáspora desarrollaron sistemas de educación en los lugares donde lograron asentarse. Sus sistemas educativos incluyeron en su currícula tanto temáticas seculares como judías. Diversas instituciones de enseñanza, además de cumplir con los requerimientos oficiales, enseñan a sus alumnos las materias tradicionales que constituyen la parte central del pensamiento judío. Sin embargo, ello no significa homogeneidad interpretativa o unicidad de sentidos.

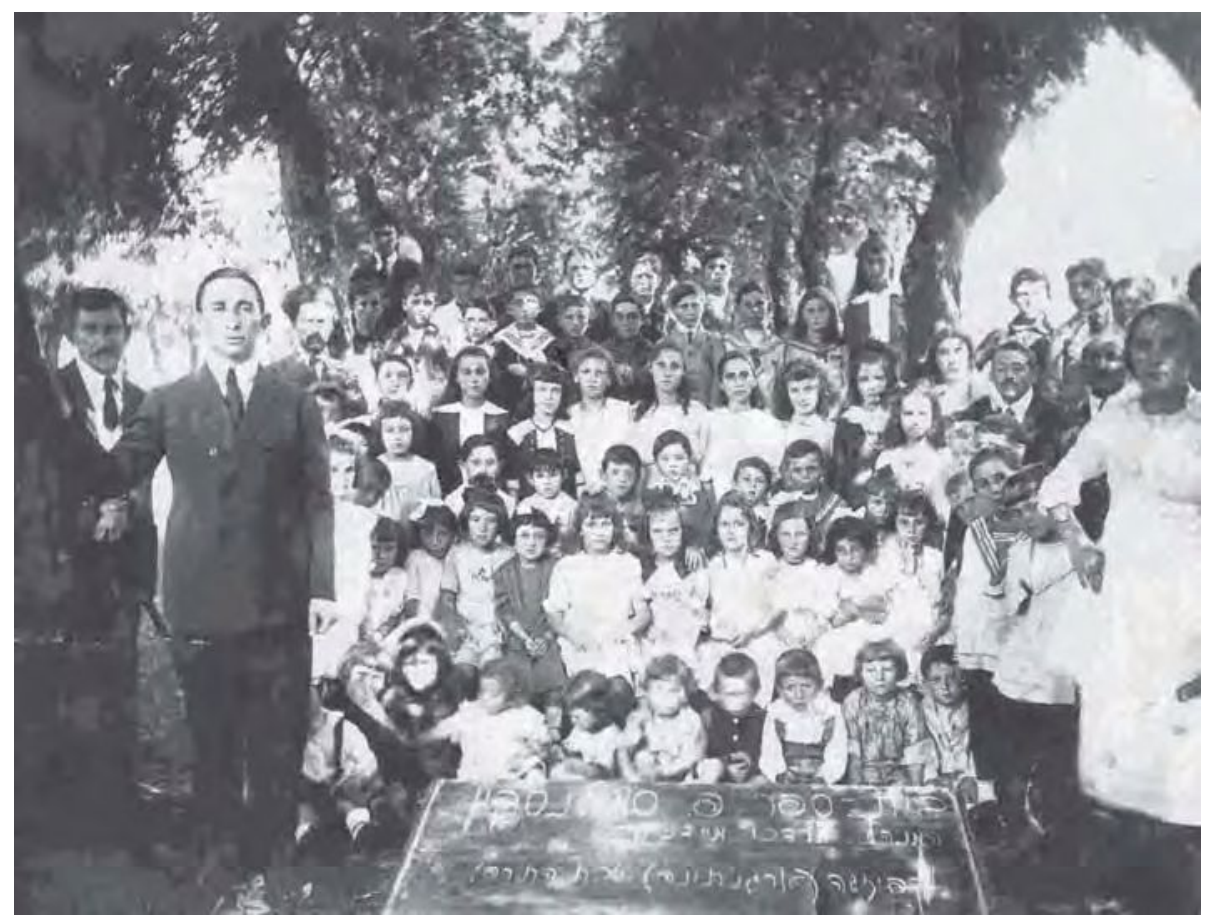

Escuela hebrea en La Capilla

Siguiendo a Avellaneda, ${ }^{85}$ podemos señalar que las formas organizativas y pedagógicas de las escuelas judías en Argentina pasaron por tres etapas fuertemente diferenciadas. La primera etapa, que se inició con la fundación de las

${ }^{85}$ Avellaneda, María Elena y Cassanello, Carina Alejandra, Las escuelas judías en las colonias agrícolas, op. cit. 
escuelas dirigidas por la JCA; una segunda, a partir de 1911, cuando fue creado el Vaad Hajinuj Arashi (Comité Principal de Educación o Consejo Central de Educación Judía), patrocinado por la más antigua organización judía de la Argentina, la Congregación Israelita de la República Argentina (CIRA); y una tercera etapa iniciada en 1938 con la instalación del Vaad Hajinuj Hamerkazi (Consejo Central de Educación Judía de la República Argentina), resultado de la amalgama del Vaad Hajinuj con el Vaad Hajinuj Haroshí, que comenzó a ocuparse de las necesidades de todas las escuelas judías del país, si bien no todas las escuelas no ashkenazíes se afiliaron inicialmente.

Durante la primera etapa, las escuelas funcionaban según el viejo modelo del Talmud Torá. Todas sus horas de instrucción estaban dedicadas a enseñar la lengua hebrea mediante su traducción a otro idioma familiar, sea idish o español, según los orígenes étnicos de los estudiantes, y al estudio de la liturgia tradicional, del Pentateuco y de la exégesis bíblica. Los maestros carecían generalmente de formación pedagógica. La enseñanza se impartía sin subdivisión en grupos según edad o nivel de conocimientos, por lo que no despertaba entusiasmo o motivación en los alumnos.

Un informe presentado por el rabino Samuel L. Halphon a la dirección de la JCA sobre el estado de la educación judía en el país provocó que se le encomendara la presentación de un plan, tendiente a la creación de un organismo que se ocupara de la educación religiosa de los niños. En 1911 se creó la obra de los cursos religiosos, confiándole la dirección de los mismos al citado rabino. Llegó a tener cerca de 7.000 alumnos diseminados en todo el país, lo que permitió afianzar la enseñanza religiosa y hebrea en las ciudades y en los pueblos de interior. La dirección de los cursos religiosos, con la dirección de Halphon y de Alberto Carmel, recibió la instrucción desde la sede central de París de la JCA de que se encargaran de la organización de la escuela hebrea en las colonias, donde la enseñanza laica estaba a cargo del Consejo Nacional de Educación. Así, el Vaad Hajinuj Arashi (Comité Principal de Educación o Comité central de Educacion Isaraelita) inició su tarea, la que tropezó con la falta de docentes capacitados para la enseñanza. De modo que la misma Dirección se ocupó de la formación, primero como aprendices a los que se les daba el adiestramiento necesario du- 
rante un año para luego desempeñarse como maestros. Una primera cohorte de 34 maestros fue a desempeñarse en las escuelas de las colonias. ${ }^{86}$

Otro tema tan importante como el anterior fue el de la definición de los contenidos de la enseñanza. De modo que estableció en 1917 un estatuto general de enseñanza y un cuerpo de inspectores responsables del cumplimiento del mismo en las escuelas dependientes del Consejo. No todos los sectores de la colectividad israelita aceptaron el nuevo programa, relata Efron.

Objetaron los ortodoxos que resultaba muy liberal, por no dedicar más tiempo a los estudios netamente religiosos, como ser las oraciones cotidianas y la Biblia; los sionistas sostenían que se dedicaban demasiadas horas a las materias religiosas y pocas a las asignaturas nacionales e idiomáticas. ${ }^{87}$

De todos modos se llegó a algunos acuerdos básicos y el programa se mantuvo hasta 1938. La JCA mandó a imprimir en castellano y hebreo los textos escolares para los alumnos de los cursos. El Reschit Daat, el Sidur (Ritual de Oraciones) y los Trozos Escogidos de la Biblia, La Historia del Pueblo Hebreo y los Principios del Judaísmo, en castellano, completan la lista.

Al finalizar la segunda década del siglo xx, traspasadas las escuelas laicas a la nación y a las provincias, la JCA comenzó a reducir los fondos destinados a las escuelas hebreas, anunciando que la continuidad de las mismas quedaría a cargo exclusivamente de las comunidades. La cesión de las escuelas demandó, como señalamos, la construcción de nuevos edificios para la educación judía. La empresa colonizadora estableció que los costos que demandaba la edificación fueran cubiertos con la contribución de los colonos: un tercio a cargo de la JCA y los dos tercios restantes a cargo de los colonos. Así se construyeron los edificios para la enseñanza del hebreo, que sirvieron como escuela y como ámbito de reunión para los integrantes de la comunidad. ${ }^{88}$

\footnotetext{
${ }^{86}$ Más tarde se trae a estos chicos, al terminar el secundario, para estudiar para Morim en el primer seminario de profesores judíos, Ilamado Majón Lelimudei Haiaadut, en la calle San Salvador de la ciudad de Buenos Aires.

${ }^{87}$ Efron, Eididio, La obra escolar en las colonias, op. cit., p. 254.

88 Ibídem, p. 257.
} 
En Entre Ríos, para ocuparse de las tareas educativas, se creó por iniciativa de Israel Yaguspy la Organización Escolar Hebrea de Entre Ríos, un organismo de educación hebrea que agrupaba los cursos religiosos y los otros establecimientos encargados de impartirla. La dirección estaba a cargo de un consejo directivo compuesto por miembros designados por las colectividades de las distintas localidades de la provincia. La primera comisión estuvo integrada por Julio Filer de Villa Domínguez, Simón Banchik de Basavilbaso y Rodberg de Concordia. Esta iniciativa fue también seguida en otras provincias del país. ${ }^{89}$

La nueva etapa comenzó a partir de la decisión adoptada por la Jevrá Kadisha Ashkenazit -la organización asquenazí para la inhumación de los muertos y ayuda a los deudos, de Buenos Aires- de unirse con otras instituciones locales y crear un Vaad Hajinuj (Comité o Consejo de Educación). El cometido de ese Vaad Hajinuj era apoyar las escuelas establecidas, alentar la fundación de otras nuevas e influenciar sobre las prácticas educacionales y las concepciones que guiaban las mismas. Los primeros en unirse al Vaad Hajinuj fueron los partidos sionistas tradicionales, los Talmud Torá, las escuelas sionistas y una de las dos asociaciones de maestros que, cerca de cincuenta años antes, se habían comenzado a organizar para la representación profesional de los docentes. En los primeros años dedicó su energía y la mayor parte de los medios de que disponía a las escuelas con las que se identificaba ideológicamente, por lo que las escuelas pertenecientes a la izquierda sionista y la izquierda antisionista generalmente no recibieron su asistencia.

Como explica Efraim Zadoff, fue así como el Vaad Hajinuj intentó influenciarlas para que cambiaran sus posturas. Sus esfuerzos de persuasión se focalizaron en tres áreas: 1) enfoque hacia la tradición judía, por ejemplo, su exigencia de que las escuelas renunciaran a funcionar en Shabat y las festividades judaicas; 2) actitudes respecto a los idiomas judíos, por ejemplo, su exigencia de que el hebreo fuese enseñado además del idish como lengua hablada; y 3) posiciones acerca del nacionalismo judío y el sionismo.

En 1935, el Gran Rabino Halfón pide un rabino más para la congregación israelita, que se ocupara de la juventud y se desempeñara como director de los cursos

89 Idem, p. 259. 
israelitas de los profesores que trabajarían en las colonias (Majón Lelimudei Haieduim). En respuesta se envía, desde el Seminario Teológico Judío de Breslau, a un suizo Ilamado Guillermo Schlessinger, recién ordenado. Schlessinger llegó como comisionado para inspeccionar las escuelas de las colonias y luego asumió en 1937 como Gran Rabino de la CIRA, cuando Halphón se enferma y vuelve a París. ${ }^{90}$

El año 1938 marcó la iniciación de un proceso de siete años de reconciliación entre los campos ideológicos y de ingreso al Vaad Hajinuj de las escuelas del ala izquierda, proceso signado por el compromiso ideológico de ambas partes. De esta manera, el Vaad Hajinuj Hamerkazí (Consejo Central de Educación Judía de la República Argentina) pasó a ser un espacio en el cual todos los movimientos ideológicos judíos que regenteaban escuelas actuaban juntos, así como la autoridad central en materias educativas, que catalizaba y cristalizaba el apoyo organizado de la comunidad judía a sus escuelas.

Así, el Vaad Hajinuj diseñó una política educativa promulgando una normativa formal en base a unas pocas pautas, elaboró programas mínimos de estudios que fueron aceptados por la mayoría de las escuelas, estandarizó las condiciones laborales de los maestros, al mismo tiempo que definió las calificaciones requeridas para dar empleo a los mismos e impedir el ingreso de maestros sin la adecuada formación profesional, estableció un seminario de maestros que suministró el equipo docente necesitado por el sistema educacional judío a medida que el mismo se iba expandiendo, después de que la Shoá destruyó las comunidades del este europeo de donde habían venido los maestros hasta entonces. Alentó la creación de institutos preescolares e incluso estableció un seminario para la formación de maestros especializados en esta área, y organizó las escuelas y las ayudó a satisfacer las exigencias planteadas por las autoridades educativas gubernamentales, que, a partir de 1939, impusieron la supervisión de todas las escuelas.

Los dos acontecimientos relevantes en la historia del pueblo judío durante el periodo bajo estudio marcaron una profunda impronta en el desarrollo de la edu-

\footnotetext{
90 La Sinagoga Argentina, Seminario Rabínico Latinoamericano, Marshall T. Meyer, en: http://www.seminariorabinico.org.ar/nuevoSite/website/contenido.asp?sys=2\&id=38.
} 
cación judía en el país. El Holocausto, que tan duramente golpeó en la vida y la identidad nacional de los judíos, produjo cambios en las escuelas en lo que atañe a lo ideológico y organizativo. Por otro lado, la creación del Estado de Israel influyó en la educación judía al fomentar decisivamente al idioma hebreo, después de un debate que había durado una década sobre las posiciones relativas de importancia que las dos lenguas nacionales, el idish y el hebreo, debían tener en la enseñanza de las escuelas. ${ }^{91}$

Las escuelas judías del interior del país estuvieron vinculadas durante muchos años con la Congregación Israelita de la República Argentina, que durante décadas les había brindado apoyo espiritual y también material. Por esta razón, en 1945, esta misma Congregación decidió la creación de un marco especial destinado a la formación de docentes judíos para las escuelas del interior del país. Así surgió el Majon Lelimudei Halahadut, en cuyas aulas se formaron varios de los intelectuales judíos más importantes de la comunidad. Durante las décadas del cuarenta y el cincuenta, el Majón fue el ámbito en el que se formaron decenas de estudiantes provenientes del interior, muchos de los cuales retornarían a sus lugares de origen para dedicarse a la docencia. ${ }^{92}$

Ahora bien, si retrotraemos el análisis para observar cómo fue la evolución de la enseñanza religiosa en Colonia Clara, luego de la cesión de los edificios escolares al Consejo Nacional de Educación podremos constatar los cambios que venimos observando en otros capítulos.

Se trasladaron veinte escuelas de enseñanza laica donde también se impartía educación judía, y hubo que construir nuevos edificios. Estos nuevos emplazamientos dan cuenta de la sustantiva reducción del ámbito geográfico y de acción en las colonias, para concentrarse los servicios educativos en los pueblos y en las ciudades. Proceso que también refleja las mutaciones que se estaban produciendo en la dinámica poblacional.

\footnotetext{
${ }^{91}$ Efraim Zadoff, "La educación judía en Buenos Aires Organización e institucionalización (1935-1967)", en Mundo Israelita, 28 de agosto de 2007.

92 Rubel, Yaacov, "Creación, apogeo y crisis de los institutos de formación docente dependientes de la AMIA", en Mundo Israelita, 8 y 15 de diciembre de 2000.
} 


\section{Un nuevo escenario: el abandono de las colonias}

naciamos con una estampilla en el cuerpo que nos enviaba a las ciudades.

Se desprende del trabajo realizado por Jedidio Efron, ${ }^{93}$ un relevamiento censal en la casi totalidad de las localidades, provincias y entonces territorios nacionales de Argentina en el año 1941 a pedido de la Jewish Colonization Association, que en la provincia de Entre Ríos los alumnos que concurrían a las escuelas judías en 1939 disminuyeron en 1943 en un 31\%. De ese universo, la reducción más importante se produjo en las colonias, alcanzando el 51,8\%, en los pueblos el $28,3 \%$ y en las ciudades el 12,5\%. ¿Cómo se explica esta significativa disminución? En primer lugar, por el desplazamiento de los alumnos, que para completar el $4^{\circ}$ y $5^{\circ}$ grado del ciclo primario obligatorio debían trasladarse a los pueblos más cercanos y, si aspiraban a completar la educación secundaria, debían instalarse en las ciudades que ofrecían un servicio educativo ampliado.

Estos desplazamientos rural-urbanos provocaban el cierre de escuelas por falta de alumnos, y las que lograban la permanencia lo hacían por el reagrupamiento con niños de otros grupos de la colonia.

El mencionado estudio demuestra que en las ciudades entrerrianas los alumnos no disminuyeron, sino que aumentaron, pasando del $31.5 \%$ al $40 \%$ del total del alumnado. En los pueblos los guarismos casi no presentan variación (35.8\% a $37.2 \%)$. Sin embargo, en las colonias caían del $32.6 \%$ al $22.8 \%$.

En los pueblos de Colonia Clara estos desplazamientos y reagrupamientos se constatan del siguiente modo: en Villa Domínguez concurrían 42 alumnos a la escuela y 17 niños al jardín de infantes; en Villa Clara concurrían 30 alumnos y en La Capilla, que hasta 1930 era una de las escuelas con mayor cantidad de alumnos -tuvo hasta tres maestros-, hubo que incorporar a los niños del grupo Barón de Hirsch para que pudiera seguir funcionando. Lo que demuestra la reducción de ${ }^{93}$ Efron, Jedidio, Informe presentado a la Dirección General de la JCA en Buenos Aires con fecha del 16
de febrero de 1944. Censo levantado en la provincia de Entre Ríos. 
niños en edad escolar y por ende la disminución del servicio educativo, que se veía obligado a cerrar los establecimientos.

La disminución neta entre ambas fechas fue de ocho escuelas, aunque hubo dos escuelas nuevas y otras dos reabiertas. La baja fue del $47 \%$ en las colonias y del $8.3 \%$ en los pueblos. Fueron además clausurados diez cursos. El sostenimiento económico de estos establecimientos lo proveían los padres de los alumnos con la contribución de la Chevra Kaduscha, los cursos religiosos de Buenos Aires y la Organización Escolar Hebrea de Entre Ríos.

Como ocurrió en los centros urbanos, y de modo particular en Buenos Aires, la creación del Estado de Israel motivó un regreso y un florecimiento de la enseñanza hebrea. Sin embargo, en las colonias el proceso migratorio marcaba la tendencia inexorable a la reducción de servicios por la disminución de la población en edad escolar.

En Colonia Clara, el administrador, en su informe retrospectivo presentado en año 1954, confirma que la disminución de alumnos, tanto en las escuelas laicas como en las religiosas que funcionaban en los grupos, obedecía «a que los colonos se han mudado a los pueblos". Esta disminución se puede comprobar en detalle en los cuadros siguientes.

\section{CURSOS RELIGIOSOS EN COLONIA CLARA}

\begin{tabular}{|c|c|c|c|}
\hline Año & $\mathrm{N}^{\circ}$ de cursos & Número de maestros & Número de alumnos \\
\hline 1944 & 8 & 6 & 122 \\
\hline 1945 & 8 & 6 & 124 \\
\hline 1946 & 8 & 6 & 109 \\
\hline 1947 & 8 & 6 & 96 \\
\hline 1948 & 4 & 5 & 77 \\
\hline 1949 & 8 & 6 & 134 \\
\hline 1950 & 8 & 6 & 150 \\
\hline 1951 & 8 & 6 & 152 \\
\hline 1952 & 3 & 3 & 80 \\
\hline $1953 *$ & 5 & 5 & 113 \\
\hline
\end{tabular}

Fuente: Informe del administrador de Colonia Clara, marzo de 1954.

* Incluyen el jardín de infantes (Gan) que funciona en Villa Domínguez. 
En tanto la escuela oficial mantenía una matrícula que presentaba una tendencia decreciente, debemos señalar que los cursos estaban integrados también por niños no judíos, los que prontamente serían mayoría.

\begin{tabular}{|c|c|c|c|c|c|c|c|}
\hline \multicolumn{5}{|c|}{$\mathrm{N}^{\circ}$ de escuelas } & \multicolumn{4}{c|}{$\mathrm{N}^{\circ}$ de maestros } \\
\hline Año & Ncl & Pvcial & Total & Ncl & Pvcial & Total & Alumnos \\
\hline 1944 & 17 & 3 & 20 & 31 & 21 & 52 & 1964 \\
\hline 1945 & 17 & 4 & 21 & 31 & 22 & 53 & 1938 \\
\hline 1946 & 17 & 4 & 21 & 31 & 22 & 53 & 1920 \\
\hline 1947 & 17 & 4 & 21 & 32 & 22 & 54 & 1883 \\
\hline 1948 & 17 & 4 & 21 & 32 & 22 & 54 & 1857 \\
\hline 1949 & 17 & 4 & 21 & 32 & 22 & 54 & 1812 \\
\hline 1950 & 17 & 4 & 21 & 32 & 22 & 54 & 1782 \\
\hline 1951 & 17 & 4 & 21 & 32 & 22 & 54 & 1740 \\
\hline 1952 & 17 & 4 & 21 & 32 & 22 & 54 & 1670 \\
\hline 1953 & 15 & 4 & 19 & 28 & 22 & 50 & 1620 \\
\hline
\end{tabular}

Fuente: Informe del administrador de Colonia Clara, marzo de 1954.

Las cartas estaban echadas. La población judía se estaba marchando a las ciudades. Las escuelas se despoblaban y las hebreas disminuían sus servicios por falta de alumnos. Un solo datos más. En la década de 1950, en la escuela Nº 60 Feliciano Chiclana de Villa Clara, el 50\% de los alumnos eran judíos. En la actualidad concurren 550 alumnos, de los cuales sólo 6 son niños judíos. Y en tanto la escuela hebrea que contaba con 70 alumnos en la década señalada, en la actualidad sólo brinda enseñanza a 8 alumnos. ${ }^{94}$

${ }^{94}$ Entrevista a Marta Muchinik, encargada del Museo de Villa Clara. 

capítulo seis 



\section{El cooperativismo en Colonia Clara: el Fondo Comunal}

El cooperativismo cumplió un rol muy importante en la ayuda para las necesidades de los colonos: no solamente era un movimiento de crear una cooperativa comercial sino que todos los colonos estaban imbuidos de un sentido de colaboración, mutualismo y ayuda mutua, dentro del cual entró el sistema cooperativo. Pero no hubo únicamente cooperativas de "producción y consumo" (recibía la producción de los colonos y los abastecía de productos alimenticios, vestimenta y herramientas y accesorios para las maquinarias, $y$

los asesoraba en las técnicas de laboreo, etc.). Además hubo hospitales y servicios sanitarios, cooperativas de consumo de carne, de pan, de elaboración de productos lácteos, cooperativas de créditos que actuaban en coordinación con las cooperativas de producción y consumo. ${ }^{1}$

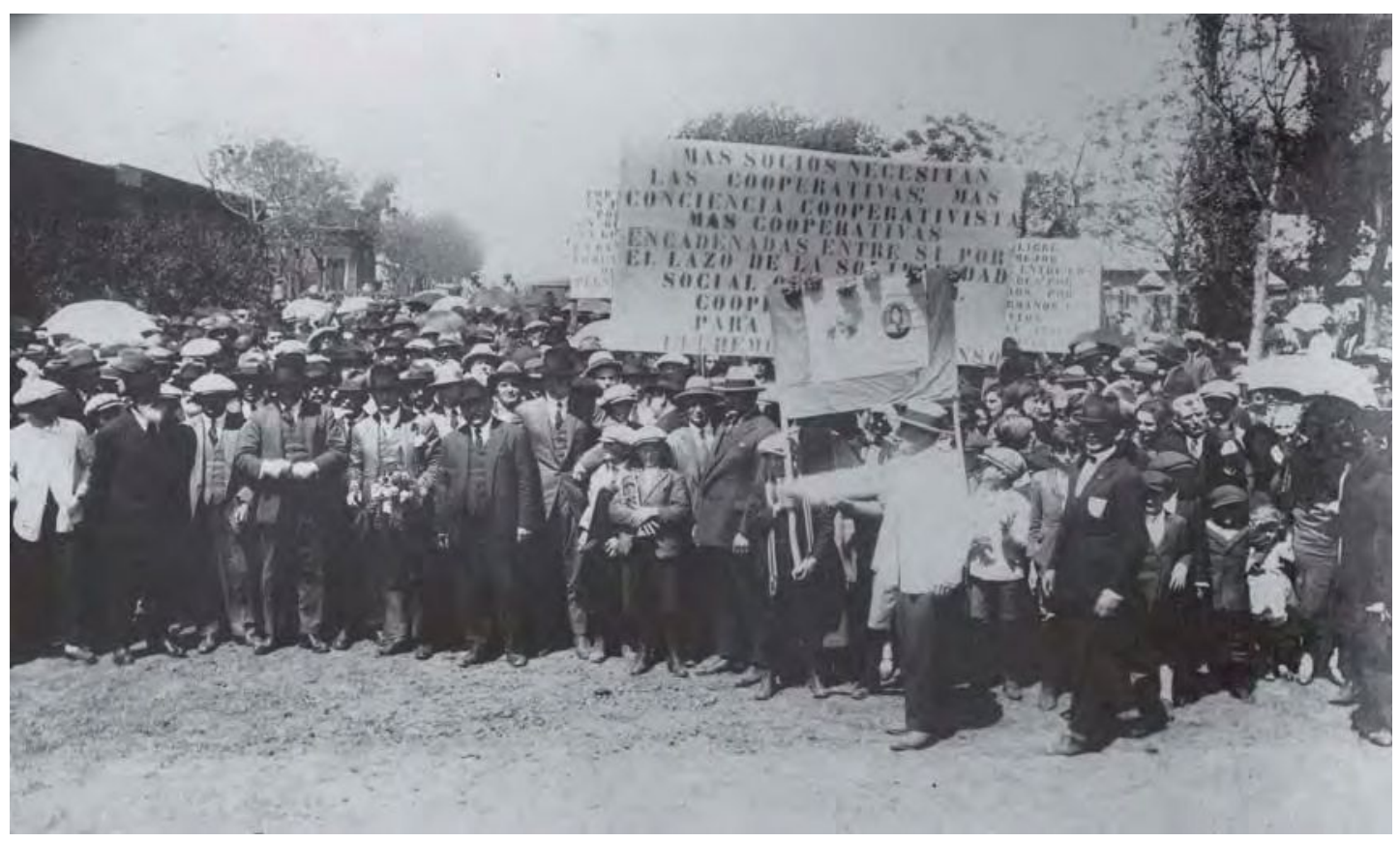

Manifestación de Colonos Cooperativistas en Villa Dominguez, 1923.

\footnotetext{
${ }^{1}$ Este extenso párrafo inicial pertenece a Julio Mazo Efron, nieto e hijo de colonos, quien se ha convertido en un interlocutor imprescindible para realizar nuestro estudio sobre Colonia Clara, respuesta a cuestionario semiestructurado.
} 
Las causas del surgimiento del cooperativismo en la Argentina son variadas, pero, sin duda, entre ellas, la cuestión inmigratoria aparece como elemento gravitante, señala Graciela Mateo, historiadora especialista en el tema. ${ }^{2}$ Justamente, en y desde Entre Ríos - donde la colonización ha sido una nota distintiva-, el movimiento cooperativista no puede separarse del proceso de colonización judía. Como tampoco puede la historia del cooperativismo entrerriano separarse de la historia de Colonia Clara.

Una de las singularidades del cooperativismo entrerriano, de su ideario y de su experiencia, señala Celia López, ${ }^{3}$ fue su carácter esencialmente docente, armonizador de criterios, eficaz en lo educativo, y su combatividad en lo gremial, defensor a ultranza de los intereses chacareros, lo que condujo a la temprana concreción de federaciones y entidades de segundo grado.

Estos inmigrantes europeos que se insertaron en el medio agrario desde fines del siglo xIx intentaron replicar algunas de las formas de organización y acción colectiva que habían conocido en sus lugares de procedencia y que en cierto modo podrían retroalimentar su identificación y pertenencia regional. Trajeron consigo el ideario cooperativista al ingresar al modelo de acumulación capitalista agroexportador, signado por la libre empresa y la competencia comercial, buscando los instrumentos necesarios para adaptar la experiencia anterior al nuevo escenario, generando un cambio sociocultural de enorme trascendencia en el país. Así, la doctrina inglesa, la experiencia alemana y la ideología socialista ${ }^{4}$ constituyeron los tres pilares del movimiento.

Desde sus orígenes, el cooperativismo intentó cumplir el papel de base empresarial de los productores agropecuarios con un doble objetivo: el primero, de

\footnotetext{
${ }^{2}$ Mateo, Graciela, "Cooperativismo agrícola en el litoral pampeano: su expansión, entre la tradición y la política agraria peronista". Disponible en http://www.fee.tche.br/sitefee/download/jornadas/2/h1005.pdf.

${ }^{3}$ López, Celia, "Ciclo productivo y marco institucional. Bancos agrícolas y cooperativas agrarias entrerrianas entre 1920 y 1940". Disponible en http://eh.net/XIIICongress/cd/papers/57L\%F3pez39.pdf .

${ }^{4}$ Miguel Kipen, abogado y dirigente de la Cooperativa Fondo Comunal, conoció y mantuvo intercambios epistolares con Karl Kausky, intelectual que se dedicó especialmente al problema agrario y el papel de las cooperativas. Ver Carpeta Miguel Kipen, Archivo IWO. En el plano nacional, en las primeras décadas del siglo xx, el socialismo presenta un programa agrario que, aunque no puede concretar en la práctica, incentiva la formación de cooperativas en el campo. Ver Juan B. Justo, "La cuestión agraria", en Discursos y escritos políticos, Buenos Aires, El Ateneo, 1933, pp. 141-155.
} 
carácter social, estaba destinado a la prestación de un servicio basado en principios de solidaridad, libre asociación y gestión democrática; el segundo, de carácter económico, estaba orientado a la defensa de los intereses y a la mejora de los ingresos y situación económica de sus asociados. Desde un criterio funcional, las cooperativas agrarias pueden cubrir diversas actividades, necesidades 0 servicios, tales como el aprovisionamiento, la producción o la transformación y la comercialización, cumpliendo una o varias de esas fases. ${ }^{5}$

La necesidad de debatir entre pares, para después peticionar ante las autoridades, ha sido una constante en el movimiento cooperativo agrario. En esos tiempos de organización, los liderazgos eran pocos pero muy marcados. En Colonia Clara surgieron los dirigentes mejor orientados en la teoría y la práctica cooperativas. Miguel Sajaroff, ${ }^{6}$ Miguel Kipen, ${ }^{7}$ Isaac Kaplan, ${ }^{8}$ David Merener ${ }^{9}$ y Marcos Wortman ${ }^{10}$ son dignos ejemplos de esta dirigencia y del inmigrante que, afincado

\footnotetext{
${ }^{5}$ El ingeniero Juan L. Tenenbaum presenta en el II Congreso Agronómico de Río Grande del Sud, Brasil (1936), una clasificación que es aceptada para su uso en Argentina, Brasil y Uruguay, reconociendo, de acuerdo con la cantidad de funciones que cada cooperativa desempeña, dos grandes grupos: uniactivas, es decir, especializadas, como puede ser una bodega cooperativa que se dedica exclusivamente a la fabricación de vino; y multiactivas, aquellas cooperativas de campaña que tienen almacén, sección de comercialización, de crédito, etcétera. Más datos sobre clasificación de cooperativas en Banco de la Nación Argentina, Curso sobre Cooperativismo, Buenos Aires, Talleres Gráficos «Index», 1955, pp. 92-95. Hernández Perlines, en su artículo "¿Son competitivas las cooperativas agrarias?", distingue entre monovalentes, bivalentes, multivalentes, con o sin sección de crédito, en Revista de Debate sobre Economía Pública Social y Cooperativa, № 18, Valencia, julio, 1995, CIRIEC, pp. 9-40. Citado por Graciela Mateo, op. cit.

${ }^{6} \mathrm{Nació} \mathrm{en} \mathrm{Mariupol,} \mathrm{Crimea} \mathrm{(Rusia).} \mathrm{Se} \mathrm{graduó} \mathrm{como} \mathrm{ingeniero} \mathrm{agrónomo} \mathrm{en} \mathrm{Alemania.} \mathrm{Llegó} \mathrm{al} \mathrm{país} \mathrm{en} 1899$ y se instaló en Colonia Clara, en el grupo Leven. Ha sido reconocido como el maestro e inspirador del movimiento cooperativista en el país. Fue una figura singular, respetuosa y respetada por la enorme mayoría de la colectividad judía y no judía. La honestidad, el sentido de la justicia y la búsqueda de la armonía social marcaron su larga vida en el país. Proveniente de una familia con importantes recursos económicos, llegó a Colonia Clara por la invitación que le hiciera su cuñado, el médico Noé Yarcho. Adquirió 500 hectáreas. Fue un colono con importantes recursos económicos que murió en la pobreza, terminando sus días en una casa que le cedió en préstamo la Fraternidad Agraria. Su humildad, la honestidad y su compromiso con el ideal cooperativista inquebrantable fueron su legado, que permanece intacto en la memoria colectiva de la región.

${ }^{7}$ Nació en Melitopol (Rusia), en 1878. En San Petersburgo ingresó al Partido Obrero Social Demócrata, y participó en una huelga de estudiantes en el Instituto Tecnológico, motivo por el que se lo expulsó. Estuvo detenido en Siberia, desde donde huyó y emigró a Suiza, donde se recibió de abogado. Llegó a Argentina en 1912 y se asentó en colonia Leven, muy cerca de su cuñado Sajaroff.

${ }^{8}$ Nació en Svisloch, provincia de Minsk (Rusia), y llegó a Argentina a los diecisiete años junto a sus padres y cinco hermanos, traídos por la JCA. Se instaló en el grupo Desparramados.

${ }^{9}$ Nació en Carmel y contaba con veintiséis años cuando fue electo para ingresar al Consejo Directivo del Fondo Comunal.

${ }^{10}$ Sus padres fueron establecidos por la JCA en el grupo Kiriat Arba. Llegó al país con tres años de edad. Concurrió sólo a la escuela primaria. Fue un autodidacta. Muy joven se adhirió como socio del Fondo Comunal, integrando ya en 1918 el Consejo Directivo.
} 
en el suelo argentino, contribuyó al desarrollo de la agricultura y del cooperativismo agrario.

Como decíamos, el cooperativismo intenta, en general, cumplir el papel de base empresarial de los productores agropecuarios con un objetivo de carácter social y económico. Sin embargo, una particularidad en las colonias judías estuvo en que fue, además, un instrumento de educación y generador de formas de convivencia para una vida armoniosa, basada en el bien común, así como también el espacio político y de defensa de los colonos ante los embates y las exigencias impuestas por la empresa colonizadora.

Las cooperativas agrarias judías, y en particular sus federaciones, trazaron un proyecto de defensa de los colonos frente a los programas de acción de los distintos elencos administrativos de la JCA que perseguían el cumplimiento estricto de normas establecidas por la Oficina Central de París, las que se distanciaban y se contraponían -en demasiadas ocasiones- a las necesidades, expectativas y demandas que la experiencia colonizadora en el país imponía a los colonos. Estas tensiones y las formas de resistencias marcaron la acción gremial que se movía en dos planos. Por un lado, la búsqueda de acción cooperativa en la esfera económica trabajando mancomunadamente con entidades provinciales y nacionales, y, por otro, una acción solidaria con base étnica, que, si bien contenía estrategias de acción económica, iba más allá para construir un frente común de resistencia y de sobrevivencia ante la JCA.

Otra de las singularidades es que estas cooperativas fueron creadas por la acción directa de la empresa colonizadora, aportando recursos económicos y colaboración para el desarrollo de la ayuda mutua y la solidaridad entre los colonos. Sin embargo, a medida que la institución fue adquiriendo experiencia y solidez en el plano social y algunos avances en el plano económico, comenzó un largo proceso de enfrentamientos signado por una relación asimétrica debida a los niveles de dependencia de los colonos y por las estrictas demostraciones de estas asimetrías ejercidas por los administradores de la JCA. 


\section{Las cooperativas en las colonias de la JCA en Entre Ríos y sus redes de acción}

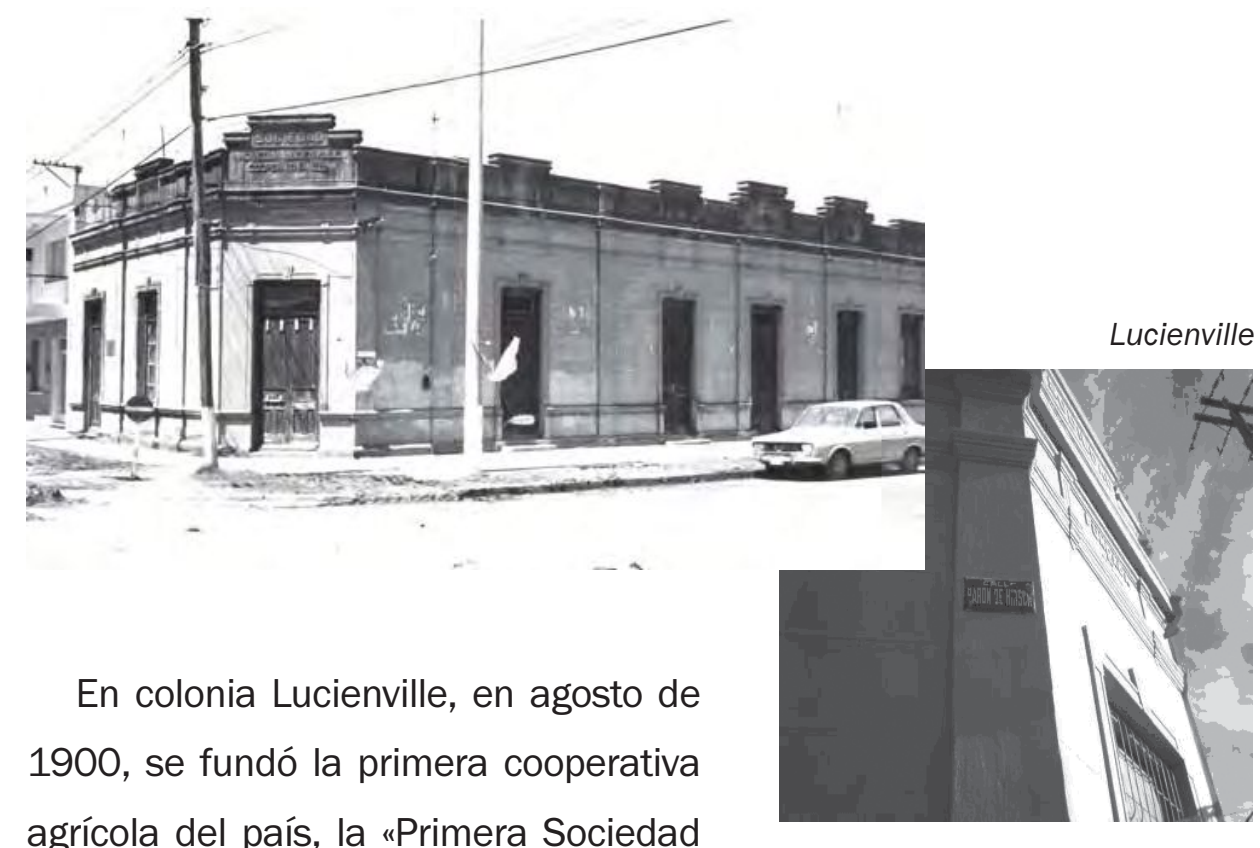

Agrícola Israelita" (Der Ersshter Idisher land-virshaftlijer Farein, en idish) en Basavilbaso, convirtiéndose en 1907 en la "Cooperativa Agrícola Lucienville Ltda.", en homenaje a Lucien Hirsch, hijo del barón de Hirsch. Esta entidad -creada por directa iniciativa de la Jewish Colonization Association- desde el comienzo adoptó un sistema de actuación que sirvió luego de modelo para la mayoría de las cooperativas mixtas o multiactivas que poblaron toda la zona cerealera del país. Tres fueron los objetivos de sus fundadores: adquirir conocimientos de índole agrícola, formar una caja de ahorros y préstamos, y adquirir artículos para la cosecha a precios ventajosos.

Dos aspectos, crédito y abastecimiento, formaban la base de esta nueva cooperativa, que se encargaba de la venta de cereales y mezclas y poco después de constituida ya contaba con un almacén de consumo, corralón de maquinaria agrícola, depósito en las estaciones ferroviarias y un fondo de semillas. Más allá de sus funciones económicas, esta entidad ejerció una verdadera influencia de orden moral, ya que la educación agrícola, la organización de bibliotecas y la conformación de centros culturales fueron también sus preocupaciones principales. ${ }^{11}$

\footnotetext{
${ }^{11}$ Ver en detalle Fistein, Nora, Colonia Lucienville. El rescate del pasado mantendrá viva la memoria, Basavilbaso, 2004.
} 
Las cooperativas agrarias tenían que abarcar las dos funciones básicas del comercio local de aquella época en la campaña: el negocio de ramos generales, que significa ya un primer paso para sustituir el comercio privado por el cooperativo, y la provisión de crédito.

La segunda cooperativa, denominada Cooperativa Agrícola Fondo Comunal, se fundó en Colonia Clara en 1904 y se constituyó en el eje del cooperativismo entrerriano, como lo veremos en detalle en páginas posteriores.

Tempranamente, los dirigentes del Fondo Comunal se abocaron a pensar en los ámbitos de encuentros, las modalidades y formas que podrían adquirir las federaciones de cooperativas, convencidos de que la unidad de las mismas les daría las fuerzas necesarias para el logro de objetivos comunes y operaciones económicas conjuntas, una de base étnica y otra como grupo de presión integrado por chacareros entrerrianos. Las exigencias de la empresa colonizadora fueron el catalizador para la búsqueda de alianzas entre las colonias judías, cuya presión se sumaba a las problemáticas del desarrollo agrario capitalista.

Fruto de estas pioneras acciones, la provincia de Entre Ríos fue la sede en junio de 1913 del primer congreso de cooperativas, ${ }^{12}$ reunido en la localidad de Lucas González, oportunidad en la que se constituyó la Confederación Entrerriana de Cooperativas, que se inició con la compra en común de materiales e implementos para sus asociados. Si bien esta primera entidad de segundo grado tuvo una vida efímera -fue refundada en 1930 con el actual nombre de Federación Entrerriana de Cooperativas-, dejó un saldo favorable, porque desde ese momento las cooperativas rompieron su estado de aislamiento, al considerarse parte integrante de un proceso económico social que necesitaba del esfuerzo solidario.

El segundo congreso de las cooperativas de Entre Ríos se reunió en octubre de 1913 , donde se analizaron las necesidades del crédito agrario y las formas en que

\footnotetext{
12 Inauguró las deliberaciones el ingeniero Víctor Etcheverry - presidente de la Comisión organizadoramanifestando "que el Congreso era fruto de la idea del señor Alejandro Mohor, gerente de "La Agrícola Regional" y del anhelo del presidente del Fondo Comunal, Don Isaac Kaplan, aquí presentes", y contó con la participación de cinco cooperativas y una asociación agraria: Fondo Comunal, de Domínguez; Sociedad Agrícola Argentina, de Basavilbaso; Unión entre Agricultores, de Urdinarrain; Agrícola Regional, de Crespo: La Mutual, de Lucas González; Círculo de Obreros, de Urdinarrain. Ver Merener, David, El cooperativismo en Entre Ríos. Los Congresos Argentinos de la Cooperación, Ediciones Intercoop Argentina, Cuadernos de Cultura Cooperativa, 1972, p. 17.
} 
las cooperativas podrían resolverlo. Luego, en otra reunión en Basavilbaso, se analizó el problema de los arrendamientos rurales, la gestión ante los poderes públicos de la exención de impuestos y patentes y el mejoramiento de la calidad de la semilla, estableciéndose el intercambio de las variedades más aptas para la región y que hayan dado buenos rendimientos, y la difusión de los conocimientos del cooperativismo.

En 1916, por iniciativa del Fondo Comunal, se convocó a un congreso de las colonias judías en Buenos Aires al que asistieron los delegados de casi todas las colonias de la JCA en el país, cuyo objetivo era enfrentar de manera federativa los embates que padecían los colonos por los desalojos impuestos por la empresa colonizadora. Se abría de este modo la otra área de acción gremial. La experiencia del trabajo federativo en la esfera económica les había dotado de práctica y entrenamiento para encarar una empresa muy complicada, como veremos en detalle en páginas siguientes.

El año 1919 fue prolífero en congresos cooperativos, tanto en el ámbito local como nacional: en abril volvió a reunirse en Lucas González un foro, ${ }^{13}$ en el que se aprobó definitivamente el estatuto de la Federación Entrerriana de Cooperativas Agrícolas; en mayo un nuevo encuentro tuvo lugar en la localidad de Urdinarrain, en el que se trataron, entre otros temas, la fabricación de bolsas, el papel de las cooperativas de lechería y de los molinos harineros; en tanto en el mes de octubre se llevó a cabo en Buenos Aires el Primer Congreso Argentino de la Cooperación, convocado por el Museo Social Argentino, en el que participaron ochenta entidades. Su temario fue amplio, siendo uno de los puntos más importantes la necesidad de sancionar una ley general que contemplara aspectos y caracteres de estas entidades no previstos en los artículos 392, 393 y 394 del Código de Comercio, que regulaban el funcionamiento de estas asociaciones. También se propuso sancionar una ley especial para las cooperativas agrícolas.

\footnotetext{
${ }^{13}$ Se trata del Tercer Congreso de Cooperativas de Entre Ríos, presidido por Miguel Sajaroff. Como delegados del FC participaron Miguel Kipen y Marcos Wortman. Se aprobó además el despacho sobre arrendamientos agrícolas, solicitud de preferencia a las cooperativas en los espacios ferroviarios para el almacenamiento de las cosechas, solicitud de crédito al Banco de la Nación Argentina para semilla, entre otros tópicos.
} 
Organizar el Segundo Congreso Argentino de la Cooperación, reunido en Paraná en 1921, significó para la provincia de Entre Ríos un honor y una enorme responsabilidad, por lo que tanto funcionarios como cooperativistas se concentraron en la tarea. Por otro lado, la elección de esta sede demostraba el reconocimiento de la tradición cooperativista inaugurada en las colonias judías. El aparato estadístico provincial, de reconocida eficacia, fue instruido para trabajar a pleno, a fin de ofrecer a los organizadores una acabada versión de la vida agraria cooperativa regional. Según el Censo Agrícola levantado en 1920, en el año 1918-1919 se registraban 19 cooperativas agrícolas con 3.953 socios activos, de los cuales 2.087 eran propietarios y 1.866 eran arrendatarios. ${ }^{14}$ La superficie que en conjunto tenían sembrada los asociados era de 30.000 hectáreas. El gobierno entrerriano sancionó previamente a la reunión del congreso la Ley de Fomento de Cooperativas y otra complementaria, eximiendo de impuestos a estas entidades. El gran tema seguía siendo la urgente sanción de la Ley Nacional de Cooperativas y la adecuación en tiempo y forma de todas las entidades del país a sus futuras normas. Mientras tanto, el gobierno provincial recomendaba en particular dictar una ley que contemplase sólo las cooperativas agrícolas, y dentro de sus considerandos, introducir la propaganda didáctica y la defensa del agricultor, acordar líneas especiales con el Banco Nación y promover la construcción de silos y elevadores, como también todo lo necesario a la concurrencia de la industria lechera, a la que se le asigna un importante papel dentro de la economía rural diversificada.

El movimiento cooperativo agrario institucionalizado inició su ciclo en 1922, al fundarse en Rosario la primera entidad de segundo grado que prosperó en el país, la Asociación de Cooperativas Rurales Zona Central. La Asociación de Cooperativas Argentinas (ACA), como se denominaba desde 1927, inicialmente constituida por cooperativas de Córdoba y Santa Fe, incorporaba en las décadas siguientes asociaciones primarias de Entre Ríos, Misiones y del Territorio del Chaco.

\footnotetext{
${ }^{14}$ El capital suscripto ascendía a $\$ 500.000$ y el realizado era de $\$ 150.000$, en tanto el fondo de reserva llegaba a $\$ 6.789 .179$. Las ventas en conjunto de estas cooperativas era de $\$ 157.000$, sus edificios estaban valuados en $\$ 157.000$ y la superficie que en conjunto tenían sembrada los asociados era de 30.000 hectáreas.
} 
La primera ley de Cooperativas $N^{0} 11.388$, sancionada en 1926, contribuyó a la consolidación de un movimiento integrado por auténticas cooperativas, organizadas bajo los principios rochdaleanos en los que la ley se inspiraba, y les otorgaba estatuto legal en el marco de la política nacional. En estas instituciones, la comercialización de productos primarios, bajar los costos de intermediación y el auxilio a los productores rurales eran sus misiones primordiales. En ese contexto propicio, dos fervientes propulsores del cooperativismo entrerriano habitantes de Colonia Clara, el agrónomo Miguel Sajaroff y el abogado Isaac Kaplan, retomaron el viejo proyecto de fundar la Federación Agraria Israelita, luego denominada Fraternidad Agraria, ${ }^{15}$ institución que agrupaba todas las cooperativas establecidas en las colonias judías del país.

\section{Sociedad Cooperativa Agrícola Fondo Comunal de Colonia Clara}

Tener una libreta del Fondo Comunal, y ver que no se tenía que pagar en el momento, era todo un privilegio a los ojos de un niño. ${ }^{16}$

La historia de la Cooperativa Fondo Comunal es también la historia de Colonia Clara.

Esta institución desempeñó una función social, económica, educativa y cultural que excedió largamente el ámbito de la colonia para convertirse en los portavoces

\footnotetext{
${ }^{15}$ La Fraternidad Agraria era un largo anhelo que fue presentado por primera vez en la sesión del 14 de junio de 1910 del Fondo Comunal por Miguel Sajaroff, explicando la necesidad de federar las cooperativas de las colonias de la JCA. Se reunieron luego en Buenos Aires el 14 de noviembre de 1910, dando nacimiento a la Confederación Agrícola Argentina Israelita, cuya constancia firman los doce delegados presentes. En 1911 se realizó un Segundo Congreso en Buenos Aires y el tercero en Rivera, colonia Barón Hirsch en 1912. El nombre fue cambiado por el de Fraternidad Agraria por dos motivos: su semejanza al nombre de la Federación Agraria Argentina y a causa de la ley de cooperativas № 11.388, que había entrado en vigor y que prohibía toda expresión de religión, raza, partido, etcétera.

${ }^{16}$ Entrevista a Yauda Kuzniecky Levit, abogado y educador. "Nací el 19 de Enero de 1934 en La Capilla, a los tres años y medios mis padres se trasladaron a Villa Domínguez, lugar donde curse mi escuela primaria. En Villa Domínguez pasé mi infancia, celebré mi Bar Mitzva, mayoría de edad religiosa en la religión judía y a esa misma edad me trasladé a Buenos Aires donde permanecí en un internado cursando mis estudios secundarios, pues en Villa Domínguez no había escuela secundaria. Un año más tarde mis padres pasaron a vivir a Buenos Aires». En la actualidad vive en la República de Panamá.
} 


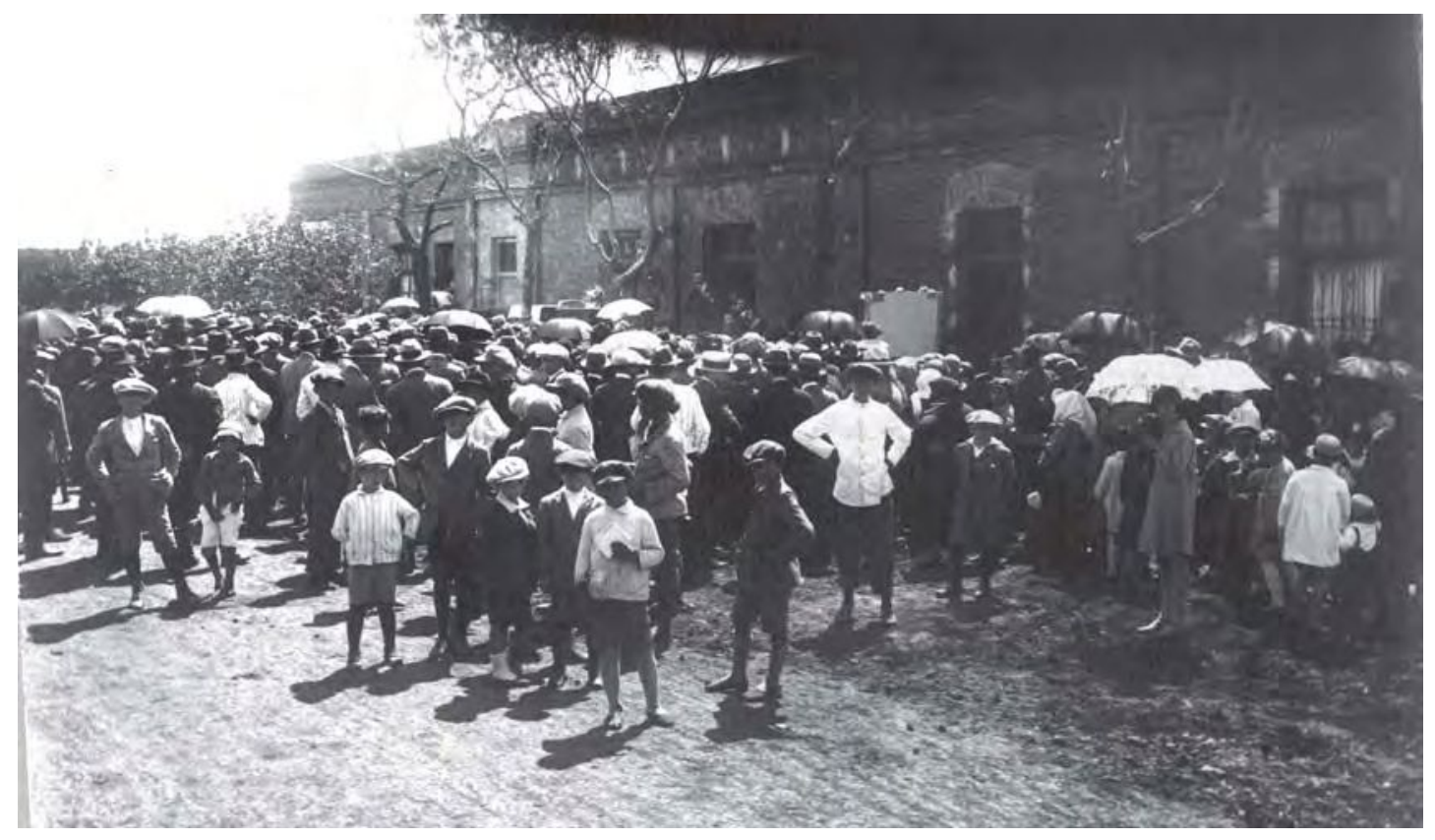

Inauguración del Almacén del Fondo Comunal en Villa Domínguez, 1917. 
de las demandas, necesidades y aspiraciones de los colonos judíos que, junto a otras instituciones cooperativas no judías, incidieron en la determinación de una política provincial y nacional de protección a los chacareros argentinos. Sin dudas, el Fondo Comunal fue la más importante de las cooperativas agrícolas entrerrianas, por la cantidad de socios -cerca del millar-, por el capital social suscripto y realizado y sus fondos sociales, por la magnitud de las actividades que cubrían -distribución de mercaderías, provisión de implementos agrícolas y artículos de consumoy la comercialización de cereales y productos de granja y ganado que sus socios entregaban, por la capacidad de alentar la incorporación tecnológica y conocimiento estratégico en la producción agropecuaria y sus derivados industriales. Al tiempo de ser un centro para la actividad económica, la cooperativa se convirtió en un punto de reunión, de encuentro, al que se concurría no sólo por necesidades materiales, sino también a conversar, a tomar una copa, a intercambiar opiniones con los conocidos. ${ }^{17}$ Fue también la institución que enfrentó los intereses de los grandes monopolios comercializadores de granos, y por supuesto los intereses de la empresa colonizadora: toda su trayectoria está marcada por la relación con la JCA.

El Fondo Comunal fue un ámbito de gestión democrática con activa participación de los socios en las asambleas generales, foro donde el debate, la confrontación y la búsqueda de consensos otorgaron una práctica política para el abordaje de temas que iban más allá de las preocupaciones económicas. En este espacio adquirieron prácticas por las que los habitantes se fueron convirtieron en ciudadanos. En las asambleas generales extraordinarias los socios elegían y podían ser elegidos, mediante un acto electoral, a los consejeros que integrarían la Comisión Directiva y los actores que se desempeñarían en los cargos de presidente, vicepresidente, secretario, gerente y síndico, elenco responsable de la conducción de la institución con un mandato que se renovaba anualmente. Se aprobaba el presupuesto y el balance de la gestión, se debatía el orden del día preparado por el Consejo Directivo y se abría también la deliberación sobre otros temas que podían ser propuestos por los socios presentes. Estas asambleas fueron la caja de resonancia de las demandas y expectativas de los colonos.

\footnotetext{
${ }^{17}$ Kreimer, Jaime, Aportes de la colectividad judía al cooperativismo nacional, Rosario, Centro Cultural Israelita, 1984.
} 
El Consejo de Administración se reunía dos veces al mes en asambleas ordinarias, sesiones convocadas por el presidente, en las cuales se diseñaba y preparaba el presupuesto, se delineaba las acciones económicas, sociales y culturales, se atendían las demandas de los socios y se buscaban las soluciones a través de la constitución de comisiones creadas a tal efecto; se proponían y elegían los delegados de los distintos foros donde debería intervenir la cooperativa; se recibían los informes de estas misiones; etcétera. Todas las resoluciones se adoptaban mediante rigurosa votación. Las distancias, los malos caminos y la inclemencia del clima no impedían que los consejeros se reunieran religiosamente para abocarse a la tarea encomendada. Ser elegido para integrar la conducción del Fondo Comunal era un honor, pero también un deber al que no se podía desoír y difícilmente renunciar.

En las asambleas se trataban también otros temas vinculados a la vida comunitaria, la relación con otras instituciones y con el Estado provincial y nacional. A modo de ejemplo de la multiplicidad de cuestiones que se analizaban, podemos rescatar un acontecimiento vinculado a la discriminación étnica, por el peso de este problema en la comunidad judía, y para dar cuenta de la forma en el tratamiento de esta cuestión: en la asamblea general de julio de 1935, el jefe de policía del Departamento de Villaguay solicitó permiso para hacer uso de la palabra, invocando la representación del Poder Ejecutivo de la provincia, para felicitar a los asambleístas por su cultura societaria y para hacer saber a la colectividad israelita que no debía dar importancia a ciertas alarmas que propagaban "ciertos elementos", que sólo intentaban perturbar la tranquilidad, para concluir señalando que:

el gobierno de la Provincia reprimirá con brazo enérgico cualquier tentativa de perturbación a esta colectividad pacífica y laboriosa, acreedora a la consideración y respeto, conforme los establece la Constitución Nacional. ${ }^{18}$

En respuesta a ello, el señor Moisés Gleser pidió a los 101 asambleístas presente un voto de aplauso al Poder Ejecutivo de la provincia.

${ }^{18}$ Acta No 656, Asamblea General Extraordinaria del 21 de julio de 1935, p. 63. 
La moral y normas de conducta esperadas en los colonos, los desafíos que impondrían las nuevas inversiones económicas o las reducciones en momentos de crisis, los alcances y los gastos que demandaban la participación y el trabajo con otras cooperativas e instituciones locales y nacionales, las expectativas por el desarrollo cultural, entre otros tantos temas, eran motivo de intensas discusiones que se desarrollaban en jornadas que sólo podían postergarse por motivos de lluvia.

Nos proponemos en este capítulo historiar los primeros cincuenta años de la cooperativa Fondo Comunal, que coinciden con nuestro período de estudio sobre Colonia Clara, contando para ello como fuente documental con las Actas de Sesiones, importante acervo documental resguardado en el Archivo y Museo de Villa Domínguez, los intercambios epistolares y correspondencia de los principales dirigentes reunidos en los Archivos personales, las memorias institucionales, los informes de los administradores de la JCA, las publicaciones periódicas propias -EI Colono Israelita Argentino y El colono cooperador- y las editadas por los actores del cooperativismo -El Campo, dirigido por Marcos Wortman, con la colaboración de Kipen, Zeigner, entre otros-, así como artículos publicados en periódicos tanto locales como nacionales.

Con fines analíticos, es posible realizar una periodización de su trayectoria, la que nos permite observar con mayor detenimiento las transformaciones sociales y políticas de la institución, convirtiéndose a la vez en un ángulo privilegiado para detectar las variadas aristas y problemáticas que fueron dando múltiples densidades a la experiencia colonizadora, no sólo en el plano económico, sino también en el social y cultural.

La primera etapa, a la que denominaremos Génesis del Fondo Comunal, abarcó desde 1904 hasta 1908. Fue producto de una alianza estratégica entre la empresa colonizadora y los colonos por la que se delinearon los objetivos y se pusieron a prueba los alcances de la solidaridad y la ayuda mutua para lograr el arraigo de los colonos a la tierra. La segunda, que cubrió el período 1908-1916, se inició con la asunción de Miguel Sajaroff como presidente del Fondo Comunal y donde se perfila cierta autonomía de la cooperativa de la JCA, producto de la autoadministración. Una tercera etapa, que denominaremos como afianzamiento y desarrollo del Fon- 
do Comunal, entre 1917 y 1930, se caracterizó por la emergencia de líneas internas y corrientes ideológicas que enfrentaron decididamente la política de la empresa colonizadora, con activa participación gremial reivindicativa y de fortalecimiento de los lazos cooperativos que le otorgaron proyección nacional. Finalmente, una cuarta etapa que se desarrolló a partir de los cambios y reacomodamientos impuestos por la crisis del treinta, a la que denominaremos como resurgimiento, consolidación y crecimiento, entre 1938 y 1954, donde las notas características surgen del entrecruzamiento de un sostenido crecimiento económico y diversidad productiva incentivada por la institución -ahora multivalente- con la introducción de cambios tecnológicos ocurridos en el ámbito de la producción y el comercio, lo que sin duda favoreció el proceso de desarrollo rural en su sentido más amplio, es decir, desde la perspectiva de la mejora en las condiciones materiales de existencia de la población rural; fenómeno que se traduce en un amplio acceso de los socios a la propiedad de la tierra, concomitantemente con el despoblamiento rural debido al desplazamiento de los colonos del campo hacia las ciudades. Todas estas transformaciones estratégicas se traducen en un distanciamiento efectivo de la empresa colonizadora.

\section{Primera etapa: Nacimiento del Fondo Comunal. 1904-1908}

El 21 de noviembre de 1904 se fundó el Fondo Comunal (FC, en adelante) como institución de ayuda mutua y luego como cooperativa. La reunión se llevó a cabo en La Capilla, en el salón "Zijron Moische" ("Memoria de Moisés"), y se nombró a los señores Adolfo Leibovich como presidente y a Benjamin Mellibovsky como secretario (ambos pertenecientes a la Administración de la JCA). El Consejo Directivo estuvo compuesto por Noe Yarcho, Moisés Abramovich, M. Kostianovsky, Isaac M. Sas, Schaye Toff, Ch. Bakman, Pinjos Saltzman, I. Idelshon, León Garbovetzky, Gregorio Glass, D. Venziani y W. Moss, estos últimos directores de la JCA.

Si bien la Administración de la JCA concentró todo el desarrollo de la vida social, cultural y económica de la colonia, y desde un principio brindó a los colo- 


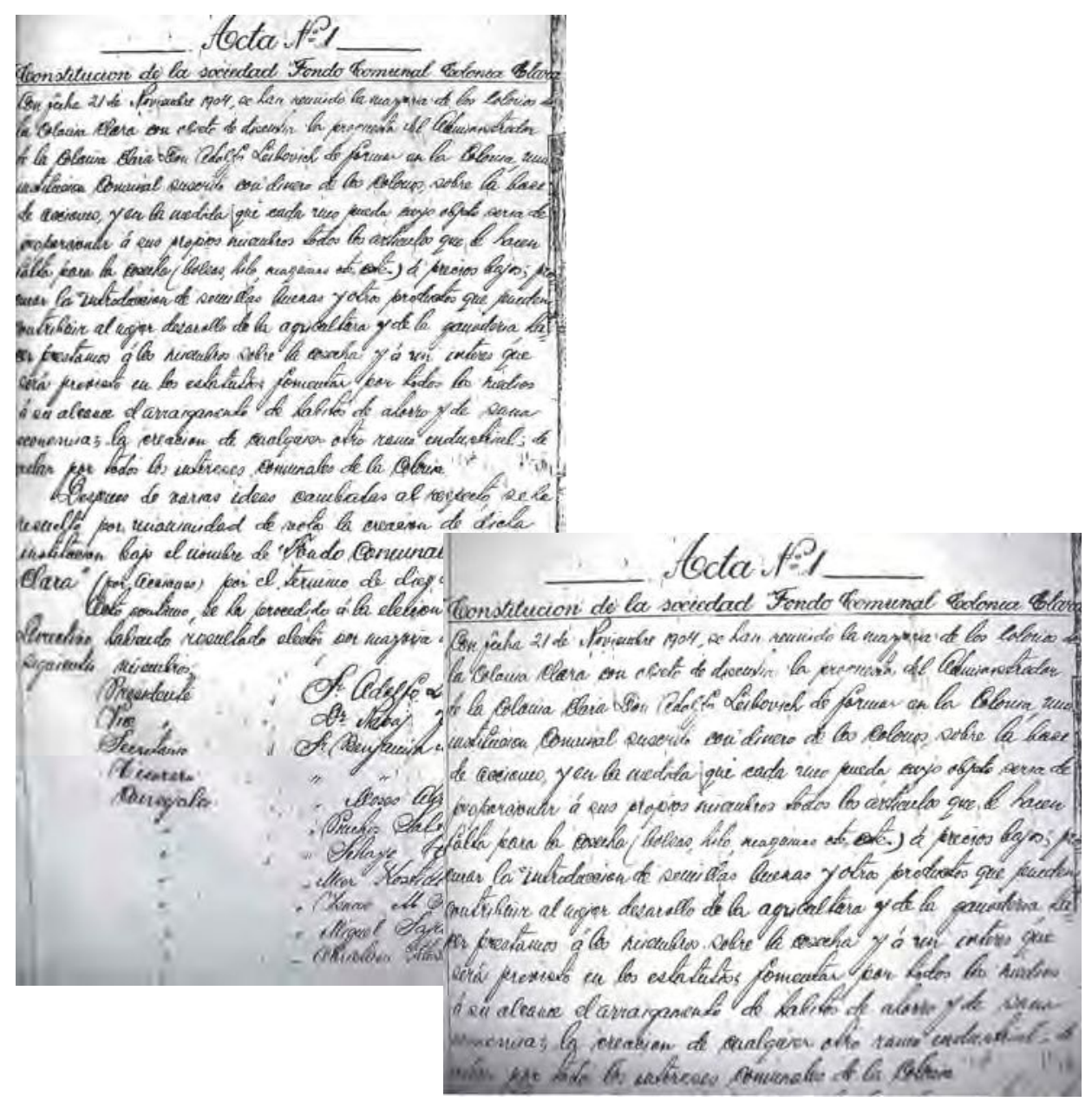

Copia del Acta Fundacional

nos una infraestructura social básica -escuelas, sinagogas, instituciones sanitarias, cajas de crédito, mediación ante la policía y el gobierno y otras necesidades de la vida cultural y social-, se podía observar un descontento generalizado en los colonos por la vulnerabilidad económica en que los sumergía cultivar la tierra en parajes vírgenes, que entre otras causas combinaba la escasa calificación para emprender semejante desafío y la baja o nula rentabilidad que obtenían de esta tarea. Los continuos movimientos de protestas, las migraciones de los colonos que no resistían a la dura experiencia de granjeros, los escasos resultados productivos y la acumulación de una deuda cada vez más abultada con la JCA crearon un ambiente de descontento generalizado, en el que se entretejieron diferentes alternativas para sobrellevar la experiencia colonizadora. 
En Colonia Clara se registraron intentos, por parte de los administradores de la JCA, de crear una especie de caja que otorgara créditos y realizara operaciones comerciales, como la compra de bolsas, hilo, harina, etcétera. Pero los delegados que representaban a los distintos distritos de toda la colonia no lograban ponerse de acuerdo.

El anuncio de la inauguración de una nueva línea férrea que conectaría a Villaguay con Concordia suponía la apertura de nuevos horizontes para la venta de maíz, pastos secos, entre otros productos, lo que incentivó a los actores para la búsqueda de ámbitos de actuación conjunta. El administrador Lapiné en 1901 convocó a los delegados de todas las colonias y les propuso organizar una sociedad que se ocupara de los intereses de la colonia, de ayuda mutua, etcétera. ${ }^{19}$

Esta propuesta fue trasladada y presentada a los directores de la Administración Central de París, los señores Sonnenfeld y Averbaj, durante su segunda visita al país en 1902. Se avanzó en el proyecto de creación de una institución que tuvie-

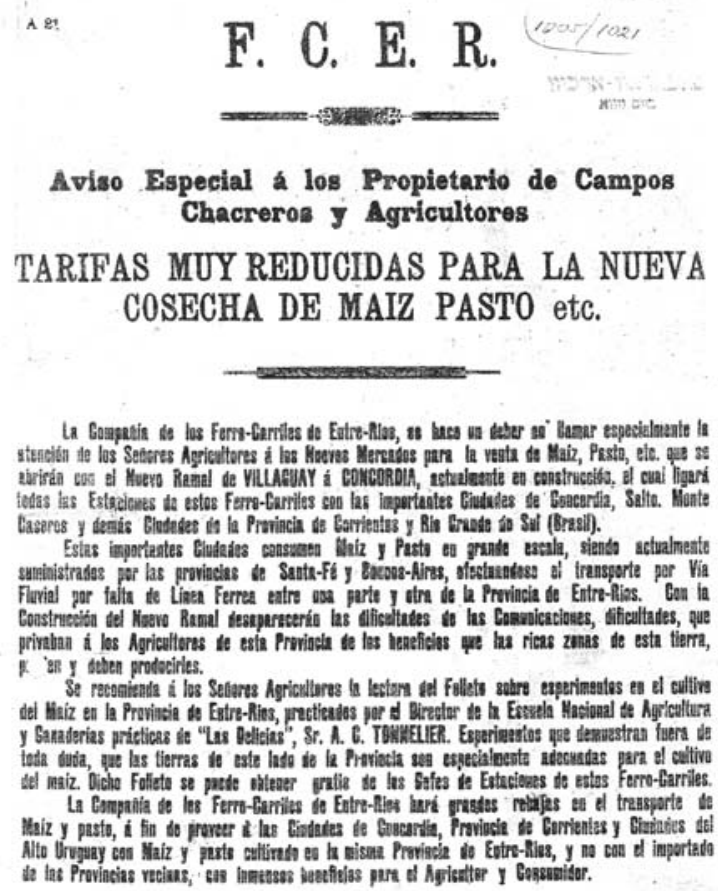

Parane, Agosto 1 de 1901

BOLLETT HOLT

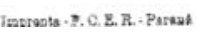

19 Fondo Comunal. Cincuenta años de su vida. (1904-1954), Villa Domínguez, Sociedad Cooperativa Agrícola Limitada, 1957, p. 35. 
ra como fin aconsejar y defender los intereses de los socios, y que fuera mediadora en los conflictos entre los colonos y los administradores de la JCA. Isaac Fridland fue el responsable de la redacción del «Reglamento de la Sociedad Protectora y de Socorros Mutuos de la Colonia Clara de la J.C.A.». El artículo segundo del mencionado reglamento fijaba claramente los objetivos a cumplir:

Su finalidad es aconsejar, apoyar y defender los intereses de los socios, ser mediadores en las relaciones entre la Dirección General de la J.C.A. o su representante en la colonia y los colonos que pertenecen a esta sociedad, y velar porque siempre haya entendimiento entre ellos.

a) Ser mediadora en las relaciones de los asociados entre sí.

b) Crear los fondos necesarios, que destinará para ayudar a los socios en caso de fracasos de cosechas o desgracias imprevistas, crear instituciones de interés general, administrándolas, y regular todo asunto que pertenezca a los asociados en general.

c) Estar siempre inclinada hacia toda buena acción que no se aparte de la base fundamental de protección y ayuda mutua. ${ }^{20}$

Debemos destacar que en este reglamento ya se habían fijado las reglas de convivencia que marcarán fuertemente la experiencia colonizadora judía. La Comisión Directiva era la encargada de establecer los modos de protección y en particular las mediaciones en las diferentes divergencias que podrían devenir entre los colonos y la JCA, así como las controversias entre los socios de la institución, cuyo veredicto era terminante.

Ningún socio tiene derecho a rechazar la intervención de la C.D. ante cualquier incidente que ocurriere entre él y otro socio, y es obligación moral de cada socio no comparecer ante el juzgado, sino cuando la C.D. se declare incompetente, o en casos criminales. (Art. $\left.8^{\circ}\right)$

${ }^{20}$ Archivo Miguel Sajaroff, Fundación IWO, Buenos Aires. Texto en idish y la traducción al español. 
Se establecían dos categorías de socios, los activos y los honorarios, quienes gozarían de todos los beneficios, pero también, solidariamente, sufrirían las perdidas que se produjeren. Para ser socios activos debían ser colonos de la JCA y "gozar de buena reputación" (Art. 15).

Todos los socios que cumplan con las condiciones son iguales y tienen los mismos derechos de recibir protección, ser ayudados, ser electos en asamblea como miembro de la C.D., participar de los debates, votar en las asambleas y presentar proyectos que mejoren la marcha de la institución (Art. 19).

En este primer proyecto estuvieron fijados los lineamientos básicos de una asociación que buscaba instrumentos de ayuda mutua, pero también formas pacíficas de convivencia en Colonia Clara, que atravesaba importantes conflictos imposibles de ser acallados y que se traducían, por un lado, en continuas emigraciones de colonos y, por otro, en importantes movimientos de resistencia, los que contribuían a la profundización de un clímax social que provocaba importantes incertidumbres.

Grandes grupos de colonos abandonaron la colonia para ir a instalarse al sur de la provincia de Buenos Aires, en las tierras de una compañía privada que les ofrecía cómodas condiciones de pago por contrato y sin patronazgos. Entre 1901 y 1902 se fueron 250 familias y muchas de ellas se llevaron los útiles de labranza sin pagar por ello, como una pequeña venganza de los colonos frente a las arbitrariedades de los administradores. Lo reconocía el propio Director General de la JCA, Dr. Sonnenfeld, quien estaba de acuerdo que las razones de los abandonos eran económicas sin embargo estaban agravadas por la arrogancia, inflexibilidad, e incluso el sadismo que caracterizaban el trato de los administradores para con los colonos, sin que los Directores de Buenos Aires hicieran nada para modificar estas actitudes. ${ }^{21}$

No debemos perder de vista que la "cuestión social»"22 en los grandes centros urbanos había adquirido una visibilidad contundente a partir de la aplicación del

\footnotetext{
${ }^{21}$ Avni, Haim, Argentina y la historia de la inmigración judía. 1810-1950, Jerusalén, Editorial Universitaria Magnes, 1983, p.211.

22 Ver Suriano, Juan, La cuestión social en Argentina, 1870-1943, Buenos Aires, La Colmena, 2000.
} 
Estado de Sitio y el dictado de la Ley de Residencia de 1902, en tanto que la circulación de ideas y de proyectos políticos alternativos y libertarios generaban temor en las clases dirigentes. El Estado nacional se debatía y aplicaba políticas que oscilaban entre la coacción y la integración social, en tanto el grupo de los «intelectuales reformistas ${ }^{23}$ comenzaba a buscar y diseñar nuevos instrumentos para la intervención en el plano social, mientras los colonos rusos eran observados por inspectores como Juan Bialet Massé, ${ }^{24}$ un polifacético médico catalán (además fue abogado, ingeniero agrónomo y empresario), quien había recibido el encargo de realizar un estudio sobre el estado de los trabajadores y la producción en la Argentina. La idea de hacer un informe sobre el estado de las clases obreras se había gestado durante el segundo gobierno de Julio A. Roca, a través del entonces ministro del Interior, Joaquín V. González, quien preparaba el proyecto de Ley Nacional del Trabajo.

En el plano provincial, el gobierno de la provincia de Entre Ríos, en 1904, encomendó a Eugenio Scheppens ${ }^{25}$ realizar una inspección y la confección de un infor-

${ }^{23}$ Ver Zimmermann, Eduardo, "Los intelectuales y el reformismo liberal", en Desarrollo Económico, N 124, enero-marzo, 1992, p. 563.

24 «Por lo que hace a su población, se tiene allí en ejemplo más notable del estado de atraso en que viven algunos inmigrantes. Los rusos que vinieron hace veinte años, hicieron sus viviendas en cuevas, completamente parecidas a las de la época de transición entre la edad de piedra y la del bronce, tales como las describe H. Rosny en sus Orígenes del Hombre; y de ahí que los hijos del país las hayan designado 'Las Vizcacheras'. Ahora han entendido las ventajas de la vivienda aérea, pero no las del cultivo racional. Apenas arañan la tierra, y, naturalmente, lo menores accidentes de la naturaleza les hacen perder las cosechas. Son de mala fe, que dan que hacer a la justicia, ellos solos, más que todas las colonias juntas, y tan exigentes que a cada rato amenazan con irse, con lo cual mucho ganaría la provincia. Cuando yo he comparado el modo de ser de estos colonos con el de los indios, no he podido menos de sentirme molesto por la injusticia humana, porque entre unos y otros, en verdad, no hay punto de comparación ni en inteligencia, ni en fuerza, ni en moralidad; la superioridad del mocoví se impone, pero no se la toma en cuenta". En Bailet Massé, Juan, Informe sobre el estado de la clase obrera, Buenos Aires, Hyspamerica ediciones Argentina S.A., 1985, p. 156.

${ }^{25}$ En su informe confidencial describía: "Para la agricultura: es el peor elemento que se haya establecido en esta provincia:

a) Sus chacras son una inmundicia, por la infinidad de abrojos grandes que las cubren

b) No siembran ni legumbres, ni verduras

c) Sus chacras son pésimamente aradas

d) No cultivan árboles frutales

e) Sus instrumentos y costosa maquinaria agrícola quedan tirados y a la intemperie, adonde quiera, en plena chacra, en las calles, etc.

f) Tienen dos letargos al año, y cada uno dura de 3 a 4 meses

Abandonan sus chacras y sacuden sus deudas para ir a otra parte. Hay como 400 familias israelitas que han abandonado ya las colonias de la JCA. Muchos dejan la agricultura para establecer tiendas u ocuparse de cobradores, corredores, comisionistas de toda clase". En Eugenio Scheppens, Resumen del Informe de la JCA en Entre Ríos, 25 de junio de 1904, Archivo JCA, Fundación IWO, p. 1. 
me, que debía seguir un criterio y tópicos ya establecido, para la observación de las colonias judías en el territorio provincial. Las observaciones de los dos inspectores fueron lapidarias, tanto por la aseveración de la ineptitud de estos inmigrantes para la agricultura, como por su condición de pueblo judío que los convertía en habitantes conflictivos y por lo tanto, rechazables. Estos informes son claves para determinar la presencia de una temprana política coercitiva destinadas al control y represión de la cuestión social, donde la inmigración, el gremialismo, el anarquismo y el socialismo eran una preocupación de las clases dominantes cuyo imaginario las catalogaba como deformaciones externas, ajenas al cuerpo social de la Nación y por lo tanto, extirpables.

En este contexto se realizó la primera reunión, en 1904, en La Capilla, que marcó el inicio del FC. Mucho tuvo que ver que Adolfo Leibovich asumiera en ese mismo año la Administración de Colonia Clara, ya que fue un agente de la JCA que provenía de las filas de los primeros contingentes emigrados de la Rusia zarista, y como hijo de un pionero de la colonización santafecina conocía profundamente las necesidades y demandas de los colonos asentados en nuestro país.

En el primer estatuto del FC aprobado en la asamblea general del $1^{\circ}$ de febrero de $1905^{26}$ se expone cuál es la finalidad que se pretendía alcanzar:

una caja de créditos integrada por acciones, que facilitara créditos a sus socios para que estos pudieran adquirir cuanto necesitaban para la cosecha y para la vida diaria; al mismo tiempo debía procurar formar el hábito del ahorro y de una economía sana en la administración y en el hogar del colono. ${ }^{27}$

También deben tenerse en cuenta que los demás capítulos del estatuto amplían esta finalidad, otorgándole un carácter enteramente cooperativista. Por ejemplo: además de las operaciones de crédito, se debe proporcionar a los socios los artículos necesarios para la época de la cosecha (art. 23). Dentro de las funciones del directorio, una es conseguir para la institución la ayuda moral y material de la

\footnotetext{
${ }^{26}$ El 30 de mayo de 1906, el FC fue reconocido jurídicamente por el gobierno de Entre Ríos.

27 Fondo Comunal. Cincuenta años de su vida, op. cit., p. 48.
} 
JCA; apoyo del gobierno; de las instituciones ferroviarias; hacer propaganda para la organización de un almacén cooperativo donde los colonos adquieran todos los artículos de consumo o implementos agrícolas a precios convenientes; tratar por todos los medios posibles de que los colonos perciban precios convenientes por su producción; organizar ferias y concursos para estimular el mejor sistema de trabajo, etc. (art. 46, capítulo 6).

Los hombres encargados de la redacción del reglamento relatan que se inspiraron en la experiencia de los veintiocho pioneros de Rochdale, ${ }^{28}$ quienes tomaron como modelo los estatutos de una sociedad de socorros mutuos para los casos de enfermedad y entierro de Manchester que se denominaba Rational Sick and Burial Society. Por otro lado, fueron consultados los estatutos de la Sociedad Rural de Concordia y de una Sociedad de ayuda mutua de San José, los dos de la provincia de Entre Ríos.

La decisión de crear una entidad representativa de los colonos fue una iniciativa de la Administración de la JCA, pero el sostenimiento en el tiempo y el arduo proceso para concitar la adhesión obedeció al esfuerzo de los pioneros que se trazaron un ideal cooperativo y solidario, como señala Isaac Kaplan. ${ }^{29}$ La brújula que pudo guiar esta empresa fueron hombres con dedicaron todas sus energías para poner en marcha esta asociación, que estuvo plagada de inconvenientes y de oposiciones férreas, que se denominaban en la época discrepancias «por elementales razones prácticas".

\footnotetext{
${ }^{28}$ Almacén Cooperativo, en la ciudad de Rochdale, Inglaterra, el 24 de octubre de 1844. Fundada por los Equitativos Pioneros de Rochdale, un grupo de 28 tejedores de la fábrica de tejido de esa ciudad, despedidos tras realizar una huelga e inspirados en las ideas del socialista Robert Owen, que dieron origen a uno de los hechos económicos más importante del siglo xix. Organizaron la entidad tal como las actuales cooperativas de consumo: le dieron carácter legal; los miembros fueron al mismo tiempo dueños y usuarios; se rigieron por un sistema democrático (un solo voto por socio) y abierto; no tenían como meta las ganancias y admitían sólo una renta limitada del capital; realizaban reuniones periódicas en las que se daba información a los socios; y la contabilidad debía ser llevada con método, los balances debían ser comunicados y estar a disposición de los socios. Lo que la distinguió, y a su vez le permitió sobrevivir y posteriormente desarrollarse, fue la declaración de Leyes y objetos de la Sociedad de Pioneros Equitativos de Rochdale. Fueron reglas expresas, criterios prácticos, que serían luego adoptados como base doctrinaria del cooperativismo y en adelante se convirtieron en norma para toda organización cooperativa. En Corral, Verónica A. y Marshall, Carolina M., Cooperativas Agrarias en Argentina, disponible en http://www.ucema.edu.ar/posgrado/download/tesinas2006/MADE_Corral.pdf.

${ }^{29}$ Kaplan, Isaac, Recuerdos de un agrario cooperativista, 1895-1925, Buenos Aires, Ciìrculo de Estudios Cooperativistas de Buenos Aires, 1962.
} 
Un episodio puede echar luz sobre lo expresado. La constitución del FC se hacía sobre la base de que cada colono debía suscribir tres acciones de $\$ 10$ cada una, entregando \$3 en el acto y el resto al final de la cosecha, "al pie de la trilladora». Un grupo de hombres que se jactaban de ser "prácticos" difundían la premisa de que en vez de invertir treinta pesos en acciones de FC era más conveniente comprar tres vacas, que darían cría y acumularían capital individual para cada uno, con más provecho que la inversión en una sociedad común. ${ }^{30}$

La cooperativa, aún limitada al crédito y a la comercialización, constituyó un intento de ampliar la masa de capital en juego y conseguir con ello una mejor posición en el proceso de acumulación. La cooperativa era el medio más idóneo para la pequeña explotación, a fin acceder a los beneficios que obtenían las grandes y superar los obstáculos que el menor tamaño imponía. El desarrollo de un movimiento asociativo de este tipo es una prueba clara de que los procesos de concentración y centralización del capital operan en la agricultura como en cualquier otro lado. El mismo chacarero es más "grande" por el sólo hecho de afiliarse a una cooperativa -recordemos que para hacerlo es necesario participar con capital, de modo que no todos pueden-, como bien lo advierte Sartelli. ${ }^{31}$

Los primeros años de actividad estuvieron llenos de confusión entre los límites de las funciones de la JCA y las incumbencias del FC, institución que debía defender los intereses de los socios y a los colonos todos. Debemos recordar que la Dirección del FC era ejercida por el administrador y el contador de la JCA, que físicamente funcionaba en el edificio de la empresa colonizadora. Una coyuntura favorable en los inicios fue que Leibovich tuvo la sensibilidad y la destreza para conjugar las exigencias de la empresa colonizadora, contemplando los intereses y protegiendo a los colonos. Fueron las acciones desplegadas por él las que permitieron que, cuando el FC llegó a tener los primeros \$2.000 en acciones, de inmediato la JCA les prestó $\$ 40.000$ destinados a facilitar créditos a los socios para semilla, para la compra de animales y otras necesidades parecidas. ${ }^{32}$

\footnotetext{
30 Fondo Comunal. Cincuenta años de su vida, op. cit., p. 45.

${ }^{31}$ Sartelli, Eduardo, "Campo de batalla. Crisis agraria, tecnología y cooperativas en el agropampeano, 1910-1935", presentada en VI Jornadas Inter Escuelas Departamentos de Historia, La Pampa, 1997.

32 Fondo Comunal. Cincuenta años de su vida, op. cit., p. 53.
} 
Por esta confusión entre la Administración de la JCA y el FC es que no se podía hablar de una libre elección de socios al FC, como bien lo deja planteado Isaac Kaplan cuando relata que todo colono que entrara a la Administración de la JCA salía de ella siendo ya socio del FC. No era cuestión de si el colono quería o no adherirse, ni si se debía solamente a que el administrador lo conquistara con su trato, sino que el colono necesariamente debía concurrir a él, puesto que era quien decidía acerca de todo y de todos. ${ }^{33}$

Esta falta de límites se constituyó en un problema para la consolidación de espacios que ostentarían intereses en pugna, pues la situación llevó a que muchos de los colonos y la gran mayoría de los administradores sostuvieran muy convencidos que nada podía existir sin la supervisión y verificación de la JCA.

Según registran las actas del FC, ${ }^{34}$ en el primer año de vida se realizaron dieciséis sesiones, en las cuales se trataron los problemas y preocupaciones de los integrantes: la compra de bolsas e hilo sisal, que fue la primera operación comercial; se elaboró el reglamento de préstamos en dinero efectivo, que se establecía a razón de dos pesos por hectárea, cuando el interesado hubiera sembrado quince hectáreas como mínimo, dejándose expresamente establecido - para fijar el concepto de moralidad administrativa y el sentido de incompatibilidad en el manejo de la cosa pública - que de este beneficio no podían gozar los miembros del C.D. Un aporte no menor fue la contribución que realizó la JCA para fortalecer el lanzamiento, otorgando un crédito de $\$ 15.000$ y dos vagones de trigo para semilla. También se abocaron a gestionar rebajas en los ferrocarriles para el trasporte de cereales, con pocos resultados iniciales.

Un tema que concitó muchas energías fue la provisión de alimentos para que los productores de trigo tuvieran harinas para el consumo de sus familias todo el año. Al principio se estableció un depósito de dos pesos por bolsa, pago que sería completado al retirarlas, permitiéndoles una compra colectiva ventajosa en los molinos de la zona. Sin embargo, no solucionaba los problemas de fondo: contar

\footnotetext{
${ }^{33}$ Nace la cooperativa con 377 socios. En 1905 fueron 385. En 1906 fueron 436. En 1907 fueron 531. En 1908 fueron 589 socios, número que fue evolucionando hasta alcanzar a 732 socios en 1954,, para el fin del período analizado por los responsable de realizar una puesta al día al cumplirse los cincuenta años del FC, p. 153.

${ }^{34}$ Actas del Fondo Comunal, Archivo y Museo de Villa Domínguez.
} 
con reservas para los años en que las cosechas eran malas y que los ingresos por granja y ganadería cubrieran las necesidades de los colonos. Se implementó, entonces, un sistema de canje de trigo con los molinos.

La falta de semilla para la siembra próxima fue un tema constante en el FC. Se establecieron préstamos a los colonos que demostrasen que tenían no menos de treinta hectáreas ya preparadas para la siembra, además de solicitar la provisión de trigo a la JCA.

La rama más importante de las operaciones comerciales del FC fue hacerse cargo de la venta de cereales y otros granos a fin de poder defender mejor sus intereses ${ }^{35}$, para cuyo fin se dictó el reglamento respectivo. La base del sistema era la venta conjunta o cooperativa dejando de lado toda estrategia especulativa basada en la acumulación esperando mejores precios, los que podían subir o descender según las reglas del mercado y que para competir no se disponía de una infraestructura mínima e indispensable. Los socios tenían la obligación de entregar el grano cosechado, y, para sortear a los comerciantes locales que fijaban las condiciones y los precios según sus propias conveniencias, se levantó la empresa cooperativa que se apropiaba de la plusvalía que quedaba retenida en la esfera del comercio. Con la figura del ingeniero Miguel Sajaroff - que convenció a los colonos de la necesidad de aunar esfuerzos-, se realizaron los trámites para la adquisición y la construcción de los galpones para guardar las bolsas de cereales junto a los rieles del ferrocarril y los trámites de venta directa a las grandes firmas comercializadoras. En 1906 se unieron 58 colonos de Leven, Sonnenfeld, Rosh Pina, Rachel y las Moscas, juntando 2.400 toneladas. $^{36}$

Un elemento singular fue la Comisión de Arbitrajes (Acta $N^{\circ} 12$ ), organismo de enorme trascendencia en la vida social y moral, ya que estableció formas de convi-

\footnotetext{
35 Esta resolución se aprobó en octubre de 1907, y empezó a ser efectiva desde 1908, continuando durante el tiempo de vida de la institución.

${ }^{36}$ Puede verse el significado capitalista de una cooperativa al observar cómo el FC negocia la venta de cereales. En la primera venta, en 1908, la negociación colectiva obtuvo 60 centavos más sobre el precio de plaza. Era el resultado de representar a 700 agricultores juntos. Todas las pequeñas triquiñuelas del acopiador (adulteración de pesas, calidad, etcétera) eran anuladas por la cooperativa. Al mismo tiempo, consiguieron imponer el sistema de venta "a fijar precio", que permitía negociarlo cuando el cereal se vendía y no antes de ser cosechado. En Eduardo Sartelli, "Campo de batalla. Crisis agraria, tecnología y cooperativas en el agropampeano, 1910-1935", op. cit., p. 16.
} 
vencia ante la multiplicidad de pequeños inconvenientes que suscitaban enfrentamientos por razones muchas veces insignificantes: el daño ocasionado por los animales de uno en el sembrado del vecino, los reclamos por los turnos para el uso de las máquinas trilladoras, la trilla de parvas, la pérdida de animales, etcétera.

La función arbitral era vista como un complemento necesario para el cumplimento de una vida armoniosa y basada en el bien común que ante conflictos, generalmente domésticos, se dirimieran con la intervención de amigables componedores, evitando de este modo que se llevaran estos pleitos ante la justicia, donde por regla general ambas partes solían salir perdiendo. La función arbitral tenía especialmente el objeto de predisponer los ánimos para una reconciliación, como corresponde a personas que por su ideal cooperativista desean que el hombre sea más comprensivo y esté orientado hacia las prácticas de solidaridad para con sus semejantes.

Las partes en litigio debían firmar una documentación de compromiso ${ }^{37}$ y aceptar las bases del reglamento ${ }^{38}$ para los arbitrajes. El incumplimiento de los veredic-

37 «Declaración: Declaramos por la presente que de común acuerdo, voluntad y deliberadamente, sometemos las divergencias existentes entre nosotros para ser dirimidas por la Comisión Arbitral del Fondo Comunal. Declaramos asimismo conocer y aceptar el reglamento que rige los arbitrajes, el cual nos comprometemos a acatar en todas sus partes, como también el fallo que resultase, que aceptamos desde ya con carácter de inapelable", Cincuenta años de acción cooperativa, op. cit., p. 79.

${ }^{38}$ REGLAMENTO PARA LOS ARBITRAJES EN EL FONDO COMUNAL. 1) El socio que tuviera alguna divergencia con otros y deseare arreglarla por un arbitraje de amigables componedores en el Fondo Comunal deberá llenar una fórmula especial dirigida al secretario de la "Comisión Arbitral", pidiendo el arbitraje; 2) Antes de iniciar el estudio, la "Comisión Arbitral" hará firmar a ambas partes una declaración de que someten voluntariamente y deliberadamente sus divergencias al arbitraje, comprometiéndose a aceptar con carácter inapelable el fallo que resultare. También deberá leerse ante las partes el reglamento de los arbitrajes; 3) Además de la declaración de que habla el artículo anterior, la "Comisión Arbitral» hará firmar documentos que garanticen el estricto cumplimiento de su fallo; 4) Si en el curso del estudio del asunto sometido al arbitraje, algunas de las partes faltare el respeto a la Sociedad, a los árbitros o a la parte contraria, el presidente de la "Comisión Arbitral" la llamara al orden; en casi de repetirse esta conducta, el mismo presidente podrá dar por anulado el arbitraje; 5) El socio que negare u obligare a recurrir a los documentos firmados para cumplir el fallo, no tendrá derecho a pedir más arbitrajes en el Fondo Comunal ni ser llamado por otro con el mismo objeto; 6) Sin perjuicio de lo que establece el artículo anterior, la "Comisión Arbitral" podrá pedir del C.D. del Fondo Comunal la adopción de cualquier medida disciplinaria contra el socio que se negare o dificultare el cumplimiento del fallo; 7) Una vez fallado en un asunto, las partes, si así lo desean, podrán pedir copia autenticada del fallo. Los documentos firmados quedarán en poder de la "Comisión Arbitral» hasta que se haya dado cumplimiento al fallo respectivo; 8) Por cada arbitraje el Fondo Comunal percibirá la suma de 10 a $25 \$ \mathrm{~m} / \mathrm{n}$ de cada una de las partes. La "Comisión Arbitral" fijará en cada caso la suma a cobrase, estando facultada para no cobrar nada en un asunto de menor cuantía o siendo pobres los litigantes. El dinero proveniente de loas arbitrajes ingresará íntegramente al «Fondo de Propaganda". Cincuenta años de acción cooperativa, op. cit., p. 80. 
tos o la negativa de algún socio a aceptar un arbitraje era motivo de sanción estatutaria que establecía hasta la expulsión. El trabajo de la Comisión Arbitral muchas veces demandó largas jornadas: a menudo los árbitros debían realizar viajes para comprobar los hechos denunciados en las audiencias, demandando gastos que eran cubiertos por la cooperativa entendidos como acciones naturales de la misma.

Prontamente apareció la necesidad de encontrar canales de comunicación entre los colonos, tanto entre los grupos y como con los pueblos. Los caminos eran huellas profundas o senderos imprecisos en un amplio territorio. Se estableció un sistema de información, una especie de informador mercantil con publicaciones de avisos abonados. Se publicaba en ellos la necesidad de comprar una vaca lechera, un repuesto para el arado de mancera, vender un ternero, etcétera.

Los objetivos iniciales se irán transformando lentamente para tornar al FC en una institución organizadora de la vida en la colonia. En las primeras sesiones se trataron los nuevos alcances: la asignación de subvenciones provisorias de ayuda a viudas y ancianos; la necesidad de contar con estrategias de formación para que los productores optimicen sus recursos; capacitación para el manejo de la economía a partir de conferencias a cargo de especialistas, así como una circulación de información concientizadora de los alcances del cooperativismo para lograr la adhesión y el compromiso de los socios y la obligación de intervenir en la prestación de servicios sanitarios a la comunidad, a partir de la asignación de fondos al Hospital Clara, ${ }^{39}$ para cubrir su déficit permanente.

EI FC fue una institución que transformó a lo colonos en actores activos del desenvolvimiento social y económico de la región. El conocimiento integral del movimiento les dio a los socios la posibilidad de ejercer desde fuera o desde dentro un estricto control de las acciones emprendidas. Ser socio del FC era la

\footnotetext{
39 En 1914 se fundó la Sociedad Sanitaria Israelita con el fin de sostener la atención sanitaria de las colonias a través del Hospital Clara, en un modesto hospital ubicado a 2.000 metros de la estación ferroviaria, luego denominado Hospital Dr. Noé Yarcho, primer hospital israelita de Sudamérica. Noé Yarcho fue el médico que organizó el primer equipo de salud mientras recorría en sulky casi toda la provincia curando enfermos. Se había recibido de médico en Rusia y especializado en Inglaterra. Para costearse los estudios daba clases de religión a las familias pudientes, siendo una de ellas la de los acaudalados comerciantes Sajaroff, cuya hija María fue su alumna y luego se convirtió en su esposa.
} 
oportunidad para acceder a importantes beneficios económicos, pero también era la tabla de salvación en los momentos de penurias. Sin embargo, la pertenencia se constituía en un compromiso moral, donde deberes y obligaciones se conjugaban con derechos. La vigilancia de los socios sobre la actuación de sus dirigentes fue siempre muy severa, "en el Fondo Comunal no se concibe que un miembro del Directorio pueda pecar en lo más mínimo en su condición de socion. ${ }^{40}$

Las asambleas fueron siempre numerosas y las críticas a la labor de los Consejos son cosas normales; se las considera muy saludables, pero no se escucha al socio que haya faltado a sus deberes para con la cooperativa; en las asambleas predomina el concepto de que no critica el que sabe, sino el que puede, es decir, el que tiene autoridad moral para ello y está acreditado como tal en su ficha de operaciones con la cooperativa. ${ }^{41}$

Esta institución fue un espacio donde el colono aprendió a defender sus intereses y también a escuchar e intercambiar opiniones. Un espacio de socialización, de contención y de ayuda para vivir la experiencia de colono agrícola en suelo argentino en el que los judíos "vinieron buscando el amparo del techo, del pan, de la ilusión bajo la solemne protección de la Cruz del Sur». ${ }^{42}$

El FC se convirtió además en el anclaje que pudo detener el movimiento de emigración de los colonos, conjuntamente con la activa participación de quien era su presidente y administrador de la JCA, Adolfo Leibovich, quien reorganizó la colonia intentando poner fin a las múltiples dificultades que atravesaban sus habitantes. En primer lugar, se propuso terminar con la determinación obstinada del anterior administrador Lapiné, quien se había empeñado en organizar las primeras colonias con la asignación de lotes con una extensión de veinticinco a cincuenta hectáreas, según el modelo y estilo que había conocido en Rusia, sin tener en cuenta las necesidades y requerimientos para una explotación rural que

\footnotetext{
${ }^{40}$ Fondo Comunal. Cincuenta años de su vida. (1904-1954), op. cit., p. 70.

${ }^{41}$ Ibídem.

${ }^{42}$ Fairman, Silvia C., Mate y Samovar, Buenos Aires, Lumen, 2000, p. 9.
} 
brindase posibilidades de subsistencia. Así, debió reagrupar y reasignar los lotes, ahora de 150 hectáreas aproximadamente, "lo que se considera hasta hoy día como 'tipo de chacra' suficiente para que un colono, mediante su trabajo, pueda prosperar en ella». ${ }^{43}$

Por otro lado, Leibovich fue el responsable de la renegociación de las deudas que los colonos habían adquirido con la empresa ante la Administración Central de la JCA en París. Las deudas acumuladas por los colonos eran imposibles de ser saldadas con el trabajo en la chacra, por lo que se imponía la necesidad de una reducción sustancial. Había que convencer a la JCA de rebajar lo adeudado y aceptar que si bien representaba una contracción de sus ingresos, era el único camino. Esta misión fue encarada personalmente por Leibovich, quien viajó a París para negociar con el presidente de la JCA, Narcisse Leven, y con los señores Sonnenfeld y Meyerson, representantes de la Administración Central, a los que debía demostrarles con argumentos convincentes que los colonos no podrían firmar un contrato aceptando pagar una deuda que acumularon a su pesar y que les sería imposible pagar. Contó con la ayuda del ex director de Buenos Aires, David Cazés, que se encontraba allí en calidad de asesor en los asuntos de Argentina, para coronar con éxito su misión. La JCA aceptó que se rebajara la deuda de los colonos "haciéndole una quita a todo aquello en lo que en ella había habido de superfluo e improductivo y colocando al colono en una situación financiera saneada y normal». ${ }^{44}$

Estas acciones unidas a la creación del FC incidieron fuertemente en la detención del proceso de desplazamiento de los colonos, como lo demuestra el cuadro siguiente:

\footnotetext{
${ }^{43}$ Leibovich, Adolfo, Apuntes Íntimos. 1870-1946, Buenos Aires, Imprenta López, 1947, p. 72.

${ }^{44}$ Leibovich, Adolfo, op. cit., p. 75. En octubre de 1907 Leibovich tuvo que dejar la Administración de Colonia Clara, pues recibió la orden de hacerse cargo de las colonias de la JCA en Brasil.
} 


\section{Evolución de instalación de colonos en Colonia Clara}

\begin{tabular}{|c|c|c|}
\hline Años & Clara & Salieron \\
\hline 1895 & 569 & 20 \\
\hline 1896 & 545 & 63 \\
\hline 1897 & 494 & 100 \\
\hline 1898 & 475 & 32 \\
\hline 1899 & 459 & 17 \\
\hline 1900 & 527 & - \\
\hline 1901 & 557 & - \\
\hline 1902 & 523 & 24 \\
\hline 1903 & 515 & 8 \\
\hline 1904 & 475 & 40 \\
\hline 1905 & 516 & - \\
\hline 1906 & 493 & \\
\hline 1907 & 565 & 23 \\
\hline 1908 & 650 & - \\
\hline 1909 & 687 & - \\
\hline 1910 & 696 & - \\
\hline 1911 & 699 & - \\
\hline 1912 & 743 & - \\
\hline
\end{tabular}

Fuente: Fraternidad Agraria, La historia de la Fraternidad Agraria, nov., 1948.

Segunda etapa: Miguel Sajaroff presidente del Fondo Comunal. 19081917

Todos para uno y uno para todos.

Esta etapa comienza con cambios sustanciales. Un colono, Miguel Sajaroff, asumió la presidencia del Fondo Comunal e inauguró un ciclo de autoadministración, lo que generó fuertes desafíos a partir de intentar terminar con la tutela directa de 
la JCA y, por ende, la asunción de la responsabilidades de afirmarse a partir de sus propias fuerzas, asumiendo los riesgos que podría representar la falta de concurrencia de la empresa colonizadora a la hora de solicitar créditos para afrontar los años de crisis, los que se habían conseguido con cierta facilidad en la etapa anterior porque el presidente era también el administrador de la JCA. ${ }^{45}$

Esta separación tuvo su primera mani-

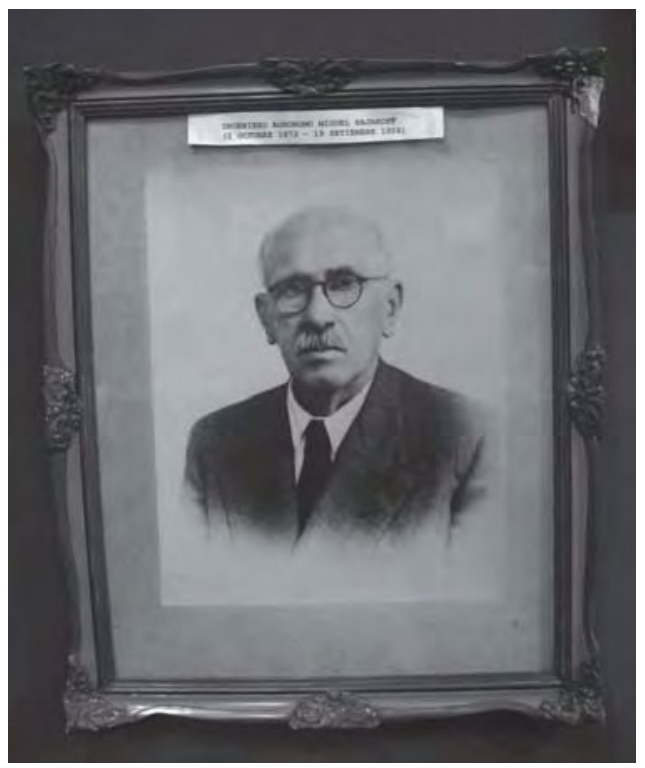
festación en la sede física del FC: se alquiló el edificio que se ocupaba en Collin a la JCA.

El desafío más importante, como institución defensora de los intereses de lo colonos, se presentó en este primer año de vida independiente a partir de una nueva propuesta para la firma de los nuevos contratos con la JCA: se trataba de un tercer modelo con cláusulas favorables a la empresa, que ponía a prueba la capacidad de resistencia de los asociados y los márgenes reales de negociación del FC.

Las modificaciones eran trascendentes. El colono ya no figuraba como comprador de su predio, sino como un simple "ocupante» -situación que no le permitiría obtener créditos en ninguna parte-. Además, según la misma cláusula, en caso de que no cumpliese cualquier punto, o no pagara la cuota anual a su debido tiempo,

\footnotetext{
${ }^{45}$ El informe del FC sobre el ejercicio 1907-1908 especifica la ayuda que recibió de la JCA en forma de créditos: en 1905-1906, $\$ 40.000$ sin intereses; en 1906-1907, $\$ 60.000$; y en $1908 \$ 75.000$ con un interés del $4 \%$.

${ }^{46}$ Seidel Zeigner, colono y maestro alberdino en Colonia Clara, recrea en su pequeño libro el efecto que creó esta palabra en los colonos, que los llevó a no firmar los nuevos contratos: «La palabra cuestionada era IPSO FACTO, puesta en letra cursiva en el texto del contrato: nadie pudo traducir la malhadada expresión latina y las conjeturas se multiplicaban: 'Una trampa, en la que se nos quiere hacer caer' decían unos. 'Seremos desalojados como ratas al menor incumplimiento del contrato', 'si llegamos a firmar' - sostenían otros- 'Son mejores los contratos viejos' argüían algunos y 'hay que negarse a firmar mientras esa dichosa palabrita no sea retirada'... Y un verdadero movimiento de resistencia se propagó por todas las colonias de la zona. Con el correr de los días los ánimos fueron aquietándose. Alguien logró averiguar en Villaguay el significado de la 'misteriosa' palabra y el agitado mar volvió a adquirir su calma habitual. Por mucho tiempo la expresión Ipso facto quedó en el ambiente como una manifestación de duda entre los viejos inmigrantes, quienes no firmaban ningún documento ni convenio sin preguntar: "no contiene, por ahí, algún pequeño ipso facto?...'”. En Zeigner, Seidel, Carmel (la Hija del Coronel). Recuerdos de Infancia, op. cit., p. 41.
} 
la JCA tenía derecho a declararlo anulado ipso facto $^{46}$ y recuperar la tierra, con todas las construcciones, plantaciones y otras mejoras, sin ninguna responsabilidad de devolver el importe de los pagos hechos, como tampoco reconocer ninguna indemnización al colono. Completaba los cercenamientos que el único árbitro entre situaciones de litigio sería la Dirección Central de la JCA en París, quitando de esta función a Alliance Israélita Universelle, como se había fijado en tiempos en que vivía el barón de Hirsch. ${ }^{47}$

Esta propuesta fue el dispositivo que puso en el escenario, una vez más, que las condiciones eran impuestas por la empresa colonizadora, así como las limitadas formas de negociación y la restringida capacidad de resistencia de los colonos frente a un contrato leonino.

Cincuenta y seis colonos solicitaron la convocatoria a una asamblea para abordar este tema. Las discusiones fueron acaloradas -como la mayoría de las sesiones-, donde se pudieron escuchar las argumentaciones que sostenían la inconveniencia de la firma de este contrato debido a los alcances inaceptables de la propuesta, que no sólo comprometía el pago infinito de cuotas, lo cual se trasladaría hasta los hijos, sino que acarreaba la pérdida de las tierras, así como de las mejoras que los colonos habían hecho, no sólo para su valoración actual, pues ya triplicaba el precio original de la tierra. Todo había sido ganancias para una empresa que se alejaba cada vez más de los principios que guiaron al barón de Hirsch y que sólo podrían triunfar si se negaran todos juntos (terminando con las prácticas individuales de firmar cada uno por separado y en silencio).

La relación con la JCA se volvió cada vez más tensa. Las discrepancias eran variadas, pero dos episodios pueden ser representativos de las asimetrías entre estas dos instituciones: las penurias económicas de los colonos que los convertía

\footnotetext{
${ }^{47}$ En los primeros contratos de promesa de venta que se otorgó a los colonos, visados por el barón de Hirsch, decía: "Art. 10 - Toda diferencia que pudiere suscitar entre el colono y la Dirección local en Buenos Aires, en razón de la interpretación o ejecución del presente contrato, será sometida a juicio inapelable de un árbitro común y único. A este efecto las partes contratantes declaran de antemano aceptar en esta calidad una persona con domicilio en Buenos Aires, que será designada cada año por el Presidente de 'L'Alliance Israélite Universelle de París'». Archivo IWO y Archivo y Museo de Villa Domínguez.

${ }^{48}$ Es muy interesante observar el sumo cuidado con que los colonos se relacionan con la JCA. Solicitan al presidente de la Comisión Directiva que publique una nota desconociendo los dichos por un colono anónimo que ataca a la JCA y cuyo periódico lo escribe como "un prestigioso colono" o "caracterizado
} 
en asiduos demandantes de préstamos a la JCA y el problema del acceso a la tierra para los hijos. ${ }^{48}$

En una reunión del 3 de febrero de 1909 con Moss, director general de la JCA en Buenos Aires, el presidente del FC le solicitó que, debido al momento crítico que atravesaba la economía de la colonia, no cobrase intereses por los préstamos otorgados a los colonos, además de requerirle un crédito de un millón de pesos ${ }^{49}$ a pagar en el término de diez años, demandas estas que fueron desoídas. Sin embargo, el administrador respondió sobre el tema de la colonización para los jóvenes, señalando que la idea del barón de Hirsch había sido colonizar únicamente a quienes habían sufrido persecuciones en Rusia. En cuanto a las necesidades de sus hijos, debían ocuparse de ello los mismos progenitores. ${ }^{50}$ Ahora bien, si el problema era general, entendía el burócrata que los podría ayudar enviando una nota trasladando la inquietud recibida a la Administración Central de París. La Comisión Directiva denunciaba también lo injusto que era el trato con las viudas y con los colonos ancianos, a los cuales se amenazaba con quitarles el contrato de Promesa de Ventas y darles a cambio contratos de arrendamientos. También solicitaban que se debía aumentar la extensión de tierras, pues había agricultores que sólo poseían cincuenta hectáreas para su explotación y ello era a todas luces insuficiente. Los directores y administradores en Argentina respondían siempre: "sin París nada se puede hacer». ${ }^{51}$

Un acontecimiento menor desnudó estos enfrentamientos y la intransigencia de los administradores ante las demandas del FC. En el grupo Barón Guinzburg se suscitó un incidente entre el padre de un alumno y el maestro de la escuela. El FC citó a los dos a recurrir a un arbitraje para zanjar las diferencias, lo que era habitual y aceptado por los socios, pero el maestro se negó a concurrir. Dirigió su queja

israelita»: "Repudian todos los ataques injustos y sin fundamentos dirigidos a la J.C.A. aprovechan la oportunidad para manifestar á esta sociedad su sentimiento de respeto y gratitud por todo el bien que les hace sobre todo por haberlos sacado de la esclavitud rusa haciéndolos disfrutar de la libertad que la República Argentina brinda á todos los habitantes sin distinción de raza y religión y autoriza a su presidente para que dé publicación de la protesta». Acta № 72, Asamblea General, 21 de febrero de 1909, p. 2-3.

49 Frente al silencio del administrador, envía luego un memorándum en el que ya pedía solamente $\$ 200.000$ para semilla, $\$ 300.000$ para vacas lecheras y $\$ 75.000$ para inventario (50 años..., op. cit., p. 183).

${ }^{50}$ Acta $N^{\circ} 72$, Asamblea General del FC, 21 de febrero de 1909, p. 1.

${ }^{51}$ Acta $N^{\circ} 96$, reunión del Consejo Directivo con la Asistencia del Señor D. Veneziani, Director General del la JCA, 13 de enero de 1910, p. 56. 
a la JCA y esta le comunicó al FC que aquel maestro era su empleado y que por lo tanto no debía someterse a arbitrajes de la cooperativa.

Como respuesta, el ingeniero Sajaroff e Isaac Kaplan, presidente y secretario respectivamente del FC, publicaron una Carta $\mathrm{Abierta}^{52}$ en la que quedaron plasmadas las diferencias entre las dos instituciones:

declaramos solemnemente nuestro franco reconocimiento y respeto a la noble idea y fecunda actuación de la J.C.A, creadora y patrocinadora de nuestras instituciones comunales, pero con todo y eso nunca habíamos sancionado la investidura patriarcal que sus directores en ésa se quieren adjudicar con respecto a nuestra vida institucional, moralmente libre e independiente, ni tampoco jamás les hemos conferido las extrañas prerrogativas de darnos lecciones de urbanidad cuando tales no se piden [...] pero lo que nos preocupa mayormente y constituye una seria amenaza al desarrollo de nuestra sociabilidad, es que en este caso aislado, unido a una larga serie de otros análogos y llevados al terreno de principios generales, revela en el seno de la Dirección General los rasgos sintomáticos de morbosidad orgánica de sus conceptos y métodos de acción relativos a los colonos, colonias y sus instituciones en general [...] Siempre respetuosos de la personalidad de los señores directores, condenamos tan sólo el régimen atávico de la Dirección General, que imbuida de su muy arraigado espíritu de infalibilidad imaginaria y exclusivismo "à outrance», procede con frecuencia ciega e impulsivamente, sin preocuparse de observar ni analizar los efectos muchas veces estériles, contraproducentes y aun antisociales de sus actos.

La extensa Carta Abierta contiene un párrafo revelador que, escrito sin ánimos de ofender ni herir, sino tan sólo con el propósito de dejar constancia pública, describía lo que consideraban era la actuación de los administradores de la JCA en Argentina:

que reside en el organismo enfermizo de la Dirección General, que sin programa de acción bien definido, sin móviles de pujanza, sin iniciativas propias, sin sanas rela-

${ }^{52}$ Carta Abierta, 20 de diciembre de 1911. Archivo Sajaroff, IWO. 
ciones, ni el contacto mutuamente respetuoso con el ambiente en que actúa, hace gala de su completo aislamiento espiritual y feudalismo anacrónico.

Finalmente, expusieron su opinión sobre la torpeza de los procedimientos y múltiples funciones que asumían -más allá de la ya compleja actividad de patrocinar y promover la colonización e inmigración israelita-, vinculadas a la educación laica y religiosa de los niños y, más aún, pretendiendo incidir en la moralidad pública de las colonias con métodos y formas anticuadas y adversas a los principios altamente humanitarios de la JCA, que resentían las relaciones entre ellos:

constituyéndose siempre en jueces únicos e inapelables de nuestras iniciativas, esperanzas, aspiraciones y en general en todo lo bueno o malo que pueda revelar nuestra vida comunal en su conjunto.

La tirantez duró algunos meses. ${ }^{53}$ Sajaroff continuó denunciando con firmeza "el intolerable desequilibrio social en las relaciones con la Dirección general con las colonias y sus instituciones", pero ello no obturaba el reconocimiento y el respeto que sentían por la labor de colonización realizada por la JCA, y que estos conflictos respondían "a que la acción no es accidental ni personal sino que sociológicamente bien natural e inevitable en las etapas del desarrollo normal y diferenciación de nuestras colectividades". ${ }^{54}$

Las fuerzas de Miguel Sajaroff estuvieron puestas al servicio de la causa para enseñar el significado y sentido del cooperativismo y asentar el concepto de solidaridad y esfuerzo propio. El ideario cooperativo explicado por Sajaroff consistía en poner en contacto a los productores con los consumidores, quitándose el peso de los intermediarios. El proyecto que hermanaba a productores y consumidores debía extenderse no sólo dentro de las fronteras del país, sino del mundo, en naves cooperativas que, al regresar al país, traerían en trueque los productos e implementos que las instituciones solidarias de otras latitudes elaborasen y crearan. De

${ }^{53}$ El problema se solucionó cuando los padres de los niños que concurrían a la escuela del grupo Barón Guinzburg decidieron no enviarlos, ante lo cual la JCA resolvió el traslado del maestro a otro establecimiento educativo.

${ }^{54}$ Aclarando. Carta de Miguel Sajaroff (50 años..., op. cit., p. 189). 
este modo, las personas se unirían bajo la bandera del cooperativismo, que es la justicia e igualdad para todos.

Sajaroff sabía que había que comenzar a dar otros pasos para la defensa conjunta a través de una federación de las cooperativas judías. El proyecto fue presentado por primera vez en la sesión del 14 de junio de 1910 al consejo directivo del FC, donde explicó la necesidad de unir las asociaciones de las colonias de la JCA. Doce delegados se reunieron luego en Buenos Aires, el 14 de noviembre de 1910, dando nacimiento a la Confederación Agrícola Argentina Israelita.

No era esa una tarea fácil: había que preparar el proyecto de estatuto y ni siquiera teníamos a quien consultar. Sajaroff se dedicaba en cuerpo y alma a esa iniciativa. Preparaba borradores, comparábamos, reformábamos, tratábamos de profundizar, para lograr una idea clara nosotros mismos, y poder así llevar al congreso una cosa hecha y defendible, pues sabíamos que para convencer a otros debe estar primero convencido uno mismo, sobre todo cuando se trata de ideas nuevas. ${ }^{55}$

En 1911 se realizó un segundo congreso en Buenos Aires y el tercero en Rivera, colonia Barón Hirsch, en 1912.

Sajaroff estaba en la gloria. El ya veía la masa agraria del país organizada. Los países limítrofes lo iban a imitar, luego... y luego... veíamos una larga cadena de cooperativas uniendo el continente. Algo glorioso. ${ }^{56}$

La orientación estaba establecida y penetró fuertemente el espíritu de los asociados al FC. Se organizaron cursos nocturnos para adultos y para la juventud; se asumió la administración del molino de La Capilla con el objeto de tener pan del trigo propio; se propuso gestionar recursos ante la JCA para socorrer a los inmigrantes pobres, asignando para ello el monto del interés obtenido en el ejerci-

55 En Kaplan, Isaac, Anécdotas, cartas y discursos de Don Miguel Sajaroff, Buenos Aires, Círculo de Estudios cooperativistas de Buenos Aires, 1965, p. 26.

56 Ibídem. 
cio 1908-1909; se realizaron remates-ferias en Domínguez, para vender animales sin intermediarios. Al finalizar el primer año de la gestión de Sajaroff, se señalaba con orgullo la ampliación de los alcances del FC al recibir la adhesión de las colonias de San Salvador, General Campos y San Antonio.

El crecimiento del cooperativismo incidió positivamente en la economía doméstica de los colonos. En el ámbito de la compra de maquinaria, nuevamente una porción de plusvalía podía ser recapturada si se actuaba como un solo gran capital. Las casas mayoristas de implementos agrícolas tenían sus agentes exclusivos, que en los convenios se quedaban con una bonificación del 30 al 40\% sobre el total de las ventas. El FC hizo valer su peso y consiguió "suprimir intermediarios y ahorrar para el colono el porcentaje de los agentes". ${ }^{57}$

Veamos otra anécdota contada por Kaplan: en 1910 los chacareros consiguieron comprar ventajosamente setenta espigadoras por el solo hecho de presentarse cooperativamente, a pesar de confesar que la caja cooperativa carecía de capital. La compra se hacía en Buenos Aires a la casa "A. C." y la respuesta del gerente no podía ser más ejemplificadora: "Ustedes tienen crédito ilimitado en nuestra casa». No era para menos: en la temporada 1911-1912, Colonia Clara había sembrado 60.000 hectáreas de trigo, lino y avena y comprado cooperativamente 500.000 bolsas y 3.000 ovillos de hilo sisal. Este "capitalista colectivo" tiene la misma fuerza, a la hora de negociar, que uno solo capaz de sembrar semejante espacio. Es más: ese año la cosecha se perdió por lluvias. Nadie pudo pagar a la cooperativa y esta quedó endeudada con dieciocho acreedores. Kaplan viajó a Buenos Aires y discutió con todos, especialmente con el dueño de la fábrica de bolsas. Había problemas, los documentos estaban por vencer, pero, una vez más, nuestro capitalista colectivo obtuvo lo que quería: la renovación de los pagarés del FC en sus propios términos. ${ }^{58}$

EI FC adquirió alambres por vagones y en grandes cantidades, al igual que maquinarias y otros implementos para el trabajo. Las chacras fueron deslindadas y alambradas. Se repartieron entre los asociados semillas, bolsas e hilos. Se repara-

\footnotetext{
${ }^{57}$ Kaplan, Isaac, Recuerdos de un agrario cooperativista. 1895-1925, Buenos Aires, Círculo de Estudios Cooperativistas de Buenos Aires, 1969.

58 Ibídem. Citado también por Sartelli, Eduardo, op. cit., p. 17.
} 
ron los caminos, la juventud fundó bibliotecas, se preparó la publicación del El Colono Israelita Argentino, ${ }^{59}$ adquiriéndose una imprenta propia.

\section{La invasión de langosta}

La producción agrícola recibía fuertes quebrantos. Una intensa sequía hizo que se perdieran casi íntegramente las cosechas, decayó la producción láctea y en el ciclo siguiente, 1909-1910, la producción se perdió en un 70\% por las heladas y la langosta; el ganado padeció epidemias que mermaron fuertemente los stocks; el grupo Rachel devolvió la trilladora que le había suministrado el FC debido a que carecía de medios para pagarla. En el ciclo 1910-1911 la langosta volvió a destruir un $70 \%$ de la cosecha. Los colonos sólo obtenían su magro pan de la producción láctea.

En 1911 redoblaron sus esfuerzos sembrando 50.000 hectáreas en lugar de las 14.000 del año anterior. Si bien los rindes no fueron los esperados porque las Iluvias malograron las cosechas, se puede observar el impacto diferenciado en la producción: con los 450.000 pobladores de toda la provincia de Entre Ríos se sembraron ese año 495.000 hectáreas (225.000 con trigo y 190.000 con lino). De esa superficie, 50.000 hectáreas fueron cultivadas por 732 colonos, socios del Fondo Comunal. ${ }^{60}$

Un dato significativo se puede observar en el interior de la experiencia: la incipiente segmentación que se producía entre los agricultores, según el informe de la Comisión Revisadora de Cuentas, encargada de resguardar los aportes al FC. El señor Kostianovsky, como miembro de la mencionada comisión, informaba:

\footnotetext{
${ }^{59}$ En la reunión del 11 de octubre de 1909 se comunica a los asociados que conjuntamente con la Cooperativa de Lucienville se editará El colono Israelita Argentino, publicación semanal, con la redacción de I. D. Fingerman y B. Bendersky, con una remuneración mensual de $\$ 75$ y $\$ 50$ respectivamente, y en el que colaborará un cuerpo de redacción integrado por Halperin, Papiermaister y el doctor Yarcho. En septiembre de 1912 dejó de aparecer debido a los problemas económicos que atravesaba la colonia -y, por ende, el FC-, que se quedó sin un órgano de difusión hasta que en 1917 se publica El Colono Cooperador.

60 Fondo Comunal. Cincuenta años de su vida. (1904-1954), op. cit., p. 98.
} 


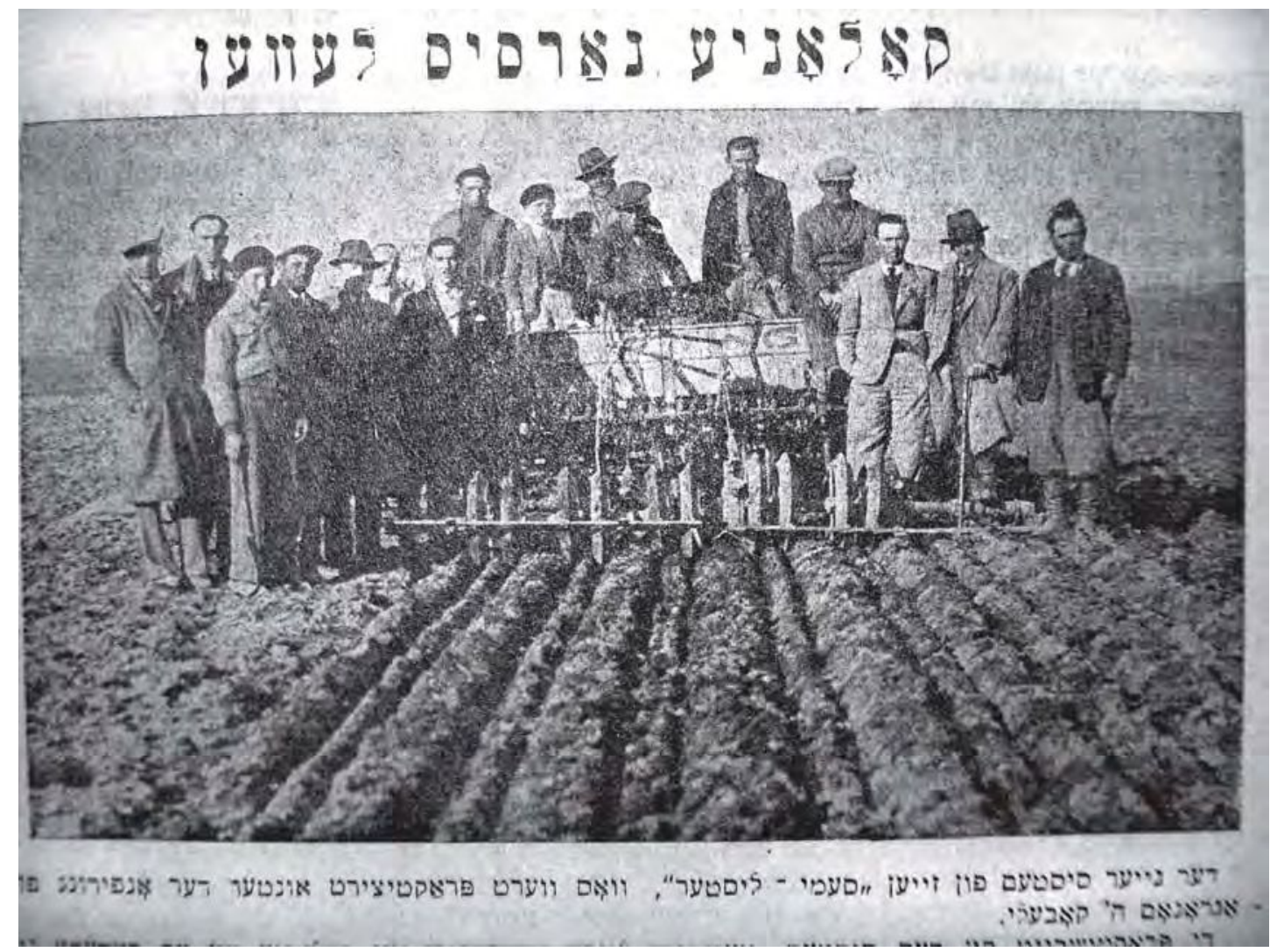


la comisión ha revisado las cuentas atrasadas de todos los miembros y les han dividido en 3 categorías, pertenecen a la primera los que pueden pagar íntegro sus deudas; a la segunda los que pueden pagar parte de su deuda y a la tercera los que no pueden pagar nada y merecen consideración. ${ }^{61}$

Esta estratificación social irá acompañada de una serie de beneficios, que redundarán diferencialmente para aquellos que contaron con mayores y mejores oportunidades para la acumulación ${ }^{62}$. La cercanía a los administradores locales les aseguraba contar las mejores chacras, no sólo con mayor extensión, sino ventajosamente ubicadas y con mejores tierras. Las relaciones cordiales con la burocracia local les brindaban oportunidades, como por ejemplo con el sistema de "trasferencias" con el que se pretendió que las tierras impagas quedaran en manos de los colonos más pudientes, quedando a cargo de la JCA la supervisón de esta prerrogativa. De modo que surgen dos grupos diferenciados; uno de ellos favorables a las propuestas de desalojo promovidas por la JCA ya que se benefician con estas medidas y otro representado por los colonos que no poseían tierras sino tan solo la promesa de venta. Estos grupos reflejan sus tensiones dentro del F.C., en el que tendrá mayor gravitación el grupo que representa a los más perjudicados por la política de la empresa colonizadora.

Durante los años de crisis los acreedores del FC fueron tolerantes y esperaron confiados el cobro de sus créditos. ${ }^{63}$

\footnotetext{
${ }^{61}$ Acta N 105, Comisión Directiva del FC, mayo de 1910, p. 78. Se resuelve demandar a diez socios de la primera categoría.

62 En los Recuerdos de Infancia Seidel Zeigner describe estas diferencias sociales: "No lejos de allí, en la loma de una típica cuchilla entrerriana, estaba ubicada la chacra de don I...., con su casa algo distinta de la generalidad de las viviendas de los colonos, rodeada de árboles y jardín. Es que don I...., hombre culto e inteligente, pertenecía a un grupo de personas que gozaban del favor o la simpatía de los funcionarios de la Empresa y consiguientemente del privilegio de contar con chacras de mayor extensión, ventajosamente ubicadas y alambradas en su perímetro, como también de haber sido provistas de mejores herramientas y animales. Se trataba de un reducido grupo de familias que dentro del nivel general de las colonias israelitas podría calificarse de "pequeña aristocracia". Un ambiente de exquisita cultura reinaba en el hogar de don I...; allí se alternaban las rudas labores de la chacra y la granja con la lectura, la música y otras expansiones espirituales." En Zeigner, Seidel, Carmel (la Hija del Coronel). Recuerdos de Infancia, op. cit., p.47.

${ }^{63}$ Las demandas por el cobro de deudas son múltiples. Estas notas de reclamo están guardadas en el Archivo de Miguel Sajaroff. Elegimos algunas de ellas como muestra de las demandas y del peso de la figura de Sajaroff como garantía de pagos: "Por la presente nos permitimos dirigirnos a Ud. particularmente imponiéndolo de lo que ocurre con los vencimientos del Fondo Comunal de la Colonia Clara [...]
} 
Dos notas distintivas en este sentido: los quebrantos económicos de los colonos estaban sostenidos por el prestigio del FC y por la fuerza de un líder que procedía a efectuar recortes en los préstamos. Sin embargo, hacía esfuerzos denodados por conseguir recursos para otorgarlos para el levantamiento de las cosechas, las que se perdían por excesos de lluvias, como nuevamente ocurrió en el ciclo 1912-1913. Los desánimos en los colonos hacían que algunos se retiraran y pusieran trabas para canjear trigo por harina, ya que no concebían la propuesta de que debían guardarse parte del trigo para canjearlo por harina y semillas cuando, sin dudas, las deudas eran tan importantes. ${ }^{64}$

A pesar de la crisis sostenida, se ofreció a la JCA un aumento en la contribución anual para las escuelas de la colonia, con el objetivo de que la empresa no las entregara a la Administración provincial; se resolvió cubrir la deuda del hospital, que ya había adquirido autonomía; se decidió trasladar la oficina de La Capilla a Villa Domínguez y aplicar un 10\% de los excedentes anuales para apoyar las bibliotecas de la colonia.

Isaac Kaplan, gerente del FC y un hombre de infatigable compromiso y trabajo por el mantenimiento de la institución, escribía a Samuel I. Hurvitz, colono

\footnotetext{
Hoy hemos cobrado $\$ 2.000$ a cuenta de los importes vencidos [...] (resta un saldo $\$ 2.044,78)$. A estar a lo que Ud., nos ha prometido después de la última renovación que fue concedida en atención especial a Ud. personalmente, que los vencimientos serían pagados puntualmente, nos permitimos suponer de que Ud. no se halle enterado en falta de cumplimiento de un todo, y por ello es que le damos este aviso rogándole quiera interponer su influencia para que a la mayor brevedad posible sea cubierto este saldo con más los intereses por el atraso". En Carta de Hasenclever \& $C^{\circ}$, del 2 de junio de 1913, a Miguel Sajaroff, Archivo Sajaroff, Doc. 87, Archivo IWO.

"Muy señor mío: Fondo Comunal: Como le ha de ser perfectamente conocido, la Sociedad, después de todas las liquidaciones aún esta en descubierto con la casa en $\$ 2474,35$. Lamentablemente ya pasan meses y me es imposible obtener este saldo y la correspondencia lenta y cansadora con la Administración actual lógicamente principia molestar".

"Es comprensible cuando se toma en cuenta que las personas que han intervenido en el negocio y base de cuyas gestiones y peso moral se ha ligado todo, y que fueron Ud. y el Sr. Sajaroff, que yo me dirija Ud. y espero que no dejar de hacer uso de su influencia, como también transmití mi pedido al Sr. Sajaroff a fin de dar solución rápida y la que corresponde con el saldo".

"En repetidas veces, tanto Ud. como el Sr. Sajaroff me han asegurado y garantizado que para fines de abril todo será pago a la casa y no habrá de que pensar". "Como ve lamentablemente no es así y si bien no esta en tela de juicio la seguridad del crédito, me es completamente incómodo ante mis superiores tener que reunir a combinaciones para otra cosecha y prorroga del pago, tanto peor efecto hace esto, cuando se trata relativamente de un importe chico y los mismos intereses de la Sociedad inducen a cancelar esta cuenta desde ya". En Carta del Administrador de Luis Dreyfus \& cíe a David Horovitz, Archivo Sajaroff, Doc. 91, Archivo IWO.

${ }^{64}$ Fondo Comunal. Cincuenta años de su vida. (1904-1954), op. cit., p. 100.
} 
de Lucienville, una carta que desnuda las peripecias y los esfuerzos inclaudicables:

Antes que nada, seguramente, querrá usted saber qué tal anda -o no anda- el Fondo Comunal. Sí, amigo mío; no anda, se bambolea, y se invierte toda la energía para que, bamboleándose, no pierda el equilibrio. Es bastante difícil evitarlo, puesto que hay varios señores generosos que tratan de empujarla para que caiga lo más pronto posible. Sin embargo, creo que superaremos todas las dificultades.

Fueron los años 1912 hasta 1916 muy difíciles, por razones de índole climática en la región, pero también debido al impacto de la crisis general que afectó al país.

En el orden interno, el FC procedió a reajustar las áreas de incumbencias y a desempeñarse de manera más eficiente: separó el hospital, la biblioteca, algunas obras de beneficencia y emancipó la sucursal de San Antonio y la de Santa Isabel, las que se transformaron en La Unión Cooperativa Agrícola y Cooperativa Agrícola Santa Isabel, respectivamente. Impulsó la diversificación de la producción con la siembra de trigo tipo húngaro, lino San Martín y maíz amargo, y se logró también que sus socios obtuvieran los primeros préstamos del Banco de la Nación.

\section{Contactos políticos}

Los hombres que tenían a cargo la dirección del FC, si bien desconfiaban de la política partidaria y otros abiertamente la rechazaban, sabían que debían contar con la ayuda de los poderes públicos provinciales para el desarrollo de la vida económica y social de la institución y de la colonia. Ante las visitas a la región, era importante enviar delegados a los efectos de tener visibilidad, tal como lo expresa la siguiente carta que envía Isaac Kaplan a Sajaroff:

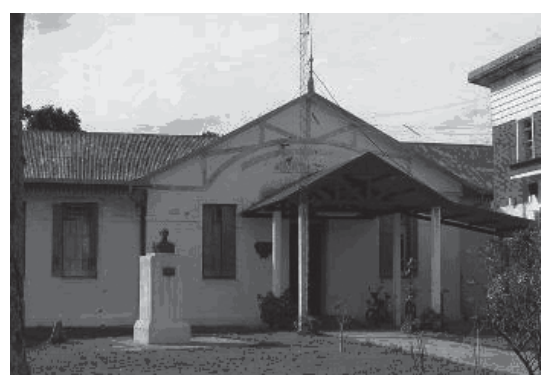

Hospital de Villa Dominguez

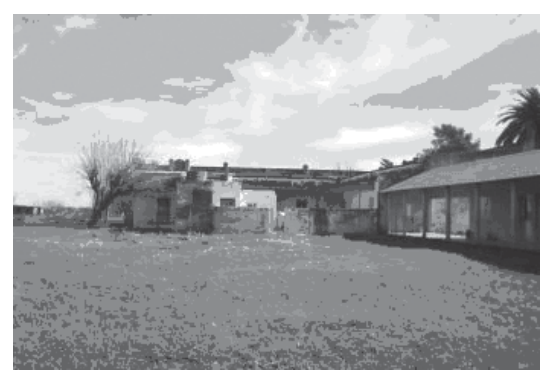




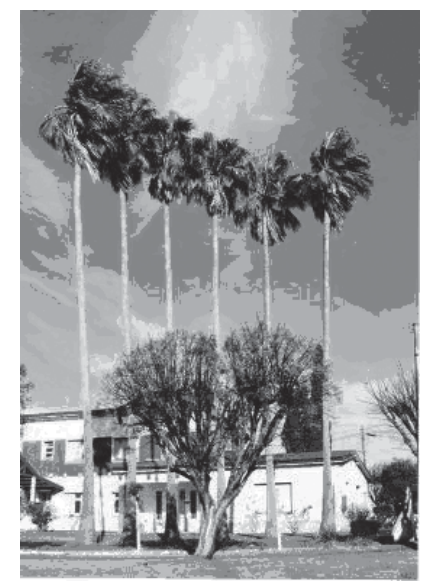

Hoy llegará a Villaguay en gira de propaganda el ex Ministro Dr. Teureyro con su comitiva, según hablé ayer con Señor L. Sidi conviene que vayan unas 2 personas mañana martes a Villaguay para saludarle. Por la situación de la colonia y la política nuestra conviene mucho de hacer este paso para entrar en relaciones amistosas con la gente influyente, ahora quien es la persona apta para tal misión es Ud., y no hay otro Señor Sajaroff le ruego yo en nombre del F.C para que acepte Ud. tal misión que tal vez con el tiempo podrá dar sus beneficios para la colonia. Sé que Ud. no es muy partidario de estas cosas pero sé también que Ud. ha hecho muchos sacrificios para la colonia y hará muchos más todavía y espero que Ud. lo aceptará.

A mi parecer sería bien que lo acompañara el Dr. Volcovich, persona con título y de representación. ${ }^{65}$

\section{Tercera etapa: Afianzamiento del Fondo Comunal. 1917-1930}

\section{Las corrientes internas}

Esta etapa comienza con un acontecimiento que marcará el inicio de una serie de planteamientos que atravesarán la vida política en la colonia: la emergencia de dos posturas diferentes, un ala conservadora y otra reformista, para encarar los problemas de la experiencia colonizadora. La primera, formada por la vieja generación, los fundadores del FC, defensores a ultranza de que la política partidaria era perjudicial para el buen desarrollo de la institución y que la militancia de algu-

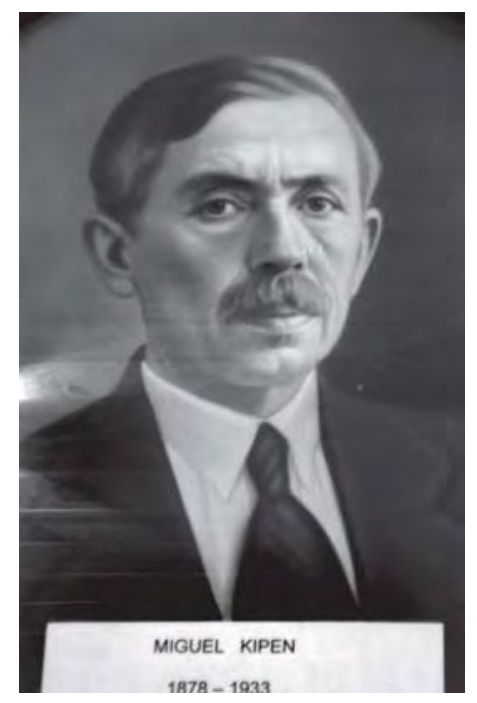

${ }^{65}$ Carta de Isaac Kaplan dirigida a M. Sajaroff, Est. Domínguez, 2 de marzo de 1914. Archivo Sajaroff, doc. 53, Archivo IWO. 
nos de sus socios podía comprometer la institución y, aun más, a toda la colectividad judía, se manifestaban generalmente con un espíritu conciliador hacia la JCA, postura que se enfrentaba casi con intolerancia a personas que detentaban constancia y espíritu de lucha, tales como Marcos Wortman, ${ }^{66} \mathrm{Mi}-$ guel Kipen, Adolfo Rubinstein y sus más jóvenes seguidores, como David Merener, todos afiliados al Partido Socialistas, que eran, además, observadores con profun-

${ }^{66}$ Nos detendremos en el análisis de la personalidad de Marcos Wortman, notoriamente el más combativo dirigente de aquel entonces. Alumno y discípulo dilecto de Kipen, dueño de una vasta cultura adquirida en los salones de las bibliotecas o en sus contactos cotidianos con las familias más cultas de la colonia, como Ios Chertcoff. El modo más sencillo de entender su pensamiento es seguir el hilo de su discurso, ya en las asambleas, ya desde la tribuna cooperativa, o desde las páginas de El campo, su propio periódico, publicado en Villa Domínguez entre los años 1927-1931. Allí aparece con meridiana claridad su pensamiento, y por la cantidad de adhesiones y cartas recibidas puede medirse, además, la proyección de su personalidad sobre la masa agraria, y lo acertado de su accionar: "Nuestro país necesita aumentar su población, pero necesita aumentar la población rural, y no la población urbana. En las ciudades grandes y chicas, sobra población que permanece ociosa y gravita en perjuicio de la clase trabajadora al provocar la rebaja de los salarios y el empeoramiento de las condiciones de trabajo. Si no se aborda con energía y con clara visión política u social la solución de nuestro fundamental problema agrario, el progreso argentino seguirá, como hasta la fecha, siendo precario...". El joven y activo director de El campo viajaba de continuo por las colonias, recogiendo in situ las opiniones y problemas de los agrarios, en especial de los grupos juveniles, que eran sus fieles seguidores. Las páginas de su periódico reflejaban estas tareas, contribuyendo a plasmar lo que Wortman llamaba el despertar de las fuerzas juveniles. La agremiación, uno de sus más caros anhelos, se concreta por la doble vía institucional en la que todos estos hombres múltiples se movieron, la del ámbito estrictamente colonizador, concretada en la Fraternidad Agraria, Cooperativa de Cooperativas, la OJA -Organización Juvenil Agraria- y el Fomento Agrario Israelita Argentino, mientras que, por el lado oficial, fundaron la Federación Entrerriana de Cooperativas Agrícolas, luego Federación Entrerriana de Cooperativas -FEDECO- y participaron de la fundación de la Asociación de Cooperativas Argentinas -ACA-, aunando ideas, criterios y acciones en pro del mejoramiento de la situación de los agrarios. Una de sus mejores intervenciones, que lo muestra en su momento más brillante, es el discurso que por invitación de la mesa directiva pronunciara en el acto de apertura del Primer Congreso Nacional de Cooperativas Agrícolas, Capital Federal, 19 al 22 de marzo de 1932. Representó en aquel momento al Fondo Comunal y estuvo acompañado en la ocasión por Miguel Kipen, David M. Merener, Isaac Kaplán y Aarón Dorfman, vertiendo, entre otros, los siguientes conceptos: "Tan honda es la crisis que atravesamos, tan complejos y diversos son los factores que la determinan, tantos son los intereses que ella afecta, que hasta los hombres más optimistas han terminado por perder la esperanza de una posible solución. Corresponderá una vez más a los agricultores organizados el honor de infundir nuevas esperanzas a la Nación. El hecho de que este Congreso se celebre en medio de la crisis espantosa en que se debate todo el país en general y los agricultores en particular, el hecho mismo de que hayan concurrido aquí representa en forma clara el espíritu de trabajo que anima a los productores de la tierra. No venimos aquí para confesarnos derrotados, no venimos tampoco a implorar misericordia, venimos, sí, para buscar ante todo y sobre todo, dentro de nuestros propios medios, en la acción solidaria, las medidas para poder solucionar nuestros problemas, que no son nuestros, sino de todo el país, venimos a buscar el apoyo de los poderes públicos, no para defender lo que es nuestro, sino lo que es patrimonio y orgullo del país, la agricultura...”. En Celia Gladys López, "Liderazgos Europeos en el Cooperativismo Agrario Argentino-El Caso Entrerriano", XI Congreso de Historia Agraria, Aguilar de Campoo, 15 de junio de 2005, Seminario de Historia Agraria, SEHA, Departamento de Historia e Instituciones Económicas y Economía Aplicada, Universidad de Valladolid. Disponible en http:// www.seha.info/pdfs/ii_asociacionismo/II-gladyslopez.pdf. 
da simpatía de las transformaciones que la revolución de 1917 había provocado en Rusia. ${ }^{67}$ Los representantes de las dos tendencias antagónicas tenían activa participación en el FC, donde desarrollaban una ferviente actividad buscando lograr el apoyo y la adhesión de los colonos.

Los ecos del congreso de las colonias judías celebrado en Buenos Aires en 1916, reunido por iniciativa del FC, al que concurrieron delegados de casi todas las colonias de la JCA en el país, marcaban el clima de enfrentamiento y de malestar con la empresa que había procedido a desalojar a colonos y a reducir los predios a otros - lo que significaba también la antesala de la expulsión-, y actuaban como el telón de fondo en las sesiones de la comisión directiva.

Las conclusiones del congreso se traducían en los siguientes reclamos: 1) si un colono quisiera pagar su chacra con antelación al contrato, la JCA debe aceptarlo; 2) al saldar el colono la cuenta con antelación -total o parcialmente-, la JCA deberá descontar los intereses respectivos; y 3) el colono que quiera o deba abandonar sus tierras, podrá transferirlas a otro de manera de obtener de él una compensación por las mejoras que hubiere efectuado. ${ }^{68}$

Las primeras discrepancias en el plano interno aparecieron en 1917, cuando se realizó en La Capilla un acto en homenaje a la acción desplegada por Miguel Sajaroff al frente del FC y se propuso otorgarle una recompensa pecuniaria por su tarea como presidente, la que fue rechazada categóricamente por el homenajeado. Este hecho loable del líder puso de manifiesto la emergencia de importantes diferencias, ya que algunos de los colonos sostuvieron que de este modo solamente los socios de posición económica holgada podrían ocupar ese puesto, pues hacerse cargo del mismo requería abandonar la chacra, contratar un peón que lo reemplazara y, por que su-

\footnotetext{
${ }^{67}$ Un folleto convoca a una reunión que se hizo en el club social Barón de Hirsch el 2 de abril de 1917. Se lee en el texto: «Interpretando un verdadero y justificado anhelo popular, la Comisión Directiva del Club en su última reunión resolvió festejar, mediante un acto público el triunfo de la Revolución Rusa, y exteriorizar su adhesión a ese movimiento trascendental que marca un paso gigantesco por el camino de la redención humana. En consecuencia queda invitado el pueblo a concurrir a este acto que se llevará a cabo el miércoles 2 de corriente a las 2 p.m. en nuestro local. Abrirá el acto el Sr. Marcos Wortman, luego el Sr. Miguel Kipen dará una conferencias sobre el alcance político, económico y social de la revolución". En Caja JCA, Archivo IWO, 1005/440.

${ }^{68}$ Estas exigencias de los congresistas fueron con el tiempo, y luego de duros enfrentamientos, aceptadas por la empresa, luego de una serie de juicios que demostraban la pertinencia de las demandas según la legislación argentina.
} 
puesto, que fuera remunerado. Este acontecimiento, que puede ser considerado menor, estaba poniendo de relieve que la experiencia colonizadora estaba generando una segmentación de clase entre aquellos chacareros que poseían mejores condiciones para la acumulación de capital y otro sector cuya capacidad era más limitada, cuyos niveles de ingresos lo ubicaban por debajo del nivel de subsistencia.

Marcos Wortman, joven brillante y combativo, entrará en escena solicitando mayor apertura en la toma de decisiones, permitiendo también la participación de los jóvenes, ${ }^{69}$ la necesidad de encarar con energía la relación contractual y de dependencia con la empresa colonizadora, así como también consentir la posibilidad del ingreso de la política partidaria en la cooperativa.

\section{La agenda: cómo enfrentar los desalojos y los alcances de las trasferencias de tierras}

Los problemas eran complejos y serios y se discutían en un clima muy tenso. El tema de los desalojos de colonos mantenía en alerta la atención de los socios.

En la asamblea del 11 de septiembre de 1917, veinte grupos de la colonia enviaron delegados para abordar este tema: había una lista de cuarenta colonos expuestos al desalojo, a quienes la JCA les había otorgado un plazo de diez días para desocupar la chacra. Los asambleístas sostenían que los desalojos afectaban generalmente a los colonos pobres, que las transferencias ${ }^{70}$ sólo en muy po-

\footnotetext{
${ }^{69}$ En la reforma al estatuto del FC que se realizó en 1927 se puso de manifiesto, en los largos debates, la posible incorporación de los jóvenes hijos de colonos y de la esposas como socios de la misma. Las posturas entre las dos tendencias fueron bien diferenciadas, una que pretendía que existiese una sola categoría de socios con deberes y obligaciones para obtener sus derechos a usufructuar de los beneficios de la institución y la otra que propiciaba la apertura a nuevos socios, ampliando el espacio de formación y educación en las prácticas cooperativistas que redundaría en la consolidación de la institución. Ver Actas № 465 a 468, del 16 de junio a 31 de julio de 1927.

${ }^{70}$ Las trasferencias fueron reglamentadas por la JCA, donde se establecía: 1) el colono debe pagar toda su deuda a la JCA; 2) el socio o la persona a quien transfiere debe ser persona trabajadora, dispuesta a dedicarse a las tareas del campo y a trabajar por sí misma la tierra, pues no se puede tomar por socio o transferir el campo a quien quiera especular con él; 3) se permite aceptar como socio, o transferir el campo, al hijo o yerno de otro colono, siempre que esto no incida en el trabajo de las tierras de este último; 4) el reglamento no debe ser empleado como recurso para que unos pocos posean muchas chacras y que los colonos más ricos exploten a los más pobres; 5) cada pedido debe ser presentado a la Dirección, previo estudio de la Administración local, provisto de todos los datos necesarios.
} 
cos casos representaban una solución y que se debía solicitar a la JCA que dejara cincuenta hectáreas de tierras favorables para los ancianos y aquellos que no podían trabajar la tierra con sus propias manos. Las posibilidades de maniobras del FC eran, según el grupo de opinión conservador, muy limitadas. Se designó una comisión para analizar este punto que estuvo integrada por M. Wortman, M Kostianovsky, M. Lieberman, M. Matusevich y A. Gleser, y prontamente las discrepancias emergieron entre las dos posturas: Miguel Sajaroff, que proponía esperar hasta después de la cosecha para adoptar medidas contra la JCA, y una actitud más combativa encarnada por Wortman, que no ahorraba críticas contra Sajaroff y la Comisión Directiva que imponían, por mayoría, sus criterios.

A la fogosidad de Wortman se contraponía un criterio moderado pero que conseguía algunas prerrogativas: que el FC tendría derecho a intervenir en la elección de nuevos candidatos para la colonización; ${ }^{71}$ que las transferencias pudieran hacerse a los hijos de los colonos; que los desalojos sólo podrían efectuarse con quienes ni vivían en las chacras o las subalquilaban; y que la JCA se hiciera cargo de las deudas que los socios y ex socios mantenían con el FC. ${ }^{72}$

En este período, los vínculos institucionales se ampliaron a partir de los contactos con la Administración provincial y nacional. Fue un acontecimiento la llegada del gobernador de la provincia de Entre Ríos, Miguel Laurencena, junto a su ministro de Gobierno, Antonio Sagarna, en visita a las colonias Lucienville y Clara $^{73}$ en noviembre de 1917, quienes señalaban que el objetivo del viaje era para conocer «directamente y en sus variados aspectos, este fenómeno económico, religioso, político, educacional y social argentino y particularmente entrerriano: la colonización israelita». ${ }^{74}$

\footnotetext{
${ }^{71}$ La propuesta de Sajaroff, que fue bien recibida por la JCA, establecía que "Los colonos que quieran transferir sus chacras las entregarán a sus cooperativas, y éstas deberán buscar el candidato y los recursos económicos".

72 En 1919, la JCA se hace cargo del 57\% de las deudas antiguas de los socios y del $50 \%$ de las de los ex socios (50 años..., op. cit., p. 198).

73 «Se preparó una recepción popular, pero Sajaroff no concurrió al acto. Esto llamó la atención de las visitas, que se sintieron un poco molestas. Repetidas veces me preguntaron la razón y yo no sabía dar una respuesta razonable. Al día siguiente le pregunté el motivo de su ausencia, que todos habían considerado una falta de tacto. Me dijo: - Yo también lo considero así. Pero qué quiere, yo no me presto para estas ceremonias. Sé que he faltado a la etiqueta, a la hospitalidad, pero es un defecto mío que no puedo vencer." En Kaplan, Isaac, Anécdotas, cartas y discursos de Don Miguel Sajaroff, op. cit., 1965. ${ }^{74}$ Fondo Comunal. Cincuenta años de su vida. (1904-1954), op. cit., p. 110.
} 
La comunicación del ejecutivo provincial sobre su política para afianzar el trabajo de la Federación Entrerriana de Cooperativa generó mucho impacto, la que tendría como misión negociar con el Banco de la Nación Argentina la asignación de créditos para sus asociados, en tanto se otorgarían tres becas de estudios para jóvenes que se capacitaran para desempeñarse como gerentes de cooperativas.

Ese mismo año se pusieron en contacto con los representantes en la Cámara de Diputados de la nación para apoyar el pedido de la Federación Agraria Argentina de no gravar con impuestos los productos agropecuarios que se exportaban.

En 1917 se inauguró el almacén cooperativo, un anhelo largamente acariciado. Al año siguiente asumió Miguel Kipen como presidente y Marcos Wortman como secretario del FC (hombres afiliados al Partido Socialista), y en varias sesiones se discutió insistentemente sobre la conveniencia de evitar la intromisión de la política partidaria en la cooperativa. ${ }^{75}$

Se trasladó la sede física del FC a Villa Domínguez y se adquirió la casa para el funcionamiento en La Capilla. Se compraron los galpones situados en Domínguez y Clara que pertenecían a la JCA. Se alquiló un depósito en Concepción del Uruguay como puerto cercano que facilitaría las exportaciones si se concretaban los envíos directos a cooperativas europeas. El hecho de comprar galpones en los puertos

\footnotetext{
${ }^{75}$ En una nota firmada por 26 socios, dirigida al síndico del FC, se requiere la convocatoria a una asamblea invocando un tema presupuestario, pero el trasfondo era el de discutir un tema que "no convenía escribirlo, que habría que decirlo verbalmente y que lo diría". El señor Concejal Sas hace una serie de consideraciones "para demostrar que el hecho que el Presidente y el Secretario son socialistas perjudica y pueden ser de consecuencias graves para el Fondo Comunal y para la Colonia en General", por lo que solicitan que el presidente Miguel Kipen y el secretario Marcos Wortman renuncien a sus cargos. Kipen solicita la palabra y dice: «En cuanto a mi actuación política rechazo categóricamente las acusaciones que se me hacen porque además de ser absurdas son completamente falsas. Nadie -sin exponerse a mentir a sabiendas- podría demostrar un solo hecho que involucre mi injerencia política como presidente. Respecto de mi actuación política -personal- reclamo para mí el mismo derecho que para todos los socios, es decir la libertad absoluta de profesar las ideas que le gusten. La neutralidad del Fondo Comunal en materia política no hay que interpretarla en el sentido de que cada socio individualmente estaba impedido de profesar determinadas ideas políticas". Luego de otras consideraciones sobre el verdadero concepto de "actuación política" y las relaciones existentes entre luchar en el terreno cooperativista y en el político, se explayó demostrando la indeclinable necesidad que asistía a los colonos de intervenir activamente en política. Sostuvo que «si existía algún peligro estaba en aquéllos que deseando congraciarse con el Gobierno o los caudillos no rechazaban medios por más ruines que fuesen". Wortman describió la asamblea como histórica, porque los asociados podían tener a sus dirigentes presentes y dispuestos a ser juzgados. Sajaroff coincidió en que era histórica porque "hay que ventilar, aclarar y así nos orientamos mejor". Puestos a votar la renuncia solicitada, por gran mayoría fue rechazada. Acta del 27 de febrero de 1919.
} 
para comercializar por sí mismos las cosechas incentivaba la participación de los socios, así como la tarea de concientizar sobre los beneficios del trabajo cooperativo a través de conferencias y del periódico El Colono Cooperador. ${ }^{76}$

\section{"Invocando" una vez más al barón de Hirsch para hacer frente a una agenda compleja: la colonización de los hijos, los impuestos a la tierra y los desalojos.}

En la agenda de las sesiones comenzaron a tratar los temas que marcarían los nuevos esfuerzos a encarar: la colonización de los hijos de colonos, la creación de un fondo con ese propósito - con el aporte de 50 centavos por cada hectárea que cada socio adherido poseía-, el reforzamiento de los vínculos con las otras cooperativas y los problemas inherentes a la calificación técnica, instrucción y educación de los colonos.

Las relaciones entre el FC y la JCA atravesaron ciclos de aproximación y otros de distanciamiento y enfrentamientos turbulentos. La década del veinte se inició con un acercamiento, en particular por el anuncio de la visita del doctor Oungre, director de la JCA, a Colonia Clara. La preparación de la agenda de temas para ser expuestos ante el director les demandó un arduo trabajo a los concejales de la Comisión Directiva del Fondo Comunal, quienes, junto a los representantes de las cooperativas Agricultores Unidos, los de Palmar Yatay y los de Santa Isabel debían consensuar una única posición -cuando existían criterios divergentes- y, por otro lado, debían ser capaces de encontrar la estrategia adecuada para lograr y obte-

\footnotetext{
${ }^{76}$ El 30 de abril de 1917 apareció el primer número bajo la dirección de Miguel Kipen, en el que se puede leer que el objetivo del boletín era combatir la indiferencia de los socios respecto de su cooperativa, además de crear un ámbito de difusión y debates en torno al ideario cooperativista. Kipen continuó como redactor hasta el $N^{\circ} 25$ (30/11/19). Los N ${ }^{\circ} 26$ al 32 estuvieron bajo la redacción de Israel Makransky, periodista y conocedor de varios idiomas. Los número 33 y 34 estuvieron bajo la dirección del Israel D. Fingerman, colono erudito y antiguo director de El Colono Israelita Argentino. Luego, Isaac Kaplan ocupó la dirección del periódico, desde el № 35 (octubre de 1921) al № 382 (mayo de 1947), y dejó su cargo por motivos de salud. Desde febrero de 1922 cumplió con la periodicidad mensual. Hasta fines de 1927, El colono Cooperador fue el órgano periodístico del Fondo Comunal. En septiembre de 1927 pasó a depender del la Federación Agraria Israelita Argentina, luego Fraternidad Agraria, que continuó apareciendo luego del alejamiento de Kaplan, bajo la dirección de Abraham Gabis.
} 
ner los mejores resultados frente a un "adversario" común. Convencido de que los problemas capitales, tales como la política de colonización, el desarrollo de una política estable y de un programa coherente de la empresa vinculada a los colonos, la reforma de los contratos y de plazos razonables fijados para su cumplimiento, no podrían ser abordados en su totalidad, sino que «Es necesario tratar únicamente lo que tiene probabilidad de llevarse a cabo", propuso Aron Kaplan, vocero destacado de la línea conservadora. ${ }^{77}$

Entonces, las demandas se restringieron a los temas más acuciantes. El primero, las transferencias de los campos, que ponía en cuestión, por un lado, la imposibilidad de pago de las deudas de los colonos y, por otro, los criterios de elegibilidad de los candidatos para tomar posesión de las chacras y a quién correspondía esa prerrogativa: a los colonos organizados en la cooperativa o a la empresa colonizadora.

La posición más radicalizada la detentaba José Axentzoff, quien sostenía en el tema de las transferencias que "La cuestión no es únicamente ver quién viene sino quién se va", que "se debe dejar por sentado que las transferencias no resuelven debidamente el problema de la colonización, sino que fomentan también el acaparamiento de campos en manos de los colonos más ricos o comerciantes locales", en tanto se debía exigir a la JCA la refinanciación de los contratos que asegurara la estabilidad de los colonos y la imposibilidad de desalojo. ${ }^{78}$

La sesión preparatoria demandó dos días de intensos intercambios. Se acordaron los puntos básicos y se fijó que la presentación de demandas se haría de manera conjunta representando a todas las cooperativas judías de la provincia. Finalmente, el 14 de julio de 1920 se realizó la reunión en la que el director escuchó las demandas ${ }^{79}$ y se comprometió a tratar de darles un curso favorable.

\footnotetext{
${ }^{77}$ Acta 293 del 17 de mayo de 1920, p. 36.

78 Proponía que entregase el título de propiedad a los colonos con más de diez años de instalación y título hipotecario para aquellos que tuvieran deudas. Acta 293 del 17 de mayo.

${ }^{79}$ En la sesión del 17 de mayo de 1920 se prepara el siguiente orden del día para tratarlo en la reunión conjunta con el doctor Oungre: 1) transferencias; 2) deudas atrasadas; 3) que los campos desocupados no pertenecen a la JCA sino a la colonización; 4) sistema de administración; 5) un solo precio por la tierra; 6) selección de personal de la JCA; 7) participación del FC en los asuntos de la JCA dentro de las colonias.
} 
Algunos inconvenientes gravitantes salieron a la luz. El problema de la sobretasa que denunciaban los colonos correspondía al impuesto a los latifundios que había aplicado la provincia de Entre Ríos desde 1918 con la Ley N ${ }^{\circ} 2.571 .{ }^{80}$ Como la JCA era propietaria de grandes extensiones de tierra, cuya titularidad detentaba pues no había entregado la propiedad a los colonos sino tan sólo una Promesa de Venta, por lo que los cánones a pagar eran los correspondientes a esta categoría, y como la empresa trasfería el pago de impuestos a los colonos, estos debían abonar sobre esta categoría sin ser propietarios. ${ }^{81}$ El compromiso asumido por el director fue el de realizar gestiones ante el gobierno provincial para la eximición de estas tasas diferenciales para los colonos con Promesa de Venta, pero les aconsejó seguir esperando y pagando hasta obtener la resolución, ya que la empresa no podía hacerse cargo de estos impuestos

pues deben tener en cuenta que la J.C.A no puede desembolsar ese dinero puesto que esto lo privaría de venir en ayuda de sus hermanos de Oriente, en la medida necesaria. ${ }^{82}$

Ante la interpelación de Axentzoff sobre la responsabilidad de la empresa y que era una cuestión doblemente injusta para los colonos - los que también colaboraban con los judíos pobres de Europa en la medida de sus posibilidades con contribuciones al Comité Central de Buenos Aires-, por lo tanto sostenía que la sobretasa la debía pagar la JCA, el señor Oungre reconocía que

la justicia está de parte de los colonos, pero que la J.C.A no está en condiciones de pagar esta diferencia [y les promete] tomar todas las medidas posibles para librar al colono de esta carga y hasta si fuera necesario recurriría a la Diplomacia Británica. ${ }^{83}$

\footnotetext{
80 La Ley 2.571 de contribución territorial sancionada en 1918 establecía un revalúo de la propiedad rural cada cinco años, a los efectos de ajustar el impuesto territorial. Estableció un sistema de proporción ascendente comenzando con 25 hasta el $40 \%$ para propiedades de 20.000 o más hectáreas.

${ }^{81}$ En la sesión del 28 de febrero de 1922 de la Comisión Directiva, se leyó una carta enviada por Marcos Wortman denunciando la sobretasa, y luego de varias consideraciones se llegó a la conclusión de que "legalmente el Fondo Comunal, no podrá hacer nada por cuanto en sus contrato con los colonos está establecido que los impuestos creados y a crearse serán por cuenta del colono". Acta № 340, p. 150.

${ }^{82}$ Acta $\mathrm{N}^{\circ}$ 297, 14 de julio de 1920, p. 55.

${ }^{83}$ Acta 297, p. 55.
} 
El tema era retomado por el periódico El Campo:

Los colonos israelitas, gracias a los contratos leoninos que la empresa les hizo firmas, pagan por lotes de 100 o 150 hectáreas contribuciones tan elevadas como si fueran poseedores de 20.000 hectáreas o más. ¡Es una enormidad! ¡Es algo que no tiene nombre! ¿lgnorará el gobierno provincial lo que ocurre en su provincia? ¡Cuesta creerlo! ¿Entonces...? ${ }^{84}$

Las transferencias no solucionaban el problema de los colonos, ya que las deudas atrasadas -las que requerían un pago de interés mayor- ${ }^{85}$ provocaban mayor vulnerabilidad en los más pobres, lo que generaba una segmentación social notable dentro del colectivo "colonos". Este grupo, los más pobres, era el objeto de preocupación y de la defensa pública de Wortman y Axentzoff, lo que conducía a estos dirigentes sostener enfrentamientos con los grupos conservadores dentro de la Comisión Directiva del FC.

Un episodio entre muchos otros da muestras de lo dicho. José Axentzoff fue denunciado por proferir injurias y denostado por ser un elemento conflictivo que debía ser alejado de la institución. Los agravios imputados por los colonos ${ }^{86}$ respondían a que Axentzoff solicitaba se les hiciera un boicot a aquellos concejales que adquirían chacras en transferencias. Este tema será retomado provocando encendidos debates en las asambleas posteriores.

Transcurrieron unos pocos días desde la visita del director Oungre, cuando se recibió una carta en la que expresaba la satisfacción por la tarea que realizaba el FC:

He podido comprobar con verdadero placer los adelantes hechos de algunos años a esta parte por la institución que usted tan dignamente dirige. Al Fondo Comunal le

${ }^{84}$ El campo. Periódico agrario, edición del $1^{\circ}$ de mayo de 1927, p. 1.

${ }^{85} \mathrm{El}$ aumento sube del 4 al 6\%. El director Oungre explica que ese tipo de interés es más bajo que el de cualquier banco y que él tenía idea de aumentarlo. Acta 297, p. 56.

${ }^{86}$ La carta leída en la sesión del 10 de agosto de 1920 estaba firmada por M. Efron, M. Genijovich, luda Efron y A. Gleser, y se acuerda que sea publicada en el boletín El Colono Cooperador. En la sesión del 31 de octubre de 1920 se presenta una lista con 34 firmas que exigía Axentzoff para presentar su renuncia a la concejalía y se resuelve informar al interesado de ello. Acta 305, p. 76. 


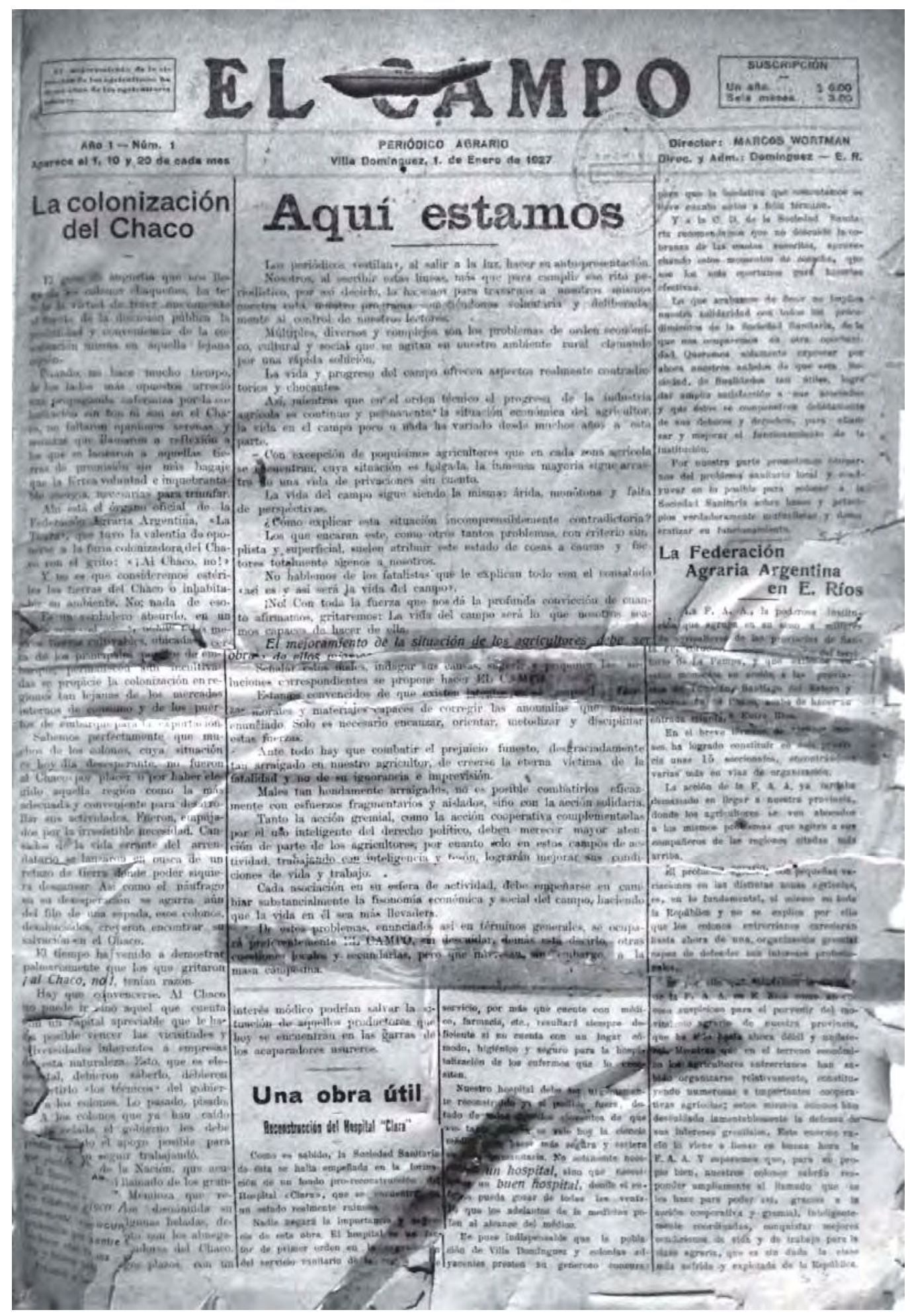


espera, en el camino de la cooperación, un futuro brillante, y tengo la certeza de que su influencia será cada vez mayor para el progreso y la felicidad de la colonia. Creo que, a fin de que la labor del Fondo Comunal de resultados inmejorables, es necesario que los socios se esfuercen por lograr el aumento en efectivo del propio capital de la institución. De tal manera, el Fondo Comunal podrá ampliar sus actividades y extender la zona de su influencia benefactora. ${ }^{87}$

Sin embargo, esta misiva tenía también otro sentido: tener siempre presente el mandato de "no olvidar" y volver a reafirmar el compromiso fundante entre los colonos y la JCA, recordar el "deber" asumido con la figura aglutinante del barón de Hirsch y tener siempre presente la promesa y la misión de estos hombres de convertirse en trabajadores agrícolas, y reconocer a la empresa como portadora del ideal de Hirsch. Los colonos debían acordarse que:

En efecto, pude comprobar que los colonos se entregan con dedicación y actividad a las tareas agrícolas y que los resultados por ellos obtenidos constituyen una honra para ellos, para la obra del Barón de Hirsch y para el judaísmo en general. Los colonos son cada vez más concientes de la misión que deben cumplir en la vida y de las obligaciones que han contraído para con la institución a la que el Barón de Hirsch encomendó la tarea de realizar su noble y generoso ideal. ${ }^{88}$

Los lazos de cooperación con otras entidades, ya sea la Federación Agraria Israelita, la Fraternidad Agraria Argentina o la Asociación de Cooperativa Argentina, demostraban el trabajo por afianzar el proyecto. Su objetivo primordial era eliminar la competencia entre los chacareros, reforzando su fuerza de negociación frente al comercio. Por supuesto que estos vínculos no estuvieron libres de tensiones. Entre 1927 y 1929, el FC dejó de pertenecer a la Federación Agraria Israelita, ${ }^{89}$ así como fueron muy fuertes los rechazos a seguir expandiendo la acción gremial:

\footnotetext{
${ }^{87}$ Carta del 21 de julio de 1920, enviada luego de la visita a Colonia Clara. Archivo Sajaroff, IWO, p. 201. 88 Ibídem.

${ }^{89}$ El punto en cuestión era establecer a través de qué federación se venderían las cosechas, si a través de la unión de cooperativas judías o a través de alianzas con las cooperativas de la región, es decir, las cooperativas de la provincia. La Federación Israelita, en su reunión de mayo de 1928, en su IV Congreso
} 
Ante la asamblea que debía enviar los delegados al congreso de las colonias judías, Marcos Pustilnik reclamaba: ${ }^{90}$

hay muchas «lindas ideas" que cuestan dinero y no traen ninguna utilidad práctica...

Prácticamente no se pudo hasta ahora aunar los esfuerzos de un par de cooperativas locales... Iremos a crear otra vez Federaciones, que nos costará mucho trabajo y dinero, perdidos inútilmente! No sabemos todavía aprovechar al mercado local y ya soñamos con el mercado Europeo.

Se aceptó el proyecto de Aarón Kaplan de crear escuelas para jóvenes, donde se impartiría enseñanza técnica: mecánica, herrería, carpintería. Se insistió con los socios sobre la necesidad de trabajar con una producción mixta, explicando que si bien eran un aliciente los buenos rindes que producían las nuevas semillas para forraje, en particular el Sudan Grass y el Sorgo Azucarado, no se debía abandonar la producción de la granja. Con estos motivos se dispuso otorgar premios a los socios que entregaran la mejor calidad de crema y huevos.

A partir de 1921, la JCA empezó a tomar cartas en el asunto de la colonización de los hijos de los colonos, a través de limitadas opciones. Don Samuel Kaplan, alto funcionario de la empresa, ofreció al FC dos lotes que se podían comprar a \$ 150 la hectárea, ubicados uno en General Campos y otro en el departamento de Concordia, para los cuales se ofrecía que el $80 \%$ del valor sería aportado por la JCA o a través de un crédito del Banco Hipotecario a pagar en 33 años. ${ }^{91}$ También propuso colonizar a los jóvenes en las tierras de reserva que quedaban vacantes en las colonias, pero con la condición de que las parcelas asignadas estuvieran alejadas de los campos de los progenitores. Con este fin se decidió abrir un registro de los interesados. Consciente el administrador de que estas medidas eran

de Colonos Judíos realizado en Moisés Ville, redactó una declaración en la que establecía el deber de afianzar las operaciones conjuntas para lograr la unificación y alcanzar los objetivos comunes, y llama la atención al FC y la Sociedad Agrícola de Lucienville, que en el ejercicio anterior habían optado por vender junto a las cooperativas entrerrianas. Entendía que no hubo en ello intenciones aviesas, pero les solicitaba que se comprometieran para en el futuro seguir la comercialización junto a las israelitas.

${ }^{90}$ Acta $\mathrm{N}^{\circ} 415,8$ de marzo de 1925, p. 96.

${ }^{91}$ Acta $\mathrm{N}^{\circ} 343$ del 18 de mayo de 1922, en la que se acepta la propuesta de ir a inspeccionar los campos junto a los delegados de la Sociedad Agrícola y la JCA, siendo designados Sajaroff y Sidi. 
insuficientes para dar salida a la problemática, se comprometía a seguir estudiando el tema.

En una nueva reunión del C.D. con el director Isaac Starkmeth en 1922 se logró el compromiso de que, en el caso que un colono tuviera consigo en la chacra tres hijos solteros, uno de ellos, y como excepción, podría tener una chacra en transferencia. ${ }^{92}$

Pero veamos los alcances reales de esta "conquista". Quizás otra anécdota pueda ser ilustrativa de las arbitrariedades en las decisiones que los administradores de la JCA imponían a "sus" colonos. Elijo, entre muchos otros, el caso de Marcos Wortman, que, si bien es distintivo por provenir de un joven con voz y acción combativa, este aspirante cumplía con las condiciones que requería el director Starkmeth para acceder a las transferencias de tierra. Sin embargo, sufrió las inequidades de la posición de fuerzas de los actores.

En noviembre de 1922, Wortman envió una carta a la Comisión Directiva solicitando la intermediación del FC para colonizarse, con la especificación del lote requerido, propuesta que fue apoyada por el concejal Levorsky. No obstante, la decisión de ese colectivo, en voz de Sajaroff, sostuvo que no debían tratarse casos individuales, sino confeccionar una lista con todos los aspirantes a la colonización y luego dar los pasos necesarios para trabajar en la ubicación de los mismos. ${ }^{93} \mathrm{EI}$ tema quedó congelado hasta que su padre, don Salomón Wortman, dos años después, envió una nueva carta ${ }^{94}$ a la Comisión Directiva en la que expresó su deseo de transferir parte de su chacra a su hijo, adelantando el dinero para la transacción. La transferencia nunca se concretó.

Podría pensarse que la discriminación se debía a las represalias contra un adversario incansable. Sin embargo, las arbitrariedades eran mucho más democráticas: podían alcanzar a todos. Quizás el caso Schejtman sea representativo de esto. Este colono, al que desalojaron de su chacra, solicitó la ayuda del FC y también de la cooperativa de Basavilbaso, quienes enviaron cartas de reclamo a la Dirección

\footnotetext{
92 Si el candidato era aceptable, pagaría el 25\% del predio y el resto en diez años. Tratándose de una transferencia de padre a hijo, se incluiría el importe de la deuda del padre y lo abonaría con el 25\%, y el resto en veinte años. Acta $N^{\circ}$ 354, 10 de diciembre de 1924, p. 191. También en Acta № 363 del 20 de marzo de 1923, p. 210.

${ }^{93}$ Acta $N^{\circ} 352$, p. 182.

${ }^{94}$ Acta $N^{\circ} 396,11$ de junio de 1924, p. 45.
} 
de la JCA en Buenos Aires denunciando el error cometido al quitarle su campo. ${ }^{95}$ Cuando finalmente la Dirección respondió a la misiva, informaba que, si bien "este colono no es capaz ni suficiente responsable por actos que fueron motivo del desalojo", se le aconsejaba que firmara el contrato de arrendamiento por la tierra que ocupa actualmente con la perspectiva de otorgarle después un contrato de Promesa de Venta y que de ningún modo reconsiderarían lo dicho. ${ }^{96}$

Entretanto, se abría el juego de aparente colaboración mutua: la Administración de la JCA en Buenos Aires enviaba una nota al FC en la que pedía su intervención sobre los 56 colonos atrasados en sus pagos. Se nombró una comisión integrada por Isaac Kaplan, Adolfo Glezer y Boris Levosky para ayudar en el tema. ${ }^{97}$

La aparición de una nota en el periódico ldische Zeitung, en la que se informaba sobre la situación de los colonos atrasados en los pagos y de las medidas tomadas contra ellos por la empresa colonizadora, provocó la irritación de los administradores, quienes enviaron una carta condenatoria al Consejo Directivo del FC. Les recordaban que los acuerdos y los trabajos conjuntos entre sus instituciones no podían ser públicos ni mucho menos publicados. Algunos asociados temían por las represalias que podía establecer la empresa, la que tenía la potestad de no cumplir con las últimas concesiones.

El informe realizado por la comisión ad hoc para estudiar la situación de los colonos atrasados fue una nueva chispa que puso de manifiesto la intransigencia y forma autoritaria en que la empresa comunicaba su posición, dando cuenta de que

la amenaza del desalojo como una continua pesadilla que pesa sobre la colonia y esto entorpece el adelanto de la colonización: todos están de acuerdo que empleando todas las medidas de cobranza es un derecho inviolable que le corresponde a la J.C.A. Pero bajo ningún concepto puede la J.C.A quitarle la chacra conside-

\footnotetext{
${ }^{95}$ Acta $N^{\circ} 394,12$ de mayo de 1924, p. 39.

${ }^{96}$ Acta $\mathrm{N}^{\circ} 396,11$ de junio de 1924, p. 47.

${ }^{97}$ Acta No 355, 31 de diciembre de 1922, p. 194. El informe de la comisión da cuenta de situaciones diferenciadas entre los colonos: "hay algunos que son buenos colonos y sus atrasos son relativamente normales, a los cuales hay que dejar continuar en sus chacras sin ningún cambio; algunos que conviene que transfieran parte de su chacra a uno o varios de sus hijos, otros que deben transferir a ajenos, unos que les convendría quedar con 50 hectáreas en arrendamiento a \$2 la hectárea, y algunos que para normalizar su situación es necesario una consulta jurídica». Acta №364, 28 de marzo de 1923, p. 211.
} 
rando que si es sierto (sic) que el colono debe dinero a la J.C.A también es sierto que la tierra corresponde al que la trabaja. ${ }^{98}$

El clima de resistencia fue incentivado por Wortman, que desafiaba abiertamente a la JCA y difundía su oposición:

La J.C.A tiene todos los atributos que caracterizan a toda empresa explotadora, con el agravante de la mistificación, pues pretende pasar por filantrópica. Es el lobo vestido con la piel de ovejas. ${ }^{99}$

Wortman replicó a un informe ${ }^{100}$ que presentó la JCA a Le Breton, ministro de Agricultura de la Nación, cuyo objetivo era solicitar tierras fiscales localizadas en el Chaco para ampliar la colonización y en donde se daba cuenta de las extensiones adquiridas en el país, ${ }^{101}$ la cantidad de colonos que ya habían adquirido sus títulos de propiedad, a los que ella denomina "emancipados", la tierras aún dispuestas para la colonización, etcétera, señalando que:

pero ni en broma dice cuánto le han costado estas tierra y a qué precios las han "vendido" a los colonos. Cualquier empresa de las tantas que actúan en la república, al ser acusada de explotadora y de realizar ganancias excesivas a costa del pueblo, se defiende con las cifras de sus balances, las que a su juicio prueban lo infundado de las inculpaciones. Pero la J.C.A sólo publica lo que le conviene; nadie conoce sus balances, porque no los da a publicidad. ${ }^{102}$

Este fogonero y líder de las voces más radicalizadas fue elegido presidente del FC para el período 1924-1925, y en votación secreta obtuvo la mayoría absoluta

${ }_{98}$ Acta $N^{0} 370,1$ de julio de 1923, p. 221.

99 Su opinión se difundía a través de artículos publicado en Di Prese y en La Vanguardia de la Capital Federal y en un folleto que se titulaba "La colonización israelita en Argentina" (La Vanguardia, 11 de noviembre de 1923), de amplia difusión fuera y dentro de la colonia.

100 La obra de la Jewis Colonization Association en la Argentina. Nota presentada al ministro de Agricultura, Dr. T. Le Bretón, En Mundo Israelita, edición del 29 de junio de 1923.

${ }^{101}$ Se indica que desde 1992 hasta 1923 la JCA había adquirido 586.479 hectáreas en las provincias de Entre Ríos, Santa Fe, Buenos Aires, Santiago del Estero y en el territorio de La Pampa. Sobre ese total, estaban colonizadas 362.461 hectáreas con un total de 2.588 familias de agricultores, de las cuales 391 habían recibido el título de propiedad. Ibídem.

102 Marcos Wortman, "La colonización israelita en la Argentina», op. cit. 
de los votos, marcando el nivel de aceptación logrado en los socios de la cooperativa.

En su discurso de asunción decía lo siguiente:

Hace varios años que trabajo como concejal. Mi trabajo dentro del consejo fue arduo y accidentado. Muchas veces he discutido apasionadamente mi actuación dentro como fuera del consejo; muchas veces tuve que presentarme ante la masa de socios para ser juzgado, y muchas veces obtuve pruebas inequívocas de confianza.

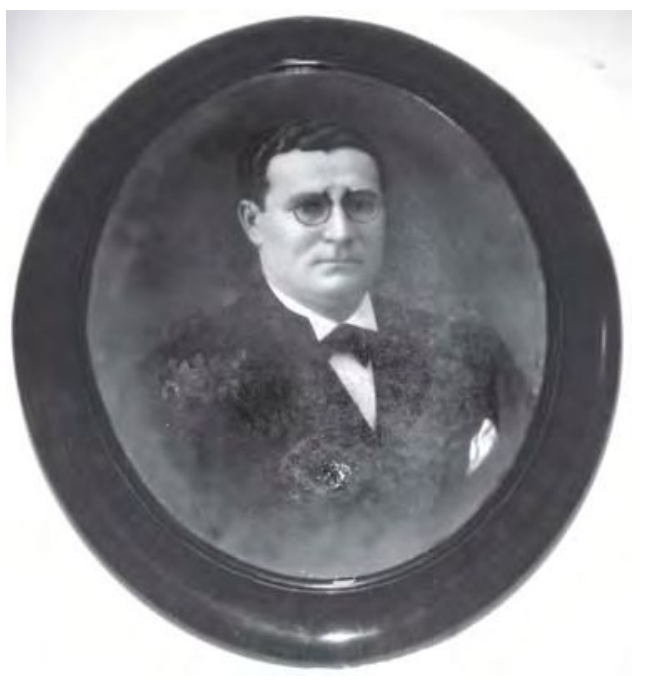

Marcos Wortman

Ahora que asumo este puesto de honor, trabajo y responsabilidad, digo: a mis amigos, ayúdenme a trabajar y a los contrarios, déjenme trabajar y controlen mi trabajo. ${ }^{103}$

La mayor vehemencia de Wortman tampoco trajo mejoras sustanciales. Se seguía discutiendo el problema de los colonos que estaban atrasados en sus pagos, que no recibían sus títulos hipotecarios y que sufrían los recargos de un interés mayor. La institución colonizadora insistía en una estrategia de estudiar caso por caso, se reservaba el derecho de otorgar algunas facilidades para aquellos colonos que demostraban que vivían en sus chacras y especulaba y justificaba las pocas concesiones otorgadas, en que los estallidos de oposición

no tenían la paciencia, la tenacidad y la extraordinaria tolerancia de quienes recomendaban una política más mesurada, y el exigirse antes que nada a sí mismo el mayor esfuerzo, comprensión y buena voluntad. ${ }^{104}$

La Administración de la JCA decía muy poco sobre un dato abrumador que presentaba Isaac Kaplan, extraído de un estudio realizado por la Fraternidad Agraria, donde se demostraba que entre 1921 y 1927, un promedio de cuarenta colonos abandonaron sus campos por el apremio con que la JCA exigía los pagos. ${ }^{105}$

${ }^{103}$ Acta $N^{\circ}$ 406, 28 de octubre de 1924, p. 72.

10450 años..., op. cit., p. 205.

105 Ídem, p. 206. 
Tan sólo se comprometía a estudiar caso por caso. El doctor Weill, director de la JCA en Buenos Aires, les retransmitía lo que la Casa Central de París respondía ante las demandas de la Fraternidad Agraria:

Referente a los colonos atrasados -objeto de la segunda carta- nuestra Administración Central, tomando en consideración los argumentos que exponen, no juzga sin embargo que haya lugar de adoptar al respecto medidas de carácter general, pero está dispuesto a examinar siempre en la mayor benevolencia todos los casos señalados y excepcionales que se presentarán. ${ }^{106}$

Se realizaban reuniones a partir de misiones de colonos que se trasladaban a la sede de la JCA en Buenos Aires y, a la inversa, de los directores que se dirigían a las colonias, sin que se hallasen soluciones sustanciales, y el temario de problemas era siempre el mismo. Visitas que eran recibidas en la sede capitalina siempre y cuando Wortman no formase parte de la delegación.

\section{Tramitar en la justicia}

La S.A. "Jewish Colonization Associatión" sigue universalmente en todos sus asuntos con los colonos, el sistema de obstruccionismo basado en la minucias de la ley, evitando en todo lo posible las discusiones del asunto. ${ }^{107}$

Ahora bien, ¿qué ocurría si el colono intentaba recurrir a la justicia para dirimir los reclamos? En líneas generales, los dirigentes del FC habían sostenido que recurrir al Poder Judicial no era el camino pertinente. De hecho, habían diseñado la estrategia de mediación para saldar las controversias y tan sólo en los

\footnotetext{
106 Nota de Weil al presidente de la Federación Agraria Israelita Argentina del 7 de diciembre de 1926. En Caja Villa Domínguez, Entre Ríos, Archivo IWO.

${ }^{107}$ Alberto Cippolla, procurador en el Caso Kasakevich Bernardo contra la Jewis Colonization Asocciation. Legajo 13/54, 1924. En Archivo y Museo de Villa Domínguez.
} 
casos extremos se podría contemplar recurrir a las demandas judiciales, las que, consideraban, no sólo acarreaban pérdida de tiempo, sino también de los escasos recursos económicos que poseían sus asociados. No dudaban en señalar que fueron ellos los que intentaron frenar las demandas hacia la JCA. Sin embargo, las presentaciones a la justicia fueron variadas e importantes. Elegimos en esta ocasión tan sólo dos casos, cuyos expedientes judiciales son lo suficientemente representativos de este campo de acción en las diferentes colonias asentadas en nuestro país, ya que concentran una serie de cuestiones que echan luz sobre las condiciones de la colonización agraria patrocinada por la JCA, las exigencias de los administradores y las posiciones de fuerza de los actores involucrados al recurrir a la justicia. Los colonos que reclamaban en la justicia, difícilmente podrían llegar a obtener un veredicto favorable a sus reclamos, tampoco tenían los recursos económicos para sostenerse en la colonia mientras esperaba que trascurrieran los derroteros que requerían las tramitaciones en los diferentes juzgados. Veamos.

El 10 de febrero de 1921, Julio Halperín (que firma Julio Alperín) entregó a los señores B. Neminovsky y J. Greitz, administradores de la Colonia Clara N ${ }^{\circ} 2$ sita en el territorio nacional de La Pampa, la suma de $\$ 2.000$ con el objeto de suspender los trámites de desalojo de su chacra.

Esta chacra estaba siendo arrendada por la doña Nechame, viuda de Halperín, quien había fallecido. Y por haber vencido el término del contrato de arrendamiento, su hijo Julio llegó a un acuerdo con la JCA por el que esta se comprometía, al recibir el mencionado pago, a suspender el juicio de desalojo y otorgar el respectivo contrato de Promesa de Venta. Julio Halperín, de acuerdo con esta transacción y normalizada la situación, siguió trabajando la chacra hasta el 19 de enero de 1923. A partir de esta fecha, transfiere la mencionada chacra de 150 hectáreas al señor Bernardo Kasakevich, quien comienza a trabajarla con el acuerdo de los administradores locales. Para hacer efectiva la transacción, Julio Halperín le endosa el recibo por los $\$ 2.000$, es decir, el comprobante de pago y el compromiso de otorgamiento de un contrato de Promesa de Venta, por el cual el señor Kasakevich le reintegra los $\$ 2.000$ en efectivo y todo parece funcionar normalmente. Hasta que el 25 de diciembre de 1923 le llegó la orden de desalojo. 
Como nunca se había formalizado el contrato de Promesa de Venta, más allá de las reiteradas solicitudes realizadas y producido el desalojo, el señor Kasakevich inició una demanda judicial a la JCA el 24 de mayo de 1924. El proceso judicial comenzó a recorrer un intrincado derrotero: por incompetencia de jurisdicción se le dio traslado al Juez en lo Civil y Comercial Dr. Mariano de Vedia y Mitre el 13 de agosto de 1924; luego a la Exma. Cámara, la que declaró la incompetencia de la jurisdicción comercial -cuando se trata de pleitos sobre inmuebles-; se recurrió a la jurisdicción civil; se solicitó la estipulación de la suma arraigo por las costas del juicio; establecida la misma por el Juzgado Civil en $\$ 800$, la parte demandante presentó la fianza personal del letrado Isaac Nissensohn. En una actuación siguiente, esta cifra fue apelada por la JCA, solicitando un monto mayor.

Las dilaciones son observadas por el letrado Alberto Cipolla, en representación de Kasakevich, el 9 junio de 1925, donde señala a la Cámara que la parte demandada ya ha recibido los $\$ 2.000$ y que en un caso extremo dicha suma podría responder holgadamente a las costas y gastos del juicio, y que la empresa colonizadora

Agarrándose -permítaseme la expresión- en todos los detalles de la ley, evitado en todo lo posible las discusiones de fondo [...] Si habría de seguirse a la demandada en su forzosa escrupulosidad, se necesitaría una fortuna para arraigar el más insignificante de los juicios que un colono tuviera con ella. ${ }^{108}$

Transcurridos largos tres años, los trámites judiciales seguían aún su curso. ${ }^{109}$ En 1927, Kasakevich tuvo que dejar el territorio de La Pampa y se trasladó a Buenos Aires, fijando domicilio en Capital Federal. Ya nada podía hacer en la colonia.

\footnotetext{
108 Ídem.

109 El doctor Cipolla solicitaba en memorial a la Excelentísima Cámara que "En situación de que se informa en el escrito de fs. 37 , es decir el domicilio de mi mandante en esta capital y corrido traslado a la parte demandada que no evacua -ver fe. 38-39- reconociendo tácitamente la verdad de los hechos expuestos en el mencionado escrito, el señor juez a que dicta la resolución apelada que, a todas luces, es absolutamente precedente, por estar en concordancia con sus antecedentes inmediatos y con la jurisprudencia uniforme y reiterada al respecto [...] Si el demandante traslada su domicilio a la jurisdicción del Juzgado, queda sin efecto el arraigo ordenado". Memorial del 23 de julio de 1927.
} 
Mejor suerte tuvo el colono Abraham Nemirovsky, quien, patrocinado por el Estudio del doctor Isaac Nissensohn, inició una demanda judicial en 1923 a la JCA para obtener la escritura con la traslación de dominio de la chacra $N^{\circ} 209$, de una superficie de 69 hectáreas, ubicada en el grupo Palacios de la colonia Moisés Ville, departamento de San Cristóbal, provincia de Santa Fe. El litigio tuvo fin en 1926, cuando el abogado Rolón, patrocinante de la JCA, solicitó un acuerdo de partes. Contamos para nuestro estudio con el expediente judicial, ${ }^{110}$ frondoso documento de aproximadamente 300 páginas, pieza clave para observar este caso, pero, como señalábamos anteriormente, también representativo de muchas otras actuaciones en el campo judicial.

Los hechos fueron los siguientes. Abraham Nemirovsky obtuvo su contrato de Promesa de Venta de la chacra el 28 de mayo de 1918, asumiendo el compromiso de abonar \$3.959,60, de los cuales entregó al contado $\$ 514,86$, debiendo abonar el resto en anualidades de $\$ 283,15$ cada una, en las cuales se hallaban incluidos los intereses del capital al 4\% anual, conforme el artículo tercero del mencionado contrato. Un dato significativo para este caso es que el pago de la anualidad se debía realizar el $1^{\circ}$ de abril cada año.

En 1923, previendo que el $1^{\circ}$ de abril era domingo, se adelantó el mencionado colono a depositar el dinero en la escribanía del doctor Isidoro Brener, con domicilio en Moisés Ville, ya que tenía conocimientos sobre el requerimiento de estricta puntualidad en el pago exigido por los administradores locales, y el atraso podría dar cabida a la rescisión de contrato de Promesa de Venta.

Neminosky tenía planeado ceder su tierra a un particular (al señor Santos Bonzi), acto terminantemente prohibido por el contrato firmado. Efectivamente, este vecino le había adelantado el dinero para cumplir con la totalidad de la deuda, situación que ponía en escena un procedimiento no contemplado en el compromiso original: la posibilidad de abonar la totalidad de cuotas adeudadas $y$, por lo tanto, obtener el derecho de solicitar la escritura definitiva de dominio del inmueble.

\footnotetext{
110 Legajo 43/37. Cuerpo 4. Años 1922. Estudio del Dr. Isaac Nissensohn. Nemirovsky Abraham contra Jewish Colonitazion Assoc. Juzgado Dr. Figueroa.
} 
Los administradores de la JCA fundamentaron la falta de pago, ya que consideraron que el depósito efectuado lo había hecho un tercero y que el mismo debía concretarse personalmente por el responsable del compromiso de pago. Alegaron el incumplimiento de la obligación de pago y establecieron el protesto del contrato. Esto obligó al colono a entablarle un juicio para que se aceptara el dinero, cosa que los administradores hicieron posteriormente. Este último acto daba claras señales de que había inicialmente una intencionalidad de buscar algún pretexto para anular los contratos.

La pertinencia de presentar en nuestro trabajo esta pieza jurídica radica en que nos brinda elementos estratégicos para observar las condiciones exigidas para la colonización, como también pone de manifiesto los fundamentos que nutren y explican las perspectivas de análisis sobre los alcances de la experiencia colonizadora y las expectativas y demandas de los colonos.

El abogado patrocinante del colono, doctor Alfredo Silberstein, los planteó al explicar que el contrato firmado -compuesto por doce artículos y uno adicionaltendía exclusivamente a garantizar el pago de la deuda. Todo lo que el colono tenía, el mismo inmueble, las construcciones que en él se hicieran, los útiles de labranza, las máquinas agrícolas, animales, objetos muebles, cosechas etcétera, todo lo que pudiese significar una muestra de la actividad del colono, quedaba sujeto a la deuda que tenía con la empresa en calidad de garantía de la misma, lo que

crea así una situación incómoda, violenta, de verdadero terror, pues las tales garantías, que excesivamente se toma la demandada, hacen hasta casi imposible respirar libremente, bajo pena de violar el ya mencionado contrato.

Continúa en su presentación explicando que:

ante tamaña espada de Damocles - la rescisión del contrato ante el menor pretexto- nazca en el colono el deseo de emanciparse de la tutela ejerce la "Jewish Colonization Association" -y según la demandada ejerce benéficamente- librándose del oneroso contrato que lo ata. 
Dado que el colono había ofrecido el pago total de la deuda más los intereses estipulados y que no podía llevar a término definitivo la cesión de derechos y acciones con la consiguiente escrituración porque, prima facie, se lo impedía el contrato de promesa de venta, sostuvo la demanda que, de acuerdo con la legislación argentina establecida en el Código Civil: "Mi mandante tiene el legítimo interés en liberarse de la obligación y puede hacerlo en pleno derecho". ${ }^{111}$

El punto de vista de los abogados de la JCA para el rechazo a esta argumentación se basaba dos líneas argumentativas. ${ }^{112}$ Por un lado, en la jurisprudencia ya establecida que demostraba la improcedencia de la demanda (probada en los casos de Lieb Sigal y Meyer Kweitel) y que a pesar de ello los colonos eran incentivados por "intermediarios" ${ }^{113}$ que les aseguraban la modificación de los fallos contrarios a las pretensiones invocadas. Por otro, en que las cláusulas del contrato estaban fijadas de antemano y que los colonos firmaron libremente y voluntariamente, por lo cual toda argumentación sobre lo forzoso de las cláusulas o las restricciones que imponía el contrato debieron ser tenidas en cuenta antes de firmar y consentir el mismo.

Ahora bien, aquellos dos casos citados, que sentaron los precedentes aludidos, se fundaban en el dictamen del doctor Ernesto Quesada -fiscal de la $2^{\circ}$ Excma. Cámara de Apelaciones-, en el que se sostenía que la JCA era una empresa de colonización con carácter religioso y social, que

buscaba mantener en centros homogéneos una población rural homogénea, y que tal población fuera resueltamente moral, por lo cual le imponía restricciones en la manera de cultivar la tierra y del tiempo durante el cual debía hacerlo: no quería vender lisa y llanamente, ni permitir la especulación con los lotes, sino formar un núcleo de población rural de gente de la misma raza y religión.

\footnotetext{
111 Presentación realizada al Juez en lo Civil por Alfredo Silberstein, procurador matriculado bajo el $\mathrm{N}^{\circ}$ 642, con fecha 4 de septiembre de 1924.

112 Descarga y contrademanda con fecha 6 de octubre de 1925, Leg. 4365.

113 Permítanme introducir una nota de color. El doctor Silberstein responde a esta alusión de la siguiente manera: «Señor Juez: No me hago cargo de la alusión de 'intermediarios', que, por otra parte, e indudablemente, nos comprende a todos, puesto que el escrito que contesto no trae al firma del Barón de Hirsch, ni la de los directores de la empresa, en su carácter de sucesora o continuadora de aquel». Ídem.
} 
Por lo tanto, "Solo en esas condiciones consentía en admitir colonos y cada uno de estos al firmar el contrato, sabía que tales eran las condiciones a que quedaba sometido".

El colono, al firmar el contrato, contraía el compromiso de que su parcela debía dedicarla a la agricultura y ganadería, que sólo podría ser trabajada por él y con la ayuda de su familia y que jamás podría ser explotada por terceros, salvo autorización por escrito de la Asociación, ni establecer o dejar instalar en ella comercio, industria o establecimiento alguno, pues este acuerdo no era simplemente de compra-venta, sino en contrato de colonización con un plan determinado (contemplado por el Código Civil). ${ }^{114}$ Para mantener y asegurar la homogeneidad, la Asociación obligaba al colono a no ceder ni empeñar a terceros su contrato, o arrendar o dejar instalarse, sin el consentimiento previo y por escrito de ella, trato que voluntariamente aceptaba el interesado al formalizar el convenio.

Debía también tenerse en cuenta, sostenía el doctor Avelino Rolón, que los colonos habían recibido adelantos, ayudas y condonaciones tanto en gastos de viaje como para su instalación, "que obedecen a los propósitos de beneficencia del barón de Hirsch para sus correligionarios". Señalaba que la obra del barón tenía por objeto premiar

la realización del plan de transformación del israelita indigente en colono próspero, arraigado a la tierra que cultiva, apartado del ejercicio del comercio o industria, desenvolviéndose entre correligionarios y bajo la égida de la Asociación de correligionarios; querría ahora, recibida la liberalidad desligarse de sus compromisos, a trueque de introducir en la colonización que se realiza elementos extraños que la desnaturalicen, y no obstante que al acogerse a la Asociación, había libremente consentido en aquellos compromisos que venía a ser un freno al deseo de faltar a sus obligaciones, porque traen apoyada a la rescisión del contrato y la pérdida de todo lo pagado.

\footnotetext{
${ }^{114}$ Artículo 1.168 del Código Civil: toda especie de prestación puede ser objeto de contrato, sea que consista en la obligación de hacer, sea en la obligación de dar alguna cosa, que se trate de alguna cosa presente o futura de la propiedad, uso o posesión de la cosa.
} 
Los abogados de la JCA sostenían que, como Abraham Nemirovsky había violado este compromiso, la empresa decidía entablar una contrademanda basada en el incumplimiento de pago así como en el intento de cesión de la chacra, lo que suponía ipso facto la rescisión del contrato y la desocupación del terreno sin que esté obligada la empresa a indemnización alguna, según lo establecía la cláusula $4^{\mathrm{a}}, 5^{\mathrm{a}}$ y $11^{\mathrm{a}}$ de dicho contrato, más las costas del juicio.

Presentada la contrademanda, continuó un largo recorrido por las diferentes instancias judiciales y jurisdiccionales, las cuales nos permiten observar cómo el estudio de doctor Nissensohn puso en funcionamiento un equipo de profesionales y unas estrategias de relevamiento de pruebas destinados a poner en escena las múltiples demandas y denuncias contra los administradores locales de la JCA, con lo que intentarían demostrar, a través de informes de testigos claves, cómo habían sido las actuaciones que daban cuenta de varias irregularidades. ${ }^{115}$ Entre ellas, el trato discrecional y diferenciado que agudizaba la vulnerabilidad de las viudas e hijos menores para seguir al frente de la tierra, que los obligaba a abandonar el campo a través de juicios de desalojo. También demostrar la cantidad de juicios tramitados y en trámite contra los colonos sobre rescisión de contratos; explicar cómo se habían tramitado juicios sucesorios y si se había dictado declaratoria de herederos y si de estas se concretaron señalar a favor de quienes se establecieron o si se habían declarado vacantes (situación que permitía otorgar nuevos contratos más favorables a la empresa). Preguntar si la JCA arrendaba tierras a personas

\footnotetext{
${ }^{115}$ Se solicita se cite a siete testigos de de Moisés Ville; a Santos Bonzi domiciliado en Palacios; se pide informe al Juez de Paz de la ciudad de Bahía Blanca, Dr. Martín Esandi para que informe sobre los juicios seguidos allí sobre rescisión de contrato de David Michelson; Samuel Burcat, Bernardo Becker; Salomón Slatapolsky, León Leibman; Meyer Mellicovsky, Froim Tolchinsky; Suseción de Felipe Borodovsky; sucesión de Israel jabut; sucesión de Moisés Ritoff; sucesión de Isaac Ratuschni; suceción de Moiche Chain Halperin o Heperín, Israel Pecaroff o sucesión; sucesión de Abraham Mirensky Barochow o Barujow, Abraham Belaposlsky, David Goisen, Adolfor Strocovsky y jaime Nosovisky. Se solicita al Juez de Paz de Santa Rosa, La Pampa, Dr. Floreal Pérez informe sobre los juicios tramitados o en trámite seguidos a los colonos: Bernardo Kankevich; Salomón Medcedioff; Arón Golbom; Tobías Jersonsky; Marcos Cabacov, Isaac Nudelman; Marcos Mellicovsky; Salomón Bransburg; León Leibman; Boris Mill; meyer Seggloff; José Margulis; Bernardo Schnaider; Osías Kasitsky; Manuel Lemcof; José Kastizky; José Slatapolsky; Spollansky Moisés o sucesión de Israel Jabut; Manuel Jackin; Jaime Guilinetz; Lázaron Chervinsky; Pedro Sitnitzky; León Kasañevich; Srul o Israel Pechersky; Moisés Schwartzman; Felipe o Lipe Kavuschansky o sucesión de; al Sr. Juez de Santa Rosa (Pampa central) Dr. Erneste Sourrille a fin de que se sirva informar se en su secretaria se tramitan los siguiente juicios sobre rescisión de contrato y cobro de pesos a otros diecinueve colonos. Ídem.
} 
no judías, que no necesitaban protección alguna, indicando las extensiones y ubicación de las mismas, y si algunos de ellos podían señalar si no se cobraba a los colonos pobres las primeras anualidades, dándoles contratos de arrendamientos, y, por último, si hubo transferencias de chacras de unos a otros colonos y cuántas de esas se conocían.

Demasiados tópicos que ponían de relieve los tratos diferenciales e irregularidades que los elencos administrativos preferían silenciar: la proliferación de juicios eran la antesala de las continuas expulsiones. Se arrendaban tierras a no judíos y las transferencias de tierras eran un mecanismo usual. Por lo tanto, la mejor salida para la JCA era llegar a un acuerdo con este colono que tuvo la capacidad de responder al juicio porque contó con la solvencia e idoneidad de un estudio jurídico dispuesto a la defensa de los más débiles en la contienda.

\section{Colonización y tierra para los hijos}

El problema de la colonización de los hijos y la creación y sostenimiento del Fondo de Colonización ocupó un renglón principal entre las preocupaciones del FC, tarea que tenía la responsabilidad de tramitar la Fraternidad Agraria. Se estableció que el FC cobrara las contribuciones que realizaran los socios.

Un momento de alegría se vivió cuando se tomó conocimiento de que la Fraternidad Agraria había comprado 4.700 hectáreas aptas para la agricultura en la estación de Alcaraz, contando con el auxilio de la JCA con un préstamo que cubría el 90\% del valor de la tierra, y se estudiaba arrendar campos cerca de Domínguez para aplicarlos a la colonización. ${ }^{116}$ Ello tuvo corta duración, ya que prontamente la JCA comunicó que quien decidiría en la elección de los candidatos a colonizarse era la propia empresa y de acuerdo con sus criterios habituales, lo que volvía la situación a punto cero, pues justamente las formas de colonización y los requisitos

\footnotetext{
${ }^{116}$ La compra se realizaba con el aporte del 10\% del capital y quedando a cargo de la Fraternidad Agraria la organización de la colonización. El precio de la tierra era de \$105 la hectárea. Sajaroff, jubiloso, solicitaba seguir trabajando en forma conjunta, adquiriendo juntos el material de consumo y sobre todo los implementos agrícolas. Acta № 522, 23 de diciembre de 1929, p. 245.
} 
establecidos por la JCA eran los que habían llevado a los enfrentamientos. Se sumaba a ello la noticia que había llegado a la Comisión Directiva que el vicepresidente de la Fraternidad Agraria, el Sr. Banchik, había adquirido campos en la misma operación para usufructo personal. No obstante Sajaroff informó a los socios que Banchik había desistido de dicha operación, se redactó una resolución condenatoria. ${ }^{117}$

Ahora bien, ¿qué se estaba discutiendo? Con fines analíticos podríamos diferenciarlo en dos o tres planos: por un lado, las condiciones de la colonización, la rentabilidad de la experiencia, las posibilidades de pagos que los contratos establecían, el acceso a la propiedad de la tierra y las consecuencias económico sociales que ello traía aparejado; por otro lado, los juegos de poder entre la empresa colonizadora y los intentos de autonomía por parte de los colonos organizados en instituciones de ayuda mutua y de resistencia; con el trasfondo de la compleja figura de la JCA, institución filantrópica que era además una empresa que perseguía rentabilidad económica y que, amparada en esta dualidad, especulaba entre la imposición de condiciones rígidas y el otorgamiento de ciertos beneficios que se confundían o se fundían en principios provenientes de un plano moral o trascendente que descolocaba a los colonos y a sus dirigentes.

Los inconvenientes provenían, en primer lugar, de las modificaciones a los contratos de Promesa de Venta que imponía la empresa con las nuevas cláusulas que recortaban ciertos beneficios otorgados en los primeros convenios. ${ }^{118}$ En segundo lugar, el no cumplimiento o los atrasos en los pagos de las anualidades creaban

\footnotetext{
117 «Habiendo llegado a conocimiento de la C.D. que en el campo que compró la F.A. participaban también intereses personales de algunos que intervinieron en la compra, hace pública su protesta por tal actitud y recomienda para el futuro tener especial cuidado en deslindar en absoluto los intereses de las personalidades de los dirigentes." Acta № 524, 15 de enero de 1930, p. 259 (se trataba de una potencial adquisición de 700 hectáreas por el señor Banchik, integrante de la Comité Ejecutivo de la Fraternidad Agraria).

${ }^{118}$ Siguiendo a Wortman, es el fin de la época de los "halagos y subsidios" que se desplegó cuando los abandonos de los campos los llevaban a la ciudad, cuyo fenómeno alarmó a los dirigentes de la JCA, quienes se apresuraron a enviar emisarios encargados de hablar con los colonos y convencerlos de la grave responsabilidad que pesaba sobre ellos. Cuando se quejaban de su afligente situación material que les imposibilitaría cumplir con sus obligaciones con la empresa, esta, a través de sus representantes más autorizados, les prometía el oro y el moro con tal de que permanecieran en el campo, trabajándolo. Pero esta época de comprensión y ayuda (porque la JCA, para crear la psicología que convenía a sus planes ulteriores, subsidió a "sus colonos") duró poco. Marcos Wortman, "La colonización israelita en la Argentina", op. cit.
} 
condiciones diferenciales que exponían a los colonos morosos a los desalojos de sus chacras, situación que generaba, a su vez, una segmentación social y económica entre aquellos chacareros que lograban que los rindes de su explotación agraria les permitieran ponerse al día con las deudas y por ende emanciparse y el grupo de colonos cuyos ingresos no les alcanzaban para pagar las anualidades, que refinanciaban sus deudas con intereses diferenciales que sólo los conducían a aumentar la deuda y a enfrentarse con el desalojo. Fenómeno que se encadenaba o despertaba condenas morales sobre lo que significaba un colono "honrado y trabajador" y aquellos a quienes se los consideraba posibles especuladores que, debido al aumento del valor de la tierra, no dudaban en desprenderse de ella a través de ventas prohibidas o de la sublocación, con el agravante de traicionar, además, el mandato del Gran Benefactor.

Las cartas estaban echadas. Se estaba asistiendo, por un lado, a un proceso que cristalizaba un enfrentamiento de clase, que provenía de diferentes niveles de acumulación y de divergencia de intereses entre colonos empobrecidos -que en el mejor de los casos devenían en arrendatarios- y colonos capitalistas o farmers, según la categoría propuesta por Waldo Ansaldi. ${ }^{119}$ Se establecía así un puja entre estos colonos, los más débiles, que eran asistidos por la acción política de los sectores de izquierda, y aquellos que habían logrado cubrir sus deudas y que tenían una situación holgada, que se avenían a aceptar y justificaban que la Administración de la empresa colonizadora pudiera expulsar a los "elementos improductivos", "sin acreditada capacidad" para afianzar la colonización, limites imprecisos y de dudosa transparencia que sólo reconocían un clivaje de clase, que se trataba de ocultar detrás de un discurso moralizante.

Más aun, los colonos que podían beneficiarse de esa válvula de escape denominada "transferencias" eran aquellos que cumplían las condiciones legales para conseguirlas y además contaban con el visto bueno de la JCA: es decir, el grupo meritocrático (los colonos "honestos" y «laboriosos») que no mantenía ninguna deuda con la JCA, que por regla general ya había logrado sus títulos de propiedad o se

\footnotetext{
${ }^{119}$ Ansaldi, Waldo, "La pampa es ancha y ajena. La lucha por las libertades capitalistas y la construcción de chacareros como clase». Disponible en http//www.catedras.fsoc.uba.edu.ar/udishal.
} 
hallaba muy cerca de hacerlo, era el que podría acceder a nuevas tierras para ampliar su propia parcela o bien podía entregársela en explotación a sus hijos o yernos. ${ }^{120}$ Un hijo de colono cuyo padre no hubiese cumplido con sus pagos era un candidato no elegible y, por lo tanto, no era acreedor de una "transferencia".

En este contexto trabajaba el FC, como un mediador que, a través de la acción gremial, lograba interceder para flexibilizar algunas exigencias ante los desalojos. Constituían comisiones especiales encargadas de analizar los casos de colonos que estaban atrasados en sus pagos, logrando ciertas concesiones -o conquistas, en sus propias palabras- para que el hijo o el yerno de aquellos pudiera asociarse en la transferencia, siempre y cuando asumiera el compromiso de abonar la deuda pendiente.

\section{Las reformas estatutarias}

En el plano interno, el FC se abocaba a dar dos pasos importantes vinculados a las formas de la acción cooperativa, producto de la maduración y ampliación de los ámbitos de operación de la institución. Por un lado, se modificó el Reglamento de Funcionamiento, ${ }^{121}$ ampliando la base asociativa con la incorporación de nuevos socios y la transformación más efectiva del capital social, por otro, se modificó el Reglamento de Arbitrajes.

\footnotetext{
${ }^{120}$ El presidente de la Comisión Directiva del FC informa de una actitud impropia de los socios Adolfo Ayental, Jacobo Efron y Marcos Pustilnik para con la cooperativa. "Se trata de lo siguiente: hace un par de meses que sobre el campo de Ayental pesaba un desalojo, habiéndolo tramitado la J.C.A por estar atrasado en sus pagos. El Fondo Comunal activó con constancia para que no se desalojara de la chacra y consiguió que la Dirección General permitiere transferirla habiéndose designado también dos buenos candidatos para adquirirla y cuando el asunto ya estaba resuelto con la intervención del F.C el propio interesado logró enajenar la chacra mediante la transferencia de derechos y acciones al Sr. Jacobo Efron, en cuya operación, según informes que se tienen participó el Sr. Marcos Pustilnik." Informaba el presidente Flesler que la actitud de los socios sentaban un mal precedente. Además, que estos socios habían sido advertidos sobre la incorrección de la acción, sin embargo hicieron oídos sordos, pues prevalecía su interés personal en la adquisición de nuevas tierras. El señor Pustilnik venía desempañándose como concejal desde 1918, fue secretario en 1922-1924 y presidente del FC entre 1927 y 1928 . En Acta No 527, 24 de abril de 1930, p. 279.

${ }^{121}$ Se nombra una comisión encargada de presentar el proyecto de reforma compuesta por Miguel Kipen, Marcos Wortman, Isaac Kaplan, Moisés Gleser y Leon Sidi. Acta Nº 458, 21 de marzo de 1927, p. 218.
} 


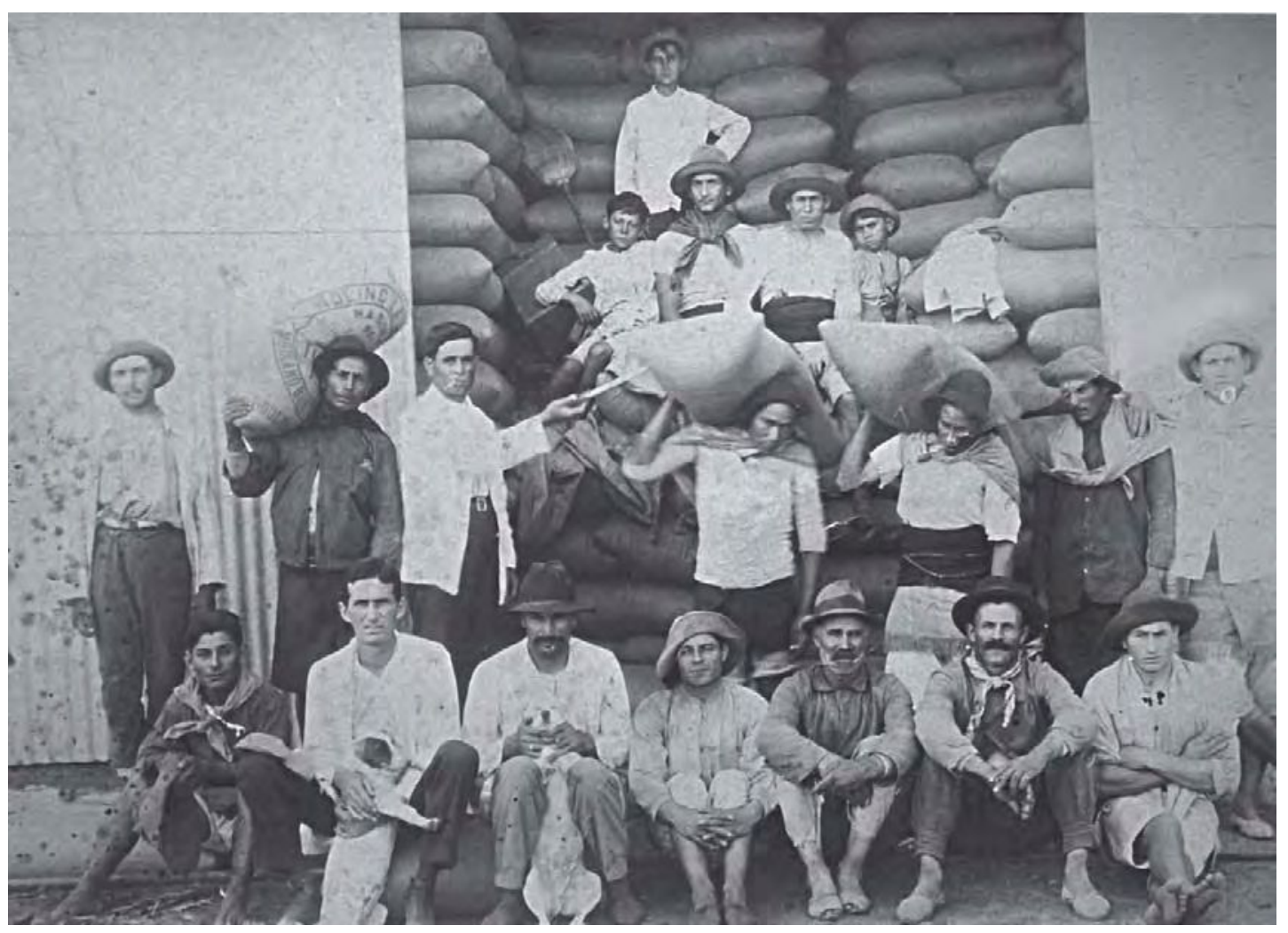

Galpón del Fondo Comunal, Villa Clara. 
El nuevo reglamento para el funcionamiento estuvo compuesto por 11 capítulos y 63 artículos, los que fueron aprobados en asamblea general. Los objetivos, ahora ampliados, de la Sociedad Cooperativa Agrícola eran:

Art. 3: 1) Fomentar la agricultura, la ganadería y las industrias derivadas de todas sus manifestaciones, ilustrar a los colonos sobre los métodos culturales más adecuados, para la explotación de sus campos, mejorando así la situación económica del agricultor, para que por medio de la ayuda mutua pueda afrontar todas las tareas agrícolas y sus posibles contingencias.

2) Facilitar operaciones de crédito a sus socios.

3) Tratar de independizar al agricultor con la supresión de intermediarios en la compra de los artículos de consumo, cosecha, construcción, maquinaria agrícola y todos los accesorios para la agricultura y ganadería como también la venta de los productos agropecuarios y su industrialización.

4) Crear secciones de crédito, seguros, ahorros u otros que armonicen con los fines arriba expresados.

5) Buscar en beneficios de la Sociedad el apoyo de las Reparticiones del Estado, de Ferrocarriles, Bancos u otras instituciones que directa o indirectamente puedan propender a la más fácil y eficaz realización de los fines de la sociedad. ${ }^{122}$

Sin lugar a dudas, algunos tópicos fueron mucho más debatidos que otros. La ampliación de la base societaria, y por ende el capital social, fue uno de ellos, ya que estaba vinculado con la determinación de quiénes podrían ser los socios del FC y sobre la potencialidad de los recursos económicos que ellos proveerían a la institución. Finalmente, se suprimió la categoría de socio adherente ${ }^{123}$ y se aceptó la incorporación de los hijos y de las esposas de los colonos a partir de la suscripción de acciones con mayor facilidad de pagos para asegurar el ingreso.

\footnotetext{
${ }^{122}$ Acta No 466, 19 de junio de 1927, p. 255.

${ }^{123}$ El señor Manuel Seiguerman pide se manifieste con claridad que hay parte de los socios activos que no quieren a los jóvenes hijos de colonos. El señor Marcos Efron pide la palabra para decir que en su concepto debe subsistir la categoría de adherente para hijos de agricultores, pero se opone a conceder voz y voto a los adherentes no colonos por cuanto a ellos sólo les interesa el consumo y no deben participar en la Dirección de la Cooperativa. Acta № 464, 12 de junio de 1927, p. 245.
} 
También el mensaje educador de Sajaroff tuvo su peso al recordar a los concejales que

la entidad "socio" no es el padre o jefe de familia sino la familia misma, quien es el factor de producción y consumo por lo cual deben darse amplias facilidades para el ingreso como socio a las esposas e hijos de colonos mayores de 18 años [...] el aporte por acciones es insignificante en relación a las operaciones que efectúa la cooperativa de modo que el ingreso con mayor o menor cantidad de acciones no debe ser tomado como limitante [les explica que existen] cooperativas europeas que trabajan con capital social que no provienen de acciones y donde cada socio tiene únicamente la obligación de cumplir estrictamente los reglamentos y es responsable moral y materialmente por las operaciones de la sociedad. ${ }^{124}$

Finalmente prevaleció un criterio de uniformidad y se estableció que podían ser socios de la cooperativa:

a) Los agricultores del radio de acción de la cooperativa siempre que sean personas de buenos antecedentes, capaces de adquirir derechos y contraer obligaciones y que no tengan intereses contrarios; b) las esposas e hijos de colonos mayores de 18 años de edad que se dediquen a la agricultura y c) se admitirán también como socios "otras personas no colonos", en cuyo caso deberán ser aceptados por el Consejo Directivo con la mayoría de 3/4 parte de los miembros presentes. ${ }^{125}$

Las acciones se fijaron en un valor de $\$ 10 \mathrm{~m} / \mathrm{n}$ cada una. Al ingresar, el socio debía comprar diez acciones, pagando en el acto por lo menos $\$ 50$, y el resto durante el transcurso del año en ejercicio. Las esposas e hijos debían suscribir diez acciones abonando de inmediato dos y el resto en ocho años a valor de $\$ 10$ por año, o con el importe de sus dividendos si los tuvieran en igual plazo (art. 4 y 5).

${ }^{124}$ Acta No 466, 19 de junio de 1927, p. 253.

125 Ídem, p. 257. 
La ampliación de la base societaria permitió, además, la incorporación de las mujeres en las asambleas, cuyo ingreso fue festejado por el ingeniero Sajaroff: "deseo hacer votos que todos nuestros socios (mujeres) se incorporen activamente a nuestra vida societaria". La señora Seignerman denunciaba ante la asamblea general la despreocupación del presidente y del gerente del FC por la sección granja y les recordaba que era el único sustento del agricultor. ${ }^{126}$

El tópico que establecía las formas de convivencia era el sistema de arbitraje o de mediación ante las diferencias o conflictos de intereses entre los habitantes de Colonia Clara. Este sistema, que fue establecido en los primeros años de funcionamiento de la cooperativa y al que se recurrió en muchísimas ocasiones, como se puede observar en la lectura de las actas de esta institución, requirió de ajustes para el mejor cumplimiento. Con este objetivo se creó una Comisión Arbitral, integrada por tres concejales pertenecientes a la Comisión Directiva cuya tarea tendría una duración anual. Tendrían la tarea de interceder ante el pedido expreso de los socios, por la que deberían

firmar ambas partes una declaración que se someten voluntariamente y deliberadamente sus divergencias al arbitraje, comprometiéndose a aceptar con carácter inapelable, el fallo que resultare. (art. 2)

Si alguno de los socios involucrados no cumplía con las formas establecidas o con los fallos arribados, podían tomarse medidas disciplinarias, que iban desde no poder volver a solicitar ninguna otra mediación a otras más severas. Por cada arbitraje, el FC percibía la suma de 10 a 25 pesos de cada una de las partes, estando facultado a no cobrar nada en asuntos de menor cuantía o siendo pobres los litigantes. El dinero proveniente de los arbitrajes ingresaba al Fondo de Propaganda de la Institución. ${ }^{127}$

\footnotetext{
${ }^{126}$ Acta $N^{\circ} 678$, Asamblea General del 2 de noviembre de 1936, p. 147.

127 Acta No 440, 10 de mayo de 1926, p. 156.
} 


\section{El impacto de la crisis de 1930}

La crisis del 1930 afectó directamente al FC, como a los colonos todos, pero tuvo efectos más profundos en los sectores más vulnerables de la estructura social.

En particular la baja de los precios, cuando ya se había adelantado a los socios un $80 \%$ del valor de las entregas de cereales a base de precios anteriores, produjo deudas al FC, en su mayoría imposibles de pagar. Se avecinaba una época de aguda crisis y de grandes dificultades. Se aprueba entonces una moción del Consejo Directivo del FC que solicita:

1) El C.D. tomado en cuenta la crisis actual, vería con agrado que la JCA haga su cobranza con liberalidad,

2) EI C.D. resuelve gestionar créditos al Banco de la Nación a todos aquellos socios que los necesiten. ${ }^{128}$

Se recurrió a créditos, que fueron otorgados por el Banco de la Nación Argentina, cuyos fondos se distribuyeron prontamente entre los socios. Las deudas de la cooperativa fueron muy importantes, en particular porque los asociados estaban confiados en que sólo en una última instancia el FC emprendería acciones contra ellos, lo que la ubicaba en un complicado espacio para negociar con los acreedores. Las grandes empresas, tales como "Magione y Mosto", esperaban confiadamente, pues sabían que llegados mejores tiempos cobrarían todo. En cambio, las firmas comerciales más pequeñas se mostraban inflexibles y hubo que recurrir a grandes esfuerzos para pagarles.

El año agrícola 1932-1933 fue el de mayor impacto negativo para el FC, sólo comparable a la gran crisis de 1914. A la desvalorización de la producción agrícola se sumó que fue un año de grandes invasiones de langosta, más el fracaso total de la cosecha: el trigo se perdió por razones climáticas y el lino por la langosta.

La crisis se sobrellevó por la intervención del Estado nacional, que, a través del Banco Nación giraba créditos para cubrir la bancarrota. No obstante, el presupues-

${ }^{126}$ Acta N ${ }^{\circ} 678$, Asamblea General del 2 de noviembre de 1936, p. 147.

127 Acta $\mathrm{N}^{\circ} 440,10$ de mayo de 1926, p. 156. 

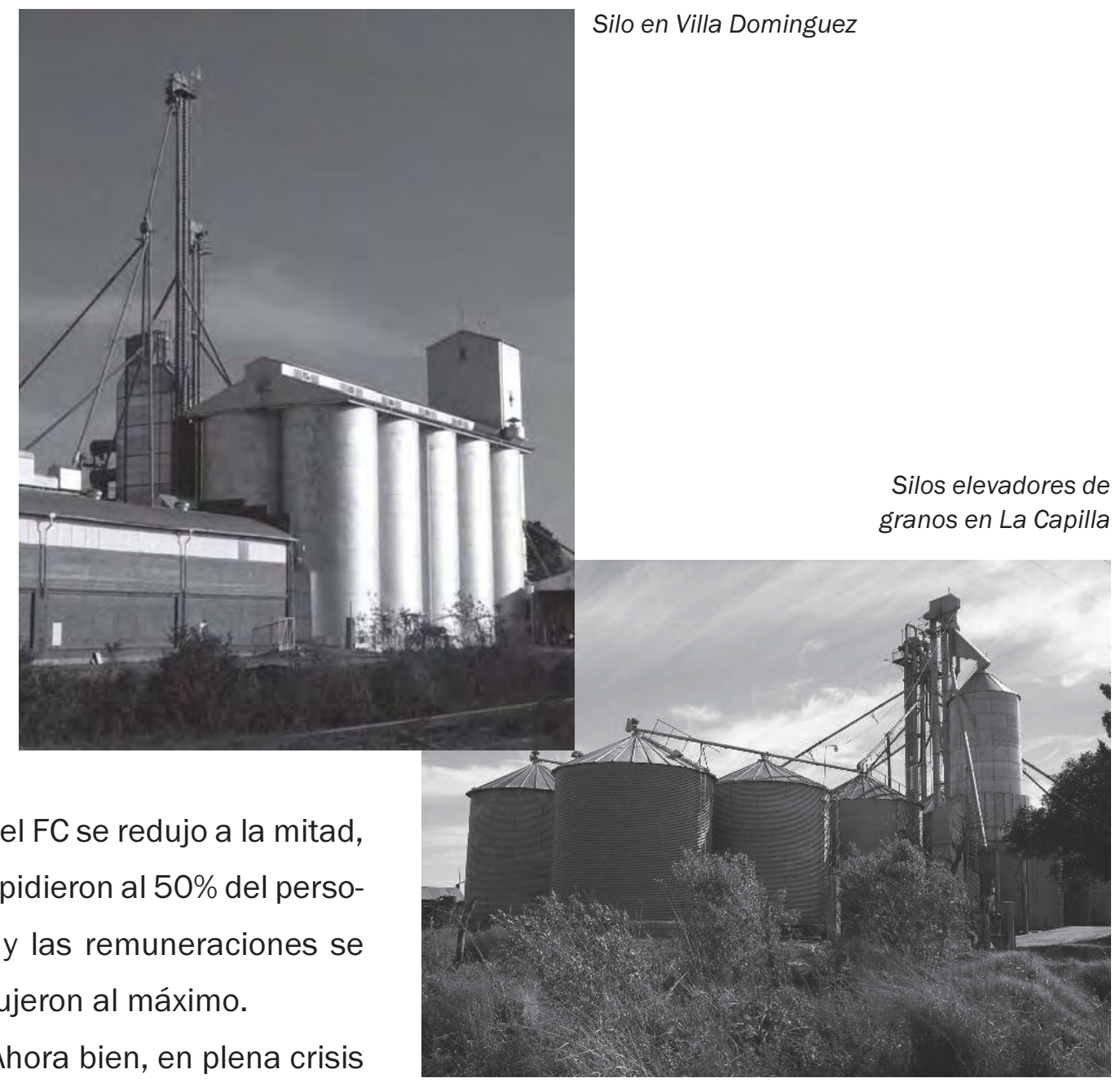

se introdujo una innovación

tecnológica que gravitó luego para el despegue: se reemplazó la vieja trilladora por la moderna cosechadora y se fundaron las primeras cremerías.

La construcción del elevador de granos, inaugurado el 22 de noviembre de 1931, brindaba no sólo la economía de envases, manipuleo y mejoramiento de los granos, sino un instrumento de defensa de la producción. ${ }^{129}$

La creación de las juntas reguladoras impactó en los precios, provocando un aumento del $20 \%$ para el trigo y una suba considerable en el precio de la leche, lo

\footnotetext{
129 Los trámites para su construcción estuvieron a cargo de Aarón Kaplan y Miguel Kipen, quienes solicitaron ayuda al gobierno provincial como garantes del oneroso emprendimiento. La ayuda no fue posible por las muertes del gobernador y el vicegobernador de la provincia, lo que truncó los trámites de garantía. Se asumió la construcción desde el FC, que, al cambiar la conducción del Consejo Directivo, resolvió -acuciado por las secuelas de la crisis- deshacerse de él, quedando como locatario del elevador "Aaron Kaplan". Este elevador, junto al de Villaguay, fueron expropiados por el Poder Ejecutivo nacional, pasando a la órbita de la Comisión Nacional de Granos y Elevadores.
} 
que otorgó cierto respiro a los productores que debían cumplir con las deudas contraídas por las semillas para los dos últimos años, cuando la cosecha había fracasado completamente.

Los años 1935-1937 no posibilitaron la recuperación necesaria, por las cosechas escasas y los problemas habituales. Entonces se recrearon estrategias de intervención a escala local: incentivar la entrega de la producción al FC, reservar parte de las semillas para la cosecha próxima y vender la producción a los molinos. Por otro lado, aconsejar y convencer a los socios sobre la necesidad de realizar una explotación racional y diversificada para poder cubrirse cuando un área de producción fracasaba.

\section{Cuarta etapa: resurgimiento, consolidación y crecimiento. 1938-1954}

\section{La actividad económica}

La memoria institucional del Fondo Comunal describe este período como los tiempos en que se produjeron finalmente los logros de principios, de ideales y actividades solidarias que fueron trazados desde los orígenes de la estrategia cooperativa. ${ }^{130}$

Una conjunción feliz entre expansión de actividades tradicionales y nuevas ramas de explotación; una mayor conciencia en la conducción de los intereses colectivos y solidaridad más efectiva entre dirigentes y dirigidos, asociadas a una buena situación económica general; todo esto les otorgaba un clima de satisfacción.

El administrador de la JCA en Colonia Clara explicaba que:

la mejora de la situación económica de la Colonia, cuyos síntomas aparecieron en el año 1938, después de 8 años de depresión, se ha acentuado a principios de 1939, después de la excepcional cosecha 1938/39 [...] los colonos no pudieron disimular su gran sensación de alivio, confianza y deseo de seguir adelante, para

130 Fondo Comunal. 50 años, op. cit., p. 137. 


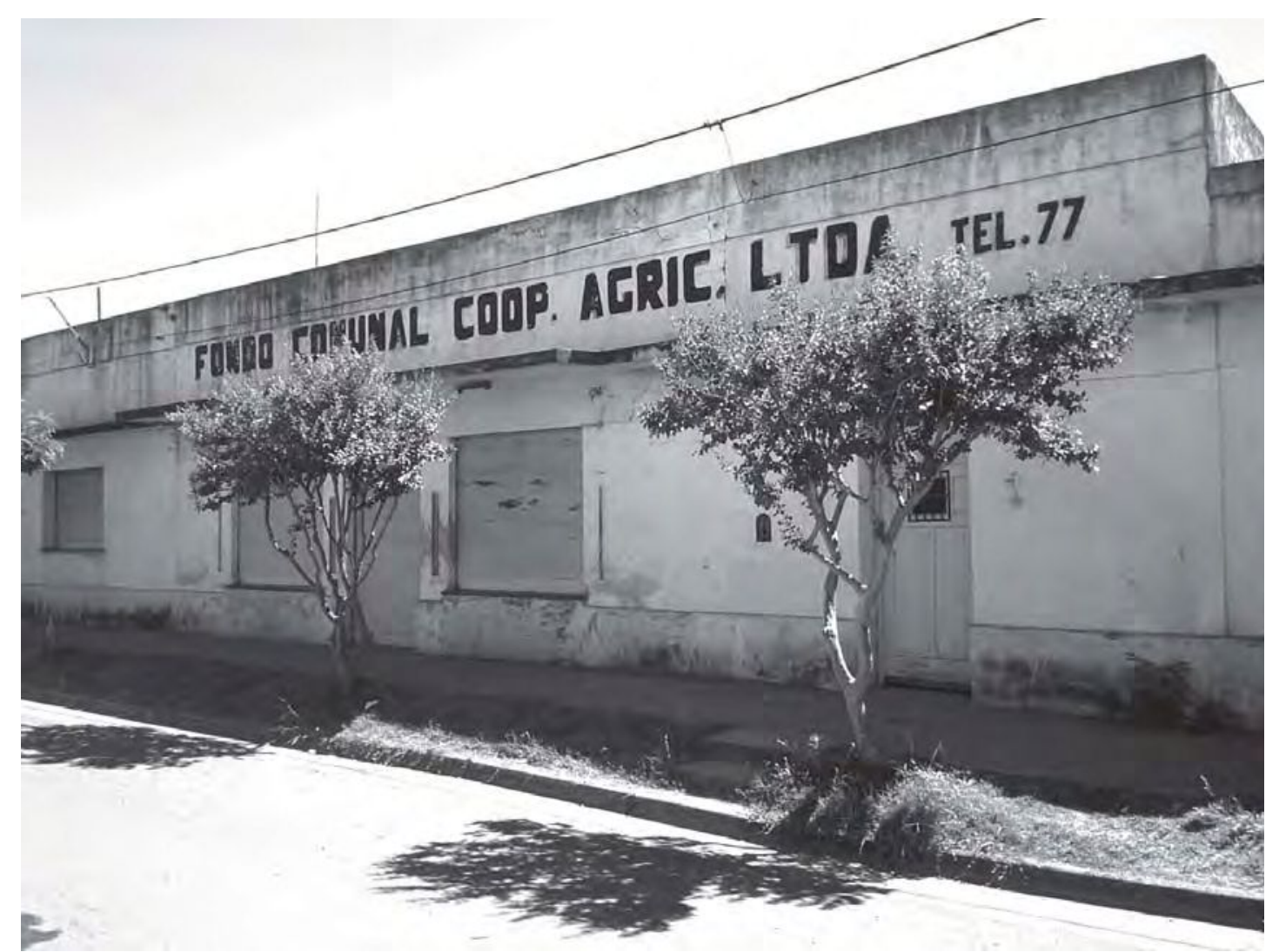

Sucursal del Fondo Comunal en Villa Clara 
llegar a los índices económicos de los años normalmente buenos [...] la mejora de las situación económica permitió a todos los colonos amortizar en forma apreciable sus deudas...131

Mayor distribución de artículos de consumo y buenas cosechas que aumentan sus beneficios, ayudados por el decreto del gobierno nacional que fija precios básicos, marcaban la buena época. Se trabajó fuertemente con los socios para que entregaran los cereales sanos, secos y limpios para evitar gastos y realizar mejor la clasificación y tipificación. Se indicó que sembraran trigo duro o semiduro, que eran los más apropiados para la conservación y comercialización, y se establecieron nuevos canales de comunicación y propaganda para fortalecer la producción lechera.

El espacio para el almacenamiento de las cosechas se comenzó a resolver con el alquiler de un nuevo depósito en Concepción del Uruguay.

Se realizaron importantes esfuerzos para la defensa de la producción de la sección granja. Se afianzaron los canales de venta mediante la concentración de la leche en Villa Clara para el envío a Concordia y en Villa Domínguez para el envío a Villaguay, destinada al consumo de la población. Aumentó el funcionamiento de las cremerías y la venta de producción avícola, que no sólo cubría el mercado local, sino que era trasladada a la Capital Federal para ser vendida por medio de la Fraternidad Agraria en su puesto en el Mercado de Concentración.

El C.D. en las sesiones del ciclo 1944-1945, comenzó a estudiar las formas de facilitar a los socios el pago de sus deudas, que se habían acumulado durante los años de crisis, aprobándose una resolución mediante la cual se concedía toda clase de facilidades y una reducción al $4 \%$ del interés anual. Por otro lado, se propuso ayudar a los colonos con mayores dificultades económicas, en particular para el grupo que no pudo obtener del Banco Nación créditos para semillas, instaurando un nuevo fondo para ayudar en primer término a 59 socios que lo solicitaron.

Con una economía saneada y con la expansión productiva, el FC pudo ampliar su infraestructura edilicia y de servicios. En el ejercicio 1946-1947 compraron el

131 Informe Anual de 1939, p. 7. 
terreno para la ampliación de la casa central, terminaron la instalación del gallinero modelo, adquirieron los terrenos donde estaban instaladas las cremerías de La Capilla y de Barón Guinzburg, terminaron las ampliaciones de la sucursal Leven, construyeron el galpón en La Capilla para almacenar mil toneladas de cereales y compraron el primer camión para el transporte de cereales y mercaderías, se creó la sección comercialización de haciendas, para la defensa de la producción ganadera de la colonia.

La cooperativa se propuso ser un instrumento de integración vertical del capital agrario, ocupando todos los pasos del proceso de producción, transporte y comercialización, recapturando plusvalía que antes escapaba hacia otros actores.

En 1953 ingresó al seno del FC un nuevo desafío. Adheridos al Plan de Industrialización Cooperativo impulsado por la provincia de Entre Ríos, y en particular contando con el auspicio de la Federación Entrerriana de Cooperativas, se decide encarar un plan de industrialización que se iniciaría con una fábrica de aceite y una mantequería, para asegurar, además, la subsistencia de la explotación tambera. La asamblea aprobó por unanimidad la suscripción de $\$ 250.000$ m/n de acciones en la FEDECO para el desarrollo del plan industrial. ${ }^{132}$

La diversificación de la producción, y en particular la producción de granja, les permitió a los socios obtener los recursos económicos para el acceso a una canasta de consumo ampliada y a un mejor nivel de vida.

Los colonos: la propiedad de la tierra, las transferencias y la recuperación de tierra para los judíos

Superados los años de crisis, y con la emergencia de las buenas oportunidades que la estructura productiva brindaba a los colonos, vuelve a la palestra el problema siempre latente: la necesidad de contar con nuevas tierras y con la ayuda económica para la instalación de nuevas colonizaciones, en particular para la colonización de los hijos de los colonos.

${ }^{132}$ Acta № 27, Asamblea General Extraordinaria, 3 de septiembre de 1953, p. 195. 


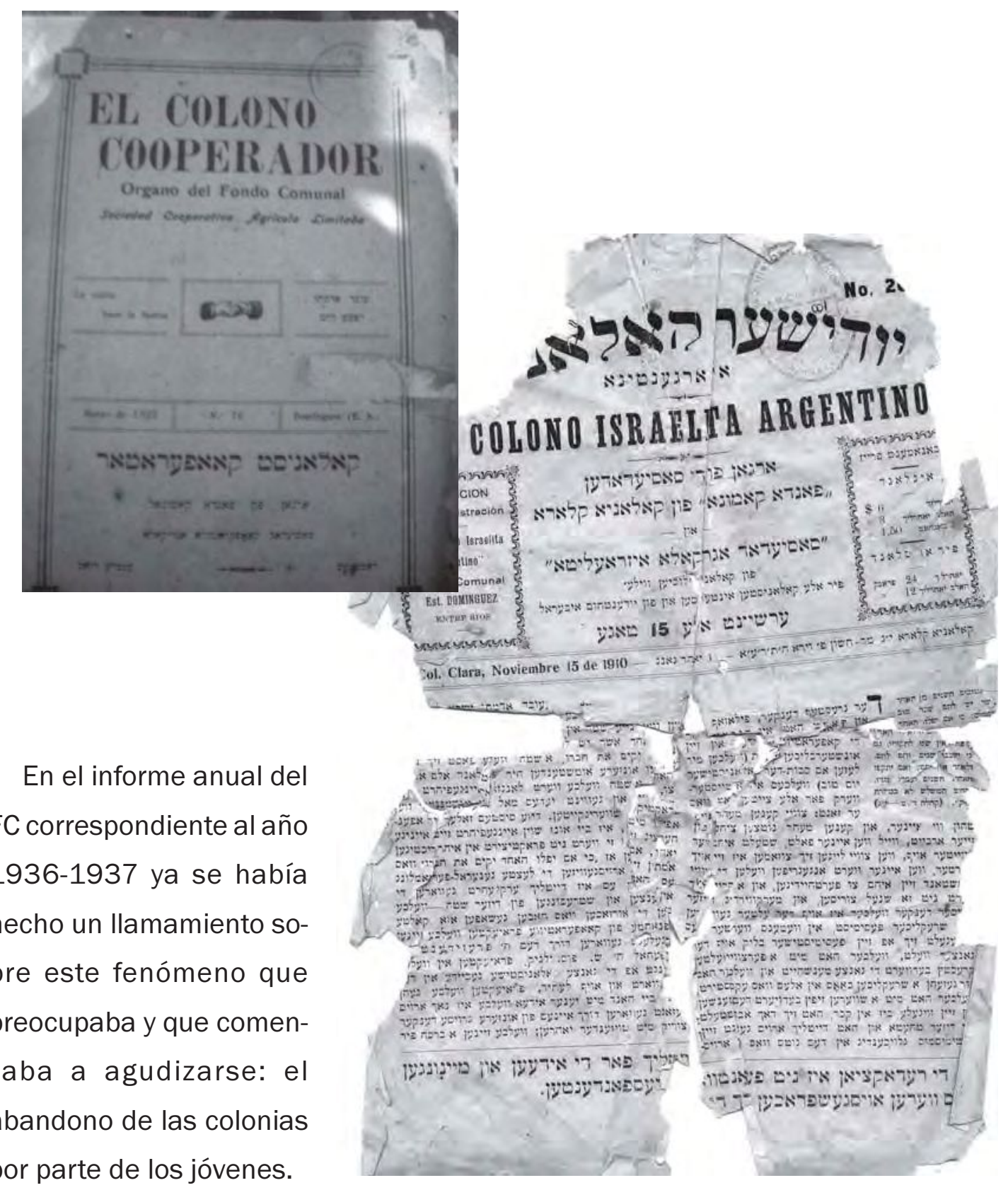

El impacto de la crisis

afectó a los socios y generó un deterioro en el compromiso con la institución, por lo que el Directorio reclamó revertir la pasividad y demostrar mayor responsabilidad. El número de socios que había alcanzado a 584 en 1931 descendía en 1937 a 468. Así fue como se tomaron medidas drásticas contra 12 colonos, que fueron excluidos del FC por no cubrir el pago de su cuota después de múltiples trámites y el otorgamiento de facilidades. Ante otras situaciones vinculadas a los quebrantos económicos de otros socios, actuó de manera ejemplar. Dos acontecimientos dan 
muestras de lo señalado. Para evitar el remate y liquidación de una chacra, un grupo de socios acudió privadamente, ofreciendo sus garantías crediticias ante una entidad bancaria para impedir el desalojo.

El informe del administrador de Colonia Clara explica detalladamente que en 1938 estaba por rematarse la chacra de Marcos Pustilnik, un predio de cien hectáreas localizado en el grupo Barón Guinzburg, pero que un grupo de sesenta colonos sacaron de los bancos el importe necesario, levantando la hipoteca y salvando la chacra. Como garantía del dinero prestado, Pustilink hipotecó su chacra a favor de tres chacareros, representantes de los colonos. ${ }^{133}$

Lo mismo ocurrió un año antes, cuando, a pedido de Miguel Sajaroff, la institución de crédito agrario Fomento Agrario Israelita Argentino S.A. impidió que un banco rematara la chacra del colono Salomón Pomerantz. ${ }^{134}$

El caso Salomón Wortman, padre de Marcos, revistió especial importancia. La situación suscitó una seria discusión con la JCA, ya que el hombre había quedado solo en la chacra con una deuda abultada y la empresa había establecido la ejecución del campo. La memoria oficial del Fondo Comunal sostiene que

Fueron las gestiones del F.C. las que posibilitaron que la venta se realice en condiciones aceptables y que la chacra pasase a manos de "buenos" colonos o de sus hijos. $^{135}$

Sin embargo, una mirada más detenida sobre los derroteros de la historia familiar ofrece matices muy interesantes, sobre todo porque se trata de un colono con cierta capacidad de presión, por su posibilidad de cuestionar públicamente los excesos de la empresa colonizadora, lo que fue duramente sancionado por la JCA al no permitirle el acceso a la propiedad de la tierra, norma que fue vista con beneplácito por el sector de los chacareros meritocráticos, que no dudaron en recurrir a prácticas reñidas con la moral y la solidaridad.

133 Informe Anual 1939 de Colonia Clara, Ingeniero Samuel Kogan, Archivo y Museo histórico de Domínguez, p. 7.

${ }^{134}$ El dinero sacado de los bancos quedará garantizado con el campo a favor de dos contribuyentes con firmas y serán los señores Adolfo Gleser y Julio Feldamn. En Acta № 703, AGE, 15 de mayo de 1938, p. 251. 135 Fondo Comunal: 50 años de colonización..., op. cit., p. 209. 
La situación de penuria económica, y, por ende, las dificultadas para cubrir las anualidades requeridas, venían de tiempo atrás. En tiempos de la visita del señor Oungre -director de la JCA en Buenos Aires- en 1928 a Colonia Clara y en reunión con la Comisión Directiva se trató el tema, y el director informó que

no le asiste ningún espíritu de venganza, sino que no puede hacer arreglos con Salomón Wortman por haber seguido el juicio hasta el final y que tomarán en consideración la propuesta que se les haga, con exclusión de Marcos Wortman, por haber éste no criticado, sino ofendido a los dirigentes de la J.C.A. ${ }^{136}$

Un año después, en 1929, don Salomón solicitaba al Consejo Directivo que se le acuerden intereses por los \$6.000 que tenía en depósito en la cuenta corriente a favor de la JCA. Como excepción, se acepta el pedido por "tratarse de un caso muy especial». ${ }^{137}$ Fue justamente en esa misma sesión donde el concejal Seidel Zeigner denunció el entorpecimiento de la solución del caso Wortman provocado por dos concejales del FC, por lo que se decide crear una comisión investigadora para echar luz al respecto. Como el tema no llegaba a ser dilucidado, en la siguiente sesión otros concejales sostuvieron que no se podía dejar pasar el asunto, pues se trataba de una cuestión que estaba relacionada con la moralidad de los que formaban parte del Directorio. El señor Galansky dice expresamente: «a la colonia no le interesa solamente el orden material sino también moral", y se exige que Zeigner concrete los cargos, quien denunció como delatores a los señores Marcos Pustilnik y Moisés Graschinsky. ${ }^{138}$

Podemos inferir que los viejos enfrentamientos políticos con Marcos eran los impedimentos que hacían más difícil la superación del trance económico recurriendo al sistema de transferencias. La voz de denuncia del dirigente hacia la empresa colonizadora no sólo molestaba a sus administradores, sino que también fastidiaba a los grupos más conservadores, que buscaban congraciarse con la JCA $y$, de paso, recibir beneficios personales y diferenciados. Finalmente, el "asunto

\footnotetext{
${ }^{136}$ Acta No 490, 4 de junio de 1928, p. 68.

${ }^{137}$ Acta $N^{\circ} 519,21$ de octubre de 1929, p. 226.

138 Acta No 520, 4 de noviembre de 1929, p. 229.
} 
Wortman" concluyó como tanto otros. El $1^{\circ}$ de julio de 1937 se produjo el remate de su chacra. ${ }^{139}$

Como Wortman tenía una importante deuda con el FC, fue la cooperativa quien adquirió en el remate la chacra en cuestión, y procedió luego a su venta a Yauda Efron y Jacobo Mosovich, quienes asumieron el precio pagado en el remate, más la deuda que tenía Wortman con el FC. ${ }^{140}$

Como es posible observar, la delación y el interés personal y de clase se conjugaban con otros muchos casos, en los que la solidaridad y cooperación demostrada tuvieron una importante repercusión no sólo en la colonia, sino también en el ambiente agrario y cooperativo del país.

El 4 de mayo de 1938, en reunión de la Comisión Directiva con el doctor Orenstein, director de la central de la JCA, se le vuelven a exponer los problemas vinculados al asentamiento de los colonos. El director les explicó que el año anterior la empresa ubicó en nuevas colonias y sobre las reservas de tierras de las colonias viejas a cien colonos judíos alemanes, y que debían seguir dando lugar y colonizar exclusivamente a judíos perseguidos y necesitados que provenían de Europa. Por lo tanto, los hijos podían ser colonizados en esas colonias -por supuesto, alejadas de Clara - o en tierras de pastoreo o por transferencias. ${ }^{141}$

Del conjunto de nuevos emigrados producto de la violencia europea, Colonia Clara recibe a dos familias polacas, según el informe del administrador local. ${ }^{142}$

Observemos el siguiente cuadro que presenta la situación contractual de los colonos en los años 1938-1939:

\footnotetext{
139 Entretanto, los señores B. y Abraham Glagovsky se ofrecían como compradores, asegurándole al viejo Salomón una suma de \$165 la hectárea, sea cual fuera el precio que el campo tuviera en remate. Sólo quedaba pendiente la aprobación de la adquisición por la JCA, aunque ellos ya eran propietarios de dos chacras.

${ }^{140}$ Acta No 688, Asamblea General Extraordinaria, 18 de julio de 1937, p. 182.

${ }^{141}$ Otra opción que les presentaba era que los padres destinaran cierta extensión de tierra de sus chacras para la colonización de sus hijos y que estas podrían tener 75 hectáreas para realizar una explotación intensiva. Las colonias nuevas estaban fuera de Colonia Clara, por lo que no podrían recurrir a una provisión familiar de los recursos para su explotación.

142 «Spirer Jacobo... una familia de 5 personas, todas trabajadoras, las que se han arraigado bien y dan buen resultado [...] Klarrierch, M y Udelman, E. Al principio había dificultades con su instalación debido a los continuos conflictos familiares. Últimamente las discrepancias han desaparecido y los trabajos siguen con total normalidad."
} 


\begin{tabular}{|lcc|}
\hline & 1938 & 1939 \\
\hline Colonos emancipados & 337 & 362 \\
\hline Colonos con título hipotecario & 115 & 104 \\
\hline Colono con Promesa de Venta & 153 & 131 \\
\hline Colonos arrendatarios & 187 & 199 \\
\hline Quinteros & 5 & 5 \\
\hline salieron & $8^{143}$ & \\
\hline transferencias & 9 & \\
\hline Total & 797 & $801^{144}$ \\
\hline
\end{tabular}

Fuente: Informe Anual 1939 de Colonia Clara, Archivo y Museo Histórico de Domínguez.

Se desprende de la lectura del cuadro anterior que se produjo un aumento de los colonos "emancipados", es decir, veinticinco chacareros que lograron la escritura y la traslación de dominio, porque pudieron pagar la hipoteca o cumplir con las anualidades del contrato de Promesa de Venta. También se observa un aumento considerable de colonos arrendatarios, lo que nos permite señalar que las nuevas instalaciones se realizaban en esta modalidad. El movimiento alcanzó a nueve nuevas instalaciones que se efectuaron sobre las chacras que habían pertenecido a tres ancianos desalojados con juicios sucesorios y sobre otras chacras de tres colonos desalojados y las que fueron transferidas a familiares. ${ }^{145}$

Del mismo informe del administrador de Colonia Clara se desprende una situación preocupante. Según los estudios realizados por el informante y elevados a la Dirección General de la JCA, las deudas de 72 colonos eran superiores al valor de sus chacras, por lo que aconsejaba realizar

\footnotetext{
${ }^{143}$ Salidas: Colonos Desligados: 1 quintero, Simón Thou, desligado por ser elemento no apropiado para la colonización. Se lo dejó sobre la quinta en calidad de arrendatario simple, 1 colono arrendatario, Lipe Herz, desligado voluntariamente; 3 colonos con Promesa de Venta por desalojo y recesión de contrato 3 ex colonos ancianos, 2 voluntariamente y 1 por desalojo. En Informe Anual 1939 de Colonia Clara, Archivo y Museo histórico de Domínguez, p. 10.

144 Ingresos: 2 colonos polacos; 1 con crédito reducido por espera de la familia, 6 hijos de colonos.

145 Informe Anual 1939 de Colonia Clara, Archivo y Museo histórico de Domínguez, p. 10.
} 
ciertas rebajas para equilibrar la situación de dichos colonos de acuerdo a la realidad. Hay varios casos de deudas que oscilan de \$200 a \$250 la hectárea, circunstancia por la cual los colonos no pueden hacer frente a sus obligaciones aun en los años buenos. ${ }^{146}$

La hectárea de campo, si bien su precio oscilaba según la cercanía a los pueblos, se vendía ese mismo año entre $\$ 190$ y $\$ 130 .{ }^{147}$

Se puede deducir que prontamente estos 72 colonos no podrían cumplir con los pagos, lo que representaba, más allá de sus buenas intenciones y del trabajo intenso, que estaban expuestos a que los administradores de la empresa le enviasen el telegrama de desalojo.

Condiciones leoninas, imposibilidad de acceder a la propiedad o al arrendamiento de tierras y escasas o nulas posibilidades de inserción laboral rentable en el campo, incitaban al desplazamiento de los hijos de los colonos a los centros urbanos. Los jóvenes buscaban salidas y, por ende, las perspectivas de la emigración preocupaban a los colonos nucleados en el FC.

En las sesiones del C.D. se abordaba el tema intentando encontrar las mejoras necesarias para elevar el estándar de vida y para optimizar los métodos de explotación agropecuaria. Las discusiones se centraban en estudiar la mejor manera de aprovechar la técnica y sobre la necesidad de acceder a la maquinaria moderna que -aunque costosa - racionalizaría las labores agrícolas y desarrollaría la industrialización de la producción. Se analizaba la posibilidad de trabajar la tierra con métodos intensivos, lo que requería mayor capital y calificación técnica para encarar la empresa, recursos estos que no poseían.

La reiterada lejanía e indiferencia de la JCA para encarar el problema de la colonización de los hijos llenaba de pesimismo a los socios reunidos en asamblea:

no nos responde la J.C.A pues cuando tenemos hijos para colonizar no hay tierras o no nos llevan el apunte y cuando no hay hijos en dichos momentos nos dicen tener tierras [...] los hombres de la ciudad no conocen en absoluto nada de la coloniza-

\footnotetext{
146 Ídem, p. 10.

147 Ídem p. 9.
} 
ción, pero no obstante ese pesimismo que yo observo se debe en gran parte a la colonia misma, esa inactividad de parte de nosotros, de nuestras propias fuerzas.

Algunos explicaban que el éxodo de los jóvenes a la ciudad no sólo respondía a penurias económicas, sino

por haberse desvirtuado el ideal de colonización que quería imprimir el Barón de Hirsch, hace falta algo de espiritualismo y de confianza en el mañana siguiendo en la cotidiana tarea agrícola.

Otros pedían a los delegados que trasmitieran a la JCA el desánimo en el que quedaban los chacareros cuando sus vecinos migraban a la ciudad: "[describan] las situaciones solitarias en que quedan aquellos colonos cuyos vecinos se ausentan a la ciudad". ${ }^{148}$

Fruto de estas preocupaciones, el Fomento Agrario Israelita, S.A., y por el intermedio del FC, se adquirieron dos chacras en la Colonia Leven, donde fueron instalados dos colonos en 1948. Este hecho fue considerado como una conquista societaria que abrió además nuevos canales para lograr el arraigo de los jóvenes en las colonias, intentando poner un freno al éxodo de la población rural a los centros urbanos. Trataban de detener el movimiento de expulsión poblacional que se agudizaba y del que, hoy sabemos, ya no habría retorno. Mientras tanto se propusieron intervenir en todas las transacciones referentes a las chacras de la colonia, pretendiendo interceder por aquellos colonos que tenían escasos recursos económicos debido a que sus reducidos lotes les impedía mantener una explotación racional, pero en particular ocuparse en ubicar "a los candidatos de su preferencia» en las chacras que vendían los colonos para irse a la ciudad.

Una preocupación no menor estaba flotando en el aire: la apropiación de tierras por agricultores no judíos. Esos "candidatos de preferencias" a los que hacíamos mención eran colonos judíos, por lo que intentaban recuperar para las filas de su grey religiosa las chacras que estaban siendo adquiridas por hacendados de la región, no judíos.

${ }^{148}$ Acta No 703, Asamblea General Extraordinaria, 24 de abril de 1938, p. 247. 
El segundo punto del orden del día de la sesión del 14 de mayo de 1948 lo expresaba de la siguiente manera:

Ante los serios síntomas de disgregación que afectan a nuestras colonias, por los múltiples factores de índole económica y social, que deciden a muchos colonos a abandonar sus chacras, lo que repercute desfavorablemente en la estabilidad de los que quedan, el Consejo Directivo considera conveniente movilizar a las instituciones locales y financieras de nuestra colectividad a fin de conseguir los medios para readquirir las chacras y reorganizarlas, conservando y afianzando la integridad de la colonia. ${ }^{149}$

Estas demandas se tramitaban a través de la Fraternidad Agraria, la entidad gremial que solicitaba la intervención de la empresa colonizadora, que no respondía. El ejercicio 1950-1951 fue de gran progreso económico. Sin embargo, el optimismo que generaban los logros económicos se veía ensombrecido pues

entre los asociados no se vislumbra el entusiasmo por el arraigo en la tierra ni la confianza en el futuro, y así ralean las filas por la atracción de la gran ciudad que seduce al hombre de campo..$^{150}$

Recién en 1952 el director Weill notificaba en conferencia de prensa que la JCA se ocuparía de estos temas:

Otra cuestión es la readquisición de chacras de colonos que por distintas razones deciden deshacerse de sus predios y los venden a colonos vecinos. Junto con la Fraternidad Agraria y las cooperativas se ha decidido que esas tierras no deben pasar a manos extrañas, para mantener el «ishuv» judío de las colonias. En el curso de este año la J.C.A ya ha desembolsado \$ 83.000 para este fin. Hay en gestión préstamos por $\$ 167.000$ y en estudio tenemos solicitudes de crédito por $\$ 54.000$.

\footnotetext{
${ }^{149}$ Acta de la sesión del 14 de mayo de 1948.

150 Fondo Comunal: Cincuenta años... op. cit., p. 143.
} 
De manera que de resolverse lo que está en estudio habremos invertido $\$ 300.000$ para readquisiciones.

Un análisis diacrónico del movimiento de los colonos realizado por el administrador de Colonia Clara entre los años 1944 y 1953 es revelador de la conformación de una nueva estructura social y de la nueva dinámica poblacional.

El primer dato es el gran salto cuantitativo en el proceso de emancipación de los colonos. Es decir, el acceso a la propiedad de la tierra se extendió a 254 colonos, los que habían podido cumplir con las deudas hipotecarias a través de la facilidad que los créditos les brindaron. En particular los otorgados por el Banco Nación, créditos a largo plazo y con un interés del 4\%, posibilitaron que 34 colonos llegasen a la propiedad de su tierra, a los que se sumaban otros 27 que contaron con el apoyo de los créditos otorgados por entidades crediticias de base cooperativa.

En 1938, el total de colonos asentados en la colonia era de 797, de los cuales habían adquirido la propiedad de la tierra 337. Quince años después, en 1953, eran 662 los propietarios, lo que nos permite ver, en principio, ${ }^{151}$ la incidencia que los rindes económicos y las posibilidades de acceso al crédito posibilitaron, esto es, que el $80 \%$ de los colonos lograra una transformación sustancial en la estructura económica y social.

Por otro lado, el número de desalojos por incumplimientos disminuyó considerablemente (un sólo desalojo en 1944; otro en 1945 y el último en 1947) y las transferencias de propiedad fueron diez. Ahora bien, el abandono voluntario se convirtió en la nota distintiva: entre los años 1944 y 1953 se fueron voluntariamente 73 familias de Colonia Clara.

Este abandono se tradujo en un volumen considerable de ventas de la tierra y en la explotación de la chacra mediante el trabajo de peones, en tanto los propietarios trasladaban su morada a la ciudad.

La adquisición de predios en los tres pueblos más importantes de la colonia siguió una tendencia creciente. En 1939 se habían vendido 323 solares en total.

${ }^{151}$ Ver la incidencia de la Ley № 2.933 de la provincia de Entre Ríos, sobre ausentismos de la tierra. 
Villa Domínguez, sede de la Administración de la JCA, del Fondo Comunal, del Banco Popular agrícola, del hospital más importante de la colonia y de varias instituciones culturales, políticas y de beneficencia, se había convertido en el lugar de reuniones, conferencias y congresos de varias sociedades. ${ }^{152}$ Villa Clara, segundo pueblo en importancia -sede del Juzgado de Paz de la colonia, de la Caja Rural, con sucursal del Fondo Comunal y de varias casas cerealistas y de comercio- atraía a los colonos. Y La Capilla sufría el retraso porque las vías del tren la habían dejado a un lado (era el tercero en jerarquía). En el período 1944-1953, la venta de solares y reservas vendidas en los pueblos por la JCA a particulares, instituciones públicas, sociales y comerciales ronda aproximadamente las 171 hectáreas. ${ }^{153}$

Los reacomodamientos de la propiedad de las tierras que pasaban a manos de no judíos preocupaban a la JCA y al Consejo Directivo del Fondo Comunal. La documentación da cuenta de que se vendieron 39 chacras con una extensión aproximada de 3.590 hectáreas. Tan sólo 5 chacras con una extensión de 550 hectáreas fueron vendidas de "extraños" a israelitas.

Ahora bien, en el interior de la colonia, en la que la JCA ya no disponía tierras en reserva, se iba produciendo el reordenamiento y un reagrupamiento de tierras en un doble proceso, por un lado a través de la instalación de 71 colonos, hijos o yernos de colonos y, por otro, con la ampliación de los campos de los colonos ya establecidos que benefició a 64 propietarios. Podemos entonces sostener que aquellos colonos que optaron y pudieron seguir en la explotación agropecuaria ahora consolidada encontraban en esta coyuntura ventajas favorables: podían ampliar sus propiedades con tierras que se ponían a la venta e interceder efectivamente para que la asignación de chacras fuese a sus familiares.

En las asambleas generales y ordinarias de los socios del FC se sostenía con insistencia que a aquellos pocos jóvenes que optaban por quedarse a trabajar en el campo se les debían otorgar todas las oportunidades y posibilidades para su afianzamiento, pues serían los continuadores de la experiencia colonizadora, obra

152 Entre ellas, la Organización Escolar Hebrea Entrerriana, la Organización provincial de la lucha contra el antisemitismo, la Organización de maestros, varias organizaciones sionistas, entre otras sociedades de menor importancia.

153 Informe del administrador de Colonia Clara, 1944-1954, Anexo, p. 6. 
que debían defender, pues la misma era también su propia trascendencia y la de la colectividad judía, que en tierra de libertad se convirtió en agricultora cumpliendo con la misión que el barón de Hirsch le había encomendado.

Les preocupaba el afianzamiento de los jóvenes, tema del que se hablaba mucho y se realizaba muy poco, denunciaban los asambleístas. ${ }^{154}$ Don Miguel Sajaroff señalaba que el problema de la juventud del campo era un problema mundial, aunque, si se esmeraban, ellos podrían encontrar una solución parcial: "Sería una solución que nos propongamos que ningún joven de la Colonia que quiera trabajar la tierra se vaya, se le deben de proveer los medios". ${ }^{155}$

Una iniciativa por fuera del ámbito económico fue la creación de la sección cultural propuesta por el Movimiento Juvenil Agrario, confiados en que «realice una obra útil para el mejoramiento de la vida social en nuestro medio»:156 "Agrocul está llamada a traernos lo que quisimos y reclamábamos, es una fuerza unificada y nos traerá los atractivos de la ciudad al campo, y esperamos que por ello disminuya el éxodo del campo a la ciudad", señalaba entusiasmado Manuel Gleser. ${ }^{157}$

Sin embargo, desde las asambleas, que eran la caja de resonancia de las preocupaciones, se denunciaba, concomitantemente, que, más allá de los programas culturales, el problema eran las transferencias, ya que eran una "verdadera esclavitud para nuestros jóvenes, porque el valor que deben pagar por la tierra, es superior a las posibilidades de dar cumplimiento a las obligaciones contraídas».. ${ }^{158}$

Una serie de medidas de carácter tributario incidieron también para que se produjeran los cambios en la titularidad de la tierra. En abril de 1944, la JCA denuncia a través de una solicitada ${ }^{159}$ que la Dirección General de Rentas de la provincia ha demandado a la empresa a pagar \$10.103.670 por impuestos que había dejado de pagar desde 1933, por el denominado impuesto al ausentismo, infringiendo la

\footnotetext{
154 "Jacobo Efron: al referirse al problema de la juventud, dice que se habla mucho, pero nadie propone solucionarlo. Dice que el F.C. invitó en cierta ocasión a que sea la juventud la que plantee sus problemas. Reconoce la gravedad del asunto, pero que no ve que se traiga algún proyecto para solucionarlo". En Acta de la Asamblea General Extraordinaria, 19 de octubre de 1944, p. 7.

155 Ídem, p. 9.

${ }^{156}$ Sostenía Saúl Putterman, Acta N ${ }^{\circ} 5$ de la Asamblea General Extraordinaria, 14 de noviembre de 1945, p. 32.

${ }^{157}$ Acta N N 10, Asamblea General Extraordinaria, 26 de octubre de 1947.

158 Acta No 4 de la Asamblea General Extraordinaria, 2 de octubre de 1945, p. 28.

159 El Atlántico, 20 de abril de 1944, p. 3.
} 
Ley $N^{\circ} 2.933$. Esta cifra se desglosaba en $\$ 1.613 .888,71$ correspondiente a impuestos atrasados y $\$ 8.069 .443,55$ por multas por las supuestas infracciones. Si bien la citada ley exceptuaba del pago del impuesto a

las personas o compañías colonizadoras que venden fracciones de tierra, respecto de éstas, siempre que en el contrato se fije la obligatoriedad de otorgar la escritura definitiva cuando estuviere abonado el $50 \%$ del importe total, debiendo presentar los contratos al P.E. para gozar los beneficios de la ley.

La Dirección de Rentas fundaba su resolución condenatoria en que

en los contratos de venta a los colonos no se ha tenido en cuenta el $50 \%$ sobre el valor de la tierra, sino que incluye en aquél otras deudas ajenas, lo que eleva el importe del contrato, violando de esta forma la condición expresa del inc. 3 del Art. 5 [...] como consecuencia de la acumulación de deudas distintas a la de la tierra, los colonos no pueden cumplir con sus compromisos. ${ }^{160}$

Lo interesante de este conflicto es que la JCA debía explicar que "esas deudas ajenas" a las que debía hacer frente el colono eran los préstamos concedidos por la empresa para la instalación y habilitación de animales, implementos agrícolas, construcciones y dinero que hacía la JCA al momento de establecerse y cuyo valor se incluía en el contrato, pero sin incorporarlo al precio de la tierra, y que si bien se habían producido demoras en el acceso a la propiedad de la tierra, señalaba que en la provincia de Entre Ríos ${ }^{161}$ el $77 \%$ había llegado a la titularidad en menos de 25 años, y que sólo 254 colonos se habían demorado más de ese plazo, debido a que «el sistema de colonización de la J.C.A permite a los agricultores obtener la propiedad sin grandes dificultades". ${ }^{162}$

\footnotetext{
160 lbídem.

${ }^{161}$ Según informa la JCA, en la provincia se habían colonizado 197.200 hectáreas, de las cuales se habían escriturado definitivamente 122.200 , que fueron otorgadas en propiedad a 900 colonos, restando 75.000 hectáreas ocupadas por 880 .

162 Ibídem.
} 
Ahora queda claro que el impuesto al latifundio y al ausentismo se convertía en un incentivo eficaz para acelerar la maquinaria en manos de la JCA que permitiría el acceso a los títulos de propiedad y a la "emancipación» de la empresa.

Cuando finalmente el grupo de colonos que resistieron los avatares de la experiencia colonizadora lograron el asentamiento como chacareros en Colonia Clara, ya que obtuvieron los recursos económicos para acceder a los títulos de propiedad, comenzó a acentuarse el fenómeno de despoblamiento de los campos. Un dato no menor en la faz productiva en la región acompaña este proceso: el avance de la ganadería ${ }^{163}$ sobre la agricultura, tarea que requiere de menos mano de obra y otorga a los propietarios buenas ganancias.

\section{La reunión en Londres: final de época}

La relación entre el FC y la JCA empieza una nueva etapa. Este ciclo nació con una invitación a la primera reunión de los colonos, cuya delegación estuvo compuesta entre otros por S. W. Rosenthal, M. Melman y M. Matzkin, con la Administración Central de la JCA a realizarse en Londres en el mes de enero de 1949.

Los delegados de las colonias reunidos en la Fraternidad Agraria prepararon un extenso documento en el que fijaban posición en torno a importantes núcleos temáticos o tópicos

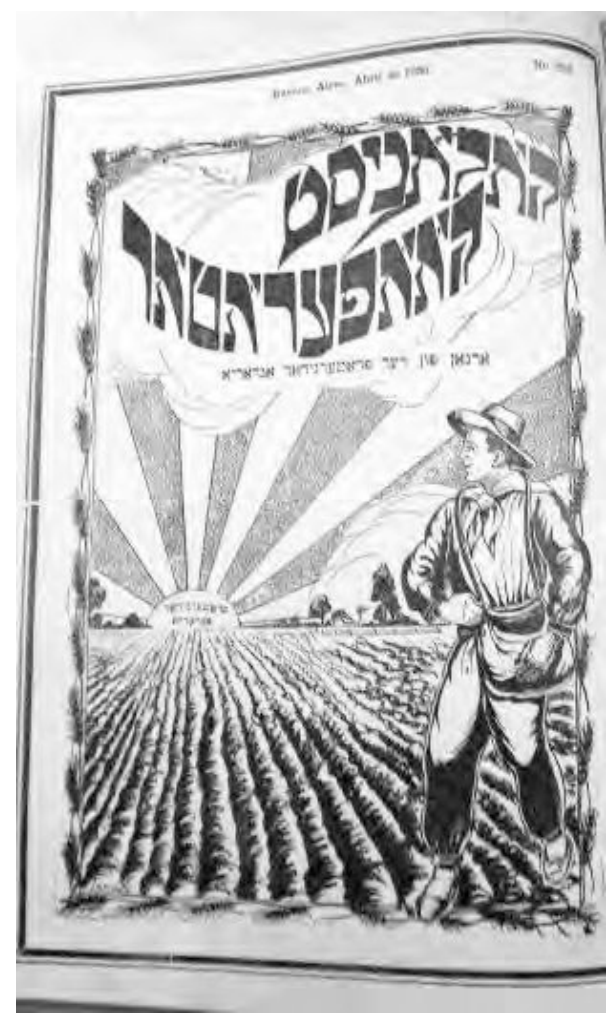

\footnotetext{
${ }^{163}$ El proyecto de instalar el Remate Feria da cuenta de ello: "defender nuestra producción ganadera que por sí sola representa un 30\% de nuestra economía, siendo lógico que nuestra cooperativa encare este asunto". Acta № 13 de la Asamblea General Extraordinaria, 5 de septiembre de 1948, p. 85. Jaime Novidelsky, en contra del proyecto, sostiene que "no considera necesaria la instalación del Remate Feria, ya los colonos tienen poca hacienda y que muchos abandonarían sus chacras". Ídem, p. 86. "Kopel Zeigner. Manifiesta su pesimismo en cuanto al porvenir de la colonia, el éxodo a la ciudad de muchos colonos y especialmente de los jóvenes es notable; considera que no hay para quien construir y por lo tanto las iniciativas no tienen lugar", ídem, p. 87.
} 
que consideraban que caracterizaron la colonización y la actuación de los administradores de la JCA. ${ }^{164}$ Los capítulos fueron: Homenaje al barón y baronesa de Hirsch; el papel de la JCA; la colonización, una mirada retrospectiva; atribuciones y obligaciones; funcionarios; relaciones con las cooperativas; colonización de hijos de colonos (medida de no colonizar a hijos cerca de los padres, no alquilar reservas a colonos judíos); desalojos y reducción de chacras; readquisición de chacras; siete años flacos; nueva página; resumen y anexos.

Los redactores del documento sostenían que, si bien podían acordar que había que dejar que el "pasado pase", entendían que esta circunstancia era una excelente ocasión para reseñar una historia de los maltratos, de falta de reconocimiento a los pioneros de la experiencia colonizadora, que en las cinco décadas transcurridas ningún miembro del Consejo Central de París visitó la Argentina y que lo que conocieron fue a través de escritos de sus empleados, burócratas y sólo expertos cobradores, que jamás reconocieron la obra de las cooperativas, que no favorecieron la colonización de los hijos y que sólo "consiguieron que los hijos estén lejos de los padres, pero no en las chacras, o que los padres se acerquen a los hijos en las ciudades". ${ }^{165}$ Y continuaban los reproches: que hicieron oídos sordos cuando se les solicitó readquirir las tierras - las que ya habían pasado a manos de no judíospara mantener la obra del barón de Hirsch, y tampoco se avinieron a formar un banco de fomento agrícola, ya que «la respuesta fue negativa y con tono sarcástico", medidas imprescindibles para consolidar la obra colonizadora.

El capítulo "Nueva Página» es revelador del momento. La empresa colonizadora buscaba inaugurar un nuevo tipo de relación y desplegar una política de olvido sobre los enconos del pasado. Los colonos señalaban que se avenían a ello pues, además, no les quedaba otro remedio, pero advertían que la nueva época requería de cambios fundamentales:

El elemento colonizado actualmente, pertenece a la segunda y tercera generación, criados en un ambiente libre e independiente, mismo los inmigrantes entienden las

\footnotetext{
${ }^{164}$ Fraternidad Agraria, Historia de la Fraternidad Agraria, noviembre de 1948. Archivo IWO, Caja Villa Domínguez.

165 Ídem, p. 3.
} 
cosas de distinta manera en comparación a los llegados de hace 50 años. Los representantes de los colonos se turnan periódicamente, sus actos son controlados por la masa de los asociados, por lo que deben estar al tono con las circunstancias y con la actualidad, mientras los funcionarios de la J.C.A siguen con sus normas anticuadas y difícilmente podrán encausarse a nuevos métodos. Entiéndase que no es cuestión de edad, sino de mentalidad. ${ }^{166}$

Los colonos señalaban que el propósito que los guiaba era la consolidación y el desarrollo de la obra del barón de Hirsch, objetivo que compartían con los administradores. Ahora bien, deseaban expresar y que quedara muy en claro que reconocían a la JCA como institución, pero rechazaban que cualquier empleado de ella cualquiera fuera la jerarquía dentro de la empresa- se arrogara el derecho de encarnar la obra del barón de Hirsch, pues "Sostenemos que los verdaderos ejecutores de la misión de la J.C.A son los colonos". ${ }^{167}$

Cincuenta años después, la asimetría en la relación había virado sustancialmente. Los colonos agremiados en la Cooperativa Fondo Comunal y en la Fraternidad Agraria presentaban condiciones y exigían cambios que, con encono, explicitaba el administrador de la JCA de Colonia Clara:

Ya en muchas oportunidades se habló y escribí sobre la "colaboración" que nos prestaban las cooperativas; se trataba, casi siempre, de una "supuesta colaboración". Mientras las cooperativas eran débiles y necesitaban de la J.C.A -apoyo material y moral- se mostraban bajo una faz amistosa, se trabajaba en mayor armonía y concordancia; luego al afianzarse la situación material de ellas, al llegar a ser grandes y poderosas han cambiado - por culpa de algunos de sus dirigentes- volviéndose agresivas contra la J.C.A, y en ciertas oportunidades tenían actividades contrarias a la J.C.A y n/s. intereses en la colonia. ${ }^{168}$

\footnotetext{
${ }^{166}$ Fraternidad Agraria, op. cit., p. 48.

167 Ídem, p. 1.

168 Informe sobre Colonia Clara, marzo de 1954, p. 11.
} 
La nueva época marca el fin de la dependencia en términos contractuales y económicos, pero también en el plano simbólico. Las nuevas generaciones nacidas en el país eran ahora en su gran mayoría productores agrícolas propietarios de sus chacras, los que se integraban libremente al desarrollo económico social de la región, asociados a una entidad cooperativa que había logrado consolidar un gran prestigio a través de la ampliación de su radio de acción, que se traducía en más y mejores servicios que aseguraban una elevación en los ingresos y, por ende, mejoras en el nivel de vida. Mejoras que se traducían concomitantemente en la libre determinación de dónde fijar las moradas, y como a tantos otros argentinos, la elección los conducía hacia las ciudades.

\section{Recapitulando}

Como señalamos al inicio de este extenso capítulo nuestro propósito consistió en analizar el derrotero de la cooperativa Fondo Comunal, ya que por un lado nos permite reconstruir la historia de Colonia Clara y por otro recobrar las expectativas y demandas de los colonos y sus derroteros para convertirse en chacareros propietarios de su tierra en la llanura entrerriana.

La literatura especializada y las historias institucionales reconocen en el cooperativismo agrario uno de los legados más importantes de la comunidad judía a la sociedad argentina, fenómeno reconocible y por ende más conocido.

Una mirada más detenida demuestra que la acción solidaria y cooperativa desarrollada por esta institución sirvió como un elemento estratégico para la contención y el arraigo a los agricultores, quienes sin créditos debían recurrir a los comerciantes y acopiadores locales que se presentaban al momento de la cosecha para cobrarse sus deudas y fijando arbitrariamente el precio del grano, a merced de la inclemencias del tiempo y de las plagas que los conducía a la quiebra económica y por ende los llevaba a abandonar la colonia en busca de mejores oportunidades.

La formación de la cooperativa estuvo inducida por la compañía colonizadora que se abrogaba el derecho de colocar como presidente de la Institución al administrador de la colonia, coyuntura favorable para esa etapa inaugural por la experiencia e idonei- 
dad del Administrador Adolfo Leibovich quien actuó como puente entre las demandas de los colonos y sus urgentes necesidades logrando la asignación de recursos por parte de la Administración Central de la JCA para sostener la obra colonizadora.

Un dato singular de la experiencia cooperativa fue que contó con la participación de hombres con sólida formación intelectual adquirida en Europa, que evidentemente constituían una pequeña elite dentro del ámbito rural, quienes se convirtieron en los líderes de los colonos a los que trasladaron su ideología y se convirtieron en los portavoces para enfrentar las exigencias desmedidas y las arbitrariedades de los sucesivos elencos administrativos de la compañía, sosteniendo de este modo etapas de conflictividad y duros enfrentamientos.

De modo que las sucesivas etapas del Fondo Comunal están marcadas por el conflicto con la empresa colonizadora que demostraba su accionar omnipresente en la vida comunitaria y por los intentos de defensa de los derechos de los agricultores, que ante el menor incumplimiento eran desalojados de sus chacras y expulsados de la colonia.

Los alcances de la acción de la cooperativa cumpliendo un papel de base empresarial de los productores agropecuarios con un objetivo de carácter social y económico, fue también un instrumento de educación y generador de formas de convivencia para una vida armoniosa, así como también el espacio político y de defensa de los colonos ante los embates y las exigencias impuestas por la empresa colonizadora que perseguían el cumplimiento estricto de normas establecidas por la Oficina Central de París, las que se distanciaban y se contraponían, como lo demostramos, a las necesidades, expectativas y demandas que la experiencia colonizadora en el país imponía a los colonos. Estas tensiones y las formas de resistencias marcaron la acción gremial que se movía en dos planos. Por un lado, la búsqueda de acción cooperativa en la esfera económica trabajando mancomunadamente con entidades provinciales y nacionales, y, por otro, una acción solidaria con base étnica, que, si bien contenía estrategias de acción económica, iba más allá para construir un frente común de resistencia y de sobrevivencia ante la JCA.

Los alcances de las acciones emprendidas por la cooperativa en la esfera productiva y económica -estimulo a la producción y diversificación, creación de sus 
propios mecanismos de comercialización y almacenamiento, la instauración de un sistema de crédito y la introducción de tecnología que mejorara los rindes agropecuarios- se combinaba con la preocupación permanente por la educación y capacitación de los socios que les brindase herramientas para consolidar la obra del barón Mauricio de Hirsch: convertirse en agricultores en suelo argentino.

Como toda institución social no estuvo libre de tensiones y de enfrentamientos entre los distintos actores sociales que la componían. La estratificación social reconocía formas diferentes de encarar la relación con la JCA. Sectores más combativos lideraban los enfrentamientos con la empresa colonizadora y en el plano interno hacían frente a los sectores "meritocráticos" que acordaban con la política de la JCA y a partir de ello obtenían mejores oportunidades para la acumulación. En tanto un tercer núcleo que se ubicaba en un rol intermedio pretendía a través de la cooperativa crear un fondo especial para rescatar a los colonos que se hallaban en problemas y ofrecían una organización total para combatir las arbitrariedades de la JCA, actuando como moderadores dentro del F.C. entre los sectores enfrentados. Este conflicto permaneció durante mucho tiempo y se trasladó también a la Fraternidad Agraria.

El acceso a la propiedad de la tierra no fue fácil ni fue para todos. La promesa de venta de la tierra fue para muchos sólo una promesa como los muestras los constantes juicios de desalojos. Los hijos de los colonos que demandaban tierra para colonizarse en la cercanía de los progenitores no lo conseguían y se marchaban a las ciudades, dando inicio a un lento pero inexorable despoblamiento rural que vaciaba a Colonia Clara.

Los viejos socios del Fondo Comunal se debatían en torno a cómo arraigar a los jóvenes a través del Fondo de Colonización, del programa cultural Agrocul, etc... En tanto pasaban los años y el acceso al crédito y los mejores rindes de la producción agropecuaria permitía a los viejos pobladores cumplir con las deudas y «emanciparse" de la empresa colonizadora para decidir libremente donde asentar su morada. Los colonos judíos, siguiendo la dinámica poblacional de la mayoría de la población rural de la provincia de Entre Ríos se trasladaban a los centros urbanos. 


\title{
Consideraciones finales
}

I

\begin{abstract}
Los que habian abandonado la tierra eran los débiles. Eran los débiles que, incapaces de adaptarse a la nueva vida, habian muerto. Sí, habían muerto para la tierra porque eran incapaces de sacar de ella los elementos necesarios para la vida, y debían seguir su atávica existencia borrascosa, llena de mercantilismo y de servidumbre, sin la altivez inherente al hombre libre y laborioso. Eran los débiles y cobardes porque, incapaces de seguir la ascensión hacia la cumbre, se habían precipitado en el blando lecho de lodo que se extendía a sus pies.
\end{abstract}

Gregorio FingermanN, «LA Eterna LEY».

Este párrafo con el que inicio el capítulo final fue publicado el 22 de noviembre de 1909 en el primer número de El Colono Israelita Argentino, el órgano de difusión de las cooperativas agrarias Fondo Comunal de la Colonia Clara y la Sociedad Agrícola Israelita de Lucienville. Creo que es un buen punto llegada, pues es lo suficientemente significativo para entender el peso del mandato de convertirse en agricultores con el que debieron tramitar la experiencia colonizadora en Argentina los judíos asquenazíes asentados en Colonia Clara, en la provincia de Entre Ríos.

¡Débiles y cobardes eran todos los que se marcharon de Colonia Clara y débiles y cobardes serán todos aquellos que abandonen sus chacras! Además, se los reputaba como traidores porque, al desertar, desobedecían el mandato que les legó el barón Mauricio de Hirsch, quién, sacándolos de la opresión y de la servidumbre, los había guiado a la Tierra Prometida, que no era Palestina sino Argentina, en la lejana América del Sur, para ser redimidos como campesinos, redimidos por el trabajo de la tierra, en libertad. 
Quizás el tono enérgico del texto inicial de la publicación obedecía al espíritu educador y a la búsqueda de anclajes para arraigar al colono a las fértiles pero vírgenes tierras entrerrianas, un modo de alentarlos para continuar en la experiencia y no desfallecer en el camino. Habían trascurrido dieciocho años desde la fundación de la colonia y la empresa no había sido fácil, y, como se avizoraba, tampoco lo sería en el futuro.

Resulta necesario volver a advertir que la inmigración judía a la Argentina fue peculiar. Las causas que determinaron esta emigración fueron diferentes de las de otros grupos migrantes: fue una migración forzada, de origen urbano con destino rural y con una relación contractual con la empresa colonizadora. La violencia y persecución a las que fueron sometidos hizo que la decisión de emigrar, en la mayoría de los casos, fuera distinta a la de los grupos emigrantes no judíos que arribaron masivamente a nuestro país. Para ellos, el tema a afrontar no era la emigración para "hacer la América" y regresar luego al terruño, sino el destierro definitivo.

Estos hombres y mujeres que salieron de la Rusia zarista eran una población que vivía en centros urbanos, a la que le estaba vedado expresamente el acceso a la tierra y su trabajo. Marginados y hacinados en la Zona de Residencia, padecían la intolerancia y el antisemitismo del régimen autoritario y las continuas persecuciones de grupos exaltados que en pogroms atentaban contra sus vidas y sus escasas pertenencias materiales. El barón Mauricio de Hirsch, como respuesta a esta situación, creó la institución filantrópica Ilamada Jewish Colonization Association (JCA) para facilitar su traslado hacia otros países del mundo y con el doble propósito de establecer colonias agrícolas y conformar una clase campesina judía.

Regreso entonces al texto de Fingermann, con el que se proponía enseñar el amor a la tierra y para ello recurría a la imagen de la mujer-madre, alegoría fecunda para entablar relaciones complejas entre amores, culpas y responsabilidades.

Hay ciertos puntos de contacto entre la mujer y la tierra. La tierra es la mujer honrada que no quiere caricias triviales de las prostitutas. Como la mujer, quiere ser amada y comprendida por sus gustos. Para que la tierra fructifique es menester darle lo que necesita y no falsear lo que desea. La tierra no es madrastra. Es la madre 
natural y legítima a la vez, y una madre no engaña... Mas, si alguna vez comete ingratitudes, culpa es del hombre, injusto generalmente, que la impulsa a ello.

El citado autor reconocía que los primeros años de la colonización y la vida en colonia no fueron fáciles, época donde la "naturaleza de las cosas y de los hombres parecían haberse confabulado para poner obstáculos en la marcha progresiva de la colonia». Podemos suponer que no le resultara fácil encontrar explicaciones felices o razones convincentes a la hora de sostener que esa madre que no comete ingratitudes los volvía más vulnerable con años de sequías o de inundaciones o de invasiones de langostas que arruinaban el esfuerzo de todo un año de labor intensa.

Mas, en todo caso, y regresando a un plano terrenal, podríamos sostener que la falta de guías, de expertos y/o profesionales agropecuarios que los capacitaran e indicaran -además de haberles provisto de instrumentos de labranza idóneoscómo roturar la tierra virgen, cómo acceder a la gramínea más indicada y conocer los ciclos productivos para obtener los rindes necesarios a fin de contar con los recursos económicos para abonar las anualidades en tiempo y forma, de modo de ser eximidos de los intereses diferenciados por la mora -los que sumaban un $6 \%$ anual de la cuota-, constituía la razón de peso que conducía a la desazón de los chacareros que pensaban en abandonar la colonia.

Una vez más, Fingermann reforzaba lo que otrora les habían indicado el barón de Hirsch y el director de la Escuela de la Alliance Israélite Universelle, M. Dallen, al despedirlos de la Europa. El deber de no olvidar la misión de ese traslado del pueblo judío a la tierra americana: demostrar al mundo que el judío podía abandonar el comercio para volcarse a actividades productivas y regenerativas como el cultivo de la tierra, redimido por el trabajo de la tierra.

Los hijos pródigos, que volvían a la madre tierra, tras vagar dudoso durante dos mil años, no conservaban ya su imagen en la memoria [...] Separados de la tierra, fueron adoptados por el comercio y el lucro, madrastra falsa y egoísta, que vino a abrirles un círculo estrecho de mezquinas ambiciones. Pero ahora, la tierra exigía a los hombres un amor verdadero para responder con igual cariño y gratitud. Pero iqué 
tarea difícil, sacar aquellos hábitos adquiridos durante tantos siglos en los brazos de la prostituta! Hábitos fortificados y trasmitidos de generación en generación para servir de arma, y no sucumbir en la lucha por la vida [...] y he aquí el desbande: Rotos los azadones, enmohecidos los arados, los hombres inconcientes buscan los falsos halagos de la prostituta que su sangre envenenara, y cuyo virus circulara aún por sus venas. Se lanzan al galope desenfrenado detrás de la fortuna, esperando que de su mágica urna cayese el oro para saciar su sed y dejan a la mujer legítima llorar con lágrimas de abrojos la ingratitud e inconsciencia de los hombres.

La tentación de volver al comercio o al trabajo artesanal o industrial estaba reprimida, pues los contratos firmados prohibían expresamente el abandono del campo, tanto el de Promesa de Venta como el de los arrendamientos, y explícitamente establecían que las chacras debían ser trabajadas personalmente por el colono o por los miembros de su familia, sin ayuda de peones, salvo en los tiempos de cosecha o con el consentimiento previo de la JCA. ${ }^{1}$

Estos inmigrantes asentados en la llanura entrerriana debían convertirse en los "gauchos judíos" que, trabajando la tierra, dejaran atrás el estigma de ser "una raza calificada como pedigüeña y avarienta, lucrativa y sórdida, [para ser transformada] en un pueblo de trabajo edificante, honroso y pacífico".

Este autor de referencia concluye su alegato en que "si bien muchos habían desertado, otros quedan aferrados a la tierra, como los niños ante un peligro se agarran y resguardan en el regazo de la madre".

Nuestro trabajo analizó cómo fue la experiencia colonizadora en Colonia Clara, la más importante de las colonias de Entre Ríos, no sólo por la extensión geográfica sino por el establecimiento de diversas instituciones económicas, sociales y culturales que le imprimieron las notas características del modo y ritmo del proceso de integración al país receptor. Colonia Clara, fundada en 1892, es representativa del conjunto de colonias que cobijaron a inmigrantes provenientes de la Euro-

\footnotetext{
$1_{\text {«Art. }} 4^{\circ}$ Los terrenos arrendados deben ser destinados solamente para la agricultura y ganadería, con exclusión de cualquier otro de destino". Contrato de arrendamiento entre la Jewish Colonization Association y Fridel Rabinovich, fracción de 137 hectáreas en el grupo barón Hirsch de la Colonia Clara, abril de 1906. En Archivo IWO, Caja JCA.
} 
pa oriental que, huyendo de la discriminación y persecución política de la Rusia zarista, se asentaron en la pampa argentina para poner en marcha una experiencia productiva y social condensadora de múltiples sentidos. Luego de los acomodamientos iniciales que se extendieron hasta la primera década del siglo xx y de una prolongada etapa de consolidación, comenzó a partir de mediados de los años 1940 un lento pero permanente proceso de despoblamiento de las colonias por el traslado de su población a los centros urbanos.

Particularmente se estudió cómo fue la vida de los «que quedaron aferrados a la tierra", y en este recorrido necesariamente tuvimos que indagar y descubrir las razones de los abandonos, los que, entendíamos, no podían ser explicados solamente como cobardía, debilidad o traiciones, como lo hacía Fingermann.

Sólo una mirada detenida sobre las condiciones de la experiencia colonizadora pudo brindarnos las claves para explicar las polisémicas causas de los abandonos. Entre ellas emergían las más conocidas y luego las más silenciadas.

Entre las primeras se hallaban las que responden a percepciones nutridas por ciertos prejuicios que sustentan los imaginarios colectivos: a los judíos no le atrae el campo, son citadinos por naturaleza; ante la mínima oportunidad, abandonarán el campo, porque no les gusta la vida rural. Si acordáramos que esta aseveración es correcta, deberíamos extenderla al conjunto de los habitantes de la provincia de Entre Ríos, ya que en 1895 la población rural era del 66,5\%, la que desciende a 46,5\% en 1947, a 39,2\% en 1970, para integrar el 17,8\% en $2001 .^{2}$ Además, debemos tener en cuenta que:

En 1947 el total de la población de la provincia es de 787.362 habitantes. El 91,6\% declara ser católica (720.976 personas). Los responsables de la confección del Censo describen como que profesan como religión ISRAELITA, 11.876 ciudadanos. Los judíos sólo representan el 1,5\% de la población total.

Ahora bien, nuestra investigación demuestra que muchos colonos judíos se fueron del campo no sólo porque lo eligieron. Muchos fueron desalojados y expulsa-

\footnotetext{
2 "Los sentidos de la tierra: entre la explotación ciega y la producción sustentable", en http:// www.fts.uner.edu.ar/publicaciones/fondo/num39/Shunk39.pdf.
} 
dos, costado de la experiencia hasta ahora menos conocido. Experiencias silenciadas por propios y ajenos. El peso que la misión encomendada por el gran benefactor, representada en la imagen de una mano tendida para la salvación, fue utilizado por los diferentes elencos administrativos - la burocracia de la JCA-, que, pretendiendo encarnar la obra del barón de Hirsch, se apropiaban de la promesa y lealtad al filántropo para aplicar medidas arbitrarias, desconociendo las demandas de los colonos que "inventaban" la agricultura en una tierra fértil pero virgen. Obra magna pero difícil a la vez la que nos detuvimos a analizar a lo largo de seis capítulos.

\section{II}

Otras razones acompañaron mis desvelos para emprender esta tarea. Un comentario casual pero lo suficientemente inquietante me ayudó a definir con mayor agudeza mi trabajo. La voz de un joven porteño, integrante de un grupo de estudios académicos sobre judaísmo en Argentina, señaló:

otra vez estos viejos hablando de la epopeya, una vez más señalando el esfuerzo que tuvieron que realizar para asentarse en las colonias, otra vez el mito del esfuerzo y de la tarea ciclópea que no dejan de repetir, una y otra vez!!

El tono del comentario era de molestia. Expresaba su fastidio por la repetición de la narración sobre una gesta heroica que le resultaba exagerada y que tan sólo obedecía al interés de encontrar en el pasado elementos que legitimaran su presente, dándole un poco de brillo a su opaca vida de anciano, tan poco apreciada en la sociedad contemporánea. Exageraciones de los viejos, en perspectiva de los jóvenes.

Entonces me preocupé por preguntar y preguntarme cuánto se conocía sobre esa experiencia colonizadora que había quedado en el pasado, que reunía además el pecado de no haber podido demostrar que los judíos pueden ser agricultores, pues en cuanto tuvieron la oportunidad se fueron a las ciudades. 


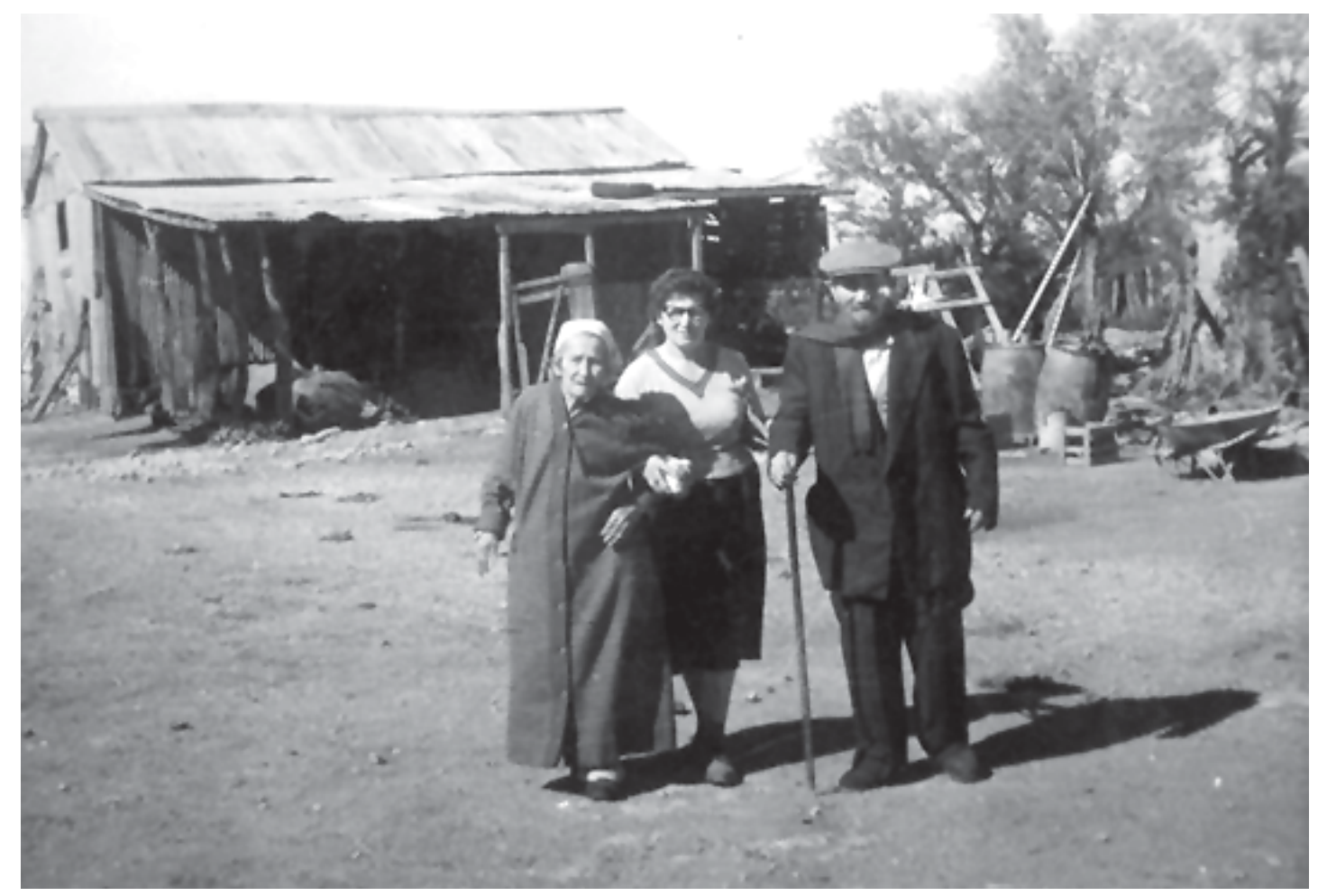

Recurrí a la producción académica para estudiar cómo había sido abordada la colonización agraria judía en nuestro país, y grande fue mi sorpresa al constatar que los trabajos eran escasos y que los pocos estudios que se habían realizado no habían tenido como objeto de análisis al colono judío inmigrante, de modo que su perspectiva no había sido tomada como punto de partida para la reconstrucción histórica, social, cultural e ideológica de la inmigración en las colonias de la JCA.

No obstante, las fuentes documentales, si bien dispersas en distintos repositorios y diseminadas en instituciones o en hogares de los descendientes, estaban dispuestas a brindarnos información estratégica para recuperar las voces de estos actores sociales. No menos importante fue la colección de memorias, de anecdotarios, de biografías e historias de vida, documentales y películas realizados por los descendientes de aquellos colonos, quienes se aferraban a distintos soportes para que la memoria de sus antepasados siguiera estando presente, im- 
portantes intentos para cuidar que ese patrimonio tangible e intangible no cayera en el olvido. ${ }^{3}$

Sin embargo, los historiadores no habíamos sido capaces de pasar del campo de las memorias al plano de la historia, con las reglas intransferibles de nuestro oficio, para poner en el escenario de la producción historiográfica un proceso social, económico, político y cultural singular de honda gravitación en el plano regional y nacional.

En mi memoria profesional, recordaba la invitación en los pasillos de mi Facultad de Humanidades en la que Leonardo Senkman me incitaba a continuar sus primeros abordajes sobre colonización y su preocupación por los procesos de "acriollamiento" de los judíos en el país. En aquellos días, mis preocupaciones intelectuales estaban abocadas a analizar el peso del pasado reciente y los desgarros que las dictaduras en el Cono Sur habían infringido a las sociedades, así como a indagar en los recorridos de esas memorias traumáticas suramericanas. En este derrotero hallé un nuevo punto de encuentro con el tema. La literatura del exilio me devolvía al mismo escenario de la colonización agraria judía en nuestro país. Estos escritores exiliados de la década de 1970, radicados en Europa, habitando el obligado desarraigo, comenzaban nuevas búsquedas de anclajes familiares e identitarios. Esas indagaciones los conducían a comprobar que volvían a desandar los caminos del éxodo forzado de sus abuelos. Cien años después, el camino era inverso. Otros regímenes autoritarios los obligaban a marcharse de su suelo, como el régimen zarista habían hecho con sus antepasados. Esta incursión los conducía al barón de Hirsch, a la JCA y a la experiencia colonizadora en Argentina.

En particular, Alicia Dujovne ponía nuevas pistas a mi trabajo. Esta prolífera autora narra que cuando a su padre se le preguntaba por el lugar de nacimiento,

\footnotetext{
${ }^{3}$ Legado. Memorias de la colonización judía en la Argentina, escrita y dirigida por los cineastas Vivian Imar y Marcelo Trotta sobre la base de una idea de Baruj Tenembaum, y producida por la fundación internacional Raoul Wallemberg, 2001; De Bessarabia a Ente Ríos, con guión y dirección de Pedro Banchik, 2005; Herederos, realizada por Mercedes Prelat con la colaboración de Nora Fistein, Basavilbaso, 2004. Haciendo Patria (David Blaustein, 2007) narra la historia de tres generaciones en la familia del director, estableciendo analogías y diferencias entre la migración huyendo de la persecución en la Rusia zarista y el exilio político de Argentina bajo la dictadura militar.
} 
este no podía precisarlo. Su evocación del pueblo natal se prestaba a dudas. Siempre decía: "Estaba situado en Entre Ríos o en el norte de Santa Fe», moviendo la mano con el mismo gesto de "más o menos", el mismo gesto de indeterminación que utilizaba para definir el origen de sus padres, "Besarabia, Moldavia, Ucrania, Rumania». Carlos Dujovne nació en Carmel, grupo de la Colonia Clara. Ese gesto de indeterminación fue otra imagen fundante para mi trabajo: me propuse reconstruir la experiencia colonizadora, con la paciencia necesaria del trabajo de un porfiado artesano, recolectando las piezas dispersas pero claves para explicar cómo fue la historia de la inmigración agraria en Entre Ríos.

No estaba sola en la tarea. Los aportes teóricos de la historia social renovada se constituían en los soportes que guiaron mi trabajo. Las categorías experiencia, condiciones materiales, vida cotidiana, sociabilidad, historia del poder, imaginarios, memoria, olvido y silencios, lugares de memoria, entre otras tantas, se disponían para sostener mi tarea, que se ocuparía de un colectivo social poco estudiado, el cual abordé sin distanciamiento afectivo, pero con la rigurosidad interpretativa y crítica que la disciplina exige.

Los antecedentes teóricos y metodológicos de la microhistoria me brindaron las herramientas para la elección de caso en estudio: Colonia Clara, una de las dieciséis colonias asentadas en el país, cuyo análisis me permitió poner a prueba la posibilidad de generalización de la experiencia colonizadora judía en Argentina.

Pude reconstruir el entramado de los grupos y aldeas que componían Colonia Clara y señalar en un minucioso listado los nombres de cada uno de los colonos que fueron sus pobladores, documento que adjuntamos en el Anexo a este cuerpo. También adjuntamos la cartografía confeccionada por la JCA con los solares asignados a los colonos, donde en letra manuscrita se pueden identificar los apellidos y la extensión de la chacra donde trabajaron y transitaron la experiencia de chacarero en la llanura del distrito Bergara, en el departamento de Villaguay, los judíos que vinieron de la Europa del Este.

Logré constatar el peso y singularidad de algunas de sus instituciones asociativas. Las cooperativas agrarias, consideradas tradicionalmente como el gran legado del judaísmo al país, fueron además las piezas claves para el arraigo a la tierra de los colonos y sostenimiento en el tiempo de la experiencia coloniza- 
dora. Otras colonias, como Mauricio, en la provincia de Buenos Aires, se despoblaron y desvanecieron muy rápidamente, situación que ha sido explicada por su cercanía a grandes centros poblados, pero en particular por la carencia de una cooperativa que protegiera la producción económica y que también les brindara la posibilidad de construir un modo de vida y de integración social que trasciende la esfera económica.

El Fondo Comunal, la cooperativa agraria S.A., esta estrategia de ayuda mutua y de defensa ante el capital monopólico y la empresa colonizadora, nos brindó el ángulo de observación privilegiado para explicar cómo fue la experiencia colonizadora desde la mirada del colono. Ámbito donde estos chacareros se convirtieron en ciudadanos, donde dirimieron diferencias ideológicas y se retroalimentaron en el debate y el disenso, donde acordaron silenciar cuestiones a ser resueltas entre un "nosotros" judío y que no debían salir hacia el afuera, donde encontraron formas de acuerdo para la vida armoniosa a través de las mediaciones y arbitrajes. Una caja de resonancia de las virtudes como también de las delaciones y comportamientos reñidos con la ética, que nos brinda también los colores necesarios para dar cuenta de la policromía de la experiencia colonizadora, la que mucho tuvo de gesta épica, como fue descripta por Gerchunoff en Los gauchos judíos, con tanto peso en la memoria de la colectividad judía, pero también por la más silenciada Lluvias salvajes de Natalio Budassoff.

Pude constatar también los debates, las angustias y la zozobra de los socios sobre la asimetría de la relación con la empresa colonizadora, quien hacía valer sus recursos financieros y el poder compulsivo que le otorgaba el contrato que firmaba con sus colonos.

En este ejercicio de balance y de conclusiones no cerradas considero que un aporte fue la descripción de la vulnerabilidad de los colonos ante la hegemonía de la empresa colonizadora y de los sucesivos elencos administrativos que impusieron condiciones estrictas y en demasiadas ocasiones arbitrarias, por ende, de difícil cumplimiento, que colocaban al colectivo colonos en condiciones de subalternidad y dependencia desmedida. La mirada estricta, el control exacerbado de la burocracia empresarial, preocupada por la rentabilidad de la empresa colonizadora - la que no padeció ningún quebranto pues se cubrió ampliamente 


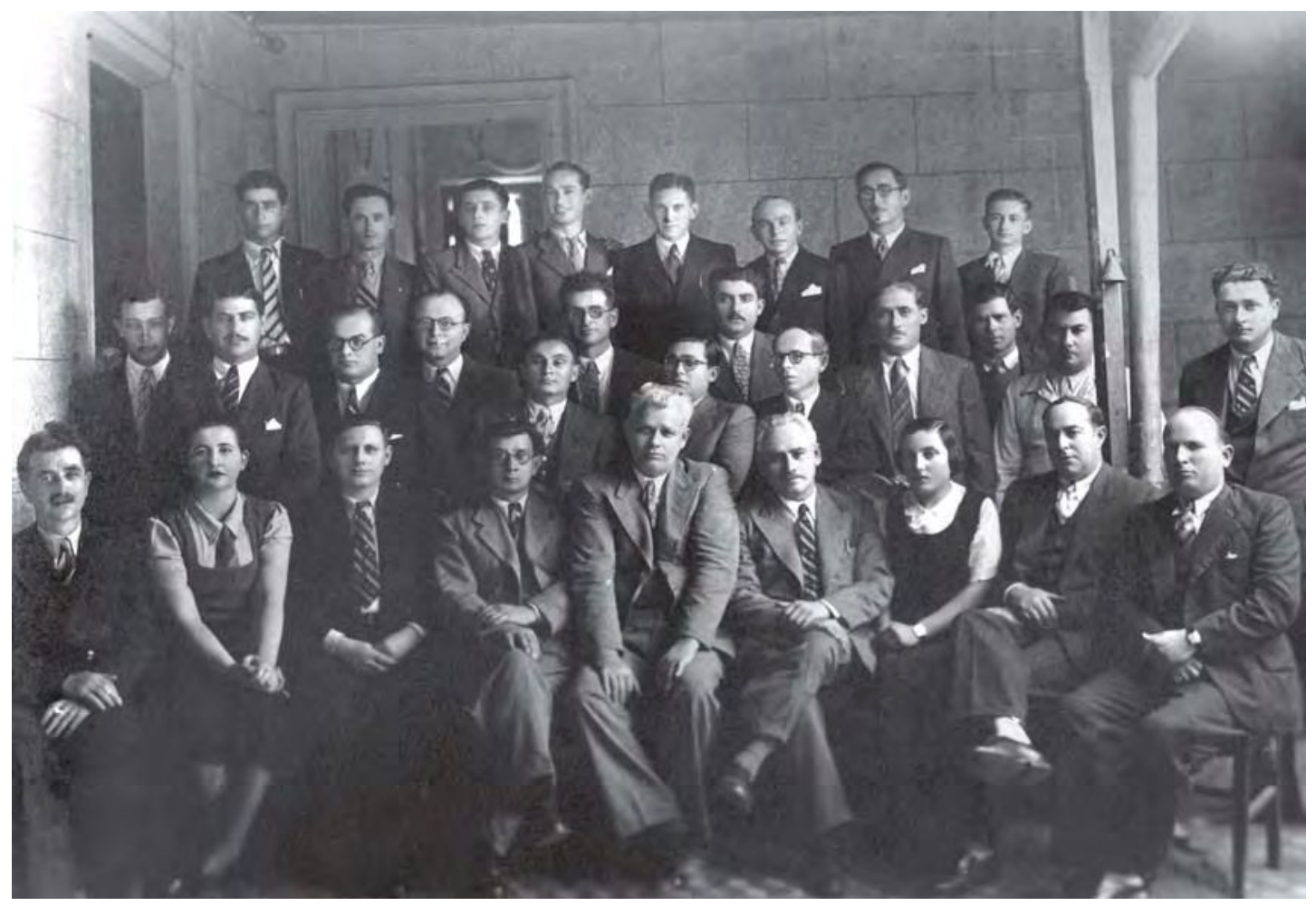

Empleados del Fondo Comunal, 1938-1939. 
con contratos leoninos la cobranza holgada de los dineros invertidos-, condujo a situaciones de desesperación de muchos que debieron abandonar la colonia, desalojados por el incumplimiento, el atraso o falta de pago o algún motivo de infracción a las condiciones establecidas por la JCA. De modo que no todos los colonos abandonaron voluntariamente la colonia.

\section{III}

Pero, entonces, ¿a todos los judíos no les fue bien?, ¿no eligieron marcharse voluntariamente porque el campo los agobiaba?

Estas son preguntas que pudimos responder con nuestra investigación. No a todos los judíos les fue bien ni todos se marcharon voluntariamente del campo. Las razones fueron múltiples y tuvieron distinto peso a lo largo de los sesenta años que constituyeron nuestro período de observación. Con esta salvedad podemos sostener que los motivos que explican las deserciones se pueden agrupar, en primer lugar, en torno a la torpeza, incompetencia e intransigencia de los administradores de la JCA y sus condiciones desmedidas, y en segundo lugar en la dureza del trabajo agrario y la escasa rentabilidad que la experiencia colonizadora brindaba a estos hombres y mujeres. Finalmente, hubo otras razones para abandonar la colonia buscando "un sitio más poblado y más culto, en el que sus conocimientos lingüísticos Ilorasen menos" ${ }^{4}$, alegoría que pretendo que comprenda también al conjunto de niños, ya que para seguir sus estudios primarios debían trasladarse a los pueblos y para completar la escuela secundaria e ingresar a la universidad, asentarse en las grandes ciudades.

Los abandonos voluntarios se hicieron visibles en la década de 1940. Habían trascurrido largamente los veinte años del contrato de Promesa de Venta de la tierra. Si en 1937, de los 797 agricultores de Colonia Clara, habían podido convertirse en propietarios de sus chacras 337 colonos, en 1952 los propietarios eran 662 , favorecidos por la posibilidad de créditos y los rindes económicos. Estas

${ }^{4}$ Dujovne Ortiz, Alicia, El Camarada Carlos. Itinerario de un enviado secreto, Buenos Aires, Aguilar, 2007, p. 24. 
trasformaciones permitieron que el $80 \%$ de los colonos pudieran, ahora "emancipados", decidir qué hacer con sus tierras y dónde instalar su morada. Entre los años 1944 y 1953, se fueron voluntariamente 73 familias de Colonia Clara.

Quizás otra constatación ayude a responder estas preguntas con mayor contundencia. Una buena historia social entrerriana, asignatura pendiente, podrá brindar los elementos que demuestren y respondan fehacientemente esos interrogantes. Esa historia que señale cómo fue el capitalismo agrario en la provincia, que indique los niveles de rentabilidad de la producción y la conformación de la estructura social, podrá explicar también que este "abandono" no fue exclusivo de los judíos, sino que obedeció a un comportamiento generalizado de la población que encontraba en las ciudades mayores oportunidades laborales y mejoras en los estándares de vida.

En perspectiva de los colonos - plasmadas en sus memorias, pero también en la demanda gremial y política-, otro fenómeno condicionó los abandonos: la imposibilidad de los hijos para acceder a la tierra. Como pudimos constatar, esta demanda fue presentada muy tempranamente a los administradores de la JCA. La nueva generación de jóvenes nacidos en nuestro país que solicitaban colonizarse, es decir, acceder al trabajo de la tierra de manera independiente, no tuvo lugar en los planes colonizadores. Dos presupuestos lo impedían. Por un lado, los administradores de la JCA de París sostenían que la obra del barón de Hirsch había establecido que sus prioridades estaban en el socorro de las víctimas europeas, por lo que el problema o destino de los hijos de los colonos era una responsabilidad de los progenitores. Por otro lado, estaba terminantemente prohibido colonizar a los parientes en las cercanías de las chacras, porque ello, sostenían, conduciría al latifundio. Proponían como alternativa para las nuevas generaciones que iniciaran su vida independiente de la tutela familiar en las nuevas colonias, en particular en las tierras adquiridas en los territorios nacionales del Chaco y de La Pampa. Los argentinos podemos entender que estas opciones no eran muy convocantes, ni a principio ni durante todo el siglo xx. Quizá tampoco lo serían hoy, cuando se observan cambios tecnológicos que han elevado las condiciones de vida rural y las distancias se han acortado por el sistema vial y la infraestructura social básica que, aunque con deficiencias, existen. 
Los colonos responsabilizaron a la empresa de no haber contribuido a arraigar a los jóvenes en el campo. Cuando la JCA fue capaz de entender que esta demanda se fundaba en razones de peso para continuar con la experiencia colonizadora y demostró su voluntad de asignar recursos y eliminar las prohibiciones, en los inicios de la década de 1950, los jóvenes ya se habían marchado a las ciudades. Nada se podía hacer.

\section{IV}

Recobrar las voces de los actores de la experiencia colonizadora también posibilitó adentrarnos en un ámbito más silenciado. Los jóvenes que se marchaban de la colonia a las ciudades -y particularmente a las grandes, las que les abría importantes oportunidades de inserción laboral y amplias posibilidades de ascenso social- fueron los responsables del llamado a los hermanos y luego a los padres. Las familias que ya residían en los centros urbanos invitaban a sus parientes y a los paisanos a compartir la vida citadina. Estos testimonios también dan cuenta de que la inserción en las grandes ciudades no fue fácil. La tramitación del traslado no fue para todos una experiencia feliz. Hubo una profunda añoranza por la vida

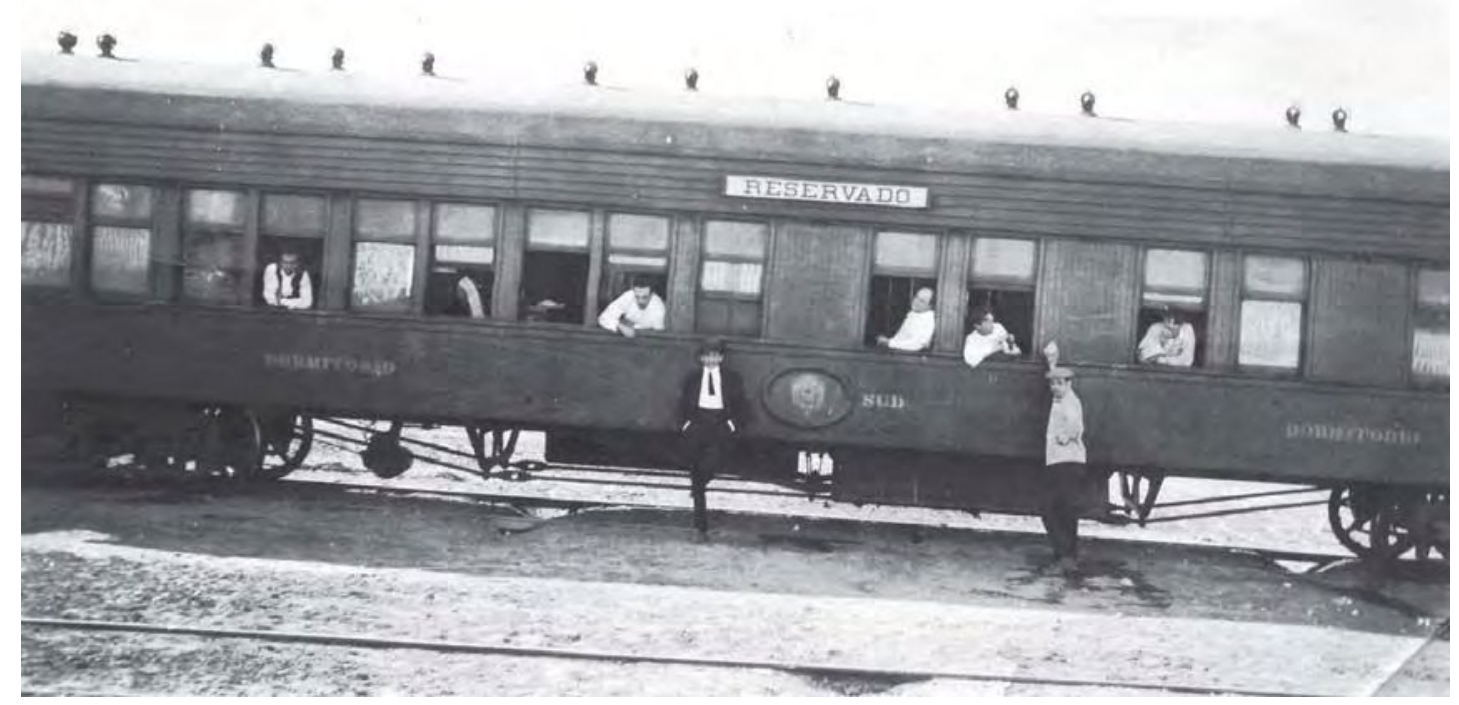


sencilla y un modo de vida en el que las bombachas y las alpargatas les recordaban el placer de pisar un suelo y un paisaje que sentían como suyos, que habían construido con esfuerzo, cuya familiaridad les hacía sentir como propio, constitutivo de su identidad. Es conmovedor el relato del viejo colono que el día anterior a su viaje abrazó a cada uno de sus árboles y se despidió de su tierra silenciosamente. Al sentarse en el tren que lo trasladaba a Buenos Aires, no pudo mirar por la ventana el paisaje que dejaba atrás, fijando sus ojos en el vacío, agobiado por el sentimiento de traición por abandonar a sus paisanos para responder al llamado de sus hijos afincados en la ciudad. Cuenta su viuda que nunca fue feliz vendiendo cigarrillos en un quiosco ubicado en la esquina de Junín y Corrientes. ${ }^{5}$

V

Y si de asignaturas pendientes se trata, muchas son las que quedan a mi cargo. Finalizada esta primera etapa de trabajo, puedo señalar algunas que abordaré en

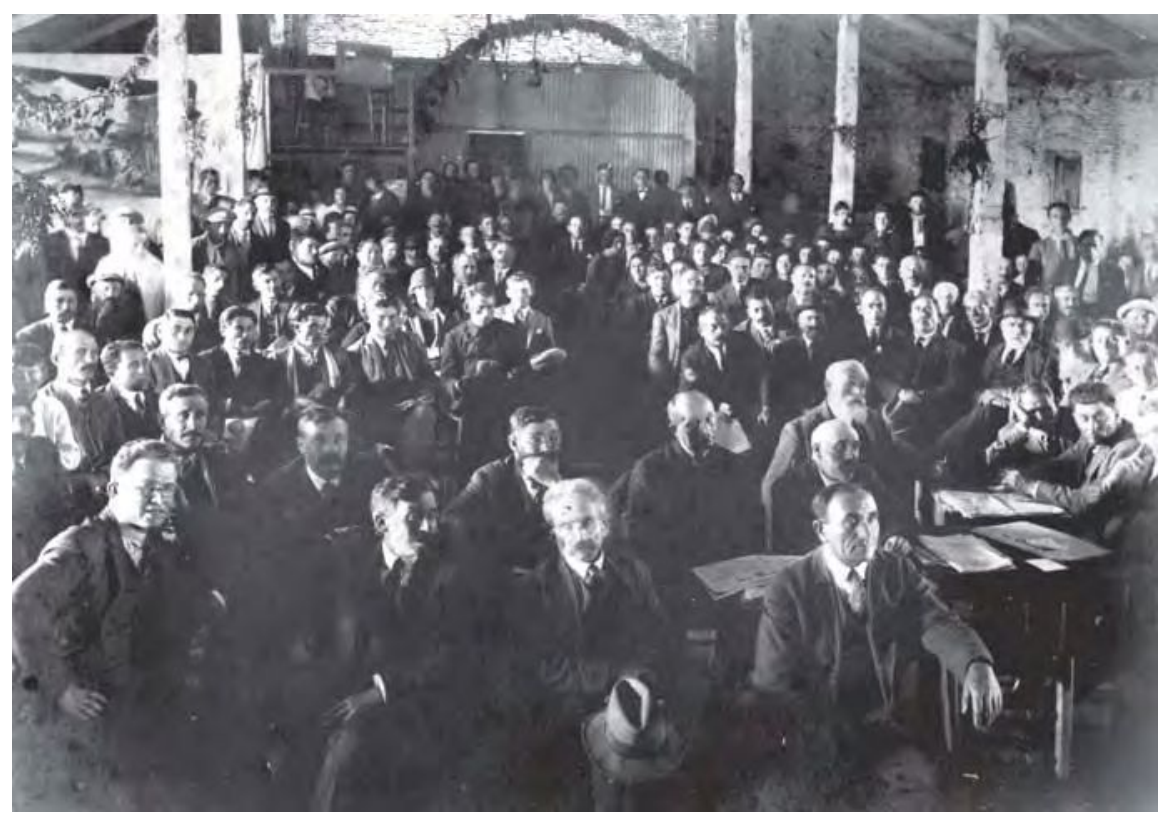

\footnotetext{
${ }^{5}$ Liebermann, José, Tierra Soñada. Episodios de la colonización agraria judía en la Argentina. 1889-
} 1959, Buenos Aires, Luis Lasserre y Cía. Editores, 1959, p. 184. 
las próximas. Tan sólo entre líneas esbocé algunos avances de estas preocupaciones, compelida por la necesidad de focalizar mi escrito en los objetivos trazados para esta primera fase.

Es imprescindible analizar la vida política y los impactos de la política partidaria, el ideario político y sus organizaciones e instituciones, así como las relaciones con las instituciones judías y no judías. Recuperar el impacto de la mirada de los otros, los alcances del antisemitismo, estudiar a los "otros" dentro de Colonia Clara, detectar el peso de la administración y de las autoridades no judías, observar a la población autóctona y su radicación en términos de vecindad, entre otros tantos.

Quedaron intactas demasiadas cajas que contienen cartas, escritos y documentos personales de hombres y mujeres cuyos espacios biográficos nos permitirán enriquecer las reconstrucciones de la vida cotidiana y las trayectorias personales, así como observar las formas de comprender el mundo. Otras también con registros y actas de las instituciones sociales y religiosas y otros tantos textos inéditos.

También, si las energías continúan luego de realizar estos estudios imprescindibles, me propongo contribuir a la escritura de la historia social de la provincia de Entre Ríos, porque, como lo ha dicho de manera inmejorable Alberto Gechunoff, "De allá soy, amigos míos. Soy de los contornos de Villaguay». ${ }^{6}$

\footnotetext{
${ }^{6}$ Gerchunoff, Alberto, Entre Ríos, mi país, Buenos Aires, Plus Ultra, 1973, p. 58.
} 


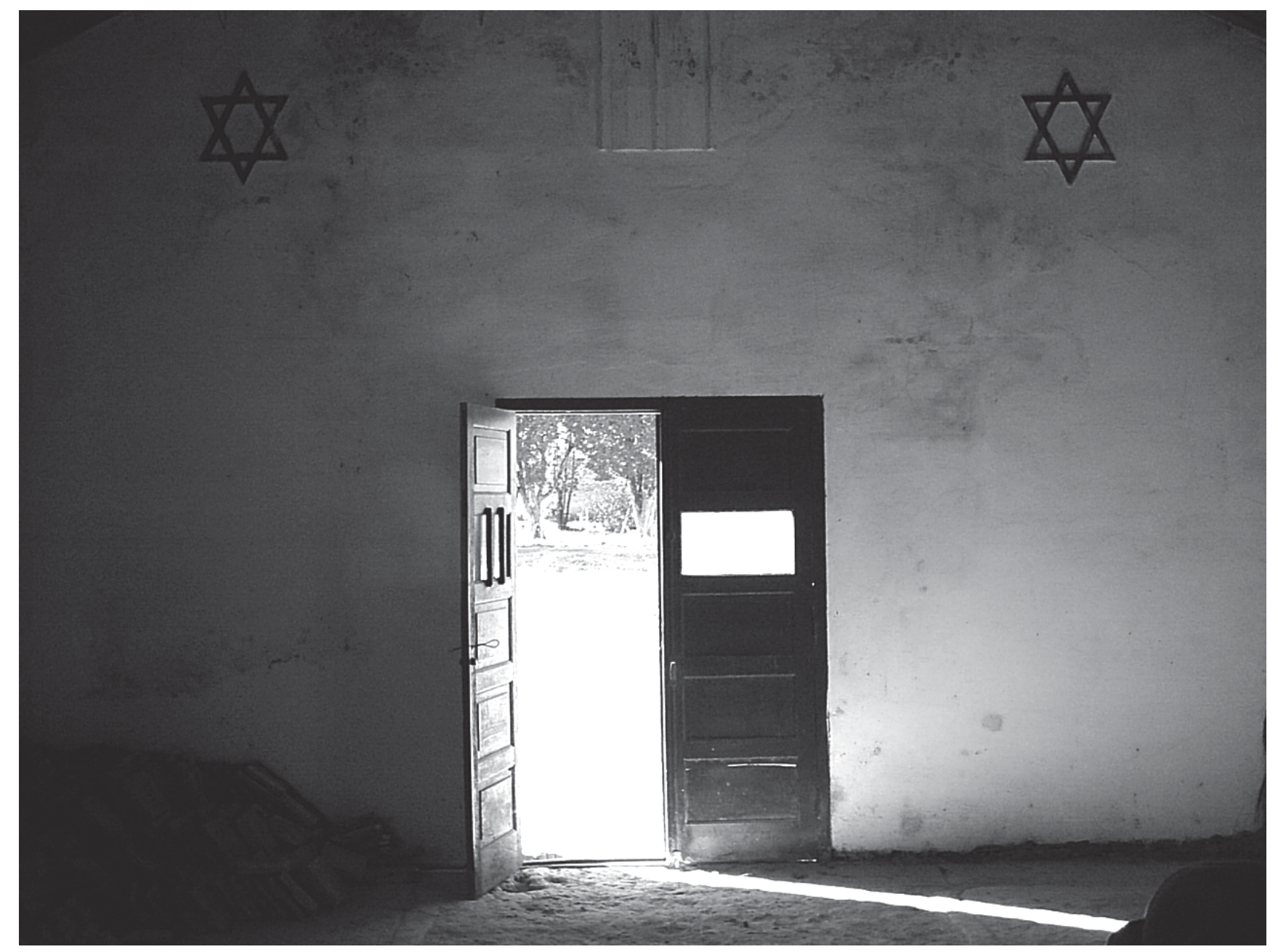

Historia y memoria de la colonización Judía agraria en Entre Ríos. La experiencia de Colonia Clara, 1890-1950 | 361 



\section{Bibliografía}

\section{Bibliografía citada}

AA.VV., Crónicas Judeoargentinas/1. Los pioneros en idish 1890/1944, Buenos Aires, Editorial Milá, 1987.

Anderson, Benedict, Reflexiones sobre el origen y la difusión del nacionalismo, México, FCE, 1993.

Antequeda, Manuel, Breve exposición sobre las escuelas ruso-alemanas e israelitas. Escuelas nacionales. Ley Láinez de la provincia de Entre Ríos, Buenos Aires, Imprenta Mentruyt, 1909.

Armus, Diego, "Diez años de historiografía sobre la inmigración masiva a la Argentina", en Estudios Migratorios Latinoamericanos, № 4, 1986.

Ascolani, Adrián (comp.), La educación en Argentina. Estudios de Historia, Rosario, Ediciones del Arca, 1999.

Avni, Haim, "La agricultura judía en Argentina. ¿Éxito o fracaso?», en Desarrollo Económico, Vol. 22, No 88, enero-marzo de 1983.

- Argentina y la Historia de la inmigración judía. 1810-1950, Buenos Aires, Editorial Universitaria Magnes, 1983.

Bailet Massé, Juan, Informe sobre el estado de la clase obrera, Buenos Aires, Hyspamerica ediciones Argentina S.A., 1985.

Bargman, Daniel, "Construcción de la Nación entre la asimilación de inmigrantes y el particularismo. Las escuelas de las colonias agrícolas judías", en Maronese, Leticia (comp.), Patrimonio cultural y diversidad creativa en el sistema educativo, Buenos Aires, Gobierno de la Ciudad de Buenos Aires, 2006.

Benmergui, Alicia, Historia de Rivera. Disponible en: www.milimcultural.com.ar/historia/index.htm. Bertoni, Lilia Ana, Patriotas, cosmopolitas y nacionalistas. La construcción de la nacionalidad argentina a fines del siglo xx, Buenos Aires, FCE, 2001.

Bjerg, María, Historia de la inmigración en la Argentina, Buenos Aires, Edhasa, 2009.

Bosh, Beatriz, Historia de Entre Ríos, Buenos Aires, Plus Ultra, 1978.

Botana, N. y Gallo E., De la República posible a la República verdadera (1889-1910), Buenos Aires, Ariel, 1997.

Budasoff, Natalio, Lluvias salvajes, Buenos Aires, Ediciones Mosaicos, 1962.

Carioli, Susana, Colonia Mauricio. Génesis y desarrollo de un ideal, Buenos Aires, Editorial del Archivo, 1991. 
Carli, Sandra, "Modernidad, diversidad cultural y democracia en la historia educativa entrerriana. (1883-1930), en Puiggrós, Adriana, Historia de la educación en la Argentina. Tomo IV: La educación en las provincias y territorios nacionales, Galerna, 1993.

- Entre Ríos. Escenario Educativo, 1883-1930, Paraná, Facultad de Ciencias de la Educación de la UNER, 1995.

Casanova, Julián, La historia social y los historiadores, Barcelona, Crítica, 1997.

Chartier, Roger, El mundo como representación, Barcelona, Gedisa, 1999.

Chiaramonte, S., Finvarb, E. y otros, Tierra de promesas. 100 años de colonización judía en Entre Ríos. Colonia Clara, San Antonio y Lucienville, Buenos Aires, Ediciones Nuestra Memoria, 1995.

Corral, Verónica A. y Marshall, Carolina M., Cooperativas Agrarias en Argentina. Disponible en: http://www.ucema.edu.ar/posgrado/download/tesinas2006/MADE_Corral.pdf.

Devoto, Fernando, Historia de la inmigración en la Argentina, Buenos Aires, Sudamericana, 2003.

Dubnov, Simón, Historia contemporánea del pueblo judío, Buenos Aires, Sociedad Hebraica Argentina, 1925.

Dujovne Ortiz, Alicia, El árbol de la gitana, Buenos Aires, Alfaguara, 1997.

- El Camarada Carlos. Itinerario de un enviado secreto, Buenos Aires, Aguilar, 2007.

Epstein, Diana, "Maestros marroquíes. Estrategia educativa e integración. 1892-1920", en Anuario IEHS, $N^{\circ}$ 12, 1997, Facultad de Ciencias Humanas, Universidad Nacional del Centro, Tandil, Argentina.

Fairman, Silvia C., Mate y Samovar, Buenos Aires, Lumen, 2000.

Feierstein, Ricardo, Historia de los Judíos Argentinos, Buenos Aires, Ameghino Editora, 1999.

Feierstein, Ricardo, Vida cotidiana de los judíos argentinos. Del gueto al country, Buenos Aires, Sudamericana, 2007.

Fernández, Alejandro E. (ed.), La inmigración española en la Argentina. Buenos Aires, Biblos, 1999.

Fistein, Nora, Colonia Lucienville. El rescate del pasado mantendrá viva la memoria, Basavilbaso, 2004.

Flier, Patricia, Los desvelos de los historiadores ante el pasado reciente: los desafíos metodológicos al incorporar los estudios de los imaginarios autoritarios. Los archivos del terror, Quito, junio de 2009. Publicado en Actas.

Fontana, Josep, Historia: análisis del pasado y proyecto social, Barcelona, Crítica, 1999.

Frischer, Dominique, El Moisés de las Américas. Vida y obra del barón de Hirsch, Buenos Aires, El Ateneo, 2004.

Gellner, Ernest, Naciones y nacionalismo, Madrid/Buenos Aires, Alianza, 1991.

Gerchunoff, Alberto, Los gauchos judíos, Buenos Aires, Biblioteca Nacional y Ediciones Colihue, 2007.

- Entre Ríos, mi país, Buenos Aires, Plus Ultra, 1973. 
- "Noticias sobre la inmigración judía", en 50 años de colonización judía en la Argentina, Buenos Aires, DAIA, 1939.

Gerstner, Laura Oliva., Biblio 3W Revista Bibliográfica de Geografía y Ciencias Sociales (Serie documental de Geo Crítica), Universidad de Barcelona, Vol. XIII, № 779, 25 de marzo de 2008.

Ginzburg, Carlo, El queso y los gusanos, Barcelona, Muchnik Editores S.A, 1994.

Gómez Sollano, Marcela y Corenstein Zaslav, Martha, "La educación judía en México y Argentina. Tendencias pedagógicas y zonas fronterizas". Disponible en: www.comie.org.mx/ congreso/memoria/v9/.../PRE1178898469.pdf.

González y González, Luis, Obras 5 (Primera parte). Pueblo en vilo, México, El Colegio Nacional, 2002.

Gutiérrez, Talía Violeta, Educación, agro y sociedad. Políticas educativas en la región pampeana. 1897-1955, Buenos Aires, Universidad Nacional de Quilmes, 2007.

Haupt, Georges, El historiador y el movimiento obrero, Madrid, Siglo XXI, 1986.

Heffes, Gisela (comp.), Judíos/Argentinos/Escritores, Buenos Aires, Ediciones Atril, 1999. Herzl, Tehodor, The complete Diary, 1895, en Herzl Press and T. Yoseloff, 1960.

Hobsbawm, Eric, Sobre la historia, Barcelona, Crítica, 1998.

Huyssen, A., En busca del futuro perdido. Cultura y memoria en tiempos de globalización, México, FCE, 2002.

Jelin, Elizabeth, Los trabajos de la memoria, Madrid/Buenos Aires, Siglo XXI, 2002.

Jitrik, Noé, El ejemplo de la familia. Ensayos y trabajos sobre literatura argentina, Buenos Aires, Eudeba, 1998.

- La historia crítica de la literatura argentina, Buenos Aires, Emecé, 2007.

Justo, Juan Bautista, Discursos y escritos políticos, Buenos Aires, El Ateneo, 1933

Korol, Juan Carlos y Sábato, Hilda, Cómo fue la inmigración irlandesa en Argentina, Buenos Aires, Plus Ultra, 1981.

Kreimer, Jaime, Aportes de la colectividad judía al cooperativismo nacional, Rosario, Centro Cultural Israelita, 1984.

Lewin, Boleslao, "Los judíos en el agro argentino", en Mundo Israelita, ediciones del 15 de mayo de 2008, 5 de junio de 2008 y 26 de junio de 2008 .

- Cómo fue la inmigración judía a la Argentina, Buenos Aires, Plus Ultra, 1971.

Liberman, Arnoldo, Éxodo y exilio. Saldos y retazos de una identidad, España, Sefarad Editores, 2006.

Liebermann, José, Tierra Soñada. Episodios de la colonización agraria judía en la Argentina. 1889-1959, Buenos Aires, L y L ediciones, 1959.

López de Borche, Celia, Cooperativismo y Cultura, Entre Ríos, Editorial de Entre Ríos, 1987. Ameghino Editora, 1999.

López, Celia, "Ciclo productivo y marco institucional. Bancos agrícolas y cooperativas agrarias entrerrianas entre 1920 y 1940". Disponible en: http://eh.net/XIIICongress/cd/ papers/57L\%F3pez39.pdf. 
López, Susana Mabel, Representaciones de la Patagonia. Colonos, científicos y políticos (1870-1914), La Plata, Ediciones Al Margen, 2002.

Maronese, Leticia (comp.), Patrimonio cultural y diversidad creativa en el sistema educativo, Buenos Aires, Gobierno de la Ciudad de Buenos Aires, 2006.

Mateo, Graciela, "Cooperativismo agrícola en el litoral pampeano: su expansión, entre la tradición y la política agraria peronista”. Disponible en: http://www.fee.tche.br/sitefee/ download/jornadas/2/h10-05.pdf.

Mendelson, José, "Génesis de la colonia Judía en la Argentina", en 50 años de colonización judía en la Argentina, Buenos Aires, DAIA, 1939.

Merener, David, El cooperativismo en Entre Ríos. Los Congresos Argentinos de la Cooperación, Buenos Aires, Ediciones Intercoop Argentina, Cuadernos de Cultura Cooperativa, 1972.

Míguez, Eduardo José, "Acerca de la inmigración italiana en una compilación reciente (L'Italia nella società argentina)", en Devoto, F. y Rosoli, G., Estudios Migratorios Latinoamericanos, $\mathrm{N}^{\circ} 10,1988$.

Miranda, Justo José, Villaguay, mi pueblo, Entre Ríos, Ediciones Comarca, 1977. Moradiellos, Enrique, El oficio del historiador, Madrid, Siglo XXI, 1994.

Moya, José C., "Notas sobre las fuentes para el estudio de la inmigración española en Buenos Aires", en Estudios Migratorios Latinoamericanos, N 4, 1986.

Mulhall. M. G., Manual de las Repúblicas del Plata, Buenos Aires, Imprenta del Standard, Londres, Edward Stanford, 1876.

Ochoa de Eguileor, Jorge, ¿Dónde durmieron nuestros abuelos. Los hoteles de inmigrantes de la ciudad de Buenos Aires, Buenos Aires, ICOMOS, 2000.

Onega, Gladys S., La inmigración en la literatura argentina (1880-1910), Buenos Aires, CEAL, 1982.

Otero, Hernán (dir.), El mosaico argentino. Modelos y representaciones del espacio y de la población, siglos XIX-XX, Buenos Aires, Siglo XXI, 2004.

Panettieri, José, La crisis de 1890, Buenos Aires, CEAL, 1984.

Patroni, Adrián, Los trabajadores en la Argentina, Buenos Aires, Imprenta, Litografía y Encuadernación Chacabuco 664 y 67, 1897.

Prieto, Adolfo, La literatura autobiográfica argentina, Buenos Aires, CEAL, 1982.

Puiggrós A., Historia de la educación en la Argentina, Tomo IV: La educación en las provincias y territorios nacionales, Galerna, 1993.

Quiroga, Osvaldo, Villa Domínguez... 100 años de Historia. 1890-1990, Comisión Profestejo del Centenario.

Reguera, Andrea, "La individualización de la inmigración. Inserción e identidad en tierras nuevas. Argentina (1840-1904)", en Boletín Americanista, N53, 2003.

Ricoeur, Paul, La lectura del tiempo pasado: memoria y olvido, Madrid, Universidad Autónoma de Madrid, 1999. 
Rojas Mix, Miguel, El Imaginario. Civilización y cultura del siglo XXI, Buenos Aires, Prometeo Libros, 2006.

Romero, Elena, "La Religión Judía", en La espiral, Espacio para el Pensamiento y las Culturas del Valle del Ebro. Disponible en: http://www.laespiral.es.

Rubel, Yaacov, "Creación, apogeo y crisis de los institutos de formación docente dependientes de la AMIA", en Mundo Israelita, 8 y 15 de diciembre de 2000.

Samuel, Raphael, "Historia popular. Historia del pueblo", en Historia popular y teoría socialista, Madrid, Crítica, 1984.

Sarlo, Beatriz, "Literatura e Historia”, en Boletín de Historia Social Europea, № 3, La Plata, 1991.

Sartelli, Eduardo, Campo de batalla. Crisis agraria, tecnología y cooperativas en el agropampeano, 1910-1935, presentada en VI Jornadas Inter Escuelas Departamentos de Historia, La Pampa, 1997.

Schallman, Lázaro, Orígenes de la colonización agrícola judía en la Argentina, Buenos Aires, Instituto Judío Argentino de cultura e información, 1964.

- Historia de los "pampistas", Buenos Aires, Congreso Judío Latinoamericano, 1971.

Schers, David, "Inmigrantes y política: los primeros pasos del Partido Sionista Socialista Poalei Sion en la Argentina, 1910-1916", en ElAL, Universidad de Tel Aviv, Vol. 3, № 2 , julio-diciembre de 1992.

Schmuckler, Héctor, "La memoria en riesgo". Quinta ponencia de "Crecer en el GuetoCrecer en el Mundo", Encuentro Internacional de Intelectuales Judíos, Rosario, Argentina. Disponible en: www.jccenters.org.

Sebreli, Juan José, La cuestión judía en Argentina, Buenos Aires, Tiempo Contemporáneo, 1968.

Senkman, Leonardo, "La nación imaginaria de los escritores judíos latinoamericanos", en Revista Iberoamericana, Vol. LXVI, № 19, abril-junio de 2000.

- "Identidades colectivas de los colonos judíos en el campo y la ciudad entrerrianos", en Boxer Liwerant, J. y Gojman de Bakal, A., Encuentro y Alteridad: Vida y Cultura Judía en America Latina, México, Fondo de Cultura Económica, Universidad Nacional Autónoma de México, Universidad Hebrea de Jerusalem, 1999.

- La colonización judía. Gente y Sociedad, Buenos Aires, Centro Editor de América Latina, 1984.

- "Los gauchos judíos. Una lectura desde Israel, Universidad Hebrea de Jerusalén", en Estudios Interdisciplinarios de America Latina y el Caribe, Vol. 10, № 1, enero-junio de 1999

Shallman, Lázaro, "Evocación de una figura olvidada de la colonización judía», en Mundo israelita, edición del 27 de agosto de 1960.

Shalom Argentina: huellas de la colonizacioin judiìa, Buenos Aires, Ministerio de Turismo, Cultura y Deporte, 2001. 
Sigwald Carioli, Susana, Colonia Mauricio; Génesis y desarrollo de un ideal, Carlos Casares, Archivo Histórico Antonio Mayo, 1978.

Sokolov, Nahum, Histoire du sionisme, Londres, 1910.

Stutschewsky, Joachim, Memorias de un músico judío [en hebreo]: (La vida sin compromiso), Tel Aviv, 1977.

Suriano, Juan, La cuestión social en Argentina, 1870-1943, Buenos Aires, La Colmena, 2000.

Tedesco, Juan Carlos, Educación y Sociedad en la Argentina. (1880-1945), Buenos Aires, Siglo XXI, 1986.

Todorov, Tzvetan, Los abusos de la memoria, Barcelona, Paidós, 2000.

Toker, Eliahu (selección y traducción), El resplandor de la palabra judía. Antología de la poesía ídish del siglo XX, Buenos Aires, Pardés, 1981.

Traverso, Enzo, Los marxistas y la cuestión judía, La Plata, Ediciones Al Margen, 2003. - El pasado, instrucciones de uso. Historia, memoria, política, Madrid, Marcial Pons, 2007.

Vásquez Bronfman, Ana, Las jaulas Invisibles, Santiago de Chile, LOM Ediciones, 2002. Weyne, Olga, Descripción de un ciclo de colonización agrícola. Entre Ríos entre 1870 y 1914, Buenos Aires, Instituto Torcuato Di Tella, 1988.

Zablotsky, Edgardo, El proyecto del Barón de Hirsch. ¿Éxito o fracaso?, Universidad CEMA, mayo de 2005.

- "Colonia Mauricio. Reinterpretación de su aparente fracaso". Doc. de Trabajo 264, UCEMA, mayo 2004. Disponible en: www.ucema.edu.ar/ eez/Publicaciones/...UCEMA/ Revista_Analisis-9-06.pdf.

Zadoff, Efraim, «La educación judía en Buenos Aires Organización e institucionalización (1935-1967), en Mundo Israelita, edición del 28 de agosto de 2007.

\section{Memorias e Informes citados}

Aizicovich, Samuel, Viaje al país de la esperanza, Buenos Aires, Milá, 2006.

Alpherson, Marcos, Colonia Mauricio: memorias de un colono judío, Comisión Centenario de la colonización judía en colonia Mauricio, Carlos Casares.

Arcuschin, María, De Ucrania a Basabilbaso, Buenos Aires, Marymar, 1986.

Bendersky, Benito, "Testimonios de la Vida en la Colonia" (en ídisch), traducción de Rafael Bekenstein: "Oif ídishe felder" (En campos judíos), Buenos Aires, 1931.Brodsky, Norberto, Anécdotas y vivencias de mi buena y larga vida, Buenos Aires, Milá, 2007.

Chajchir, Mauricio, Viaje al país de la esperanza. Relato de un viajero del Pampa.

Corrente WIZO, publicación oficial de la WIZO do Brasil y traducido del portugués al español por el director de Comunicación del Congreso Judío Latinoamericano, Pedro Olschansky, mayo de 2005.

Dickman, Enrique, Recuerdo de un militante socialista, Buenos Aires, La Vanguardia, 1949. 
Dr. Noe Yarcho, su vida, su obra: anécdotas y testimonios sobre la vida del primer médico judío en las colonias agrícolas argentinas, Buenos Aires, Circulo Bnei Akiva, 1986.

Efron, Jedidio, Amdur, mi pueblo natal (en idisch), Buenos Aires, Comité de Homenaje a la Memoria de ledidio Efron, 1973.

- "La Obra escolar en las colonias Judías", en Fondo Comunal, 50 años de vida. (19041954), Villa Domínguez, Sociedad Cooperativa Agrícola Limitada, 1957.

Eidman, José, Diario de mi vida. Mi llegada a la Argentina. Mi cambio definitivo de domicilio a Resistencia, 1952.

Fondo Comunal, 50 años de vida. (1904-1954), Villa Domínguez, Villa Domínguez, Sociedad Cooperativa Agrícola Limitada, 1957.

Fraternidad Agraria, Historia de la Fraternidad Agraria, noviembre de 1948. Archivo IWO, Caja Villa Domínguez.

Garfunkel, Boris, Narro mi vida, Buenos Aires, Optimus, 1960.

Gerchunoff, Alberto, Entre Ríos, mi país. Autobiografía, Buenos Aires, Futuro, 1950.

- Argentina, país de advenimiento, Buenos Aires, Losada, 1952.

Goldemberg, Susana, Cuentos de la abuela gringa, Buenos Aires, Lumen, 1996.

Gukowski, Hélène, Rescate de la herencia cultural. Vida... en las colonias, Buenos Aires, Contexto, 1991.

Hecker de Utchitel, Julia, Vivencias, Np, nd.

Hojman, Baruj, Colonización y cooperación Agraria judía en la Argentina, Buenos Aires, 1961.

Horvath, Ricardo, Memoria y recuerdos de Blackie, Buenos Aires, Colección Todo es Historia, 1979.

Hurvitz, S. I., Colonia Lucienville. $37^{\circ}$ aniversario de la colonización. Homenaje a Mauricio de Hirsch, Buenos Aires, 1932 (en Idish, traducido por Jorge Zentner).

Informe Anual, Colonia Clara, presentado a la Dirección General de la JCA, correspondiente al año 1939. Algunas Impresiones sobre Colonia Clara (1934-1939) Estrictamente Confidencial. Realizado por Ingeniero Samuel Kogan.

Informe del administrador de Colonia Clara, 1944-1954. Algunas Impresiones sobre Colonia Clara sobre movimientos de colonos habidos durante los 10 últimos años. 19441954. Estrictamente Confidencial.

Informe presentado a la Honorable Cámara de Diputados de la provincia de Entre Ríos, febrero de 1921, sobre situación de las Colonias de la JCA, realizado por las Cooperativas Lucienville y Fondo Comunal.

Informe sobre las Colonias de la J.C.A. en Entre Ríos, Estrictamente Confidencial confeccionado por Eugenio Scheppens, 25 de junio de 1904.

Itzigsohn, Sara et al., Integración y marginalidad: Historia de vidas de inmigrantes judías en la Argentin, Buenos Aires, Pardes, 1965.

Jurkowicz, Marta, Cuando las mujeres hacen Memoria. Testimonios de historia oral de la inmigración judía en la Argentina, Buenos Aires, Grupo Editor Latinoamericano, 1999. 
Kaplan, Isaac, Anécdotas, cartas y discurso de Don Miguel Sajaroff, Buenos Aires, Circulo de Estudios Cooperativistas de Buenos Aires, 1965.

- Recuerdos de un agrario cooperativista, 1895-1925, Buenos Aires, Ciirrculo de Estudios Cooperativistas de Buenos Aires, 1962.

Kleiner, Alberto (comp.), Informe de la Jewish Colonization Association sobre la colonización judía en Argentina y Brasil, 1927, Buenos Aires, Libreros y Editores del Polígono, 1983.

Kleiner, Alberto (comp.), Notas y documentos sobre las colonias judías en la Argentina, Buenos Aires, Libreros y Editores del Polígono, 1983.

Leibovich, Adolfo, Apuntes Íntimos. 1870-1946, Buenos Aires, Imprenta López, 1947.

Leven, Narcisse, Cinquante ans d'historie, París, París, 1920, T. II.

Liebermann, José, Aporte judío al agro argentino, Publicación del Instituto Judío Argentino de Cultura e información, Buenos Aires, s/f.

Marchevsky, Elías, El tejedor de Oro. Memorias de un colono judío, Buenos Aires, El bastión, 1947.

Memorias de la Jewish Colonization Association. Su obra en la República Argentina. 18911941, Buenos Aires, 1942.

Memorias de la Jewish Colonization Association. Su obra en la República Argentina. 18911954, Buenos Aires, 1954.

Memorias de la Jewish Colonization Association. Su obra y su finalidad, Buenos Aires, 1961. Miranda, Justo José, Villaguay, mi pueblo, Entre Ríos, Comarca, 1977.

Rapport de L’Administration Centrale pour 1898, Archivo JCA, Fundación IWO.

Schapira, Saúl, Memorias, 1930.

Stutschewsky, Joachim, Memorias de un músico judío [en hebreo]: (La vida sin compromiso), Tel Aviv, 1977.

Tenenbaum, Juan L., Las Colonias agrícolas judías de la Argentina. Primera Conferencia de Investigadores y estudiosos judeo-argentinos en el campo de las Ciencias Sociales y la Historia, Buenos Aires, 1961

Verbitsky, Gregorio, Rivera: Afán de medio siglo, Buenos Aires, Julio Kaufman, 1955.

Wilcken, Guillermo, Las colonias. Informe sobre el estado actual de las colonias agrícolas de la República Argentina, Buenos Aires, Imprenta Oficial, 1873.

Yuchak, Jacobo, Arraigo y Desarraigo, Buenos Aires, 1997, inédito.

- Búsqueda y reencuentro, Buenos Aires, 1996, inédito.

Zeigner, Seidel, Carmel, La Hija del Coronel. Recuerdos de Infancia, 1975.

\section{Bibliografía General Consultada:}

AA.VV, Cien años de narrativa judeoargentina. 1889-1989, Buenos Aires, Milá, 1990. Aizenberg, Edna, "Borges, Gerchunoff y el gaucho ‘judío'», en Raíces, Buenos Aires, primavera 1991. 
Ansaldi, Waldo (comp.), Conflictos obrero-rurales pampeanos. 1900-1937, Buenos Aires, CEAL, 1993, Colección Biblioteca Política Argentina, N 402, 403 y 404.

Ansaldi, Waldo, «Una cabeza sin memoria es como una fortaleza sin guarnición. La memoria y el olvido como cuestión política", en Agora. Revista de Ciencias Sociales, Nueva Época, $\mathrm{N}^{\circ} 7$, Valencia, diciembre de 2002.

Arfuch, Leonor, El espacio biográfico. Dilemas de la subjetividad contemporánea, Buenos Aires, FCE, 2002.

Baczko, Bronislaw, Los imaginarios sociales. Memorias y esperanzas colectivas, Buenos Aires, Nueva Visión, 1991.

Ballent, Anahí y Gorelik, Adrián, "País urbano o país rural: la modernización territorial y sus crisis", en Crisis económica, avance del Estado e Incertidumbre política. (1930-1943). Director del Tomo Alejandro Cattaruza, Nueva Historia Argentina, Tomo 7, Buenos Aires, Sudamericana, 2001.

Barsky O. y Gelman, J., Historia del agro argentino, Buenos Aires, Grijalbo, 2001.

Blanc Blocquel, Adriana et. al., "Conformación del mercado de trabajo en la provincia de Santa Fe (1870-1900). Algunas aproximaciones", en Anuario, Rosario, Escuela de Historia, $\mathrm{N}^{0} 12,1986-1987$.

Boari, Patricia, Fistein, Nora V., Odriozola, Antonio M. et al., "Cooperativa Agrícola Lucienville Ltda", en Mundo Agrario, Vol. 8, № 16, ene./jun. 2008.

Bonaudo, Marta y Sonzogni, Elida, "Cuando disciplinar fue ocupar (Santa Fe, 1850-90)", en Mundo Agrario, Vol. 1, № 1, jul./dic., 2000. Disponible en: http://www.scielo.org.ar/ scielo.php?script=sci_arttext\&pid=\$1515-59942000000200003\&lng=es\&nrm=iso $>$.

Bottarini, Roberto, "Leer, escribir, votar. La conflictiva definición del currículum ciudadano", en Cucuzza, Héctor Rubén (dir) y Pineau, Pablo (co-dir.), Para una historia de la enseñanza de la lectura y la escritura en la argentina, Buenos Aires, Miño y Dávila, 2004.

Boxer Liwerant, J. y Gojman de Bakal, A., Encuentro y Alteridad: Vida y Cultura Judía en America Latina, México, FCE, Universidad Nacional Autónoma de México, Universidad Hebrea de Jerusalem, 1999.

Cesaretti, Fernando y Pagni, Florencia, "La cuestión social en la Argentina, 1890-1910. Una visión desde la saga de Josecito el memorioso", en Mundo Agrario. Revista de estudios rurales, Vol. 4, № 7, segundo semestre de 2003, Centro de Estudios Histórico Rurales, Universidad Nacional de La Plata.

Cherjovsky, Iván, "San Martín versus Maurice de Hirsch: los festejos por el cincuentenario de Moisés Ville", ponencia presentada en Jornadas Bicentenario "Perspectivas, debates y desafíos para las Ciencias Sociales", Tandil, 18, 19 y 20 de agosto de 2010.

Cibotti, Ema, "Del habitante al ciudadano: la condición del inmigrante", en Nueva Historia Argentina. El progreso, la modernización y sus límites (1880-1916), Buenos Aires, Sudamericana, 2000.

Cortés Conde, Roberto, El progreso argentino 1880-1914, Buenos Aires, Sudamericana, 1979. 
Devoto, Fernando y Otero, Hernán, "Veinte años después. Una lectura sobre el crisol de razas, el pluralismo cultural y la historia nacional en la historiografía argentina", en Estudios Migratorios Latinoamericanos, Año 17, N 50, 2003.

Divdonsky, Ricardo F., Diccionario abreviado sobre las colonias Judías en Entre Ríos, Buenos Aires, Ediciones S.J.L., 1987.

Djenderdjian, Julio, Expansión agrícola y colonización en Entre Ríos, 1850-1890: Ios límites y las condiciones de un difícil proceso de cambio productivo, avance de investigación presentado en Reunión Red de Estudios Rurales, Instituto Ravignani, Buenos Aires, abril de 2007.

- Gringos en las pampas. Inmigrantes y colonos en el campo argentino, Buenos Aires, Sudamericana, 2008.

Dujovne, Alejandro, "Entre el iluminismo y la Shoá: paradojas del encuentro entre los judíos y la modernidad", en Prácticas de oficio. Investigación y reflexión en Ciencias Sociales, $N^{\circ} 2$, julio de 2008.

Escliar, Myriam, Mujeres extraordinarias. Biografías noveladas, Buenos Aires, Ensayos, 2009.

Fiksel, Aron, Kaleka, Esteban, Maskin, Jacobo y Kanuicki, Enrique, Tierras vírgenes, Buenos Aires, Pioneros Film, 1965.

Flier, Patricia, "La sociedad del 80: la élite, el inmigrante, el conflicto", en Minellono, María (comp.), Las tensiones de los opuestos. Libros y autores de la literatura argentina del 80, Buenos Aires, Grupo Editorial Latinoamericano, 2003.

Forster, Ricardo, El exilio judío, Buenos Aires, Eudeba, 1999.

Freidenberg, Judith Noemi, The invention of the Jewish gaucho: Villa Clara and the construction of Argentine identity, Austin, TX , University of Texas Press, 2009.

- Memorias de Villa Clara, Museo Histórico Regional de Villa Clara, Entre Ríos, Buenos Aires, Antropofagia, 2005.

Gallo, Ezequiel, La pampa gringa, Buenos Aires, Sudamericana, 1983.

Gardiol, Rita M., Argentina's Jewish Short Story Writers, Ball State Monograph Number Thirty-Two, Ball State University, Muncie, Indiana 47306, 1986.

Girard, Rene, La violencia y lo sagrado, traducción de Joaquín Jordá, Barcelona, Anagrama, 1983.

Girbal-Blacha, Noemí, Ayer y hoy de la Argentina rural. Gritos y susurros del poder económico, Buenos Aires, Red de Editoriales de Universidades Nacionales, 2001.

Goldberg, Florinda, "Literatura Judía latinoamericana. Modelos para armar", en Revista Iberoamericana, Vol. LXVI, No 191, abril-junio 2000.

Gori, Gastón, Colonización suiza en la Argentina. Colonizadores de San Carlos hasta 1860, Santa Fe, 1947.

- Inmigración y colonización, Buenos Aires, Eudeba, 1965.

Grela, Plácido, El grito de Alcorta, Buenos Aires, CEAL, 1985.

Halbwachs, Maurice, Les Cadres Sociaux de la Mémoire, Paris, Albin Michel, 1994. 
Halperin Donghi, Tulio, El espejo de la Historia. Problemas argentinos y perspectivas latinoamericanas, Buenos Aires, Sudamericana, 1987.

Itzigsohn, José A, "La atención médica en las colonias agrícolas de la Argentina", en Judaica Latinoamericana, Estudios históricos-sociales, Vol. 2, editado por Amilat, 17-26, Jerusalem, Universidad Magnes y Universitaria Hebrea, 1993.

James, Daniel y Lobato, Mirta Zaida, "Fotos familiares, narraciones orales y formación de identidades: Ios ucranianos de Berisso", en revista Entrepasados, Año XII, No 24/25, Buenos Aires, 2003.

Jelin, Elizabeth y Langland, Victoria (comps.), Monumentos, memoriales y marcas territoriales, Madrid, Siglo XXI, 2003.

Jelin, Elizabeth y Kaufman, Susana (comps.), Subjetividad y figuras de la memoria, Madrid, Siglo XXI, 2006.

Johnson, Paul, La historia de los Judíos, Barcelona, Vergara, 2003.

Joutard, Philippe, Esas voces que nos Ilegan del pasado, Buenos Aires, FCE ,1999.

Kantor, Manuel, Sobre la obra y el anecdotario de Alberto Gerchunoff, Buenos Aires, 1960 (separata). Este libro fue reproducido por el Congreso Judío Latinoamericano en 1969.

Klein, Alberto, Cinco siglos de Historia: una crónica de la vida en la Argentina, Buenos Aires, Comité Judío Americano, 1976.

Langland, Victoria, "Fotografía y memoria", en Jelin, E. y Longoni, V. (comps.), Escrituras, imágenes y escenarios ante la represión, Madrid-Buenos Aires, Siglo XXI, 2005.

Levinsky, Roxana, Herencias de la inmigración judía en la Argentina, Buenos Aires, Prometeo, 2005.

López, Celia, «Alemanes del Volga en el Cooperativismo Entrerriano: La Agrícola Regional de Crespo en sus primeros veinte años", Fac. de Humanidades, Unco, VIII Jornadas Interescuelas.

- «Pioneras del Cooperativismo Entrerriano: Cooperativas Lucienville y Fondo Comunal en sus Inicios", Fac. de Humanidades, UNAF, XVIII Encuentro de Geohistoria Regional, Formosa, 1997.

- Ciclo productivo y marco institucional. Bancos agrícolas y cooperativas agrarias entrerrianas entre 1920 y 1940.

- Origen, Desarrollo y Ocaso de una Colonia Modelo. Grupo San Gregorio-Colonia Clara. 1894-1945, Concepción del Uruguay, Ediciones el Pensador, 1986.

López, María Pía, La versión y/o las versiones escolares de la historia. Entre Ríos, 18871914, Paraná, UNER, 2009.

Lvovich, Daniel, Nacionalismo y antisemitismo en la Argentina, Buenos Aires, Javier Vergara editor, 2003.

Maffia, Marta M., ¿Dónde están los inmigrantes?, La Plata, Ediciones Al Margen, 2002. Mazo, Julio, Historia de los Ashkenazim de Resistencia, Resistencia, Banco del Iberá con la Cultura, 1987. 
McGee Deutsch, Sandra, Crossing borders, claiming a nation. A history of Argentine Jewish women, 1880-1955, EE.UU., Duke University Press, 2010.

Mélich, Joan-Carles, La lección de Auschwitz, Madrid, Herder, 2004.

Mendelsohn, Ezra, On Modern Jewish Politics, Oxford University Press, 1993.

O'Connell, Arturo, "La Argentina en la depresión; los problemas de una economía abierta", en Desarrollo Económico № 92, 1984.

Ospital, María S., Inmigración y nacionalismo: la Liga Patriótica y la Asociación del Trabajo (1910-1930), Buenos Aires, CEAL, 1994.

Panettieri, José, Argentina. Historia de un país periférico. 1860-1914, Buenos Aires, Centro

Editor de América Latina, 1986.

Panettieri, José, Inmigración en la Argentina, Buenos Aires, Macchi, 1970.

Panettieri, José, Las primeras leyes obreras, Buenos Aires, Centro Editor de América Latina, 1984.

Panettieri, José, Los trabajadores, Buenos Aires, Jorge Álvarez, 1968.

Passerini, Luisa, "Work ideology and consensos under italian fascismo", en History Workshop, № 8, 1979.

Pollak, Michael, Memoria, olvido, silencio. La producción social de identidades frente a situaciones límite, La Plata, Ediciones Al Margen, 2006.

Portelli, A. et al., Historia oral e historias de vida, San José, Costa Rica, FLACSO, Sede Académica de México, México, 1988.

Prieto, Adolfo, La literatura autobiográfica argentina, Buenos Aires, CEAL, 1982.

Raña, E. S., Investigación agrícola La Provincia de Entre-Ríos. Obra descriptiva escrita con motivo de la Exposición Universal de Chicago..., Paraná, Tipografía, Litografía y Encuadernación "La Velocidad", 1893.

Reguera, Andrea, "La individualización de la inmigración. Inserción e identidad en tierras nuevas. Argentina (1840-1904)", en Boletín Americanista, N53, 2003.

Robin, Regine, Identidad, memoria y relato. La imposible narración de sí mismo, Buenos Aires, UBA, 1996.

Roda, Cecilia, «Entre la clase y la etnia. Las colonias judías de Entre Ríos. Comunicaciones», en Razón y Revolución, № 6, otoño de 2000.

Rofman, A. y Romero, L. A., Sistema Socioeconómico y estructura regional en la Argentina, Buenos Aires, Amorrortu, 1997.

Sarlo, Beatriz, "Contar la historia", en Tiempo presente, Buenos Aires, Siglo XXI, 2002.

Schenkolewski-Kroll, Silvia, "Isaac Kaplan y la tierra: Argentina, Eretz Israel y el Estado de Israel», en Judaica Latinoamericana, III, Jerusalem, 1997.

Scherman Filer, Jorge, Identidad y teología: Huellas y tensiones en textos de escritores chilenos de ascendencia judía. Disponible en: http://www.alalite.org/files/chile2008/ ponencias/Jorge\%20Scherman.pdf.

Schwarzstein, Dora, La Historia Oral, Buenos Aires, CEAL, 1991.

Senkman, Leonardo (comp.), El antisemitismo en la Argentina, Buenos Aires, Centro Editor de América Latina, 1989. 
Senkman, Leonardo y Saúl Sosnowski, Fascismo y nazismo en las letras argentinas, Buenos Aires, Lumiere, 2009.

Suez, Perla, Letargo, Buenos Aires, Norma, 2000.

Toker, Eliahu y Weinstein, Ana E., En el espejo de la lengua ídish, selección de textos argentinos, Secretaria de Cultura de la Nación.

- Sitios de la memoria: los cementerios judíos de Liniers y Tablada / idea, investigación, organización y textos, Buenos Aires, AMIA, Comunidad Judía, 2005.

Toker, Eliahu, Alberto Gerchunoff, entre gauchos y judíos, Buenos Aires, Secretaria de Cultura de la Nación-Biblos, 1994. Disponible en: http://www.eliahutoker.com.ar.

Tzvi Tal, "Terror, etnicidad y la imagen del judío en el cine argentino contemporáneo", en Nuevo Mundo Mundos Nuevos, Cuestiones del tiempo presente, 2010. Disponible en: http:// nuevomundo.revues.org/index58355.html.

Vezzetti, Hugo, "Pensar la memoria", en Altamirano, Carlos (ed.), La Argentina en el siglo XX, Buenos Aires, Ariel-Universidad Nacional de Quilmes, 1999.

- Pasado y presente. Guerra, dictadura y sociedad en Argentina, Buenos Aires, Siglo XXI, 2002. Weyne, O., Descripción de un ciclo de colonización agrícola. Entre Ríos entre 1870 y 1914, Buenos Aires, Instituto Torcuato Di Tella, 1988.

White, Hayden, El contenido de la forma. Narrativa, discurso y representación histórica, España, Paidós, 1992.

Winsberg, Morton D., "Jewish Agricultural Colonization in Entre Ríos", en American Journal of Economics and Sociology, $N^{\circ} 27$ (julio de 1968), $N^{\circ} 27$ (octubre de 1968), $N^{\circ} 28$ (abril de 1969).

- Colonia Barón Hirsch: A Jewish Agricultural Colony in Argentina, University of Florida Monographs, Social Sciences N 19, Gainesville, Florida, University of Florida Press, 1964. Yerushalmi, Hayim Yosef, Zajor. La historia judía y la memoria judía, España, Anthropos, 2002.

Yerushalmi, Y., Loraux, N. y otros, Usos del Olvido, Buenos Aires, Nueva Visión, 1998.

\section{Archivos consultados:}

Archivo del Fondo Comunal de Villa Domínguez

Archivo General de la Nación

Archivo Histórico de la provincia de Entre Ríos

Archivo Museo Histórico Municipal de Villaguay

Asociación Israelita de Villaguay

Centro de Documentación e Información sobre el Judaísmo Argentino Marc Turkov, Asociación Mutual Israelita Argentina (AMIA)

Centro de Investigaciones Históricas "Carlos Castello" del Museo Histórico Regional de Villaguay 
Instituto Científico Judío (IWO)

Museo y Archivo Regional de las colonias del Centro de Entre Ríos. Villa Domínguez

5. Entrevistas realizadas por la autora:

Olga Kipen, Basabilbaso

Mauricio Flier, Villaguay

Diana Lejtman, Villaguay

Raúl Kipen, Paraná

6. Cuestionarios semiestructurados respondidos por:

Daniel Aldo Teveles (Buenos Aires, Argentina)

Julio Mazo Efron (Tel Aviv, Israel)

Luis Carlos Caplan (Nueva York, Estados Unidos)

Yauda Kuzniecky Levit (Panamá)

Mauricio Soiget (Buenos Aires, Argentina)

Silvio Huberman (Buenos Aires, Argentina)

Nina Irene Stein (Buenos Aires, Argentina)

Judith Noemí Freidenberg (Maryland, Estados Unidos)

Juan Flier (Rosario, Argentina) 
anexo 



\section{Listado de pasajeros en el barco "Orione" 22 de junio de 1894}

\begin{tabular}{|c|c|c|c|c|c|}
\hline № ORDEN & & APELLIDO & NOMBRES & EDAD & PROFESION \\
\hline 1. & & Seigermann & Gdalie & 58 & Agricultor \\
\hline 2. & & Seigermann & Lea & 56 & Agricultor \\
\hline 3. & & Seigermann & Nuchime & 30 & Agricultor \\
\hline 4. & & Seigermann & Schullim & 26 & Agricultor \\
\hline 5. & & Seigermann & Yankel & 23 & Agricultor \\
\hline 6. & & Seigermann & MosesBeer & 11 & \\
\hline 7. & & Seigermann & Tcharna & 31 & $\bar{A}$ gricultor \\
\hline 8. & & Seigermann & Ruchlia & 19 & Agricultor \\
\hline 9. & & Seigermann & Abraham & 43 & Agricultor \\
\hline 10. & & Seigermann & Liba & 43 & Agricultor \\
\hline 11. & & Seigermann & Hersch & 11 & \\
\hline 12. & & Seigermann & Meer & 5 & \\
\hline 13. & & Seigermann & Elke Lea & 22 & Agricultor \\
\hline 14. & & Seigermann & Witta Feiga & 17 & Agricultor \\
\hline 15. & & Seigermann & Henda & 13 & Agricultor \\
\hline 16. & & Seigermann & Schabra & 68 & Agricultor \\
\hline 17. & & Seigermann & Bassia & 63 & Agricultor \\
\hline 18. & & Reigermann & Ytta & 52 & Agricultor \\
\hline 19. & & Reigermann & MosesBeer & 29 & Agricultor \\
\hline 20. & & Reigermann & Zudik & 17 & Agricultor \\
\hline 21. & & Reigermann & Schulim & 25 & Agricultor \\
\hline 22. & & Reigermann & Aarón & 15 & Agricultor \\
\hline 23. & & Reigermann & Pincus & 13 & Agricultor \\
\hline 24. & & Reigermann & Ruchla & 21 & Agricultor \\
\hline 25. & & Leventhal & Leib & 63 & Agricultor \\
\hline 26. & & Leventhal & Rosa & 60 & Agricultor \\
\hline 27. & & Ydelsohn & Sosie & 38 & Agricultor \\
\hline 28. & & Ydelsohn & Liba & 28 & Agricultor \\
\hline 29. & & Ydelsohn & Moses & 13 & Agricultor \\
\hline 30. & & Ydelsohn & Leiser & 5 & \\
\hline 31. & & Leventhal & Sara & 15 & Agricultor \\
\hline 32. & & Leventhal & Dina & 11 & \\
\hline 33. & & Leventhal & Etta & 13 & Agricultor \\
\hline 34. & Singereisky & Singerensky & Yzul & 39 & Agricultor \\
\hline 35. & Singereisky & Singerensky & Rivka & 40 & Agricultor \\
\hline 36. & Singereisky & Singerensky & Benzion & 15 & Agricultor \\
\hline 37. & Singereisky & Singerensky & Ysaac Meier & 11 & Agricultor \\
\hline 38. & Singereisky & Singerensky & Joseph & 5 & Agricultor \\
\hline 39. & Singereisky & Singerensky & Chaia & 17 & Agricultor \\
\hline 40. & Singereisky & Singerensky & Ytta & 7 & \\
\hline 41. & & Weissmann & Yankel & 17 & Agricultor \\
\hline 42. & & Weissmann & Sura & 14 & Agricultor \\
\hline 43. & & Gitzis & Alter & 36 & Agricultor \\
\hline 44. & & Gitzis & Feiga & 33 & Agricultor \\
\hline 45. & & Gitzis & Motes & 1 & \\
\hline 46. & & Gitzis & Perla & 12 & \\
\hline 47. & & Gitzis & Etta & 4 & \\
\hline 48. & & Sitzer & Berko & 45 & Agricultor \\
\hline 49. & & Sitzer & Moses & 11 & \\
\hline
\end{tabular}




\begin{tabular}{|c|c|c|c|c|c|}
\hline № ORDEN & & APELLIDO & NOMBRES & EDAD & PROFESION \\
\hline 50. & & Sitzer & Mordke & 9 & \\
\hline 51. & & Sitzer & Schimon & 6 & \\
\hline 52. & & Sitzer & Bella & 23 & Agricultor \\
\hline 53. & & Sitzer & Etta & 3 & \\
\hline 54. & & Ripsmann & David & 22 & Agricultor \\
\hline 55. & & Ripsmann & Sara & 17 & Agricultor \\
\hline 56. & & Ripsmann & Etla & 15 & Agricultor \\
\hline 57. & & Lapeinson & Ysaac & 53 & Agricultor \\
\hline 58. & & Lapeinson & Lea & 37 & Agricultor \\
\hline 59. & & Lapeinson & Moses & 24 & Agricultor \\
\hline 60. & & Lapeinson & Charna & 23 & Agricultor \\
\hline 61. & & Lapeinson & Chaia & 17 & Agricultor \\
\hline 62. & & Lapeinson & Abraham & 16 & Agricultor \\
\hline 63. & & Lapeinson & Yankel & 6 & \\
\hline 64. & & Lapeinson & Schmiel & 4 & \\
\hline 65. & & Lapeinson & Chara & 18 & Agricultor \\
\hline 66. & & Lapeinson & Rewka & 11 & \\
\hline 67. & & Lapeinson & Sivscha & 10 & \\
\hline 68. & & Salamoniches & Favvel & 26 & Agricultor \\
\hline 69. & & Kersmann & Alter & 18 & Agricultor \\
\hline 70. & & Kaufmann & Ysaac & 54 & Agricultor \\
\hline 71. & & Kaufmann & Ruchla & 53 & Agricultor \\
\hline 72. & & Kaufmann & Scheina & 21 & Agricultor \\
\hline 73. & & Kaufmann & Yankel & 15 & Agricultor \\
\hline 74. & & Kaufmann & Naftule & 12 & Agricultor \\
\hline 75. & & Kaufmann & Berko & 25 & Agricultor \\
\hline 76. & & Kaufmann & Chaia & 9 & \\
\hline 77. & Rabinovich & Rabinovvitch & Eschiel & 55 & Agricultor \\
\hline 78. & Rabinovich & Rabinovvitch & Sasia & 54 & Agricultor \\
\hline 79. & Rabinovich & Rabinovvitch & Berko & 21 & Agricultor \\
\hline 80. & Rabinovich & Rabinovvitch & Yankel & 19 & Agricultor \\
\hline 81. & Rabinovich & Rabinovvitch & Hersch & 16 & Agricultor \\
\hline 82. & Rabinovich & Rabinovvitch & Rosa & 23 & Agricultor \\
\hline 83. & Rabinovich & Rabinovvitch & Sara & 12 & \\
\hline 84. & Rabinovich & Rabinovvitch & Dvoire & 10 & \\
\hline 85. & & Schkolnik & Yzul & 65 & Agricultor \\
\hline 86. & & Schkolnik & Lea & 59 & Agricultor \\
\hline 87. & & Schkolnik & Heniers Hersch 26 & 26 & Agricultor \\
\hline 88. & & Schkolnik & Ysaac & 18 & Agricultor \\
\hline 89. & & Schkolnik & Bella & 15 & Agricultor \\
\hline 90. & & Schkolnik & Sara & 12 & \\
\hline 91. & & Schkolnik & Chavs & 9 & \\
\hline 92. & & Kaufmann & Hersch & 14 & Agricultor \\
\hline 93. & & Kaufmann & Rivvka & 15 & Agricultor \\
\hline 94. & & Kaufmann & Chana & 9 & \\
\hline 95. & & Lebrinsky & Fischel & 29 & Agricultor \\
\hline 96. & & Lebrinsky & Marie & 27 & Agricultor \\
\hline 97. & & Lebrinsky & Menasche & 2 & \\
\hline 98. & & Lebrinsky & Perla & 6 & \\
\hline 99. & & Lebrinsky & Reise & 4 & \\
\hline 100. & & Finkel & Sara & 65 & Agricultor \\
\hline 101. & & Weissmann & Michel & 34 & Agricultor \\
\hline 102. & & Weissmann & Lea & 36 & Agricultor \\
\hline 103. & & Weissmann & Bella & 3 & \\
\hline 104. & & Sinland & Abraham & 25 & Agricultor \\
\hline 105. & & Sinland & Mindel & 20 & Agricultor \\
\hline 106. & & Weissmann & Schulim & 26 & Agricultor \\
\hline 107. & & Weissmann & Sara & 22 & Agricultor \\
\hline 108. & & Heller & Taube & 45 & Agricultor \\
\hline 109. & & Heller & Ydel & 18 & Agricultor \\
\hline 110. & & Heller & Michel & 14 & Agricultor \\
\hline 111. & & Heller & Ysaac & 11 & \\
\hline 112. & & Heller & Aarón & 5 & \\
\hline 113. & & Heller & Ruckla & 21 & Agricultor \\
\hline
\end{tabular}




\begin{tabular}{|c|c|c|c|c|c|}
\hline № ORDEN & & APELLIDO & NOMBRES & EDAD & PROFESION \\
\hline 114. & & Heller & Guittel & 9 & \\
\hline 115. & & Heller & Chara & 66 & Agricultor \\
\hline 116. & & Feinsilber & Hami & 26 & Agricultor \\
\hline 117. & & Feinsilber & Bala & 22 & Agricultor \\
\hline 118. & & Braverman & Yzul & 58 & Agricultor \\
\hline 119. & & Braverman & Chara & 45 & Agricultor \\
\hline 120. & & Braverman & Baruch & 19 & Agricultor \\
\hline 121. & & Braverman & Hersch & 13 & Agricultor \\
\hline 122. & & Bortman & Moschino & 34 & Agricultor \\
\hline 123. & & Bortman & Brucka & 22 & Agricultor \\
\hline 124. & & Bortman & David & 4 & \\
\hline 125. & & Bortman & Isaac & 3 & \\
\hline 126. & & Burman & Yankel & 35 & Agricultor \\
\hline 127. & & Burman & Civia & 26 & Agricultor \\
\hline 128. & & Burman & Uscher & 7 & \\
\hline 129. & & Burman & Isaac & 1 & \\
\hline 130. & & Burman & Rosa & 6 & \\
\hline 131. & & Burman & Divoira & 4 & \\
\hline 132. & & Yurgel & Nochim & 52 & Agricultor \\
\hline 133. & & Yurgel & Malka & 52 & Agricultor \\
\hline 134. & & Yurgel & Sucher & 19 & Agricultor \\
\hline 135. & & Yurgel & Baruch & 18 & Agricultor \\
\hline 136. & & Yurgel & Abraham & 8 & \\
\hline 137. & & Yurgel & Solel & 14 & Agricultor \\
\hline 138. & & Yurgel & Chara & 10 & \\
\hline 139. & & Bendersky & Chaia & 41 & Agricultor \\
\hline 140. & & Bendersky & Perla & 43 & Agricultor \\
\hline 141. & & Bendersky & Baruch & 17 & Agricultor \\
\hline 142. & & Bendersky & Chara & 22 & Agricultor \\
\hline 143. & & Bendersky & Rosa & 21 & Agricultor \\
\hline 144. & & Bendersky & Bella & 14 & Agricultor \\
\hline 145. & & Bendersky & Nessa & 4 & \\
\hline 146. & & Bendersky & Rika & 9 & \\
\hline 147. & & Roisenfeld & Liler & 50 & Agricultor \\
\hline 148. & & Roisenfeld & Lea & 50 & Agricultor \\
\hline 149. & & Roisenfeld & Sucher & 15 & Agricultor \\
\hline 150. & & Roisenfeld & Schulim & 13 & Agricultor \\
\hline 151. & & Roisenfeld & Sara & 20 & Agricultor \\
\hline 152. & & Kremenchutzky & $\mathrm{N}$ & 26 & Agricultor \\
\hline 153. & & kremenchutzky & Lea & 23 & Agricultor \\
\hline 154. & & Kremenchutzky & Schlema & 5 & \\
\hline 155. & & Kremenchutzky & Chaia & 1 & \\
\hline 156. & & Segal & Haim & 28 & Agricultor \\
\hline 157. & & Segal & Dwoira & 26 & Agricultor \\
\hline 158. & & Segal & Berko & 2 & \\
\hline 159. & & Segal & Ytta & 4 & \\
\hline 160. & Orlander & Oclander & Tobie & 35 & Agricultor \\
\hline 161. & Orlander & Oclander & Rucklia & 27 & Agricultor \\
\hline 162. & Orlander & Oclander & Yona & 7 & \\
\hline 163. & Orlander & Oclander & Meer & 8 & \\
\hline 164. & Orlander & Oclander & Sissel & $11 / 2$ & \\
\hline 165. & Axelrud & Anselrud & Abraham & 48 & Agricultor \\
\hline 166. & Axelrud & Anselrud & Uscher & 21 & Agricultor \\
\hline 167. & Axelrud & Anselrud & Asriel & 15 & Agricultor \\
\hline 168. & Axelrud & Anselrud & Berko & 11 & Agricultor \\
\hline 169. & Axelrud & Anselrud & Ytta & 25 & Agricultor \\
\hline 170. & Axelrud & Anselrud & Henda & 22 & Agricultor \\
\hline 171. & Axelrud & Anselrud & Hema & 17 & Agricultor \\
\hline 172. & Axelrud & Anselrud & Feiga & 7 & Agricultor \\
\hline 173. & & Oklander & Moses & 33 & Agricultor \\
\hline 174. & & Oklander & Echeved & 30 & Agricultor \\
\hline 175. & & Oklander & Yona & 9 & \\
\hline 176. & & Oklander & Lazar & 8 & \\
\hline 177. & & Oklander & Sura & 5 & \\
\hline
\end{tabular}




\begin{tabular}{|c|c|c|c|c|c|}
\hline № ORDEN & & APELLIDO & NOMBRES & EDAD & PROFESION \\
\hline 178. & & Heimichovitz & Haimser & 41 & Agricultor \\
\hline 179. & & Heimichovitz & Ricla o Richa & 40 & Agricultor \\
\hline 180. & & Heimichovitz & Leib & 19 & Agricultor \\
\hline 181. & & Heimichovitz & Michel & 17 & Agricultor \\
\hline 182. & & Heimichovitz & Abraham & 12 & Agricultor \\
\hline 183. & & Heimichovitz & Ysaac & 4 & \\
\hline 184. & & Heimichovitz & Sura & 8 & \\
\hline 185. & & Heimichovitz & María & 5 & \\
\hline 186. & & Heimichowitch & Mordel & 21 & Agricultor \\
\hline 187. & & heimichowitch & Etta & 20 & Agricultor \\
\hline 188. & & heimichowitch & Rossia & 1 & Agricultor \\
\hline 189. & Moscovich & Moschkowitz & Moses & 50 & Agricultor \\
\hline 190. & Moscovich & Moschkowitz & Etta & 45 & Agricultor \\
\hline 191. & Moscovich & Moschkowitz & Ruvin & 18 & Agricultor \\
\hline 192. & Moscovich & Moschkowitz & Perla & 15 & Agricultor \\
\hline 193. & & Oklander & Ysaac & 50 & Agricultor \\
\hline 194. & & Oklander & Sara & 42 & Agricultor \\
\hline 195. & & Oklander & Dvora & 17 & Agricultor \\
\hline 196. & & Oklander & Sittel & 15 & Agricultor \\
\hline 197. & & Lippschiltz & Josse & 34 & Agricultor \\
\hline 198. & & Lippschiltz & Gitta? & 33 & Agricultor \\
\hline 199. & & Lippschiltz & Uscher & 8 & \\
\hline 200. & & Lippschiltz & Abraham & 5 & \\
\hline 201. & & Lippschiltz & Meer & 4 & \\
\hline 202. & & Lippschiltz & Daniel & 1 & \\
\hline 203. & & Lippschiltz & Asmmia & 15 & Agricultor \\
\hline 204. & & Lippschiltz & Bella & 13 & Agricultor \\
\hline 205. & & Lippschiltz & Malza/Malka & 11 & \\
\hline 206. & & Lipschitz & Hersch & 24 & Agricultor \\
\hline 207. & & Lipschitz & Schevva & 20 & Agricultor \\
\hline 208. & & Sobelmann & Smul & 32 & Agricultor \\
\hline 209. & & Sobelmann & Menasche & 7 & \\
\hline 210. & & Sobelmann & Yacob & 1 & \\
\hline 211. & & Sobelmann & Dvoire & 10 & \\
\hline 212. & & Sobelmann & Chara & 6 & \\
\hline 213. & & Sobelmann & Lea & 5 & \\
\hline 214. & & Sobelmann & Bassia & 3 & \\
\hline 215. & & Sobelmann & Etta & 32 & Agricultor \\
\hline 216. & & Funko & Hirsch & 39 & Agricultor \\
\hline 217. & & Funko & Chara & 39 & Agricultor \\
\hline 218. & & Funko & Leiba & 19 & Agricultor \\
\hline 219. & & Funko & Yacob & 16 & Agricultor \\
\hline 220. & & Funko & Menasche & 15 & Agricultor \\
\hline 221. & & Funko & Baruch & 7 & \\
\hline 222. & & Funko & Eliukin & 2 & \\
\hline 223. & & Funko & Malza/Malka & 5 & \\
\hline 224. & & Funko & Etta & 1 & \\
\hline 225. & Padlog & Podloy & Yzul & 31 & Agricultor \\
\hline 226. & Padlog & Podloy & Sara & 28 & Agricultor \\
\hline 227. & Padlog & Podloy & Josè & 8 & \\
\hline 228. & Padlog & Podloy & Morduk & 1 & \\
\hline 229. & Padlog & Podloy & Ester & 6 & \\
\hline 230. & Padlog & Podloy & Feiga & 3 & \\
\hline 231. & & Mobilansky & David & 17 & Agricultor \\
\hline 232. & & Mobilansky & Wolf & 14 & Agricultor \\
\hline 233. & & Mobilansky & Menasche & 10 & \\
\hline 234. & & Mobilansky & Schlema & 6 & \\
\hline 235. & & Mobilansky & Chara & 19 & Agricultor \\
\hline 236. & & Goresman & Helman & 24 & Agricultor \\
\hline 237. & & Goresman & Rosa & 22 & Agricultor \\
\hline 238. & & Goofman & Mackma & 51 & Agricultor \\
\hline 239. & & Goofman & Sara & 47 & Agricultor \\
\hline 240. & & Goofman & Haim & 20 & Agricultor \\
\hline 241. & & Goofman & Abraham & 7 & \\
\hline
\end{tabular}




\begin{tabular}{|c|c|c|c|c|c|}
\hline № ORDEN & & APELLIDO & NOMBRES & EDAD & PROFESION \\
\hline 242. & & Goofman & Slata & 21 & Agricultor \\
\hline 243. & & Goofman & Chara & 17 & Agricultor \\
\hline 244. & & Slillman/Stillman Fame & & 58 & Agricultor \\
\hline 245. & & Slillman/Stillman Fame & Selde & 22 & Agricultor \\
\hline 246. & & Slillman/Stillman Fame & Moses & 17 & Agricultor \\
\hline 247. & & Slillman/Stillman Fame & Marian & 24 & Agricultor \\
\hline 248. & & Slillman/Stillman Fame & Rivka & 15 & Agricultor \\
\hline 249. & & Yussin & Abraham & 52 & Agricultor \\
\hline 250. & & Yussin & Chara & 50 & Agricultor \\
\hline 251. & & Yussin & Leiba & 21 & Agricultor \\
\hline 252. & & Yussin & Hersch & 23 & Agricultor \\
\hline 253. & & Yussin & Bruche & 23 & Agricultor \\
\hline 254. & & Yussin & Aron & 1 & \\
\hline 255. & & Yussin & Yzul & 26 & Agricultor \\
\hline 256. & & Yussin & Henia & 26 & Agricultor \\
\hline 257. & & Yussin & Civia & $11 / 2$ & \\
\hline 258. & Yankelevich & Chaskelewitch & Froiko & 25 & Agricultor \\
\hline 259. & & Chaskelewitch & Feiga & 24 & Agricultor \\
\hline 260. & & Lipschitz & Benzion & 7 & \\
\hline 261. & & Gittlin & Nessain & 29 & Agricultor \\
\hline 262. & & Gittlin & Nechenie & 21 & Agricultor \\
\hline 263. & & Gittlin & Noah & 17 & Agricultor \\
\hline 264. & & Gittlin & Yszrul & 13 & Agricultor \\
\hline 265. & & Gittlin & Keila & 19 & Agricultor \\
\hline 266. & & Gittlin & Perla & 58 & Agricultor \\
\hline 267. & & Beletschinska & María & 21 & Agricultor \\
\hline 268. & Moscovich & Moschvovich & Schlema & 23 & Agricultor \\
\hline 269. & Moscovich & Moschvovich & Elka & 18 & Agricultor \\
\hline 270. & & Furer & Schlema & 48 & Agricultor \\
\hline 271. & & Furer & Mache & 48 & Agricultor \\
\hline 272. & & Furer & Matur & 22 & Agricultor \\
\hline 273. & & Furer & Rachmiel & 13 & Agricultor \\
\hline 274. & & Furer & Selma & 11 & \\
\hline 275. & & Furer & Bella & 17 & Agricultor \\
\hline 276. & & Furer & Chara & 15 & Agricultor \\
\hline 277. & & Scholinz & Samuel & 18 & Agricultor \\
\hline 278. & & Scholinz & Sara & 19 & Agricultor \\
\hline 279. & & Suratschkes & Rosenzvit & 43 & Agricultor \\
\hline 280. & & Suratschkes & Risca & 40 & Agricultor \\
\hline 281. & & Suratschkes & Ysaac & 15 & Agricultor \\
\hline 282. & & Suratschkes & Morka & 13 & Agricultor \\
\hline 283. & & Suratschkes & Selim & 8 & \\
\hline 284. & & Suratschkes & Sossia & 20 & Agricultor \\
\hline 285. & & Suratschkes & Sura & 18 & Agricultor \\
\hline 286. & & Suratschkes & Rachel & 12 & \\
\hline 287. & & Suratschkes & Golda & 5 & \\
\hline 288. & & Suratschkes & Dima & 3 & \\
\hline 289. & & Suratschkes & Frima & 1 & \\
\hline 290. & ¿Levenson? & Leventon & A & 41 & Agricultor \\
\hline 291. & ¿Levenson? & Leventon & Selda & 36 & Agricultor \\
\hline 292. & ¿Levenson? & Leventon & Abraham & 13 & Agricultor \\
\hline 293. & ¿Levenson? & Leventon & Leila & 14 & Agricultor \\
\hline 294. & Padlog & Podlog & Hirsch & 50 & Agricultor \\
\hline 295. & Padlog & Podlog & Beilla & 49 & Agricultor \\
\hline 296. & Padlog & Podlog & Abraham & 19 & Agricultor \\
\hline 297. & Padlog & Podlog & Moses & 16 & Agricultor \\
\hline 298. & Padlog & Podlog & Ruvvin & 8 & \\
\hline 299. & Padlog & Podlog & Dobrusch & 20 & Agricultor \\
\hline 300. & Padlog & Podlog & María & 11 & \\
\hline 301. & Padlog & Podlog & Haime & 47 & Agricultor \\
\hline 302. & Padlog & Podlog & Hema & 32 & Agricultor \\
\hline 303. & Padlog & Podlog & Bezolel & 19 & Agricultor \\
\hline 304. & Padlog & Podlog & Muckine & 4 & \\
\hline 305. & Padlog & Podlog & Leib & 2 & \\
\hline
\end{tabular}




\begin{tabular}{|c|c|c|c|c|c|}
\hline № ORDEN & & APELLIDO & NOMBRES & EDAD & PROFESION \\
\hline 306. & Padlog & Podlog & Scheina & 8 & \\
\hline 307. & Padlog & Podlog & Tcharna & 68 & Agricultor \\
\hline 308. & Matusevich & Matozovitch & Froim & 30 & Agricultor \\
\hline 309. & Matusevich & Matozovitch & Zittla & 20 & Agricultor \\
\hline 310. & Matusevich & Matozovitch & Elie & $11 / 4$ & \\
\hline 311. & Matusevich & Matozovitch & Natta & 7 & \\
\hline 312. & Matusevich & Matozovitch & Zippe & 5 & \\
\hline 313. & Matusevich & Matozovitch & Cossia & $21 / 2$ & \\
\hline 314. & Matusevich & Matozovitch & Minda & $11 / 2$ & \\
\hline 315. & Schejtman? & Schlechtman & Pincus & 52 & Agricultor \\
\hline 316. & Schejtman? & Schlechtman & Lea & 52 & Agricultor \\
\hline 317. & Schejtman? & Schlechtman & Muchin & 24 & Agricultor \\
\hline 318. & Schejtman? & Schlechtman & Leiser & 19 & Agricultor \\
\hline 319. & Schejtman? & Schlechtman & Dwdoira & 22 & Agricultor \\
\hline 320. & Schejtman? & Schlechtman & Renie & 17 & Agricultor \\
\hline 321. & Schejtman? & Schlechtman & Reissie & 14 & Agricultor \\
\hline 322. & & Salzman & Pincus & 40 & Agricultor \\
\hline 323. & & Salzman & Esher & 39 & Agricultor \\
\hline 324. & & Salzman & Schlema & 18 & Agricultor \\
\hline 325. & & Salzman & Yankel & 14 & Agricultor \\
\hline 326. & & Salzman & Dwoira & 6 & \\
\hline 327. & & Salzman & Todres & 23 & Agricultor \\
\hline 328. & & Salzman & Enta & 21 & Agricultor \\
\hline 329. & Ragatki & Rogalzka & Daniel & 57 & Agricultor \\
\hline 330. & Ragatki & Rogalzka & Vitta & 59 & Agricultor \\
\hline 331. & Ragatki & Rogalzka & Elie & 21 & Agricultor \\
\hline 332. & Ragatki & Rogalzka & Meer & 18 & Agricultor \\
\hline 333. & Ragatki & Rogalzka & Schlema & 13 & Agricultor \\
\hline 334. & & Mirtchuk & Yzul & 41 & Agricultor \\
\hline 335. & & Mirtchuk & Mincha & 41 & Agricultor \\
\hline 336. & & Mirtchuk & Sisenka & 18 & Agricultor \\
\hline 337. & & Mirtchuk & Ysaac & 16 & Agricultor \\
\hline 338. & & Mirtchuk & Rucklia & 10 & \\
\hline 339. & & Ygancher & Simón & 47 & Agricultor \\
\hline 340. & & Ygancher & Blume & 44 & Agricultor \\
\hline 341. & & Ygancher & Ysaac & 21 & Agricultor \\
\hline 342. & & Ygancher & Morduk & 7 & \\
\hline 343. & & Ygancher & Rucka & 22 & Agricultor \\
\hline 344. & & Ygancher & Rivka & 16 & Agricultor \\
\hline 345. & Giguer? & Schiger & Josse & 49 & Agricultor \\
\hline 346. & Giguer? & Schiger & Sura & 42 & Agricultor \\
\hline 347. & Giguer? & Schiger & Mooses & 21 & Agricultor \\
\hline 348. & Giguer? & Schiger & Hersch & 19 & Agricultor \\
\hline 349. & Giguer? & Schiger & Mordke & 15 & Agricultor \\
\hline 350. & Giguer? & Schiger & Leisser & 13 & Agricultor \\
\hline 351. & Giguer? & Schiger & Heila/hecla & 18 & Agricultor \\
\hline 352. & & Bendersky & Moses & 36 & Agricultor \\
\hline 353. & & Bendersky & Sura & 31 & Agricultor \\
\hline 354. & & Bendersky & Leib & 12 & Agricultor \\
\hline 355. & & Bendersky & Beniamen & 6 & \\
\hline 356. & & Bendersky & Abraham & 3 & \\
\hline 357. & & Bendersky & ysaac & 2 & \\
\hline 358. & & Melamud & Selma & 8 & \\
\hline 359. & & Melamud & Chaia & 23 & Agricultor \\
\hline 360. & & Melamud & Bima & 21 & Agricultor \\
\hline 361. & & Melamud & Lea & 17 & Agricultor \\
\hline 362. & & Melamud & Yankel & 16 & Agricultor \\
\hline 363. & & Melamud & Hamich & 24 & Agricultor \\
\hline 364. & & Melamud & Feiga & 22 & Agricultor \\
\hline 365. & & Schapira & Moses & 37 & Agricultor \\
\hline 366. & & Schapira & Rachel & 35 & Agricultor \\
\hline 367. & & Schapira & Noé & 16 & Agricultor \\
\hline 368. & & Schapira & Schema & 9 & \\
\hline 369. & & Schapira & Morduck & 2 & \\
\hline
\end{tabular}




\begin{tabular}{|c|c|c|c|c|c|}
\hline № ORDEN & & APELLIDO & NOMBRES & EDAD & PROFESION \\
\hline 370. & & Schapira & Sara & 13 & Agricultor \\
\hline 371. & & Schapira & Ema & 10 & \\
\hline 372. & & Schapira & Schija & 5 & Agricultor \\
\hline 373. & Kuschneroff? & Huschinerff & Hersch & 42 & Agricultor \\
\hline 374. & Kuschneroff? & Huschinerff & Tauba & 38 & Agricultor \\
\hline 375. & Kuschneroff? & Huschinerff & Leib & 17 & Agricultor \\
\hline 376. & Kuschneroff? & Huschinerff & Abraham & 15 & Agricultor \\
\hline 377. & Kuschneroff? & Huschinerff & Joseph & 13 & Agricultor \\
\hline 378. & Kuschneroff? & Huschinerff & Mendel & 8 & \\
\hline 379. & Kuschneroff? & Huschinerff & Rachel & 4 & \\
\hline 380. & Kuschneroff? & Huschinerff & Malka & 9 & \\
\hline 381. & Kuschneroff? & Huschinerff & Moise & 4 & \\
\hline 382. & Saitzof? & Saiezeff & Joseph & 21 & Agricultor \\
\hline 383. & Saitzof? & Saiezeff & Ester & 20 & Agricultor \\
\hline 384. & Saitzof? & Saiezeff & Chamaia & 20 & Agricultor \\
\hline 385. & Saitzof? & Saiezeff & Chaia & 18 & Agricultor \\
\hline 386. & & Kaplan & Elie & 36 & Agricultor \\
\hline 387. & & Kaplan & Rose & 35 & Agricultor \\
\hline 388. & & Kaplan & Aizins & 10 & \\
\hline 389. & & Kaplan & Gnessia & 12 & \\
\hline 390. & & Kaplan & Sara & 8 & \\
\hline 391. & & Kaplan & Schlema & 6 & \\
\hline 392. & & Kaplan & Etta & 4 & \\
\hline 393. & & Kaplan & Mascka & 1 & \\
\hline 394. & & Feldman & Ychiel & 36 & Agricultor \\
\hline 395. & & Feldman & Scharna & 35 & Agricultor \\
\hline 396. & & Feldman & Aarón & 8 & \\
\hline 397. & & Feldman & Ruvvin & 2 & \\
\hline 398. & & Feldman & Sara & 14 & Agricultor \\
\hline 399. & & Feldman & Feiga & 6 & Agricultor \\
\hline 400. & & Funk & Zalel & 53 & Agricultor \\
\hline 401. & & Funk & Feiga & 45 & Agricultor \\
\hline 402. & & Funk & Scklema & 17 & Agricultor \\
\hline 403. & & Funk & Yankel & 13 & Agricultor \\
\hline 404. & & Funk & Froim & 2 & \\
\hline 405. & & Funk & Esther & 19 & Agricultor \\
\hline 406. & & Funk & Rachel & 9 & \\
\hline 407. & & Funk & Chara & 8 & \\
\hline 408. & & Funk & Lea & 4 & \\
\hline 409. & & Blugermann & Froim & 47 & Agricultor \\
\hline 410. & & Blugermann & Moise & 16 & Agricultor \\
\hline 411. & & Blugermann & Meer & 15 & Agricultor \\
\hline 412. & & Blugermann & Abraham & 10 & \\
\hline 413. & & Blugermann & Selmam & 4 & \\
\hline 414. & & Blugermann & Schlome & 5 & \\
\hline 415. & & Blugermann & Rachel & 6 & \\
\hline 416. & & Lipschitz & Leib & 49 & Agricultor \\
\hline 417. & & Lipschitz & Chana & 49 & Agricultor \\
\hline 418. & & Lipschitz & Liba & 16 & Agricultor \\
\hline 419. & & Lipschitz & Abraham & 30 & Agricultor \\
\hline 420. & & Lipschitz & Miva & 25 & Agricultor \\
\hline 421. & & Lipschitz & Yeruchin & 2 & \\
\hline 422. & & Lipschitz & Wolf & 2 & \\
\hline 423. & & Feldman & Yzrul & 35 & Agricultor \\
\hline 424. & & Feldman & Rebeca & 26 & Agricultor \\
\hline 425. & & Feldman & Schamuel & 2 & \\
\hline 426. & & Feldman & Leiba & $11 / 2$ & \\
\hline 427. & & Feldman & Rachel & 5 & \\
\hline 428. & & Blugermann & Ester & 19 & Agricultor \\
\hline 429. & Rosenthal? & Roisemtula & Yzul & 42 & Agricultor \\
\hline 430. & Rosenthal? & Roisemtula & Sara & 33 & Agricultor \\
\hline 431. & Rosenthal? & Roisemtula & Yudel & 15 & Agricultor \\
\hline 432. & Rosenthal? & Roisemtula & Malza/Malka & 9 & \\
\hline 433. & & Kaner & Haim & 26 & Agricultor \\
\hline
\end{tabular}




\begin{tabular}{|c|c|c|c|c|c|}
\hline № ORDEN & & APELLIDO & NOMBRES & EDAD & PROFESION \\
\hline 434. & & Kaner & Ana & 23 & Agricultor \\
\hline 435. & & Weisman & David & 54 & Agricultor \\
\hline 436. & & Weisman & Passa & 54 & Agricultor \\
\hline 437. & & Weisman & Abraham & 23 & Agricultor \\
\hline 438. & & Weisman & Pessa & 22 & Agricultor \\
\hline 439. & & Utchitel & Berks & 48 & Agricultor \\
\hline 440. & & Utchitel & Esther & 38 & Agricultor \\
\hline 441. & & Utchitel & Schlema & 19 & Agricultor \\
\hline 442. & & Utchitel & Joseph & 17 & Agricultor \\
\hline 443. & & Utchitel & Malka & 10 & \\
\hline 444. & & Utchitel & Yankel & 7 & \\
\hline 445. & & Utchitel & Yzul & 5 & \\
\hline 446. & & Utchitel & Chana & 14 & Agricultor \\
\hline 447. & & Utchitel & Lea & 1 & \\
\hline 448. & & Weissmann & Schulim & 54 & Agricultor \\
\hline 449. & & Weissmann & Chara & 47 & Agricultor \\
\hline 450. & & Weissmann & Schema & 23 & Agricultor \\
\hline 451. & & Weissmann & Froim & 21 & Agricultor \\
\hline 452. & & Weissmann & ysaac & 17 & Agricultor \\
\hline 453. & & Weissmann & Hersch & 9 & \\
\hline 454. & & Weissmann & Pincus & 6 & \\
\hline 455. & & Weissmann & Rivka & 14 & Agricultor \\
\hline 456. & & Weissmann & Malka & 11 & \\
\hline 457. & & Barcovvsky & Samuel & 36 & Agricultor \\
\hline 458. & & Barcovvsky & Chara & 34 & Agricultor \\
\hline 459. & & Barcovvsky & David & 12 & \\
\hline 460. & & Barcovvsky & Schaia Wolff & 4 & \\
\hline 461. & & Barcovvsky & Ester & 13 & Agricultor \\
\hline 462. & & Barcovvsky & Blume & 8 & \\
\hline 463. & Dunayevich? & Dunavvich & Tobia & 34 & Agricultor \\
\hline 464. & Dunayevich? & Dunavvich & Tcharna & 28 & Agricultor \\
\hline 465. & Dunayevich? & Dunavvich & Gdalie & 7 & \\
\hline 466. & Dunayevich? & Dunavvich & Wolf & 3 & \\
\hline 467. & Dunayevich? & Dunavvich & Elie & 2 & \\
\hline 468. & & Feldmann & Zurich & 27 & Agricultor \\
\hline 469. & & Feldmann & Ytta & 17 & Agricultor \\
\hline 470. & & Rubalsky & Charkel & 49 & Agricultor \\
\hline 471. & & Rubalsky & Ester & 43 & Agricultor \\
\hline 472. & & Rubalsky & Joseph Haim & 15 & Agricultor \\
\hline 473. & & Rubalsky & Wolko & 11 & \\
\hline 474. & & Rubalsky & Siler & 9 & \\
\hline 475. & & Rubalsky & Rubin Noach & 18 & Agricultor \\
\hline 476. & & Rubalsky & ysaac & 15 & Agricultor \\
\hline 477. & & Rubalsky & Schmuel & 13 & Agricultor \\
\hline 478. & & Rubalsky & Rivka & 17 & Agricultor \\
\hline 479. & & Rubalsky & Malka & 7 & \\
\hline 480. & & Rubalsky & Gittla & 3 & \\
\hline 481. & & Raskowsky & Begiamin & 32 & Agricultor \\
\hline 482. & & Raskowsky & Cipa & 29 & Agricultor \\
\hline 483. & & Raskowsky & Schimel Sch & 3 & \\
\hline 484. & & Aksenfeld & Uscher & 25 & Agricultor \\
\hline 485. & & Aksenfeld & Reissie & 20 & Agricultor \\
\hline 486. & & Soem & Ysabella & 21 & Agricultor \\
\hline 487. & & Raskansky & Mendel & 53 & Agricultor \\
\hline 488. & & Raskansky & Sobel & 54 & Agricultor \\
\hline 489. & & Raskansky & Moses & 24 & Agricultor \\
\hline 490. & & Raskansky & Chaika & 15 & Agricultor \\
\hline 491. & & Raskansky & Etla & 12 & \\
\hline 492. & & Kleimann & Moschko & 38 & Agricultor \\
\hline 493. & & Kleimann & Ruchile & 38 & Agricultor \\
\hline 494. & & Kleimann & Abraham & 14 & Agricultor \\
\hline 495. & & Kleimann & Berko & 11 & \\
\hline 496. & & Kleimann & Simón & 7 & \\
\hline 497. & & Kleimann & Mordko & $11 / 2$ & \\
\hline
\end{tabular}




\begin{tabular}{|c|c|c|c|c|}
\hline № ORDEN & APELLIDO & NOMBRES & EDAD & PROFESION \\
\hline 498. & Kleimann & Pincus Herch & 4 & \\
\hline 499. & Kleimann & Gittla & 8 & \\
\hline 500. & Raitzer & Yosel & 37 & Agricultor \\
\hline 501. & Raitzer & Zivia & 33 & Agricultor \\
\hline 502. & Raitzer & Haim & 13 & Agricultor \\
\hline 503. & Raitzer & Yankel & 8 & \\
\hline 504. & Raitzer & Michel & 4 & \\
\hline 505. & Raitzer & Chara & 14 & Agricultor \\
\hline 506. & Raitzer & Frima & 2 & \\
\hline 507. & Finkel & Schlema & 47 & Agricultor \\
\hline 508. & Finkel & Godda & 46 & Agricultor \\
\hline 509. & Finkel & Schulim Sch & 19 & Agricultor \\
\hline 510. & Finkel & Froim & 18 & Agricultor \\
\hline 511. & Finkel & Narschovva & 15 & Agricultor \\
\hline 512. & Finkel & Tcharna & 6 & \\
\hline 513. & Raskowsky & Berko & 37 & Agricultor \\
\hline 514. & Raskowsky & Lea & 35 & Agricultor \\
\hline 515. & Raskowsky & Moschko & 21 & Agricultor \\
\hline 516. & Raskowsky & Simón & 16 & Agricultor \\
\hline 517. & Raskowsky & Haim & 16 & Agricultor \\
\hline 518. & Raskowsky & Lasar & 12 & \\
\hline 519. & Raskowsky & ysaac & 9 & \\
\hline 520. & Raskowsky & Creime & 5 & \\
\hline 521. & Raskowsky & Rucklia & 7 & \\
\hline 522. & Raskowsky & Dwoira & 4 & \\
\hline 523. & Wranesky & Schoel & 49 & Agricultor \\
\hline 524. & Wranesky & Chara & 44 & Agricultor \\
\hline 525. & Wranesky & Lea & 22 & Agricultor \\
\hline 526. & Wranesky & Chanza & 20 & Agricultor \\
\hline 527. & Wranesky & Rosa & 9 & \\
\hline 528. & Ymas & Abraham & 46 & Agricultor \\
\hline 529. & Ymas & Leia & 40 & Agricultor \\
\hline 530. & Ymas & Haim & 20 & Agricultor \\
\hline 531. & Ymas & David & 17 & Agricultor \\
\hline 532. & Ymas & Yankel & 9 & \\
\hline 533. & Ymas & Mariann & 21 & Agricultor \\
\hline 534. & Ymas & Chara & 19 & Agricultor \\
\hline 535. & Ymas & Yosel & 4 & \\
\hline 536. & Chalezci & Wolf & 43 & Agricultor \\
\hline 537. & Chalezci & Rachel & 42 & Agricultor \\
\hline 538. & Chalezci & Joseph & 24 & Agricultor \\
\hline 539. & Chalezci & Chana & 24 & Agricultor \\
\hline 540. & Chalezci & Yankel & 2 & \\
\hline 541. & Romansky & Muchin & 52 & Agricultor \\
\hline 542. & Romansky & Frima Ytta & 35 & Agricultor \\
\hline 543. & Romansky & Abraham & 21 & Agricultor \\
\hline 544. & Romansky & Joseph & 17 & Agricultor \\
\hline 545. & Romansky & Feiga & 14 & Agricultor \\
\hline 546. & Romansky & Malka & 12 & \\
\hline 547. & Blugermann & Abe & 48 & Agricultor \\
\hline 548. & Blugermann & Frima & 45 & Agricultor \\
\hline 549. & Blugermann & Elu & 23 & Agricultor \\
\hline 550. & Blugermann & Meer & 18 & Agricultor \\
\hline 551. & Blugermann & ysaac & 13 & Agricultor \\
\hline 552. & Blugermann & Yankel & 7 & \\
\hline 553. & Blugermann & Chara & 16 & Agricultor \\
\hline 554. & Blugermann & Chana & 10 & \\
\hline 555. & Sollert & Abraham & 34 & Agricultor \\
\hline 556. & Sollert & Chara & 23 & Agricultor \\
\hline 557. & Sollert & Yohuda & $11 / 2$ & \\
\hline 558. & Sollert & Scheindel & 3 & \\
\hline 559. & Sbarsky & Samuel & 37 & Agricultor \\
\hline 560. & Sbarsky & Esteher & 34 & Agricultor \\
\hline 561. & Sbarsky & Hersch & 12 & \\
\hline
\end{tabular}




\begin{tabular}{|c|c|c|c|c|c|}
\hline № ORDEN & & APELLIDO & NOMBRES & EDAD & PROFESION \\
\hline 562. & & Sbarsky & Yacob & 2 & \\
\hline 563. & & Sbarsky & Etta & 11 & \\
\hline 564. & & Sbarsky & Chana & 9 & \\
\hline 565. & & Sbarsky & Rosa & 2 & \\
\hline 566. & Kuschneroff? & kuschmireff & Hersch & 37 & Agricultor \\
\hline 567. & Kuschneroff? & kuschmireff & Gittel & 35 & Agricultor \\
\hline 568. & Kuschneroff? & kuschmireff & Leib & 17 & Agricultor \\
\hline 569. & Kuschneroff? & kuschmireff & Naftule & 16 & Agricultor \\
\hline 570. & Kuschneroff? & kuschmireff & Selmam & 1 & Agricultor \\
\hline 571. & Kuschneroff? & kuschmireff & Rivka & 13 & Agricultor \\
\hline 572. & Kuschneroff? & kuschmireff & Dvosia & 9 & \\
\hline 573. & Kuschneroff? & kuschmireff & Lea & 6 & \\
\hline 574. & Kuschneroff? & kuschmireff & Ytta & 3 & \\
\hline 575. & & Brodsky & Abraham & 59 & Agricultor \\
\hline 576. & & Brodsky & Bela & 55 & Agricultor \\
\hline 577. & & Brodsky & Sossia & 22 & Agricultor \\
\hline 578. & & Brodsky & Samuel & 37 & Agricultor \\
\hline 579. & & Brodsky & Sara & 32 & Agricultor \\
\hline 580. & & Brodsky & Hersch & 2 & \\
\hline 581. & & Brodsky & Frima & 9 & \\
\hline 582. & & Brodsky & Fride & 7 & \\
\hline 583. & & Brodsky & Eidel & 5 & \\
\hline 584. & & Brodsky & Leib & 33 & Agricultor \\
\hline 585. & & Brodsky & Feiga & 25 & Agricultor \\
\hline 586. & & Brodsky & Lea & 6 & \\
\hline 587. & & Brodsky & Frada & 5 & \\
\hline 588. & & Brodsky & Chaia & $11 / 2$ & \\
\hline 589. & & Brasckevies & ysaac & 34 & Agricultor \\
\hline 590. & & Brasckevies & Ruckla & 30 & Agricultor \\
\hline 591. & & Brasckevies & Hersch & 8 & \\
\hline 592. & & Brasckevies & Freide & 7 & \\
\hline 593. & Bogatin & Bagatine & Salomón & 37 & Agricultor \\
\hline 594. & Bogatin & Bagatine & Dina & 28 & Agricultor \\
\hline 595. & Bogatin & Bagatine & Meir & 10 & \\
\hline 596. & Bogatin & Bagatine & Moise & 7 & \\
\hline 597. & Bogatin & Bagatine & Edel & 5 & \\
\hline 598. & & Sbarsky & Leib & 31 & Agricultor \\
\hline 599. & & Sbarsky & Bazcka & 24 & Agricultor \\
\hline 600. & & Sbarsky & Schmerke & 2 & \\
\hline 601. & & Sbarsky & Guessa & 1 & \\
\hline 602. & Seiligson & Seligion & Schmerko & 35 & Agricultor \\
\hline 603. & Seiligson & Seligion & Rackel & 39 & Agricultor \\
\hline 604. & Seiligson & Seligion & Selmann & 10 & \\
\hline 605. & Seiligson & Seligion & Seilig & 8 & \\
\hline 606. & Seiligson & Seligion & ysaac & 5 & \\
\hline 607. & Seiligson & Seligion & Sara & 12 & \\
\hline 608. & Seiligson & Seligion & Machman & 7 & \\
\hline 609. & Seiligson & Seligion & Mascha & 3 & \\
\hline 610. & Seiligson & Seligion & Bassia & 1 & \\
\hline 611. & Seiligson & Seligion & Ysik & 53 & Agricultor \\
\hline 612. & Seiligson & Seligion & Lea & 49 & Agricultor \\
\hline 613. & Seiligson & Seligion & Alter & 23 & Agricultor \\
\hline 614. & Seiligson & Seligion & Risca & 18 & Agricultor \\
\hline 615. & & Stammer & Alter & 42 & Agricultor \\
\hline 616. & & Stammer & Lea & 38 & Agricultor \\
\hline 617. & & Stammer & Simón & 15 & Agricultor \\
\hline 618. & & Stammer & ysaac & 12 & \\
\hline 619. & & Stammer & Yankel & 10 & \\
\hline 620. & & Stammer & Meer & 1 & \\
\hline 621. & & Stammer & Sprinza & 8 & \\
\hline 622. & & Stammer & Sossia & 7 & \\
\hline 623. & & Melamud & Muchin & 55 & Agricultor \\
\hline 624. & & Melamud & Mackma & 20 & Agricultor \\
\hline 625. & & Weissmann & Schulim & 54 & Agricultor \\
\hline
\end{tabular}




\begin{tabular}{|c|c|c|c|c|c|}
\hline № ORDEN & & APELLIDO & NOMBRES & EDAD & PROFESION \\
\hline 626. & & Weissmann & Chaia & 47 & Agricultor \\
\hline 627. & & Weissmann & Schema & 23 & Agricultor \\
\hline 628. & & Weissmann & Froim & 21 & Agricultor \\
\hline 629. & & Weissmann & ysaac & 17 & Agricultor \\
\hline 630. & & Weissmann & Hersch & 9 & \\
\hline 631. & & Weissmann & Pincus & 6 & \\
\hline 632. & & Weissmann & Rivka & 14 & Agricultor \\
\hline 633. & & Weissmann & Malka & 11 & \\
\hline 634. & & Barcovvsky & Samuel & 36 & Agricultor \\
\hline 635. & & Barcovvsky & Chara & 34 & Agricultor \\
\hline 636. & & Barcovvsky & David & 12 & \\
\hline 637. & & Barcovvsky & Schaia Wolff & 4 & \\
\hline 638. & & Barcovvsky & Ester & 13 & Agricultor \\
\hline 639. & & Barcovvsky & Blume & 8 & \\
\hline 640. & Dunayevich? & Dunavvich & Tobia & 34 & \\
\hline 641. & Dunayevich? & Dunavvich & Tcharna & & \\
\hline 642. & Dunayevich? & Dunavvich & Gdalie & & \\
\hline 643. & & & wolf & & \\
\hline 644. & & & Elie & & \\
\hline 645. & & Feldman & Zurich & & \\
\hline 646. & & & Ytta & & \\
\hline 647. & Rabalsky & Rubalsky & Charkel & & \\
\hline 648. & Rabalsky & Rubalsky & Ester & & \\
\hline 649. & Rabalsky & Rubalsky & Joseph Haim & & \\
\hline 650. & Rabalsky & & Wolko & & \\
\hline 651. & Rabalsky & & Siler & & \\
\hline 652. & Rabalsky & & Rubin Noach & & \\
\hline 653. & Rabalsky & & ysaac & & \\
\hline 654. & Rabalsky & & Schmuel & & \\
\hline 655. & Rabalsky & & Rivka & & \\
\hline 656. & Rabalsky & & Malka & & \\
\hline 657. & Rabalsky & & Gittla & & \\
\hline 658. & & Raskowsky & Begiamin & & \\
\hline 659. & & Raskowsky & Cipa & & \\
\hline 660. & & Raskowsky & schmiel sch & & \\
\hline 661. & & Aksenfeld & Uscher & & \\
\hline 662. & & & Reissie & & \\
\hline 663. & & Soem & Ysabella & & \\
\hline 664. & & Raskansky & Mendel & & \\
\hline 665. & & Raskansky & Sobel & & \\
\hline 666. & & Raskansky & Moses & 24 & Agricultor \\
\hline 667. & & Raskansky & Chaika & 15 & Agricultor \\
\hline 668. & & Raskansky & Etta & 12 & \\
\hline 669. & & Kleimann & Moschko & 38 & Agricultor \\
\hline 670. & & Kleimann & Ruchile & 38 & Agricultor \\
\hline 671. & & Kleimann & Abraham & 14 & Agricultor \\
\hline 672. & & Kleimann & Berko & 11 & \\
\hline 673. & & Kleimann & Simón & 7 & \\
\hline 674. & & Kleimann & Mordko & $11 / 2$ & \\
\hline 675. & & Kleimann & Pincus Herch & 4 & \\
\hline 676. & & Kleimann & Gittla & 8 & \\
\hline 677. & & Raitzer & Yosel & 37 & Agricultor \\
\hline 678. & & Raitzer & Zivia & 33 & Agricultor \\
\hline 679. & & Raitzer & Haim & 13 & Agricultor \\
\hline 680. & & Raitzer & Yankel & 8 & \\
\hline 681. & & Raitzer & Michel & 4 & \\
\hline 682. & & Raitzer & Chara & 14 & Agricultor \\
\hline 683. & & Raitzer & Frima & 2 & \\
\hline 684. & & Finkel & Schlema & 47 & Agricultor \\
\hline 685. & & Finkel & Godda & 46 & \\
\hline 686. & & Finkel & Schulim Sch & 19 & \\
\hline 687. & & Finkel & Froim & & \\
\hline 688. & & Finkel & Narschovva & & \\
\hline 689. & & Finkel & Tcharna & & \\
\hline
\end{tabular}




\begin{tabular}{|c|c|c|c|c|c|}
\hline № ORDEN & & APELLIDO & NOMBRES & EDAD & PROFESION \\
\hline 690. & & Raskowsky & Berko & 37 & \\
\hline 691. & & Raskowsky & Lea & 35 & \\
\hline 692. & & Raskowsky & Moschko & 21 & \\
\hline 693. & & Raskowsky & Simón & 16 & \\
\hline 694. & & Raskowsky & Haim & 16 & \\
\hline 695. & Serebrenik & Gerebrenus & Yzul & 42 & Agricultor \\
\hline 696. & Serebrenik & Gerebrenus & Henia & 32 & Agricultor \\
\hline 697. & Serebrenik & Gerebrenus & Baruch & 23 & Agricultor \\
\hline 698. & Serebrenik & Gerebrenus & David & 15 & Agricultor \\
\hline 699. & Serebrenik & Gerebrenus & Schlema & 5 & \\
\hline 700. & Serebrenik & Gerebrenus & Ydel & $6 \mathrm{~m}$ & \\
\hline 701. & Serebrenik & Gerebrenus & Sima & 13 & Agricultor \\
\hline 702. & Serebrenik & Gerebrenus & Gittel & 11 & \\
\hline 703. & Serebrenik & Gerebrenus & Perel & 8 & \\
\hline 704. & Serebrenik & Gerebrenus & Abba/abraham & 38 & Agricultor \\
\hline 705. & Serebrenik & Gerebrenus & Rivka & 37 & Agricultor \\
\hline 706. & Serebrenik & Gerebrenus & Gittel & 13 & Agricultor \\
\hline 707. & Serebrenik & Gerebrenus & Leia & 11 & \\
\hline 708. & Serebrenik & Gerebrenus & Feiga & 9 & \\
\hline 709. & Vites? & Wittis & Samuel & 54 & Agricultor \\
\hline 710. & Vites? & Wittis & Bassia & 48 & Agricultor \\
\hline 711. & Vites? & Wittis & Golda & 15 & Agricultor \\
\hline 712. & Vites? & Wittis & Rebeca & 16 & Agricultor \\
\hline 713. & Vites? & Wittis & Sara & 10 & \\
\hline 714. & Strenbann & Staremban & Haim & 40 & Agricultor \\
\hline 715. & Strenbann & Staremban & Eidel & 34 & Agricultor \\
\hline 716. & Strenbann & Staremban & ysaac & 15 & Agricultor \\
\hline 717. & Strenbann & Staremban & Rucklia & 17 & Agricultor \\
\hline 718. & Strenbann & Staremban & Hennia & 10 & \\
\hline 719. & & Goldemberg & Moses & 34 & Agricultor \\
\hline 720. & & Goldemberg & Scheindel & 31 & Agricultor \\
\hline 721. & & Goldemberg & Aba/abraham & 5 & \\
\hline 722. & & Goldemberg & Schlema & 2 & \\
\hline 723. & Feiman & Feiman & Yankel & 30 & Agricultor \\
\hline 724. & Feiman & Feiman & Elka & 29 & Agricultor \\
\hline 725. & Feiman & Feiman & Sania & $11 / 2$ & \\
\hline 726. & Jakubsky & Yagaubiky & Haim & 43 & Agricultor \\
\hline 727. & Jakubsky & Yagaubiky & Hennia/Ana & 41 & Agricultor \\
\hline 728. & Jakubsky & Yagaubiky & Froim & 20 & Agricultor \\
\hline 729. & Jakubsky & Yagaubiky & Benzion & 3 & \\
\hline 730. & Jakubsky & Yagaubiky & Rivka & 11 & \\
\hline 731. & Tzepilovan & Ciplonan & Marcus & 51 & Agricultor \\
\hline 732. & Tzepilovan & Ciplonan & Chara & 46 & Agricultor \\
\hline 733. & Tzepilovan & Ciplonan & Moses & 18 & Agricultor \\
\hline 734. & Tzepilovan & Ciplonan & ysaac & 16 & Agricultor \\
\hline 735. & Tzepilovan & Ciplonan & Schlema & 14 & Agricultor \\
\hline 736. & Tzepilovan & Ciplonan & Yosse & 12 & Agricultor \\
\hline 737. & Tzepilovan & Ciplonan & Tobia & 9 & Agricultor \\
\hline 738. & Moguiliansky & Moilansky & Selmann & 35 & Agricultor \\
\hline 739. & Moguiliansky & Moilansky & Hanna/Clara & 35 & Agricultor \\
\hline 740. & Feinsilber & Feinsilber & Leib & 20 & Agricultor \\
\hline 741. & & Fucks & Muchin & 23 & Agricultor \\
\hline
\end{tabular}




\section{Listado de pasajeros en el barco "Sirio" 20 de septiembre de 1894}

\begin{tabular}{|c|c|c|c|}
\hline OBSERV & Apellido & Nombres & Edad \\
\hline MOGUILANSKY & $\begin{array}{l}\text { MOHILANSKY } \\
\text { MOHILANSKY } \\
\text { MOHILANSKY } \\
\text { MOHILANSKY } \\
\text { MOHILANSKY } \\
\text { MOHILANSKY }\end{array}$ & $\begin{array}{l}\text { D. HIRSCH } \\
\text { REIDKA } \\
\text { YEZKO } \\
\text { ABRAM } \\
\text { RISSA } \\
\text { BELLA }\end{array}$ & $\begin{array}{l}44 \\
43 \\
17 \\
15 \\
23 \\
8\end{array}$ \\
\hline ILVOVSKY & $\begin{array}{l}\text { YLWOWSKY } \\
\text { YLWOWSKY } \\
\text { YLWOWSKY } \\
\text { YLWOWSKY } \\
\text { YLWOWSKY } \\
\text { YLWOWSKY } \\
\text { YLWOWSKY } \\
\text { YLWOWSKY }\end{array}$ & $\begin{array}{l}\text { DAVID } \\
\text { SURA } \\
\text { BARUCH } \\
\text { LAZARE } \\
\text { SCHMIL } \\
\text { YZUL } \\
\text { GOLDA } \\
\text { RUCHLIA }\end{array}$ & $\begin{array}{l}43 \\
41 \\
19 \\
14 \\
12 \\
6 \\
22 \\
17\end{array}$ \\
\hline CRIMAN & $\begin{array}{l}\text { KRIMANN } \\
\text { KRIMANN } \\
\text { KRIMANN } \\
\text { KRIMANN } \\
\text { KRIMANN }\end{array}$ & $\begin{array}{l}\text { YZUL } \\
\text { ETTA } \\
\text { NAFUI } \\
\text { ARON } \\
\text { LEA }\end{array}$ & $\begin{array}{l}36 \\
30 \\
9 \\
5 \\
2\end{array}$ \\
\hline ZIBELMAN & $\begin{array}{l}\text { CIBELMANN } \\
\text { CIBELMANN } \\
\text { CIBELMANN } \\
\text { CIBELMANN } \\
\text { CIBELMANN } \\
\text { CIBELMANN } \\
\text { CIBELMANN } \\
\text { CIBELMANN } \\
\text { CIBELMANN }\end{array}$ & $\begin{array}{l}\text { SAMUEL } \\
\text { CHANA } \\
\text { YZUL } \\
\text { CHAIA } \\
\text { MANIA } \\
\text { KEA } \\
\text { PESSIA } \\
\text { LIBA } \\
\text { WOLKO }\end{array}$ & $\begin{array}{l}34 \\
33 \\
3 \\
13 \\
13 \\
11 \\
6 \\
4 \\
0 / 12\end{array}$ \\
\hline ROITER & $\begin{array}{l}\text { RAITER } \\
\text { RAITER } \\
\text { RAITER } \\
\text { RAITER } \\
\text { RAITER } \\
\text { RAITER }\end{array}$ & $\begin{array}{l}\text { MOSCHKO } \\
\text { BASSIA } \\
\text { FARIS } \\
\text { SCHACHNE } \\
\text { CHANA-REISSIA } \\
\text { ROCHLA }\end{array}$ & $\begin{array}{l}45 \\
43 \\
22 \\
13 \\
17 \\
2\end{array}$ \\
\hline SLOICH & $\begin{array}{l}\text { SLOIEZ } \\
\text { SLOIEZ } \\
\text { SLOIEZ } \\
\text { SLOIEZ }\end{array}$ & $\begin{array}{l}\text { DAVID } \\
\text { SLATA } \\
\text { SCHMIL } \\
\text { MARIAN }\end{array}$ & $\begin{array}{l}31 \\
26 \\
4 \\
3\end{array}$ \\
\hline ROITER & $\begin{array}{l}\text { REITER } \\
\text { REITER } \\
\text { REITER } \\
\text { REITER } \\
\text { REITER }\end{array}$ & $\begin{array}{l}\text { LEVI } \\
\text { LEA } \\
\text { MORDKO-MEIER } \\
\text { WITTA } \\
\text { BRANA }\end{array}$ & $\begin{array}{l}48 \\
48 \\
27 \\
17 \\
13\end{array}$ \\
\hline
\end{tabular}




\begin{tabular}{|c|c|c|c|}
\hline OBSERV & Apellido & Nombres & Edad \\
\hline & REITER & FREIDA & 23 \\
\hline & REITER & SCHLEMA & 2 \\
\hline \multirow[t]{12}{*}{ ZIVAC/SIVAK } & SIWAK & NUS,YSAAK & 33 \\
\hline & SIWAK & KUNA & 32 \\
\hline & SIWAK & SARA & 14 \\
\hline & SIWAK & MACHLA & 6 \\
\hline & SIWAK & REISA & \\
\hline & SIWAK & CHAIA & 56 \\
\hline & WESTMAM & SCHLEMA & 32 \\
\hline & WESTMAM & CESSA & 29 \\
\hline & WESTMAM & REFUL & 7 \\
\hline & WESTMAM & HERSCH & 4 \\
\hline & WESTMAM & MORDKO & 2 \\
\hline & WESTMAM & SCHMUL & 1 MES? \\
\hline \multirow[t]{16}{*}{ GOLDFARB } & GOLDFARL & BENZION & 52 \\
\hline & GOLDFARL & FREIDA & 50 \\
\hline & GOLDFARL & ABRAM & 18 \\
\hline & GOLDFARL & AISIK & 14 \\
\hline & GOLDFARL & SCHMIL & 10 \\
\hline & GOLDFARL & MARIAN & 26 \\
\hline & GOLDFARL & DINZA & 22 \\
\hline & BLINDER & NUCHIM & 42 \\
\hline & BLINDER & RICKLA & 31 \\
\hline & BLINDER & SCHIMUL ELME & 20 \\
\hline & BLINDER & BENZION & 12 \\
\hline & BLINDER & ESTER & 10 \\
\hline & BLINDER & GOILA & 9 \\
\hline & BLINDER & RIWKA & 75 \\
\hline & BLINDER & MOLKA & 2 \\
\hline & KRASNOFF & SCHIFRA & 20 \\
\hline \multirow[t]{19}{*}{ CRASNARENCO } & KRIMACHEMKO & WOLF & 27 \\
\hline & KRIMACHEMKO & FREIDA & 24 \\
\hline & KRIMACHEMKO & DWOIRA & 2 \\
\hline & KRIMACHEMKO & YEZKO & 45 \\
\hline & KRIMACHEMKO & SCHENDEL & 44 \\
\hline & KRIMACHEMKO & SUNA & 3 MESES \\
\hline & KENNER & NUCHIN & 46 \\
\hline & KENNER & ODEL & 43 \\
\hline & KENNER & LEIB & 13 \\
\hline & YLUSERANSKY & ROSA & 16 \\
\hline & SCHWEITZER & SARA & 17 \\
\hline & DIRECTOR & HAIM & 39 \\
\hline & DIRECTOR & REISA & 32 \\
\hline & DIRECTOR & MICHEL & 15 \\
\hline & DIRECTOR & MENDEL & 9 \\
\hline & DIRECTOR & YEZKO & 4 \\
\hline & DIRECTOR & CHAIA PURA & 13 \\
\hline & DIRECTOR & ESTHER MALKA & 11 \\
\hline & DIRECTOR & LIVIA & 6 \\
\hline \multirow[t]{4}{*}{ LADISINSKY } & LADIGENSWY & HIRSEL & 44 \\
\hline & LADIGENSWY & BRUCHA & 40 \\
\hline & LADIGENSWY & ELIE & 19 \\
\hline & LADIGENSWY & BENZION & 17 \\
\hline
\end{tabular}




\begin{tabular}{|c|c|c|c|}
\hline OBSERV & Apellido & Nombres & Edad \\
\hline & LADIGENSWY & LIPA & 12 \\
\hline & LADIGENSWY & RUCHLA & 21 \\
\hline & LADIGENSWY & GITTLA & 15 \\
\hline & LADIGENSWY & SCHENDEL & 8 \\
\hline \multirow[t]{3}{*}{ MELLIBOVSKY } & MEGIBOWSKY & CHASKEL & 26 \\
\hline & MEGIBOWSKY & OSNA & 20 \\
\hline & MEGIBOWSKY & CHAIKA & 2 \\
\hline \multirow[t]{8}{*}{ MELLIBOVSKY } & MEGIBOWSKY & CHAIM & 45 \\
\hline & MEGIBOWSKY & FREIDA & 45 \\
\hline & MEGIBOWSKY & YUNA & 16 \\
\hline & MEGIBOWSKY & FEINIL & 8 \\
\hline & MEGIBOWSKY & DAVID & 4 \\
\hline & MEGIBOWSKY & CHANA & 13 \\
\hline & MEGIBOWSKY & LEA & 11 \\
\hline & MEGIBOWSKY & PERLA & 9 \\
\hline \multirow[t]{10}{*}{ MOGUILANSKY } & MOHILANSKY & PEISACH & 46 \\
\hline & MOHILANSKY & PEISA & 44 \\
\hline & MOHILANSKY & DAVID & 24 \\
\hline & MOHILANSKY & WAW-MALKA & 11 \\
\hline & MOHILANSKY & ABRAM & 7 \\
\hline & MOHILANSKY & LEISER & 5 \\
\hline & MOHILANSKY & YEZKO & 3 \\
\hline & MOHILANSKY & TAUBA & 21 \\
\hline & MOHILANSKY & CHAIA & 19 \\
\hline & MOHILANSKY & SLATA & 9 \\
\hline \multirow[t]{12}{*}{ CORNFELD } & KORNFELD & BERKO & 34 \\
\hline & KORNFELD & FEIGA & 34 \\
\hline & KORNFELD & TOBY & 8 \\
\hline & KORNFELD & MEER & 4 MESES \\
\hline & KORNFELD & ROCHLA & 8 \\
\hline & RESNIK & YANKEL & 33 \\
\hline & RESNIK & RUCHLA & 23 \\
\hline & RESNIK & SCHMUL & 16 \\
\hline & RESNIK & SAMSON & 3 \\
\hline & RESNIK & YEZKO & 2 \\
\hline & RESNIK & GITLA & 13 \\
\hline & RESNIK & RESNIK & 55 \\
\hline \multirow[t]{9}{*}{ BRAVERMAN } & BRAVERMANN & MORDKO & 42 \\
\hline & BRAVERMANN & MALKA & 36 \\
\hline & BRAVERMANN & ANSCHEL & 19 \\
\hline & BRAVERMANN & ABRAM & 15 \\
\hline & BRAVERMANN & MOSCHKO & 10 \\
\hline & BRAVERMANN & IANKEL & 7 \\
\hline & BRAVERMANN & BRANA & 17 \\
\hline & BRAVERMANN & CHANA & 12 \\
\hline & BRAVERMANN & CHAIA & 2 \\
\hline \multirow[t]{7}{*}{ MOGUILANSKY } & MOHILANSKY & JOSEPH & 66 \\
\hline & MOHILANSKY & MALKA & 63 \\
\hline & MOHILANSKY & ESTHER GRIMBERG & 30 \\
\hline & MOHILANSKY & SCHLEMA & 30 \\
\hline & MOHILANSKY & LEISER & 6 \\
\hline & MOHILANSKY & MENDEL & 4 \\
\hline & MOHILANSKY & LEIB & 2 \\
\hline \multirow[t]{3}{*}{ CHECHELNIZKY } & TCHICHELNIERZIRKI & WOLKO & 32 \\
\hline & TCHICHELNIERZIRKI & MASSA & 32 \\
\hline & TCHICHELNIERZIRKI & MUSCHKS & 3 \\
\hline
\end{tabular}




\begin{tabular}{|c|c|c|c|}
\hline OBSERV & Apellido & Nombres & Edad \\
\hline & TCHICHELNIERZIRKI & SARA & 13 \\
\hline & TCHICHELNIERZIRKI & PESSA & 6 \\
\hline & TCHICHELNIERZIRKI & PERLA & 6 MESES \\
\hline \multirow[t]{5}{*}{ LIVSCHITZ } & LIFSCHITZ & ABRAM & 32 \\
\hline & LIFSCHITZ & MINZA & 31 \\
\hline & LIFSCHITZ & BERKO & 14 \\
\hline & LIFSCHITZ & CIRLA & 3 \\
\hline & PARIENTE & GOROSCHAN & 42 \\
\hline \multirow[t]{9}{*}{ HOIJMAN } & HOCHMANN & MOSCHKO & 43 \\
\hline & HOCHMANN & RIWKA & 40 \\
\hline & HOCHMANN & PINCUS & 18 \\
\hline & HOCHMANN & SELEG & 14 \\
\hline & HOCHMANN & CHANANIA & 6 \\
\hline & HOCHMANN & NACHMANN & 3 \\
\hline & HOCHMANN & LEA & 21 \\
\hline & HOCHMANN & ETLA & 16 \\
\hline & HOCHMANN & CHAIA & 8 \\
\hline \multirow[t]{12}{*}{ COSARINSKY } & KASARINSKY & MORDSKO & 53 \\
\hline & KASARINSKY & DWOIRA & 51 \\
\hline & KASARINSKY & ABRAM & 23 \\
\hline & KASARINSKY & WOLKA & 16 \\
\hline & KASARINSKY & MENICHA & 22 \\
\hline & KASARINSKY & SCHIFRA & 21 \\
\hline & KASARINSKY & LEA & 16 \\
\hline & KASARINSKY & ESTHER & 13 \\
\hline & KASARINSKY & FREIDA & 24 \\
\hline & KASARINSKY & MOSCHKO & 1 \\
\hline & KASARINSKY & FEIGA & 2 \\
\hline & & GRUPO KILEY & \\
\hline \multirow[t]{18}{*}{ GERSCHKOVICH } & HERSCHKOWITCH & PINCUS & 38 \\
\hline & HERSCHKOWITCH & FREIDA & 32 \\
\hline & HERSCHKOWITCH & ABRAM & 5 \\
\hline & HERSCHKOWITCH & PASSA & 11 \\
\hline & HERSCHKOWITCH & CHAIKA & 52 \\
\hline & HERSCHKOWITCH & HERSKO & 16 \\
\hline & HERSCHKOWITCH & BERKO & 15 \\
\hline & HERSCHKOWITCH & YEZKO & 13 \\
\hline & PERPER & CHUNA & 44 \\
\hline & PERPER & MALKA & 35 \\
\hline & PERPER & ABRAM & 14 \\
\hline & PERPER & YEZKO & 3 \\
\hline & PERPER & MARIA & 17 \\
\hline & PERPER & PERLA & 9 \\
\hline & PERPER & SARA BUNA & \\
\hline & PERPER & CHAIA-FREIDA & 8 MESES \\
\hline & PERPER & BLUMA & 62 \\
\hline & & GRUPO NOVILN & \\
\hline \multirow[t]{8}{*}{ IZCOVICH/ITZKOVICH } & YEZKOWICH & YEZKO & 50 \\
\hline & YEZKOWICH & RIWA & 48 \\
\hline & YEZKOWICH & MEER & 17 \\
\hline & YEZKOWICH & WOLFF & 17 \\
\hline & YEZKOWICH & GITTEL & 18 \\
\hline & YEZKOWICH & MIRA & 13 \\
\hline & YEZKOWITCH & YEZKO & 26 \\
\hline & YEZKOWITCH & BRANA & 22 \\
\hline
\end{tabular}




\begin{tabular}{|c|c|c|c|}
\hline OBSERV & Apellido & Nombres & Edad \\
\hline & YEZKOWITCH & EFRAIM & 8 MESES \\
\hline \multirow[t]{5}{*}{ ITZKOVICH } & YEZKOWICH & MENDEL & 30 \\
\hline & YEZKOWICH & ESTER & 25 \\
\hline & YEZKOWICH & ABR-HIRSCH & 1 \\
\hline & YEZKOWICH & YTTA & 6 \\
\hline & YEZKOWICH & LEA & 4 \\
\hline \multirow[t]{15}{*}{ KAMIN } & KANINE & LEISER & 36 \\
\hline & KANINE & SLAWA & 27 \\
\hline & KANINE & SCHLEMA & 17 \\
\hline & KANINE & ITZKO & 8 \\
\hline & KANINE & SAMSON & 6 \\
\hline & KANINE & RUWIN & 3 \\
\hline & KANINE & ROSA & 10 \\
\hline & KANINE & LUBA & 9 MESES \\
\hline & CIRZULSKY & RAFAEL & 26 \\
\hline & CIRZULSKY & CHANA & 24 \\
\hline & & GRUPO KILEY & \\
\hline & FEIMBERG & FREIDE & 20 \\
\hline & LASCHAK & FROIM & 17 \\
\hline & LASCHAK & BEER & 14 \\
\hline & & VARIOS COLC & \\
\hline \multirow[t]{6}{*}{ RABINOVICH } & RABINOWITCH & ETTA & 48 \\
\hline & RABINOWITCH & HAIM & 12 \\
\hline & RABINOWITCH & BARUCH & 10 \\
\hline & RABINOWITCH & MINZA & 21 \\
\hline & RABINOWITCH & RUCHEL & 19 \\
\hline & RABINOWITCH & CHAIA & 17 \\
\hline
\end{tabular}

TOTAL PERSONAS: 230 



\section{Colonos en Colonia Clara por grupo o aldea (1941)}

\section{Grupo Baron Guinzburg}

\begin{tabular}{|c|c|c|c|c|}
\hline APELLIDO & NOMBRES & HECTAREAS & generaciòn & observaciones \\
\hline Attelman & Jacobo & 157 y 102 & 2 & comprò de Padlog Marcos \\
\hline Blinder & Benjamin & 166 & 2 & \\
\hline Bortnik & A. & 206 & 2 & \\
\hline Brodsky & A. & 105 & 2 & vive en concordia \\
\hline Budasoff & Natalio & 83 & 1 & \\
\hline Carpman & Bernardo & 56 & 1 & ex Schnitman Yauda \\
\hline Carpman & Bernardo & 156 & 1 & \\
\hline Chechelnitzky & Berta e hijo & 169 & 2 & \\
\hline Chertcoff & David & 113 & 2 & \\
\hline Dancis & Elias & 76 & 2 & \\
\hline Dikenstein & Rafael & 104 & 2 & vendido a vecinos \\
\hline Director & Miguel & 180 & 2 & \\
\hline Dorfman & Aron & 85 & 2 & \\
\hline Dubner & Benjamìn & 97 & 1 & \\
\hline Duldman & Hugo & 53 & 1 & \\
\hline Elstein & Salomòn y Marcos & 152 & 3 & ex Chertcoff \\
\hline Ferdman & Julio & 152 & 2 & \\
\hline Fijtman & Ysaac & 89 & 2 & vendido a vecinos \\
\hline Fink & Santiago & 153 & 3 & \\
\hline Fuldauer & Hugo & 53 & 1 & \\
\hline Galante & Dr.E. & 62 & 2 & ex chacra de Budeisky L. \\
\hline Gleser & Manuel & 53 y 75 & 3 & ex Dorfman Gregorio \\
\hline Gleser & Adolfo & 152 & 2 & ex Kant Calman \\
\hline Glinberg & Luis & 100 & 2 & ex chacra de Budeisky L. \\
\hline \multirow[t]{2}{*}{ Glinberg } & Salomòn suc & & & \\
\hline & hijo Leon & 167 & 2 & vendiò a Blinder 115 has. \\
\hline Glusman & Adolfo & 112 & 2 & \\
\hline Glusman & Abraham & 165 & 2 & \\
\hline Goldenberg & Josè & 155 & 2 & vive en B.A \\
\hline Goldenberg & Marian y Moises & 203 & 1 & \\
\hline Grunman & Ysaac & 115 & 2 & \\
\hline Gurny & Natalio & 145 & 1 & ex chacra de E.Bronstein, vive en BA \\
\hline Haimovich & Kiva & 77 & 2 & ex Saroca Israel \\
\hline Haimovich & Kiva & 90 & 2 & \\
\hline Heller & Rosa y Samuel & 159 & 3 & \\
\hline Jramoy & Ynes & 66 & 1 & \\
\hline Kaller & Salomòn y Naum & 166 & 3 & \\
\hline Kasvin & Gregorio & 98 & 2 & \\
\hline Kasvin & Simòn & 139 & 2 & \\
\hline Kohan & Lazaro & 161 & 1 & ex Cosarinsky Adolfo \\
\hline Korman & vda.e hijo manuel & 109 & 3 & \\
\hline Korman & vda e hijo Luis & 98 & 2 & \\
\hline Kornfeld & Tobìas & 105 & 2 & \\
\hline Kosarinsky & Abraham suc. & 217 & 2 & B. Hipotecario $\$ 14.000$ vive en Urug. \\
\hline Kraiseburd & L.sucesiòn & 174 & 2 & vive en Clara \\
\hline Kreimer & Salomòn suc. & 216 & 2 & \$10.000 Banco Naciòn \\
\hline Kreimer & David S. & 163 & 2 & Clara \\
\hline Kreimer & Dora y Abraham & 164 & 2 & vendiò a Dardik Josè \\
\hline
\end{tabular}




\begin{tabular}{|c|c|c|c|c|}
\hline APELLIDO & NOMBRES & HECTAREAS & generaciòn & observaciones \\
\hline Kreimer & Rosa e Ysrael & 145 & 2 & \\
\hline Kuperstein & Peisaj y Abraham & 54 & 2 & \\
\hline Leikis & Abraham suc. & 100 & 2 & \\
\hline Leikis & A.suc.e Ysaac & 70 & 1 & \\
\hline Litvin & Leib & 152 & & \\
\hline Litvin & Moises & 158 & 2 & \\
\hline Litvinoff & Bernardo & 62 & 1 & Clara \\
\hline Lulkin & Salomòn & 106 & 2 & \\
\hline Mas & Josè & 65 & 2 & \\
\hline Moscovich & Benjamin suc. & 142 & 2 & $\$ 6.000$ particular \\
\hline Muchnik & Salomòn suc. & 163 & 2 & \\
\hline Muchnik & Simòn & 113 & 2 & \\
\hline Najemson & Meer & 151 & 2 & $\$ 8000$ y P.F \\
\hline Ostrovsky & Josè & 45 & 1 & ex Schlosman \\
\hline Padlog & M.suc.e hijos & 102 & 2 & vend.los derechos a Altman Jacobo \\
\hline Pavè & Juan y Gregorio & 72 & 3 & \\
\hline Pipkin & Josè y Elìas & 93 & 2 & Bs.As \\
\hline Pomerantz & S. & 131 & 2 & ex Monastersky Gregorio \\
\hline Pomerantz & Ysaac & 80 & 2 & vendido a vecinos \\
\hline Pustilnik & Marcos & 104 & 2 & $\$ 14.000$ a particular \\
\hline Pustilnik & Marcos & 56 & 2 & ex Taràn Ysrael \\
\hline Pustilnik & Marcos & 82 & 2 & \\
\hline Rabinovich & R.Suc. & 163 & 2 & \\
\hline Roiter & Salomòn & 162 & 1 & \\
\hline Rubin & Juan & 40 & 2 & \\
\hline Schejter & Josè y Bernardo & 147 & 2 & \\
\hline Schlosman & Jacobo & 54 & 2 & \\
\hline Schmoisman & David & 58 & 2 & ex Monastersky Isaac \\
\hline Schmoisman & Samuel & 177 & 1 & $\$ 18.000 \mathrm{BHN}$ \\
\hline Schmukler & Hersch & 159 & 2 & vendiò a vecinos \\
\hline Schnitman & Cesar & 89 & 3 & $\$ 8.000$ a part. \\
\hline Schnitman & Boris suc. & 152 & 2 & \\
\hline Sitlonik & Josè & 119 & 1 & \\
\hline Spirer & Jacobo Samuel & 83 & 1 & \\
\hline Stubrin & J. E Ysaac & 158 & 2 & vendiò a vecinos vive en Clara \\
\hline Stubrin & Sevalino & 160 & 2 & Bs.As. \\
\hline Taran & Jacobo & 56 & 2 & \\
\hline Tcach & Benjamìn & 77 & 1 & \\
\hline Toer & Salomòn suc. & 97 & 2 & \\
\hline Vainer & Ysaìas & 163 & 3 & \\
\hline Vainer & Pedro & 82 & 3 & vive en Clara \\
\hline Volcovich & Dr.Jorge & 154 & 1 & ex Vaisman Abraham \\
\hline Voscoboinik & Josè & 112 & 1 & \\
\hline Woscoboinik & Ysaac & 66 & 2 & ex Schlosman \\
\hline Yncevich & Bernardo y Aròn & 160 & 2 & \\
\hline Yuseffof & Juan & 77 & 1 & \\
\hline Yusefoff & Julio & 82 & 1 & \\
\hline Zibelman & Bernardo & 94 & 2 & \\
\hline Zibelman & Ysrael & 94 & 2 & \\
\hline
\end{tabular}

\section{Grupo Barreros}

$\begin{array}{lllll}\text { Boverman } & \text { Salomón } & 185 & 2 & \text { ex Beker vive en Paranà } \\ \text { Breitman } & \text { Abraham } & 72 & 1 & \\ \text { Enguelberg } & \text { Elias } & 91 & 1 & \\ \text { Foiguel } & \text { Elias } & 147 & 1 & \text { Bs.As } \\ \text { Goliante } & \text { Scholem } & 131 & 2 & \\ \text { Goliante } & \text { Moises Suc. } & 164 & 2 & \text { Bs.As } \\ \text { Kuselevich } & \text { Isaac } & 133 & 2 & \\ \text { Nudelman } & \text { Bernardo } & 70 & 1 & \end{array}$




\begin{tabular}{lllcl}
\hline APELLIDO & NOMBRES & HECTAREAS & generaciòn & observacio \\
\hline Oclander & Adolfo & 130 & 2 & \\
Pavé & Marcos & 165 & 2 & \\
Pavé & Salomón & 117 & 2 & Vendiò a vecinos \\
Pavé & Jacobo & 100 & 2 & \\
Pavé & Gregorio & 4 & 2 & Bs.As \\
Perlman & Naftule & 163 & 1 & \$6.000 Fomento Agrario \\
Schalamuk & Santiago & 105 & 2 & \\
Schalamuk & Ysaac & 52 & 2 & \\
Schatzky & Jacobo y Aron & 160 & 2 & \\
Serguey & Leib & 168 & 2 & \\
Teveles & Zelig & 133 & 2 &
\end{tabular}

\section{Grupo Belez}

\begin{tabular}{|c|c|c|c|c|}
\hline Bahaslavsky & Luis & 174 & 2 & ex Costianovsky M. \\
\hline Bugacoff & Berta y Samuel & 147 & 2 & \\
\hline Celman & José & 112 & 1 & \\
\hline Costianovsky & Aron & 84 & 2 & vive en Clara \\
\hline Cravetz & Abraham & 107 & 2 & \\
\hline Dikenstein & Julio & 172 & 2 & \\
\hline Fridman & Manuel & 135 & 1 & vendió \\
\hline Galante & Mauricio & 80 & 3 & \\
\hline Golbert & Julio & 104 & 2 & \\
\hline Golomb & Ksiel & 33 & 2 & vive en Clara \\
\hline Graschinsky & Jaime y $\mathrm{E}$. & 164 & 2 & ex Silberstein M. \\
\hline Grinman & Salomón & 50 & 2 & ex Robrinsky E. \\
\hline Groschinsky & León & 68 & 3 & ex Brahais M.vibe en Clara \\
\hline Kuschneroff & Julio & 125 & 2 & vive en Clara \\
\hline Lew & José & 115 & 2 & \\
\hline Lipcovich & Marcos & 95 & 2 & \\
\hline Mas & Jacobo & 187 & 2 & \\
\hline Mas & David & 52 & 2 & \\
\hline Mas & Saúl & 167 & 2 & \\
\hline Mas & Natalio & 130 & 3 & \\
\hline Mirson & Jaime & 103 & 1 & \\
\hline Najemson & Jaim Suc. & 174 & 2 & \\
\hline Najemson & Suc. & 65 & 2 & \\
\hline Paley & Moises e Isaac & 15 & 1 & vendió a Muchnik Miguel \\
\hline Schulman & José & 189 & 2 & \\
\hline Schvartzberg & & & & \\
\hline y Kleiman & & 158 & 1 & ex Bolomb Aisisl \\
\hline Subovsky & Moises & 179 & 2 & Clara \\
\hline Sujanovich & Jacobo & 101 & 2 & \\
\hline Sujenovich & Simón & 67 & 2 & vendió a vecinos \\
\hline Tauber & Levy Isaac & 14 & 1 & \\
\hline Teveles & Bernardo & 70 & 2 & \\
\hline Yoguel & Meer & 104 & 2 & \\
\hline Yoguel & Mauricio & 112 & 2 & \\
\hline Zirulsky & Rafael Suc. & 132 & 2 & \\
\hline
\end{tabular}

\section{Grupo Achiras}

$\begin{array}{lllll}\text { Barujovich } & \text { Gregorio } & 150 & & \text { vendiò a extraños } \\ \text { Bricman } & & 159 & 1 & \text { ex Gabe Manuel } \\ \text { Flesler } & \text { Rafael } & 151 & 2 & \\ \text { Hutin } & \text { Enrique } & 176 & 2 & \\ \text { Kosoy } & \text { Moises suc. } & 151 & 2 & \end{array}$




\begin{tabular}{|c|c|c|c|c|}
\hline APELLIDO & NOMBRES & HECTAREAS & generaciòn & observaciones \\
\hline Pave & Juan & 151 & 2 & vendiò a extraños vive en Dguez \\
\hline Rabinovich & Jacobo & 160 & 2 & $\$ 18000$ a part \\
\hline Rubinstein & Abraham suc. & 157 & 2 & vive en Bs.As \\
\hline Salkind & Samuel & 184 & 2 & $\$ 5000$ a part. \\
\hline Samuiloff & Sucesiòn & 151 & 2 & \\
\hline Scheps & Luis & 155 & 2 & $\$ 15.000$ \\
\hline Schoj & Gregorio & 192 & & vendiò a extraños \\
\hline Slavkin & Hermanos & 188 & 2 & \\
\hline Stavsky & Boruj & 62 & 1 & vendiò a extraños \\
\hline Volosin & Naum & 150 & 2 & \\
\hline Vortman & Rafael & 152 & 2 & vendiò a Scheps M., Salkind Abr. \\
\hline
\end{tabular}

\section{Grupo Baron Hirsch}

\begin{tabular}{|c|c|c|c|c|}
\hline Edelstein & León & 62 & 2 & \\
\hline Edelstein & Salomón & 62 & 2 & vendidos a vecinos \\
\hline Efron & Yanda Suc. & 161 & 2 & B Italia $\$ 13000$ Bs. As. \\
\hline Efron & David Suc. & 133 & 3 & \\
\hline Efron & Schevaj & 112 & 2 & \\
\hline Garber & Abraham Suc & 124 & 2 & Bs. As. \\
\hline Graschinsky & Francisco Suc & 126 & 2 & Bs. As. \\
\hline $\begin{array}{l}\text { Huberman } \\
\text { F Comunal }\end{array}$ & $\begin{array}{l}\text { Scholen } \\
\text { F Comunal }\end{array}$ & 164 & 1 & \$9000 B. H. M. 2 ${ }^{\mathrm{a}}$ hipotecada \\
\hline Huberman & Salomón & 165 & 1 & \$3000 Banco Nación \\
\hline Isaac & Adolfo & 88 & 2 & \\
\hline Isac & Benjamin & 86 & 2 & \\
\hline Krapivka & Simon & 124 & 2 & \$4000 Banco Nación \\
\hline Kreiman & B. Suc. & 130 & 2 & \\
\hline Rabinovich & Jaim & 50 & 2 & \\
\hline Rabinovich & Suc. & 137 & 2 & \\
\hline Roitman & Adolfo Suc. & 124 & 2 & \\
\hline Rosenthal & W. S & 112 & 2 & \\
\hline SAS Isaac M. & Greg.y Benj. & 205 & 2 & $\$ 12000$ Bco Hip. Nac. \\
\hline Vindichansky & L.y Y. & 175 & 2 & \$2000 Banco Nación \\
\hline Ydeses & Simón Suc. & 137 & 2 & \\
\hline Concordi & & & & 3 viven en la ciudad \\
\hline
\end{tabular}

\section{Grupo Carmel}

$\begin{array}{ll}\text { Bresler } & \text { Matias } \\ \text { Buxs } & \text { Rubin suc } \\ \text { Fink } & \text { Gregorio } \\ \text { Glass } & \text { Leon Suc. } \\ \text { Gleser } & \text { Moises y Bdo } \\ \text { Gleser } & \text { Moises y Bdo } \\ \text { Groisman } & \text { Elias } \\ \text { Jaimovich } & \text { Felipe } \\ \text { Jrus } & \text { Marcos } \\ \text { Jucid } & \text { Pedro } \\ \text { Kaleka } & \text { David } \\ \text { Kaler } & \text { Lazaro } \\ \text { Kremenchutzky } & \text { Lazaro Suc. } \\ \text { Merener } & \text { Ysaac y Dav. } \\ \text { Merener } & \text { Luis y David } \\ \text { Merenlender } & \text { Osias } \\ \text { Mosovich } & \text { Jacobo } \\ \text { Olijavetzky } & \text { Gil y Moises } \\ \text { Pekerman } & \text { Salomòn }\end{array}$

$\$ 6000$ Bco,Naciòn Villaguay ex Kohan Jacobo

1 vive en la ciudad

$\$ 6000$ Bco.Hip.Nac. 


\begin{tabular}{lcccc}
\hline APELLIDO & NOMBRES & HECTAREAS & generaciòn & observaciones \\
\hline Ynguerscher & y Oclander & 76 & 1 & \$2200 Bco.Naciòn \\
Zeigner & Moises & 121 & 1 & Vendiò a vecinos
\end{tabular}

\section{Grupo desparramados}

\begin{tabular}{|c|c|c|c|c|}
\hline Albertinsky & Abraham & 157 & 2 & \\
\hline Albertinsky & Rajmiel & 35 & 2 & \\
\hline Baron & Miguel & 44 & 1 & \\
\hline Baron & Salomon Suc. & 95 & 1 & \\
\hline Baskin & Abraham & 65 & 1 & vendió a extraños \\
\hline Bercovich & Salomon & 73 & 1 & \\
\hline Bercovich & Abr. & 71 & 1 & \\
\hline Berenstein & Pablo & 146 & 2 & \\
\hline Bortnik & Naum & 100 & 2 & \\
\hline Britvin & Moises & 70 & 1 & \\
\hline Buks & Bregorio & 75 & 2 & \\
\hline Cibulovsky & Josè & 125 & 2 & \\
\hline Cravetz & Benjamin & 37 & 1 & \\
\hline Dlugovitzky & José Suc. & 77 & 2 & \\
\hline Dlugovitzky & Abraham & 48 & 2 & Dominguez \\
\hline Elstein & Fabio & 149 & 2 & \\
\hline Elstein & Salomòn & 170 & 2 & \\
\hline Elstein & Salomòn & 76 & & ex Bezchinsky \\
\hline Engueberg & Elieser & 21 & 1 & vendió a Adolfo Smukler \\
\hline Flier & David & 74 & 1 & \\
\hline Friedland & Sucesiòn & 295 & 2 & vendiò a Charchir \\
\hline Galante & Isaac & 72 & 1 & \\
\hline Genijovich & Marcos & 161 & 2 & ex Kitroser \\
\hline Genijovich & Abraham & 74 & 2 & \\
\hline Genijovich M. & & & & \\
\hline y Graschinsky M. & & 157 & 2 & \\
\hline Glusman & Gregorio & 75 & 2 & 5 viven en las ciudades \\
\hline Graschinsky & Jaime & 150 & 2 & \\
\hline Graschinsky & Jaime & 105 & & ex Genijovich M \\
\hline Graschinsky & Leon & 50 & 3 & ex Zepeñuk \\
\hline Groschinsky & Meer & 78 & 2 & \\
\hline Gueller & Isaac & 150 & 2 & \\
\hline Halperin & Salomòn & 144 & 2 & \\
\hline Halperin & Bregorio & 96 & 2 & \\
\hline Halperin & Moises & 101 & 1 & \\
\hline Heine y Leser & Filip y Luis & 37 & 1 & 3 viven en Dominguez y Clara \\
\hline Hoijman & Josè & 142 & 1 & \\
\hline Hojman & Tevel y Aler & 100 & 2 & \\
\hline Hojman & León & 63 & 1 & \\
\hline Isac & Samuel & 44 & 2 & \\
\hline Kaplan & Josè & 50 & 2 & ex Kaplan Aron \\
\hline Kaplan & Ysaac & 150 & 2 & Bs.As. \\
\hline Kaplan & José Isaac & 101 & 2 & \\
\hline Katzenelson & Simón Suc. & 167 & 2 & \\
\hline Kobrinsky & Ysrael suc. & 150 & 3 & \\
\hline Kohan & Lazaro & 277 & 2 & \\
\hline Kohan & Leib & 150 & 2 & \\
\hline Kohan & Miguel & 150 & 2 & \\
\hline Koraj & David & 119 & 2 & \\
\hline Koval & Bernardo & 50 & 2 & \\
\hline Levit & Hersch & 152 & 1 & \\
\hline Levitzky & Manuel & 65 & 2 & ex Kaplan Aron \\
\hline Liebschutz & Miguel & 152 & 1 & ex Daschevsky \\
\hline Liscovsky & Bregorio & 125 & 2 & \\
\hline Lvovsky & Boris & 165 & 2 & \\
\hline Malchansky & Samuel & 134 & 1 & \\
\hline Malchansky & Samson & 25 & 2 & \\
\hline
\end{tabular}




\begin{tabular}{|c|c|c|c|c|}
\hline APELLIDO & NOMBRES & HECTAREAS & generaciòn & observaciones \\
\hline Malchansky & Naum y Abraham & 160 & 2 & \\
\hline Manulis & Samuel & 37 & 1 & \\
\hline Maynstern & Manfrid & 27 & 1 & \\
\hline Oyernitzky & Jacobo & 35 & 2 & ex Kaplan Aron \\
\hline Pattin & David suc. & 223 & 2 & \\
\hline Peisajovich & Ysrael & 102 & 2 & \\
\hline Peisajovich & Marcos Suc. & 99 & 2 & \\
\hline Peisajovich & Moises & 75 & 2 & vendido a vecinos \\
\hline Rejtman & Sujer & 75 & 1 & ex Blusman \\
\hline Sajaroff & Jaime & 75 & 1 & \\
\hline Salmons & Otto & 28 & 1 & \\
\hline Saroca & Moises & 149 & 2 & \\
\hline Saroca & Moises & 180 & 2 & ex Yarcho \\
\hline Saroca & José & 150 & 2 & \\
\hline Saroca & Simón Suc. & 149 & 3 & \\
\hline Savitzky & Noej & 30 & 2 & \\
\hline Savitzky & Moises & 30 & 2 & \\
\hline Savitzky & Lazaro & 30 & 2 & \\
\hline Segal & Samuel suc. & 143 & 2 & \\
\hline Seltzer & Yjiel & 155 & 2 & \\
\hline Seltzer & Alejandro & 152 & 2 & \\
\hline Serebrinsky & Jaime & 153 & 2 & vendió 75 has a vecinos \\
\hline Sidi & Leon suc. & 107 & 1 & vendiò a Resnicoff \\
\hline Slotnik & Benjamin y Marcos & 75 & 2 & \\
\hline Stein & Simón & 149 & 2 & \\
\hline Stern & Ysaac & 150 & 2 & \\
\hline Stern & Manuel & 75 & 3 & \\
\hline Stern & Jaime & 151 & 2 & \\
\hline Stern & Bela & 30 & 1 & \\
\hline Straijman & Israel & 75 & 2 & \\
\hline Sukovsky & Isaac & 75 & 2 & vendió 25 has a Ext. Y 50 a Halperin David \\
\hline Teveles & Gregorio & 121 & 3 & \\
\hline Toer & Samuel & 70 & 2 & \\
\hline Yconikoff & Abraham suc & 151 & 2 & vendiò a Zepeñuk Abr. \\
\hline Zepeñuk & Bernardo & 100 & 2 & \\
\hline Zinovoy & Abraham & 50 & 1 & \\
\hline Zlotnitzky & viuda & 100 & 1 & \\
\hline
\end{tabular}

\section{Grupo Domingo Calvo}

\begin{tabular}{|c|c|c|c|c|}
\hline Fuks & Abraham & 91 & 1 & \\
\hline Glinberg & Leon & 75 & 2 & \\
\hline Halperin & Salomon & 184 & 1 & \\
\hline Hojman & Nuse & 142 & 1 & \\
\hline Karschenbaum & Abraham & 150 & 1 & vendió 50 has a vecinos \\
\hline Kreiman & Luisa y Luis & 148 & 2 & vendió a vecinos \\
\hline Leff & Samuel & 60 & 2 & vive en Clara \\
\hline Lev & Benjamin & 152 & 2 & \\
\hline Lev & Bernardo & 60 & 2 & \\
\hline Magram & Israel Suc. & 150 & 2 & \\
\hline Mas & José & 150 & 2 & \\
\hline Ornis & Isaac & 150 & 1 & \\
\hline Puterman & Saul & 100 & & \\
\hline Roiter & Salomon & 74 & 2 & \\
\hline Rosenberg & Hilel & 50 & 2 & \\
\hline Rosenberg & Elias, Jaime, Isaac & 150 & 2 & vendió 120 has a Extraños \\
\hline Rosenberg & Samuel & 100 & 2 & abandono1944 \\
\hline \multicolumn{2}{|c|}{ Rosenberg Vda e hijos } & 150 & 2 & \\
\hline Susevich & Jacobo & 151 & 2 & \\
\hline Tcach & Benjamin & 75 & 1 & \\
\hline Teper & Jacobo & 75 & 1 & ex Braslavsky L. \\
\hline Teper & Jacobo & 150 & 1 & ex Kreimer Jacobo \\
\hline
\end{tabular}




\begin{tabular}{lcccc}
\hline APELLIDO & NOMBRES & HECTAREAS & generaciòn & observaciones \\
\hline Uner & Lazaro & 91 & 1 & \\
Zaslavsky & León & 151 & 2 & vendió a vecinos vive en Clara
\end{tabular}

\section{Grupo Eben Harosch}

$\begin{array}{lllll}\text { Albertinsky } & \text { Leib Suc. } & 100 & 2 & \text { vendió a vecinos } \\ \text { Ayernitzky } & \text { Isaac } & 175 & 2 & \\ \text { Finguerman } & \text { Isaac } & 126 & 2 & \\ \text { Gleser } & \text { Adolfo } & 150 & 2 & \\ \text { Gleser } & \text { Adolfo } & 50 & & \text { de Carmel } \\ \text { Gleser } & \text { Moises y Bernardo } & 140 & 3 & \\ \text { Oyernitzky } & \text { Jacobo } & 153 & 1 & \\ \text { Peisajovich } & \text { Jaim } & 151 & 2 & \\ \text { Polack } & \text { Berl } & 150 & 2 & \\ \text { Scheps } & \text { Elias } & 74 & 2 & \text { vendió a vecinos } \\ \text { Scheps } & \text { Isaac } & 74 & 2 & \text { vendió a vecinos }\end{array}$

\section{Grupo Fainberg}

\begin{tabular}{|c|c|c|c|c|}
\hline Abramovich & León & 82 & 3 & vendió 25 has a Rosenberg Otto ex Hertjovich \\
\hline Albertinsky & Aron & 103 & 2 & \\
\hline Axenfeld & Rosa & 175 & 1 & vive en Rosario \\
\hline Axenfeld & Abraham & 146 & 1 & vendió a vecinos vive en Clara \\
\hline Bercovich & Moises & 76 & 1 & \\
\hline Davidovich & Lazaro & 94 & 1 & \\
\hline Dikenstein & Rosa & 78 & 2 & \\
\hline Dikenstein & Jacobo & 40 & 1 & 3 viven en las ciudades viven en Clara \\
\hline Efron & Mauricio & 112 & 2 & \\
\hline Efron & Suc, Abr y Mauricio & 154 & 3 & \\
\hline Efron & Jacobo & 171 & 3 & ex Perper \\
\hline Galansky & David & 99 & 1 & $\$ 9000$ Bco Hip Nac \\
\hline Givre & Rodolfo & 102 & 1 & vendio a Pasdeovsky Adolfo vive en Clara \\
\hline Glinberg & Luis & 163 & 2 & \\
\hline Glusman & David & 100 & 1 & \\
\hline Graschinsky & J y E. & 163 & & ex Danievich \\
\hline Graschinsky & J. YE & 74 & & ex Benejovich J. \\
\hline Guilischinsky & Aron & 100 & 1 & \\
\hline Hertzovich & Bregorio Suc. & 92 & 2 & \\
\hline Kamin & Leon Gregorio y Salomòn & 151 & 2 & \\
\hline Katz & Salomon & 182 & 2 & vendió a Roitman Hnos \\
\hline Lefcovich & Suc. & 152 & 2 & Bs. As. \\
\hline Lefcovich & Abraham Suc & 150 & 2 & \\
\hline Muchnik viuda & & 143 & 1 & Bs. As. \\
\hline Pecar & Angel & 111 & 2 & \\
\hline Repetur & Moises & 153 & 2 & \\
\hline Schvartz & Julio & 155 & 1 & \\
\hline Seiguerman & Jacobo & 40 & 1 & vendió a Davidovich Jaime \\
\hline Silberman & Mauricio & 164 & 2 & \\
\hline Siseles & Moises & 112 & 1 & \\
\hline Stern & Moises & 142 & 3 & ex Seiguerman Hnos \\
\hline Vaisman & Benjamin & 153 & 2 & \\
\hline Ydelson & Luis & 68 & 2 & \\
\hline
\end{tabular}

\section{Kiriat Arbah}

$\begin{array}{lllll}\text { Charchir } & \text { Juan y José } & 168 & 2 & \\ \text { Efron } & \text { Janda } & 75 & & \text { ex Vortman }\end{array}$




\begin{tabular}{|c|c|c|c|c|}
\hline APELLIDO & NOMBRES & HECTAREAS & generaciòn & observaciones \\
\hline Glagovsky & Abraham & 175 & 2 & \\
\hline Hirsch & Enrique & 149 & 2 & \\
\hline Isac & Isidoro & 151 & 2 & $\$ 14000$ Bco Italia \\
\hline Kremenchusky & Abraham & 124 & 2 & \\
\hline Kremenchusky & Lazaro Suc & 101 & 3 & \\
\hline Levitzky & Manuel & 152 & 2 & \\
\hline Loiber & Efroim & 100 & 1 & vendió 50 has a Rosenberg (comerc) \\
\hline Mosovich & Jacobo & 75 & & \\
\hline Smilchuk & Abraham & 75 & 1 & $\begin{array}{l}\text { Vive en Concepcion del Uruguay } \\
1 \text { vive en la ciudad }\end{array}$ \\
\hline
\end{tabular}

\section{Leven}

\begin{tabular}{|c|c|c|c|c|}
\hline Berenson & Miguel & 140 & 1 & \\
\hline Binderman & Boris & 137 & 2 & \\
\hline Boverman & Aron & 137 & 2 & Hip Part \$5150 vendió a Extr \\
\hline Burman & Isaac & 75 & 2 & vive en Bs As \\
\hline Dardik & José & 165 & 2 & vendido a Extr \\
\hline Freidenberg & Abraham & 190 & 1 & \\
\hline Furer & Naum & 60 & 2 & \\
\hline Furman & Matias & 140 & 1 & \\
\hline Giguer & Isaac & 165 & 1 & vendió a vecinos \\
\hline Glagovsky & Bernardo & 156 & 1 & \\
\hline Golub & Leon & 74 & 1 & vendió a Extr \\
\hline Grinberg & Salomón & 168 & 1 & ex Burman \\
\hline Ideses & Isaac & 65 & 1 & vendio a vecinos \\
\hline Ideses & Menasche & 60 & 1 & \\
\hline Krapivka & Adolfo & 85 & 2 & \\
\hline Lejtman & Juan & 127 & 1 & \\
\hline Lejtman & Moises & 170 & 1 & \\
\hline Lifschitz & Salomón Suc & 132 & 2 & \\
\hline Matucevich & Salomón & 112 & 2 & \\
\hline Meikler & Isaias & 126 & 1 & vendió a Schmoisman y Matrajt \\
\hline Merchuk & Sinje & 142 & 2 & \\
\hline Novidelsky & Jaime & 77 & 1 & \\
\hline Novidelsky & Manuel & 60 & 1 & \\
\hline Oclander & Suc & 164 & 2 & Bs As \\
\hline Padlog & Marcos Suc & 172 & 3 & \\
\hline Padlog & José & 155 & 2 & vendió a vecinos \\
\hline Padlog & Moises & 150 & 2 & \\
\hline Padlog & Jacobo & 141 & 2 & vendió a vecinos \\
\hline Peisajovich & Isaac Suc & 162 & 2 & \\
\hline Peisajovich & Salomón & 161 & 2 & Libaros \\
\hline Rejtman & José & 101 & 2 & San Salvador \\
\hline Rejtman & Julio & 68 & 2 & vendido a vecinos Bs As \\
\hline Rejtman & Samuel & 170 & 2 & \\
\hline Rosenfeld & León & 164 & 2 & \\
\hline Schmoisman & Juan & 68 & 1 & \\
\hline Schmoisman viuda & & 144 & 1 & \\
\hline Schmukler & Luis & 150 & 2 & \\
\hline Serebrinsky & David & 152 & 2 & $\$ 8000$ Part \\
\hline Soirefman & Gregorio & 68 & 2 & \\
\hline Soirefman & Kalman & 121 & 2 & \\
\hline Soirefman & José & & & \\
\hline Teveles & Gdalie & 155 & 2 & \\
\hline Uchitel & Israel & 161 & 2 & $\$ 17000$ Bco Hip Nac \\
\hline Uchitel & Viuda e hijos & 155 & 2 & $\$ 10000$ Part \\
\hline Vaisman & Simón & 120 & 2 & \\
\hline Yunguerman & Salomón & 99 & 2 & \\
\hline Yunguerman & Adolfo & 99 & 2 & 7 viven en los pueblos \\
\hline Yusem y Lifschitz & & 115 & 2 & \\
\hline Zonis & M. S. & 168 & 1 & Clara \\
\hline
\end{tabular}




\begin{tabular}{llccl}
\hline APELLIDO & NOMBRES & HECTAREAS & generaciòn & obser \\
\hline \multicolumn{2}{l}{ Grupo Rosh Pinah } & & & \\
Anajovich & Aron suc. & 164 & 3 & vendido a vecinos \\
Bekenstein & Osias & 89 & 2 & \\
Bekenstein & Bernardo & 89 & 2 & \\
Efron & Samuel & 101 & 2 & \\
Efron & Tanjum & 161 & 2 & ex Stenberg \\
Levit & Jacobo & 140 & 2 & ex Rabinovich \\
Levit & Hersch & 151 & & \$6000 Bco.Naciòn \\
Liberman & Marcos & 121 & 1 & vendido a vecinos \\
Salkind & Leon y Jaime & 181 & 2 & \\
Yankilevich & Ysaac & 84 & &
\end{tabular}

\section{Grupo San Vicente}

$\begin{array}{lllll}\text { Althaus } & \text { Alberto } & 72 & 3 & \\ \text { Aranovich } & \text { Salomòn } & 150 & 1 & \text { Clara } \\ \text { Baranoff } & \text { Juan } & 323 & 2 & \text { Vendió a un extraño } \\ \text { Dancis } & \text { Ysaac } & 144 & 1 & \\ \text { Davidovich } & \text { Abraham } & 77 & 1 & \text { Zarate } \\ \text { Fainstein } & \text { Ysaac } & 185 & 2 & \text { ex Berman } \\ \text { Fainstein } & \text { Jacobo } & 145 & 1 & \text { Clara } \\ \text { Fainstein } & \text { Ysaac } & 106 & & \\ \text { Frid } & \text { Rubin, suc. } & 113 & 1 & \\ \text { Frid } & \text { Yaskel } & 100 & 1 & \text { abandonó 1944 } \\ \text { Gold } & \text { Josè } & 75 & 1 & \\ \text { Grinman } & \text { Salomòn } & 88 & 1 & \\ \text { Hoijman } & \text { Salomòn } & 120 & 1 & \\ \text { Hojman } & \text { Nuce } & 143 & 1 & \\ \text { Kañevsky } & \text { Jaime } & 176 & 1 & \text { Clara } \\ \text { Katz } & \text { Moises } & 40 & 1 & \\ \text { Kesler } & \text { Antonio } & 75 & 1 & \\ \text { Kohan } & \text { Ysaac } & 162 & 1 & \text { Clara } \\ \text { Kreiserman } & \text { Abraham } & 232 & 1 & \\ \text { Muchnik } & \text { Marcos } & 88 & 2 & \\ \text { Najemson } & \text { Clara,Meer y Aròn } & 158 & 2 & \\ \text { Paley } & \text { Kiva y Leon } & 100 & 1 & \\ \text { Resnicoff } & \text { Gregorio } & 184 & 1 & \text { vendio a Baranoff Juan } \\ \text { Schejtman } & \text { David } & 149 & 1 & \\ \text { Schmoisman } & \text { Abraham } & 176 & 1 & \\ \text { Socolovsky } & \text { Miguel } & 150 & 2 & \text { ex Guerberoff Bsh } \\ \text { Vischnevsky } & \text { Ysaac } & 192 & 2 & \text { 3 viven en Clara } \\ & & & & \text { 2 en las ciudades } \\ & & & & \end{array}$

Berman Rebeca vendiò a Fainstein, Guerberoff Leib vendiò a Vischnevsky Ysaac, Hurvitz David vendiò a extraños, Bidmy Moises vendiò a extraños y Yujnovsky Aròn a Extraños.

\section{Grupo Sonenfeld (San Gregorio)}

$\begin{array}{llll}\text { Aisikovich } & \text { Sebastián } & 171 & 2 \\ \text { Bendersky } & \text { Benito } & 150 & 2 \\ \text { Bendersky } & \text { Rubin } & 75 & 3 \\ \text { Charchir } & \text { Isaac } & 75 & 2 \\ \text { Charchir } & \text { Jaime y Jacobo } & 48 & 2 \\ \text { Eidman } & \text { Jacobo } & 30 & 2 \\ \text { Fainman } & \text { Jacobo } & 30 & 1 \\ \text { Finkelstein } & \text { Moises } & 80 & 1\end{array}$




\begin{tabular}{|c|c|c|c|c|}
\hline APELLIDO & NOMBRES & HECTAREAS & generaciòn & observaciones \\
\hline Finkelstein & David & 75 & 1 & \\
\hline Flesler & Jacobo & 119 & 2 & \\
\hline Furer & Moises & 128 & 3 & vendido a extr \\
\hline Furman & Moises & 153 & 2 & \\
\hline Goldenberg & Viuda & 136 & 2 & ex Lifchitz Suc. \\
\hline Goldin & Noej & 64 & 1 & vendió a vecinos \\
\hline Goldin & M. L.y Rubin & 100 & 2 & vendió a vecinos \\
\hline Kaplan & Jacobo & 181 & 1 & ex Ferer S. \\
\hline Kardunsky & Moises & 71 & 1 & \\
\hline Kaufman & Leon & 64 & 2 & \\
\hline Kaufman & David y Mauricio & 103 & 2 & \\
\hline Kremenchusky & Aron & 142 & 1 & vendió 100 has a extr y 44 has a vecinos \\
\hline Kremenchusky & Salomón & 50 & 2 & \\
\hline Kremenchusky & Efroin & 106 & 2 & \\
\hline Lindenbaum & Jacobo & 58 & 1 & \\
\hline Merchuk & Isaac & 40 & 2 & \\
\hline Merchuk & Benjamin & 75 & 3 & \\
\hline Neuman & Gregorio & 56 & 1 & \\
\hline Niemetz & Salomón Suc. & 104 & 3 & vendió a Fondo Comunal \\
\hline Nitzberg & Ines y Fraim & 75 & 1 & vendió a vecinos \\
\hline Oclander & Jaim & 90 & 2 & \\
\hline Padlog & Naum y Abraham & 165 & 2 & \\
\hline Rogatky & Elias & 137 & 1 & vendido a vecinos \\
\hline Rogatky & Samuel & 78 & 2 & \\
\hline Roiter & Jaime & 82 & 1 & \\
\hline Rosenfeld & Julio & 108 & 2 & \\
\hline Schatzky & Jacobo & 95 & 2 & ex Lifchitz Bs. As. \\
\hline Schejtman & José & 100 & 3 & \\
\hline Schejtman & Luis & 108 & 2 & \\
\hline Schejtman & Jaime & 50 & 3 & \\
\hline Segal & J.Leib & 132 & 1 & \\
\hline Segal & Gregorio & 143 & 2 & \\
\hline Seiguerman & Berl & 159 & 2 & \\
\hline Seiguerman & Manuel & 46 & 3 & \\
\hline Serebrenik & Adolfo & 130 & 2 & \\
\hline Serebrenik & Salomón & 131 & 2 & vendido a Fondo Comunal Bs. As. \\
\hline Soirefman & Abraham & 135 & 2 & \\
\hline Sperling & Bern suc. & 53 & 2 & \\
\hline Stilman & Viuda e hijos & 158 & 3 & \\
\hline Yankelevich & Aron & 146 & 1 & abandonó \\
\hline Yurguel & Abraham & 90 & 2 & \\
\hline Zapiach & Mauricio & 133 & 2 & \\
\hline Zipilivan & Berta e hijos & 143 & 2 & \\
\hline Zipilivan & Viuda & 83 & 2 & viven en Bs. As. \\
\hline
\end{tabular}

\section{Grupo Ydah}

$\begin{array}{lllll}\text { Efron } & \text { Yauda } & 50 & 3 & \\ \text { Flesler } & \text { Jaime } & 56 & 1 & \\ \text { Grinstein } & \text { Bert y Moises } & 71 & 2 & \\ \text { Huttin } & \text { Jaime } & 50 & 2 & \text { vendió a vecinos } \\ \text { Jucid } & \text { Pedro } & 75 & & \\ \text { Koladetzky } & \text { Tevel } & 75 & 2 & \\ \text { Koleika } & \text { Victor } & 46 & 1 & \\ \text { Korn } & \text { Mendel e hijo } & 101 & 2 & \\ \text { Koval } & \text { Jaime B. Suc } & 155 & 2 \\ \text { Oljavetzky } & \text { Gil } & 171 & 2 & \\ \text { Oljavetzky } & \text { Juan } & 100 & 2 & \\ \text { Rejtman } & \text { León } & 50 & 2 & \\ \text { Roitman } & \text { Jacobo } & 61 & 1\end{array}$




\begin{tabular}{lcccc}
\hline APELLIDO & NOMBRES & HECTAREAS & generaciòn & observac \\
\hline Schatzky & Aisik Suc & 173 & 3 & \\
Schmukler & Marcos & 62 & 1 & ex Brinsterin Abraham \\
Sukovsky & Walf & 71 & 1 & vendido a vecinos \\
Vainer & Pedro & 66 & 3 & vendió a vecinos \\
Zaigner & Kapel & 111 & 2 &
\end{tabular}

\section{Las Moscas}

$\begin{array}{lllll}\text { Edelcop } & \text { Noej } & 167 & 2 & \\ \text { Gurny } & \text { Juan } & 143 & 2 & \\ \text { Gurny } & \text { Rosario } & 85 & 2 & \text { vendido a vecinos } \\ \text { Gurny } & \text { Enrique } & 86 & 2 & \$ 8000 \text { B H N } \\ \text { Matucevich } & \text { Efraim } & 157 & 1 & \\ \text { Morenlender } & \text { Suc } & 152 & 2 & \text { \$8000 B H N } \\ \text { Padlog } & \text { Ramón } & 155 & 2 & \\ \text { Pomerantz } & \text { Gdalie } & 116 & 2 & \text { vive en Dominguez } \\ \text { Savulsky } & \text { Jaime Suc } & 125 & 2 & \text { \$6900 Bco Hip Nac vendió a vecinos } \\ \text { Vainer } & \text { León } & 149 & 2 & \$ 10.000 \\ \text { Vainer } & \text { José } & 85 & 2 & \\ \text { Vainer } & \text { Samuel } & 144 & 2 & \end{array}$

\section{Miguel}

$\begin{array}{ll}\text { Acst } & \text { Salomón } \\ \text { Gupspan } & \text { Clara viuda } \\ \text { Gurevich } & \text { Isaac } \\ \text { Ideses } & \text { Yones } \\ \text { Kolameisky } & \text { Luis } \\ \text { Kreiman } & \text { Efroim } \\ \text { Krischkantzky } & \text { Bernardo } \\ \text { Lvovsky } & \text { Boris } \\ \text { Lvovsky } & \text { Israel } \\ \text { Lvovsky } & \text { Samuel } \\ \text { Roitman } & \text { Andrés } \\ \text { Roitman } & \text { Ester y Gregorio } \\ \text { Rosenfeld } & \text { Osias } \\ \text { Schinder } & \text { Miguel } \\ \text { Schmukler } & \text { Luis } \\ \text { Schmukler } & \text { Jaime } \\ \text { Schmunis } & \text { Adela y Luis }\end{array}$

62
113
50
100
63
175
112
53
73
44
50
126
56
280
139
125

vendido a vecinos

vendido a vecinos

ex M. Abranovich

\section{Perlisa}

\begin{tabular}{|c|c|c|c|c|}
\hline Althaus & Suc & 176 & 2 & vive en Domínguez \\
\hline Boguslavsky & Luis & 158 & 2 & \\
\hline Elfand & Suc & 156 & 2 & vendió a vecinos Bs As \\
\hline Fink & Mateo & 175 & 2 & \\
\hline Fink & Salomón & 159 & 2 & \$2000 Bco Hip Nac \\
\hline Fumberg & Gregorio & 105 & 1 & \\
\hline Grinberg & Israel & 119 & 2 & \\
\hline Grinberg & Efroim & 101 & 2 & \\
\hline Grinberg & Antonio y Salomón & 90 & 1 & \\
\hline Groschinsky & Pinjos y Moises & 154 & 2 & Bs As \\
\hline Groschinsky & J. E. & 148 & 2 & ex Schinder M. \\
\hline Guerschuny & Salomón & 90 & 1 & \\
\hline Isac & David & 87 & 2 & \\
\hline
\end{tabular}




\begin{tabular}{llccl}
\hline APELLIDO & NOMBRES & HECTAREAS & generaciòn & observaciones \\
\hline Kamin & Salomón & & & \\
Kaplan & Moises & 164 & 2 & Bs As \\
Katz & Suc & 162 & 2 & \$6500 Bs. As. \\
Kreiman & Leib & 90 & 2 & \\
Kunin & Salomón y David & 155 & 2 & \\
Kunin & David & 124 & 2 & \\
Lvovsky & Israel & 50 & & \\
Lvovsky & Lazaro & 109 & 2 & 2 viven en los pueblitos \\
Lvovsky & Feliciano & & & \$20000 Bco Hip Nac vendido a vecinos \\
Perelstein & Gregorio & 362 & 2 & Clara \\
Pipkin & José & 153 & 2 & 4 viven en las ciudades \\
Raitzin & Bernardo & 75 & 1 & \\
Roitman & Saul & & & \\
Schinder & Gregorio & 156 & 2 & \\
Selmanovich & Isaac & 156 & 2 & \\
Selmanovich & José & 155 & 2 & \\
Trupkin & Salomón Suc & 84 & 1 & \\
& & &
\end{tabular}

\section{Rajel}

$\begin{array}{ll}\text { Abramovich } & \text { Pablo } \\ \text { Abramovich } & \text { Meer } \\ \text { Abramovich } & \text { Salomón } \\ \text { Abramovich } & \text { Aron } \\ \text { Babich } & \text { Isaac Suc } \\ \text { Bekenstein } & \text { Osias } \\ \text { Efron } & \text { Gdalie } \\ \text { Galagovsky } & \text { Bernardo } \\ \text { Galante } & \text { Scholen } \\ \text { Gueller } & \text { Marcos y David } \\ \text { Gueller } & \text { Felix } \\ \text { Guerschenoff } & \text { León Suc } \\ \text { Kremenchusky } & \text { Abraham } \\ \text { Lifschitz } & \text { Samuel y Efraim } \\ \text { Rabey } & \text { Moises } \\ \text { Samberg } & \text { Max y Jacobo } \\ \text { Savulsky } & \text { Israel } \\ \text { Tieffenberg } & \text { Benito } \\ \text { Vainer } & \text { León }\end{array}$

100
129
50
113
217
50
140
127
82
156
111
150
50
154
131
150
175
112
75

vendido a vecinos viven en Dguez Bs. As.

Bs As

ex Kreiman Angel

Bs. As.

ex Banchik

$\$ 20000$ Part Dguez

ex Radunsky

vendido a Extraños

$\$ 6600$ Bco Nación Dguez

Uruguay

3 viven en los pueblitos

4 viven en las ciudades 


\section{Colonos en Colonia Clara por orden alfabético y grupo}

\begin{tabular}{|c|c|c|c|}
\hline APELLIDO & NOMBRES & HECTÁREAS & GRUPOS \\
\hline Abramovich & Aron & 113 & RAJEL \\
\hline Abramovich & León & 82 & GRUPO FAINBERG \\
\hline Abramovich & Meer & 129 & RAJEL \\
\hline Abramovich & Pablo & 100 & RAJEL \\
\hline Abramovich & Salomón & 50 & RAJEL \\
\hline Acst & Salomón & 62 & MIGUEL \\
\hline Aisikovich & Sebastián & 171 & GRUPO SONENFELD (San Gregorio) \\
\hline Albertinsky & Abraham & 157 & GRUPO DESPARRAMADOS \\
\hline Albertinsky & Aron & 103 & GRUPO FAINBERG \\
\hline Albertinsky & Leib Suc. & 100 & GRUPO EBEN HAROSCH \\
\hline Albertinsky & Rajmiel & 35 & GRUPO DESPARRAMADOS \\
\hline Althaus & Alberto & 72 & GRUPO SAN VICENTE \\
\hline Althaus & Suc & 176 & PERLISA \\
\hline Anajovich & Aron suc. & 164 & GRUPO ROSH PINAH \\
\hline Aranovich & Salomòn & 150 & GRUPO SAN VICENTE \\
\hline Attelman & Jacobo & 157 y 102 & Grupo Baron Guinzburg \\
\hline Axenfeld & Abraham & 146 & GRUPO FAINBERG \\
\hline Axenfeld & Rosa & 175 & GRUPO FAINBERG \\
\hline Ayernitzky & Isaac & 175 & GRUPO EBEN HAROSCH \\
\hline Babich & Isaac Suc & 217 & RAJEL \\
\hline Bahaslavsky & Luis & 174 & GRUPO BELEZ \\
\hline Baranoff & Juan & 323 & GRUPO SAN VICENTE \\
\hline Baron & Miguel & 44 & GRUPO DESPARRAMADOS \\
\hline Baron & Salomón Suc. & 95 & GRUPO DESPARRAMADOS \\
\hline Barujovich & Gregorio & 150 & GRUPO ACHIRAS \\
\hline Baskin & Abraham & 65 & GRUPO DESPARRAMADOS \\
\hline Bekenstein & Bernardo & 89 & GRUPO ROSH PINAH \\
\hline Bekenstein & Osias & 50 & RAJEL \\
\hline Bekenstein & Osias & 89 & GRUPO ROSH PINAH \\
\hline Bendersky & Benito & 150 & GRUPO SONENFELD (San Gregorio) \\
\hline Bendersky & Rubin & 75 & GRUPO SONENFELD (San Gregorio) \\
\hline Bercovich & Abr. & 71 & GRUPO DESPARRAMADOS \\
\hline Bercovich & Moisés & 76 & GRUPO FAINBERG \\
\hline Bercovich & Salomón & 73 & GRUPO DESPARRAMADOS \\
\hline Berenson & Miguel & 140 & LEVEN \\
\hline Berenstein & Pablo & 146 & GRUPO DESPARRAMADOS \\
\hline
\end{tabular}

Berman Rebeca vendiò a Fainstein, Guerberoff Leib vendiò a Vischnevsky Ysaac, Hurvitz David vendiò a extraños, Bidmy Moisés vendiò a extraños y Yujnovsky Aròn a Extraños.

$\begin{array}{lccl}\text { Binderman } & \text { Boris } & 137 & \text { LEVEN } \\ \text { Blinder } & \text { Benjamin } & 166 & \text { Grupo Baron Guinzburg } \\ \text { Boguslavsky } & \text { Luis } & 158 & \text { PERLISA } \\ \text { Bortnik } & \text { A. } & 206 & \text { Grupo Baron Guinzburg } \\ \text { Bortnik } & \text { Naum } & 100 & \text { GRUPO DESPARRAMADOS } \\ \text { Boverman } & \text { Aron } & 137 & \text { LEVEN } \\ \text { Boverman } & \text { Salomón } & 185 & \text { GRUPO BARREROS } \\ \text { Breitman } & \text { Abraham } & 72 & \text { GRUPO BARREROS }\end{array}$




\begin{tabular}{|c|c|c|c|}
\hline APELLIDO & NOMBRES & HECTÁREAS & GRUPOS \\
\hline Bresler & Matias & 81 & GRUPO CARMEL \\
\hline Bricman & & 159 & GRUPO ACHIRAS \\
\hline Britvin & Moisés & 70 & GRUPO DESPARRAMADOS \\
\hline Brodsky & A. & 105 & Grupo Baron Guinzburg \\
\hline Budasoff & Natalio & 83 & Grupo Baron Guinzburg \\
\hline Bugacoff & Berta y Samuel & 147 & GRUPO BELEZ \\
\hline Buks & Bregorio & 75 & GRUPO DESPARRAMADOS \\
\hline Burman & Isaac & 75 & LEVEN \\
\hline Buxs & Rubin suc & 100 & GRUPO CARMEL \\
\hline Carpman & Bernardo & 56 & Grupo Baron Guinzburg \\
\hline Carpman & Bernardo & 156 & Grupo Baron Guinzburg \\
\hline Celman & José & 112 & GRUPO BELEZ \\
\hline Charchir & Isaac & 75 & GRUPO SONENFELD (San Gregorio) \\
\hline Charchir & Jaime y Jacobo & 48 & GRUPO SONENFELD (San Gregorio) \\
\hline Charchir & Juan y José & 168 & KIRIAT ARBAH \\
\hline Chechelnitzky & Berta e hijo & 169 & Grupo Baron Guinzburg \\
\hline Chertcoff & David & 113 & Grupo Baron Guinzburg \\
\hline Cibulovsky & Josè & 125 & GRUPO DESPARRAMADOS \\
\hline Costianovsky & Aron & 84 & GRUPO BELEZ \\
\hline Cravetz & Benjamin & 37 & GRUPO DESPARRAMADOS \\
\hline Cravetz & Abraham & 107 & GRUPO BELEZ \\
\hline Dancis & Elias & 76 & Grupo Baron Guinzburg \\
\hline Dancis & Ysaac & 144 & GRUPO SAN VICENTE \\
\hline Dardik & José & 165 & LEVEN \\
\hline Davidovich & Abraham & 77 & GRUPO SAN VICENTE \\
\hline Davidovich & Lazaro & 94 & GRUPO FAINBERG \\
\hline Dikenstein & Jacobo & 40 & GRUPO FAINBERG \\
\hline Dikenstein & Julio & 172 & GRUPO BELEZ \\
\hline Dikenstein & Rafael & 104 & Grupo Baron Guinzburg \\
\hline Dikenstein & Rosa & 78 & GRUPO FAINBERG \\
\hline Director & Miguel & 180 & Grupo Baron Guinzburg \\
\hline Dlugovitzky & Abraham & 48 & GRUPO DESPARRAMADOS \\
\hline Dlugovitzky & José Suc. & 77 & GRUPO DESPARRAMADOS \\
\hline Dorfman & Aron & 85 & Grupo Baron Guinzburg \\
\hline Dubner & Benjamìn & 97 & Grupo Baron Guinzburg \\
\hline Duldman & Hugo & 53 & Grupo Baron Guinzburg \\
\hline Edelcop & Noej & 167 & LAS MOSCAS \\
\hline Edelstein & León & 62 & Grupo Baron Hirsch \\
\hline Edelstein & Salomón & 62 & Grupo Baron Hirsch \\
\hline Efron & Gdalie & 140 & RAJEL \\
\hline Efron & Samuel & 101 & GRUPO ROSH PINAH \\
\hline Efron & Tanjum & 161 & GRUPO ROSH PINAH \\
\hline Efron & David Suc. & 133 & Grupo Baron Hirsch \\
\hline Efron & Jacobo & 171 & GRUPO FAINBERG \\
\hline Efron & Janda & 75 & KIRIAT ARBAH \\
\hline Efron & Mauricio & 112 & GRUPO FAINBERG \\
\hline Efron & Schevaj & 112 & Grupo Baron Hirsch \\
\hline Efron & Suc, Abr y Mauricio & 154 & GRUPO FAINBERG \\
\hline Efron & Yanda Suc. & 161 & Grupo Baron Hirsch \\
\hline Efron & Yauda & 50 & GRUPO YDAH \\
\hline Eidman & Jacobo & 30 & GRUPO SONENFELD (San Gregorio) \\
\hline Elfand & Suc & 156 & PERLISA \\
\hline Elstein & Fabio & 149 & GRUPO DESPARRAMADOS \\
\hline Elstein & Salomòn & 76 & GRUPO DESPARRAMADOS \\
\hline Elstein & Salomòn & 170 & GRUPO DESPARRAMADOS \\
\hline Elstein & Salomòn y Marcos & 152 & Grupo Baron Guinzburg \\
\hline Engueberg & Elieser & 21 & GRUPO DESPARRAMADOS \\
\hline Enguelberg & Elias & 91 & GRUPO BARREROS \\
\hline Fainman & Jacobo & 30 & GRUPO SONENFELD (San Gregorio) \\
\hline Fainstein & Jacobo & 145 & GRUPO SAN VICENTE \\
\hline Fainstein & Ysaac & 106 & GRUPO SAN VICENTE \\
\hline Fainstein & Ysaac & 185 & GRUPO SAN VICENTE \\
\hline Ferdman & Julio & 152 & Grupo Baron Guinzburg \\
\hline Fijtman & Ysaac & 89 & Grupo Baron Guinzburg \\
\hline
\end{tabular}




\begin{tabular}{|c|c|c|c|}
\hline APELLIDO & NOMBRES & HECTÁREAS & GRUPOS \\
\hline Finguerman & Isaac & 126 & GRUPO EBEN HAROSCH \\
\hline Fink & Gregorio & 105 & GRUPO CARMEL \\
\hline Fink & Mateo & 175 & PERLISA \\
\hline Fink & Salomón & 159 & PERLISA \\
\hline Fink & Santiago & 153 & Grupo Baron Guinzburg \\
\hline Finkelstein & David & 75 & GRUPO SONENFELD (San Gregorio) \\
\hline Finkelstein & Moisés & 80 & GRUPO SONENFELD (San Gregorio) \\
\hline Flesler & Jacobo & 119 & GRUPO SONENFELD (San Gregorio) \\
\hline Flesler & Jaime & 56 & GRUPO YDAH \\
\hline Flesler & Rafael & 151 & GRUPO ACHIRAS \\
\hline Flier & David & 74 & GRUPO DESPARRAMADOS \\
\hline Foiguel & Elias & 147 & GRUPO BARREROS \\
\hline Freidenberg & Abraham & 190 & LEVEN \\
\hline Frid & Rubin, suc. & 113 & GRUPO SAN VICENTE \\
\hline Frid & Yaskel & 100 & GRUPO SAN VICENTE \\
\hline Fridman & Manuel & 135 & GRUPO BELEZ \\
\hline Friedland & Sucesiòn & 295 & GRUPO DESPARRAMADOS \\
\hline Fuks & Abraham & 91 & GRUPO DOMINGO CALVO \\
\hline Fuldauer & Hugo & 53 & Grupo Baron Guinzburg \\
\hline Fumberg & Gregorio & 105 & PERLISA \\
\hline Furer & Moisés & 128 & GRUPO SONENFELD (San Gregorio) \\
\hline Furer & Naum & 60 & LEVEN \\
\hline Furman & Matias & 140 & LEVEN \\
\hline Furman & Moisés & 153 & GRUPO SONENFELD (San Gregorio) \\
\hline Galagovsky & Bernardo & 127 & RAJEL \\
\hline Galansky & David & 99 & GRUPO FAINBERG \\
\hline Galante & Dr.E. & 62 & Grupo Baron Guinzburg \\
\hline Galante & Isaac & 72 & GRUPO DESPARRAMADOS \\
\hline Galante & Mauricio & 80 & GRUPO BELEZ \\
\hline Galante & Scholen & 82 & RAJEL \\
\hline Garber & Abraham Suc & 124 & Grupo Baron Hirsch \\
\hline Genijovich & Marcos & 161 & GRUPO DESPARRAMADOS \\
\hline Genijovich & Abraham & 74 & GRUPO DESPARRAMADOS \\
\hline \multicolumn{4}{|l|}{ Genijovich M. } \\
\hline Y Graschinsky M. & & 157 & GRUPO DESPARRAMADOS \\
\hline Giguer & Isaac & 165 & LEVEN \\
\hline Givre & Rodolfo & 102 & GRUPO FAINBERG \\
\hline Glagovsky & Abraham & 175 & KIRIAT ARBAH \\
\hline Glagovsky & Bernardo & 156 & LEVEN \\
\hline Glass & Leon Suc. & 178 & GRUPO CARMEL \\
\hline Gleser & Adolfo & 50 & GRUPO EBEN HAROSCH \\
\hline Gleser & Adolfo & 150 & GRUPO EBEN HAROSCH \\
\hline Gleser & Adolfo & 152 & Grupo Baron Guinzburg \\
\hline Gleser & Manuel & 53 y 75 & Grupo Baron Guinzburg \\
\hline Gleser & Moisés y Bdo & 66 & GRUPO CARMEL \\
\hline Gleser & Moisés y Bdo & 69 & GRUPO CARMEL \\
\hline Gleser & Moisés y Bernardo & 140 & GRUPO EBEN HAROSCH \\
\hline Glinberg & Leon & 75 & GRUPO DOMINGO CALVO \\
\hline Glinberg & Luis & 100 & Grupo Baron Guinzburg \\
\hline Glinberg & Luis & 163 & GRUPO FAINBERG \\
\hline Glinberg & Salomòn suc hijo Leon & 167 & Grupo Baron Guinzburg \\
\hline Glusman & Abraham & 165 & Grupo Baron Guinzburg \\
\hline Glusman & Adolfo & 112 & Grupo Baron Guinzburg \\
\hline Glusman & David & 100 & GRUPO FAINBERG \\
\hline Glusman & Gregorio & 75 & GRUPO DESPARRAMADOS \\
\hline Golbert & Julio & 104 & GRUPO BELEZ \\
\hline Gold & Josè & 75 & GRUPO SAN VICENTE \\
\hline Goldenberg & Josè & 155 & Grupo Baron Guinzburg \\
\hline Goldenberg & Marian y Moisés & 203 & Grupo Baron Guinzburg \\
\hline Goldenberg & Viuda & 136 & GRUPO SONENFELD (San Gregorio) \\
\hline Goldin & M. L.y Rubin & 100 & GRUPO SONENFELD (San Gregorio) \\
\hline Goldin & Noej & 64 & GRUPO SONENFELD (San Gregorio) \\
\hline Goliante & Moisés Suc. & 164 & GRUPO BARREROS \\
\hline Goliante & Scholem & 131 & GRUPO BARREROS \\
\hline
\end{tabular}




\begin{tabular}{|c|c|c|c|}
\hline APELLIDO & NOMBRES & HECTÁREAS & GRUPOS \\
\hline Golomb & Ksiel & 33 & GRUPO BELEZ \\
\hline Golub & Leon & 74 & LEVEN \\
\hline Graschinsky & Francisco Suc & 126 & Grupo Baron Hirsch \\
\hline Graschinsky & J y E. & 163 & GRUPO FAINBERG \\
\hline Graschinsky & J. YE & 74 & GRUPO FAINBERG \\
\hline Graschinsky & Jaime & 105 & GRUPO DESPARRAMADOS \\
\hline Graschinsky & Jaime & 150 & GRUPO DESPARRAMADOS \\
\hline Graschinsky & Jaime y E. & 164 & GRUPO BELEZ \\
\hline Graschinsky & Leon & 50 & GRUPO DESPARRAMADOS \\
\hline Grinberg & Antonio y Salomón & 90 & PERLISA \\
\hline Grinberg & Efroim & 101 & PERLISA \\
\hline Grinberg & Israel & 119 & PERLISA \\
\hline Grinberg & Salomón & 168 & LEVEN \\
\hline Grinman & Salomón & 50 & GRUPO BELEZ \\
\hline Grinman & Salomòn & 88 & GRUPO SAN VICENTE \\
\hline Grinstein & Bert y Moisés & 71 & GRUPO YDAH \\
\hline Groisman & Elias & 68 & GRUPO CARMEL \\
\hline Groschinsky & León & 68 & GRUPO BELEZ \\
\hline Groschinsky & Meer & 78 & GRUPO DESPARRAMADOS \\
\hline Groschinsky & Pinjos y Moisés & 154 & PERLISA \\
\hline Groschinsky & J. E. & 148 & PERLISA \\
\hline Grunman & Ysaac & 115 & Grupo Baron Guinzburg \\
\hline Gueller & Felix & 111 & RAJEL \\
\hline Gueller & Isaac & 150 & GRUPO DESPARRAMADOS \\
\hline Gueller & Marcos y David & 156 & RAJEL \\
\hline Guerschenoff & León Suc & 150 & RAJEL \\
\hline Guerschuny & Salomón & 90 & PERLISA \\
\hline Guilischinsky & Aron & 100 & GRUPO FAINBERG \\
\hline Gupspan & Clara viuda & 113 & MIGUEL \\
\hline Gurevich & Isaac & 50 & MIGUEL \\
\hline Gurny & Enrique & 86 & LAS MOSCAS \\
\hline Gurny & Juan & 143 & LAS MOSCAS \\
\hline Gurny & Natalio & 145 & Grupo Baron Guinzburg \\
\hline Gurny & Rosario & 85 & LAS MOSCAS \\
\hline Haimovich & Kiva & 77 & Grupo Baron Guinzburg \\
\hline Haimovich & Kiva & 90 & Grupo Baron Guinzburg \\
\hline Halperin & Bregorio & 96 & GRUPO DESPARRAMADOS \\
\hline Halperin & Moisés & 101 & GRUPO DESPARRAMADOS \\
\hline Halperin & Salomón & 184 & GRUPO DOMINGO CALVO \\
\hline Halperin & Salomòn & 144 & GRUPO DESPARRAMADOS \\
\hline Heine y Leser & Filip y Luis & 37 & GRUPO DESPARRAMADOS \\
\hline Heller & Rosa y Samuel & 159 & Grupo Baron Guinzburg \\
\hline Hertzovich & Bregorio Suc. & 92 & GRUPO FAINBERG \\
\hline Hirsch & Enrique & 149 & KIRIAT ARBAH \\
\hline Hoijman & Josè & 142 & GRUPO DESPARRAMADOS \\
\hline Hoijman & Salomòn & 120 & GRUPO SAN VICENTE \\
\hline Hojman & León & 63 & GRUPO DESPARRAMADOS \\
\hline Hojman & Nuce & 143 & GRUPO SAN VICENTE \\
\hline Hojman & Nuse & 142 & GRUPO DOMINGO CALVO \\
\hline Hojman & Tevel y Aler & 100 & GRUPO DESPARRAMADOS \\
\hline Huberman & Salomón & 165 & Grupo Baron Hirsch \\
\hline Huberman & Scholen & 164 & Grupo Baron Hirsch \\
\hline Hutin & Enrique & 176 & GRUPO ACHIRAS \\
\hline Huttin & Jaime & 50 & GRUPO YDAH \\
\hline Ideses & Isaac & 65 & LEVEN \\
\hline Ideses & Menasche & 60 & LEVEN \\
\hline Ideses & Yones & 100 & MIGUEL \\
\hline Isaac & Adolfo & 88 & Grupo Baron Hirsch \\
\hline Isac & Benjamin & 86 & Grupo Baron Hirsch \\
\hline Isac & David & 87 & PERLISA \\
\hline Isac & Isidoro & 151 & KIRIAT ARBAH \\
\hline Isac & Samuel & 44 & GRUPO DESPARRAMADOS \\
\hline Jaimovich & Felipe & 178 & GRUPO CARMEL \\
\hline Jramoy & Ynes & 66 & Grupo Baron Guinzburg \\
\hline
\end{tabular}




\begin{tabular}{|c|c|c|c|}
\hline APELLIDO & NOMBRES & HECTÁREAS & GRUPOS \\
\hline Jrus & Marcos & 118 & GRUPO CARMEL \\
\hline Jucid & Pedro & 75 & GRUPO YDAH \\
\hline Jucid & Pedro & 77 & GRUPO CARMEL \\
\hline Kaleka & David & 45 & GRUPO CARMEL \\
\hline Kaler & Lazaro & 302 & GRUPO CARMEL \\
\hline Kaller & Salomòn y Naum & 166 & Grupo Baron Guinzburg \\
\hline Kamin & Salomón & & PERLISA \\
\hline Kamin & Leon Gregorio y Salomòn & 151 & GRUPO FAINBERG \\
\hline Kañevsky & Jaime & 176 & GRUPO SAN VICENTE \\
\hline Kaplan & Josè & 50 & GRUPO DESPARRAMADOS \\
\hline Kaplan & José Isaac & 101 & GRUPO DESPARRAMADOS \\
\hline Kaplan & Moisés & 164 & PERLISA \\
\hline Kaplan & Ysaac & 150 & GRUPO DESPARRAMADOS \\
\hline Kaplan & Jacobo & 181 & GRUPO SONENFELD (San Gregorio) \\
\hline Kardunsky & Moisés & 71 & GRUPO SONENFELD (San Gregorio) \\
\hline Karschenbaum & Abraham & 150 & GRUPO DOMINGO CALVO \\
\hline Kasvin & Gregorio & 98 & Grupo Baron Guinzburg \\
\hline Kasvin & Simòn & 139 & Grupo Baron Guinzburg \\
\hline Katz & Moisés & 40 & GRUPO SAN VICENTE \\
\hline Katz & Salomón & 182 & GRUPO FAINBERG \\
\hline Katz & Suc & 162 & PERLISA \\
\hline Katzenelson & Simón Suc. & 167 & GRUPO DESPARRAMADOS \\
\hline Kaufman & David y Mauricio & 103 & GRUPO SONENFELD (San Gregorio) \\
\hline Kaufman & Leon & 64 & GRUPO SONENFELD (San Gregorio) \\
\hline Kesler & Antonio & 75 & GRUPO SAN VICENTE \\
\hline Kobrinsky & Ysrael suc. & 150 & GRUPO DESPARRAMADOS \\
\hline Kohan & Lazaro & 161 & Grupo Baron Guinzburg \\
\hline Kohan & Lazaro & 277 & GRUPO DESPARRAMADOS \\
\hline Kohan & Leib & 150 & GRUPO DESPARRAMADOS \\
\hline Kohan & Miguel & 150 & GRUPO DESPARRAMADOS \\
\hline Kohan & Ysaac & 162 & GRUPO SAN VICENTE \\
\hline Koladetzky & Tevel & 75 & GRUPO YDAH \\
\hline Kolameisky & Luis & 63 & MIGUEL \\
\hline Koleika & Victor & 46 & GRUPO YDAH \\
\hline Koraj & David & 119 & GRUPO DESPARRAMADOS \\
\hline Korman & vda e hijo Luis & 98 & Grupo Baron Guinzburg \\
\hline Korman & vda.e hijo manuel & 109 & Grupo Baron Guinzburg \\
\hline Korn & Mendel e hijo & 101 & GRUPO YDAH \\
\hline Kornfeld & Tobìas & 105 & Grupo Baron Guinzburg \\
\hline Kosarinsky & Abraham suc. & 217 & Grupo Baron Guinzburg \\
\hline Kosoy & Moisés suc. & 151 & GRUPO ACHIRAS \\
\hline Koval & Bernardo & 50 & GRUPO DESPARRAMADOS \\
\hline Koval & Jaime B. Suc & 155 & GRUPO YDAH \\
\hline Kraiseburd & L.sucesiòn & 174 & Grupo Baron Guinzburg \\
\hline Krapivka & Adolfo & 85 & LEVEN \\
\hline Krapivka & Simon & 124 & Grupo Baron Hirsch \\
\hline Kreiman & B. Suc. & 130 & Grupo Baron Hirsch \\
\hline Kreiman & Efroim & 175 & MIGUEL \\
\hline Kreiman & Leib & 90 & PERLISA \\
\hline Kreiman & Luisa y Luis & 148 & GRUPO DOMINGO CALVO \\
\hline Kreimer & David S. & 163 & Grupo Baron Guinzburg \\
\hline Kreimer & Dora y Abraham & 164 & Grupo Baron Guinzburg \\
\hline Kreimer & Rosa e Ysrael & 145 & Grupo Baron Guinzburg \\
\hline Kreimer & Salomòn suc. & 216 & Grupo Baron Guinzburg \\
\hline Kreiserman & Abraham & 232 & GRUPO SAN VICENTE \\
\hline Kremenchusky & Abraham & 50 & RAJEL \\
\hline Kremenchusky & Abraham & 124 & KIRIAT ARBAH \\
\hline Kremenchusky & Aron & 142 & GRUPO SONENFELD (San Gregorio) \\
\hline Kremenchusky & Efroin & 106 & GRUPO SONENFELD (San Gregorio) \\
\hline Kremenchusky & Lazaro Suc & 101 & KIRIAT ARBAH \\
\hline Kremenchusky & Salomón & 50 & GRUPO SONENFELD (San Gregorio) \\
\hline Kremenchutzky & Lazaro Suc. & 92 & GRUPO CARMEL \\
\hline Krischkantzky & Bernardo & 112 & MIGUEL \\
\hline Kunin & David & 124 & PERLISA \\
\hline
\end{tabular}




\begin{tabular}{|c|c|c|c|}
\hline APELLIDO & NOMBRES & HECTÁREAS & GRUPOS \\
\hline Kunin & Salomón y David & 155 & PERLISA \\
\hline Kuperstein & Peisaj y Abraham & 54 & Grupo Baron Guinzburg \\
\hline Kuschneroff & Julio & 125 & GRUPO BELEZ \\
\hline Kuselevich & Isaac & 133 & GRUPO BARREROS \\
\hline Lefcovich & Abraham Suc & 150 & GRUPO FAINBERG \\
\hline Lefcovich & Suc. & 152 & GRUPO FAINBERG \\
\hline Leff & Samuel & 60 & GRUPO DOMINGO CALVO \\
\hline Leikis & A.suc.e Ysaac & 70 & Grupo Baron Guinzburg \\
\hline Leikis & Abraham suc. & 100 & Grupo Baron Guinzburg \\
\hline Lejtman & Juan & 127 & LEVEN \\
\hline Lejtman & Moisés & 170 & LEVEN \\
\hline Lev & Benjamin & 152 & GRUPO DOMINGO CALVO \\
\hline Lev & Bernardo & 60 & GRUPO DOMINGO CALVO \\
\hline Levit & Hersch & 151 & GRUPO ROSH PINAH \\
\hline Levit & Jacobo & 140 & GRUPO ROSH PINAH \\
\hline Levit & Hersch & 152 & GRUPO DESPARRAMADOS \\
\hline Levitzky & Manuel & 65 & GRUPO DESPARRAMADOS \\
\hline Levitzky & Manuel & 152 & KIRIAT ARBAH \\
\hline Lew & José & 115 & GRUPO BELEZ \\
\hline Liberman & Marcos & 121 & GRUPO ROSH PINAH \\
\hline Liebschutz & Miguel & 152 & GRUPO DESPARRAMADOS \\
\hline Lifschitz & Salomón Suc & 132 & LEVEN \\
\hline Lifschitz & Samuel y Efraim & 154 & RAJEL \\
\hline Lindenbaum & Jacobo & 58 & GRUPO SONENFELD (San Gregorio) \\
\hline Lipcovich & Marcos & 95 & GRUPO BELEZ \\
\hline Liscovsky & Bregorio & 125 & GRUPO DESPARRAMADOS \\
\hline Litvin & Leib & 152 & Grupo Baron Guinzburg \\
\hline Litvin & Moisés & 158 & Grupo Baron Guinzburg \\
\hline Litvinoff & Bernardo & 62 & Grupo Baron Guinzburg \\
\hline Loiber & Efroim & 100 & KIRIAT ARBAH \\
\hline Lulkin & Salomòn & 106 & Grupo Baron Guinzburg \\
\hline Lvovsky & Boris & 53 & MIGUEL \\
\hline Lvovsky & Boris & 165 & GRUPO DESPARRAMADOS \\
\hline Lvovsky & Feliciano & & PERLISA \\
\hline Lvovsky & Israel & 50 & PERLISA \\
\hline Lvovsky & Israel & 73 & MIGUEL \\
\hline Lvovsky & Lazaro & 109 & PERLISA \\
\hline Lvovsky & Samuel & 44 & MIGUEL \\
\hline Magram & Israel Suc. & 150 & GRUPO DOMINGO CALVO \\
\hline Malchansky & Naum y Abraham & 160 & GRUPO DESPARRAMADOS \\
\hline Malchansky & Samson & 25 & GRUPO DESPARRAMADOS \\
\hline Malchansky & Samuel & 134 & GRUPO DESPARRAMADOS \\
\hline Manulis & Samuel & 37 & GRUPO DESPARRAMADOS \\
\hline Mas & David & 52 & GRUPO BELEZ \\
\hline Mas & Jacobo & 187 & GRUPO BELEZ \\
\hline Mas & José & 150 & GRUPO DOMINGO CALVO \\
\hline Mas & Josè & 65 & Grupo Baron Guinzburg \\
\hline Mas & Natalio & 130 & GRUPO BELEZ \\
\hline Mas & Saúl & 167 & GRUPO BELEZ \\
\hline Matucevich & Efraim & 157 & LAS MOSCAS \\
\hline Matucevich & Salomón & 112 & LEVEN \\
\hline Maynstern & Manfrid & 27 & GRUPO DESPARRAMADOS \\
\hline Meikler & Isaias & 126 & LEVEN \\
\hline Merchuk & Benjamin & 75 & GRUPO SONENFELD (San Gregorio) \\
\hline Merchuk & Isaac & 40 & GRUPO SONENFELD (San Gregorio) \\
\hline Merchuk & Sinje & 142 & LEVEN \\
\hline Merener & Luis y David & 175 & GRUPO CARMEL \\
\hline Merener & Ysaac y Dav. & 113 & GRUPO CARMEL \\
\hline Merenlender & Osias & 86 & GRUPO CARMEL \\
\hline Mirson & Jaime & 103 & GRUPO BELEZ \\
\hline Morenlender & Suc & 152 & LAS MOSCAS \\
\hline Moscovich & Benjamin suc. & 142 & Grupo Baron Guinzburg \\
\hline Mosovich & Jacobo & 55 & GRUPO CARMEL \\
\hline Mosovich & Jacobo & 75 & KIRIAT ARBAH \\
\hline
\end{tabular}




\begin{tabular}{|c|c|c|c|}
\hline APELLIDO & NOMBRES & HECTÁREAS & GRUPOS \\
\hline Muchnik & Marcos & 88 & GRUPO SAN VICENTE \\
\hline Muchnik & Salomòn suc. & 163 & Grupo Baron Guinzburg \\
\hline Muchnik & Simon & 113 & Grupo Baron Guinzburg \\
\hline Muchnik viuda & & 143 & GRUPO FAINBERG \\
\hline Najemson & Clara, Meer y Aròn & 158 & GRUPO SAN VICENTE \\
\hline Najemson & Jaim Suc. & 174 & GRUPO BELEZ \\
\hline Najemson & Meer & 151 & Grupo Baron Guinzburg \\
\hline Najemson & Suc. & 65 & GRUPO BELEZ \\
\hline Neuman & Gregorio & 56 & GRUPO SONENFELD (San Gregorio) \\
\hline Niemetz & Salomón Suc. & 104 & GRUPO SONENFELD (San Gregorio) \\
\hline Nitzberg & Ines y Fraim & 75 & GRUPO SONENFELD (San Gregorio) \\
\hline Novidelsky & Jaime & 77 & LEVEN \\
\hline Novidelsky & Manuel & 60 & LEVEN \\
\hline Nudelman & Bernardo & 70 & GRUPO BARREROS \\
\hline Oclander & Adolfo & 130 & GRUPO BARREROS \\
\hline Oclander & Jaim & 90 & GRUPO SONENFELD (San Gregorio) \\
\hline Oclander & Suc & 164 & LEVEN \\
\hline Olijavetzky & Gil y Moisés & 111 & GRUPO CARMEL \\
\hline Oljavetzky & Gil & 171 & GRUPO YDAH \\
\hline Oljavetzky & Juan & 100 & GRUPO YDAH \\
\hline Ornis & Isaac & 150 & GRUPO DOMINGO CALVO \\
\hline Ostrovsky & José & 45 & Grupo Baron Guinzburg \\
\hline Oyernitzky & Jacobo & 35 & GRUPO DESPARRAMADOS \\
\hline Oyernitzky & Jacobo & 153 & GRUPO EBEN HAROSCH \\
\hline Padlog & Jacobo & 141 & LEVEN \\
\hline Padlog & José & 155 & LEVEN \\
\hline Padlog & M.suc.e hijos & 102 & Grupo Baron Guinzburg \\
\hline Padlog & Marcos Suc & 172 & LEVEN \\
\hline Padlog & Moisés & 150 & LEVEN \\
\hline Padlog & Naum y Abraham & 165 & GRUPO SONENFELD (San Gregorio) \\
\hline Padlog & Ramón & 155 & LAS MOSCAS \\
\hline Paley & Kiva y Leon & 100 & GRUPO SAN VICENTE \\
\hline Paley & Moisés e Isaac & 15 & GRUPO BELEZ \\
\hline Pattin & David suc. & 223 & GRUPO DESPARRAMADOS \\
\hline Pave & Juan & 151 & GRUPO ACHIRAS \\
\hline Pavè & Juan y Gregorio & 72 & Grupo Baron Guinzburg \\
\hline Pavé & Gregorio & 4 & GRUPO BARREROS \\
\hline Pavé & Jacobo & 100 & GRUPO BARREROS \\
\hline Pavé & Marcos & 165 & GRUPO BARREROS \\
\hline Pavé & Salomón & 117 & GRUPO BARREROS \\
\hline Pecar & Angel & 111 & GRUPO FAINBERG \\
\hline Peisajovich & Isaac Suc & 162 & LEVEN \\
\hline Peisajovich & Jaim & 151 & GRUPO EBEN HAROSCH \\
\hline Peisajovich & Marcos Suc. & 99 & GRUPO DESPARRAMADOS \\
\hline Peisajovich & Moisés & 75 & GRUPO DESPARRAMADOS \\
\hline Peisajovich & Salomón & 161 & LEVEN \\
\hline Peisajovich & Ysrael & 102 & GRUPO DESPARRAMADOS \\
\hline Pekerman & Salomòn & 112 & GRUPO CARMEL \\
\hline Perelstein & Gregorio & 362 & PERLISA \\
\hline Perlman & Naftule & 163 & GRUPO BARREROS \\
\hline Pipkin & José & 153 & PERLISA \\
\hline Pipkin & Josè y Elìas & 93 & Grupo Baron Guinzburg \\
\hline Polack & Berl & 150 & GRUPO EBEN HAROSCH \\
\hline Pomerantz & Gdalie & 116 & LAS MOSCAS \\
\hline Pomerantz & S. & 131 & Grupo Baron Guinzburg \\
\hline Pomerantz & Ysaac & 80 & Grupo Baron Guinzburg \\
\hline Pustilnik & Marcos & 56 & Grupo Baron Guinzburg \\
\hline Pustilnik & Marcos & 82 & Grupo Baron Guinzburg \\
\hline Pustilnik & Marcos & 104 & Grupo Baron Guinzburg \\
\hline Puterman & Saul & 100 & GRUPO DOMINGO CALVO \\
\hline Rabey & Moisés & 131 & RAJEL \\
\hline Rabinovich & Jacobo & 160 & GRUPO ACHIRAS \\
\hline Rabinovich & R.Suc. & 163 & Grupo Baron Guinzburg \\
\hline Rabinovich & Jaim & 50 & Grupo Baron Hirsch \\
\hline
\end{tabular}




\begin{tabular}{|c|c|c|c|}
\hline APELLIDO & NOMBRES & HECTÁREAS & GRUPOS \\
\hline Rabinovich & Suc. & 137 & Grupo Baron Hirsch \\
\hline Raitzin & Bernardo & 75 & PERLISA \\
\hline Rejtman & José & 101 & LEVEN \\
\hline Rejtman & Julio & 68 & LEVEN \\
\hline Rejtman & Samuel & 170 & LEVEN \\
\hline Rejtman & Sujer & 75 & GRUPO DESPARRAMADOS \\
\hline Rejtman & León & 50 & GRUPO YDAH \\
\hline Repetur & Moisés & 153 & GRUPO FAINBERG \\
\hline Resnicoff & Gregorio & 184 & GRUPO SAN VICENTE \\
\hline Rogatky & Elias & 137 & GRUPO SONENFELD (San Gregorio) \\
\hline Rogatky & Samuel & 78 & GRUPO SONENFELD (San Gregorio) \\
\hline Roiter & Jaime & 82 & GRUPO SONENFELD (San Gregorio) \\
\hline Roiter & Salomón & 74 & GRUPO DOMINGO CALVO \\
\hline Roiter & Salomòn & 162 & Grupo Baron Guinzburg \\
\hline Roitman & Andrés & 50 & MIGUEL \\
\hline Roitman & Ester y Gregorio & 126 & MIGUEL \\
\hline Roitman & Jacobo & 61 & GRUPO YDAH \\
\hline Roitman & Saul & & PERLISA \\
\hline Roitman & Adolfo Suc. & 124 & Grupo Baron Hirsch \\
\hline Rosenberg & Elias, Jaime, Isaac & 150 & GRUPO DOMINGO CALVO \\
\hline Rosenberg & Hilel & 50 & GRUPO DOMINGO CALVO \\
\hline Rosenberg & Samuel & 100 & GRUPO DOMINGO CALVO \\
\hline Rosenberg Viuda e hijos & & 150 & GRUPO DOMINGO CALVO \\
\hline Rosenfeld & Julio & 108 & GRUPO SONENFELD (San Gregorio) \\
\hline Rosenfeld & Osias & 56 & MIGUEL \\
\hline Rosenfeld & León & 164 & LEVEN \\
\hline Rosenthal & W. S & 112 & Grupo Baron Hirsch \\
\hline Rubin & Juan & 40 & Grupo Baron Guinzburg \\
\hline Rubinstein & Abraham suc. & 157 & GRUPO ACHIRAS \\
\hline Sajaroff & Jaime & 75 & GRUPO DESPARRAMADOS \\
\hline Salkind & Leon y Jaime & 181 & GRUPO ROSH PINAH \\
\hline Salkind & Samuel & 184 & GRUPO ACHIRAS \\
\hline Salmons & Otto & 28 & GRUPO DESPARRAMADOS \\
\hline Samberg & Max y Jacobo & 150 & RAJEL \\
\hline Samuiloff & Sucesiòn & 151 & GRUPO ACHIRAS \\
\hline Saroca & José & 150 & GRUPO DESPARRAMADOS \\
\hline Saroca & Moisés & 149 & GRUPO DESPARRAMADOS \\
\hline Saroca & Moisés & 180 & GRUPO DESPARRAMADOS \\
\hline Saroca & Simón Suc. & 149 & GRUPO DESPARRAMADOS \\
\hline SAS Isaac M. & Greg.y Benj. & 205 & Grupo Baron Hirsch \\
\hline Savitzky & Lazaro & 30 & GRUPO DESPARRAMADOS \\
\hline Savitzky & Moisés & 30 & GRUPO DESPARRAMADOS \\
\hline Savitzky & Noej & 30 & GRUPO DESPARRAMADOS \\
\hline Savulsky & Israel & 175 & RAJEL \\
\hline Savulsky & Jaime Suc & 125 & LAS MOSCAS \\
\hline Schalamuk & Santiago & 105 & GRUPO BARREROS \\
\hline Schalamuk & Ysaac & 52 & GRUPO BARREROS \\
\hline Schatzky & Aisik Suc & 173 & GRUPO YDAH \\
\hline Schatzky & Jacobo & 95 & GRUPO SONENFELD (San Gregorio) \\
\hline Schatzky & Jacobo y Aron & 160 & GRUPO BARREROS \\
\hline Schejter & Josè y Bernardo & 147 & Grupo Baron Guinzburg \\
\hline Schejtman & David & 149 & GRUPO SAN VICENTE \\
\hline Schejtman & Jaime & 50 & GRUPO SONENFELD (San Gregorio) \\
\hline Schejtman & José & 100 & GRUPO SONENFELD (San Gregorio) \\
\hline Schejtman & Luis & 108 & GRUPO SONENFELD (San Gregorio) \\
\hline Scheps & Elias & 74 & GRUPO EBEN HAROSCH \\
\hline Scheps & Isaac & 74 & GRUPO EBEN HAROSCH \\
\hline Scheps & Luis & 155 & GRUPO ACHIRAS \\
\hline Schinder & Gregorio & 156 & PERLISA \\
\hline Schinder & Miguel & 280 & MIGUEL \\
\hline Schlosman & Jacobo & 54 & Grupo Baron Guinzburg \\
\hline Schmoisman & Abraham & 176 & GRUPO SAN VICENTE \\
\hline Schmoisman & David & 58 & Grupo Baron Guinzburg \\
\hline Schmoisman & Samuel & 177 & Grupo Baron Guinzburg \\
\hline
\end{tabular}




\begin{tabular}{|c|c|c|c|}
\hline APELLIDO & NOMBRES & HECTÁREAS & GRUPOS \\
\hline Schmoisman & Juan & 68 & LEVEN \\
\hline Schmoisman viuda & & 144 & LEVEN \\
\hline Schmukler & Hersch & 159 & Grupo Baron Guinzburg \\
\hline Schmukler & Jaime & 139 & MIGUEL \\
\hline Schmukler & Luis & 150 & LEVEN \\
\hline Schmukler & Luis & 151 & MIGUEL \\
\hline Schmukler & Marcos & 62 & GRUPO YDAH \\
\hline Schmunis & Adela y Luis & 125 & MIGUEL \\
\hline Schnitman & Boris suc. & 152 & Grupo Baron Guinzburg \\
\hline Schnitman & Cesar & 89 & Grupo Baron Guinzburg \\
\hline Schoi & Gregorio & 192 & GRUPO ACHIRAS \\
\hline Schulman & José & 189 & GRUPO BELEZ \\
\hline Schvartz & Julio & 155 & GRUPO FAINBERG \\
\hline Schvartzberg y Kleiman & & 158 & GRUPO BELEZ \\
\hline Segal & Samuel suc. & 143 & GRUPO DESPARRAMADOS \\
\hline Segal & Gregorio & 143 & GRUPO SONENFELD (San Gregorio) \\
\hline Segal & J.Leib & 132 & GRUPO SONENFELD (San Gregorio) \\
\hline Seiguerman & Berl & 159 & GRUPO SONENFELD (San Gregorio) \\
\hline Seiguerman & Jacobo & 40 & GRUPO FAINBERG \\
\hline Seiguerman & Manuel & 46 & GRUPO SONENFELD (San Gregorio) \\
\hline Selmanovich & Isaac & 156 & PERLISA \\
\hline Selmanovich & José & 155 & PERLISA \\
\hline Seltzer & Alejandro & 152 & GRUPO DESPARRAMADOS \\
\hline Seltzer & Yjiel & 155 & GRUPO DESPARRAMADOS \\
\hline Serebrenik & Adolfo & 130 & GRUPO SONENFELD (San Gregorio) \\
\hline Serebrenik & Salomón & 131 & GRUPO SONENFELD (San Gregorio) \\
\hline Serebrinsky & David & 152 & LEVEN \\
\hline Serebrinsky & Jaime & 153 & GRUPO DESPARRAMADOS \\
\hline Serguey & Leib & 168 & GRUPO BARREROS \\
\hline Sidi & Leon suc. & 107 & GRUPO DESPARRAMADOS \\
\hline Silberman & Mauricio & 164 & GRUPO FAINBERG \\
\hline Siseles & Moisés & 112 & GRUPO FAINBERG \\
\hline Sitlonik & Josè & 119 & Grupo Baron Guinzburg \\
\hline Slavkin & Hermanos & 188 & GRUPO ACHIRAS \\
\hline Slotnik & Benjamin y Marcos & 75 & GRUPO DESPARRAMADOS \\
\hline Smilchuk & Abraham & 75 & KIRIAT ARBAH \\
\hline Socolovsky & Miguel & 150 & GRUPO SAN VICENTE \\
\hline Soirefman & Abraham & 135 & GRUPO SONENFELD (San Gregorio) \\
\hline Soirefman & Gregorio & 68 & LEVEN \\
\hline Soirefman & José & & LEVEN \\
\hline Soirefman & Kalman & 121 & LEVEN \\
\hline Sperling & Bern suc. & 53 & GRUPO SONENFELD (San Gregorio) \\
\hline Spirer & Jacobo Samuel & 83 & Grupo Baron Guinzburg \\
\hline Stavsky & Boruj & 62 & GRUPO ACHIRAS \\
\hline Stein & Simón & 149 & GRUPO DESPARRAMADOS \\
\hline Stern & Bela & 30 & GRUPO DESPARRAMADOS \\
\hline Stern & Jaime & 151 & GRUPO DESPARRAMADOS \\
\hline Stern & Manuel & 75 & GRUPO DESPARRAMADOS \\
\hline Stern & Ysaac & 150 & GRUPO DESPARRAMADOS \\
\hline Stern & Moisés & 142 & GRUPO FAINBERG \\
\hline Stilman & Viuda e hijos & 158 & GRUPO SONENFELD (San Gregorio) \\
\hline Straijman & Israel & 75 & GRUPO DESPARRAMADOS \\
\hline Stubrin & J. E Ysaac & 158 & Grupo Baron Guinzburg \\
\hline Stubrin & Sevalino & 160 & Grupo Baron Guinzburg \\
\hline Subovsky & Moisés & 179 & GRUPO BELEZ \\
\hline Sujanovich & Jacobo & 101 & GRUPO BELEZ \\
\hline Sujenovich & Simón & 67 & GRUPO BELEZ \\
\hline Sukovsky & Isaac & 75 & GRUPO DESPARRAMADOS \\
\hline Sukovsky & Walf & 71 & GRUPO YDAH \\
\hline Susevich & Jacobo & 151 & GRUPO DOMINGO CALVO \\
\hline Taran & Jacobo & 56 & Grupo Baron Guinzburg \\
\hline Tauber & Levy Isaac & 14 & GRUPO BELEZ \\
\hline Tcach & Benjamin & 75 & GRUPO DOMINGO CALVO \\
\hline Tcach & Benjamìn & 77 & Grupo Baron Guinzburg \\
\hline
\end{tabular}




\begin{tabular}{|c|c|c|c|}
\hline APELLIDO & NOMBRES & HECTÁREAS & GRUPOS \\
\hline Teper & Jacobo & 75 & GRUPO DOMINGO CALVO \\
\hline Teper & Jacobo & 150 & GRUPO DOMINGO CALVO \\
\hline Teveles & Gdalie & 155 & LEVEN \\
\hline Teveles & Gregorio & 121 & GRUPO DESPARRAMADOS \\
\hline Teveles & Gregorio & 135 & GRUPO BARREROS \\
\hline Teveles & Moisés & 50 & GRUPO BARREROS \\
\hline Teveles & Zelig & 133 & GRUPO BARREROS \\
\hline Teveles & Bernardo & 70 & GRUPO BELEZ \\
\hline Tieffenberg & Benito & 112 & RAJEL \\
\hline Toer & Salomòn suc. & 97 & Grupo Baron Guinzburg \\
\hline Toer & Samuel & 70 & GRUPO DESPARRAMADOS \\
\hline Trupkin & Salomón Suc & 84 & PERLISA \\
\hline Uchitel & Israel & 161 & LEVEN \\
\hline Uchitel & Viuda e hijos & 155 & LEVEN \\
\hline Uner & Lazaro & 91 & GRUPO DOMINGO CALVO \\
\hline Vainer & Abraham & 81 & LAS MOSCAS \\
\hline Vainer & José & 85 & LAS MOSCAS \\
\hline Vainer & León & 75 & RAJEL \\
\hline Vainer & León & 149 & LAS MOSCAS \\
\hline Vainer & Pedro & 66 & GRUPO YDAH \\
\hline Vainer & Pedro & 82 & Grupo Baron Guinzburg \\
\hline Vainer & Samuel & 144 & LAS MOSCAS \\
\hline Vainer & Ysaìas & 163 & Grupo Baron Guinzburg \\
\hline Vaisman & Benjamin & 153 & GRUPO FAINBERG \\
\hline Vaisman & Simón & 120 & LEVEN \\
\hline Vindichansky & L.y Y. & 175 & Grupo Baron Hirsch \\
\hline Vischnevsky & Ysaac & 192 & GRUPO SAN VICENTE \\
\hline Volcovich & Dr.Jorge & 154 & Grupo Baron Guinzburg \\
\hline Volosin & Naum & 150 & GRUPO ACHIRAS \\
\hline Vortman & Rafael & 152 & GRUPO ACHIRAS \\
\hline Voscoboinik & Josè & 112 & Grupo Baron Guinzburg \\
\hline Woscoboinik & Ysaac & 66 & Grupo Baron Guinzburg \\
\hline Yankelevich & Aron & 146 & GRUPO SONENFELD (San Gregorio) \\
\hline Yankilevich & Ysaac & 84 & GRUPO ROSH PINAH \\
\hline Yconikoff & Abraham suc & 151 & GRUPO DESPARRAMADOS \\
\hline Ydelson & Luis & 68 & GRUPO FAINBERG \\
\hline Ydeses & Simón Suc. & 137 & Grupo Baron Hirsch \\
\hline Yncevich & Bernardo y Aròn & 160 & Grupo Baron Guinzburg \\
\hline Ynguerscher & y Oclander & 76 & GRUPO CARMEL \\
\hline Yoguel & Mauricio & 112 & GRUPO BELEZ \\
\hline Yoguel & Meer & 104 & GRUPO BELEZ \\
\hline Yunguerman & Adolfo & 99 & LEVEN \\
\hline Yunguerman & Salomón & 99 & LEVEN \\
\hline Yurguel & Abraham & 90 & GRUPO SONENFELD (San Gregorio) \\
\hline Yuseffof & Juan & 77 & Grupo Baron Guinzburg \\
\hline Yusefoff & Julio & 82 & Grupo Baron Guinzburg \\
\hline Yusem y Lifschitz & & 115 & LEVEN \\
\hline Zaigner & Kapel & 111 & GRUPO YDAH \\
\hline Zapiach & Mauricio & 133 & GRUPO SONENFELD (San Gregorio) \\
\hline Zaslavsky & León & 151 & GRUPO DOMINGO CALVO \\
\hline Zeigner & Moisés & 121 & GRUPO CARMEL \\
\hline Zepeñuk & Bernardo & 100 & GRUPO DESPARRAMADOS \\
\hline Zibelman & Bernardo & 94 & Grupo Baron Guinzburg \\
\hline Zibelman & Ysrael & 94 & Grupo Baron Guinzburg \\
\hline Zinovoy & Abraham & 50 & GRUPO DESPARRAMADOS \\
\hline Zipilivan & Berta e hijos & 143 & GRUPO SONENFELD (San Gregorio) \\
\hline Zipilivan & Viuda & 83 & GRUPO SONENFELD (San Gregorio) \\
\hline Zirulsky & Rafael Suc. & 132 & GRUPO BELEZ \\
\hline Zlotnitzky & viuda & 100 & GRUPO DESPARRAMADOS \\
\hline Zonis & M. S. & 168 & LEVEN \\
\hline
\end{tabular}




\section{Colonos asentados en colonias de la J.C.A. en Argentina}

\begin{tabular}{|c|c|c|c|}
\hline No Lugar & Descripcion Gral.(Nombres,etc) & Años & Observaciones \\
\hline $2020 ?$ & Israelson Gregorio, nota & 1969 & Reserva \\
\hline 1565 Avigdor & Abramczik Siegmund, contrato sub arriendo para ganadería & 1948 & \\
\hline 2215 Avigdor & Abramezik Siegmund, nota, abandono & 1953 & \\
\hline 1493 Avigdor & Aizicovich Samuel, contrato, plano, cartas & $1946-55$ & Reserva \\
\hline 4341 Avigdor & Albornoz Jeronimo, contrato & $1948-54$ & \\
\hline 5973 Avigdor & Alterthum Juan, Promesa de Venta, desligado, notas & $1942-1945$ & \\
\hline 2197 Avigdor & Appel Bernard, contrato de arriendo, abandono & $1938-43$ & \\
\hline 1573 Avigdor & Appel Bernard, contrato sub arriendo para ganadería & 1945 & \\
\hline 5956 Avigdor & Appel Juan, desligado, notas & 1947-1949 & \\
\hline 542 Avigdor & Appel Mendel, contrato, plano, carta & $1932-60$ & \\
\hline 2171 Avigdor & Apt Herman, contrato de arriendo & 1936 & \\
\hline 855 Avigdor & Arcusin Gregorio y Jacobo, y Engelberg Bernardo, contrato, plano & $1951-65$ & Reserva \\
\hline 607 Avigdor & Arcusin Gregorio, contrato, plano & $1950-51$ & \\
\hline 608 Avigdor & Arcusin Jacobo, contrato, plano & $1950-68$ & \\
\hline 1533 Avigdor & Arcusin Jaime, sub arriendo para ganadería & 1950 & \\
\hline 2654 Avigdor & Arcusin Marcos y Engelberg Bernardo, contrato, plano & 1950 & \\
\hline 609 Avigdor & Arcusin Marcos, contrato, plano, cartas & $1944-66$ & \\
\hline 4346 Avigdor & Ayala Marciano, contrato & $1950-53$ & \\
\hline 1014 Avigdor & Ayala Mercedes, contrato, plano & 1965 & Reserva \\
\hline 4299 Avigdor & Barrios Andres, nota & 1973 & Reserva \\
\hline 1550 Avigdor & Beberstein Sigmund, contrato sub arriendo para ganadería & $1938-49$ & \\
\hline 1111 Avigdor & Behrend Benno, contrato, plano, cartas & $1946-56$ & \\
\hline 6070 Avigdor & Bendit Ricardo, contrato & $1942-1944$ & \\
\hline 2173 Avigdor & Bendix Josef, contrato de arriendo, notas, abandono & $1936-41$ & \\
\hline 3668 Avigdor & Benitez Ceferino, nota & 1971 & Reserva \\
\hline 2177 Avigdor & Berg Artur, contrato de arriendo, notas, abandono & $1938-43$ & \\
\hline 1501 Avigdor & Berg Walter, contrato sub-arriendo (para ganadería) & 1940 & \\
\hline 6067 Avigdor & Berg Walter, contrato, nota & 1941-1949 & \\
\hline 1098 Avigdor & Beverstein Hermann, contrato, plano, cartas & $1944-59$ & \\
\hline 2172 Avigdor & Beverstein Siegmund, contrato de arriendo, abandono & $1936-42$ & \\
\hline 2168 Avigdor & Beverstein Walter, contrato locación para carniceria & $1938-40$ & \\
\hline 834 Avigdor & Beverstein Walter, contrato, plano & $1951-64$ & Reserva \\
\hline 1566 Avigdor & Boeniger Max, contrato sub arriendo para ganadería & 1948 & \\
\hline 2216 Avigdor & Boeninger Max, contrato de arriendo, notas, abandono & $1940-51$ & \\
\hline 543 Avigdor & Braslavsky Jaime Rful, contrato, plano & $1932-61$ & \\
\hline 2174 Avigdor & Breitstein Max, contrato de arriendo, notas, desalojo & $1937-42$ & \\
\hline 534 Avigdor & Bresler Jaime, contrato, plano & $1932-66$ & \\
\hline 3538 Avigdor & Bresler Jaime, nota & 1971 & Reserva \\
\hline 541 Avigdor & Bronstein Isaac, contrato, plano & $1951-64$ & \\
\hline 1540 Avigdor & Burghardt Arthur y Helmut, sub arriendo para ganadería & 1951 & \\
\hline 1040 Avigdor & Burghardt Artur y Juan, contrato, plano & $1937-60$ & \\
\hline 53 Avigdor & Burghardt Arturo, y Helmut Juan, contrato, plano, ensanche & 1954 & \\
\hline 3536 Avigdor & Caplan Martin, nota & 1971 & Reserva \\
\hline 3185 Avigdor & Centro Union Israelita, plano, notas & 1968 & De reserva \\
\hline 1184 Avigdor & Cohan Iwan y Werner, contrato, plano & $1932-59$ & \\
\hline 1531 Avigdor & Cohn Ivan, sub arriendo para ganadería & 1951 & \\
\hline 1523 Avigdor & Coop. Agricola Avigdor, sub arriendo para ganadería & 1945 & \\
\hline 3534 Avigdor & Cooperativa Agricola «Avigdor», plano nota & $1962-68$ & Reserva \\
\hline
\end{tabular}


3744 Avigdor 785 Avigdor 854 Avigdor 844 Avigdor 4339 Avigdor 4366 Avigdor 835 Avigdor 602 Avigdor 1519 Avigdor 2230 Avigdor 1512 Avigdor 2854 Avigdor 48 Avigdor

1538 Avigdor 5962 Avigdor 2204 Avigdor 1547 Avigdor 1028 Avigdor 2234 Avigdor 3666 Avigdor 544 Avigdor 1119 Avigdor 5958 Avigdor 2192 Avigdor 1580 Avigdor 6075 Avigdor 1577 Avigdor 40 Avigdor 5960 Avigdor 4343 Avigdor 1120 Avigdor 549 Avigdor 2175 Avigdor 832 Avigdor 1110 Avigdor 6076 Avigdor 6073 Avigdor 1569 Avigdor 2228 Avigdor 1518 Avigdor 19 Avigdor 58 Avigdor 32 Avigdor 1185 Avigdor 1121 Avigdor 540 Avigdor 52 Avigdor 5957 Avigdor 6072 Avigdor 2187 Avigdor 1517 Avigdor 3664 Avigdor 4344 Avigdor 339 Avigdor 2183 Avigdor 5971 Avigdor 2203 Avigdor 2220 Avigdor 1587 Avigdor 4356 Avigdor 550 Avigdor 3535 Avigdor 1506 Avigdor 1101 Avigdor 2170 Avigdor 1515 Avigdor 7 Avigdor
Cooperativa Agricola «Ocavi», contrato

Cooperativa Agricola Avigdor Ltda., contrato, plano

Cooperativa Agricola Avigdor Ltda., contrato, plano

Cooperativa Agricola Avigdor Ltda., contrato, plano, correspondencia

Cooperativa Agricola Ltda., contrato

Corcovado H., notas

Coronel Fortunato, contrato, notas

Czarlinsky Carlos, contrato, plano, cartas

Czarlinsky Felix, sub arriendo para ganadería

Danziger David, contrato, nota, abandono

De Levie Alfred, contrato sub arriendo para ganadería

De Levie Alfred, contrato, plano, cartas

De Levie Alfredo, contrato, plano, correspondencia

Dellheim Jacob, sub arriendo para ganadería

Dellheim Jakob, Promesa de Venta, desligado

Dessauer Carlos, contrato de arriendo, notas, abandono

Deuchkron Georg, contrato sub arriendo para ganadería

Deutschkron Georg y Lothar, contrato, plano, cartas

Deutschkron Herman, contrato, nota, abandono

Diaz Felix, nota

Disenfel Isaac, contrato, plano

Druker Isaac, contrato, plano, cartas

Dymant Abram, Promesa de Venta

Ehrenfeld Kurt Jose, contrato de arriendo

Ehrenfeld Kurt, contrato sub arriendo para ganadería

Eiser Herman y Teodor, contrato, notas

Eiser Herman, contrato sub arriendo para ganadería

Engelberg Bernardo, contrato, plano

Erb Erich, desligado, notas

Establecimientos Bovril, plano, notas

Fink Isaac, 1 nota

Fink Isaac, contrato, plano

Fink Salomon, contrato de arriendo

Fogel David, contrato, plano

Fogel User Mailas y Leib, contrato, plano, cartas

Freitag Bertold, contrato, notas

Freitag Bertold, contrato, notas

Freitag Jakob, contrato sub-arriendo para ganadería

Freitag Jakob, contrato, nota, abandono

Freudenstein Herman y Sally, contrato sub arriendo para ganadería

Freudenstein Hermann, contratos, planos, cuentas

Freudenstein Hermann, contrato, plano

Freudenstein Hermann, contratos, plano

Freudenstein Sally, contrato, plano

Friedemann Julius, contrato, plano

Friedman Leopoldo y Friedman Alfredo, contrato, plano

Fritz Perl, contrato, plano

Froelich Itzig, notas

Fuchs Walter, contrato, notas

Gabriel Jakob, contrato de arriendo, notas

Gabriel Jorge Moises, contrato sub arriendo para ganadería

Gariboglio Abel, contrato, plano, nota

Gariboglio Eduardo, contrato, notas

Gariboglio Luis Carlos, contrato, plano, cartas

Geismar Fritz, contrato de arriendo, notas, abandono

Gerson Hans, Promesa de Venta, desligado, notas

Gerson Leopold, contrato de arriendo, abandono

Gerson Richarad, contrato, nota, abandono

Gerson Richard, sub arriendo para ganadería

Goldemberg Bernardino y Berner Moises, contrato

Goldstaud Manfred, contrato, plano, carta

Golstand Leonardo, nota

Gottlich Samuel, contrato sub-arriendo para ganadería

Grunenwald Egon, contrato, plano, cartas

Grunewald Karl, contrato de arriendo anulado

Grunewald Siegfried, contrato sub-arriendo para ganadería

Grungwald Harry, contratos facturas
1953-71

1938-1941

1936-50

1946

1938-1951

1946

1950-59

1938

1951-1951

1970

1952-63

1937-43

1952-60

1938-67

1943-1944

1943-1944

1945

1939-40

1941

1945-59

1954-56

1951-60

1922-60

1949-60

1938-62

1939

1932-1949

1934-1944

1938-50

1941

1955-70

1944-54

1966

1937-42

1938-1945

$1939-40$

1938-40

1945

1969

1955-63

1971-72

1941

$1922-61$

1938-41

1938-41

1938-56

Reserva

Reserva

Reserva

Reserva
Reserva

Reserva

Reserva

Reserva 
4367 Avigdor 605 Avigdor 1532 Avigdor 3462 Avigdor 1514 Avigdor 5774 Avigdor 1025 Avigdor 11 Avigdor

5970 Avigdor 836 Avigdor

2195 Avigdor 1507 Avigdor 1508 Avigdor 2210 Avigdor 5954 Avigdor 2176 Avigdor 1505 Avigdor 1502 Avigdor 1581 Avigdor 2214 Avigdor 2855 Avigdor 589 Avigdor 5955 Avigdor 5918 Avigdor 2237 Avigdor 6077 Avigdor 1537 Avigdor 1567 Avigdor 2218 Avigdor 2219 Avigdor 2194 Avigdor 1570 Avigdor 50 Avigdor 1100 Avigdor 6074 Avigdor 4340 Avigdor 2232 Avigdor 1582 Avigdor 5964 Avigdor 2223 Avigdor 1536 Avigdor 596 Avigdor 5845 Avigdor 554 Avigdor 2023 Avigdor 1590 Avigdor 2202 Avigdor 2180 Avigdor 340 Avigdor 1186 Avigdor 54 Avigdor 1541 Avigdor 9 Avigdor 1568 Avigdor 1104 Avigdor 1187 Avigdor 1562 Avigdor 33 Avigdor 57 Avigdor 1118 Avigdor 1592 Avigdor 784 Avigdor 1583 Avigdor 55 Avigdor 1530 Avigdor 783 Avigdor 853 Avigdor
Guarrochena Hijos de Pablo, contrato

Gumbert Moritz, contrato, plano, cartas

Gumbert Moritz, sub arriendo para ganadería

Gutierrez Cecilio, nota

Gutman Bernnard, contrato, sub arriendo para ganadería

Gutman Jose, contrato, plano, notas

Gutman Saly, contrato, plano, cartas

Gutman Saly, contratos, plano

Gutmann Bernhard, Promesa de Venta, desligado, notas

Harberts Eduardo, contrato, plano

Heimenrath Levi, contrato de arriendo, abandono

Heimenrath Siegfried, contrato sub-arriendo para ganadería

Herman Julius, contrato sub-arriendo para ganadería

Hermann Julius, notas, abandono

Hess Julius Sucesion, notas

Heuman Beni, contrato de arriendo, abandono

Hirsch Brand Roberto, contrato sub-arriendo para ganadería

Hirschberg Fritz Perl y Nathan, contrato sub-arriendo (para ganadería)

Hirschberg Martin, contrato sub arriendo para ganadería

Hirschberg Martin, contrato, notas abandono

Hirschbrand Hans y Robert, contrato, plano

Hirschbrand Max y Walter, contrato, plano

Hirschbrand Roberto, desligado, notas

Hirschbrand Roberto, plano de lote

Hirschman Markus, contrato de arriendo, abandono

Hoffman Sandor, contrato, notas

Horst Hecht, sub arriendo para ganadería

Isaac Josef, contrato sub arriendo para ganadería

Isaac Joseph, contrato de arriendo notas, abandono

Itzkovitz Isidor, contrato, nota, abandono

Jakob Siegmund, contrato de arriendo

Janovsky Jakob, contrato sub-arriendo para ganadería

Janowsky Jacobo

Janowsky Max y Robert, contrato, plano

Jastrow Manfred, contrato, notas

Jefatura de Policia de La Paz, contrato

Josef Meier, contrato, nota, abandono

Joseph Emil, contrato sub arriendo para ganadería

Joseph Emil, Promesa de Venta, desligado

Kaczewski Salomon, contrato, nota, abandono

Kadden A. y W. y Kahn Sally, sub arriendo para ganadería

Kadden Aron Adolfo y Walter, contrato, plano

Kaiser Alfredo, Escritura

Kaiser Daniel, contrato, plano

Kaiser Daniel, nota

Katz Alfred, sub arriendo para ganadería

Katz Alfredo, contrato de arriendo abandono

Katz Marcus, contrato de arriendo, notas

Kaufman Karl, contrato, plano

Kaufman Karl, contrato, plano, cartas

Kaufmann Enrique, contrato, plano

Kaufmann Karl, sub arriendo para ganadería

Khan Albert, correspondencia, contrato arriendo, plano

Khan Alberto, contrato sub arriendo para ganadería

Khan Sally, contrato, plano, cartas

Kirchheimer Jakob y Max, contrato, plano, cartas

Kogan Fabian, contrato sub arriendo para ganadería

Kogan Fabian, contrato, plano

Kogan Fabian, contrato, plano, cancelacion

Kohan Abraham Isaac, contrato, plano, cartas

Kohan Adolfo, sub arriendo para ganadería

Kohan Alberto, contrato, plano

Kohan Gregorio y Oscar, contrato sub arriendo para ganadería

Kohan Gregorio, contrato, plano

Kohan Gregorio, sub arriendo para ganadería

Kohan Oscar, contrato, plano

Kohan Oscar, contrato, plano
$1932-39$

1936-59

1950

1971

1946

1948-1961 Reserva

1953

1938-50

1938-1941

1953-54

1937-45

1940

1941

1940

1938-1940

$1936-46$

1940

1940

1945

1940-48

1941-49

1936-60

1948-1950

1949

1938-43

1954-1957

1943

1948

$1938-51$

1938-45

1936-41

1945

1938-59

1949-60

1944-47

1945-50

1938-46

1945

1939-1946

1938-46

1951

1940-55

1963

1968

1970

1945

1940-51

1937-42

1966

1942-66

1937-58

1953

1948-56

1949

1922-57

1941-60

1947

1950-62

1937-49

19567

1946

$1952-56$

1946

1949-54

1949

1952

1951-62
Reserva

Reserva

Reserva

Reserva (1)

Reserva

Reserva

Reserva 
1534 Avigdor 2025 Avigdor 547 Avigdor 546 Avigdor 597 Avigdor 2186 Avigdor 2193 Avigdor 5883 Avigdor 1543 Avigdor 4365 Avigdor 1548 Avigdor 592 Avigdor 5953 Avigdor 831 Avigdor

51 Avigdor

5847 Avigdor 545 Avigdor 1578 Avigdor 601 Avigdor 1564 Avigdor 2207 Avigdor 1520 Avigdor

1528 Avigdor 6 Avigdor 1546 Avigdor 1555 Avigdor 2167 Avigdor 1503 Avigdor 1509 Avigdor 2233 Avigdor 1107 Avigdor 5773 Avigdor 1585 Avigdor 5966 Avigdor 1563 Avigdor 593 Avigdor 1557 Avigdor 1556 Avigdor 1109 Avigdor 5965 Avigdor 548 Avigdor 1554 Avigdor 1539 Avigdor 5967 Avigdor 3662 Avigdor 1511 Avigdor 2206 Avigdor 1574 Avigdor 2188 Avigdor 1013 Avigdor 1549 Avigdor 603 Avigdor 2191 Avigdor 2182 Avigdor 6071 Avigdor

4357 Avigdor 4345 Avigdor 1529 Avigdor 1116 Avigdor 2190 Avigdor 1510 Avigdor 6069 Avigdor 5849 Avigdor 1551 Avigdor 2224 Avigdor
Kohan Oscar, sub arriendo para ganadería

Kohan Silvio, plano, nota

Koselevich Manuel, contrato, plano, carta

Krasnobroda Moises Mailech, contrato, plano, carta

Kugelman Max y Senta Kayser de, contrato, plano

Kugelman Max, contrato de arriendo, abandono

Kugelman Siegmund, contrato de arriendo, abandono

Kuhl Alberto, contrato, notas

Kuhl Alberto, sub arriendo para ganadería

La Dayrico, contrato, plano, notas

Lang Hans y Pfeifer Herbert, sub arriendo para ganadería

Lang Hans, contrato, plano, cartas

Lange Leo, Boleto de Compra y Venta rescindido

Lange Martin y Karl, contrato, plano

Lange Martin y Karl, contratos, plano, correspondencia

Latashen Marco, nota

Latashen Marcos, contrato, plano

Leeser Louis, contrato sub arriendo para ganadería

Leiser Rosa Heine de y Rolf, contrato, plano

Lenkiewicz Hedvig M. de, contrato sub arriendo para ganadería

Levenbach Abraham, contrato de arriendo, abandono

Levenbach Abraham, Seligmann Alfred, contrato sub-arriendo para ganadería

Levenrach Ernesto, sub-arriendo para ganadería

Levensohn Abraham, contratos

Levensohn Abraham, sub-arriendo para ganadería

Levinsky Siegmund, contrato sub arriendo para ganadería

Levy Hugo, contrato de pastoreo

Levy Hugo, contrato sub-arriendo (para ganadería)

Lew Jose, cpntrato sub arriendo para ganadería

Lewin Louis, contrato, nota, abandono

Lewinsky Bernardo y Siegmund, contrato, plano, cartas

Lewinsky Siegmund, contrato, plano, notas

Lichtenauer Moritz, contrato sub-arriendo para ganadería

Lichtenauer Moritz, Promesa de Venta, desligado, notas

Lichtenstein Siegfried, contrato sub-arriendo para ganadería

Lichtenstein Siegfried, contrato, plano, cartas

Liepman Juan y Rodolfo, contrato sub-arriendo para ganadería

Lifschitz Isaac, contrato sub-arriendo para ganadería

Lifschitz Isaac, contrato, plano

Linder Ruber Karl, Promesa de Venta, desligado

Lis Gregorio, contrato, plano

Llacer Miguel, contrato sub arriendo para ganadería

Loeb Bernardo, contrato de pastoreo

Loeb Ferdinand, Promesa de Venta, desligado, notas

Lopez Esther, nota

Maciel Elias, contrato sub arriendo para ganadería

Mallek Leib, contrato de arriendo abandono

Mange Leo, contrato sub arriendo para ganadería

Mange Leon, contrato de arriendo , abandono

Martinez Juan, contrato, plano

May Julius, sub arriendo para ganadería

May Paul, contrato, plano, cartas

Meyer Hugo, contrato de arriendo

Milkuschutz Otto Rudolf, contrato de arriendo , abandono

Minkel Frida Metzger de, y Koch Otto y Seiligman Alfred, contrato,

testimonio, notas

Monserrat Vicenta Z. de, nota

Nasta, Pautaso y Villaraza, contrato

Nathan Nathan, sub arriendo para ganadería

Nejamkin Abraham, contrato, plano, cartas

Neumann Isidor, contrato de arriendo, notas, abandono

Neumeyer Carlos, contrato sub-arriendo para ganadería

Neumeyer Karl, contrato, notas

Nijamkin Abraham, contrato, nota, Readquisición de la JCA

Nirnstein Gustav, contrato sub arriendo para ganadería

Nirnstein Gustav, contrato, notas, abandono
1945

1938-1939

1947

1937-58

1951

1951

1951-61

1938-1947

1949-63

1946

1946

1940-1951

1971

1945

1940-49

1945

1937-43

1965

1946

1938-59

1936

1937-42

1938-1946

1969

1951-54

1947

1954

1937-50

1949

1938-1942

1959

1946

1938-51
Reserva

Reserva

Reserva

Reserva

Reserva

Reserva 
2231 Avigdor 3187 Avigdor 4342 Avigdor 1103 Avigdor 1579 Avigdor 2221 Avigdor 2227 Avigdor 2185 Avigdor 1558 Avigdor 535 Avigdor 2212 Avigdor 1006 Avigdor 3537 Avigdor 1099 Avigdor 1190 Avigdor 4347 Avigdor 1504 Avigdor 2169 Avigdor 2179 Avigdor 2205 Avigdor 1189 Avigdor 2201 Avigdor 1188 Avigdor 5968 Avigdor 3663 Avigdor 594 Avigdor 5850 Avigdor 1575 Avigdor 2229 Avigdor 1525 Avigdor 1571 Avigdor 2198 Avigdor 5961 Avigdor 1030 Avigdor 538 Avigdor 1106 Avigdor 1545 Avigdor 1102 Avigdor 5809 Avigdor 553 Avigdor 2630 Avigdor 3533 Avigdor 1588 Avigdor 1542 Avigdor 1113 Avigdor 1591 Avigdor 10 Avigdor 2225 Avigdor 1522 Avigdor 1967 Avigdor 2213 Avigdor 1552 Avigdor 2217 Avigdor 1527 Avigdor 551 Avigdor 536 Avigdor 1559 Avigdor 598 Avigdor 1513 Avigdor 2196 Avigdor 599 Avigdor 8 Avigdor 1560 Avigdor 2235 Avigdor 6068 Avigdor 2189 Avigdor 1037 Avigdor
Noer Hugo, contrato, nota, abandono

Noguera Evangelista, nota

Nuñez Pablo L., contrato

Nusbaum Lev, contrato, plano, cartas

Nussbaum Ema de, contrato sub arriendo para ganadería

Ochs Georg, contrato, nota, abandono

Openheimer Leopold, contrato, nota, abandono

Openheimer Max, contrato de arriendo, nota, abandono

Oppenheimer Max, contrato sub arriendo para ganadería

Ostrovsky Oscar Osvaldo, contrato, plano

Pasternak Jacobo, contrato, notas, abandono

Pfeifer Manfred, contrato, plano

Pfeifer Manfred, nota

Pfeiffer Manfred, notas

Pfeofer Herbert, contrato, plano, cartas

Piedrabuena Vicente, contrato

Pitman Salomon y Suscov Moises, contrato sub-arriendo para ganad

Pittan Seelig y Suscov Moses, contrato de arriendo

Plaut Bernhart, contrato de arriendo, notas, abandono

Plaut Fritz, contrato de arriendo, abandono

Plaut Fritz, contrato, plano, cartas

Plaut Rudi, contrato de arriendo, abandono

Pollak Joaquin, contrato, plano, cartas

Popovici Salomon Hersch, Promesa de Venta, desligado, notas

Portillo S. Antonio, nota

Preisler Markus, contrato, plano, cartas

Preisler Moises, (carátulas solamente), Readquisición de la JCA ?

Preizler Marcos, contrato sub arriendo para ganadería

Ransenberg Albert, contrato, nota abandono

Ransenberg Albert, sub-arriendo para ganderia

Rhorheimer Ludwig, contrato sub-arriendo para ganadería

Rohrheimer Ludwig, contrato de arriendo, abandono

Rosenblat Siegfried, Promesa de Venta

Rosenblatt Felix y Ludwig, contrato, plano, cartas

Rosenblatt Siegmund y Arno, contrato, plano

Rosenblatt Siegmund, contrato, plano, cartas

Rosenthal Herman y Sally, sub arriendo para ganadería

Rosenthal Saly y Hermann, contrato, plano, cartas

Rubinsky Samuel, contrato

Rubinsky Samuel, contrato, plano, cartas

Salomon Alfredo, contrato, plano, cartas

Salomon Alfredo, plano, nota

Salomon Alfredo, sub-arriendo para ganadería

Salomon Ernesto, sub-arriendo para ganadería

Salomon Ernst, contrato, plano, cartas

Salomon Jose y Rodolfo, sub-arriendo para ganadería

Salomon Joseph Rudolf y Moritz, contratos, correspondencia

Salomon Martin, contrato de arriendo, abandono

Salomon Salomon, sub arriendo para ganadería

Saltiel Elias y Aizicovich Samuel, plano, nota

Sandmann Max, contrato, notas, abandono

Sandmann Rudi, contrato sub arriendo para ganadería

Sandmann Rudi, contrato, notas, abandono

Saphir Bernardo, sub arriendo para ganadería

Schejtman Benjamin, contrato, plano, carta

Schmuler Aaron, contrato, notas

Schreiner Siegfried, contrato sub-arriendo para ganadería

Schreiner Siegfried, contrato, plano, cartas

Schusterman Gerardo, contrato sub arriendo para ganadería

Schutz Salo, contrato de arriendo, abandono

Schutz Wilhelm, contrato, plano, cartas

Seelig W. y Wildau W., correspondencia, contratos arriendo y plano.

Seelig Wilhelm, contrato sub arriendo para ganadería

Seemann Spunt Zalel, contrato de arriendo, abandono

Seligman Algred, contrato, notas

Sichel Friedrich, contrato de arriendo, abandono $\quad 1937-49$

Skierer Berta R. de, contrato, plano

1938-46
1971

De reserva

1952-56

$1938-60$

1946

1938

1938-46

1936-42

1947

1932-70

1938

1963-65 Reserva

1971

1966

1938-61

1947-51

1938-46

1939

1937-42

1937-45

1937-57

1939-44

1945-72

1941-1950

1971

1940-60

1960-1965

1945

1938-46

1942

1945

1938-50

1940

1937-60

1952-58

1937-58

1951

1922-63

1968-1970

1965-69

1946

1957-68

1945

1951

1940-61

1946

1938-59

1938-46

1942

1966

1938-47

1947

1947

1944

1961-63

1961-66

1946

1945-67

1944

1937-47

1942-58

1937-59

1947

1938-43

1942

1948-59
Reserva

Reserva

Reserva
Reserva

Reserva

Reserva
Reserva

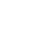


1033 Avigdor 590 Avigdor 3665 Avigdor 5812 Avigdor 537 Avigdor 1589 Avigdor 794 Avigdor 1115 Avigdor 1015 Avigdor 5959 Avigdor 606 Avigdor 2199 Avigdor 1553 Avigdor 5972 Avigdor 604 Avigdor 1572 Avigdor 595 Avigdor 2184 Avigdor 2200 Avigdor 1516 Avigdor 1027 Avigdor 1114 Avigdor 1117 Avigdor 3230 Avigdor 533 Avigdor 3463 Avigdor 2211 Avigdor 1521 Avigdor 5969 Avigdor 552 Avigdor 591 Avigdor 49 Avigdor 2226 Avigdor 1535 Avigdor 600 Avigdor 1576 Avigdor 1561 Avigdor 56 Avigdor 1526 Avigdor 2208 Avigdor 539 Avigdor 5848 Avigdor 2209 Avigdor 3669 Avigdor 782 Avigdor 1026 Avigdor 1544 Avigdor 2222 Avigdor 852 Avigdor 2181 Avigdor 2236 Avigdor 4358 Avigdor 5963 Avigdor 2178 Avigdor 1524 Avigdor 3667 Avigdor 1584 Avigdor 2808 Baron Hirsch

1122 Baron Hirsch 2540 Baron Hirsch 2979 Baron Hirsch 3521 Baron Hirsch 6474 Baron Hirsch 1925 Baron Hirsch 4948 Baron Hirsch 6489 Baron Hirsch
Skierer Jacobo Szmil, contrato, plano, cartas

Skierer Julio, contrato, plano

Sociedad Sanitaria Israelita, plano, nota

Soirefman Victor, contrato

Soirefman Victor, plano, notas

Spierer Jacobo Szmil, sub-arriendo para ganadería

Spierer Jacobo Szmil, contrato, plano

Spierer Salomon, contrato, plano

Stavitzky Aron, contrato, plano

Steiner Curt Sucesion, desligado, notas

Stern Heinz, contrato, plano, cartas

Stern Max, contrato de arriendo, abandono

Stern Max, contrato sub-arriendo para ganadería

Stern Siegbert, Promesa de Venta, desligado, notas

Sternberg Berthold y Heinz, contrato, plano

Sternberg Bertold, contrato sub-arriendo para ganadería

Sternberg Gustav y Luis, contrato, plano, cartas

Straus David, contrato de arriendo, Rescisión de contrato

Straus Natan, contrato de arriendo abandono por Alia

Strauss Hugo, contrato sub-arriendo para ganadería

Strauss Hugo, contrato, plano, cartas

Strauss Teo, contrato, plano, cartas

Strauss Walter, contrato, plano, cartas

Strauss Walter, plano, nota

Strinbaum Salvador, contrato, plano

Svachka Juan Emilio, nota

Tesler Mendel David, contrato, notas, abandono

Tichaver Gunter, sub-arriendo para ganadería

Tichaver Gunther, Promesa de Venta, desligado, notas

Uscheroff Leon, contrato, notas

Visacovsky Salomon, contrato, plano

Walfisch Alfredo, contrato, plano

Wallheimer Leby, contrato de arriendo, abandono

Wartelsky Egon y Preizler Marcos sub-arriendo para ganadería

Wartelsky Egon, contrato, plano, ensanche

Wartelsky Wolf, contrato sub arriendo para ganadería

Weil Walter, contrato sub arriendo para ganadería

Weil Walter, contrato, plano, cancelacion

Weismann Herrmann, sub-arriendo para ganadería

Weissman Herman, contrato de arriendo, notas, abandono

Werner Selig, contrato, plano, carta

Werner Selig, contrato, plano, nota

Wertheimer Julius, contrato de arriendo, abandono

Wilches Tomasa K. de, nota

Wildau Herbert, contrato, plano

Wildau Herbert, contrato, plano, cartas

Wildau Herbert, sub arriendo para ganadería

Wildau Oskar y Heinz, contrato, notas, abandono

Wildav Oscar y Herbert, contrato, plano

Wilhelm Konrad, contrato de arriendo, abandono

Wollheim David, contrato de arriendo, abandono

Yostar Antonio, nota

Zack Aron, Promesa de Venta, desligado notas

Zack Tobias, contrato de arriendo, abandono

Zack Tobias, sub arriendo para ganadería

Zaragoza Carmen, nota

Zlaschevsky Jacobo, contrato sub arriendo para ganadería

4 colonos venden tierras al Ferrocarril Sud, con la autorización de la

J.C.A., contratos

Ablin Jaime, contrato, plano, cartas

Ablin Rafael, contrato, plano, cartas

Abrashkin Moises, contrato, plano notas

Aisemberg Salomon, contrato, plano, notas

Aisemberg Samuel, contrato locación de terreno y pastoreo

Akselrod Jose, contrato, plano, cartas

Algava Alfonso Aharon, contrato

Algava Alfonso, contrato arriendo de campo, notas
Reserva

$1967-68$

1971

1932-71

1951

1955

1954

1965

1937-1942

1940-59

1938-43

1946

1938-1946

1937-59

1945

1945-60

1936-41

1938-50

1946

1943-59

1952-65

1954

1968

1932-73

1971

1940

1947

1939-1948

1966-69

1950-61

1937-59

1938-45

1950

1938-60

1945

1947

1937-59

1942

1940

1955-56

1963

1939

1971

1952-56

1945-56

1955

1939-50

1951-55

1937-42

1938-43

1971

1939-1941

1937-42

1945

1971

1945

1931

1932-58

1917-48

1905-27

1923-52

1942-45

1905-24

1958

1940-45
Reserva

Reserva

Reserva

Reserva

Reserva

Reserva

Reserva

Reserva 
2073 Baron Hirsch 296 Baron Hirsch 2437 Baron Hirsch 3179 Baron Hirsch 4362 Baron Hirsch 4302 Baron Hirsch 6392 Baron Hirsch 4360 Baron Hirsch 3241 Baron Hirsch 1151 Baron Hirsch 3507 Baron Hirsch 1180 Baron Hirsch 2082 Baron Hirsch 1747 Baron Hirsch 326 Baron Hirsch 5757 Baron Hirsch 6679 Baron Hirsch 6605 Baron Hirsch 2763 Baron Hirsch 1143 Baron Hirsch 3341 Baron Hirsch 5691 Baron Hirsch 1154 Baron Hirsch 5686 Baron Hirsch 6522 Baron Hirsch 3481 Baron Hirsch 2713 Baron Hirsch 3350 Baron Hirsch 6682 Baron Hirsch 4955 Baron Hirsch 3773 Baron Hirsch 6676 Baron Hirsch 6587 Baron Hirsch 3368 Baron Hirsch 3356 Baron Hirsch 1179 Baron Hirsch 6491 Baron Hirsch 1145 Baron Hirsch 3355 Baron Hirsch 5751 Baron Hirsch 1138 Baron Hirsch 2684 Baron Hirsch 2645 Baron Hirsch 5753 Baron Hirsch 1137 Baron Hirsch 2899 Baron Hirsch 466 Baron Hirsch 6476 Baron Hirsch 3336 Baron Hirsch 1750 Baron Hirsch 2911 Baron Hirsch 5564 Baron Hirsch 2690 Baron Hirsch 3530 Baron Hirsch 3028 Baron Hirsch 1136 Baron Hirsch 3339 Baron Hirsch 3332 Baron Hirsch 1342 Baron Hirsch 297 Baron Hirsch 2086 Baron Hirsch 6452 Baron Hirsch 848 Baron Hirsch 2896 Baron Hirsch 3223 Baron Hirsch 6512 Baron Hirsch 6479 Baron Hirsch
Alperin Teodoro, contrato

Altman Mario, contrato, plano

Altman Mario, contrato, plano, notas

Alvarez Benjamin, contrato de arriendo y pastoreo

Alvarez Benjamin, contrato, plano

Alvarez Valentin, contrato, plano, cartas

Amaral Albertino, contrato de pastoreo

Amaral Albertino, contrato, plano

Amoros Felipe A., contrato de pastoreo

Amstibovsky Jacobo, contrato, plano, cartas

Anton Eusebio, contrato

Aravsky Abraham, contrato, plano

Aravsky Moises, contrato, plano, cartas

Aravsky Nison y Moises, contrato, plano,cartas

Ares Pascasio hijo, contrato, plano

Ares Pascasio, contrato, plano, nota

Arstein Jose, Escritura de terreno (Rivera)

Artola Jose y Miguel, Artola Dolores, Artola Martin, Escritura de terreno

Aschkenazy Eugenio, plano, cartas

Asner Szame, contrato, plano, cartas

Asociacion Israelita Jevra Kadisha, contrato, plano

Avrusky Abraham, notas

Azserut Miguel, contrato, plano, cartas

Bab Hugo y Julio, notas, contrato

Baer Leopold, contrato Promesa de Venta de terreno, notas

Bakken Alberto T., contrato

Balanovsky Mario Lazaro y Esther Rebeca, contrato, plano, cartas

Balanovsky Moises, contrato

Baltian Gregorio, Escritura de terreno (Rivera)

Baltian Guillerma, contrato

Baltian Jacobo y Juan, contrato (Rivera)

Baranovsky Eugenio G., Escritura de terreno (Rivera)

Bargar Paulino Patricio, Escritura de terreno

Bart Francisco, contrato, plano, cartas

Barth Rufino, contrato

Baschkier Alfred Salomon y Baszkir David, contrato, plano, cartas

Baszkier Henrik y Mordchay, contrato arriendo de campo y casa

Baszkir Mordchaj, contrato, plano, cartas

Bauntrog Jose, contrato

Bayer Juan, contrato, nota

Beiderman Peisah, contrato, plano, cartas

Beiderman Peisaj, contrato de pastoreo

Bekerman Aaron, contrato, plano, cartas

Bekerman Aron, contrato, plano, nota

Bekerman Naum, contrato, plano, cartas

Belensky Jacobo, contrato, plano, cartas

Benezra Marcos, contrato, notas

Benezra Meer, contrato de pastoreo

Berdichevsky Jose, contrato, plano

Berjman Isaac, contrato, plano, cartas

Besdovsky Jose, contrato, plano, cartas

Besedovsky Jose, Maria y Rosa, contrato, plano, notas

Bilder Isaac, contrato, plano, cartas

Bilder Salomon, contrato

Bilder Salomon, plano, notas

Biliansky Manuel, contrato, plano, cartas

Bintel Simon, contrato

Blaistein Teodoro, contrato, plano

Blaistein Zelig, contrato arrendamiento

Blejman Bernardo, contrato, plano, carta

Blejman Bernardo, contrato, plano, cartas

Blejman Carlos, contrato locación de terreno

Blejman Juan y Marcos, contrato, plano

Blejman Juan, contrato, plano, cartas

Blejman Marcos, contrato, notas

Bloom Ayman, contrato arriendo de terreno

Bloom Isaac, contrato arriendo de campo
1949

$1927-60$

1971

1933-47

1948

Reserva

1939-61

1941-47

1948

$1938-43$

$1935-52$

1953

$1935-55$

$1937-59$

$1917-55$

1957

1941-1957 Reserva

1960

1952-53

1930

$1938-50$

1942

1906-1929

1921-53

1923-1953

1940-50

1936-43

1935-67

1953

1960

1958

1950

1952

1957

1951

1935-55

1938-46

1935-59

1951-55

1939-1956

1929-51

1939-44

1949-50

1955-56

1931-50

1922-49

1921-53

1939-47

1942-47

1905-26

1929-41

1906-1940

1947-52

1933-44

1909-30

1935-56

1947

1942

1925-35

1935-49

1950-59

$1945-46$

1952

1926-49

1921-69

1935-43

1940-41
Reserva

Reserva

Reserva

Ensanche

Reserva

Reserva

Reserva

Reserva

Reserva

Reserva

Reserva 
2536 Baron Hirsch 2553 Baron Hirsch 1196 Baron Hirsch 1343 Baron Hirsch 6680 Baron Hirsch 6681 Baron Hirsch 1358 Baron Hirsch 1140 Baron Hirsch 6495 Baron Hirsch 5840 Baron Hirsch

3484 Baron Hirsch 800 Baron Hirsch 3391 Baron Hirsch 705 Baron Hirsch 2325 Baron Hirsch 686 Baron Hirsch 1131 Baron Hirsch 1956 Baron Hirsch 1749 Baron Hirsch 1069 Baron Hirsch 2402 Baron Hirsch 2554 Baron Hirsch 681 Baron Hirsch 4076 Baron Hirsch 3546 Baron Hirsch 815 Baron Hirsch 3677 Baron Hirsch 6412 Baron Hirsch 816 Baron Hirsch 6414 Baron Hirsch 3676 Baron Hirsch 6451 Baron Hirsch 2838 Baron Hirsch 3670 Baron Hirsch 1175 Baron Hirsch 3335 Baron Hirsch 1021 Baron Hirsch 1923 Baron Hirsch 4949 Baron Hirsch 5702 Baron Hirsch 2718 Baron Hirsch 2716 Baron Hirsch 3542 Baron Hirsch 739 Baron Hirsch 786 Baron Hirsch 2052 Baron Hirsch 5756 Baron Hirsch 1955 Baron Hirsch 1734 Baron Hirsch 1964 Baron Hirsch 3014 Baron Hirsch 1586 Baron Hirsch 6497 Baron Hirsch 6513 Baron Hirsch 4953 Baron Hirsch 6583 Baron Hirsch 3311 Baron Hirsch 3312 Baron Hirsch

2014 Baron Hirsch 732 Baron Hirsch

808 Baron Hirsch 3485 Baron Hirsch 1349 Baron Hirsch 1129 Baron Hirsch
Bloom Salomon, contrato, cartas

Blumenthal Federico (Fritz), contrato, notas

Blumenthal Federico, contrato, plano

Bogudlof Abraham, contrato, plano, cartas

Bolognini Huben Evet, Escritura de terreno (Rivera)

Bondar Gregorio, Escritura de terreno (Rivera)

Borun Abe, contrato

Bradichansky Aron, contrato, plano, cartas

Braun Alex, contrato arriendo de campo, notas

Breitman Hermanos (Sociedad), contrato, plano, Readquisición de la

JCA

Breitman Hermanos, contrato

Breitman Hermanos, nota, plano

Brilz Francisco, contrato, plano, cartas

Brisanoff Cecilio y Elena G. de, contrato, plano

Britcovsky Simon, contrato de pastoreo

Brodsky Aron, contrato, plano, carta

Brofman Gregorio, contrato, plano, cartas

Bronstein Adolfo, contrato, plano, cartas

Buchner Leon y Moises, contrato, plano

Budnik Jacobo, contrato, plano, cartas

Budnik Simon, contrato, notas

Bulstein Jose, contrato, plano, cartas

Bulstein Julio, contrato, plano, carta

Bulstein Naum, contrato, plano, notas

Butkevich Antonio, contrato

Capristo Antonio, contrato, plano

Carballo Manuel, contrato, nota

Carbayo Martin, contrato de pastoreo

Careluk Maria, contrato, plano

Carpintiro Manuel, contrato de pastoreo

Carrera Hipolito, contrato, nota

Casado David, contrato locación de terreno

Casado David, contrato, plano, cartas

Casciato Juan, contrato de pastoreo

Castro Bernabe, contrato, plano

Catovsky Isaac, contrato

Cejpek Juan, contrato

Champanier Isaac, contrato, plano, cartas

Charni Abraham, contrato

Charni Salomon, contrato, plano, notas

Charny Jose, contrato, plano, cartas

Cheit Efraim y Isidoro, contrato, plano, cartas

Cheit Isidoro, nota

Cherny Isaac, contrato

Cherny Isaac, contrato, plano

Cherny Isaac, contrato, plano, cartas

Cherny Lucio y Satanovsky Marcos contrato, plano, notas

Cherny Moses, contrato, plano, cartas

Cloner Lazaro, contrato, plano, cartas

Club Deportivo Rivera, notas

Cohen Jacobo, contrato, plano, cartas

Cohen Salomon, contrato de arriendo

Cohn Jacobo, contrato arriendo de campo, notas

Cohn Martin, contrato arriendo de terreno, nota

Condoff Jacobo, contrato

Conrad Francisco, Escritura compra de terreno

Cooperativa Agropecuaria de Rivera, contrato, plano, notas

Cooperativa de Consumo Ltda. De Colonia Lapin, contrato, plano, cartas

Cooperativa de Tamberos, Boleto de Compra

Cooperativa de Tamberos, contrato, plano, plano del cementerio, y corrales cedido por J. A. C.

Cooperativa Tamberos Baron Hirsch Ltda., contrato, plano

Copelov Salomon, contrato

Copilov Naum, contrato, plano

Corsunsky Ruben, contrato, plano, cartas
Reserva

$1955-57$

$1921-35$

1960

1960

1931-35

1912-59

1938-40

1948-1953

1940-46

1953

1957

1948

1933-44

1906-27

1931-51

1921-41

1938-58

1917-55

1917-67

1925-48

1909-27

1943-60

1941-46

1949-51

1966-69

1942-44

1949-52

1942-47

1972

1945-46

1948-49

1938-44

1933-56

1946

1965

1906-24

1958

1907-1921

1947-59

1941-59

1971

1948-54

1948-52

1930-37

1952-1957

1900-45

1907-26

1966

1910-29

1949

1938

1942-44

1958

1951

1957

1957

1968-71

1920-50 Reserva

1949-52

1935-47

$1925-47$

$1935-56$
Reserva

Reserva

Reserva

Reserva

Reserva

Reserva

Reserva

Reserva

Reserva

Reserva

Reserva

Reserva

Reserva

Reserva

Reserva

Reserva 
1741 Baron Hirsch 4954 Baron Hirsch 6601 Baron Hirsch 5705 Baron Hirsch 6518 Baron Hirsch 2055 Baron Hirsch 1939 Baron Hirsch 358 Baron Hirsch 4352 Baron Hirsch 6658 Baron Hirsch 6659 Baron Hirsch 1168 Baron Hirsch 2965 Baron Hirsch 1496 Baron Hirsch 3732 Baron Hirsch 6485 Baron Hirsch 1344 Baron Hirsch 3547 Baron Hirsch 845 Baron Hirsch 6507 Baron Hirsch 3682 Baron Hirsch 4349 Baron Hirsch 6510 Baron Hirsch 91 Baron Hirsch 5851 Baron Hirsch

3239 Baron Hirsch 2897 Baron Hirsch 4968 Baron Hirsch 2629 Baron Hirsch

842 Baron Hirsch 2919 Baron Hirsch 89 Baron Hirsch 2263 Baron Hirsch 3029 Baron Hirsch 363 Baron Hirsch 2541 Baron Hirsch 3525 Baron Hirsch 6433 Baron Hirsch

3508 Baron Hirsch 6525 Baron Hirsch 463 Baron Hirsch 814 Baron Hirsch 6408 Baron Hirsch 5708 Baron Hirsch 462 Baron Hirsch 6528 Baron Hirsch 3227 Baron Hirsch 6505 Baron Hirsch 2518 Baron Hirsch 4950 Baron Hirsch 701 Baron Hirsch 2822 Baron Hirsch 3237 Baron Hirsch 3472 Baron Hirsch 737 Baron Hirsch 2974 Baron Hirsch 3539 Baron Hirsch 1164 Baron Hirsch 1128 Baron Hirsch 3509 Baron Hirsch 6436 Baron Hirsch 2557 Baron Hirsch 6684 Baron Hirsch 2959 Baron Hirsch
Cotler Israel, contrato, plano, cartas

Cuevas Jose, contrato

Cufre Telesforo Eduardo, Escritura de terreno

Daen Gers, contrato

Danziger Jacobo Suc., contrato arriendo de terreno, notas

Dayan Isaac, contrato, plano

Dayan Isaac, contrato, plano, cartas

Dazinger Enrique, escritura

De Ponga Valentin, contrato, plano

Dechand Jose y Luis, Escritura de terreno (Rivera)

Dechand Pedro, Escritura de terreno (Rivera)

Deino Isaac, contrato, plano, cartas

Deino Luis, contrato, plano, notas

Delgado Jose Vidal, contrato, plano, cartas

Demarchi Pablo, contrato, plano, notas

Dembo Luis, contrato de pastoreo

Dick Gregorio, contrato, plano, cartas

Dickerman Gregorio, contrato

Dickerman Lazaro, contrato, plano

Diek Bernardo, notas

Dietrich Jose e Hijos, contrato, plano, notas

Dietrich Juan, contrato, plano, nota

Dikerman Wolf, contrato arriendo de terreno, notas

Dimenstein Leon, contrato, plano

Direccion General de Escuelas de la Provincia de Buenos Aires,

Escritura, Readquisición (Permuta)

Director Abraham, contrato de arriendo

Dolinsky Abraham, contrato, plano, cartas

Donación al Ministerio de Educación, contrato

Donación de terreno de la Colonia Baron Hirsch para la construc -

ción de una escuela agricola, contrato, plano, notas

Donación para Escuela No. 1, contrato, plano

Dr. Sonenberg Abel, contrato, plano

Dreyzin Moises, contratos, plano, correspondencia

Drucaroff Salomon, contrato de pastoreo

Drucaroff Salomon, contrato, plano

Ducardt Juan Pedro, contrato, plano, carta

Dujovne Jose, contrato, plano, cartas

Dukart Anastasi Weinberger de, contrato, plano, notas

Dunayevich Gregorio, contrato extraccion de minerales de laguna Chasilauquen

Echeverria Emilio, contrato

Ehrlich Sally, contrato arriendo de terreno

Eidis Abraham, contrato, notas, cartas

Eidis Naum, contrato, plano

Eldot Heinz, contrato de pastoreo

Eliosoff Ana B. de, Contrato, plano, notas

Eliosoff Ana Bariscovsky de, contrato, plano

Eliosoff Gregorio, contrato arriendo de terreno

Epstein Jose, contrato, plano, notas

Epstein Moises, contrato arriendo de terreno, notas

Epstein Nosson y Moises, contrato, plano, cartas

Ermantraud Pedro, contrato

Errecalde Raul, contrato, plano

Esevich Bernardo, contrato, plano, cartas

Esevich Leon, contrato de arriendo

Esevich Leon, contrato de pastoreo

Esevich Leon, contrato, plano

Esevich Leon, contrato, plano, cartas

Espringer Felsinger Andres, contrato nota

Esterkin Cecilia, contrato, plano

Esterkin Jose, contrato, plano

Everstz Bartolome, contrato

Fabrica de Conservas Rivera, contrato de pastoreo

Faierman Abraham, contrato, plano, cartas

Faifer Ventelin, Escritura de terreno (Rivera)

Fainstein Miguel, contrato, plano, notas
Reserva

Reserva

Reserva

$1950-58$

1960

1960

1935-61

1916-29

1955

1930-31

$1940-49$

1925-35

$1943-45$

$1949-51$

$1938-45$

1951-57

1957-1958

1938-43

1909-26

1928-1934

1934-48

1937-49

1952-1960

1948

1954

1934-39

1922-26

1932-45

1909-31

1935-72

1935-55

1950-60

1941-42

1953

1939-49

1924-58

1949-51

1942-47

1954-1958

1930-48

1921-42

1929-49

1935-46

1930-56

1958

1953-48

1946-49

1929-47

1940-44

1947-53

1907-29

1966-68

1970

1935-56

1953

1942-46

1938-55

1960

1908-29
Reserva

Reserva

Reserva

Reserva

Reserva

Reserva

Reserva

Reserva

Reserva

Reserva

Reserva

Reserva

Reserva

Reserva

Reserva 
2975 Baron Hirsch 3310 Baron Hirsch 4966 Baron Hirsch 277 Baron Hirsch 6456 Baron Hirsch 6443 Baron Hirsch 2693 Baron Hirsch 5555 Baron Hirsch 6398 Baron Hirsch 6426 Baron Hirsch 3225 Baron Hirsch 6429 Baron Hirsch 6683 Baron Hirsch 6514 Baron Hirsch 1953 Baron Hirsch 3775 Baron Hirsch 3510 Baron Hirsch 6598 Baron Hirsch 4359 Baron Hirsch 3497 Baron Hirsch 6417 Baron Hirsch 2084 Baron Hirsch 3228 Baron Hirsch 3353 Baron Hirsch 4947 Baron Hirsch 1127 Baron Hirsch 2858 Baron Hirsch 2970 Baron Hirsch 3483 Baron Hirsch 3774 Baron Hirsch 6445 Baron Hirsch 2074 Baron Hirsch 5754 Baron Hirsch 5752 Baron Hirsch 1139 Baron Hirsch 2646 Baron Hirsch 1350 Baron Hirsch 5706 Baron Hirsch 3020 Baron Hirsch 5725 Baron Hirsch 2845 Baron Hirsch 5566 Baron Hirsch 3528 Baron Hirsch 6515 Baron Hirsch 301 Baron Hirsch 5732 Baron Hirsch 3016 Baron Hirsch 2900 Baron Hirsch 1735 Baron Hirsch 2075 Baron Hirsch 2893 Baron Hirsch 1958 Baron Hirsch 6462 Baron Hirsch 2444 Baron Hirsch 1919 Baron Hirsch 85 Baron Hirsch 474 Baron Hirsch 279 Baron Hirsch 1172 Baron Hirsch 3317 Baron Hirsch 3671 Baron Hirsch 6438 Baron Hirsch 1233 Baron Hirsch 4957 Baron Hirsch 4946 Baron Hirsch 6395 Baron Hirsch 1150 Baron Hirsch
Fainstein Miguel, contrato, plano, notas

$1905-29$

Feiman Leon y Moises, contrato, plano, cartas

Feininger Antonio, contrato

Feldman Elias, contrato, plano

Feldman Jacobo, contrato de pastoreo

1958

$1930-56$

$1943-45$

$1943-45$

Feldman Jacobo, contrato, plano

Feldman Jacobo, contrato, plano, notas

Feldman Jacobo, convenio locación de terreno

Feldman Jose, contrato arriendo de campo

Feldman Salomon y Jose, contrato, plano, cartas

Feldman Salomon, contrato arriendo de terreno

Feldman Salomon, Escritura de terreno (Rovera)

Feldman Victorio, contrato promesa de Venta, notas

Ferdman Gregorio, contrato, plano, cartas

Fernandez Jose, contrato (Rivera)

Fernandez Maria Lopez de, contrato

Fernandez Nicanor, Escritura de terreno

Fernandez Raul, boleto, nota

Fernandez Raul, contrato

Ferner Domingo, contrato de pastoreo

Fisch David y Jonas, contrato, plano, cartas

Fisch Isaac, contrato, plano, cartas

Fischkin Abraham, contrato

Fischquin Daniel, contrato

Fixel Marcos, contrato, plano, cartas

Fradis Jaime y Halsband Salomon contrato, plano

Fradis Jaime y Halsband Salomon contrato, plano, notas

Fraidis Jaime y Halsband Salomon, contrato

Franchi Enrique, contrato (Rivera)

Frenkel Jaime y leudkin Isaac, contrato arriendo de terreno

Frenkiel Chaim Wolf, contrato, plano, cartas

Fritz Francisco, contrato, plano, nota

Fucks Jaime, contrato, plano, nota

Fuks Gregorio, contrato, plano, cartas

Fuks Jaime, contrato, plano, cartas

Fuks Uscher, contrato, cartas

Furman Anaadres, contrato

Furman Andres, contrato, plano, cartas

Furman Naum e hijos, contrato, nota, plano

Furman Salomon, contrato, plano, cartas

Furman Salomon, contrato, plano, notas

Gabay Miguel, contrato, Boleto de Compra

Galanty Moises, contrato arriendo de terreno, notas

Gamarnik Bernardo, contrato, plano, correspondencia

Gavinoser Israel, contrato, plano, notas

Gavinoser Jose, contrato, plano, cartas

Gayetzky Natalio y Marcos, contrato, plano, cartas

Geler Moises, contrato, plano, cartas

Geler Samuel, contrato, cartas

Gelman Abram, contrato, plano, cartas

Gelman Gregorio, contrato, plano, cartas

Gelman Jacobo, contrato locación de terreno

Gelman Salomon y Gregorio, contrato

Gelman Salomon, contrato, plano, cartas

German Abraham, contrato, plano

German Marcos y Juan, contrato, plano, carta

German Marcos, contrato, plano

Gertner Carlos, contrato, plano

Gertner Pedro, contrato, plano, notas

Gette Pablo, contrato, plano, notas

Giggi Jose, contrato de pastoreo

Giller Noe, contrato, plano, cartas

Gimenez Teofilo, contrato

Glaser Jose, contrato

Glaser Jose, contrato de pastoreo y testimonio

Glazer Oscar, contrato, plano
$1947-48$

1921-1945

Reserva

$1942-45$

$1942-43$

$1948-49$

1945-46

1960

1943-45

1901-25

1949

1953

1955

1966-70

1950

1942-43

1937-53

1943-59

1951

1958

1916-59

1939-44

1907-29

1937-45

1950

1944-45

1931-53

1935-1956

1955-1956

1929-50

1949-50

1925-49

1910-1932

1909-29

1915-1945

1949-50

1909-1940

1967-74

1942-55

1930-48

1923-1948

1907-29

1910-49

1932-48

1938-48

1916-49

1918-41

1943-45

1941

1901-25

1907-26

1947-52

1930-52

1957

1955-57

1956-57

1943-44

1906-23

1958

1958

1941-48

1935-59
Reserva

Reserva

Reserva

Reserva

Reserva

Reserva

Reserva

Reserva

Reserva 
4066 Baron Hirsch 1197 Baron Hirsch 6415 Baron Hirsch 6386 Baron Hirsch 2685 Baron Hirsch 2903 Baron Hirsch 6685 Baron Hirsch 6584 Baron Hirsch 2973 Baron Hirsch 1070 Baron Hirsch 5727 Baron Hirsch 2078 Baron Hirsch 6454 Baron Hirsch 2083 Baron Hirsch 6421 Baron Hirsch 2514 Baron Hirsch 81 Baron Hirsch 1152 Baron Hirsch 284 Baron Hirsch 813 Baron Hirsch 3486 Baron Hirsch 3025 Baron Hirsch 2825 Baron Hirsch 6494 Baron Hirsch 6413 Baron Hirsch 706 Baron Hirsch 6475 Baron Hirsch 4067 Baron Hirsch 6416 Baron Hirsch 1745 Baron Hirsch 2851 Baron Hirsch 1228 Baron Hirsch 6589 Baron Hirsch 6394 Baron Hirsch 6670 Baron Hirsch 3526 Baron Hirsch 83 Baron Hirsch 3357 Baron Hirsch 3769 Baron Hirsch 5733 Baron Hirsch 3222 Baron Hirsch 3313 Baron Hirsch 3362 Baron Hirsch 411 Baron Hirsch

723 Baron Hirsch 6594 Baron Hirsch

1020 Baron Hirsch 1354 Baron Hirsch 1341 Baron Hirsch 350 Baron Hirsch

682 Baron Hirsch 704 Baron Hirsch 3224 Baron Hirsch 807 Baron Hirsch 2583 Baron Hirsch 3468 Baron Hirsch 3467 Baron Hirsch 1345 Baron Hirsch 2967 Baron Hirsch 6686 Baron Hirsch 2555 Baron Hirsch 291 Baron Hirsch 1351 Baron Hirsch 6599 Baron Hirsch
Gleizer Jose y Samson, contrato

$1925-60$

Glik Mauricio, contrato, plano

Glik Mauricio, Escritura y Testimonio

Goisen Gregorio, contrato alquiler de terreno

Goisen Gregorio, contrato, plano, cartas 1947-48

Goisen Gregorio, contrato, plano, cartas 1948-56

Goisen Gregorio, Escritura de terreno (Rivera)

Granjeros Unidos Soc. Coop., contrato

Granjeros Unidos Sociedad Cooperativa Agraria Ltda., Escritura de terreno

Granjeros Unidos Sooc. Coop. Agricola, contrato, plano

Grata Helena G de, contrato

Gratch Luis, contrato

contrato, plano, cartas

Guberman Elias, contrato, plano, carta

Gueler Jacobo Isaac, contrato, plano

Gueler Jacobo y Moises, contrato, cartas

Gueler Jacobo, contrato, plano

Gueler Jaime, contrato, carta

Gueller Isaac, contrato de arriendo

Gueller Jacobo, contrato

Guertzenstein Salomon, contrato, plano, cartas

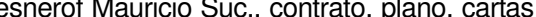

Guiles Marcos, Escritura de terreno (Rivera)

Guilis Salomon, contrato, plano, cartas

Guilis Victor, contrato, plano, correspondencia

Guinzberg Salomon, contrato

Guinzburg Miguel J., Testimonio de Escritura de terreno
$1935-57$

1960

1960

$1909-29$

$1943-52$

1952

$1937-49$

1943-44

1935-59

1942-45

1911-59

1918-26

1945-59

1921-48

1951

1937-45

1905-30

1948-49

1938-45

1942

1948

1932-48

1930-61

1944-45

1923-49

1948-52

1908-24

1960

1941-48

1959

1952-65

1907-26

1951

1950

1930-1953

1951-52

1941-56

1941

1955-

D110756

1948

1953-59

1965

1933-42

1920-35

1957-58

Reserva

Reserva

Reserva

Reserva

Reserva

Reserva

Reserva

1908-27

1948

1910-49

1929-52

1933-48

1933-44

1936-45

$1928-40$

1960

1944-52

1942-59

1921-40

1950
Reserva

Reserva 
2901 Baron Hirsch 6508 Baron Hirsch 6504 Baron Hirsch

6581 Baron Hirsch 6672 Baron Hirsch 3308 Baron Hirsch 3477 Baron Hirsch 1170 Baron Hirsch 473 Baron Hirsch 282 Baron Hirsch 6468 Baron Hirsch 846 Baron Hirsch 6602 Baron Hirsch 3390 Baron Hirsch 1957 Baron Hirsch 98 Baron Hirsch 6678 Baron Hirsch 6662 Baron Hirsch 3393 Baron Hirsch 6457 Baron Hirsch 1177 Baron Hirsch 1920 Baron Hirsch 1954 Baron Hirsch 635 Baron Hirsch 6498 Baron Hirsch 2717 Baron Hirsch 1494 Baron Hirsch 2971 Baron Hirsch 6425 Baron Hirsch 2085 Baron Hirsch 2962 Baron Hirsch 1073 Baron Hirsch 3772 Baron Hirsch 1165 Baron Hirsch 2968 Baron Hirsch 6480 Baron Hirsch 295 Baron Hirsch 1126 Baron Hirsch 1166 Baron Hirsch 1067 Baron Hirsch 5843 Baron Hirsch 5687 Baron Hirsch 1157 Baron Hirsch 285 Baron Hirsch 2818 Baron Hirsch 792 Baron Hirsch 6441 Baron Hirsch 680 Baron Hirsch 1495 Baron Hirsch 2932 Baron Hirsch 684 Baron Hirsch 2909 Baron Hirsch 2076 Baron Hirsch 1352 Baron Hirsch 2647 Baron Hirsch 6420 Baron Hirsch 6411 Baron Hirsch 3471 Baron Hirsch 3221 Baron Hirsch 2691 Baron Hirsch 1608 Baron Hirsch 707 Baron Hirsch 2649 Baron Hirsch 1125 Baron Hirsch 2902 Baron Hirsch 3022 Baron Hirsch
Guitin Samuel, contrato, plano, cartas

Guralnik Leib G. contrato arriendo de terreno, nota

$1938-42$

Gurevich Hermindo, Promesa de Venta, contrato de arriendo de terreno

Haiser Felipe, Escritura compra de terreno

$1931-47$

1954

1960

Felpe, Escritura de terreno (Huergo)

1931-59

$1942-47$

$1935-61$

$1939-48$

$1932-48$

$1944-48$

$1949-51$

1954

1957

1921-46

1907

1960

1960

1957

1943-45

1909-50

1907-25

1906-25

1916-36

1938-45

1941-66

1949-55

1908-29

1943-44

1942-49

1909-29

1921-59

1949-50

1944-51

1909-29

1940-48

1941-49

1950-51

1955-60

1957

1949-1957

1917-1936

1923-62

1911-59

1949

1953

1943-49

1907-27

1953-55

1929-44

1905-26

1939-1939

1923-48

1921-46

1948-50

1943-44

1942-43

1937-46

1938-45

1947-48

1937-55

1946

1943-60

1930-50

1925-49

1909-30
Reserva

Reserva

Reserva

Reserva

Reserva

Reserva

Reserva

Reserva

Reserva

Reserva

Reserva 
2577 Baron Hirsch 3480 Baron Hirsch 2694 Baron Hirsch 99 Baron Hirsch 733 Baron Hirsch 2907 Baron Hirsch 2712 Baron Hirsch 702 Baron Hirsch 3474 Baron Hirsch 5865 Baron Hirsch 2972 Baron Hirsch 821 Baron Hirsch 3478 Baron Hirsch 2695 Baron Hirsch 2246 Baron Hirsch 6585 Baron Hirsch 1743 Baron Hirsch 2036 Baron Hirsch 3361 Baron Hirsch 703 Baron Hirsch 6477 Baron Hirsch 3026 Baron Hirsch 6506 Baron Hirsch 302 Baron Hirsch 6403 Baron Hirsch 2513 Baron Hirsch 3516 Baron Hirsch 1232 Baron Hirsch 5684 Baron Hirsch 6596 Baron Hirsch 3333 Baron Hirsch 4967 Baron Hirsch 2519 Baron Hirsch 1736 Baron Hirsch 1353 Baron Hirsch 6657 Baron Hirsch 3506 Baron Hirsch 6496 Baron Hirsch 3502 Baron Hirsch 2535 Baron Hirsch 276 Baron Hirsch 299 Baron Hirsch 6432 Baron Hirsch

6671 Baron Hirsch 3352 Baron Hirsch 2515 Baron Hirsch 642 Baron Hirsch 1153 Baron Hirsch 3344 Baron Hirsch 2988 Baron Hirsch 6597 Baron Hirsch 4943 Baron Hirsch 1199 Baron Hirsch 2715 Baron Hirsch 6466 Baron Hirsch 336 Baron Hirsch 3019 Baron Hirsch 2960 Baron Hirsch 6402 Baron Hirsch 6409 Baron Hirsch 799 Baron Hirsch 1132 Baron Hirsch 3240 Baron Hirsch 6569 Baron Hirsch 1991 Baron Hirsch 2923 Baron Hirsch
Kaplan Abraham, contrato, notas

$1942-49$

Kaplun Gregorio, contrato

Kaplun Gregorio, contrato, plano

Reserva

Kaplun Isaac, contrato, plano

Kaplun Mauricio, contrato, plano

Kaplun Simon, contrato, plano, cartas

Kaplun Valentin, contrato, plano, cartas

Kapustiansky Frida Vovchuk de, contrato, plano

Kapustiansky Jaime, contrato

Kapustiansky Jaime, contrato

Kapustiansky Jaime, contrato, plano, cartas

Karabelnicoff L. y Lapaco A., contrato, plano

Karabelnicoff Leon, contrato

Karabelnicoff Leon, contrato, plano

Karabelnicoff Samuel, contrato

Karabelnicolff Leon y Cia. S.R.L., Escritura de terreno

Kasac Osias, contrato, plano, cartas

Kasakevich Abel, contrato de arriendo

Kasakevich Mauricio, contrato

Kasakevich Mauricio, contrato

Kasakevich Mauricio, contrato de pastoreo

Kasakevich Mauricio, contrato plano, notas

Katz Jose, contrato arriendo de terreno, notas

Katz Martin Kurt, contrato, plano, carta

Katz Martin, contrato de pastoreo

Katz Samuel B., contrato, plano, cartas

Katz Samuel, contrato

Kaufman Elias, contrato, plano, cartas

Kazakevich Leon, contrato, notas

Keringer Margarita Hollman de, Escritura de terreno, incompleto

Kijel Aaron y Resnicof Salomon, contrato

Kin Gaspar, contrato

Klausner Marcos, contrato, plano, cartas

Klein Manuel, contrato, plano, cartas

Kleinman Boruj, contrato

Kloster Venancio, Escritura de terreno (Rivera)

Kloster Victorio, contrato

Koffler Abraham, contrato arriendo de terreno, notas

Konrad Emilio, contrato

Konrad Natalio, contrato, plano, cartas

Koppl Leo e Israel, contrato, plano

Koppl Leopoldo Israel y Leo, contrato, plano, carta

Korabelnicoff Leon, contrato extraccion de minerales de la laguna

Chasilauquen, plano

Korobka Gregorio y Jacobo, Escritura de terreno (Rivera)

Korovka Juan, contrato

Kosak Elias, contrato, plano, cartas

Kovalevsky Pablo, contrato, plano, cartas

Kozak Naum, contrato, plano, cartas

Kraf Adan, contrato

Kriguer Zavel y Leon, contrato, plano, notas

Kripak Jose, Escritura de terreno

Kuhin Jose, contrato

Kuntz Mateo, contrato, plano, cartas

Kuperman Hans y Horst, contrato plano, cartas

Kupersmit Luisa Vda. de, contrato de pastoreo

Kupersmit Manuel y Schaigorodsky Jacobo, contrato

Kuris Jacobo, contrato, plano notas

Kuschelevsky Moises, contrato, plano, cartas

Labato Ildefons y Carbayo Jose, convenio locación de terreno

Lafriarne Facundo, contrato arriendo de habitación

Langberg Schamson, contrato

Langberg Schamson, contrato, plano, cartas

Lapaco Antonio y Bautista, contrato de arriendo

Lapaco Antonio y Victor, Escritura compra de terreno (ilegible)

Lapaco Antonio, Boleto de Compra

Lapaco Antonio, contrato, plano
$1939-47$

$1947-48$

$1907-26$

$1948-53$

$1923-54$

$1945-58$

1929-48

1935-42

1936

1918-29

1948-51

1939-47

1947-48

1949

1956-60

1927-48

1949

1941

1948

1939-46

1918-44

1936-42

1942-53

1943-46

1954-55

1930-63

1907-23

1910-1927

1954

1941

1957

1942-58

1935-48

1925-40

1960

1953

1938-41

1953

1930-56

1955-59

1939-52

1941-44

1960

1951

1953-55

1908-31

1931-5

1953

1917-51

1957

1957

1957

1937-58

$1944-45$

1956-65

1905-29

1905-29

1941-46

1942

1953

1939-55

1932-47

1961

1963

1935-39
Reserva

Reserva

Reserva

Reserva

Reserva

Reserva

Reserva

Reserva

Reserva 
812 Baron Hirsch 726 Baron Hirsch 736 Baron Hirsch 4956 Baron Hirsch 6431 Baron Hirsch 2081 Baron Hirsch 1942 Baron Hirsch 638 Baron Hirsch 3527 Baron Hirsch 3465 Baron Hirsch 6654 Baron Hirsch 6669 Baron Hirsch 6655 Baron Hirsch 6690 Baron Hirsch 725 Baron Hirsch 1231 Baron Hirsch 1156 Baron Hirsch 1134 Baron Hirsch 6527 Baron Hirsch 1914 Baron Hirsch 6502 Baron Hirsch 3476 Baron Hirsch 801 Baron Hirsch 3354 Baron Hirsch 2905 Baron Hirsch 3349 Baron Hirsch 4077 Baron Hirsch 847 Baron Hirsch 6434 Baron Hirsch 1183 Baron Hirsch 3776 Baron Hirsch 4351 Baron Hirsch 3505 Baron Hirsch 1346 Baron Hirsch 3358 Baron Hirsch 6397 Baron Hirsch 6499 Baron Hirsch 3678 Baron Hirsch 3024 Baron Hirsch 5731 Baron Hirsch 643 Baron Hirsch 3479 Baron Hirsch 1738 Baron Hirsch 6435 Baron Hirsch 3548 Baron Hirsch 3520 Baron Hirsch 6473 Baron Hirsch 6427 Baron Hirsch 2542 Baron Hirsch 2720 Baron Hirsch 365 Baron Hirsch 6511 Baron Hirsch 6656 Baron Hirsch 469 Baron Hirsch 5685 Baron Hirsch 3475 Baron Hirsch 1746 Baron Hirsch 3482 Baron Hirsch 6449 Baron Hirsch 2931 Baron Hirsch 1234 Baron Hirsch 1916 Baron Hirsch 2936 Baron Hirsch 3337 Baron Hirsch 3531 Baron Hirsch 5734 Baron Hirsch 6516 Baron Hirsch
Lapaco Antonio, contrato, plano

Lapaco Antonio, contrato, plano

Lapaco Victor y Lobato Ildefonso, contrato, plano

Lapitzondo Luis, contrato

Lapuente Agustin, contrato locación de casa

Leimsidier Usher Isidoro, contrato, plano, cartas

Leiserson Ete Vda., contrato, plano, cartas

Leiserson Vladimir, contrato, plano, cartas

Leiterfuter Jaime, contrato, plano, notas

Leizerson Lazaro, contrato

Leonardt Andres Leo, Escritura de terreno (Rivera)

Leonardt Francisco, Escritura de terreno (deteriorado) (Rivera)

Leonardt Ramon Miguel, Escritura de terreno (Rivera)

Leonardt Valentin, Escritura de terreno

Lerer S. y Lerer Ester Z. de, contrato, plano

Levinstein Pedro, contrato, plano

Levit Naum, contrato, plano, cartas

Levy Artur, contrato, plano, cartas

Lewkowitz Else Zichel vda. de, contrato arriendo de terreno, notas

Lifschutz Jose, contrato, plano, cartas

Lipovsky Samuel, contrato locación de terreno, notas

Lis Emma, contrato

Liss Dina, contrato, notas

Liss Genia B. de, contrato

Liss Guillermo, contrato, plano, cartas

Liss Leon, contrato

Llernovoy Salomon, contrato, plano, cartas

Llosuk Nicolas, contrato, plano

Lobato Idelfonso, contrato arriendo de terreno

Loewy Francisco, contrato, plano, cartas

Loo Margarita Adhemar, contrato (Rivera)

Lopez Felix, Rafael y Luis, contrato plano, notas

Lopez Joaquin, contrato

Lublin Adolfo, contrato, plano, cartas

Lumansky David, contrato

Lumerman Gregorio, convenio de locación de campo

Lumerman Peisaj, contrato arriendo de campo,

Mantova Edmundo Marcelino, contrato, nota

Marchevsky Aizik y Samuel, plano, notas

Marchevsky Elias, y Jose, contrato, plano, notas

Marchevsky Samuel Aaron, contrato, plano

Marchevsky Samuel, contrato, notas

Marck Jaime y Gregorio, contrato, plano

Marcuse Geerg y Harry, contrato de pastoreo y arriendo de terreno

Marcuse Gerhard, contrato, nota

Marcuse Harry, contrato, plano, notas

Marek Gregorio y Lipovsky Levy, contrato locación de terreno y pastoreo

Marek Gregorio, contrato arriendo de campo

Marek Moises, contrato, plano, cartas

Marominsky Aron, contrato, plano, cartas

Marominsky Moises, contrato, plano, carta

Marosoff Boris, contrato arriendo de terreno, notas

Marsal Fernando C., Escritura de terreno (Rivera)

Maskin Leon, contrato, notas, carta

Mastitz Rafael, nota y convenio

Matzkin Bernardo y Leon, contrato

Matzkin Bernardo y Ramon, contrato, plano, cartas

Matzkin Ramon, contrato

Medveden Moises, contrato de pastoreo

Melamed Lazaro, contrato, plano

Melamed Lazaro, contrato, plano, cartas

Melamed Lazaro, contrato, plano, cartas

Melamed Miguel, contrato, plano

Melman Moises, contrato

Melman Moises, contrato de pastoreo

Melman Moises, contrato, plano, notas

Mendelevich Nissen, contrato arriendo de terreno, notas
$1949-51$

1947-48

1948

1958

1942

1938-60

$1906-25$

1924-52

1945-53

1935-43

1960

1959

1960

1960

1948

$1905-24$

$1931-61$

$1935-55$

1939-57

1918-25

1935-41

1936-48

1953

1954

1917-49

1953

1935-60

1949-51

1942-44

1939-50

1949

1951-58

1953

1922-35

1949

1944-45

1937-50

1966-69

1910-30

1947-1948

1909-31

1931-43

1916-48

1942-48

1943-45

1940-61

1934-47

1942-43

1915-56

1921-57

1950-59

1938-45

1960

1953

1920-1928

1935-46

1931-55

1941-46

1943-44

1929-36

1907-22

1906-25

1954

1951

1939-47

1930-1959

1930-41
Reserva

Reserva

Reserva

Reserva

Reserva

Reserva

Reserva

Reserva

Reserva

Reserva

Reserva 
352 Baron Hirsch 2966 Baron Hirsch 3023 Baron Hirsch 2539 Baron Hirsch 1146 Baron Hirsch 6529 Baron Hirsch 3514 Baron Hirsch 6458 Baron Hirsch 475 Baron Hirsch 6418 Baron Hirsch 2509 Baron Hirsch 6447 Baron Hirsch 2719 Baron Hirsch 1355 Baron Hirsch 837 Baron Hirsch 798 Baron Hirsch 1149 Baron Hirsch 5568 Baron Hirsch 2556 Baron Hirsch 823 Baron Hirsch 2958 Baron Hirsch 1237 Baron Hirsch 3389 Baron Hirsch 3771 Baron Hirsch 3680 Baron Hirsch 4962 Baron Hirsch 636 Baron Hirsch 810 Baron Hirsch 278 Baron Hirsch 3238 Baron Hirsch 4301 Baron Hirsch 280 Baron Hirsch 6478 Baron Hirsch 2852 Baron Hirsch 6461 Baron Hirsch 2711 Baron Hirsch 1169 Baron Hirsch 6669 Baron Hirsch 6524 Baron Hirsch 3334 Baron Hirsch 2027 Baron Hirsch 3153 Baron Hirsch 1135 Baron Hirsch 92 Baron Hirsch 6500 Baron Hirsch 3673 Baron Hirsch 811 Baron Hirsch 6399 Baron Hirsch 1744 Baron Hirsch 6424 Baron Hirsch 3470 Baron Hirsch 633 Baron Hirsch 4350 Baron Hirsch 1162 Baron Hirsch 4959 Baron Hirsch 6677 Baron Hirsch 6604 Baron Hirsch 827 Baron Hirsch 3679 Baron Hirsch 1158 Baron Hirsch 1356 Baron Hirsch 4965 Baron Hirsch 6419 Baron Hirsch 300 Baron Hirsch 3777 Baron Hirsch 6446 Baron Hirsch 6687 Baron Hirsch
Merkel Juan, contrato, plano

Merpert Iser, Jacobo y Salomon, contrato, plano, notas 1906-29

Michnik Leon, contrato, plano cartas 1917-30

Mijnovich Mateo, contrato, plano cartas 1927-52

Mikey David Szloma, contrato, plano 1931-50

Milner Boris, contrato arriendo de terreno

Milner Isaac, contrato de pastoreo 1935-45

Milner Isaac, contrato de pastoreo 1943

Milner Isaac, contrato, plano, carta 1928-53

Milner Marcos, contrato locación de terreno y casa

Milner Marcos, contrato, plano, cartas 1930-59

Milner Salomon, contrato arriendo de campo 1940-47

Milner Teobaldo y Salomon, contrato, plano, cartas, notas 1915-59

Minik Benjamin, contrato, plano, cartas 1922-46

Ministerio de Educación, p/ Escuela No. 9, contrato, plano, carta 1950-54

Mirkin Jose, contrato

Mirkin Jose, contrato, plano, cartas

Mirochnik Adolfo, contrato, plano, cartas

Moguiliansky Berta M. de, contra to, plano, cartas

Moguiliansky Carlos, contrato

Moguiliansky Isaac, contrato, plano, cartas

Moguiliansky Jacobo, contrato, plano, cartas

Mollecker Mateo y Ana Hefner de, contrato, plano, cartas

Mompel Francisco Carlos, contrato (Rivera)

Moscoso Diogenes G., nota

Moscoso Godofredo, contrato

Mosnaim Abraham, contrato, plano, cartas

Mosnaim Aron, contrato, plano

Mosnaim Naum, contrato, plano

Mosnaim Siske, contrato de pastoreo

Municipalidad Adolfo Alsina, Donación, nota (Rivera)

Naiman Abraham, (Cecilia Risin de), contrato, plano

Naiman Moises, contrato arriendo de campo

Neiman Moises, contrato, plano, cartas

Nossen Guillermo, contrato de pastoreo

Nossen Guillermo, contrato, plano cartas

Nossen Heribeto Jorge, contrato, plano, cartas

Nudelman Jaime, Escritura de terreno

Nurnberger Ernesto, contrato arriendo de terreno, Promesa de Venta

Obispado de Bahia Blanca, contrato

Ofenhenden Sara Rivkin de, contrato, plano, notas

Omar Jose, contrato de arriendo

Orinov Bernardo, contrato, plano, cartas

Orinov Salomon, contratos, plano

Orlansky Samuel, contrato arriendo de campo

Ortiz Paez Manuel y Neistat Marcela de, contrato, nota

Oserin Pedro y Hnos., contrato, plano

Oserin Pedro, contrato de pastoreo

Oseroff Moises, contrato, plano, cartas

Oseroff Pablo, contrato arriendo de terreno

Ostrovsky Abraham, contrato

Ostrovsky Herman, contrato, plano, cartas

Otarola Estanislao y Alberto, contrato, plano, nota

Palacin Enrique, contrato, plano, cartas

Pamies Alberto, contrato

Pardes Jacobo W., Escritura de terreno (Rivera)

Pardo Cesar, escritura de terreno

Parteniuk Damian, contrato, plano

Pascasio Ares, contrato, plano, notas

Peker Jose, contrato, plano, cartas

1953

1935-59

$1925-40$

1935-50

1951

1907-29

1947-59

1957

1950-54

1971-1971

1958

1911-60

1949-52

1948

1937-47

1964-72

1909-56

1940-45

1950

1943-49

1938-59

$1955-61$

1960

1939-52

1941

1965

1933-45

1909-55

1909-26

1938-44

1966-69

1950-52

1941-43

1931-48

1942-45

1937-44

1907-48

1950-58

1957

1958

1960

1955

1948-51

1958-72

1931-65

1923-40

1958

Penisi Rosario C. de, contrato

Perez Carlos, contrato de locación

1942

$1923-49$

1949

1938-45

1960

Reserva

Reserva

Reserva

Reserva

Reserva

Reserva

Reserva

Reserva

Reserva

Reserva

Pesci Humberto, contrato (Rivera)

Petap Miguel, contrato arriendo de terreno

Pfoh Andres, Escritura de terreno (Rivera)
Reserva

Reserva

Reserva

Reserva 
3499 Baron Hirsch 3515 Baron Hirsch 2696 Baron Hirsch 3512 Baron Hirsch 6483 Baron Hirsch 6430 Baron Hirsch 1731 Baron Hirsch 5724 Baron Hirsch 6532 Baron Hirsch 2521 Baron Hirsch 461 Baron Hirsch 2823 Baron Hirsch 3770 Baron Hirsch 2576 Baron Hirsch 471 Baron Hirsch 2689 Baron Hirsch 2262 Baron Hirsch 6664 Baron Hirsch 6465 Baron Hirsch

824 Baron Hirsch 327 Baron Hirsch 325 Baron Hirsch 3500 Baron Hirsch 3236 Baron Hirsch 1144 Baron Hirsch 90 Baron Hirsch 2516 Baron Hirsch 5726 Baron Hirsch 96 Baron Hirsch 3347 Baron Hirsch 344 Baron Hirsch 4961 Baron Hirsch 3367 Baron Hirsch 2143 Baron Hirsch 86 Baron Hirsch 735 Baron Hirsch 97 Baron Hirsch 6400 Baron Hirsch 1737 Baron Hirsch 1732 Baron Hirsch 3674 Baron Hirsch 4353 Baron Hirsch 1174 Baron Hirsch 4944 Baron Hirsch 4964 Baron Hirsch 3498 Baron Hirsch 94 Baron Hirsch 2820 Baron Hirsch 3021 Baron Hirsch 3731 Baron Hirsch 3675 Baron Hirsch 822 Baron Hirsch 6470 Baron Hirsch 6455 Baron Hirsch 275 Baron Hirsch 1133 Baron Hirsch 3540 Baron Hirsch

348 Baron Hirsch 1347 Baron Hirsch 6509 Baron Hirsch 3681 Baron Hirsch 6487 Baron Hirsch 2079 Baron Hirsch 3338 Baron Hirsch 281 Baron Hirsch
Pfoh Manuel, contrato

Philipsthal Werner, contrato

Pirotzky Guillermo, contrato, plano 1947-48

Pirotzky Saul, contrato 1933-42

Pirotzky Saul, contrato arriendo de campo y pastoreo 1940-46

Pirotzky Saul, contrato arriendo de campo, nota 1942-43

Pirotzky Saul, contrato, plano

Pirovsky Luis, contrato, plano, notas

Pisarenco Naum, contrato arriendo de terreno

Pisarenko Kosiel, contrato, plano, notas, cartas

Plato Bernardo, contrato, notaas

Pogarelsky Mauricio, contrato, plano

Potach Teodoro, contrato (Rivera)

Potak Pedro, contrato, plano, cartas

Potap Marcos, contrato, plano, carta

Potap Miguel, contrato, plano, cartas

Povolotzky Leon, contrato

Povolotzky Raquel F., Escritura de terreno (deteriorado)

Prilutzky Gregorio y Dubroff Leon, Testimonio y plano de extracción de minerales

Prokop Llosick, contrato, plano

Prost Jacobo, contrato, plano, carta

Prost Pedro, contrato, plano

Puprullinka Jeronimo, contrato

Raisman Leon, contrato de arriendo y pastoreo

Rapfoiguel Moises, contrato, plano, cartas

Ratuschny Jose, contrato, plano

Ratuschny Marcos, contrato, plano, cartas

Ratuschny Vera G. de, y otros, contrato, plano, notas

Ratusny Sneer, contrato, plano, correspondencia

Ravich Benjamin, contrato

Rebol Hilarion, contrato, plano

Repeti Florencio, contrato

Repp Jose, contrato, plano, cartas

Reskin Benjamin Leon, contrato

Resnicoff Abraham, contrato, plano

Resnicoff Jaime, contrato, plano

Resnicoff Jose, contrato, plano, correspondencia

Resnicoff Moises, contrato de pastoreo

Resnicoff Oscar, contrato, plano

Reznik Samuel, contrato, plano, cartas

Richard Victor Santiago, contrato, nota

Richard Victor y Elida, nota

Ripani Luis, contrato, plano

Rivas Epifanio, contrato

Rivas Juan C. y Basilio, contrato

Rivas Juan Carlos y Basilio, contrato

Rivkin Benjamin, contrato, plano

Rivkin Benjamin, contrato, plano, cartas

Rivkin Benjamin, contrato, plano, cartas

Rodriguez Gonzalez Pedro, contrato, plano

Rodriguez Gregorio, contrato, nota

Rodriguez Gregorio, contrato, plano

Rodriguez Quintin, contrato de pastoreo

Rodriguez Rogelio y Vda. de, contrato de pastoreo

Roitberg Jacobo, contrato, plano

Roitberg Leon y Boris, contrato, plano, cartas

Roitburd Jacobo y Moisies, Schaigorodsky Abraham e Isidoro,

contrato, nota

Roitman Abraham, contratos pastoreo, plano 1931-58

Roitman Moises, contrato, plano 1925-52

Roitman Samuel, contrato arriendo de terreno 1938-44

Rondau Robert, contrato, nota

Rosemberg Abisch, contrato arriendo de campo

Rosemberg Osias, contrato, plano, cartas

Rosemblat Jacobo, contrato

Rosenberg Abisch, contrato, sin plano
Reserva

1929-49

1921-55

1947-48

1949

1959

1941-44

1949-51

1957

1956-57

1951

1939-47

1935-50

1925-26

1949-55

1922-1953

1907-26

1953

1950-58

1958

1957

1949

1908-26

1948-52

1907-26

1941-47

1932-48

1930-59

1966-68

1970

1933-57

1958

1958

1950

1908-26

1948-49

1905-30

1929-30

1967-69

1949-51

1944

$1940-48$

1910-52

1924-50

1968-71

1967-71

1943-45

1909-49

1951

1938-48
Reserva

Reserva

Reserva

Reserva

Reserva

Reserva

Reserva

Reserva 
6520 Baron Hirsch 3342 Baron Hirsch 2842 Baron Hirsch 6389 Baron Hirsch 467 Baron Hirsch 468 Baron Hirsch 2512 Baron Hirsch 3541 Baron Hirsch 2723 Baron Hirsch 3513 Baron Hirsch 6401 Baron Hirsch 6526 Baron Hirsch 1616 Baron Hirsch 6663 Baron Hirsch

6666 Baron Hirsch 6600 Baron Hirsch 345 Baron Hirsch 1159 Baron Hirsch 4960 Baron Hirsch 3768 Baron Hirsch 87 Baron Hirsch 304 Baron Hirsch 2964 Baron Hirsch 1952 Baron Hirsch 2520 Baron Hirsch 3473 Baron Hirsch 1181 Baron Hirsch 2511 Baron Hirsch 3027 Baron Hirsch 88 Baron Hirsch 3469 Baron Hirsch 6459 Baron Hirsch 830 Baron Hirsch 1742 Baron Hirsch 797 Baron Hirsch 6595 Baron Hirsch 3343 Baron Hirsch 3188 Baron Hirsch 3346 Baron Hirsch 6423 Baron Hirsch 1148 Baron Hirsch 2989 Baron Hirsch 2686 Baron Hirsch 6387 Baron Hirsch 1922 Baron Hirsch 724 Baron Hirsch 3392 Baron Hirsch 2894 Baron Hirsch 3351 Baron Hirsch 2443 Baron Hirsch 2692 Baron Hirsch 2013 Baron Hirsch 2510 Baron Hirsch 4942 Baron Hirsch 370 Baron Hirsch 6533 Baron Hirsch 2537 Baron Hirsch 2976 Baron Hirsch 4951 Baron Hirsch 6453 Baron Hirsch 1198 Baron Hirsch 293 Baron Hirsch 2507 Baron Hirsch 3229 Baron Hirsch 2895 Baron Hirsch 3348 Baron Hirsch
Rosenberg Guetzel, contrato arriendo de terreno, nota.

$1939-41$

Rosenfeld Francisco, contrato, plano

Rosenfeld Francisco, contrato, plano, cartas

Rosenfeld Rafael, contrato locación de campo y pastoreo

1942

Rosenfeld Rafael, contrato, notas

Rosenfelt Simon, contrato, plano, cartas

Rosenthal Enrique y Lotario, contrato, plano, cartas

Rosenthal Lotario, contrato, nota

Rosenthal Lotario, contrato, plano cartas

Rosquin Gregorio, contrato

Rosso Romulo, contrato arriendo de campo y pastoreo

Rothman Ernesto, contrato arriendo de terreno, notas

Rubin Falik, contrato, cartas

Rubio Ernesto M. y Acevedo Jose L.(La Fraternidad), Escritura de terreno (deteriorado)

Rubio Manuel Ernesto, Escritura de terreno (deteriorado) (Rivera) 1959

Rudolf Juan, Escritura de terreno

Ruiz Eleuterio, contrato, plano 1944-58

Rusansky Benjamin, contrato, plano, cartas

Ruseft Alberto, contrato 1958

Ruseft Alberto, contrato (Rivera) 1956

Sack Leon, contrato, plano 1907-26

Sack Reveca Tarchitzky de, contrato, plano, carta 1918-49

Safian Isaac, contrato, plano, cartas 1909-29

Safranchik Essil, contrato, plano, cartas 1906-25

Sagan Jacobo Manuel, contrato, plano, cartas 1920-56

Samsanovsky Naom, contrato de pastoreo 1935-45

Sander Daniel, contrato, plano, cartas 1939-50

Saper Jaime Simon y Pascual, contrato, plano, cartas 1940-57

Saslavsky Abraham, plano, notas 1915-30

Saslavsky David, contrato, plano 1909-26

Saslavsky Marcos, contrato 1937-48

Saslavsky Marcos, contrato de pastoreo 1941-48

Saslavsky Marcos, contrato, plano 1948-51

Saslavsky Marcos, contrato, plano, cartas 1916-48

Saslavsky Moises, contrato

Sauer Constantino, Escritura de terreno

Savo Demetrio, contrato

Scalese Jorge Anibal, contrato de arriendo, nota

Schaab Eduardo, contrato

Schaefer Heriberto, contrato de pastoreo

Schaigorodsky Adolfo, contrato, plano, carta

Schaigorodsky Adolfo, contrato, plano, cartas

Schamsanovsky Jaime, contrato, plano, cartas

Schamsanovsky Naon, contrato de locación de terreno

Schamsanovsky Naon, contrato, plano

Schamsanovsky Naum, contrato, plano

Schap Andres, contrato, plano, notas

Schatz Isidoro, contrato, plano, cartas

Scheider Juan, contrato

Schejter Israel, contrato, plano

Schejter Manuel e Israel, contrato

Scher ljiel, Boleto de Compra

Schifrin Moises y Abel, contrato, cartas

Schifrin Moises, contrato

Schiler Enrique, contrato, plano

Schimanovich Bernardo, testimonio, incompleto

Schitz Isaac, contrato, plano, cartas

Schlapacoff Natan, contrato, plano, cartas

Schmid Enrique, contrato

Schmukler Bernardo, contrato locación de terreno

Schmukler Bernardo, contrato, plano

Schmukler Bernardo, contratos

Schmukler Jacobo y Simon, contrato, plano, cartas

Schneider Alejandro, contrato de arriendo, notas

Schneider David, contrato, plano, cartas

Schneider Federico, contrato
$1948-49$

$1935-47$

Reserva

Reserva

Reserva

Reserva

De reserva

1953

$1944-45$

$1947-55$

$1927-51$

1948-59

$1935-46$

$1907-27$

$1947-48$

1957

$1937-49$

1953-56

1939

1948

1971

1921-65

1957

1935-57

1913

1920-59

1906-28

1958

1942-46

1933-57

1921-49

1916-65

1950-72

1927-60

1953
Reserva

Reserva

Reserva

Reserva

Reserva

Reserva

Reserva

De reserva 
3517 Baron Hirsch 3518 Baron Hirsch 2022 Baron Hirsch 6481 Baron Hirsch 2843 Baron Hirsch 687 Baron Hirsch 796 Baron Hirsch 6390 Baron Hirsch 93 Baron Hirsch 2021 Baron Hirsch 286 Baron Hirsch 6405 Baron Hirsch 5729 Baron Hirsch 6440 Baron Hirsch 5728 Baron Hirsch 1142 Baron Hirsch 464 Baron Hirsch 6493 Baron Hirsch 2400 Baron Hirsch 6667 Baron Hirsch 2978 Baron Hirsch 287 Baron Hirsch 3524 Baron Hirsch

3672 Baron Hirsch 2418 Baron Hirsch 6460 Baron Hirsch 2578 Baron Hirsch 2700 Baron Hirsch 6404 Baron Hirsch 640 Baron Hirsch 2913 Baron Hirsch 5569 Baron Hirsch 6396 Baron Hirsch 806 Baron Hirsch 2701 Baron Hirsch 5730 Baron Hirsch 5556 Baron Hirsch 4963 Baron Hirsch 3683 Baron Hirsch 6694 Baron Hirsch 289 Baron Hirsch 2977 Baron Hirsch 2969 Baron Hirsch 6406 Baron Hirsch 1167 Baron Hirsch 1068 Baron Hirsch 6484 Baron Hirsch 288 Baron Hirsch 1230 Baron Hirsch 1229 Baron Hirsch 3060 Baron Hirsch 6519 Baron Hirsch 1348 Baron Hirsch 6428 Baron Hirsch 2019 Baron Hirsch 734 Baron Hirsch 3235 Baron Hirsch 6463 Baron Hirsch 470 Baron Hirsch

1751 Baron Hirsch 354 Baron Hirsch 294 Baron Hirsch 1147 Baron Hirsch 82 Baron Hirsch 1739 Baron Hirsch 688 Baron Hirsch
Schneider Pascual, contrato, plano, cartas

Schpeier Julio Israel y Max (Albrech?), contrato

Schufer Guersch Jacob, Boleto de Compra

Schufer Jacobo, contrato arriendo de campo y pastoreo

Schufer Jacobo, contrato, plano, cartas

Schulkin David, contrato, plano, cartas

Schulkin Israel, contrato

Schulkin Israel, contrato locación de terreno y pastoreo

Schulkin Jacobo, contrato, plano

Schulman Abraham, nota, Boleto de Compra

Schulman David, contrato, plano

Schulman Israel y Leon, contrato locación de terreno

Schulman Israel, contrato, plano, notas

Schulman Jaime, contrato de pastoreo y arriendo de terreno

Schulman Leon, contrato, plano, notas

Schulman Marcos, contrato, plano, cartas

Schulsky Frida Adler de, contrato, plano

Schultz Georg, contrato arriendo de campo

Schuster Carlos, contrato, plano, cartas

Schvachsa Pedro, Escritura de terreno (deteriorado) (Rivera)

Sclapacoff Abraham, contrato, plano, notas

Scop Bruje S. de y Enrique Guitin, contrato

Seevalt Miguel y Weinberger Jose, donación al Consejo Nacional de

Educación, contrato, plano, notas

Seevalt Miguel, contrato, plano, notas

Selman Gregorio, contrato, plano

Seltzer Bernardo, contrato de pastoreo

Seltzer Bernardo, contrato, plano, cartas

Seltzer Bernardo, contrato, plano, cartas

Seltzer Berta B.de, contrato de pastoreo

Seltzer Jaime, contrato, plano, cartas

Seltzer Jose, contrato, plano, cartas

Seltzer Jose, contrato, plano, notas

Seltzer Leon, contrato arriendo de lote

Seltzer Leon, contrato, plano

Seltzer Mauricio, contrato, plano, cartas

Seltzer Salomon, contrato, plano, notas

Selzer Jaime y Mauricio, contrato, plano, notas

Serrano Julio F., contrato

Setevich Juan y Pedro, contrato, plano, notas

Sigal Manuel, Escritura de terreno (Rivera)

Sigal Marcos, contrato, plano

Sigal Salomon y Leon, contrato, plano, cartas

Sigal Samuel, contrato, plano, cartas

Sigaloff Jose, contrato arriendo de casa y terreno

Sigaloff Jose, contrato, plano, cartas

Silberman Samuel, contrato, plano, cartas

Silberschmidt Siegfried, contrato de pastoreo

Silberschmidt Siegfried, contrato, plano, correspondencia

Simkin Hilel, contrato, plano, cartas

Simkin Manuel, contrato, plano

Simkin Marcos, contrato, plano, cartas

Simoni Richard, contrato arriendo de terreno, notas

Simonstein Simon, contrato

Simonstein Simon, contrato arriendo de terreno y pastoreo

Sits Adolfo, Boleto de Compra

Sitz Adolfo, contrato

Sitz Isaac, contrato

Sitz Marcos, contrato locación de terreno

Sitz Marcos, plano, escritura, carta

Sitz Moises, contrato, plano, cartas

Sitz Moises, notas

Slabovik Oizer, contrato

Slavin Isaac, contrato, plano, cartas

Slimovich Isaac, contrato, plano

Slobinsky Salomon, contrato, plano, cartas

Slovinsky Vovik, contrato, plano, carta
Ensanche

Reserva

Reserva

Reserva

1954

1941-45

1907-26

1969

1917-48

1943-45

1930-1952

1935-42

1930-1951

1947-56

1915-56

1938-50

1952-58

1959

1905-28

1922-55

1961

Reserva

1956-57

1926

1943-49

1957-58

1948

1942-47

1911-34

1940-41

1915-1938

1941-44

1949-50

1947-48

1916-1948

1916-1956

1958

1955-57

1960

1947-56

1906-28

1906-29

1935-42

1953-61

1910-59

1940-47

1938-52

1905-24

1906-24

1908-27

1935-45

1940

1942-46

1969

1948-59

1944-45

1943-45

1952

1942-57

1972

1909-49

1931-50

1910-26

1907-26

1905-27

Reserva

Reserva

Reserva

Reserva

Reserva

Reserva

Reserva

Reserva

Reserva

Reserva

Reserva 
6444 Baron Hirsch 6471 Baron Hirsch 1072 Baron Hirsch 1130 Baron Hirsch 2963 Baron Hirsch 2688 Baron Hirsch 4952 Baron Hirsch 5565 Baron Hirsch 683 Baron Hirsch 2508 Baron Hirsch 4941 Baron Hirsch 6442 Baron Hirsch 292 Baron Hirsch 1141 Baron Hirsch 347 Baron Hirsch 6501 Baron Hirsch 6665 Baron Hirsch 3501 Baron Hirsch 3523 Baron Hirsch 1924 Baron Hirsch 2573 Baron Hirsch 793 Baron Hirsch 298 Baron Hirsch 1176 Baron Hirsch 6437 Baron Hirsch 1071 Baron Hirsch 6450 Baron Hirsch 820 Baron Hirsch 5690 Baron Hirsch 2517 Baron Hirsch 465 Baron Hirsch 459 Baron Hirsch 1171 Baron Hirsch 5567 Baron Hirsch 303 Baron Hirsch 634 Baron Hirsch 738 Baron Hirsch 1918 Baron Hirsch 2906 Baron Hirsch 3464 Baron Hirsch 2687 Baron Hirsch 6464 Baron Hirsch 2918 Baron Hirsch 6439 Baron Hirsch 2035 Baron Hirsch 357 Baron Hirsch 809 Baron Hirsch 1173 Baron Hirsch 833 Baron Hirsch 80 Baron Hirsch 2721 Baron Hirsch

6521 Baron Hirsch 6490 Baron Hirsch 6488 Baron Hirsch 4945 Baron Hirsch 3778 Baron Hirsch 6482 Baron Hirsch 2856 Baron Hirsch 685 Baron Hirsch 3487 Baron Hirsch 5750 Baron Hirsch 1155 Baron Hirsch 1802 Baron Hirsch 3466 Baron Hirsch 2819 Baron Hirsch 1733 Baron Hirsch
Smelenzoff Esteban, contrato de pastoreo

Smelnitzky Isaac, contrato, plano, cartas 1923-49

Smetniansky Isaac, contrato, plano 1929-51

Smud Jacobo, contrato, plano, cartas $1909-29$

Smud Mauricio, plano, cartas 1948

Soich Federico Lelis, contrato 1958

Soifer Leon, contrato, plano, notas

Sokolsky Soy, contrato, plano, carta

Solovioff Isaac, contrato

Sombra Transito, contrato de pastoreo

Soquiransky Hermindo, contrato, plano

Soquiransky Marcos, contrato, plano, cartas

Soquiransky Oscar, contrato, plano, carta

Soquiransky Osias y Mauricio, contrato arriendo, notas

Sotovia Domingo, Escritura de terreno (deteriorado) (Rivera)

Spada Rafael, contrato

Speier Julio Israel y Albrech Max, contrato, plano, cartas

Spivak Salomon, contrato, plano, cartas

Sraigman Jacobo y Svaigman Teodoro, contrato, notas

Srulevich Ana M. de, contrato, plano

Srulevich Ana Mastitz de, contrato, plano, carta

Stark Julio, contrato, plano

Steimberg Jaime, contrato de pastoreo y arriendo de terreno

Steimberg Jaime, contrato, plano, carta

Stele Federico, contrato de terreno

Stele Federico, contrato, plano

Stezovsky Marcos e Isaac, contrato, plano, notas

Strauss Mauricio, contrato, plano, cartas

Strauss Miguel, contrato, notas

Strauss Samuel, contrato, plano, cartas

Stritzler Natan, cartas, plano

Strocovsky Herman, contrato, plano, notas

Strocovsky Isaac, contrato, plano, correspondencia

Stronguin Saul, cartas, plano

Stronguin Saul, contrato, plano

Sturzman Enrique, contrato, plano, cartas

Sufer Samuel, contrato, plano, cartas

Sufer Simon, contrato

Sufer Simon, contrato, plano, cartas

Sulkin Abraham, contrato de pastoreo

Sulkin Abraham, contrato, plano

Sulman Marcos, contrato arriendo de terreno y pastoreo

Sulman Meier, contrato arriendo

Surkin Mauricio, cartas, notas

Surkin Mauricio, contrato, plano

Surkin Pedro, contrato, plano, cartas

Svachka Alejandro, contrato, plano

Svetliza Jaime, contrato, plano

Swarsensky Elisa S. de, y Swarsensky Juan, y Mathusius Joaquín, contrato, plano, cartas

Szarazgat Emil, contrato arriendo de terreno, notas

Tajchman Abraham, contrato arriendo de campo, notas

Teitelbaum Adolfo, contrato arriendo de casa, notas

Tejedor Antonio e Hijo, contrato

Tenchenco Nicolas, contrato (Rivera)

Tendler Abraham, contrato de pastoreo

Tendler Jacobo, contrato, plano

Teplitzky Bernardo, contrato, plano, carta

Teplitzky Jose, contrato

Teplitzky Jose, contrato, plano, notas

Teplitzky Jose, plano, notas

Teplitzky Leon, contrato, plano, cartas

Teplitzky Marcos, contrato

Teplitzky Marcos, contrato, plano

Teplitzky Marcos, contrato, plano, cartas
Reserva

$1909-1940$

$1906-27$

1957

1943-49

$1925-55$

$1911-50$

1965

1916-41

1959

1953

$1941-54$

$1909-24$

$1922-49$

1951-53

$1924-49$

1935-59

$1942-44$

$1924-59$

$1943-45$

$1948-51$

1909-1928

$1935-57$

$1931-48$

1935-55

1957

1918-1940

1915-56

1907-37

1948

1907-25

1912-59

$1935-42$

1947-59

$1944-49$

1935-38

1940-47

1949

1965-71

1951-56

1935-59

1949-51

1909-26

1941-57

1940-43

$1937-40$

$1938-40$

1958

1949

$1939-46$

1939

$1909-27$

$1944-45$

1948-1956 Reserva

1965-73

1911-26

$1934-46$

1948

1932-48
Reserva

Reserva

Reserva

Reserva

Reserva

Reserva

Reserva

Reserva

Reserva 
2450 Baron Hirsch 6503 Baron Hirsch 6668 Baron Hirsch 4940 Baron Hirsch 819 Baron Hirsch 639 Baron Hirsch 2722 Baron Hirsch 849 Baron Hirsch 6467 Baron Hirsch 283 Baron Hirsch 84 Baron Hirsch 2538 Baron Hirsch 2775 Baron Hirsch 6391 Baron Hirsch 6393 Baron Hirsch 6603 Baron Hirsch 2776 Baron Hirsch 6582 Baron Hirsch 6469 Baron Hirsch 2898 Baron Hirsch 2077 Baron Hirsch 1163 Baron Hirsch 818 Baron Hirsch 641 Baron Hirsch 3226 Baron Hirsch 6422 Baron Hirsch 4958 Baron Hirsch 2769 Baron Hirsch 1951 Baron Hirsch 1748 Baron Hirsch 3511 Baron Hirsch 6472 Baron Hirsch 4361 Baron Hirsch 95 Baron Hirsch 2961 Baron Hirsch 2824 Baron Hirsch 6448 Baron Hirsch 6486 Baron Hirsch 472 Baron Hirsch 6407 Baron Hirsch 3503 Baron Hirsch 6719 Baron Hirsch 3529 Baron Hirsch 3522 Baron Hirsch 356 Baron Hirsch 1182 Baron Hirsch 3504 Baron Hirsch 380 Baron Hirsch 6531 Baron Hirsch 3316 Baron Hirsch 3394 Baron Hirsch 290 Baron Hirsch 6523 Baron Hirsch 6530 Baron Hirsch 1178 Baron Hirsch 2908 Baron Hirsch 1943 Baron Hirsch 1124 Baron Hirsch 6410 Baron Hirsch 3345 Baron Hirsch 458 Baron Hirsch 6388 Baron Hirsch 1752 Baron Hirsch 460 Baron Hirsch 2904 Baron Hirsch 2746 Baron Hirsch 6661 Baron Hirsch
Teplitzky Naum, contrato de arriendo

Teplitzky Wolf,contrato arriendo de terreno

$1935-41$

Tieri Horacio, Escritura de terreno (muy deteriorado) (Rivera) 1959

Tieri Indalecio, contrato

Tiro Federal de Rivera, contrato, plano

Tiverovsky Leon, contrato, plano, carta

Tiverovsky Simon, contrato, plano, cartas

Traiber Francisco, contrato, plano

Traiber Isaac, contrato de pastoreo

Traiber Isaac, contrato, plano, carta

Traiber Sevel, contrato, plano

Trutner Moises, contrato, plano, cartas

Trutwer Moises, contrato de pastoreo

Uberman Isaac, contrato arriendo fracción de campo $\quad 1940-47$

Uberman Nisel, contrato de pastoreo 1941-46

Ullman Pablo, Escritura de terreno

Umansky Elias, contrato, plano

Uribe Echeverria Jose A., escritura compra de terreno

Uscheroff Mauricio, contrato de pastoreo

Vaiser Simon, contrato, plano, cartas

Vaisman Aron Zelig, contrato, cartas

Van Geldern Herman, contrato, plano

Vasileff Nicolas, contrato, plano

Veber Abram, contrato, plano, cartas

Veber Marcos, contrato, plano, notas

Vega Gennario, contrato de pastoreo

Venier Ludovico A., contrato

Vestfrid Miguel, contrato, plano

Vestfrid Zelig, contrato, plano, cartas

Vischnivetzky Seilig, contrato, plano, cartas

Vita Juan, contrato

Vita Vicente, contrato de pastoreo

Vita Vicente, plano, nota

Vitaver Julia de Fefferman, contrato, plano

Voadovosoff Simon, contrato, plano, notas

Vodovosof Aron, contrato, plano, cartas

Vodovosoff Aron, contrato de pastoreo

Vodovosoff Aron, contrato de pastoreo

Vodovosoff Ramon, contrato, plano, cartas

Voloj Abraham, contrato de pastoreo

Vscheroff Mauricio, contrato

Wagner Aurelio, Escritura de terreno

Wagner Juan, contrato

Waisman Israel y Mauricio, contrato, plano, cartas

Waisman Jacobo Ignacio y Soquiransky Oscar, nota

Wasserbach Munich Moises y Abraham, contrato, plano, cartas

Weber Constantino, contrato

Weimberger Pedro, Gregorio y Juan, contrato, plano, carta

Weinbaum Abraham, contrato arriendo de terreno

Weinberger Reinhard Pedro y Jose Ambrosio, contrato, plano, cartas

Weinzettel Francisco, contrato, plano, notas

Wercman Bejrysz Jacobo y Srul, contrato, plano, correspondencia

Werner Elkan, contrato arriendo de terreno, nota

Werner Loewy, contrato arriendo de terreno

Wertheimer Nathan, contrato, plano, cartas

Wilensky Fabio, contrato, plano

Wilensky Marcus, contrato, plano

Wischnievsky Eliezer, contrato, plano, cartas

Wischnievsky Lipman, contrato arriendo de terreno

Witkin Jacinto Leon, contrato

Witkind Isaac, contrato, plano

Witkind Isaac, convenio de locación de terreno

$1949-51$

$1929-34$

$1945-57$

$1950-52$

1944-48

1922-48

1907

1923-49

1955

1939-42

1950

1944-46

1935-58

1937-52

1935-50

1949-51

1909-50

1943-59

1943-48

1958

1939-41

1909-25

1906-26

1953

1938-46

1948

1939-42

1905-29

1948-49

1943-44

$1944-47$

1948

1940-43

1953

1960

1931-47

1916-54

1972

1938-50

1953

1952-59

1943-44

1957-58

1957

1941-52

$1939-45$

1941-44

1936-50

1929-44

1912-25

1934-50

1942-43

1953

1926-59

1940-45

1941-53

1943-55

1935-69

1935-45

1960

Yudchak Israel, contrato, plano, cartas

Yuguelson Isaac, contrato de arriendo y pastoreo

Yungblut Enrique A., Escritura de terreno (Rivera)
Reserva

Reserva

Reserva

Reserva

Reserva

Reserva

Reserva

Reserva

Reserva

Reserva

Reserva 
6660 Baron Hirsch 637 Baron Hirsch 6352 Baron Hirsch 1740 Baron Hirsch 2080 Baron Hirsch 6492 Baron Hirsch 3395 Baron Hirsch 6517 Baron Hirsch 3340 Baron Hirsch 6729 Basavilbaso 3850 Basavilbaso 3212 Basavilbaso 1767 Basavilbaso 3567 Basavilbaso 5800 Basavilbaso 3830 Basavilbaso 3887 Basavilbaso 4824 Basavilbaso 3832 Basavilbaso 3929 Basavilbaso 1772 Basavilbaso 3953 Basavilbaso 3941 Basavilbaso 3966 Basavilbaso 3158 Basavilbaso 4818 Basavilbaso 5169 Basavilbaso 2057 Basavilbaso 3885 Basavilbaso 3952 Basavilbaso 4731 Basavilbaso 1161 Basavilbaso 3845 Basavilbaso 4265 Basavilbaso 4664 Basavilbaso 3872 Basavilbaso 4681 Basavilbaso 4683 Basavilbaso 168 Basavilbaso 2803 Basavilbaso 1768 Basavilbaso 4130 Basavilbaso 178 Basavilbaso 3122 Basavilbaso 3875 Basavilbaso 4684 Basavilbaso 3823 Basavilbaso 1012 Basavilbaso 3822 Basavilbaso 3141 Basavilbaso 518 Basavilbaso 3924 Basavilbaso 3969 Basavilbaso 1708 Basavilbaso 1707 Basavilbaso 4449 Basavilbaso 1720 Basavilbaso 254 Basavilbaso 3111 Basavilbaso 167 Basavilbaso 3829 Basavilbaso 5638 Basavilbaso 251 Basavilbaso 2815 Basavilbaso 4676 Basavilbaso 4749 Basavilbaso 1963 Basavilbaso
Yungblut Pio Antonio, Escritura de terreno (Rivera)

1960

Yuquelson Felipe, contrato, plano

Zac Salomon, contrato de terreno

Zack Salomon, contrato, plano

Zalcberg Israel, Jacobo y David, contrato, cartas

Zenger Joseff, contrato arriendo de campo, notas

Zentner Pedro, contrato, plano, cartas

Zucker Leo Suc., contrato arriendo de terreno, notas

Zupienko Stanislao, contrato, plano

61 nombres detallados, Escritura No.187, compra de solares (y Clara)

Abramovich Ichie, contrato

$\begin{array}{ll}\text { Abramovich Ichie, contrato } & 1940-43 \\ \text { Abramovich Ischie, contrato de arriendo y pastoreo } & 1934-40\end{array}$

Abramovich Jose, contrato, plano, cartas

Abramson Chaim y Aizik, contrato

Abramzon Fichell, contrato, plano, notas

Abrigo Robustiano, contrato

Acosta Tomás, contrato

Afremor Enrique, contrato

Almada Gregorio, contrato

Altamirano Martin H., contrato

Alter Bernardo y Dora, contrato, plano, cartas

Alvarez Jose, contrato

Alvarez Laurindo, contrato

Alzamora Jaime, contrato, notas

Alzogaray Benita, contrato de arriendo

Andrasnik Leon, contrato

Apfelbaum Gabriel, contrato, plano, notas

Aquerman $\mathrm{s} / \mathrm{n}$, contrato, plano

Aranda Hipolito, contrato

Araujo Alejo, contrato

Arce Anatolio, contrato

Arcuchen Mujen, contrato, plano, cartas

Arcucin Leon, contrato

Arcuschin Kive y Moses, contrato, plano, cartas

Arcuschin Miguel e Ignacio, contrato, plano, notas

Arcusin Abraham, contrato

Arcusin Abram, contrato, plano, notas

Arcusin Froim, contrato, plano, cartas

Arcusin Jacobo y Alberto, contrato, plano

Arcusin Jacobo, contrato, plano

Arcusin Jose, contrato, plano, cartas

Arcusin Jose, contrato, plano, notas

Arcusin Leon, contrato, plano

Arcusin Marcos, contrato, notas

Arcusin Simon, contrato

Arcusin Simon, contrato, plano, cartas

Arias María, contrato

Arino Alfredo, contrato, plano

Arredondo Juana, contrato

Asociación Tfila L. Moises, contrato de arriendo

Atlas Jose, contrato, plano

Avanzini Carlos, contrato

Avanzini Francisco y Reula Francisco J., contrato

Bacalor Benjamin, contratos, plano

Bacalor Samuel, contrato, plano, notas

Baez María M. de, nota

Bajaroff Esther Efron de, contrato, plano, cartas

Bajaroff Gregorio, contrato, plano, carta

Bajaroff Isaac, Abraham y Francisco contrato, plano, notas

Balbachan Berta y Simon, contrato, plano

Balbi Jose Maria, contrato

Banchik Moises (ex Siser David), contrato, plano, notas

Banchik Simje, contrato, plano

Banchik Simje, contrato, plano, cartas

Banchik Simje, contrato, plano, cartas

Barinstein Samuel, contrato

Bebinca Eduardo Lazaro, nota
Reserva

$1935-52$

1943

1929

$1922-51$

$1912-1950$

1922-39

$1945-48$

1925

$1917-46$

1945-48

1930-59

1932-48

1946-49

1940-43

1934-43

1925

1900-1924

1918-29

1945-46

1947-54

1929

1946-57

1939-40

1924-35

1906-1930

1943-46

1907-1924

1904-1925

1947-50

1947-49

1923-59

1943-46

1931-52

1906-45

1945-46

1922-1925

1919-26

1965

1921-43

1928-46

1926-51

1939-1940

1940-1941

1916-48

1912-48

1971

1938

1912-51

1901-47

1896- 1953

1945-47

1927-1932

1914-25

1949-1949 Reserva

1906-1923

1929

1967

Reserva 
4797 Basavilbaso 3882 Basavilbaso 3893 Basavilbaso 3935 Basavilbaso 3118 Basavilbaso 3733 Basavilbaso 4815 Basavilbaso 3126 Basavilbaso 4806 Basavilbaso 3165 Basavilbaso 4745 Basavilbaso 2812 Basavilbaso 2806 Basavilbaso 4278 Basavilbaso 3884 Basavilbaso 1867 Basavilbaso 1854 Basavilbaso 4763 Basavilbaso 203 Basavilbaso 4710 Basavilbaso 3164 Basavilbaso 1861 Basavilbaso 4732 Basavilbaso 3862 Basavilbaso 2800 Basavilbaso 3723 Basavilbaso 4656 Basavilbaso 5177 Basavilbaso 3490 Basavilbaso 3869 Basavilbaso 3564 Basavilbaso 2429 Basavilbaso 4775 Basavilbaso 257 Basavilbaso 5166 Basavilbaso 3210 Basavilbaso 169 Basavilbaso 4801 Basavilbaso 1792 Basavilbaso 3818 Basavilbaso 3922 Basavilbaso 3154 Basavilbaso 3833 Basavilbaso 3218 Basavilbaso 3873 Basavilbaso 4740 Basavilbaso 3942 Basavilbaso 3220 Basavilbaso 5905 Basavilbaso 3860 Basavilbaso 261 Basavilbaso 171 Basavilbaso 4110 Basavilbaso 4701 Basavilbaso 4811 Basavilbaso 4725 Basavilbaso 4715 Basavilbaso 3855 Basavilbaso 4744 Basavilbaso 4601 Basavilbaso 3139 Basavilbaso 3716 Basavilbaso 4772 Basavilbaso 1966 Basavilbaso 3186 Basavilbaso 3737 Basavilbaso 2648 Basavilbaso
Belobokoff Boris, contrato

Benitez Urbano, contrato

1951-54

Bentacour Victor, contrato

1945-48

1937-41

Bergaglio Eduardo, contrato

1904-29

1929-39

Bernard Marta Elba, contrato, plano

1925

1940-42

1926

1941-42

1935-38

1949

1947

1904-43

$1935-47$

1900-46

1910-45

1928

1924-47

1929-1935

1940-43

1909-61

1929-1944

1936-51

1947

1945-50

1910-1929

1907-1924

1970

1945-47

1940-42

1920

1928

1927-42

1906-1947

1928-45

1947

1928

1901-44

1942

1939-49

1935-45

1945-46

1940-41

1940-41

1929

1935-43

1940-44

1944

1942-44

1920-47

1947

1931

1930

1926

1930

1939

1935-55

1928-1931

1901-1927

1947

1949

1928

1966

1971

1942

Cooperadora Escuela No. 90, nota, plano

Reserva

Reserva

Reserva

Reserva

Reserva

Coler Moises, contrato, plano, cartas

Comisaria de Basabilbaso, contrato de arrendamiento
Concejo General de Educación de Entre Ríos, contrato, plano

\section{Reserva}

Reserva

De reserva

Cooperativa de Tamberos, contrato, plano

Reserva 
3842 Basavilbaso 2892 Basavilbaso 3736 Basavilbaso 3970 Basavilbaso 3907 Basavilbaso 3923 Basavilbaso 193 Basavilbaso 4807 Basavilbaso 4751 Basavilbaso 3945 Basavilbaso 5171 Basavilbaso 4270 Basavilbaso 4643 Basavilbaso 3926 Basavilbaso 3834 Basavilbaso 1774 Basavilbaso 1770 Basavilbaso 789 Basavilbaso 4765 Basavilbaso 4388 Basavilbaso 3901 Basavilbaso 3944 Basavilbaso 4741 Basavilbaso 4730 Basavilbaso 4766 Basavilbaso 4757 Basavilbaso 3878 Basavilbaso 4131 Basavilbaso 3113 Basavilbaso 4267 Basavilbaso 2405 Basavilbaso 1858 Basavilbaso 5636 Basavilbaso 4717 Basavilbaso 3958 Basavilbaso 3155 Basavilbaso 3960 Basavilbaso 4704 Basavilbaso 4733 Basavilbaso 4703 Basavilbaso 3827 Basavilbaso 3714 Basavilbaso 3209 Basavilbaso 4667 Basavilbaso 4668 Basavilbaso 4470 Basavilbaso 4454 Basavilbaso 4679 Basavilbaso 4447 Basavilbaso 4674 Basavilbaso 4456 Basavilbaso 4630 Basavilbaso 4461 Basavilbaso 4780 Basavilbaso 4758 Basavilbaso 4779 Basavilbaso 3861 Basavilbaso 4734 Basavilbaso 4468 Basavilbaso 4474 Basavilbaso 3810 Basavilbaso 4665 Basavilbaso 1753 Basavilbaso 4671 Basavilbaso 3849 Basavilbaso 3565 Basavilbaso 3819 Basavilbaso
Cooperativa Tamberos Basavilbaso, contrato, nota Cooperativa Tamberos de Basavilbaso

Cooperativa Tamberos Nueva Esperanza, contrato, plano

Corra Alejo D., contrato

Correa Jacobo A., contrato

Corti Ercoli, contrato

Coster Dionisio, contrato, plano

Cozza Francisco, contrato

Cuchuk Jacobo, contrato

Cuffre Alejandro C., contrato

Cusnir Seftel, contrato, plano, notas

Damp Salomon y Marcos, contrato, plano, cartas

Dardik Luis, contrato, plano, notas

Davadi Idelfonso, contrato

Denis Jose Maria, contrato

Derincovsky Einaj, contrato, plano

Derincovsky Isaac, contrato, plano, cartas

Destino Hospital, Nota sobre escritura

Dines Natalio, contrato

Direccion Nacional de Vialidad, contrato

Dominguez Eusebio, contrato

Draganenko Nadia K. de, contrato

Dragonenko Afanacio, contrato

Dragun Pedro, contrato

Dubini Aquiles J., contrato

Duimovich Martin, contrato

Dujovne Bernardo, contrato

Dujovne Bernardo, contrato, plano, cartas

Dujovne Isaac, contrato, plano, cartas

Dujovne Salomon, contrato, plano, cartas

Dujovne Saul, contrato, plano

Dujovne Saul, contrato, plano, cartas

Dujovne Saul, contrato, plano, notas

Dulitzky Natalio, contrato

Dure Rosa, contrato

Dvoymoch Luis, contrato de arriendo

Dziura Stanislaw, contrato

Edelcop Rebeca Dardik de, contrato

Edelcopp Marcos, contrato

Edelstein Moises, contrato

Egro Sinforosa C. de, contrato

Ekardt Pedro, contrato

Elberg Enrique, contrato de arriendo

Elberg Schaie y Taubas David, contrato, plano, notas

Embon Abraham, contrato, plano, notas

Embon Alberto Meilich, contrato, plano, notas

Embon Jacobo y Leon, contrato, plano, notas

Embon Jacobo, contrato, plano, cartas

Embon Jose, contrato, plano, notas

Embon Moises y Pinjus, contrato, plano, cartas

Embon Moris, contrato, plano, cartas

Embon Naum, contrato, plano, notas

Embon Zelig, contrato, plano, cartas

Erujemovich Salomon, contrato, plano, notas

Escudero Timoteo, contrato

Farber Israel, Marcos y Juan, contrato, plano, cartas

Farber Juan y Marcos, contrato

Faurie Florencio, contrato

Feldman Abraham, contrato, plano, notas

Feldman Aron y Santiago, contrato, plano, cartas

Feldman Jacobo, contrato

Feldman Leon, contrato, plano, notas

Feldman Moises, contrato, plano, cartas

Finvarb Adolfo, contrato, plano, cartas

Fischer Abraham Jaime, contrato

Fischer Isaac, contrato

Fischer Jacobo, contrato
1944-47

1948-50

1943

1940-42

1938-46

1939-1940

1923-47

1926

1929

1940-1942

1901-1924

1901-30

1906-1927

1940-1941

1944-46

1938-48

1922-50

1954

1928

1942

1935-41

1934-39

1929

1929-1935

1928-1932

1929

1947-49

1916-46

1903-29

1925-1930

1922-25

1945

1928-1938

1930

1932-47

1935-40

1944-46

1929

1929

1928-1930

$1930-40$

1940-41

1929-43

1900-1930

1900-1929

1910-1924

1894-1939

1894-1923

1926-34

1906-1923

1925-1942

1906-1935

1924-1941

1924-1925

1929

1890-1925

1938-40

1929-1944

1900-1918

1900-1924

1939-44

1895-1930

1922-59

1896-1923

1933-37

1940-42

$1942-43$
Reserva

Reserva

Reserva

Reserva 
3206 Basavilbaso 173 Basavilbaso 271 Basavilbaso 3568 Basavilbaso 184 Basavilbaso 185 Basavilbaso 174 Basavilbaso 189 Basavilbaso 4773 Basavilbaso 4785 Basavilbaso 4677 Basavilbaso 4641 Basavilbaso 4670 Basavilbaso 4680 Basavilbaso 256 Basavilbaso 5829 Basavilbaso 3910 Basavilbaso 4673 Basavilbaso 4446 Basavilbaso 3561 Basavilbaso 3856 Basavilbaso 4600 Basavilbaso 3918 Basavilbaso 5161 Basavilbaso 4793 Basavilbaso 4718 Basavilbaso 3933 Basavilbaso 3892 Basavilbaso 5637 Basavilbaso 3820 Basavilbaso 4778 Basavilbaso 3937 Basavilbaso 4692 Basavilbaso 2406 Basavilbaso 3808 Basavilbaso 3840 Basavilbaso 4453 Basavilbaso 4138 Basavilbaso 1728 Basavilbaso 4690 Basavilbaso 3812 Basavilbaso 3219 Basavilbaso 3559 Basavilbaso 3858 Basavilbaso 204 Basavilbaso 3124 Basavilbaso 3846 Basavilbaso 3100 Basavilbaso 4869 Basavilbaso 4595 Basavilbaso 4632 Basavilbaso 4687 Basavilbaso 994 Basavilbaso 3925 Basavilbaso 3896 Basavilbaso 1757 Basavilbaso 4814 Basavilbaso 3201 Basavilbaso 3909 Basavilbaso 3883 Basavilbaso 4465 Basavilbaso 4108 Basavilbaso 3204 Basavilbaso 3898 Basavilbaso 3161 Basavilbaso 3894 Basavilbaso 1724 Basavilbaso
Fischer Jacobo, contrato de arriendo 1931-41

Fishtein Moises e Israel, $\quad$ 1927-47

Fistein Pablo, contrato, plano 1916-51

Fistein Salomon y Pablo, contrato 1940-41

Fistein Salomon, contrato, plano $\quad 1914-51$

Flesler Bernardo, contrato, plano 1911-47

Flesler Leon, contrato, plano $\quad$ 1927-47

Frankel Nisen, contrato, plano $\quad$ 1932-47

Fredes Domingo, contrato 1928

Freiberg Aron, Salomon y Jose, contrato, plano, notas 1901-1949

Freiberg Natalio y Meier, contrato, plano, notas 1900-1925

Freidemberg Israel B., contrato, nota, plano 1906-1928

Freidenberg Alberto y Jacobo, contrato, plano, cartas 1900-1924

Frenkel Elias, contrato, plano, cartas 1903-1923

Frenkel Isaac (ex Svartzman Jose e hijo Marcos), contrato, plano

Frenkel Isaac, contrato $\quad 1935$

Frenkel Naum, contrato 1937-39

Frenkel Saul, contrato, plano, cartas $\quad$ 1894-1923

Frenkel Saul, contrato, plano, notas 1902-18

Frenkel Siegfried, contrato de pastoreo $\quad 1941-1941$

Frenquel Siegfried, contrato, nota 1938-39

Fridman Abraham y Alejandro, contrato, plano, cartas 1900-1927

Fridman Fany Alperin de, contrato 1937-1939

Friedlander David J., contrato, plano, notas 1906-1919

Friedlander Julio y Miguel, contrato. Plano, notas 1905-1928

Friedrich Julio, contrato 1930

Frutos Antonio M., contrato $\quad 1937-40$

Frutos Juana R., contrato 1934-45

Furman Jaime y Muchnik Salomon, contrato, plano, notas 1895-1931

Futuransky David, notas 1942-44

Gabe Isaac y Jose, contrato, plano, notas 1906-1922

Gaitan Nicolasa, contrato 1935-40

Galichio Jose, contrato 1932

Gardenblum Adolfo, contrato, plano 1921-25

Gartenblum Abraham, contrato 1943-44

Gartenblum Adolfo, contrato 1938-1938

Gartenblum Adolfo, contrato, plano, cartas 1922-1953

Gartenblum Adolfo, contrato, plano, notas 1947-52

Geler Salomon, contrato, plano 1936

Geller Salomon, contrato 1931

Giesberg Adolfo, contrato 1942-43

Giesberg Adolfo, contrato de pastoreo $\quad 1942-1942$

Giesberg Ema Kiefer de, contrato 1936-46

Giesberg Sali, contrato, notas 1935-43

Gisburg Abraham, contrato, plano 1944-47

Giter Benjamin , contrato de arriendo 1939-40

Glik Marcos, contrato, nota 1933-36

Gluschankoff Abraham, contrato, plano, cartas 1926-48

Gluschankoff Abraham, contrato, plano, notas 1929

Gluschankoff Leivik y Naum, contrato, plano, notas 1905-1926

Gluschankov Elias, contrato, plano, notas $\quad 1916-1932$

Glushankoff Uscher, contrato, plano, notas 1918-1929

Glusnecoff Leon, contrato, plano, cartas 1914-38

Godoy Jose Maria, contrato $\quad$ 1939-1940

Goldblum Matias, contrato 1945

Goldentaer Abel e hijo Jacobo, contrato, plano, cartas 1904-52

Goldstein Moises, contrato 1926

Gombinsky Abraham, contrato de arriendo, juicio 1926-40

Gonzalez Esteban, contrato 1937-1948

Gonzalez Juan N., contrato

Gorbacovsky Jacobo, contrato, plano, notas 1900-1918

Gorbato Manuel, contrato 1928

Gorelik Susi, contrato de arriendo 1926-40

Gorgano Aurelio, contrato $\quad$ 1930-37

Goudard Luis Edmundo, contrato de arriendo 1948

Goudaurd Mario G., contrato $\quad 1932-40$

Gramoy Salomon, contrato, plano 1936 
1899 Basavilbaso 4783 Basavilbaso 5176 Basavilbaso 3072 Basavilbaso 2655 Basavilbaso 1855 Basavilbaso 3890 Basavilbaso 268 Basavilbaso 4786 Basavilbaso 3120 Basavilbaso 208 Basavilbaso 1719 Basavilbaso 519 Basavilbaso 4459 Basavilbaso 3162 Basavilbaso 3974 Basavilbaso 4136 Basavilbaso 3876 Basavilbaso 4107 Basavilbaso 3817 Basavilbaso 267 Basavilbaso 2804 Basavilbaso 4458 Basavilbaso 3070 Basavilbaso 4635 Basavilbaso 2419 Basavilbaso 3874 Basavilbaso 4769 Basavilbaso 4719 Basavilbaso 3955 Basavilbaso 3117 Basavilbaso 259 Basavilbaso 1758 Basavilbaso 4268 Basavilbaso 4812 Basavilbaso 4764 Basavilbaso 3959 Basavilbaso 4748 Basavilbaso 263 Basavilbaso 249 Basavilbaso 265 Basavilbaso 4652 Basavilbaso 4591 Basavilbaso 4755 Basavilbaso 214 Basavilbaso 4787 Basavilbaso 3207 Basavilbaso 4713 Basavilbaso 5158 Basavilbaso 3880 Basavilbaso 3205 Basavilbaso 3216 Basavilbaso 206 Basavilbaso 2869 Basavilbaso 6039 Basavilbaso 4782 Basavilbaso 5864 Basavilbaso 4686 Basavilbaso 4663 Basavilbaso 272 Basavilbaso 4139 Basavilbaso 181 Basavilbaso 5167 Basavilbaso 201 Basavilbaso 3140 Basavilbaso 4273 Basavilbaso 5819 Basavilbaso
Gramoy Simon, Leon y Ruben, contrato, plano, cartas

$1924-46$

Granovsky Jacobo, contrato, plano, notas

Grinberg Abraham, contrato, plano, notas

Grinman Jaime, contrato, plano, notas

Gueler Rosa Clara Borodovsky de contrato, plano

Guerchanik Marcos, contrato, plano, cartas

Guinis Gregorio, contrato

Guinsberg Lipe, contrato, plano, carta

Guinsburg Enrique, contrato, plano, notas

Guinsburg Leon, contrato, plano, notas

Guinsburg Moises, contrato, plano

Guinzburg Adolfo, contrato

Guinzburg Aron y Bernardo, contrato, plano, cartas

Guinzburg Aron, contrato, cartas, plano

Guinzburg Ignacio, Aron y Moises, contrato de arriendo

Guinzburg Manuel, contrato

Guinzburg Moises, contrato, plano, notas

Guiter Bencion, contrato

Gurevich Abraham, contrato

Gurman Abraham y Candel Enrique, contrato

Gurman Abraham, contrato, plano

Gurman Abraham, contrato, plano

Gurman Abraham, contrato, plano, cartas

Gurman Gabriel y Abraham, contrato plano, cartas

Gurman Gabriel, contrato, plano, notas

Gurman Gerschon, contrato, plano

Gurmar Abraham, contrato

Gurovich Adolfo, contrato

Gurovich Moises, contrato

Guspero Emilio, contrato

Gutkin Adolfo, contrato, plano, notas

Hecker Abraham, contrato, plano

Hecker Elias, contrato, plano, cartas

Hecker Leib y Marcos, contrato, plano, cartas

Helman Agustín, contrato

Hendlin Adolfo, contrato

Hernandez Juan, contrato

Herrera Juan, contrato

Hick Gregorio, contrato, plano, carta

Hick Moises, contrato, plano

Hick Moises, contrato, plano

Hik Aron, contrato, plano, notas

Hik Luis, contrato, plano, cartas

Hirsch Juan B., contrato

Hiskin Gregorio y Aron, contrato, plano

Hocsman Abraham, contrato, plano, notas

Hocsman Juan, contrato de arriendo

Hocsman Mauricio, contrato

Hoxman Simon y Jose, contrato, plano, notas

Hualde Pedro, contrato

Hurevich Elias, contrato de arriendo

Hurovich Abraham, contrato de arriendo

Hurovich Adolfo, contrato, plano

Hurovich Frida Levit de, contrato, plano, cartas

Hurovitz Moises y Ramon, contrato, testimonio, plano

Huruvich Abraham, contrato, plano, notas

Hurvich Elias, contrato

Hurvich Elias, contrato, plano, notas

Hurvitz Samuel, contrato, plano, notas

Hutin Bernardo, contrato, plano

Hutin Bernardo, contrato, plano, cartas

Hutin Jose, contrato, plano

Hutin Simon, Bernardo y Jose, contrato, plano, notas

Hutin Simon, contrato, plano

Iglesia Evangelica Alemana San Antonio, contrato de arriendo

Imas Jose, contrato, plano, cartas

Imas Jose, Waisman Felipe, Reillansky Ignacio, Kaplan Tobias,
1904-1928

1904-1924

$1908-28$

$1947-48$

$1906-46$

1940

1921-46

$1905-1929$

1923-29

1947-63

1943

1946-52

1923-1938

1930-45

1935-1946

1910-46

1944-54

1928

1942-1942

1937-46

1947-50

1901-1938

1924-28

1904-1926

1926

1945-46

1928

1930-1936

1946-1947

1896-1929

1916-44

1942-47

1914-30

1926

1928

1944-48

1929

1925-40

1925-30

1926-40

1908- 1939

1903-1925

1929

1924-47

1901-1929

1929-41

1929-1936

1901-1918

1918-36

1925-42

1937-43

1924-47

1947-51

1905-1932

1900-1925

1936

1900-1925

1900-1929

1925-46

1922-52

1937-47

1910-1947

1932-51

1932-45

1900-30

1921
Reserva

Reserva

Reserva 
3156 Basavilbaso 2817 Basavilbaso 176 Basavilbaso 192 Basavilbaso 1714 Basavilbaso

1776 Basavilbaso

1715 Basavilbaso 4723 Basavilbaso 4816 Basavilbaso 4706 Basavilbaso 4695 Basavilbaso 3157 Basavilbaso 4729 Basavilbaso 2922 Basavilbaso 1729 Basavilbaso 198 Basavilbaso 197 Basavilbaso 4659 Basavilbaso 3067 Basavilbaso 4747 Basavilbaso 258 Basavilbaso 3112 Basavilbaso 5168 Basavilbaso 4803 Basavilbaso 3555 Basavilbaso 3560 Basavilbaso 1769 Basavilbaso 4696 Basavilbaso 4450 Basavilbaso 3554 Basavilbaso 4274 Basavilbaso 5156 Basavilbaso 3709 Basavilbaso 3866 Basavilbaso 3930 Basavilbaso 3977 Basavilbaso 3099 Basavilbaso 517 Basavilbaso 3073 Basavilbaso 5860 Basavilbaso 3215 Basavilbaso 166 Basavilbaso 5162 Basavilbaso 175 Basavilbaso 4466 Basavilbaso 3708 Basavilbaso 4623 Basavilbaso 5882 Basavilbaso 1877 Basavilbaso 4472 Basavilbaso 4266 Basavilbaso 438 Basavilbaso 5900 Basavilbaso 4870 Basavilbaso 5880 Basavilbaso
Frenkel (?) Saul, Glass David, Heralde Catalina, Rossi Francisco, Arcuschin Aaron, Man Naum, Brich Conte Ramon, Gomez Francisca Perez de, Arcusin Simon y Froim, Mariash Jose, Wagner Jose, Jajam Mauricio, Mayo Isaac, Levit Natalio, Strusberg Abraham, Robles Constantino Daniel, Sociedad Agricola Israelita, Mu?oz Hernan, Schvartzman Guitel, Zentner Jose, Erijimovich Moises,Man Naum, Villanova Natalio Martin, Hualde Catalina, Chianella Catalina Machao, Tofalo Juan Jose, Furman Jaime, Alperin Isaac, Navarro Moises(Mauricio), Hocsman Moises(o Mauricio), Registro de Escrituras de solares vendidos por la JCA Irrazabal Manuel y Baldomero, contrato de arriendo 1935-48 Israelson Jaime, contrato, plano, cartas 1947-49 Itkin Leon, contrato, plano 1923-47 Izraelson Salomon, contrato, plano 1925-47

J.C.A., compra de parcelas por: Orcajo B.,

Alperin de Fridman D. Fany, Perez H.; Diaz de Zapata E.; Sc 1944

J. C. A., ventas a:Retamar Criserio, Bentancor Magdalena Coglionesse; Rosseini Santiago A. 1937

Jacub Moises, contrato, plano

Jaimovich Gregorio, contrato 1930

Jaimovich Gregorio, contrato 1925

Jaimovich Israel, contrato $\quad 1930$

Jaimovich Natalio, contrato 1930

Jasovich Flidel, contrato de arriendo 1935-46

Jerusalimsky Note, contrato 1930

Jevra Kadischa, contrato, plano

Jmelnitzky Cecilia B. de, contrato, plano

Jramoy Simon, contrato, plano

Jramoy Tovie, contrato, plano, notas

Jurman Boris, contrato, plano, cartas

Jusid Naum, contrato

Jusid Simon, contrato, plano

Kachurin Hilel , plano, notas

Kandel Manuel, contrato, plano, notas

Kaplan Tovias, contrato

1930-38

1937

1946-47

1947-47

1906-1928

1905-28

1929

$1915-42$

1903-29

1921-1947

1926

1940-42

$1936-42$

$1922-50$

Katzenstein Sally, contrato

1930

$1918-40$

Kesselman Mauricio, contrato, plano, cartas

Kesselman Salomon, contrato

Kesselman Tobias y Salomon, contrato, plano, cartas

1930

1903-30

Kesselman Tobias, contrato, plano, notas

Kesselman Zelik y Hermanos, contrato

1901-1918

$1935-47$

$1945-46$

$1946-50$

$1920-41$

$1895-1928$

1908-47

$1901-28$

1924-1936

1936-38

$1938-47$

1907-1919

1938-51

1904-1918

1922-39

$1925-1950$

1925-1943

$1917-45$

1906-1924

$1900-25$

$1920-48$

1895-1929

1929-1942

Kosoy Benjamin y Samuel, contrato plano, notas

Kossoy Manuel Suc., judicial

Kossoy Manuel, contrato, plano, notas

Kossoy Manuel, contrato, plano, notas, Readquisición
Reserva

Reserva 
1710 Basavilbaso 4276 Basavilbaso 4651 Basavilbaso 3123 Basavilbaso 4660 Basavilbaso 4638 Basavilbaso 3903 Basavilbaso 791 Basavilbaso 4720 Basavilbaso

3851 Basavilbaso 1004 Basavilbaso 3837 Basavilbaso 5633 Basavilbaso 3899 Basavilbaso 3689 Basavilbaso 3886 Basavilbaso 3557 Basavilbaso 3954 Basavilbaso 4737 Basavilbaso 3217 Basavilbaso 260 Basavilbaso 4647 Basavilbaso 4598 Basavilbaso 5172 Basavilbaso 4666 Basavilbaso 3868 Basavilbaso 5779 Basavilbaso 4133 Basavilbaso 3841 Basavilbaso 165 Basavilbaso 4636 Basavilbaso 5174 Basavilbaso 3902 Basavilbaso 4781 Basavilbaso 1775 Basavilbaso 4789 Basavilbaso 2816 Basavilbaso 4280 Basavilbaso 3075 Basavilbaso 5160 Basavilbaso 3553 Basavilbaso 4628 Basavilbaso 6043 Basavilbaso 4593 Basavilbaso 4777 Basavilbaso 4802 Basavilbaso 4448 Basavilbaso 4742 Basavilbaso 3857 Basavilbaso 3563 Basavilbaso 3919 Basavilbaso 3854 Basavilbaso 4767 Basavilbaso 3916 Basavilbaso 3947 Basavilbaso 3897 Basavilbaso 4800 Basavilbaso 3066 Basavilbaso 4455 Basavilbaso 4743 Basavilbaso 250 Basavilbaso 4658 Basavilbaso 1759 Basavilbaso 440 Basavilbaso

2407 Basavilbaso
Kossoy Rafael, contrato, plano, notas

1943-61

Koval Idel, contrato, plano, cartas

Koval Idel, Registro de hipoteca

Koval Jacobo, contrato, notas

Kupervaser Bernardo, contrato, plano, notas

$1900-31$

1933

Casi ilegible

Kupervaser Jose y Gregorio, contrato, plano, notas

Kusbyt Miguel, contrato

Lagocen Bernardo, contrato, plano

Lande Jose, contrato

Lanfir Jaime, contrato

Lanfir Jaime, contrato, plano, cartas

Langsner Manuel, contrato

Latashew Leon, contrato, plano, notas

Ledesma Adrian, contrato

Ledesma Emerenciano, contrato

Legras Eugenio A., contrato

Lempert Jacobo, contrato

Lencina Camilo, contrato

Lencinas Sebastián, contrato

Levenbug Jose, contrato de pastoreo

Levenbug Jose, contrato, plano, carta

Levensohn Leon, contrato, plano, notas

Levenson Jacobo y Pedro, contrato, plano, cartas

Levin Naum y Salomon, contrato, plano, notas

Levit Israel, contrato, plano, notas

Levitt Abraham, contrato

Levitt Abraham, contrato, plano, notas

Levitt Samuel y Adolfo, contrato, plano, cartas

Levy Wilhelm, contrato

Levy Wilhelm, contrato, plano

Lewin lankel y Jasovich Matias, contrato, plano, nota

Liascovich Perla y Abraham, y Levin Salomon, contrato, plano, notas

Libardi Jose, contrato

Lifschitz Isaac, contrato, plano, cartas

Lifschitz Manuel, contrato, plano

Lifschitz Manuel, contrato, plano, notas

Lifschitz Mauricio, contrato, plano

Lifschitz Mauricio, contrato, plano, cartas

Linovsky Alter, contrato, plano, cartas

Lipavezky Abraham, contrato, plano, notas

Lipovetky Manuel, contrato

Lipovetzky Israel, Isaac, Moises y Jaime, contrato, plano, notas

Lipovetzky Jaime, contrato, testimonio, notas

Lischinsky Jacobo, contrato, plano, cartas

Lizza Juan S., contrato

Lobosco Julio Francisco, contrato

Loiber Moses, contrato, plano, cartas

Lopez Pedro, contrato

Lowenstein Julius y Ludwig, contrato, notas

Lowenstein Luis, contrato de pastoreo

Luna Enrique, contrato

Machevsky Aizik, contrato

Maciel Cecilio, contrato

Madalena Francisco, contrato

Magallanes Prudencia, contrato

Magnani Guido, contrato

Maidanek Mordejai, contrato

Maislos Isaac, contrato, plano, notas

Maislos Marcos, contrato, plano, cartas

Malochnik Clara A. de, contrato

Man Abraham e Ignacio, contrato, plano

Man Bernardo, contrato, plano, notas

Man Enrique, contrato, plano

1894-1940

1920-1937

1902-1927

1934-38

1930-53

1930-

D15251936

1930-40

1905-42

1939-40

1924-1939

1932-38

1941-42

1945-46

1905-46

1947-1948

1929-1945

1944-47

1920-41

1906-1929

1894-1926

1904-1933

1895-1929

1944-1944

1946-48

1928-56

1938-45

1937-51

1906-1929

1904-1929

1934-42

1901-1924

1943-48

1904-1928

1948-49

1904-31

1905-48

1908-1919

1935-36

1906-1927

1906-1934

1901-1926

1928

1928

1894-1918

1929

1937-47

1941-46

1937-1938

1934-36

1928

1937-1948

1947-57

1932-38

1928-1930

1911-43

1904-1942

1929

1923-25

1923-1930

1946-47

1923

contrato, plano

Man Naum, contrato, plano

Reserva

Reserva 
3074 Basavilbaso 4711 Basavilbaso 3864 Basavilbaso 183 Basavilbaso 3125 Basavilbaso 1763 Basavilbaso 190 Basavilbaso 182 Basavilbaso 4776 Basavilbaso 3203 Basavilbaso 3956 Basavilbaso 1726 Basavilbaso 4649 Basavilbaso 4662 Basavilbaso 4634 Basavilbaso 3148 Basavilbaso 3807 Basavilbaso 3824 Basavilbaso 3963 Basavilbaso 172 Basavilbaso 4688 Basavilbaso 4135 Basavilbaso 4646 Basavilbaso 4788 Basavilbaso 4096 Basavilbaso 4700 Basavilbaso 5173 Basavilbaso 4693 Basavilbaso 5170 Basavilbaso 1003 Basavilbaso 3968 Basavilbaso 1727 Basavilbaso 3934 Basavilbaso 3888 Basavilbaso 1713 Basavilbaso 3566 Basavilbaso 3843 Basavilbaso 4738 Basavilbaso 3978 Basavilbaso 788 Basavilbaso 829 Basavilbaso 3152 Basavilbaso 4467 Basavilbaso 4469 Basavilbaso 3119 Basavilbaso 4655 Basavilbaso 1717 Basavilbaso 1756 Basavilbaso 4633 Basavilbaso 4792 Basavilbaso 4795 Basavilbaso 2438 Basavilbaso 390 Basavilbaso 2809 Basavilbaso 5876 Basavilbaso 3975 Basavilbaso 3821 Basavilbaso 6344 Basavilbaso 3971 Basavilbaso 3110 Basavilbaso 1718 Basavilbaso 4810 Basavilbaso 3936 Basavilbaso 3889 Basavilbaso 5801 Basavilbaso 3921 Basavilbaso 3900 Basavilbaso
Man Naum, contrato, plano, notas

Man Sara Edelcop de, contrato

Maravankin Abraham, contrato, notas

Maravankin Abraham, contrato, plano

Maravankin Isaac, contrato de arriendo

Maravankin Israel, contrato, plano, cartas

Maravankin Jose, contrato, plano

Maravankin Moises, contrato, plano

Marcovich Alter, contrato

Marcovich Isaac, contrato de arriendo

Marcovich Marcos, contrato

Marcovich Marcos, contrato, plano

Margulis Jaime y Rosa, contrato, plano, notas

Marias Ignacio, plano, notas

Mariasch Alter David, contrato, plano, notas

Marovankin Salomon, contrato de arriendo

Marques Damian, contrato, plano

Marquez Pereira Damian, contrato, nota

Martinez Vicente, contrato

Maskin Abraham, contrato, plano

Maskin Abraham, contrato, plano, notas

Maskin Alejandro, contrato, plano, cartas

Maskin Moises, contrato, plano, notas

Maskin Schloime y Alejandro, contrato, plano, notas

Matlis Elias, contrato

Matzkin Adolfo, contrato

Matzkin Bernardo, contrato, plano, notas

Matzkin Jose, contrato

Matzkin Leon, contrato, plano, notas

Matzkin Marcos, contrato, plano, cartas

Mendoza Sebastian, contrato

Merenlender Paulina M. de, contrato, plano

Merlo Brigida P. de, contrato

Merlo Silvio, contrato, nota

Meyer Carlos, contrato, plano, cartas

Meyer Otto y Helmut, contrato

Meyer Otto y Helmut, contrato

Michaut Juan C., contrato

Milman Simon, contrato

Ministerio de Educación, contrato, plano

Ministerio Salud Pública, plano

Minos Carmen M. de, contrato de arriendo

Minuchin Jose, contrato, plano, cartas

Mizrahi Juda, contrato, plano, cartas

Moguilevsky Benjamin, contrato, plano, cartas

Moguilevsky Benjamin, contrato, plano, notas

Moguilevsky Leon, contrato, plano

Moguilevsky Leon, contrato, plano, cartas

Moguilevsky Marcos, contrato, plano, notas

Moguilevsky Samuel, contrato, plano, notas

Moguilevsky Wolf y David, contrato, plano, notas

Municipalidad de Basabilbaso, contrato, plano

Municipalidad de Basavilbaso), contrato, plano, carta

Municipalidad de Basavilbaso, (donación), contrato, plano

Municipalidad de Basavilbaso, contrato, planos, Readquisición, (Permuta)

Municipalidad de Basavilbaso, Donación de la J.C.A., contrato

Muniz Teresa C. Vda. de, e hijos, contrato, plano

Muñoz Matilde Rosa M. De, contrato de venta de terreno

Naurocky Miguel, contrato

Nejamkin Jose , contrato, plano, notas

Nemirovsky Jacobo, contrato, plano

Nirenberg Jose, contrato

Nunez Julio C., contrato

Ogguier Felix M., contrato

Olijavetzky David, contrato, plano, notas

Orcajo Bernavel, contrato

Orcajo Gabino, contrato
1924-28

1929

1945-47

1916-47

1941-44

$1922-57$

1902-52

1947-47

1928

1926-46

1943-1944

1956

1904-1929

1905-1927

1905-1928

$1930-45$

1949

1946

1939-42

1924-50

1910-1928

1924-46

1924-1929

1904-1928

1928

1930

1916-1925

1929-30

1904-1926

1923-35

1937-41

1956

1937-42

1947-48

1940-48

1944-46

1946-50

1929

1919-45

1949-51

1949

1935-43

1904-1918

1903-1924

1925-29

1924-1929

1944

1922-59

1924-1929

1906-1928

1905-1928

1942

1959-60

1948-49

1944

1945

1947

1919

1944-46

1895-1949

1937

1926

1935-40

1934-47

1936-52

1941-43

1935-40
Reserva

Reserva

Reserva

Reserva - Donación

Reserva

Reserva

Reserva 
3946 Basavilbaso 3831 Basavilbaso 269 Basavilbaso 180 Basavilbaso 3939 Basavilbaso 3144 Basavilbaso 4303 Basavilbaso

3908 Basavilbaso 5175 Basavilbaso 5635 Basavilbaso 4271 Basavilbaso 3904 Basavilbaso 4817 Basavilbaso 3202 Basavilbaso 3917 Basavilbaso 3957 Basavilbaso 3913 Basavilbaso 4739 Basavilbaso 199 Basavilbaso 270 Basavilbaso 4791 Basavilbaso 4457 Basavilbaso 3914 Basavilbaso 1725 Basavilbaso 3200 Basavilbaso 4596 Basavilbaso 4471 Basavilbaso 3163 Basavilbaso 3558 Basavilbaso 4460 Basavilbaso 4197 Basavilbaso 3143 Basavilbaso 4808 Basavilbaso 4631 Basavilbaso 1764 Basavilbaso 4823 Basavilbaso 2431 Basavilbaso 3149 Basavilbaso 3101 Basavilbaso 4759 Basavilbaso 4798 Basavilbaso 3949 Basavilbaso 4653 Basavilbaso 1754 Basavilbaso 4196 Basavilbaso 4109 Basavilbaso 3710 Basavilbaso 4799 Basavilbaso 4281 Basavilbaso 4269 Basavilbaso 4678 Basavilbaso 210 Basavilbaso 3950 Basavilbaso 3839 Basavilbaso 2056 Basavilbaso 4746 Basavilbaso 4736 Basavilbaso 209 Basavilbaso 4756 Basavilbaso 3912 Basavilbaso 3906 Basavilbaso 3159 Basavilbaso 3826 Basavilbaso 3961 Basavilbaso 3121 Basavilbaso 4640 Basavilbaso
Ortegaza Silvestre, notas

Ortegosa Ruperto, contrato

Paikin Salomon y Jacobo

Pais Virginio, contrato

Palatnik Ana S. Furrer de, contrato de arriendo

Palma Jose y Hnos., Cremeria de la Granja Blanca, contrato, plano, notas

Paredes Tomas J., contrato

Pasik Leon, contrato, plano, notas

Pasik Leon, contrato, plano, notas

Pasik Mauricio, contrato, plano, cartas

Pauwels Carlos, contrato

Pavlotzky Abraham, contrato

Pavlotzky Salomon, contrato de arriendo

Pereyra Rosa Vda. de, contrato, notas

Perez Isidoro R., contrato

Perez Ramon A., contrato

Perez Teodoro, contrato

Perlin Jacobo Simon, contrato, plano

Perlin Jacobo, contrato, plano

Perlin Samil, Miguel y Salomon, contrato, plano, notas

Perman Jaime, Enrique y Leon, contrato, plano, notas

Perret Jose E., contrato

Petasni Boris, contrato, plano

Petasny Enrique, contrato de arriendo

Pilnik Julio, contrato, plano, notas

Pilnik Leizer, contrato, plano, cartas

Pinus Aron (abandono), contrato de arriendo

Pinus Aron, contrato, plano, nota

Pinus Bernardo, contrato, plano, notas

Pinus Ezequiel, Leon y Naum, contrato, plano, cartas

Pinus Jose, contrato de arriendo

Pirovani Isidoro, Jose y Pedro, contrato

Pitman Aron y Erijimovich Moises, contrato, plano, notas

Pitman Benjamin y Salomon, contrato, plano

Podolsky Mosco, contrato, plano

Polak Samuel, contrato, plano

Pomerantz Isaac, contrato de arriendo

Pomerantz Jacobo, contrato, plano, cartas

Porchetto Celestino, contrato

Potritkin Israel, contrato

Prado Faustino, contrato

Ptasny Leon, contrato, plano, notas

Rabenko Manuel, contrato, plano, carta

Rabey Moises, contrato, plano, notas

Rabin Rosa y Carolina, contrato

Rabinoovich Isaac, contrato

Rabinovich Isaac, contrato

Rasquin Zelig, contrato, plano, cartas

Resnitzky Jacobo, Isaac, Julio y Marcos, contrato, plano, notas

Resnitzky Leon, contrato, plano, cartas

Resnitzky Moises, contrato, plano

Reynoso Eduardo, contrato

Rijter Enrique, contrato

Rinfeld Jose, contrato, plano, cartas

Risso Domingo L., contrato

Risso Enrique, contrato

Rister Marcos, contrato, plano

Rivero Florencio, contrato

Rivero Jose, contrato

Rodriguez Caceres Constancia, contrato

Rodriguez Dionisio, contrato de arriendo

Rodriguez Serapio, contrato

Rodriguez Tomasa L. de, contrato

Rogarky Jose, contrato, plano, cartas

Rogarky Moises, contrato, plano, notas
$1925-51$

1946-1947

1939

1919-42

Reserva

1946-1947

1922-1925

1926-1941

1905-30

1934-37

1925

1922-46

1946-1947

1945-1946

1935-48

1929

1947-47

1909-46

1903-1928

1904-1939

1936-1946

1936

1925-42

1912-1926

1904-1924

1940-45

1927-40

1905-1938

1910-32

1921-40

1926

1894-1928

1922-54

1925

1919

1945

1904-31

1928

1928

1947-50

1906-1930

1925-52

1906-34

1928

1940-1940

1928

1900-30

1895-1930

1908-1924

1926-57

1947

1932-42

1926-38

1928

1929

1950-58

1929

1935-47

1937-1948

1945-48

1945-47

1931-48

1912-28

1901-1929 
3865 Basavilbaso 1755 Basavilbaso 1762 Basavilbaso 4624 Basavilbaso 4698 Basavilbaso 3870 Basavilbaso 3208 Basavilbaso 4141 Basavilbaso 4275 Basavilbaso 4279 Basavilbaso 2805 Basavilbaso 3116 Basavilbaso 3556 Basavilbaso 3835 Basavilbaso 3147 Basavilbaso 3214 Basavilbaso 3809 Basavilbaso 3844 Basavilbaso 3962 Basavilbaso 4642 Basavilbaso 4272 Basavilbaso 191 Basavilbaso 4705 Basavilbaso 4462 Basavilbaso 4264 Basavilbaso 3859 Basavilbaso 1859 Basavilbaso 1712 Basavilbaso 4761 Basavilbaso 4714 Basavilbaso 4127 Basavilbaso 516 Basavilbaso 4813 Basavilbaso 3895 Basavilbaso 4804 Basavilbaso 5830 Basavilbaso 1796 Basavilbaso 4097 Basavilbaso 4805 Basavilbaso 4594 Basavilbaso 3863 Basavilbaso 851 Basavilbaso 3867 Basavilbaso 2781 Basavilbaso 3562 Basavilbaso 3828 Basavilbaso 3712 Basavilbaso 3931 Basavilbaso 4452 Basavilbaso 3964 Basavilbaso 996 Basavilbaso 266 Basavilbaso 3713 Basavilbaso 3928 Basavilbaso 264 Basavilbaso 4784 Basavilbaso 2421 Basavilbaso 3166 Basavilbaso 215 Basavilbaso 5804 Basavilbaso 6040 Basavilbaso 2871 Basavilbaso 4451 Basavilbaso 6041 Basavilbaso 194 Basavilbaso 3816 Basavilbaso 4129 Basavilbaso
Rogatky Abraham, contrato

Rogatky Abraham, contrato, cartas

1946-59

Rogatky Moises y Naum, plano, notas

1923-67

Roimeser Aron, Mendel y Clara, contrato, plano, cartas

1901-1928

Roimezer Mendel, contrato

Roimiser Aron, contrato

Roitman Marcos, contrato de arriendo

Roitman Salomon, contrato, plano, notas

Rojkin Casildo, contrato, plano, notas

Rojkin Manuel, plano, notas

Rojkind Casildo, contrato, plano

Rojman Isaac , plano, notas

Rollansky Naum, contrato

Rosas Florindo, contrato

Rosenfeld Moische, contrato de arriendo

Rosenfeld Moische, contrato de arriendo

Rosquin Leon B., contrato

Rosquin Leon B., contrato

Rossini Santiago, contrato

Rovner Elias, contrato, plano, notas

Rovner Jacobo, plano, notas

Rtischev Simon, contrato, plano

Rubin Isaac Salomon, contrato

Rubin Jacobo, contrato, plano, notas

Rubinstein Israel, contrato, plano, notas

Rudminsky Jacobo, contrato

Rudminsky Jacobo, contrato, plano, cartas

1930-1948

$1945-46$

$1928-40$

$1917-55$

1900-30

1930

1929-47

1894-1929

1934-36

1943-44

$1940-41$

$1932-41$

$1944-46$

1946

1938-1939

1894-1924

1900-1930

1929-49

1930

1901-1937

1900-28

1942-43

1919-46

1911-63

1928

1939

19927-47

1930-57

1926

1935-40

1926

1910-1931

1901-36

1928-44

1926

1904-1926

1945-54

1952

1939-46

1930-45

1944

1918-47

1940-45

1946-1947

1926-1940

1934-48

1905-35

1909-46

1919-40

1942

1931-40

1904-1929

1926

1916-43

1938-50

1937-1956

1919-1938

1918-47

1915-1940

1919-1939

1902-47

1942

1934-46
Schalum Jacobo, contrato, plano, notas

Scheidman Moises, contrato, plano

Scheinker Simon, contrato

Scheinker Simon, contrato, plano, cartas
Reserva

Reserva

Reserva

Reserva 
1857 Basavilbaso 2782 Basavilbaso 4822 Basavilbaso 3071 Basavilbaso 4760 Basavilbaso 4724 Basavilbaso 164 Basavilbaso 4654 Basavilbaso 200 Basavilbaso 4685 Basavilbaso 4629 Basavilbaso 4637 Basavilbaso 5178 Basavilbaso 4464 Basavilbaso 3213 Basavilbaso 1970 Basavilbaso 5828 Basavilbaso 5634 Basavilbaso 4754 Basavilbaso 4774 Basavilbaso 4648 Basavilbaso 1002 Basavilbaso 4675 Basavilbaso 5165 Basavilbaso 1765 Basavilbaso 3973 Basavilbaso 1760 Basavilbaso 3814 Basavilbaso 177 Basavilbaso 3838 Basavilbaso 4697 Basavilbaso 3142 Basavilbaso 6042 Basavilbaso 1716 Basavilbaso 1723 Basavilbaso 196 Basavilbaso 515 Basavilbaso 5803 Basavilbaso 997 Basavilbaso 3115 Basavilbaso 1730 Basavilbaso 5817 Basavilbaso

1721 Basavilbaso 3915 Basavilbaso 3951 Basavilbaso 4277 Basavilbaso 179 Basavilbaso 3825 Basavilbaso 3927 Basavilbaso 2653 Basavilbaso 3871 Basavilbaso 3891 Basavilbaso 212 Basavilbaso 4820 Basavilbaso 3811 Basavilbaso 2404 Basavilbaso 5805 Basavilbaso 5179 Basavilbaso 3853 Basavilbaso 1773 Basavilbaso
Scheveloff Jose, contrato, plano, cartas

Schmoisman Aaron, contrato, plano

Schnitman Cesar, contrato

Schoj Leon y Susi, contrato, plano, notas

Schub Gregorio, contrato

Schusterman Schoil, contrato

Schvartz Isaac, contrato, plano

Schvartz Jacobo, contrato, plano, notas

Schvartz Manuel, contrato, plano

Schvartz Mauricio, contrato, plano, notas

Schvartz Salomon, contrato, plano, notas

Schvartzman Froim, contrato, plano, notas

Schvartzman Jose, contrato

Schvartzman Luis, contrato, plano, cartas

Schwartz Mauricio y Manuel, contrato de arriendo

Schwartzkoff Samuel, nota

Schwartzman Jose, contrato

Schwartzman Juan, Luis y Mauricio, contrato, plano, notas

Sebsovich Maria, contrato

Sehin Aron, contrato

Sein Miguel, contrato, plano, notas

Selman Salomon y Mosovich Juan, contrato, plano, cartas

Selman Salomon, contrato, plano, notas

Serebrinsky Isaac, contrato, plano, notas

Serebrinsky Manuel, contrato, plano, cartas

Serebrinsky Moises y Alejandro, contrato

Shein Gregorio, contrato, plano

Sheveloff Jose, contrato

Siedlecki David S., contrato, plano

Silvera Martin, contrato

Simerman Aron, contrato

Sinagoga Beth Abraham, contrato de arriendo

Singer Salomon, contrato, testimonio, notas

Sirota Marcos, contrato, plano

Skaff Marcos, contrato, plano

Slavkin Miguel, contrato, plano

Slavkin Pablo, contrato, plano, carta

Slipchinsky Leon, contrato, plano, notas

Smerling Abraham e hijo Moises, contrato, plano

Smoisman Isaac, plano, notas

Smoisman Israel M., contrato, plano

Sociedad Agrícola Israelita, Wolcoff Simon, Kitzis Salomon, Hillkirk

W. John, Traverso Ernesto Domingo, Cano Juan, Fabre Felix,

Mandrioli Jose, Saintotte Pedro, Volcoff Simon, Biassoni Francisco, Tolini Jose, Feldman Israel, Guisband Juan Bautista, Alvarez Teofilo

E., Gurovich Adolfo, Edelcopp Marcos, Feiock Federico, Germano Severo Miguel Ciancio, Gomez Rogelio, Martinez Pedro, Bregliano Felipe, Gomez Genaro, Leibovich Aaron, Registro de Escrituras de terrenos vendidos por la JCA

Socolovsky Aida Siutcos de, contrato, plano

Soldatti Blanca, contrato

Solis Alfredo N., contrato

Soltz Pablo, contrato, plano, notas

Solz Samuel, contrato, plano

Sosa Juan, contrato

Sosa Maria Pilar de, contrato

Spaisman Elias y Manuel, contrato, plano

Spaisman Jose E., contrato

Spinetti Maximo Ricardo, contrato

Stavitzky Marcos, contrato, plano

Stegeman Guillermo, contrato

Stein Isaac, contrato

Stein Salomon, contrato, plano

Steingard Jacobo, contrato, plano, notas

Steingard Jacobo, solo una hoja suelta parte de un contrato

Straus Hermann I., contrato

Strinbaum Isac, contrato, plano, cartas

1910-46

1929-45

1925

1907-28

1928

1930

1946-47

1924-1929

1937-47

1924-1925

1924-1929

1913-1929

1936

1905-1918

1935-39

1967

1936

1899-1931

1929

1928

1924-1929

1905-56

1906-1923

1931-1940

1912-52

1945-47

1922-47

1944-46

1927-50

1945-46

1930

1923-47

1926-1937

1944

1936

1925-51

1935-47

1925-1956

1900-35

1901-29

1937

1922

Reserva

Reserva 
3813 Basavilbaso 5164 Basavilbaso 2792 Basavilbaso 274 Basavilbaso 4821 Basavilbaso 3905 Basavilbaso 202 Basavilbaso 4132 Basavilbaso 4592 Basavilbaso 5802 Basavilbaso 2786 Basavilbaso 3848 Basavilbaso 3069 Basavilbaso 255 Basavilbaso 262 Basavilbaso 170 Basavilbaso 3852 Basavilbaso 4722 Basavilbaso 6345 Basavilbaso 5639 Basavilbaso 4639 Basavilbaso 1771 Basavilbaso 4128 Basavilbaso 211 Basavilbaso 1766 Basavilbaso 3150 Basavilbaso 4140 Basavilbaso 3972 Basavilbaso 5163 Basavilbaso 3836 Basavilbaso 5154 Basavilbaso 1711 Basavilbaso 3877 Basavilbaso 4669 Basavilbaso 252 Basavilbaso 186 Basavilbaso 4702 Basavilbaso 4762 Basavilbaso 253 Basavilbaso 4771 Basavilbaso 1856 Basavilbaso 4473 Basavilbaso 4661 Basavilbaso 5818 Basavilbaso 3940 Basavilbaso 4809 Basavilbaso 5155 Basavilbaso 4699 Basavilbaso 3711 Basavilbaso 4645 Basavilbaso 4625 Basavilbaso 1761 Basavilbaso 1706 Basavilbaso 4819 Basavilbaso 3881 Basavilbaso 3911 Basavilbaso 2797 Basavilbaso 3943 Basavilbaso 3976 Basavilbaso 4770 Basavilbaso 3879 Basavilbaso 3938 Basavilbaso 3920 Basavilbaso 3965 Basavilbaso 4379 Basavilbaso 2873 Basavilbaso 273 Basavilbaso
Strusberg Jacobo, contrato

1945-46

Strusberg Jacobo, contrato, plano, notas

Strusberg Mari K., contrato, plano

Sujovolsky Enrique, contrato, planos, cartas

Suñer Pio, contrato

Sunier Pio Alberto, contrato

Susman Bernardo, contrato, plano

Susman Moises, contrato, plano, notas

Susman Pedro, plano, notas

Sutin Luis, contrato, plano, notas

Svartman Samuel, contrato, plano

Svartzman Samuel, contrato

Svetlisa Fisel, contrato, plano, notas

Svetliza Miguel, contrato, plano

Tacus Leon (ex Yentl Suc. e hijo), contrato, plano, carta

Tarasiuk Aisik, contrato, plano

Tarasiuk Leon, contrato

Tavarovsky Jaime, contrato

The River Plate Dairy Company Ltd., contrato venta de terreno

Tolcacher Abraham, contrato, plano, notas

Tolcacher Bernardo, contrato, plano, notas

Tolcachier Bernardo y Mario, notas, plano

Tolcachier Enrique, contrato, plano, notas

Tolcachier Leon, contrato, plano

Tolcachier Marcos, Gregorio y Aron, contrato, plano, cartas

Tolcachier Rosa K. de, contrato de arriendo

Tolcachier Samuel, contrato, plano, cartas

Tolcachier Sara K. de, contrato

Tolcachir Bernardo, contrato, plano, notas

Tolcachir Leon, contrato

Tovorosky Leon, contrato, plano, notas

Tovorovsky Bernardo, contrato, plano

Tovorovsky Enrique, contrato

Tovorovsky Jaime, contrato, plano, cartas

Tovorovsky Juan y Bernardo, contrato, plano

Tovorovsky Leon, contrato, plano

Traitel Naum, contrato

Traversa Antonio, contrato

Trosman Aaron, contrato, plano, carta

Turri Pablo A., contrato

Uchitel Salomon, contrato, plano, cartas.

Uchitel Salomon, contrato, plano, notas

Uchitel Salomon, contrato, plano, notas

Umansky Jose, Registro de Escritura

Urriste Martires, contrato

Vadell Celestino, contrato

Vaiman Elias, contrato, plano, notas

Vaiman Jaime y Wolkoff Gregorio, contrato

Vaiman Jose, contrato

Vaiman Jose, contrato, plano, notas

Vaiman Leon, Bernardo y Jaime, contrato, plano, notas

Vainberg Isaac, contrato, plano, cartas

Vaisberg Jacobo, contrato, plano, notas

Varesi Lorenzo, contrato

Velazquez Miguel, contrato

Velzi Pascual P., contrato

Velzi Pascual, plano

Velzi Pedro P., contrato

Vialidad Nacional, contrato, plano, nota

Villanova Felix y Natalio, contrato

Villareal Aurelia y Monzon Genaro, contrato

Villareal Timoteo y Ana, contrato

Villarreal Rudecindo, contrato

Villaverde Isidoro, contrato

Villaverde Isidoro, convenio

Vinocur Ignacio, contrato, plano

Vinocur Samuel, contrato, plano, correspondencia
1932-1955

$1925-46$

1926-53

1925

1938-1939

1928-47

1924-46

1901-1956

1919-1947

1929-45

1939-40

1906-28

1925-33

1918-41

1928-51

1940-41

1930

1915

1904-1932

1907-1928

1946

1946-1947

1922-47

1926-53

1944-46

1925-46

1945-47

1906-1919

1938-39

1905-1919

1916-48

1948-54

1906-1922

1902-43

1923-47

1930

1928

1904-43

1928-1936

1919-45

1900-1924

1900-1926

1923

1946-1947

1926

1908-1918

1930-1956

1940-42

1905-1930

1905-1927

1922-47

1912-52

1925

1919-40

1944-1945

1947

1934-45

1941-43

1928

1919-36

1946-48

1937-1938

1941-47

1948

1945-50

1912-55
Reserva

Reserva

Reserva

Reserva

Reserva 
4597 Basavilbaso 4768 Basavilbaso 2802 Basavilbaso 1863 Basavilbaso 3815 Basavilbaso 3114 Basavilbaso 4463 Basavilbaso 1709 Basavilbaso 4626 Basavilbaso 4707 Basavilbaso 195 Basavilbaso 4622 Basavilbaso 4672 Basavilbaso 3068 Basavilbaso 4796 Basavilbaso 4137 Basavilbaso 207 Basavilbaso 4753 Basavilbaso 5157 Basavilbaso 4657 Basavilbaso 4752 Basavilbaso 3160 Basavilbaso 3199 Basavilbaso 5159 Basavilbaso 4134 Basavilbaso 4627 Basavilbaso 4750 Basavilbaso 3211 Basavilbaso 4650 Basavilbaso 4682 Basavilbaso 3847 Basavilbaso 3932 Basavilbaso 3948 Basavilbaso 3967 Basavilbaso 3151 Basavilbaso 5815 Basavilbaso

4794 Basavilbaso 187 Basavilbaso 4716 Basavilbaso 4790 Basavilbaso 4599 Basavilbaso 188 Basavilbaso 1722 Basavilbaso 4735 Basavilbaso 4644 Basavilbaso 213 Basavilbaso 6838 Clara 45 Clara 3376 Clara 5573 Clara 4883 Clara 5075 Clara 3277 Clara 3397 Clara 2024 Clara 2087 Clara 29 Clara 2155 Clara 3742 Clara 2151 Clara 4512 Clara 27 Clara
Vinocur Zelig e Ignacio, contrato, plano, cartas

Viola Francisco, contrato

Visacovsky Salomon, contrato, plano

Visacovsky Sofia S. de Salomon, contrato, plano

Viscovsky Salomon, contrato

Visnevetzky Jose, plano, notas

Volij Naum, contrato, plano, cartas

Volii Salomon, contrato, plano, notas

Volin Marcos y Alberto, contrato, plano, nota

Voloschin Marcos, contrato

Volosin Marcos, contrato, plano

Volosin Naum, contrato

Volosin Samuel, contrato, plano, notas

Vugman Jacobo (Suc.), contrato, plano, notas

Vugman Santiago, contrato, plano, notas

Waiman Voli, contrato, plano, cartas

Wainman Gregorio, contrato, plano

Wegert Augusto, contrato

Weinberg Salomon, contrato, plano, notas

Weisberg Samuel, contrato, plano, notas

Winocur Selig, contrato de venta, cancelación de hipoteca

Wolf Ferdinand, contrato de arriendo

Wolosin Jacobo, contrato de arriendo

Wulfsohn Gregorio, contrato, plano, notas

Wulfsohn Jacobo, contrato, plano, notas

Wulfsohn Julio, User, Jaime y Leiser, contrato, plano, notas

Yalovetzky Jose, contrato de venta, escritura

Yeguer Wolf Ber, contrato de arriendo

Yentel Benjamin, contrato, plano, notas

Yosolovich Jaskel, contrato, plano, cartas

Yurman Boris, contrato

Yurman Boris, contrato

Zapata Carlos, contrato

Zapata Maria C. de, contrato

Zapata Rafael, contrato de arriendo

Zelinguer Israel, Weitzman Gregorio, Henkin Miguel, Finochio Felix,

Banchik Simje, Kreis Pedro, Molinelli Emiliano Tobias, Scheiber

Alberto Godofredo, Rubinsky Moses, Hutt Alejandro, Pitman Aron,

Umansky Sara Toch de, Rosse Isidoro Guerino, Rossi Alejandro

Vicente, Jasovich Adolfo, Registro de Escrituras de terrenos

vendidos por la JCA

Zentner Ersch. Contrato, plano, notas

Zentner Jaime, contrato, plano

Zentner Jose, contrato

Zentner Mendel, contrato, plano, notas

Zentner Moises, contrato, plano, notas

Zentner Motel, contrato, plano

Zentner Pablo, contrato, plano

Zieg Federico, contrato

Zimerman Aron, contrato, plano, notas

Ziplis Leon, contrato, plano

Selmanovich Isaac, escritura, plano, notas (Grupo Perlisa),

Abramovich Leon y Aron

Abramovich Meier, contrato, plano, notas

Abramovich Moses, contrato, plano, notas

Abramovich Pablo, contrato

Abramovich Pablo, contrato, plano, notas

Abramovich Salomon, contrato, plano notas

Abramovich Samuel, contrato, plano, notas

Acst Abraham, Boleto de Compra

Acst Abraham, contrato, plano, cartas

Acst Abraham, Valber Sara Acst, contratos, plano

Acst Salomon, contratos de arriendo

Aguirre Gabriel, contrato, plano

Aizicovich Sebastian y Yurgel A., contrato de pastoreo anulado

Aizicovich Sebastián, contrato, plano, cartas

Aizicovitch Samuel, cancelación contrato
1905-1926

1928

1947-50

$1909-45$

1944-46

$1901-29$

1906-1918

1921-48

1905-1927

1930

1924-51

1921-1929

1906-1923

1903-29

1907-1928

1945-47

1942-51

1929

1906-1918

1906-1929

1929-1938

1938-42

1925-47

1906-1918

1907-46

1900-1927

1929-1947

1931-41

1904-1925

1901-1925

1939-48

1940-42

1954-59

1945-58

1948-50

1924

1900-1928

1943-47

1930

1895-1928

1900-1927

1944-47

1937-39

1929-1931

1915-1935

1924-47

1895-1935

1930-52

1901-29

1894-1918

1933

1895-1927

1920-24

1900-25

1970

1945-59

1924-64

1936-42

1948

1934

1930-51

1962

Reserva

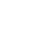


4689 Clara 2342 Clara 407 Clara 3280 Clara 5838 Clara 36 Clara

4325 Clara

4318 Clara

2724 Clara

2312 Clara

6849 Clara

4501 Clara

4893 Clara

2053 Clara

4376 Clara

2153 Clara

2920 Clara

2666 Clara

2103 Clara

2323 Clara

2864 Clara

1915 Clara

3135 Clara

3244 Clara

4909 Clara

527 Clara

2102 Clara

5608 Clara

3387 Clara

5083 Clara

5082 Clara

3255 Clara

4860 Clara

3804 Clara

2832 Clara

3252 Clara

3251 Clara

4378 Clara

2309 Clara

3302 Clara

4875 Clara

3686 Clara

2669 Clara

6777 Clara

2590 Clara

2369 Clara

1075 Clara

4899 Clara

5913 Clara

41 Clara

1295 Clara

4489 Clara

5625 Clara

3399 Clara

4321 Clara

2144 Clara

2391 Clara

4314 Clara

2764 Clara

6847 Clara

46 Clara

3719 Clara

5859 Clara

4868 Clara

2336 Clara

2152 Clara
Albarracin Fructuoso A., contrato

1931

Albertinsky Abraham, contrato, notas

Albertinsky Clara Epstein de y Albertinsky Abraham, contrato, plano

$1940-42$

Albertinsky Leon, contrato, plano, notas

Albertinsky Moises, Esther y Rainr Isaac, contrato, plano

Albertinsky Simon y Abraham, contrato, planos, correspondencia

Almada Bonifacio, contrato de arriendo

Almada Nemesio, contrato de arriendo

Alperin David y Salomon, contrato, plano, cartas

Alperin Salomon, contrato, notas, abandono

Althaus Vda de Jose e hijo Benjamin, contrato, plano, notas (grupo

Perlisa)

Anijovich Aron, contrato, plano, cartas

Antivero Domingo, contrato

Aquino Rosa Juan, contrato

Aranda Exequiel, contrato

Aranovich Mauricio, contrato de arriendo anulado

Aranovich Salomon, contrato, plano, cartas

Aranovich Samuel y Mauricio, contrato, plano, cartas

Aronson Isaac y Fuksman Abraham, arriendo anulado

Arschintag Berta F. de, contrato

Arzobispado de Parana en Basavilbaso, contrato, plano

Asernitzky Isaac, notas, plano

Asociacion Kneset Israel, contrato de arriendo

Atelman Simje y Jacobo, contrato de arriendo, plano, notas

Axelrud Hersch, contrato

Axenfeld Abraham, contrato, plano, cartas

Axenfeld Rosa, notas, transferencia

Axenfeld User, Rosa Flom Viuda de, contrato, plano, notas

Babich Isaac y Sara C. de, contrato, plano

Banchik Mauricio, contrato, plano, notas

Barajovich Gregorio, contrato, plano, notas

Baranoff Elias, contrato, plano

Baranoff Elias, contrato, plano, notas

Barbosa Ramon, contrato, plano

Baron Jose, contrato

Baron Miguel, contratos, plano, notas

Baron Salomon, contrato, plano, notas

Barreto Juan, contrato

Bashkansky Angel, contrato

Baskin Abraham, contrato, plano, notas

Basquin Slata, contrato de arriendo

Bastian Victor M., nota

Beckenstein Isaias y Bernardo, contrato, plano, notas

Beiguelman Jacobo, Escritura de terreno, incompleto

Bekenstein Bernardo, contrato, plano, cartas

Bekenstein Isaias, contrato

Bendersky Benjamin y Ruben, contrato, plano

Bendersky Rubin, contrato

Berchadsky Fany Vda. de y Utin Ignacio, contrato de promesa de venta

Bercovich Abraham, contrato, plano

Bercovich Moises, contrato, plano, cartas

Bercovich Salomon, contrato, plano. cartas

Berenson Miguel, contrato, plano, notas

Berenstein Pablo, contrato, plano, notas

Beron Feliciano, contrato de arriendo

Berschadsky Fany, contrato de arriendo anulado

Biblioteca Max Nordau, contrato de arriendo

Biblioteca Popular D. F. Sarmiento, contrato de arriendo

Bidner Moises, contrato, plano, cartas

Bidner Moises, contrato, plano, notas (grupo San Vicente)

Binderman Bernardo y otros,correspondencia,contrato, plano

Biondi Josefina, contrato, plano

Blaistein David, contrato, (Readquisición ?)

Blaistein David, contrato, plano, notas

Blinder Benjamin, contrato

Blinder Benjamin, contrato de arriendo
1923-55

$1900-31$

1954-1955

$1938-54$

1919

$1936-46$

$1928-57$

$1907-36$

1895-1930

$1900-49$

1932-1939

1937

1939-48

1935

1929-39

1906-32

1919-36

$1939-40$

1939

1924-31

1932-45

1895-1923

1923-1933

1895-1925

1919-38

1900-1939

1894-1925

1921-1928

1909-1928

1903-43

1912-1942

1946

1949-51

1922-48

1925-31

1939-1941

1946

1934-53

1931-1932

1972

$1934-35$

1929

1921-48

1943-44

1900-56

1932-1936

1920-1967

1930-49

1926-60

1921-1938

1901-1922

1895-1925

1939-1940

1928

1937-51

1945

1930-36

1905-30

1928-47

1929-40

1923-1936

1909-1933

1940-41

1935

Reserva

Reserva

Reserva

Reserva

Reserva

Reserva

Reserva

Reserva 
4004 Clara 3704 Clara 2124 Clara 3780 Clara 4502 Clara 5879 Clara 5919 Clara 2454 Clara 378 Clara 560 Clara

6851 Clara 5597 Clara 5627 Clara 4328 Clara 4327 Clara 4876 Clara 2354 Clara 2338 Clara 1079 Clara 5619 Clara 2126 Clara 4901 Clara 3545 Clara 2299 Clara 556 Clara 3799 Clara 1701 Clara 4908 Clara 5067 Clara 5601 Clara 4322 Clara 4708 Clara 2313 Clara 1688 Clara 2277 Clara 2337 Clara 3300 Clara 4084 Clara 6875 Clara

1018 Clara 3797 Clara 3791 Clara 2283 Clara 532 Clara

4479 Clara 2813 Clara 3134 Clara 2384 Clara 2284 Clara 2456 Clara 5747 Clara 1294 Clara 4898 Clara 4263 Clara 5881 Clara 2330 Clara 5086 Clara 4934 Clara 3687 Clara 3190 Clara 3133 Clara 2349 Clara 2441 Clara 5745 Clara 2795 Clara 787 Clara
Blinder Bernardo y Jaime, contrato, plano, notas

Bodeman Francisco, contrato

Bogdanoff Abraham, contrato, notas, desalojo

Bogdanoff Jose, contrato

Bohoslavsky Rosa K, de, y Luis, contrato, plano, cartas

Bondar Jose, contrato, plano

Bortnik Lia S. de, judicial

Bortnik Naum, contrato, plano, cartas, notas

Bouyon Justo, contrato, plano

Boverman Bernardo, contrato, plano

Braslavsky Leizer, contrato, plano, nota (grupo Domingo Calvo)

Braver Isaac, contrato, plano, notas

Braver Jacobo, contrato, plano, notas

Bravo Alberto, contrato, nota

Bravo Miguel, contrato

Bresler Matias, contrato, notas

Bresler Miguel, contrato de pastoreo

Bricman Jose, contrato de pastoreo

Britvin Moises, contrato, plano, cartas

Bronstein Elias, contrato, plano, notas

Bronstein Moises, contrato de arriendo anulado

Brounstein Mendel, Perez Norberto, contrato, plano

Bubis Abraham, nota

Budasof Natalio y Birman Israel, contrato, plano, desalojo

Budeske Lazaro, contrato, plano

Bullinsky Juan, contrato

Burdenik Gregorio, contrato, plano, notas

Burman Abraham, contrato

Burman Isaac, contrato, plano, notas

Burman Jacobo, contrato, plano, notas

Cabrera Faustino, contrato de arriendo

Calderon Fermin, contrato

Canevsky Antonio, contrato

Canievsky Jaime, contrato, plano, cartas

Caplan Jaime, contratos, notas

Carpman Bernardo, contrato

Carpman Bernardo, contrato, plano, notas

Carrera Enrique, contrato (Dominguez)

Casarinsky Lazaro transfiere a Voscoboinik Jose e Israel, contrato,

plano, notas (grupo Guinzburg)

Castellanos Esteban, contrato, plano

Castro Carlos, contrato

Castro Marcelino C., contrato

Celman Salomon, contrato, notas, abandono

Chajchir Jacobo Jose, contrato, plano

Chajchir Moses, Jacobo y Jaime, contrato, plano, cartas

Chamiak Pedro, contrato, plano, cartas

Chavez Epifanio, contrato de arriendo

Chemelez Marcos, contrato de pastoreo

Cherevsky Jose, contrato, abandono

Chertkoff Simon, contrato, plano, cartas

Chevra Kaduscha-Cementerio, contrato, plano, nota

Chichelnitzky Miguel, Maximo y Alejandro, contrato, plano

Chiron Moishe y Faivel, contrato

Chisty Rafael, contrato, plano, cartas

Cibulosque Jose, contrato

Cibulovsky Abraham, contrato

Cibulovsky Jose y Jacobo, contrato, plano, notas

Cigler Hersch, contrato

Club Deportivo San Antonio, contrato

Club Juventud Unida de Pueblo Cazes, contrato de arriendo

Club Social, Biblioteca Jaim Najman Bialik, contrato de arriendo

Comisaria de Policia de Dominguez

Comisaria de Policia, contrato, plano

Comisión Sinagoga del Grupo Belez, contrato, plano, nota

Comisión Social Rosh Pina, contrato, plano

Consejo Nacional de Educación, contrato, plano
$1946-48$

$1912-48$

1932-47

1895-1938

1924-1930

1952

1911-56

1959

1906-26

1906-30

1906-1920

1915-1923

1970

1963-69

1922-1948

1941-42

1940-42

1921-47

1898-1921

1932

1930-1935

1969

1919-43

1895-1921

1947-48

1915-51

1918-1926

1924-1928

1900-1920

1936-42

1930

1939

1908-20

1935-40

1940-41

1924-48

1953

$1908-43$

1965

1926-41

1942-43

1917-43

1940-53

1894-1931

1947-48

1919-51

1919-51

1938-44

1923-52

1941-1956

1911-58

1934-1935

1906-23

1928-1943

1939

1900-1956

1934-1935

1939-41

1945-48

1945-51

1940-42

1941

1956

1946

1952
Reserva

Reserva

Reserva

Reserva

Reserva

Reserva

Reserva

De reserva

Reserva

Reserva

Reserva

Reserva 
1017 Clara

4326 Clara

5755 Clara

4386 Clara

3803 Clara

2857 Clara

2356 Clara

1324 Clara

3796 Clara

3785 Clara

1682 Clara

5073 Clara

2674 Clara

34 Clara

403 Clara

3702 Clara

2457 Clara

2350 Clara

4877 Clara

1690 Clara

3789 Clara

2675 Clara

5623 Clara

3247 Clara

4709 Clara

1689 Clara

2670 Clara

3315 Clara

1076 Clara

2927 Clara

4372 Clara

4385 Clara

4382 Clara

3801 Clara

5866 Clara

3271 Clara

6874 Clara

3717 Clara

2434 Clara

758 Clara

1320 Clara

3787 Clara

3105 Clara

2799 Clara

4017 Clara

6885 Clara

2314 Clara

2339 Clara

4855 Clara

4871 Clara

2326 Clara

2116 Clara

3381 Clara

3284 Clara

5081 Clara

5070 Clara

1620 Clara

3384 Clara

717 Clara

123 Clara

5614 Clara

2417 Clara

2162 Clara

136 Clara
Coop. Carniceria La Union de Ing. Sajaroff, contrato, plano

Cooperativa Agricultores Unidos, contrato de arriendo

Cooperativa Carniceria «La Unión», contrato, plano, nota

Cooperativa Carniceria La Sindical, (Zalazar, Cabrera), contrato de

pastoreo

Cooperativa Fondo Comunal «Clara», contrato, plano

Cooperativa Fondo Comunal, contrato, plano

Cooperativa Fondo Comunal, contratos de arriendo

Corman Manuela e Isaac, contrato, plano, cartas

Correia Americo, contrato

Correia Joaquin, contrato

Cosarinsky Abraham, contrato, plano, cartas

Cosarinsky Adolfo, contrato, plano, notas

Costianovsky Isaias, contrato, plano, notas

Costianovsky Jose, contrato, plano

Costianovsky Jose, contrato, plano

Cravetz Abraham, contrato

Cravetz Abraham, contrato, plano, cartas

Cravetz Benjamin, contrato

Cravetz Benjamin, contrato, notas

Creimer Salomon, contrato, plano, cartas

Cytranovich David, contrato

Danses Isaac y Elias, contrato, plano

Danses Isaac, contrato, plano, notas

Dardick Boruch, contrato de arriendo, plano, notas

Darrichon Juan, contrato

Daschevsky Moses, contrato, plano, cartas, notas

Davidovich Abraham, contrato, plano, notas

Davidovich Israel, contrato, plano, cartas

Davidovich Jaime, contrato, plano, cartas

Davidovich Lazar, contrato

De Bernardi Andres, Jaquet, Lucio y Lascow Vladimiro, contrato

Dercahez Francisco, contrato de arriendo

Diaz juan C., contrato de pastoreo

Diaz Juan Ciriaco, contrato, plano

Dikensatein Jacobo, contrato, Readquisición

Dikenstein Abraham, contrato, plano, cartas

Dikenstein Jacobo y Abraham Suc., contrato, planos, notas (grupo

Feinberg)

Dirección Nacional de Vialidad, contrato

Dirección Nacional de Vialidad, contrato

Director Bernardo, contrato, plano, correspondencia

Director Noe, contrato, plano, cartas

Dlugovitzky Bernardo, contrato

Dlugovitzky Bernardo, contrato

Dlugovitzky Bernardo, contrato, plano

Dlugovitzky Jose y Abraham, contrato plano, notas

Dorfman Aaron, contrato plano, notas

Dorfman Abraham, contrato de arriendo

Dorin David, contrato, notas

Dragun Jacobo, contrato, plano, notas

Dreispiel Luis A., contrato de arriendo, notas

Druker Samuel, contrato de pastoreo anulado

Dubrof Pedro, nota testimonio, desalojo

Dunayevich Tobias, contrato, plano, cartas

Edelcopp Noe y Bernardo, contrato, plano, notas

Edelstein Salomon, contrato, plano, notas

Effron Jauda, contrato, plano, notas

Efron David, contrato

Efron David, contrato, plano, cartas

Efron Elias, contrato, plano

Efron Fabian, contrato, plano, correspondencia

Efron Gdalie, contrato, plano, cartas

Efron Jacobo y Mauricio, contrato plano

Efron Jacobo, contrato de pastoreo anulado

Efron Kaome e Hijo Samuel, contrato, plano
Reserva

1919-39

1931-1956 Reserva

1934-43

1947

1941

1941-42

1912-57

1940-41

1932-47

1900-20

1904-1927

1900-36

1932-60

1956-61

1945

1923-48

1940-42

1925-1943

1895-1919

1931-49

1926-36

1908-1922

1906-22

1928-1930

1894-1920

1909-35

1959

1944-61

1928-36

1935-1936

1940

1939

1929-47

1937

1900-25

1919-49

1938-42

1941

1916-51

1922-58

1951

1946

1947-52

1924-51

1900-35

1941

1940-49

1912-1949

1929-1933

1939

1932-35

1900-27

1895-1938

1904-1950

1897-1927

1955

1900-29

1948-49

1923-47

1900-1921

1939

1938

1895-1925
Reserva

Reserva

Incluye varias

carpetas

Reserva

Reserva

Reserva

Reserva

Reserva

Reserva

Reserva

Reserva

Reserva 
2395 Clara 5863 Clara 5606 Clara 2828 Clara 125 Clara 2663 Clara 2341 Clara 2088 Clara 6013 Clara 2668 Clara 4888 Clara 718 Clara 4476 Clara 2145 Clara 5618 Clara 2678 Clara 4848 Clara 3281 Clara 4500 Clara 2714 Clara 2344 Clara 790 Clara 1606 Clara 4897 Clara 4308 Clara 4491 Clara

3273 Clara 5877 Clara 4863 Clara 3363 Clara 5593 Clara 4377 Clara 120 Clara 3404 Clara 5615 Clara 5632 Clara 2306 Clara 4976 Clara 47 Clara 4851 Clara 2123 Clara 3130 Clara 4383 Clara 3721 Clara 2095 Clara 3784 Clara 4014 Clara 2070 Clara 324 Clara 3360 Clara 2924 Clara 4862 Clara 5084 Clara 3283 Clara 4978 Clara 115 Clara 5572 Clara 3405 Clara 5589 Clara 610 Clara 2420 Clara 2296 Clara 5872 Clara 2281 Clara 4013 Clara 4011 Clara
Efron Leon y Jacobo, contrato

1936-43

Efron Leon, contrato, notas, Readquisición

Efron Marcos, contrato, plano, notas

Efron S. Jacobo, contrato, plano, cartas

Efron Schevach, contrato, plano

Efron Tanjum e hijo Salvador, contrato, plano, notas

Eidman Gregorio, contrato, notas

Eidman Gregorio, contrato, plano, cartas

Elfand J. Suc., plano

Elfand Jaime, notas

Elkin Meer, contrato

Elstein Marcos, contrato, plano

Elstein Salomon y Marcos, contrato, plano, cartas

Elstein Salomon, contrato de arriendo para pastoreo

Elstein Salomon, contrato, plano, notas

Elstein Simon, contrato, plano

Embon Gregorio, contrato, plano, notas

Engelberg Eliezer, contrato, plano, cartas

Enguelberg Elias, contrato, plano, cartas

Entelman Pedro, contrato, plano, cartas

Escuela Hebrea Laica del grupo Baron Hirsch, contrato

Escuela No. 114, nota, plano

Escuelas Laica y Hebrea, contrato, plano, cartas

Espindola Anacleta, contrato

Espindola Ricarda M. de, contrato de arriendo

Fainstein Jacobo e Isaac, contrato, plano, notas

Fainstein Jacobo, contrato, plano, notas

Fatelevich Samuel, contrato

Fatelevich Samuel, contrato, plano, notas

Ferdman Isaias, contrato, plano

Ferdman Julio, contrato, plano, notas

Fernandez Adan, contrato

Fijtman Isaac, contrato, plano, correspondencia

Fingerman Isaac e Israel David, contrato, plano, cartas

Fink Abraham, contrato, plano, cartas

Fink Salomon, plano, notas

Finkelstein David y Kosoy David, contrato, notas, desalojo

Finkelstein David, contrato

Finkelstein Moises, contrato, plano

Finvarb Leon, contrato, plano, notas

Finvarb Osias, contrato de arriendo, desalojo

Fister Rolando, contrato de arriendo

Fleita Gregorio, contrato de arriendo

Fleitas Gregorio, contrato

Flesler Jacobo, contrato, plano, cartas

Flesler Jaime, contrato

Flesler Jaime, contrato, plano, notas

Flesler Rafael, contrato, plano, cartas

Flier David, contrato, plano

Fondo Comunal Agricola, contrato, plano

Fondo Comunal, contrato

Fradkin Luis, contrato, plano, notas

Freiberg Naftule, contrato, plano, notas

Freidenberg Abraham, contrato, plano notas

Frid Jaskel, contrato, notas

Frid Leon y Anecimo, contrato, plano

Friedland Isaac, contrato, plano, notas

Fueguel Elias, contrato, plano, notas

Fueguel Elias, contrato, plano, notas

Fuks Abraham, contrato, plano

Fuksman Francisco, contrato

Fuldauer Hugo, contrato

Fumberg Gregorio, contrato, plano, notas

Fumberg Rafael y Saul, contrato, abandono

Furer Moises, contrato, plano, cartas

Furman Mateo, Leopoldo y Trul, contrato, plano, cartas
1930-1936

1904-1920

1947-50

1915-47

1895-39

1940-42

$1931-49$

1930

1900-32

1936-1937

1948-52

1928-1945

1920

1906-1921

1947

1909-1925

1913-31

1923-1959

1910-57

$1940-48$

1949-54

1956

1919-1932

1934-45

1924-

D22041939

1907-23

1945

1925-1934

1948

1906-1920

1939-47

1922-47

1894-1939

1895-1921

1895-1929

1944-48

1928-1937

1932-47

1908-1925

1928-40

1948-53

1938

1929-40

1936-56

1940-42

1926-49

$1915-46$

1923-49

1949-50

1936

1924-1928

1902-1927

1903-49

1915-1936

1918-47

1894-1915

1906-25

1906-1919

1938-49

1926

1941-43

1929-1946

1937-48

1923-47

1915-47
Reserva

Reserva

Reserva

Reserva

Reserva
Reserva

Reserva

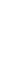

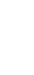

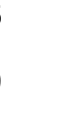


2788 Clara

2878 Clara

525 Clara

2794 Clara

1330 Clara

2303 Clara

5592 Clara

558 Clara

3543 Clara

2831 Clara

2586 Clara

2664 Clara

6852 Clara

2389 Clara

2269 Clara

4504 Clara

391 Clara

3299 Clara

20 Clara

485 Clara

482 Clara

6848 Clara

5596 Clara

3250 Clara

612 Clara

2324 Clara

127 Clara

2289 Clara

3722 Clara

6882 Clara

2830 Clara

5949 Clara

3379 Clara

5610 Clara

1687 Clara

5581 Clara

2783 Clara

2377 Clara

6833 Clara

5605 Clara

2840 Clara

2459 Clara

2633 Clara

3263 Clara

6879 Clara

4902 Clara

2333 Clara

1321 Clara

1318 Clara

3739 Clara

2453 Clara

4921 Clara

2382 Clara

2100 Clara

4882 Clara

5093 Clara

5858 Clara

2310 Clara

3795 Clara

2107 Clara

4920 Clara

6839 Clara

2387 Clara 2853 Clara
Furman Mauricio, contrato, plano

Furman Mauricio, contrato, plano, cartas

Furman Moises y Natalio, contrato, plano, carta

Furman Natalio, contrato, plano

Furrer Moises, plano, nota

Furrer Naum, contrato, abandono

Furrer Salomon y Roberto, contrato, plano, notas

Gabe Manuel, contrato, plano, carta

Gaier Alejandro, plano, nota

Galansky David, contrato, plano

Galante Isaac, contrato, plano, cartas

Galante Mauricio, contrato, plano cartas

Galante Moises, contrato, plano, nota (grupo Barreros)

Ganionsky Juan, contrato de pasto reo

Ganz Manuel, contrato

Garber Abraham, contrato, plano, notas

Garbovetzky David, contrato, plano

Gartenblum Abraham, contrato, plano, cartas

Gartenblum Abraham, contratos, plano, cuentas

Gelfenbein Celia Galante de (ex Daschevsky), contrato, plano, carta

Geller Catalina Schojet de, contrato, plano, cartas

Genijovich Abraham y Graschinsky Jaim(transferido), contrato,

plano, notas (grupos Desparramados y Fainberg)

Genijovich Marcos, contrato, plano, notas

Gerschunoff Leon, contrato, plano, notas

Gersuny Salomon, contrato, plano, carta, contrato a prueba

Giguer Luis, contratos, cartas

Giguer Moises y Natalio, contrato, plano

Gilitchinsky Abraham, contrato, notas

Gimenez Gregorio, contrato, plano

Giver Rodolfo, contrato, plano, notas (grupo Feinberg)

Givre Rodolfo, contrato

Gl?ck Adolfo, contrato de arriendo, notas

Glagovsky Boris e hijo Abraham, contrato, plano, cartas

Glagovsky Boris, contrato, plano, notas

Glas Gregorio, contrato, plano, cartas

Gleser Adolfo, contrato, plano, notas

Gleser Moises y Bernardo, contrato, plano

Gleser Moises, contrato de pastoreo

Gleser Salomon e Hijos Suc., escritura, plano, notas

Gleser Salomon, contrato, plano, notas

Glezer Jacobo, contrato

Glimberg Leon, contrato, plano, cartas

Glimberg Luis, contrato, plano, notas

Glinberg Luis, contrato, plano, notas

Glinberg Manuel, Isaac y Rafael y Broitman (sin nombre), conntrato, plano, notas (grupo Guinzburg)

Gluk Abraham, contrato

Gluk Adolfo, contrato de pastoreo

Glusman Abraham B., contrato, plano, cartas

Glusman Abraham y Leon, contrato, plano, cartas

Glusman Abraham, contrato, plano

Glusman David, contrato, plano, cartas

Glusman Gregorio, contrato

Glusman Gregorio, contrato de pastoreo

Glusman Gregorio, contrato, plano, cartas

Glusman Marcos, contrato, notas

Glusman Moses, contrato, plano, notas

Glusman Moses, contrato, Readquisición

Goald Jose, contrato, notas

Godoy Pedro, contrato

Golbert Isaac, arriendo anulado

Gold Jose e Idel, contrato

Goldberg Julio y Abraham, escritura, plano, notas, desalojo a la sucesión (Grupo Belez)

Goldemberg Jaime, contrato de pastoreo

Goldemberg Jaime, contrato, plano
1946

1947

1923-44

1946

1949

1939

1895-1920

1910-26

1968

1949-53

1921-46

1928-49

1900-30

1945-47

1941-46

1905-31

1924-62

1944-48

$1945-49$

1909-47

1909-42

1895-1941

1900-1920

1894-1924

1919-47

1930-44

1915-56

1938-43

1929-39

1919-40

1949

1939-1943

1894-1929

1900-1920

1894-1961

1895-1919

1940-45

1945-52

1921-30

1903-1920

1952

1928-61

1947-48

1910-25

1900-40

1934-1941

1940-41

1911-57

1911-48

1948

1912-57

1936

1944

1938-58

1905-1935

1906-1928

1936-1947

1937-46

1940-41

1936-38

1934-1942

1900-1956

1945

1941
Reserva

Reserva

Reserva

Reserva

Reserva

Reserva

Reserva

Reserva

Reserva

Reserva

Reserva 
6873 Clara

4923 Clara

2286 Clara

4496 Clara

2416 Clara

4511 Clara

43 Clara

4850 Clara

6079 Clara

2125 Clara

2129 Clara

1685 Clara

1686 Clara

2280 Clara

2588 Clara

2735 Clara

5844 Clara

4304 Clara

3743 Clara

3697 Clara

2161 Clara

6861 Clara

2839 Clara

4387 Clara

5080 Clara

5584 Clara

3275 Clara

2355 Clara

5810 Clara

2370 Clara

1049 Clara

2060 Clara

1332 Clara

4892 Clara

2320 Clara

2728 Clara

1091 Clara

2640 Clara

2372 Clara

6867 Clara

315 Clara

6880 Clara

6836 Clara

4859 Clara

5628 Clara

5822 Clara

3385 Clara

5604 Clara

5058 Clara

5071 Clara

4727 Clara

2916 Clara

1323 Clara

4856 Clara

4173 Clara

5852 Clara

2105 Clara

5059 Clara

6840 Clara

4867 Clara

4712 Clara

1083 Clara
Goldemberg Moises y Aranovich Salomon, contrato, plano, notas (grupo Guinzburg)

Goldenberg Jaime, contrato

Goldenberg Moises, contrato de pastoreo anulado

Goldenberg Sofia S. de y Salomon y Jaime, plano, notas

Goldin Noej, contrato

Goldin Noej, contrato, plano, notas

Goldin Ruben, contrato, planos

Goldman Adolfo Leon, contrato, plano, notas

Goldsmit Jacobo, contrato

Goldstein Leon, contratos

Golodnitzky Leon, contrato de arriendo anulado

Golomb Ksiel, contrato, plano, cartas

Golomb Lea Vda. de y Aizik, contrato, plano, cartas

Goltz Jacobo, contrato, notas, abandono

Golub Leon, contrato, plano, cartas

Golub Leon, contrato, plano, cartas

Gomez Pedro, contrato, plano, notas, Readquisición de la JCA

Gomez Timoteo, contrato, plano, notas

Gonzalez Máximo, contrato

Gonzalez Rito, contrato

Gorbat Abraham, contrato de arriendo anulado

Grabois Manuel, contrato, plano, nota

Grachinsky Moises, contrato, plano

Graschinsky Francisco y Moises, contrato, plano, cartas

Graschinsky Francisco, contrato, plano, notas

Graschinsky Jaim, contrato, plano, notas

Graschinsky Jaime, contrato, plano, notas

Graschinsky Leon, contrato

Graschinsky Manuel, contrato, plano

Graschinsky Moises, contrato de pastoreo

Graschinsky Simon y Moises, contrato, plano, cartas

Grichinsky Manuel, contrato, plano, cartas

Grimberg Antonio, contrato, plano, cartas

Grinberg Fernando, contrato

Grinberg Juan, contrato de arriendo de pastoreo

Grinberg Salomon, contrato, plano, cartas

Grinman Salomon, contrato, plano, cartas

Grinman Salomon, contrato, plano, cartas

Grinman Samuel, contrato de pastoreo

Grinstein Manuel, Rosa, Moises, Elias y Osias, contrato, plano,

notas (grupo lda)

Groisman Abraham, contrato, plano

Grümberg Berl transfiere a Olijavetzky ljiel y Moises, contrato, plano,

notas (grupo Carmel)

Grupo Baron Guinzburg) Smukler Bernardo-desalojo judicial de

Smukler y Flia. y otros

Gueiman Alberto, contrato, plano, notas

Gueler Felix, contrato, plano, notas

Gueler Isaac, contrato

Gueler Jaime, Marcos y David, contrato, plano, notas

Guerberoff Leib, contrato, plano, notas

Guerchanik I., cancelacion de hipoteca

Guerchunoff Leon y Kreman Angel, contrato, plano, notas

Guibaut Juan B., contrato

Guilichinsky Aron, contrato, plano

Guiter Rosa Pollak de, contrato, plano, cartas

Guitman Adolfo, contrato, plano, notas

Gupspan Jacobo y Clara L. de, contrato, plano, cartas

Gupspun Leopoldo, contrato, plano, Readquisición

Gurevich Isaac, notas, desalojo

Gurni Aaron, contrato, plano, notas

Gurni Jose, escritura, plano, notas (grupo Las Moscas)

Gutman Jaime, contrato, plano, notas

Guyot Carlos, contrato

Halperin Gregorio y Abraham, contrato, plano, cartas
1898-1943

1932-1934

1938

1902

D23041931

1941

$1924-40$

1933-49

1917-1925

1936-1942

1930-43

1936

1900-20

1895-1920

1936-41

1924-48

1915-48

1961-1964

1919-42

1952

1939-40

1936

1895-1922

1949-50

1895-1931

1900-1928

1900-1919

1894-1923

1941-48

1953-1964

1945-50

1945-47

1915-46

1944-59

1930-1942

1938-42

1922-50

1926-47

1938-48

1945

Reserva

Reserva

Reserva

1901-40

1919-55

1894-1950

1895-1939

1908-1928

1894-1949

1940

1894-1929

1895-1920

1963-1964

1895-1927

1931

1928-40

1934-57

1908-1925

1912-46

1928-1935

1935-40

1905-1928

1900-1930

1908-1928

1929-1948

1927-51 
2592 Clara 6862 Clara 37 Clara

313 Clara

2276 Clara

2118 Clara

2385 Clara

3279 Clara

116 Clara

2094 Clara

2523 Clara

2291 Clara

4019 Clara

611 Clara

2067 Clara

2265 Clara

1691 Clara

4728 Clara

2156 Clara

6856 Clara

4498 Clara

3763 Clara

5096 Clara

42 Clara

128 Clara

2665 Clara

2877 Clara

4927 Clara

131 Clara

396 Clara

2604 Clara

3695 Clara

2288 Clara

5630 Clara

5078 Clara

5079 Clara

2302 Clara

4009 Clara

5600 Clara

317 Clara

322 Clara

3532 Clara

4499 Clara

2272 Clara

4324 Clara

1088 Clara

2311 Clara

3496 Clara

3253 Clara

4373 Clara

2810 Clara

4878 Clara

5094 Clara

5857 Clara

4487 Clara

3136 Clara

4879 Clara

30 Clara

3276 Clara

5577 Clara

1108 Clara

4894 Clara

5689 Clara

3690 Clara

3243 Clara

5068 Clara

2275 Clara
Halperin Salomon y Alperin Julio, contrato, plano, cartas

Halperin Salomon, contrato, plano, notas (grupo Desparramados)

Heine Felipe, contrato, planos

Heller Samuel, contrato, plano

Herstig Tobias, contrato, plano, notas

Hertzovich Salomon, arriendo anulado

Herzovith Gregorio, contrato de arriendo, notas

Hirsch Maria L. de y Enrique, contrato, plano, notas

Hojman Abraham, contrato, plano

Hojman Aron y Jaime, cancelacion de hipoteca

Hojman Aron, contrato, plano, cartas

Hojman Jaime, contrato

Hojman Jose, contrato, plano

Hojman Leon, contrato, plano

Hojman Salomon, contrato, plano, cartas

Holtzman Santiago, contrato de pastoreo anulado

Horovitz David, contrato, plano, cartas

Hualde Remigio R., contrato

Huberman David, contrato de arriendo anulado

Huberman Salomon, contrato, plano, nota (grupo Baron Hirsch)

Huberman Scholem, plano, cartas

Huck David, contrato (Dominguez)

Hutin Enrique, contrato, plano, notas

Hutin Jaime, contrato, planos

Iconicoff Abraham y Kisil, contrato, plano

Idelson Jose y Luis, contrato, plano, cartas

Idelson Luis, contrato, plano

Ideses Jonas, contrato

Ideses Simon, contrato, plano

Idesis Isaac, contrato, plano

Idesis Menasche, contrato, plano

Iglesias Ramon Hugo, contrato

Ikonicoff Carlos K., contrato anulado

Inguercher Marcos y Oclander Dora Barajovich de, contrato, plano, notas

Isaac Adolfo, contrato, plano, notas

Isaac Benjamin, contrato, plano, notas

Isaac David, contrato

Isaac Isidoro, contrato, plano, cartas

Isaac Nisan, contrato, plano, notas

Isaac Samuel y David, contrato, plano, carta

Jaimovich Elias, contrato, plano

Jaimovich Elias, nota

Jaimovich Felipe, contrato, plano, notas

Jefatura de Policia de Villaguay, contrato de arriendo

Jirom Pablo, contrato de arriendo

Jramoy Ines G. de e hijo Jaime, contrato, plano, cartas

Jromoy Leon, contrato, notas, abandono

Jruz Jaime Tomás, contrato

Jucid Pedro, contrato, plano, notas

Junta de Fomento Comunal de Villa Dominguez, contrato, plano, cartas

Junta de Fomento de Villa Clara, contrato

Junta de Fomento Dominguez, contrato

Jurin Jose, contrato, plano, notas

Jurin Jose, contrato, Readquisición

Jusefoff Jaime, contrato, plano, cartas

Juventud Israelita «Kadima», contrato de arriendo

Kaleca David, contrato

Kaler Aron, contrato, plano

Kaler Lazar, contrato, plano, cartas

Kaler Lazar, contrato, plano, notas

Kalika Victor, contrao, plano, cartas

Kam Benjamin, contrato

Kamin Leon y Gregorio, contrato, plano, notas

Kamin Marcos, contrato

Kantt Kolman, contrato, plano, notas

Kaplan Aron, contrato, plano, notas

Kaplan Efroim, contrato, desalojo
1895-46

$1895-1931$

1958-45

1922-58

$1933-40$

1936

1900-45

1894-1949

1921-47

1957

1915-57

1937

1900-31

1931-51

1928-45

1938

1902-19

1931

1936

1900-30

1900-1931

1940-41

1910-1928

1938-47

1910-25

1900-32

1928-47

1934-1935

1911-28

1923-50

1915-48

1952-54

1938-41

1894-1929

1927-1949

1895-1928

1939-46

1943-51

1894-1920

1915-46

1926-41

1971

1894-1931

1941

1935-36

1926-47

1907-46

1970

1921-48

1940-1942

1948

1923-1927

1908-1928

1935

1917-1939

1919-50

1926-1941

1949-62

1904-23

1904-1919

1922-56

1937-1942

1909-1960

1945-47

1895-1924

1895-1927

1915-48
No. ilegible

Reserva

Reserva

Reserva 
6854 Clara 2359 Clara 3259 Clara 6853 Clara 4918 Clara 3305 Clara 2368 Clara 2667 Clara 3786 Clara 4478 Clara 4503 Clara 2063 Clara 4974 Clara 6860 Clara

2133 Clara 307 Clara

4178 Clara 1296 Clara 3688 Clara 6080 Clara 5873 Clara 4008 Clara 3359 Clara 5089 Clara 4865 Clara 2131 Clara 2271 Clara 2321 Clara 5098 Clara 2928 Clara 2292 Clara 377 Clara 3403 Clara 142 Clara 5626 Clara 3254 Clara 4833 Clara 4873 Clara 2390 Clara 2778 Clara 2160 Clara 2527 Clara 2287 Clara

2363 Clara 1097 Clara 4483 Clara 2122 Clara 6871 Clara 2089 Clara 6877 Clara 4481 Clara 5617 Clara 2069 Clara 2295 Clara 395 Clara 3378 Clara 4903 Clara 3762 Clara 2433 Clara 2426 Clara 5074 Clara 1090 Clara 5624 Clara 5097 Clara 3248 Clara
Kaplan Isaac, contrato, plano, nota (grupo Espinillos) 1903-30

Kaplan Jacobo, contrato de pastoreo 1945-47

Kaplan Jose, contrato, plano, notas $\quad 1900-41$

Kaplan Moises, contrato, plano, notas (grupo Perlisa) 1903-30

Kardonsky Moses, contrato 1935

Kardunsky Naum, contrato, plano, cartas 1922-57

Karpman Gregorio, contrato de arriendo, nota 1942-43

Karschenboim Abe y Ichiel, plano cartas 1908-32

Kasvin Marcos, contrato 1937-38

Kasvin Simon, contrato, plano, cartas 1905-1959

Katz Leon, contrato, plano, cartas 1895-1931

Katz Salomon, notas, plano 1915-46

Katzenelson Nision, contrato 1936-1940

Katzenelson Simon, contrato, plano, notas (grupos Desparramados

y Los Naranjos)

Kaufman Jose, contrato de arriendo anulado

Kaufman Leon y Dionicio, contrato, plano, carta

Kaufman Peisaj y Pedro, contrato, notas

Kesler Anton, contrato, plano, cartas

Kettin Jorge, contrato

Kilschtein Jaime, contrato, notas

Kilstein Jose, contrato

Kipen Debora y Wladimiro, contrato, plano, notas

Kleinman Davic, contrato

Kobrinsky Isaac e Hilel, contrato, plano, notas

Kofman Isia, contrato, plano, notas

Kogan Salomon, escritura de desalojo

Kohan Bernardo, contrato, abandono

Kohan Fabian, contrato de pastoreo

Kohan Isaac Tulio y Lazaro, contrato, plano, notas

Kohan Isaac y Leon, contrato, plano

Kohan Isaac, contrato de pastoreo anulado

Kohan Israel, contrato, plano

Kohan Jacobo, contrato, plano, cartas

Kohan Lasar, contrato, plano

Kohan Leon, contrato, plano, notas

Kohan Miguel, contrato, plano, notas

Kohanovsky Aron, contrato, plano, notas

Kohen Vidal, contrato

Kohon Elias, contrato de arriendo, notas

Kohon Lazaro e Isaac Julio, contrato, plano

Koifman Leon, contrato de arriendo anulado

Koifman Mauricio, contrato, plano, cartas

1921-39

$1922-52$

1904-46

1937-57

1949-55

$1915-1941$

1942

1913-47

1951

1895-1928

1908-1919

1935

1941

1938-39

1907-1928

Kolker Samuel, contrato(A) para edificar Hospital y Farmacia; (B) 1938

contrato de pastoreo anulado

Kolomeisky Luis, contrato

Kolomeisky Luis, contrato, plano, correspondencia

Kolomesky Luis, contrato, plano, notas

Konstantinovsky Jaime, contrato, notas, desalojo

Korach David e Hijos, contrato, plano, notas (grupo La Capilla)

Korach Jacobo, contrato, plano, notas

Korinfeld Tobias, contrato, plano, notas (grupo Guinzburg)

Korn Mendel y David, contrato, plano, cartas

Korsunsky Leon, contrato, plano, notas

Kossoy Moises, contrato, plano, cartas

Koval Bernardo, contrato de pastoreo

Koval Bernardo, contrato, plano

Koval Jaime, contrato, plano, notas

Koval Noej, contrato

Koval Santiago y Rosa, contrato (Dominguez)

Kovalevsky M., contrato, plano

Kovalivker Meer, contrato, plano

Kraiselburd Leon, contrato, plano, notas

Krapivka Adolfo, contrato, plano, cartas

Krapivka David, contrato, plano, notas

Kreiman Angel, contrato, plano, notas

Kreiman Efroim, contrato, plano, notas

1915-1949
1930

1937

1959

1895-1931

1903-25

1909-1923

1895-1924

1909-1921

1931-1938

1940-51

1929-42

1936

1922-60

Reserva

Reserva

Reserva

1944

1942-50

1912-44

1895-1943

1949-62

1911-45

1894-1949

1910-1921

1915-46

1937-43

1925-58

1900-45

1931-1935

1941-44

1919

1920

1895-1953

1916-58

1900-1922

1900-1928

1900-22 
4018 Clara

4486 Clara

762 Clara

140 Clara

2066 Clara

3764 Clara

5688 Clara

5602 Clara

3265 Clara

4494 Clara

2452 Clara

2294 Clara

137 Clara

3372 Clara

1317 Clara

4169 Clara

4174 Clara

316 Clara

341 Clara

2392 Clara

5575 Clara

5576 Clara

614 Clara

2315 Clara

3307 Clara

613 Clara

4973 Clara

3303 Clara

4970 Clara

3720 Clara

4887 Clara

3738 Clara

5591 Clara

3268 Clara

4375 Clara

3129 Clara

2322 Clara

2140 Clara

2934 Clara

3314 Clara

4495 Clara

2109 Clara

5587 Clara

3373 Clara

5580 Clara

2318 Clara

4477 Clara

5598 Clara

2439 Clara

2671 Clara

3781 Clara

6850 Clara

5095 Clara

2789 Clara

2388 Clara

523 Clara

6881 Clara

35 Clara

2166 Clara

2921 Clara

1911 Clara

2608 Clara

3266 Clara

3272 Clara

5904 Clara

2374 Clara
Kreimer David S., contrato, plano, cartas

Kreimer Dora y Abraham, contrato, plano, notas

Kreimer Inak, contrato, plano, correspondencia,

Kreimer Jacobo, contrato, plano, correspondencia

Kreimer Luisa y Luis, contrato, plano, cartas

Kreimerman Jaime, contrato (La Capilla)

Kreiserman Abraham, contrato, plano, notas

Kremenchugsky Lazar, contrato, plano, notas

Kremenchusky Abram, contrato, plano, notas

Kremenchutzky Aron, contrato, plano, cartas

Kremenchutzky Efroim, contrato, plano, notas

Kremenchutzky Salomon, contrato anulado

Kreserman Abraham, contrato, plano

Krimenchusky Lazaro y Manuel, contrato, plano, cartas

Krischautzky Joses, contrato, plano, cartas

Krischkavtzky Bernardo, contrato, plano, cartas

Kunin Abraham, contrato, plano, notas

Kunin David y Salomon, contrato, plano

Kunin David, contrato

Kunin David, contrato de arriendo

Kuperman Isaac, contrato, plano, notas

Kuperman Luis, contrato, plano, notas

Kuperstein Abraham y David, contrato, plano, cartas

Kuperstein Aron, contrato

Kuperstein Isaac, contrato, plano, cartas

Kuperstein Jacobo, contrato, plano, carta

Kupervaser Abraham, contrato, notas

Kuselevich Isaac, contrato, plano, notas

La River Plate Dairy Co.(Dayrico) Ltda., contrato

Larrea Nicasio, contrato

Larroza Isabelino, contrato

Larroza Juan y Dolores, contrato

Lefcovich Abraham, contrato, plano, notas

Lefcovich Mauricio, contrato, plano, notas

Leguizamon Jose M., contrato de arriendo

Leiba Alejandra, contrato de arriendo

Leibovich Aron, contrato

Leibovoch Aron, contrato de arriendo anulado

Leikach Gregorio, contrato, plano

Leikin Marcos y Leon, contrato, plano, nota

Leikis Abraham e Isaac, contrato, plano, notas

Leikis Abraham, Autorizacion de Negocio-anulado

Lejtman Juan, contrato, plano, notas

Levit Herch y Jacobo Moises, contrato, plano, notas

Levite Hersch, contrato, plano, notas

Levitzky Jose, contrato (Dominguez)

Levitzky Manuel, contrato, cartas

Levovsky Boris, contrato, plano, notas

Levovsky Feliciano, contrato, plano

Levovsky Israel y Lazar, contrato, plano, cartas

Lew Alberto y Chervin Aizik, contrato

Lew Benjamin e hijo Bernardo, contrato, plano, nota (grupo Domingo

Calvo)

Lew Benjamin, contrato, plano, notas

Lew Jaime y David, contrato, plano

Lew Jose, contrato de pastoreo

Lew Jose, contrato, plano, carta

Lew Samuel y Benjamin, contrato, plano, notas (grupo Domingo Calvo)

Lew Samuel y Gregorio, recibos

Liebeschutz Miguel, contrato de arriendo anulado

Liebeschutz Mina K, de, contrato, plano

Lifschitz Abraham, contrato, plano, cartas

Lifschitz Efraim, contrato, plano, cartas

Lifschitz Ichiel :contrato, plano, notas

Lifschitz Moises y Jose, contrato, plano, notas

Lifschitz Salomon, contrato de arrendamiento

Lifschitz Salomono, contrato, notas
1912-31

1900-1950

1912-52

1908-24

$1932-48$

1937-46

1922-1939

1904-1920

$1900-25$

1900-1945

1935-52

1938

1904-25

1924-29

1948-50

1929-46

1912-46

1911-46

1955-60

1936-53

1901-1918

1905-1918

1927-50

1909-44

1942-51

1918-50

1929-1935

1928-57

1927-1939

1940

1931-1945

1941-48

1895-1920

1910-39

1938-1940

1930-49

1939-40

1937

1929-32

1957

1895-1948

1918-31

1905-1919

1920-29

1894-1919

1937-47

1922-1931

1899-1920

1941

1905-36

1938-51

1907-39

1906-1928

1946

1944

1911-49

1932-41

1951-52

1937

1938-41

1900-52

1942-48

1900-25

1895-1925

1944.

1930-43
Reserva

Reserva

Reserva

Reserva

Reserva 
4880 Clara

5811 Clara

1319 Clara

615 Clara

2115 Clara

5842 Clara

3261 Clara

530 Clara

4012 Clara

4864 Clara

561 Clara

4179 Clara

2821 Clara

306 Clara

3800 Clara

2841 Clara

4896 Clara

2278 Clara

6844 Clara

5064 Clara

3699 Clara

4484 Clara

2149 Clara

481 Clara

763 Clara

4933 Clara

308 Clara

4931 Clara

6341 Clara

388 Clara

1326 Clara

715 Clara

4881 Clara

4872 Clara

2136 Clara

3779 Clara

2319 Clara

3693 Clara

4313 Clara

4380 Clara

5621 Clara

3402 Clara

5595 Clara

2279 Clara

5062 Clara

1909 Clara

3406 Clara

2332 Clara

114 Clara

2353 Clara

2798 Clara

5910 Clara

4381 Clara

3145 Clara

4490 Clara

309 Clara

2729 Clara

3294 Clara

3383 Clara

3386 Clara

5066 Clara

2347 Clara

3231 Clara

2561 Clara

6338 Clara

838 Clara
Lips Herz, contrato de arriendo

Liscovsky Celio y Jose, contrato, plano

Liscovsky Celio y Jose, contrato, plano, cartas

Liscovsky Gregorio, contrato, plano

Litvak Roberto, arriendo, desalojo

Litvin Abraham, Escritura, Readquisición de la JCA

Litvin Berta Schusteroff de, contrato, plano, notas

Litvin Leiba, contrato, plano

Litvin Salomon y Aron, contrato, plano cartas

Litvinoff Moises, contrato, plano, notas

LitvinSalomon y Aron, contrato, plano, cartas

Livovsky Israel y Feliciano, contrato, plano, cartas

Livovsky Sofia Kohon de, contrato, plano, cartas

Loiber, Sucesión de Efroim, contrato, plano

Loschkin Salomon, contrato

Loschkin Salomon, contrato, plano, cartas

Lozdan Manuel, contrato

Lulkin Isaac y Leon, contrato de arriendo

Lvovsky David y Boris e Israel, contrato, plano, notas, judicial

(Grupo Miguel)

Lvovsky Samuel, contrato, plano, notas

Macrachuk Martin, contrato

Magram Israel, contrato, plano, cartas

Magram Simon, contrato de arriendo

Maisules Jose y Abraham Nisun, contrato, plano, cartas

Malchansky Naum y Abraham, contrato, plano, correspondencia

Malchansky Naum, contrato

Malchansky Samson y Adolfo, contrato, plano, carta

Malek Abraham, contrato

Malek Pedro, contrato de pastoreo

Malek Pedro, plano, notas

Mamid Jose, contrato, plano, cartas

Man Miguel y Feliciano, contrato, plano

Manulis Samuel, contrato, notas

Marco Carlos J., contrato, plano, notas

Marcoff Jacobo, contrato de pastoreo anulado

Margenrot Tobias, contrato

Marinof Luis, contrato

Martinez Pascual, contrato

Martinez Pascual, contrato de arriendo

Martinez Pascual, contrato de pastoreo

Mas Angel, contrato, plano, notas

Mass Angel, contrato, plano, notas

Mass David, contrato, plano, notas

Mass Elias, contrato, notas

Mass Jose y Angel, contrato, plano, notas

Mass Saul, contrato, plano, cartas

Matesevich Efroim, contrato, plano, cartas

Matzkin Miguel, contrato anulado

Matzkin Miguel, contratos, plano, correspondencia

Matzkin Natalio, contrato de pastoreo

Matzkin Natalio, contrato, plano, notas

Matzkin Samuel y Miguel, contrato de arriendo

Mauleon Martin, contrato de pastoreo

Meikler Isaias, contrato de arriendo

Meikler Isaie, contrato, plano, notas

Merchuk Abraham, contrato, plano, carta

Merchuk Leopoldo, contrato, plano, notas

Merener David, contrato, plano, notas

Merener isaac y David, contrato, plano, notas

Merenlender Moises, contrato, plano, cartas

Meresman Geronimo, contrato, plano, notas

Meyerstein Manfred, contrato

Michnik Jacobo, notas

Michnik Samuel, contrato, plano

Milman Salomon y Pedro, contrato arriendo de lote, notas

Ministerio de Educación, p/ Escuela No. 100, plano
1924-1936

1950-1969

1919-48

$1910-53$

1926-46

1936-1943

1895-1925

1906-25

1923-51

1908-1923

$1936-44$

1942-46

1947

$1915-48$

1949

1949-50

1932-1942

1940

1895-1930

1924-1928

1941-42

1915-1959

1934

1909-46

1952-37

1931-1937

1928-57

1932

1946-1947

1943-65

1940-53

19491949

1925-1945

1929-1934

1926-31

1931-49

1938

1936-46

1918-47

1937-46

1900-1921

1922-26

1906-1920

1941

1923-1928

1911-39

1900-32

1942

1943-49

1945-46

1947-1947

1943

1937

1938-47

1903-1948

1930-60

$1910-48$

1946-48

1900-47

1895-1943

1924-1928

1940

1971

1960

1935-1941

1952-54

Reserva

Reserva

res

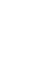

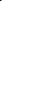


4315 Clara

3694 Clara

4854 Clara

3718 Clara

4384 Clara

4969 Clara

4971 Clara

1077 Clara

4015 Clara

2163 Clara

6342 Clara

4979 Clara

4932 Clara

2165 Clara

6081 Clara

6078 Clara

5060 Clara

5088 Clara

3802 Clara

3761 Clara

134 Clara

2282 Clara

2933 Clara

2062 Clara

2117 Clara

2135 Clara

2059 Clara

138 Clara

2773 Clara

716 Clara

2093 Clara

2034 Clara

4910 Clara

2770 Clara

1057 Clara

2065 Clara

2127 Clara

1082 Clara

122 Clara

617 Clara

1962 Clara

305 Clara

1080 Clara

4886 Clara

4936 Clara

4310 Clara

4982 Clara

1160 Clara

2304 Clara

4493 Clara

2331 Clara

2662 Clara

135 Clara

5582 Clara

3792 Clara

3724 Clara

5874 Clara

5631 Clara

760 Clara

3260 Clara

4172 Clara

5854 Clara

5578 Clara

2110 Clara

6077 Clara

5609 Clara
Miño Jose M., contrato de arriendo

$1945-49$

Mino Paulino, contrato

Minuchin Simon, contrato, plano, notas

$1949-55$

Minuet Nasaria R. de, contrato, plano

Minuet Ramon, contrato de arriendo

Mirchuk Benjamin, contrato

Mirchuk Isaac, contrato

Mirson Jaime, contrato, plano

Mischnik Samuel, contrato, plano, notas

Miskin Salomon, contrato de arriendo anulado

Mitzberg Fermin, contrato de pastoreo

Moalem Tofie Aniz, contrato

Moguilner Meilaj, contrato

Mohilner Meilaj, contrato de arriendo anulado

Moisenko Adolfo, contrato, notas testimonio

Monastirsky Adolfo, contrato, notas

Monastirsky Gregorio, contrato, plano, notas

Monastirsky Isaac, contrato, plano, notas

Monzon Eloy, contrato, plano

Morilla Ireneo, contrato (Dominguez)

Moscovich Benjamin, contrato, plano

Moscovich Julio, contrato, abandono

Mosovich Jacobo, contrato, plano

Mosovich Jacobo, contrato, plano, cartas

Mostovoy Jose, contrato de arriendo

Muchnik Jacobo, contrato de arriendo

Muchnik María Kohan de, y Muchnik Jacobo, contrato, plano, cartas

Muchnik Moises y Salomon, contrato, plano

Muchnik Salomon y Miguel, contrato, plano

Murlender Osias, contrato, plano

Murlender Osias, contrato, plano, cartas

Murlender Osias, Escritura incompleta

Nagel Eisig, contrato

Nagel Eisik, contrato, plano

Najemson Abraham, contrato, plano, cartas

Najemson Jaime, contrato, plano, cartas

Najemson Meier, contrato de arriendo anulado

Niemetz Paulina e hijo Leonardo, contrato, plano

Nitzberg Fermin (Froim), contrato, plano, correspondencia

Novidelsky Jaime, contrato, plano, cartas

Novidelsky Jaime, para Escuela Nacional No. 112, contrato, plano,

cartas

Novidelsky Manuel, contrato, plano

Nudelman Bernardo, contrato, plano, cartas

Nujimovich Isidoro, contrato

Nuñez Fernando, contrato

Nuñez Fernando, contrato de arriendo

Nusbaum Armando, contrato

Obholz Francisco, propiedad de J.C.A., plano

Obrellan Moises, contrato, abandono

Oclander Adolfo, contrato, plano, cartas

Oclander Jaime, contrato

Oclander Moses, contrato, plano, cartas

Ogernitzky Jacobo y Asernitzky Isaac, contrato y plano

Ogernitzky Jacobo, contrato, plano, notas

Ojeda Faustina, contrato

Ojeda Faustina, contrato, plano

Ojman Nuci, contrato

Ojman Nuci, contrato, plano, notas

Olchtud Gregorio y Olchtud Samel, contrato, plano

Olijavetzky Jiel, contrato, plano, cartas

Olijavetzky Rosa y Abraham, contrato, plano, cartas

Olkernitzky Jacobo, Israel e Isaac, contrato, plano (Readquisición ?)

Ornes Isaac, contrato, plano, notas

Ostrovsky Jose, transferencia de arriendo

Ostrovsky Motel, contrato, notas

Padlog Elias, contrato, plano, notas
1910-1929

1939

1938

1934-1941

1943-1946

$1915-49$

1904-52

1936

1946-1947

1936-1937

1923-1941

1944

1915-1936

1912-1941

1895-1928

1900-1928

1929-47

1941

1909-25

1925-44

1930-35

1922-47

1936-42

1923-34

1931-46

1895-1928

1941-42

1949-53

1930-48

1964

1927-1935

1930-42

1920-59

1921-45

1931

1895- 1950

1932-47

1921-48

1967

Reserva

Reserva

Reserva

Reserva

Reserva

Reserva

1924-48

1914-47

1931-1941

1932-1932

1934-55

1934-1941

1957

1915-45

1903-1947

1939-44

1900-38

1907-25

1895-1919

1921-50

1949-50

1943

1906-1929

1922-52

1910-25

1922-56

1928-1935

1906-1919

1932-34

1919-1931

1900-1956 
3309 Clara

321 Clara

616 Clara

1331 Clara

6866 Clara

2589 Clara

3788 Clara

2790 Clara

2829 Clara

2379 Clara

5914 Clara

1328 Clara

4891 Clara

4890 Clara

5588 Clara

4925 Clara

117 Clara

31 Clara

4983 Clara

1105 Clara

2606 Clara

4176 Clara

3249 Clara

3242 Clara

2768 Clara

5613 Clara

397 Clara

5579 Clara

5090 Clara

4834 Clara

44 Clara

5612 Clara

4317 Clara

3301 Clara

4320 Clara

529 Clara

3371 Clara

4975 Clara

4853 Clara

5620 Clara

5814 Clara

5855 Clara

4861 Clara

4497 Clara

3398 Clara

2784 Clara

132 Clara

144 Clara

4917 Clara

2638 Clara

2071 Clara

2064 Clara

2329 Clara

3401 Clara

4312 Clara

5057 Clara

389 Clara

1292 Clara

126 Clara

4311 Clara

4316 Clara

4492 Clara

4485 Clara

4510 Clara

4919 Clara
Padlog Jacobo, contrato, nota $\quad$ 1950-55

Padlog Jacobo, contrato, plano 1927-46

Padlog Jose, contrato, plano, cartas $\quad 1920-47$

Padlog Julio, contrato, plano, cartas 1948-58

Padlog Marcos, Moises y Ramon, contrato, plano, notas (grupo

Baron Guinzburg)
Padlog Moises, contrato, plano, cartas

Padlog Naum, contrato 1950-52

Padlog Ramon, contrato, plano

Paicovsky Juan, contrato

Paikovsky Juan, contrato de pastoreo

Paley Isaac y Moises, judicial

Paley Paulina Karpman de, contrato, plano

Pastor Fernandez, contrato

1946

1949

$1945-48$

1941

1928-48

1929-1930

$1932-1937$

Pattin David Sucesion, contrato, plano, notas

Pave Antonia E. de, contrato 1933-1936

Pave Benjamin, contrato, plano

Pave Benjamin, contratos, plano

Pave Gregorio, contrato

Pave Gregorio, contrato, plano, cartas

Pave Gregorio, contrato, plano, cartas

Pave Jacobo, contrato, plano, notas

Pave Juan, contrato de arriendo, plano, notas

Pave Marcos, contrato de arriendo, plano, notas

Pecar Angel, contrato, plano

Peisajovich Isaac, contrato, plano, notas

Peisajovich Israel, contrato, plano

Peisajovich Israel, contrato, plano, notas

Peisajovich Jaime, contrato, plano, notas

Peisajovich Janon, contrato, plano, notas

Peisajovich Moises, contrato, planos

Peisajovich Salomon, contrato, plano, notas

Peralta Miguel, contrato de arriendo

Perelman Marcos y Naftule, contrato, plano, cartas

Perelstein Arturo, contrato de arriendo

Perelstein Gregorio, contrato, plano, carta

Perelstein Gregorio, contrato, plano, notas

Perez Antonio y Hernandez Pedro contrato

Perman Moises, contrato, notas

Perper Abraham, contrato, plano, notas

Perper Cuna Suc., Testimonio de Sucesion

1946-47

$1949-59$

1934-1940

$1916-53$

$1921-56$

$1915-46$

$1909-22$

1895-1924

1931

1895-1921

$1909-48$

1904-1919

1900-1928

1909-1922

1924-47

1909-1921

$1945-48$

$1915-49$

1941

1911-55

1906-29

1932-1937

1909-1925

1895-1921

1919-1921

1928-1935

Readquisición

Pinus Jose, contrato, plano, notas

Pipkin Jose y Elias, contrato, plano, cartas

Pipkin Jose, contrato, plano, cartas

1908-1928

1926-1939

1900-25

$1944-45$

1900-25

$1909-25$

Podlog Ramon, contrato, plano

1909-25

1947-48

1911-48

$1922-46$

1940-46

1915-25

1945

1964

1925-57

1895-1948

$1941-47$

1924-52

1944-50

1894-1946

1900-1939

1900-48

1934-1935

Quiroga Juan, contrato de arriendo

Rabey Moises, contrato, plano, cartas

Rabinovich Fridel, contrato, plano, cartas

Rabinovich Gregorio, contrato
Reserva

Reserva

Reserva

Reserva 
5065 Clara 4509 Clara 2137 Clara 4507 Clara 1683 Clara 4922 Clara 4874 Clara 4374 Clara 2316 Clara 4914 Clara 4915 Clara 2305 Clara

2307 Clara 4911 Clara 2598 Clara 2730 Clara 5087 Clara 3282 Clara 4889 Clara 4480 Clara 2130 Clara 3270 Clara 3146 Clara 719 Clara 3805 Clara 3758 Clara 6864 Clara 3741 Clara 2793 Clara 4482 Clara 1086 Clara 1297 Clara 5063 Clara 394 Clara

4177 Clara 3298 Clara 3297 Clara 3794 Clara 6319 Clara 2154 Clara 2526 Clara 6846 Clara 2522 Clara 4006 Clara 2732 Clara 2101 Clara 4935 Clara 2090 Clara 4906 Clara 1089 Clara 4721 Clara 6865 Clara

4977 Clara 141 Clara 5586 Clara 6858 Clara 6082 Clara 2632 Clara 6863 Clara 4007 Clara 4924 Clara 5585 Clara 483 Clara 6348 Clara 4900 Clara
Rabinovich Jacobo, contrato, plano, notas

$1910-1931$

Rabinovich Jaime, contrato, plano, notas

Rabinovich Maltze Vda. De, contratos de arriendo

Rabinovich Ruben, contrato, plano, notas

Radunsky Etel Vda. De e hijo Estevan, contrato, plano, cartas

Ragatky Samuel, contrato

Raifaizen Isaac, contrato de arriendo

Raim Constancio, Cuidador ad Honorem, convenio

Raiser Salomon, contrato (Dominguez)

Raitzin Bernardo, contrato, nota

Rapaport Abraham, contrato, plano, notas

Rasquin Julio y Brailovsky Isabelino, contrato, notas, transfe-rido

Rechtman Sujer, contratos de arriendo

Registro Civil de La Capilla, contrato

Regner Luis, contrato, plano

Rejtman Juan, contrato, plano, cartas

Rejtman Julio y Naftuli, contrato, plano, notas

Rejtman Leon, contrato, plano, cartas

Rejtman Moises, contrato

Rejtman Samuel, contrato, plano, notas

Resnicoff Abraham, contrato de arriendo anulado

Resnicoff Gregorio, contrato, plano, notas

Resnicoff Isaac, contrato de arriendo

Resnitzky Abraham, contrato, plano

Retamar Anastasio, contrato, plano

Rios Isauro, contrato (Dominguez)

Ripetur Moises, contrato, plano, nota (grupo Fainberg)

Rodriguez Juan Julio, contrato, plano

Rogarky Samuel, contrato, plano

Rogatky Elias, contrato, plano, cartas

Roiter Jaime, contrato, plano, cartas

Roiter Mauricio, contrato, plano, cartas

Roitman Adolfo, contrato, plano, notas

Roitman Andres, contrato, plano

Roitman Gregorio, contrato, plano, cartas

Roitman Jacobo, contrato, plano, notas

Roitman Saul y Jacobo, contrato, plano, cartas

Rojas German Isaias, contrato

Rojkis Santiago, contrato arriendo de lote

Romestvensky Abraham, contrato de arriendo y desalojo

Rosemberg Jaime, contrato, plano cartas

Rosenberg Elias, escritura, plano, notas (grupo Domingo Calvo)

Rosenberg Sundel, contrato, notas

Rosenfeld Julio y Marcos, contrato, plano, notas

Rosenfeld Marcos, contrato, plano, cartas

Rosenfeld Nisen, notas, desalojo

Rosenfeld Nusan, contrato

Rosenfeld Oiser, contrato, plano

Rosenthal Israel, contrato

Rosenthal Walter, contrato, plano, cartas

Rosetti Mariano, contrato

Rozenfeld Pedro y Suc. Sara Yurge, contrato, plano, notas (grupo Leven No. 1)

Rubin Juan, contrato

Rubinstein Abraham, contrato, plano

Rubinstein Marcos, contrato, plano, notas

Rueter Salomon, contrato, plano, nota (grupo Domingo Calvo)

Sacson Moises, contrato, notas, testimonio

Sadigursky Jaime, contrato, plano, cartas

Sajanovich Simon, contrato

Sajaroff Jaime, contrato, plano, cartas

Sajaroff Miguel, contrato

Sajaroff Miguel, contrato, plano, notas

Saks David, contrato, plano, carta

Salas Ireneo, contrato de arriendo y pastoreo

Salas Irineo, contrato de arriendo
$1927-48$

1919-39

$1900-45$

1895-1920

1934-1943

1931-1932

1935

1938-47

1925-1935

1926-1936

1926-43

$1925-43$

1919-1926

1955

$1948-53$

1904-1928

1926-39

1930-1938

1908-1952

1932

1908-1929

$1940-45$

$1947-60$

1939-46

1939-47

1909-43

1948

1930-46

1895-1937

1924-52

1912-58

1904-1928

1924-59

1904-47

1923-46

1929-48

1939-41

1929-1930

1935

1915-55

1921-30

1921-23

1900-47

1948

1935-44

1930-48

1923-1932

1915-55

1930

1900-42

1928-1941

1913-29

1901-1918

1905-31

1935-1942

1947-48

1931

1924-54

1932-1937

1901-1919

1912-48

1927-1932

1928-1931
1931-1935
Reserva

Reserva

Reserva

Reserva 
2158 Clara

2796 Clara

4972 Clara

4937 Clara

2371 Clara

3400 Clara

2607 Clara

2298 Clara

3782 Clara

2266 Clara

3756 Clara

22 Clara

1029 Clara

4016 Clara

2120 Clara

4323 Clara

4929 Clara

133 Clara

4005 Clara

2440 Clara

2141 Clara

2268 Clara

4986 Clara

2308 Clara

2297 Clara

3306 Clara

1123 Clara

1112 Clara

23 Clara

404 Clara

2884 Clara

4895 Clara

2661 Clara

5611 Clara

4905 Clara

4852 Clara

3267 Clara

124 Clara

2378 Clara

21 Clara

5839 Clara

2142 Clara

4488 Clara

5808 Clara

2380 Clara

3495 Clara

2635 Clara

2397 Clara

337 Clara

5061 Clara

4984 Clara

5871 Clara

2290 Clara

2428 Clara

3257 Clara

1327 Clara

3703 Clara

2807 Clara

2111 Clara

2091 Clara

118 Clara

6886 Clara

143 Clara

526 Clara

3380 Clara
Salcovsky Dora Bohacof de, contrato de arriendo

Salcovsky Dora V. de, contrato

Saler Isaac, contrato

Saler Juan, contrato

Salkin Jaime, contrato de pastoreo

Salkind Samuel, contrato, plano, cartas

Salmanovich Jose, contrato, plano, cartas

Salmons Otto, contrato, notas, abandono

Salter Adolfo, contrato

Saltzman Berta K. de, contrato anulado

Salzman Berta Kunin de, contrato (Dominguez)

Salzman, contratos, plano

Samoiloff Isaac y Sofia T. de, contrato, plano, cartas

Sandberg Maximo y Jacobo, contrato, plano, cartas

Sandel Israel, contrato de arriendo, desalojo

Santa Cruz Servando, Pires Eusebio, contrato de arriendo

Sapollnik Daniel, contrato

Saroka Moises, contrato, planos

Saroka Simon Suc., contrato, plano, cartas

Sas Gregorio y Fink Salomon, contrato, plano

Sas Isaac M., contrato de arriendo anulado

Sas Isaac Miguel, contrato de pastoreo anulado

Sas Isaac, contrato

Saslavsky Moises, contrato, notas desalojo

Savitky Clara Fridman de e hijo Jaime, contrato, abandono.

Savitzky clara Natenson de, contrato, plano, notas

Savitzky Lazaro, contrato, plano, cartas

Savitzky Moises, contrato, plano, cartas

Savulsky Chaim y Jasmino y Jacobo, correspondencia, contrato, plano

Scaeps Naum, contrato, plano

Schalamuk Isaac, contrato, plano, cartas

Schaposnik Daniel, contrato

Schatzky Aizik Sucesión, contrato plano, cartas

Schatzky Suc. de Iser, contrato, plano, notas

Schayevich Chaskel, contrato

Scheinberg Ramon y Ana, contrato, plano, notas

Schejter Jose y Bernardo; contrato, plano, notas

Schejtman David, contrato, plano

Schejtman Jaime, contrato de pastoreo

Schejtman Jaime, contrato, plano

Schejtman Luis, Escritura, Readquisición de la JCA

Schejtman Mauricio, contrato de arriendo anulado

Schejtman Naum y Luis, contrato, plano, cartas

Schejtman Naum, contrato

Schejtman Naum, contrato de pastoreo

Schejtman Naum, nota

Schejtman Sofia R. de, contrato, plano, cartas

Scheps Guillermoo, contrato de pastoreo

Scheps Isaac, contrato, plano, carta

Scheps Luis y Meyer y Naum, contrato, plano, notas

Scheps Luis, contrato

Scheps Luis, contrato, notas, Readquisición

Scheps Meier, contrato de pastoreo anulado

Scheps Meyer, contrato, plano

Schinder David, contrato, plano, notas

Schinder Gregorio y Naum, contrato, plano, cartas

Schinder Miguel, contrato

Schinder Miguel, contrato, plano

Schlosman Leon, notas, contrato

Schmaisman Juan, Boleto de Compra, plano

Schmaisman Juan, contrato, plano

Schmilchuk Adolfo, Merseman Gerónimo, contrato, plano

Schmoisman Abraham, contrato, plano

Schmoisman Bernardo y Samuel, contrato, plano, cartas

Schmoisman Esther R. de, contrato, plano, notas
1941

1936-42

1938

1942-43

1936-49

1909-57

1894-1931

$1928-41$

1919-38

1932

1908-25

1915-47

1941

1937

1938-39

1934-1938

1915-37

1916-42

1932-55

1911-50

1932-46

1935-55

1956-61

1925-53

1925-1940

1919-38

1895-1920

1923-1933

1908-1925

1901-25

1937-47

1944

1923-49

1945

1928

1895-1948

1950-

D27321959

1944

1972

1946-48

1946

1908-46

1910-1959

1938-1944

1942

1938

1942

1909-24

1912-48

1945-46

1947-51

1895-1939

1948

1921-47

1900-30

1909-25

1919-26

1900-29
Reserva

Reserva

Reserva

Reserva

Reserva

Reserva 
2917 Clara 2327 Clara

1078 Clara

2317 Clara

2128 Clara

5072 Clara

5878 Clara

2061 Clara

5583 Clara

5091 Clara

2460 Clara

557 Clara

3388 Clara

129 Clara

2293 Clara

4907 Clara

1912 Clara

2676 Clara

2376 Clara

4505 Clara

3798 Clara

2114 Clara

6870 Clara

4832 Clara

2134 Clara

4930 Clara

3264 Clara

2364 Clara

2912 Clara

2731 Clara

5607 Clara

2844 Clara

5629 Clara

2525 Clara

1081 Clara

6869 Clara

6843 Clara

3700 Clara

2159 Clara

6841 Clara

3274 Clara

5603 Clara

4985 Clara

6842 Clara

3296 Clara

5616 Clara

2285 Clara

2672 Clara

6834 Clara

2106 Clara

6855 Clara

28 Clara

4508 Clara

3137 Clara

3364 Clara

3131 Clara

3696 Clara

4980 Clara

2361 Clara

2826 Clara

2929 Clara

4926 Clara

2104 Clara

4987 Clara

4904 Clara

1087 Clara

6083 Clara
Schmoisman Samuel, contrato

Schmoisman Samuel, contrato de pastoreo

Schmukler Adolfo, contrato, plano, cartas.

Schmukler David, contrato

Schmukler Jacobo, contrato de arriendo anulado

Schmukler Luis y Ersch, contrato, plano, notas

Schmukler Luis, contrato

Schmunis Juan Leon y Simje, contrato, plano, cartas

Schmunis Moses, contrato, plano, notas

Schnitman Boris, contrato, plano, cartas

Schnitman Cesar y Bernardo, contrato, plano, cartas

Schnitman Cesar, contrato, plano

Schnitman Cesar, contrato, plano, notas

Schnitman Salomon, contrato, plano

Schnitman Yuda, contrato anulado

Schoijet Gregorio, contrato

Schoj Gregorio, contrato, plano, cartas

Schojet Jose, contrato, plano, cartas

Schulman Isaac, contrato

Schulman Jose, contrato, plano, cartas

Schulman Simon, contrato

Schulman Simon, contrato simple anulado

Schvartz Julio y Samuel, contrato, plano, notas (grupo Fainberg)

Schvartzman Jaime, contrato, plano, notas

Schvartzman Martin, contrato de locación anulado

Segal Boris, contrato

Segal Gregorio; contrato, plano, notas

Segal Gregorio, contrato de pastoreo

Segal Jose, contrato, plano

Segal Jose, contrato, plano, cartas

Segal Samuel, contrato, plano, notas

Seigierman Manuel, contrato

Seiguerman Berl, contrato, plano, notas

Seiguerman Jacobo, contrato, plano, cartas

Seiguerman Manuel, contrato, plano, cartas

Selser Alejandro, contrato, plano, notas (grupo Balvanera)

Selser ljil y Alejandro, escritura, plano, notas

Seltzer Jacobo, contrato

Selzer Alejandro, contrato de pastoreo anulado

Serebrenik Adolfo, escritura, plano, notas (grupo Sonenfeld)

Serebrenik David, contrato, plano, cartas

Serebrenik Israel, contrato, plano, notas

Serebrenik Salomon, contrato

Serebrenik Salomon, escritura, plano, notas (grupo Sonenfeld)

Serebrinsky Jaime, contrato, plano, notas

Serguey Leon, contrato, plano, notas

Sibulovsky Abraham, contrato de pastoreo

Sidi Rosa Leff de, plano, notas

Sigal Leon, escritura, plano, notas

Sigutkin David, notas, transferencia

Sijanovich Jacobo, contrato (grupo Belez)

Silberman David (Suc.), planos, contrato

Silberstein Marcos, contrato, plano, cartas

Sinagoga Bet David, contrato de arriendo

Sinagoga Bet Jacob, contrato, plano

Sinagoga Bet Jacov, contrato de arriendo

Sindicato de Oficios Varios, contrato

Sirota Jacobo, contrato

Siseles Moises, contrato

Siselis Moises, contrato, plano

Siselis Moses, contrato, plano

Siser David, contrato

Siser Moises, notas, desalojo

Sitlionik Jose, contrato, notas

Sivack Colmen, contrato

Slavkin David, Manuel y Bernardo, contrato, plano, cartas

Slavkin Naum, contrato, testimonio, notas
1940

Reserva

1939

1915-59

1938

1931-36

1900-1932

1944

1915-48

1903-1919

1906-1928

1940-47

1942-46

1924-26

1909-25

1937

1925-1936

1910-31

1928-37

1943-45

1895-1931

1938-46

1919-26

1910-51

1909-1925

1937

1932

1895-1925

1942-46

$1939-40$

1948

1909-1920

1952

1903-1956

1926-52

1927-62

1919-43

1901-39

1938-42

1936

1927-30

1901-23

1900-1920

1934

1922-30

1912-50

1895-1921

1939

1922-36

1906-31

1936-38

1928

1924-49

1897-1933

1919-50

1948

1919-48

1945

1936-1943

1944

1947

1930-36

1934-1935

1938-47

1900-1941

1919-1931

1910-57

1936-1949
Reserva

Reserva

Reserva

Reserva 
2099 Clara

4866 Clara

488 Clara

5092 Clara

2334 Clara

1907 Clara

6084 Clara

1084 Clara

4917 Clara

392 Clara

3806 Clara

1322 Clara

4885 Clara

3246 Clara

6868 Clara

2112 Clara

2398 Clara

393 Clara

2274 Clara

2138 Clara

314 Clara

3407 Clara

759 Clara

3295 Clara

2164 Clara

2725 Clara

2072 Clara

6878 Clara

2343 Clara

524 Clara

1011 Clara

765 Clara

2357 Clara

3258 Clara

4319 Clara

2157 Clara

6837 Clara

4010 Clara

755 Clara

2455 Clara

1906 Clara

4691 Clara

1325 Clara

2524 Clara

5825 Clara

2113 Clara

2270 Clara

3365 Clara

3132 Clara

2096 Clara

2733 Clara

3103 Clara

2396 Clara

486 Clara

2827 Clara

4849 Clara

6857 Clara

5085 Clara

323 Clara

2605 Clara

6876 Clara

4884 Clara

2734 Clara

2679 Clara

2068 Clara
Slotnik Marcos, contrato, plano

Slutzky Isaac y Ana V., contrato, plano, notas

Smolinsky Alejandro, contrato, plano, carta

Snitman luda, contrato, plano, notas

Sociedad de Damas de Villa Dominguez, contrato de arriendo

Socolovsky Miguel, contrato, plano, cartas

Socolovsky Smerel Suc., contrato, notas, testimonio

Soirefman Abraham y Pablo, contrato, plano, cartas

Soirefman Gregorio, contrato

Soirefman Jose, contrato, plano

Soirefman Naum, contrato

Soirefman Victoria de y Victor y Naum, contrato, plano

Sonenblum David, contrato

Sones Mozes, contrato de arriendo, plano, notas

Soroka Moises e hijo Israel, transferido por Jaimovich Israel,

contrato, plano, notas (grupo Guinzburg)

Sorokin Salomon, contrato simple anulado

Sperlin Benito, contrato de pastoreo

Sperling Bernardo, contrato, plano

Spierer Samuel J., contrato, notas, abandono

Sreider Meyer, contrato de arriendo anulado

Stavsky Boruj, contrato, plano

Steimberg Simon e Hirsch, contrato, plano, cartas

Stein Luisa M. de, contrato, plano, correspondencia

Stein Manuel y Luis Maria, contrato, plano, cartas

Stein Manuel, contrato de pastoreo

Stein Simon y Benjamin, contrato plano, cartas

Sterin Isaac y Sterin Moises, contrato, plano, cartas

Sterin Jaime, contrato, plano, notas (Grupo Espinillos)

Sterin Moises, contrato

Sterin Moises, contrato, plano

Sterin Nicolas y Carlos, contrato, plano

Strajman Israel, contrato, plano

Stubrin Isaac y Efron, contrato de pastoreo

Stubrin Isaac y Jaime, contrato, plano, notas

Stubrin Isaac, contrato de arriendo

Stubrin Savelino, contrato de arriendo anulado

Stubrin Simon y Savelino, escritura, plano, notas (Grupo Guinzburg)

Subovsky Abraham y Rebeca, contrato, plano, notas

Subovsky Marcos, contrato, plano

Sucovsky Isaac, contrato, plano, cartas

Sucovsky Wulf, plano, cartas

Suñer Alberto P., contrato

Susevich Jacobo y Salomon, contrato, plano, cartas

Susevich Marcos, contrato, plano, cartas

Susman Naum, Seldes Nicolás, Escritura, notas

Susterman Zelman, nota, arriendo anulado

Sutin Mauricio, contrato, abandono

Talmud Tora «Baron Hirsch», contrato

Talmud Tora «Baron Hirsch», contrato de arriendo

Taran Jacobo, contrato, plano, cartas

Tauber Isaac Levi, contrato, plano, cartas

Tauber Isaac Levy, contrato

Tauber Levi Isaac y Malek Pedro y Nitzberg Fermin, contrato de pastoreo

Tebiles Isaac, contrato, plano, carta

Teplitzky Abraham, contrato, plano

Teplitzky Bernardo, contrato, plano, notas

Teveles Guedalie, contrato, plano, nota (grupo Leven)

Teveles Zelig, contrato, plano, notas

Tevelez Gregorio, contrato, plano

Tevelez Gregorio, contrato, plano, cartas

Tevelz Bernardo, contrato, plano, notas (grupo Belez)

Thou Simon, contrato

Ticach Abraham, contrato, plano, cartas

Ticach Benjamin, contrato, notas

Ticach Bernardi, contrato, plano, cartas
1930-49

1908-1930

1922-52

1923-1928

1939-42

1905-31

1909-1930

$1912-57$

1935

1940-59

1949-50

1909-53

1931

1901-22

1899-1940

1924-26

1946

1912-49

1939-48

1921-36

1924-51

1894-1927

1937-50

1945-52

1936

1928-50

1928-56

1904-40

1940-41

1928-44

1965

$1912-59$

1941-42

1900-25

1941-1942

1936

$1900-1924$

1912-47

1932-52

1938-50

1918-31

1933

1915-53

1943-53

1919-1938

1941

1940

1948

1923-48

1912-48

1924-57

1946

1946-47

1942-48

1949

1909-1925

1902-30

1905-1928

1934-49

1911-57

1925-30

1934-1939

1948-51

1920-38

1946
Reserva

Reserva 
2424 Clara

5599 Clara

2677 Clara

4981 Clara

2383 Clara

3138 Clara

2146 Clara

5875 Clara

2328 Clara

3544 Clara

3691 Clara

6835 Clara

398 Clara

3793 Clara

3269 Clara

5590 Clara

38 Clara

3760 Clara

2587 Clara

2267 Clara

5069 Clara

559 Clara

2451 Clara

4292 Clara

4694 Clara

3759 Clara

3740 Clara

2119 Clara

3698 Clara

6005 Clara

3783 Clara

5862 Clara

139 Clara

2358 Clara

3262 Clara

3382 Clara

1692 Clara

3375 Clara

5869 Clara

3374 Clara

2139 Clara

4857 Clara

2054 Clara

6845 Clara

6883 Clara

4913 Clara

3377 Clara

4175 Clara

4726 Clara

2121 Clara

119 Clara

2273 Clara

3278 Clara

3245 Clara

130 Clara

2386 Clara

531 Clara

5622 Clara

2394 Clara

2584 Clara

2585 Clara

6859 Clara

2340 Clara

1329 Clara

2373 Clara
Tiefenberg David, contrato, plano

Tieffemberg Benito y Menache, contrato, plano, notas

Toer Salomon, contrato, plano, cartas

Toer Samuel, contrato

Toer Samuel, contrato de pastoreo

Toff Marcos, contrato de arriendo

Tohv Simon, cancelacion

Tolcachier Samuel y Cecilia, contrato

Tolchinsky Efroim, contrato de arriendo anulado

Tolchinsky Efroim, nota

Torres Julia, contrato

Transferido a Kamir Lazar, Tevelez Zelig y Braslavsky Bernardo,

escritura, plano, notas (Grupo Belez)

Trupkin Carlos, contrato, plano, carta

Trussi Angel, contrato

Uchitel Israel, contrato, plano, notas

Uchitel Jose, contrato, plano, notas

Uner Mauricio, contrato, plano

Union Juvenil Democratica y Libertad, contrato (Dominguez)

Vainer Abraham, contrato, plano, cartas

Vainstein Moises, contrato, abandono

Vaisman Abraham y Aaron, contrato, plano, notas

Vaisman S. e hijo Pincus, contrato, plano, cartas

Vaisman Simon, contrato, plano

Vallaco C. Barbero P., De Gorgis, y Groso Jose, contrato, plano

Velazquez Abraham, contrato

Velazquez Pedro, contrato (Dominguez)

Vernaz Josefa V. de, contrato

Videloff Sergio, arriendo anulado

Villagra Florentino, contrato

Villagra Ramon, transferido por Kleinman Gregorio, contrato, notas

Villalba Encarnacion, contrato

Visnevetzky Aron, contrato, nota

Voloshin, contrato, plano

Volosin Silvestre, contrato de arriendo, notas

Voscoboinik Jose: contrato, plano, notas

Wainer Jose, contrato, plano, cartas

Wainer Leon, contrato, plano, cartas

Wainer Leon, contrato, plano, cartas

Wainer Moises, contrato

Wainer Pedro, contrato, plano, cartas

Waintrub Samuel, contrato de arriendo

Waisenstein Moises, contrato, plano, notas

Waisman Benjamin, contrato, plano

Weiner Samuel, contrato, plano, notas (grupo Las Moscas

Wendichansky Leon y Jacobo, contrato, plano, notas (grupo Baron Hirsch)

Windels Martin, contrato

Wolcomich Jorge, contrato, plano, cartas

Wortman Salomon y Rafael, contrato, plano, cartas

Wouterlood Martin, contrato

Wulf Meiles, contrato de arriendo

Yankelevich Francisco, contrato, plano

Yankelevich Jose, contrato, abandono

Yankilevich Aron, contrato, plano, cartas

Yarcho Isaac, contrato de arriendo, plano, cartas

Yogel Meer, contrato, plano

Yoguel Mauricio, contrato

Yoguel Mauricio, contrato, plano, carta

Yujnovsky Aron, contrato, plano, notas

Yungerman Santiago, contrato de pastoreo, notas

Yunguerman Adolfo, contrato, plano, cartas

Yunguerman Salomon, contrato, plano, cartas

Yurgel Abraham, contrato, plano, nota (grupo Sonenfeld)

Yurguel Gregorio, contrato, notas

Yusefoff Israel, contrato, plano, cartas

Yusem Hersch, contratos, notas, arriendos
1921

1894-1920

1900-37

1936

1944

$1937-48$

1944

1943

$1939-41$

1972

$1948-49$

Reserva

$1894-1930$

1948-49

1951-53

1895-1925

1905-1919

1930-52

1940-42

1909-60

1940

1895-1927

1895-1926

1913-58

1929-48

1931

1940-45

1949

1929-40

1938-50

1919-1947

1923-50

1929-1936

1909-25

1930-47

1904-25

1922-29

1905-19

1894-1929

1937

1904-52

1924-34

1923-1925

1930-37

1900-1930

1906-30

1922-1939

1895-1929

1910-46

1931

1936-39

1940-47

19936-48

1900-40

1895-1923

1911-25

1945

1911-44

1906-1922

1945-47

1922-53

1942-51

1895-1931

1940-42

1940-57

1912-43 
2393 Clara

2399 Clara

121 Clara

3692 Clara

4912 Clara

2448 Clara

3757 Clara

3701 Clara

4295 Clara

3790 Clara

1074 Clara

3304 Clara

6884 Clara

2335 Clara

528 Clara

4506 Clara

2926 Clara

5574 Clara

2727 Clara

2726 Clara

6872 Clara

2591 Clara

3256 Clara

5594 Clara

2092 Clara

2097 Clara

4858 Clara

2351 Clara

2814 Clara

2458 Clara

1085 Clara

2925 Clara

1360 Clara Vieja

1370 Clara Vieja

1258 Clara Vieja

1432 Clara Vieja

1402 Clara Vieja

1439 Clara Vieja

1440 Clara Vieja

1250 Clara Vieja

1442 Clara Vieja

555 Clara Vieja

1445 Clara Vieja

1390 Clara Vieja

1254 Clara Vieja

1681 Clara Vieja

1252 Clara Vieja

1406 Clara Vieja

1257 Clara Vieja

1239 Clara Vieja

1452 Clara Vieja

1247 Clara Vieja

1396 Clara Vieja

1457 Clara Vieja

1384 Clara Vieja

1446 Clara Vieja

1433 Clara Vieja

1680 Clara Vieja

1361 Clara Vieja

1399 Clara Vieja

1395 Clara Vieja

1444 Clara Vieja

1411 Clara Vieja

1378 Clara Vieja

1363 Clara Vieja
Yusem Israel, contrato de arriendo

$1937-40$

Yusim Mauricio, contrato

Yussem Mauricio, contrato, plano

1946

1936-47

1925-49

Zalkwar Hersch, contrato, notas

Zalsman Pincos, plano

Zapata Alfonso C., contrato (Dominguez)

1927-1934

1924 ?

$1945-48$

$1949-54$

1928-49

1945-50

$1936-51$

$1912-50$

Zapiach Mauricio, contrato, plano, cartas

Reserva

Zaslavsky Leon y Abraham, contrato, plano, cartas

Zeigner Isaac transfiere a Pekerman Abraham y Juchak Moises, contrato, plano, notas (grupo Carmel)

Zeigner Israel, contrato

Zeigner Kopel, contrato, plano, carta

Zeigner Osias y Moses, contrato, plano, notas

Zeigner Osias, contrato, plano

Zepeñuk Abraham, contrato, plano, notas

Zibelman Bernardo, contrato, plano, cartas

Zibelman Samuel, Simon, Jose, Santiago y Abraham, contrato,

plano, cartas

Zinovoy Abraham, contrato, plano, notas (grupo Las Talas) 1919-44

Zipilivan Alejandro, contrato, plano, cartas $\quad$ 1924-46

Zipilivan David, contrato, plano, notas $\quad 1921-24$

Zipilivan David, contrato, plano, notas

Ziplivan Berta F. de y Marcos, contrato, plano, cartas 1940-61

Zirulsky Rafael Suc., contrato, plano

Zlochevsky Miguel, contrato, plano, notas

Zlotnitzky Adolfo, contrato de arriendo

Zlotnitzky Adolfo, contrato, plano

Zlotnitzky Blume A. de, y Marcos contrato, plano, cartas

Zlotnitzky Samuel, contrato, plano, cartas

Zlotnitzky Samuel, contrato, plano, cartas

Aizicovich Efroim y Sebastian, contrato, plano

Bermant Rebeca, contrato, plano, cartas

Bezchinsky Jacobo, contrato, plano, cartas

Blinder Benjamin, contrato, plano, cartas

Boverman Salomon, contrato, plano, cartas

Brodsky Aron y Adela, contrato, plano, cartas

Buhacoff Berta Vda. De y Manuel, contrato, plano, cartas

Buks Rubin y Samuel, contrato, plano, cartas

1894-1930

1940-41

$1912-48$

1900-31

1930-39

1904-1918

$1912-58$

$1932-58$

$1900-1920$

1911-61

1908-1925

1941-42

1947

$1927-49$

1943-49

1934-60

1895-1931

1909-29

1905-29

1895-1938

1900-30

1923-38

$1895-1958$

1900-48

1917-39

1932-46

1923-49

1899-1941

1911-29

1925-1930

1895-1936

1895-1929

1900-29

1921-30

1895-1948

1921-29

1917-28

1922-42

1920

1895-1938

1895-1938

$1895-1930$

1895-1952

1924-49

1904-29

1901-40

1925-49

1921-28

1895-1931

Reserva

Reserva

Reserva

Gueller Isaac y otros, contrato, plano, cartas

Guilichensky Aron, contrato, plano, cartas

Gurny Aron, contrato, plano

Gurny Samuel, contrato, plano, cartas 
1435 Clara Vieja 1438 Clara Vieja 1246 Clara Vieja 1316 Clara Vieja 522 Clara Vieja 1679 Clara Vieja 1400 Clara Vieja 562 Clara Vieja 1447 Clara Vieja 1408 Clara Vieja 1453 Clara Vieja 1676 Clara Vieja 1248 Clara Vieja 1405 Clara Vieja 1243 Clara Vieja 1407 Clara Vieja 1410 Clara Vieja 1253 Clara Vieja 1242 Clara Vieja 1245 Clara Vieja 1441 Clara Vieja 1241 Clara Vieja 1675 Clara Vieja 1409 Clara Vieja 1240 Clara Vieja 1365 Clara Vieja 1404 Clara Vieja 1443 Clara Vieja 1677 Clara Vieja 1450 Clara Vieja 1397 Clara Vieja 1238 Clara Vieja 1458 Clara Vieja 1249 Clara Vieja 1437 Clara Vieja 1448 Clara Vieja 1244 Clara Vieja 1255 Clara Vieja 1315 Clara Vieja 1259 Clara Vieja 1662 Clara Vieja 1684 Clara Vieja 1449 Clara Vieja 1665 Clara Vieja 1398 Clara Vieja 1403 Clara Vieja 1434 Clara Vieja 1314 Clara Vieja 1436 Clara Vieja 1678 Clara Vieja 1431 Clara Vieja 1664 Clara Vieja 1401 Clara Vieja 1251 Clara Vieja 1256 Clara Vieja 3638 Cohen Oungre 429 Cohen Oungre 3624 Cohen Oungre 3551 Cohen Oungre 423 Cohen Oungre 2028 Cohen Oungre 3233 Cohen Oungre 507 Cohen Oungre 3623 Cohen Oungre 3648 Cohen Oungre 3607 Cohen Oungre 3647 Cohen Oungre
Haimovich Kiva, contrato, plano, cartas

$1924-40$

1905-31

Ideses Simon y Jones, contrato, plano, cartas

1895-1929

1944

Kaler Naum, contrato, plano, cartas

Kaler Salomon, contrato, plano

Kasvin Gregorio, contrato, plano, cartas

Kobrinsky Elias, contrato, plano, cartas

Korman Luis, contrato, plano, carta

Kreiman Benjamin, contrato, plano, cartas

Kreiman Leon y Moises, contrato, plano, cartas

Kreimer Jacobo, contrato, plano

Kuschnaroff Julio y Santiago, contrato, plano, cartas

Lejtman Moises, plano, cartas

Levitzky Moises y Leon, contrato, plano, cartas

Lieberman Marcos, contrato, plano, cartas

Lifschitz Jose, Samuel y Efraim, contrato, plano, cartas

Lipcovich Marcos, contrato, plano, cartas

Litvin Abraham, contrato, plano, cartas

Litvin Moises, contrato, plano, cartas

Litvinoff Bernardo, plano, cartas

Lulkin Salomon, contrato, cartas

Mas David, contrato, plano, cartas

Mass Natalio, contrato, plano, cartas

Muchnik Marcos, contrato, plano, cartas

Najemson Bernardo y Najemson Dora R., contrato, plano, cartas

Najemson Clara L. Mier y Leon, contrato, plano, cartas

Najemson Meyer, contrato, plano, cartas

Padlog Naum y Abraham, contrato, plano, cartas

Pave Juan y Gregorio, contrato, plano, cartas

Pave Salomon, contrato, plano, cartas

Pecar Angel, contrato, plano, cartas

Pustilnik Marcos, contrato, plano, cartas

Rabinovich Rajmil y Jaime, contrato, plano

Rejtman Jose, plano, cartas

Rosemberg Elias, Jaime e Isaac, contrato, plano, cartas

Sajanovich Simon, contrato, plano, cartas

Salkind Leon, contrato, plano, cartas

Sas Isaac Miguel, plano, cartas

Schalamuk Santiago, contrato, plano, cartas

Schatzky Jacobo, cartas, plano

Scheps Meyer, contrato, plano, cartas

Schmukler Luis, contrato, plano, cartas

Schmukler Marcos, contrato, cartas

Seiguerman Salomon, contrato, plano, cartas

Sijanovich Jacobo, contrato, plano, cartas

Siselis Moises, contrato, plano, cartas

Soirifman Abraham, contrato, plano

Soroka Jose y Lazaro, contrato, plano, cartas

Stein Manuel, contrato, plano, cartas

Stern Isaac y Ana, contrato, plano, cartas

Stilman Teodoro, contrato, plano

Teveles Moises, contrato, plano, cartas

Toer Samuel, contrato, plano, cartas

Wortman Salomon y Pedro, contrato, plano, cartas

Zusevich Isaac Bernardo y Aron, contrato, plano, cartas

$1906-48$

1895- 1947

1922-29

$1926-55$

$1900-29$

$1922-47$

$1925-30$

1895-1930

1900-29

1911-59

1900-59

1894-1949

1928-50

1909-36

1895-1930

1919-29

1911-39

1925-30

1900-49

1922-50

1895-1930

1906-51

1904-29

1895-1965

1925-44

1895-1939

1911-28

1912-30

1894-1931

1922-29

1909-40

1894-1936

1901-29

1909-29

1911-51

1921-29

1946-50

1908-20

1901-38

1941-50

1924-51

1912-39

1895-1949

1926-47

1895-1946

1895-1938

1895-1947

1907-49

1924-30

1900-29

1900-29

1946

1937-57

1945-47

1940-47

1930-57

1965

1967-70

1950-59

1945-46

1941-44

1945-46

1941-43
Reserva

Reserva 
3644 Cohen Oungre 431 Cohen Oungre 3577 Cohen Oungre 3652 Cohen Oungre 3195 Cohen Oungre 1372 Cohen Oungre 456 Cohen Oungre 422 Cohen Oungre 238 Cohen Oungre 1385 Cohen Oungre 3622 Cohen Oungre 3606 Cohen Oungre 506 Cohen Oungre 5759 Cohen Oungre 3178 Cohen Oungre 1392 Cohen Oungre 445 Cohen Oungre 454 Cohen Oungre 3621 Cohen Oungre 3193 Cohen Oungre 2849 Cohen Oungre 237 Cohen Oungre 925 Cohen Oungre 430 Cohen Oungre 497 Cohen Oungre 1369 Cohen Oungre 3633 Cohen Oungre 235 Cohen Oungre 3653 Cohen Oungre 234 Cohen Oungre 424 Cohen Oungre 3636 Cohen Oungre 1969 Cohen Oungre 436 Cohen Oungre 233 Cohen Oungre 3192 Cohen Oungre

1389 Cohen Oungre 1019 Cohen Oungre 3549 Cohen Oungre 1005 Cohen Oungre 446 Cohen Oungre 1368 Cohen Oungre 3640 Cohen Oungre 3632 Cohen Oungre 3183 Cohen Oungre 3168 Cohen Oungre 3642 Cohen Oungre 426 Cohen Oungre 3587 Cohen Oungre 498 Cohen Oungre 1462 Cohen Oungre 3177 Cohen Oungre 3198 Cohen Oungre 449 Cohen Oungre 3593 Cohen Oungre 1367 Cohen Oungre 3580 Cohen Oungre 457 Cohen Oungre 3592 Cohen Oungre 1366 Cohen Oungre 3584 Cohen Oungre 453 Cohen Oungre 3599 Cohen Oungre 521 Cohen Oungre 3171 Cohen Oungre 3175 Cohen Oungre
Bazterrica Jose, contrato

Bercovich Oungre, contrato, plano

Berdichevsky David, contrato

Berdichevsky David, contrato

Berdichevsky David, contrato de pastoreo

Berditchevsky David, contrato, plano, cartas

Berkner Abraham, contrato, plano, carta

Berkner Marcos, contrato, plano

Berknier Aizik o Alejandro, contrato, plano

Berman Abraham e hijo Semaj, contrato, plano, cartas

Berman Abraham y Moises, contrato

Berman Bernhard, contrato

Berman Bernhard, contrato, plano

Berman Moises y Semaj, nota

Berman Moises, contrato de arriendo

Berman Moises, contrato, plano, cartas

Berman Semaj y Moises, contrato, plano

Berner Isidoro y Abraham, contrato, plano

Berner Isidoro y Penchansky Jonas, contrato, notas

Blank Elias, contrato de pastoreo

Blank Gregorio, contrato, plano, cartas

Blank Hersch Gregorio, contrato, plano

Blank Maria Venedik de y Hojman Miguel, contrato, plano, cartas

Blondheim Salomon, contrato, plano

Blumenthal Alfredo, contrato, carta, notas

Blumenthal Leopold, contrato, plano,cartas

Blumzak Israel, contrato

Blumzak Israel, contrato, plano

Bonn Erwin, contrato

Bonn Erwin, contrato, plano

Brenner Julio o Juda y Brenner Abraham, contrato, plano

Brenner Julio y Blank Maria, contrato

Bresler Marcos, contrato, nota, plano

Bresler Mauricio, contrato, plano

Bronstein Leiba, contrato, plano

Bronstein Moises, Stirin Elias y Neuman Francisco, contrato de

pastoreo

Burman Samuel, contrato, plano

Cabrera Ventura, contrato, plano

Campi Hermanos, contrato

Centurion Nicasio, contrato, plano

Charchir Luis, contrato, plano

Chicom Moises, contrato, plano, cartas

Chiron Moises, contrato

Cobiler Fanny K. de, contrato

Cooperadora Escuela No. 111, nota

Cooperativa Agricola «Ocavi», contrato de arriendo

Coval Guedalie y Koval Jose, contrato

Cygler Rafael, contrato, plano, carta

Czarlinsky Gerhard y Rotschild Walter, contrato

Czarlinsky Gerhard, contrato, plano

Dvoretzky Efraim, contrato, plano, cartas

Dvoretzky Esther de e hijo Efraim, contrato de arriendo

Engelberg A. y Straus Luis, contrato

Engelberg Adolfo, contrato, plano

Engelberg Jose, contrato

Enguelberg Jose, contrato, plano, cartas

Feld Simon, contrato

Feld Simon, contrato, plano, carta

Fisman Iziel, contrato de pastoreo

Fisman Iziel, contrato, plano, cartas

Fraenkel Georg, contrato

Girsovich Abraham, contrato, plano

Glatstein David y Kupper Lazaro y Sandomirsky Boris, contrato

Glatstein David, contrato, plano

Goldentais Pedro, contrato de arriendo

Guirsovich Abraham, contrato de arriendo
$1943-44$

1938-57

1948

$1942-47$

1941

1952-59

1955-63

1930-56

1922-60

1930-51

1945-46

1945-46

1951-59

1956

1946-47

1946-56

1956-65

1929-58

1945-47

1943-44

1950-59

1926-56

1928-59

1930-54

1951-60

1957-39

1945-46

1933-53

1946-47

1943-58

1930-58

1944-45

1967

1930-59

1935-48

1943

1922-56

1965

1952-54

1965

1931-52

1936-59

1946-47

1945-46

1970

1946-47

1947

1936-59

1946-48

1938-60

1922-59

1946

1947-48

1930-57

1946-47

1936-59

1947

1931-51

1946-47

1932-59

1944-49

1930-58

1946-48

1935-59

1946

1946
Reserva

Reserva

Reserva

Reserva

Reserva

De reserva 
3650 Cohen Oungre 3197 Cohen Oungre 3645 Cohen Oungre 514 Cohen Oungre 3620 Cohen Oungre 1483 Cohen Oungre 933 Cohen Oungre 3619 Cohen Oungre 236 Cohen Oungre 3654 Cohen Oungre 1364 Cohen Oungre 3603 Cohen Oungre 3608 Cohen Oungre 1463 Cohen Oungre 3575 Cohen Oungre 1362 Cohen Oungre 1391 Cohen Oungre 3616 Cohen Oungre 444 Cohen Oungre 3170 Cohen Oungre 3631 Cohen Oungre 441 Cohen Oungre 499 Cohen Oungre 3578 Cohen Oungre 926 Cohen Oungre 3597 Cohen Oungre 1387 Cohen Oungre 3598 Cohen Oungre 224 Cohen Oungre 216 Cohen Oungre 205 Cohen Oungre 3655 Cohen Oungre 3605 Cohen Oungre 3630 Cohen Oungre 3191 Cohen Oungre 3194 Cohen Oungre 3594 Cohen Oungre 3637 Cohen Oungre 447 Cohen Oungre 1383 Cohen Oungre 3583 Cohen Oungre 5760 Cohen Oungre 3618 Cohen Oungre 442 Cohen Oungre 3617 Cohen Oungre 1371 Cohen Oungre 439 Cohen Oungre 1377 Cohen Oungre 239 Cohen Oungre 1382 Cohen Oungre 3172 Cohen Oungre

3579 Cohen Oungre 450 Cohen Oungre 520 Cohen Oungre 509 Cohen Oungre 3615 Cohen Oungre 494 Cohen Oungre 3629 Cohen Oungre 3596 Cohen Oungre 3614 Cohen Oungre 492 Cohen Oungre 505 Cohen Oungre 3588 Cohen Oungre 508 Cohen Oungre 3169 Cohen Oungre 451 Cohen Oungre
Guirsovich Benjamin, contrato

1941

Gumbert Siegfried, contrato

Heinrich Alfons, contrato

Heinrich Alfons, contrato, plano, notas

Heinrich Alfonso, Eichengruen Rudolf y Holstein Herbert, contrato

Heinrich Walter, contrato, plano, cartas

Hermann Salomon, contrato, plano, cartas

Herz Siegfried, contrato

Herz Siegfried, contrato, plano

Herz Wilhelm, contrato

Herz Wilhelm, contrato, plano, cartas

Hess Abraham, contrato

Hirsch Gualterio, contrato

Hiskin Jacobo, contrato, plano, cartas

Holdstein Herbert y Schlesinger Gustavo, contrato

Holdstein Herbert, contrato, plano, cartas

Hutterer Bernardo, contrato, plano, cartas

Irijimovich Aizik, contrato

Irijimovich Alejandro y Jacobo, contrato, plano

Jelin Basia K. de, contrato de arriendo

Jramoy Benjamin, contrato

Jramoy Francisco, contrato, plano, carta

Kaiser David, contrato, plano, carta

Kaiser Herman, contrato

Kaiser Hermann, contrato, plano

Kaiser Max, contrato

Kaiser Max, contrato, plano, cartas

Kamp Joseph y Kronthal Felix, contrato

Kamp Joseph, contrato, plano

Karger Jack, contrato, plano, correspondencia

Kasanetz Natalio,contrato, plano, carta

Kasanetz Rafael y Rubinzal Jacobo, contrato

Katz Eugen, contrato

Katz Werner, contrato

Katz Werner, contrato de pastoreo

Katz Werner, y Lederman Lena y Sosna Iser, contrato de pastoreo

Kaufman Marcos, contrato

Keilin Israel y Shaul Salomon, contrato

Keilin Israel, contrato, plano, carta

Kil Manuel, contrato, plano

Kirscheimer Jacob, contrato

Klaus Herz, contrato, plano, nota

Kobiler Ruben, contrato

Kobyler o Cubiler Ruben, contrato, plano

Kofman Salomon, contrato

Kofman Salomon, contrato, plano, cartas

Koval Jose, contrato, plano

Kronthal Felix, contrato, plano, cartas

Kutzwor Erich, contrato, plano

Lachman Nathan, contrato, plano, cartas

Lachman Nathan, Rabinovich Nipsel y Saul Guideon, contrato de arriendo

Lachmann Nathan, contrato

Lederman Sigmund, contrato, plano

Leff Elena S. de, contrato, plano, cartas

Lew Gela, contrato, plano, cartas

Lew Guela D. de, contrato

Lindenberg Meta Karger de, contrato, plano, carta

Lowenstein Otto y Nassan R. y Waldman Hugo, contrato

Maier Isidor, contrato

Mendelevich Bernard y Schleseinger Gustavo, contrato

Mendelevich Bernardo, contrato, plano, carta

Mendelsohn Rosa Maria e hijo Heriberto, contrato, plano, cartas

Merchuck Greegorio, contrato

Merenlender Abraham, contrato, plano

Milgram Abraham, contrato de arriendo

Moses Hans Adolfo, contrato, plano
Ensanche

Reserva

$1942-43$

$1939-59$

$1945-46$

$1946-48$

$1930-53$

$1947-48$

1938-56

1944-47

1945-48

1925-59

1945-46

1945-46

1930-48

1951-59

1948

1938-60

1946

1944-55

1946-48

1940-48

1938-57

1932-56

1943-44

1945-46

1945-46

1945-46

1946-47

1946-47

1925-52

1922-57

1941-43

1956-1960

1945-47

1927-53

1945-46

1925-57

1932-57

1940-52

1939-58

1930-60

1945-46

1947-48

1939-56

1943-60

1932-60

1945-46

1949-59

1945-46

1946

1945-46

1932-59

1940-64

1946-47

1926-57

1945-46

1948-57 
1381 Cohen Oungre 3613 Cohen Oungre 1379 Cohen Oungre 1393 Cohen Oungre 3646 Cohen Oungre 3628 Cohen Oungre 1380 Cohen Oungre 448 Cohen Oungre 510 Cohen Oungre 240 Cohen Oungre 243 Cohen Oungre 1394 Cohen Oungre 3552 Cohen Oungre 935 Cohen Oungre 493 Cohen Oungre 437 Cohen Oungre 934 Cohen Oungre 443 Cohen Oungre 433 Cohen Oungre 496 Cohen Oungre 2029 Cohen Oungre 713 Cohen Oungre 1388 Cohen Oungre 455 Cohen Oungre 3569 Cohen Oungre 3174 Cohen Oungre 3589 Cohen Oungre 1376 Cohen Oungre 3635 Cohen Oungre 3595 Cohen Oungre 428 Cohen Oungre 500 Cohen Oungre 513 Cohen Oungre 1386 Cohen Oungre 3656 Cohen Oungre 714 Cohen Oungre 3627 Cohen Oungre 1375 Cohen Oungre 3611 Cohen Oungre 242 Cohen Oungre 3576 Cohen Oungre 3643 Cohen Oungre 1476 Cohen Oungre 241 Cohen Oungre 3591 Cohen Oungre 504 Cohen Oungre 3641 Cohen Oungre 5903 Cohen Oungre 495 Cohen Oungre 3574 Cohen Oungre 3612 Cohen Oungre 434 Cohen Oungre 435 Cohen Oungre 931 Cohen Oungre 3586 Cohen Oungre 503 Cohen Oungre 3626 Cohen Oungre 3173 Cohen Oungre 932 Cohen Oungre 3639 Cohen Oungre 3167 Cohen Oungre 432 Cohen Oungre 3649 Cohen Oungre 3602 Cohen Oungre 3571 Cohen Oungre 3601 Cohen Oungre 3570 Cohen Oungre
Moses Max, contrato, plano, cartas,

$1940-57$

Nassan Rudolf, contrato

Netel Jacobo, contrato, plano, cartas

$1945-47$

Neuman Francisco Fischel, contrato, plano, cartas $\quad$ 1922-47

Neuman Hermann, contrato 1945-46

Neumark Moritz, contrato 1945-46

Neumark Moritz, contrato, plano, cartas 1939-54

Ostrovsky Adolfo, contrato, plano 1925-56

Pargament Jaime, contrato, plano 1929-59

Penchansky Jona y Marcos, contrato, plano 1930-59

Penchansky Marcos, contrato, plano 1950-54

Philippsberg Ludwig, contrato, plano, cartas 1937-59

Pierotti Ramon Carlos, contrato 1942-47

Plevinsky Enrique, contrato, plano, cartas 1953-63

Plewinsky Moritz, contrato, plano, carta 1939-59

Polirer Mendel, contrato, plano 1930-57

Pomerantz Salomon, contrato, plano, cartas

Rabey Isaac, contrato, plano 1931-58

Rabey Leon, contrato, plano $1942-57$

Rabey Pedro, contrato, plano $\quad$ 1951-60

Rabey Pedro, contrato, plano

Rabinovich Nissel, contrato, plano

Rabinovich Nissel, contrato, plano, cartas

Raby Izak Wolff, contrato, plano 1937-57

Reinberg Jacob, contrato 1939-40

Reinberg Jakob, contrato de arriendo 1945-46

Rentlinger Emil y Walter Kurt, contrato 1946-47

Reutlinger Emil, contrato, plano, cartas

Rllepka Moises, contrato 1944-45

Roitberg Salomon, contrato 1946-47

Rose Leo, contrato, plano 1937-57

Rosenthal Erich, contrato, plano, cartas 1940-60

Rotschild Enrique Walter, contrato, plano, cartas 1941-59

Rubinzal Jacobo Ber, contrato, plano, cartas 1931-56

Salomon Herman, contrato

Sanchez Eufronio, contrato, plano

Sandomirsky Boris, contrato

Sandomirsky Boris, contrato, plano, cartas

Sandomirsky Jacobo, contrato

Sandomirsky Jacobo, contrato, plano 1931-59

Saul Guideon, contrato $\quad$ 1947-48

Saul Guidon, contrato

Saul Guidon, contrato, plano

Saul Shalom o Salomon, contrato, plano 1922-55

Schabitay Saul, contrato, nota 1946

Schabitay Saul, contrato, plano $\quad 1940-60$

$1947-48$

Schack Moritz, contrato de arrendamiento 1946

Schack Moritz, contrato, plano 1951-60

Schisel Jaime, contrato 1947

Schissel Jaime, contrato $\quad 1945-47$

Schissel Jaime, contrato, plano 1931-57

Schissel Josef y Fischel Hersch, contrato, plano 1929-57

Schlesinger Gustav y Carlos, contrato, plano

Schonstadt Albert, contrato 1946-47

Schonstat Albert, contrato, plano, cartas

Seligman Hermann, contrato 1945-46

Shabetay Saul, contrato de arriendo

Sklarovsky Isaac, contrato, plano 1922-59

Soijet Saul y Jramoy Benjamin, contrato 1946-47

Sosna Iser, contrato de arriendo 1946-47

Sosna Iser, contrato, plano 1929-56

Stein Leopold, contrato 1940

Stein Salomon, contrato 1945-46

Stern Frieda, contrato, notas 1938-43

Sternberg Philipp, contrato, nota $\quad 1940-46$

Stiefel Berta Schener de, contrato 1940-43
Reserva

Reserva

Reserva 
3610 Cohen Oungre 930 Cohen Oungre 3176 Cohen Oungre 928 Cohen Oungre 1478 Cohen Oungre 3581 Cohen Oungre 3550 Cohen Oungre 929 Cohen Oungre 3590 Cohen Oungre 3651 Cohen Oungre 3604 Cohen Oungre 3585 Cohen Oungre 3609 Cohen Oungre 512 Cohen Oungre 3573 Cohen Oungre 502 Cohen Oungre 3634 Cohen Oungre 501 Cohen Oungre 2708 Cohen Oungre 927 Cohen Oungre 3572 Cohen Oungre 3625 Cohen Oungre 425 Cohen Oungre 1374 Cohen Oungre 3582 Cohen Oungre 3600 Cohen Oungre 511 Cohen Oungre 452 Cohen Oungre 427 Cohen Oungre 3196 Cohen Oungre 1373 Cohen Oungre 754 Curbelo 2698 Curbelo 741 Curbelo 742 Curbelo 747 Curbelo 746 Curbelo 740 Curbelo 709 Curbelo 777 Curbelo 2868 Curbelo 767 Curbelo 6385 Dora

6367 Dora

5891 Dora

6353 Dora

5988 Dora

5889 Dora

6366 Dora

6539 Dora

1023 Dora

6384 Dora

338 Dora

6381 Dora

6370 Dora

1024 Dora

4300 Dora

5974 Dora

2030 Dora

6380 Dora

6571 Dora 6831 Dora

5987 Dora 4335 Dora
Stirin Elias, contrato

1946-47

Stirin Salomon, contrato, plano

Straus Friedrich, contrato de arriendo

Strauss Friedrich, contrato, plano, cartas

Strauss Louis y Adolfo Walter, contrato, plano, cartas

Tchudnovsky Boris, contrato

The River Plate Dairy Ltd., contrato

Traidel Elsa Hertz de, contrato, plano, cartas

Treidel Fritz, contrato, notas

Tsadok Schaul y Salomon, contrato

Tschudnovsky Boris, contrato

Urbine Jose, contrato

Vinograd Chana y Jacobo, contrato

Vinograd Marcos, contrato, plano

Vinograd Moises, contrato

Vinograd Moises, contrato, plano, carta

Vinograd Salomon, contrato

Vinograd Salomon, contrato, plano, cartas

Vinograd Salomon, contrato, plano, cartas

Wachsmann Sigmund, contrato, plano

Waksman Siegfried, contrato

Waldman Hugo, contrato

Waldman Hugo, contrato, plano

Walter Curt, contrato, plano, cartas

Wencymer Salomon y Avidon Mendel contrato, notas

Wolff Siegfried y Schkolnik Simon, Campi Hermanos, contrato

Yelin Gregorio, contrato, plano

Yelin Salomon Latman, contrato, plano, carta

Zlotnitzky Bernardo o Zlotnicky Berko, contrato, plano

Zlotnitzky Bernardo, contrato de arriendo

Zweig Erich, contrato, plano, cartas

Adler Salomon y Jaime, Mendelovich Abraham, contratos, plano

Finvarb Simeon y Finberg Juan, contrato, plano

Haase Leo, contrato, plano, cartas

Haase Moses, contrato, plano, correspondencia

Kobrinsky Benjamin, contrato

Kobrinsky Enrique, contrato, plano

Lupu Hers, contrato, plano, correrspondencia

Mendelovich Abraham, contrato, plano

Muruvankin Iser, contrato, plano, cartas

Roidburd Simon, contrato, plano, cartas

Vernick Bernardo y Voloy Vladimiro, contrato, plano, cartas

Arcusin Jaime y Lazaro, contrato de pastoreo

Arcusin Jaime, contrato de pastoreo

Arcusin Jaime, plano, escritura

Arcusin Julio, contrato arriendo de pastoreo

Arcusin Lazaro y Jaime, plano de lotes

Arcusin Lazaro, plano, escritura

Arcusin Luis, contrato de pastoreo

Ayres Lopez y Eulogio Quiñones (Colonos Unidos), Escritura de terreno, incompleto.

Azar Salomon, contrato, plano

Azas Salomon, contrato alquiler de habitación

Bercoff Benjamin, contrato, plano, carta

Castillo Francisco, contrato de pastoreo

Castillo Hermenegildo, contrato de pastoreo

Castillo Roberto, contrato, plano

Chaud Antonio y Elias, y Chiaffi Carlos, contrato, plano

Compañia Agraria Argentina, plano de lotes

Cooperadora Amigos de los Ninos contrato, plano

Cooperativa Colonos Unidos Ltda., convenio de traslado y contrato alquiler de edificio

Cooperativa Colonos Unidos Ltda., Escritura compra de terreno

Cooperativa Colonos Unidos Ltda., Escritura compra de terreno, incompleta

Cooperativa Colonos Unidos, plano de lotes

Cordoba Ambrosio, contrato, plano, cartas
1929-59

$1946-48$

$1939-64$

$1939-59$

$1939-48$

1933-37

1938-54

1946-47

1941

1945-46

1937-48

1945-46

1931-59

1946-48

1929-60

1945-48

1929-59

1960

1939-60

1950-51

1945-46

1938-59

1942-61

1940-47

1946-1951

1949-59

1931-56

1930-57

1940-41

1938-55

1933-D77449

1947-48

1938-40

1937-50

1949

1916-49

1940-50

1949

1926-50

1947-50

1915-48

1948

1944-1950

1944-1954

1922-1942

1952-1953

1916-1952

1943

1952

1964

1950

1966

1947

1942-1943

1963

1972

1931

1963

$1945-52$

1952

1953

1952

1941-64
Reserva

Reserva

Reserva

De Reserva

Reserva

Reserva

Reserva 
6364 Dora 6363 Dora 6369 Dora 6373 Dora 5884 Dora 6356 Dora

5897 Dora 5976 Dora

6375 Dora

5986 Dora

5885 Dora

5692 Dora

6359 Dora

2033 Dora

2032 Dora

2031 Dora

2937 Dora

3705 Dora

6355 Dora

6372 Dora

4336 Dora

361 Dora

3491 Dora

5693 Dora

5899 Dora

5694 Dora

3492 Dora

5984 Dora

5892 Dora

5890 Dora

5975 Dora

3189 Dora

5983 Dora

6368 Dora

3706 Dora

3707 Dora

6377 Dora

5982 Dora

5695 Dora

4371 Dora

6357 Dora

362 Dora

6361 Dora

364 Dora

6365 Dora

5985 Dora

2575 Dora

5898 Dora

6360 Dora

346 Dora

5696 Dora

6371 Dora

5980 Dora

5888 Dora

6379 Dora

5978 Dora

5894 Dora

5895 Dora

2403 Dora

5893 Dora

5979 Dora

6362 Dora

6376 Dora
Cordoba Juan, contrato de pastoreo y arriendo de terreno

Cordoba Manuel, contrato arriendo de pastoreo

Cordoba Manuel, contrato de pastoreo

Coria Roberto, contrato de pastoreo

Cuzevitzky o Kusevitzky Juda, planos, escritura, arrendamiento

Edelstein Pedro Suc., contrato arriendo de terreno y casa

(abandono)

Efron Esther K. De y Efron Moises, plano, escritura

Efron Moises y Esther K., Plano de lotes

Feldman Jacobo, contrato locación fracción de campo

Feldman Jacobo, plano de lote

Feldman Jacobo, plano, escritura

Finkelstein Rajmiel, contrato, nota

Firbank Alfredo, contrato arriendo de terreno y pastoreo

Firman Isaac, notas, plano

Glikman Elias, plano, Boleto de Compra

Glikman Manuel, contrato, plano

Glikman Manuel, contrato, plano, cartas

Gomez Pedro Jose, contrato, plano, notas

Grosman Guenis Jose, contrato arriendo de pastoreo, Promesa de Venta

Guizio Vicente, convenio de alquiler de galpón

Ibañez Victor M., contrato, plano, notas

J.C.A., venta a Campos Eustaquio, escritura, plano

Jerez Miguel, contrato, plano, cartas

Kira Isidoro, contrato, nota

Kohon Jose y Abraham, judicial

Kriztal Elias, contrato, plano, notas

Kuperstein Adolfo, contrato, plano, notas

Kuperstein Adolfo, plano de lote

Kuperstein Adolfo, plano, escritura

Kusevitzky Manuel e hijo Jacobo, plano, escritura, ensanche

Kusevitzky Manuel, Plano de lotes

Leguizamon Carlos Augusto, contrato, plano, nota

Leguizamon Carlos, planoo de lote

Levinson Ramon, nota de alquiler de galpón

Mainardi Atelmo, contrato, plano, notas

Mateo Ramon F., contrato, nota

Mena Maria, contrato de pastoreo

Mesura de Lotes, propiedad de JCA: donación a la Cooperadora

Amigos del Niño

Ozcheroff Hersh, contrato, plano, notas

Pagalday Pabla E. Laserna de, contrato, plano

Patolsky Isaac y Jaime, contrato de pastoreo, arriendo de galpón

Patolsky Israel, escritura, plano

Patolsky Jose, contrato arriendo de terreno y pastoreo

Patolsky Manuel Leon, escritura, plano

Peralta Silverio, contrato de pastoreo

Potolsky Jose e Ibañez M. Victor, planos de lotes

Potolsky Jose, contrato, plano

Potolsky Jose, planos, escritura, arrendamiento

Rosenberg Fischel, contrato arriendo de casa, terreno, notas,

Testimonio

Rosenstein Moises, contrato, plano, carta

Rubinstein Simon, notas

Sanchez Carlos G., convenio por alquiler de habitación

Saslaver Moises, plano de lote

Saslaver Moises, plano, escritura

Schafer Isaac, contrato de pastoreo y fracción de campo

Schafer Jaime e Isaac, planos de lotes

Schafer Jaime, plano, escritura

Schaffir Isaac, plano, escritura

Scherman Abraham, contrato, plano

Scherman Abraham, escritura, plano, ensanche

Scherman Abraham, plano de lote

Scherman Pesaj, contrato arriendo de pastoreo

Serra Piuherrera, contrato de pastoreo
1941-1945

1941-1943

1942-1943

1945

1920-1950

1928-1951

1925-1958

1951

1944-50

1950

1920-1950

1911-1924

1940-1948

1963

1962

1964

1954

1968-69

1911-1945

1944

1962-66

1972

1952-64

1912-1935

1937

1911-1931

1966-69

1954

1928-1976

1922-1966

1931

1963-7

1963

1942-1943

1966-69

1968-69

1945-49

1957

1911-1934

1963

1925-1949

1972

1931-1949

1972

1941-1946

1953-1962

1925-57

1931-1958

1926-1954

1966

1912-1925

1942

1951

1911-1952

1934-45

1954

1917-1954

1928-1954

1972

1928-1960

1953

1929-1942

1945-46
Reserva

Reserva

Reserva

Reserva

Reserva

Reserva

Reserva

Reserva

Reserva

De reserva

Reserva

Reserva

Reserva

Reserva

Reserva

Reserva

Reserva 
343 Dora

6383 Dora

5981 Dora

5886 Dora

6378 Dora

5977 Dora

5896 Dora

6358 Dora

5887 Dora

6382 Dora

6374 Dora

6354 Dora

802 El Escabel

5707 La Pampa

4297 Leonard Cohen

817 Leonard Cohen

4364 Leonard Cohen 4294 Leonard Cohen 4298 Leonard Cohen 1008 Leonard Cohen 1009 Leonard Cohen 4348 Leonard Cohen 2449 Leonard Cohen 2850 Leonard Cohen 2848 Leonard Cohen 3766 Leonard Cohen 5807 Leonard Cohen 4291 Leonard Cohen 3767 Leonard Cohen 2699 Leonard Cohen 4293 Leonard Cohen 4334 Leonard Cohen 2447 Leonard Cohen 2987 Leonard Cohen 700 Lopez Berro 3765 Lopez Berro 694 Lopez Berro 711 Lopez Berro 692 Lopez Berro 693 Lopez Berro 2642 Lopez Berro 689 Lopez Berro 698 Lopez Berro 699 Lopez Berro 841 Lopez Berro 690 Lopez Berro 691 Lopez Berro 2942 Lopez Berro 697 Lopez Berro 2656 Lopez Berro 695 Lopez Berro 696 Lopez Berro 2874 Lopez Berro 2872 Lopez Berro 2791 Lopez Berro 1821 Mauricio 109 Mauricio 3044 Mauricio 2007 Mauricio 2008 Mauricio 6636 Mauricio 6630 Mauricio 674 Mauricio 6623 Mauricio 658 Mauricio renuncia al mismo

Silberman Jacobo Ernesto, contrato, carta

Silberman Simon, contrato de pastoreo y arriendo de lote

Silberman Simon, plano de lote

Silberman Simon, plano, escritura

Silberstein Jose, contrato de pastoreo y arriendo

Silberstein Jose, plano de lote

Silberstein Jose, plano, escritura

Silberstein Leon, contrato arriendo de terreno (abandono)

Silberstein Salomon, plano, escritura

Vasquez Cenovio, contrato de pastoreo

Villareal Severo y Zarco Juan, contrato de pastoreo

Zank Mendel, contrato arriendo de terreno y pastoreo

Estado Nacional Argentino, contrato

Sujanovich Sara M. de, contrato

Albornoz Prudencio, contrato, plano notas

Alperin Salomon y David, contrato, plano

Antivero Facundo, contrato, plano

Banegas Rafael, contrato, plano, notas

Barreto Ramon, contrato, plano, notas

Campi Aguedo Domingo, contrato, plano

Campi Agustin, contrato, plano

Campi Jose, contrato, plano

Kohan Jacobo, contrato, plano

Kohan Jacobo, contrato, plano

Kurt Herz, contrato, plano

Lopez Caro, contrato, plano, notas

Maier Isidoro, Registro Crédito Prendario

Molina Pedro, contrato, plano, notas

Monzon Silverio, contrato, plano, cartas

Schcolnik Miguel, contrato, plano cartas

Urbine Hermanos, contrato, plano, notas

Woulter Lood Alberto, Carlos y Abelardo, contrato, plano, notas

Wulfsohn Jacobo, User y Julio, contrato, plano

Zlotnitzky Bernardo, contrato, plano, cartas

Bocasovich Jose, contrato, plano

Coninanza Francisco, contrato, plano

Fink Benjamin, contrato, plano

Fridman Marcos y Salil, contrato, plano

Gadyi David, contrato, plano

Golden Idel, contrato, plano

Goldin Idel, contrato, plano, cartas

Kilstein Ignacio, contrato, plano, carta

Noejovich Isaac, contrato, plano

Resnichenco Salomon, Jaime y Benjamin, contrato, plano, cartas

Rivelis Pascual, contrato, plano

Rosin Natalio, contrato, plano, carta

Roskin Isaac, contrato, plano, cartas

Schvartzman Isaac, nota, plano

Seiguer Samuel Manuel, contrato, plano, correspondencia

Sitcoff Osias, contrato, plano, nota

Smucler Jose, contrato, plano

Steingart Bernardo, contrato, plano

Sulkin Fanny y Celmira, contrato, plano, cartas

Vinocur Jacobo y Samuel, contrato, plano, cartas

Vinocur Leon, contrato, plano, cartas

Abelson Isaias Suc., contrato, plano

Abelson Selig, contrato, plano, correspondencia

Adamovsky Fisel, contrato plano, notas

Alpersohn Abraham, contrato, plano, cartas

Alpersohn Marcos, contrato, plano

Aquerman Bernardo, Escritura de lote

Balanofsky Simon, Escritura compra de lote

Balonofsky Simon, contrato, plano

Barber Idel, Escritura de lote

Belchik Moises, contrato, plano
1951-56

1933-43

1950

1917-1950

1933-45

1931

1930-1955

1929-1949

1917-1950

$1948-49$

$1945-46$

1928-1941

1953

1940-1945

1947-52

1951

1965

1947-52

1947-54

1965

1965

1965

1947

1950

1950

1950

1940

1947-51

1950

1948-54

1948

1960-65

1947-55

1948-51

1943-48

1948-49

1926-28

19491949

1948

1936-48

$1945-48$

1942-51

1938-49

1908-40

1955

1915-57

1922-51

1954-55

1938-52

1948

1948

1939-48

1947-51

1930-47

1946-48

1901-21

1908-31

1908-35

1904-19

1896-1919

1918

1911

1927-29

1910

1896-1913
Reserva

Reserva

Clara No. 2

Reserva

Reserva

Reserva

Reserva

Reserva

Reserva

Reserva

Reserva

Reserva

Reserva

Reserva

Reserva

Reserva

Reserva

Reserva

Reserva

Reserva

Reserva

Reserva

Reserva

Reserva

Reserva

Reserva

Reserva 
6649 Mauricio 5038 Mauricio 3013 Mauricio 1807 Mauricio 1994 Mauricio 6643 Mauricio 108 Mauricio 3045 Mauricio 667 Mauricio 3046 Mauricio 5035 Mauricio 1801 Mauricio 5039 Mauricio 1808 Mauricio 628 Mauricio 663 Mauricio 5017 Mauricio 106 Mauricio

3054 Mauricio 4997 Mauricio 3042 Mauricio 4991 Mauricio

1451 Mauricio 3049 Mauricio 1997 Mauricio 6644 Mauricio 2415 Mauricio 6652 Mauricio 5031 Mauricio 5028 Mauricio 5024 Mauricio 113 Mauricio

3000 Mauricio 1813 Mauricio 5022 Mauricio 5002 Mauricio 6642 Mauricio 5013 Mauricio 6634 Mauricio 2999 Mauricio 2425 Mauricio 3057 Mauricio 6635 Mauricio

2047 Mauricio 672 Mauricio 6641 Mauricio 105 Mauricio 3007 Mauricio 4988 Mauricio 6622 Mauricio 4994 Mauricio 102 Mauricio 2991 Mauricio 3005 Mauricio 627 Mauricio 6647 Mauricio 6640 Mauricio 2993 Mauricio 1806 Mauricio 654 Mauricio 2048 Mauricio 2410 Mauricio 6632 Mauricio 6648 Mauricio
Beltran Miguel, Nota sobre Escritura de lote

Bercovich Abraham, contrato, plano, notas

1905-1925

Berkowitch Israel, contrato, plano, notas

Berlatzky Eduardo, plano, cartas

Binderman Anschel, contrato, plano, cartas

Blejer Sise, escritura de lote

Bluvchtein Mauricio, contrato, plano

Bolotnicoff Jacobo, contrato, plano, notas

Bolotnikoff Jose, contrato, plano

Bondar Meier, contrato, plano, notas

Borenstein Jose, contrato, plano, notas

Borenstein Leon , contrato, plano, cartas

Borochovich Abraham Suc., contrato, plano, notas

Borojovich Isaac, contrato, plano, cartas

Braverman Isaac Leon, contrato, plano

Braverman Moses, contrato, plano

Broitman Gil, contrato, plano, notas

Broitman Noej e Hijos Tomas y Naum, contrato, plano,

correspondencia

Brover Natalio, contrato, plano, notas

Brunstein Moises, contrato, plano, notas

Brunstein Salomon, contrato, plano, notas

Chernis David, contrato, plano, notas

Chernitz Natalio, contrato, plano, cartas

Chertcoff David, contrato, plano, notas

Dairsch Marcos, contrato, plano, cartas

Daj Abraham, Escritura de lote

Dayan Jacobo, contrato, plano

Del Monte Jose, Escritura de terreno

Diner Abraham, contrato, plano, cartas

Diner Benjamin, contrato, plano, notas

Diner Isaac, contrato, plano, notas

Diner Israel y Jaime, contrato de promesa de venta, plano,

correspondencia

Dinitz Israel, contrato, plano, cartas

Doctorovich Jose, contrato, plano, cartas

Doctorovich Moses, contrato, plano notas

Dolberg Vigdor, contrato, plano, notas

Dolberg Vigdor, Escritura de lote (deteriorado)

Dopchiz Hirsch Aaron, contrato, plano, cartas

Edelman Elias, Escritura de lote

Edelman Jacobo, contrato, plano, cartas

Edelman Jose, contrato

Edelman Mendel, contrato, plano, notas

Edelman Samuel, Escritura de lote y Contrato Promesa de Venta

Faingold Marcos, contrato, plano, cartas

Farber Carlos, contrato, plano, cartas

Feller Elias, Escritura de lote (mal estado)

Ferder Leon, contrato, plano

Finkelstein Boris, contrato, plano, cartas

Finkelstein Uscher, contrato, plano, notas

Fitterman Samuel, Escritura de lote

Flomenbaum Elias, contrato, plano notas

Flomenboim Marcos, contrato, plano

Frenkel Abraham, contrato, plano cartas

Frenkel Leon, contrato, plano, cartas

Fridman Samuel, contrato, plano, cartas

Fuxman Moises, Escritura de lote

Galanternik Bencion, Escritura de lote (deteriorada)

Galanternik Sabulan, contrato, plano, notas

Garber Azriel, cartas, plano

Garfunkel Boris, contrato, plano

Gass Samuel, contrato, plano, cartas

Gerschman (sin nombre part.), contrato

Gerschman Jaime B., Escrituras compra de lotes

Gerschman Jaime, Daj Abraham, Escritura de lote
1896-1920

$1910-32$

1896-1920

1925

1918-29

1917-35

$1901-15$

1908-35

1908-1925

$1922-46$

1903-1925

1901-22

$1908-27$

1896-1915

1896-1921

1917-29

1908-22

1896-1918

1904-22

1894-1922

1904-20

1905-36

1906-20

1925

1924

1928

1905-1925

1896-1921

1896-1921

1917-32

1896-1917

1909-32

1894-1921

1901-1918

1895-1921

1913

1896-1917

1921

1904-23

1909-16

1894-1920

1908-30

1925

1921-29

1896-1916

1903-1918

1909

1902-1922

1908-29

1894-1917

1896-1916

1911-27

1935

1925

1896-1917

1905-32

1902-13

1896-1920

1918

$1911-25$

1935 
5020 Mauricio 659 Mauricio 5021 Mauricio 2049 Mauricio 5001 Mauricio 1798 Mauricio 5920 Mauricio 1803 Mauricio 1805 Mauricio 3061 Mauricio 5030 Mauricio 2986 Mauricio 3003 Mauricio 1811 Mauricio 2772 Mauricio 3004 Mauricio 5000 Mauricio 623 Mauricio 5025 Mauricio 4998 Mauricio 1818 Mauricio 5045 Mauricio 2994 Mauricio 671 Mauricio 2012 Mauricio 631 Mauricio 6646 Mauricio 1823 Mauricio 2011 Mauricio 3001 Mauricio 632 Mauricio 1797 Mauricio 2990 Mauricio 665 Mauricio 3047 Mauricio 2038 Mauricio 6626 Mauricio 1820 Mauricio 3062 Mauricio 3002 Mauricio 3041 Mauricio 619 Mauricio 5009 Mauricio 4835 Mauricio 3009 Mauricio 3055 Mauricio 5016 Mauricio 6639 Mauricio 5015 Mauricio 4999 Mauricio 679 Mauricio 2039 Mauricio 3065 Mauricio 3051 Mauricio 5049 Mauricio 5026 Mauricio 1809 Mauricio 3008 Mauricio 660 Mauricio 2003 Mauricio 2004 Mauricio 3011 Mauricio 4993 Mauricio 5019 Mauricio 6645 Mauricio 5011 Mauricio 5012 Mauricio
Gersenovitz Marcos, contrato, plano notas

Gerstel Lazaro, contrato, plano

Gerstel Moises, contrato, plano, cartas

Glik Marcos, contrato, plano, cartas

Goldenberg Abraham, contrato, plano, notas

Goldfarab Jose, contrato, plano, cartas

Grinberg Benjamin, promesa de venta

Grobo Copatel Abraham, contrato plano, cartas

Groisman Moises, cartas, plano

Grunman Jonas, contrato, plano, cartas

Grunmann Cecilia Rein de, y Marcos e Hirsch, contrato, plano, cartas

Grunmann Moises, contrato, plano, notas

Guitelman David, contrato, plano, cartas

Guitelman Raul, contrato, plano, cartas

Herman Naum, contrato, plano, notas

Hochberg Abraham y Salomon y Serafina de, contrato, plano, cartas

Hochman Wolf, contrato, plano, notas

Hochraich Leya Staricoff de, contrato, plano

Hoichrach Moises, contrato, plano, notas

Hojberg Salomon y Schardonofsky Felix, contrato, plano, notas

Hojraj Jaime, contrato, plano, cartas

Holzcan Ischiel, contrato, plano, notas

Holzcan Israel, contrato, plano, cartas

Holzkan Manuel, contrato, plano

Jacuboff Salomon, contrato, plano cartas

Jacuboff Salomon, contrato, plano, cartas

Jacuboff Salomon, Escritura de lote, cancelación

Jaitt Israel, contrato, plano

Kachanovsky Gabriel, contrato, plano, cartas

Katz Moses, contrato, plano, cartas

Katz Samuel, contrato, plano, cartas

Katzef Jacobo, contrato, plano, cartas

Katzeff Aron, contrato, plano, cartas

Katzeff Moses, contrato, plano

Keilis Ermindo y Suriz Julio, contrato plano, notas

Keilis Israel, contrato, plano

Kerberg Jose, Escritura de compra de lote

Kesler Jacobo, contrato, plano, cartas

Kesselman Abraham, contrato, plano, notas

Kleinman Isaac, contrato, plano, cartas

Kleinman Leon, contrato, plano

Kohan Elias, contrato, plano, cartas

Kohan Meyer, contrato, plano, notas

Kohan Moses, contrato, plano, notas

Kohan Pincus, contrato, plano, notas

Kolker David, contrato, plano, notas

Kolker Jacobo, contrato, plano, notas

Kraiterman Salomon, Escrituras de lotes

Kreinberg Salomon, contrato, plano cartas

Krell Isaac, contrato, plano, notas

Kur Salomon, contrato, plano

Kveitel Meier, contrato, plano

Larger Abe, contrato, plano, notas

Leiderman Moses (Sucesión), contrato, plano, notas

Lejtman Jaime, contrato, plano, notas

Lejtman Moises, contrato, plano, cartas

Lembersky Leon, contrato, plano, cartas

Lembersky Moises, contrato, plano, notas

Lerner Aron, contrato, plano

Lerner Berco, contrato, plano, cartas

Lerner Jonas, contrato, notas

Lerner Jonas, plano, notas

Lerner Pascual, contrato, plano, notas

Levin Aron, contrato, plano, notas

Liajovetzky Alejandro, Escritura de lote

Lifschitz Moises, contrato, plano, notas

Lusin Samuel, contrato, plano, cartas
1895-1929

1901-13

1896-1921

1908-20

1901-1918

1908-31

1918-1930

$1935-44$

1904-32

$1902-15$

1894-1945

1894-1916

1896-1916

1906-22

1942

1896-1916

1901-1918

1907-27

1917-1918

1904-1918

1904-22

1904-1925

1901-17

1908-28

1896-1920

1904-25

1941

1922-48

1896-1934

1896-1917

1902-25

1908-31

1896-1917

1894-1915

1907-36

1896-1920

1910

1901-24

1894-1915

1901-16

1906-22

1902-26

1896-1921

1896-1918

1896-1916

1905-23

1896-1921

1925-29

1901-1921

1896-1918

1908-29

1896-1920

1901-19

1900-23

1896-1918

1896-1918

1906-22

1896-1916

1901-13

1904-20

1920

1896-1920

1904-1922

1896-1921

1926

1901-1921

1900-1921 
662 Mauricio 1816 Mauricio 3015 Mauricio 107 Mauricio 100 Mauricio 5007 Mauricio 5042 Mauricio 2984 Mauricio 5040 Mauricio 2005 Mauricio 3006 Mauricio 618 Mauricio 2983 Mauricio 1815 Mauricio 1993 Mauricio 2050 Mauricio 2041 Mauricio 1817 Mauricio 5004 Mauricio 2006 Mauricio 6633 Mauricio 2423 Mauricio 5044 Mauricio 4836 Mauricio 5023 Mauricio 624 Mauricio 1812 Mauricio 5036 Mauricio 4992 Mauricio 1804 Mauricio 5027 Mauricio 649 Mauricio 2009 Mauricio 1795 Mauricio 5052 Mauricio 6653 Mauricio 656 Mauricio 3017 Mauricio 2992 Mauricio 5046 Mauricio 655 Mauricio 5051 Mauricio 3043 Mauricio 2860 Mauricio 6628 Mauricio 6638 Mauricio 5047 Mauricio 669 Mauricio 112 Mauricio 1999 Mauricio 6651 Mauricio 5006 Mauricio 2985 Mauricio 5048 Mauricio 103 Mauricio 6629 Mauricio 5008 Mauricio 651 Mauricio 648 Mauricio 630 Mauricio 621 Mauricio 622 Mauricio 670 Mauricio 5037 Mauricio 1822 Mauricio 3018 Mauricio
Mactas Moses, contrato, plano

Malamud Alfonso y Bernardo, contrato, plano, carta

Malamud Isaac, contrato, plano, cartas

Matiches Salomon e hijo Jose, contrato, plano

Mellibovsky Pablo Jose, contrato, plano, correspondencia

Mijalevsky Ezequiel, contrato, plano, cartas

Moiguer Fidel, contrato, plano, notas

Mutschnik David, contrato, plano, notas

Naiberg Jaime, contrato, plano, notas

Naiberg Moises, contrato, plano, notas

Nemichinitzer David, contrato, plano, cartas

Nemichinitzer Israel, contrato, plano

Neuberg Salomon, contrato, plano, cartas

Nisenbaum Abraham, contrato, plano, cartas

Nisenbaum Leon, contrato, plano, cartas

Nissensohn Lazar Sucesion, contrato, plano, cartas

Noremberg Jacobo, contrato, plano, cartas

Norenberg Isaac, contrato, plano, cartas

Odesky Wolf, contrato, plano, notas

Oks Abraham, contrato, plano

Oves N. N., Escritura de lote (deteriorado)

Papisarevsky Jose, contrato, plano

Pelman Jacobo, contrato, plano, notas

Pelman Zeide, contrato, plano, notas

Pickelny Abraham, contrato, plano, cartas

Pisarevsky Jose, contrato, plano

Pisretzky Jose (ex Margulis Wolf) cartas, plano

Polak Abraham, contrato, plano, notas

Polak Golda G. Vda. de, contrato, plano, notas

Popovsky Aron, contrato, plano, cartas

Pustilnik Jose, contrato, plano, notas

Rabinovich Berl, contrato, plano

Rabinovich Israel, contrato, plano, cartas

Rabinovich Natalio, contrato, plano, cartas

Rabinovich Samuel, contrato, plano, notas

Rabinovich Samuel, Escritura de terreno y notas

Rabinovitz Samuel, contrato, plano, cartas

Radutzky David, contrato, plano, cartas

Raijelson Max, contrato, plano, cartas

Raiter Salomon, contrato, plano, notas

Raitzin Adolfo, contrato, plano

Raitzin Julio, contrato, plano, notas

Raitzin Salomon, contrato, plano, notas

Rapoport Nicolas, contrato, plano

Rattner Adolfo, escritura compra de lote

Rechansky Juan, Escrituras de lote

Rempel Sissel, contrato, plano, notas

Resnicoff Benjamin, contrato, plano

Resnik Abe, contrato, plano, correspondencia

Reznik Lazaro, contrato, plano, cartas

Ricci Vicente, Escritura de terreno

Rimsky Miguel, contrato, plano, notas

Rogoff Israel, contrato, plano, cartas

Rogoff Jose, contrato, plano, notas

Roitman Jose, contrato, plano

Romerstein Salomon, escrituras compra de lote

Rosenfeld Abraham, contrato, plano, notas

Rosenvasser Salomon, contrato, plano

Rosenzveig Aron, contrato, plano, cartas

Rosmarin Nejemie, contrato, plano, cartas

Rozenzwaig Alter (Suc.), contrato, plano

Rozenzwaig Bernardo, contrato, plano, cartas

Rozenzwaig Paulina Felisa Flomrnbaum de, contrato, plano

Rubinstein Kolman, contrato, plano, notas

Saidman David, contrato, plano, cartas

Saslavsky Lazaro, Mirel P. de y Felix, Marcos, Mauricio, Natal,

Yenta, Luisa Golda, Rebeca, Salomon, Abraham y Clara, contrato,
1896-1913

1909-35

$1895-1920$

1910-29

1922-29

1896-1921

1896-1921

1894-1916

1900-1921

1913-19

1896-1916

1908-26

1894-1916

1909-35

1898-1920

1896-1921

1900-20

1906-22

1896-1918

1904-19

1911

1926

1904-1925

1896-1018

1894-1921

1908-27

1908-34

1906-1925

1894-1922

1916-35

1906-1924

1901-13

1905-20

1905-22

1907-1928

1926-36

1894- 1913

1896-1920

1896-1917

1904-1925

1896-1913

1900-1918

1904-22

1937-39

1910

1925-27

1907-1925

1907-28

1926-31

1901-20

1931

1896-1921

1896-1916

1904-1925

1912-29

1911-25

1895-1921

1896-1913

1909-13

1910-25

1901-26

1896-1926

1908-28

1909-1925

1922-46

1896-1920
Reserva

Reserva 
629 Mauricio 673 Mauricio 1824 Mauricio 5034 Mauricio 652 Mauricio

5033 Mauricio 2996 Mauricio 1819 Mauricio 2044 Mauricio 6627 Mauricio 2046 Mauricio 4839 Mauricio 4841 Mauricio 4840 Mauricio 4838 Mauricio 664 Mauricio 2001 Mauricio 3063 Mauricio 2000 Mauricio 1995 Mauricio 676 Mauricio 2043 Mauricio 2042 Mauricio 4996 Mauricio 5029 Mauricio 3056 Mauricio 5041 Mauricio 4995 Mauricio 675 Mauricio 647 Mauricio 626 Mauricio 4990 Mauricio 2051 Mauricio 2010 Mauricio 1799 Mauricio 1800 Mauricio 625 Mauricio 2413 Mauricio 2981 Mauricio 3053 Mauricio 2045 Mauricio 2995 Mauricio 5043 Mauricio 1814 Mauricio 678 Mauricio 2998 Mauricio 5010 Mauricio 6624 Mauricio 653 Mauricio 1810 Mauricio 4837 Mauricio 657 Mauricio 6637 Mauricio 5005 Mauricio 2980 Mauricio 111 Mauricio 1016 Mauricio 661 Mauricio 620 Mauricio 5032 Mauricio 2040 Mauricio 3052 Mauricio 3058 Mauricio 2997 Mauricio 666 Mauricio 1996 Mauricio plano, notas

Saslavsky Marcos, contrato, plano, cartas

$1908-26$

1908-30

1908-37

Savransky Jose, contrato, plano, cartas

Schapira Abraham, contrato, plano cartas

Schapira David, contrato, plano

Schapira Saul, contrato, plano, notas

Schapira Schaye, contrato, plano, cartas

Schapochnik Hirsh, contrato, plano, cartas

Scharaschansky Vda. de,contrato, plano, cartas

Schargarodsky Emilio, Escritura compra de lote

Schargorodsky Guedalia, contrato, plano, cartas

Schargrodsky Abraham, contrato, plano, cartas

Schargrodsky Emilio, contrato, plano, notas

Schargrodsky Eusebio, contrato, plano, notas

Schargrodsky Jacobo, contrato, plano, notas

Schenkerman Naum, contrato, plano

Schenquerman Boris, contrato, plano, cartas

Schenquerman Simon, contrato, plano, notas

Schenqverman Mateo, contrato, plano, cartas

Scherdenovsky Salomon, contrato plano, cartas

Scherf Leon, contrato, plano

Schielman Suc. de Israel, contrato, plano

Schijman Samuel, contrato, plano, cartas

Schilman Mauricio, contrato, plano, notas

Schmilchuk Moises, contrato, plano cartas

Schmilchuk Schaye, coontrato, plano notas

Schmukler David, contrato, plano, cartas

Schmukler Jose, contrato, plano, notas

Schneider Ermindo, contrato, plano

Schneider Mendel, nota, plano

Schraiber Jacobo, contrato, plano, cartas

Schreiber Wolf, contrato, plano, notas

Schuster Abraham, contrato, plano, cartas

Schuster Abraham,contrato,plano, cartas

Schuster David, contrato, plano, cartas

Schute Jacobo, contrato, plano, cartas

Schvartzman Fridel, contrato, plano

Sekzer Naum, contrato

Seltzer Lazaro, contrato, plano, cartas

Sigal Jose, contrato, plano, notas

Sigal Joseph Leib, contrato, plano, cartas

Sigal Sandalio, contrato, plano, cartas

Silber Moises, contrato, plano, cartas

Silber Natalio, plano, cartas

Silberberg Leon, contrato, plano, cartas

Silbermannn Jacobo, contrato, plano, cartas

Silberstein Moises, contrato, plano, notas

Simsilevich Abraham, Escritura de lote

Sobol Marcos, contrato, plano, carta

Socoler Benjamin, contrato, plano, cartas

Spack Froim, contrato, plano, notas

Spack Moses, contrato, plano, cartas

Staricoff Kivo y Steinberg Moises, Escritura de lote, deteriorado

Staricoff Mauricio y Sverdlik Jose, contrato, plano, notas

Starikoff Jacobo, contrato, plano, cartas

Stein Jacobo, contrato, plano

Steinberg Meice e Isaac, contrato, plano

Strauch Ignacio, notas, plano, cartas

Sugarman George, contrato, plano

Sverdlik Aaron y Jose, contrato, plano, cartas

Sverdlik Meier, contrato, plano, cartas

Sverdlik Salomon (Suc.), contrato, plano, notas

Tabacman Jaime, contrato, plano, notas

Tabacman Marcus, contrato, plano, cartas

Tabacman Moises, contrato, plano, cartas

Taffel Mark, contrato, plano, cartas
1903-1925

1896-1913

1904-1925

1895-1917

1904-24

1894-1921

1910

1896-1920

1909-1918

1901-1918

1918-1921

1896-1918

1902-15

1905-20

1896-1915

$1905-20$

1898-1920

1921-29

1895-1920

1896-1929

1903-1918

1896-1925

1900-23

1896-1921

1906-1922

1926-48

1896-1913

1908-27

1897-1922

$1895-1921$

1902-20

1907-31

1922-48

1908-28

1918

1900-1916

1906-23

1901-20

1895-1917

1896-1921

1910-34

1910-29

1901-17

1896-1921

1910

1896-1913

1902-22

1902-1918

1896-1915

1925

1904-1918

1894-1916

1918-31

1956-65

1894-1911

1907-26

1904-1925

1896-1925

1896-1923

1904-23

1894-1917

1901-15

1901-20
Reserva

Reserva 
5921 Mauricio 4989 Mauricio 3012 Mauricio 104 Mauricio 3050 Mauricio 5003 Mauricio 5014 Mauricio 3010 Mauricio 1998 Mauricio 6631 Mauricio 2037 Mauricio 2412 Mauricio 2430 Mauricio 6650 Mauricio 5018 Mauricio 110 Mauricio 2411 Mauricio 668 Mauricio 6625 Mauricio 3064 Mauricio 2427 Mauricio 3048 Mauricio 3059 Mauricio 2982 Mauricio 6675 Mauricio 5050 Mauricio 650 Mauricio 101 Mauricio 677 Mauricio 2002 Mauricio 6910 Moisesville

5134 Moisesville 4396 Moisesville 4282 Moisesville 958 Moisesville 888 Moisesville 2954 Moisesville 4434 Moisesville 3322 Moisesville 964 Moisesville 1273 Moisesville 2955 Moisesville 367 Moisesville 6933 Moisesville 5247 Moisesville 26 Moisesville 1063 Moisesville 4422 Moisesville 6810 Moisesville 5366 Moisesville 872 Moisesville 3030 Moisesville 2255 Moisesville 1900 Moisesville 1637 Moisesville 24 Moisesville 2252 Moisesville 366 Moisesville 896 Moisesville 5841 Moisesville 4152 Moisesville 580 Moisesville 6547 Moisesville 3093 Moisesville 3094 Moisesville 342 Moisesville
Tavosnanska Idel, promesa de venta y judicial

1923-1943

Teper Jaime, contrato, plano, notas

Tepper Nathan, contrato, plano, notas

$1903-1918$

Tesler Bencion, contrato, plano, correspondencia

Tesler Jacobo (Ex Krell Mauricio), contrato, plano, notas

$1900-20$

1912-29

$1903-23$

1901-1923

.

Tesler Samuel, contrato, plano, notas

Tocker Jacobo, contrato, plano cartas

Tokman Felix, contrato, plano, cartas

Trujman Adolfo, Escritura compra de lote

Uris Jose, contrato, plano

Vaserman (sin nombre part.), contrato

Viner Pincos, contrato

Volij Schulim, Escritura de lote

Wagmaister Froim, contrato, plano cartas

Wagmaister Natalio y Aron Tomas Manuel, contrato, plano

Wainfeld (sin nombre part.), contrato

Wainfeld Kolmen, contrato, plano

Waisman David, Escritura compra de lote

Weingast Marcos e Isidoro, contrato, plano, notas

Weinstein Abraham, contrato

Weinstein Bernardo, contrato, plano, notas

Weinstein Marcos, contrato, plano, notas

Weisman Marcos, contrato, plano, cartas

Weissman Isaac, Escritura de terreno, plano, notas

Wilder Lazar, contrato, plano, notas

Wilensky Leon, contrato, plano

$1901-1921$

$1896-1915$

$1903-20$

1911

1896-1920

1918

1920

1936

1896-1922

1918-31

1918

$1919-28$

1910

1896-1915

1920

1908-36

1901-23

$1896-1916$

1929

1896-1917

1901-13

1904-29

1921-29

1896-1920

Zablotzky lchiel, contrato, plano, cartas

Abadenky Leib, Wulfson W. y Isacson B. Suc., contrato de terreno, plano, notas (grupo Monigotes)

Abeliansky Benjamin, contrato, plano, notas

Aberbach Benjamin, contrato, plano, cartas

Ablin Adolfo, contrato, plano, notas

Abramson David B., contrato, plano

Abramson Mauricio, contrato, plano, correspondencia

Abramson Salomon, nota

Acosta Eliseo Transito, contrato

Adler Arthur, contrato, plano, notas

Adler Raul, contrato, plano, cartas

Adler Salo Siegfried, contrato, plano

Adler Tobias, contrato, plano, cartas

Ajun Leon, contrato, plano

Akoschnik Simon, contrato de terreno, plano, nota (grupo Zadok Kahn)

Albano Luis, contrato

Alberguer Hermann, planos, contratos

Alexenicer Mauricio y Ka+C3805ffman I., contrato, cartas

Alexinicer Salomon, contrato, plano, notas

Allasino Adolfo para Bocha Club, Escritura de terreno (Las Palmeras)

Allasino Adolfo, contrato

Alperovich Naum, contrato, plano, cartas

Alperovich Naum, contrato, plano, cartas

Alperstein Jacobo, contrato

Alperstein Jacobo, Salomon y Simon, contrato, plano, cartas

Alperstein Wulf, contrato, plano, cartas

Altberger Hermann, contratos, plano

Ambasch Abraham, contrato

Ambasch Abraham, contrato, plano, carta

Ambasch Abraham, contrato, plano, cartas

Ambasch Abraham, Escritura, Readquisición de la JCA

Ambasch Froim, contrato, plano, notas

Ambasch German Isidoro y Jaime, contrato, plano, correspondencia

Ambasch German, compra de solar, incompleto

Ambasch Herman, contrato, plano, notas

Ambasch Isidoro, contrato, plano, cartas

Ambasch Jaime, contrato, plano
1906-18

$1902-1928$

$1903-24$

$1905-28$

$1910-61$

$1943-59$

1966

1960

1938-58

$1931-58$

1940-51

1943-61

1943-59

$1906-28$

1948-1949

1956-65

1906-20

1896-1915

1950

1941-1949

1931-52

$1955-59$

1952

1900-25

$1902-46$

$1945-50$

1952

1895 - 1958 Reserva

1953-54

1954

1894-1926

1928-66

1916

$1907-29$

1953-60

1954-59
Reserva

Reserva

Reserva

De ensanche 
6712 Moisesville 1866 Moisesville 5942 Moisesville 5223 Moisesville 5763 Moisesville 5254 Moisesville 4432 Moisesville 6788 Moisesville

373 Moisesville 1200 Moisesville 5127 Moisesville 5767 Moisesville 5335 Moisesville 4389 Moisesville 2533 Moisesville 5350 Moisesville 5332 Moisesville 1599 Moisesville 6742 Moisesville 4186 Moisesville 6809 Moisesville 6917 Moisesville 3038 Moisesville 3031 Moisesville 952 Moisesville 5368 Moisesville 6608 Moisesville 970 Moisesville 6725 Moisesville 6610 Moisesville 4181 Moisesville 1634 Moisesville 3091 Moisesville 5239 Moisesville 5303 Moisesville 1624 Moisesville 5826 Moisesville 5388 Moisesville 6800 Moisesville 5700 Moisesville 1205 Moisesville 232 Moisesville 4145 Moisesville 6806 Moisesville 960 Moisesville 2951 Moisesville 225 Moisesville 5107 Moisesville

880 Moisesville 5908 Moisesville 1274 Moisesville 1287 Moisesville 5813 Moisesville 5933 Moisesville 895 Moisesville 6906 Moisesville

6064 Moisesville 1235 Moisesville 2755 Moisesville 5131 Moisesville 1275 Moisesville 1780 Moisesville 2947 Moisesville 163 Moisesville
Andelsman Sofia, Escritura de terreno (Las Palmeras)

1910

Arcavi Meyer y Abraham, contrato, plano, cartas

Areco Horacio y Enrique, contrato de arriendo, nota

$1925-27$

Argello Casimiro, contrato

Arnodo Jose, Ambrosio y Domingo, contrato, plano, nota

Arnolfo Pedro, contrato

Arredondo Lorenzo, contrato

Asociacion Israelita de Beneficencia y Culto, Escritura de terreno

(Las Palmeras)

Astore Evaristo, contrato, plano

Aurutzky Abraham, contrato, plano, cartas

Averbach Jacobo, contrato, plano, notas

Azaretzky Aron y Bernardo, contrato, plano, notas

Azaretzky Juan, contrato

Azaretzky Luis, comprobante de pago

Azaretzky Moises, contrato, plano, cartas

Azaretzky Salomon, contrato

Azaretzky Zelig y Koraj Jasquel, contrato, notas

Azeretzky Aron y Bernardo, cartas, plano

Azeretzky Froim, Juan y Selig, Escritura de terreno (Las Palmeras)

Azeretzky Jose y Froim, contrato, plano, cartas

Azeretzky Salomon, Escritura de terreno (Las Palmeras)

Azeretzky Zelig y Juan, contrato, terreno, plano, notas (grupo Bialistok)

Badrian Wilhelm y Martin, contrato, plano, cartas

Baer Kurt, contrato, plano, notas

Baer Moritz, contrato, plano, cartas

Balbin Ildefonso, contrato

Balestreri Segundo, Escritura de terreno (Virginia)

Ballbom Feliz, contrato, plano, cartas

Banquer Selig, Escritura de terreno (Las Palmeras)

Barberan Francisco N., Escritura de terreno (Virginia)

Barembaum Noemi R. Vda. de, plano, notas

Barg Berta Lerner de, contrato, plano, cartas

Barg Saie, contrato, plano, notas

Barg Samuel, contrato

Barg Samuel, contrato

Barg Samuel, contrato, plano, cartas

Barmaimon Mauricio, contrato, notas

Barreto Jose, contrato

Barreto Jose, Escritura de terreno (Las Palmeras)

Bartfeld Jacobo, contrato, plano, notas

Baruch Leon, contrato, plano

Basch Alfredo, contrato, plano

Bass Juan y Halperin Pedro, contrato, plano, cartas

Baudino Estela Castillo de, Escritura de terreno (Las Palmeras)

Baum Alfred, contrato, plano

Baum Clementin y Norberto y Arnoy y Mario, contrato, plano, notas

Baum Silvano, contrato, plano

Bebder Aizik, Nemirovsky Abraham Segal Marcos y Urinovsky

Samuel contrato, plano, notas

Becker Samuel, contrato, plano, cartas

Becman Jose, contrato de arriendo

Becman Jose, contrato, plano, cartas

Becman Julio, contrato, plano, cartas

Behrendt Manfred, certificacion de Sucesion

Behrendt Nathan-Manfred y Kurt , promesa de venta, notas

Beker Salomon, contrato, plano, cartas

Benado David y Jacobo, subdivisión a: Wangler Carlos; a Epstein A

e I. Teper; a Helman Luis, contrato de terreno, plano, notas (grupo 7)

Bender Aizik, contrato, notas

Bendersky Jaime, contrato, plano, cartas

Bercleid Selig, contrato, plano, cartas

Bercovitch Moises, contrato, plano, notas

Berelejis David, contrato, plano, cartas

Berezovsky Hertz y Bernardo, contrato, plano, cartas

Berinstein Isidoro, contrato, plano notas

Berkleid Selig, contrato, plano

$1905-25$

$1929-54$

1912-58
Reserva

1939-1946

1937-1956

1941-1944

1963

1961

1959

1913-40

1905-1938

1953-1956

1946-1947

1967

1925-58

1949-1950

1946-1952

1952-65

1931

1900-59

1949-52

1906-65

1939-60

1945-61

1941-58

1941-1944

1928

1939-67

1927

1966

1907-30

1922-47

1906-29

1947-1948

1944-1950

1922-54

1919-1939

1945-1951

1950

1902-1928

1909-41

1945-64

1909-32

1956

1945-62

1938-60

1961-64

1913-1935

1943-60

1948

1953-61

1945-60

llegible

1939-1945

1904-58

1913-41

1908

1907-40

1951-60

1909-1928
Reserva

Reserva

Reserva

Ensanche

(de ensanche)

Ensanche

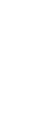


1782 Moisesville 5806 Moisesville

6551 Moisesville

6576 Moisesville 2626 Moisesville 862 Moisesville 3035 Moisesville 5329 Moisesville 5222 Moisesville 6820 Moisesville 3084 Moisesville 4440 Moisesville 1791 Moisesville 2625 Moisesville 2624 Moisesville 5932 Moisesville 4435 Moisesville 4190 Moisesville 1853 Moisesville 408 Moisesville 4164 Moisesville 5709 Moisesville 886 Moisesville 1039 Moisesville 6905 Moisesville 1285 Moisesville 2547 Moisesville 5255 Moisesville 351 Moisesville 893 Moisesville 6899 Moisesville 6750 Moisesville 5373 Moisesville 943 Moisesville 379 Moisesville 5268 Moisesville 2946 Moisesville 6745 Moisesville 6740 Moisesville 5233 Moisesville 5202 Moisesville 5353 Moisesville 967 Moisesville 6916 Moisesville 1640 Moisesville 1056 Moisesville 1793 Moisesville 4443 Moisesville 5282 Moisesville 5699 Moisesville 4409 Moisesville 567 Moisesville 6558 Moisesville 3324 Moisesville 1220 Moisesville 1777 Moisesville 5833 Moisesville 1788 Moisesville 5824 Moisesville 1193 Moisesville 1937 Moisesville 5868 Moisesville 1632 Moisesville 5133 Moisesville 6578 Moisesville
Berkman Meer, contrato, plano, cartas

$1901-27$

Berman Jacobo Suc. y Vda. de Berman, y Abraham, Martin y

1905-1954

Salomon, contrato, plano, notas y testimonios judiciales

Berman Mauricio y Torres Pio Jose, y Cornejo Apolinaria, Córdoba

Clotilde y Lipovetzky Marcos y Mandelbaum Israel, compra de solares 1943

Bernardo Boris, Escritura compra de terreno 1929

Berndt Benno, contrato, plano, cartas

Berndt Herbert, contrato, plano

Berndt Herbert, contrato, plano, cartas

Berrone Juan, contrato

Bertero Miguel, contrato

Bertolotti Pedro, Escritura de terreno (Las Palmeras)

Betzer Jacobo e Israel, contrato, plano, cartas

Bianchi Jose Mario, contrato

Bilik David, contrato, plano, cartas

Binder Leon, contrato, plano, cartas

Binder Salomon, contrato, plano, cartas

Binder Zize y Salomon, contrato de arriendo

Blahuta Miguel, contrato

Bleger Gershon, contrato, plano, cartas

Blejer Alter, contrato, plano, cartas

Blejer Benjamin, contrato, plano, carta

Bloj Jose, contrato, plano, cartas

Blum Federico, contrato

Blum Fritz o Federico, contrato, plano, cartas

Blumenfeld David, plano, cartas

Blumenfeld Luis, contrato de terreno, plano, notas (grupo Wavelberg)

lumenthal David, contrato, plano, cartas

Blumenthal Gustavo y Jose, contrato, plano, cartas

Bodello Francisco, contrato

Bodello Lorenzo, contrato, plano, correspondencia

Bodrero Emmy Katz de, contrato, plano, cartas

Bokser Alejandro, contrato de terreno, plano, nota (grupo Monigotes)

Bokser Eliezer, Escritura de terreno (Las Palmeras)

Bokser Luis, contrato

Bokser Luis, contrato, plano, cartas

Bokser Marcos, contrato, plano, carta

Bolo Juan J., contrato

Bonzi Pedro, contrato, plano, notas

Borenstein Samuel, Escritura de terreno (Las Palmeras)

Borgna Bartolome Juan, Escritura de terreno (Las Palmeras)

Borgonovo Norberta F. de, contrato

Borgonovo Teresa T. de, contrato

Borodovsky Motel, contrato

Borodovsky Rosa Garber de, contrato, plano, cartas

Boscoboinik Elias, contrato de terreno,plano, notas (grupo Monigotes)

Brauer Kurt, contrato, plano, cartas

Braunstein David, contrato, plano, cartas

Braunstein Leon y Minasnicoff, contrato

Brave Lucia Rosso de, contrato

Brener Isidoro, contrato, notas

Brestovitzky Jacobo y Raquel, contrato, plano, notas

Brestovizky Benjamin, Israel y Jacobo Suc., contrato, plano, notas

Briff Jose Sucesion, contrato, plano, notas, correspondencia

Brignone Antonio Jose, Escritura compra de terreno

Brufman Leon Mauricio, contrato, plano, notas

Brufman Mauricio y Bernardo, contrato, plano

Brufman Mauricio, contrato, plano, cartas

Brujis Aron y Luis, contrato

Brujis Elias, contrato, plano, cartas

Brujman Bernardo, contrato

Bublik Armando y Luis, contrato, plano, cartas

Bublik Jose, contrato, plano, cartas

Burman Samuel, contrato, plano, notas

Busel Jose, contrato, plano, cartas

Busel Moises, contrato, plano, notas

Bussone Andres, Escritura compra de terreno
1939-67

$1958-59$

1949-60

1946-1952

1940-1944

1950

1905-29

1957

1901-29

1953-67

1953-67

1924-1941

1960

1910-24

1904-25

1950-56

1894-1932

1949

1947-58

1909-30

1926-42

1939-51

1955-64

1941-1948

1942-58

1938-54

1924-43

1935

1941-1947

1947-62

19459

1937-1941

1943-55

1930

1931

1947-1949

1945-1953

1950-1951

1929-56

1921-43

1938-48

1905-42

1949

1951

1942-1953

1905-1928

1895-1923

1900-14

1924

1907-47

1920-39

1905-35

1929-1931

1907-20

1927

1942-57

1902-20

1899-1957

1922-54

1904-1928

1929
Reserva

Reserva

Reserva

Reserva 
5380 Moisesville 1272 Moisesville 6056 Moisesville 5392 Moisesville 856 Moisesville 5743 Moisesville 5203 Moisesville 5744 Moisesville 6696 Moisesville 6803 Moisesville 5390 Moisesville 4305 Moisesville 6730 Moisesville 6790 Moisesville 5285 Moisesville 5391 Moisesville 1609 Moisesville 6776 Moisesville 4429 Moisesville 804 Moisesville 959 Moisesville 563 Moisesville 5772 Moisesville 6272 Moisesville 5263 Moisesville 3184 Moisesville 4397 Moisesville 5124 Moisesville

4398 Moisesville 5130 Moisesville 2545 Moisesville 5258 Moisesville 5357 Moisesville 3330 Moisesville 5345 Moisesville 3032 Moisesville 5228 Moisesville 900 Moisesville 5376 Moisesville

4442 Moisesville 5217 Moisesville 6553 Moisesville 1972 Moisesville 5370 Moisesville 3661 Moisesville 6560 Moisesville 6728 Moisesville 5374 Moisesville 5333 Moisesville 5298 Moisesville 2707 Moisesville 6014 Moisesville 3735 Moisesville 5218 Moisesville 1611 Moisesville 840 Moisesville 5208 Moisesville 5278 Moisesville 1047 Moisesville 6720 Moisesville 5927 Moisesville 3734 Moisesville 1829 Moisesville 6793 Moisesville 1878 Moisesville
Cabral Santiago, contrato

1943-1944

Caminer Fritz, contrato, plano, cartas

Caminer Fritz, contrato, testimonio

Carch Francisco, contrato

Caspari Hans, contrato, plano, cartas

Castelli Alfredo, contrato, plano, notas

Castillo German, contrato

Catena Domingo, contrato, plano, notas

Cattaneo Luis y Jose, Escritura de terreno, nota (Las Palmeras)

Cauda Dominga Roldan de, Escritura de terreno (Las Palmeras)

Cauda Felipe, contrato

Cauda Felipe, contrato, plano

Cauda Felipe, Escritura de terrenos (Las Palmeras)

Cauda Juan y Jose, Escritura de terreno (Las Palmeras)

Cavia Timoteo, contrato

Cavia Timoteo, contrato

Cejanovsky Naum, contrato, plano, cartas

Centro Las Palmeras Bochas Club, Escritura de terreno (Las Palmeras)

Chazarreta Benjamin Cruz, contrato

Chegoriansky Adolfo, contrato, plano

Ciocan Jacobo, contrato, plano, cartas

Ciocan Naum, contrato, plano carta

Cipolatti Aurelio C. y Juan V., contrato, plano, notas

Club Circulo de Monigotes, contrato

Club Deportivo de Virginia, contrato

Club Deportivo Las Palmeras, contrato, plano, notas

Cociovitch Jacobo, contrato, plano, notas

Cociovitch Naum, Kanzepolsky Yudel, y Daitch Moises, contrato, plano, notas

Cociovitch Noe, Naum y Moises, contrato, plano, cartas

Cohan David, contrato, plano, notas

Cohn Georg, contrato, plano, cartas

Cohn George, contrato

Cohn Herman, contrato, notas

Cohn Hermann, contrato, plano, cartas

Cohn Rodolfo, contrato

Cohn Rudolf, contrato, plano, cartas

Collino Miguel, contrato

Colodner Leon, contrato, plano

Comisión de Fomento de Las Palmeras, donación para Plaza

Pública (a perpetuidad)

Comisión de Fomento de Mosesville contrato

Comisión de Fomento de Palacios, contrato

Comisión de Fomento de Virginia, Escritura compra de terreno

Comisión de Fomento Las Palmeras, plano, notas

Comisión de Fomento, contrato

Comisión de Fomento, contrato, nota, plano

Consejo de Educación Provincial, Escritura compra de terreno

Consejo Nacional de Educación, Escritura de terreno (Las Palmeras)

Cooperadora Escuela Nacional No. 54, contrato

Cooperativa de Carne de Monigotes, contrato

Cooperativa de Ganaderos de Palacios, contrato

Cooperativa de Ganaderos Palacios Ltda., contrato, plano, cartas

Cooperativa de los Tamberos de Las Palmeras plano

Cooperativa de Tamberos de Virginia plano, nota

Cooperativa de Tamberos Unidos de Las Palmeras, contrato

Cooperativa de Tamberos, contrato, plano

Cooperativa Ganadera de Capivara Ltda., contrato, plano

Cooperativa Ltda. De Ganaderos de Palacios, contrato

Cooperativa Tamberos Unidos Algarrobal, contrato, nota

Corach Luis y Jaskel, contrato, plano, cartas

Corach Oscar, Escritura de terreno (Las Palmeras)

Cornejo Eloisa, contrato de arriendo

Cornejo Eloisa, contrato, plano

Cornejo Isaac, contrato, plano, cartas

Cosoy Jacinta W. de, Escritura de terreno (Las Palmeras)

Cosoy Leon, contrato, plano, cartas
1938-51

1953-1958

1944-1945

1937-60

1951-1956

1945-1946

1943-1956

1937-39

1954

1944-1946

1947

1930-35

1962

1942-1947

1950

1954-56 Reserva

1965

1960

1952-53

1940-62

1954-61

1943-1956

1941-1942

1940-1940

1967

1909-24

1908-1937

1898-

1904-1927

1938-67

1941-1948

1949-1956

1938-47

1948

1941-67

1946-1947

1943-51

1935

1954

1939-1945

1957

1966

1940-1941

1966-67

1931

1927

1946-1947

1946-1950

1945-1946

1956-58

1952

$1942-50$

1940-1945

1956

1953-54

1943-1948

1941-1946

1956-65

1928

1938-1943

1958

1936-60

1945

1904-26
Reserva

Reserva

Reserva

De reserva

Ensanche y reserva

Reserva

Reserva

Reserva

Reserva

Reserva

Reserva 
4417 Moisesville 1191 Moisesville 4188 Moisesville 5197 Moisesville 6819 Moisesville 6912 Moisesville

6931 Moisesville

5834 Moisesville 2615 Moisesville 5363 Moisesville 6780 Moisesville 1279 Moisesville 6562 Moisesville 4430 Moisesville 1875 Moisesville 1054 Moisesville 1868 Moisesville 5305 Moisesville 4408 Moisesville 4189 Moisesville 2652 Moisesville

6781 Moisesville 2915 Moisesville 5213 Moisesville 5544 Moisesville 4150 Moisesville 4418 Moisesville 5698 Moisesville 4153 Moisesville 1192 Moisesville 6756 Moisesville 6935 Moisesville

6892 Moisesville 5377 Moisesville 5219 Moisesville 922 Moisesville 2017 Moisesville 6774 Moisesville 5144 Moisesville 3078 Moisesville 3287 Moisesville 963 Moisesville 5486 Moisesville 946 Moisesville 1291 Moisesville 5543 Moisesville 5210 Moisesville 5274 Moisesville 938 Moisesville 731 Moisesville 956 Moisesville 5931 Moisesville 75 Moisesville 861 Moisesville 5770 Moisesville 2256 Moisesville 3095 Moisesville 1876 Moisesville 891 Moisesville 5928 Moisesville 972 Moisesville 858 Moisesville 5723 Moisesville
Costinovsky Salomon, contrato, plano, cartas

1904-28

Cremeria El Porvenir, contrato, plano, cartas

Crispin Elias, contrato, plano, notas

Crispin Valentin, contrato

Crispin Valentin, Escritura de terreno (Las Palmeras)

Daitch Aizik e Isaac, contrato de terreno, plano, notas (grupo La

Juanita)

Daitch Herz Jose, Israel y Moises, contrato de terreno, plano, notas (grupo Viriginia)

Daitch Jose y Socolsky Jaime, contrato

Dajtscher Jose y Fichtembaum Jose, contrato, plano, cartas

Davicino Modesto, contrato

Davicino Pedro M., Escritura de terreno (Las Palmeras)

Davidsohn Roberto, contrato, plano, cartas

Deportivo Futbol Club Virginia, Escritura compra de terreno

Destefanis Oscar R. y Elvira, contrato

Dlugovitzky Jaskel, contrato, plano, cartas

Dobry Jose, contrato, plano, cartas

Dobry Simje, contrato, plano, cartas

Dolinsky Bernardo, contrato, notas

Dolinsky Mauricio y Schaie y Boris, contrato, plano, cartas

Dolinsky Zoraj, contrato, plano, cartas

Donación de la J.C.A. al Estado Nacional Argentino en presencia del presidente Peron, contrato, plano

Donación para Escuela No. 744, Escritura de terreno (Las Palmeras)

Dr. Feigues Isaac, contrato, plano

Draghi Carlos, contrato

Driben Noe, contrato, plano, nota

Dubitzky Abraham e Hijo Moises, contrato, plano, cartas

Dubkovsky Moises, contrato, plano, notas

Dubrovsky Benjamin, contrato, plano, notas

Dubrovsky Hinda e hijos Israel y Leon, contrato, plano, cartas

Dubrovsky Marcos, contrato, plano

Dubrovsky Marcos, Escritura de terreno (Las Palmeras)

Dubrovsky Marcos, Moises y Boruj, contrato de terreno, plano notas (grupo Bialistok)

Ducach Abraham, contrato, plano, notas (grupo Mutchnik)

Dutruel Ricardo y Eduardo Suc., contrato

Dzieviatizky Rafael, contrato

Eidelman Nisel, contrato, plano, cartas

Eidelman Nissel y otros, plano, notas, Boleto de Compra

Elberg Ruth Marion Cohn de, Escritura de terreno (Las Palmeras)

Elfenbein Adolfo y Joison Gregorio, contrato, plano, notas

Elin Moises y Sebastian, contrato, plano, notas

Elkan Herman y Seiferheld, contrato, plano, cartas

Epelbaum Samuel, contrato, plano, cartas

Epstein Benjamin, contrato, notas

Epstein David, contrato, plano

Epstein Juan, contrato, plano, cartas

Epstein Max, plano, nota

Epstein Samuel, contrato

Epstein Samuel, contrato

Epstein Simon, contrato, plano, carta

Estado Nacional Argentino (Tiro Federal), contrato, plano

Faerverguer Hirsch, contrato, plano, cartas

Faerverguer Jose, contrato, plano

Fain Alfredo, contratos, plano

Fain Herman y Alfredo, contrato, plano, cartas

Fain Herman, plano, nota

Faingold Jacobo, contrato

Fainman Manuel y Daniel, contrato, plano, notas

Fainstein Abraham, contrato, plano, cartas

Farkas Abraham Isaac, contrato, plano, correspondencia

Farkas Abraham, contrato de arriendo, notas

Farkas Isidoro, contrato, plano, cartas

Farkas Raquel G. de e Hijos, contrato, plano, correspondencia

Farladansky Aizik y Kleinerman Mauricio, contrato, plano, notas
1944-57

Reserva

1915-32

$1945-1949$

1949

1926-62

1900-27

1920-1937

1948-57

1948-1950

1952-58

1938-48

1961

1960

1900-26

1912-40

1906-25

1944-1950

1894-1964

1905-24

1951

1960

1940-43

1940-1945

1907-1930

1900-26

1902-28

1904-1928

1900-26

1953-57

1929

1904-28

1906-29

1937-1954

1942-1945

1954-67

1964-66

1963

1905-1928

1900-27

1939-67

1936-53

1949-1957

1955-62

1913-67

1908-1930

1943

1941-1942

1954-63

1948

1931-53

1930-1954

1956-60

1939-65

1954-1956 Reserva

1952

1905-29

1904-26

1948-54

$1931-1945$

1927-54

$1900-52$

1904-1919
Reserva

Reserva

Reserva

Reserva

Reserva 
961 Moisesville 5307 Moisesville 4159 Moisesville 1203 Moisesville 5277 Moisesville 1204 Moisesville 5748 Moisesville 5111 Moisesville 5835 Moisesville 6930 Moisesville 1931 Moisesville 1895 Moisesville 6557 Moisesville 5331 Moisesville 1051 Moisesville 5109 Moisesville 5145 Moisesville 2835 Moisesville 3753 Moisesville 969 Moisesville 231 Moisesville 162 Moisesville 2254 Moisesville 5272 Moisesville 226 Moisesville

803 Moisesville 1065 Moisesville 4156 Moisesville 1053 Moisesville 4091 Moisesville 3488 Moisesville 5309 Moisesville 6577 Moisesville 1293 Moisesville 2528 Moisesville 5232 Moisesville 5289 Moisesville 5381 Moisesville 5935 Moisesville 5358 Moisesville 13 Moisesville 25 Moisesville 5236 Moisesville 6813 Moisesville 2251 Moisesville 5917 Moisesville 2620 Moisesville 3752 Moisesville 911 Moisesville 161 Moisesville 962 Moisesville 894 Moisesville 953 Moisesville 936 Moisesville 1289 Moisesville 3321 Moisesville 3034 Moisesville 1194 Moisesville 5837 Moisesville 1215 Moisesville 4151 Moisesville 942 Moisesville 2948 Moisesville 2238 Moisesville 1208 Moisesville 6748 Moisesville
Feierverger Salomon, contrato, plano, cartas

1934-62

Feigues Isaac, contrato, notas

Feitelovich Miguel Suc., contrato, plano, cartas

1944-1953

1900-32

1896-1941

1943-1945

1913-41

Feldman Gregorio, contrato

Feldman Gregorio, contrato, plano

Feldman Gregorio, contrato, plano, nota

Feldman Julio, contrato, plano, notas

Feldman Pedro, contrato

Feler Mauricio, contrato de terreno, plano, nota (grupo Mutchnik)

Felman Herman, contrato, plano, cartas

Felperin Salomon e Isaac, contrato, plano, cartas

Ferreira Pedro, Escritura compra de terreno

Ferrero Pedro, contrato

Fideleff Bernardo (ex Freiberg ludel), contrato, plano, cartas

Fideleff Bernardo, contrato, plano, notas

Fideleff Isaac, contrato, plano, notas

Fideleff Isaac, plano, Boleto de Compra/Venta

Fingerhut Cecilio, contrato

Fingerhut Cecilio, contrato, plano, cartas

Fingerhut Enrique, contrato, plano

Fingerhut Jaime David, contrato, plano

Fink Jacobo, contrato

Finkelstein Szmul, contrato, notas

Firman Samuel, contrato, plano, correspondencia, donación a la provincia

Firstemberg Jaime M., contrato, plano, notas

Fischer Leon, contrato, plano, cartas

Fischman Benzion e hijos y Waxemberg Luis, contrato, plano, notas

Fistein Jaime, plano, carta

Fistemberg Jaime Marcos, contrato

Fixman Samuel Mauricio, contrato, plano, cartas

Fixman Samuel, contrato

Flis Mateo, Escritura compra de terreno

Fogel Dora Vda. De Wolff Fogel, contrato, plano, cartas

Fogel Wolff, contrato, plano, cartas

Franco Domingo, contrato

Franco Domingo, contrato

Franco Domingo, contrato

Frank Alex, contrato de arriendo, nota

Frank Alex, contrato, nota

Frank Ludwig, contratos arriendo, planos

Frank Ludwig, contratos, plano

Franzotti Pedro C., contrato

Franzotti Pedro, Escritura de terreno (Las Palmeras)

Fridman Flora, contrato

Fridman Flora, judicial

Fritzler Bernarado y Cohn Werner contrato, plano, cartas

Fritzler Bernardo y Cohn Werner, contrato

Fritzler Gunther, contrato, plano, cartas

Fritzler Jorge, contrato, plano

Fritzler Julius y Fritzler Walter, contrato, plano, cartas

Fritzler Maximo y Esteban, contrato, plano, cartas

Fritzler Paul y Fritzler Arnold, contrato, plano, cartas

Froimovich Gentil, contrato, plano, carta

Gabay Adolfo y Samuel, contrato, plano, cartas

Gabay Isaac, contrato, plano, cartas

Gabay Luis o Leon, contrato, plano, cartas

Gabay Santiago, contrato, plano, cartas

Gabay Schaye, contratos

Gaisinsky Meer, contrato, plano, cartas

Galagovsky Abraham, contrato, plano, cartas

Galagovsky David, contrato, plano, cartas

Galagovsky Israel y Jacobo, contrato, plano

Galagovsky Moises, contrato

Galagovsky Sucesion y Abraham, contrato, plano, cartas

Galeano Rufino, Escritura de terreno (Las Palmeras)
Reserva

1896-1927

1940

$1921-27$

$1907-20$

$1900-25$

1934

1946-1948

1909-34

1920-1936

$1905-1928$

1931-32

1966

1922-57

1961-64

1953-59

1952

1952-1957

1953-64

1939-53

1908-20

1907-31

1913-34

1938-61

1967

1945-1948

1929

1951-62

1940-67

1946-1951

1942-1946

1942-1943

1942-1953

1949-1953

1941-59

1953-59

1946-1950

1953

1953

1951

1946-67

1966

1939-65

1954-59

1949-62

1945-65

1943-67

1952-64

1944-67

1923-60

1906-61

1944-57

1921-1940

1926-39

1906-26

1954-62

1926-54

1963

1898-1940

1929
Reserva

Reserva

Reserva

Reserva 
730 Moisesville 2890 Moisesville 5334 Moisesville 5570 Moisesville 6796 Moisesville 6937 Moisesville 6716 Moisesville 5297 Moisesville 6564 Moisesville 4149 Moisesville 4192 Moisesville 5549 Moisesville 1046 Moisesville 857 Moisesville 885 Moisesville 897 Moisesville 3106 Moisesville 5279 Moisesville 5275 Moisesville 6824 Moisesville 5367 Moisesville 4306 Moisesville 4161 Moisesville 1626 Moisesville 6747 Moisesville 2529 Moisesville 3325 Moisesville 2546 Moisesville 5557 Moisesville 5349 Moisesville 72 Moisesville 3086 Moisesville 892 Moisesville 780 Moisesville 5295 Moisesville 2939 Moisesville 6691 Moisesville 6921 Moisesville

5153 Moisesville 6938 Moisesville 1636 Moisesville 5394 Moisesville 5395 Moisesville 5306 Moisesville 5941 Moisesville 5341 Moisesville 5142 Moisesville 355 Moisesville 4410 Moisesville 583 Moisesville 5926 Moisesville 5110 Moisesville 5923 Moisesville 6550 Moisesville 6761 Moisesville 5906 Moisesville 5231 Moisesville 6552 Moisesville 5195 Moisesville 3754 Moisesville 4191 Moisesville 805 Moisesville 1894 Moisesville 6758 Moisesville 5204 Moisesville 3320 Moisesville
Ganaderos Unidos, contrato, plano, carta

Ganaderos Unidos, contrato, plano, cartas

Gandino Antonio y Alejandro, contrato

Garbulsky Benjamin, plano, cartas

Garbulsky Isaac, Escritura de terreno (Las Palmeras)

Garbulsky Matus Suc., contrato de terreno, plano, notas (grupo 4)

Garello Juan, Escritura de terreno (Las Palmeras)

Garnes Alberto, contrato

Gdack Lorenzo, Escritura compra de terreno

Gelbard abraham, contrato, plano, cartas

Genzelovich Adolfo, contrato, plano cartas

Genzelovich Adolfo, Samuel y Tobias, contrato, plano, notas

Genzelovich Samuel, contrato, plano

Gerson Abraham, contrato, plano, notas, cartas

Gerson Menno Alberto, contrato, plano, cartas

Gerson Meno Alberto, contrato, plano

Gerson Moritz y Herman, contratos, planos, cartas

Ghione Jose A., contrato

Gianelli Francisco, contrato

Gianti Sabastian, Escritura de terreno (Las Palmeras)

Gigena Silvestre, contrato

Gille Miguel y Domingo, contrato, plano

Glasberg Abraham y Suc. Cecilio, contrato, plano, cartas

Glasman Hirsch y Jose, contrato, plano, cartas

Glassman Paulina F. de, Escritura de terreno (Las Palmeras)

Glaz Jaime, contrato, plano, cartas

Glaz Jaime, contrato, plano, cartas

Glembotzky Isaac, contrato, plano, cartas

Glombovsky Jacobo, contrato, plano, notas

Glukman Gregorio, contrato

Glukman Gregorio, contrato, plano

Glukman Manuel y Leon, contrato, plano, cartas

Gojberg Rosa, contrato, plano, cartas

Goldberg Manuel, contrato, plano, correspondencia

Goldberg mauricio T., contrato, nota

Goldberg Tomas Mauricio, contrato, plano, cartas

Goldemberg Moises, Escritura de terreno

Goldenstein Fanny transfiere a Slepoy Bernardo y Dora, contrato de terreno, plano, nota-judicial

Goldin Bernardo, contrato, plano, notas

Goldin Guerschon, contrato de terreno, plano, notas (grupo Monigotes)

Goldin Hirsch y Prilik Abraham, contrato, plano, cartas

Goldin Hirsch, contrato

Goldin Miguel, contrato

Goldin Nice, contrato

Goldin Nice, contrato de arriendo

Goldin Nice, contrato, notas

Goldin Selman, contrato, plano, notas

Goldman Jose, contrato, plano

Goldstein Abraham, contrato, plano, cartas

Goldstein Dora Szabo de, contrato,plano, cartas

Goldstein Max, contrato de sucesion y arriendo

Goldstein Mendel, Jacobo y Reuben, contrato, plano, notas

Goldstein Moritz, plano, contrato

Goldvaser Bernardo, Escritura compra de terreno

Goldwaser Bernardo, Escritura de terreno (Las Palmeras)

Golstein Arturo, ensanche de chacra

Gonchar Jaime, contrato

Gonzalez Felipe, Escritura compra de terreno, Incompleta-ilegible

Gonzalez Mateo, contrato

Gooperativa Ganaderos de Palacios, contrato, plano

Grad David, Jaikel e Israel, contrato, plano, notas

Grad Hirsch y Faivel, contrato, plano

Grad Hirsch, contrato, plano, cartas

Grad Hirsch, Escritura de terreno (Las Palmeras)

Grande Domingo, contrato

Grinberg Pedro y Leon, contrato, plano, cartas

$\begin{array}{ll}1948 & \text { Reserva } \\ 1939-40 & \text { Reserva } \\ 1946-1949 & \\ 1909-1930 & \\ 1947 & \\ 1898-1927 & \\ 1936 & \\ 1943-1944 & \\ 1929 & \\ 1900-26 & \\ 1900-24 & \\ 1901-1932 & \\ 1909-27 & \\ 1946-59 & \\ 1955-56 & \\ 1938-51 & \\ 1900-60 & \\ 1943-1947 & \\ 1942-1948 & \\ 1951 & \\ 1941-1944 & \\ 1938-48 & \\ 1896-1932 & \\ 1907-47 & \\ 1929 & \\ 1958-65 & \\ 1934-59 & \\ 1945-60 & \\ 1898-1915 & \\ 1949-1950 & \\ 1951-59 & \\ 1900-29 & \\ 1915-54 & \\ 1928-63 & \\ 1942-1950 & \\ 1942-56 & \text { Reserva } \\ 1925-28 & \\ \end{array}$

1904-28

1941-1952

$1905-28$

$1901-46$

$1935-1040$

1937-1948

1936-1952

1936-1944

$1946-1950$

1905-1928

1959

1900-24

$1954-64$

1938-1951

1905-1936

1938-1947

1937

1928-64

1947-1949

1932-1949

1937

1944-1946

1942

1900-24

1952

1908-21

1929

1945-1947

1931-59

Reserva
Reserva

Reserva 
6897 Moisesville 1058 Moisesville 6757 Moisesville 1784 Moisesville 4412 Moisesville 1639 Moisesville 4423 Moisesville 5292 Moisesville 2837 Moisesville 950 Moisesville 374 Moisesville 1 Moisesville 5267 Moisesville 3088 Moisesville 6717 Moisesville 3089 Moisesville 6907 Moisesville

6920 Moisesville

1785 Moisesville 3087 Moisesville 6889 Moisesville 4068 Moisesville 4406 Moisesville 6048 Moisesville 5385 Moisesville 6902 Moisesville

1214 Moisesville 5211 Moisesville 5327 Moisesville 4287 Moisesville 6733 Moisesville 2787 Moisesville 2859 Moisesville 1286 Moisesville 1270 Moisesville 6703 Moisesville 1283 Moisesville 4142 Moisesville 879 Moisesville 4419 Moisesville 2618 Moisesville 6762 Moisesville 2882 Moisesville 5924 Moisesville 5561 Moisesville 937 Moisesville 1489 Moisesville 5318 Moisesville 2888 Moisesville 6759 Moisesville 228 Moisesville 3289 Moisesville 5558 Moisesville 1889 Moisesville 6913 Moisesville

3085 Moisesville 5135 Moisesville 3285 Moisesville 2910 Moisesville 5198 Moisesville 1781 Moisesville 5562 Moisesville 864 Moisesville
Grines Jacobo e Israel, contrato, plano, notas

$1906-29$

Grinfeld Aisik, contrato, plano, cartas

Grobek Leon, Escritura de terreno (Las Palmeras)

Groberman Salomon y Mauricio, contrato, plano, cartas

Grosvald Aron Hersch, contrato, plano, notas

Grosvald Boris, Abraham y Salomon, contrato, plano, cartas

Grosvald Ire, contrato, plano, cartas

Grosvald Mauricio, contrato

Grosvald Mauricio, contrato, plano

Grunwald Juan y Margaretee Schaul, contrato, plano, cartas

Grunwald Juan, contrato, plano

Grunwald, Alfred, contratos, arriendo, correspondencia

Guelbert Akive, contrato, notas

Guelbert Akive, contrato, plano, notas

Guelbert Akive, Escritura de terreno

Guelbert David y Nathan, contrato, plano, notas

Guelier Schloime transfiere a Yedlin Mauricio y Horovitz Jacobo, contrato de terreno, plano, notas (grupo 9)

Guenzelovich Abraham Moises, contrato de terreno, plano, nota (grupo Zadok Kahn 4)

Guerchanik Ida Schmulevich de, contrato, plano, cartas

Guestrin Jose, Hirsch y Sebastian, contrato, plano, cartas

Guestrin Sebastian, contrato, plano, notas (grupo Monigotes)

Guglielmone Pedro y Francisco, contrato, plano, notas

Gutman Abraham Suc., contrato, plano, notas

Gutman Abraham y Marcos, plano

Gutman Abraham, contrato

Gutman Isaac transferido de Gorbat Moses, contrato de terreno

(grupo Monigotes)

Gutman Isaac y Jose, contrato, plano, cartas

Gutman Isaac, contrato

Gutman Isaac, contrato, notas

Gutman Isaac, contrato, plano, cartas

Gutman Isaac, Escritura de terreno (Las Palmeras)

Gutman Samuel, contrato

Halperin Abraham, notas, plano

Hammerschlag Julio, contrato, plano, cartas

Hammerschlag Julius, contrato, plano, cartas

Hardy . . . . ?, Escritura de terreno (Las Palmeras)

Harf Bernardino y Heriberto : contrato, plano, cartas

Hecht Jose, contrato, plano, cartas

Heiman Ludwig y Manfredo, contrato, plano, cartas

Heller Pinjos, contrato, plano, cartas

Helman Jose, contrato, plano, cartas

Helman Luis, Escritura de terreno (Las Palmeras)

Henesch Israel, contrato, plano, cartas

Hengel Enrique, plano, contrato

Henin Meilach, contrato, plano, notas

Hertzfeld Herbert y Eva Ciocan de, contrato, plano, carta

Hilsenrath Benzion, contrato, plano, cartas

Hilsenrath Moises A., contrato

Hilsenrath Moises, contrato, plano, cartas

Hindelman Pedro, Escritura de terreno (Las Palmeras)

Hirschhaut Berisch, contrato, plano, correspondencia

Holand Leiba, contrato, plano, notas

Horovitz Abraham, contrato, plano, notas

Horovitz Naum, contrato, plano, cartas

Husman Teodoro y Adolfo, contrato de terreno, plano, notas (grupo

La Juanita y Monigotes

Indelman Pedro y Rubin, contrato, plano, notas

loschpe Jose, contrato, plano, notas

loscowicz Uszer, contrato, plano, cartas

Isaacson Saul y Rufino, contrato, plano

Isaacson Saul, contrato

Isakson Berl y Saul, contrato, plano, carta

Itzko Abraham, contrato, plano, notas

Jacobs Bendix, contrato, plano, cartas
$1905-20$

1929

$1907-27$

1901-21

1902-46

1907-28

1943-1949

1949

1945-61

1956-58

1941-50

1931-1952

1909-29

1936

1956-65

Reserva

Reserva

1909-42

1901-28

1908-27

1906-29

1928-20

1953-61

1894-1923

1929

1943-1944

1908-43

1909-39

1943-1944

1935-1952

1904-28

1934

1945

1937

1949-64

1940-48

1911

1938-67

1909-33

1939-51

1909-28

1948-67

1928

1939-54

1938-1951

1905-1918

1963-72

1938-46

1945-1946

1948-58

1928

1953-64

1923-49

1896-1915

1906-25

1935-67

1894-1929

1909-1938

1925-58

1940

Reserva

1945-1948

1911-27

1904-1918

1938-61
Reserva

Reserva 
947 Moisesville 5316 Moisesville 939 Moisesville 18 Moisesville 17 Moisesville 5227 Moisesville 6816 Moisesville 6692 Moisesville 5139 Moisesville 572 Moisesville 579 Moisesville 1905 Moisesville 6047 Moisesville 1209 Moisesville 5102 Moisesville 4436 Moisesville 1276 Moisesville 971 Moisesville 5256 Moisesville 2914 Moisesville 2259 Moisesville 4146 Moisesville 4393 Moisesville 1933 Moisesville 5054 Moisesville 904 Moisesville 5336 Moisesville 5940 Moisesville 878 Moisesville 5126 Moisesville 5354 Moisesville 5301 Moisesville 1932 Moisesville 1903 Moisesville 1886 Moisesville 6887 Moisesville 4171 Moisesville 5241 Moisesville 6814 Moisesville 6929 Moisesville 5151 Moisesville 5118 Moisesville 3326 Moisesville 5101 Moisesville 3751 Moisesville 5550 Moisesville 69 Moisesville 5149 Moisesville 5326 Moisesville 4427 Moisesville 4184 Moisesville 2621 Moisesville 1883 Moisesville 1223 Moisesville 1940 Moisesville 1225 Moisesville 1947 Moisesville 6699 Moisesville 76 Moisesville 573 Moisesville 1949 Moisesville 909 Moisesville 5721 Moisesville 4092 Moisesville 4155 Moisesville 865 Moisesville 3715 Moisesville
Jacobsohn Johanna Z. Vda. de, contrato, plano, cartas

1951-62

Jait Leizer, contrato

Jakobs Siegfried, contrato, plano, cartas

Jakomovsky Jaime, contratos, plano

Jakomovsky Jaime, contratos, plano

Jarovsky David, contrato

Jarovsky Jacobo, Escritura de terreno (Las Palmeras)

Jarovsky Jose, Escritura de terreno

Jarovsky Kadish, contrato, plano, notas

Jarovsky Samuel Wolff, contrato, plano, carta

Jarovsky Wolff (Sucesion), carta

Jarowsky Marcos y Sofia, contrato, plano, cartas

Jarowsky W. Sucesion, planos

Jeifetz Adolfo, contrato, plano, cartas

Jeison Moises, contrato, plano, notas

Jeremias Alberto, contrato, nota

Jeremias Alberto, contrato, plano, cartas

Jeremias Calman, contrato, plano, cartas

Jeremias Jose, contrato

Jevra Kadischa, contrato, plano

Jevra Keduscha, contrato

Jmelnitzky Benjamin, contrato, plano, notas

Joison Alter, contrato, plano, notas

Joison Judel, contrato, plano

Jonas Jose, cancelacion de hipoteca

Jonas Josef contrato, plano,

Joscovich Uscher, contrato

Jotomliansky Adolfo, contrato de arriendo

Junguer Simon, contrato, plano, correspondencia

Kaller Ana H. de, contrato, plano, notas

Kaller Bernardo, Dosoretz Salomon y Teitelbaum Moises, contrato

Kaller Bernardo, contrato

Kaller Boris y Mario, contrato, plano, cartas

Kaller Tobias, contrato, plano, cartas

Kamenetzky Jaime, contrato, plano, cartas

Kamenetzky Jose, contrato, plano, nota (grupo Zadok Kahn)

Kamenetzky Leon, plano, notas

Kamenetzky Samuel, contrato

Kamenetzky Samuel, Escritura de terreno (Las Palmeras)

Kamin Peisaj, contrato de terreno, plano, notas (grupo 6)

Kamin Salomon, contrato, plano, notas

Kamin Tobias, contrato, plano, notas

Kaminker Jacobo, contrato, plano, notas

Kanaskevich Israel, contrato, plano, notas

Kansepolsky Nissim Naum, contrato

Kanter Abraham, Meer y Jose, contrato, plano, nota

Kantor David, contratos, plano

Kantor Zundel, contrato, plano, notas

Kanzapolsky Yudel, contrato

Kanzepolsky Abraham, Trumper Nosen, contrato

Kanzepolsky Moises, plano, notas

Kanzepolsky Nisim Naum, contrato, plano, cartas

Kanzepolsky Yudel, contrato, plano, cartas

Kaplan Aizik, contrato, plano

Kaplan Aizik, contrato, plano, cartas

Kaplan Bernardo y Natalio, contrato, plano, cartas

Kaplan David y Abraham, contrato, plano, cartas

Kaplan Enrique, Escritura de terreno

Kaplan Herman y Marcos, contrato, plano

Kaplan Herman, contrato, plano, correspondencia

Kaplan Jacobo, contrato, plano, cartas

Kaplan Moises, contrato, plano, correspondencia

Kaplan Pincus, contrato, plano, notas

Kaplan Pincus, Noe y otros, contrato

Kaplan Schulem, contrato, plano, cartas

Kaplinsky Clara Schaltz de e Hijos, contrato, plano, cartas

Karlen Abelino Antonio, contrato, notas
1945-1946

1954-62

1952-58

1938-59

1942-1948

1948

1925-27

1905-1938

1901-61

1908

1896- 1925

1928

1925-40

1921-1928

1954-1956

1931-57

1936-53

1940-1944

1939-40

1954

1908-32

1900-24

1905-20

1965

1938-62

1932-1946

1935-1944

1940-56

1904-1936

1950-1951

19441953

1953-60

1903-25

1909-26

1903-29

1910-30

1947-1950

1952

1904-27

1904-1928

1928

1935-48

1904-1928

1966

1900-1932

1933-60

1908-1928

1935-1948

1966

1910-30

1957

1900-26

1900-39

1907-19

1931-39

1895-1951

1907-32

1906-60

1909-60

1903-22

1930-51

1903-1919

1943-62

1894-1919

1945-52

1946-55

Reserva

.


874 Moisesville 825 Moisesville 6351 Moisesville

3 Moisesville 1631 Moisesville 67 Moisesville 5697 Moisesville 1281 Moisesville 951 Moisesville 588 Moisesville 945 Moisesville 6718 Moisesville 867 Moisesville 2753 Moisesville 578 Moisesville 6016 Moisesville 1064 Moisesville 1206 Moisesville 1946 Moisesville 6066 Moisesville 1961 Moisesville 375 Moisesville 3292 Moisesville 5346 Moisesville 6063 Moisesville 1852 Moisesville 6807 Moisesville 4391 Moisesville 5120 Moisesville 1218 Moisesville 5943 Moisesville 887 Moisesville 6738 Moisesville 1934 Moisesville 5106 Moisesville 1622 Moisesville 6755 Moisesville 6792 Moisesville 1038 Moisesville 2881 Moisesville 372 Moisesville 957 Moisesville 6801 Moisesville 1280 Moisesville 944 Moisesville 158 Moisesville 2562 Moisesville 5246 Moisesville 5299 Moisesville 6822 Moisesville 3329 Moisesville 2534 Moisesville 5141 Moisesville 5799 Moisesville 2098 Moisesville 4401 Moisesville 74 Moisesville 965 Moisesville 6815 Moisesville 5375 Moisesville 1778 Moisesville 6811 Moisesville 1865 Moisesville 1873 Moisesville 6802 Moisesville 586 Moisesville
Kartun Paulina B. de y Kartun Jose, contrato, plano, cartas

Kartun Perlina Briff de e hijos, contrato, plano, notas

Katz Abraham y Montagna Jorge, Juan, Laureano, contrato de compra de lotes, plano, escritura

Katz Abraham, contratos (Monigotes)K

Katz Alfredo, contrato, plano, cartas

Katz Daniel Israel

Katz Ezequiel, Juda, Peisach y Esther, contrato, plano, notas

Katz Guillermo, contrato, plano, cartas

Katz Gustav y Nussbaum Manfred, contrato, plano, cartas

Katz Isidoro, contrato, plano, carta

Katz Natalio, contrato, plano, cartas

Katz Peisach, Escritura de terreno (Las Palmeras)

Katzenellbogen Juan, contrato, plano, cartas

Katzenellbogen Ludovico, contrato, plano, cartas

Katzenellboguen Heriberto, contrato, plano, carta

Katzenellenbogen Heriberto, plano

Kauffman Sosie, contrato, plano, carta

Kaufman Elias y Luis, contrato, plano, cartas

Kaufman Luis y Elias, contrato, plano, cartas

Kavinovsky Chaim, contrato de arriendo, nota

Khaler Boris, contrato, plano, cartas

Khon Luis, contrato, plano, carta

Kirschberg Helmut, contrato, plano, notas

Kirschberg Herman, contrato

Kirschberg Herman, contrato, notas

Kischitsky Jose, Rodolfo y Juolio contrato, plano

Kischitzky Julio, Escritura de terreno (Las Palmeras)

Kivatinetz Benjamin, contrato, plano cartas

Kivatinetz Simon, contrato, plano, notas

Klas Aron, Bernardo y Juan, contrato, plano

Klass Juan, contrato de arriendo, notas

Klein Sally, contrato, plano, cartas

Kleinerman Abraham Mauricio, Escritura de terreno (Las Palmeras)

Kleinerman Judel, contrato, plano, cartas

Kletzky Marcos y Salomon, contrato, plano, notas

Kletzky Mauricio, contrato, plano, cartas

Kletzky Mauricio, Escritura de terreno, ilegible (Las Palmeras)

Kletzky Mauricio, Escritura de terreno, ilegible (Las Palmeras)

Kogan Elias, contrato, plano, cartas

Kohan David, Jaime y Berta, contrato, plano

Kohan Isaac, contrato, plano, carta

Kohan Jacobo, contrato, plano

Kohan Jacobo, Escritura de terreno (Las Palmeras)

Kohan Samuel, contrato, plano, cartas

Kohen Moises, contrato, plano, cartas

Kohl Wilheim Rudolf y Guillermo, contrato, plano

Kohl Wilhelm y Neter Paul, contrato

Kohn Alberto, contrato

Kohn Alberto, contrato

Kohn Alberto, Escritura de terreno (Las Palmeras)

Kohn Luis y Kohan Leib, contrato, plano, notas

Kohn Moises, contrato, plano, cartas

Kohon Abraham, contrato, plano, notas

Kohon Gregorio, Luis y Marcos, contrato, plano, notas

Kohon Moises, contrato, plano, cartas

Koifman Marcos, contrato, plano, notas

Koloditzky Mendel Suc., contrato, plano

Konigheim Gustav y Konigheim Max Julius, contrato, plano, cartas

Kopelman Isaac, Escritura de terreno (Las Palmeras)

Kopelman Jose, contrato

Kopelman Jose, contrato, plano, cartas

Kopelman Jose, Escritura de terreno (Las Palmeras)

Kopelman Seiman, contrato, plano, cartas

Koraj Jaskel, contrato, plano, cartas

Koraj Jasquel, Escritura de terreno (Las Palmeras)

Koraj Rajmiel, contrato, plano
1906-56

1928-52

1961-1962

Reserva 715

1929-52

1938-58

1953-60

1904-1928

1947-62

$1942-58$

1951-60

1954-62

1921

1946-62

1955-63

1951-67

1961

1896-1920

1907-40

1908-21

1908-1939

1907-67

1948-58

1938-60

1948-1949

1954-1956

1902-58

1962

1956-58

1894-1924

1905-39

1937-1944

1939-67

1931

1906-20

1928

1919-42

?

1945

1905-29

1904-50

1952-58

1926-53

1954

1952-67

1955-62

1938-59

1959

1948-1949

1944-1945

1950

1927-47

1953-67

1927-1949

1906-1926

1945-59

1907-23

1931-61

1938-56

1947

1943-1945

1912-35

1948

1903-26

1920-26

1954

1952-60
Reserva

Reserva

Ensanche 
1936 Moisesville 4180 Moisesville 5180 Moisesville 568 Moisesville 575 Moisesville 566 Moisesville 5552 Moisesville 955 Moisesville 6888 Moisesville 2751 Moisesville 5291 Moisesville 6721 Moisesville 569 Moisesville 159 Moisesville 1498 Moisesville 1884 Moisesville 5312 Moisesville 574 Moisesville 1222 Moisesville 77 Moisesville 5356 Moisesville 4194 Moisesville 15 Moisesville 5055 Moisesville 14 Moisesville 12 Moisesville 1645 Moisesville 6707 Moisesville 2432 Moisesville 4414 Moisesville 828 Moisesville 859 Moisesville 2250 Moisesville 4439 Moisesville 5300 Moisesville 5317 Moisesville 4093 Moisesville 2628 Moisesville 2258 Moisesville 4193 Moisesville 1035 Moisesville 4445 Moisesville 5379 Moisesville 4147 Moisesville 863 Moisesville 3286 Moisesville 2956 Moisesville 2543 Moisesville 1282 Moisesville 1929 Moisesville 5766 Moisesville 1635 Moisesville 6926 Moisesville

5264 Moisesville 949 Moisesville 5925 Moisesville 3318 Moisesville 5762 Moisesville 6914 Moisesville

921 Moisesville 5359 Moisesville 1288 Moisesville 2609 Moisesville 6695 Moisesville 1059 Moisesville
Korin Getze e hijo, contrato, plano, cartas

$1909-20$

Korn Adolfo, contrato, plano, notas

Korn Feivel, contrato, plano, notas

Koss Luis y Mauricio, contrato, plano, carta

Koss Pedro Simon, contrato

Koss Pedro, Isidoro, David y Maria

Kotliarevsky Moises y David, contrato, plano, nota

Kotliarsky Julio, contrato, plano, cartas

Kovatinitz Salomon, contrato, plano, notas (grupo Monigotes)

Kowalsky Herbert y Sra., contrato plano, cartas

Kowalsky Herbert, contrato

Kreinin Herman, Escritura de terreno (Las Palmeras)

Kremer Aron y Alberto, contrato, plano, carta

Kritzler Karl Manfred, contrato, plano

Krupick Benjamin, contrato, plano, cartas

Krupick Simje, contrato, plano, cartas

Krupik Fanny F. S. de, contrato

Krupik Moises, contrato, plano, carta

Krupik Pablo, contrato, plano, cartas

Krupik Samson, contrato, plano

Krupnik Isaac y Saul, contrato, notas

Krupnik Isaac y Saul, plano, nota

Krupnik Itzko, contratos, plano

Krupnik Saul, cancelacion de hipoteca

Krupnik Saul, correspondencia, contratos

Krupnik Saul, planos

Kulemeyer Julius, contrato, plano, cartas.

Kunin Ana Goldin de, Escritura de terreno

Kurdobrin Leon, contrato

Kurdobrin Leon, contrato, plano, cartas

Kurman Isidoro y Moises, contrato, plano

Kurman Isidoro y Natalio, contrato, plano, cartas

Kurman Isidoro, contrato

Kurman Isidoro, contrato

Kurman Isidoro, contrato

Kurman Isidoro, contrato

Kurman Isidoro, contrato, notas

Kurman Isidoro, contrato, plano, cartas

Kurman Naum, contrato

Kusevitzky Aaron, contrato, plano, notas

Kuvischansky Leiser, contrato, plano, cartas

La Mutua Agricola Ltda., contrato, plano

Laizo Alfonso, contrato

Lapovsky Jacobo, contrato, plano, cartas

Laster Abraham y Fritz, contrato, plano, cartas

Laster Abraham, contrato, plano, notas

Laster Chaim, contrato, plano, cartas

Laster Meier Leib, contrato, cartas

Lebovic Abraham Hers, contrato, plano, cartas

Lebovici Yscher, contrato, plano, cartas

Leibovich Abraham, Hersch y Ernesto, plano, nota

Leibovich Catalina D. de, contrato, plano, cartas

Leibovich Esther Waintral Vda.de, contrato de terreno, plano, notas (grupo Zadok Kahn II)

Leibovich Jaime, contrato, notas

Leibovich Marcos, contrato, plano, cartas

Leibovich Moises, contrato de arrendamiento

Leibovich Samuel, contrato, plano, cartas

Leibovich Samuel, contrato, plano, notas

Lerner Bernardo, contrato de terreno, plano, notas y ensanche

(grupo Monigotes)

Leschinsky Boris, contrato, plano, cartas

Levi Cille, contrato

Levi Cilli Jacob Vda. De, contrato, plano, cartas

Levin Abraham, contrato, plano, cartas

Levin Elias, Escritura de terreno

Levin Faivel e Hijos, contrato, plano, cartas
$1925-58$

1906-1927

1952-60

1931-47

1928-60

1909-1963

1925-58

1920-29

1950-60

1943-1945

1928

1950-61

1950-59

1926-48

1904-26

1944-1948

1955-61

1898-1967

1952-59

1949-1956

1949-65

1929-60

1965

1950

1956

1938-67

1911

1919

1908-23

1907-67

1928-61

1953

1957

1944-1947

1945-1948

1959-6

1948

1949

1902-24

1908-29

1956-61

1942-1943

1900-27

1938-51

1938-46

1945-60

1940-49

1930-65

1913-20

1956-1956 Reserva

1922-41

1908-27

1944-1948

1953-62

1937-1945

1958-67

1956-1960

Reserva

1908-60

1944-67

1952-1955

1931-65

1948-67

1920-27

1898-1920
Reserva

Ensanche 
5944 Moisesville 1050 Moisesville 2242 Moisesville 3327 Moisesville 5 Moisesville 584 Moisesville 899 Moisesville 2244 Moisesville 6918 Moisesville 1236 Moisesville 890 Moisesville 576 Moisesville 5296 Moisesville 387 Moisesville 1603 Moisesville 913 Moisesville 2530 Moisesville 1610 Moisesville 1904 Moisesville 3750 Moisesville 6010 Moisesville 968 Moisesville 6614 Moisesville 2750 Moisesville 5257 Moisesville 1269 Moisesville 6709 Moisesville 1887 Moisesville 3082 Moisesville 778 Moisesville 3684 Moisesville 5338 Moisesville 5238 Moisesville 6817 Moisesville 6749 Moisesville 70 Moisesville 1207 Moisesville 6688 Moisesville 1779 Moisesville 2248 Moisesville 565 Moisesville

65 Moisesville 585 Moisesville 908 Moisesville 66 Moisesville 2249 Moisesville 4 Moisesville 1602 Moisesville 6898 Moisesville

1210 Moisesville 2953 Moisesville 5846 Moisesville 1794 Moisesville 6826 Moisesville 6611 Moisesville 1271 Moisesville 64 Moisesville 6808 Moisesville 3107 Moisesville 2619 Moisesville 5056 Moisesville 571 Moisesville 5915 Moisesville 2883 Moisesville 1201 Moisesville
Levin Jacobo, contrato de arriendo

$1931-1944$

evin Julio, ex Raschkovsky Hnos., contrato, plano, cartas

1906-34

Levin Moises Elias, contrato

Levin Moises Elias, contrato, plano, cartas

1958

$1942-59$

Levin Moises Elias, contratos, escrituras

$1952-59$

$1945-64$

Lin Salomon, contrato, plano, correspondencia

$1945-51$

1958

evin Vidal, contrato

Levin Vidal, contrato de terreno, plano, notas (grupo 9)

1944-67

1924-42

$1947-54$

Levinzonas Moze y Zlate Muze, contrato, plano, cartas

1909-71

Levisman Moises, contrato

Levisman Moises, contrato, plano

Levisman Natalio, contrato, plano, cartas

Levisman Pinjos, contrato, plano, cartas

Lew Sprinca R. de y Aba, contrato, plano, cartas

Lewin Artuhr, contrato, plano, cartas

Lewin Isaac, contrato, plano, cartas

Liberchuk Abraham y Jacobo, contrato

Liberchuk Jacobo y Abraham, plano

Liberchuk Jacobo, contrato, plano

Liberchuk Jacobo, Escritura de lote (Virginia)

Liberchuk Leiba y Marcos, contrato, plano, cartas

Liberchuk Marcos, contrato

Liberchuk Samuel Carlos y Moises, contrato, plano, cartas

Lichak Marcos, Escritura de terreno (Las Palmeras)

Lievenbuk Abraham, contrato, plano, cartas

Lifschitz Pinjos, contrato, plano, notas

Lifschitz Salomon, contrato, plano

Linares Dalmiro, contrato, plano, notas

Linguer Juan B., contrato

Lionetto Domingo, contrato

Lionetto Domingo, Escritura de terreno (Las Palmeras)

Lipchak Leon, Escritura de terreno (Las Palmeras)

Lipner Daniel y Berta Perl, contrato, plano

Liponetzky Salomon, contrato, plano, cartas

Lipsky Jacobo, Escritura de terreno (incompleto)

Lirman Israel, contrato, plano, cartas

Literat Ruben y Esther, contrato

Litvack Sofia Rosa Charne Rebeca y Catalina, contrato, planos, correspondencia

Litvak Guillermo Jacobo y Jaime, contrato , plano

Litvak Isaac, contrato, plano, carta

Litvak Leon, contrato, plano, cartas

Litvak Leon, contrato, planos

Litvak Manuel Benjamin, contrato, nota

Litvak Manuel Benjamin, contratos, facturas

Litvak Manuel y Benjamin, cartas, plano

Litvak Najman vende a Gregorio Gerschunof,el que transfiere a

Stein Rufino, contrato de terreno, plano, nota (grupo Mutchnik)

Locman Marien Suc., contrato, plano

Loschacoff Aron, contrato, plano, notas

Loschacoff Isaac Abraham, nota, Readquisición de la JCA

Loschacoff Moises, contrato, plano, cartas

Lovera Bernardo, Escritura de terreno (Las Palmeras)

Lovino Enzo Nicolas, Escritura de terreno (Virginia)

Lowenstein Bella y Julius Heinz, contrato, plano, cartas

Lowenstein Ernesto, contratos, plano, título propiedad

Lowenstein Ernesto, Escritura de terreno (Las Palmeras)

Lowenstein Pablo, cancelacion de hipoteca

Lowenstein Pablo, contrato, plano cartas

Lowenstein Siegbert, cancelacion de hipoteca

Lowenstein Siegbert, contrato, plano

Lowenstein Sigfried, solicitud

Lowenstern Julio y Bella, contrato, plano, cartas

Lublinsky Jacobo, contrato, plano, cartas
1943-1947

1958-60

1955-59

1953-65

1939-54

1938-46

$1907-25$

1966

1957

1957-61

1913

1944-60

1941-1946

1926-67

1910

1908-25

1902-27

1928-53

1966-67

1945-1948

1947-1948

1948

1929

1955-60

1905-41

1937

1908-35

1954

$1930-60$

1959-65

1952-60

1930-52

1900-60

1953

1954-74

1954

Reserva

Reserva

Reserva

1906-43

1906-40

1927-60

1963

1913-25

1952

1963

1951-67

1942-59

1965

1966

1953-61

1965

1953-62

1964

1940-51

1912-40 
3083 Moisesville 5571 Moisesville

5221 Moisesville 4283 Moisesville 5559 Moisesville 1941 Moisesville 6702 Moisesville 4425 Moisesville 5196 Moisesville 1789 Moisesville 4286 Moisesville 2245 Moisesville 4426 Moisesville 1043 Moisesville 6805 Moisesville 5240 Moisesville 5383 Moisesville 1926 Moisesville 4111 Moisesville 6785 Moisesville 884 Moisesville 866 Moisesville 1032 Moisesville 227 Moisesville 1627 Moisesville 5147 Moisesville 1619 Moisesville 5209 Moisesville 1268 Moisesville 6058 Moisesville 5410 Moisesville 1643 Moisesville 2623 Moisesville 6062 Moisesville 3108 Moisesville 1974 Moisesville 4416 Moisesville 6775 Moisesville

1880 Moisesville 5143 Moisesville 6726 Moisesville 2748 Moisesville 1202 Moisesville 6924 Moisesville 6789 Moisesville 6783 Moisesville 5122 Moisesville 6827 Moisesville

4112 Moisesville 5323 Moisesville 6693 Moisesville 6825 Moisesville 6764 Moisesville 6771 Moisesville 5936 Moisesville 5929 Moisesville 1055 Moisesville 1901 Moisesville 2949 Moisesville 2957 Moisesville 5253 Moisesville 5308 Moisesville 368 Moisesville 3040 Moisesville
Lublinsky Leon, Marcos y Jacobo, pla+C4406no, notas Ludner Viuda de Jose, y Enrique, Simon, Isaac y Boris, contrato, plano, notas

Maccario Andres, contrato

Maguid Israel Suc., contrato, plano cartas

Makler Hirsch, Felipe y Froim, contrato, plano, notas

Malajovich Isaac, contrato, plano, cartas

Malajovich Moises, Escritura de terreno (Las Palmeras)

Malajovich Moses, contrato, plano, cartas

Malenky Benjamin, contrato

Malenky Gedalie, contrato, plano, cartas

Malenky Jose, Israel, Adolfo y Aron contrato, plano, notas

Maler Jaime, contrato

Mamut Elbio Anibal, contrato, plano, notas

Marcipar Israel y Kivatinetz Adolfo, contrato, plano, cartas

Marcomino Valentin R., Escritura de terreno (Las Palmeras)

Marcomino Valentin, contrato

Marguletz Israel, contrato

Marsipan Jaime, contrato, plano, cartas

Martinez Cipriano, contrato, plano

Martinez Higinio, Escritura de terreno (Las Palmeras)

Matzkin Jose, contrato, plano, correspondencia

Matzkin Moises, contrato, plano, cartas

Meersohn Jacobo, contrato, plano, testamentaria

Meinrath Karl Heinz, contrato, plano, correspondencia

Menke Theo, cartas, plano

Meragelman Najman, contrato, plano, notas

Merli Miguel, contrato, plano, cartas

Merlin Cecilio y Menashe, contrato

Merlin Cecilio, contrato, plano, cartas

Merlin Marcos, contrato, nota

Merlin Marcos, contrato, notas

Merlin Menasche, contrato, plano, cartas

Meyer Walter, contrato, plano, cartas

Migliore Tomas, contrato

Mijalevich Salomon, cancelacion de hipoteca

Mijalevich Salomon, contrato, plano, cartas

Mindes Leon y Kantor Jose, contrato, plano, cartas

Ministerio de Educación, donación de JCA, Escuela No. 744 (Las

Palmeras)

Minond Salomon, contrato, plano, cartas

Miskin Isaac, contrato, plano, notas

Miskin Israel, Escritura de terreno (Las Palmeras)

Misneevich Abraham e Isaac, contrato, plano, cartas

Mitnik Salomon y Abraham y Rosiansky Naum, contrato, plano

Mitnik Zelik Suc., contrato de terreno, plano, nota (grupo Wavelberg)

Mlodzik Czeslaw, Escritura de terreno (Las Palmeras)

Mlodzik Tomas, Escritura de terreno (Las Palmeras)

Moises Moses, contrato, plano, notas

Molina Bernardo S. y Balbino Rodolfo, Escritura de terreno (Las

Palmeras)

Mondino Guillermo, contrato, plano

Monteserin Jose, contrato

Monteserin Jose, Escritura de terreno

Monteserin Oclides, Escritura de terreno (Las Palmeras)

Montesin Jose, Escritura de terreno y nota (Las Palmeras)

Montesin Jose, Escritura de terreno y nota (Las Palmeras)

Montian David, contrato de arriendo

Morawsky Herman, contrato de arriendo, promesa de venta

Morgenstern Samuel, contrato, plano, cartas

Moscovich David, contrato, plano, cartas

Moscovich Leib y Marcos, contrato, plano, cartas

Moscovich Meier Jose, contrato, plano

Moscovich Meier, contrato

Moscovich Meier, contrato

Moscovich Meier, contrato, plano, carta

Moscovicz Benjamin y Adler Eta, contrato, plano, notas
$1900-28$

$1898-1930$

1930-1954

$1894-1928$

1896-1947

1909-19

1912

1894-1915

1945-1945

1912-36

1908-28

1955

1966

1907-28

1956

1947-1948

1944-1946

1901-20

1957-61

1960

1945-54

1943-59

1908-29

1948-62

1939-47

1906-1928

1942-55

1943-1944

1944-60

1953-1957

1954-1959

1922-48

1952-67

1944-1950

1956

1927-57

1901-28

\section{0}

1903-26

1922-1958

1926

1960

1900-41

1908-28

1960

1952-60

1896-1927

\section{2}

1950-61

1946-1949

1925-27

1952

1942

1937

1942-1943

1938-1950

1902-35

1901-25

1932-62

1944-60

1940-1944

1944-1946

1948-62

1930-62
Reserva

Reserva

Reserva

Reserva

ensanche

Reserva 
2952 Moisesville 5212 Moisesville 3109 Moisesville 2749 Moisesville 906 Moisesville 5344 Moisesville 581 Moisesville 6765 Moisesville 5389 Moisesville 6731 Moisesville 1644 Moisesville 6915 Moisesville 4195 Moisesville 5226 Moisesville 779 Moisesville 5320 Moisesville 918 Moisesville 6769 Moisesville 5224 Moisesville 2532 Moisesville 5722 Moisesville 941 Moisesville 6829 Moisesville 907 Moisesville 5768 Moisesville 966 Moisesville 2253 Moisesville 1892 Moisesville 5053 Moisesville 6724 Moisesville 1022 Moisesville 1897 Moisesville 4415 Moisesville 6698 Moisesville 382 Moisesville 5758 Moisesville 916 Moisesville 5386 Moisesville 6607 Moisesville 5378 Moisesville 6561 Moisesville 6580 Moisesville

6545 Moisesville 5361 Moisesville 6786 Moisesville 4183 Moisesville 4394 Moisesville 898 Moisesville 5248 Moisesville 5146 Moisesville

1893 Moisesville 6894 Moisesville 3097 Moisesville 5547 Moisesville 5867 Moisesville 1213 Moisesville 3288 Moisesville 5152 Moisesville 5225 Moisesville 570 Moisesville 6011 Moisesville 406 Moisesville 877 Moisesville 2401 Moisesville 6555 Moisesville
Moscovicz Smil, contrato, plano, cartas

1931-62

oscovies Zelman, contrato

Moses Alberto , contrato, plano, cartas

Moses Kurt y Hermanos, contrato plano, cartas

Moses Walter, contrato, plano

Moszco Met Jankel, contrato

Mrejen Mardoche, contrato, plano, correspondencia

Mularz Gerson, Escritura de terreno (Las Palmeras)

Musseto Octavio, contrato

Mussetto Octavio, Escritura de terreno (Las Palmeras)

Mutzmajer Miguel, contrato, plano, cartas

Naiman Leon, contrato de terreno, plano, notas (grupo Monigotes)

Naimogin Jose, Bernardo y Pedro, contrato, plano, cartas

Nesis Elias, contrato

Neter Erna Lowenstein de, contrato, plano, correspondencia

Neter Paul, contrato

Neter Paul, contrato, plano, cartas

Neto Beatriz J, Escritura de terreno (Las Palmeras)

Neto Domingo, contrato

Neuman Julius Werner, contrato, plano, cartas

Nijamkin Isaac, contrato, plano, notas

Nisnevich Abraham y Isaac, contrato, plano, cartas

Nomina detallada de 144 Escrituras de terreno (Las Palmeras)

Notcovich Bernardo, contrato, plano, cartas

Notcovich Moises y Lipe, contrato, plano, notas

Notcovich Moises y Zipe, contrato, plano, cartas

Notkovich Boris, contrato, plano

Notkovich Lipe, contrato, plano, cartas

Notkovich Moises y Lipe, cancelacion de hipoteca

Novick Cecilio, Escritura de terreno (Las Palmeras)

Novick Jose Luis, contrato, plano

Novick Jose, contrato, plano, cartas

Novick Leib, Cecilio y Abraham, contrato, plano, notas

Novick Leon, Escritura de terreno (Las Palmeras)

Novick Raul y Pablo, contrato, plano, carta

Nussbaum Julia Meyer de, contrato, plano, nota

Nussbaum Theo, contrato, plano, cartas

Oettel Enrique, contrato

Oggero Aldemar M., Escritura de terreno (Virginia)

Oggero Esteban y Miguel, contrato

Oggero Faustino Americo, Escritura compra de terreno

Oggero Faustino, Rodolfo, Jose; Lunek Pedro Gualberto; Parmit

Adela Zanger de, Escritura compra de terrenos

Oggero Jose, compra de solares

Orellano Ciriaco, contrato

Orellano Ciriaco, Escritura de terreno (Las Palmeras)

Orlian Samuel, plano, notas

Orlian Schaie, Samuel y Jose, contrato, plano, cartas

Osatinsky Jaime, contrato, plano, correspondencia

Ostapivk Teodoro, notas

Ostrovsky Samuel y Meilach, y Berdichevsky Samuel, contrato, plano, notas

Padlubne Jaskel, contrato, plano, cartas

Paikin Abraham, contrato, plano, notas (grupo Monigotes)

Palchik Bernardo, contrato, plano, notas

Palchik Samuel, contrato, plano, nota

Panichelli Luis, contrato, plano, Readquisición

Paris Marcos, contrato, plano, cartas

Paris Mendel, contrato, plano, notas

Parmat Moises, contrato

Parmit Moises, contrato

Parmit Moises, contrato, plano

Peisenstadt Hirsch, plano

Pels Irma Ida Hausdorf de, plano, carta

Pelz Hugo, contrato, plano

Pereira Marcos, contratos y planos

Peretti Bartolome, Escritura compra de terreno
1951-1954

1939-58

1947-60

1944-62

1940-1948

1957-67

1940

1944-1945

1935

1919-48

1924-43

1905-24

1939-1949

1940-56

1945-1946

1947-58

1939

1939-1946

1941-48

1910-1919

1958-62

1944-65

1939-1956

1922-56

1952

1900-25

1965

1927

1965

1903-25

1904-23

1916

1938-59

1955-1956

1942-56

1943-1944

1963

1937-1945

1958

1962

1927

1950-1951

1960

1929-59

1900-24

1914-55

1956

1905-1928

1904-25

1909-29

1926-29

1905-1930

1937

1926-39

1928-61

1930-1944

1940-1947

1932-60

1960

1944-56

1938-56

1936-50

1939
Reserva

Reserva

Reserva

Reserva

Reserva 
5930 Moisesville 6579 Moisesville

5294 Moisesville 2940 Moisesville 6903 Moisesville

2261 Moisesville 1491 Moisesville 402 Moisesville 3748 Moisesville 1628 Moisesville 2260 Moisesville 3745 Moisesville 2614 Moisesville 1290 Moisesville 721 Moisesville 2880 Moisesville 4337 Moisesville 6812 Moisesville 5362 Moisesville 5207 Moisesville 3660 Moisesville 6795 Moisesville 868 Moisesville 6828 Moisesville 5290 Moisesville 6559 Moisesville 5265 Moisesville 1787 Moisesville 5259 Moisesville 6900 Moisesville 6901 Moisesville

5382 Moisesville 1052 Moisesville 6715 Moisesville 5206 Moisesville 4407 Moisesville 6779 Moisesville 6908 Moisesville

1044 Moisesville 5937 Moisesville 5371 Moisesville 6566 Moisesville 5250 Moisesville 5771 Moisesville 6542 Moisesville 5099 Moisesville

3096 Moisesville 6768 Moisesville 4411 Moisesville 2622 Moisesville 3076 Moisesville 6732 Moisesville 1928 Moisesville 5539 Moisesville 5703 Moisesville 6941 Moisesville

3081 Moisesville 6925 Moisesville 5322 Moisesville 6754 Moisesville 5325 Moisesville
Perl Mates, contrato de arrendamiento Perrone Miguel y Bonacina Luis y Bernard Carlos, Escritura compra de terreno

Pessutto Jose, contrato

Peterlin Julio, Elidio, Greegorio y Alejandro, contrato, plano

Piner Pablo y Spiner Juana Suc., contrato de terreno, plano, notas

(grupo Monigotes)

Pinery Salomon, contrato

Pins Adolfo, contrato, plano, cartas

Pins Harry y Kurt, plano

Pins Kurt, contrato

Pins Max, contrato, plano, cartas

Pletnitzky David, contrato

Pliss Abraham, contrato

Pliss Abraham, contrato, plano, cartas

Pluda Berta Treter de, contrato, plano, cartas

Podlubne Jasquel, contrato, plano

Podlubne Moises, contrato, plano, cartas

Poissot Juan B., contrato, plano, notas

Poissot Juan, Escritura de terreno (Las Palmeras)

Poissot Lorenzo y Salvador, contrato

Poissot Lorenzo, contrato

Poissot Lorenzo, contrato, nota

Poissot Lorenzo, Escritura de terreno (Las Palmeras)

Poissot Pedro Juan y otros (ex Goler Salomon), contrato, plano, cartas

Poissot Pedro, Escritura de terreno (Las Palmeras)

Poljovich Alejandro, contrato

Poljovich Basilio, Escritura compra de terreno

Pomerantz Israel y Avner, contrato

Pomerantz Israel, Rajmiel y Abner, contrato, plano, cartas

Pomerantz Samuel, contrato

$1930-1936$

1963

1943-1944

1954-55

Reserva

1933-61

1941

1938-56

1956

1966

1939-56

1945

1966

1942-67

1938-48

1920-29

$1909-51$

1944-55

1952

1948-1949

1943-1944

1948-71

1946

1912-52

1952

1941-1943

1932

1942-1948

1908-63

1941-1948

Pomerantz Samuel, contrato de terreno, plano, nota (grupo Zadok Kahn) 1927-52

Pomerantz Samuel, contrato de terreno, plano, notas (grupo Zadok Kahn)

Ponce Santiago, contrato

Portnoy Hirsch, plano, cartas

Portugalli Luis, Escritura de terreno (Las Palmeras)

Pot Antonio y Osualdo, contrato

Press Israel y Marcos, contrato, plano, cartas

Presser Bernardo G., Escritura de terreno, deteriorado (Virginia)

Pribulsky Hirsch Enrique e Hilel, contrato de terreno, plano, notas (grupo Bialistok)

Prillelstensky Moises y Marcos, contrato, plano, cartas

Prullansky Hersch, contrato de arriendo, notas

Puntillo Orfilio, contrato

Quintero Anastasio, Escritura compra de terreno

Quinteros Anastasio, contrato

Quinteros Anastasio, contrato, plano, notas

Quiroga Salvador Jose, Escritura compra de terreno

925-59

$1943-1945$

1934

1937

$1943-1945$

1894-1923

1964

$1902-28$

$1900-28$

1942-1943

1941-1944

1925

1944-1948

1948-1956

1950

Reserva

1894-1935

notas

Rabinovich Jaime, contrato, plano, cartas

Rabinow Marcos, Escritura de terreno (Las Palmeras)

Rachmiel Schloime, contrato, plano, cartas

Radovitzky Abraham Isaac, contrato, plano, cartas

Radovitzky Jose e Israel, contrato, plano, notas

Raimondo Jose, Ana C. Vda. De, Escritura de terreno (Las Palmeras)

Rajmil Jose, contrato, plano, cartas

Rajovitzky Jaime y Manuel, contrato, plano, nota

Rajovitzky Pablo (Faitel), contrato, plano, notas

Rechter Jaime, Cantin Eugenio y Saposnik Sneer, Suc. de Rechter

Isaac, contrato de terreno, plano, notas (grupo 1)

Reisin Jacobo, contrato, plano, cartas

1907-29

1939

1902-21

1956-67

1894-1924

1934

1909-20

1908-1930

1910-29

1896-1928

1909-27

Reitich Guitel Brener de, contrato de terreno, plano, notas (grupo No. 1) 1896-1928

Reitich Leiva, contrato

Reizin Jose, Escritura de terreno (Las Palmeras) 1936

Rejovitzky Hirsch, contrato
1943-1946

1936-1946
Reserva

Reserva

Reserva

34

30
46


5251 Moisesville 1621 Moisesville 5715 Moisesville 1927 Moisesville 4284 Moisesville 1061 Moisesville 4400 Moisesville 6893 Moisesville 910 Moisesville 4402 Moisesville 6911 Moisesville 6751 Moisesville 4338 Moisesville 5314 Moisesville 4437 Moisesville 5764 Moisesville 5548 Moisesville 3079 Moisesville 6744 Moisesville 6823 Moisesville 5242 Moisesville 6767 Moisesville 1888 Moisesville 5260 Moisesville 4441 Moisesville 6606 Moisesville 4285 Moisesville 6054 Moisesville 2544 Moisesville 564 Moisesville 5234 Moisesville 4163 Moisesville 5136 Moisesville 869 Moisesville 4842 Moisesville 3746 Moisesville 1898 Moisesville 230 Moisesville 883 Moisesville 1948 Moisesville 6940 Moisesville 5108 Moisesville 5563 Moisesville 6613 Moisesville 3037 Moisesville 1879 Moisesville 3080 Moisesville 5114 Moisesville 1221 Moisesville 4390 Moisesville 5713 Moisesville 4185 Moisesville 4421 Moisesville 6615 Moisesville 5351 Moisesville 5546 Moisesville 6919 Moisesville 3090 Moisesville 5288 Moisesville 5719 Moisesville 4433 Moisesville 1930 Moisesville 5769 Moisesville 5249 Moisesville 5712 Moisesville 2247 Moisesville 4144 Moisesville
Rejovitzky Hirsch, contrato, nota

Rejovitzky Jacobo, contrato, plano, cartas

Rejovitzky Jacobo, contrato, plano, notas

Rejovitzky Jose, contrato, plano, cartas

Rejovitzky Juan, contrato, plano, notas

Rejovizky Jacobo, contrato, plano, cartas

Resnick Genzel y Salomon, Bernardo y Leon, contrato, plano, cartas

Resnik Bernardo, contrato, plano, notas (grupo Virginia)

Resnik Jacobo y Catalina P. de e hijos Raul y Zulema 1927-56

Resnik Jacobo, contrato, plano, cartas

Riback Meier, contrato de terreno, plano, nota (grupo Zadok Kahn 5)

Riboldi Gaitano Pedro, Escritura de terreno (Las Palmeras)

Ribotta Mateo B., contrato, plano, notas

Ribotta Pedro, Bautista y Bartolo, contrato, notas

Rivero Justorio, contrato

Rodriguez Claudio, contrato, plano, notas

Rogovsky David, contrato, plano, nota

Rogovsky Leib, contrato, plano, cartas

Rogovsky Leib, escritura de terreno (Las Palmeras)

Rogovsky Salomon Isaac, Escritura de terreno (Las Palmeras)

Rogovsky Salomon, contrato

Rogovsky Salomon, escritura de terreno (Las Palmeras)

Roitman Peretz, contrato, plano, cartas

Roldan Ubaldo, contrato

Rolon Alfonso, contrato

Rolutti Santiago, Escritura de terreno (Virginia)

Rosenblat Abraham, contrato, plano cartas

Rosenfarb Julio, contrato, notas

Rosenfarb Julio, contrato, plano, cartas

Rosenfarb Ruben, contrato, plano

Rosenfel Jose, contrato

Rosenstein Jacobo (ex Loschakoff Moises, contrato, plano, cartas

Rosenstein Jacobo y Samuel, contrato, plano, notas

Rosenthal Ernesto, contrato, plano

Rosenthal Martin, contrato, plano, notas

Rotchild Ricardo, contrato

Rotenberg Hirsch, contrato, plano, cartas

Rotenberg Mordko Hersz, contrato, plano

Rothschild Ricardo, contrato, plano, cartas

Rotman Isaac, contrato, plano, cartas

Rotman Leiva, contrato de terreno, plano, notas (grupo Monigotes)

Rotman Moses y Gerchunoff Gregorio, contrato, plano, notas

Rotman Samuel, contrato, plano, notas

Rotman Samuel, Escritura de lote (Virginia)

Rotschild May y Ricardo, contrato, plano, cartas

Rubin Isaac, contrato, plano, cartas

Rubin Simon y Juana Orlovsky de, contrato, plano, notas

Rubinstein Gerschon, contrato, plano, cartas

Rud Isaac, contrato, plano, cartas

Ruderman Moises, contrato, plano, cartas

Rudoy Ezre, contrato, plano, notas

Rudoy Ezri, plano, notas

Rudoy Hinda S. Vda. de Samuel, contrato, plano, cartas

Rulutti Santiago, Escritura de lote (Virginia)

Ruppen Jose P., contrato

Sabah Jose Sucesion de, contrato, plano, notas

Sacks Pinjos, contrato de terreno, plano, nota (grupo Palacios)

Saienz Saul y Abraham, contrato, plano, cartas

Saks Pinjos, nota

Saks Pinjus y Meer, contrato, plano, notas

Sala Ignacio, contrato

Salz Jose, contrato, plano, cartas

Salzman Aron, contrato, plano, nota

Sanchez Pedro G., notas

Sandler Hirsch, contrato, plano, notas

Saphir Bernardo, contrato

Sapir Pinjas, Luis y Herman, contrato, plano, notas
1944-1948

1933-55

1906-1918

1920-21

$1902-28$

1898

$1900-23$

$1920-29$

1908-23

$1908-28$

1935

1953-55 Reserva

1945-1953

1960

1956

1926-1946

1904-27

1930

1950

1947-1950

1939

1903-25

1942-1948

1957

1927

1904-28

1949-1953

1943-67

1950-60

1946-1947

1922-32

1909-1937

1944-61

1905-1924

1966

1905-63

1953-65

1953-57

1908-21

1905-28

1915-1936

1899-1918

1912

1939-51

1906-26

1902-27

1904-1928

1915-39

1906-28

1905-1919

1928-1929

1896-1913

1913

1950-1955

1901-1930

1904-28

1902-29

1942

1901-1919

1964

1908-20

1954-1956

1956

1896-1919

1954

1896-1932
Reserva

Reserva 
4187 Moisesville 5542 Moisesville 4289 Moisesville 912 Moisesville 5711 Moisesville 6609 Moisesville 5720 Moisesville 5365 Moisesville 4363 Moisesville

4158 Moisesville 3290 Moisesville 6049 Moisesville 5545 Moisesville 5718 Moisesville 5339 Moisesville 870 Moisesville 882 Moisesville 5148 Moisesville 1874 Moisesville 1891 Moisesville 6766 Moisesville 6942 Moisesville

6714 Moisesville 6763 Moisesville 6798 Moisesville 5199 Moisesville 5243 Moisesville 5343 Moisesville 78 Moisesville 6772 Moisesville 1042 Moisesville 1034 Moisesville 6708 Moisesville 6737 Moisesville 5128 Moisesville 5121 Moisesville 5823 Moisesville 6928 Moisesville

1612 Moisesville 1278 Moisesville 5237 Moisesville 6743 Moisesville 6799 Moisesville 5372 Moisesville 4160 Moisesville 1284 Moisesville 5716 Moisesville 6722 Moisesville 6746 Moisesville 1045 Moisesville 1638 Moisesville 6704 Moisesville 6904 Moisesville 405 Moisesville 1031 Moisesville 6701 Moisesville 6818 Moisesville 5119 Moisesville 5384 Moisesville 1790 Moisesville 5315 Moisesville 6770 Moisesville 5302 Moisesville 5310 Moisesville
Saposnik Jaime y Sneer, contrato, plano, notas

Saposnikoff Rubin, contrato, plano, nota

Saracins Eernesto, contrato, plano, notas

Saskin Jacobo, contrato, plano, correspondencia

Saslavsky Miguel, contrato, plano, notas

Savarecio Pedro E., Escritura de terreno (Virginia)

Scaliter Wolf, contrato, plano, notas

Scarafia Francisco, contrato

Scarfia Vidal, Domingo, Jose, Leonidas y Bernardino, contrato,

plano, cartas

Schain Abraham, contrato, plano, notas

Schallmach Philipp, contrato, plano, notas

Schapira Jose, plano

Schapira Meyer, contrato, plano, nota

Schapira Wolf y Samson, contrato, plano, notas

Scharfspitz Enrique, contrato

Scharfspitz Enrique, contrato, plano, cartas

Scheiberg Suc. de Bencion y Marcos, contrato, plano

Scheinberg Jose y Rubin, contrato, plano, notas

Schendery Aron y Menis Tobias, contrato, plano, cartas

Schereschevsky Hirsch, contrato, plano, cartas

Schereschevsky Rosa S. de, escritura de terreno (Las Palmeras)

Schereschevsky Samuel y Naum, contrato de terreno, plano, notas

(grupo Zadok Kahn 1)

Schijman Abraham, Escritura de terreno (deteriorado) (Las Palmeras)

Schijman Abraham, Escritura de terreno (Las Palmeras)

Schijman Isaac, Escritura de terreno (Las Palmeras)

Schijman Mauricio, contrato

Schijman Mauricio, contrato

Schijman Mauricio, contrato

Schijman Mauricio, contrato, plano

Schijman Mauricio, Escritura de terreno (Las Palmeras)

Schilman Hirsch, contrato, plano, cartas

Schilman Salomon y Faivich, contrato, plano, cartas

Schimanovich Bernardo, Escritura de terreno

Schinoff Moises, Escritura de terreno (Las Palmeras)

Schlaien Bernardo, notas, plano

Schlaien Isaac, contrato, plano, notas

Schlain Boris, Yakimovsky Leiser, contratos, notas

Schliserman Abraham y Jacobo y Manuel, contrato de terreno, plano, nota (grupo Mutchnik)

Schliserman Jose y Juan, contrato, plano, cartas

Schliserman Mauricio, contrato, plano, cartas

Schlosberg Kasriel, contrato

Schlosberg Kasriel, Escritura de terreno (Las Palmeras)

Schlosberg Kasriel, Escritura de terreno (Las Palmeras)

Schlosberg Sender, contrato

Schmidberg Pablo (ex Werbin Aron Suc.), contrato, plano, notas

Schmitz Carlos, contrato, plano, cartas

Schneier Herz, contrato, plano, notas

Schnitman Miguel, Escritura de terreno (Las Palmeras)

Schnitman Miguel, tapa de una copia - incompleto (Las Palmeras)

Schor Marcos, contrato, plano

Schub Aizik y Jacobo, contrato, plano, cartas

Schufer Selug, Escritura de terreno

Schujman Isidoro, contrato de terreno, plano, notas (grupo Mutchnik)

Schujman Isidoro, contrato, plano

Schujman Naum, contrato, plano, cartas

Schujovitzky ..... ? Escritura de terreno (Las Palmeras)

Schujovitzky David, Escritura de terreno (Las Palmeras)

Schujovitzky Faivel, contrato, plano notas

Schujovitzky Israel, contrato

Schvartzman Jose y Rabinovich Hirsch, contrato, plano, cartas

Scladnik Aron, contrato

Scotto Juan Jose, Escritura de terreno y nota (Las Palmeras)

Seballos Luis, contrato

Segal David, contrato
1906-24

1906-1930

1943-55

1937-64

1911-1919

1963

1896-1919

1948-1951

1939-58

1909-32

1951-58

1937

1909-1930

1898-1919

1946-1950

1931-52

1904-54

1921-1928

1916-26

1904-25

1939

1922-28

1910

1928

1953

1945-1946

1947-1950

1948-1950

1951-59

1950

1894-1928

1905-29

1911

1931

1909-1939

1910-1924

1925-1936

1904-27

1905-46

1958-67

1947-1950

1930

1954

1941-1943

1894-1932

1938-51

1901-1918

1928

?

1907-28

1922-41

1911

1927-42

1956

1909-29

1912

1949

1928-1928

1943-1947

1901-36

1945-1947

1937

1944-1955

1935-1948
Reserva

Reserva

Reserva 
2943 Moisesville 843 Moisesville 5554 Moisesville 1786 Moisesville 1890 Moisesville 3685 Moisesville 4399 Moisesville 5214 Moisesville 6784 Moisesville 2597 Moisesville 5201 Moisesville 4405 Moisesville 3128 Moisesville

3127 Moisesville

1492 Moisesville 6706 Moisesville 68 Moisesville 3293 Moisesville 5123 Moisesville 6727 Moisesville 5273 Moisesville 1641 Moisesville 4392 Moisesville 1630 Moisesville 5714 Moisesville 4428 Moisesville 6909 Moisesville 5907 Moisesville 1219 Moisesville 4148 Moisesville 6697 Moisesville 1959 Moisesville 582 Moisesville 79 Moisesville 4404 Moisesville 948 Moisesville 16 Moisesville 5347 Moisesville 5934 Moisesville 5313 Moisesville 6554 Moisesville 5244 Moisesville 954 Moisesville 1945 Moisesville 1212 Moisesville 5104 Moisesville 6711 Moisesville 2257 Moisesville 3077 Moisesville 876 Moisesville 6791 Moisesville 6895 Moisesville 5324 Moisesville 5283 Moisesville 2863 Moisesville 383 Moisesville 1965 Moisesville 63 Moisesville 914 Moisesville 1633 Moisesville 1499 Moisesville 826 Moisesville 5360 Moisesville 4444 Moisesville
Segal David, contrato

Segal David, contrato, plano, correspondencia

Segal Marcos, contrato, plano, notas

Segal Naum, contrato, plano, cartas

Segal Schaim y Salomon, contrato, plano, cartas

Seixas Francisco, contrato

Seltzer Azriel, contrato, plano, cartas

Senderovich Hirsch, contrato

Senn Juan, Escritura de terreno (Las Palmeras)

Sepliarsky Bernardo, contrato, plano, cartas

Sequeira Sergio, contrato

Seselovsky Abraham y Jose, contrato, plano, cartas

Sexer Ida Waisman de, Schlaen Eva de, Schapira Elisa de, y Segal

Luisa de, contratos, titulos de propiedad, escrituras de venta,

declaratoria de herederos, contratos de venta, cancelacion de hipoteca

Sexer Israel y Jacobo H. (Hirsch) Sexer (o Sescer o Sezcer),

contrato, escritura, planos

Sexer Saya Aron, contrato, plano, cartas

Sibrac Leib, Escritura de terreno

Siegber y Lowenstein Max, contratos, plano

Siegbert Gerson, contrato, plano, cartas

Sigal Berl, contrato, plano, notas

Silberman Boris, Escritura de terreno (Las Palmeras)

Silberman Leon, contrato

Silberman Leon, contrato, plano, cartas

Simonovich Jacobo y Kaufman Salomon, contrato, plano, notas

Singer Jacobo Simon, contrato, plano, cartas

Singer Zalel, contrato, plano, notas

Sinner Alberto, contrato

Sirkovich Kalman, contrato de terreno, plano, notas (grupo Monigotes)

Sirota Daniel y Jaime, contrato de arriendo

Skidelsky Abraham, contrato, plano, cartas

Skidelsky Isaac, contrato, plano, notas

Skidelsky Julio, Escritura de terreno

Skidelsky Salomon y Herz, contrato, plano, cartas

Slabovik Francisco, contrato, plano, cartas, notas

Slabovik Leonidas, contratos, plano

Slain David y Schlaen Boris, contrato, plano, notas

Sletean David, contrato, plano, cartas

Sletean Ernesto Samuel, contratos, correspondencia

Sletean Samuel, contrato

Slinger David, contrato de arriendo, nota

Slinger Manuel, contrato

Slinger Mendel Mordko, Escritura compra de terreno

Slinger Mendel, contrato

Slomovich Mendel, contrato, plano, cartas

Slonimsky Felipe, contrato, plano, cartas

Slonimsky Jose y Marcos, contrato, plano, cartas

Slonimsky Samuel y Felipe, contrato, plano, notas

Slullitil Samuel, Escritura de terreno (Las Palmeras)

Smulovitz Pedro, contrato

Smulovitz Peretz, contrato, plano, cartas

Snitifker Jose, contrato, plano, correspondencia

Snitifker Jose, Escritura de terreno (Las Palmeras)

Sobol Nissen, contrato, plano, notas (grupo Mutchnik)

Soc. Anonima Jose Paviolo Ltda., contrato

Sociedad Anonima de Ganaderos Unidos, contrato

Sociedad Rural de Moisesville, contrato, plano

Sociedad Servicio Sanitario Mutuo «Baron Hirsch», contrato, plano

Soesman Erich(para el Salon Social), contrato, plano, cartas

Soesman Erich, contratos, plano, testimonios

Soesman May Meyer, contrato, plano, cartas

Sokol Abraham, contrato, plano, cartas

Sonder Gustav, contrato, plano, cartas

Sonder Werner S., contrato, plano

Sorcineli Hugo, contrato

Sorcinelli Bruno Hugo, contrato
1955

Reserva

1935-55 Reserva

1908-1928

1920-35

1900-25

1966

1906-23

1942-1944

1960

1945-55

1945-1946

1904-23

1909-59

1954-56

1943-57

1911

1939-64

1952-67

1896-1937

1926

1941-1947

1922-56

1908-24

1937-59

1895-1918

1960

1910-28

1943

1925-52

1900-26

1917

1896-1920

1953-65

1949-59

1903-23

1962-64

1940-54

1948-1950

1942-1943

1945-1947

1950

1948-1948

1930-53

1908-19

1906-40

1902-1928

1910

1950

1896-1927

1924-56

1961

1908-30

1926-1945

1942-1948

1947-60

1891-1959

1952-60

1953-59

1939-51

1906-47

1933-48

1952-64

1950-1951

1955
Reserva

Reserva

Reserva

Reserva 
5286 Moisesville 873 Moisesville 3331 Moisesville 1497 Moisesville 5205 Moisesville 5100 Moisesville 5321 Moisesville 4403 Moisesville 860 Moisesville 2414 Moisesville 6612 Moisesville 905 Moisesville 5266 Moisesville 5710 Moisesville 5216 Moisesville 5328 Moisesville 1060 Moisesville 5284 Moisesville 4424 Moisesville 1216 Moisesville 2846 Moisesville 3092 Moisesville 5540 Moisesville 4170 Moisesville 4438 Moisesville 919 Moisesville 2241 Moisesville 3033 Moisesville 5746 Moisesville 3036 Moisesville 6057 Moisesville 6548 Moisesville 5229 Moisesville 5269 Moisesville 6563 Moisesville 5553 Moisesville 1041 Moisesville 6752 Moisesville 1642 Moisesville 3039 Moisesville 1625 Moisesville 2891 Moisesville 1217 Moisesville 6059 Moisesville 6556 Moisesville 1277 Moisesville 1938 Moisesville 1950 Moisesville 6705 Moisesville 5330 Moisesville 71 Moisesville 5287 Moisesville 5117 Moisesville 6923 Moisesville

4413 Moisesville 5270 Moisesville 6710 Moisesville 5551 Moisesville 4395 Moisesville 5938 Moisesville 6939 Moisesville 5939 Moisesville 3323 Moisesville 4431 Moisesville 1860 Moisesville 1597 Moisesville
Sorkin Isidoro, contrato

Sosna Miguel, contrato, plano, correspondencia

1942-1944

$1953-65$

Speisky Israel, contrato, plano, cartas

Speisky Israel, contrato, plano, cartas.

Speisky Jose, contrato

Speisky Mauricio y Meijel, contrato, plano, notas

Spiner Israel, contrato

Spiner Naum, contrato, plano, cartas

Springuer Sali y Katz Julio, contrato, plano, cartas

Sprintz Bernardo, contrato

Sprintz Bernardo, Escritura de lote (Virginia)

Stampler Leon, contrato, plano, cartas

Staravolsky Bernardo, contrato, nota

Staravolsky Guetzel, contrato, plano, notas

Staravolsky Jacobo, contrato

Staravolsky Jacobo, contrato, notas

Staravolsky Meier, contrato, plano, cartas

Starck Lubo y Jose, contrato

Stark Isaac, Juan, Isidoro, contrato, plano, cartas

Stark Jose, Mauricio y David, contrato, plano, cartas

Starovolsky Bernardo, contrato, plano

Steiman Isaac, contrato, plano, cartas

Sterenberg Jaime, Salomon y Samuel, contrato, plano, nota

Sternberg Abraham y Mauricio , y Grosvald Mauricio, plano, notas

Stodola Alfonso, contrato

Strass Adolf, contrato, plano, cartas

Strass Otto, contrato

Strass Otto, contrato, plano, notas

Strass Otto, plano, nota

Strauss Siegfried, contrato, plano, notas

Strauss Siegfried, contrato, testimonio

Stutman Rafael, Escritura compra de solar

Suarez Manuel, contrato

Sub Comite Pro Inmigrantes Israelitas, contrato

Sulzyn Filimon, Escritura compra de terreno

Suriz Julio S., contrato, plano, notas

Sverdlov Mendel, contrato, plano, cartas

Svidersky Isaac, Escritura de terreno (Las Palmeras)

Szabo Chaim Ber, contrato, plano, cartas

Szabo Peretz, contrato, plano, notas

Szingier Mordko Mendel, contrato, plano, cartas

Tamberos Unidos de Las Palmeras, contrato, plano, cartas

Tapuaj Abraham, contrato, plano, cartas

Taranto Jacobo, contrato, testimonio, notas

Tarditti Catalina D. de, Escritura compra de terreno

Targovnik Benzion, contrato, plano, cartas

Tarlovsky Jacobo, contrato, plano, cartas

Tarlovsky Jose Hirsch, contrato, plano, cartas

Tascella Rogelio, Escritura de terreno (Las Palmeras)

Tassone Jose, contrato

Tcach Guedalia, contrato, plano

Tcach Guedalie, contrato, nota

$1949-58$

1922-67

1943-1944

1911-1967

1944-1948

1894-1923

$1900-61$

1918

1912

1909-56

1944-1956

1894-1919

1940-1946

1935-1945

1905-20

1942-1943

1911-28

1901-40

1949-50

1905-29

1902-1928

1910-30

1957

1939-59

1958

1942-61

1948-1956

1939-51

1953-1956

1921

1946-1950

1929-1948

1962

1901-1933

1906-28

1935

1940-48

1944-60

1922-52

1939-40

1913-67

1919-1943

1937

1904-45

1903-20

1894-1920

1911

1946-1950

1902-59

1942-1955

Teitelbaum Aron y Tobias, y Gerchunoff Gregorio, contrato, plano, notas 1902-1939

Teitelbaum David y Mauricio, contrato de terreno, plano, nota (grupo

Zadok Kahn No. 1)

Teitelbaum Jaime, Tobias ,Aron y Jose, contrato, plano, cartas

1902-28

1905-67

Tenembaum Luis y Nesis Elias, contrato, notas

Tenembaum Noe, Escritura de terreno

1935-1956

1910

$1902-1960$

1904-24

1937-1942

1896-1960

1934-1944

1936-47

$1961-65$

$1894-1925$

$1944-56$

Tenis Club Las Palmeras, contrato de arriendo

Tessera Rito, contrato de arriendo

Tibul Jacobo, contrato, plano, cartas

Tiro Federal y Centro Deportivo de Mosesville

Tissembaum Isaac, contrato, plano, cartas

Tissembaum Jacobo, contrato, plano, cartas
Reserva

Reserva

Reserva

Reserva 
5560 Moisesville 5215 Moisesville 2243 Moisesville 5319 Moisesville 917 Moisesville 5105 Moisesville 6787 Moisesville 5230 Moisesville 6782 Moisesville 5364 Moisesville 6797 Moisesville 6739 Moisesville 6773 Moisesville 5116 Moisesville 5717 Moisesville 1960 Moisesville 4182 Moisesville 1062 Moisesville 6936 Moisesville

5115 Moisesville 5276 Moisesville 6061 Moisesville 1048 Moisesville

3098 Moisesville 1935 Moisesville 6734 Moisesville 5765 Moisesville 1896 Moisesville 6736 Moisesville 6896 Moisesville 6760 Moisesville 1908 Moisesville 5369 Moisesville 5821 Moisesville 5387 Moisesville 5245 Moisesville 5271 Moisesville 4154 Moisesville 1623 Moisesville 2239 Moisesville 5132 Moisesville 229 Moisesville 5252 Moisesville 902 Moisesville 1629 Moisesville 920 Moisesville 1227 Moisesville 5281 Moisesville 3291 Moisesville 5355 Moisesville 1831 Moisesville 5200 Moisesville 5352 Moisesville 1490 Moisesville 6891 Moisesville 2422 Moisesville 6616 Moisesville 6546 Moisesville 6713 Moisesville 5220 Moisesville 1036 Moisesville

1885 Moisesville 5337 Moisesville 4143 Moisesville
Tissembaum Moises y Salomon, contrato, plano, nota

1905-1917

issenbaum Jacobo, contrato, notas

Tissenbaum Miguel, contrato

Tissera Rito, contrato

Tolcachier Bernardo, contrato, plano, cartas

Tolcachir Marcos, contrato, plano, notas

Toldo Basilio y Ernesto, Escritura de terreno (Las Palmeras)

Toldo Francisco E., contrato

Toldo Francisco, Escritura de terreno (Las Palmeras)

Toldo Jose, contrato

Toldo Rosa F. de, Escritura de terreno (Las Palmeras)

Torretta Mateo, Escritura de terreno (Las Palmeras)

Toseto Carlos T., Escritura de terreno (Las Palmeras)

Trepetujin Benjamin, contrato, plano, notas

Trilnick Manuel, contrato, plano, notas

Trilnik SchmarJohn, contrato, plano, cartas

Trumper Aaron, plano, notas

Trumper Bernardo y Selig e Isaac, contrato, plano, cartas, ensanche

Trumper Boris transfiere a Rosenblat Aaron, contrato de terreno,

plano, notas (grupo No. 2)

Trumper Boris y Bernardo, contrato, plano, notas

Trumper Boris, contrato

Trumper Herman e Isaac y Boris, contrato, notas

Trumper Herman, Emilio, Selig, Boris e Isaac, contrato, plano,

cartas, ensnches

Trumper Hirsch, contrato, plano, cartas

Trumper Jose e Hijos, contrato, plano, cartas

Trumper Nosen, Escritura de terreno (Las Palmeras)

Turquetti Victorio, contrato, plano, notas

Tverdovsky Israel, contrato, plano cartas

Tverdovsky Leiba Jacobo, escritura de terreno (Las Palmeras)

Ulmansky Jacobo y Raul, contrato, plano, notas (grupo Zadok Kahn)

Ulmansky Raul, Escritura de terreno (Las Palmeras)

Vacs Jose, contrato, plano, cartas

Valenzuela Ubaldo, contrato

Vigdorovitz Bernardo y Podlubne Abraham, Escrituras e Indice

Vila Jose, contrato

Villa Juan, contrato

Visconti Carlos Nobile Domingo, contrato

Volinetz Pascual, contrato, plano, notas

Volkomirsky Bernardo, contrato, plano, cartas

Volkomirsky Elias, contrato, plano

Volochin Salomon, contrato, plano, notas

Voloschin Adolfo, contrato, plano

Voloschin Leon, contrato

Wachtel Leopoldo, contrato, plano, cartas

Wachtel Nathan, contrato, plano, cartas

Waibschnaider Moises, contrato, plano, cartas

Waibsnaider Adolfo, contrato, plano, cartas

Waibsnaider Luis y Adolfo, contrato, nota

Waibsznaider Luis, contrato, plano, cartas

Wainschenker Israel $\mathrm{H}$., contrato, nota

Wainschenker Israel Hirsch, plano, cartas

Wainstein Salomon, contrato

Waintraub Abraham, contrato

Waintraub Ernesto, contrato, plano

Waischenker Leib, contrato, plano, notas (grupo Mutchnik)

Waisman Isaac, contrato, plano

Waisman Marcos, Escritura compra de lote

Waisman Marcos, Escritura compra de terreno

Waisman Marcos, Escritura de terreno (Las Palmeras)

Waiss Enrique, contrato, notas

Wapnarsky Isaac, Jacobo y Luis, y Fridenberg J., contrato, plano, cartas

Wapnarsky Samuel, contrato, plano, cartas

Waxemberg Abraham, contrato

Waxemberg Abraham, contrato, plano, cartas
1941-1952

1958

1945-1946

1952-58

1906-1928

1961

1946-1947

1960

1948-1950

1947

1931

1963

1905-1927

1905-1924

1898-1920

1910-30

1903-63

1898-1942

1901-1927

1942-1944

1938-1952

1921-67

1907-29

1895-1920

1932

1955-1956

1907-25

1931

1903-29

1928

1906-26

1941-1945

1920-937

1943-1947

1948-1948

1944-1946

1907-19

1922-55

1963

1905-1928

1945-64

1953-1958

1944-62

$1939-52$

1952-59

1925-42

1944-1949

1942-49

1950-1953

1953

1945-1946

1950-1950

1922-47

1908-29

1918

1913

1913

1910

1952-1957

1895-29

1909-26

1940-1950

1907-32
Reserva

Reserva 
5129 Moisesville 4157 Moisesville 4420 Moisesville 2574 Moisesville 5541 Moisesville 6927 Moisesville 2879 Moisesville 6890 Moisesville 6778 Moisesville 5138 Moisesville 1832 Moisesville 6932 Moisesville

5112 Moisesville 5113 Moisesville 5150 Moisesville 4843 Moisesville 6723 Moisesville 1224 Moisesville 940 Moisesville 3319 Moisesville 5137 Moisesville 889 Moisesville 160 Moisesville 2950 Moisesville 881 Moisesville 6735 Moisesville 3328 Moisesville 2531 Moisesville 5293 Moisesville 5342 Moisesville 915 Moisesville 4162 Moisesville 3747 Moisesville 871 Moisesville 2548 Moisesville 1195 Moisesville 2759 Moisesville 1864 Moisesville 875 Moisesville 1783 Moisesville 6934 Moisesville 6700 Moisesville 5409 Moisesville 5235 Moisesville 577 Moisesville 6050 Moisesville 5348 Moisesville 6741 Moisesville 5340 Moisesville 6794 Moisesville 6804 Moisesville 1944 Moisesville 4165 Moisesville 5311 Moisesville 6055 Moisesville 6821 Moisesville 5304 Moisesville 6753 Moisesville 587 Moisesville 5280 Moisesville 5140 Moisesville 1226 Moisesville 2941 Moisesville 1862 Moisesville 5125 Moisesville 6922 Moisesville
Waxemberg Abraham, contrato, plano, notas

Waxemberg Akiva, contrato, plano, cartas

Waxemberg Jacobo, contrato, plano, cartas

Waxemberg Luis y Samuel, plano contrato, cartas

Waxemberg Luis, contrato, plano, nota

Waxenberg Moses, contrato de terreno, plano, nota (grupo Palacios)

Weinberg Maximo, contrato, plano, cartas

Weinschelbaum Abraham,contrato, plano, notas (grupo Monigotes)

Weinschelbaum Noe, Escritura de terreno, deteriorado (Virginia)

Weisburd Israel B., contrato, plano, notas

Weisemberg Meier, cartas, plano

Weisenberg Benjamin, Jose Tobias y David, contrato de terreno,

plano, notas (grupo Viriginia)

Weller David y Abraham, contrato, plano, notas

Weller hirsch, contrato, plano, notas

Werbin Abraham, contrato, plano, notas

Werbin Israel, contrato, plano, notas

Widgorovitz Bernardo, Escritura de terreno (Las Palmeras)

Widgorovitz Leib, contrato, plano, cartas

Wieder David, contrato, plano, cartas

Wieder Jaskel, contrato, plano, notas

Wigdorovitz Leib, contrato, plano, notas

Wildau Helmuth y Werner, contrato, plano, correspondencia

Wildau Rudi, contrato, plano

Wildorf Karl, Herbert y Max, contrato, plano, cartas

Wildorff Herbert, contrato, plano, cartas

Wilner Moises, Escritura de terreno (Las Palmeras)

Winer David, contrato, plano, notas

Winer Jaime Israel, contrato, plano

Winer Jaime Marcos, contrato

Winer Jaime Marcos, contrato

Winer Jaime Marcos, contrato, plano, correspondencia

Wodovosoff Moises, contrato, plano notas

Wolf Jose y Kurt, contrato

Wolf Siegfried, contrato, plano, cartas

Wolff Abraham J. y Manfred, contrato, plano, cartas

Wolff Kurt, contrato, plano, cartas

Wolff Manfredo, contrato, plano

Wolff Moses, contrato, plano, cartas

Wolff o Walff Jose Israel, Wolff Kurt, contrato, plano, cartas

Wolfson Wolf, contrato, plano, cartas

Wolinetz Jose Suc.de, contrato de terreno, plano, notas (grupo Bialistok) 1904-28

Wolinetz Pascual, Escritura de terreno (Las Palmeras) 1916

Wolkovicz Henriyk, contrato, notas 1954-1958

Woloschin Meilej, contrato

Woloschin Meilej, contrato, plano, cartas 1953-58

Woloschin Meilej, plano, lotes y croquis $\quad$ 1953-1961

Woodgate Alberto Guillermo, contrato, nota 1948-1950

Wulfsohn Wolf Dora Vda. De, Escritura de terreno (Las Palmeras) 1931

Wulfson Herman y Ramon, contrato 1946-1952

Wulfson Herman y Ramon, Escritura de terreno (Las Palmeras) 1945

Wulfson Isaac, Escritura de terreno (Las Palmeras) 1956

Wulfson Mordje y Bernardo, contrato, plano, carta 1905-19

Yakamovsky Moises, contrato, plano, notas 1929-67

Yakimovsky Marcos y Trepetujin Leon, contrato 1944-1950

Yakimovsky Marcos, contrato, notas, testimonio 1951-1953

Yakimovsky Meyer y Salikes Isaac, escritura de terreno (Las Palmeras) 1950

Yakimovsky Meyer y Ulmansky Marcos, contrato 1944-1948

Yakimovsky Samuel Suc, Escritura de terreno (Las Palmeras) 1935

Yakimovsky Selik, contrato, planos, carta $\quad 1953-60$

Yakomovsky Moises, contrato 1942-1948

Yalovetzky Nuchim, contrato, plano, notas 1906-1935

Yatvetzky Suc. e hijo Julio, contrato, plano, cartas $\quad$ 1900-42

Yedlin Bernardo, y Kaplan Pablo, Israel e Isaac, contrato, plano, cartas 1954-55

Yedlin Hirsch, contrato, plano, cartas 1900-25

Yedlin Hirsch, contrato, plano, cartas 1909-1937

Yedlin Marcos, contrato de terreno, plano, notas (grupo No. 9) 1909-30
Reserva

Reserva

Reserva

Reserva 
5749 Moisesville 6051 Moisesville 5103 Moisesville 5922 Moisesville 1211 Moisesville 5261 Moisesville 903 Moisesville 1601 Moisesville 923 Moisesville 6052 Moisesville 5393 Moisesville 3749 Moisesville 901 Moisesville 2240 Moisesville 6565 Moisesville 2549 Moisesville 5505 Montefiore 5512 Montefiore 5529 Montefiore 6535 Montefiore 5535 Montefiore 5531 Montefiore 5189 Montefiore 5433 Montefiore 1473 Montefiore 2018 Montefiore 4000 Montefiore 1469 Montefiore 332 Montefiore 5408 Montefiore 6046 Montefiore 729 Montefiore 5495 Montefiore 5188 Montefiore 5508 Montefiore 5420 Montefiore 5435 Montefiore 5476 Montefiore 5785 Montefiore 1460 Montefiore 2643 Montefiore 4122 Montefiore 5787 Montefiore 5182 Montefiore 6568 Montefiore 371 Montefiore 5474 Montefiore 5428 Montefiore 5492 Montefiore 6350 Montefiore 5778 Montefiore 5784 Montefiore 5183 Montefiore 6567 Montefiore

3519 Montefiore 3992 Montefiore 5468 Montefiore 5519 Montefiore 3979 Montefiore 3993 Montefiore 6830 Montefiore 6549 Montefiore 5500 Montefiore 6573 Montefiore 5442 Montefiore 5783 Montefiore
Yedlin Marcos, contrato, plano, notas

Yunger Simon, plano

Zabotinsky Alejandro y Farber David, contrato, plano, notas

Zadovsky Jacobo, contrato de promesa de venta

Zadunaisky Israel, contrato, plano, cartas

Zalesnik Abraham, contrato

Zaleznik Abraham, contrato, plano, correspondencia

Zaliaznik Jacobo, contrato, plano, cartas

Zamors Alfredo y Leo, contrato, plano, cartas

Zamory Leo, croquis de lote

Zeltzer Jose, contrato

Zinger Carlos, contrato

Zinger Carlos, contrato, plano, cartas

Zmijevsky Pablo, contrato, plano

Zoccola Lorenzo, Escritura compra de terreno

Zocol Leon, contrato, plano, cartas

Adler Samuel, contrato

Adler Smil, nota

Ainstein Jaime, contrato

Ainstein Jaime, Testimonio, incompleto

Alegre Alberto, contrato

Anteproyecto de Contrato entre JCA y el Ministerio de Agricultura

Apel Isaac y Enrique, contrato, plano, notas

Apel Isak Herman, contrato

Apel Simon Mario, contrato, plano, cartas

Apel Simon, Mario y Guillermo, plano, Boleto de Compra

Apel Simon, Mario y Guillermo, plano, contrato, cartas

Apel Zelman, contrato, plano, cartas

Apisdorff Jose, contrato, plano

Arias Daturnino, contrato, notas

Asnes Isaac, contrato, notas

Asociacion Israelita de Beneficencia, contrato

Avila Avelino, contrato

Baranbaum Salomon e Isaac, contrato, plano, notas

Barenbaum Salomon, contrato, notas

Belcott Juan, contrato

Beltramo Antonio, contrato

Beresover Dora D. de, contrato

Beresover Naum, contrato, plano, notas

Beresover Samuel, contrato, plano, cartas

Bergwerk Maximiliano, contrato plano

Berman Adolfo, contrato, plano, notas

Berman Isaac L., contrato, plano, notas

Berman Jacobo, contrato, plano, notas

Berman Mauricio , Escritura compra de terreno

Berman Mauricio, contrato, plano, carta

Berman Selik, contrato

Bliman Isaac y Jacobo, Berco Ricer, contrato

Bliman Isaac, contrato

Bliman Isaac, contrato de arriendo de pastoreo

Bliman Isaac, contrato, plano, nota

Bliman Isaac, contrato, plano, notas

Bliman Jacobo Bernardo, contrato, plano, notas

Bliman Maria F. de y Martinez Julio y Torres Jesus, Escritura

compra de terreno

Bonzi Jose Modesto, contrato, plano, notas

Bordovich Abraham, contrato, plano, notas

Borguino Nilado, contrato

Borodovsky Carlos, contrato

Borodovsky Carlos, contrato, plano, notas

Borodovsky Elias, contrato, plano, notas

Bravo Elba Evelina, Escritura de terreno - incompleta (Pueblo)

Bravo Elva Avelina, Escritura compra de solar

Bravo Gregoria de, contrato

Bravo Gregoria Ojeda de, Escritura compra de terreno

Bressan Jose, contrato

Brod Elias y Moises, contrato, plano, notas
1937-1959

1961

1905-1928

1924-1925

1905-40

1944-1948

1937-67

1948-55

1938-59

1963

1942-1948

1966

1922-67

1960

1925

1940-67

1951-1954

1947

1944-1957

1937

1948-1951

1936

1928-1958

1943-1945

1951-58

1966

1963-1964

1922-58

1954-64

1942-1951

1914-1933

1948

1943-1955

1917-1960

1943-1948

1945-1946

1942-1946

1944-1954

1941-1956

1913-54

1951

1929-52

1913-1967

1926-1943

1950

1942-58

1943-1944

1941-1946

1952-1956

1941-1942

1943-1953

1956-1958

1925-1956

1954

1944-61

1939-59

1942-1946

1945-1947

1950-56

1925-53

1942

1950

1942-1948

1950

1942-1948

1925-1955
Reserva

Reserva

Reserva

Reserva

Reserva

Reserva 
5534 Montefiore 6673 Montefiore

6536 Montefiore 5501 Montefiore 5469 Montefiore 5404 Montefiore 4354 Montefiore 5400 Montefiore 3988 Montefiore 5436 Montefiore 360 Montefiore 4296 Montefiore 329 Montefiore 1830 Montefiore 728 Montefiore 5523 Montefiore 5465 Montefiore 6543 Montefiore 5405 Montefiore 5498 Montefiore 6537 Montefiore 5479 Montefiore 4003 Montefiore 5429 Montefiore 5502 Montefiore 1598 Montefiore 2945 Montefiore 5510 Montefiore 1872 Montefiore 6544 Montefiore 5406 Montefiore 6592 Montefiore 6832 Montefiore 6540 Montefiore 6590 Montefiore 2478 Montefiore 5489 Montefiore 1881 Montefiore 5460 Montefiore 5527 Montefiore 1472 Montefiore 1840 Montefiore 5516 Montefiore 5525 Montefiore 3985 Montefiore 6015 Montefiore 3980 Montefiore 5450 Montefiore 2015 Montefiore 5457 Montefiore 750 Montefiore 3997 Montefiore 5490 Montefiore 5481 Montefiore 5461 Montefiore 1870 Montefiore 5520 Montefiore 1468 Montefiore 1833 Montefiore 1971 Montefiore 5473 Montefiore 222 Montefiore 6065 Montefiore 4126 Montefiore 5184 Montefiore 3998 Montefiore
Castelli Juan F., contrato

Castelli Juan F.y Sepliarsky Bernardo (Cooperadora Escuela

Nacional No. 182), Escritura de terreno

Castro Carmelo y Castillo Segundino y Del Valle Perez, Testimonio

Castro Cristobal, contrato

Centro Sionista de Montefiore, contrato

Chech Wladislaw, contrato, notas

Chopp Aurelio R., contrato, plano, cartas

Club Atletico Montefiore, contrato

Cohen Isaac, Moises, Jose y Jaime, contrato, plano, notas

Comisión de Fomento de Montefiore, contrato

Consejo Nacional de Educación, nota, plano

Cooperativa de Tamberos de Montefiore Ltda., contrato

Cooperativa de Tamberos Wawelberg, contrato, plano

Cooperativa Fraternal, contrato, plano, cartas

Cooperativa La Fraternal Agricola LT.D.A., contrato, plano

Cooperativa La Fraternal Agricola, contrato

Cooperativa Tamberos de Montefiore, contrato

Cordoba Jesus y Oviedo Transito, compra de solar, incompleto

Cordoba Juan, contrato

Cordoba Juan, contrato

Crespin Cesarea y Barreto Josefa y Angel y Nieto Mario, Testimonio

Dante Luciano, contrato

Davidovich Israel, contrato, plano, cartas

Delutis Antonio, contrato

Dominguez Agustin, contrato, notas

Dominguez Agustin, contrato, sub arriendo para ganadería

Driben Samson, contrato, plano

Dribin Samson, contrato

Ehrlich Symche, contrato, plano, cartas

Eidman Jose, compra de solares, incompleto

Eidman Jose, contrato

Eidman Jose, Escritura de terreno

Eidman Jose, Escritura de terreno, Incompleta (Pueblo)

Eidman Salomon, contrato compra de terreno, incompleto

Eidman Salomon, Escritura compra de terreno

Eksztejn Michel, contrato, plano, cartas

Epstein Leon y Miguel, contrato, nota

Erukimovich Aron, contrato, plano, cartas

Estela Luis, contrato

Feldman Lemel, contrato

Feldman Meer, contrato, plano, cartas

Feldman Wolf y Lemel, contrato, plano, cartas

Firman Jacobo, contrato

Fischman Adolfo y Jose, contrato

Fischman Jose, contrato, plano, notas

Fischman Jose, plano

Flam Israel, contrato, plano, notas

Flam Victor, contrato

$1948-1951$

1948

1960

$1945-1955$

1942-1946

1944-1958

Fligman Isidoro (ex Miedvetzky Salomon), cartas, plano, Boleto de com 1964

Fligman Isidoro, contrato

Fligman Isidoro, contrato, plano, cartas

Fligman Moises y Samuel, contrato, plano, notas

Fogel Jacobo, contrato

Franchim Dante, contrato

Freibrum Samuel y Moises, contrato, nota

Freibrun Moises y Samuel,contrato, plano, cartas

Freibrun Moises, contrato

Freibrun Simon, contrato, plano, cartas

Friedman Herman y Martin, contrato, plano, cartas

Friedman Herman, notas

Friedman Martin, contrato

Friedman Segismundo, contrato, plano

Froimovich Lazaro, contrato, notas

Galanter Bernardo, contrato, plano, notas

Galanter Bernardo, contrato, plano, notas

Galanter Isaac y Mordje, contrato, plano, notas
1960

1946-1950

1963

1941-1937

1972

1947

1965

1942-55

1947-48

$1947-1948$

1941-1943

1948

1944-1945

1944-1947

1963

1944

1921-47

1941-1945

1944-1947

1935-55

1946-55

1945-1946

1938-46

1939-48

1942-1947

1935

1938

1935 ?

1935

1925-59

1935-1944

1913-45

1946-1952

1946-1947

1946-58

1922-56

1949-1954

1946-1949

1949-68

1954

1925-61

1927-1947

1945-1947

1947-58

Reserva

Reserva

Reserva

Reserva

Reserva

Reserva

Reserva

1942-61

1954-1960

1935-1940

1945-1955

1926-51

1945-1946

1934-52

1938-58

1966-70

1944-1947

1955-58

1908-1933

1949-56

1913-1954

1948-56
Reserva

Reserva

Ensanche 
5480 Montefiore 245 Montefiore 5798 Montefiore 5444 Montefiore 3981 Montefiore 2471 Montefiore 5788 Montefiore 1921 Montefiore 1869 Montefiore 2479 Montefiore 5458 Montefiore 5524 Montefiore 4125 Montefiore 5425 Montefiore 1837 Montefiore 5796 Montefiore 5793 Montefiore 5494 Montefiore 1836 Montefiore 6588 Montefiore 5426 Montefiore 5466 Montefiore 5441 Montefiore 5443 Montefiore 2480 Montefiore 5455 Montefiore 476 Montefiore 2706 Montefiore 3982 Montefiore 5989 Montefiore 5491 Montefiore 5781 Montefiore 5363 Montefiore 1464 Montefiore 5511 Montefiore 1846 Montefiore 5419 Montefiore 4121 Montefiore 5518 Montefiore 5704 Montefiore 1471 Montefiore 2771 Montefiore 1840 Montefiore 400 Montefiore 5789 Montefiore 1467 Montefiore 2473 Montefiore 5526 Montefiore 5507 Montefiore 2472 Montefiore 5483 Montefiore 3989 Montefiore 5782 Montefiore 217 Montefiore 4001 Montefiore 1475 Montefiore 3987 Montefiore 5449 Montefiore 1850 Montefiore 5791 Montefiore 5403 Montefiore 5416 Montefiore 218 Montefiore 5399 Montefiore 5509 Montefiore 1847 Montefiore 727 Montefiore
Garcia Miguel, contrato

Gelber Manuel, contrato, plano, correspondencia

Gelber Manuel, contrato, plano, notas

Gelbert Leon, contrato

Gelbert Leon, contrato, plano, notas

Gelbert Naum, contrato, plano

Glaz Aron, contrato, plano, notas

Glaz Moises, contrato, plano, cartas

Glaz Natalio, contrato, plano, carta

Gluck Majer, contrato, plano, cartas

Gluk Benjamin y Jose, y Levy Elias contrato, plano, carta

Glük Benjamin, contrato, nota

Goldfarb Godael, contrato, plano, cartas

Goldfarb Godel, contrato, nota

Goldfarb Moises, contrato, plano, cartas

Goldman Elias, contrato, plano, notas

Goldman Esther e hijo Gregorio, contrato, plano, notas

Goldman Gregorio y Elias, contrato

Goldman Salomon, contrato, plano, cartas

Goldvaser Bernardo, Escritura compra de terreno

Grimald Miguel, contrato, nota

Grimalt Miguel, contrato

Guelbert Naum, contrato

Guelbert Naum, contrato

Guimpel Moises, contrato, plano, cartas

Gurevich Bernardo, contrato

Guterman Gregorio, contrato, plano

Guterman Gregorio, contrato, plano, cartas

Guterman Isaac y Gregorio, contrato, plano, cartas

Guterman Oscar, plano, escritura, notas

Gutierrez Jesus, contrato

Haber Marcos y Enrique, contrato, plano, notas

Haber Marcos, contrato

Heker Israel, contrato, plano, cartas

Heker Jose, contrato

Hoffnung Isaac, contrato, plano, cartas

Huttes Bernardo, contrato, notas

Huttes Bernardo, contrato, plano, cartas

Institucion Cultural El Progreso, contrato

Itzcovich Markman B., contrato, notas, plano

Judchak Moises, contrato, plano, cartas

Judchak Naum, contrato, plano, cartas

Juffe Jaime, contrato, plano, carta

Juffe o Joffe Jaime, contrato, plano

Kabatzky Moises, contrato, plano, notas

Kapeika Jacobo, contrato, plano, cartas

Katz Isaac, contrato, plano, cartas

Katz Jose, contrato, nota

Katz Zelig, contrato, nota

Katz Zelig, contrato, plano, cartas

Kleinberg Simon, contrato

Kleinberg Simon, contrato, plano, cartas, notas

Kleinrot Majer, contrato, plano, notas

Klincovitzky Abraham e hijo Marcos, contrato, plano

Klincovitzky Elias y Marcos, contrato, plano, cartas

Klinkovitzky Elias, contrato, plano, cartas

Koss Luis y Mauricio, contrato, plano, cartas

Krichak Isaac y Hoffnung Isaac, contrato

Krichak Luisa Aronson de, contrato, plano, cartas

Krojn Leiba Chaim, contrato, plano, notas

Kusnir Salomon, contrato

Kusñir Salomon, contrato

Kusnir Salomon, contrato, plano

La Fraternal Agricola Ltda., contrato

Lajer Jose, contrato, nota

Lederman Julio, contrato, plano, cartas

Lerner Bernardo, contrato, plano
1941-1945

$1926-56$

1956

1946-1955

$1949-56$

$1925-54$

1925-1956

$1922-45$

$1927-55$

$1940-48$

1946-1947

1947-1948

1941-53

1943-1944

$1947-58$

1945-1958

1925-1956

1954-1958

$1925-46$

1937

1943-1944

1943

1942

1944-1946

1926-57

1944-1948

1950-56

1957-60

1925-56

1925-1956

1946-1959

1925-1956

1928-1933

1922-58

1950-1954

1922-53

1940-1953

1925-53

1945-1946

1905-1918

1922-58

1931-42

1922-44

1952-56

1925-1956

1922-52

1925-50

1945-1948

1952-1953

1945-55

1944-1946

1913-39

1939-1958

1925-61

1944-56

1950-58

1954-64

1945-1952

1919-45

1939-1956

1953-1956

1941-1943

1914-56

1946-1955

1943-1945

1922-63

1946-48
Reserva

Reserva 
6541 Montefiore 2475 Montefiore 5422 Montefiore 5424 Montefiore 6591 Montefiore 5470 Montefiore 1604 Montefiore 328 Montefiore 2944 Montefiore 6586 Montefiore 2481 Montefiore 5504 Montefiore 6044 Montefiore 5502 Montefiore 6575 Montefiore 5499 Montefiore 2760 Montefiore 1842 Montefiore 6534 Montefiore 5464 Montefiore 5537 Montefiore 246 Montefiore 5437 Montefiore 5478 Montefiore 5396 Montefiore 5453 Montefiore 1838 Montefiore 5467 Montefiore 5415 Montefiore 6060 Montefiore 369 Montefiore 2477 Montefiore 3996 Montefiore 5438 Montefiore 5432 Montefiore 4355 Montefiore 5514 Montefiore 1882 Montefiore 5402 Montefiore 376 Montefiore 1500 Montefiore 4288 Montefiore 6045 Montefiore 5412 Montefiore 6349 Montefiore 5446 Montefiore 5533 Montefiore 5786 Montefiore 2474 Montefiore 5401 Montefiore 5185 Montefiore 5521 Montefiore 5780 Montefiore 3986 Montefiore 6674 Montefiore 4290 Montefiore 5414 Montefiore 1605 Montefiore 2482 Montefiore 751 Montefiore 4002 Montefiore 5417 Montefiore 5454 Montefiore 6012 Montefiore 5462 Montefiore 5488 Montefiore 5475 Montefiore
Lerner Simon, Escritura compra de solar

1926

Levi Raquel L. de, contrato, plano, cartas

$1935-53$

Lipovetzky Boris, contrato, notas

Lipovetzky Leon, contrato

Lipovetzky Leon, Escritura de terreno

Lipovetzky Marcos, contrato

Lipovetzky Marcos, contrato, plano, cartas

Lipovetzky Simon, contrato, plano

Lipovetzky Simon, contrato, plano, cartas

Lipsky Jacobo, Escritura de terreno y Poder General, incompleto

Lis Fajvel, contrato, plano, cartas

Lisman Jaime, contrato

Lisman Simon, contrato, notas

Maidana Ramon, contrato

Maidana Ramon, Escritura compra de terreno

Maleh Isaac, contrato

Mandelbaum Isaac, contrato, plano

Mandelbaum Moises e Isaac, contrato, plano, cartas

Manheim Isidoro y Teloni Jose, Testimonio, incompleto

Manheim Isidoro, contrato

Manheim Isidoro, contrato

Manheim Isidoro, contrato, plano

Marchisio Pedro y Miguel, contrato

Marchsio Pedro, contrato

Martinez Julio, contrato

Martinez Julio, contrato

Mendelson Pedro, contrato, plano, cartas

Mendez Francisco y Marcelino, contrato

Mendez Francisco, contrato

Miedvietzky Salomon, contrato

Miedwietzky Miguel, contrato, plano, carta

Miedzwiecki Kalman o Carlos, contrato, plano, cartas

Miedzwiecki Salomon, contrato, plano, cartas

Migliore Alfredo, contrato, notas

Mijoevich Jose, contrato

Milanesio Rodolfo B., contrato, plano, cartas

Molinari Luis, contrato, nota

Moscovich Maier, contrato, plano, cartas

Moscovich Meer, contrato, notas

Moses Raul y Marcos, contrato, plano

Munoz Eliseo, contrato, plano

Munoz Jose, contrato, plano, cartas

Namtz Manuel, contrato, notas

Nusan Gregorio, contrato

Nusan Gregorio, contrato de explotacion ganadera

Nusan Jacobo, contrato

Nusan Jacobo, contrato

Nusan Jacobo, contrato, plano, notas

Nussenbaum Marcos, contrato, plano, cartas

Oettel Enrique Emilio, contrato

Order David, contrato, plano, notas

Order David, Sofia y Natalio, contrato

Order Natalio, contrato, notas

Paris Simon, contrato, plano, cartas

Pelliza Luis A.,(Consejo Nacional de Educación), Escritura de terreno

Perez Candido Marcel, contrato, plano, cartas

Perez Gabriel, contrato, nota

Perez Mariano, contrato, plano, cartas

Plavnik Bernardo y Fraimovich Francisco, contrato, plano, cartas

Pluda Gershon, contrato, plano

Pluda Gregorio, contrato, plano, notas

Pluda Guerschon, contrato

Pluda Jacobo, contrato

Pluda Jacobo, mesura de lote, fotocopia

Podlubne David y Jaime, contrato

Policia de Montefiore, contrato

Ponce Juan F., contrato
1941-1947

1943-1946

1935

1940-1941

1926-54

1963-64

1940-55

1922

$1941-48$

1927-1946

1913-1941

1941-1949

1950

1947-1948

1960

1922-58

1956

1943-1945

1946-1959

1925-58

1942-1944

1943-1948

1946-1951

1947-1948

1922-45

1935-1945

1943-1945

1945-1963

1952-58

1943-59

1939-61

1943-1944

1943-1946

1955-58

1949-1954

1936-45

1953-1959

1959-60

1956

1944-59

1913-1927

1943-1944

1945-1945

1946-1948

1949-1954

1930-1958

1939-56

1947-1949

1926-1953

1945-1946

1946-1952

1951-64

1922

1948-51

1939-1946

1950-56

1919-53

1943-51

1955-60

1940-1950

1946-1947

1954

1930-1933

1943-1944

1943-1945
Reserva

Reserva

Reserva

Reserva

Reserva

Reserva

Reserva

Reserva

Reserva 
5517 Montefiore 5186 Montefiore 5397 Montefiore 5411 Montefiore 5761 Montefiore 3657 Montefiore 5427 Montefiore 1848 Montefiore 5472 Montefiore 1845 Montefiore 1835 Montefiore 5423 Montefiore 3994 Montefiore 401 Montefiore 5482 Montefiore 247 Montefiore 5530 Montefiore 220 Montefiore 219 Montefiore 5431 Montefiore 5484 Montefiore 5407 Montefiore 5496 Montefiore 384 Montefiore 5794 Montefiore 1839 Montefiore 409 Montefiore 5471 Montefiore 1470 Montefiore 5190 Montefiore 5538 Montefiore 5187 Montefiore 5181 Montefiore 5795 Montefiore 1474 Montefiore 5515 Montefiore 1851 Montefiore 1992 Montefiore 5528 Montefiore 924 Montefiore 2757 Montefiore 6593 Montefiore 2709 Montefiore 3984 Montefiore 5522 Montefiore 3730 Montefiore 221 Montefiore 5447 Montefiore 5194 Montefiore 5493 Montefiore 477 Montefiore 5459 Montefiore 5418 Montefiore 6347 Montefiore 223 Montefiore 1902 Montefiore 1871 Montefiore 5532 Montefiore 5193 Montefiore 5456 Montefiore 349 Montefiore 5192 Montefiore 3990 Montefiore 5916 Montefiore 5451 Montefiore 1466 Montefiore 3983 Montefiore
Poy Trinidad, contrato

1949-1951

Ratner Alter, contrato, plano, notas

Reinero Mario, contrato

River Plate Dairy, contrato

Rojas Angel y Tomas Luis, contrato, plano, nota

Rojas Angel y Victorio, contrato, plano

Roldan Gabino, contrato, nota

Rorh Enrique, contrato, plano, cartas

Roth Benjamin, contrato

Roth Salomon Chaim, contrato, plano, cartas

Rozenzvaig Manuel, contrato, plano, cartas

Ruiz Victorio, contrato

Rycer Moises, contrato, plano, cartas

Rycer Moises, plano

Saben, Berta y Cia., contrato, nota

Salman May, contrato, plano

Salomon Manuel, contrato

Salomon Manuel,, contrato, plano

Salomon Marcos, contrato, plano

Sanmiguel Oscar, contrato

Sastre Angel, contrato

Satalovsky Marcos, contrato, nota

Satalovsky Zudik y Marcos, contrato, nota

Schedrovitzky Alejandro, contrato, plano

Schedrovitzky Aron y David, contrato, plano, notas

Schedrovitzky Salomon, contrato, plano, cartas

Schedrovitzky, contrato, plano, cartas

Scher Marcos e Isaac, contrato

Scherr Marcos, contrato, plano, cartas

Schturman Samuel y Jaime, contrato, plano, notas

Schugurensky Mauricio, contrato

Schugurensky Mauricio, contrato, plano, notas

Schulman Osias, contrato, plano, notas

Schutzer Wolf, contrat, plano, notas

Schvartzman Esra, contrato, plano, cartas

Schvartzman Ezra, contrato, notas

Schwartzman Ezra, contrato, plano, carta

Seltzer Abraham, Boleto de Compra

Sepliarsky Bernardo, contrato, nota

Sepliarsky Bernardo, contrato, plano

Sepliarsky Bernardo, contrato, plano, cartas

Sepliarsky Bernardo, Escritura de terreno, deteriorada

Sepliarsky Bernardo, plano, nota

Sigalovsky Esther G. de, contrato, plano, notas

Silberstein Jacobo, contrato

Silva Antonio E., contrato, plano, nota

Smolorenko Abraham, contrato, plano

Smolorenko Abraham, y Hoffnung Isaac, contrato

Sorger Manuel, contrato, notas

Sorger Simon, contrato

Sorger Simon, contrato, plano

Soroka Aaron e Iser, y Levy Elias, contrato

Soroka Moises y Wainer Moises y Gurevich Bernardo, contrato, notas

Soroka Moises, contrato de arriendo de campo

Soroka Moises, contrato, plano

Spiegel Moises y Matias, contrato, plano, cartas

Starer Aron, contrato, plano, cartas

Starer Simon, contrato

Starer Zelig, contrato, plano, notas

Starosvetzky Moises, contrato

Starosvietzky Moises, contrato, planos, carta

Starosviezky Elias, contrato, plano, notas

Staroswietzky Abraham Jacobo, contrato, plano, carta

Staroswietzky Moises, judicial

Starovetzky Jaime, contrato

Stuker Nejemias, contrato, plano, cartas

Sucatzky Jacobo y Jose, contrato, plano, notas
$1919-1950$

1946-1946

1931-1940

1935-1956

1969-70

1943-1944

1922-45

1943-1944

1922-55

$1922-58$

1941-1943

1940-61

1956

1944-1945

1943-51

1948-1950

1953-61

1929-55

1941-1949

1938-1943

1944- 1946

1940-1950

1958-59

1925-1958

1922-34

1954-56

1945-1954

1913-51

1912-1958

1950-1955

1913-1943

1917-1951

1939-1952

1922-43

1937-1943

1913-39

1970

1946-1953

1954-57

1960

1939

1958

1953-64

1946-1949

1960

1942-60

1944-1950

1952-1963

1954-1955

1925-51

1944-1954

1925-1941

1940-1950

1940-51

1922-56

1922-58

1935-1946

1928-1952

1945-1948

1954-58

1928-1943

1945-56

?

1947-1950

1922-52

1925-59
Reserva

Reserva

Reserva

Reserva

Reserva

Reserva

Reserva

Reserva 
2016 Montefiore 359 Montefiore 5452 Montefiore 4123 Montefiore 5440 Montefiore 3999 Montefiore 1841 Montefiore 5434 Montefiore 4124 Montefiore 5445 Montefiore 2470 Montefiore 2469 Montefiore 3991 Montefiore 5792 Montefiore 5513 Montefiore 5398 Montefiore 1607 Montefiore 6570 Montefiore 5448 Montefiore 353 Montefiore 1844 Montefiore 5477 Montefiore 1843 Montefiore 1834 Montefiore 330 Montefiore 2938 Montefiore 331 Montefiore 6574 Montefiore 5439 Montefiore 5485 Montefiore 749 Montefiore 244 Montefiore 5797 Montefiore 1913 Montefiore 5536 Montefiore 5413 Montefiore 5497 Montefiore 1910 Montefiore 5191 Montefiore 399 Montefiore 5430 Montefiore 248 Montefiore 2756 Montefiore 6572 Montefiore 5421 Montefiore 5790 Montefiore 3995 Montefiore 1477 Montefiore 5506 Montefiore 2476 Montefiore 5487 Montefiore 1461 Montefiore 5853 Montefiore? 4588 Narcisse Leven 4528 Narcisse Leven 4544 Narcisse Leven 4044 Narcisse Leven 318 Narcisse Leven 1487 Narcisse Leven 381 Narcisse Leven 2616 Narcisse Leven 335 Narcisse Leven 6032 Narcisse Leven

3232 Narcisse Leven 1649 Narcisse Leven 1646 Narcisse Leven
Sucatzky Jose, Boleto de compra, plano, notas

Sucatzky Jose, escritura, plano, notas

Sucatzky Luis, contrato

Sucatzky Luis, contrato, plano, cartas

Svetliza Jose, contrato, notas

Svetliza Jose, contrato, plano, cartas

Szmolorenco Leon, contrato, plano, cartas

Sztrikler Szyia, contrato

Sztuker Abraham, contrato, plano, notas

Taub Abraham y Samuel, contrato

Taub Abraham, contrato, plano

Taub Saul, acontrato, plano, cartas

Tauber David O., contrato, plano, cartas

Tauber Kopel y Akiva, contrato, plano, notas

Teloni Augusto, contrato

Teloni Gino, contrato, nota

Theiler Pablo, Serafin y otros, contrato, plano, cartas

Theiler Serafin, Herminio y Valentin, Escritura compra de terreno

Thoireff Selig, contrato

Tissenbaum Louis, contrato, plano

Tittman lauda y Benjamin, contrato, plano, cartas

Tittman Isaac y Klinkovitzky Abraham, contrato

Tittman Isaac, contrato, plano, cartas

Tobias Marcos, contrato, plano, cartas

Tobias Markus, contrato

Tobias Salomon, contrato, plano, cartas

Torres Antonio Sebastian, contrato

Torres Toribia Montes de, Escritura compra de terreno

Tregerman Hersch y Berman Jacobo, contrato, notas

Treguerman Hersch, contrato

Tzoireff Zelig, contrato, plano

Vaisberg Abraham, contrato, plano

Vaisberg Abraham, contrato, plano, notas

Vaserman Moises, contrato, plano

Vega Isidoro, contrato, nota

Vega Julio, contrato, nota

Vega Julio, contrato, notas

Veisman Leon, contrato, plano, cartas

Veisman Leon, contrato, plano, notas

Villareal Policarpio, contrato, plano

Villareal Policarpo, contrato

Voichik Moises, contrato, plano

Volcoff Elias, plano, nota

Wico Julia, Escritura compra de terreno

Wolcoff Elias y Julio, contrato

Wolcoff Jacobo, contrato, plano, notas

Wolcoff Julio, contrato, plano, notas

Wolkoff Elias, contrato, plano, cartas

Wolojviansky Isidoro, Podlubne David, contrato, nota

Yeguer Salomon Leib, contrato, plano, cartas

Yudchak Naum, contrato

Yudchak Naum, contrato, plano, cartas

Bliman Jacobo Bernardo, solamente caratula

Abramovsky Adolfo y Gravitzky Zelig, contrato

Abramson David, contrato de pastoreo

Abramson David, contrato, plano

Abramson Naum, contrato

Aizandorff Leon, contrato, plano, carta

Aizendorf Jacinto, contrato, plano, cartas

Anuchnik Leon, contrato, plano, carta

Arcuschin Mateo, contrato, plano cartas

Asociacion Comunidad Isr. Religiosa Col. Narcisse Leven, contrato

Asociacion Comunidad Israelita Religiosa Jevra Kedusch, contrato, planos

Azendorff Jacinto y Herederos, contrato, plano, notas

Bajarsky Vigdel, cartas, plano

Balanovsky Jose, contrato, plano, cartas
1954-64

$1968-72$

$1947-1950$

$1925-52$

1944-1945

$1913-61$

$1919-44$

1941-1947

$1925-58$

$1944-1950$

$1945-51$

$1940-57$

1945-65

1939-1956

1950-1951

1946-1953

1922-56

1950

1928-1947

1945-59

1922-44

1944-1950

1922-58

1922-56

1963-64

1954

1951-65

1950

1933-1944

1935-1942

1925-60

1960-61

1913-1948

1913-55

1934-1951

1944-1944

1944-1947

1927-43

1913-1926

1947-54

1941-1944

1943-48

1960

1950

1943-1948

1927-1947

1952-61

1948-59

1929-1948

1940-58

1940-1943

1913-37

1958

1945-1950

1942-1945

1944-1950

1927-41

1919-55

1910-67

1953-59

1946-60

1965

1935-1950

1910-67

1931-39

1911-65
Reserva

Reserva

Reserva

Reserva

Reserva

Reserva

Reserva

Reserva

Ensanche

Reserva

Reserva 
4538 Narcisse Leven 1304 Narcisse Leven 4561 Narcisse Leven 4541 Narcisse Leven 60 Narcisse Leven 59 Narcisse Leven 62 Narcisse Leven 3493 Narcisse Leven 4619 Narcisse Leven 4605 Narcisse Leven 320 Narcisse Leven 319 Narcisse Leven 4026 Narcisse Leven 4608 Narcisse Leven 6053 Narcisse Leven 4027 Narcisse Leven 4020 Narcisse Leven 5994 Narcisse Leven 1654 Narcisse Leven 4515 Narcisse Leven 1427 Narcisse Leven 4065 Narcisse Leven 4028 Narcisse Leven 4024 Narcisse Leven 1480 Narcisse Leven 4370 Narcisse Leven 6621 Narcisse Leven 4602 Narcisse Leven 5990 Narcisse Leven 4059 Narcisse Leven 4542 Narcisse Leven 1298 Narcisse Leven 1415 Narcisse Leven 4369 Narcisse Leven 2780 Narcisse Leven 4513 Narcisse Leven 4612 Narcisse Leven 1306 Narcisse Leven 1311 Narcisse Leven 1092 Narcisse Leven 1479 Narcisse Leven 4539 Narcisse Leven 311 Narcisse Leven 4607 Narcisse Leven 5993 Narcisse Leven 4035 Narcisse Leven 1973 Narcisse Leven 4531 Narcisse Leven 4618 Narcisse Leven 4052 Narcisse Leven 4527 Narcisse Leven 1423 Narcisse Leven 1007 Narcisse Leven 333 Narcisse Leven

6036 Narcisse Leven 1482 Narcisse Leven 4524 Narcisse Leven 4613 Narcisse Leven 4037 Narcisse Leven 4045 Narcisse Leven 4545 Narcisse Leven 1660 Narcisse Leven 4025 Narcisse Leven 6007 Narcisse Leven 4036 Narcisse Leven 4526 Narcisse Leven
Barabasch Moises, contrato de arriendo

Bararasch Moises, contrato, plano, cartas

Barenbaum Isaac, contrato

Barenbaum Jose, contrato de arriendo

Barenboim Abraham, contrato, plano

Barenboim Isaac, contrato, plano

Barenboim Isaac, contrato, titulo

Barindorf Gregorio, contrato, cartas, plano

Bartolome Serafin, contrato, nota

Bayarsky Vigdel y Anuchnik Leon, contrato

Bayarsky Vigdel, contrato

Beker Leon, contrato, plano, carta

Bendersky Boris Suc., contrato, plano, notas

Bendersky Boris, contrato

Bendersky Leon, planilla

Bendersky Mendel e Ida R. de, contrato, plano, cartas

Berchadsky Abraham, contrato, plano notas

Berdichevsky Boris, contrato, notas

Biliansky Abraham, contrato, plano, notas

Biliansky Leon, contrato de arriendo

Braverman Jose, contrato, plano, cartas

Bril David, contrato

Bril Jacobo, contrato, plano, notas

Budeisky Leon, contrato, plano, notas

Budeisky Mauricio, plano, cartas

Buffagne Alberto L., contrato, plano notas

Buffagne Alberto L., Testimonio Venta de lote

Buffagne Alberto, contrato

Burstein Meer, contrato, escritura, notas

Clotter Francisco y Clara, contrato, cartas

Colodner Marcos e Hirsch y Baremboim Isaac, contrato de pastoreo

Colodner Marcos, contrato, plano, cartas

Colodni Quirsch, contrato, plano, cartas

Concejo Municipal de Bernasconi, Donación (Un peso), contrato

Cooperativa agricola EI Progreso, contrato, plano, cartas

Cooperativa El Progreso, contrato, plano, cartas

Cooperativa Ganadera «El Porvenir» contrato, nota

Cruglac Israel, contrato, plano, cartas

Cruglac Nisan, contrato, plano, cartas

Cruglak Israel y Nisan, contrato, plano, cartas

Cruglak Manuel, contrato, plano, cartas

Cruglak Nisen e Israel, contrato de arriendo

Cucueff Leon, contrato, plano, carta

Cueneff Leon, contrato

Cupersmid Moses y Ruben, contrato, notas

Dikerman David, contrato

Drutz Samuel, contrato, plano, cartas

Dujoven Jose y Lipovetzky Isaac, contrato de arriendo

Dujovne Abraham, contrato

Dujovne Abraham, contrato, notas

Dujovne Leon, contrato de arriendo

Dujovne Maria L. de y Leon, contrato, plano, cartas

El Progreso Soc. Coop. Agricola, contrato, plano

El Progreso Soc. Cooperativa Agricola, contrato, planos, correspondencia

Elbert Leon, contrato, notas

Elbirt Moises, contrato, plano

Enquin Moises y Marolo Jose, contrato, plano, notas

Enquin Moises, contrato

Epelman Salomon, contrato

Epstein Naum, contrato

Epstein Naum, contrato, plano

Epstein Naum, contrato, plano, cartas

Erijimovich Gregorio y Samuel, contrato, plano, cartas

Erujimovich Bersch, contrato, notas

Esterkin Jaime, contrato, notas

Faingold Efraim, contrato de arriendo
$1945-1950$

1931-61

1944-1949

1944-1945

1959

1916-50

1962-64

1964-71

1947-1948

1950-1950

1960

1909-60

1924-61

1943-1950

1909-1922

1909-38

1911-48

1910-1929

1931-65

1938-1939

1933-64

1934-44

1909-37

1900-65

1909-61

1951-69

1954

1949-1950

1911-1926

1931-43

1944-1951

1909-65

1962-65

1941

1943-44

1937-48

1944-1952

1955-58

1955-64

1945-50

1935-49

1944-1950

1931-59

1944-1945

1909-1925

1931-41

1909-60

1941-1942

1947-1949

1935-50

1944-1948

1911-65

1960-65

1947-65

1910-1924

1940-58

1947-56

1946-1946

1926-41

1939-55

1944-1949

1908-51

1909-61

1910-1919

1909-41

1939-1940
Reserva

Reserva

Reserva

Ensanche

Reserva 
4560 Narcisse Leven 1455 Narcisse Leven 4038 Narcisse Leven 2436 Narcisse Leven 1674 Narcisse Leven 775 Narcisse Leven 4546 Narcisse Leven 2408 Narcisse Leven 4522 Narcisse Leven 1305 Narcisse Leven 1310 Narcisse Leven 1417 Narcisse Leven 1651 Narcisse Leven 4053 Narcisse Leven 5999 Narcisse Leven 4518 Narcisse Leven 1095 Narcisse Leven 1429 Narcisse Leven 1484 Narcisse Leven 1647 Narcisse Leven 4050 Narcisse Leven 4043 Narcisse Leven 4586 Narcisse Leven 1658 Narcisse Leven 6037 Narcisse Leven 4547 Narcisse Leven 1666 Narcisse Leven 776 Narcisse Leven

310 Narcisse Leven 1488 Narcisse Leven 1650 Narcisse Leven 4580 Narcisse Leven 4585 Narcisse Leven 6619 Narcisse Leven 6617 Narcisse Leven 6538 Narcisse Leven 644 Narcisse Leven 4611 Narcisse Leven 769 Narcisse Leven 4530 Narcisse Leven 6009 Narcisse Leven 4587 Narcisse Leven 1648 Narcisse Leven 4559 Narcisse Leven 768 Narcisse Leven 1430 Narcisse Leven 4532 Narcisse Leven 1465 Narcisse Leven 6038 Narcisse Leven 1615 Narcisse Leven 1485 Narcisse Leven 4549 Narcisse Leven 4566 Narcisse Leven 4557 Narcisse Leven 4534 Narcisse Leven 4058 Narcisse Leven 4551 Narcisse Leven 1656 Narcisse Leven 1659 Narcisse Leven 2617 Narcisse Leven 2610 Narcisse Leven 4567 Narcisse Leven 312 Narcisse Leven 1663 Narcisse Leven 4606 Narcisse Leven 4022 Narcisse Leven
Faingold Efroim, contrato, plano

Faingold Efroim, contrato, plano, cartas

1944-1949

1940-65

Finkelstein Gregorio, contrato, notas $\quad$ 1909-41

Fliguer Abraham, contrato, plano

1967

Fliguer Abraham, contrato, plano, cartas $\quad 1958-64$

Fliguer Leon, contrato, plano 1923-51

Fliguer Leon, contrato, plano 1944-1949

Freidenberg Jose, contrato 1925

Freidin Maria Vda. de, contrato de arriendo 1938-1943

Freidin Naum, plano, cartas $\quad 1910-49$

Frenkel Moises, contrato, plano, cartas 1909-36

Fur Elias, contrato, plano, cartas 1910-65

Glujoy Salomon, Juan, Berta y Maria de Schumajer, contrato, plano, cartas 1944-65

Goaldberg Mauricio Tomas, contrato, cartas $\quad$ 1934-44

Goffman Abram, contrato, notas 1909-1924

Goldberg Gregorio, contrato de arriendo 1938-1939

Goldberg Gregorio, contrato, plano, cartas

Goldberg Jacobo, contrato, plano, cartas $\quad$ 1959-68

Goldberg Jacobo, contrato, plano, cartas $\quad$ 1949-55

Goldberg Marcos, contrato, plano, cartas $\quad$ 1944-59

Goldberg Salomon y Shafir Azriel, contrato 1935-44

Gorbach Israel, contrato, notas $\quad 1934-50$

Goss Eduardo, contrato 1949

Grinovsky Libe Ch. De y Abraham, contrato, plano, cartas $1910-54$

Guiles Ricardo, contrato, planos 1951-1959

Guilis Abraham y Jose y Ricardo, contrato, plano 1944-1951

Guilis Abraham, contrato, plano, cartas $\quad 1911-64$

Guilis Jose, Moises Mayor, Ricardo y Gregorio,

contrato, plano, corresponden

Guitin Jacobo, contrato, planos

Gurbanov Salomon, contrato, plano, cartas $\quad 1911-56$

Gurbanov Salomon, contrato, plano, cartas

Gurevich Gregorio, contrato, nota 1916-1946

Gusol Enrique, contrato $\quad$ 1948-1949

Gusol Enrique, Testimonio Venta de lote 1953

Herman Jorge, Escritura de lote, Testimonio 1953

Herman Juan, Testimonio de venta de lotes 1953

Hurevich David, contrato, plano $1949-60$

Hurevich Gregorio y Cezi y Raskin Salomon y Kasañetz Isaac,

Hurevich Gregorio y Hurevich Sezi, contrato, plano, correspondencia $\quad$ 1910-59

Hurevich Sezi y Yudchak Mauricio, contrato de arriendo 1941-1942

Hurevitz David, plano 1955

Idler Mauricio y Aisendorff Jacinto, contrato 1947-1950

Idler Mauricio, contrato, plano, cartas $1935-65$

Jaimsky Marcos, contrato, plano 1944-1949

Jaimsky Marcos, contrato, plano, correspondencia 1935-66

Jampolsky Saul, contrato, plano, cartas

Jaras Isaac y Solovioff Abraham, contrato de arriendo 1944-1950

Jaras Isaac, contrato, plano

Jaratz Moises, contrato, notas

Jinkis Adolfo, contrato, plano, cartas

Jospa Isaac y Aizik, contrato, plano, cartas

Jospa Isaac, contrato, plano

Kañevsky Palte, contrato, nota

Katz Abraham, Matzkin Adolfo y Rusansky Abraham, contrato

Katz David y Wainberg Idel, contrato de arriendo

Katz David, contrato

Katz David, contrato, plano

Katz David, contrato, plano, cartas

Katz Gregorio, contrato, carta

Katz Gregorio, contrato, plano, cartas

Katz Marcelo, contrato, plano, cartas

Katz Mordje y Zaselsky Jacobo, contrato

Kazañetz Isaac, contrato, plano

Kazañetz Isaac, contrato, plano, cartas

Kerner Daniel, contrato

Kerner Elias y Esther A. de, contrato, plano, cartas
Ensanche

Ensanche

1928-49

1911-1925

1926-50

1911-55

1944- 1950

1944-1947

1944-1945

1945-1945

1938-1939

1944-1949

1925-61

1962-64

1922-60

1960

1944-1950

1961-64

1910-60

1950-1951

1911-65 
1421 Narcisse Leven 4523 Narcisse Leven 4964 Narcisse Leven 4537 Narcisse Leven 4550 Narcisse Leven 1672 Narcisse Leven 4583 Narcisse Leven 1459 Narcisse Leven 1657 Narcisse Leven 5991 Narcisse Leven 4525 Narcisse Leven 4558 Narcisse Leven 6034 Narcisse Leven 1652 Narcisse Leven 4166 Narcisse Leven 4568 Narcisse Leven 1424 Narcisse Leven 4521 Narcisse Leven 4040 Narcisse Leven 5996 Narcisse Leven 4041 Narcisse Leven 4529 Narcisse Leven 4514 Narcisse Leven 4565 Narcisse Leven 1418 Narcisse Leven 4047 Narcisse Leven 1313 Narcisse Leven 1066 Narcisse Leven 646 Narcisse Leven 1613 Narcisse Leven 4570 Narcisse Leven 1661 Narcisse Leven 4057 Narcisse Leven 757 Narcisse Leven 4543 Narcisse Leven 1428 Narcisse Leven 1670 Narcisse Leven 4519 Narcisse Leven 4569 Narcisse Leven 4616 Narcisse Leven 1414 Narcisse Leven 6618 Narcisse Leven 334 Narcisse Leven 4571 Narcisse Leven 4051 Narcisse Leven 1419 Narcisse Leven

4552 Narcisse Leven 1975 Narcisse Leven 4609 Narcisse Leven 6620 Narcisse Leven 2847 Narcisse Leven 1093 Narcisse Leven 4603 Narcisse Leven 1614 Narcisse Leven 1413 Narcisse Leven 4581 Narcisse Leven 4061 Narcisse Leven 4535 Narcisse Leven 4615 Narcisse Leven 1667 Narcisse Leven 1299 Narcisse Leven 1976 Narcisse Leven 4584 Narcisse Leven 1456 Narcisse Leven 4572 Narcisse Leven 4617 Narcisse Leven
Klass Jacobo y Elias, contrato, plano, cartas

Kleiman Isaac, contrato de arriendo

Kogan German Suc., contrato, plano, notas

Kogman Mark, contrato de arriendo

Kohan Jaime, contrato, plano

Kohan Salvador, contrato, plano, cartas

Korsunsky Jacobo y Manulis Pedro, contrato, nota

Korsunsky Jacobo, contrato, plano, cartas

Korsunsky Moises, contrato, plano, cartas

Kovensky Isaac, contrato, notas

Krasnopolsky Abraham, contrato de arriendo

Krasnopolsky Abraham, contrato de pastoreo

Krasnopolsky Miguel, contratos, planos

Krasnopolsky Samuel, contrato, plano, cartas

Krasnopolsky Samuel, contrato, plano, cartas

Krasnopolsky Samuel, Petasny Israel y Rajkin A., contrato

Krasnopolsky Samuel, plano, notas

Kreinis Abraham, contrato de arriendo

Krell Manuel, contrato, notas

Krichmar Jaime, contrato, notas

Krischtul Marcos, contrato, cartas

Kristal Marcos, contrato de arriendo

Kruglak Manuel, contrato de arriendo

Lande Isaac, contrato

Lande Isaac, contrato, plano, cartas

Lastfoiguel Peretz, contrato

Levit David y Salomon, contrato, plano, cartas

Levit Salomon, contrato

Levit Salomon, contrato, plano, cartas

Libachevsky Kaime, contrato, plano, cartas

Libaschevsly Jaime, contrato de ensanche

Llernovoy Enso y Jaime, contrato, plano

Llesmovoy Jaime, contrato

Lliernovoy Jaime, contrato, plano sin escritura

Ludman David y Zelione Bernardo, contrato de pastoreo

Ludman David, contrato, plano, cartas

Ludman Jose y Guillermo, contrato, plano, cartas

Ludman Jose, contrato de arriendo

Ludman Jose, contrato, notas

Luñansky Gregorio, contrato

Lunasky Salomon, contrato, plano, cartas

Lupin Seferino, Testimonio, Venta de lote

Lupin Victoriano, contrato, carta

Malgnes Ruben, contrato de ensanche

Mantian Simje, contrato de pastoreo

Manulis Pedro,acepta que en parte de la chacra se construya

una sinagoga, contrato, plano, cartas

Marias Juan, contrato, plano

Mariasch Juan, contrato, plano, cartas

Marolo Jose, contrato

Marolo Jose, Testimonio Venta de lote

Matzkin Getzel, contrato, plano

Matzkin Getzel, contrato, plano, cartas

Matzkin Guetzel, contrato

Matzkin Leon, contrato, plano, cartas

Matzkin Marcos R., contrato, plano, cartas

Matzkin Marcos, contrato

Matzkin Natalio, contrato

Matzkin Natalio, contrato, plano

Milstein Boris, contrato

Milstein Boris, contrato, plano, cartas

Montian Jaime, contrato, plano, cartas

Mortvina Moises, contrato, plano, cartas

Navas Manuel, contrato

Nudelman Abraham, contrato, plano, cartas

Nudelman Jose, contrato de ensanche

Olivi Norberto S., contrato
1910-65

1939-1943

1936-59

1943-1945

1944-1949

1925-61

1945-1951

1935-61

1910-65

1910-1922

1928-1940

1944-1948

1949-1951

1910-55

1958-67

1944-1947

1961

1930-39

1932- 1943

1909-1925

1909-53

1941-1942

1938-1939

1944-1948

1910-50

1940- 1941

1909-49

1961

1930-61

1931-65

1944-1949

1910-60

1938-1939

1961

1944-1945

1946-61

1931-61

1938-1939

1944-1947

1946-1946

1961-66

1953

1965

1944-1945

1943

1909-64

1944-1949

1910-61

1945-1950

1953

1950

1910-67

1947-1948

1933-65

1910-64

1946- 1946

1937-57

1945-1950

1944-1948

1910-65

1910-59

1909-65

1949-1950

1922-58

1944-1947

1946-1947
Reserva

Reserva

Reserva

Ensanche 
4540 Narcisse Leven 4023 Narcisse Leven 1412 Narcisse Leven 4553 Narcisse Leven 4589 Narcisse Leven 4564 Narcisse Leven 4573 Narcisse Leven 773 Narcisse Leven 4520 Narcisse Leven 73 Narcisse Leven 770 Narcisse Leven 1307 Narcisse Leven 1309 Narcisse Leven 4046 Narcisse Leven 1422 Narcisse Leven 1301 Narcisse Leven 4475 Narcisse Leven 4060 Narcisse Leven 5997 Narcisse Leven 4614 Narcisse Leven 4582 Narcisse Leven 1094 Narcisse Leven 4590 Narcisse Leven 4574 Narcisse Leven 2613 Narcisse Leven 752 Narcisse Leven 1668 Narcisse Leven 4610 Narcisse Leven 753 Narcisse Leven 4029 Narcisse Leven 6008 Narcisse Leven 1669 Narcisse Leven 39 Narcisse Leven 4621 Narcisse Leven 4579 Narcisse Leven 1454 Narcisse Leven 1300 Narcisse Leven 2409 Narcisse Leven 4575 Narcisse Leven 1420 Narcisse Leven 4554 Narcisse Leven 1416 Narcisse Leven 1977 Narcisse Leven 1308 Narcisse Leven 4620 Narcisse Leven 4536 Narcisse Leven 6000 Narcisse Leven 5992 Narcisse Leven 1312 Narcisse Leven 3494 Narcisse Leven 4533 Narcisse Leven 4055 Narcisse Leven 4555 Narcisse Leven 771 Narcisse Leven 1426 Narcisse Leven 4517 Narcisse Leven 4167 Narcisse Leven 1481 Narcisse Leven 4021 Narcisse Leven 3755 Narcisse Leven 6035 Narcisse Leven 1618 Narcisse Leven 2 Narcisse Leven 1655 Narcisse Leven 1486 Narcisse Leven 1425 Narcisse Leven 4048 Narcisse Leven
Olivi Norberto S.,contrato de arriendo

Parnes Abraham, contrato, plano, notas

Pelasne Simon, contrato, plano

Persner Moises Alter, contrato

Petasne Simon, contrato

Petasni Marcos, contrato

Petasny Ignacio, contrato

Petasny Ignacio, contrato, plano, correspondencia

Pevsner Moises, contrato de arriendo

Pevsner Moises, contrato, plano

Pevsner Simon Jose, contrato, plano, correspondencia

Prullansky Luis, contrato, plano, cartas

Pruyansky Isaac, contrato, plano, cartas

Rajman Sara Vda. de, contrato

Rakita Cecilio, notas

Raskin Abraham y Salomon, contrato, plano, cartas

Raskin Abraham, contrato

Raskin Herman y Rivke, contrato

Rosemberg Sima Vda. de, e hijo Elias, contrato, notas

Rosembuj Mauricio, contrato

Rusansky Jaime, contrato

Rusansky Jaime, contrato, plano, cartas

Rusansky Samuel y Gurbanov Salomon, contrato

Saltz Federica B. de, contrato

Schabas Israel, contrato, plano, cartas

Schabas Israel, contrato, plano, correspondencia

Schabas Israel, Enrique y Mauricio, contrato, plano, cartas

Schabas Mauricio, contrato, nota

Schamis Gregorio, contrato, plano

Scheingold Berta K. de e hijos, contrato, cartas

Schejter Jacobo, contrato, notas

Scher ljiel y Juan, contrato, plano, carta

Scher ljiel, contrato, plano

Scher Zanvil y Juan, contrato

Schibovsky Marcos, contrato

Schibovsky Marcos, contrato, plano, cartas

Schlumansky Manuel, contrato, plano, cartas

Schmukler Luis, contrato, plano

Schoijet Isaac, contrato

Schoijet Isaac, contrato, plano, cartas

Schumajer Abraham, contrato

Schumajer Abraham, contrato, plano, cartas

Schumajer Mauricio, contrato, plano, cartas

Schumansky Jose, contrato, plano, cartas

Schumansky Manuel, contrato

Schumansky Manuel, contrato de arriendo

Schut Meyer y Jose, contrato, notas

Sclovich Abram, contrato, notas

Senderovsky Abraham, contrato, plano, cartas

Senderovsky Adolfo, contrato, nota

Senderovsky Leon, contrato de arriendo

Senderovsky Leon, contrato, notas

Senderovsky Zacarias y Leon, contrato, plano

Senderovsky Zacarias, contrato, plano, correspondencia

Silberberg Leon, contrato, plano, cartas

Siplovich Boris, contrato de arriendo

Siplovich Naum, contrato, notas

Siplovich Naum, contrato, plano, cartas

Skverer Miguel, contrato, plano, notas

Sociedad Cooperativa Agricola El Progreso, contrato

Sociedad Cooperativa Agricola El Progreso, contrato, plano, notas

Soifer Jose Pascual, contrato, plano, cartas

Soifer Levi, Josce Pascual, contratos arriendo, correspondencia

Soifer Luis, contrato, plano, cartas

Solovioff Abraham, contrato, plano

Solovioff Abraham, contrato, plano, cartas

Solovioff Isaac, contrato
1944-1948

$1911-60$

$1910-61$

1944-1949

1949- 1950

1944-1945

1944-1949

1909-59

1938-1939

1911-59

1957-64

1909-61

1934-64

1916-43

1966

1925-61

1938-1939

1911-40

1909-1925

1945-1946

1950-1951

1965-69

1945-1947

1944-1945

1961-66

1908-60

1931-64

1945-1950

1908-61

1910-56

1911-1931

1911-65

1951-56

1947-1949

1944-1948

1935-64

1910-64

1923-25

1944-1948

1911-64

1944-1950

1951-64

1931-70

1941-52

1947-1948

1949-1950

1909-1925

1911-1925

1931-49

1968-72

1943

1935-43

1944-1949

1910-64

1911-64

1938-1939

1961-64

1909-55

1926-64

1949-50

1951-1959

1955-65

1910-60

1934-65

1959

1931-55

1934-41
Ensanche

Ensanche

Reserva

Ensanche

Reserva

Ensanche 
5912 Narcisse Leven 4039 Narcisse Leven 772 Narcisse Leven

4563 Narcisse Leven 5995 Narcisse Leven 61 Narcisse Leven 4576 Narcisse Leven 1303 Narcisse Leven 756 Narcisse Leven 1096 Narcisse Leven 1671 Narcisse Leven 4062 Narcisse Leven 5998 Narcisse Leven 4042 Narcisse Leven 4577 Narcisse Leven 6001 Narcisse Leven 4030 Narcisse Leven 4556 Narcisse Leven 1617 Narcisse Leven 1653 Narcisse Leven 4031 Narcisse Leven 4032 Narcisse Leven 4049 Narcisse Leven 4604 Narcisse Leven 4063 Narcisse Leven 4056 Narcisse Leven 5911 Narcisse Leven 4516 Narcisse Leven 4054 Narcisse Leven 4548 Narcisse Leven 1673 Narcisse Leven 645 Narcisse Leven 4034 Narcisse Leven 4168 Narcisse Leven 1302 Narcisse Leven 4033 Narcisse Leven 4578 Narcisse Leven 4562 Narcisse Leven 6033 Narcisse Leven 6024 Palmar 5738 Palmar 2593 Palmar 1986 Palmar 6315 Palmar 1985 Palmar 5665 Palmar 5666 Palmar 5739 Palmar 6029 Palmar 4828 Palmar 5672 Palmar 151 Palmar 6329 Palmar 5742 Palmar 2611 Palmar 6333 Palmar 6328 Palmar 6085 Palmar 6326 Palmar 6324 Palmar 6331 Palmar 147 Palmar 155 Palmar 5681 Palmar 2596 Palmar 1989 Palmar
Teitelbaum Isaac y Francisco, contrato de promesa de venta

Teitelbaum Isaac, contrato, cartas

Tolcachin Salomon y Tolcachin Bernardo, contrato, plano, correspondencia

Torcachir Bernardo y Matzkin Abraham, contrato

Trosman David, contrato, notas

Tsiquinovsky Icie, contratos, planos

Tsiquinovsky Isaias, contrato, notas

Tuber David, contrato, plano

Vaimsky Marcos, contrato, plano

Vainberg Carlos, contrato, plano, cartas

Vaisman Leon y Benjamin, contrato, plano,carta

Veadimirsky Adolfo, contrato

Vekselman Isaac, contrato, notas

Vinocur Abraham, contrato

Vinocur Abraham, contrato, nota

Vinokur Salomon, contrato, notas

Visotzky Jacobo, contrato

Visotzky Marcos, contrato

Vladimirsky Salomon, contrato, plano, cartas

Waimberg Idel y Carlos, contrato, plano, cartas

Wainer Marcos, contrato, notas

Waiser David, contrato, notas

Waiser Isaac, notas

Wischñevsky Fanny E. de, contrato

Wischñevsky Fany Enquin de, contrato

Wischnevsky Felix, contrato, notas

Wischnievsky F. Plano de lote

Yampolsky Berl, contrato de pastoreo

Yampolsky Bernardo, contrato

Yampolsky Jose y Pablo, contrato

Yampolsky Jose, contrato, plano, cartas

Yampolsky Pablo, contrato, plano

Yudchak Erman, contrato, notas

Zacelsky Bernardo, contrato, plano, notas

Zaselnik Bernardo, contrato, plano, cartas

Zelione Abraham, contrato, cartas

Zelioni Abraham, contrato

Zukerman Zelig, contrato

Zukerman Zelik, contrato

Adler Abraham, contrato, notas

Aizicovich Efroim, contrato, plano, notas

Ajemblit Moises, contrato, plano, cartas

Altman David, contrato, plano, cartas

Amado Pedro, contrato arriendo de casa y terreno

Antik Jacobo, contrato, plano, cartas

Bargman Israel, contrato, plano, notas

Barinstein David, contrato, plano, notas

Bendersky Samuel, contrato, plano, notas

Bercovich Jaime, contrato

Bernater Salomon, contrato, plano, notas

Braslavsky Jacobo, plano, notas

Braverman Benjamin, contrato, plano

Caceres Ramon, contrato arriendo de lote para casa

Candel Gregorio, contrato, plano, notas

Carpman Saul y Abraham, contrato, plano, cartas

Carraud Enrique, contrato arriendo de lote

Caseres Juan, contrato arriendo de lote

Corinfeld Abraham, contrato, notas

Cuello Cristobal, contrato arriendo de casa y Transferencia

Delgado Carlos M., contrato arriendo de casa

Derazne Isaac, contrato arriendo de lote

Epstein David, contrato, plano

Epstein Jaime, contrato, plano

Fradkin Hilel e Israel, contrato, plano, notas

Fraiman Bernardo, contratao, plano, cartas

Fraiman Jaime, contrato, plano, cartas
1930

1916-41

1909-51

1944-1950

1911-1942

1935-64

1944-1946

1909-49

1959

1947

1909-61

1938-1939

1909-1940

1931-43

1944-1949

1909-1922

1932-1933

1938-1945

1910-64

1909-59

1909-42

1910-41

1940-44

1936-1956

1941-44

1916-43

1931

1934-39

1935-41

1944-1950

1931-59

1951

1911-24

1944-59

1909-51

1910-41

1944-1949

1944-1945

1947-1951

1932-1941

1912-1932

1916-45

1928-48

1917-1939

1929-48

1912-1944

1912-1927

1912-1939

1934-1938

1912-1946

1913-1929

1916-48

1945-1947

1944-1948

1929-47

1931-1932

1945-1947

1942-1946

1947-1960

51945

1947-1949

1932-60

1929-48

1912-1930

1947-51

1916-48 
2264 Palmar 6022 Palmar 5675 Palmar 1981 Palmar 2644 Palmar 6272 Palmar 2836 Palmar 4845 Palmar 5659 Palmar 157 Palmar 2631 Palmar 6023 Palmar 6271 Palmar 6321 Palmar 5656 Palmar 148 Palmar 5663 Palmar 2498 Palmar 154 Palmar 6031 Palmar 5657 Palmar 5740 Palmar 4827 Palmar 6317 Palmar 6330 Palmar 4829 Palmar 152 Palmar 5679 Palmar 2703 Palmar 1979 Palmar 2866 Palmar 5658 Palmar 2495 Palmar 6311 Palmar 5680 Palmar 5668 Palmar 4847 Palmar 149 Palmar 1984 Palmar 2445 Palmar 5661 Palmar 2496 Palmar 4826 Palmar 5678 Palmar 6334 Palmar 1980 Palmar 5870 Palmar 5737 Palmar 156 Palmar 6322 Palmar 2660 Palmar 2493 Palmar 2494 Palmar 6017 Palmar 5735 Palmar 5669 Palmar 6277 Palmar 6327 Palmar 2442 Palmar 5677 Palmar 6312 Palmar 6306 Palmar 6309 Palmar 2862 Palmar 3729 Palmar 6320 Palmar 153 Palmar
Fraiman Jaime, contrato, plano, cartas

Freiberger Hugo, contrato, notas

Fridman Salomon, contrato, plano, notas

Frujter Naum, plano, cartas

Fuks Jaime, contrato, plano, cartas

Fuks Jose, contrato de arriendo de casa

Fuks Marcos, contrato, plano, cartas

Fuks Marcos, contrato, plano, notas

Fuks Salomon, contrato, plano, notas

Furrer Benzion Gregorio, contrato, plano

Furrer Gregorio, contrato, plano, cartas

Ganz Jose, contrato, notas

Garcia Juan B., contrato de arriendo de casa

Gonzalez Liberato y Polo Pedro, contrato arriendo de casa

Halperin Jacobo, contrato, plano, notas

Hejt David, contrato, plano

Hocsman Isaac (ex Rebrej Motel), contrato, plano, notas

Hurevitz Naum y Ruben, contrato plano, cartas

Husz Jacobo, contrato, plano

Ideses Meir, contrato, notas

Irijimovich Salomon, contrato, plano, notas

Jajam Jose y Sadigursky Luisa K. de, contrato, plano, notas

Jromoy Jacobo, contrato, plano, cartas

Kamin Juan Sucesion, contrato arriendo de lote y casa

Katz Abraham, contrato arriendo de lote

Katz Clara L. de e Hijos, contrato, plano, notas

Kazanietz Jose, contrato, plano, correspondencia

Kazanitz Abe Hirasch, contrato, plano, notas

Kazanitz Rafael, contrato, plano

Kazanitz Rafael, contrato, plano, cartas

Kohan Leon y Jose, contrato, plano, cartas

Kohan Sara, Leon y Jose, contrato, plano, notas

Kolnik Bencion, contrato, plano, cartas

Kolnik Moises, contrato de arriendo de casa

Kotler Carlos, contrato, plano, notas

Kreiserman Mauricio, contrato, plano, notas

Kreizerman Jose, contrato, plano, notas

Kriguer Gregorio y Abraham, contrato, plano

Krinberg Leon y Meier, contrato, plano, cartas

Kroger Juan, contrato, plano

Lapidus Adolfo y Gregorio, contrato, plano, notas

Latascheff Salomon, contrato, plano, cartas

Lijavetzky Moises y Gregorio, contrato, plano, notas

Lischinsky Abraham, contrato, plano, notas

Malek Jacobo, contrato aarriendo de lote

Mandel Samuel Isaac, contrato, plano, cartas

Matzkin Natalio, contrato, plano

Matzkin Natalio, contrato, plano, notas

Maurman Genendl K. de, contrato, plano

Maxit Ricardo S., contrato arriendo de casa

Mendelevich Cecilia Swarzman de, contrato, plano, cartas

Mendelevich Elias, contrato, plano, cartas

Milman Moises y Miguel, contrato, plano, cartas

Milman Moises, contrato, notas

Milman Salomon, contrato, plano, notas

Minces Samuel, contrato, plano, notas

Molina Jose Maria, contrato de arriendo de casa

Monson Ireneo y Vda. de Lopez, contrato arriendo de terreno

Moscovich Seidel Roberto, contra to, plano

Nemirovsky Manuel, contrato, plano, notas

Noir Mauricio y Carraud Alicia, contrato arriendo de casa

Olkenitzky Jacobo, contrato de arriendo de casa

Patrone Santiago E., contrato de arriendo de casa

Peragallo Juan Libio, contrato, plano

Peragallo Juan, contrato, plano, nota

Pereyra Salvador, contrato arriendo de casa

Podlischevsky Marcos, contrato, plano
1926-53

1940-1946

1912-1952

1930-49

1948

1945

1949

1928-1939

1912-1925

1932-48

1947-48

1932-1942

1945-1945

1945-1950

$1912-1925$

1932-48

1912-1932

1912-51

$1930-48$

1912-1945

1913-1925

1912-1934

1912-1938

1919-1931

1936-1947

1912-1947

1925-48

1912-1929

1948

1916-48

1947

1913-1945

1928-53

1945-1948

1912-1935

1912-1928

1923-1942

1932-48

$1912-48$

1930

$1912-1949$

1912-49

1913-1928

1912-1953

1932-1945

1938-49

1929-1939

1912-1939

1927-48

1945-1947

1929-48

1929-42

1923-47

1944-1945

1912-1930

$1912-1925$

1940-1940

1931-1933

1937

1912

1919-1947

1945-1946

1945-1947

1947

1946

1945-1948

1932-60
Reserva

Reserva

Reserva

Reserva

Reserva

Reserva

1954

Reserva 
6025 Palmar 6021 Palmar 4368 Palmar 6332 Palmar 2779 Palmar 2876 Palmar 6278 Palmar 6337 Palmar 5741 Palmar 5682 Palmar 6028 Palmar 2595 Palmar 2650 Palmar 5674 Palmar 5736 Palmar 4844 Palmar 5683 Palmar 1978 Palmar 6297 Palmar 5673 Palmar 6020 Palmar 1988 Palmar 5660 Palmar 5701 Palmar 2634 Palmar 150 Palmar 6299 Palmar 5662 Palmar 2612 Palmar 5671 Palmar 6335 Palmar 4846 Palmar 6323 Palmar 4830 Palmar 2762 Palmar 6298 Palmar 5676 Palmar 6019 Palmar 2875 Palmar 5664 Palmar 5820 Palmar 6325 Palmar

5667 Palmar 2446 Palmar 4825 Palmar 1987 Palmar 1983 Palmar 5816 Palmar

6026 Palmar 6018 Palmar 6300 Palmar 4831 Palmar 2497 Palmar 4307 Palmar 6027 Palmar 2594 Palmar 5670 Palmar 6030 Palmar 2935 Palmar 2435 Palmar

1982 Palmar 1990 Palmar 6336 Palmar
Polak Max, contrato, notas

1931-1941

Polichevsky Marcos, contrato

Policia de Palmar (Donación), contrato, plano, cartas

1943

Ponce Andres, contrato arriendo de lote

Postan Manuel, contrato, plano, cartas

Postan Manuel, contrato, plano, cartas

Postel Hermanos, contrato de arriendo de casa

Smoisman Jose, Escritura

Sociedad de Beneficencia Baronesa Clara, contrato arriendo

de Sala de Primeros Auxilios J.J

Suster Sfroim, contrato, plano

Trupp Gregorio, Irijumovich Salomon, Iconicoff Jacobo, Rabinovich

Gregorio, Krivitzky Elias, Fridman Salomon, Kreizerman Jose,

escrituras de terrenos vendidos por JCA

Usatinsky Boris y Samson Isaac, contrato, notas

Usatinsky Israel, Testimonio

Vainstub Salomon, contrato, plano, notas

Vaisman Smil, contrato, plano, cartas

Vazon Juan, contrato, plano, notas

Vertberger Anton, contrato, notas

Viner Gregorio e hijo Julio, plano, contrato, cartas

Viner Isaac y Gregorio, contrato, plano, notas

Voloschin Samuel, contrato, notas

Waingartin Moises y Maidanik Mordejai, contrato, plano, cartas

Waingortin Mauricio y Maidanik Moises y Mordjai, contrato, plano notas

Wainstube Jacobo, contrato, plano cartas

Weibel Israel, contrato, plano, cartas

Wilkinson Esther L. de, contrato arriendo de lote
1937-42

1947

1942-43

1947

1945

1918-1947

$1912-1934$

1912-1930

1932-1944

1938-46

1948

1912-1929

1918-1930

1912-1939

$1912-1930$

1925-52

1945-1947

1912-1952

1943-1948

1926-48

1912-1943

$1912-1943$

1947-48

1932-48

1934-1935

$1912-1931$

1937-50

1912-1929

1945-1949

1912-1948

1945-1950

1912-1937

1929-30

1937-1940

1912-1929

1934-1947

1947

1912-1926

1952

1931-1947

1912-1927

1948

1912-1945

1946-48

1916-48

1922

1912-1942

1937-1942

1948

Reserva

Reserva

Reserva

Reserva

Resera

Reserva

Reserva

Reserva

1912-1947

1928-48

1930

1931-1947

1928-46

1912-1929

1912-1943

1930-32

1929-35

Reserva

Reserva

1920-48

1928-48

1945-1945 
2300 San Antonio 4225 San Antonio 3449 San Antonio 2362 San Antonio 490 San Antonio 3448 San Antonio 986 San Antonio 4198 San Antonio 2352 San Antonio 3452 San Antonio 2464 San Antonio 4333 San Antonio 489 San Antonio 2930 San Antonio 3437 San Antonio 4928 San Antonio 4211 San Antonio 2765 San Antonio 5654 San Antonio 4254 San Antonio 4214 San Antonio 4331 San Antonio 4309 San Antonio 3444 San Antonio 4235 San Antonio 4939 San Antonio 2348 San Antonio 2346 San Antonio 6346 San Antonio

2108 San Antonio 6004 San Antonio 4250 San Antonio 3416 San Antonio 4259 San Antonio 3434 San Antonio 3455 San Antonio 3427 San Antonio 3409 San Antonio 4207 San Antonio 3430 San Antonio 982 San Antonio 4221 San Antonio 2345 San Antonio 2148 San Antonio 4206 San Antonio 999 San Antonio 3413 San Antonio 4938 San Antonio 4226 San Antonio 4237 San Antonio 984 San Antonio 2132 San Antonio 2465 San Antonio 3440 San Antonio 977 San Antonio 2463 San Antonio 4232 San Antonio 4236 San Antonio 4245 San Antonio 5652 San Antonio 4230 San Antonio 5645 San Antonio 3445 San Antonio 3435 San Antonio 4255 San Antonio 2468 San Antonio
Aisicovich Jacobo, contrato, notas transferido

$1909-44$

Aizicovich Abraham, contrato, plano, notas

Alperin Salomon, contrato

Amerman Daniel, contrato, plano

Amerman Fabian, contrato, plano, notas

Aravsky Isaac, contrato, plano, cartas

Backman Chaim, plano, nota

Bacman Mauricio y Tevelez Bernardo, contrato de arriendo

Baschcansky Pablo, contrato, plano, notas

Bashkansky Pablo y Marcos, contrato, plano, cartas

Bastian Miguel Angel, contrato, nota

Berensohn Jose, contrato, plano, carta

Bernard Vitorio Augusto, contrato, plano

Brailovsky Rebeca e Isabelino, contrato, plano, cartas

Braslavsky Isaac, contrato

Braun Chabse, contrato, plano, cartas

Brodsky David, contrato, plano

Brodsky David, contrato, plano, notas

Brunstein Idel, contraato, plano, cartas

Caplan Moses, plano, cartas

Carpman Samuel, contrato de arriendo

Cesar Samuel, contrato de arriendo

Cesar Samuel, contrato, plano, notas

Cesar Victor, contrato, plano, notas

Colpachy Rosa e Ignacio, contrato, notas

Comisión Cultural del grupo Carlos Calvo, contrato

Comisión Escolar del grupo Hambis, contrato de arriendo

Culpachi Jacobo y Culpachi Rosa Grinberg, contrato de arriendo de campo e inmueble

Daniel Jaime, notas, desalojo

Davidovich Bernardo, contrato, notas

Disenfeld Abraham, contrato, plano, cartas

Doren Marcos, contrato, plano, cartas

Dorin Gregorio, contrato, plano, notas

Dorin Leon y Feliciano, contrato, plano, cartas

Dorin Leon, contrato, plano, notas

Dorin Luis, contrato

Drucker Saul, contrato, plano, cartas

Engelberg Naum, contrato, plano, cartas

Eppel Mauricio, contrato, plano, notas

Eppel Salomon, contrato, plano

Fainstein Bernardo y Rosa, contrato, plano, notas

Fainstein Bernardo, contrato de arriendo

Fainstein Bernardo, contrato de arriendo anulado

Fainstein Leib, plano, notas

Fainstein Samuel, contrato, plano

Falicoff Rosa e hijos Jose y Bernardo, contrato, plano, notas

Forschberg Schaie, contrato, notas

Fukelman Hersch, contrato, plano, cartas

Fuquelman David, contrato, plano, notas

Galperin Gregorio, contrato, plano, cartas

Ganzberg Angel, contrato de arriendo anulado

Garbate Jaime, contrato, plano, cartas

Gelfan Sara Tormman de, contrato, plano, notas

Gilitchensky Abraham, contrato, plano

Gilitchensky Abraham, contrato, plano, cartas

Gitlin Moises, contrato, plano, notas

Gleser Jaime, contrato, plano, cartas

Glezer Jacobo M., contrato, plano, cartas

Goldman Adolfo, contrato, plano, notas

Gordin Moises, contrato, plano, cartas

Gorodner Jaime, contrato, plano, notas

Grabois David, contrato, plano, notas

Grimberg Federico y Bernardo, contrato, plano, notas

Grinberg Federico, contrato, plano, cartas

Grinberg Gregorio, contrato, plano, cartas
1941-44

1943-47

$1915-50$

$1908-42$

1901-30

$1940-42$

$1936-50$

1947-48

1955

1911-47

1919-36

1938-48

1907-1942

1901-28

1929-30

1907-1921

1915-25

1901-31

1916-27

1945-1946

1945-56

1901-21

1925-1941

1945-50

1940-41

1942

1934-47

1945-1948

1910-25

1945-58

1901-24

1939-55

1910-55

1941

1935-55

1922-48

1941-49

1915-49

1906-28

1940-41

1932

1906-30

1915-29

1909-49

1904-1936

1894-1922

1906-19

1918-33

1932

1922-55

1927-52

1918-41

1927-53

1901-20

1907-22

1906-27

1900-1939

1907-20

1906-1949

1915-48

1948-56

1915-25

1929-56
Reserva

Reserva 
4260 San Antonio 3432 San Antonio 3454 San Antonio 4262 San Antonio 991 San Antonio 4257 San Antonio 4244 San Antonio 2486 San Antonio 6002 San Antonio 5909 San Antonio 2636 San Antonio 3414 San Antonio 4204 San Antonio 3428 San Antonio 975 San Antonio 2801 San Antonio 4219 San Antonio 2365 San Antonio 5651 San Antonio 4200 San Antonio 2861 San Antonio 4243 San Antonio 4249 San Antonio 2484 San Antonio 4210 San Antonio 3447 San Antonio 3443 San Antonio 992 San Antonio 5644 San Antonio 2485 San Antonio 2462 San Antonio 3436 San Antonio 146 San Antonio 4248 San Antonio 3421 San Antonio 974 San Antonio 4227 San Antonio 2366 San Antonio 5640 San Antonio 5655 San Antonio 484 San Antonio 4247 San Antonio 4234 San Antonio 2375 San Antonio 998 San Antonio 2461 San Antonio 990 San Antonio 973 San Antonio 5641 San Antonio 995 San Antonio 993 San Antonio 3412 San Antonio 2487 San Antonio 2360 San Antonio 3461 San Antonio 4239 San Antonio 989 San Antonio 4223 San Antonio 4238 San Antonio 480 San Antonio 2627 San Antonio 3396 San Antonio 4220 San Antonio 4242 San Antonio 4222 San Antonio 6003 San Antonio 708 San Antonio
Grinberg Marcos, contrato, plano, cartas

$1908-22$

Grinberg Rafael, contrato, plano, notas

Grinberg User y Andres, contrato, plano, cartas

Grinstein David y Abraham, contrato, plano, cartas

$1934-50$

$1915-55$

1901-24

$1922-36$

$1908-25$

1907-27

1933-47

1945-1951

1943

1948

$1949-59$

1915-30

1913-45

$1910-43$

1947

1901-19

1942

1907-1938

1907-30

1930

1906-28

1907-25

1938-51

1925-30

1935-51

1916-58

1907-36

1901-1934

1911-50

1915-52

1929-57

1917-47

1908-26

1940-54

1912-43

1910-22

1942-43

1919-1937

1901-1919

1918-53

1907-26

1909-21

1943-44

1930

1939-47

1912-45

1924-44

1915-1937

1908-30

1927-37

1943-49

1926-47

1941-42

1919-56

1907-29

1901-47

1901-19

1901-19

1926-49

1947-48

1925-1951

1907-28

1907-28

1907-48

1946-1948

1942-49

(

Latute Salomon, contrato, plano, cartas

eikin Aron, contrato, plano, cartas

Leikin Leon, contrato, notas

Leikin Marcos y Leon, contrato, plano
Reserva

Reserva 
2467 San Antonio 3418 San Antonio 2301 San Antonio 3438 San Antonio 985 San Antonio 5653 San Antonio 4256 San Antonio 2381 San Antonio 5650 San Antonio 3366 San Antonio 2785 San Antonio 4215 San Antonio 4208 San Antonio 4209 San Antonio 3104 San Antonio 3420 San Antonio 2147 San Antonio 4218 San Antonio 4252 San Antonio 2466 San Antonio 3415 San Antonio 2483 San Antonio 4332 San Antonio 3410 San Antonio 3102 San Antonio 5642 San Antonio 4251 San Antonio 3423 San Antonio 4217 San Antonio 3442 San Antonio 4224 San Antonio 978 San Antonio 4253 San Antonio 4229 San Antonio 5648 San Antonio 3453 San Antonio 4330 San Antonio 4203 San Antonio 988 San Antonio 3426 San Antonio 976 San Antonio 987 San Antonio 5647 San Antonio 4213 San Antonio 4228 San Antonio 3425 San Antonio 3429 San Antonio 3433 San Antonio 145 San Antonio 3457 San Antonio 4199 San Antonio 3458 San Antonio 981 San Antonio 3441 San Antonio 5832 San Antonio 4212 San Antonio 3456 San Antonio 4202 San Antonio 4246 San Antonio 980 San Antonio 4261 San Antonio 4231 San Antonio 5643 San Antonio 3431 San Antonio 2367 San Antonio 1001 San Antonio 3411 San Antonio
Leikin Marcos y Leon, contrato, plano, cartas

Leikin Salomon y Adolfo, contrato, plano, cartas

Lemel Isaac y David, contrato, notas, abandono

Levin Gregorio, contrato, plano, notas

Lifschitz Manuel, contrato, plano, cartas

Lis Icek y Gregorio, contrato, plano, notas

Liscovich Adolfo, contrato, plano, notas

Litvin Aaron, contrato de pastoreo

Litvin Aron, contrato, plano, notas

Litvin Samuel y Benjamin, contrato, plano, notas

Loschkin Uscher, contrato, plano

Loschkin Uscher, contrato, plano, notas

Man Ers y Moises, contrato, plano, notas

Man Ignacio, contrato, plano, cartas

Man Moises, contrato

Man Moises, contrato, plano, notas

Marckman Abraham, contrato de arriendo anulado

Marcoff Moses, contrato, plano, cartas

Medvedovsky Bernardo, contrato, plano, notas

Medvedovsky Jose y Rubin, contrato, plano, cartas

Medvedovsky Moises y Adolfo, contrato, plano, notas

Medvedovsky Moises, contrato, plano, cartas

Mendez Educadio, contrato de arriendo

Milstein Leon y Osias, contrato, plano, cartas

Milstein Osias, contrato

Mitelman Julio (ex Seldes Samuel), contrato, plano, notas

Mitelman Julio, contrato, plano, cartas

Mitelman Simon, contrato, plano, cartas

Najles Pedro, contrato, plano, notas

Nejamkin Aron, contrato, plano, notas

Nejamkin Leon, contrato, plano, cartas

Nisenblat Rosa R. de (ex A. Dorin), contrato, plano, cartas

Palatnik Leon, contrato, plano, notas

Pekerman Abraham, plano, cartas, notas

Perelroisen Gregorio, contrato, plano, notas

Perelroisen Naum, contrato, plano, notas

Pinella Antonio,contrato de arriendo

Pipman Osias, contrato, plano, notas

Presman Leon, contrato, plano, cartas

Rabin Pincus, contrato

Rabin Pincus, contrato, plano, cartas

Rabinovich Israel, contrato, plano, cartas

Rain Julio, contrato, plano, notas

Remestvensky Rubin, contrato, plano, notas

Rochkin Abraham, contrato, plano, cartas

Roitman Abraham, contrato, plano, cartas

Roitman Salomon Suc., contrato, plano, cartas

Rojkin Benjamin, contrato, plano, notas

Rojkind Isaac, contrato, plano

Rosemberg Alejandro, Abraham y Marcos, contrato, plano, cartas

Rosenberg Efroim, contrato, plano, notas

Rosenfeld Jacobo y Abraham, contrato, plano, notas

Rosenfeld Moises, contrato, plano, cartas

Rosenfeld Salomon,, contrato, plano, cartas

Rosenstein Mauricio y Samuel, contrato, notas

Rubinsky Hersch, contrato, plano, cartas

Rubinsky Natalio, contrato, plano, notas

Rubinstein Marcos, contrato, plano, cartas

Rubinstein Pablo, contrato, plano, notas

Salzman Abram (ex Beker Suc.), contrato, plano

Salzman Felipe, contrato, plano, notas

Salzman Marcus, contrato, plano, cartas

Salzman Simon (ex Melamedoff Nuchim), contrato, plano, notas

Schargorodsky Golde y Salomon, contrato, plano, cartas

Scheffler Alfredo, contrato de pastoreo

Schejtman Mauricio, contrato, plano, cartas

Schmuckler David, contrato, plano, notas
$1942-52$

$1915-57$

$1909-40$

$1936-48$

1936-39

1941-1963

$1908-25$

1944-47

1907-1941

$1943-51$

1939-45

1907-28

1908-56

1929

1946

1948-56

1932

1900-19

1912-25

1945-52

1910-49

1929-47

1934-37

1923-59

1946

1916-1938

1912-25

1910-46

1901-19

1928-52

1907-19

1906-42

1900-25

1907-19

1921-1939

1909-53

1931-41

1913-38

1907-50

1937-46

1904-41

1905-38

1915-1931

1907-28

1908-19

1928-48

1947-49

1945-56

1930-50

1915-53

1907-30

1940-56

1914-39

1927-48

1936-1937

1906-28

1944-51

1906-30

1902-26

1915-49

1909-23

1900-20

1900-1936

1919-48

1934-45

1930-36

1915-49 
5831 San Antonio 3419 San Antonio 3424 San Antonio 4216 San Antonio 5836 San Antonio 979 San Antonio

1000 San Antonio 4205 San Antonio 478 San Antonio 983 San Antonio 479 San Antonio 2150 San Antonio 3417 San Antonio 487 San Antonio 4201 San Antonio 4233 San Antonio 491 San Antonio 4240 San Antonio 4258 San Antonio 3451 San Antonio 3450 San Antonio 3439 San Antonio 3408 San Antonio 3460 San Antonio 3459 San Antonio 3422 San Antonio 4241 San Antonio 5649 San Antonio 4329 San Antonio 5646 San Antonio 3446 San Antonio 4074 Santa Isabel 6149 Santa Isabe 2566 Santa Isabe 6183 Santa Isabe 6231 Santa Isabel 6106 Santa Isabe 6214 Santa Isabel 6216 Santa Isabe 6114 Santa Isabel 4087 Santa Isabe 6280 Santa Isabe 6285 Santa Isabel 4081 Santa Isabe 1338 Santa Isabe 6139 Santa Isabe 6135 Santa Isabe 4106 Santa Isabe 6305 Santa Isabel 6226 Santa Isabe 6292 Santa Isabel 6108 Santa Isabe 2767 Santa Isabe 6340 Santa Isabe 4118 Santa Isabel 2559 Santa Isabel 6137 Santa Isabe 5775 Santa Isabe 4103 Santa Isabe 6087 Santa Isabe 6130 Santa Isabe 6262 Santa Isabe 2599 Santa Isabe 2697 Santa Isabe 5945 Santa Isabe 6132 Santa Isabel
Schmukler Israel y Marcos, contrato

Schmukler Jacobo y Manuel, contrato planos, cartas

1937

Schusel Gregorio, contrato, plano, notas

Schwarzbein Gregorio y Engelberg Moises, contrato, plano, cartas

Sckerdt Alejandro Sucesion, contrato

Seldes Nicolas, Seldes Clara S. de y Susman Saul, contrato, plano, cartas

Seldes Rubin, contrato, plano, cartas 1906-36

Senkman Luis, contrato, plano, cartas 1900-30

Sibulosky Abram, contrato, plano, cartas 1939-47

Sincofsky Idel, contrato, plano 1914-39

Sincosky Jose y Sincofsky Abraham, contrato, plano, carta 1937-50

Sincovsky Abraham, contrato de pastoreo 1934

Soltz Adolfo, contrato, plano, notas $1924-49$

Stein Salomon, contrato, plano, cartas 1920-49

Stein Salomon, contrato, plano, notas $1928-43$

Stilman Abraham, contrato, plano, cartas 1907-20

Stocalin Rosa M. de, contrato, plano 1925-54

Suttin Aron y Abraham, contrato, plano, cartas 1901-23

Svitkoy Moises y Samuel, contrato, plano, notas 1907-25

Titievsky Mehir y Santiago Miguel, contrato, plano, cartas 1912-55

Titievsky Simon y Naum, contrato, plano, cartas 1910-55

Toer Abraham, contrato, plano, cartas 1938-58

Udelsman Efroim, contrato, plano, notas 1945-47

Umansky Gregorio,, contrato, plano, notas 1932-58

Umansky Osias, contrato, plano, cartas 1911-47

Umansky Salomon, contrato, plano, notas

Utin Samson, contrato, plano, notas 1907-27

Veitzman Gregorio, contrato, plano, notas $\quad$ 1907-1933

Villa Enrique, contrato de arriendo

Vitcoff Israel, contrato, plano, notas

Woskoboinik Froim y Samuel, contrato, plano, cartas

Aguirre Fausto, contrato

Aguirre Servando, contrato de arriendo

Aisemberg Jacobo y Adolfo, contrato, plano, cartas

Altman David, contrato de pastoreo

Altman David, contrato de pastoreo

Antik Jacobo, contrato de pastoreo

Appel Benjamin, contrato de arriendo de casas, notas

Apter Moises, contrato de pastoreo, notas

Arculis Jose, contrato de pastoreo

Azuaga Maria, contrato

Azuaga Maria, contrato de arriendo de casa

Bainer Jacobo, contrato arriendo de campo

Ballesteros Aurelia, contrato

Banchik Angel, contrato, plano, cartas

Baranoff Jacobo, contrato de pastoreo

Bendersky Mauricio, contrato, notas

Benitez Juan, contrato

Benitez Juan, contrato de arriendo de casa

Bercovich Jaime, contrato de alquiler, Promesa de Venta, notas 1912-1935

Berg Herman, contrato arriendo de campo 1939-1941

Berg Hermann, contrato de pastoreo 1943-1944

Bergman Arturo, contrato, plano

Biblioteca Popular La Cultura, contrato arriendo de casa

Blatt David, contrato

Blatt Moses Suc., contrato, plano, cartas

Blatt Pedro, contrato de alquiler

Blinder Fany A. de , y Schnitman Abraham, contrato, plano, notas

Blinder Jacobo, contrato

Blinder Jacobo, contrato

Bolchinsky Adolfo, contrato de pasatoreo

Bolchinsky Adolfo, contrato de pastoreo

Bolchinsky David, contrato, plano

Bolchinsky Faino, contrato, plano cartas

Bolchinsky Gregorio, contrato de pastoreo

Bolchinsky Jaime y Ramos Romulo, contrato de pastoreo
1931

1945-1950

1927

1908-36

1948-1948

1912-1930

1939

1937-1937

1943-1943

1942-1942

1911-39

$1948-53$

1943-1946

1943-1943 
6170 Santa Isabel 6303 Santa Isabel 2565 Santa Isabe 419 Santa Isabel 6167 Santa Isabe 720 Santa Isabel 6129 Santa Isabel 4102 Santa Isabel 4075 Santa Isabel 3725 Santa Isabel 5901 Santa Isabel 6283 Santa Isabe 3180 Santa Isabel 1702 Santa Isabel 6284 Santa Isabel 6159 Santa Isabe 6188 Santa Isabel 6270 Santa Isabe 1968 Santa Isabe 3659 Santa Isabe 3182 Santa Isabel 2641 Santa Isabe 5946 Santa Isabel 6202 Santa Isabel 6133 Santa Isabe 6125 Santa Isabe 6215 Santa Isabel 6269 Santa Isabel 2651 Santa Isabe

6197 Santa Isabe 6260 Santa Isabe 3489 Santa Isabe

6199 Santa Isabel 5947 Santa Isabe 3181 Santa Isabel 4083 Santa Isabel 2705 Santa Isabel 2752 Santa Isabel 6243 Santa Isabel

6196 Santa Isabel 6244 Santa Isabe 6160 Santa Isabel 1704 Santa Isabel 4114 Santa Isabe 6232 Santa Isabel 6123 Santa Isabel 6222 Santa Isabe 2579 Santa Isabe 6247 Santa Isabel

2885 Santa Isabel 6111 Santa Isabel 6276 Santa Isabel 4082 Santa Isabel 4119 Santa Isabel 6279 Santa Isabe 2680 Santa Isabel 6225 Santa Isabel 6184 Santa Isabe 6102 Santa Isabe 6173 Santa Isabel 6204 Santa Isabel 6092 Santa Isabe 6240 Santa Isabel
Bolchinsky Jaime, contrato de pastoreo

Bolchinsky Jaime, nota

Bolchinsky Lazaro, contrato, plano, cartas

Bolchinsky Simon, contrato, plano, carta

Bonder Jose, contrato de pastoreo, notas

Bourren Meyer Felix, contrato, plano, cartas

Bouvet Agustin, contrato de pastoreo

Burdman Israel, contrato

Camino Roberto Teodoro, contrato

Candil Carlos y Azuaga Ramon, contrato, plano, notas

Candill Alejandro, contrato de venta de la JCA, escritura

Celman Salomon, contrato arriendo de campo

Cementerio Israelita, nota, plano

Cheresky Dora Schwartz de, contrato, plano, cartas

Cheresky Jose, contrato arriendo de lote, Promesa de Venta

Colman Julio S., contrato de pastoreo

Comisión Escolar del Grupo Berro, contrato de arriendo

Comisión Sinagoga Bet Jitzjak, contrato de arriendo de solar

Cooperadora Escuela Nacional No. 122, nota, plano

Cooperadora Escuela No. 113, plano, nota

Cooperadora Sanitaria Pedernal, nota recibo

Cooperativa Agricola «La Union» contrato, plano, cartas

Cooperativa Agricola La Union, contrato de pastoreo

Cooperativa La Luchadora, contrato alquiler de casa

Cooperativa Tamberos La Nueva Esperanza, contrato de pastoreo

Corenfeld Abraham, contrato de pastoreo, nota

Crupnik Jose, contrato de alquiler

Dehovne Schaya, contrato de arriendo de habitación, nota, testimonio

Donación de la J.C.A. al Estado Nacional Argentino en presencia

del presidente Peron, contrato, plano

Dreispiel Luis A., contrato de pastoreo

Elberg Enrique A., contrato de arriendo, notas

1972-73

Epstein Berta Weibel de, Oscar Leonardo, Jose y Rosalia, nota

Epstein Salomon y Jaime, contrato de pastoreo

Epstein Salomon, contrato de pastoreo

Escuela Nacional No. 123 , nota

Etchevarne Jacinto y otros, contrato

Fabian Georg, contrato, plano, cartas

Fabian Georg, contrato, plano, cartas

1930-1932

Falicoff Samuel y Benjamin, contrato de arriendo, testimonio, notas

Falicoff Simon, contrato de alquiler de casa, notas

Falicoff Simon, contrato de arriendo de lote, testimonio

Fatelevich Ana Kreiman de, contrato de pastoreo, nota

Finbarg Simeon y Finberg Juan, contrato, plano, cartas

Finkel Moises, contrato

Finvarb Leon, contrato de pastoreo

Finvarb Osias, contrato de pastoreo

Finvarb Osias, contrato de pastoreo, notas

Finvarb Simeon, plano, nota

Firman Fermina Vda. de Isaac Firman, contrato de arriendo de

campo, testimonio, notas

Fischman Bernardo, contrato, plano, cartas

Fischman Jacobo, contrato de arriendo

Fleita Francisco, contrato de arriendo de casa

Fleitas Clemente, contrato

Fleitas Urbano, contrato

Fleitas Urbano, contrato de arriendo de casa

Flischfisch Nujem, Moises e Isaac contrato, plano, cartas

Fraiman Jaime, contrato de pastoreo

Freiberger Hugo, contrato de pastoreo

Freiberger Hugo, contrato de pastoreo

Fridman Marcos y Paulina, contrato de pastoreo

Frujter Najman, contrato de pastoreo

Fuks Jacobo Elias, contrato

Fuks Jacobo Elias, contrato de pastoreo
1945-1946

1945

1908-26

$1938-52$

1944-1947

$1943-49$

1944

1939

1961

1938-49

1962

1938-1946

1969-71

$1912-49$

1938-1946

1932

1934-1936

1945-1949

1966

1963-71

1970

1942-48

1945-1947

1938-1945

1945-1950

1942-1946

1935-1940

1936-1947

1951

1935

1936-1937

Reserva

1945-1947

1943-1945

1971

1951

1960

1937-60

1935-1937

1912-1929

1944-1945

1949

1933

1942-1946

1942

1946

1960

1929-1933

1915-51

1937-1941

1945-1947

1952

1949

1945-1947

1916-48

1946

1945-1946

1945-1946

1945-1946

1945-1947

1937-1946

1947
Reserva

Reserva

De reserva

Reserva

Reserva

De reserva

Reserva

Reserva

Reserva

De reserva

(n)

87


6161 Santa Isabel 6264 Santa Isabe 6206 Santa Isabe 6113 Santa Isabel 6186 Santa Isabe 6090 Santa Isabel 2747 Santa Isabe 6296 Santa Isabe 6242 Santa Isabe 6121 Santa Isabe 6144 Santa Isabe 1703 Santa Isabe 2754 Santa Isabe 2569 Santa Isabe 5948 Santa Isabe 4071 Santa Isabe 5827 Santa Isabe 3727 Santa Isabel 3728 Santa Isabe 6147 Santa Isabe 6213 Santa Isabe 4101 Santa Isabel 4090 Santa Isabe 2058 Santa Isabel 417 Santa Isabel 6091 Santa Isabel 5777 Santa Isabe 6273 Santa Isabe 2603 Santa Isabe 4113 Santa Isabel 2572 Santa Isabel 2741 Santa Isabe 2761 Santa Isabel 4095 Santa Isabe 4104 Santa Isabe 6265 Santa Isabel 6165 Santa Isabe 4079 Santa Isabel 6259 Santa Isabel 413 Santa Isabel 6158 Santa Isabel 6236 Santa Isabe 2600 Santa Isabe 2774 Santa Isabel 6120 Santa Isabe 1594 Santa Isabel 6177 Santa Isabel 2558 Santa Isabe 6140 Santa Isabe 2740 Santa Isabe 6233 Santa Isabe 6117 Santa Isabel 6286 Santa Isabel

6220 Santa Isabel 6234 Santa Isabel 6143 Santa Isabel 6138 Santa Isabel 1261 Santa Isabel 6263 Santa Isabel 2582 Santa Isabe 2777 Santa Isabel 6268 Santa Isabel 2560 Santa Isabe 6293 Santa Isabel 4094 Santa Isabel 6205 Santa Isabel
Fuks Jacobo, contrato de arriendo

1932

Fumberg Rafael y Saul, contrato de arriendo de campo, notas

Furrer Bencion, contrato de pastoreo

Furrer Gregorio, contrato de pastoreo

Ganz Jose y Hysz Yankel, contrato de pastoreo

Ganz Manuel, contrato

Gersanik Aron y Szejnbam y Jakob, contrato, plano, cartas

Glick Moises, contrato arriendo de campo, notas

Glik Jacobo, contrato de arriendo de campo, notas

Gnuth Johan, contrato de pastoreo

Gnuth Johan, contrato de pastoreo

Goldman Catalina Vda, de, contrato, plano, cartas

Goldsmid Jacobo, contrato, plano, cartas

Goldsmid Jose, contrato, plano, cartas

Goldsmit Jacobo, contrato de pastoreo

Gomez Ramona, contrato

Gomez Tomasa Vda. de, contrato

Gorbato Juan, contrato, plano

Gorbato Leon, contrato, plano

Gorbato Manuel, contrato de pastoreo

Gorostegui V. Fernando, contrato de pastoreo

Gorskin David y Nijamkin Naum, contrato

Gorskin David, contrato

Gorsky Adolfo, contrato, plano

Gorsky Aizik, contrato, plano, carta

Gottfried Alter, contrato

Gottfried Leon, contrato, plano, notas

Graetzer Friedrich, contrato de arriendo de campo, notas

Grinstein Elias, contrato, plano, cartas

Grinstein Gregorio, contrato, plano

Grinstein Leon, contrato, plano, cartas

Grinstein Moises e Isaac, contrato plano, cartas

Grunstein Moises, contrato, plano, cartas

Grurchky Leon, contrato

Gruschky Benjamin, contrato

Gruschky Marcos, contrato de arriendo de campo, nota

Gruschny Leon, contrato de pastoreo

Guardia Roque, contrato

Guardia Roque, contrato de arriendo de casa y campo

Gubspun Celio, contrato, plano, carta

Gubspun Jose, contrato de pastoreo.

Gubspun Jose, contrato de pastoreo

Guerschanik Moses, contrato, plano, cartas

Guerschanik Salomon, contrato, plano

Guiot Armando, contrato de pastoreo

Gurevich Adolfo, contrato, plano, cartas

Gurevich Israel, contrato de pastoreo

Gurevich Samuel, contrato, plano, cartas

Haase Moises, contrato de pastoreo

Haiden Chaim Josef, contrato, plano, cartas

Halpert Wolf, contrato de alquiler, notas

Hejt David, contrato de pastoreo

Heller Berta e Hijo Moises Sucesion, contrato arriendo de campo, notas, testimonio

Herstig Lazaro Jacobo y Elias, contrato de alquiler

Herstig T. Y Fridman S., y Mendelevich A., contrato de pastoreo

Herstig Tobias, contrato de pastoreo

Hert Tovie, contrato de pastoreo

Hertzriken Leon, contrato, plano, cartas

Hojman Hilel, contrato de arriendo, notas

Hojman Hilel, contrato, plano, cartas

Hojman Hillel, contrato, plano

Holzheim Georg, contrato de arriendo

Horovitz Simon, contrato, plano, cartas

Hurovitz Miguel, contrato arriendo de casa

Hurowitz Miguel, contrato

Isak Abraham e Israel y Jaime, contrato de pastoreo
1937-1938

1943

1943-1946

1934-1942

1940

1916-58

1930-1943

1931-1935

$1945-1946$

1945-1946

1933-49

1940-49

1908-29

1941

1970

1931

1947

1947

$1932-46$

1946

1946

1953

1908-28

1935-48

1943-45

1939-55

1936-38

1909-28

1949

1912-29

1918-49

1947-58

1947

1939

1945-46

1933

1960

1937-47

1916-46

1943-45

1943

1909-20

1913-50

1942-43

1921-47

1934

1908-36

1946-47

1938-49

1930-36

1945-47

1915-38

1932-33

1943

1945-46

1931

1917-48

1939-1942

1928-40

1941-42

1939-1946

1909-36

1932-1945

1925

1935-47
Reserva

Reserva 
6178 Santa Isabe 6235 Santa Isabe 6238 Santa Isabe 6195 Santa Isabel 6166 Santa Isabe 2570 Santa Isabe 2887 Santa Isabe 6163 Santa Isabel 6193 Santa Isabe 6192 Santa Isabe 6098 Santa Isabel 6246 Santa Isabe 1359 Santa Isabe 2580 Santa Isabe 2886 Santa Isabel 6131 Santa Isabe 6291 Santa Isabel 6124 Santa Isabe 1264 Santa Isabe 6302 Santa Isabe 6290 Santa Isabe 6128 Santa Isabe 4086 Santa Isabe 6295 Santa Isabel 1266 Santa Isabe 5776 Santa Isabe 1262 Santa Isabe 3369 Santa Isabel 1265 Santa Isabe 1333 Santa Isabe 2704 Santa Isabe 5952 Santa Isabe 6119 Santa Isabel 6179 Santa Isabe 2743 Santa Isabe 6142 Santa Isabe 4117 Santa Isabe 386 Santa Isabel 6294 Santa Isabel 5950 Santa Isabel 2710 Santa Isabel 1340 Santa Isabel 6257 Santa Isabe 2602 Santa Isabe 4116 Santa Isabel 6230 Santa Isabe 2552 Santa Isabe 6136 Santa Isabe 4098 Santa Isabe 6250 Santa Isabe 3658 Santa Isabe 6141 Santa Isabel 6157 Santa Isabe 6109 Santa Isabe 6219 Santa Isabel 6171 Santa Isabe 6245 Santa Isabe 6251 Santa Isabe 4105 Santa Isabe 6261 Santa Isabe 6174 Santa Isabel 1826 Santa Isabel 6151 Santa Isabe 1596 Santa Isabe 6181 Santa Isabel 1593 Santa Isabe 6145 Santa Isabel
Jaliper Jose, contrato de pastoreo Jarupkin Isaac, contrato de pastoreo

1943 Jarupkin Marcos, contrato de pastoreo Jarupkin Moises, contrato de pastoreo Kaas Israel, contrato de pastoreo Kanievsky Fama Vda. de, plano, contrato, cartas

$1943-47$

1933

1908-29

Kanigel Baruch, contrato, plano, cartas

Kanigel Bernardo, contrato de pastoreo

Kasanietz Jose y Schelubsky Mauricio, contrato de pastoreo, nota Kasanietz Rafael y Rubinzahl Natan, contrato de pastoreo, nota

Kasanietz Rafael, contrato de pastoreo

Kasanietz Rafael, contrato de pastoreo

Kass Israel, contrato, plano, cartas

Kass Salomon, contrato, plano, cartas

Kelmanovich Juan y Gregorio, contrato, plano, cartas

Kitztein Jose, contrato de alquiler

Kohan Clara Bonder Vda. de, Testimonio, nota

Kohan Isaias, contrato de pastoreo

Kohan Leon, contrato, plano, cartas

Kohan Sofia Galiper de, contrato arriendo de casa

Kohon Bernardo y Clara, contrato de arriendo de campo, notas

Kohon Isaias, contrato de pastoreo

Kohon Samuel, contrato

Kohon Samuel, contrato arriendo de casa

Kohon Samuel, contrato, cartas

Kohon Samuel, contrato, plano, notas

Komarofsky Moises, contrato, plano, cartas

Komarofsky Rafael y Marcos, contrato, plano, notas

Komarofsky Rafael, contrato, plano, cartas

Komarofsky Samuel, contrato, plano, cartas

Komarovsky Felipe, contrato

Komarovsky Marcos, contrato de pastoreo y ensanche

Komarovsky Salomon, contrato, testimonio

Korenfeld Israel y Kaas Salomon, contrato de pastoreo

Korenfeld Israel, contrato, plano, cartas

$\begin{array}{ll}\text { Korenfeld Israel, contrato, plano, cartas } & 1917-48 \\ \text { Korenfeld Israel, Matlis Isaac y Hertzeriken Isaac, contrato de pastoreo } & 1942-44\end{array}$

Koval Bernardo, contrato

Kunin Rafael, contrato, plano

Latacheff Salomon, contrato arriendo de casa

Leibovich Marton, contrato de arriendo, nota

Leibovich Moises, contrato, nota

Lernik Gregorio, contrato, plano, cartas

Lewinsky Siegmund, contrato de arriendo y pastoreo, notas

Liberman Aron, contrato, plano, cartas

Lischinsky Abraham, contrato

Lischinsky Naum, contrato de pastoreo, notas

Lischinsky Naum, contrato, plano cartas

Litvak Roberto, contrato de pastoreo

Locaso Salvador, contrato

Luftman Berek, contrato de arriendo de campo notas

Lugrin Hector Suc., nota

Lupu Hersch, contrato de pastoreo

Magram Ramon, contrato de pastoreo,y testimonio

Maisules Jose, contrato

Maisules Jose, contrato de pastoreo

Maisuls Jose, contrato de pastoreo

Mandel Samuel I., contrato de pastoreo

Mariasch Joel, contrato de arriendo de campo, testimonio, notas

Martinez Elena, contrato

Mass Elias, contrato de arriendo, notas

Matles Elias, contrato de pastoreo

Matlis Bernardo, contrato, plano, cartas

Matlis Elias, contrato de alquiler

Matlis Isaac, contrato, plano, cartas

Matlis Moises e Isaac, contrato de pastoreo

Matlis Moises, contrato, plano, cartas

Matzkin Benjamin y Samuel, contrato de pastoreo
Reserva

$1915-48$

1941

1940-41

1942

1936-48

$1943-44$

1945-47

1952

1957

1948

1916-46

1922-48

1908-61

$1922-54$

1924-49

1948-61

$1945-46$

1943-45

1945-1946

1928

1960

1948

1939

1934-48

1921-46

1938-43

1910-38

1944

1946-47

1908-34

1943

1934

1932-1935

1970

1945-46

1932-1935

1941-1943

1942

1945-47

1948

1912-1935

1939

1936-37

1934

1917-47

1932

1931-48

1945-46

1922-47

1945-1946

Reserva 
6316 Santa Isabel 6134 Santa Isabe 6209 Santa Isabe 6101 Santa Isabe 4099 Santa Isabe 1267 Santa Isabe 1827 Santa Isabel 6239 Santa Isabe 1699 Santa Isabe 1260 Santa Isabe 6093 Santa Isabe 2025 Santa Isabe 6304 Santa Isabe 4089 Santa Isabe 6318 Santa Isabe 6307 Santa Isabe 6281 Santa Isabe 5076 Santa Isabel 6201 Santa Isabe 6189 Santa Isabe 6258 Santa Isabel 6237 Santa Isabe 2564 Santa Isabe 6249 Santa Isabe 418 Santa Isabel 6187 Santa Isabel 2683 Santa Isabe 6301 Santa Isabe 6127 Santa Isabe 6203 Santa Isabe 6172 Santa Isabel 1263 Santa Isabe 6254 Santa Isabel 415 Santa Isabel 6200 Santa Isabe 2745 Santa Isabel 6252 Santa Isabel

4120 Santa Isabel 412 Santa Isabel 2639 Santa Isabe 420 Santa Isabel 2766 Santa Isabel 6253 Santa Isabe 414 Santa Isabel 6146 Santa Isabel 2739 Santa Isabel 4085 Santa Isabe 6308 Santa Isabe 4080 Santa Isabe 6190 Santa Isabel 2550 Santa Isabel 421 Santa Isabel 2833 Santa Isabel 2581 Santa Isabel 6218 Santa Isabel

2567 Santa Isabel 6168 Santa Isabe 6154 Santa Isabe 1339 Santa Isabe 2834 Santa Isabel 6122 Santa Isabel 416 Santa Isabel 4069 Santa Isabel 2673 Santa Isabel 5902 Santa Isabel
Matzkin Benjamin, contrato arriendo de lote, notas

1934-1951

Matzkin Benjamin, contrato de pastoreo

Maurman Genendel Vda. De, contrato de pastoreo 1945-46

Medvedovsky Manuel, contrato de pastoreo 1941

Medvedovsky Samuel, contrato

Melloff Elias, contrato, cartas

Melman Jose Pincas, contrato, plano, cartas 1931-40

Mendelevich Abraham, contrato de pastoreo 1946

Mendelevich Abraham, contrato, plano 1922-48

Mendelevich Jose, contrato, plano, cartas 1938-48

Mendelevich Moises, contrato 1945-46

Mendeliovoch Sofia Heiden de, Boleto de Compra 1970

Michlnitzky B., transfiere a Kotliar Jose, nota de Transferencia de casa 1941

Migliora Carlos, contrato 1952

Migliora Juan y Ramon, contrato arriendo para taller 1921-1936

Migliora Pierino Carlos, contrato de arriendo de casa $\quad$ 1937-47

Milecki Jose, contrato arriendo de campo, notas 1948

Milgram Elias, contrato, plano, notas $1921-1943$

Milman Jaime, contrato de pastoreo

Milman Manuel, contrato de pastoreo 1945-47

Milman Moises y Koval Moises, contrato de pastoreo 1945

Milman Moises, contrato de pastoreo 1945-47

Minitz Manuel, contrato, plano, cartas 1908-28

Miskin Jose, contrato de arriendo de campo 1940-1941

Miskin Jose, contrato, plano, carta 1934-48

Miskin Naum y Jose, contrato de pastoreo 1945-46

Moscovich Benjamin, contrato, plano, cartas 1939-51

Moscovich Julio, nota

Moscovich Roberto, contrato de pastoreo

Moscovich Seidel, contrato de pastoreo

Moseinko Mauricio, contrato de pastoreo, nota

Munich Aron, contrato, plano

Munitz Marcos, contrato de arriendo de campo, testimonio, notas

Munitz Samuel, contrato, plano

Muravchik Aron, contrato de alquiler

Musicovsky Leon, contrato, plano cartas

Najamkin Teresa B. de, e hijos, contrato de arriendo de campo,

testimonio, notas

Nemirovsky Adolfo, contrato

Nijamkin Felipe, contrato, plano, carta

Nijamkin Naum, contrato, notas

Nijamkin Naum, contrato, plano, carta

Notcovich Lazaro, contrato, plano cartas

Notkovich Luis, contrato de arriendo

Notkovich Luis, contrato, plano, carta

Obelar Quintin, contrato de alquiler

Ostrovsky Salomon, contrato, plano, cartas

Paiz Jose, Azuaga Maria y Sanger Federico, contrato

Papasolus Santiago, contrato de arriendo de casa

Papazoglu Juan, contrato

Parnes Isaac, contrato de pastoreo

Parnes Samuel, contrato, plano, cartas

Pasternak Fischel, contrato, plano, carta

Pecheny Armando, contrato, plano

Pecheny Armando, contrato, plano, cartas

Pecheny Gregorio y Luisa Berguer de, contrato de pastoreo y

habitación, nota

Pecheny Gregorio, contrato, plano cartas

Peisajovich Gregorio, nota

Peralta Manuel, contrato de pastoreo

Perelmuter Mendel, contrato, plano, cartas

Perilmutter Jacobo, contrato, plano

Perl Alter, 2 contratos de pastoreo

Perlmuter Jacobo, contrato, plano

Pfefferman Julio, contrato

Pirichinsky Clara Sch. De, contrato, plano, cartas

Pocin Moises, contrato de arrendamiento
1947

$1942-43$

1936-1946

1945

1948

1909-1936

1946-48

1935-1937

1914-49

1908-1941

1936

$1916-48$

1948

$1938-48$

$1929-58$

1940-1941

1933-47

1932

$1908-49$

1952

1945-47

1960

1945-46

1908-43

1932-48

1949-58

1947-50

1935-1943

1908-35

1944

1932

1929-40

1949-58

1945-31

1938-53

1967

1947-48

1944
Reserva

Reserva

Reserva

Reserva 
6089 Santa Isabel 6175 Santa Isabel 6241 Santa Isabel 6006 Santa Isabel 2870 Santa Isabe 1337 Santa Isabe 6097 Santa Isabe 6256 Santa Isabel 6110 Santa Isabe 6182 Santa Isabe 6176 Santa Isabe 6180 Santa Isabe 6164 Santa Isabe 6275 Santa Isabe 6148 Santa Isabel 6169 Santa Isabe 6088 Santa Isabel 5951 Santa Isabe 3726 Santa Isabe 6100 Santa Isabe 6094 Santa Isabe 6095 Santa Isabe 2758 Santa Isabel

6156 Santa Isabe 2601 Santa Isabel 6208 Santa Isabel 6248 Santa Isabel 2742 Santa Isabe 4088 Santa Isabe 6274 Santa Isabe 1334 Santa Isabel 6211 Santa Isabel 4115 Santa Isabel 6153 Santa Isabe 6207 Santa Isabel 6212 Santa Isabe 6155 Santa Isabe 1357 Santa Isabel 850 Santa Isabel 4070 Santa Isabel 6086 Santa Isabe 6099 Santa Isabe 1595 Santa Isabe 2637 Santa Isabel 6210 Santa Isabel 1600 Santa Isabel 2681 Santa Isabe 6107 Santa Isabe 1825 Santa Isabe 2551 Santa Isabel 5077 Santa Isabel 2682 Santa Isabe 6096 Santa Isabel 6282 Santa Isabel 1335 Santa Isabe 1336 Santa Isabel 1705 Santa Isabel 4073 Santa Isabe 6255 Santa Isabel 6118 Santa Isabel 6185 Santa Isabel 1828 Santa Isabel 3370 Santa Isabel 6194 Santa Isabel 1700 Santa Isabel 1010 Santa Isabel
Podlichevsky Majrim y Epstein Salomon, contrato

Podlichevsky Marcos, contrato de pastoreo, inventario 1945-46

Polak Zalyl, contrato de arriendo de campo, notas 1931-35

Polo Jose Maria Sucesion, contrato, notas 1926-1947

Postan David y Jaime, contrato, plano

Postan David y Jaime, contrato, plano, carta

Postan David, contrato de pastoreo

Postan Manuel, contrato de arriendo

Postan Manuel, contrato de pastoreo

Postan Manuel, contrato de pastoreo, nota

Postel Samuel, contrato de pastoreo

Posternak Fisel, contrato de pastoreo

Pozza Guido, contrato de pastoreo

Quintana Pablo, contrato de arriendo de casa

1947

Romero Jose, contrato de pastoreo

Rosemberg Abraham y Bolchinsky Adolfo, contrato, plano, cartas,

division de condominio

Rosman Fabio y Kohen Leon, contrato de pastoreo

Rotnistcovsky Israel, contrato, plano

Rubinzhal Natan, contrato de pastoreo

Saboliansky Leon, contrato de arriendo de campo

Saiovici Lazar, contrato, plano, cartas

Sanger Federico, contrato

Sanger Federico, contrato de arriendo de casa

Saposnicoff Moises, contrato, plano,cartas

Saslavsky Boruch, contrato de arriendo, notas, testimonio

Scheinfeld Natalio, contrato

Scheinfeld Natalio, contrato de arriendo

Schelubsky Mauricio, contrato de pastoreo

Schmerkin Gregorio, contrato de pastoreo

Schmerkin Moises, contrato de pastoreo

Schmukler Inda N. de y Jose Adolfo, contrato, plano, cartas

Schmukler Jose A., contrato, plano

Schneider David, contrato

Schneider David, contrato

Schneider David, contrato de pastoreo

Schneider David, contrato, plano, cartas

Schneider Isaac, contrato, plano, notas

Schneider Moises, contrato de arriendo de alquiler de casa

Schneider Nahum, contrato

Schneiderman Isaac y Jose, contrato, plano, cartas

Schneiderman Jacobo, contrato

Schnitman Abraham, contrato, plano, cartas

Schvartz Bernardo y Leon, y Schazman Elias, contrato, plano, cartas

Schvartzman Ignacio, contrato. plano, notas

Schvartzman Samuel, Jacobo y Adolfo, contrato, plano, notas

Sclar David, contrato

Sclar David, contrato arriendo de campo, notas

Serebrinsky David y Julio, contrato, plano, cartas

Serebrinsky Pedro, contrato, plano, cartas

Siebzehner Perla B. de, contrato, plano

Silva Diego, contrato

Sirota Gregorio, contrato de arriendo

Sirota Jose, contrato de pastoreo

Sitcoff Sa?ie y Rebeca, contrato de pastoreo

Sitlonik Pablo, contrato, plano, cartas

Slavkin Naum, contrato de pastoreo, nota

Smilinsky Samuel, contrato, plano, cartas

Soc. Cooperadora Escuela Nacional No. 155, contrato, plano
$1922-43$

$1942-43$

$1936-1940$

1945-1946

1945-1950

1934

1945-1947

1933

1940-41

1943-44

$1945-47$

1937-38

1938-39

1947-51

1943-46

1933-45

1940

1909-54

1943-1947

1909-19

1940-47

1935-39

$1938-48$

1952

1945-48

1908-34

1912-1928

1934

1932

1945-47

1946

1932

1908-40

1950

1924

1937-39

1945-47

1928-48

1948

1929-1936

1936-47

1908-48

1941

1942-48

1913-45

1909-1946

1909-48

1940-41

1937-1939

1911-42

1924-44

1922-49

1967

1936-1941

1942-47

1945-47

1913-37

1919-29

1945-46

1918-52

Reserva

Reserva

Reserva

Reserva

1964

Reserva 
2889 Santa Isabel 4100 Santa Isabel 6228 Santa Isabe

6191 Santa Isabe 6229 Santa Isabe 6105 Santa Isabe 2867 Santa Isabe 2568 Santa Isabe 6266 Santa Isabe 6150 Santa Isabe 385 Santa Isabel 6221 Santa Isabe 6313 Santa Isabe 2571 Santa Isabe 5861 Santa Isabe 6267 Santa Isabe 6152 Santa Isabe 2736 Santa Isabe 410 Santa Isabel 6126 Santa Isabel 6217 Santa Isabe 6289 Santa Isabe 6198 Santa Isabe 2737 Santa Isabe 4078 Santa Isabe 2563 Santa Isabe 6115 Santa Isabe 6112 Santa Isabel 3234 Santa Isabe 6287 Santa Isabe 6162 Santa Isabe 2811 Santa Isabel 6227 Santa Isabe 6103 Santa Isabe 6104 Santa Isabe 6116 Santa Isabel 1917 Santa Isabe 2738 Santa Isabel 748 Santa Isabel 4072 Santa Isabe 6223 Santa Isabe 6288 Santa Isabe 6224 Santa Isabe 2744 Santa Isabel 722 Villaguay 1695 Walter Moss 2490 Walter Moss 5856 Walter Moss 1694 Walter Moss 744 Walter Moss 710 Walter Moss 1697 Walter Moss 743 Walter Moss 2488 Walter Moss 712 Walter Moss 2500 Walter Moss 781 Walter Moss 2499 Walter Moss 795 Walter Moss 2492 Walter Moss 2491 Walter Moss 2504 Walter Moss 2702 Walter Moss 761 Walter Moss 2506 Walter Moss 2659 Walter Moss
Sociedad Cooperativa Agricola «La Union», contrato

1940

Sociedad Cultural Max Nordau, contrato, plano

1948

Socolovsky Ana S. de, Luisa y Rafael y Noejovich Berta S. De,

contrato de alquiler, testimonio, notas

Socolovsky Bernardo, contrato de pastoreo $\quad 1945-47$

Solcovsky Leon, contrato de pastoreo 1946-47

Soskin Pedro, contrato de pastoreo

Spectaroff Naum, contrato, plano

Spectoroff Isaac, contrato, plano, cartas

Spectoroff Naum, contrato de arriendo

Spectoroff Naum, contrato de pastoreo, notas

Spekman Rafael, contrato, plano

Stern Alter, contrato de pastoreo, notas

Stilman Adolfo y Benjamin, contrato arriendo de lote, notas.

Stilman Israel, contrato, plano, cartas

Stilman Israel, contrato, Readquisición

Stilman Jaime, contrato de arriendo

Stilman Salomon, contrato de arriendo de casa

$1941-42$

1947

1913-29

1938-1941

1932-1944

1960

1930-1931

1924-1938

1908-29

1936

1939

1932-33

1916-48

(

1936

1942

1946-47

1938-1942

1945-1946

1928-48

1966

1941

1941-42

1941-42

1947-68

Uner Elias, contrato
Usatinsky Bernardo Suces., contrato plano, notas

1928-1945

1944-1946

1930

1945-47

$1941-46$

$1940-46$

1942-43

1948

$1908-48$

$1922-64$

1970

1930-34

1938-1944

1930-1935

$1930-48$

1947

1928-48

1926-50

1925-1934

$1922-48$

$1922-50$

1949

$1922-48$

$1915-50$

$1912-48$

$\begin{array}{lr}\text { Gubspun Rosa V. de.contrato, plano } & 1941-49 \\ \text { Gupspan Leopoldo, contrato, plano, cartas } & 1912-38\end{array}$

$\begin{array}{lr}\text { Gubspun Rosa V. de.contrato, plano } & 1941-49 \\ \text { Gupspan Leopoldo, contrato, plano, cartas } & 1912-38\end{array}$

Hatelevich Ana Kreiman de, y Hatelevich Roberto, contrato, plano, cartas 1928-52

Hiskin Pedro, contrato, plano, cartas $\quad 1908-29$

Jarupkin Esther, contrato, plano $\quad 1948-52$

Jarupkin Jose y Jacobo, contrato, plano, cartas 1915-48

Jarupkin Marcos, Isaac y Jaime, contrato, plano, cartas 1913-48

Jeschan Moises, contrato, plano, cartas $\quad 1909-40$

Kohon Isaias, contrato, plano, cartas $\quad 1948-50$

Kohon Isaias, contrato, plano, correspondencia 1915-47

Kontarovsky Julio, contrato, plano, cartas $\quad 1908-48$

Korsunsky Gregorio y Mochkovsky Moises, contrato, plano 1929-48
Reserva

Reserva

Reserva

Reserva

Reserva

Reserva

Reserva 
2505 Walter Moss 766 Walter Moss

2502 Walter Moss 2658 Walter Moss 839 Walter Moss 764 Walter Moss 6310 Walter Moss 1698 Walter Moss 2657 Walter Moss 1693 Walter Moss 2865 Walter Moss 1696 Walter Moss 6339 Walter Moss 774 Walter Moss 2489 Walter Moss 745 Walter Moss 6314 Walter Moss 2501 Walter Moss 2503 Walter Moss
Lebedinsky Fany F. de, contrato, plano, cartas

Leikis Rebeca Slafkin de y Leikis Aaron, contrato, plano,

$1912-48$

Lemesoff Jacobo, Manuel y Mauricio, contrato, plano, cartas

Maislus Jose y Abraham, contrato plano, cartas

Ministerio de Educación , p/ Escuela No. 122, contrato, plano

$1909-30$

1948

1952

Minsky Miguel, contrato, plano

Moseinko Felipe Sucesion, contrato, notas

Moseinko Moises, contrato, plano, cartas

Muravchik Fany Tmur de, contrato, plano

Muravchik Luis, contrato, plano, cartas

Pais Floro, contrato, plano, notas

Perman Salomon, contrato, plano, cartas

Sandel Jose y Leon, contrato arriendo de lote

1923-52

$1933-1943$

$1915-48$

1948

$1915-48$

$1943-47$

$1948-52$

$1944-45$

Saslavsky Jose, contrato, plano

$1918-48$

Sborovsky Benjamin, contrato, plano, cartas

$1912-48$

Svirsky Sofia Kosunsky de, contrato, plano

$1928-52$

Tmur Isaac Sucesion, contrato, Testimonio, notas

$1938-39$

$1908-52$

1908-36

Reserva

Reserva

(

Voloj Zlata J. de y Maximo, contrato, plano, cartas
Reserva

Reserva 



\section{Actividades culturales realizadas en Colonia Clara entre 1924 y 1943 -selección-}

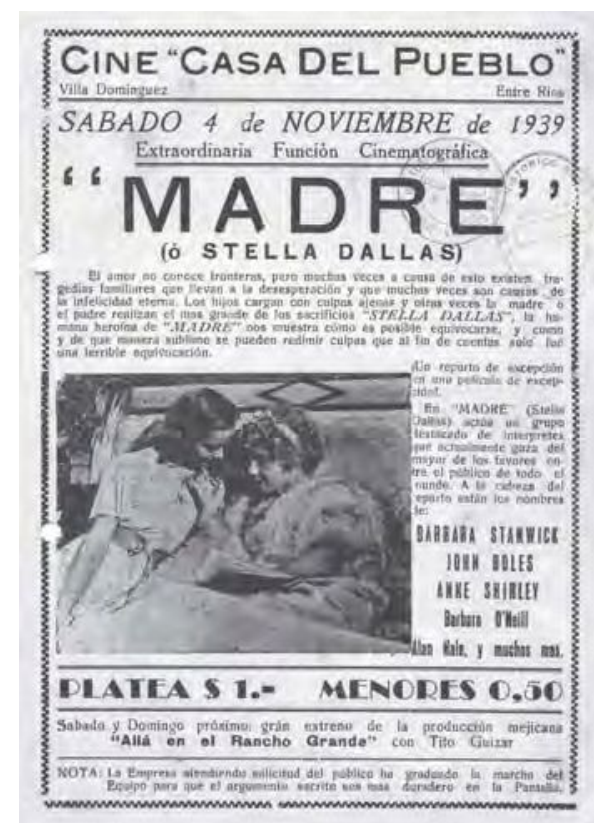

"Madre", cine-teatro.

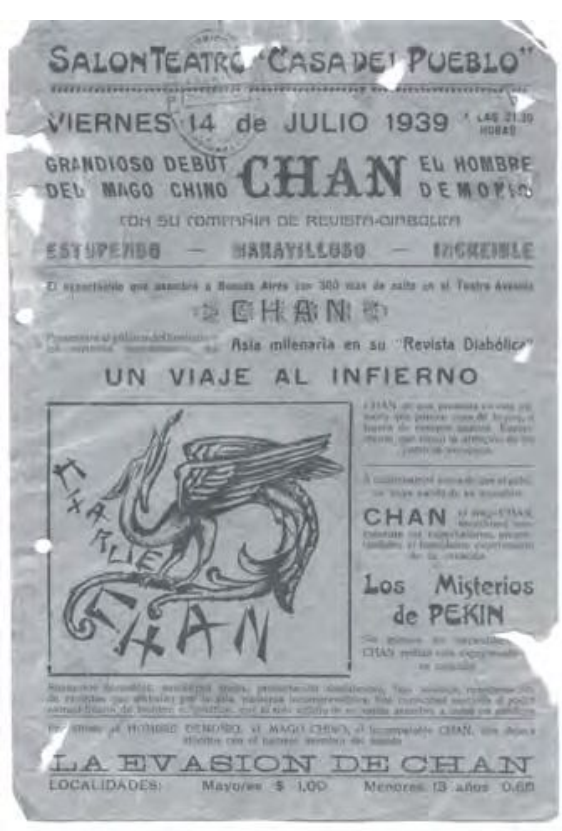

Magia china en Dominguez

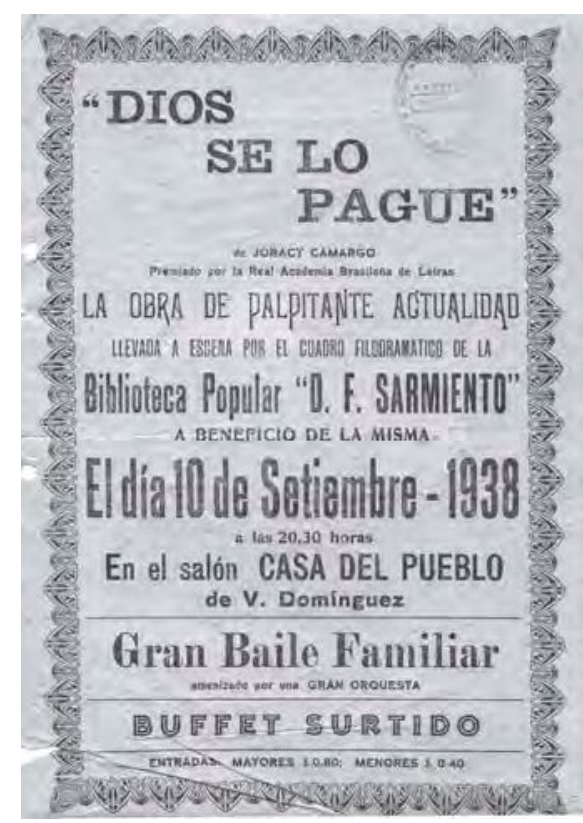

Obra de Joracy Camargo

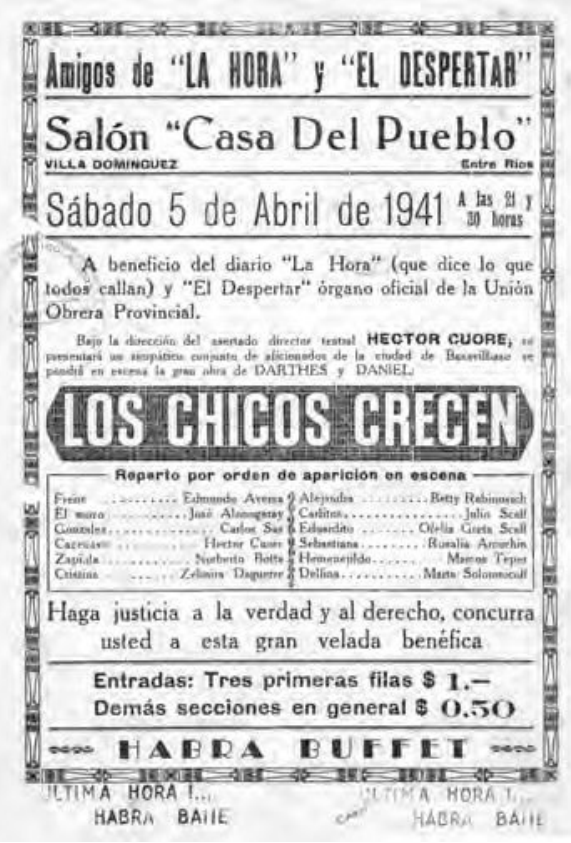

Héctor Cuore 


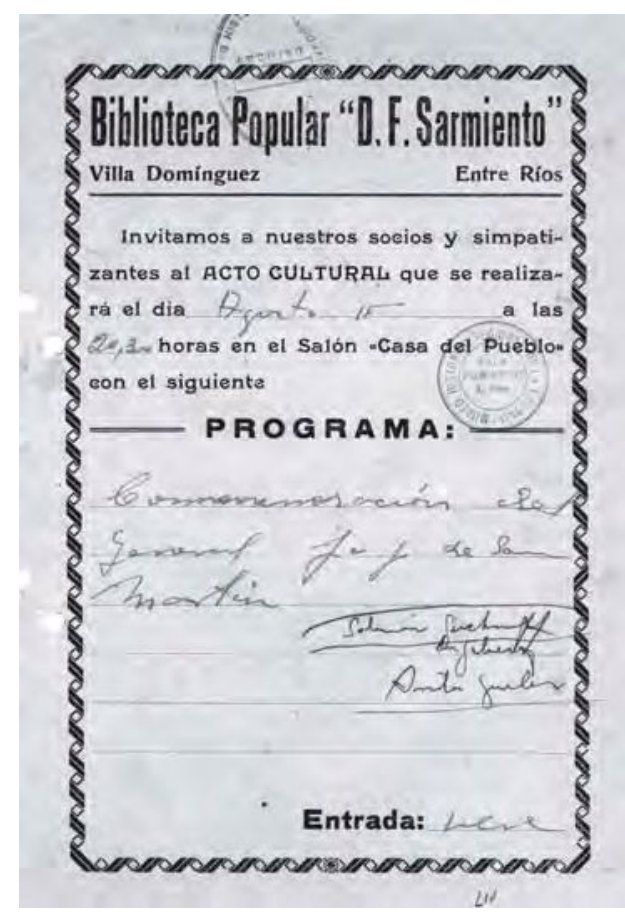

Acto conmemorativo al Gral. San Martín

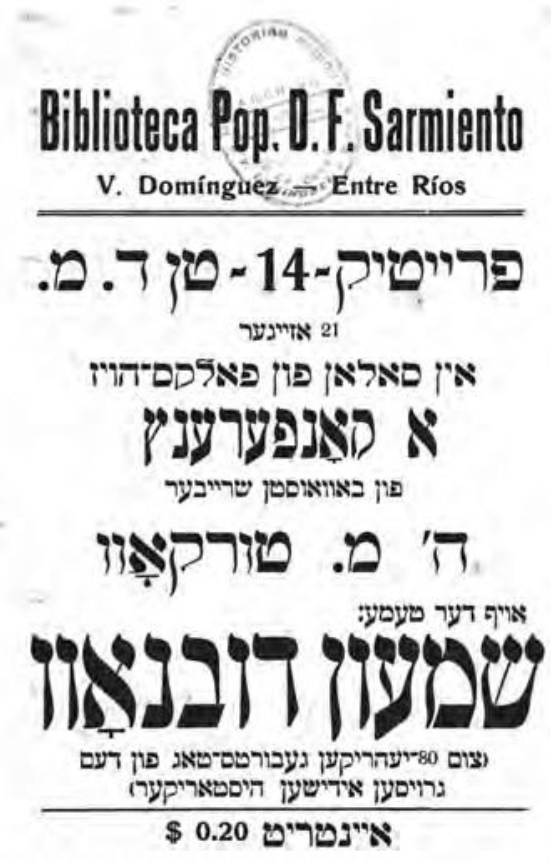

Aviso en idish

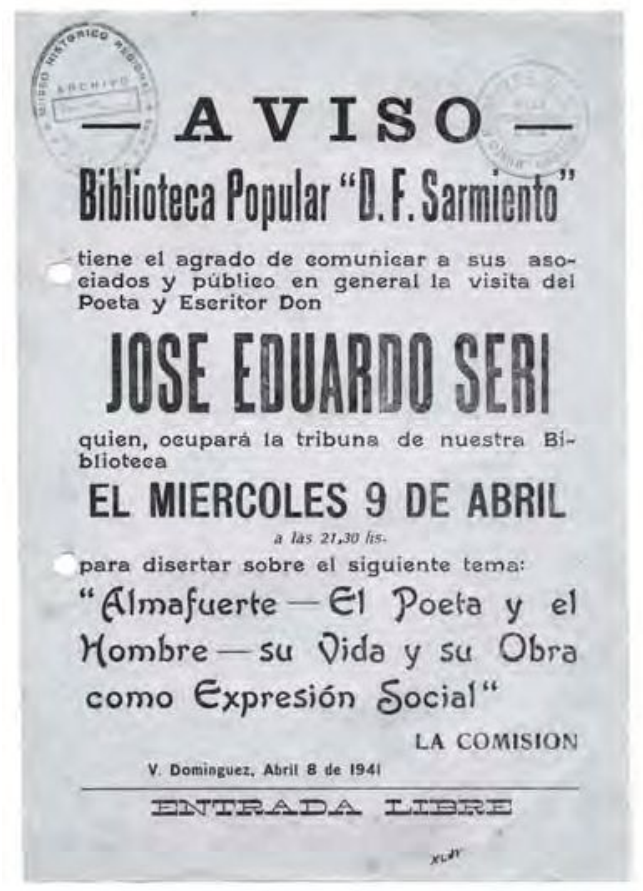

Almafuerte, vida y obra

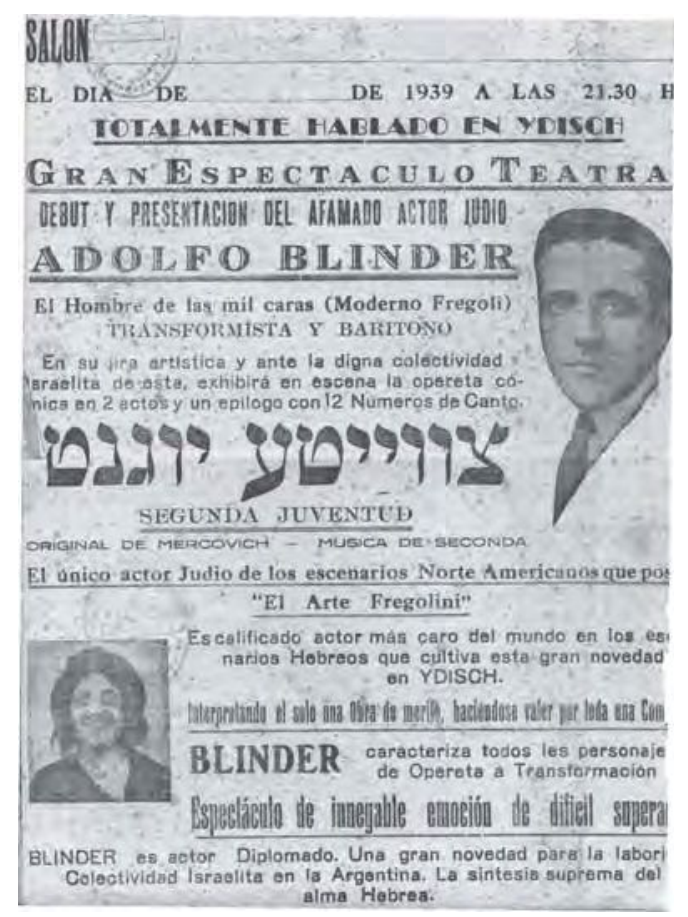

Adolfo Blinder, espectáculo teatral 


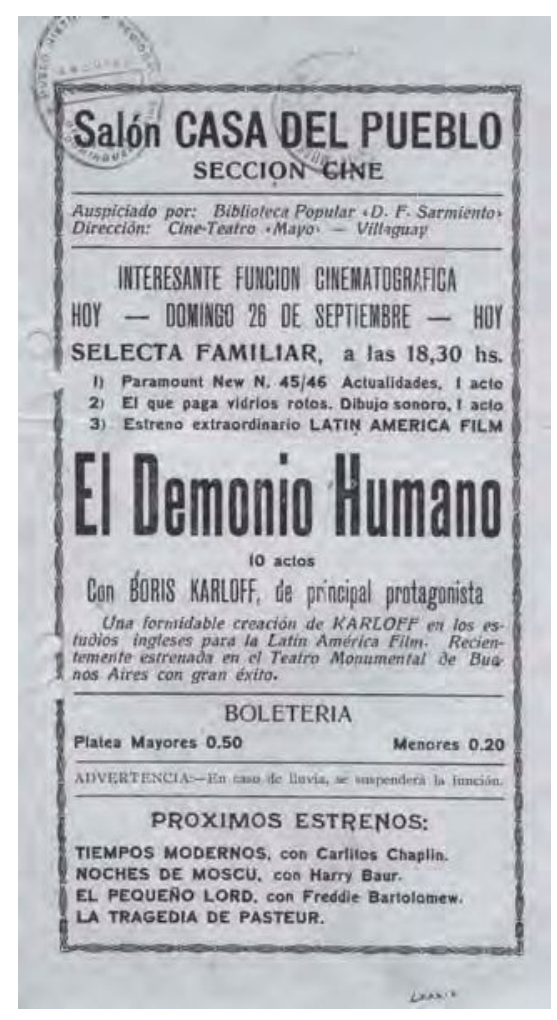

Boris Karloff, El demonio humano

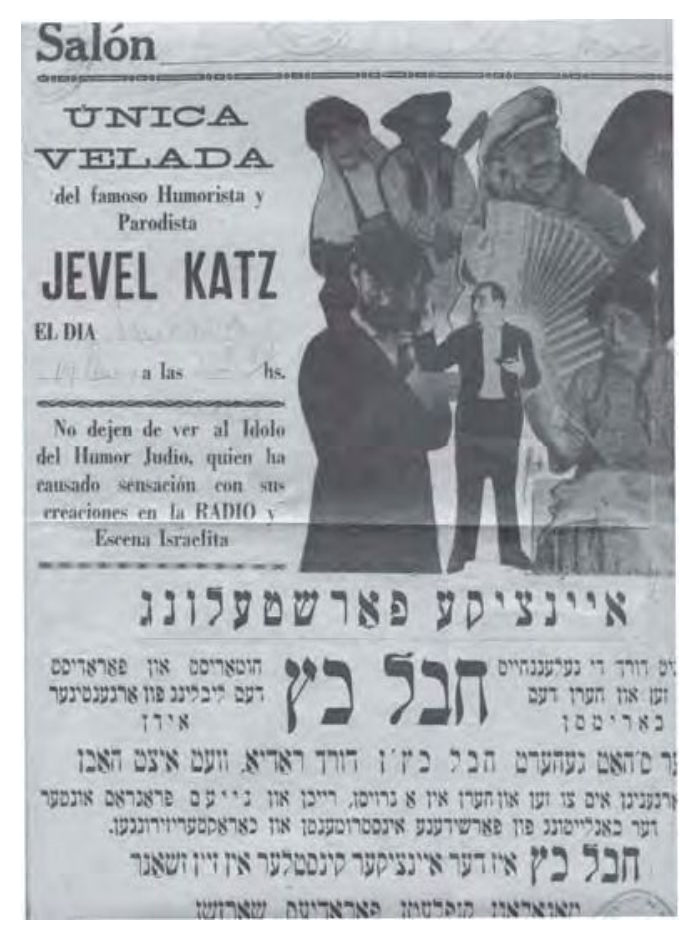

Jevel Katz, velada humorística

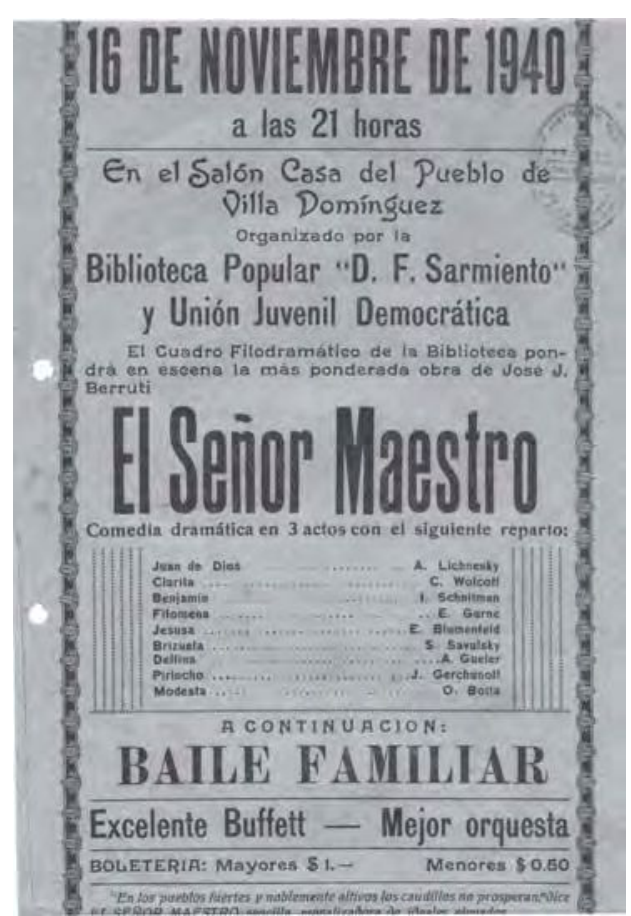

Comedia dramática en Biblioteca

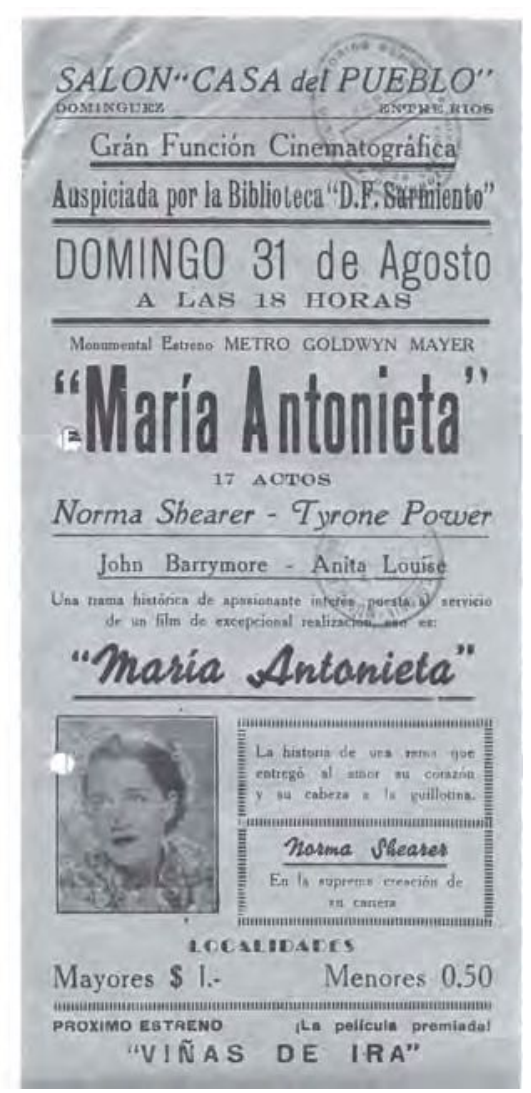

Función cinematográfica, "María Antonieta”, Norma Shearer y Tyrone Power 


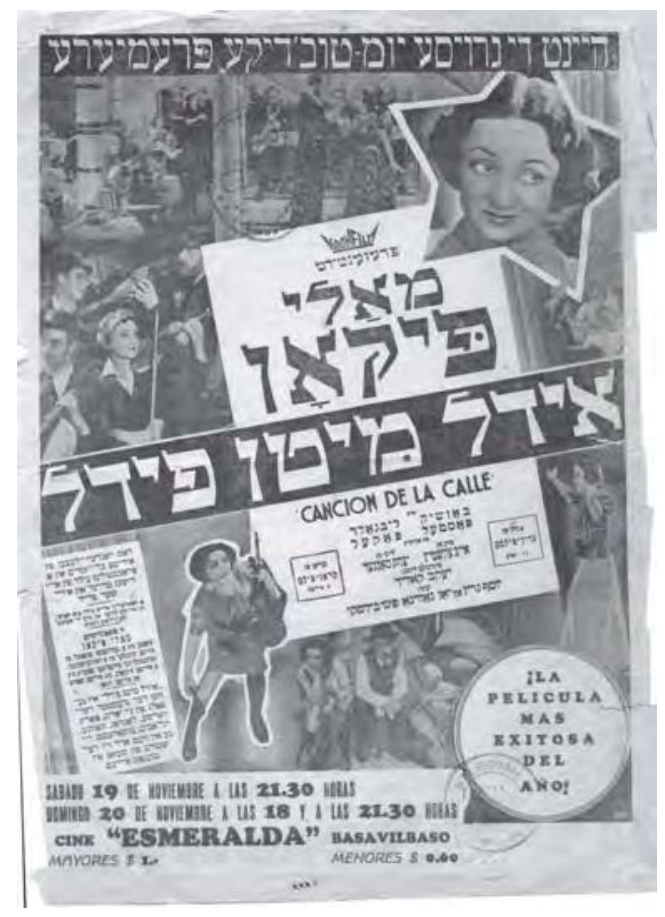

Kron Film, cine Esmeralda, Basavilbaso.

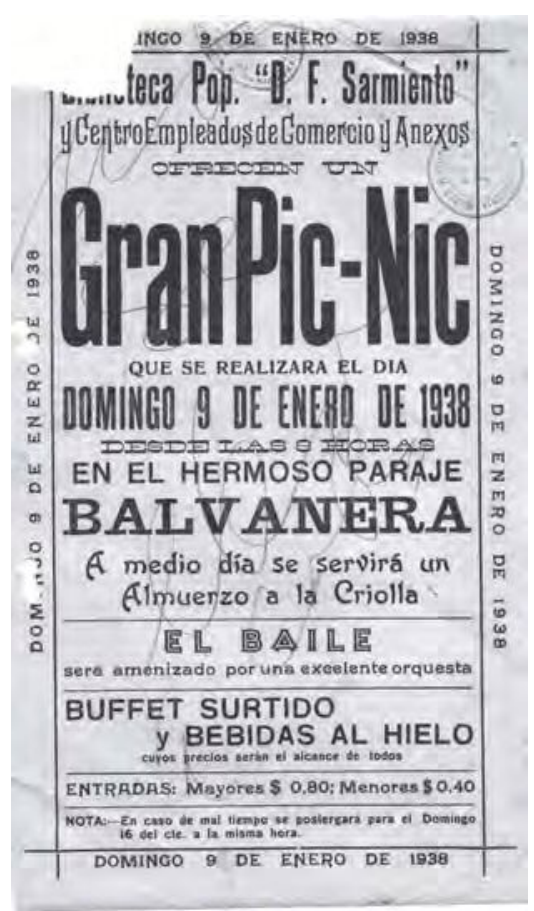

Pic Nic en Balvanera

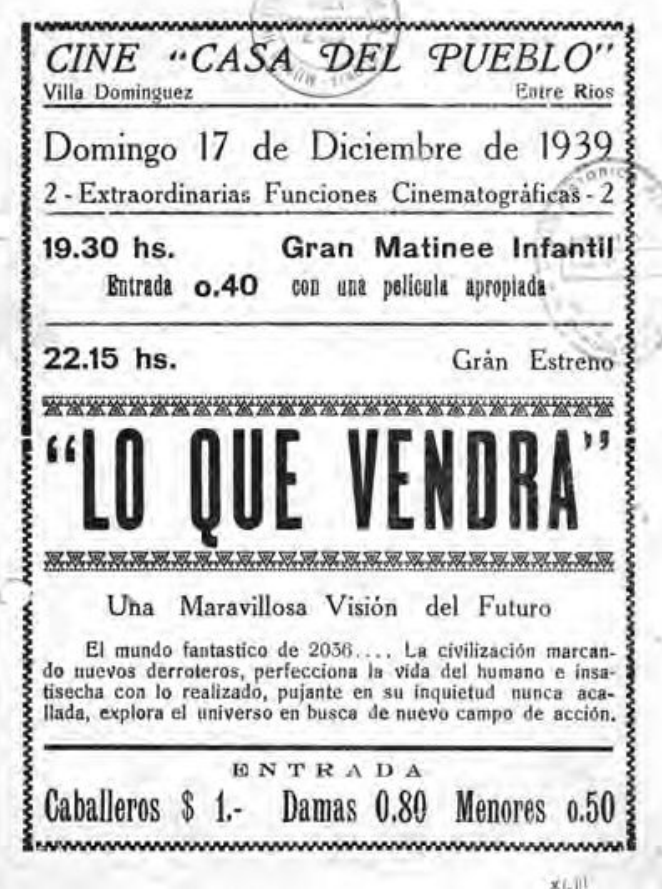

Película "Lo que vendrá", matiné infantil.

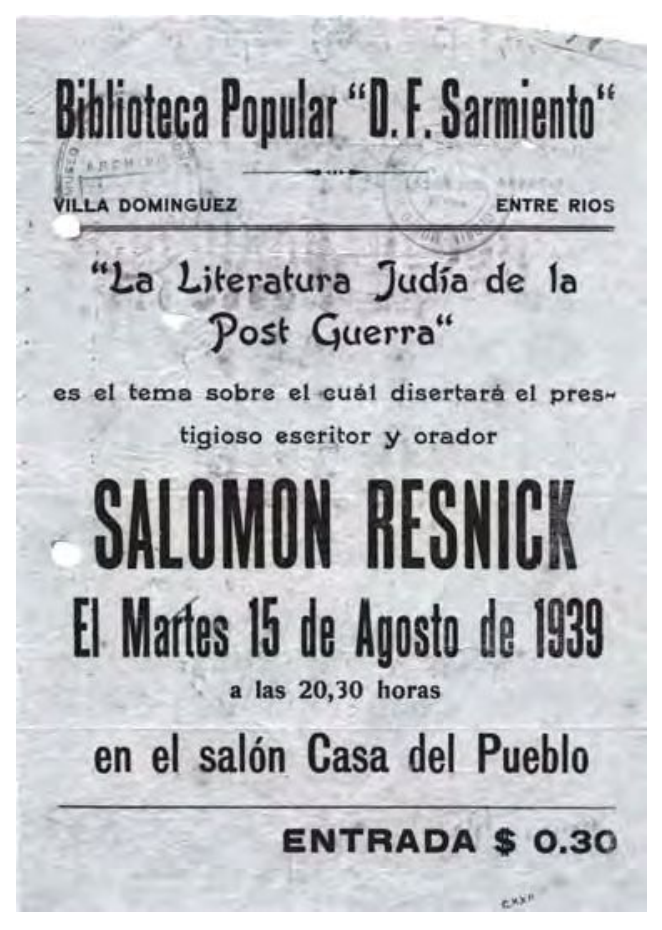

Salomon Resnik, escritor y orador disertará sobre la Literatura Judía de la Post Guerra 


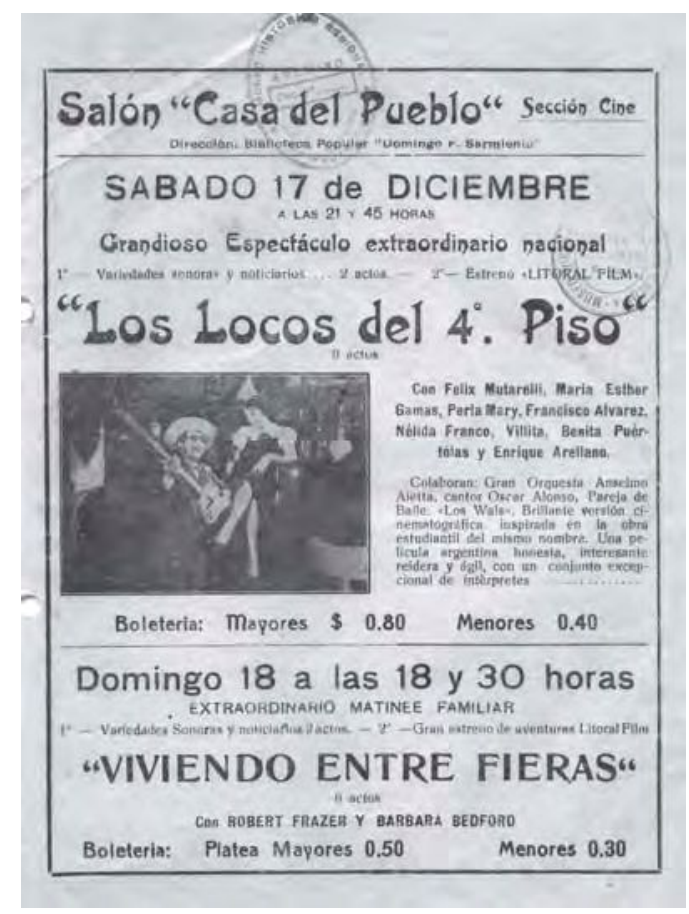

Sección cine, espectáculo con Félix Mutarelli.

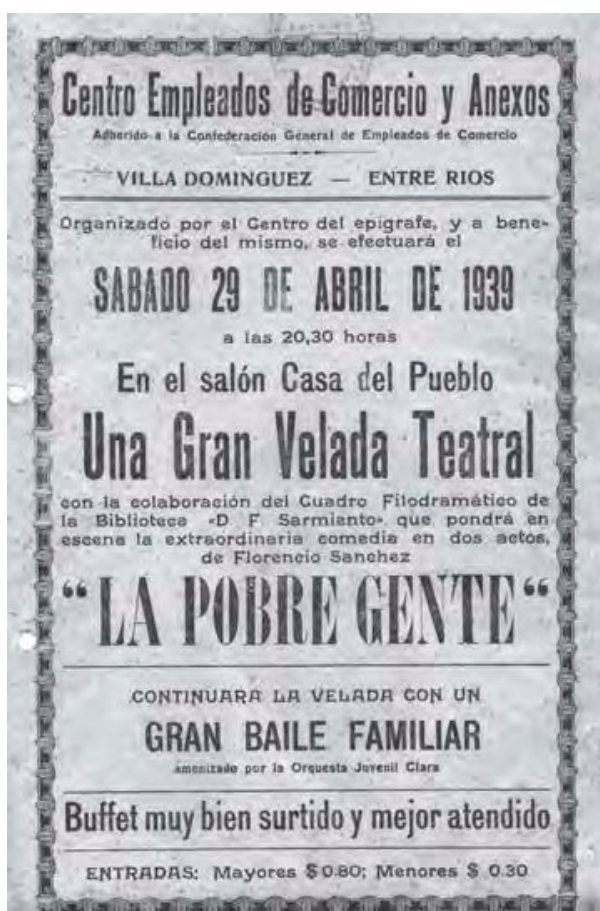

Obra teatral "La pobre gente"

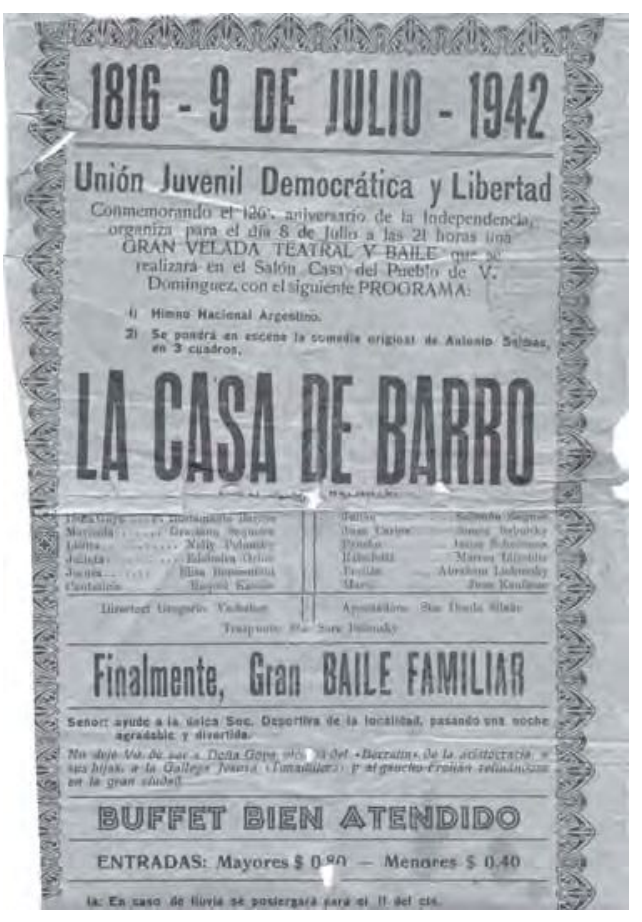

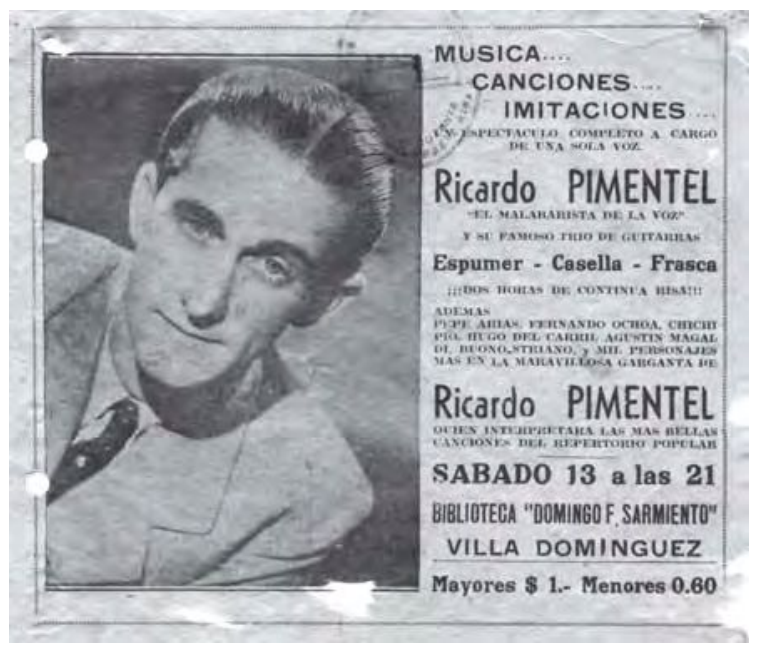

Pimentel y su famoso trío en Villa Dominguez

Velada teatral y baile, comedia original "La casa de barro" 
